
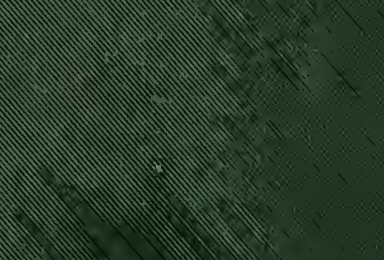
mo $m$
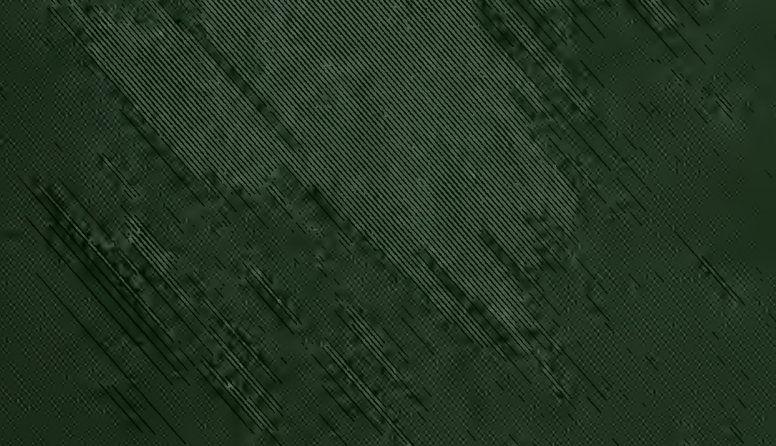

$\ldots$

$1 / 2$
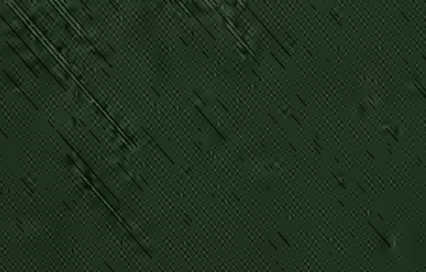

$4 \times 1 \times 2$ 


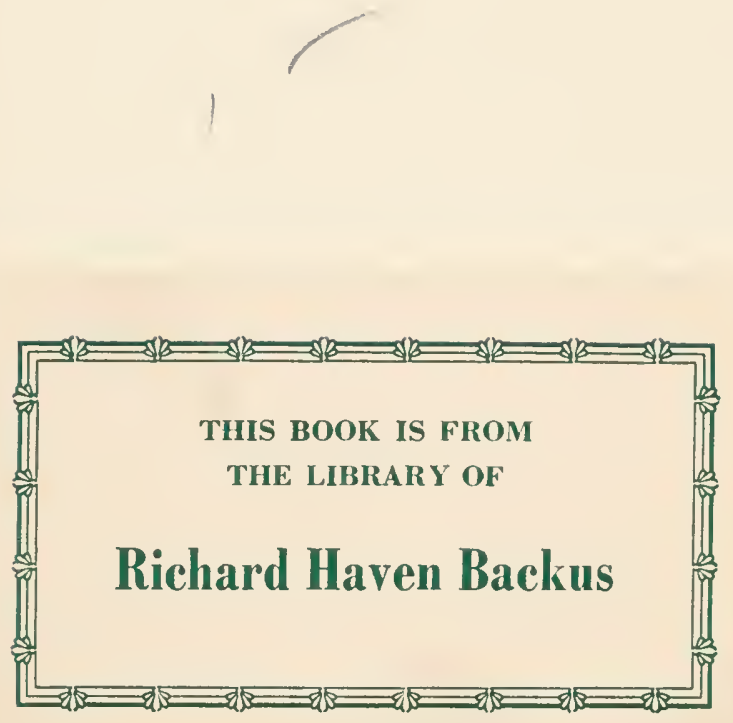



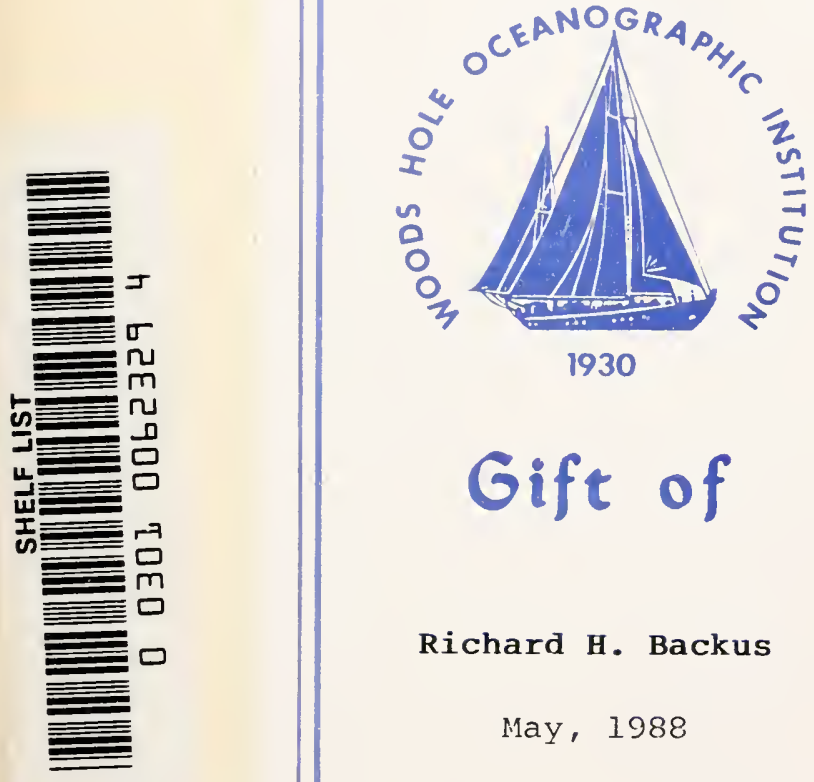

Richard H. Backus

May, 1988 



\title{
University of the State of New York
}

\section{New York State Museum}

Frederick J. H. Merrill Director

\author{
Bulletin 60
}

ZOOLOGY 9

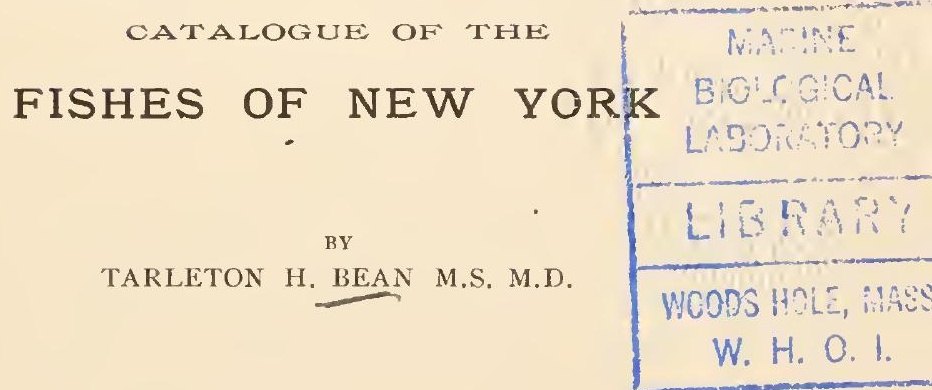

Preface......................... 3

Introduction ..................... 5

Marsipobranchii, lampreys............ II

Hyperoartii, lampreys................ II

Pisces, the fishes.................. I7

Asterospondyli, typical sharks......... I7

Cyclospondyli, cyclospondylous sharks.... 43 Batoiđei, rays ................... 46

Selachostomi, paddlefishes ............ 60

Chondrostei, sturgeons .............. $6_{3}$

Rhomboganoidea, gar pikes........... 69

Cycloganoidea, bowfins................ 73

Nematognathi, catfishes ............. 76

Plectospondyli, carplike fishes......... 97
Apodes, eels .... ................... 169

Isospondyli, isospondylous fishes..... . . I 77

Iniomi, lantern fishes ............... $28_{5}$

Haplomi, pikelike fishes.............. 287

Synentognathi, synentognathous fishes.... 3 ${ }^{17}$

Hemibranchii, half-gills ............ 335

Lophobranchii. tuftgills ............. 347

Acanthopteri, spiny-rayed fishes....... 35 I

Plectognathi, fishes with ankylosed jaws.. 608

Pediculati, pediculate fishes............ 733

Recorded distribution of New York fisbes .......................... 739

Index $\ldots \ldots \ldots \ldots \ldots \ldots \ldots \ldots \ldots \ldots \ldots 74$ 



\section{New York State Museum}

Frederick J. H. MERRILL Director

\section{Bulletin 60}

ZOOLOGY 9

CATALOGUE OF THE

\section{FISHES OF NEW YORK}

\section{PIEFACE}

In 1836 , under the influence of public interest, Secretary of State John A. Dix presented to the legislature a plan for a natural history survey of the state, which was carried out with success and credit and resulted in the publication of a large number of valuable reports. Not the least important of these were the contributions of James E. De Kay to the zoology of New York, which appeared in 1842 and 1813.

Since that time comparatively little official recognition had been given to the progress of biologic study, till in 1897 the writer secured the able serrices of Mr Gerrit S. Miller $\mathrm{jr}$ in preparing a preliminary list of New York mammals. Following this appeared in October 1900 a key to the land mammals of northeastern North America by the same author, and in April 1900 a check list of the birds of New Iork by Dr Marcus S. Far' who is now engaged in the preparation of a detailed catalogue of the birds of New Tork. A list of reptiles and batrachians by Messrs Eckel and Paumier has recently appeared; and in the present bulletin Dr Tarleton H. Bean gives to the citizens of the state the benefit of his natural talent and long training as an 
ichthyologist. It is hoped and believed that the results of this work will be of much practical use to the public at large and to the teachers and students in the schools of the state.

By special request of the author his synonymies are printed in the form in which they were prepared by him.

Frederick J. H. Merrill

Albany N. I. July 1902 
New Yolk las an extensive water area and a great diversity of surface. Its principal roainage basins are: thr. Frrat lakes, the St Lawrence river, including Lake Champlain, the Ohio basin, the Susquelanna, the Helaware, the Hudson and several small streams adjacent to it in the southeastern part of the state. The inland lakes, in the central and mestern part of the state, almost all communicate with Lake Ontario. Chautauqua lake belongs to the Ohio basin. Lake Otsego and two small lakes east of Keuka lake, empty into the Susquehanna. The Adirondack lakes for the most part belong to the St Lawrence drainage basin, some of them emptying into Lake Champlain, and a few into the upper waters of the Hudson.

Long Island has a larger number of species than all the remainder of the state. The number of marine species in its waters is 217 , and its fresh waters contain 27 species, of which 13 have been recently.introduced.

In the bays of the south side of the island, wherein the water is brackish or nearly fresh, and where there is a luxuriant growth of water plants, young menladen and alcwives are extremely abundant.

One of the fresh-water fishes is a hybrid trout, artifically produced; another is the black-nosed dace, which is perhaps doubt. fully recorded from Long Island; and 13 species liare been recently introduced, as before remarked.

I The permanent residents in fresh water are the following: horn pout, chub sucker, roach, brook trout, striped mud minnow, banded pickerel, chain pickerel, fresh-water killy, pirate perch, fresh-water silversicle, sunfish, yellow perch, and .Johnny darter. Most of these 13 species, or perhaps all of them, could easily have been introduced by man within the last century or two.

Mitchill recorded only three fresh-water species from Long Island. These are: yellow percls, brooli trout and pickerel. To the pickerel he applied the name $\mathrm{Es}$ ox lucius, a species 
which dous not occur on the island. He mentioned also the bony-scaled pike, Es ox os s u s, concerning which he says: "A few years ago I had a large and complete specimen from Long Island, which agrees in the main with the descriptions extant." This was doubtless a mistake of locality. The yellow perch was transplanted by Mitchill in 1790 from Ronkonkoma pond to Success pond, in Queens county, a distance of 40 miles. Prior to 1790, he states, there were no yellow perch in Snccess pond. Do Kay also knew only a few species of fresh-water fishes in Long Island waters-the yellow perch, roach, banded pickerel, and brook trout.

It seems probable that some of the early writers on New York fishes must hare had access to collections from Long Islandr and yet a number of species might have existed without discovery during the time of their observations. The present number of species whose date of introduction is not recorded is rery small, and most of the so called native fishes represent species which lend themselves readily to the purpose of artificial introduction.

It is a matter of record that some species of fresh-water fishes identical with those found in Long Island waters, have been swept out of the Hudson river by spring floods, and several such species hare been seen at Gravesend bay, Long Island. It is certain that incursions of fresh-water forms conld have taken place from time to time in the streams of the north side, and also on the south side of Long Island. Once established in that way, their wider dissemination through the agency of man, aquatic birds, and even through their own movenents conld be very easily accomplished.

Of the fresh-water fishes known to Mitchill and De Kay, the brook trout can live in fresh and salt water indifferently; the chain pickerel is frequently found in brackish water; the yellow perch is one of the fish which have been brought down from the Hudson by flonds into Graresend bay; the roach is a common resident of lakes in New Tork and Brooklyn parks, and its distribution has been greatly extended through the agency of man. 
The number of fishes included in this catalogue is 375 , of which 371 are named, and the following four, which have only recently been discorered in the state, should be added to the list: no. 76 ?

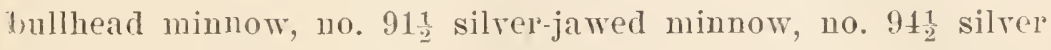
chub, no. $255 \frac{1}{2}$ northern darter. Of these species 217 are marine, 141 fresh-water, and 17 anadromous. The number of introrluced species is 15, and the number whose occurrence in New York waters is doubtful is 18 . The small number of freshwater species would be remarkable but for the fact that no "xtensive inrestigations have recently been made of the fresh waters of the interior of the state, and the catalogue is in that respect simply incomplete.

The anadromous species are the following: no. 1 sea lamprey, no. 35 common sturgeon, no. 37 short-nosed sturgeon, no. 101 eel, no. 112 hickory shad, no. 113 branch herring, no. 114 glut herring, no. 115 shad, no. 130 quinnat salmon, no. 131 Atlantic salmon, no. 134 steelhead, no. 137 rainbow trout, no. 143 smelt, no. 170 10-spined stickleback, no. 171 two-spined stickleback, no. 260 striped bass, no. 261 white perch. Besides these, the following marine species occasionally run up into fresh water for shorter or longer distances: no. 158 silver gar, no. 223 bluefish, no. 224 crab-eater, no. 321 naked goby, no. 346 tomcod, no. 368 hogcholer.

The introduced species are: no. 71 tench, no. 74 golden ide, no. 99 goldfish, no. 100 carp, no. 130 quinnat salmon, no. 131 Atlantic salmon, no. 182 landlocked salmon, no. 133 Lake Tahoe trout, no. 134 steelhead, no. 135 brown trout, no. 136 Lochleven trout, no. 137 rainbow trout, no. 138 Swiss lake trout, no. 141 saibling, uo. 142 golden trout.

The fish shose pertinence to the New York fauna is doubtful are the following: no. 73 Le u $\mathrm{c}$ is cus margarita, no. 162 loncheak, no. 208 amberfish, no. 226 small dolphin, no. 26: wreckfisl. 110. 263 spotted grouper, no. 265 coachman, no. 290 Zenofsis. nu. 301 globefish, no. 302 hairy bowfish. no. 303 burfisli, no. 317 sea poacher, no. 327 shanny, no. 328 blenny, no. 329 suakefish, no. 837 red gurnard, no. 356 cusk, no. 359 rough dab. 
The fishes represent 99 families. The lampreps include 4 species; the sharks 18 species; the catfishes 14 species, of which 2 are marine; suckers 9 species; minnows or carps 39 species; herrings 10 species; salmon family, which includes the trout and whiteish, 20 species, one half of which number have been introduced; pikes 6 species; killy fishes 5 species; sticklebacks 5 species; silversides 5 species; the mackerel family 10 species; the pompano family 18 species; sunfishes 1:3 species; perches, including the darters, 17 species; sea basses $S$ species; weakfisl. family 10 species; sculpins 8 species, equally divided between the fresh and salt waters; sea robins 5 species, one of which. the red gurnard, probably never occuried in our waters, thougl. it has been assigned to New York; codfishes 12 species, one of them a permanent resident in fresh water; flounders 10 species, but one of these is of doubtful occurrence.

The species whose existence in New York water's has onlyrecently been reported, and which are not numbered in this catalogue, are the bullhead minnow, Cli o l a vigila $\mathrm{x}$ Baird \& Girard, the silver-jawed minnow, Eric r m b a buc ca t a Cope, silver chub, Hy o p s is a $\mathrm{mb}$ lops Rafinesque, and the northern darter, Et heos to ma bor e a l e Jordan. The first three of these species have been found in the western part of New York, and the northern darter has been recorded in the basin of St Lawrence river, from Montreal to Lake Ontario.

The nimes used in this catalogue are substantially those employed by Jordan and Evermann in bulletin 47, United States National Inseme and I am indebted to these authors for many of the descriptions of the genera. There are some departures, however, from the names emploved in that bulletin, for reasons which appear to me satisfactory; for example, the name Etrumeus sadina is discarded for the round herring, and the specific name te $\mathrm{r}^{2} \mathrm{~s}$ of De Kay is used in its stead, because Mitchill's type bore a close resemblance to the shad. It has a spot behind the gill cover, a wide and toothless mouth, a projecting lower jaw, and $\mathbf{1 5}$ anal rays. There is no probability that Mitchill had the round herring before him for this description. 
The glut herring in my list is called $\mathrm{Cl}$ u p e a c y a $\mathrm{n} \mathrm{o} \mathrm{n} \mathrm{o} \mathrm{t} 0$ m Storer; Mitchill's name, a e s t i r a $\mathrm{l}$ is, appear's to be a synonym of $\mathrm{mediocr}$ is and m a $\mathrm{t} t \mathrm{ow}$ a $\mathrm{ca}$ of the same author. Its relation to the hickory shad was long since pointed out by Dr Gill. Mitchill stated that the fish has seren or eight dark roundish spots extending in the direction of the lateral line. His figure shows a row of eight dark spots on the side extending to the end of the dorsal fin on the level of the eye.

The name Coregon us I a bra dor i cus, for the Labrador whitefish, is omitted because that species is identical with the common whitefish. The characters by which the Labrador whitefisl were supposed to be distinguished are untenable, precisely the same character's being found in the whitefish and there being no other basis of separation.

The author has discovered that $K$ ir $t I$ and i a $l$ a $c$ in i a $t$ a Swain is identical with $K$. $r$ a g $\mathrm{l}^{\circ}$ a $\mathrm{n}$ s Goode \& Bean.

The species Querimana grans is beliered to be the young of M ugil triehodon Poey; and the genus Queri$\mathrm{m}$ a $\mathrm{n}$ a was found to be the young state of $\mathrm{M} \mathrm{u} \mathrm{gil}$.

The name $\mathrm{Ne}$ o m a e $\mathrm{n}$ is bla $\mathrm{ekford}$ is retained for the red suapper for the reasons clearly given in the 19th Report of the Commissioners of Fisheries of New York, 1890. There is absolutely no proof that the name a y a should be applied to this species.

The synonymy giren for the species is limited usually to authors who wrote specially on the fishes of New Tork, or adjacent regions, and to the well known general catalogues of recent writer's on ichthyology. One principal aim has been to give as many references as possible to illustrations of species.

The descriptions of the fishes are based chiefly on collections studied by the author, many of which were obtained in his own field work. The results of investigations made by parties for the United States Fish Commission lave also been incorporated in the text.

Illustrations of the species would have added greatly to the report; but the time was not arailable for obtaining drawings 
for this purpose. Artificial keys also would have been an additional advantage; but, as references are giren in erery case to bulletins 16 and 47 of the United States National Museum, which contain complete series of artificial keys, this feature was omitted.

The author hopes ere long to prepare a new account of the fishes of New York, containing illustrations of all the species, together with keys for identification, but can not complete such an undertaking till after the inland waters of the state have been more thoroughly and systematically investigated.

Tarleton H. Bean

Washington D. C. 1902 


\section{Class MARSIPOBRANCHII}

Order HYPEROARTII

Family PETRONIYZONTIDAE Lampreys

Genus permonyzon (Artedi) Linnaeus

Lampreys with the supraoral lamina armed with two or three separate teeth, pointed, and close together, not forming a crescent-shaped plate; anterior lingual tooth with a median depression; buccal disk large, witl numerous teeth arranged in concentric series; dorsal fins separate, the second joined to the caudal.

\section{Petromyzon marinus Linnaeus}

\section{Great Sea Lamprey; Lamprey Eel}

Petromyzon marimus Livnaeus, Syst. Nat. ed. X, 230, 1758; Mitchill, Trans. Lit. and Phil. Soc. N. Y. I, 461, 1815; Günther, Cat. Fish. Brit. Mus. VIII, 501, 18т0; JordAN \& GIlbert, Bull. 16, U. S. Nat. Mus. 11, 1SS3; Jordan \& Evermann, Bull. 47, U. S. Nat. Mus. 10, pl. I, fig. $3,1896$.

Petromyzon americamus Le Sueur, Trans. Am. Phil. Soc. Phila. I, 383, 1818; De Kay, N. Y. Fauna, Fishes, 379, pl. 66, fig. 216, 1842; Storer, Hist. Fish. Mass. 275, pl. XXXVIII, fig. 4, 1867.

Petromyzon appendix DE KAY, N. Y. Fauna, Fishes, 381, pl. 64, fig. 211, $18+2$ (young).

Body cylindric, eellike, stont, somewliat compressed behind. The mouth is terminal, subcircular in shape and suctorial. It is strongly armed with large conical teeth or cusps mounted on papillae, those of the inner series being bicuspid. Guarding the throat are crescent-shaped plates, bearing pectinate lingual teeth; a pair of these plates on either side and another pair below them. The mandibulary plate has seven cusps.

There are seven branchial apertures on each side of the head, the first not far behind the eye; the distance of the last opening from the tip of the snout is contained about five times in the total length. Eye rather small, covered by membrane. The first dorsal originates in about the middle of the length; it is little developed and well separated from the second dorsal which is confluent with the anal. The anal is rery low and 
only about half as long as the second dorsal. The rent is far back, opposite the origin of the second dorsal.

The specimen described, number $1065 t$ in the U. S. National Museum collection, is 28 inches long.

The sea lamprey or lamprey eel inhabits the north Atlantic, ascending streams to spawn and sometimes becoming landlocked. In some interior waters of New York the landlocked form has received the name, un i color, of De Kay. The species ranges southward on our coast to Virginia. In the Delaware, Susquehanna and their tributaries this is a common fish. Its larval form, which is blind and toothless, is extremely abundant in muddy sandflats near the mouths of small streams and is a very important bait for hook and line fishing.

The sea lamprey grows to a length of 3 feet. It is dark brown in color, mottled with black and white. In the breeding season in spring the males have a high fieshy ridge in front of the dorsal. The spawning is believed to take place in May or June. The eels cling to the rocks by means of their suctorial mouths and the eggs are deposited in shallow water on a rough bottom where the current is swift. Some observers state that they make nests by heaping up stones in a circle and deposit the eggs under the stones. The oraries are large, but the eggs are very small.

The food of the lamprey is chiefly animal matter and the fish is somewhat of a parasite, burowing into the side of shad, sturgeon and some other species. The teeth are adapted for this method of feeding. The tooth-bearing bone of the upper side of the mouth contains two teeth which are placed close together. On the bone corresponding with the lower jaw there are seven or nine stout cusps. There are numerous teeth around the disk, the first row on the side of the mouth containing bicuspid teeth; the others are simple. The tooth on the front of the tongue has a deep median groove. The species is adapted for fastening itself to otler fishes and extracting from them their blood. 
The lamprey is considered a good food fish in some localities, but in other places it is rarely eaten. In Connecticnt and Massachusetts the species is highly esteened. It is proserved by salting for sereral Weeres before using. The fish is sometimes caught with the hands or by means of a jole armed with a hook in the end. Is it is found in shallow water and will not usually relinquish its hold on the bottom, its capture is easily effected.

The sea Iampres has been obtained iu Gravesend bay in small numbers in March, Ipril and June. It is not adapted to captivity because of the impracticability of furnishing it with proper food.

2 Petromyzon marinus unicolor (DeKay)

\section{Lake Lamprey}

Ammocotes unicolor DE KAY, N. Y. Fauna, Fishes, 3S3, pl. 79, fig. 250, 1S42. Petromyzon marimus subsp. dorsatus Wilder in Jordan \& Gilbert, Bull. 16, U. S. Nat. Mus. S69, 1882.

Petromyzon murimls unicolor MeEK, Ann. N. I. Ac. Sci. 284, 1SS6; JornAx \& Evermanr, Bull. 47, L. S. Nat. Mus. 10, 1896.

De Kay described this lamprey muler the name A m m o co etes un i c o lor in Zoology of New Jork; or the New York Faun,, pt 4, Fishes, p. 38:, pl. 79, fig. 250. His description was made from a specinen 4 inches long and $-\frac{3}{10}$ of an inch in depth. The plate represents it as haring the dorsal scarcely perceptible, beginning to rise at about the middle of its length, but at no point exceeding $-\frac{1}{10}$ of an inch in hight. The anal is sinilar to the dorsal and like the latter continuous with the caudal. Dr De Kay received specinens from the Rer. Zadock Thompson, who obtained them from Lake Champlain.

This rariety is distingnished from the common marine lamprey only by its size, its mniform dark coloration, more pronounced dorsal ridge, and the less degree of separation of the dorsal fins. It inlabits the lakes of northern and central New York and is not anadromous.

Prof. Seth E. Meek has published in the Annals of the New For\% Arademy of Seicnees 4:29?, the following notes on the species. 
The lake lamprey is found in larger numbers than the brook lauprey, and reaches a much larger size.

During the spring of 1886 more than a thousand individuals were taken from Cayuga lake inlet, and all of them within 5 miles of Ithaca. They began to ascend the inlet to spawn on May 21, and continued to do so until late in June.

Their nests are excarations made in the bed of the stream, in shallow water, usually just above ripples. The eggs are deposited in the fine sand and gravel at the bottom of these nests, and the embryos developed there. The larvae live in the sand along the edge of the stream just below the water line. This species is parasitic on bullheads, suckers, and other large, soft-rayed fishes.

Of the whole number captured and brought to the university by fishermen within two weeks, 480 were males and 265 females.

The longest male specimen was 17 inches, and the shortest 9 inches. The longest female measured 14 inches, and the slortest 10 inches. A small female 7 inches long, taken later, contained eggs which were quite immature.

Inuring the spring a crest is developed upon the back of the male between the nape and the dorsal fin. A smaller crest is developed upon the rentral surface of the female, between the rent and the caudal fin. This was at first supposed to be characteristic of the males of Cayuga lake, and was made the basis of a new specific name; but it has since been found in specimens from the Atlantic slope, and it is said by Seeley to occur in European specimens during the breeding season. This crest is seasonal and sexual. The sexes, at other seasons, can not be easily distinguished, if at all.

More recent accounts of this lamprey are those of Prof. H. A. Surface in the Bulletin U. S. Fish Commission for 1897 and the 4 th anmal Report of the Commissioners of Fisheries, Game and Forest of the State of New Tork.

\section{Genus iснтичомуzon Girard}

Differs from $\mathrm{Pet}$ o $\mathrm{m} \mathrm{z}$ on in laving the anterior lingual tooth divided by a median groove and the dorsal fin notched, but not separated into two portions. Size small. Habitat, fresh waters of eastern United States.

\section{Ichthyomyzon concolor (Kirtland)}

\section{Silver Lamproy}

Ammocortes comrolor Kirtuand, Bost. Jour. Nat. Hist. II1, 473, 1840, with plate (larva).

Petromyzon concolor Jorddx of Fordice, Ann. N. Y. Ac. Sci. 282, 1886. 
Ichthyomyzon argenteus JordaN \& GILbert, Bull. 16, U. S. Nat. Mus. 10, $18 S 2$.

Ichthyomyzon concolor Jordax of Evermaxn, Bull. 47, U. S. Nat. Mus. 11, 1896.

The silver lamprey belougs to the subgenus I c h th y o m y z o n of Girard. The tooth on the front of the tongue is dirided in two parts by a median groove and the dorsal fin is continuous but deeply notched. The maxillary tooth is bicuspid; the teeth on the disk are in about four series and all small. The tooth-bearing bone of the lower part of the month has seven cusps. The head (from tip of disk to first gill opening) is two fifteenths of the total length; with the gill openings its length is contained four and three fourths times in the total. There are 51 muscular impressions from gills to rent. The body is rather stout, compressed posteriorly. The head is broad and the buccal disk large with its edges not conspicuously fringed. Color bluish silvery, sometimes with blackish mottlings. Above each gill opening there is a small bluish blotch.

The silver lamprey or mud eel is found in the Great lakes region and the Ohio and Mississippi valleys. It grows to a length of 12 inches and is usually found in deep water, but runs up the small streams to spawn in the spring. It is a troublesome parasite on the lake sturgeon, the paddlefish, yellow perch and some other species. It becomes fixed to the skin by means of its suctorial disk and the irritation of its teetl sonetimes causes deep ulcers at the point of attachment. This lamprey lias the same peculiarities of development as the sea lamprey and sometimes remains in the larval condition, blind and toothless, till it has reached a length of $S$ inches.

\section{Genus LametreA Gray}

Small lampreys inhabiting brooks of Europe and North America. The dorsal fin either notched or divided into two parts, the posterior part continuous with the anal aronnd the tail; supraoral lamina. broad, crescentic, with a large obtuse cusp at each end and sometimes a minute median cusp; lingual teeth small, with a crescentic toothed edge, the median denticle en- 
larged; buccal disk small, with few teeth which are never tricuspiol.

The genus Lampetra is best distinguished from $\mathrm{Pe}$. trom y z o n by the structure of its so called maxillary tooth, which has the form of a crescent-shaped plate with terminal cusps and, sometimes, an additional median cusp. In $\mathrm{Pe}$ trom y o n this bony plate is short and contains two or three teeth which are very closely placed.

\section{Lampetra wilderi (Gage)}

Small Black Lamprey; Pride

Lampetia wilderi Gage, in Jordan \& Evermann, Bull. 47, U. S. Nat. Mus. 13,1896 .

Petromyzon nigrum Rafinesque, Ich. Ohien. 84, 1820. (Name preoceupied). Ammocotes miger Jordan \& Gilbert, Bull. 16, U. S. Nat. Mus. 9, 1882.

Ammocortes branchialis Jordan \& Fordice, Ann. N. Y. Ac. Sci. 293, 1886; GAGE, in Wilder Quarter-Century Book, 436, 1893.

The high dorsal fin is divided into two parts by a deep notch. Several of the teeth on the side of the bnceal disk are bicuspid and the rest simple. The mandibulary plate is nearly straight and has eight or 10 cusps of nearly equal size. The length of the head including the gills is contained four and three fourths times in the total. There are 67 muscular impressions from gills to vent. In the spring a prominent anal papilla is present. The head is larger than the space occupied by the gill openings and is contained eight and one third times in the total; the depth, 14 times. The eyes are large; the mouth moderately small. The lips are conspicuously fringed with papillae. The teeth change considerably with age; young examples have no median cusp on the maxillary plate.

This lamprey is bluish black above, the lower parts silvery.

The brook or mud lamprey, also known as the small black lamprey, is found in the Great lakes region, the Ohio valley and the upper Mississippi valley. It occurs also in Cayuga lake, New York. According to Jordan it ranges west to Minnesota and south to Kentucky. It grows to a length of $S$ inches. Dr Jordan considers it identical with the common brook lamprey of Europe, $\Lambda$. b r a n c h i a lis. 
This lamprey ascends the small streams in the spring to spawn just as the silver lamprey does. It is parasitic and its spawning habits are similar to those of the sea lamprey. It clings to stones and clods of earth while depositing its eggs and is believed by some persons to die after spawning. The probability is that it goes to deep water where it remains till the spawning season again approaches.

May 8, 1886, Prof. Gage and Dr Meek caught five specimens in Cayuga lake inlet. More of them were seen but not captured. May 22 they risited the inlet a second time but saw no specimens.

The five individuals obtained were all males, and all were busily engaged in building nests. They ascend the inlet to spawn about two weeks earlier than the large lake lamprey, and in smaller numbers.

The life history of the brook or small black lamprey is well related by Prof. Surface in the articles referred to in the notes on the lake lamprey.

\section{Class PISCES \\ Subclass SELACHII \\ Sharks and Skates}

Order Asterospondil

Typical Sharks

Family PSEUDOTRIAIIDAE

\section{Genus pseubotriakis Capello}

Body elongate; mouth wide, with a very short labial fold around the angle; snout depressed, rounded, moderately long; nostrils inferior, near the mouth, but not confluent with it; eyes oblong, lateral, without nictitating membrane; spiracles well developed behind the eye; gill openings moderate, in adrance of the pectoral; jaws armed with numerous rows of small, tricuspid teeth; first dorsal fin, opposite the space between pectorals and ventrals, long and low, gradually increasing in hight posteriorly; second dorsal behind ventrals, opposite and similar to anal; rentrals and pectorals well developed; no pit at the root of caudal 
fin, the basal lobe of which is very low and long; skin with minute asperities.

\section{Pseudotriakis microdon Cajello}

\section{Peixe Carago (Portugal)}

Pseudotrialis microdon Capelzo, Jorn. Sci. Math. Phys. e nat. Lisboa, I, 321, pl. V, 1868; Günther, Cat. Fish. Brit. Mus., VIII, 395, 1870; BeAN, Proc. U. S. Nat. Mus. VI, 147, 18S3; Jordan \& Evermann, Bull. 4i, U. S. Nat. Mus. 27, pl. IV, fig. 14, 1896.

The greatest hight of the bory is at the origin of the first dorsal; it is contained eight and three sevenths times in the total length. The hight at the origin of ventrals is contained nine and one half times in total length. The hight of head at the first gill opening is a little greater than that of body at the ventral origin, while its hight at the angle of the mouth is a little less than one eleventh of the total length. The least hight of the tail equals the hight of the anal, and is contained 25 times in total length.

The head is somewhat depressed in front, with moderately sharp snout, which is nearly twice as long as the distance of its tip from the mouth. The distance from snout to last gill opening is contained fire times in total length. The distance from snout to first gill opening, measured horizontally, equals twice the hight of body at origin of second dorsal. The distance between the first and last gill openings equals nearly twice the length of the eye. The hight of the first gill opening is about equal to the distance between the angle of the mouth and the spiracle. The hight of the head at angle of mouth is contained 11 times and at the first gill opening nine times in total length. The length of the snout equals one half the body hight at origin of first dorsal. The distance of mouth from snout, measured on the axis of the fish, equals one third width of mouth. The distance from snout to angle of mouth, obliquely taken, equals one fourth the distance from snont to last gill opening. The distance between eye and spiracle equals that from mouth to nostril. The distance from angle of mouth to spiracle is about equal to hight of first gill opening. The spirarle is moderately 
large, the length of its opening being contained twice in the hight of fonrth gill opening. The oblong eye is placed near the dorsal profile; the length of the orbit is about one half the greatest light of second dorsal; the length of the eve equals about one fourth width of mouth. The length of upper jaw is slightly more than that of lower, and nearly equals the distance between the spiracles. The distance from the mouth to the nostril is about one fourth least hight of tail; the distance between nostrils equals four times the distance from eye to spiracle. The interorbital space equals one half the length of second dorsal base. The distance between the spiracles equals four times their greatest length.

The first dorsal is rery long and low, highest behind its middle, the length of its base equal to seven times its greatest light; its distance from the snout is a little more than twice the greatest length of pectoral. The second dorsal is distant from the end of the first a length equal to nearly twice its greatest hight; the length of its base is somewhat more than the body hight at origin of first dorsal. The second dorsal begins at a distance from the end of the first, which is equal to the hight of body at rentral origin; the length of its base equals twice the interorbital distance; its hight equals nearly twice the length of the orbit. The anal is entirely under the second dorsal, but its base is a little less than five serenths as long as that of the latter; the greatest hight of the anal equals the least hight of caudal peduncle.

The caudal originates at a distance from the end of the second dorsal about equal to the hight of the anal; it is divided by a notch into a sliort npper portion, whose length is very little more than the greatest hight of first dorsal, and a very low and long lower portion, the longest margin of which is nearly twice as long as the snout. The distance of the candal from the end cf anal base equals one fourth the length of second dorsal base.

The distance of pectoral from snout is contained five times in total length; the length of pectoral equals nearly twice the width of its base, and is a little more than one nintly of total length. 
The greatest width of pectoral equals twice the hight of anal, and is contained $12 \frac{1}{3}$ times in total length.

The origin of the ventral is slightly in advance of the end of first dorsal, and is behind the middle of total length a distance equal to the interorbital space. The length of ventral equals that of lower jaw. The width of ventral base equals that of pectoral base; the greatest width of rentral slightly exceeds its length.

Color. When received the margins of the fins were apparently faded; the original color was probably grayish brown with dark margins on all the fins except the first dorsal. Capello states that his example was chestnut brown.

Remarks. The gills and mouth were obstructed by sand. The only parasites discovered on the animal were a couple of isopods, one of which was found in the eye cavity.

MEASUREMENTS

Total length

Body

Hight at origin of first dorsal. ...........

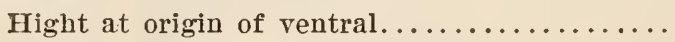

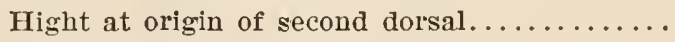

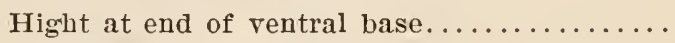

Least hight of caudal peduncle............

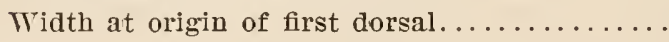

\section{Head}

Distance from tip of snout to first gill opening

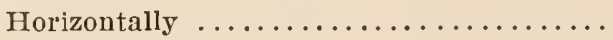

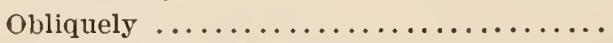

Distance from tip of snout to last gill opening.

Distance from first gill opening to fifth.......

Distance from first gill opening to fourth.....

Distance from first gill opening to third.......

Distance from first gill opening to second.....

Hight of first gill opening..............

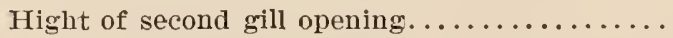

Hight of third gill opening..............

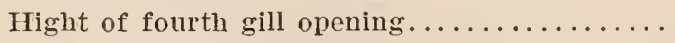

Hight of fifth gill opening . . . . . . . . . .

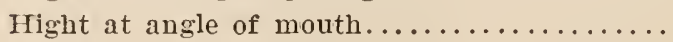

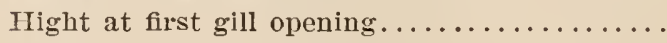

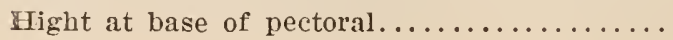

Millimeters

2950

Hundredths of length

100

$\begin{array}{cc}350 & 12 \\ 310 & 10.5 \\ 210 & 7 \\ 210 & 7 \\ 118 & 4 \\ 250 & 8.5\end{array}$

425

14.4

450

15.3

583

20

133

4.5

102

62

27

75

73

72

70

68

265

325

9

11

342 
MEASUREMEXTS

Millimeters

Distance from tip of snout to eye (horizontally).

Distance from tip of snout to mouth (horizontalls)

Distance from tip of smont to mouth (obliquely).

Distance flom tip of snout to angle of month

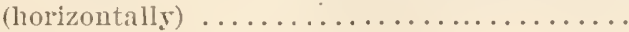

Distance from tip of snout to angle of mouth

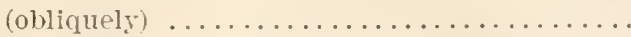

Distance from tip of snout to spiracle (horizonta.lli)

Greatest length of spiracle.

Length of opening of spiracle.............

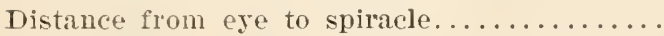

Distance from angle of mouth to spiracle....

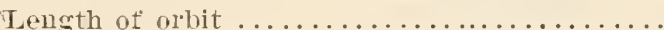

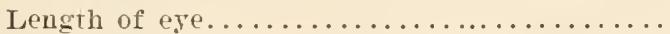

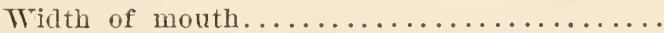

Length of upper jaw to angle of mouth......

Length of lower jaw to angle of mouth......

Distance from mouth to nostril ............

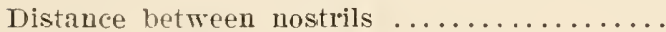

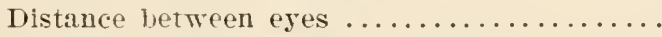

Distance between eyes on cartilage.........

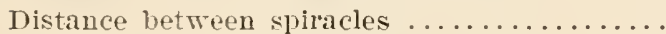

First dorsal

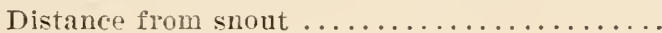

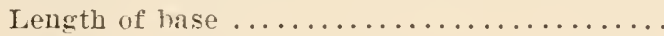

Greatest hight $\ldots \ldots \ldots \ldots \ldots \ldots \ldots \ldots \ldots$

second dorsal

Distance from end of first dorsal...........

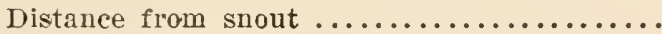

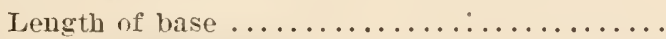

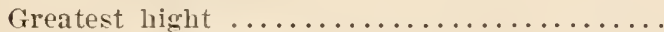

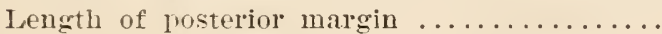
Anal

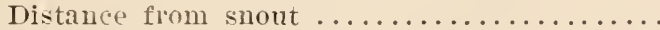

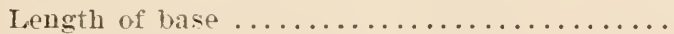

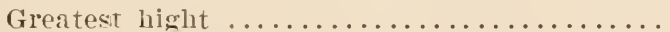

Length of anterior margin.............

Length of posterior margin..............

Caudal

Distance from end of second dorsal..........

Distance of tip from end of second dorsal....

Greatest width 176

Hondredths

of length

6

$\begin{array}{rr}90 & 3 \\ 147 & 5\end{array}$

280

305

10.3

256

9.7

56

2

35

31

74

so

2.7

$6 \mathrm{~S}$

2.3

270

219

9

215

30

125

182

\section{4}

7.3

142

226

4.2

6.2

4.8

7.7

$\begin{array}{rc}1000 & 34 \\ 670 & 22.7 \\ 95 & \ldots \ldots \ldots .\end{array}$

310

10.5

1980

67

365

12.5

158

5.4

55

2087

70.7

250

8.5

119

4

233

47

116

620

21

232 
MEA6UREMENTS

Millimeters Hundredtho $9 \mathrm{~S}$

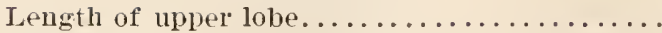

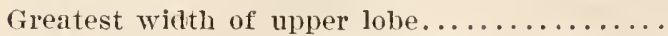

Distance of lower lobe from anal base.......

Length of anterior margin of lower lobe.......

Length of longest margin of lower lobe...... Pectoral

Distance from snout $\ldots \ldots \ldots \ldots \ldots \ldots \ldots$

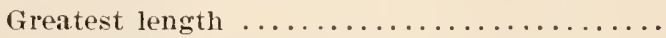

Width of base $\ldots \ldots \ldots \ldots \ldots \ldots \ldots \ldots \ldots \ldots$

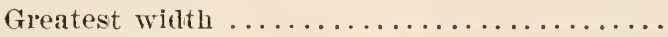

Ventral

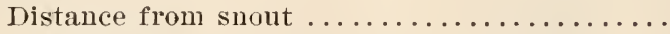

Greatest length $\ldots \ldots \ldots \ldots \ldots \ldots \ldots \ldots \ldots$

Length of posterior margin (last ray)........

Willth of base $\ldots \ldots \ldots \ldots \ldots \ldots \ldots \ldots \ldots \ldots$

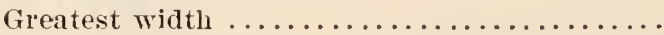

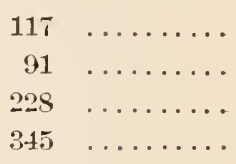

590

20

330

11.2

169

5.7

240

8

\begin{tabular}{|c|c|}
\hline 16.55 & $5 \beta$ \\
\hline 215 & T. 3 \\
\hline 108 & $\ldots$ \\
\hline 170 & 5.7 \\
\hline 222 & 7.5 \\
\hline
\end{tabular}

Only two specimens of this shark have been recorded-the type described by Capello from the coast of Portugal, and an example about 9 feet, 8 inches long which came ashore in excellent condition at the Amagansett life-saring station on Long Island, Feb. 8, 185:3. The latter specimen was forwarded to the U. S. National Museum, Washington 1). C.

A figure of the species is published in Oceanic Ichthyology. pl. 5, fig. 17 .

\section{Family GALEIDAE}

\section{Requiem shurks}

\section{Genus nestems Covier}

Body slender, elongate; mouth small, crescent-shaped, with well developed labial folds at the angles, snout rather long and depressed; teeth in both jaws rery blunt, small, lhombir, manyrowed, arranged like parement; spiracles small, just behind the eyes; "ye large, oblong; pectorals large; rentrals well dereloped; first dorsal large, not far behind pectorals, somewhat lareger than second dorsal; anal opposite to and smaller than secoud dorsal; basal lobe of candal little dereloped, the tail nearly straight; embeyo without placental attachment to the uterus. 


\section{Mustelus canis (Mitchill)}

\section{Dog shat : Smooth Dogfish}

Squalus emis Mrtchild, Trans. Lit. \& Phil. Soc. N. Y. I, 480, 1815.

Mustchs canis IIE KAY, N. Y. Fauna, Fishes, 355, pl. Rit, tig. 209, 1842; STorer, Hist. Fish. Mass. 251, pl. XXXVI, fig. 2. 2u. 1s67; Jordar \& Gildert, Bull. 16, U. S. Nat. Mus. 20, 1683; Jordax \& Eveminar, Bull. 47, U. S. Nat. Mus. 29, 1896.

Body cylindric, elongate, tapering greatly from the dorsal fin to the tail: head flattened above, one fourth of total length without caudal; snout obtusely pointed, one third as long as the head. Hight of bodr equals one half length of head. Nostrils large. semilunar, midway between tip of suout and angle of month. Eye two fifths as long as the snout. Teeth in about 10 rows. smooth, flattened, the posterior edges of each tooth slightly elerated. Spirarles small, circular, near the lower posterior angle of the exe. Gill openings moderate, half length of snont, the last two orel the base of the pectorals. Hight of dorsal fin, measured from middle of its base, slightly greater than depth of hody. Length of pectoral equal to base of dorsal. End of rentral base midway between tip of snout and tip of caudal, the length of the fin scarcely one third length of head. Candal fin as long as the head, its lower lobe short, blunt, about one third as long as the upper. Color ashen gras abore, sometimes with pale spots, white beneath; outer edges of the dorsals and anal with a black margin. specially in young; iris greenish yellow. Length 3 feet.

This is known as the dogshark, smooth dogfish and houndfish. It is extremely common in the north Itlantic and is a source of great annosance to anglers. The sliark is not eaten but it is used in making fertilizers and oil is prepared from its lirer. It occurs in Graresend bay in August, september and October. In captivity it is restless and delicate, often coming to the surface of the water and struggling as if tring to escape. Its food consists of small crustaceans, seaweed, etc.

\section{Genus Gateocendo Müller \& Henle}

Body cylindric, elongate, tapering; mouth crescentic; teeth in both jaws large, oblique, coarsely serrate on botl margins; 
outer margin with a deep notch; spiracles present; the last two gill openings orer the pectoral base; caudal fin with a pit at the root above and below; first dorsal fin above the space between pectorals and ventrals. Size large.

\section{Galeocerdo tigrinus Müller \& Henle}

\section{Tiger Shark: Leopard Shark}

Galeocerdo tigrinus Müller \& Hexle, Plagiostomen, 59. pl. 23. 1838; GüNTHER, Cat. Fish. Brit. Mus. VIII, 378, 1870; Jordan \& Gilbert, Bull. 16, U. S. Nat. Mus. 21, 1SS3; Jordan \& Evermann, Bull. 47, U. S. Nat. Mus. 32, 1896; Sмith, Bull. U. S. F. C. for 1S97, SS, 189 S.

The caudal fin forms about one third of the total length and exceeds the space between the dorsals; the second dorsal is in advance of the anal; upper jaw with a long labial fold; teeth $\frac{25}{25}$. Color yellowish gray, whitish beneath, brown on the middle of the back and with numerous brown cross bands and spots on the sides; adults nearly uniform brown. Said to reack a length of 30 feet.

Tropical seas, occasionally found in summer northward to Cape Cod and to San Diego.

Dr H. M. Smith has published the following record of its occurrence near Wroods Hole Mass. "Present every yfar in variable abundance, and caught in traps in Vineyard sound and Buzzards bay. The last species of shark to appear in this region, rarely coming before August. It remains until October. Usual length, 5 feet." The writer has seen a tiger shark fully 9 feet long in a trap at Marthas Vineyard.

\section{Genus Prionace Cantor}

Body and head slender; teeth in both jaws strongly serrated in adults, broad in the upper jaw, narrow, straight and claviform in the lower; spiracles absent; first dorsal large, its origin midway between axils of pectorals and ventrals; second dorsal much smaller than first, usually equal to anal; embryo without placental attachment to uterus; size large; inhabiting warm seas. 


\section{S Prionace glauca (Linnaeus)}

\section{Great Blue Shark}

Squalus glaucus Linnaeus, Syst. Nat. ed. X, 235, 1758.

Carcharias (Prionodon) glaucus vüLlen \& Hexle, Plagiostomen, 36, nl. II, 1838.

Carcharias glaucus Güntuen, Cat. Fish. Brit. Mus. VIII, 364, 1870.

Carchartinus glaucus Jordax \& GILBERT, Bull. 16, U.S. Nat. Mus. 22. 1883. Prionace glanca Jordan \& Evermaxx, Bull. 47, U. S. Nat. Mus., 33, pl. IV, fig. 16; pl. V, fig. 16a, 1896; Sмiтн, Bull. U. S. F. C. for 1S97, 8s, 1898.

Snout very long; nostrils rather nearer to the mouth than to the tip of snout; a slight groore at the angle of the mouth; teeth of the upper jaw oblique, slightly constricted near the base; lower teetl narrow, lanceolate, with a broad base in the adult, triangular in the roung. Pectoral fin long, falciform, extending to below the dorsal. Color light bluish gray above, paler below.

The great blue shark is common in the Mediterranean and is found occasionally on our Atlantic and Pacific coasts.

Dr H. M. Smith records it as a very rare species at Moods Hole Mass., only a single individual being certainly known from that locality, taken from a trap in July $187 \%$.

\section{Genus carcharmos Blainville}

Body rather robust, the head broad and depressed; mouth inferior, with the teeth in both jaws strongly serrated in the adult, less so or entire in the roung; those in the upper jaw broad or narrow, those below narrow, straight, and nearly erect. No spiracles. First dorsal large, placed not far behind pectorals; pectorals falcate; second dorsal small. Embryos attached by placenta to the uterus.

\section{Carcharhinus obscurus (Le Sneur)}

\section{Dusky Shark}

Squalus obscurrs Le Sueur, Jour. Ac. Nat. Sci. Phila. I, 223, pl. 9, 1818. Carcharias (Prionodon) obscurus Müller \& Henle, Plagiostomen, 46, 1841.

Carcharias obscurus De KAY, N. Y. Fauna, Fishes, 350, pl. 61, fig. 201, 1ऽ12. (Copy of Le Sueur); Storer, Hist. Fish. Mass. 243, pl. XXXYi, fig. 2, 1S67; Güxtmer, Cat. Fish. Brit. Mus. VIII, 366, 1870.

Carcharhinus obscurus Jordan \& GILBERT, Bull. 16, U.S. Nat. Mus. 22, 1SS3; Jordan \& Evermann, Bull. 47, U. S. Nat. Mus. 35, 1S96; Silth, Bull. U. S. E. C. for 1897, S8, 1898.

Head broad, somewhat pointed, flattened above and below; snout sharp edged, rounded and wide at the end; eves large, 
ncarly circular; nostrils oblique, near the tip of the snout; gillopenings unequal, the first large, the last small and orep the origin of the pectoral; the second dorsal smaller than the anal, and much produced leehind; pertorals rery long, warrow, falciform, their outer margin four times the inner. Color dusky abore, dark cleas blue in youmg, white below. Size large, length 9 or 10 fert.

The dusky shark inhabits the middle vtlantic and oceurs frequently on onr coast in summer. Abundant in Great Egg hay where it is called the "maneating shark." A specimen weighing 150 pounds was reported there July 2:3, and during the sante week a larger one weighing 200 pounds was landed. Young individuals measuring $21 \frac{1}{2}$ to 24 inches in length, caught with looks July 29,1887 , still bore the umbilical scar. A young example was caught in a pound at Islip T. I. in the summer of 1898 .

De Kay had no specimen of the dusky shark for examination, but depended on Le Sneur for the description and figure published in his Teu York F'amur. Mitchill has made no reference to the species.

Smith publishes the following on its occurrence at Woods Hole Mass. " Very common, but less so than the sand shark. Taken in traps and on lines fished from wharves. Comes about June 1 and remains through a part of November. The largest observed here are 12 to 14 feet long; the arerage are $S$ or 9 feet, and the smallest are 21 feet." Storer says it is not a common species in Massachusetts waters; it sometimes floats ashore in the night or becomes entangled in the mackerel nets.

The dusky shark feeds chicfly on menhaden when they are schooling.

\section{Carcharhinus milberti (Müller \& Henle)}

\section{Milbert's shark:}

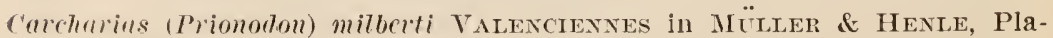
giostomen, 3S, pl. 19, fig. 3 (teeth), 1842.

Carcharius caeruleus DE KAx, N. Y. Fauna, Fishes, 349, pl. 61, fig. 200, 1S42: Jornax \& Gilbert, Bull. 16, U. S. Nat. Mus. S73, 1883.

Eulamia milberti Gill, I'roc. Ac. Nat. Sci. Phila. 262, 1864. 


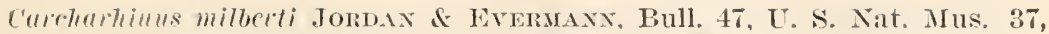

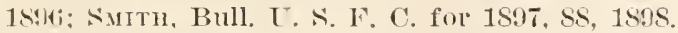

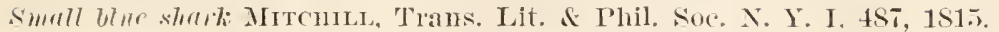

Lumul cumtatu DE KAY, X. Y. Famma, Fishes, 354, 11. 62, fig. 20\%, 1842.

Body stont, jts depth one fifth of the length withont candal; head two sevenths of total lengtle to candal base, snont prominrint, frointred, broad, thin, and firm, its length from month equal to width of month; distance between uostrils two thirds length of snout; mpper teetl rery broad, triangular, erect, serratr on both edges, without notch; lower teeth narower and more finely serrated; gill openings comparatively narrow; first dorsal begins close behind origin of pectoral, its hight somewhat greater than its base and equals one half interspace between dorsals: second dorsal very small, its base one fifth interspace between dorsals; candal moderate, its length contained two and two thirds times in length of body, its lower lobe less than one half as long as the nuper; jectorals rather small, not falcate, the length contained three and one half times ju total length withont (*andal.

The roung are slate blue on the mpper parts, the same color but less promonnced on the sides, and the lower parts whitish; adults are uniform. hluish gray above, lighter on the sides of head and bodr, white beneath, thr iris gremish blue. Some ('xalluples taken at Woods Hole Mass. in 187:3, We'p said to be of an jutense almost indigo blue.

The blue shark occurs along owr east coast in summer from Cape Cod to Florida. Yomng eximples are not uncommon in the waters of New York. In example taken at Brenton's reef, on the coast of Rhode Island, measmed 7 feet, 4 inclues and wrighed 161 pounds.

Mitchill states that it is often taken by nets in New York waters, as it commonly bites oft the line when hooked. Indiriduals seen by him were $4 \mathrm{or}^{\circ}$ f feet long. To. Kay refers to this shark a second time under the name long-tailed porbeagle, of which he saw sereral young from Sew York harbor and an adult from Brenton's reef, on the coast of Rhode Island. 
This shark was reported at Woods Hole Mass., in 1871 by Prof. Baird. Dr Smith records four examples, each about 4 feet long, from a trap near Woods Hole, Aug. 8, 1873, since which time none have been observed.

The species feeds chiefly on fish.

\section{Genus aprionodon Gill}

Suout conical, more or less produced; teeth not serrated, narrow, on a broad base, erect in both jaws or sometimes slightly oblique in the npper; dorsal over the interspace between pectorals and rentrals.

\section{Aprionodon isodon ( $V$ al. in Müller \& Henle)}

\section{Tiburon}

Carcharias isodon Valenciexnes in Müller \& Henle, Plagiostomeu, 32, 1841.

Carcharias (Aprionodon) isodon Duderil, Elasmobranches. 349, 1870.

Aprionodon punctatus Jordan \& Gilbert, Bull. 16, U. S. Nat. Mus. 2t, $18 S 3$. Carcharias punctatus Günther, Cat. Fish. Brit. Mus. VIII, 361, 1570.

A prionodon isodon PoEY. Enum. Pisc. Cubens. 200, 1875; Jordar \& ErerMANN, Bull. 47, U. S. Nat. Mus. 42, 1896.

Snout short, compressed, and rounded; nostril one third of the distance from tip of snout to angle of month, nearly as large as the eye; the distance between the nostrils equals that from tip of suont to mouth; teeth in upper jaw small, on a broad base, withont serrations, those of lower jaw similar but smaller, a small median tooth as usual; number of teeth $\frac{3}{3} \frac{1}{1}$; first dorsal - much higher and longer than the second and is separated from the last gill opening by a space equal to two thirds the length of its base; pectorals reach to below end of first dorsal; caudal pit very apparent, specially below; scales rounded posteriorly, with five keels; color abore dark gray (greenish brown, Duméril), whitish below.

The species is recorded from New York, Virginia, and Cuba. 'The tỵe specimen in the Muséc d'Histoire Naturelle, Paris, is O. $65 \mathrm{~m}=25 \frac{5}{8}$ inches long. The following measurements from the type are given by Müller and Henle. 
Inckes Lines

From tip of snout to nostril...................... 10

From nostril to mouth........................... 10

From mouth to anus....................... $10 \quad 6$

From anus to anal fin......................

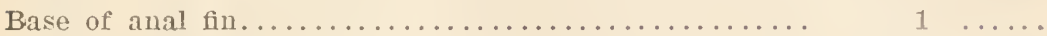

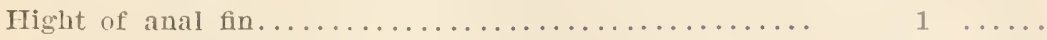

From anal fin to cavidal...................... 19

Length of caudal fin.......................

Distance from pectorial to rentral................ 4 6

Base of first dorsal fin...................... 2

Higlit of first dorsal fin..................... $\quad 2$

Base of second dolsal fin..................... 1 ....

Hight of second dorsal fin . . . . . . . . . . . . . . . . . . . 7

Length of pectoral fin. ...................... $\quad 3 \quad 4$

Wisth of pectolal fin....................... 2

Distance between nostriis .................... 16

Width of mouth ......................... $\quad 2 \ldots$

\section{Gerus scourodor Müller \& Henle}

Bodỹ slender; snout depressed; no spiracles; teeth entire $\mathrm{ol}^{2}$ little serrated, oblique and flat, the points directed sidewise so that the inner margins are more or less nearly horizoutal, the teeth in front more nearly erect; teeth not swollen at the base, each of them with a deep notch on the outer margin below the sharp point; labial folds conspicuous; first dorsal orel the inter. space between pectorals and rentrals; second dorsal rery small; rentrals small; size small.

\section{Scoliodon terrae novae (Richardson)}

\section{Sharp-nosod Shark}

Squalus (Carcharias) terrae-novac Richardson, Fauna Bor.-Amer. 25., 1836. Carcharias terrac-novae Günther, Cat. Fish. Brit. Mus. VII, 360, 1570. Carcharias (Scoliodon) terrac-notae GILL, Cat. Fisl. East Coast N. A. 59, 1861.

Squalus punctatus Mitchili, Trans, Lit. \& Phil. Soc. N. Y. I, 4S3, 1S1う. Scoliodon terrae-novae Jordan \& Gilbert, Bull. 16, U. S. Nat. Mus. 24, 1893; Jordan \& Evermann, Bull. 47, U. S. Nat. Mus. $43,1896$.

Snout moderately rounded; mouth U-shaped, with a short labial groove at its angle extending on both jaws; distance from tip of snout to nostril less than distance between nostrils: gill openings narrow; first dorsal moderate, midway between pec- 
torals and rentrals; second dorsal rery small, slightly behind, and rather smaller than anal; anal fin much shorter than distance from anal to ventrals; pectorals rather large, reaching abont to middle of first dorsal; rentrals small.

Color gray; candal fin with a narrow blackish edge. Cape Cod to Brazil, very common on the southern Atlantic coast.

The green-backed shark, Squatus punctutus, of Mitchill is said to belong to this species. His example was 31 inches long, but he was incorrectly informed that the shark reaches two or three times that size. Mitchill wote:

"Then this shark is in the water his back and sides appear greenish. But soon after his cxposure to air, and immediately after his death, the hue becomes a pale ash, leaden, or dove, with but trifling rariegations. The parts about the month, neck, and belly are of a cloar white. The upper side of the pectoral fins resembles the "olol of the back; the lower partakes of the complexion of the belly. The openings of the excretory ducts on the snout and lips are blackish.

"The sluark is rer. common on the coast of our southern states; it reaches the length of 3 feet."

Family SPHYRNIDAE

\section{Hommerheaded shark:s}

\section{Genus sempra Rafimesque}

Head laterally extended, hammer-slıped or kidney-shaped, the eyes on the "uds of the "hammer" and the nostrils anterior" mouth inferior, 'reserentic; teeth in the jaws sinilar, oblique, notched on the ontside near the base; no spiracles; last gillopening over the fectoral; first dorsal large, nearer pectorals than rentrals; second dorsal and anal small; pectorals large; a pit at the root of the candal; candal fin notehed near its tip, its lower lobe developed.

\section{1:3 Sphyrna tiburo (Limnacus) \\ Shorelhead shark:; Bommethend}

Squalus timuro Linvaeus, Syst. Nat, ed. X, 23t, 1758. Zygaena tibmo Güntrier, Cat. Fish. Brit. Mus. VIII, 3S2, 1870.

Renireps tiburo Gill, Ann. N. Y. Lyc. Nat. Hist. VIII, 412, 1S61; JondaN \& Gilbert, Bull. 16, U. S. Nat. Mus. 25, 1883.

sphyina tiburo Jorbax \& Evermans, Rull. 47, U. S. Nat. Mus. 44, pl. V, fig. $19,1 S 96$. 
Body slender and little compressed; head flat, semicircular in front, posterior margins of "hammer" short, frec, the lateral margins continnous with the anterior; first dorsal high, midway between pectorals and ventrals; second dorsal much smaller, produced behind, higher and shorter than anal; rentral and caudal fins moderate; pectorals large; mouth small; tectl small, very oblique, deeply notched on the outer margin. Head one sixth of total length to tip of caudal, slightly longer than wide.

Color miform ashy, whitish beneath. Length 5 feet. It. lantic and Pacific oceans, occurring on our coast from Long Island southward.

Neither Mitchill nor De Kay mentions the shovelhead shark, though both record the hammerliead. Prof. Baird found it a common fish in Great Egg bay in 1854 , but the species was not seen there by the writer in 1887.

\section{Sphyrna zygaena (Linnaeus)}

\section{Hammerhead sithro}

Squalus zygacna lixiaecs, Șst. Nat. ed. X, 234, 1758; Mitchll, Trans. Lit. \& Phil. Soc. N. Y. 1, 482, 1815.

Zyynena malleus DE KAY, N. Y. Fanna. Fishes, 362, pI. 64, fig. 204, 1S42; Storer, Hist. Fish. Mass, 262, pl. XXXYII, fig. 3, 1867.

sphyrna zygnena Jordax \& Ginbert, Bull. 16, U. S. Nat. Mus. 26, 1583; Jordax of Evermaxx, Bull. 47, [T. S. Nat. Mus. 45, 1896; Simti, Bull. U. S. F. C. XrII, SS, 1898.

Body elongate, cylindric; head hammer-shaped, its width two or three times its length; nostril near eye, prolonged into a groove. which runs along nearly the entire front margin of the head; eye large, placed near the angle formed by the anterior and lateral margins of the "hammer", enabling the animal to look above and beneath; three rows of white, hyaline treth in each jaw, those in upper jaw entire, acute, triangular, their tips. directed ontward from the center, with a shoulder ou thes onter side; in the center a few with shoulders on both sides; gill openings short and small, the last smallest and placed over the peetoral base: first dorsal large, quadrilateral, slightly behind pectorals, higher than wide, deeply concave behind, and pointed 
posteriorly; second dorsal rhomboidal, very small, produced posteriorly, its base extending farther backward than the anal base; pectorals placed low, subtriangular, broad, slightly concare behind; rentrals small, broad, nearly midway between the dorsal fins, produced behind; anal similar to second dorsal but somewhat larger, more concave behind; caudal equal in length to width of head, its lower lobe short, the upper ending in a small triangular portion; color uniform dusky gras, paler beneath.

The hammerhead shark reaches a length of 15 feet; it is a roracious species, found in all warm seas. Mitchill records the capture of three indiriduals in a net at Sag Harbor, in September 1S05, the largest measuring 11 feet; and on opening its belly many detached parts of a man, together with his clothing, were found in it. He had a specimen from the bay of New York. De Kay had a specimen 25 inches long which was taken in a seine in New York harbor and he saw examples 4 feet long in Hell Gate. Dr Smith publishes the following about its occurrence at Woods Hole:

Usually common; some years abundant. Taken in traps from July to October, being most numerous in July and August. Generally swims with its dorsal and caudal fins out of the water. The largest ones taken here are 7 or 8 feet long; the smallest are under $1 \frac{1}{2}$ feet; and the average are 4 feet. The name "rakehead" is an old local designation of this species.

In Great Egg Harbor bay, N. J., small examples, measuring abont 2 feet or less, are occasionally caught with hooks in August and larger ones, 5 or 6 feet long, have been seen. It is called "shorelnose shark" there. This shark is not common in Graresend bay, but is sometimes found in August and September.

\section{Family ALOPIIDAE}

\section{Thresher Shartis}

\section{Genus alopias Rafinesque}

Body fusiform, moderately elongate, the snout short and blunt; moutl horseshoe-shaped; teetl distant, flat, triangular, -entire, the third tooth of upper jaw on each side much the smallest; gill openings moderate, the last smallest and placed just 
anterior to or slightly over the pectoral base; no nictitating membrane: spiracles minute, just behind the eje, or absent, first dorsal high, triangular, midway between pectorals and rentrals; second dorsal and anal very small; pectorals long and wide, deeplc concave behind; rentrals wider than high, below the interspace between the dorsals; caudal without keel, exceedingly long and narrow, its lower lobe moderate, its upper lobe with a deep pit at its root and a notch near its tip; size large; a single species inhabiting most warm seas, and easily known by its long tail.

\section{Alopias vulpes (Gmelin)}

\section{Thresher Shark; Suingle-tail Shark}

Squalus vulpes Garelin, L. Syst. Nat. I, 1496, 1788 (fide GüNther); Mitchili, Trans. Lit. and Phil. Soc. N. Y. I, 482, 1815.

Carcharias vulpes DE KAY, N. Y. Fauna, Fishes, 348, pl. LXI, fig. 199, 1842;

. Storer, Hist. Fish. Mass. 245, pl. XXYYI, fig. 3, 1867. Alopecias vulpes Günther, Cat. Fish. Brit. Mus. VIII, 393, 1870.

Alopias rulpes Jordan \& Gilbert, Bull. 16, U. S. Nat. Mus. 27, 1883; Jordax \& Evermann, Bull. 47, U. S. Nat. Mus. 45, pl. VI, fig. 20, 1896; Sмith, Bull. U. S. F. C. XVII, 89, 1898.

Body fusiform, moderately elongate, its greatest hight one fourth of the length to the pit at the root of the caudal; head two serenths of the same length; eye one ninth as long as head; no nictitating membrane; snout short, twice as long as the eye, Flat, triangular teeth of moderate size, with entire edges, in both jaws, the third tooth of the upper jaw on each side much smaller than the others; spiracles just behind the eyes, minute or wanting; gill openings moderate, the last one over the base of the pectoral; first dorsal large, midway between pectorals and rentrals; second dorsal and anal rery small; caudal elongate, slender, forming about one half of the total length; a pit at its base, upper lobe notched near the tip, lower lobe moderate: no caudal kecl; rentrals one half as long as the pectorals; pectorals falcate, reaching to below the middle of the first dorsal.

The thresher shark is abundant in the Mediterranean and warm parts of the Atlantic and Pacific, occasionally seen off the south shore of Long Island in summer and frequently taken in Tineyard sound. It reaches a length of 20 feet. 
Mitchill described, in the Medical Repository, 8:T7, an individual measuring 13 feet and 1 inch, which was found, in 180:, on the south side of Long Island. De Kay describes the species but without mentioning any locality of its capture. His figure was basfi on a feriale specimen, about $1: 3$ feet long, in the American museum.

At Woods Hole Mass. the thresher comes in April and remains till late in the fall. It is common in Vineyard sound and is found also in Buzzards bay. In the fall the boat fishermen, fishing for cod at Gay Head, catel them with lines baited with iresh herring. Individuals 20 feet long have been caught at Menemslia.

The shark feeds on mackerel, menhaden, herring and other small fishes.

\section{Family CARCHARIDAE}

\section{Sand sharks}

\section{Genus carcharis Rafinesque}

Body moderately elongate; the snout pointed; mouth large, crescentic; teeth long, narrow, awl-shaped, not serrated, most of them with one or two small basal cusps; spiracles minute, porelike; no nictitating membrane; gill openings in advance of the pectorals, moderately large; dorsal fins nearly equal, not large, the first well belind the pectorals; caudal well developed, with. out keel, its basal lobe slort, a notch near its tip; pectorals short, not reaching to beginning of dorsal; size moderate.

\section{Carcharias littoralis (Mitchill)}

\section{S'and Sthark}

Squalıs littoralis Mitculle, Am. Month. Mag. II, 32S, 181S; LE Sterr, Jour. Ac. Nat. Sci. Phila. I, 224.

Carcharias littoralis IDE KAY, N. Y. Fauna, Fishes, 351, 1S12; JordAN \& Evermañ, Bull. 47, T. S. Nat. Mus, 46. 1896; Smith, Bull. U. S. F. C. XVII, S9, 1898.

Eumomphodus littoralis Gill, Proc. Ac. Nat. Sei. Phila. 260, 1 Stit.

Odontaspis umericauns Günther. Cat. Fish. Brit. Mus. VIII, 392, 1870.

Carcharius americauns Jordan \& Gilbert, Bull. 16, U. S. Nat. MIus. 27, 1883.

Body moderately elongate, its greatest hight contained five to six and one half times in the total length; head moderately 
pointed, its length nearly one fourth of the total in half grown individuals; eye small, longer than deep, its length one fifth that of the snout, which is nearly one fourth as long as the head. The spiracle is located behind the eye at a distance equal to three times the diameter of the eye. Two rows of teeth in function in upper jaw and three rows in lower; longest tooth of the lower jaw as long as the ere, slightly longer than the longest tooth of the vpyer jaw; terth long, awl-shaped, mostly with one or two small eusps at the base, the first and fourth of upper jaw and the first of lower jaw without cusps. Space occupied by gill openings equals one fourth of the length of the head; the deptl of the gill openings equals four times the length of the eye. The distance from the snout to the mostril equals the distance between the nostrils. The width of the mouth, including the labial folds, equals two fifths of the length of the head. The first dorsal base is entirely within the first half of the total length; it is about one third as long as the head, and somenhat exceeds the hight of the fin. The pectoral is one half as long as the head and, when extended, does not quite reach the vertical through the dorsal origin. The rentral origin is slightly behind the end of the first dorsal base; the length of the fin is nearly one third of that of the head. The caudal, measured from the. pit at its root, forms two serenths of the total length.

This small but roracious shark is common on our Atlantic coast, specially from Cape Cod to Cape Hatteras. It press on the smaller fishes. The last indiridual observed by me in Great South bay during the summer of 1895 was swimming close to the smrface neal the inlet at Fire Island, september 16.

Mitchill described this shark under the name of the ground

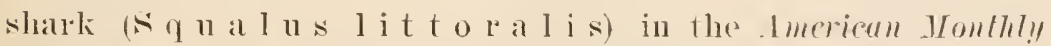

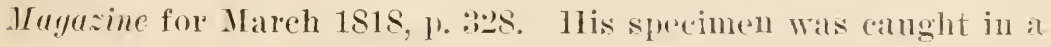
set net near New York cily, and measured abont jeet. He mentions a larger individual, $S$ feet 9 inches long, which weighed upward of 150 pounds. The fishermen ralled the fish ground shark because it is usually found along shores, or within soundings. 
According to Dr Smith this is the commonest shark of the Woods Hole region; it is found in Vineyard sound from June to November. The largest are 12 feet long. Fish, crabs and other animals are found in its stomach.

Some of the teeth of a large individual were secured from A. P. Latto at Southampton in July. Instead of a single basal cusp, as usual, certain teeth had two such cusps on each side. The last sand shark seen by me during the summer of 1898, in Great South hay, was observed september 16 near the inlet at Fire island, swimming slowly westward near the surface. A list of specimens follows.

(Teetlı) Soutlampton, Atlantic ocean

July

Clam Pond cove, Great South bay Sep. 6

i Clam Pond cove, Great South bay Sep. 6

A young male received from Gravesend bay June 26, 1895, lived in captivity till Dec. 19, 1895, when the temperature of the water in its pool was $53^{\circ} \mathrm{F}$. The following notes were made from the recently dead specimen:

Color, bronze gray with light brown blotches, the largest about as long as the eye; belly and other lower parts white; eye yellowish; tips of pectorals, rentrals, dorsals, anal and caludal above and below with a narrow black streak; numerous minute dark specks on the under surface of snout and suborbital region, extending back to angle of mouth.

Two rows of teeth in function above and three below. Length of longest tooth in lower jaw, one half inch; in upper jaw, three eighths inch.

\section{MEASUREMENTS}

Length

Depth of body.

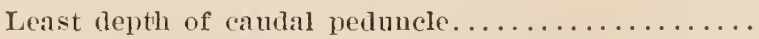

Tip of snout to perpendicular through last gillopeniug

From first to last gill opening. ................

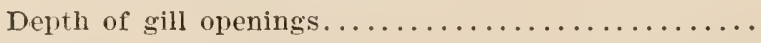

Snout

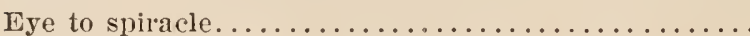

Eye

Snout to nostril

$\begin{array}{rc}\text { Fert } & \text { Inches } \\ 3 & 6 \\ \ldots & 61 / 2 \\ \ldots & 15 / s \\ \ldots & 10\end{array}$

$21 / 2$

2

$21 / 2$

$11 / 2$

$1 / 2 \operatorname{long} 3 / 8$ deep $11 / 4$ 
Width of nostril.

\begin{tabular}{|c|c|}
\hline reet & Inches \\
\hline ... & $5 / 8$ \\
\hline$\cdots$ & $11 / 4$ \\
\hline$\ldots$ & $1 / 2$ \\
\hline$\ldots$ & $2 \%$ \\
\hline$\ldots$ & 4 \\
\hline$\ldots$ & 1 \\
\hline$\ldots$ & $8 *_{1}$ \\
\hline$\cdots$ & 16 \\
\hline$\ldots$ & $31 / 2$ \\
\hline$\ldots$ & 3 \\
\hline$\ldots$ & $11 / 4$ \\
\hline$\cdots$ & 5 \\
\hline$\cdots$ & 23 \\
\hline$\ldots$ & $21 / 2$ \\
\hline$\ldots$ & $11 / 8$ \\
\hline$\ldots$ & 8 \\
\hline$\ldots$ & 12 \\
\hline$\ldots$ & $0 \% / 8$ \\
\hline$\ldots$ & 3 \\
\hline$\ldots$ & $101_{1 / 3}^{\prime}$ \\
\hline$\ldots$ & 5 \\
\hline$\ldots$ & $21 / 4$ \\
\hline
\end{tabular}

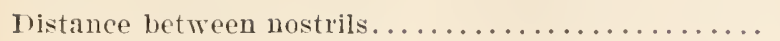

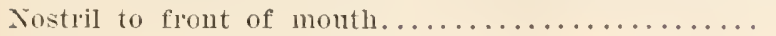

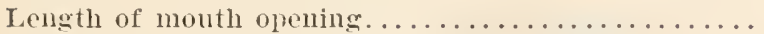

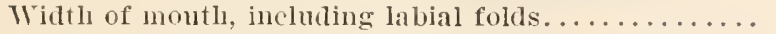

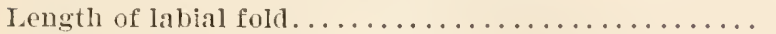

Labial foll to first gill opening. . . . . . . . . . . .

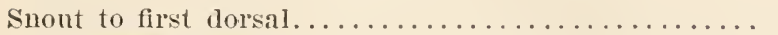

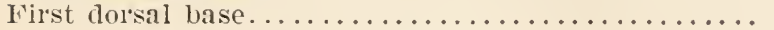

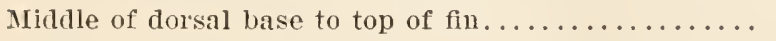

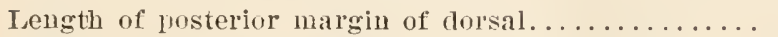

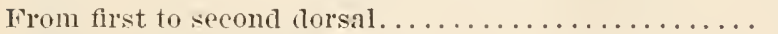

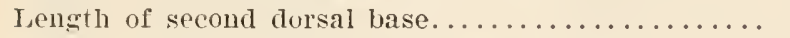

Middle of second dorsal base to top of fin..........

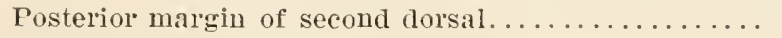

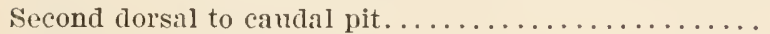

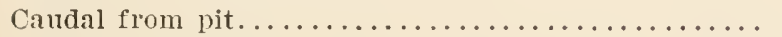

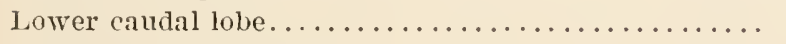

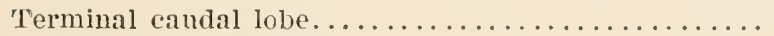

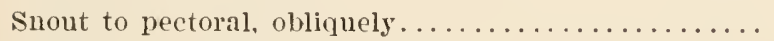

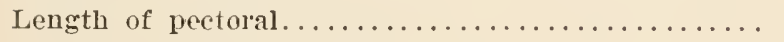

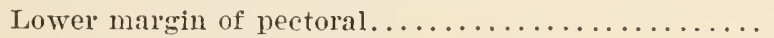

Extended pectoral not quite reaching to perpendicular through front of dorsal.

Ventral origin slightly behind end of first dorsal base

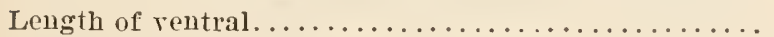

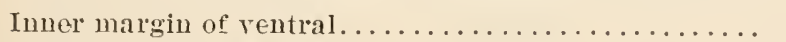

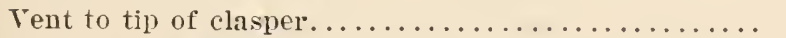

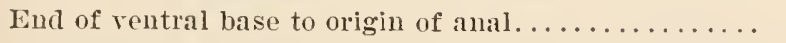

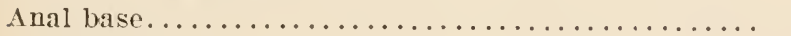

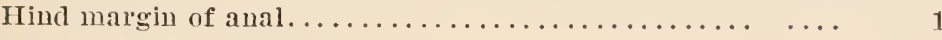

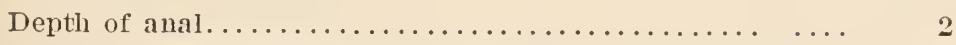

Anal base to origin of lower candal lobe........... $13 / 4$

$31 / 8$

$13 \%$

$11 / 2$

$3 \%$

3

(1)

\section{Family LANINIDAE}

\section{Iackerel Sharks}

\section{Genus isurus Rafinesque}

Body fusiform, stout; mouth wide, witl long., sharp edged, lanceolate, entire teeth having no basal cusps; suliacles minute or alsent; gill openings wide, all in adranee of pectorals, lateral, not extruling under the throat; first dorsal large, not far behind origin of pectoral; second dorsal and anal very small; peo- 
torals large; ventrals moderate; tail slender; a pit at the root of the caudal; the candal peduncle strongly keeled on each side; caudal fin lunate, its two lobes nearly equal. Size large.

\section{Isurus dekayi (Gill)}

\section{Mackerel Shark}

Lamna punctata DE KAY, N. Y. Fauna, Fishes, 352, pl. 63, figs. 206, 207, 1842 (not Squalus punctutus MitchiLL); Storer, Hist. Fish. Mass. 249, pl. XXXVII, fig. 1, 1867. (This is probably Lamua comubica). Isuropsis dekayi GiLL, Ann. N. I. Lye. Nat. Hist. 153, 1861.

Isu'us dekayi Jordan \& Gilbert, Bull. 16, U. S. Nat. Mus. Si4, 188;; Jordan \& Evermann, Bull. 47, U. S. Nat. Mus. 48, pl. VI, fig. 21, 1896.

Body fusiform, cylindric, its greatest depth equaling one fifth of the total length, and slightly exceeding the length of the head. The caudal lobes are nearly equal in length, the upper about equal to deptli of body. Gill openings wide, the last over the anterior edge of the pectoral base; middle teeth rery long, much longer and narrower than the crowded, triangular lateral teeth; first dorsal inserted behind pectorals at a distance equal to one fourth of length of head; falcate, its base equal to one third of its distance from tip of snout, its hight nearly one eighth of the total length; pectoral falcate, more than one fifth of total length, and longer than upper caudal lobe; anal and second dorsal small; caudal keel nearly one fifth of total length; deep pits at the root of the caudal above and below.

Color dark slate, lighter beneath. De Kay was informed that it is of a deep bottle green in life and the tongue is mottled with black. Storer states that all the upper part of the body is greenish, which becomes of a slate color after death; pupils black; iris dusky.

The mackerel shark reaches the length of 10 feet. It occurs from Cape Cod to the West Indies; but is rarely captured in most localities.

De Kay described a specimen 10 feet 2 inches long, taken in New York harbor, October 1S40. A somewhat smaller example was caught near the light-ship off Sandy Hook by Capt. C. II. Barnard 16 years earlier than the date of De Kay's description. Storer refers to it as the most common species of shark found in 
Massachusetts, which is not the case at present. In 1845 about 1.50 at least were captured in nets at Monhegan Me. during three weeks of mackerel fishing.

The fish was ralued for its oil, of which $11 \frac{1}{2}$ gallous hare been taken from a single liver.

This species feeds on many kinds of fish, but persistently follows the mackerel schools, and is generally known as the mackerel shark. At Provincetown it is called the blue shark.

\section{Genus Lamsa Cuvier}

Body short, stout, the back considerably elerated; snout prominent, pointed; teeth entire, pointed, triangular, with a small basal cusp on each side, one or both cusps sometimes wanting on some teeth in the young; gill openings wide, and all of them in advance of the pectoral fin; first dorsal falcate, inserted over the axil of the pectoral; second dorsal and anal very small, nearly opposite each other; pectorals falcate; caudal peduncle strongly keeled on each side; deep pits at the root of the caudal above and below; caudal lobes nearly equal in length. Size large.

\section{Lamna cornubica (Gmelin)}

\section{Porbeagle}

Squalus cornubicus GMelin, L. Syst. Nat. I, 1497, 1788.

Lamna cornubica GüNther, Cat. Fish. Brit. Mus. VIII, 3S9, 1St0; Jordan \& Gileert, Bull. 16, U. S. Nat. Mus. 30, 18s3; Bean, Bull. U. S. I*. C. IX, 198, pl. LVII, 1S91; Jordan \& Evermans, Bull. 47, U. S. Nat. M[us. 49 , pl. VI, fig. 22, 1896.

Body short, stout, fusiform, its greatest depth equaling nearly one fifth of the total length including caudal, and slightly less than the length of the head. The caudal lobes are nearly equal in length, the upper as long as the head and exceeding depth of body; caudal peduncle strongly keeled on each side; deep pits at the root of the caudal above and below. The snout is conical, pointed, its length somewhat more than the width of the mouth. Teeth entire, triangular, pointed, with a basal cusp on each side, the cusp sometimes wanting in young, $\frac{12}{11}$ or $\frac{11}{10}$ on each side in an individual about $3 \frac{1}{2}$ feet long, the third tooth of the upper 
jaw on each side small; gill openings wide and all of them in advance of the pectoral base; first dorsal falcate, inserted orer the axil of the pectoral; second dorsal and anal very small, nearly opposite each other; pectoral falcate, its length nearly equal to greatest depth of body and equals distance from angle of mouth to last gill opening.

Color dark slate, whitish beneath. Found in the Atlantic and Pacific, north to Massachusetts bay and the Gulf of Mlaska; called salmon shark at Kadiak. Reaches a lengtlı of 10 feet.

The porbeagle, salmon shark, or mackerel shark is a rery powerful and destructive species, and it has a wide distribution. If the figure of $\mathrm{L}$ a m n a p unctat a Storer be correct, his mackerel shark| must be Lam a cornubica and not Is u r u d ek a y . The advanced position of the first dorsal seems to indicate this.

\section{Genus carcharodon Smith}

Agrees with I s u r u s and Lam a except in dentition; teeth large, flat, erect, triangular, serrate; first dorsal moderate, nearly midway between pectorals and rentrals; second dorsal and anal very small; pectorals large; rentrals moderate; caudil peduncle stout; caudal lobes large and strong; deep pits at the base of the caudal fin abore and below.

\section{Carcharodon carcharias (Linnaeus)}

Great White Shark; Man-cater

Squalus carcharias Linvaeus, Syst. Nat. ed. X, 235, 1758.

Carcharias atıoodi Storer, Proc. Bost. Soc. Nat. Hist. III, 72, 1StS; Hist. Fish. Mass. 2t6, pl. XXXVI, fig. 4, 18fit.

Carcharodon carcharias Jordax \& Gilbert, Bull. 16, U. S. Nat. Mus. S75, 18S3; Jordan \& Everuann, Bull. 47, U. S. Nat. Mus. 50, 1896.

Body stout, its greatest depth contained about five or five and one half times in the total length, and equaling about three fourths of the length of the head; eye perpendicularly oblong, and about one third as long as the snout; caudal lobes large and strong, nearly equal in length, the upper about six sevenths of depth of body; caudal peduncle stout, strongly keeled, its least deptin two thirds of snout, deep pits at the base of the candal 
fin abore and below; the snout obtusely pointed, about one fifth to one sixth of length of head; mouth rery large; botlı jaws with large, triangular, serrated teeth in five rows, those in the lower jaw narrower, about 24 in each row abore and 22 below; spiracles minute or wanting; gill openings wide and all in advance of the pectoral fin; first dorsal moderately large, inserted nearly midway between pectoral and rentral bases; second dorsal and anal rery small, subequal, their bases scarcely more than one half as long as the snout; pectoral large, reaching to below the end of the dorsal when extended, rentral moderate, its length equal to nearly one fourth of that of the head. Color leaden gray, lower parts white; tips and edges of pectoral black. This shark reaches a length of 30 feet and a weight of nearly 2 tons. It is found in the temperate and tropical parts of the Atlantic and Pacific oceans, but is rare in New York waters.

The ferocity of the man-eater shark may be inferred from the following account of a specimen $\mathbf{1 3}$ feet long taken at Prorincetown Mass. and brought to Boston for exhibition.

My specimen was captured at Provincetown June 16 . . . When first seen it was swimming in about 10 feet of water on the Long point side of Provincetown harbor. A boat's crew haring given chase, a harpoon was thrown into it, when it instantly turned toward the boat and seized it with great ferocity near the bows, in which act several of its teeth were broken off. It was eventually killed by being frequently lanced.

Jordan and Evermann record an indiridual about 30 feet long, caught near Soquel Cal. which had in its stomach a young sea lion weighing about 100 pounds.

\section{Family CETORHINIDAE}

\section{Basking Sharks}

\section{Genus Cetormus Blainville}

Body stout, the skin much wrinkled and beset with small spines; snont blunt; head small; mouth moderate, with numerous small, conical teeth without cusps or serrations; spiracles minute, above the corners of the mouth; gill openings sery wide 
extending from the back almost around the throat, all of them in adrance of the pectorals; first dorsal large, midway between pectorals and rentrals; second dorsal and anal small; caudal fin lunate, the upper lobe considerably the larger; candal peduncle keeled; pectorals and ventrals large. Brain rery small. Size very large.

\section{Cetorhinus maximus (Gunner)}

\section{Basking Shark; Elephant Shark}

Squalus maximus Gunner, Trondhj. Selsk. Skrift., III, 33, tab. 2; IV, 14, tab. 3, 1765; Mitchill, Trans. Lit. \& Phil. Soc. N. Y. I, 4S6, 1815.

selachus maximus DE KAY, N. Y. Fauna, Fishes, p. 357, pl. 63, fig. 208 (partly copied from Le Sueur), 1S42; Storen, Hist. Fish. Mass. 253, pl. XXXVII, fig. 3, 1S67.

Cetorhillus maximus Jordan \& Gilbert, Bull. 16, U. S. Nat. Mus. 31, 1S83; Jordan \& Evermann, Bull. 47, U. S. Nat. Mus. 51, pl. ViI, fig. 23, 1896.

Body very stout, the skin wrinkled, rough, beset with small spines, its greatest depth contained about five times in the total length, and equaling about three fourths of the length of the head; caudal fin lunate, the upper lobe the larger, about equal to the deptl of body; caudal peduncle keeled; snout smooth, blunt, nearly half the length of head; mouth moderate; the teetl very small and numerous, conical, witlout cusps or serratures, eacli jaw with six or seven rows, about 200 in eacl row; spiracles minute, above the corners of the moutlı; eye very small, without nictitating membrane; gill openings very wide, extending from the back almost around the throat, all of them in front of the pectorals; gill-rakers slender, long and close set, resembling whalebone, whence the name, bone shark; first dorsal largo, triangular, midway between pectorals and ventrals; second dorsal small, but larger than the anal; pectoral large, reaching a little past the dorsal origin when extended; rentral large, its length nearly one third the length of the head. Color dark slate or leaden above, lighter beneath.

The basking sliark reaches a length of nearly 40 feet and is the largest of the sharks. It is an inhabitant of Arctic seas, coming southward as far as Portugal, Virginia and California. 
Mitchill refers to its capture at Provincetown Mass. and to its name of bone sluarli because of the peculiar structure of its gills. De Kay mentions the specimen which was captured in the lower harbor of $\mathrm{New}$ York in 1822 , from which he made some alterations in a drawing partly copied from Le Suemrs sketch of the same fish. Storer described an individual measmring 33 feet 3 inches. He says it is rarely observed on the coast of Massachusetts. It becomes gregarious only in the breeding season.

The oil made from the liver of the basking shark was at one time considered raluable.

\section{Order CICLOSPONDYLI}

Suborder CYCLOSPONDYLI

Family SQUALIDAE

Dogfishes

\section{Genus squaus (Artedi) Linnaeus}

Body slender, elongate; mouth slightly arched, with a long, straight, deep, oblique groove on each side, without labial folds; treth small, simple, equal in both jaws, their points turned aside so that the immer margins form a cutting edge; spiracles well developed, near the eye; gill openings moderate, all in advance of pectorals; first dorsal larger than the second, far in front of the rentrals, which are behind the middle of the body; second dorsal behind ventrals; dorsal spines strong, not grooved; caudal fin with unequal lobes, the upper elongate, broad, subtruncate at the end, the lower short and rounded; pectorals large and long, placed low down; ventrals midway between end of first and beginning of second dorsal. No anal fin.

\section{Squalus acanthias Linnaeus}

\section{Spined Dogfish}

Squalus acanthias Iinnatus, Syst. Nat. ed. X, I, 233, 1758; Jordar \& GiLBert, Bull. 16, U. S. Nat. Mus. 16, 1883; Jordan \& Evermaxi, Bull. 47 , U. S. Nat. Mus. 54, 1896.

Spinax acanthias DE KAY, N. Y. Fauna, Fishes, 359, pl. 64, fig. 210, 1842. Acanthias americanus Storer, Hist. Fish. Mass. 256, pl. XXXVIII, fig. 1, 1a, 1867.

Acanthias vulgaris Güntmer, Cat. Fish. Brit. Mus. VIII, 418, 1870. 
Body slender, moderately long, its greatest depth about one eighth of the total length, and about three fourths of the length of the head; caudal fin scarcely bent upward, its length nearly one fifth of the total length; snout pointed, its length equaling about one fourth of the length of the head; mouth slightly arched, with a long. straight, drep, oblique groove on each side, without labial folds. Teeth small, equal in both jaws, their points turned aside so that the inner margins form a cutting edge; spirarles well dereloped, just behind the eye; eye large, oblong, its diameter two thirds of the length of the snout; no nietitating membrane; gill openings narrow slits, in front of the pectorals; first dorsal morlerate, larger than the second, far in adrance of the postmedian ventrals, which are in front of the small second dorsal; pectoral when extended reaches to below the first dorsal spine, its length contained about seven times in the total, including raudal fin; ventral one fourth as long as the head.

Color dark slate or gray on upper parts, whitish below, numerous white spots on the back, becoming faint or obsolete with age. The spined dogfish reaches a length of $3 \frac{1}{2}$ feet and the weight of 20 pounds. It inhabits both coasts of the Atlantic and is recorded also from Cula. It is fomm in Gravesend bay, Long Island, only in October, and roung examples have bcen taken at Southampton in the same month. The species is eommon in summer and fall on the fishing banks off the New Jersey coast. It is not hardy in captivity.

At Woods Hole Mass., according to Dr Smith, it is less abundant than formerly, and was comparatirely scarce in 1897 . When the fish fertilizer factory was established at Woods Hole, this was the principal fish utilized in the manufacture of oil and guano; later, the scarcity or irregularity of the supply necessitated the use of menhaden.

When the horned dogfish first comes, in May, it feeds largely on ctenophores.

In Massachusetts bay the species arrives in June and remains only a few days, but returns again in September and stays till 
the middle of Norember. 'These fish are usually caught with the hook and often entangle themselves in nets, to which they do great damage. They feed on mackerel, whiting and other fislies.

The oil of the liver is an article of commelee, the flesh is useful for fertilizers, and the skin has been used for polishing: on some parts of Cape Cod the fish lus been dried for furl.

Mitchill mentions the spined dogfish only in one of his minor papers. De Kay recorded it as common on the New York coast. Te found remains of the soft clam and scales of fishes in its stomach.

\section{Subolder TECTOSPONDYLI \\ Family SQUATINIDAE \\ Angel Sharks}

\section{Genus squatisa Duméril}

Body flat, depressed as in the rays, the snout obtuse or slightly concave in front; nostrils on the front margin of the snout with skinny flaps; mouth anterior; teeth in many series, conical, pointed, distant; spiracles wide, transverse, behind the eyes; gill openings wide, very near each other, partly inferior and party hidrlen by the pectoral fins; two small, subequal dorsal fins on the tail brind the ventrals; no anal fin; camlal small, the lower lobe longer than the upper; males with small prehcusile organs; vertebrae tectospondylous.

\section{Squatina squatina (Linnaeus)}

$$
\text { Angel fish; Montifish }
$$

Squulus squalina Lixsaeus, Syst. Nat. ed. X, $233,1758$.

Squatina dumerili DE KAY, N. Y. Fauna, Fishes, 363, pl. 62, fig. 203, 1St2. Rhina squatina Günther, Cat. Fish. Brit. Mus. VIII, 4?ก, 1870.

Squatiua angelus JoRDAN of Gilbert, Bull. 16, U. S. Nat. Mus. 3., 189. Squatina squatina Jordan \& Everaman, Bull. 47, U. S. Nat. MIus. js; Sмith, Bull. U. S. F. C. XVII, S9, 1998.

Body raylilie in shape, flat, depressed, its greatest depth less than one fourteenth of the total length and about one third of the length of the head; caudal peduncle stout; caudal fin small, its lower lobe the longer; snout short, rounded; nostrils on its front margin, with skinny flaps. Mouth anterior, its width 
about equal to the interorbital width; teeth acute, small, conical, distant; spiracles large, crescentic, behind the eres; eye small, its diameter one fourth of the distance between the eyes; gill openings wide, subinferior, partly covered by the pectoral fin; two small dorsal fins, close together, belind the rentrals; anal fin wanting; pectoral fins very large, widely expanded, deeply notched at the base; ventrals very large, their length greater than that of the head; skin covered with stiff prickles, largest on the median line of the back.

Color bluish ashy gray or brown above, sometimes blotched and speckled, pale below. The monkfish reaches a length of 4 feet. It is easily recognized by its peculiar shape. It inhabits the Mediterranean and the Atlantic and Pacific coasts of the United States from Cape Cod and San Francisco southward. It is not common in New York waters, but it appears occasionally in Gravesend bay in summer and is believed to occur in this state only in bays adjacent to the Atlantic.

Mitchill, apparently, was not familiar with the species. De Kay knew the fish only from Le Sueur's descriptions and the writings of other ichthyologists. He gives the common names employed in Europe; monk, monkeyfish, kingston, shark ray, and fiddlefish. A New York fisherman informed De Kay that it was known to him as the little bullhead shark.

$\Lambda$ specimen weighing $35 \mathrm{Or}^{\circ} 40$ pounds and measuring about 4 fect was taken in a trap at Menemsha bight, Marthas Vincyard, Sep. 1, 1873. The writer saw one taken at the same place a few years later.

\section{Order BATOIDEI}

Rays

Suborder SARCURA

Family RAJIDAE

\section{Skates}

Genus RAJA (Artedi) Linnaeus

In the rays the disk is broad, rhombic; the pectorals extend to, but not around the snout; the ventrals are large and deeply notched; the tail is usually long, without serrated spine, slender, 
rounded, or depressed, with caudal fin small or absent, with two small dorsal fins, close tugether, near its tip, and with a dermal fold on each side. The skin is more or less corered with prickles and spines, males haring rows of erectile hooks near the outer angles of the pectorals. No electric organs. Eggs laid in leathery, four-angled cases, having two long tubular tendils at each end. 'Teeth in the middle of the jaws, sharp in males, blunt in females.

\section{2:3 Raja erinacea Mitchill}

\section{Common Skate; Prickly Skute; Hedgehog Ray}

Raja crinaccus Mitcinll, Am. Jour. Sci. Alts, IX, 290, pl. 6 (male), 1525;

De KaY, N. Y. Fauma, Fishes, 372 , pl. 7 S, fig. 246, 1842.

Raja cglanteria Grxther, Cat. Fislı. Brit. Mus. YIII, 462, 1570.

Raia crinacea Jordan \& Gilbert, Bull. 16. U. S. Nat. Mus. 40, 1883.

Raja crinace JoRdan e Evermaxx, Bull. 47, U. S. Nat. Mus. 6S, pl. LX, fig.

29, 1S96; Sмтт, Bull. U. S. F. C. XVII, 89, $189 \mathrm{~S}$.

Disk rhomboid, with the angles rounded; its length nearly equal to its width; spines largest on the anterior extensions of the pectorals, where they are close set, strong, laterally com. pressed and hooked backward; smaller spines scattered orer the head, above the spiracles, above and in front of the eyes, on the back, the median line of which is comparatively smooth, without cnlarged spines except in the young; a triangular pateh of spines on the shoulder girdle; inner posterior angles of the pectorals nearly smooth. Males hare tro rows of large, erectile hooks, pointing backward, near the outer angles of the pectorals. Females have groups of small scales on each side of the rent. Tail about as long as the disk; a dermal fold on each side; dorsal fins rough, connected at the base; mouth small; jaws curved, with small teeth in about 50 rows above and 48 below, the middhe ones sharp in males, all blunt in females. Color light biown, with small round spots of dark brown. Length 1 to 2 feet. (After Garman)

I very common species on our coast, from Maine to Virginia. It is one of the small rays and is not much valued for food. Eggs of this skate have been obtained in Gravesend bay in Marclı. In captivity eggs have been deposited in winter. The 
species will endure captivity during the spring, fall, and part of the winter, but not at all in summer.

Mitchill had the ray from Barnegat and from off Sandy Hook. De Kay did not see the fish, but copied the description and figure of Mitchill. Smith refers to it as the "summer skate" or "bonnet skate." It is found at Woods Hole from .June to octobes. The names "hedgehog ray" and "bonnet skate" are given in allusion to its habit of rolling itself up when caught. At Southampton 1. I. this species was taken in small numbers Ang. 3, 1898.

\section{Raja ocellata Mitchill spotted skate; Big shate}

Raju occllat MitcinLl, Trans. Lit. \& Phil. Soc. X. Y. I, 47T, 1S15; Jord. \& Evermann, Bull. 4 i, U. S. Nat. Mus. 6S, pl. X, fig. 30, 1S96; Smith, Bull. U. S. F. C. X Y II, 89, 1898.

Ruiu occllata DE KAY, N. Y. Famna, Fishes, 369, not pl. 6.5, fig. 212. 1842; Jordax \& Gilbert, Bull, 16, U. S. Nat. Mus. 40, $185: 3$.

Similar in shape to R. e r i n a c e a, but larger, with a wider mouth and with many more rows of teeth. The length of the disk slightly exceeds its width. The spines are arranged as in R. e r i n a c e a, but additional rows are present down the back and on the sides of the tail. Tail nearly as long as the disk; caudal fin not separate, with small spines; month large; jaws curved; teeth in about 90 rows above and $8 s$ below. Color light brown, with rounded dark spots; a translucent space on each side of the snout; near the posterior angle of the pectoral there is usually (but not always) a large white occllus, with a dark spot in the center and a darker border; two smaller similar spots often present. (After Garman)

The spotted skate reaches a length of nearly $: 3$ feet; its egg cases are more than twice as large as those of $R$. e r in a ce a. The species is found from New York to Massachusetts and northward.

In Mitehill described a specimen which was 30 inches long and 19 inches wide. Dr De Kay calls this species the spotted ray. He found the stomach of one filled with rock crabs, Cancer ir ror a tus. To the fishermen this and allied spe- 
cies are known as skate. It has no commercial value in Great South bay. In the traps at lslip shates reappear on October first on thcil fall migration. I female was caught near the

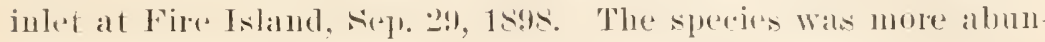
dant later in the fall.

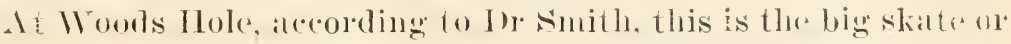
winter skate. It is common from February to June and from October 15 to the end of the trall fishing; it is absent or rey laire in summer.

\section{Raja eglanteria Bosc}

\section{Clear-nosed Sliate; Brier Ray}

Raja ẹlanteria Bosc in LAcérène, Hist. Nat. Poiss. II, 104, 109, 1800; GüTher, Cat. Fish. Brit. Mus. YII, 462, 1870; Jordan \& Everdaxx, Bull. 47. U. S. Nat. Mus. 71. 1896; Sмitri, Bull. U. S. F. C. XVII, S., 1.99. Raia eglanteria Jordax \& Gilmert, Bull. 16. I. S. Nat. Mus. 41. 1883.

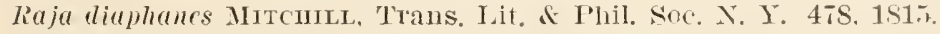

Differs from R. erinacea and R. ocellata in its acutely produced snout, smaller spines and translucent space on each side of the rostrum. The length of the disk (12 inches) equals four fifths of its width (1.5inches). Spines small and very sharp, most numerous on the front part of the pectoral, the head, the snout, the middle of the back, and the tail between the rows of enlarged spines; "nlarged spines around the eyes and spiracles, on the middle of the suout, in a median row along the back, and in two rows along atch side of the tail. The spines on the tail are very sharp, large and small ones alternating in the rows; a large spine in the middle of rach shoulder; a spine between the dorsal fins; tail as long as the disk, and with a median and two latral rows of moderately large spines and one or more intermediate rows of much smaller ones; caudal tin absent $\mathrm{rr}^{\circ} \mathrm{ver}^{\circ} \mathrm{small}$; dorsals small, the anterior larger, one winth the length of tail in hight; month moderate; teeth in about 50 rows in upper jaw and 48 in the lower.

Color pale brown, witl numerous bands, bars, lines and blotehes of darker; darker sjots in the niddle of the pectoral; each side of the snout witl a pale, translucent area. 
The clear-nosed skate, sometimes called brier ray, reaches a length of 2 feet or more. It inhabits the eastern coast of the Inited States from Cape Cod to Florida; it has been found noderately common in Great South bay in and near Fire Island inlet. Early in September both males and females were caught at Fire Island inlet and Wigo inlet, but in October the speries appeared to be scarce. It has no commercial value in the bay and is usually thrown away.

At Woods Hole Mass. it is not common. I few are taken erery year in traps at Menemsha, Marthas Vineyard.

26 Raja laevis (Mitchill)

\section{Barn-door Slate}

Raja lacris Mitchilt, Am. Month. Mag. II, 327, 1818; Jordan \& Everman., Bull. 47, U. S. Nat. Mus. 71, 1S96; Smitr. Bull. U. S. F. C. XVII, 89, $189 \mathrm{~S}$.

Raia lacvis DE KAY, N. Y. Fauna. Fishes, 370, 1812; Jordax \& Gilbert, Bull. 16, U. S. Nat. Mus. 42, 188:; STorer, Hist. Fish. Mass. 266, pl. XXXIX, fig. 2, 1867 .

Similar in shape to $\mathrm{R}$. e g l a n t e r i a, but larger and with fewer rows of teeth. The length of the disk equals three fourths of its width. The spines of the body are few and small; small patches of slightly enlarged spines on the anterior extension of the pectorals opposite the eyes and spiracles; slightly enlarged, hooked spines in several narow rows on the angles of the disk in males; a median row, more or less incomplete, of distant spines on the tail and usually a lateral row on each side, many of these lateral spines sometimes obsolete; small spines on the snout, along the anterior edges of the disk, and on the toj of the head. Tail nearly as long as the disk; two subequal dorsal fins, scarcely half as long as the snout, separated by a narrow interspace and extending to near the end of the tail; no caudal fin; eye one fifth as long as the snout; mouth large, jaws curved, teeth in about 30 rows in each jaw; length of claspers of the male equals one third of the width of the disk. Color usually brownish with paler spots, these sometimes surrounded by dark rings. 
The balu-dool skate reacless a length exceeding $t$ feet; it is used to sone extent for food. The species las been taken in Gravesend bay in october. It suffers in captivity for the want of sand and mud and because of the lack of suitable food, its average duration of life is : 1 or 1 months.

Mitchill described an individual measuring 49 inches which Was caught at a wharf in the East river Nov. 5, 181.5. At Woods Hole Mass. it is common in spring and fall, ratre in summer.

\section{Family NARCOBATIDAE \\ Electric Rays}

\section{Genus Tetronance Gill}

Rays with a large electric organ composed of many hexagonal lubes between the pectoral fins aud the head; disk rel'y broad, abruptly contracted at the tail; i wo dorsal fins, the first much the larger, its origin not far in advance of the end of the ventrals; caudal fin well developed; ventral fins large, separate; spiracles latrge, oblong, wall bolind the eves, with entire edges; mouth small; treth share; skin smooth. Seas of Europe and America.

\section{Tetronarce occidentalis (Storer) \\ 'Torpedo: (romp Fish: Numb Fiste}

T'orpedo occidcutalis STORER, Am. Jour. Sci. Arts, 165, pl. 8, 1S4:3 IIist. Wish.

Mass. 271, 11. XXXIX, tig. 5, 186i ; JordaN \& Gildert, Bull. 16, U. א. Nat. Mus. 39, 1583.

haja torpedo Mitchil, Trans. Lit. \& Phil. Soc. N. Y. I, 476, 1915.

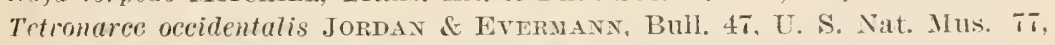
pl. XI, fig. 33, 1896; Smth, Bull. U. S. F. C. XVII, S9, 1898.

Length of disk equals six sevenths of its width and mole than one half the total length; length of base of rentrals equals one fourth the width of disk; eyes small, placed three times their diameter from tip of suout, and about the same distance from each other ; length of first dorsal base nearly equals distance between the spiracles; hight of first dorsal fin exeeeds length of suout; base of second rolsal scalcely more than one half the length of first, the hight of the fin haldly two thirds of that of 
first; cantal slightly emarginate, its width and length neatrly equal, about two serenths of width of disk. The upper surface is dark purphish brown with a few darker spots distributed over it; beneath white.

The torpedo is found on the Itlantic coast of the United States from Cape Cod to Florida; it occurs also in the West Indies. The fish is usually uncommon except in Buzzards bay and Vinevard sound. It reaches the length of 5 feet and the weight of 100 pounds.

Mitehill placed a torpedo among the fishes of New Iork on the anthority of fishermen and others who had seen the species and knew of its peculiar electric properties. De Kay did not see the fish and merely refers to the probability of its occurrence and its relation to the genus To p p d o.

The existence of a torpedo on the coast of Massachusetts was made linown hy Storer in 1813, when he described a specimen caught at Wellfleet, in Norember 184:. Capt. Atwood, a well known former resident of Provincetown Mass. informed Dr. Storer that he had received a great many porerful shocks from the fish which thew him to the groumd; these were produced by tomching the animal. He also received shocks by taking hold of a harpoon which was struck into the fish. Storer relates an anecdote illustrating the effect produced on a dog.

Mr Newcomb sr, the oldest fisherman in Boston market, stated to me that his father, who resided at Welltheet, had a dog which frequently waded into the shallow waters of the cores and brought out flounders which he had seized with his mouth. In! one of his fishing excmiosions he attacked a torpedo, which per. fectly convulsed him. He dropjed the fish and ran a way howling most piteously, and could nerer be persuaded to resume his fishing.

It Woods Hole Mass. the torpedo is most abundant in October and Norember. At times as many as six are taken at one lift of a trap at Menemsha. The smallest weigh 4 or $\bar{v}$ pounds, the largest $T \tilde{J}$ pounds. 


\section{Suborder MISTICURA}

Whip-tailed Rays

\section{Family DASYATIDAE}

\section{Sting Ruys}

\section{Genus Disyors Rafinesque}

bisk usually broader than long; pectoral fins mited in front to form the tip of the snout; tail rery slender and elongate, finless, but often with one or two membranous folds, and with a strong serrated spine near its base; skin rapely smooth, nsually more or less spinous or priclipr, tail with mumerous small spines in some species; mouth small; tecth small, parel, nsmally more or less pointed or tubereulat; a few papillat. usually in the mouth behind the lower jaw; nostrils close together; nasal ralres forming a rectangular flap, which is joined to the upper jaw by a narrow frenum; spiracles large. placed close behind the eyrs. Oroviriparous.

\section{Dasyatis centrura (Mitchill)}

\section{Common stiny Ra!!}

Raju ceulure Mrenill, Trans. Lit. \& Phil. Soe. N. Y. I, 479, 1815.

l'ustinaca hastutu ŚTorer, IIist. Fish. Mass. 26S, pl. XXXIX, fig. 3. 18kit.

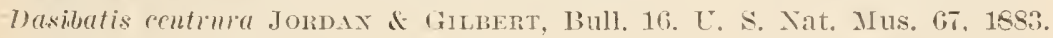
(From Garman)

Trygon hastalı Güxtıer, Cat. Fish. Brit. Mus. VIII. 476. 1870.

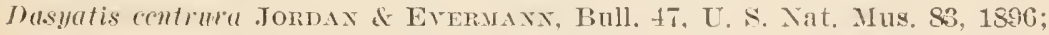
Siıti, Bull. U. S. F. C. XVII. 9n, 1S!S.

loisk quadrangular, about one fomrth wider than long; antelior margins simuous, coneare opposite the eyes, comrex toward the slightly protuberant snout and pounded over angles; posterior straighter, rery little conrex: hinder angles blunt; renlvals truncate, with rombed angles; tail more than twice as long as the body, much rompressed, lommded above, with kecl or cutameous expansion below. With one or more strong sorated spines at the termination of the anterior fifth of its length, rough on all sides with spines or tubercles. Till half grown the young are naked; as they approarh maturity broad stellate based, conical pointed, irrogularly placed burkless appear on the middle of the hinder part of the back and on the top and sides 
of the tail. Very large examples have the central part of the back closely mailed with small flattened tubercles. The buckIers bear more resemblance to those of the $R$ a $j$ a e, r a diat a and $c l$ a vata, than to the tubercles of pastina ca, hastata, or tuberculata. Mouth arched forward, with five papillae; teeth in quincunx, blunt, smooth. Color of back and tail olive brown; light to white below. From pastinaca, which this species resembles in shape, it is distinguished by the tubercles, by the length and compression of the tail, and absence of all trace of keel or expansion on its upper side. A young specimen measures from snout to tail 13.8, in length of tail 30.5 , and width of pectorals 17.5 inches. The largest specimen in the collection has a total length of 10 feet 3 inches (coll. Mus. ('omp. Zool. Cambridge Mass.). Common south of Cape Cod. Occasionally fonnd northward. (After Garman)

Formerly hundreds of individuals were caught annually in Gravesend bas, but now it is seldom seen there. The species will live in captivity several months in the spring and summer. Mitchill records it as ocenring on the coast of Long Island. The tail, he states, is 5 feet or more in length. Storer described a specimen 9 feet long. He was informed by $\mathrm{Dr}$ Yale that the fish was abundant on the flats in the harbor of Holmes's Hole, Marthas Vineyad, in July and Angust. Near Woods Hole Mass. it is common during summer, appearing early in July.

The sting ray is much dreaded by fishermen, who say that wounds made by its spines are exceedingly painful and dangerous, the slime secreted by the fish acting as a poison.

\section{Subgenus DAsYa'Ts}

\section{:9) Dasyatis hastata (De Kay)}

Kit

Pastinace hastate DE KAY, N. Y. Fauna, Fishes, 373, pl. 65. fig. '214, 1St2. Trygon hastata Storer, Syn. Fish. N. 1. 261, 1846.

Dasibatis hastata GArman, Bull. 16, U. S. Nat. Mus. 70, 1883.

Dasyatis hastata Jordan \& Evermand, Bull. 47, U. S. Nat. II S. S:, 1896.

The sting rays of the subgenus $D$ a s y a $t$ is differ from the type ce $\mathrm{n} t \mathrm{r}$ u a in having a narrow keel or expansion on the tail both above and below. 
Disk with the shape and proportions of D. centrura; anterior margins nearly straight. meeting in a blunt angle on the end of the snout, curred near the outer angle to meet the slightly convex posterior margins; inner borders convex; outer and linder angles rounded; rentrals almost entirely corered by the pectorals, their hinder margins convex; tail more than one and one half times as long as the disk, with a low keel on the upper side, a long, broad, membranous expansion below, roughened with small asperities, and with one or more serrated spines begimning in the first fourth of its length; body smooth in young. with scattered small asperities in the old; a row of narrow, compressed tubercles on the middle of the back and base of tail, their points depressed and directed backward. On each shoulder, parallel with the median row, there is a shorter row rarying in length according to age. Mouth with three papillae; jaws more curved than in centrura and less than in s a bina. Color blnish or uniform olive brown above, white beneath. NTest Indies to Brazil, north to Rhode Island.

De Kay's description of his whip sting ray is based on a female captured in September off the coast of Rhode Island by Carson Brevoort of New York. The length of the fish was 8 feet 6 inches and its weight 110 pounds. Mr Brevoort stated that the whip rays appeared to associate together, as he noticed many of similar size and appearance swimming about at the same time. They mored slowly together through the water, along the edges of the rocks, about 3 feet below the surface. When captured, the individual described by Dr De Kay whipped its tail abour with great activity in all directions. From this circumstance it derives the name of whip ray.

\section{Dasyatis say (Le Sueur)}

\section{Southern Sting Ray}

Raja say Le Sueur, Jour. Ac. Nat. Sci. Phila. I, 42, 1817.

Myliobatis? say DE KAI, N. Y. Fauna. Fishes, $376,1812$.

Trygon sayi Müller \& Hende, Plagiostomen, 166, 1811; Duméril, Elasmobranches, 603, 1870 .

Dasybatis sayi Garmax, Bull. 16, U. S. Nat. Mus. 69, 1883.

Dasyatis say Jordan \& Evermans, Bull. 47, U. S. Nat. Mus. S6, 1896. 
Disk quadrangular, about one sixth wider than long, anterior margins nearly straight, posterior and inner borders convex, outer and posterior angles rounded; snout not protruding beyond the lines of the margins, ventrals rounded; tail strong, ratlier more than one and one half times the length of disk, with a strong serrated spine, bearing a short, low cutaneous expansion behind the spine on the upper side, and a longer, little wider one below, ending nearly opposite; upper jaw undulated, lower prominent in the middle; teeth small, smooth in young and females, sharp in arlut males; thee papillae at the bottom of the mouth, and one at earh side; body and tail naked. Color olive brown in adult, reddish or yellowish in young; lower surface whitish. New York to Florida and Brazil. (After Garman)

According to Garman, a young female measured from snout to tail 7.1, length of tail was 11 , and width of pectorals 8.2 inches.

Le Sueur's type was from the New Jersey coast. Müller and Henle mention six specimens in the Museum of Natural History at Paris, which were sent from New York by Milbert. The species has not been reported recently in New York waters.

Genus p'rerioputana Müller \& Henle

Disk much broader than long, its anterior margins meeting in a very obtuse angle, its outer angles more or less acute, the form, therefore, transversely rhombic; tail very short and slender, shorter than the disk, without fin, armed with a very small serrated spine or without spine; skin smooth or rery nearly so. Size large.

\section{Pteroplatea maclura (Le Sueur)}

\section{Butterfly Ray}

Raja machura Ise Suevr, Jour. Ac. Nat. Sci. Phila. I, 41, 1817.

Pastinaca machua DE KAY, N. Y. Fanna, Fishes, 375, pl. 65, fig. 213, $18+2$. Pteroplatea maclua MüLler \& Henle, Plagiostomen, 169, 1841; Günther, Cat. Fish. Brit. Mus. VII, 487, 1870; Jordan \& Gilbert, Bull. 16, U. S. Nat. Mus. 46, 1883; Jordan \& Evermann, Bull. 47, U. S. Nat. Mus. S6, 1896; Sмiтh, Bull. U. S. F. C. XVII, 90, 1898.

Disk almost twice as broad as long, covered with smooth skin (or with minute granulations according to Le Sueur), the snout 
very little projecting, so that the anterior margin of each pectoral is slightly concare; tail two fifths to one third the length of disk, with a slight dermal fold above and below, and with one or two spines rery near its base or sometimes without spines; eyes small and near the snout; spiracles large, near the eyes; nostrils small, near the mouth, not extending to the upper lip; teeth numerous, triangular, acute, each emarginate at the base bchind; rentrals short, broad and rounded, their length less than one fifth of that of disk. Color brownish olive, sometimes bluish, fincly mabled with grayish, and finely speckled; anterior edge of disk with blotches of paler; tail with four dark blotches abore, forming half lings. Cape Cod to Brazil, common southward.

The species is now rarely seen in Graresend bay. It does not endure captivity.

Le Sueur's description was based on a specimen 6 feet 7 inches wide, taken at Newport R. I. He was inforned by fishermen that it reaches the wiuth of 15 fect. 1)e Kay copied Le Sueur's description and figure.

Dr Smith says it is rare at Troods Hole, and appears in August and September when present. It has the local name of Angel fish at Wroods Hole.

\section{Family MYLIOBATIDE}

\section{Eagle Rays}

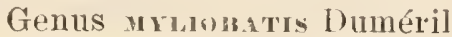

Disk broad; pectoral fins ending laterally in an acute angle, not continued forward around the snout, but ceasing on the sides of the head and reappearing in front of the snout as a fleshy protuberance (cephalic fin); tail very long and slender, whiplike, with a suall dorsal fin near its root, and one or more serrated spines; teeth hexangular, large, flat, tessellated, the middle ones much broader than long in the adult; several series of narrower teeth on each side of the median series; teeth changing considerably with age; jaws about crual; free edge of the nasal valve not deeply emarginate; slin smooth. 


\section{Myliobatis freminvillei (Le sneur)}

\section{Eagle Ray}

Myliobatis frémintillei Le Sueur, Jour. Ac. Nat. Sci. Phila. IV, 111, 1824;

DE KAY, N. Y. Fauna, Fishes, $376,1812$.

Ifyliobatis acuta STORER, Hist. Fish. Mass. 269, pl. XXXIX, fig. 4, 1867. Iyligalis freminvillei Jordan \& Gilbert, Bull. 16, U. S. Nat. Mus. 51, 1853; Jorday \& Evermati, Bull. 47, U. S. Nat. Mus. S9, 1S96; Smiti, Bull. T. S. F. C. XVII, 90, 1898.

Disk broader than loug, width to length bearing the ratio of 5 to 3 ; wirth of disk equal to leugth of tail. Diameter of eye equals abont one fourth of the intelorbital distance; spiracles behind the eyes and one and one half times as long. Width of month one lialf its distance from tip of snont. Free edge of the nasal ralve not deeply notched. Reaches a length of 4 feet. Body and lead above, reddish brown; tail lighter at the base, lout nearly black toward the tip; lower parts whitish.

The species is not uncommon, from Cape Cod to Brazil. It probably feeds on mollusks.

It was reported to me by men of the menhaden steamer Annic Morris that about $\perp u g .20,1857$, off Hereford inlet, they saw schools of sting rays at the surface "flopping along like geese." The schools were large enough to have filled a menhaden seinc. The rays were said to have two spines on the tail.

Le Suenr's description was based on a Rhode Island specimen. De Kay copied briefly from Le Suenr, and placed the fish amoug the extra-limital species. William O. Ayres found an individnal at Brook Haven I. I., which he deseribed in the Boston Journal of Natural History, $4: 290$, pl. 13. Dr Storer received portions of a specimen from Holmes' Hole Mass. Dr Simith records it as not very common at Woods Hole Mass., but taken in small numbers every year in traps.

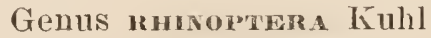

Disk broader than loug, its anterior angles more or less acute; snout more or less emarginate on the median line; cephalic fin emarginate and placed on a plane below the level of the pectorals, the snont thus appearing four-lobed; free border of the nasal valve not emarginate; teeth in 5 to 20 rows, the median 
teeth sometimes much enlarged. sometimes not much larger than the outer teetls; tail long, whiplike, with a small dorsal spine belind the dorsal fin which is at the hase of the tail; rentral fins oblong. truncated behind.

\section{:3:. Rhinoptera bonasus (Mitchill, \\ Cour-noserl Rery}

Raja bonasus Mitchilt, Trans. Lit. \& Phil. Soc. N. Y. I, 479. 181 .

Rhinoptera quadriloba DE KAY, N. Y. Fauna, Fishes, 375, pl. 66, fig. 217, 1842; Guntmer, Cat. Fish. Brit. Mus. VIII, 494. 1870; Jordan d Ghlbert, Bull. 16, U. S. Nat. Mus. 51. 18.5.

Rhimopteru bouasus Jordax \& Evermax,, Bull. 4T, U. S. Nat. Mus. 90, 1S94; Sirtit, Bull. U. S. F. C. XVII, 90, 1898.

The length of disk equals two thirds of its width; its anterior borders almost straight, posterior undulated; pectorals acutely produced; muzle deeplỵ entarginate; mouth wide; nostrils midway between montl and tip of snout; spiracles large, longer than eye; teeth in seren rows in each jaw, the median teeth more than four times as broad as long, the others gradually diminishing in size ontward; tail rery slender, as long as the body; a small dorsal fin at base of tail and a slender, serrate spine behind it; skin smooth except a few protuberances on the top of the head. Color olive brown above; beneath white. Capr Cod to Forida; not rare.

This species is now rarely seen in Gravesend bay, where it was at one time very common in the autumn. When Mitchill wrote of the fishes of $\mathrm{Yew}$ York (1S15) he stated that the cownosed ray risits the coast, usually about September, in numerous slioals, entering tlic bay and ranging rery extensively orer the flats where the soft clam lives.

These shellfish he is supposed to devour; for a shoal of comnoses roots up the salt water flats as completely as a drove of logs would do. I liare seen the water in riolent agitation when these fishes were at work in the bottom. They render it so muddy that they are concealed from sight. Frequently, however. they rise to the top and may be distinctly observed. I have seen them swim near the surface in clear water. They then support and propel themselves in their element by their large flaps as a crow or other bird, with slowly moving wings, passes through the air. They may be said to fiy rather than to swim. A full grown individual weighs about 100 pounds. 
Mitclill also states that the fislermen usually allow these rays to decay on the shores, but sometimes take out their livers for conversion into oil.

According to Ir Snitl, the cow-nosed ray is common at Woods Hole Mass.

Subclass TELEOSTOMI

True Fishes

\section{Series GANOIDEI}

Ganoid Fishes

Order SELACHOSTOMI

Padillefishes

Family POLYODONTIDAE

Paddlefishes

Genus poryodox Lacépède

Body fusiform, elongate, somewhat compressed; slin smooth or with minute ossifications; snout produced into a very long spatulate process, the inner part composed of the produced nasal bones, the sides flexible and supported by a bony network; moutl wide, terminal, but orerlunge by the snout, withont maxillaries, but witlı toothed premaxillaries; numerous fine, deciduous teeth in the jaws and on palatines; no tongue; nostrils double, immediately in front of the eye; spiracles present; operculum rudimentary, its skin produced behind into a long acute flap; no psendobranchiae; no barbels; no opercular gill; gills four and one half; gill rakers numerous, very long and slender, in a double series on each arch, the two series divided by a broad membrane; gill membranes connected but free from istllmus; one broad branchiostegal; lateral line continuous, its lower margin with short branches; air bladder cellular, entire, communicating with the dorsal wall of the esophagus; pyloric caccal in the form of a short, broad, leaflike organ, with four or five larger divisions, each being subdivided; rectum with a fully developed spiral valve; dorsal fin posterior, without spines; anal similar, and more posterior; tail heterocercal, with well devel- 
oped lower caudal lobe so that the fin is nearly equally forked; sides of the bent portion of the tail armed with small rhombic plates; upper caudal fulcrums narow, numerous; pectorals modcrate, placed low; rentrals abdominal, many-rayed.

livers of the middle United states.

\section{Polyodon spathula (Walbaum)}

\section{Paddlefish: Spoonbill Cat}

Squalus spathula Warbaum, Artedi, Gen. Pise. 522, 1792.

l'olyodon fenille LACÉPÈDE, Hist. Nat. Poiss. I, 403, 1800.

l'olyodon folium Blocf \& Scmemer, Syst. Ichth. t5i, 1801 fafter Lacélè̈le); Mitchill, Am. Jour. Sci. Arts, XII, 201. 1827; Iíntraxd, Bost. Jour. Nat. Hist. IV, 21, pl. 2, fig. 1, 1814; Günther, Cat. Fish. Brit. Mus. VIII, $3 \pm 6,1870$.

Polyodon spathula Jordax \& Gilmert, Bull. 16, U. S. Nat. Mus. S3, 1S83; JordAx \& Evermann, Bull. 47, U. S. Nat. Mus. 101, 1896.

The body of the paddirfish is fusiform with the snout much produced, spatulalike. Body scaleless, covered with smooth skin; mouth broad, terminal, somewhat resembling that of the shark; tecth in jaws very numerous and fine, deciduous; spiracles with a minute barbel. The operculum is rudimentary, its flap of skin long, reaching almost ol quite to the rentral fins; psendobranchiac absent; gill arches five, the last rudimentary; gill rakers long and in a double sreies on each arch; gill nembranes connocted, free from the isthmus; nostrils double, situated at base of blade; a continuous lateral line from npler part of head along dorsal outline to tail; eye small, directed downward and to the side; dorsal and amal fins far bark, composed of soft rays, nealy opposite; tail heterocercal, well forked; sides of the bent portion of the tail armed with rhombic plates. The pectoral fins are of moderate size and placed low; rentrals many-rayed, abdominal. The distance from eye to end of snout is about one third of the total length, including caudal. The depth of the body is contained four and one half times in the distance from "ye to base of caudal. The hight of the dorsal fir about equals the depth of the borly.

This is known as the paddlefish, spooubill or spoon-billed sturgeon, shorel fish, billfish, and duck-billed rat. Called "sal. 
mon" in westeln lotels. 'The names are derivel from the remarkable snout. which is produced into a long spatula-shaped process, corered above and below with an intricate network and with very thin flexible edges. The head and snout form nearly lialf of the entire length of the fish. The fish can not be confounded with anything else in the waters of the Tnited States. There is in China a similar fish. whicls, howprer, belongs to a different gemus.

Distribution. The single species of American patdlefish is confined to the Mississippi valley. It inhabits only the larger streams in Pennsylrania. It is common in the Allegheny and the Monongahela rivers.

Size. The paddlefish grows to a length of 6 feet, and a weight of 20 pounds $\mathrm{ol}^{2}$ more.

Habits. The species frequents muldy bottoms, but does not feed on the mud and slime, as many persons have supposed. The loug snout is useful in procuring its food, which consists chiefly of entomostracans, water worms, aquatic plants, leeches, beetles and insect larvae.

Prof. S. 1. Forbes, director of the Illinois Laboratory of Natural History, has published the first and most satisfactory account of the feeding liabits of this sharklike fish. He found very little mud mixed with the food. Prof. Forbes was informed by the fishermen that the paddefish plows up the mud in feeding with its spatulalike snout and then swims slowly backward throngh the water.

"The remarkably developerl gill rakers of this species are very numerous and fiue, in a double row on each gill arch, and they are twice as long as the filaments of the gill. By their interlacing they form a strainer scarcely less effective than the fringes of the baleen plates of the whale, and probably allow the passage of the fine silt of the river bed when this is thrown into the water by the shovel of the fish but arrests everything as large as the cyclops. I have not found anything recorded as to the spawning habits of the paddlefish. The Jonng have the jaws and palate filled with minute teeth, which disappear with age." 
Mode of capture. The fish are gemeally raught hy seining.

Edible qualities. The flesh of the fraddletish is frequently considered tough and sharklike, but individuals of 8 or 10 pounds are skimmel, and sold in some of the western markets freely, and are thought by some persons to be fairly grood for the table.

\section{Order chundiostei}

\section{Sturgeons}

Family actpenseridia

\section{Sturgeons}

Genus acuranswe Linnaeus

Body elongate, subeylindric, armed with five rows of bony bucklers, each with a median keel terminating in a spine which becomes obsolete with age; a median dorsal series of bucklers, and a lateral and abdominal series on each side, the abdominal series sometimes decidnous; between these the skin is rough with small, irregular plates. Head covered with bony plates joined by sutures; snout produced, subconic; spiracles present; mouth small, inferior, protractile, with thickened lips; no teeth; gill rakers lanceolate; four barbels in a transverse series on the lower side of the snout in front of the month; eyes small; nostrils large, double, in front of eye; gills four; an accessory operrular gill: gill membranes nuited to isthmus; psendobranchiap small or obsolete; no branchiostegals; maxillary distinct from the premaxillary; fin lays slender, all articulated; vertical fins with fulcrums; pectorals plated low; rentrals many-ayed, behind middle of body; dorsal plated pusterjorly a and somewhat belind dowal, similar; tail heteroceral, the lower "andal lobe developed; the tail not depressed or mailed; air bladder large, simple, connected with the esophagus; stomach without blind sac; rectum with a spiral valve; pancreas divided into pyloric appendages. (After Jordan and Erermann)

\section{Acipenser sturio Linnaeus}

\section{common sturyeon.}

Acipenser sturio IJnnaeus, Syst. Nat. el. X, 237, 1758; Günther, Cat. Fish. Brit. Mus. VIII, 342, 1570; Jordan \& EverManx, Bull. 47. U. S. Nat. Mus. 105, 1896; Sмrтh, Bull. U. S. F. C. XVI, 90, 1898. 
Acipenser oxyinchus Mrtulu, Trans. Lit. \& Plil, Soc. N. Y, I, 462, 1815. Acipenser oxyrhincus DE KAY, N. Y. Fauna, Fishes, 3t6, pl. 5S, fig. 189 (young), 1842.

Acipenser sturio rar. orymblynchus Jordan \& Gilbert. Bull, 16, U. S. Nat. Mus. S6, 1853.

The common or shally-nosed stmigeon has a stont, roundish and elongate body, its hight equaling one lialf the length of the head and one sixth of the total without the caudal. The least depth of the tail equals one third of the greatest body depth. The head is long, one third of total withont the candal, ant the snout is as long as the rest of the hrad in the young. The eye is one sixth as long as the snout. Two patirs of short, slender. barbels midway between the month and tip of snout. 'The front of the month is nearly under the posterior edge of the pupil. The nostrils are double, the posterior pair mole than twice as large as the anterior. The dorsal and anal fins are placed far back and opposite to each other. The distance of the ventral oldigin from the end of the lower caudal lobe equals the length of the head. The upper caudal lobe is nearly trice as long as the lower. D. 35 to $40 ;$ A. 23 to $26 ; \mathrm{V} .24$. Lateral plates 27 to 29 ; dorsal shields 10 to 14 ; rentral shields 11 or 12 .

The color of the upper parts is dark olive gray, sometimes brownish; the lower parts are light gray or whitish. The pupils are black; the iris golden.

The range of the common sturgeon includes the Itlantic ocean southward to Africa and the IVest Indies. The northern limit on our east coast appears to be Cape Cok. In the Delaware river the fish has rarely ascended as far as Port Jervis.

Dr Mitchill was the first to eall attention to the similarity between the American slarp-nosed sturgeon and the st $\mathrm{ur}$ io of Europe. The fish attains a lenghl of 12 fect in America, and it is stated tluat European examples measuring 18 feet have been taken.

'The sturgeon ascends the large rivers from the sea in spring and early summer. It is very common in the lower part of the Delaware river, where it forms the object of an important fishery. This is the species concerning which so many stories have 
becu related as to leaping into boats and injuring the occupants.

The month of the sturgeon is furnished with a rery protractile roundish tube having powerful muscles and intended for withdrawing from the mud the rarious small sleelfish and crustaceans on which the animal subsists. The mouth is surounded also with numerous tentacles, with tactile properties, which are utilized in procuring foorl.

The reproductire habits of the sturgeon and the embryology of the species have been made the subject of an exhaustive study by Prof. John A. Ryder, of the Unirersity of Pennsylva-

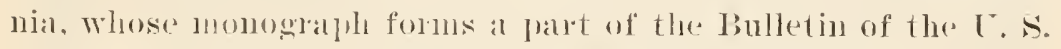
Fish commission for 1s8s. The eges have bern fertilizod and developed artificially by Seth Green and others many years ago, and in some parts of Europe the hatching of the species lats been carried on sucessfully. The I. S. Fish Commission has also recently taken up the culture both of the marine and the lake stmegeon, and these valualhle fish maly soon be realed on an extensive scale.

The utilization of the flesl, the slin and air bladder and the eggs of the sturgeon is so well known as to require little more than passing mention in this place. The smoking of the flesh and the mannfacture of caviar from the eggs are very important industries along our eastern coast.

The sturgeons aro asily taken in gill nets and pounds, but the great strength of the fish frequently entails considerable loss of apparatus.

The common sturgeon appears (Pery spring in Graresend bay, and sometimes in the fall. It is hardy in captivity.

I female $S$ feet long was brought from the mouth of the Delaware river May 20,1897 , to the New York aquarium. It sermed to take no food till December 1 , when it began to feed freely on ofrened liard clams. Early in Norember 1898, the fish was still alive and healthy. 


\section{Acipenser rubicundus Le Sueur}

\section{Lake sturgeon}

Aciplenser rubicundus LE Sueur, Trans. Am. Phil. Soc. I, 3SS, 181s; De KAY, N. Y. Fauna, Fishes, 344, pl. 5S, fig. 191, 1S42; GüNTHER. Cat. Fish. Brit. Mus. VIII, 338, 1870; Jordax \& GIldert, Bull. 16, U. S. Nat. Mus. 87, 1853; Jordax \& Evermanx, Bull. 47, U. S. Nat. Mus. 106, 1856.

Acipenser maculosus Gürtmen, Cat. Fisl. Brit. Mus. VIII, 339, 1 ș̃o.

The body of the lake sturgeon is rather more slender than that of the common sturgeon. The snout is rather blunt; in the young long and slender. The shields of the body are large, about 14 on the back, 30 or more on the side, and eight or nine along the abdomen, between pectoral and ventral fins. Each shield is surmounted by a strong hooked spine. The head is contained three and one third times in the length withont tail. Barbels fonr, rather long; eye small; dor'sal and anal fins small. placed far back as in the pike. D. 35; A. 26 .

This is known as the lake sturgeon, Ohio river sturgeon, rock sturgeon, bony sturgeon, red sturgeon and ruddy sturgeon. It inhabits the Mississippi and Ohio rivers and the Great lakes, and is abundant in the Allegheny. From the lakes it ascends the streams in spring for the purpose of spawning. Dr Richardson states the northern limit of the sturgeon in North America to be about the 55th parallel of latitude.

Size. The lake sturgeon is smaller than the common marine sturgeon, the average adult being less than 5 feet in lengtl. The arerage weight of 14,000 matne sturgeon taken at Sandusky 0 . was about 50 pounds. It frequently reaches at length of 6 feet.

Habits. In the lakes the species, according to observations of James W. Milner, inhabits comparatively shoal waters.

The food of this sturgeon is made up chiefly of shellfish, including the genera $\mathrm{Limnaea,} \mathrm{Melan} \mathrm{tho,} \mathrm{Phy} \mathrm{a} \mathrm{a,}$ Planorbis, and Valvata. Eggs of fishes are also to be found in its stomach.

In Lake Erie the species spawns in June, for which purpose it ascends the rivers in large schools till stopped by obstructions 
or insufficient depth of water. The breaching of the sturgeon is a well known habit. Instances are recorded of serious injury to persons by sturgeons throwing themselves into boats. The sturgeon will occasionally take a baited hook, but its great strength and unwieldiness make it an undesirable fish for the angler.

Large numbers of sturgeon have been destroyed by fishermen during the whitefish season simply on account of the annoyance caused by their presence in the nets. Now that the flesh is coming to be esteemed for smoking, and the demand for caviar made from their eggs has largely increased, the wanton waste of this fish has been checked. A troublesome parasite of the sturgeon is the lamprey cel (Petromyzon concolor Kirt.) which attaches itself to the skin presumably for the purpose of feeding on the mucus, which is exuded from the pores in great abundance, and remains fixed in one position so long as to penetrate to the flesh and produce a deep ulcerous sore.

The lake sturgeon was formerly not very much prized, but is rapidly growing in favor. The flesh is eaten in the fresh condition or after boiling in rinegar or curing by smoking. Smoked sturgeon is now considered almost if not quite equal to smoked halibut, and the demand for it is increasing. From the eggs of the sturgeon a good grade of caviar is produced. "The caviar is made by pressing the ora through seives, learing the membranes of the oraries remaining in the sieve, and the eggs fall through into a tub. This is continued until the eggs are entirely free from particles of membrane, when they are put into salt pickle and allowed to remain for some time."

A large specimen now in the museum of Cornell University is reported as being from Cayuga lake. Seth Green informed Dr Meek that sturgeons had occasionally been taken in that lake; but, so far as he knew, they had never been found in any other of the small lakes of central New York.

H. V. Kipp of Montezuma N. Y. wrote Dr Meek as follows:

There have not been any sturgeons taken from Caruga lake since 1880 , but quite a number before that date, and the largest known weigled 35 pounds. 


\section{Acipenser brevirostrum LeSneur}

\section{Short-nosed Sturgeon}

Acipcnser bevirostrum Le Sueur. Trans. Am. Phil. Soc. I, 390, 181S; Ryder. Bull. U. S. F. C. VIII, 237, 1890; JoRdan \& Evermann, Bull. 47, U. S. Nat. Nus. 106, 1896.

Acipenser Trevirostris Güntmen, Cat. Fish. Brit. Mus. VIII, 311, 1870; Jordan \& Gilbert, Bull. 16, U. S. Nat. Mus. S7, 18S3; Shith, Bull. U. S. F. C. XVII, 90, 1898.

In the short-nosed sturgeon the suout is very blunt and only about one fourth to one third as long as the head. The four short barbels are a little nearer to the end of the snout than to the mouth, and do not reach to the mouth. The head is one fifth to two ninths as long as the total to the fork of the tail; the distance between the eyes slightly greater than length of snout and somewhat more than one third of length of head. The average number of bucklers in the dorsal series is 10 to 11 ; in the lateral series, 25; in the rentral row, seven to eight. No preanal scutes. The unarmored part of the skin, according to recent observations of Prof. Tohn A. Rvder, is almost free from prickles and ossifications. D. $33 ;$ A. 19 to $22 ;$ V. 17 to 21 ; P. 30 to 31 ; C. 60 , its lower lobe two fifths as long as the upper, measuring from the fork. The color of the skin of the upper parts is reddish brown; lower parts nearly white; peritonem dark brown; viscera almost black.

This little-known sturgeon has not been grenerally recognized anywhere except in the Delaware and in Gravesend bay; only a few specimens have been obtained in the river, and it is rare in Gravesend bay. Prof. Ryder collected five examples at Delaware City in the spring of $18 S S$ and has published a description of the speries in the Bulletin of the U. S. Fish Commission for that year.

Size. The largest specimen known was 33 inches long; individuals 20 inches long are capable of reproducing the species.

Uses. At the present time the short-nosed sturgeon probably never comes into the markets, on account of its small size, which prevents its capture in the nets used for taking the common sturgeon. About 1817, however, it was brought in the shad season to Philadelphia and sold for $25 \mathrm{c}$ to $75 \mathrm{c}$ each. 
Reproduction. Spawning takes place in the Delaware during May. The eggs are deposited in deptlis of 1 to 5 fathoms on hard bottom in brackish or nearly fresh water. Prof. Rỹder states that the eggs are extruded by rubbing the belly either against hard places on the river bed or against the rough bodies of the males, two or more of which accompany each female. The gravid roe fish are larger than the males. Prof. Rrder found the ora more or less adhesive immediately after their remoral from the abdomen, but the sticky mucous corering is soluble in water. The period of hatching varies from four to six days.

Food. Up to the third month of its life the young sturgeon has minute conical teeth in its jaws, and at this age it is believed to subsist on "rhizopods, unicellular algae, infusoria, minute larvae of insects and worms, crustaceans, etc." Still following the observations of Prof. Rrder, we learn that the sturgeon, when it has reached a length of 1 inch to $1 \frac{1}{2}$ inches, has minute teeth on the floor of the pharynx and feeds on small water fleas; and probably algae, worms, embre fishes, insects and fresh-water copepods. Later in life the fish seeks larger crustaceans, and the adults occasionally contain fragments of mussel shells. The young fish have been caught under the ice in midwinter and are known to pass most of the year in fresh water.

A single small example of this sturgeon was brought to the New Iork aquarium from Graresend bay May 13, 1S96, and was alive and in good condition in Norember 1898.

Dr Smith records the occurrence of the species along with the common sturgeon at Woods Hole Mass:, but says it is less numerous. It is captured in the traps.

\section{Order RHONBOGANOIDEA}

Gar Pikes

Family LEPISOSTEIDAE

Gar Pikes

\section{Genus Lepisosteus Lacépède}

Body elongate, subcylindric, corered with hard, rhombic ganoid scales or plates which are imbricated in oblique series running downward and backward; both jaws more or less elon- 
gate, spatulate or beaklike, the upper jaw projecting beyond the lower; premaxillary forming most of the margin of the upper jaw; maxillary transversely divided into sereral pieces; upper jaw with an outer series of small, sharp, even teeth, then a series of large teeth, some of the anterior teeth being usually movable; next a series of fine teeth, in one row in front, becoming a band behind. In some species the inner row of these teeth contains larger ones; next the vomerine teeth, also in a long band, and posteriorly a palatine band. These bands on the roof of the mouth are frequently somewhat confluent or irregular. In young specimens some of the palatine teeth are often enlarged, these sometimes forming regular series. Lower jaw with an outer series of small teeth, next a series of large teeth, next again a broad band of fine teeth on each side. Each of the large teeth fits into a depression in the opposite jaw. Pharyngeals with rasplike teeth; tongue toothless, short, broad, emarginate, free at tip; external bones of skull very hard and rugose; eyes small; nostrils near the end of the upper jaw; an accessory gill on the inner side of the opercle; pseudobranchiae present; no spiracles; gills four, a slit behind the fourth; branchiostegals three; gill membranes somewhat connected, free from the isthmus; gill rakers very short; air bladder cellular, lunglike, somewhat functional; fins with fulcrums; dorsal fin short, rather high, posterior, nearly opposite the anal, which is similar in form; tail heterocereal, in the young produced as a filament beyoud the caudal fin; caudal convex; rentrals nearly midway between pectorals and anal; pectorals and rentrals moderate, few-rayed; stomach not caecal; pyloric appendages numerous; spiral valve of intestines rudimentary.

Fishes of the fresh waters of North America and China. (After Jordan and Evermann)

\section{Lepisosteus osseus Linnaeus}

\section{Gar Pilie; Billfish}

Esox osseus Linnaeus, Syst. Nat. ed. X, 313, 1758; Mitcinll, Trans. Lit. \& Phil. Soc. N. Y. I, 441, 1815; Am. Month. Mag. II, 321, 1818.

Lepisosteus bison DE KAY, N. Y. Fauna, Fishes, 271, pl. 43, fig. 139, 1842. 
Lepidsosteus osseus Günther, Cat. Fish. Brit. Mus. VIII, 1S70; Jordan \& Gilbert, Bull. 16, U. S. Nat. Mus. 91, 1883.

Lepisosteus osseus Jordax \& Evermaxy, Bull. 47, U. S. Nat. Mus. 109, 1896.

The garpike has an elongate, subcylindric body. Its depth is contained about 12 times in the length without the caudal. The jaws are greatly produced, the upper being the longer. The length of the head is one third of the total without caudal. Teeth in the jaws rather fine, sliarp and stiff; a single inner row of large teeth, and an outer row of small teeth on each side. The snout is more than twice as $\operatorname{long}$ as the rest of the head, its least width being from one fifteenth to one twentieth of its length. 1). $T$ to $8 ; 1.9 ; \mathrm{T} .6 ; \mathrm{T} .10$. Scales 62 to 6. .

Color greenish; the sides silvery and the belly whitish; numerous round, darli spots on the sides, most distinct posteriorly and most conspicuous in the young, becoming obscure with age. Very young individuals have a blackish lateral band. The fins are generally plain, but the rertical fins have numerous round dark spots.

The specimen described is no. 36098, U. S. National Museum. Its length is 24 inches.

This is the common long-nosed gar pike of the Great lakes, the Mississippi valley and the eastern states from Pennsylrania to South Carolina. It ranges south to Mexico and west to the plains. Additional names for the species are: billfish, swordfish, bony gar, bony pike, alligator, alligator gar, and buffalo fish. Prof. Cope recognizes two varieties of this gar in Pennsylvania. One of these abounds in the Susquehanna and the lower Delaware. He distinguishes it by its robust form, short face and gill covers and the roughened scales of the front part of the body. The other variety occurs in lakes and in the Allegheny river and is to be known by its slenderer face and gill covers, its smaller size, generally smooth scales and the absence of dark spots on the body and fins. It should be remembered, however, that the species is extremely variable in these particulars, and all of the names based on such characters have been generally discarded. 
The garpike attains to a length of 5 to 6 feet, of which the head and snout usually form about one third. The body is comparatively slender, equaling about one twelfth of the entire length.

This species is more abundant in the Great lakes and large streams than in the small rivers. It is emplratically a fish of prey and extremely tenacious of life. It spawns in shoal water, or in the streams, in the late spring and early summer months. Occasionally taken from the northern end of Cayuga lake, but not so numerous as formerly.

The garpike is said to be nowhere used for food, because its flesh is tough and is believed to be unwholesome. I have seen it, howerer, with the bill cut off and the skin removed, offered for sale in the market at Washington D. C.

\section{Lepisosteus platostomus Rafinesque}

\section{Short-nosed Gar}

Lepisostens platostomus Rafinesque, Ichth. Ohien. 72, 1820; Kirtland, Bost. Jour. Nat. Hist. IV, 20, 1844; Jordan \& EverManN, Bull. 47, U. S. Nat. Mus. 110, pl. XxII, fig. 49, 1896.

Lepidostens platystomus Günther, Cat. Fish. Brit. Mus. VIII, 329, 1870; Jordan \& Gilbert, Bull. 16, U. S. Nat. Mus. 91, 1883.

Lcpisosteus platyrhincus DE KAx, N. Y. Fauna, Fishes, 273, pl. 43, fig. 137, $18+2$.

The short-nosed garpike has an elongated body, its depth being contained seren and one half times in the length; the length of the head is less than one third of the length of body to base of tail; distance from eye to tip of snout greater than from eye to posterior edge of opercle; upper jaw slightly longer than the lower; both jaws with many long, sharp teeth. Iorsal and anal fins placed far back, near the tail; rentrals in middle of length. D. 8 ; A. 9 . About 55 rows of scales between head and candal. Fins all more or less black spotted. The specimen described, no. 3241, U. S. National Museum, from Cleveland O., is 12 inches long.

The short-nosed gar, because of its shorter snout, which eren in young specimens does not much exceed the rost of the head in length, has been considered as representing a separate subgenus, Cylindrosteus of Rafinesque. 
This fish seldom exceeds 3 feet in length. Its habits are presumboly the same as those of the long-nosed gar, and it is equally worthless for food. It may be readily distinguished from the long-nosed species by the shape of its snout and by its more robust form.

The short-nosed gar inhabits the Great lakes and the Ohio and Mississippi valleys. It is more abundant in the southern part of its labitat. It was not recorded from waters of New York by either Mitchill or De Kay.

Order CYCLOGANOIDEA

\section{Bowfins}

Family AMIIDAE

\section{Boufins}

\section{Genus Amra Linnaeus}

Body oblong, compressed behind, terete anteriorly; head subconical, anteriorly bluntislı, slightly depressed, its superficial bones corrugated and very luard, scarcely covered by skin; snout short, rounded; lateral margins of upper jaw formed by the maxillaries, which are divided by a longitudinal suture; jaws nearly even in front; cleft of the mouth nearly horizontal, extending beyond the small eye; lower jaw broad, U-shaped, the rami well separated; between them a broad bony plate, witl radiating striae, its posterior edge free; jaws each with an outer serics of conical teeth, behind which in the lower is a band of rasplike teeth; bands of small teeth on the vomer and ptery. goids; palatines with a series of larger, pointed teeth; premaxillaries not protractile; tongue thick, scarcely free at tip; nostrils well separated, the anterior with a short barbel; suborbital rery narrow; a bony plate covering the cheek, similar to the plates on the top of the head; operculum with a broad dermal border; branchiostegals 10 to 12; no pseudobranchiae or opercular gill; no spiracle; gills four, a slit behind the fourth; gill membranes not connected, free from the isthmus; two peculiar, long, lanceolate, obliquely striate appendages on each side of the isthmus, projecting backward and corered by the branchiostegal rays, 
the anterior wholly adnate to the isthmus, the posterior free behind; isthmus scaleless; gill rakers stoutish, very short; scales of moderate size, rather firm, cycloid, with a membranous border; lateral line present; dorsal fin long and low, nearly uniform; the posterior rays not much higher than the others; tail somewhat heterocercal (more so in the roung), convex behind; no fulcrums; anal fin short and low; pectoral and ventral fins short and rounded, the ventrals nearer anal than pectorals; rertebrae amphicoelian or double concave, as usual among fishes, none of them specially modified; abdominal and caudal parts of the rertebral column subequal; air bladder cellular, bifid in front, lunglike, connected by a glottis with the pharynx, and capable of assisting in respiration; stomach with a blind sac; no pyloric caeca; no closed oviduct; intestine with a rudimentary spiral valve. Fresh water's of the United States. (After Jordan and Evermann)

\section{Amia calva Lïnnaeus}

\section{Boufin; Mudfish}

Amia calva Linnaeus, Syst. Nat. ed. XII, 500, 1766; Günther, Cat. Fish. Brit. Mus. VIII, 325, 1870; De Kar, N. Y. Fauna, Fishes, 270, 18+2; Jordan \& Gilbert, Bull. 16, U. S. Nat. Mus. 94, 18S3; Jordan \& Everdian, Bull. 47, U. S. Nat. Mus, 113, 1896; Dean, 4th Ann. Rep't, N. Y. Comm. Fish, Game, Forests, 246-56, pl. of \& o and fig. I-VIII, 1899.

A mia orcidentalis DE KAy, N. Y. Fauna, Fishes, 269, pl. XXXIX, fig. 125, $18+2$.

The mudfish has a well rounded, robust body; head more or less conical; top covered with hard bony plates; body entirely covered with cycloid scales. The mouth is large; maxilla extending far past eye. Depth of body equals three fourths of length of head and is contained slightly more than five times in length of body. Distance from tip of snout to origin of dorsal equals one third of the total length including tail, the dorsal fin beginning over the end of pectoral; length of dorsal base equal to twice length of head; anal base very short, nearly one third of lengtl of head. Strong conical teeth in the jaws; in the lower jaw there is a band of finer teeth behind the outer row 
of large ones. The vomer, palatine and pterygoid bones are finely toothed. A small barbel at anterior nostril. Lateral line continuous; through 62 scales. There are seren rows of scales between dorsal and lateral line and 11 or 12 from lateral line to ventral. D. $50 ;$ A. 10 or 11.

The color in life is dark olive, the sides with greenish reticulations, the belly whitish; round dark spots on the lower jaw and gular plate. The male has a roundish black spot with an orange border at the base of the caudal fin.

The bowfin has various common names, among them mudfish, dogfish, lawyer, grindle, and John-a-grindle. Its range is as extensive as its character is generally worthless. It is found in the Great lakes and tributary streams, in the Olio and Mississippi valleys southward to Texas, and in eastern waters from Pennsylrania to Florida.

The female bowfin is larger than the male, reaching a length of 2 feet, while the male seldom exceeds 18 inches. The male is still further distinguished by the presence of a large black spot or spots, margined with orange or crimson, at the base of the tail fin. The female also has the caudal spot, but very faintly developed. The greatest recorded weight of this fish is 12 pounds.

Habits. This is one of the most voracious of all fishes. It feeds on all other fish of suitable size and also destroys other animals within reach. The capture of the bowfin by means of the trolling spoon has recently come into greatly increased favor with anglers because of the game qualities of the fish and its wonderful tenacity of life. The species has been known to live out of the water, exposed to the sunlight, 12 hours or more. The young may be kept in an aquarium or other receptacle without change of water for months. The sparning season of the bowfin is in May and June, and stagnant sloughs are favorite localities for this purpose. The eggs and young are protected by the parents, and the young remain in the pools after the falling waters cause the departure of the adults. Dr Estes, who has made the best observations on the reproduction of this 
species, states that the little ones are protected in the mouth of the parent when suddenly alarmed. The jumping of the bowfin is one of its most characteristic habits. Dr Estes saw them turn complete somersaults while in the air.

The bowfin is not a food fish, its flesh being soft and umsavory; yet Dr Goode found them highly esteemed as a sweet morsel by the negroes of the south. The young are in great demand as bait for pilie and pickerel, and both these and the adults are interesting for the aquarium because of their colors, the ease with which they endure captivity, the peculiarities of their anatomic structure and their affinities with extinct ganoids.

It is seldom taken near Ithaca and is not common at the norther'n end of Cayuga lake.

\section{Series TELEOSTEI}

Bony Fishes

Subclass OSTARIOPHYSI

Order NEMATOGNATHI

Catfishes

Family SILUTIDAE:

\section{Catfishes}

\section{Genus Feцiситияs Swainson}

Body rather elongate, little compressed; head depressed, broad above; month large, the upper jaw the longer; teeth all villiform, those on the vomer and palatines forming a more or less perfectly crescent-shaped band; barbels four; maxillary barbels bandlike, rery long; two short barbels on chin; nostrils close together, the posterior with a valve; nuchal region with a granulated, bony buckler; fontanelle large, well forward; gill membranes somewhat connected; dorsal fin short, in frout of ventrals, with one sharp spine and seven rays; pectorals with a similar spine; pectoral spines, and sometimes dorsal spines also, ending in a long, striated, bandlike filament; anal fin emarginate, shorter than candal part of rertebral column; adipose fin mod- 
erate, free behind; caudal fin widely forked; ventral rays six. Species all marine; in tropical American waters.

\section{Felichthys marinus (Mitchill)}

\section{Sea Catfish; Gaff Topsail}

Silurus marinus Mitchill, Traus. Lit. \& Plil. Soc. N. Y. I, 433, 1813.

Galcichthys marinus DE KAx, N. Y. Fauna, Fishes, 178, pl. 37, fig. 11S, 1812.

Alurichthys marinus Günthen, Cat. Fish. Brit. Mus. V, 17s, 1St4; Jondar \& Gilbert, Bull, 16, U. S. Nat. Mus. 111, 1883.

Felichthys marinus Jordan \& EvermaxN, Bull. 47, U. S. Nat. Mus. 11S, pl. XXIII, fig. 52, 1896; Simth, Bull. U. S. F. C. XVII, 90, 1898.

Body somewhat compressed, moderately elongate, its depth at dorsal origin two ninths of length to base of middle caudal rays; caudal peduncle slender, its least depth little more than one third of greatest depth of body; head short, snout rounded, length of head one fourth of total length to base of middle caudal rays; occipital buckler small, oblong, nearly uniform in breadth; band of palatine teeth nearly continuous, variable; maxillary barbel, pectoral fin and dorsal fin about equal in length; eye oblong, small, one fifth length of head; snout about one fourth of length of head; maxillary barbel reaches nearly to rentral origin; pectoral filament about to rent; dorsal, when laid back, almost to adipose fin; ventral origin slightly nearer tip of snout than base of middle caudal rays; caudal lobes unequal, the upper two sevenths of length to middle caudal rays, the lower as long as the head; adipose fin small, one third higher than wide, its length contained three and two thirds times in that of head; anal base one sixth total length to base of middle caudal rays, longest anal ray two and one third times in head; rentral one half as long as head. D. I, 7 ; 1. 2:3 (16 dereloped); P. I, 12; V. I, 5; B. 6. Vetebrae $20+30$. Color, glossy bluish above, silvery or mill white below.

The sea catfish is found from Cape Cod to Texas; common southward. Mitchill says it " is an exquisite fish for eating;" but the species is generally not ralued for food. De Kar also was informed by persons who had eaten it that the fish has an 'xquisite flaror. He states that it is frequently abundant in 
Communipaw creek, on the Jersey side of the harbor of New York. It swims frequently with its long dorsal above the surface, in the manner of sharks, and imitates those animals in roracity. Mitchill had a specimen 20 inches long.

At Woods Hole Mass., according to Dr Smith, the species is quite rare, and few have been seen recently; one was canght in a trap at Menemsha in $\mathbf{1 8 8 6 .}$

\section{Genus Hexanematichthys Bleeker}

Body moderately elongate, subterete; head depressed, armed with a bony shield above, behind which projects an occipital shield; a smaller, crescent-shaped shield at the base of the dorsal spine; these shields usually exposed but sometimes corered by the skin; skull with a fontanel; mouth moderate, the upper jaw the longer; teeth rilliform or granular, in a band in each jaw; teeth in one or two patches each on the vomer and palatines, the palatine patches without a backward projecting angle on the inmer margin; palatine teeth fixed; barbels six (no nasal barbels), close together, the posterior with a valve; maxillary barbels short, terete; eyes with a more or less free orbital margin, the upper edge sometimes adnate; dor'sal fin short, in front of the ventrals, with a sharp spine and about seven rays; adipose fin well developed, posteriorly free; caudal fin deeply forked; anal fin short; pectorals with spine; rentral rays six; skin smooth, naked, except on the occipital and nuchal regions, where it is usually confluent with the surface of the bony buckler's. Species marine.

\section{Hexanematichthys felis (Linnaeus)}

\section{Sea Catfish}

Silurus felis Linneaus, Syst. Nat. ed. XII, 503, 1766.

Arius milberti Güntier, Cat. Fish. Brit. Ius. V, 155, 1861.

Arius equestris Güntiren, 1. c. 173, 1864; BAIrd \& GinARD, Ichth. U. S. \& Mex. Bound. 32, pl. 15, 1859.

Arius felis and equestris Jordan \& Gilbert, Bull. 16, U. S. Nat. IIus. 110 , 1883.

Galeiehthys felis SмIтн, Bull. U. S. F. C. XVII, 90, 1898.

Hexanematichthys felis Jordan \& Evermann, Bull. 47, U. S. Nat. Mus. 47, 128, pl. XXIII, fig. 53, 1896. 
Body tapering, elongate, terete, its depth at dorsal origin one fifth of length to base of middle candal rays; caudal peduncle short, its least depth two fifths of greatest depth of body; head rather elongate, pointed, its length contained three and two thirds times in total to base of middle caudal rays; occipital process with a median keel, about one third of length of head, its tip convex; fontanel forming a narrow groove; top of head comparatively smooth; maxillary barbel three fourths as long as the head; longest mental barbel little more than one half of length of head; eye oblong, placed high, its length one half the length of snout, which is one third the length of head; dorsal origin somewhat behind middle of pectoral fin; dorsal base about equal to snout, highest ray slightly exceeds greatest depth of body; pectoral fin reaches about to below end of dorsal base; ventral origin midway between tip of snout and end of middle caudal rays, length of fin two and one third times in head. Distance from rent to anal origin equals longest anal ray. Length of anal base equals one half the length of head. Caudal lobes unequal, the upper one fourth longer than lower. D. I, 7; P. I, 6 ; A. 16 (13 developed); V. I, 5 .

Color steel blue, sides and belly silvery, lower parts pale. Cape Cod to Texas; common southward along the sandy coast.

Cuvier and Valenciennes received a specimen from New York, forwarded by Milbert. Of its occurrence at Woods Hole Mass. Dr Smith made the following record: "Reported to have been common in spring in Vineyard sound many years ago, being often taken with cod; now (1S9S) rery rare, and only occasionally observed since the fish commission station at Troods Hole was established. A specimen was taken in 1887 , since which time none has been reported."

\section{Genus ictalurus Rafinesque}

Body slender, elongate, compressed posteriorly; head slender, conical; superoccipital bone or process prolonged backward, its emarginated apex receiving the acuminate anterior point of the second interspinal, thus forming a continuous bony bridge from 
the head to the dorsal spine; mouth small, terminal, the upper jaw longer; teeth subulate, in a short band on each jaw; dorsal fin high, with one long spine and usually six rars; adipose fin over posterior part of anal; anal fin long, with 25 to 35 rays; ventral fins each with one simple and seven branched rars; pectoral fins each with a stout spine, retrorse serrate within, and about nine rays; caudal fin elongate, deeply forked, the lobes pointed, the upper the longer. Coloration pale or silrery, usually with dark spots on the sides. Fresh waters of North America, specially in river channels and ripples in large streams.

43 Ictalurus punctatus (Rafinesque)

Channel Cat; Spotted Cat

Siturus punctatus Rafinesque, Am. Month. Mag. 359, Sept. 1818, fide Jordan.

Ictalurus punctatus Jordan, Bull. Buffalo Soc. Nat. Hist. 95, 18т6; Man. Tert. 300, 1Si6; Jordan \& Gilmert, Bull. 16, U. S. Nat. IIus. 108, 1S83; Jordan \& Evermann, Bull. 47, U. S. Nat. Mus. 134, pl. XXV, fig. 58,1896 .

Amiums cauda-furcatus Güstmer, Cat. Fish. Brit. Mus. V, 102. 1864.

The body of the spotted catfish is rather long and slender, the depth contained fire times in the length without caudal and equal to the length of the dorsal spine. The head is moderate, convex above, its length being slightly less than one fourth the total length. The maxillary barbels are very long, longer than head; eye moderate, five and one half in head; pectoral spine two thirds of length of head; humeral process long and slender, one half the length of pectoral spine; adipose fin well developed; candal deeply forked. The least depth of the caudal peduncle equals one half the depth of body at last dorsal ray. D. I, $6 ;$ A. $24 ;$ V. I, S.

This species is variously styled the channel cat, white cat, silver cat, blue cat and spotted cat. It is found over a vast extent of country comprising the Mississippi and Ohio valleys and the Great lakes region. In the eastern states it is absent from streams tributary to the Atlantic, but occurs from Vermont southward to Georgia, westward to Montana and southwestward to Mexico. In Pennsylvania it is limited to the Ohio and its affluents. 
The adults of this species are bluish silvery, and the young are spotted with olive. It is one of the handsomest of the family of catfishes and an excellent food fish. The spotted cat grows to a length of 3 feet and a weight of 25 pounds. It is extremely rariable in color and in number of fin rays, and has, consequently, been described under more than 20 different names. It is most abundant in large clear streams. This species is less hardy than most of the other catfishes.

\section{Genus anciunus Rafinesque}

Body moderately elongated, robust anteriorly, the caudal peduncle much compressed; head large, wide, obtuse; superoccipital extended backward, terminating in a more $\mathrm{Or}^{\circ}$ less acute point, which is entirely separate from the second interspinal buckler; skin corering the bones thick; eyes rather small; mouth large, the upper jaw usually the longer; teeth in broad bands on the premaxillaries and mandibles; band of upper jaw convex in front, of equal breadth, and without backward prolongation at the angle; dorsal orer the space between pectorals and ventrals, higher than long, with a sharp spine and about six branched rays; adipose fin short, inserted orer the posterior half of the anal; anal fin usually short, with 20 or 21 rays, but varying from 15 to 35 if certain fork-tailed species really belong to the genus; caudal fin short, truncate in typical species, more or less forked in forms approaching I c t a 1 u r us; rentrals with one simple and seven branched rays; pectoral fins each with a stout spine, which is commonly retrorse serrate behind; lateral line usually incomplete; species numerous in nearly all fresh waters of the eastern United States.

\section{Ameiurus lacustris (Walbaum)}

\section{Lake Catfish}

Gadus lacustris Walbaud, Artedi, Gen. Pisc. 144, 1792. A mimus borcalis Günther, Cat. Fish. Brit. Mus. V, 100, 1 Sfit.

Ictalurus lacustris Jordax \& Gilbert, Bull. 16, U. S. Nat. MIus. 10S, $18 \$ 3$. Ictalurus nigricans Jonndx \& GILBERT. Bull. 16, U. S. Nat. Mus. SS2, $18 S$ ? Pimelodns nigricans De KAY, N. Y. Fauna, Fishes, 1S0, pl. 62, fig. 170, 1812. Amciurus lacustris Jordan \& Everaraxi, Bull. 47, U. S. Nat. Mus. 137, 1896. 
The great catfish has a stout body, a broad and much depressed head and a wide mouth. The depth of the body is contained five times in total length, without caudal; the head equals more than one fourth of this length. Maxillary barbel as long as anal base, almost as long as the head; eye rather small; dorsal base short, one half the hight of fin; adipose fin well developed; caudal not deeply forked; pectoral spine as long as dorsal spine, one half the length of head; least depth of caudal peduncle less than one half the greatest depth of body. D. I, 5 to $6 ;$ A. 25 ; V. I, S.

This is the great fork-tailed cat, Mississippi cat, Florida cat, flannel-mouth cat and great blue cat of various writers. It is also called mud cat in the St Johns river, Fla. The species is highly rariable, as we should suppose from its wide distribution.

In 1879 Prof. Spencer F. Baird received from Dr Steedman of St Louis a Mississippi river catfish weighing 150 pounds and measuring 5 feet in length. The writer described this fish as a new species related to the great black catfish of the Mississippi valley, $A \mathrm{min \textrm {r }}$ u i $\mathrm{g} \mathrm{ic}$ a $\mathrm{ns}$. At the present time it is somewhat doubtful whether or not this is merely an overgrown individual of the species under consideration, and the matter must renain in doubt till smaller examples of $\mathrm{Amiurus}$ p onderosus have been obtained.

The great fork-tailed cat is a native of the Great lakes and the Ohio and Mississippi valleys, and in the sonthern states its range extends southward to Florida; northward it ranges to Ontario.

This catfish reaches a weight of 100 pounds or more, and, if it include the giant form above referred to, we may place the maximum weight at more than 150 pounds. Dr Steedman was informed by an old fisherman that the heariest one he had ever seen weighed 198 pounds, but it is doubtful that such large individuals are to be taken, at the present time. In Lake Erie this species usually weighs from 5 to 15 pounds, and the largest specimens reach 40 pounds. 
The labbits of this fish are luesumably abont the same as those of oflue speries of the family. On account of the great sime of the fish it natmally prefers lakes and large rivers. It is a bottom feeder and will take almost any kind of bait. This species is monderfully tenacious of life. It spawns in the spring and protects its young, which follow the parent fish in great schools. Dr Theodore Gill has reviewed in Forest and stream the suliject of the catishes care of their youmes.

This is a valued food species, though not a choice fish. In Lake Erie, according to the Review of the Fisheries of the Givent Lakes recently publisled hy the I. S. Fish Commission. Ilue at fish rank next to whitefish in number of pounds taken.

In Lake Erie calfish are taken chiefly by means of sot lines, and the fishing is best during the months of June, July and August. The method of fishing is thus described in the reriew just refered to. "The apparatus consists of from "200 to 1000 hooks attached by short lines to a main line, which is from 5 to 27 fathoms long, according to the place in which set, and is held in place by poles or stakes pushed into the mud. The lines are nsually set in the lake, but occasionally slort ones are fished in the bayous and marshes. Catfish are taken with a bait of herring. Cor egonus a r tedi, or grasshoppers, and are mostly used in the families of the fishermen and their neighbor's or sold to perdlers. . The size of the catfish langes from 5 to 25 pounds, arevging $S$ or 10 pounds." In some parts of take Erie the set line fishery for catfish begins Ipril 1\%. Some of these lines have as many as 2000 hooks. In Toledo theso fish bring $4 \frac{1}{2} \mathrm{c}$ a pound. The pound nets also take a good many catfish in the spring and fall. Erie receires its smplyly of eatfish from fishermen who operate in the lake from Eres to Elk Creck with sut lines duriug the summer months. De Kay hal the species from Buffalo, where he saw specimens weighing from 25 to 30 pounds, and heard of individuals weighing 80 pounds. He states that it is usually captured br the spear. 


\section{Ameiurus natalis (Le Sueur)}

\section{Tellow Cat}

Pimelodus natalis Le Sugur, Mém. Mus. d'Ilist. Nat. V, 154, 1 S19.

Pimelodus eupreus De KíAY, N. Y. Fauna, Fishes, 1S7, 1842. (name only) A miurus natalis Günt11Er. Cat. Fish. Brit. Mus. V, 101, 1864; Jordix \& Gilbert, Bull. 16, U. S. Nat. Mfus. 105, 1883.

A meinrus natalis Jordax \& Evermaxn, Bull. 47, U. S. Nat. Mus. 139, 1596.

The rellow catfish is robust, and has a rather broad head. The mouth is wide, with the mpper jaw usually longer than the lower, sometimes equal. The dorsal profile gradually ascends from the snout to the dorsal spine. The deptl of the body at dorsal spine is contained four and two third times in the total length to base of tail. The lengtl of the liead is contained three and two third times in the body length, and equals length of anal base. Eỵe moderate; maxillary barbel reaching end of head; humeral shield little developed; dorsal and pectoral spines strong, shorter than soft rays; hight of dorsal equal to twice the length of its base; adipose fin long as in $\mathrm{N}$ o t u r us, opposite to and longer than anal; caudal rounded. D. I, 6 ; A. 24; V.I., 8 .

The sellow cat, or chubby cat, is found from the Great lakes to Virginia and Texas. It has many rarieties; three of which are mentioned by Prof. Cope as occurring in Pennsylvania, two of them in the Ohio river and its tributaries and the third in Lake Erie. The species is not credited to the region east of the Alleghanies. Dr Meek saw only a single specimen from Cayuga lake.

The length of the yellow cat sometimes reaches 2 feet but arerages much less.

Nothing special is recorded about the habits of this species. It is most abundant in sluggish streams.

\section{Ameiurus vulgaris (Thompson)}

\section{Long-jaued Catfish}

Pimelodus vulgaris Thompson. Hist. Vermont, 138, $18+2$.

Amiurus vulgaris Nelsox, Bull. Ills. Mus. Nat. Ilist. 50, 1876; Jordan \& G1Lbert, Full. 16, U. \$. Nat. Mrus. 105, 1883.

Amiurus dekayi Jordan, Mau. Vert. 302, 1876; Goode, Fish. \& Fish. Ind. U. S. I, pl. 234, 1884; BEAN, Fishes Penna. 15, pl. 18, fig. 24. 
Amcinus vulgaris Jomoñ \& Erermaxx, Bull. 47. U. S. Nat. Mus. 140, 1896.

This catfish has a stont body; its depth is one fourtl of the total length without candal. The head is contained about three and three fouth times in this length. Ere rery small; mouth large; jaws equal or sometines lower jaw projecting; barbels long; maxillary barbel as long as head. The length of the dorsal base is less than one half that of the anal, while its light is fire sixtlıs of the same length; adipose fin well dereloped. The pectoral spine is stout and about two thirds as long as the fin. Candal sfuare; anal rounded; loast deptl of caudal contained two and one third times in greatest depth of bod!. N. I, 6 ; A. $18(20) ; T^{r} . \mathrm{I}, \mathrm{S}$.

The long-jawed catfish is found in the Great lakes region and Westwarl to Manitoba. It is believed to be rery nearly related to the common catfish, A. ne bulosus, but its projecting lower jaw will serve to distinguish it. This character, howerer, me know by experience is not so satisfactory as it might be.

The species reaches the length of 18 inches and the weight of 4 pounds. It is occasionally taken in the Ohio river, but is more abundant in Lake Erie. Jordan and Erermann state its range to be from Termont to Minnesota and Illinois, chicfly northward. The L. S. National Musemm has it from Manituba. I) Meek found a single specimen which was caught near Ithaca among more than 100 of the common bullheads. It seems to be rare in that basin. Thompson, who described the fish, had specimons from Lake Champlain. The long-jamed catfisle is similar in all respects exeept its flujecting lower jaw to the enmumon

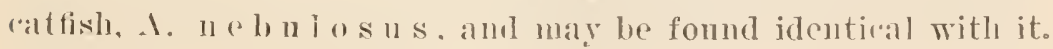

\section{Ameiurus catus (Limnaeus)}

\section{White Cat; Chamel Cat}

Silurus catus Lixxaeus, Syst. Nat. ed. $\mathbf{X}, 305,175$ S.

Pimelodus atrarius DE KAY, N. Y. Fauna, Fishes, 1SJ, pl. 36, fig. 116, 1S42. Ictalurus albillus Jordax \& GILbert, Bull. 16, U. S. Nat. Mus. 107, 1SS:? Irtalums Inphius JoRDAN \& GILBERT, 1. c. 10T. $18 \$ 3$. 
Amiurus albidus JondAx, Bull. 10, U. S. Nat. Mus. 84, 187t, figs. 15 \& 16 , 187т; BEAN, Fishes Penna. 14, pl. 18, fig. 23, 1893.

Amciurus catus Jordax \& Evermaxx, Bull, 47. U. S. Nat. Mus, 126, 1S96.

The body is stont, its deptle equal to lengilu of luad, and contained four lines in the tolal length to base of caudal fin. The maxillary barbols reach posterior end of head; mandibulary barbels sllorter; lumeral process, above pectoral, lualf lengtl of pectoral spine, very rough; dorsal fin short, inserted nearly midway bedweon tip of smout and adipose dorsal; adipose fin well developed; caudal fin slightly forked, the npper lobe longer ; anal fin long, one fifth to one fourth of tolal length to base of caudal. D. I, 6; A. 19 to 22. Pale olive bluislu, silvery below without dark spots, but sometimes with mottlings or blotches. New York to 'Texas, in coastwise streams and swamps. Introduced into California and now abundant there.

This is the white cat or cliannel cat, in I'liladelphia distinguished as the Schuylkill cat. The channel cat is one of the most abundant of its family in the Potomac river. It is abundant in the Susquehanua and common in the Schuylkill.

This species reaches a length of 2 feet and a weight of 5 pounds. It is extremely variable with age. Old examples have the mouth so much wider than it is in the roung that the have been described as a distinct species. The big-mouthed cat of Cope is now considered to be the old form of the white cat. The habits of this species agree with those of other species already mentioned. The name channel cat suggests a farorite haunt of the fish.

As a food fish it is highly prized.

Eugene Smith ${ }^{1}$ says this catfish occurs in all the larger streams subject to the tide in the vicinity of New York city. The caudal is furcate. The anal has 20 or more rays.

It is frequently caught on set lines with liver or killy bait and bites best at night. The flesh is much better flavored than that of $\mathrm{A}$. ne bulos us.

${ }^{1}$ Linn. Soc. N. Y. Proc. 1897. no. 9, p. 11 , 


\section{Ameiurus nebulosus (Le Sueur)}

\section{Horned Pout; Bullhead}

Pimelodus nebulosus LE Sueur, Mém. Mus. d'Hist. Nat. V, 149, 1819.

Pimelodus catus DE KAY, N. Y. Fauna, Fishes, 182, pl. 37, fig. 119, 1842. A miurus catus Jordan \& Gilmert, Bull. 16, U. S. Nat. Mus. 104. 1883. Silurus catus MrTchill, Trans. Lit. \& Phil. Soc. N. Y. I, 433, 1815. (not Silurus catus Linnaeus)

Amiurus nebulosus Bean, Fishes Penna, 16, pl. 19, fig. 25, 1893.

Ameiurus nebulosus Jordan \& EvermanN, Bull. 4t, U. S. Nat. Mus. 140, 1896.

The common catfish has a rery stout body, broad head and a short stout caudal peduncle. The depth of body about equals length of head, and is contained from three and one half to four and one half times in the length. Barbels eight; maxillary barbels as long as head; dorsal profile from tip of snout to dorsal fin straight and rather steep; mouth wide and terminal; teeth awl-shaped, in broad bands on the intermaxillaries and dentaries; dorsal situated in fiont of middle of body; short and high; adipose fin stout; anal large, its base equaling length of head; caudal square or slightly emarginate. D. I, 6 ; A. 20-22; P. I, 6.

This is known as the common catfisl, bullheari, hornpout, bullpout, and minister.

This species has a wider distribution than the white cat, its range including New England and extending southward to South Carolina, west to Wisconsin and southwest to Texas. It has also been transferred from the Schuylkill to the Sacramento and San Joaquin rivers, Cal. where it has multiplied so rapidly that it is now one of the most common fishes of those streams. This is the most abundant catfish in Lake Erie and its tributaries.

The species reaches a maximnm length of 18 inches and a weight of 4 pounds, but the arerage size of market specimens is much smaller. In the lower waters of the Susquehanna color rarieties of this species are not uncommon. One of them appears to be the same as the $\mathrm{Amiurus}$ marmoratus of Holbrook; this supposed color variety is found also from Illinois to Florida. The lower Susquehanna has furnished also some singularly colored examples of this fish, distinguished by 
large areas of jet black combined with lemon and white. These freaks are among the most interesting and beautiful observed in this family of fishes.

From Jordan's ILanual of the Tertebrates I quote Thoreau's account of the habits of this species:

The horned pout are "dull and blundering fellows," fond of the mud, and growing best in weedy ponds and rivers withont current. They stay near the bottom, moving slowly about with their barbels widely spread, watching for anything eatable. They will take any kind of bait, from an angleworm to a piece of a tin tomato can, without coquetry, and they seldom fail to swallow the hook. They are rery tenacious of life, "opening and shutting their mouths for half an hour after their heads hare been cut off." They spawn in spring, and the old fishes lead the young in great schools near the shore, seemingly caring for them as the hen for her chickens.

The species was obtained in Swan river at Patchogue N. Y. Ang. 12, 189S. Young were seined in Bronx river in August. Larger individuals were sent from Canandaigua lake and Saranac lake in November. Sereral albiuos were obtained from the Hackensack meadows, N. J., in August 1897. In three months they grew from 3 inches to 6 inches in length. In captivity the fish feed freely on chopped hard clams and earthworms and, occasionally, liver.

the following notes are from Engene Smith, in Proc. Linn. Soc. N. Y. 1897, p. 11-12.

Tery variable in color, from dark blackish and olive to brown and yellowish above, becoming lighter below, and often clouded on the sides. Those from tidal or running water are lighter colored than those from stagnant places or ponds.

The largest specimen found by me in the near vicinity of New Tork measured $13 \frac{1}{2}$ inches in length and weighed 1 pound 2 ounces.

At the end of the third year this fish is perhaps fully matured. The ripe cggs are of the size of large pin heads and are of an orange color; the very young fishes look like little black toad tadpoles. The spines are strongly developed at an early age. The old fisl accompanies the brood for a certain time, always swimming around the swarm of young in order to keep them together. When alarmed the parent dashes off, followed by the whole swarm. 
Dr Meek found the species very abundant throughout the entire Cayuga lake basin. Dr Evermann and Barton A. Bean obtained the following specimens in the St Lawrence river basin in 1894.

1, St Lawrence river, Cape Vincent N. Y. June 21.

:, Racket river, Norfolk N. Y. July 18.

Dr Erermann also collected specimens at the following localities of the Lake Ontario region in 1894.

Stony creek, Henderson Harbor, July 3, 4

Black river, Huntingtonville, July う

Iud creek, Cape Vincent, June 25

Mouth Salmon river, July 25

Chaumont river, July 10

Creek, Pultnejville, Aug. 7

Mouth Little Salmon creek, July 25

Sandy creek, North Mamlin, Aug. 20

Long pond, near Charlotte, Aug. 17

Stony Island, July 2, 3

Lakeriew hotel, 7 m. n. e. of Oswego, July 17

Marsh ereek, Pointbreeze, Aug. 21

49 Ameiurus nebulosus marmoratus (Holbrook)

\section{Marbled Cat}

Pimelodus marmoratus Holbrook, Jour. Ac. Nat. Sci. Phila. 54, 1855. Amiurus marmoratus Jordan \& Gilbert, Bull. 16, U. S. Nat. Mus. 104, 1883. Ameiurus nebulosus marmoratus Jordan \& Evermanx, Bull. 47, U. S. Nat. Mus. 141, 1896.

Body moderately elongate, its depth about one fourth total length to caudal base; slope of profile very steep; jaws equal or subequal; dorsal fin high, its spine more than one half as long as head, and nearer to adipose fin than to tip of snout; head long, three and one fourth times in total length to caudal base; barbels long; anal rays 21; body much mottled with brown, greenish and whitish. Lowland streams and swamps from New York to southern Indiana and Florida. The type of the mar. m or a tus of Holbrook was from South Carolina. 


\section{Ameiurus melas (Rafinesque)}

\section{Black Bullheal; Broun Catfish}

Silurus melas Rafinesque, Quart. Jour. Sci. Lit. Arts. Lond. 51, 1820.

Pimelodus pullus De IAY, N. Y. Fauna, Fishes, 184, pl. XXXVII, fig. 117, $18+2$.

Amiurus pullus Grut, I'roc. Bost. Soc. Nat. IIist. 44, 1S62; Jordan, Bull. 10,

U. S. Nat. Mus. 93, figs. 46, 47, 1S77; Goode, Fish. \& Fish. Ind. U. S.

I, pl. 233, fig. 1, 1S84; BeAn, Fishes Penna. 16, 1893.

A meiurns melas Jordan \& Evermann, Bull. 47, U. S. Nat. Mus. 141, 1896.

The body of the black bullhead is stout, short and deep. Its depth is contained about three and one half times in its length to tail; in very deep examples but three and one fifth times. The length of the head is contained three and one half times in this length. The head is broad, the dorsal profile straight and rather steep from tip of snout to dorsal fin; eye rather small; barbels long; caudal peduncle stout. 1)orsal I, 6; the spine? strong and sharply pointed. The hight of the dorsal fin equals one half the length of head. The anal has 18 rays; its base is two and one half times as long as dorsal base. The pectoral fin has one sharp spine and seven rays. Tail truncate; adipose fin well developed; teeth very fine, awl-shaped and in broad bands. Its color is usually blackish or dusky brown, approaching to black, while the lower parts are bluish white. The fins are black, tinged with red, and the barbels are black. The color is subject to considerable variation. The black bullhead reaches the length of 1 foot. It is found in the Great lakes region and in the Mississippi valley, westward to Kansas and southward to Texas.

This species was known to De Kay as the brown catfish. His specimens were from Lake Pleasant and Lake Janet, N. Y.; and he states that it is also very common in many other lakes of northern New York, where its principal use is to serve as bait for the lake trout. Dr Jordan had it from the Genesee river. Dr Evermann obtained a specimen in Mill creek at Sacketts Harbor N. Y. July 2, 1894, and doubtfully referred to this species a young individual collected in Sandy creek, at North Hamlin N. Y. Aug. 20, 1894. 


\section{Genus Nowurus Rafinesque}

Body moderately elongate, robust except in caudal part, which is much compressed; head flat and broad; mouth terminal, broad; teeth in broad villiform bands on premaxillaries and dintaries; teeth of upper jaw prolonged backward into an elongate, triangular extension; adipose fin adnate to the back; a poison gland at the base of the pectoral spine. Represented by a single species inhabiting rivers and channels.

\section{Noturus flavus Rafinesque}

\section{Stone Cat}

Toturus flavus Rafinesque. Ichth. Ohien. 68, 1820; Stoper, Syn. Fish. N. A. 15t, 18t6; Jordan \& Gileert, Bull. 16, U. S. Nat. Mus. 100, 1S\$3; Günther, Cat. Fish. Brit. IIus. Y, 10t, 1864; Bens, Fishes Penna. 1S, 1893; Jordan \& Evemant, Bull. 47, U. S. Nat. Mus. 144, 1896, pl. XXVII, fig. 63, 1900.

P'imelodus flacus DE KAY, N. Y. Fauna, Fishes, 187, 1812 (after Ǩrtland).

The stonceat has a moderately elongate hody, whose great. rst depth and width are nearly equal; the tail is much compressed, and the head flat and broad. The greatest depth of the body is nearly one fifth of the total length without the caudal; the least depth of the caudal perluncle equals nearly one half the length of head. 'The mouth is terminal, horizontal, its width equal to postorbital part of head and to length of maxillary barbel; longer barbel on chin not quite one half as long as the head. Nasal barbel when laid back reaches end of eye. The width of the band of teeth in the upper jaw equals one thiod the length of head; the backward prolongation is little longer than the eye. The distance between the eyes equals length of snout and eye. The snout is one half as long as the postorbital part of the head. The dorsal origin is at a distance from tip of snout nearly equal to one third of the total length without caudal. The dorsal base is one half as long as the head. The spine is very sharp and as long as the snont. The longest ray is nearly one half as long as the head. The rentral origin is not far behind the end of the dorsal base; the fin reaches a little beyond the vent, but not to the anal origin. The pectoral reaches to below the third dorsal ray, its spine about two fifths as long 
as the head. The anal origin is a little nearer to base of caudal than to origin of pectoral; the base is as long as the head without the snout, one fiftl of total to base of caudal, and the longest ray equals one half the length of head. The very low adipose dorsal begins orer the anal origin and continues into the caudal; in older specimens it is deeply notched. The caudal is rounded. D. I, 6 ; A. 16 ; Y. 9; P. I, 9. Length of the specimen described (no. 35sit, U. S. national museum), $6 \frac{1}{4}$ inches. In spirits the upper parts are grayish brown, and the lower surface of head and body pale. In life the fish is nearly uniform yellowish brown.

The stonecat is found from Ontario, throughont the Great lakes region, south to Virginia and Texas, west to Montana and Wyoming. It inhabits the larger streams. Dr Evermann obrained two specimens at Nine Mile point, in the Lake Ontario region, June 11, 1893.

The species has very little value as food on account of its small size. It seldom exceeds 12 inches in length, but it is a very good bait for black bass. The stonecats are much dreaded by fishermen because of the painful wounds sometimes produced by their pectoral spines. There is a minute pore in the axil of 1he pectoral, which is the outlet of a noxions lingia secreted by a poison gland. When this poison is discharged into a wound, it causes an extremely painful sore.

Genus schumeones Bleeker

Body moderately elongate, rounded anteriorly, compressed posteriorly; head flat; skin very thick, concealing bones of head; superoccipital not joined to the head of the second interspinal; mouth large, anterior, the upper jaw somewhat the longer; awlshaped teeth in broad bands in the jaws, the band in the upper jaw abruptly truncate at each end and not prolonged into a backward extension as in Leptops and $\mathrm{Noturus}$; branchiostegals nine; dorsal fin nearer to ventrals than to pectorals, with a short spine and seren rays; adipose fin long and low, adnate to the body and continuous with the caudal fin, the adipose membrane sometimes high and continuous, sometimes 
emarginate; caudal fin very obliquely truncated or rounded, its base also obliquely rounded; many rudimentary rays both above and below the caudal peduncle; anal fin short with 12 to 2.8 rays; ventrals rounded; pectoral fins with a sharp spine of varying form; rent well in front of anal fin; lateral line complete. A poison gland opening by an orifice in the axil of the pectoral, so that wounds made by the pectoral spines are very painful. Size small. Fresh waters of the eastern United States among rocks and weeds, specially in small brooks. (After Jordan and Evermanu)

\section{Schilbeodes gyrinus (Mitchill)}

\section{Stone Cat}

Silmis gyrmus IItchild, Amer. Month. Mag. II, 322, March,1S1S (Wallkill River, N. Y.); DE KAY. X. Y. Fauna, Fishes, 1S6, 1812 (generic distinction recognized).

Noturus gyrimus Rafinesque, Journ. de Physique, 421, 1S19; Ichth. Ohien. 6S, 1S20; Jordax, Man. Vert. 303, 1S76, Bull. 10, U. S. Nat. Mus. 102, figs. 66, 67, 1Sт7; Jordar \& Gilbert, Bull. 16, U. S. Nat. IIus. 9S, 1SS:; Bean, Fishes Penna. 20, 1893.

Schilbeodes gyrimis BLEekER, Act. Soc. Sc. Indo-Nederl, IV, 25S. 1S5s, fide Güntuen, Cat. Fish. Brit. Mus. V, 101, 1861; Jordix \& Evermaxx, Bull. 47 , U. S. Nat. Mus. 146, 1896.

The tadpole stonecat lias a short and stout bods, sloping rapidly downward from the dorsal origin to the tip of the snout; its greatest depth contained four and one third times in total length withont candal; its width contained fonr and one half times. The head is short, broad and depressed, its width nearly equal to its length, which is one fourth of the total without caudal. The width of the mouth equals two thirds the length of the head; the jaws nearly equal. The width of the maxillary band of teeth equals one third of length of head; there are no lateral backward extensions. The snout is short, two sevenths as long as the head. The eye is small, one serenth as long as the head. The maxillary barbel reaches to the base of the pectoral; the outer mandibulary barbel is slightly longer. The nasal barbel is one lialf as long as the head. The distance of the dorsal from the tip of snout equals that from origin of ventral to end of anal. The base is as long as the snout and eye combined; the spine is one third as long as the head, and the 
longest ray equals length of postorbital part of head. The low adipose fin begins over the anal origin and is continuous with the caudal. The rentral origin is under the end of the dorsal base, the fin does not reach to anal origin. The pectoral reaches to below the middle of the dorsal. The anal base is one fifth of total length without candal; the longest ray equals postorbital part of head. The caudal is rounded. The pectoral spine is one half as long as the head. The humeral process is one third as long as the head. D. I, 6; A. 13-15; P. I, S. Color in spirits dark brown; the belly and under surface of head paler.

The specimens described (no. 1508, U. s. National Muserm) are from $3 \frac{1}{2}$ to 4 inches long.

The general color is brownish, without blotches. Jordan in the Manual says that it has a black lateral streak, sometimes with two other streaks above this. I have found none with this feature; it is the lateral line itself which looks darker in color.

The eyes are small, beadlike and at night glisten like adamant, indicating a more noctmal habit. These fishes are called stonecatfishes, but they prefer still, muddy water. In the aquarium it is even more hardy than the common catfish and often lies on its side for hours as if dead, or remains suspended in the water in various odd positions. (After Eugene Smith) ${ }^{1}$

Dr Meek had no knowledge of the occurrence of this species near Ithata. The museum of rormell Lniversity has a few specimeus from the lake, but withont definite locality. Dr Meék and Mr Harris took several examples from a small stream near Montezuma. Dr Evermann secured a specimen in Mill creek, at Sacketts Harbor N. Y. July 2., 1841; one in Long pond, at Char. lotte N. Y. Aug. 17; and one in Guffon creek, at Chaumont N. Y. July 7 of the same year. In general it ranges in the Great lakes region, through the Mississippi and Ohio valleys, and in New York, Pennsylvania and New Jersey. Its length does not exceed 5 inches. The species is too small to be of any value except for bait, and on account of its tenacity of life it is greatly in demand for hook and line fishing, specially in the capture of the black bass, for which it is one of the best baits known.

\footnotetext{
${ }^{1}$ Linn. Soc. N. Y. Proc. 1897. no. 9, p. 12-13.
} 


\section{Schilbeodes insignis (Richardson)}

\section{llargined stone Cat}

I'imelodus insigne Iinchandsox, Fauma Bor--Amel'. IlI, 132, 1S:;6 (11:1me only, based upon the Pimclode liméc LE Steur. Mém. Mus. d'Hist. Nit. V, 155), 1819.

Notmus lemmiseatus G̈̈́turer, Cat. Fish. Brit. Mus. T, 104, 1864; Jordax, Man. Vert. 303, 1876.

Totmms insignis Jordax \& Gilbert, Bull. 16, U. S. Nat. Mus. 100, 188?; Bean, Fishes, Penna. 19, pl. 19, fig. 26, 1893.

Sirhilbeodes insignis Jordax d Evernaxx, Bull. 4i, U. S. Nat, Mus. 117, 1S!6, pl. XXYIII, fig. 66;, 1900.

The margined stone rat has a moderately elongate and low body, its width greater than its depth, and the least depth of the caudal peduncle about thee fourths the greatest deptli of body. The head is rather long and depressed, one fourth of total without caudal, the snout short and lounded. The eye is small, its length one lialf the width of interorbital space and little more than one half the length of snout. The lower jaw is slightly shorter than the upper ; the width of the mouth equals postorbital part of head. The width of the maxillary band of teeth equals one third the length of head; there is no extension backward. The maxillar barbel reaches nearly to the end of the head. Six short gill raliel's below the angle of the first gill arch. The dorsal origin is about over the middle of the space between the pectoral and rentral origins; the length of the dorsal base equals the distance between the eres, and also the length of its spine. The longest ray is lualf as long as the head. The rentral reaches beyond the reut and almost to the anal origin, its length half the head. The pectoral does not reach to the rentral origin, its spine half as long as the lead, rough along its front edge and coarsely serrate behind. 'The adipose fin is little dereloped; it begins over the anal origin and is continuous with the caulal. The anal origin is nearly midway between the jectoral origin and the base of the caudal; the base is scarcely two ninths of total length without caudal; the posterior and longest rays are scarcely one half as long as the head. The caudal is rounded. D. I, 7; A. 17; T. 10; P. I, 9. In spirits the upper parts are dark brown, the belly and under 
surface of head pale. The fins all have a narrow dark margin. The specimen described (no. 1801j L. S. National Musemm) is 4.2 inthes long.

This species, like the others of its genus, is called stone cat. and it is rery common in the susquehanna, where it is highly prized as a live bait for black bass fishing. The species ocems also in the Jelaware, but for some reason or other is not so attractive to the black bass as the susquehanna river race. It grows to the length of 10 inches.

The species ranges from New York to South Carolina, east of the Alleghenies.

The dorsal and caudal fins sometimes hare a well defined black margin, from which originated the later name, N o t u r u s maginatus. This is the Pimelodus livrée of Cuvier and Valenciennes and the $\mathrm{l}^{2}$. l e m $\mathrm{n}$ is c a t u s of tee Sueur. Cuvier and Valenciennes make the following concluding remarks about the species: "The species is probably viriparous, for the eggs are rery large, and contain a well developed embryo. The ovary contains many eggs of which the diameter exceeds 2 lines, and moreover they are taken from a small animal, for our example is 3 inches long."

\section{$5 \pm$ Schilbeodes miurus (Jordan) \\ Taricgated Stone Cat}

Noturus miurus Jordan, Ann. Lye. Nat. Hist. N. Y. 3i1, 1S7т, Bull. 10, U. S. Nat. Mus. 100, figs. 60, 61, 18ī; Jordan \& Gilbert, Bull. 16, U. S. Nat. Mus. 99, 1883.

Schilbcodes miurus Jordan \& Evermann, Bull. 4ī, U. S. Nat. Mus. 14S, 1896, pl. XXIX, fig. $68,1900$.

Body rather stont, subterete, its greatest depth contained from four and one half to five and one half times in total length without caludal; least depth of caudal peduncle three fifths of greatest depth of body. Head one fourth of total length without caudal; eye one fifth the length of head, snout about two serenths; maxillary barbels reach beyond end of head; mandibulary barbel three fifths as long as the head; lower jaw included. Dorsal origin over middle of pectoral, slightly nearer to anal than to tip of snout, the dorsal base one half as long as 
the heat; adipose fin with.a deep notch but eonnexted with the caudal, its lengtl about equal to head; amulal lomulent, its niddle rars four fifths as long as the liead; anal hase as long as the head without the snout; highest ray of Torsil expal to dorsal spine. three fifths as long as head; longest anal ray one half as long as the head, extending to middle of rentral base; rentral fin one half as long as the head; humeral process short.

Body much mottled with hack and gray and with four luoad dark hands or cross blotches; top of head, tip of dorsal, middle of adipose fin, and edge of caudal blackish; occiput dirk. I). I, $6 ;$ A. 13 to 15 ; T. I, S; P. I, S.

The variegated stone cat has been assigned to the Mississippi valley, sonth to Lonisiana, to tributaries of Lake Michigan, and to the Ohio ralles, where it is common. It appears to have been entirely orerlooked by ichthyologists till 1876. Dr Erermann collected five specimens of this fish in Sandy creek at North Mamlin N. I. Aug. 20, 1894. The probability is that it will be found in other waters of the Great lakes region. The indiriduals used for illustration are from $3 \frac{1}{2}$ inches to $4_{4}^{1}$ inches long.

Order PLECTOSPONDYLI

Carplike Fishes

Suborder ENENTOGNATHI

Carps

Famile catostomidat

Suckers

Genus carrodes Rafinesque

Pods oblong; the dorsal ontline more or less arehed; the ventral outline nearly straight; deptl from one lialf to one third of length; sides compressed, the back sharp edged; caudal peduncle short and deep; head short and deep; its upper surface rounded; eye moderate, median or anterior; suborbital bones well developed; fontanel present; mouth small, horizontal and inferior; mandible short; lips thin, the upper protractile, narrow, the lower narrow; lips feebly plicate or nearly smooth; 
jaws without cartilaginous sheath; muciferous system moderatrly dereloped; operenlal apparatus well developed, the suboperele broad; isthmus moderate; plaryngeal bones remarkably thin, laterally compressed, with a shallow furrow along the anterior margin on the inside, and another more central on the outline of the enlarged surfaces; teeth very small, compressed, nearly equally thin along the whole inner edge of the bone, forming a fine, comblike crest of minute serratures, their cutting edge rising above the inner margin into a prominent point; gill rakers slender and stiff above, becoming reduced downward; scales large, about equal over the body; lateral line well derloped, nearly straight; dorsal fin long, nearly median, somewhat in advance of ventrals, falcate, its anterior rays elerated, often filamentous; caudal fin well forked, the lobes equal; anal fin comparatively long and low, few-rayed; ventrals rather short, usually with 10 rass; pectorals short, placed low; air bladder with two chambers. Size medium or rather large. (After Jordan and Evermann)

\section{Carpiodes thompsoni Agassiz}

\section{Lake Carp; Drum}

Catostomus cyprinus Trompson, Hist. Vermont, 133, 1842.

Carpiodes thompsoni Agsssiz, Am. Jour. Sci. Arts, 191. 1855; Core, Proc. Ac. Nat. Sci. Phila. 285, 1S64; Jordan, Man. Vert. 297, 1S76; Jordax. Bull. 12, U. S. Nat. Mus. 198, 1Sis; Jordax \& Gilbert. Bull. 16, U. S. Nat. Mus. 119, $18 S 3$.

Body short and stout, the back strongly arched, the greatest depth two fifths of the length to base of caudal fin; head sliort, about one fourth of length, the snout acutely pointer; lips thin, white, meeting at a wide angle; tip of lower jaw much in advance of nostrils; maxillary reaching to below front of orbit; ere small, about one fifth length of head; dorsal about median, its rays considerably produced, the longest two thirds as long as base of fin; scales rather closely imbricated, 8-39 to 41-6. D. $27 ;$ A. 7 ; V. 10.

Abundant in the Great lakes region. Found in Take Champlain. 


\section{Genus corostomes le Suenl}

Body elongate, fusiform, rounded, tapering anteriorly and posteriorly; head long, with pointed suout; eye small, placed high; suborbital bones narrow; fontanel present, large; mouth rather large, inferior, upper lip thick, protractile, papillose, lower lip greatly developed, with a broad free margin, usually deeply incised behind, so that it forms two lobes which are often more or less separated; mandible horizontal, short; opercles moderate; pharyngeal bones moderate, their teeth shortish, vertically compressed, rapidly diminishing in size upward; scales comparatively small; typieally much smaller and crowded anteriorly; lateral line well developed, straightish; dorsal nearly median, with from 9 to 14 rays; anal fin slort and high, with seven developed rays; rentrals inserted under the middle or posterior part of dorsal, with 9 to 10 rays; caudal fin forked, the lobes nearly equal. In males the fins are higher, and the anal is swollen and tuberculate in the spring. Air bladder with two chambers, the posterior large. Vertebrae 45 to 47 . (After Jordan and Evermann)

\section{Catostomus catostomus (For'ster)}

\section{Lony-nosed Sucker}

Cyprinus catostomus Forster, Phil. Trans. LXIII, 155, tab. 6, 1773.

Catostamus hudsonius LE Suevn, Jour. Ac. Nat. Sci. Phila. I, 107, 1817; Günther, Cat. Fislı. Brit. Mus. VII, 13, 1868.

Catostomus longirostris Jordax, Bull. 12, U. S. Nat. Mus. 175, 1S7s; JordAN \& Gilbert, Bull. 16, U. S. Nat. Mus. 126, 18s:.

Catostomus nanomyzon MATiER, App. 12th Rep't Adiroudack Sury. N. Y. 36, plate, fig. 1, 1856.

Catostomus catostomus Jordan, Cat. Fish. N. A. 17, 1S85; BEAN, Fishes Penua. 25. pl. 20, fig. 30, 1893; Jordan \& Everuand, Bull. 47, U. S. Nat. Mus. 176, 1896, pl. XXXII, fig. TT, 1900.

The nortliern sucker lias an elongate body, round and tapering, with a long and rather.slender head. The depth of the body is contained about four and one half times in the length and equals length of head. The snout is much longer than in C. teres, considerably overhanging the moutl, which is large, with thick coarsely tuberculated lips. Ere small, two fiftlis as long as the snout and one sixth as long as head; its position 
in the head is exactly median. Dorsal origin equidistant from tip of snout and base of caudal; dorsal base as long as head without snout; longest ray one sixth of total length without caudal, twice as long as the last ray. Distance from rentral origin to anal origin equals length of head. Anal base one half as long as dorsal base; longest anal ray equal to longest of dorsal and twice as long as last ray. Ventral origin is under middle of dorsal; the fin equal to head without snout. Pectoral nearly one fifth of total length withont caudal. D. 10 to 11; A. 7 to 8 ; V. 10 . Scales usually about 100 in lateral line and in 28 rows from dorsal origin to rentral origin.

The northern sucker, long-nosed sucker, or red-sided sucker, as the above species is styled, occurs in the Great lakes and northwest to Alaska in clear, cold waters. It is very common in Lake Erie. It grows to a length of 2 feet and is largest and most abundant northward, in Alaska reaching a weight of 5 pounds. As a food fish the long-nosed sucker is little esteemed; but in cold countries the head and roe are used in making a palatable soup.

The males in the breeding season, in spring, are profusely corered with tubercles on the head and fins and have a broad rosy band along the middle of the body. In the Tukon river, Alaska, Dr Dall found the fish filled with spawn in April. The eggs are of moderate size and yellow in color. Nelson has seen this species seined by Eskimo in brackish estuaries of streams flowing into Kotzebue sound. W. J. Fisher has collected specimens on the peninsula of Alaska.

This was not found in Cayuga lake basin by Dr Meek, but it occurs in the Adirondack region, and Dr Meek believes it is a member of the Caruga lake fauna. Dr Evermann obtained five specimens at Grenadier island, N. Y. June 28, 1894.

The small race found by Fred Mather in the Adirondacks is the ordinary dwarf form characteristic of mountain regions. He discovered four individuals, only $4 \frac{1}{4}$ inches long, but mature and breeding " in a little mountain brook emptying into Big Moose nearly north of the Big Moose club house, by a bark 
shinty known as "Pancake Hall'." The fish were spawning, and he discovered mans eggs under the stones. The females were brown with white on belly, the male with red stripe on the side.

\section{Catostomus commersonii (Lacépède)}

\section{Common Sucker}

Cyprims commersomii LACÉPÉne, Hist. Nat. Poiss. V, 503, 610, 1803.

Cyprinus teres Mrtchild, Trans. Lit. \& Phil. Soc. N. Y. I, 45S, 1815.

Catostomns teres Günther, Cat. Fish. Brit. Mus. VII, 15, 1S6S; BeAn, Fishes Penna. 25, 1893.

Catostomus communis DE KAY, N. Y. Fauna, Fishes, 196, pl. 33, fig. 106, 1842.

Catostomns pallidus DE KAY, N. Y. Fauna, Fishes, 200, pl. 33, fig. 104, 1842. Catostomus commersoni Jordax \& Grlbert, Bull. 16, U. S. Nat. Mus. $18 \$ 3$.

Catostomes commersonii Jordax \& Evermaxx, Bull. 47, U. S. Nat. Mus. 17S, 1596, pl. XXXIV, fig. \$3, 1900.

The common sucker has a moderately stout bods, heavy at the shoulders and tapering to the tail. Its greatest depth is contained four and one half times in its length to tail, slightly more than length of head. Head conical, flattened on top; mouth rather large and the lips strongly papillose; dorsal fin situated in middle of length; rentral opposite dorsal; anal far back; second and third branched rays of dorsal highest, two thirds the length of head; third and fourth rays of anal longest, almost equal to length of head. D. 12; A. 7; T. 9. Scales 61; from dorsal to lateral line 9 , and from lateral line to ventral, 9 or 10.

The common sucker is also known as the pale sucker, white sucker, gray sucker, brook sucker, and, among the Canadian French, as the carpe blanche. It is the commonest member of its genus in waters east of the Rocky mountains. It is found from Canada to Florida and westward to Montana. Covering such a wide range of territory, the species is naturally rariable, and has been described over and orer again by many authorities under a great variety of names. The male of this sucker in spring has a faint rosy stripe along the middle of the side. The roung are brownish in color and somewhat mottled and have a dark median band or a series of large blotches. The 
adults are light olive varying to paler and sometimes darker; sides silvery.

The species reaches a length of 22 inches, and a weight of 5 pounds. It is a very common inlubitant of ponds and streams of the lowlands, and a small race occurs in certain cold mountain streams of the Adirondack region, where it is dwarfed in size and changed in color but does not differ in essential characters. Dr Rothrock also obtained a mountain race of this sucker in Twin lakes, Col, at an eleration of 9500 feet above the sea level.

The common suclier is a very indifferent food fish in the estimation of most people, but, when taken from cold waters and in its best condition, its flesh is very palatable. It takes the hook readily when baited with common earthworms.

Dr Richardson says:

It is a common fish in all parts of the fur countries, abounding in the rivers and even in landlocked marshes and ponds, but preferring shallow grassy lakes with mud bottoms. In the beginning of summer it may be seen in numbers forcing its way up rocky streams, and even breasting strong rapids, to arrive at its proper spawning places in stony rivulets; soon afterwards it returns to the lakes. Its food, judging from the contents of the stoniachs of those which I opened, is chiefly soft insects; but in one I found the fragments of a fresh-water shell. In the winter and autumn it is common in nets, and in the spawning season (June) may be readily speared, or even taken by the hand in shallow streams. It is a very soft, watery fisl, but devoid of any unpleasant flavor, and is considered to be one of the best in the conntry for making soup. Like its congeners, it is singularly tenacious of life, and may be frozen and thawed again without being killed.

1)r Meek found this species abundant throughout the entire Cayga lake basin, where it is known as the common white sucker.

D) Erermann, in his manuscripts on the fishes of Lake Ontario, taken in 1894, mentions this sucker from the following localities: Stony creek, Black river, Mud creek, Cape Vincent, mouth Salmon river, Chaumont river, creek at Pultneyville, month Little Salmon creek, Sandy creek, Long pond, Stony Island, Lakeview 
hotel, 7 miles northeast of Oswego, and Marsh creek. In the St Lawrence river basin he and Barton A. Bean obtained the young in Racket river, Norfolk N. Y., July 18 and in the st Lawrence rirer, 3 miles below Ogdensburg, July 17 . In the Lake Champlain basin these two collector's secured young and half grown specimens in the saranac river, at Plattsburg July 28, 1894.

The writer receired specimens from Canandaigua lake in November of 1896 and 1897, and seined the young in Bronx rirer in August 1897. The small mountain form was secured from Saranac lake in Norember 1897. It is conspicuous for its small size and its red color. The Canandaigua lake suckers, receired in Norember 1896, throve in captivity till July 1897, when the warm water killed them.

Color brownish, olivaceous above, silvery below; the young are much blotched and marked on sides and back. It is occasionally caught on the hook. loung ones, in captivity, though they always grub about, and though they take food offered them, do not thrive and gradually starve. They remain wild and take alarm easily and often leap out of their tank. This species enters slightly brackish water. Eugene Smith ${ }^{1}$

\section{Catostomus nigricans Le Sueur}

\section{Hog Sueker; Stone Roller}

Catostomus nigricans Le Suevr, Jour. Ac. Nat. Scl. Phila. I, 102, 1817; G̈̈ntiler, Cat. Fish. Brit. Mus. VII, 17, 1868; Jordan \& Gilbert, Bull. 16, U. S. Nat. Mus. 130, 1883; BeAn, Fishes Penna. 26, pl, 21, fig. 31. 1893; Jordan \& Evermann, Bull. 47, U. S. Nat. Mus. 181, 1896; DE KAY, N. Y. Fauna, Fishes, 202, 1812.

Exoglossum. (Hypentelium) macropterum Rafixesque, Jour. Ac. Nat. Sc. Phila. I, 420, pl. 17, fig. 3, 1S17.

The stone roller has a peculiar plysiognomy. The head is flattenced on top, the interorbital space is concave and the frontal hone short, broad and thick. The body is subterete, its depth being "ontained four and one third times in the length withont andal or equal to length of head. The eye is rather small. being contained three times in length of suout; mouth large, lips well developed and strongly papillose; fins all large;

\footnotetext{
${ }^{1}$ Linn. Soc. N. Y. Proc. 1897. no. 9, p. 13-14.
} 
the dorsal base equals two thirds of length of head, while the pectoral is considerably longer than the dorsal. Caudal moderately forked; lateral line fully dereloped, on median line of body; scales moderate, equal. I. $11 ;$ A. 7; V. 9 . Scales 7-52-7.

Specimen examined, no. 8446 , U. S. National Museum, from Cayuga lake, N. Y.

The stone roller has a wide distribution and a remarkable variety of common names. Among them are: hammerhead, stone lugger, stone toter, crawl-a-bottom, hog molly, hog mullet, mud sucker, hog sucker, banded sucker, large-scaled sucker, and black sucker. The name, shoemaker, was formerly applied to this species in Lake Erie, perhaps on account of the resemblance of its color to that of shoemaker's pitch.

Prof. Cope says that this species in Pennsylvania is most abundant in tributaries of the Ohio and in the Susquehama, while in the Delaware it is uncommon. It ranges from western New York to North Carolina and westward to Kansas. It is the most remarkable-looking of all the suckers of New York, and may always easily be distinguished by the shape of its head. The species grows very large, reaching a length of 2 feet. It delights in rapid streams of cold, clear water. Its habit is to rest quietly on the bottom, where its color protects it from observation. It is sometimes found in small schools. The spawning season is in spring, and the young are abundant in small creeks, as well as in the rivers. The food consists of insect larvae and small shells, and it is specially fitted for securing its prey under stones in the rapids.

As a food fish this sucker has little value.

\section{Genus ERImyox Jordan}

Body oblong, compressed; head moderate; mouth moderate, somewhat inferior, the upper lip well developed, freely protractile, the lower moderate, infolded, inversely $V$-shaped in outline, plicate, with 12 to 20 folds on each side; lower jaw without cartilaginous sheath, rather stronger than usual, and oblique when the mouth is closed; eye moderate; suborbital bones well 
developed. not inuch narrower than the fleshy part of the cheek below them; opereular bones moderately developed, not rugose; fontanel rather large; gill rakers rather long; pharyngeal bones weak; the teeth quite small, slender, and weak, rapidy diminishing in length upward, each tooth narrowly compressed, with a cusp on the inner margin of the cutting surface; scales rather large, more or less crowded forward; no lateral line; dorsal fin rather short and high, rays usually 11 or 12 ; pectoral fins moderate; anal fin high and short, more or less emarginate or bilobed in adult males; caudal fin moderately forked or lunate, its lobes subequal. Air bladder with two chambers. (After Jordan and Evermann)

59 Erimyzon sucetta (Lacépède)

\section{Chub Sucker}

('yprinus suctta LAcéene, Hist. Nat. Poiss. V, 503, 606, 610, 1803.

Catostomus succtta Le Sueur. Jour. Ac. Nat. Sci. Phila. I, 109, 1817.

Labco gibbosus DE KAY, N. Y. Fauna, Fishes, 194, pl. 32, fig. 101, 1842 (dor'sal incorrect).

Catostomus tuberculatus DE KAY, N. Y. Fauna, Fishes, 199, pl. 31, fig. 97, 1842.

Labeo esopus DE KAY, N. Y. Fauna, Fishes, 195, 1842.

Evimyzon goodei Jordar, Bull. 12, U. S. Nat. Mus. 148, 187S; Jordan \& Gilber', Bull. 16, U. S. Nat. Mus. 134, 18s3; Goode, Fish. and Fish. Ind. U. S. pl. 221, 1894.

Erimyzon sucetta (part) BEAN, Fishes Penna. 27, 1893.

Erimyzon sucetta Jordan \& Evermaxn, Bull, 47, U. S. Nat. Mus. 155, 1896.

The body of the ehub sucker is oblong, rather deep and compressed. Its depth one third of standard length. The head is rather short, broad abore, its length one fourth of total length to caudal. The mouth is rather small and but slightly inferior, protractile. The eye is contained fire times in length of head and slightly less than twice in its distance from tip of suout. Dorsal short, rather high, placed in midde of length; rentrals directly underneath; highest dorsal ray (fourth) not quite equal to second anal lay, about two thirds of length of head; candal slightly forked. No lateral line. D. 12 to $15 ;$ 1. 7 to $8 ;$ T. I, 7 . Scales 37 to 40 ; transrel'se 13 to 15 .

The chub sucker here described is the southern form which was first made known by Lacépède from an individual received 
from Charleston S. C. Jordan and Evermann now give the distribution of this form as extending from Virginia to Texas. It appears to reach a little farther northward if the references to De Kay are properly made. His $\mathrm{L}_{1}$ a be o gib o s u s and es opus and the Catostomus tuberculatus seem to indicate the souther'n chub sucker.

The sprecies reaches the length of 1 foot. It has rery little value as food, but the young furnish excellent food for the larger fishes and are very interesting for aquarim purposes.

60 Erimyzon sucetta oblongus (Mitchill)

Chub Sucker; Creck Fish

Cyymime oblongus Mitchild, Trans. Lit. \& Phil. Soc. N. Y. I, 459, 1815.

Labeo elegans DE KAY, N. Y. Fauna, Fishes, 192, pl. 31, fig. 100, 1St2.

Labeo oblongus DE İ́y, N. Y. Fauna, Fishes, 193, pl. 42, fig. 136, 1842. Moxostoma oblongum (rünther, Cat. Fish. Brit. Mus. VII, 21, 1868.

Erimyzon sucetta Jordan \& Gimbert, Bull. 16, U. S. Nat. Mus. 193, 1883;

Goode, Fish. and Fish. Ind. U. S. pl. 220, 18S4; Bean, Fishes Penna.

27, 1893 (part).

Erimyzon sucetta oblongus Jordan \& EverMand, Bull. 47, U. S. Nat. Mus. 186, 1896, pl. XXXVI, fig. 89, 1900.

The northern chub sucker has the body more slender, its greatest depth being less than one third of the total length without the candal. The nape is less gibbous than in E. s u c e t $t$ a. The caudal peduncle is more slender, its greatest depth being scarcely one third of the greatest depth of the body (two fifths in s u c e t ta). The head is small and short, the eye less than one fifth as long as the head, the dorsal base shorter and the fins containing fewer rays (11 in sucet ta ob $\mathrm{s}$ o $\mathrm{ng} \mathrm{us}, 14$ in s u c e $t$ t a).

This is known as the chub sucker, sweet sucker, rounded sucker, creekfish and mullet. It has a wide range, practically including all the waters of the United States east of the Rocky mountains.

The chub sucker grows to a length of about 1 foot. It is very tenacious of life and is a ready biter, but has little value for food. The young up to the length of several inches have a very distinct black lateral band. They are often found in the shelter of water lilies and other aquatic plants close to brackish waters. 
Dr Erermann collerted two specimens in Black creek, tributary of Oswego river. at Seriba Corners N. Y. July 17, 1894. Dr Neek found it rer. common about Cayuga and Montezuma X. Y., but did not observe it near Ithaca. In the market of New Tork. according to De Kay, the chub sucker makes its appearance in October, November and December. Specimens were seined in Bronx river in August 1897.

A young example sent from near Princeton N. J. by Prof. Ulric Dahlgren in September 1897 showed the following voluntary change of color. When it arrived, it had the broad, longitudinal, median band well dereloped and the rertical bands obsolete; but soon after it was placed in a tank it obscured the Jongitudinal band entirely and dereloped the rertical bands.

The food of the chub sucker consists chiefly of minute crustaceans, insect larrae and aquatic plants.

\section{Genus mirytuevi Jordan}

Body rather elongate, subterete, becoming deep and rather compressed with age; scales rather large and nearly uniform in size; lateral line interrupted in the adult, but with perfect tubes, imperfect in partly grown individuals, and obsolete in the roung; head moderate, rather broad above; month moderate, inferior, horizontal; the upper lip well dereloped, freely protractile; the lower rather small, infolded, inversely $V^{\top}$-shaped in outline, lower jaw without cartilaginous sheath; eye moderate. rather high, nearly median; suborbital bones well dereloperl: opercular bones well developed, not rery rough; fontanel rather large; gill rakers rather long; isthmus moderate; pharrngeal bones essentially as in II ox o s'to ma; dorsal fin rather short and high, inserted somewhat nearer to tip of snout than to base of caudal; pectoral fins moderate, placed low; aual high and short; rentrals short, midway between tip of snont and base of caudal; caudal fin moderately forked, the lobes equal; air bladder with two chamber's. Head in males tuberculate in spring. 
61 IMinytrema melanops (Ratinesque)

Striped sucker; Spotted sucker; sand sucker

Catostomms melanops Rafingsque, Ichth. Ohien. 57, 1820; Tirtuaxd, Bost. Jour. Nat. Hist. Y, 271, pl. 20, fig. 3, 18t5.

C'atostomus fuscialus Günther, Cat. Fish. Brit. II IIs. VII, 19, 1868.

Minytrema melenops Jordan, Bull. 12, U. S. Nat. Mus. 138, 1575; Jordan

\& Gilbert, Bull. 16. U. S. Nat. Mus. 136, 188;; Beax, Fishes Penna.

2S, pl. 21, fig. 32, 1S!3; Jordan \& Evermann, Bull. 47. U. S. Nat. Mus.

187, 1896, pl. XXXVI, fig. 90, 1900.

Body oblong, robust in adults, its greatest depth one fourth total length to base of caudal; head moderate, subconical, its length contained about four and one half times in total length; eye placed high and in the middle of length of head, its diameter 2 in snout, 5 in head; nostrils about orer the angle of the mouth; scales large, firm, in about 48 longitudinal and 12 or 13 transverse rows; dorsal origin over tip of pectoral, its base as long as its longest ray; rentrals nearly under middle of dorsal, length one sixth of total; longest anal ray nearly one fifth of total; least depth of caudal peduncle about one half the length of head. D. 12; A. 7; V. 9. Color dusky above, coppery below, usually a dusky blotch behind dorsal fin; scales mostly with a dark spot at the base, the spots forming longitudinal stripes.

The striped sucker, also called soft sucker, sand sucker and black-nosed sucker, is found in the Great lakes and south to South Carolina and Texas. In Pennsylvania it is limited to Lake Erie and the Ohio valley. In New York it is to be expected in Lake Ontario and its tributaries, and should also occur in Chautauqua lake.

The striped sucker grows to a length of 18 inches. Old males have the head tuberculate in the breeding season in the spring. The species is very readily distinguished by the dark stripes along the sides produced by spots at the base of each scale. In the roung of this sucker there is no lateral line, but in adults it is almost entire.

This sucker prefers clear, sluggish water's and grassy ponds. It readily adapts itself to life in the aquarium. It feeds almost. entirely on mollusks, insects and insect larvae. The species is 
not much esteemed as a food fish, though it is sold in large numbers.

II in ytrema melanops is normally witlout a lateral line, but this feature is occasionally partially developed and has caused some confusion in assigning certain individuals to their proper genus; indeed, one author has described and figured the striped sucker as two species, belonging to two different genera, having been misled by this undereloped character.

\section{Genus noxostons Rafinesque}

Body moderately elongate, sometimes nearly round, usually compressed; scales large, nearly unifor'm in size; lateral line compiete, straight or anteriorly curved; head varying in length, subconical; eye usually rather large, placed moderately high; suborbital bones very narrow; fontanelle well developed; mouth varying much in size, inferior, the mandible horizontal or nearly so; lips unusually well dereloped, the form of the lower varying, usually with a slight median fissure, but nerer deeply incised; lips with transverse folds which are rarely broken up to form papillae; jaws without cartilaginous sheath; muciferous system well developed; opercular bones moderately developed, nearly smooth; isthmus broad; gill raker's weak, moderately long; pharyngeal bones rather weak, the teeth rather coarser than in Erimyzon and Catostomus, strongly compressed, the Iower five or six stronger than the others, which rapidy diminish in size upward, each with a prominent internal cusp; dorsal fin nearly median, moderately long; anal fin short and high, with seven developed rays; caudal fin deeply forked; air bladder with three chambers. (After Jordan and Erermann)

\section{Moxostoma anisurum (Rafinesque)}

Thite-nosed Sucker

Catostomus anisurus RAfrxesque. Ichth. Ohien. 51, 1820; Iirmtand, Bost. Jour. Nat. Hist. V, 269, pl. 20, fig. 2, 1St5; Stower, syn. Fish. N. A. $172,1846$.

Catostomus carpio GüNtmer, Cat. Fish. Brit. Mus. VII, 20, 1S6S.

Myxostoma anisura Jordax, Man. Vert. ed. 2, 315, 1sis; Bull. 12, U. S. Nat. IIUs. 126, 1878. 
17oxostoma mism?um Jorday \& Gilbert, Bull, 16. U. S. Nat. Mus. 141, 18s3; Beax, Fishes Pemna. 2S, 1893; Jordax \& Erermaxy, Bull. 47. U. S. Nat. Mus. 100, 1896.

The body is elongate, little compressed, slightly arched anteriorly, its greatest depth contained three and one third times in the length to end of scales. The head is moderate, flat and broad abore, its length less than one fourth of the total without the caudal. Mouth slightly inferior; upper lip thin, lower strongly $V$-shaped; eye large, about one half as iong as the snout, which is rather blunt and does not project much beyond the mouth; fins all well developed. The dorsal is large; its first ray is as long as the base of the fin, or about seven eighths as long as the head. Upper margin of dorsal nearly straight. Pectorals nearly reach to ventrals; the upper caudal lobe narrow and longer than the lower. D. 15 ; A. 7 to $8 ;$ V. 8 . Scales 5 to $6-43$ to $46-4$ to 5 . Here described in part from a specimen measuring 16 inches, from Ohio.

The white-nosed sucker is found sparingly in the Ohio river and the Great lakes region; widely distributed, but nowhere abundant. Curier and Valenciennes received from Milbert a specimen sent from Lake Ontario, measuring about 2 feet. Dr Jordan says this is very closely related to the common red horse, from which it can hardly be distinguished except by its fins. Dr Evermann collected a single specimen at Fox island, N. Y. June 29,1894 ; he also obtained a specimen, 12 inches long, at Pointbreeze X. Y. Ang. 21, 1894, which he refers to this species, though indicating some characters in which it differs from the normal form of the white-nosed sucker.

\subsection{Moxostoma aureolum (Le sueur)}

\section{Red. Horse}

Catostomus aureolus Le Sieur, Jour. Ac. Nat. Sci. Fhila. I, 95, 1817; De İ́, N. Y. Fauna, Fishes, 201, pl. 42, fig. 132, 1842.

Catostomus oncida DE KAY, N. Y. Fauna, Fishes, 19S, 1S42. Oneida Lake. Catostomus duquesuii Kintuand, Bost. Jour. Nat. Iist. V, 268, pl. 20, fig. 1, pl. 21, fig. 2, 1845; Güxtrer, Cat. Fish. Blit. Mus. VII, 1S, 1868, Youghiogheny River, Pa.

Moxostoma aurcolum Jordax \& GILeERT, Bull. 16, U. S. Nat, Mus. 140, 18s3; Beax, Fishes Penna. 30, 1893; Jordan \& Evermatr, Bull. 47, U. S. Nat. Mus. 192, 1896. 
Body oblong, the back in front of dorsal elevated and compressed, head short, conical, broad between eyes. The ere is rather large, one fourth length of head, which is contained fire times in total length without caudal. The depth of the body is contained three and one half times in this length. Caudal peduncle deep, compressed, its least depth equal to one half the length of head; mouth small; the snout somewhat projecting; fins all well dereloped; the anterior rays of dorsal longest, as long as dorsal base, pectoral or longest anal rars, equaling length of head; caudal forlied; scales large, about equal in size all over the body, and fincly striated. I). $15 ; A$. \&. Scales 6-4ti -6 ; lateral line complete.

The red horse has the additional names of golden red horse, golden sucker, mullet, golden mullet, and lake mullet. It inhabits the Great lakes and the region northward, also the Ohin ralley. It is common in Lake Erie but not in the Ohio.

This species grows to a lengtl of 18 inches and is one of the handsomest of the suckers. Prof. Forbes records it from lakes of northern Illinois, also abundantly in the central part of that state.

Dr Evermann, in collecting fishes of the Lake Ontario region, secured it at the following localities: Lake Ontario, $t$ miles otf Nine Nile point, N. Y. Jume 12, 1893; lake shore, 3 miles west of Oswego, July 17. 1894; mouth samon river. July 25, 1894; Long pond, Charlotte N. Y. Aug. 17, 1894; Sandỵ creek, North Hamlin N. Y. Aug. 20, 1894.

Dr Meek identified a single specimen of the so called common red horse of Cayuga lake with Moxostoma macrolepidot um, and stated, on the authority of Mr Kiplp, that it is common at the northern end. Jordan and Erermann, lowerer, do not extend the range of $\mathrm{macr}$ a le p id o t $\mathrm{um}$ so far north, and it is probable that the common $\mathrm{Il}$ ox os tom a of Casuga lake is M. a u re o l u m.

De Kay records the species as rery common in Lake Erie. In August and September he obsered them to be full of worms. In his Teu York Fauna, Fishes, 1). 198, he deseribes a sucker or mullet under the name Oneida surker. This, he stated, is com- 
mon in Oneida lake. The species is considered identical with Moxostoma a urolum. His description shows a very close agreement with that of a u r e o l $\mathrm{um}$ given above.

The food of the red horse consists chiefly of mollusks and insects. It is not a choice food fish.

Eugene Smith ${ }^{1}$ records this form as occurring in the vicinity of New Tork city. Mention has already been made of the doubt concerning the northern limits of the range of $\mathrm{macrole}$ p i d o tu m; but for the sake of comparison the brief description of $\mathrm{macr}$ ole pid o $\mathrm{t} \mathrm{um}$ published by Jordan and Evermann is given herewith.

Head moderate, rather stont, its length four and three fiftlis in body; eye one and two thirds in snout; dorsal fin with its free edge concave; scales usually with dusky shade at base; lower fins pale. Streams abont Chesapeake and Delaware bays, and southward to Nortl Carolina. It seems in some respects intermediate between M. a u reolum and M. cras silabre, but we can not at present identify it with either.

Family CYPRINIDAE

Carps

\section{Genus campostoma Agassiz}

Body moderately elongate, little compressed; montl normal, the jaws with thick lips and rudiment of a hard sheath; premaxillaries protractile; no barbel; teeth 4-4, or 1, 4-4, 0 , with ob. lique grinding surface, and a slight hook on one or two teeth; air bladder suspended in the abdominal cavity and entirely surrounded by many convolutions of the long alimentary canal, which is six to nine times the total length of the body; ovaries similarly enclosed by the alimentary canal; peritoneum black; l'seudobranchiae present; scales moderate; lateral line present; dorsal nearly over rentrals; anal short; no spines. Herbivorons. Sexual differences rery great, the males being covered with large tubercles in spring. The singular arrangenent of the intestines in relation to the air bladder is peculiar to $\mathrm{C} \mathrm{a} \mathrm{m}$ posto m among all known fishes. (After Jordan and Evermann)

${ }^{1}$ Linn. Soc. N. Y. Proc. 1S97. no. 9, p. 14. 
64 Campostoma anomalum (Rafinesque)

\section{Stone Roller; Stone Lugger}

Rutilus amomalus RAFINEsque, Ichth. Ohien. 52, 1820.

Exoglossum dubimm Fintlaxd, Bost. Jour. Nat. IIist. T, 272, pl. 21, fig. 1, 1845 .

Cumpostoma dubium Güntrier. Cat. Fish. Brit. Mus. VII, 1S3, 18 ris.

Compostoma anomalum Agassiz, Amer, Jour. Sci. Arts. 218, 1S55; Jordar \& Gilbert, Bull. 16, U. S. Nat. Mus. 149, 18S3; BeAN, Fishes Penna. 32. 1893; Jordax \& Evermanx, Bull. 47, U. S. Nat. Mus. 205, 1896, pl. XXXIX, fig. 95, 1900.

In the stone roller the body is moderately stont and not gratly compressed; the cautal peduncle long and deep. The greatest depth of the body is contained four to four and one half times in the total length without the candal; the depth of the caudal peduncle, eight and one half to nine times in the sime length. The snout is obtuse, twice as long as the eye, and two fifths as long as the head. The maxilla rearhes to the rertical from the posterior nostril, which is more than twice as far from tip of snout as from eye. The dorsal origin is over the 20th scale of the lateral line, and the rentral origin under the 19th. The dorsal base is one half and its longest ray two thirds as long as the head. The ventral reaches nearly to vent. The pectoral is one sixth of total length without caudal. The anal origin is under the $32 \mathrm{~d}$ scale of the lateral line; the anal base is as long as the snout, and the longest ry equal to head not including the suout. The caudal is moderatuly forked. D. s; A. 7 or S. Scales S-52 to 5:3-8; teeth 4-4.

Color in spirits brownish above, lower parts pale. In living cxamples the scales are somewhat mottled with blackish, and there is a dusky vertical bar behind the opercle; lorsal and anal fins olivaceous in females and with a nearly median dusky cross bar. Breeding males have the iris orange, the dorsal and anal fins crimson, and the head and sometimes the body covered with large roundish tubercles.

The stone roller is likewise called stone toter, stone lugger, and steel-back minnow. It is a fish of rery wide distribution, ranging from western New York to Nortl Carolina and throughout the Ohio and Mississippi valleys, west to Wyoming 
and soutluwest to Texas. It is an extremely variable simeies. and everywhere common. The species grows to the length of eight incles. It has no importance as food for man. It feeds on aquatic plants. The young are hardy in the aquarium, where they feed on confervae and diatoms. The sexes are very unlike. The males in the breeding season lave the head and frequently the entire body covered with large tubercles and the upper half of the dorsal and anal fins fiery orange, with a dark cross bar about the midile of these fins.

The fish is rather sluggish, but when frightened its morements are very rapid. It is a bottom feeder.

Th Evermann collected a moderate number of specimens at the following New York localities: Salt brook, $1 \frac{1}{2}$ miles above Nine Mile point, June 11, 1893; creek, I'ultneyrille, Ang. 7, 1894; Long poud, Charlotte, Aug. 17, 1894; Marsh crcek, Point Breeze, Ang. 21, 1894.

\section{Genns cumosonus Rafinesque}

Body moderately elongate, little compressed; jaws normal; no barbel; teeth 5-5 or 4-5, moderately hooked, with well marked grinding surface; alinentary canal elongate, about twice as long as body; peritoneum black; scales rery small; lateral line short or wanting; dorsal behind rentrals; anal basis short. Size small. Colors in spring brilliant, the pigment bright red. This genus is of somewhat loubtful relationship, and shows

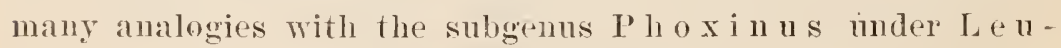
c iscus. (After Jordan and Ex(rimamn)

\section{6.) Chrosomus erythrogaster Rafinesque}

\section{Red-bellied Dace}

Luritus erythrogaster Rafinesque, Ichth. Ohien. 47, 1820; Kimtraxd, Bost. Jour. Nat. Hist. IV, pl. II, fig. 2, male and female. $18+4$.

Leucisens erythoyaster GüNtmen, Cat. Fish. Brit. Mus. VII, 247, 150 s.

Chrosomus erythroguster Core, Trans. Am. Pluil. Soc. XIII, 391; Jordux of Gilbfrt, 13ull. 16, U. S. Nat. Mus. 153, 1853; Bean. Fishes Penna. 32. 11. 22. fig. 35, 1893; Jordan of Everilaxx, Bull. 47, U. S. Nat. Muє. $209,1896$.

The red-bellied dace has a fusiform, moderately elongats and thick body, whose greatest hight is contained from four and 
one fifth to fire times, and the least depth of its caudal peduncle right and one half times, in the total length to the eandal hase. The head is conical with pointed snout as long as the eye, which is about one fourth as long as the head. The head equals we fourth of total length to candal base. The maxilla raches nearly to below the front of the eye. The lateral line varies in development, sometimes reaching to above the origin of the rentrals and continmed backward even farther at intervals, but usually not extending 10 rentrals. The dorsal origin is orer the space between the rentral origin and the rent; about 39 rows of scales between it and the nape. The dorsal base is one half as long as the head: the longest ray equals head without snout. The pectoral reaches nearly to rentral origin, and the rentral reaches rent. The anal base is two fifths as long as the head: the longest ray rqual to longest of the dorsal. The caudal is moderately forked, its middle rays two thirds as long as the outer. I. 8; 1. T; Y. 8; P. 12. Scales 1S-80 to $55-10$; tecth 5-5. Length of specimens described, from Yellow creek, 3 inches. A narrow dusky line along the top of the back; two narrow, dark bands on the sides, the lower one passing forward on the head to tip of snout; the space between the bands and below bright silvery. Breeding males have the bases of the dorsal, anal and candal fins and the area between the dark bands scarlet, while the body is corered with minute tubercles, and the fins generally are vivid yellow.

The T. S. Fish Commission parties obtained this minnow at the following localities in the Lake Ontario region: Salt brook, $1 \frac{1}{2}$ miles above Nine Mile point, June 11, 1893; Cemetery creek, or Black river, Watertown, .Tuly 5. 1S94; Long pond, Charlotte, Aug. 17,1894 . I am unable to find a reference to this species in the works of Mitchill and De Kay.

The red-bellied minnow or dace is found from Pennsylvania to Dakota and Temuessee. It is abundant in small streams, and is a strikingly beautiful fish. Along the sites are two hackish hands: one heginning above the eye and extending to the tail; another traverses the eve and follows the lateral line 
to the base of the caudal, where it ends in a black spot. The belly and the space between the bands are bright silvery, replaced by scarlet red in breeding males, which have the same color at the bases of the dorsal, caudal and anal fins. In the hight of the breeding season the fins are bright yellow, and the body is covered with small tubercles. According to Prof. Cope the red-bellied mimnow is not found in the Delaware, but it occurs in the Susquehanna and is common in the streams of western Pennsylvania. It reaches a length of 3 inches, and is similar in its habits to the stone roller, with which it associates. It prefers clear streams, which have their origin in springs. As an aquarium fish this is scarcely excelled in beanty and hardiness, and as a bait for the black bass it has few superiors.

\section{Genus hyвogratrus Agassiz}

Body elongate, somewhat compressed; month horizontal, the jaws normal, sharp edged; lower jaw with a slight, hard protuberance in front; 1 o barbel; upper jaw protractile; teeth 4-4, cultriform, with oblique grinding surface and little if any hook; alimentary canal elongate, three to 10 times the length of the body; peritoneum black; scales large; lateral line continuons; dorsal inserted before rentrals; anal basis short. Size moderate. Sexual changes rery slight, no red or black pigment distinguishing the males in spring. Species numerous, mostiy sonthwestern, not well known.

$$
\text { 1. }
$$

66 Hybognathus nuchalis A gassiz

\section{Sitvery Minnow}

IIybognathus nuchalis AGASsiz, Am. Jour. Sci. Arts. 224, 1855; GüxTHER, Cat. Fish. Brit. Mus. VII, 184, 1868; JordaN \& GilberT, Bull. 16, U. S. Nat. Mus. 156, 1893; BEAN, Fishes Penna. 33, 1893; Jordan \& Evermann, Bull. 47, U. S. Nat. Mus. 213, 1896.

Hybognathus regins Girard, Proc. Ac. Nat. Sci. Phila. 209, 18.56; Güxther, Cat. Fish. Brit. Mus. VII, 185, 1868.

Hybognathus osmerinus Cope, Proc. Am. Plìl. Soc. Phila. 466, 1870 (Raritan river, N. J.).

Body moderately stout and short, its greatest depth equaling one fourth of the total length without the candal, and the least 
depth of the candal peduncle equaling nearly one lan of the greatest depth of the bodr; body compressed, its greatest width less than one half its hight. Head short, its npprer and lower profiles tapering equally into the short and not very obtuse snout, which is as long as the eye, and three elevenths as long as the head. Mouth surall, slightly oblique, the jaws nearly equal, or the lower slightly included, the maxilla without a harbel, and reaching to below the anterior nostril. The dorsal origin is over, and the ventral origin under, the 12 th scale of the lateral line. The dorsal base is two thirds as long as the head; the longest dorsal rar equals the distance from the nostril to the end of the operculum. and the last ray is less than one half as long as the longest. The rentral roes not reach to the vent; its lengtl two thilds that of the head. The anal origin is under the $24 \mathrm{th}$ scale of the lateral line; the anal base is scarcely as long as the postorbital part of the head; the last anal ray is one third, and the longest anal ray two thirds, as long as the head. The pectoral is fonl fifths as long as the liead, and reaches to below the $11 \mathrm{th}$ scale of the lateral line. The caudal is moderate in size and deeply forked, the middle rays less than one half as long as the external rays. D. ii, 7 ; A. ii, 7; V. 8; P. 1.). Acales 6-38 to 39-4; teeth 4-4 long. much (o)mpressed. and with a long oblique grinding surface. Intestiues screll to 10 times as long as the body. The lateral line is mently decurved on about the first six scales, thence straight and median to the root of the caudal fin. Color in spirits light brown with a broad silvery band, the fins all pale. Oliraceous green above, transhcent in life; sides silvery, with bright reflections; fins unspotted. Tengtlı 4 to 7 inches.

The silvery minnow, or blunt jaw, is found in clear streams from New York to Georgia and Texas, west to the upper Missouri. In the Potomar river occurs a large variety which reaches a length of $i$ inches. This variety has a larger eye and a deeper body than the western form.

The U. S. Fish Commission collector's in the Lalie Ontario region obtained specimens at the following localities: Salt 
brook, $1 \frac{1}{2}$ miles above Nine Mile point, June 11, 189:; Mill creek, Sacketts Harbor, July 2,1894; Cemetery creek Watertown, July 5, 1894. The fish was most abundant at Mill creek.

The fish spawns in the early spring. It is extensively used for food along with the Notropis hudsonius, the so called "smelt" or "gudgeon." It takes the hook very freely luring the spawning seasou.

\section{Genus ringrimss Rafinesque}

Body rather robust, little compressed; head short and rounded, mouth small, inferior; upper jaw protractile; no barbel; teeth 4-4, with oblique grinding smface, nsually only one of the teeth hooked; dorsal orer rentrals, its first (rudimentary) ray separated from the rest by membrane, not joined to them as usual in minnows, this character most distinct in adult males, in which the skin of the first ray is thickened; anal basis short; intestinal canal clongate; peritoneum black; psendobranchiac present; scales rather small; lateral line complete or rarionsly incomplete. Size small. Breeding males with much black pigment and with large warts on the head. (After Jordan and Evermann)

\section{Pimephales promelas Rafinesque}

\section{Fathead; Blackhead Minnow}

Pimephales momelus Rafinesque, Ichth. Ohien. 58, 1820; Kunthanu, Bost. Jour. Nat. Hist. 1II, 475, pl. 27, fig. 2, 1841; Storen, Syn. Fish. N. A. 166, 1846; Güntheı, Cat. Fish. Brit. Mus. VII, 181, 1868; Jondan \& Giebert, Bull. 16, T. S. Nat. MIus, 15S, 1883; BEAx, Fishes Penna. 35, 1893; Jordan \& Evermann, Bull. 47, U. S. Nat. Mus. 217, 1896.

The fathead minnow has a short, deep-and moderately thick body, and the head short with a rery obtuse snout. The greatest depth of the body is equal to or slightly greater than length of head and is contained from three and two thirds to four and one fourth times in total length withont caudal. The least depth of the caudal peduncle equals the length of postorbital part of the head. The head forms about one fourth of the total length to base of caudal; the width of the head rquals two thirds of its length. The eye is as long as the suout and two ninths as long 
as the head. The mouth is very small, terminal, slightly oblique; the maxilla not reaching vertical through hinder nostril. The dorsal origin is above, and the ventral origin below the $21 \mathrm{st}$ seale of the lateral line. The dorsal base is two thirds as long as the head; the first ray is ahout as long as the eye, and the longest as long as the liead without the snout. The ventral reaches a little beyond the anal origin; its length equal to dorsal hase. The anal base equals nearly one half the length of head, and the longest ray is as long as the dorsal base. The caudal is moderate and not deeply forked. The lateral line is continuous on abont 20 to 28 scales, and in one specimen continued with interruptions almost to the caudal base. D. i, 8; A. i, 7; V. s; 1'. 18. Scales 9-45 to 49-6; teeth 4-t. Length of specimens described, 3 inches. Color in spirits light brown, top and sides of head darker. A broad dark band on the base of the dorsal, most distinct anteriorly and sometimes absent behind. Males in spring are dusky, with black head and the snout and chin with numerous coarse tubercles.

The fathead or blackhead is an inhabitant of the Ohio valley. and the Great lakes region west to Dakota and southwest to Texas. It is common in sluggish brooks, and instances have been known of its distribution by the action of eyclones. 1n Pennsylvania it is common in tributaries of the Ohio.

The U. S. Fish Commission has obtained specimens from the following localities in the basin of Lake Ontario: Salt brook, $1 \frac{1}{2}$ miles above Nine Nile point, June 11, 1893; Mill creek. Sackett Harbor, July :2. 1894; Three Mile reek, Oswego, July 27, 1894, where the greatest number of mdividuals was taken. Dr Meek says it is not reey common in Cayuga lake, but is easily distinguished from the other minnows by its very long intestines.

The fathead grows to a length of $2 \frac{1}{2}$ inches. The sexes differ in color, the females being olivaceous, while the males are dusky and in the spring have the head black and the snout covered with numerous large tubercles. The species has no value as food, hut is an interesting one for the aquarium. Its food consists of mud and algale, and it seems to prefer a muddy bottom. 


\section{(is Pimephales notatus (Rafinesque)}

\section{B'tunt-nosed Minnor; Spotted Minnow}

Winnilus notatus Riffinesque, Ichth. Ohien. 47, 1820.

tybmhynchus notatus Cope, Trans. Am. Phil. Soc. XiIr, 392, pl. 13, figs 1866 (the separate); (Günther, Cat. Fish. Brit. Mus. VII, 182, 186s; Jordax \& Gilbert, Bull. 16, U. S. Nat. Mus. 159, 188 s.

Pimephales uotatus JordAx, Cat. Fish. N. 1. 22, 1855; Bear, Fishes Penna. 36, 1893; Jordan of Evermany. Bull. 4i, U. S. Nat. Mus. 21S, 1896.

The blunt-nosed minnow lias a moderately elongate body and a slender caudal peduncle. The head is somewhat conical with a short and blunt snout. The greatest depth of the body nearly equals length of hrad and is two ninths of the total length withont caudal. The least depth of the caudal peduncle equals about one half of greatest depth of body. The snout is as long as the eye and one fourth as long as the head. The mouth is rery small, inferior, nearly horizontal, the maxilla reaching to below the anterior nostril and prorided with a short, thick. somewhat club-shajed barbel. The dorsal origin is slightly behind the ventral origin and over the 17 th scale of the lateral line. The dorsal base is two thirds as long as the head, and about equal to the longest ray. The rentral origin is under the 16 th scale of the lateral line; the fin does not reach to the rent. 'The anal origin is under the 27th scale of the lateral line; the base of the anal is two fifths as long as the head, and the lougest ray is equal to the postorbital part of the head. The caudal is moderately large and forked. The lateral line curves rery slightly downward as far as the rentral origin and then follows straight along the median line; it is complete. D. i, s; A. i, $\mathbf{7}$; I. S; P. 15 . Scales $6-42$ to $45-5$; teeth $4-4$. Length of specimens described, 3 inches. Color in spirits light brown; the fins except the dorsal paler. A black spot about as large as the eye on the front of the dorsal. In life the sides are bluish. Breeding males have the black on the dorsal continued backward on the membrane corering the rays and the head black, while the snout has about 14 to 17 large, pointed tubercles. A dusky shade sometimes present at base of caudal. 
The blunt-nosed mimnow is a larger species than the fathead, reaching a length of 4 inches, and its range extends from Quebec to Delaware, west to Kansas and south to Mississippi.

B. W. Eyermamm and B. A. Bean obtained it for the I. s. Fisle ('ommission in the St Lawrence rirer, 3 miles below Ogdenslourg, July 1 $\bar{\imath}, 1894$, in abundance. They found it common also at Scioto creek, coopersille N. Y. July 19, 1894. In the Lake Ontario region the Fish Commission collected the species at Cape Vincent, Grenadier island, Sacketts Harbor, Pointbreeze, Huntingtonville, Charlotte, Stony Island, Pultneyrille, Chaumont, Henderson bay, and Salt brook. Livingston Stone obtained the fish at Cape Vincent in the St Lawrence river, and presented it to the state musem at Albany. It is found in large numbers in the southern end of Cayuga like, and in streams on the flats. Not very abundant at the northern end of the lake and in streams near Ithaca, above the falls, according to the records of Dr Seth E. Meek.

The blunt-nosed minnow differs from the fathead in its larger size and in having a complete lateral line, but the sexual differences are similar in the two species. The males in spring have the head black and the snout with many large tubercles. The species is extremely variable and changes greatly with age. It frequents small and muddy streams, and its food consists of decaring regetable matter.

\section{Genus semo'rimus Rafinesque}

Body stout, moderately compressed and elongate; mouth terminal, wide, the upper jaw protractile; a small barbel just above the end of the maxillary; in most American minnows the barbel is at its tip; the maxillary barbel sometimes absent in young individuals; teeth 2, 5-4, 2, hooked, without grinding surface; scales rather large; lateral line complete; a short intestinal canal; dorsal placed behind rentrals; base of anal short. Vertebrae $22+20=42$. Fishes of large size in clear, swift streams from Canada to Virginia, west to Missouri and Wyoming. 
69) Semotilus bullaris (Rafinesque)

$$
\text { Fallish; Wind Fish; Dace; Chivin; Silver Chub }
$$

'yprinus bulluris RAfrnesque, Amer. Month. Mag. II, 120, Dec, 1stT.

cuminns rorporalis Mrtenul, Amer. Month. Mag. II, 32t, Mar. 1818. Previous notice in same work, vol. I, 289. July, 1817, insufficient to hold name. The Corporaalen of the Jutch, moreover, was the striped sprecies. alromaculatus.

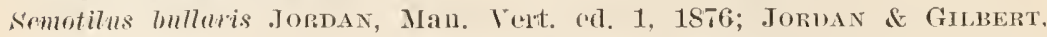

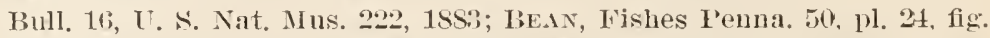
41, 1893; Goone, Fish. \& Fish. Ind. U. S. pl. 228, upper figure, 1884.

Lenciscus nilidus DeKAY, N. Y. Famm, Fishes, 209, pl. 32, fig. 105, 18t2. Lake Champlain.

Lenciscus chrysonterus DE KAY, N. I. Fauna, Fishes, 211, 11, 30, fig. 4. (poor), 1St2, harbor of New York.

Semotilus corporulis Jordan \& Everuaxi, Bull. 47, C. S. Nat. Mus, 221, 1890.

The fallfish has a moderately deep, elongate and compressed body and a stout caudal peduncle. The greatest depth is one fourth of the total length without caudal, and the least depth of the peduncle equals three eightlis of length of head. The head is rather large, one fourth of total without caudal, with pointed snout, which is two serenths of the head's length. The mouth is oblique; the jaws nearly equal, the maxilla extending to below front of eye. The eye is placed high and is about one fourth as long as the head. The dorsal origin is over the 16th or $17 \mathrm{th}$ scale of the lateral line; the base of the fin is one half. and the longest ray two thirds as long as the head. The rentral origin is under the 15 th scale of the lateral line; the fin does not reach to the vent, its length one seventh of total without caudal. The anal origin is under the 27 th scale of the lateral line; the base of the fin is one third as long as the head, and the longest ray is as long as the rentral. The caudal is large and deeply forked. The lateral line curves downward abruptly over the pectoral, becoming median orer the end of that fin. D. ii, $\mathbf{7}$; A. ii, 7; T. 8; P. 18. Scales 7-46-5; teeth 2, 5-4, 2 or $2,4-$ 4, 2, all more or less strongly looked. In spirits the upper parts are grayish brown, the sides and cheeks silvery, the lower parts whitish, the fins all pale. In life the npper parts are steel blue, the sides and belly silvery; breeding males in spring have the 
belly and lower fins rost. The specinens desceibed, no. 92020, I. S. National Musemm, are from .t. 10 b ineles lomg.

The fallfish or dace is one of the largest of the minnow fanily in Now York, reaching a lengtl of 18 inches, and it is oue of the most beautiful species as well as game in its qualities. Is a food fish, however, this is not greatly esteemed. It is extremely eommon in the Delaware river and its tributares and moderately alundant in the susquehama. The fallfish is found from Quebere to Virginia. Nitehill hat it from the Wallkill river and knew of its ocenrence in the Hudson, near Albany. Rafinesque reeorded it from the Fishkill and other tributaries of the Hut. son. De Kay knew it from Lake Champlain and from New York harbor. Evermann and Bean collected it in Scioto creek, at Coopersville, and in Saranac river, at Plattsburg, in July 1894: also in Racquette river, at Norfolk, and the St Lawrence river, 3 miles below Ogdensburg, in the same montl.

In the Lake Ontario basin the C. S. Fish Commission parties found it at Sacket Harbor, Centerville, Watertown, Oswego. Webster. Charlotte, Belleville, Hender'son bay, Henderson Harhor, and Salt brook, near Nine Mile point.

The fallfish delights in rapid, rocky portions of large streams and in the deep channels. On being hooked, it fights desperately for a short time, but its resistance is soon overcome. Thoreau describes it as a soft fish with a taste like brown papersilted, yet the boy fishermen will continue to covet and admire this handsome and ubiquitous representative of the minnow family. A colored plate of the fish, natural size, appears in the 3d Annual Repoit of the Commissioners of Fisheries, Game and Forest of the state of New Tork, 1898, facing 1. 146. There is also a good accomt of the fish by A. N. Cheney on p. 24t and 245 of the same report.

\section{Semotilus atromaculatus (Mitehill)}

\section{Horned Dace; Chub}

Cyminus atromaculatus Mrtinl, Amer. Month. Mag. II. 324, Mar. 1S1s. Wallkill river.

Leuciscus atromaculntus DE KAY, N. Y. Fauna, Fishes, 210, pl. 32. fig. 102, 1842. 
Semotilus corporalis Cope, Jour. Am. Phil. Soc. XIII, 362, pl. 10, fig. 2. (the separate), 1866; Jordan \& Gilbert, Bull. 16, U. S. Nat. Mus. 221, 1883; Goodf, Fish. \& Fish. Ind. U. S. pl. 22s, lower figure, 1884. Lencosomus corporalis Günther, Cat. Fish. Brit. Mus. VII, 269, 1868. Semotilus alromaculatus Bicknell \& Dresslar, Proc. Ac. Nat. Sci. Phila.

16, 1855; Bean, Fishes Peuna. 51, 1893; Jordan \& Evermann, Bull. 47 , U. S. Nat. Mus. 222, 1896; pl. XI, fig. 100, 1900.

'The chub has a slender and moderately elongate body, its greatest hight immediately in front of the rentrals, about equal to the length of the head without the snout and contained from four to nealy five times in the total length without the caudal. The greatest thickness of the body is about two thirds of its greatest hight. The head is thicker than the body and rather. short wilh an obtuse and moderately declivous snout, whose length is about two serenths of that of the head and considerably greater than the diameter of the eye. The eye is rather small, placed high, its diameter nearly one fifth of the length of the head and scarcely more than one half of the space between the eyes. The mouth is moderate, very slightly oblique, the jaws subequal or the lower slightly included; the end of the maxilla reaches very slightly past the rertical through the front of the eye. Maxillary barbel not evident in this example, though usually present in large individuals. The lateral line is abruptly bent downward over the first half of the pectoral, straight and nearly median during the rest of its course. The origin of the dorsal is orer the 27th scale of the lateral line, and the ventral origin is under the 24 th scale. The length of the dorsal base equals the combined length of the eye and snout. The first divided lay is the longest; its length two thirds that of the head. 'The last ray is one half as long as the longest. The ventral does not reach to the vent; its length scarcely greater than the postorbital part of the head. The anal origin is under the 37 th scale of the lateral line; the length of the anal base is a little more than one third that of the load, and thr. longest anal ray equals the postorbital part of the head. The tail is rather slender, the least depth of the caudal peduncle equaling one half the greatest depth and the distance of the anal from the origin of the middle caudal rays nearly equal to 
the length of the head. The pectoral when extruded reaches to below the 16th scale of the lateral line. The caudal is modrate in size and not very deeply forked, its middle rays being abont two thirds as long as the external rays. 1). ii, 7 ; $\Lambda$. iii, s; V.s; P. 15. Scales $9-58-6$. Teeth of right side $2+5$; of left side $\ddot{z}+4$. Those of the left side strongly and those of the right side less strongly hooked. Teetlo of the upper row with a well dereloped grinding surface.

The length of the specimen described, no. 21661, U. S. National Museum, from the Susquehanna river at Bainbridge Pa., is 4 ? inclies.

The color is bluish brown above; sides with a distinet dusky band, not so wide as the eye and becoming obsolete in the adult. Young specimens have the end of this band more pronounced, forming a black spot at the base of the caudal. A small black spot always present on the front of the base of the dorsal, its size in the specimen described being about two thirds of that of the eye. In life the belly is whitish. Breeding males have the belly rose tinted and the black dorsal spot bordered with red; they have, also, rather large tubercles on the snout.

The common chub, creek chub, smaller fallfish or horned dace. has a wider distribution than s. b u 11 a $\mathrm{r}$ is, but it does not grow quite so large, seldom exceeding 1 foot in length. Its range extends from New England to Missouri, southward to Georgia and Alabama. It is extremely common and ascends the small streams.

The U. S. Fish Commission collectors in 1894 took numerous specimens at the following localities: Sacketts Harbor, July 2; Centerville, July 24; Watertown, July 5; Oswego, July 25; Webster, Aug. 9; Charlotte, Ang. 17; Bellerille, July 12; Henderson bay, Juț 4; Henderson Harbor, July 3, and Salt brook, $1 \frac{1}{2}$ miles above Nine Mile point, June 10 and 11, 1893.

Dr Meek reported it as abundant throughout, the Cayuga lake basin. Large examples are found in Canandaigua lake. One of them measured 14 inches in July 1897. The fish is killed by 
warm water. 'The food in captivity includes hard clam, earthworms, and, occasionally, live killifish.

A. N. Cheney refers to this species on page 245 of the $3 d$ Immal Reprort of tha Commissioners of Fisheries, Game and Forest of the state of New Tork.

In Pennsylrania it is the commonest minnow in the Allegheny and Susquehanna hasins and is sufficiently common in the Delaware. Accoing to Prof. Cope it reaches 4 pounds in weight and is a fatir food fish.

This species is more characteristic of the small streams and clear ponds and it takes the hook very freely; but its proper' mission is to serve as bait for the larger and choicer fishes.

\section{Genus tinca Cuvier}

Pseudobranchiae minute; mouth anterior; lips thick but destitute of any horny covering; barbels two, one at either angle of the mouth; pharyngeal teeth in one row, 4 or 5-5 or 4, cuneiform, with a slightly hooked extremity; gill rakers short and lancen. late; dorsal fin rather short, commencing slightly behind the origin of the rentral; anal short; caudal slightly emarginate; scales small, embedded in a thick skin and covered with muens. Lateral line complete. (After Day)

\section{Tinca tinca (Linnaeus)}

Tench (Introduced)

Cyprinus tinca Linnaeus, Syst. Nat. ed. X, I, 321, 175s; Lacépède, Hist. Nat. Poiss. V, 491, 533, 1800.

Tinca vulgaris Cuvier \& Valenciennes, Hist. Nat. Poiss. XVI, 322, pl. 484, 1812; Hecket \& KNer, Süissw. Fische, 75, fig. 34, 1858; GüNTHEm Cat. Fish. Brit. Mus. VII, 264, 1868.

Tinca tinca Jomban \& Evermany, Check List Fishes N. A. 512, 1896.

B. 3 ; D. 12 to 13 ( 8 or 9 developed); P. 17; V. 9-10; A. 9-10. Scales 30 to $31-90$ to 115 . Length of head four and one third to four and three fourths; hight of body three and three fourths to four and one fourth in the total length including caudal. Eye six and one half to seven and one half in length of head; two and one fourth in length of snont; two to two and one fourth in distance between eyes. Interorbital space flat. The thickness 
of the head ronals its length exclusive of the snout. Snout bbiuse; montl anterior. jaws anteriorly of the same length, galpe wide, cleft rather shallow: Hhe maxilla reaches to beneath the posterior nostril; lips thick. Horsal origin over the end of the rentral bist, and the fin extends almost to above the anal origin: all the fins ronmeder. In the males the first of avell more of the ventral lays are thicker that in the female. Latreal line

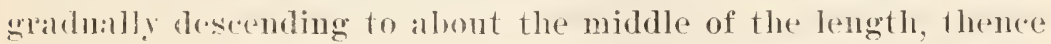
proceseding straght to the base of eatudal. Leaden or greenish, lightest beneath; fins blackish.

The tench has been introduced into the Enited states. In individnal taken in the l'otonate river neat Washington I). r. lias a grinding surface well heveloped on the pharygeal teeth, a character concerning which no mention is made in the current doscriptions.

The tench now extends throughout the fresh waters of Enrope into those of Isia Minor. Its northern limit is said to be in Finland. It may or may not be native to England. The species prefers still waters in which arputic plants abound. It is rery tenacious of life and has been observed to live a whole day ont of water. Its food consists of insects, larvae, wolms, and vegetable substances.

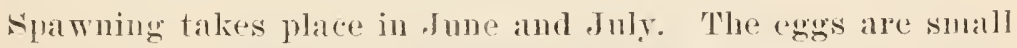
and adhesive. The rate of growth is rather latpid under falvor-

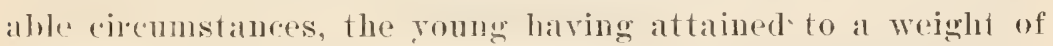
1 foumd in their first year. Individuals of the woiglit of $10 \mathrm{or}^{\mathrm{P}}$ 11 pounds are recorded, and salvianns mentioned a truele of zo pounds. Is for the quality of its flesh, opinions differe, some persons rousidering it mualatahle, while others regitrel it as delicious and wholesome.

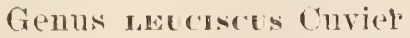

Body oblong, compressed or robust, covered witl moderate or small scales; lateral line decurved, complete, or variously imperfect; month usually larege and ferminal, the lips normal, without bapbel; teeth mostly $2,54,2$ (in American spocies some 
times 1, 5-1, 2, or even by atrophy, 1, 4-4, 1) nsually $2,5-5,23$ in the European type, hooked, with rather narrow grinding surface or none; anal basis short or more or less elongate; dorsal fin posterior, usually behind ventrals; intestinal canal short. size generally large, some species very small. A very large group, one of the largest current genera in ichthyology, represented by numerous species in the rivers of Europe, Asia, and North America. . Individual irregularities in dentition are common in this genus.

The typical species of the genus, la e u c is cus le u c is cus, is the common dace or vandoise of Europe, and differs greatly from any of the Anerican forms. The presence of various intermediate species, howerer, makes it impossible to draw any satisfactory line between the dace, L e u c is c us, on the one hand, and such extreme forms as the long-moutlued minnows, C: l in os tom 11 s, on the other.

Clinos tom us is a peculiar groul of small, fine-scaled ninnows, with the galpe of the mouth larger than in any other Cy prin id a whatever. The relationship of the species to those called Rir le a r d so n i us is howerer very close. (After Jordalu and Evermann)

\section{Nubgenus cervosmosus Girard \\ T: Leuciscus elongatus (Kirtland) \\ Red-sided Shiner}

Luxilus clomyutus KinkLand, Rep't Zool. Ohio, 169, 18:36; Bost. Jour. Nil. IIist. III, 839, pl. IV, fig. 1, $18+1$.

le'uciscus proriger Gün'rher, Cat. Flsh. Brit. Mus. VII, 245, 1868.

Squalius elongatus Jordan \& Gilbert, Bull. 16, U. S. Nat. Mus. 23:. 1883. Phoxinus elongatus Bean, Fishes Penua. 52, 1893.

Leuciscus elongatus DE KAY, N. Y. Fauna, Fishes, 214, 1S42; Storer, Syn. Fish. N. A. 161, 1St6; Günther, Cat. Fish. Brit. Mus. VII, 245, 1S6S; Jordan \& Evermann, Bull. 47, U. S. Nat. Mus. 240, 1896.

The red-sided shiner has an elongate fusiform body, its greatcst depth two ninths of the total length without the candal, its greatest width nearly one half of its depth. The caudal peduncle is long and slender, its least depth two fifths of greatest 
depth of body. The huad is large, two sevenths of total length without the caudal, with long pointed snout and wide mouth. The snout is as long as the eye and two serenths as long as the head. The width of the interorbital space is about equal to the diancter of the eyc. The lower jaw juojects strongly. The

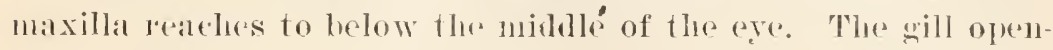
ings are wide, the membrates separated by a very narrow isthmus. The dorsal origin is over the 25 th seale of the lateral line; the base of the fin is two fifths as long as the head; the longest $1 \mathrm{ay}$ is as long as the head without the snout; the last ray is about half as long as the longest. The rentral origin is under the as scale of the lateral line; the fin extends to the vent, equaling length of eye and snout combined. The anal origin is under the $3 \pi$ th scale of the lateral line; the anal base is two fifths as long as the head; the longest ray twice as long as the last ray and one fourth of its distance from the tip of the snout. The caudal is large and deeply forked. The pectoral is two thirds as long as the head, extending to below the 17th scale of the lateral line. The lateral line is abruptly decurred over the anterior half of the pectoral. I). iii, 7 ;. . iii, 7 ; V. S; P.14. Scales 12-63-7 (sometimes 10-70-5); teeth 2, 5-5, 2, hooked, some of them with a narrow grinding surface. In spirits the rolor is dark brown; a narrow dark stripe along the middle of the side extending on the hearl and around the snout; the fins are pale. In life the back is dark bhish, the belly silvery; breeding males have the first half of the hateral stripe crimson and the belly and lower fins rosy. The specimen desiribed, number S467, I. S. National Mnsemm, from Meadville, Pal., is 3 inches long.

The red-sided shiner is found from Pennsylrania to Minnesota; abundant in clear streams of the Great lakes region and the npper Mississipji ralley. In the Take Ontario basin the U. s. Fish Commission collectors obtained it in the following loealities in 1894: Apring brook, Pulaski, July 24; Wart ereek. . July 24: Three Mile areck, Oswego, July 27. 


\section{Subgenus phoxms Rafinesque \\ 7:3 Leuciscus margarita (Cope)}

\section{Peurl II innow}

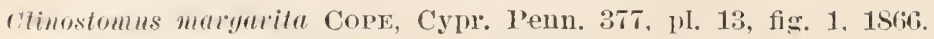
s'rnalius margaritus Jornax \& Gildert, Bull. 16, U. S. Nat. Mus. 2:5. 185:3.

Phrinus margatitus BeAx, Fishes Penua. 53, 1893.

Lencisens maryarita Güntmer, Cat. Fish. Brit. Mus. VII, 246, 1Sris; Jolnax \& Evermand, Bull. 47, I\%. S. Nat. Mus, 241, 1896.

Inzzle obtuse, month oblique, scarcely attaining the line of the anterior margin of the orbit; head four times in body to hase of caudal fin, equal to greatest depth; 'ye three fourths its diameter from end of muzzle, and equal to postero-inferior inargin of opereulum. Scales less exposed on anterior than on posterior regions: 11-58-8 to 9. The lateral line is discom. tinued 5 to $S$ scalles anterior to the caudal fin. I'haryngeal teeth slender, 2, $5-4,2$. Dorsal originating behind origin of rentrals, i, S; A. I, S; V. S, extending three fourths from its origin to the auts; $P$. 17, reaching two thirds way to ventrals.

From origin of caludal to first dorsal ray .......... 12

From first dorsal ray to hind margin of orbit....... 9.5

From first dorsal ray to end of muzzle........... 13.5

From first anal ray to eandal base............. 8

From end of muzzle to base of ventrals.......... 1:

Total length, 2 inches 6 lines.

Coloration above light olive, without dorsal line, but darker shade at origin of dorsal fin with a minute slaty dusting and a few lateral speckles of the same. Sides to halfway above the lateral line and opercula plumbeous silvery; below bright crimson (in midsmmuer) to lower margins of pectoral and rentral fins; median line below straw-coloped. Muzzle blackish; fins muspotted. (After Cope)

The pearl minnow was supposed to be limited to the susquehanna river and its tributaries, but it is now known southward to the Jannes and the head watel's of the kinawhil, and has 
been reported, somewhat doubtfully, from Cemetery creek, at Watertown N. Y. by Dr Evermann.

It is a stout-bodied little species, growing to a length of 3 inches.

\section{Genus mos Heckel}

Pharyngeal teeth in two series, $: 3,5-5,3$, forr of those in the principal row laterally compressed and hooked at the tips; lateral line complete; eyes small. Scales small; dor'sal and anal fins short, without thickened anterior rass; mouth small, terminal, oblique.

\section{Idus idus (Linnaeus)}

\section{Golden Ide (Introduced)}

Cyprinus idus Linnaeus, Syst. Nat. ed. X, I, 324, 1758.

Leuciscus idus Cuvier \& Valexciexnes, Hist. Nat. Poiss. XVII, 22S, 1S44; Günther, Cat. Fish. Brit. Mus. VII, 229, 1868.

Idus melanotus Heckel \& KNER, Süssw. Fische, 147, figs. T7, 7S, 1859.

Idus idus Jordan \& Evermaxn, Check List Fislies N. A. 512, 1896.

Body moderately elongated and compressed; least hight of caudal peduncle two fifths of greatest depth of body, which is two serenths of total length without caudal; length of head one fourth of total length without caudal; eye large, four times in head and twice in interorbital distance, about as long as the snout; month small; jaws equal in length, the maxillary reaching to below the posterior nostril; pharyngeal teeth 5, 3-3, 5, hooked, not serrated; dorsal outline almost regularly arched, similar to ventral outline, top of head slightly flattened; dorsal origin at, or somewhat behind, the middle of the length, directly over the origin of the rentral, its hight nearly equal to length of head; rentrals in advance of dorsal, and extending to the rent; pectorals short, not reaching to rentrals; candal deeply forked, its lobes equal; lateral line decurved, its second half well below the median line. Tertebrae $26+21=4 \overline{6}$. Reaches a length of 18 or 20 inches and the weight of $(0$ jounds. I). 11-12; A. $13-14$; $\mathrm{V}$. 10 . Scales 9 or $10-56$ to $59-7$, four and one half series between the lateral line and rentral fin.

A variety known as the golden ide, orfe, or gold nerfling has been introduced, for ornamental purposes, into American ponds. 
The back and sides are vermilion or orange red; belly silvery; a broad indistinct band of violet tint runs longitudinally to the tail, and divides the deep red of the back' from the pale tint of the lower parts; all fins red at base and pale at tips; iris golden red, with a black pupil.

\section{Genus ambanis Cuvier}

Subgenus votemigonus Rafinesque

Body subelliptic, strongly compressed, both back and belly curved; back narrowly compressed, almost carinated; belly behind ventral fins forming a keel over which the scales do not pass. Head small, conic; mouth small, oblique or horizontal, without barbels; scales rather large; lateral line continuous, strongly decurved; dorsal fin inserted behind the rentrals; anal fin with its base more or less elongate; teeth 5-5, hooked, with grinding surface, the edges more or less crenate or serrate; alimentary canal short, though rather longer than the body; size rather large.

Several species, one of them in coastwise fresh waters from Nora Scotia to Maryland, west to Dakota; another in rivers of the South Atlantic states and south to Texas. A peculiar form in Central park, New York city.

\section{Abramis crysoleucas (Mitchill)}

\section{Roach; Golden Shiner}

Cyprimus crysolencas Mitchill, Rep. Fish. N. Y. 23, 1814.

Cyprinus hemiplus Rafinesque, Amer. Month. Mag. II, 121, Dec. 1817.

Lake George, Lake Saratoga.

Abramis versicolor DE KAY, N. Y. Fauna, Fisbes, 191, pl. 32, fig. 103, 1 S42. Stilbe chrysoleucas DE KAY, N. Y. Fauna, Fishes, 204, pl. 29, fig. 91, 1842. Abramis americamis Günther, Cat. Fish. Brit. Mus. VII, 305, 1868.

Notemigonus chrysoleucas Jordan \& GrLberT, Bull. 16, U. S. Nat. Mus. 250, 1883; BEan, Fishes Penna. 53, pl. 24, fig. 42, 1893.

Abramis crysolencas Jordan \& Evermann, Bull. 47, U. S. Nat. Mus. 250 , 1S96, pl. XLV, fig. 111, 1900.

The body of the roach is compressed, the back elevated and the head depressed and very small. The depth of the body is one third of the total length without the caudal; the head is contained four and two third times in this length. The eye is 
contained three and one half times in the length of the head. The mouth is small, oblique, the maxillary not reaching to rertical through front of eye. The dorsal fin is much higher than long; its base is equal to the least depth of the caudal peduncle or twice the diameter of the eye, situated on middle of body opposite the space between the ventral and anal fins. Anal longer than dorsal, its longest ray slightly exceeding the length of the base. Caudal forked. Lateral line much decurved on lower half of body behind pectorals. D. S; A. 13. Scales 10-53-3. Teeth $5-5$, hooked and with grinding surface.

The roach, shiner, golden shiner or brcam is one of the commonest fishes of the eastern states. It is found from New England to Minnesota and southward. A variety of the roach replaces the common northern form from North Carolina to Texas.

Erermann and Bean obtained it at Rouse Point N. Y. and in Scioto creek, Coopersville N. Y. July 19, 1S94. In the Lake Ontario basin, the U.S. Fish Commission has it from:

Salt brook, $1 \frac{1}{2}$ miles abore Nine Mile point June 11, 1893 Cape Vincent June 21, 1894 Grenadier island June 27, 1894

Black river, Huntingtonville July 5,1894 Guffon creek, Cliaumont July 7,1894 Chaumont river July 10, 1894 Black creek, Scriba Corners July 17,1894 Mouth Salmon river, Selkirk July 25, 1894

Dr Meek secured it in sluggish water on the flats near Ithaca. The roach is abundant in the lakes of Central park and in the Bronx; it was not found in the large lake of Prospect park, Brooklyn.

Eugene Smith records its occurrence in the vicinity of New York associated with the common sunfish, killies, and catfish.

The roach grows to a length of 1 foot and a weight of $1 \frac{1}{2}$ pounds. It frequents sluggish waters, abounding in bayous and weedy ponds, as well as in tidal waters. According to Jordan, 
its favorite shelter is the rellow pond lily. It may be readily distinguished by its shape, which resembles that of the shad, and by the very long anal fin, which contains from 14 to 17 rays. The colors of this fish are greenish above and the sides silvery with golden reflectoons. Fins usually yellowish; lower fins scarlet in breeding males.

Though the roach is not a good food fish, it is taken br the. hook in large numbers and is a rery useful species for bait.

The roach, writes Engene Smith, is an active fish and lives well in the aquarium, becoming very familiar with its keeper. Owing to the small size of its gullet, the smaller individuals will at length starve unless their food is much comminuted. The fish spawned in captivity in May, and early in December of the same year the young were $1 \frac{1}{2}$ inches long. The adults do not like earthworns, but feed freely on chopped hard clams.

76 Abramis chrysoleucas roseus subsp. nov.

\section{Irish Roach; Pearl Roach}

Abramis crysolencas subspecies, Bean, Bull. Amer. Mus. Nat. Hist. N. Y. IX, 334, 1897.

The "Irish roach" or "pearl roach" of a lake in Central park, New York city, is even more distinct from the typical northern roach than is the subspecies bos $\mathrm{ci}$ of the rivers of the South Atlantic states, and should receive a name. This form is readily distinguished from A. crysole ucas by its short and deep body, uniform size of scales on all parts of the hody, and the permanent vermilion color of the pectoral, ventral, and anal fins. An example studied in the New York aquarium has D. i, 7 ; A. i, 12 ; V. i. 8 , scales $10-48-4$; teeth $5-5$, hooked, crenate, and with a grinding surface. The lateral line apparently is not so strongly decurved as in A. cr y s o le u c as.

This is a beautiful fish and extremely shy in captivity. Two females and a male were ready to spawn in the aquarium ahout the end of June 1896. The females cast their eggs, but they were inmodiately eaten by the fish. 


\section{Genus so'morss Rafinesque}

Body oblong or elongate. n! pe or less compressed; mouth normul, mostly terminal and oblique, sometimes subinferior; no barbels; teeth in ome $0 r^{\circ}$ two rows, those of the larger row always 4-4, hooked, sharp edged, or with a narrow grinding surface; scales large, often closely imbricated, those before the dorsal rarely very small; lateral line complete or nearly so, msually decurved; dorsal fin inserted above, or more usually behind, the rentrals; anal fin short or moderately long; abdomen rounded, never sharp edged. Coloration more or less silvery, often brilliant, the males in spring usually with red or white pigment and the head with small tubercles. A very large group of small fishes, specially characteristic of the fresh waters of the eastern United States, containing about 100 species, manc of them characterized by extensive individual variations. (After Jordan and Evermann)

\section{Notropis bifrenatus (Cope)}

\section{Bridled Mimnow}

Hybopsis bifrenatus Cope, Cypr. Penna. 384, 1866; Gü̈ther, Cat. Fish. Brit. Mus. VII, 211, 1868 (as a doubtful species).

Hemitremia bifienata JorDdx \& Gildert, Bull. 16, U. S. Nat. Mus. 162, 1853.

Totropis bifrenatus JomDAN, Check List Fishes N. A. 22, 1585; JoRDAN \& Erernañ, Bull, ti, U. S. Nat. Mus. 258, 1896.

Front convex between the orbits; length of muzzle equals diameter of iris band and pupil, sometimes nearly equals orbit. Iris colored in continuation of the lateral band. The lateral line rarely extends half way to the dorsal fin. while the pores of the same may be observed at the bases of the scales for half the remaining length of the animal. Length of the largest specimen, 19 lines; breadth of muzzle at nares, 1.5 lines. Radij of the scales strong.

Color above straw, the scales delirately brown edged; below impure white, with a narrow black line along base of anal fin to caudal. Along each side from candal fin aromid the end of muzzle including the end of the mandihle, a shining black band 
one and one half scales in width. This is bordered above on the muzzle, forming an are from orbit to orbit, by an orange band, which is strongly margined above by the brown of the top of the front. Opercular and suborbital regions below the black band, pure silvery. (Rearranged from Cope)

Head four and one fifth; depth four and one fifth; eye three. D. 8 ; A. 7. Scales 5-36-3; teeth 4-4. Body rather slender, the caudal peduncle somewhat contracted; head moderate, the muzzle very obtuse; mouth oblique, the jaws about equal, upper lip opposite lower part of pupil; eye large, longer than snout; lateral line developed for a very short distance. 13 scales before dorsal. Length $1 \frac{1}{2}$ to 2 inches.

This little minnow has no common name. It is found from Massachusetts to Maryland and is abundant in tributaries of the Delaware river. On account of its conspicuous colors, it is a useful bait for game fishes, specially the black bass.

\section{Notropis anogenus Forbes}

Notropis anogenus Forbes, Bull. Ill. Lab. Nat. Hist. 13S, 1SS5; MeEk, Anu.

N. Y. Acad. Sci. IV, 30t, 1sss, Canal neal Iontezuma, N. Y.; Jordan \& Evermann, Bull. 47, U. S. Nat. Mus, 259, 1 S96.

Head four and one fourth; depth four and two fifths; eye three and one fourth. D. $8 ;$ A. T. Lateral line 34 to 37,13 before dorsal. Teeth 4-4. Very similar to $\mathrm{N}$. he te rod o n, but with the lateral line usually complete; the mouth very small and very oblique, almost wholly anterior; the lower jaw included, the upper lip abore level of pupil; snout rery short, blunt, shorter than eye.' Dusky; a dusky lateral band through eye, ending in a faint black spot at base of caudal; a black speck above each pore of lateral line; chin black. Length $1 \frac{1}{2}$ inches. Western New York (Cayuga lake, Mcek) to northern Illinois; rather scarce. (After Jordan and Evermann)

According to Teek the species is quite common in the canal near Montezuma N. Y. It is the smallest of all the Cayuga lake fishes.

\section{Notropis cayuga Meek}

Notropis caynga MeEK, Ann. N. Y. Acad. Sci. IV, 305, 1S88, Cayuga Lake. N. Y.; Jordax, Bull. L. S. F. C. IX, 17, 1891; Jordax \& EvermaxN, Bull. 47, U. S. Nat. Ius. 260, 1896. 
Head four and one sixth; depth four and one half; ere three and one half. Scales 36 ; before dorsal 14. Teeth 4-4. Allied to $\mathrm{N}$. he te rodon, from which it may be best known by the absence of black on the chin. Lateral line wanting on some scales; mouth very small, anterior, the maxillary not reaching the cye; jaws subequal; eye large, equal to snout. Scales above dark edged, the outlines very sharply defined; chin not black; a black stripe through snout and eye, a dusky lateral shade and a small caudal spot. Length $2 \frac{1}{2}$ inches. Cayuga lake and northern New York, westward to Assiniboia, South Dakota, Nebraska, Kinsas and Arkansas. Not rare, but hitherto usually confounded with $\mathrm{N}$. he terodo n. (After Jordan and Erermaun)

Sereral examples were taken by Dr Meek near Ithaca. The longest was $2 \frac{2}{5}$ inches. He also obtained it from the canal near Montezuma N. Y.

The U. S. Fish Commission parties secured this minnow in many localities in 1894 .

Mouth of Little Salmon creek

July 25

Chaumont river July 10

Black creek, tributary of Oswego rirer July 17

Three Mile creek, Oswego

July 27

Great Sodus bay

Guffon creek, Chaumont Aug. 6 July 7

Four Mile creek, Nine Mile point, Irebster Aug. 9 Cemetery creek, Watertown July 5

Mud creek, Cape Vincent June 25

Mill creek, Sacketts Harbor July 2

\section{S0 Notropis heterodon (Cope)}

Albumops heterodou Core, Proc. Ac. Nat. Sci. Phila. 251, 1864.

Hybopsis lieterodon Cope, Cypr. Penna. 382, 1866.

Leueiscus heterodon Günther, Cat. Fish. Brit. Mus. TII, 261, 1S6S.

Hemitremia heterodon. Jopdax, Man. Vert. 303, 1878; JoRdAN \& GILbert, Bull. 16, U. S. Nat. Mus. 163, 1583.

Totropis heterolou Jordan, Cat. Fish. N. A. 22, 1855; Jordan \& Evermann, Bull. 47, U. S. Nat. Mus. 261, 1 S96.

Head four; deptl: four ; eye three in head. D. S; A. S. Scales $5-36-3$, the lateral line extending about half the length of 
borly; teoth 4-4, often crenate. Body moderately stout, the back somewhat elevated; head rather pointed, the muzzle acuminate; mouth oblique, lower jaw projecting, npper lip opposite upper rim of pupil; maxillary extending to opposite front of orbit; 13 scales in front of dorsal; lateral line usually more or less imperfect. Color olivaceous; chin black; a blackish rostral band; sides with a leaden or dusky band. Length $2 \frac{1}{2}$ inches. New Tork to Michigan and Kansas, common. Variable. (After Jordan and Evermann)

Common in all the sluggish water on the flats near Ithaca. Not found at the north end of the lake. where it seems to be replaced by Notropis a nogenus. Mceto

The C.S. Fish Commission collectors have obtained it at Cape Vincent X. Y. June 21, Stony Island, July 2 and 3, and at Guffon creek, Chaumont. July $\mathbf{7}, \mathbf{1 S 9 4 .}$

\section{S1 Notropis blennius (Girard)}

\section{Straw-colored Minnow}

Albumops blennius Gratid, Proc. Ac. Nat. Sci. Phila. 191, 1856. Pacific R. R. Surv. X, 261, pl. 57, figs. 13-16, 1855.

Mimnilus blemins Jordan \& Gilbert, Bull. 16, U. S. Nat. Mus. 193, 1883. Notropis blennius Jordan, Cat. Fish. N. A. 24, 1855; Jordan \& Everaraxx, Bull. 47, U. S. Nat. Mus. 261, 1896.

Body slender, elongate, its greatest depth one fifth of total length without caudal; head rather large, one fourth of total length without caudal; the eye large, a little longer than snout, one third as long as the head; mouth small, inferior, horizontal, the maxilla reaching to front of orbit; snout very obtuse; dorsal a little nearer to tip of snout than to base of caudal, its origin about orer end of pectoral, its longest ray three fourths as long as the head; teeth $4-4 ; 13$ to 15 rows of scales before dorsal. The rentral is under the base of the dorsal, its length equal to length of head without snout. D. 8 to $9 ; A .7$ to 8 . Sicales 5 to $6-32$ to $38-4$.

Color pale olivaceous; sides usually pale; usually a darker dorsal band and a small dark bloteh before dorsal, sometimes a plumbeous lateral stripe but no caudal spot; fins all plain. Length 2 to $2 \frac{1}{2}$ inches. 
This small mimnow is found in the Great lakes region, westwall to Dakota and sonth to Texas. The T. S. Fish Commission collectors secured a moderate number of specimens in 1894 at the following localities.

Cape Vincent

June 23

Grenadier island June 27

Little Stony brook. Henderson bay July 4

Big Sandy creek, Belleville

Mouth Salmon river, Selkirk July 12 Great Sodus bay July 2: Aug. 6

1) B. W. Erermann and Barton A. Bean secured 12 examples in Scioto creek. Coopersille X. I. July 19. 1894. They also took many spacimens. July 17 in the St Lawrence river, 3 miles below Ogdenstrurg X. Y. Dr Erermann observed a diffuse plumbeous band along the side, each scale in the lateral line punctate with black, making the lateral line very conspicuous. In manc a very small black spot was present at base of candal. The forsal was very low, only five ninths length of head.

\section{S. Notropis procne (Cope)}

\section{Shiner}

Hybognathus procne Cope, Proc. Ac. Nat. Sci. Phila. 279, 283, 1864. IIybopsis procne Core, Cypl. Penna. 385, pl. XI, fig. 2, 1 \&66.

Lenciscus proene Günther, Cat. Fish. Brit. Mus. VII, 260, 1868. Cliola procme Jordax \& Gilbert, Bull. 16, U. S. Nat. IIus. 169, 1853. Notropis proene Jordax, Cat. Fish. N. A. 23. 1595; Bexw, Fishes Penna.

37. 1893; Jordax \& Evermanx, Bull. 47, U. S. Nat. Mus. 261, 1896.

This little minnow has a short, slender and compressed body and a rers slender caudal peduncle. The greatest depth, at the dorsal origin equals the length of the head, which is about one fourth of the total without caudal. In some described specimens the head is contained four and three fourths times and the depth of the body fire and one fourth times in total length without caudal. The snout is short and obtuse, shorter than the eye, which is two fifths as long as the head. The mouth is terminal and small, the maxilla not reaching to front of ere. and the jaws equal. The lateral line is gently curred down- 
ward orer the pectoral and, in the specimen examined, becomes interrupted in its posterior half. The dorsal origin is over the 12 th scale of the lateral line and nearly over the ventral origin. The dorsal base is a little more than half as long as the head, and the longest ray is as long as the head. The ventral reaches to the anal origin. The anal base is half as long as the head and the longest anal ray is four fifths as long as the head. The caudal is moderately forked. D. S; A. 7; V. S; P. 13. Scales $5-32$ to 34-3; teeth 4-4. Length of specimen described, from Havre de Grace Md., $2 \frac{1}{4}$ inches. Color in spirits light brown, the belly pale and lower half of head silvery. A narrow dark line along the top of the back and a narrow dark median band continued forward on the nose. Fins all pale. In life the body is olivaceous with a dark lateral stripe. The long tail suggests the name proc ne, a kind of swallow.

The shiner is found from western New York to Maryland. Prof. Cope found it abundant in the tributaries of the Delaware and Susquehanna, in slow moring streams. It reaches the length of $2 \frac{1}{2}$ inches.

Eugene Smith records it as "rery plentiful in the small brooks directly running into tide water. It appears to approach the sea more closely than any other minnow, though it is never found in brackish water. It delights in strong currents, but in captivity lives well in the aquarium, feeding voraciously. It is almost entirely carnivorous. The Palisade ridge is probably the furthest limit of this species towards the east. It is met with in company of the suckers and the roach."

It has proved an excellent bait for the game fishes.

\section{S3 Notropis hudsonius (De Witt Clinton)}

\section{Spawon-cater; Smelt}

Clupea hudsonia De Witr Clinton, Ann. Ljc. Nat. Hist. N. Y. I, 49, pI. 2, fig. 2, 1824 (fide Günther).

Leuciscus hudsonius DE KAY, N. Y. Fauna, Fishes, 206, pl. 34, fig. 109, 1842. (Hudson river and tributaries)

Hybopsis hudsonius Core, Cypr. Penna. 3S6, pl. 12, fig. 3, 1866.

Cliola hudsonia Jordan \& Gilmert, Bull, 16, U. S. Nat. Mus. 171, $18 \varsigma 3$. 
Notropis hudsonius Jordan, Cat. Fish. ‥ A. 24, 1885; Bean, Fishes Penna. 3S, 1893; Jordan \& Evermans, Bull. 47, U. S. Nat. Mus. 269, 1\&96, pl. XIVII, fig. 119.

The spawn-eater has a moderately elongate and compressed bodr, its greatest hight contained four and one half times in the total length without caudal, and about equal to length of head. The head is conical, with short, blunt snout equal to the diameter of the eye, which is contained three and one half times in the length of the head. The space between the eyes equals length of postorbital part of head. Mouth small, nearly horizontal, the lower jaw rery slightly the shorter, the maxilla reaching the rertical through the posterior nostril. The lateral line is slightly curred downward orer the pectoral, straight and median for the rest of its course. The origin of the dorsal is over, and of the rentral under, the 13 th scale of the lateral line. The dorsal base is two thirds as long as the head, and the longest ray as long as the head. The ventral reaches nearly or quite to the rent. The anal origin is under the 24 th scale of the lateral line; the anal base is one half and the longest anal ray four fifths as long as the head. The caudal is large and deeply forked, its middle rays half as long as the outer. D. 8 ; A. S or 9 ; T. 8; P. 14 . Scales $7-38-5$; teeth $2,4-4,1$ or 2 , with a narrow grinding surface on at least two. Length of specimens described from Washington D. C. $3 \frac{1}{2}$ to $4 \frac{1}{4}$ inches. Color in spirits pale brown, the fins and all of head except upper surface pale; a broad median silvery band, its greatest width about equal to diameter of ere; a dusky spot at the root of the caudal in the young.

The spawn-eater is said to occur from Lake Superior to New York and southward. In Pennsylrania begins a form elsewhere described as $\mathrm{N}$. a $\mathrm{m}$ a $\mathrm{r} \mathrm{u}$, which differs in the structure of the pharyngeal teeth.

This minnow does not mucl frequent small streams, but is abundant in the Delaware river and also in Lake Erie. De Kay records its occurrence in the Hudson and its tributaries.

In the Lake Ontario region the U. S. Fish Commission collectors obtained numerous specimens in these localities. 
Salt brook, $1 \frac{1}{2}$ miles above Nine Mile point June $10-11,189: ?$

Cape Vincent

June 21,1894

Grenadier island

June 27, 1894

Horse island, Saclietts Harbor

June :30, 1894

Mouth Salmon river, Selkirk

July 25, 1894

Three Mile creek, Oswego

Jи1у 2т, 1894

Great Sodus bay

Aug. 6, 1S94

Long poud, Charlotte

Aug. 17, 1894

Lake shore, mouth Long pond

Aug. 17, 1894

Nine Mile point, Webster

Aug. 23, 1894

East end Lake Ontario

1894

Livingston Stone also collected the species at Cape Vincent A 1 .. 9, 1898.

In the Lake Champlain basin Erermann and Bean obtained it at Scioto creek, Coopersville, and Rouse Point July 19, 1894.

The spawn-eater reaches the length of 10 inches. Its teeth are usually four in the principal row and two in the inner. Its spawn-eating habits are not rerified.

\section{St Notropis hudsonius amarus (Girard)}

\section{Gudgeon}

IH udsonins amarus Girarn, Proc. Ac. Nat. Sci. Phila. 210, 1856. (Chesapeake Bay; Potomac liver at Washingtou)

Hybopsis storerianus Cope, Cypr. Penna, 356, 1866.

Lencisens storeriamis G̈̈ntuen, Cat. Fish. Brit. Mus. VII, 250, 1868; KintLAND, Bost. Jour. Nat. Hist. Y, 30, pl. IX, fig. 2, 1847.

Cliola storeriana JordaN \& Gilbert, Bull. 16, U. S. Nat. Mus. 170, 1883.

Notropis amarms BEAN, Fishes Penna. 39, pl. 23, fig. 37, 1893.

Notropis hudsomills amams Jornan, Cat. Fish. N. A. 24, 1855; JoRDAN \& Evermann, Bull. 47, U. S. Nat. Mus. 270, 1896.

The gudgeon has a moderately elongate and compressed body and a slender caudal pednncle. The greatest depth equals one fourth of the total length to base of caudal, and the least depth of the peduncle equals the length of the postorbital part of liead. The head is rather short with an obtuse short snout: the length of the head is neally one fourth of the total to basc of caudal. The snout is one fourth and the eye one third as long as the head. The maxilla extends to the vertical tlorough the front of 
the eye; the lower jaw is slightly included; the mouth is slightly oblique. The width of the head equals nearly two thirds of its length. The distance between the eyes equals the length of the orbit. The dorsal origin is over, and the ventral origin under, the 10th scale of the lateral line. The length of the dorsal base equals two thirds that of the head, and the longest clorsal ray is four fifths as long as the head. The anal base is as long as the postorbital part of the head and the longest ray is about tro thirds as long as the head. The rentral reaches nearly to the vent, and the pectoral to below the sth scale of the lateral line. The lateral line is very slightly bent downward over the pectoral. The caudal is moderate in size and deeply forked. D. ii, 7 ; A. ii, 7 ; V. 8; P. 15 . Scales $6-36$ to $39-4$; teeth $1,4-4,1$ or 1, 4-4, 0 in the example described, from the Susquehanna river. Length $4 \frac{1}{t}$ inches. The teeth are slightly hooked, and two or three on each side have a developed grinding surface. The color in spirits is light brown, the sides of body and lower half of head silvery; the young have a narrow dusky median lateral band, which is sometimes continued on the snout, and a more or less distinct small dark blotch at the base of the caudal. The fins are all pale.

The gudgeon or smelt of Pennsylvania is a variety of $\mathrm{N}$. l u d s o n i us of Clinton, which ranges from Lake Superior to New York and south in streams east of the Alleghanies to Georgia. The southern form is the variety amarus of Girard, which exhibits some difference in its pharyngeal teeth. The species is an extremely variable one. It grows to a length of about $S$ inches. Prof. Cope records it as abundant in the Susquehanna, specially in the lower part of the river.

This is a handsome silvery fish, and is as much used for food as its associate, the silvery minnow.

\section{S5 Notropis whipplii (Girard)}

\section{Silverfin}

Cyprinella whipplii Girard, Proc. Ac. Nat. Sci. Phila. 19S, 1856.

Photogenis spilopterus Coгe, Cypr. Penna. 37S, 1866.

Leuciscus spilopterus Güstner, Cat. Fish. Brit. Mus. VII, 254, 1868. 
Lnxilus kentuckiensis K̈IRTLAND, Bost. Jour. Nat. Hist. V, 2i, pl. VIII, fig. $3,1847$.

Hypsilepis kentuckicnsis Core, Cypr. Penna. 371, 1866.

Cliola whipplei Jordan \& Gildert, Bull. 16, U. S. Nat. Mus. 178, 1833.

Cliola analostana JoRdAN \& Gilbert, op. cit. 179, $18 S 3$.

Notropis whipplei BEAN, Fishes Penua. 39, 1893.

Notropis whipplii Jordan \& EvenMann, Bull, 47, U. S. Nat. Mus. 278, 1896, pl. XLVIII, fig. 121, 1900.

The silverfin has a moderately elongate body, which is fusiform in the adult. The caudal peduncle is short and stout. The depth of the body at the ventral fin equals nearly one fourth of the total length to the caudal base. The head is conical, compressed and with a pointed snout a little longer than the eye, which is two ninths as long as the head. The mouth is moderate, terminal, slightly oblique, the jaws nearly equal, the maxilla reaching to vertical through front of eye. The head is two ninths of the total length without caudal. 'The dorsal origin is a little behind the ventral origin and over the 15th scale of the lateral line. The length of the dorsal base equals one seventh of the total without caudal, and the longest ray is as long as the head without the snout. The ventral reaches nearly to the anal. The anal begins under the 21 st scale of the lateral line; its base is as long as the dorsal base, and its longest ray is about two thirds as long as the head. The caudal is large and moderately forked. The lateral line curves downward over the pectoral. D. 8 ; A. 9 ; V. 8 ; P. 14 . Scales $6-38$ to $41-4$; teeth $1,4-4,1$, with more or less serrate edges. Length of specimen described, from the Susquehanna river, 4 inches.

In spirits the back is brown, the sides dull silvery, the scales with a dusky margin, and the lower parts are whitish. A narrow and long black blotch on the membrane between the 6th and 7 th and another between the 7 th and 8 th dorsal rays. Lower fins pale. Males in spring have the fins partly or wholly charged with white pigment, and in the hight of the breeding season the pigment in the dorsal lias a greenish tint, and the top of the head and snout is covered with minute tubercles.

This is one of our finest minnows for the aquarium and is useful as food and bait for larger fishes. 
The silverfin ranges from western New York to Virginia and west to Minuesota and Arkansas. It is a common and rariable species. It reaches a length of 4 inches. In Pennsylrania it occurs in all the rivers and creeks, but according to Prof. Cope is least common in tributaries of the Delaware.

According to Dr Meek it is common on flats near Fall creek and in the southern end of Cayuga lake. Evermann and Bean took it in Scioto creek, Coopersville N. Y. in July 1894. In the Lake Ontario region the U. S. Fish Commission secured the following specimens:

Grenadier island

June 27, 1894

Horse island, Sacketts Harbor

June 30,1894

Cape Vincent

June 21, 1894

Mill creek, Sacket Harbor

July 2, 1894

Cemetery creek and Black river, Watertown

July 5,1894

Chaumont river

Great Sodus bay

Creek near Pultneyville

July 10, 1894

Aug. 6,1894

Aug. 7, 1894

Specimens were obtained also by Livingston Stone at Cape Vincent Aug. 9, 1S98, and presented to the State Museum.

\section{Subgenus tuxilus Rafinesque}

\section{S6 Notropis cornutus (Mitchill)}

\section{Shiner; Redfin}

Cyprinus cornutus Mitchill, Amer. Month. Mag. I, 2S9, July, 1817. (meager preliminary notice); op. cit. II, 324, Feb. 181S. (Wallkill river, N. Y.)

cyprimus megalops Rafinesque, Amer. Month. Mag. II, 121, Dec. 1817. (Hudson river, above the falls)

Lcuciscus vittutus DE KAY, N. Y. Fauna, Fishes, 212, pl. 34, fig. 108, 1842.

(Chittenonda and other tributaries of the Mohawk; also in Mohawk)

Hypsilepis cornutus Cope, Proc. Ac. Nat. Sci. Phila. 158, 1567.

Leuciscus comutus DE KAY, N. Y. Fauna, Fishes, 207, pl. 29, fig. 92, 1S42; Günther, Cat. Fish. Brit. Mus. VIII, 249, 1868.

Minnilus cornutus Jordan \& Gilbert, Bull. 16, U. S. Nat. Mus. 1S6, $18 S 3$.

Minnilus plumbeolus JordaN \& GILBert, Bull. 16, U. S. Nat. Mus. 192, 1883.

Notropis megalops Jondan, Cat. Fish. N. A. 26, 1855; BeAn, Fishes Penna. $40,1893$.

Notropis cormutus Jordax \& Evermand, Bull. 47, U. S. Nat. Mus. 281, 1896. 
The redfin when young has the body moderately elongate, but it becomes deeper with age and much compressed. The caudal peduncle is short, and its deptlu equals length of postorbital part of head. The deptli of the body at the rentral is contained three and one third to four times in the total length withont the caudal. The head is short, deep and thin, its length cue fourth of the total without caudal, its width about one half its length. The eye is as long as the suout and two seremthis as long as the head. Mouth moderate, terminal, oblique, the maxilla reaching about to vertical though front of eye. The dorsil origin is over, and the ventral origin under, the 12tlo scale of the lateral line. The length of the dorsal base equals one serenth of the total without the caudal, and its longest ray one fifth of the same length. The ventral reaches nearly or guite to rent. The anal origin is under the $23 \mathrm{~d}$ scale of the lateral line. The anal base is one lialf, and the longest ray two thirds as long as the head. The caudal is large and deeply forked. The lateral line descends in a long curve, becoming straight and median over the anal origin. I. S; A. 9; T. S; I. 15. Scales. 7-40 to 41-4; teeth 2, 1-1, 2, with narrow grinding surface. Length of specimens described, from 4 to $4 \frac{1}{2}$ inches.

The upper parts of this fish are steel blue and the seales are dusky at the edge and base. The sides are silvery, overlaid with a gilt line; there is another gilt band along the back. The belly is silvery except in spring males, in which it is a bright rosy color. The male in the breeding season las the lower jaw and the top of the head and nape corered with small tubercles. In the breeding condition this is a very handsome species, thongh the females and young lack the bright colors of the adult male.

The redfin is known also as the common shiner, dace, ronghlead, and banded dace. It is a rery widely distributed species, is extremely variable, and, as a consequence, some geographic races have received distinct names. It extends from Maine to the Rocky mountains, but is absent from the Carolinas and Texas. It grows to a length of $S$ inches. In Pennsylvania the species is common everywhere and is best known under the name of redfin. It reaches a very large size in Lake Erie. 
In New Iork Mitchill had it from the Wallkill; Rafinesque from the Hudson abore the falls. De Fay knew it from the Mohawk and some of its tributaries including the Chiltenonda. Dr Meek found it rery, common throughout the entire Caruga lake basin. Evermann and Bean collected it in the Saranac river, Plattsburg, July 2S, and in Scioto creek, Coopersville, July 19, 1894. They secured it also in the St Lawrence river, 3 miles below Ogdensburg, July 17, 1S94. The U.S. Fish Commission field parties found it very common in the Liske Ontario basin 1592 to 1894 , specimens having been recorded from: : Sacket Harbor, Clarlotte, Huntingionville, Henderson Harbor, Cape rincent, Pulaski, Oswego, I'ultneyville. Pointbreeze, Trebster, Bellerille, Scriba Corners, Wart creek, North Hamlin and Salt brook.

The redfin runs into small brooks and is most abundant in eddies and other quict parts of the streams. It has no value except as food and bait for larger fishes, specially the black bass and pike perch. The flesh is very soft and decays rapidly after death.

\section{ST Notropis cormutus fromtalis (Agassiz)}

Leuciscus frontalis Agassiz, Lake Superior, 36S, pl. 3, fig. 4, 1850, or Hypsolcpis frontalis fide GüNTHER.

Hypsitcpis cornutus gibbus Cope, Proc. Ac. Nat. Sci. Phila. 15S, 1S67.

Minnilus cornutus var. frontalis Jordan \& GILBERT, Bull. 16, U. S. Nat. Mus. 1ST, 1853.

Notropis megalops frontalis MEEK, Ann. N. I. Ac. Sci. IT, 307. 1SSS.

Notropis cornutus frontalis Jordan \& Evermaxr, Bull. 47, U. S. Nat. Mus. 2S3, 1896.

Very close to the typical cor n ut us, differing in its very heary head and in the smaller number of scales (13 to $1 S$ ) in advance of the dorsal. Great lakes; everywhere common in moutlis of brooks. Mr Meck found it scarce near Ithaca and common near Iontezuma $\mathrm{X}$. $\mathrm{Y}$.

\section{Subgenus Notropis}

\section{SS Notropis atherinoides Rafinesque}

Emerald Minnow: Rosy Minnow

Notropis atherinoides Rafixrsque, Amer. Month. Mag. II, 20\%, Jan. 181., Alburnus rubellus Agassiz, Lake Superior, 364, p1. 3. 6gs. 1-3, 1850.

Leuciscus rubellus Gunther, Cat. Fish. Brit. Mus. VII, 254, 1868. 
Minnilus rubellus and dinemus Jordax \& Gilbert, Bull. 16, U. S. Nat. Mus. 202, 1SS3.

Notropis atherinoides Jordan, Cat. Fish. X. 1. 27, 1885; MeEk, Ann. N. Y. Acad. Sci. IV, 308, 1868; Bear, Fishes Penna. 44, 1898; Jordan \& Evermax, Bull, 47, U. S. Nat. Mus. 293, 1896.

The emerald minnow or rosy minnow has a long and thin boty int the caudal peduncle moderately short and deep. The greatest depth of the body is contained four and three fourths to five and one half times in the total length to caudal base; the least depth of the caudal peduncle is contained $11 \frac{1}{2}$ times in the same length. The greatest width of the body is one half its hight. The head is of moderate size, its length two ninths of the total to candal base. 'The snout is short and somewhat pointed, its length one fourth that of the head. Eye large, about three and one fourth times in length of head; mouth oblique, noderate, the maxilla reaching front of eye. The dorsal origin is midway between the eye and the base of the caudal, orer the 17 th scale of the lateral line. The base of the fin is two fifths as long as the head, and the longest ray equals the length of the head without the snout. The ventral origin is under the 13 th scale of the lateral line, and the fin scarcely reaches to below the end of the dorsal base. The pectoral reaches to below the eighth or ninth seale of the lateral line. The anal origin is under the 24th scale of the lateral line; the base is one half as long as the head, and the longest ray equals the snout and eye combined. The caudal is rather large and deeply forked. The lateral line sweeps downward in a long and shallow curve, becoming nearly median orer the anal base. D. ii, 7 ; A. ii, 9 ; V. S; P. 14. Seales 6-39-4; tecth 2, 4-4, 2 or 1, some of them with a slight hook and narrow grinding surface. The specimens described (110. S735, U. S. National Museum) are 4 to $4 \frac{1}{2}$ inches long. In spirits the upper parts are light brown, the sides and cheeks silvery, and the belly golden brown; the fins all pale; the width of the silvery stripe equal to diameter of eye. In life the upper parts are greenish; breeding males lave the snout rosy.

The emerald minnow is found in the Great lakes region, the Ohio valley and south to Tennessee, being abundant in lakes 
and in rapids of rivers. The rariety found in Pemsylyania has a shorter snout and a smaller we than the typical a the $\mathrm{r}$ in o ides and has receired the specific name d in e'm $u$ s; but the differences are not suplosed to be constant. The emerald minnow reaches a length of 6 inches; it is gregarious like other minnows; and its golden lilteral stripe on a clear green ground makes it a handsome species.

Dr Neek found one example near Ithara, in Six Mile creek, below the falls. A few sperimens were also found in a small stream near Montezuma dry dock, in company with $X$. lythl. 11 r. Exermann and Bean caught a single example in seioto ereek, coopersille, July 19, 1894; also there specimens in the st Lamrenee rivere :3 miles below Ogdensburg July 17. 1S94. It Calpe Vineent June -1. 1894, the U. S. Fish Commission collectors took $: 9$ specimens, and at Grenadicr island, June 27, they obtatined 14 individuals. Livingston stone also collecter the speries at cape Vincent $\perp u g$. 9, 1898, and presinted specimens to the state Musemu.

\section{Notropis rubrifrons (Cope)}

\section{Rosy-faced Himnox}

Alumms rulwifrons Core. Proc. Ac. Nat. Sci. Phila. 85. 1865.

Alumellus rubifrans Cope, Cypr. Prnna. iss, pl. XIII, fig. 3, 18 fig.

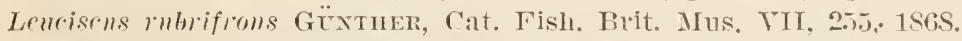

Mimilns rubrifroms and pereobromms Jordax of Gilbert, Bull. 16, L. S. Nat. MIus. 202, 1SS3.

Notropis ditcths EEax. Fishes Penna. 44, 1593.

Notropis rubrifrons Jordix, Cat. Fish. N. A. 2T, 1SS5; Jorndx \& EverM.хx, Bull. 4т, L. S. Nat, Mus, 29i, 1 s.6.

The losy-faced minnow has the hody moderately long and thin. with a short and deep caudal pedumele. The greatest druth of the body rouals one fourth, and the least depth of the perluncle. one cightl of the total lenght to base of caudal. The head is moderate in size; its width one half of its length, which is one fourth of the total to base of candal. The snout is pointed and shorter than the eye, which is one fourth to two serenths as long as the liead and equal to the distance between the eres. The mouth is oblique, aud the lower jaw projects slightly; the 
maxilla reaclies nearly to below the front of the pupil. The dorsal origin is over the 15 tl, and the ventral origin under the 12th scale of the lateral line. The base of the dorsal is half as long as the head, and the longest dorsal ray equals the length of the head witlout the suout. The ventral reaches to the vent, which is under the 18 th scale of the lateral line. The anal base is as long as the snout and eye combined, and the longest anal ray is two thirds as long as the head. The caudal is moderate in size and deeply forked. The lateral line curves gently downward over the pectoral. D. ii, $7 ; A$. ii, 8; T. S; P. 13. Scales 6-36-4; teeth 2, 4-4, 2, hooked. The specimens described are 2 inches long. In spirits the body is pale brown; a silvery shade along the median line; the head silvery except above; belly golden; fins all pale. In life the upper parts are olive green and the sides silvery. Males in the breeding condition in spring have prickles on the snout and the forehead; gill covers and dorsal base with a rosy flush. The name dilectus means delightful.

The rosy-faced minnow, though reaching a length of only 3 inches or less, is a very beautiful fish. It is abundant in the Ohio valley and extends westward to Nebraska. This is the Alburnellus rubrifrons of Cope.

The U. S. Fish Commission collections of 1894 contain this minnow from Salt brook, $1 \frac{1}{2}$ miles above Nine Mile point June 11, Mill creek, Sacket Harbor July 2, Wart creek July 24, Sandy creek, North Hamlin Aug. 20.

Evermann and Bean secured it in abundance in Racquette river, Norfolk, July 18, 1894, and they had a few specimens from Scioto creek, Coopersville, July 19, 1894.

\section{Notropis amoenus (Abbott)}

Alburnellus amœnus Aввотт, Amer. Nat. VIII, 334, 1874. Raritan River, N. J.

Notropis amonus Jordan, Bull. U. S. Fish Com. XIII, 102, 1891; Jordar \& Evermann, Bull. 47, U. S. Nat. Mus. 296, 1896.

Head four; depth five and one third (four and three fourths to five and one half); eye three and one third. D. $8 ;$ A. 10. Scales 
6-39-3. Close to Notropis rubrifrons, but the scales before dorsal smaller, as in N. photoge $\mathrm{n}$ is. Body elongate, compressed; eye large, longer than snout; mouth large, oblique, the jaws subequal, the maxillary reaching to below front of eye; 22 to 25 (rarely 18 to 20 ) scales before dorsal; lateral line much decurred; dorsal high, placed behind rentrals; pectorals moderate. Translucent green, sides silvery, with sometimes a faint plumbeous band ending in an obscure plumbeous spot. Length $3 \frac{3}{4}$ inches. Clear streams east of the Alleghanies from the Raritan to the Neuse; abundant; formerly confounded with $\mathrm{N}$, photogenis, of which it may be a variety. (After Jordan and Evermann)

Eugene Smith ${ }^{1}$ says it is perhaps a variety of $\mathrm{N}$. photogen is (Cope). Abbott mentions it from the Raritan river, near New Brunswick N. J.

\section{Notropis umbratilis lythrurus Jordan}

\section{Redfin}

Notropis lythrurus Jordan, Proc. U. S. Nat. Mus. 476, 1884.

Hypsilepis diplaemia Core, Proc. Ac. Nat. Sci. Phila. 162. 1867.

Minnilus diplaemius Jordan \& Gilbert, Bull. 16, U. S. Nat. Mus. 197, 1883.

Luxilus lucidus Girard, Pacific R. R. Surv. Fishes, 2S2, pl. LX, figs. 9-12, 1858 .

Notemigonus lueidus Jordan \& Gilbert, op. cit. 249, $18 S 3$.

Notropis lythrurus MEek, Ann. N. Y. Ac. Sci. IV, 307, 1888.

Notropis umbratilis lythrurus Jordan \& EverManN Bull. 4i, U. S. Nat. Mus. 300, 1896.

Head four and one fourtin; depth four to four and one half; eye three to four. D. 7 ; A. 11 . Seales $9-40$ to $52-3$; teeth 2 , 4-4, 2. Body compressed, the caudal peduncle long; head long, conical, rather pointed; mouth large, moderately oblique, the premaxillary on level of pupil, the maxillary reaching to below eye; lower jaw somewhat projecting; eye moderate, about equal to muzzle; scales closly imbricated, crowded anteriorly, about 30 before dorsal; dorsal fin high, inserted about midway between ventrals and anal; pectorals not reaching rentrals;

${ }^{1}$ Linn. Soc. N. Y. Proc. 1\$97. no. 9, p. 18. 
ventrals reaching to vent; caudal fin long. Coloration dark steel blue abore; pale or silvery below; a more or less evident black spot at base of dorsal in front; the fins otherwise all plain. Males with the anterior dorsal region and the head profusely covered with small whitish tubercles, the belly and lower fins being of a bright brick red in the spring. Females very pale olive, sometimes almost colorless. Length $3 \frac{1}{2}$ inches. Minnesota to western New York (Cayuga lake), North Carolina, Alabama, and Kansas; generally abundant in small, clear streams. (After Jordan and Evermann)

Dr Meek took a single specimen from a small stream near the Montezuma dry dock.

\section{Genus гнгіснтия Agassiz}

Body moderately elongate and little compressed, with usually stout caudal peduncle and long, conical nose; head rather large, sometimes broad and flat above; eye small; mouth small, subinferior, the uppre jaw fixed by the union of the upper lip to the skin of the forehead; end of maxillary with a small barbel. Teeth $2,4-4,2$ (sometimes $2,4-4,1$ ) those of the principal row usually hooked, without grinding surface. A short intestinal camal; scalles very small; lateral line decurved, continuous; dorsil origin slighty brehind ventral; base of anal short. Small fishes inhabiting clear, cold brooks and streams.

\section{Rhinichthys cataractae (Cuv. \& Val.)}

\section{Long Nosed Daee; Niagara Gudyeon}

Gobio cularactuc Cuvier \& Valenciennes, Hist. Nat. Poiss. XVI, 315, 1). $t$ si (poor), 1842 (specimen 5 inches long, from Niagara Falls, N. Y., Milbert); De Kar, N. X. Fauna, Fishes, 394; 1S42. (After Cuvier and Valenciennes)

Leuciscus nasutus Arres, Bost. Jon!. Nat. Hist. IV, 299, pl. XIII, fig. 3 (very bad), 1814. West Hartford, Conn. Specimen 51/4 inches long. Rhinichthys marmoratus $1 \mathrm{gAssiz}$, Lake Superior, 354, pl. 2, figs. 1-2, 1550;

Gunther, Cat. Fish. Brit. Mus. VII, 189, 1868.

Rhinichthys nasutus Günther, op. cit. VII, 189.

Argyreus nasutus Cope, Cypr. Penna. 369, pl. XII, fig. 5, 1866.

Ceratichthys cataractae GUNTIER, op. cit. VII, 176, 1878.

Rhinichthys cataractae Jordan \& Grbert, Bull. 16, U. S. Nat. Mus. 207. 1883; Bean, Fishes Penna. 46, 1893; Jordan \& Evermann, Bull. 47, U. S. Nat. Mus. 306, 1896 . 
The long nosed dace has a moderately elongate body, with short and stout caudal peduncle and a moderate sized head. The greatest depth is contained four and two thirds times in the total length without caudal; the least depth of the caudal peduncle eight and one half times. The width of the body equals the combined length of snout and eye. The length of the head is one fourth of the total without caudal and three times the length of the snont. The eye is placed high, one fifth to one quarter as long as the head and about two thirds as long as the interorbital wilth. The mouth is horizontal, small, placed under the snout, the lower jaw the shorter, the upper lip thick and provided with a small barbel at each end. The maxilla reaches to below the posterior nostril. The dorsal origin is above the $23 \mathrm{~d}$ scale of the lateral line, and the ventral origin is under the 20th. The dorsal base is one half, and the longest ray four fifths as long as the head. The rentral reaches a little bejond the rent and almost to the anal origin. The pectoral reaches nearly or quite to the origin of the ventral, being longer in males. The anal origin is under the 34 th scale of the lateral line and a little behind the end of the dorsal. The anal base is one half, the longest ray three fonrths as long as the head. The caudal is comparatively large and well forked. The lateral line drops gently downward in a short curve over the pectoral and becomes median over that fin. D. ii, 7; A. ii, 6; V. S; P. 12. Scales $13-57$ to $65-10$; teeth $2,4-4$, 2 , three of the principal row looker. Length of the specimen described (no. S505, U. S. National Museum) $3 \frac{1}{2}$ inches.

In spirits the color is brown mottled with grayish; the under surface of head sharply defined and pale; the fius all pale. Breeding males in spring have the lips, cheeks and lower fins crimson. The sides are without a black lateral band, which is characteristic of the black nosed species. The general color is olivaceous or dark green with the lower parts paler. The back is nearly black. Some of the scales are mottled with dark and olivaceous. The young have a trace of a dusk lateral band. The fish reaches the length of $5 \frac{1}{2}$ inches. 
The long nosed dace or Niagara gudgeon is found in New England and the Middle states, and in the Great lakes region in clear, cold water. In Pennsylvania, according to Cope, it is limited to the rapids and swift waters of the eastern part of the state.

Erermann and Bean collected 50 specimens in Saranac river, Plattsburg N. Y. July 28, 1894 , but did not find it in the St Lawrence river or in the Lake Ontario tributaries. Though Dr Meek obtained no specimens of this species from Cayuga lake basin, he believes it a nember of the fauna, as it is common in the streams south of Ithaca near Van Ettenville, Chemung co. N. Y.

The long nosed dace frequents rapids and rocky pools, and is associated in mountain regions with the brook trout. Its movements are swift and powerful and it is a very shapely little fish. As a bait for the black bass it is scarcely surpassed.

\section{Rhinichthys atronasus (Mitchill)}

\section{Black Nosed Dace; Brook Minnovo}

Cyprimus atronasns MitcniLl, Trans. Lit. \& Phil. Soc. N. Y. I, 460, 1815.

(Wallkill River; Fresli-water trout brooks of New York); Amer. Month.

Mag. I, 289, Aug. 1817. Mud-fish, from Wallkill Creek.

Cymimus viltatus Rafinesque, Amer. Month. Mag. II, 121, Dec. 1S17.

II udson Rivel above the falls.

Lenciscus atronasus DE KAY, N. Y. Fauna, Fishes, 205, pl. 23, fig. 69, 1812. Rhinichthys atronasns Güntmer, Cat. Fish. Brit. Mus. VII, 191, 186s;

Jordan \& Gilbert, Bull. 16, U. S. Nat. Mus. 208, 1883; Meer, Ann.

N. Y. Acad. Sci. 308, 1S86; BEAN, Fishes Penna. 47, pl. 23, fig. 39,

1S93; Jordan of Evermann, Bull. 47, U. S. Nat. Mus. 307, 1896. Argyreus atronasus S'Torer, Hist. Fish. Mass. 122, pl. XXI, fig. 4, 1867.

The black nosed dace has a moderately long and stout body, with a broad back, and rather small conical head. The greatest depth of the body is contained four and one fourth to four and one half times in the total length without caudal. The least depth of the caudal peduncle equals one half greatest depth of body. The head is one fourth as long as the fish to caudal base; its width is about one half its length and the snout nearly one third to two serenths. The eye is as long as the snout and mucl less than width of interorbital space. The mouth is small, 
slightly oblique and with nearly equal jaws; the maxillary barbel small or wanting; the maxilla reaches to below the front edge of the posterior nostril. The dorsal origin is nearer to root of caudal than to tip of snout, over the 26th scale of the lateral line. The length of the base is contained two and one third times in that of the hear, and the longest ray equals length of head without snout. The rentral origin is slightly in advance of the dorsal origin, and the fin extends to the vent. The pectoral reaches to the $16 \mathrm{th}$ scale of the lateral line. In breeding males it is greatly thickened. The anal origin is behind the end of the dorsal base, under the 34 th scale of the lateral line; the fin is variable in length with sex and age, sometimes five sixths as long as the head. The caudal is small and not deeply forked. The lateral line curres downward over the pectoral, soon becoming median. D. ii, 6 or 7 ; A. ii, 6;'V. 8; P. 11. Scales $10-56$ to $63-10$; teeth $2,4-4,2$, three of the principal row strongly hooked. Length of the specimens described (110. 33984, U. S. National Museum) $2 \frac{5}{5}$ to 3 inches. In spirits the upper parts are brown and are separated from the silvery lower parts by a dark lateral band, as wide as the short diameter of the eye and continued on the snout. Breeding males in spring have the lateral band and the lower fins crimson, running into orange in summer. In the young the dark nedian band extends on the tail fin.

The black nosed dace or "rockfish" is represented in our waters by two forms, one of which is found in the eastern part of the Great lakes region and from Maine to Virginia; this is replaced in the upper lake region and in the Ohio valley, southward to Georgia and Alabama, by the blunt nosed variety, Rhinichthys obtusus of Agassiz.

The species grows to-the length of 3 inches.

The collections of the U. S. Fish Commission in the Lake Ontario region contained this species from a great many localities: Cape Vincent, Great Sodus bay, Sacketts Harbor, Stony Island, Grenadier island, Oswego, Buena Vista, Belleville, Pulaski, Wart creek, Huntingtonville, Henderson bay, and Webster. The 
fish were taken in June, July and August and were rather common in most places.

Evermann and Bean took one example in the St Lawrence river, 3 miles below Ogdensburg, July 17, 1894; they secured eight specimens in the Saranac, at Plattsburg, July 2s, 1894. Aceording to Dr Neek it is common near Ithaca in all streams above and below the falls; but was not found by him near Montezuma. Nitchill described the fish from fresh-water brooks of New York containing trout, chiefly from the Wallkill, where Rafinesque also knew of its occurrence. De Kay states its habitat to be clear, fresh-water streams and rivulets of New Tork and arljoining states. Eugene Smith found it associated with darter's, blobs and small minnows in the vicinity of New York city.

This fish prefers clear small brooks. Swift and active in its movements and beautiful in colors, it is one of the most interasting inhabitants of the waters in which it lives. In the aqualium Eugene Smith observed it to eat roraciously of animal food and to be more hardy than any other minnow.

\section{Genus nxmopsis Agassiz}

Body robust, or variously elongate; mouth terminal or inferior, with lips thin or somewhat fleshy, a conspicuous barbel always present and terminal on the maxillary; a second barbel sometimes present on each side; premaxillaries protractile. 'Teeth 4-4, $01^{\circ} 1,4-4,1,01^{\circ} 0$; hooked, the grinding surface narrow or obsolete. Scales msually rather large; lateral line continuous. Dorsal inserted over, in front of, or slightly behind ventrals; anal basis short. Males usually with nuptial tubercles, and sometimes flushed with red. A large and varied group, closely allied to $\mathrm{Not}$ o p is, from which it differs chiefly in the presence of the small maxillary barbel. (After Jordan and Evermann) 
Subgenus Ekmystax Jordan

94 Hybopsis dissimilis (Kirtland)

Spotted Shiner

Luxilus dissimitis Kintland, Bost. Jour. Nat. Hist. III, 341, pI. IV, fig. 2, 1811.

Cerutichthys dissimilis Cope, Cypl. Penna. 368, pl. 12, fig. 1, 1S66; Günther, Cat. Fish. Brit. Mus. VII, 177, 1S68; JorDAx \& GilberT, Bull, 16, U. S. Nat. Mus. 215, $18 S 3$.

Hybopsis dissimilis Jordax, Cat. Fish. N. A. 29, 1S85; Beax. Fishes Penn:1. 4S, 1S93; Jordan \& Evermaxx, Bull. 47, U. S. Nat. Mus. :31s, 1894.

The spotted shiner has a long and slender body, its greatest depth being nearly one fifth of the total length withont the caudal. The caudal pelnncle is long and low, its least depth two fifths of greatest depth of body. The width of the body equals two thirds of its depth. The head is moderately large, its length one fourth of the total withont the candal. The snout is $\operatorname{lon} g$ but obtusely rounded at the point, its length one and one half times the diameter of the eye, which is two sevenths of the length of the head. The nouth is small, inforior, horizontal, the maxilla reaching to below the anterior nostril and with a small barbel at its hind end. The gill openings are separated by a very broad isthmus. The dorsal hegins over the 16th scale of the lateral line and slighty in atrance. of the ventral; the dorsal base is one half as long as the hean; the longest ray is as long as the head without the snout; the last ray is as long as the snout. The rentral reaches to the rent, its length one serenth of the total without the caludal. The jectoral reaches to below the listh scale of the lateral line. The anal origin is under the 27 th scale of the lateral line; the anal base is short, equaling the diameter of the eye; the longest ray is as long as the ventral; the last ray is one third as long as the head. The caudal is moderately large and deeply forked, the middle rays one lialf as long as the external rays. The lateral line is nearly straight and median. D. ii, 8 ; A. ii, G; V. 7; P. 15. Scales 6-43-5; teeth 4-4, looked and with a short grinding surface. In spirits the back is brown, the lower parts are whitisl, and the sides are broadly striped with silvery. In 
life the lateral stripe is bluish and overlaid with dusky spots and is continued forward through the eye around the snout. The fins are pale. The specimen described, no. $36746, \mathrm{U}$. S. Xitional Musemu, from Mrhite liver Ind., is 3. 32 inches long.

The spotted shiner occurs in the Great lakes region and Ohio valley southward to Kentucky and west to Iowa. It is abun. dant in creeks of western Pemsylvania. Kirtland had the species from the Mahoning river and from Lake Erie. The species is most common in the Great lakes and in the channels of large streams, and does not run into small brooks. It is a ready biter and is caught in large numbers by hook fishing. It is useful as bait, being emploped with minnows to bait the hooks on "set lines."

The species grows to lle length of 6 inches, and derires its name from the bluish band along the sides which is inter. rupted so as to form spots. The sides are bright silvery in color and the fins unspotted. The body is long and slender.

\section{Subgenus Hyвorsis Agassiz}

95 Hybopsis storerianus (Kirtland)

\section{Lake Minnow}

Rutilus storerianus IrrtuAnd, Proc. Bost. Soc. Nat. Hist. I, 71, 1S42. (Lake Erie)

Leuciscus storcrianus Kintland, Bost. Jour. Nat. Hist. V, 30, pl. 9, fig. 2, 1817; Güntrier, Cat. Fish. Brit. Mus. VII, 250, 1868.

Cerutichthys lncens JordaN \& Gilbert, Bull. 16, U. S. Nat. Mus. 213, 1883. Cliola storciama JoRDAN \& GILBERT, op. cit. 171, 1883.

Hybopsis storevianus Jordan, Cat. Fish. N. A. 2S, 1SS5; JordaN \& EverMANN, Bull. 47, U. S. Nat. Mus. 321, 1896.

Body elongate, compressed, the dorsal outline ascending gradually to origin of dorsal, thence descending to the caudal fin; head short, compressed, its length four and one third in total without caudal; depth of body one fourth total; eye equal to snout, one third length of head; interorbital space broad, flat, somewhat grooved, its width about equal to eye; preorbital bone large, oblong, conspicuous, silvery; mouth rather small, horizontal, the lower jaw included; edge of premaxillary below level of eye; maxillary not reaching to frout of orbit; barbel 
conspicuous; snout boldy and abruptly decurved, the tip thickened, forming a sort of pad; lateral line somewhat decurved. Rows of scales along bark converging behind dorsal. where the upper series run ont, as in Notropis cornutus. Fins rather higher and more falcate than in H. ken tuckiensis : dorsal fin inserted well forward, orer rentrals; pectoral fins pointed, not reaching rentrals; ventrals not reaching rent; caudal long, deeply forked. Teeth nsmally 1, 4-4, 0, liooked, without grinding surface. Translucent greenish alove; sides and below brilliantly silvery; checks and opercles with a bright silvery luster; fins plain; a slight plumbeous lateral shade; no caudal spot; no red. Length $\check{5}$ to 10 inches. Iake Erie to Nebraska and eastern Wyoming, Tennessee, and Arkansas; abundant in the larger streams, specially in Iowa. (After Jordan and Evermann)

Kirtland found the lake minnow only in Lake Erie, where it was frequently taken with seines in fishing for other species. The U. S. Fish Commission recently added it to the fauna of the Lake Ontario basin, three specimens haring been collected in Long pond, Charlotte, Aug. 17, 1894.

\section{Subgenus rocours Girard}

96 Hybopsis kentuckiensis (Rafinesque)

\section{Hornel Chub; River Chub}

Luxilus kentuckicnsis RAFINESQLE, Ichth. Ohien. 4S, 1820.

Semotilus biguttatus Kintr.axd, Bost. Jour. Nat. Hist. III, 344, pl. V, fig. 1, 1811.

Lcuciscus biguttatus DE KAT, N. Y. Fauna, Fishes, 214 (extralimital), 1812.

Ceratichthys biguttatus Cope, Cypr. Penna. 366, pl. 11, fig. 5, 1S66; Guntrier, Cat. Fish. Brit. Mus. VII, 178, 1S68; Jordax \& Gilbert, Bull. 16. U. S. Nat. Mus. 212, $18 S 3$.

Ceratichthys mieropogon Jondax \& Gilbert, Bull. 16. U. S. Nat. Mus. 212, $1 \mathrm{SS} 3$.

Hybopsis kentuckiensis BEAN, Fishes Penna. 49, pl. 24, fig. 40, 1S93; Jordax \& Evermañ, Bull. 47, U. S. Nat. Mus. 322, 1896.

Body stout and rather short, its greatest deptlı nearly equal to length of head and one fourth of total length without cauda]; snout long and obtuse, its length rather more than one third 
length of head, and nearly twice diameter of eye; mouth large and placed low, the maxilla reaching to below front of eve, the lower jaw shorter than upper; dorsal origin slightly nearer to root of caudal than to tip of snout, its base one half as long as the head and two thirds as long as its longest ray; rentral under front part of dorsal, its length equal to dorsal base; anal origin under 24 th scale of lateral line, longest anal ray about one serenth of total to caudal base, pectoral two thirds as long as head, and reaching to below 13 th scale of lateral line; caudal moderately forked. D. iii, $7 ;$ A. iii, 6. Scales 6-40 to 45-5. Color bluish olive, the bead darker; green and roppery reflections on the sides. Fins pale orange, pinkish in spring; lower parts white. Breeding males have the top of hrad swollen into a crest and covered with coarse tubercles, from which arises the name horned chub; they have also sometimes a red spot on each side of head. The young have a lroad dark median band and a dusky spot at the base of the tail fin.

liafinesque states that the fish is known as Iudian clubb, redtail and shiner. Other names in eastern localities are nigger rhub, river chub, jerker, horned dace and horny-head.

The species ranges from Penusylvania westward to Dakota and south to Alabama. In Pennsylrania it is common in the Susquehanna and the Ohio basin, but absent from the Delaware. Dr Meek collected a few specimens at Montezuma N. T. and found none in any of the other localities investigated. Eugene Smith refers to this species two specimens of fish from the Passaic river. The flesh of his fish appeared to be rery soft.

The horned club abounds in large rivers and is rarely seen in small brooks. This minnow grows to a length of 10 inches and is good for food. As a bait for the black bass the young horned chub, because of its endurance on a hook, can not be excelled.

\section{Genus coucsrs Jordan}

Budr elongate; head normal, not depressed, the profile convex; mouth terminal, normal, a well derelopel barleel on the anterior side of maxillary, just above its tip. Teeth 2, 4-4, 2, 
hooked, withont ginding surfatce. Seates rather small; latcral line continuous. Horsal fin over or slightly belind ventrals; anal basis short. Size rather large. This gents is rosely related to the section Nocomis under Hybopsis. from which it may be separated by the presence of two teoth in the lesser row, by the position of the bathel, and by the sublled scales. Its relations with semotilns ale equally relose. The species are not well known. (Ifter Jordan)

\section{Couesius plumbeus (Agassiz)}

\section{Lake Chub; Plumbeous Minnou; Morse Lake Minnow}

Gobio plumbens Agassiz, Lake Superior, 366, 1850.

Ceratichthys prosthemins Core, Crpr. Penna. 365, pl. XI, fis. 4, 1866.

Ceratichthys plumbers Güntmer, Cat. Fish, Brit. Mus. VII, 176, 1868.

Coursins dissimitis Jomdan of Giblert, Bull. 16, U. S. Nat. Mns. 218, 1883, in part.

Concsins prosthemins JorDax \& Gilbert, op. cit. 219, 1893; MATHER, Apl. 12th Rep. Adirondack Surv. 30, 1896.

Conesins plmmbens Jordan \& Evermany, Bull. 47, U. S. Nat. Mus. 323, 1896.

Bodr moderately elongate and somewhat compresserl; great. est depth four and one late to fom and two thirds in total length withont caudal, and equal to length of head; lead lat hex flat above, not much raised above the level of the eyes; interorbital space nearly one and one half times long dianceler of eye, which equals snout and is one fomth length of head; head four and one third in total without candal; maxillary rearehing to below front of orbit, a sulall harbel placed high at its tip, lower jaw well included. Scales small, smaller in adrance of dorsal fin. Lateral line beginning high up on the naje; alurutly descending to the median line orer the pectoral fin, and thences rumning nearly straight to the candal fin. Torsal origin midway between tip of snout and base of caudal fin. orer middle of ventral base, longest ray two thirds of head, length of base onr half of head; rentral scarcely longer than dorsal base, the fin not reaching vent; longest anal ray equal to rentral, base of anal two fiftis of head; pectoral reaching to $18 t$ h scale of lateral line; caudal deepl! forkerl, its upper lobe two nintlis of total without caudal. D. S; 1. S. Scales $13-65$ s; teeth $2,4-4$, 
2. Trown above; sides somewhat silvery, abruptly separated from the dusky upper parts; smout and top of head back as far as lind border of eye, dusky; fins plain. Jength 7 inches. Streams and lakes from Lake Superior east to the Adirondack region and Canada; more common northward. Here described from specimens from Beaver river, Herkimer co. N. Y., and Lake Lomond, near St John $\mathbf{X}$. B.

Mather had specimens from Morse lake, in the Adirondacks, and it is reported also from Serenth lake, Fulton Chain. The species is known from Iake Superior east to the Adirondacks and New Brunswick. Agassiz lad it from Lake Huron as well as Lake Superior.

\section{Genus Exoglosstrir Rafinesque}

Body rather short and stout, subterete; Iower jaw threelobed, the dentary bones being close together and completely unitud, not forming a wide arch as in the minnows generally; upper jaw not protractile; pharyngeal bones small, the teeth hooked, and without grinding surface, 1, 4-4, 1. Scales moderate; lateral line complete. Dorsal origin is nearly over the beginning of the rentral; anal fin short; isthmus broad; gill rakers weak; pseudobranchiae present; air bladder normal; alimentary canal short; peritonem white. Size large. No marked sexnal peculiarities; the males with some black pigment in spring.

\section{$9 S$ Exoglossum maxillingua (Le Sueur)}

\section{Cut-lips: Nigger Chub}

Cyprinus maxillingua L.e Sueur, Jour. Ac. Nat. Sci. Phila. I, S5, 181ī, Pipe Creek, Maryland.

Exoglossum anmulatum Rafinesque, Jour. Ac. Nat. Sci. Phila. I, 421, 1S18. Iudson River.

E.roglossum nigresecus Rafinesque, op. cit. I, 421, 1S1S. Lake Champlain. Eroglossum rithtum Rafinesque, op. cit. I, 421, 1S1S. Hudson River.

Exoplossum maxillingua Agassiz, Amer.Jour. Sci.Arts, XIX, 215, 1S55; Core, Crrn. Penna. 360, pl. XI, fig. 1, 1866; Günther, Cat. Fish. Brit. Mus. TII, 1SS, 1S6S; JordaN \& Gilbert, Bull. 16, U. S. Nat. Mus, 160, 1SS3; Beax, fishes Penna. 36, pl, 22, fig. 36, 1593; Jordan \& Everuanx, Bull. 47 , U. S. Nat. Mus. 327, 1S96, pl. LIV, fig. 140, head below.

The cut-lips has a stout, short and thick bodr, its greatest hight nearly equal to the length of the hear, and one fourth of 
the total withont caudal. The caudal peduncle is short and deep, its least depth about one half the head. The snout is short and obtusely conical, its length somewhat greater than the eye and nearly equal to one third of the head. The maxilla reaches to below the nostrils, its length equaling that of the snout. Head four and one fifth in total to base of eaudal. The dorsal origin is nearly orer the ventral origin and in the vertical through the $23 d$ seale of the lateral line. The dorsal base is about one half as long as the head, and its longest ray equals twice the distance from the dorsal origin to middle of eye. The pectoral is about as long as the longest dorsal ray, and the rentral reaches to the anal origin. The base of the anal is one hialf as long as the longest anal ray. The caudal is moderately forked. D. 8; A. 7. Scales 9-54-6; teeth 1,4-4, 1. Length of specimen described, $4 \frac{3}{4}$ inches; from Takoma Park D. C. Color brown or olivaceons, darker above; a short and narrow dark bar above root of pectoral; young with a dusky bar at the caudal base. Fins dusky, their extremities pale.

The cut-lips may be readily distinguished by the three-lobed lower jaw, the dentary bones being closely united and the lower lip represented by a fleshy lobe on each side of the mandible.

The cut-lips is known also as chub, butter chub, nigger chub, and day chub. It is a rery common species in the Susquehamna and its tributaries. Its range is not extensive, reaching only from western New York to Yirginia. In New York it occurs in Lake Ontario, the St Lawrence, Lake Champlain, Cayuga lake, and the Hulson river. The T. S. Fish Commission has it from the following New York localities in the Lake Ontario basin:

Mouth Salmon river, Selkirk.

Big Sandy creck, Belleville.

Wart creek, Buena Vista.

Little Stony brook, Henderson bay.

Big Stony creek, Henderson Harbor.

Spring brook, Pulaski.

Black river, Iluntingtonville.

All of these were obtained in July, 1894. Evermann and Bean collected it also in the st Lawrence, 3 niles below Ogdensburg, 
July 17, 1894, and in Scioto creek, Coopersville and Saranac river, Plattsburg, July 19, 1894.

Dr Heek found it in small numbers in Six Mile creek and FalI creek below the falls. It inhabits clear running water.

The fish grows to the length of 6 inches and may be at once distinguished from all of the other minnows by its three-lobed lower jaw. It is believed that this singular structure of the mouth enables the fish to scrape mollusks from their hold on rocks, as its stomach usually contains small shellfish. It takes the look readily.

\section{Genus canassius Nilsson}

This genus differs from $\mathrm{C} \mathrm{y} \mathrm{p} \mathrm{r} \mathrm{in} \mathrm{us} \mathrm{in} \mathrm{being} \mathrm{without} \mathrm{barbels;}$ its pharyngeal teeth are compressed, in a single series, 4-4.

Temperate Asia and Europe. Domesticated and degenerated into numerons varieties. (After Giinther)

Pharyngeal teeth spatulate, four in a row on each side; mouth terminal, withont barbels; base of the dorsal fin elongate; anal fin short; both fins witl a spine which is serrated behind. (After Heckel and Ḱner)

Body oblong, compressed and elevated; mouth terminal, without barbels; teeth 4-4. molar, but compressed; scales large; lateral line continuous; dorsal fin very long, with the third ray dereloped into a stout spine, which is serrated belind; anal short with a sinilar spine; rentrals well forward. (After Nilsson)

\section{Carassius auratus (Limnaeus)}

Goldfish (Introduced)

Cyprinus auratus Lindaeus, Syst. Nat. ed. X, I, 322, 175s; Cuvier \& Valenciennes, Hist. Nat. Poiss. XVI, 101. 1S12; De KAY, N. Y. Fauna, Fishes, 190. 1St?; Storer, Hist. Fish. Mass. 115, pl. XXI, fig. 1, 1867. Carassius aurutus BleEker, Syst. Cypl. rev. Ned. 'Tijdschr. Dierk. I, 255, 1863; Atlas Ichth. Cypr. 74, 1863; Günther, Cat. Fish. Brit. Mus. VII, 32, 1S6S; JornAN \& Gtlbert, Bull. 16. U. S. Nat. Mus. 253, 1SS3; Goode, Fish \& Fish. Ind. U. S. I, pl. 231, 1S84; BEAN, Fishes Penna. 54, pl. 25, fig. 43, 1893; Jorday \& Evemann, Check List Fish. N. A. $512,1896$.

The body of the goldfish is oblong, stout, with the back elevated and compressed. Its depth at dorsal origin is contained 
about two and one half times in the total length without the tail; the head is contained three and one third times in this length. The head is small in front of eye, being depressed on snout, and the dorsal profile from tip of snout to dorsal fin is very steep. The rather small eye equals one fifth or less of length of head. Mouth terminal, oblique, rather small, the maxilla not reaching the vertical from front of eye. No barbels. Teeth compressed, 4-4. The dorsal fin is high and long, commencing over the seventh scale of the lateral line and running back to near the caudal; its longest rays, first and second, a little longer than the spine, equal to one half of depth of body, or length of head from pupil to its posterior end. From the third to the last the rays gradually decrease in size, the last being less than half the length of the longest. The first dorsal spine is minute, one fourth the length of second, which is strong and coarsely serrated. The anal is short, the length of its base being but two thirds the length of its longest rays; first spine small, one third the length of second, which is stout and serrated. Pectoral fin broad and rounded, its length three fifths of that of head, or equal to longest anal ray. It reaches to ventral, which is placed well forward. Caudal fin large; scales large, deeper than long; lateral line median, complete, almost straight. D. II, 18; A. II, 7; V. 9. Scales 5-30-6. The specimen described is from the fish ponds, at Washington D. C. Length 8 inches.

The common goltfish or silverfish is a native of $A$ sia. whence it was introduced into Europe and from there into America, where it is now one of the commonest aquarium fishes and is extremely abundant in many of our streams. In Pennsylyania it abounds in the Delaware and schnylkill river.

De Kay made the following remarks about the goldfish, or golden carp, as he styles it.

The golden carp, or goldfish, as it is more generally called, was introduced from China into Emope in the early part of the 17th century, and probably shortly after found its way to this country. They breed freely in ponds in this and the adjoining states. They are of no use as an article of food, but are kept 
in glass vases as an ornament to the parlor and drawing-room. They are said to display an attachment to their owners, and a limited obedience to their commands.

They are introduced into lakes, ponds, fountains and reservoirs generally. An individual was kept in a fountain at $42 d$ strect and ath arenue, New York, by Patrick Walsh nine years, and was then presented to the aquarium.

At the Cold Spring Harbor hatchery, L. 1., several varieties were hatched from the same lot of eggs. These included the normal form, the typical fantail, and one which was so deepbodied that it could scarcely balance itself in swimming.

The goldfish in the New York aquarium were never troubled by fungus or parasites.

In many of our streams and ponds, the goldfish has run wild, and hundreds of the olivaceous type will be secured to one of a red color. In the fauna of the moraine ponds and in quarry holes, the goldfish stands first. It will breed in foul water where only catfish and dogfish [ $\mathrm{Tm} \mathrm{br}^{\mathrm{m}}$ ] can be found. Eugene Smith

The goldfish is extremely variable in color and form. It is usually orange, or mottled with black and orange, yet in some streams, and even in pond culture, silvery individuals are often more common than any of the mottled varieties. The species grows to the length of 12 inches. It spawns early in the spring and is subject to many dangers and is attacked by numerous enemies. The fish, however, is extremely hardy, prolific, and tenacious of life.

\section{Genus crpruxs Linnaeus}

Body robust, compressed, resembling that of the buffalo fish; mouth moderate, anterior, with four long barbels; snout blunt, rounded; teeth molar, broad and truncate, 1, 1, 3-3, 1, 1; scales large; lateral line continuous; dorsal fin very long, with a stout spine, serrated behind; anal fin short, also with a spine. Large fishes of the fresh waters of Asia; introduced into Europe and America as food fishes. It las been generally introduced into private ponds in nearly all parts of the United States; from these it has escaped into the streams and lakes, and is now an 
abundant fish in most of our larger, warmer rivers and in the ponds and bayous of the Mississippi valley. On the south shore of Lake Erie (and in the Mississippi near Quincy Ill. and the Delaware river) it has become well established and is of considerable commercial inportance. (After Jordan and Evermann)

\section{Cyprinus carpio Limnaeus}

\section{Carp (Introduced)}

Cyprinus carpio Linnaeus, Syst. Nat. ed. X, I, 320, 1758; Cuvier \& Valenciennes, Hist. Nat. Poiss. XVI, 23, 1842; De KaY, N. Y. Fauna, Fishes, 1SS, 1S12; Heckel \& KNer, Süssw. Fische, 51, fig. 21, 1858; Günther, Cat. Fish. Brit. Mus. VII, 25, 1865; Jordan \& Gilbert, Bull. 16, U. S. Nat. IIus. 254, 18s3; Goode, Fish. \& Fish. U. S. I, pl. 230, Leather carp, 18s4; American Fishes, 411, figure, 18ss; BEAN, Fishes Penna. 55, pl. 1, colored, 1893; Jordan \& Evermanv, CheckList Fishes N. A. 512, 1896.

The carp has a stout and moderately elongate body and a small head. The greatest depth equals one third of the length without the caudal fin. The length of the head is nearly one fourth of the total to the base of the tail. The caudal peduncle is about two fifths as deep as the body, and the candal fin is strongly forked. The eye diameter is contained six and one half times in the length of the head. The mouth is moderate, the upper jaw not extending to front of eye. The dorsal begins at a distance from tip of snout equal to twice length of head; the length of its base equals twice length of pectoral; the longest ray equals length of head without the snout; the last ray is two fifths as long as the head. The anal begins under the 15 th ray of the dorsal; its longest ray is two thirds as long as the head and more than twice as long as the last ray; the length of its base is about two fiftlis of length of head. The rentral begins under the second ray of the dorsal; its length nearly equals longest dorsal ray. Tlie pectoral is nearly one fifth of total length without the candal. The long spines of the dorsal and anal are strongly serrate along their hinder edges. A barbel on the upper lip and another at the angle of the mouth on each side; the longest barbel about equal to diameter of eye. Three varieties are recognized, the scale, the mirror and the 
leather carp, based chiefly on the scaling of the body. The leather carp is nearly naked, and is said to be the best variety; the mirror carp has a few large scales irregularly placed; and the scale variety has the body completely scaled. The color is olivaceous, varying into dusky and blue. In the leather carp the lower parts are more or less suffused with yellowish. D. III, $20 ;$ А. III, 5; V. I, 7; P. 15 . Scales 5-38-5.

The carp is a native of Asia and has been introduced into Europe and America as a food fish, chiefly for pond culture. It thrives in all warm and temperate parts of the United States and reaches its best condition in open waters. In Texas it has grown to a length of 23 inches in 11 montlis after planting. The leather variety is most hardy for transportation. Mr Hessel has taken the carp in the Black and Caspian seas; salt water seems not to be objectionable to it, and it will live in stagnant pools, though its flesh will be decidedly inferior in such waters. The carp hibernates in winter except in warm latitudes, takes no food and does not grow; its increase in size in temperate latitudes occurs only from May to August.

Reproduction. The spawning season begins in May and continues in some localities till August. A carp weighing 4 to 5 pounds, according to $\mathrm{Mr}$ Hessel, yields from 400,000 to 500,000 eggs; the scale carp contains rather more than the other varieties. Inring the spawning the fish frequently rise to the sur. face, the female accompanied by two or three males. The female drops the eggs at intervals during a period of some days or weeks in shallow water on aquatic plants. The eggs adhere in lumps to plants, twigs and stones. The hatching period varies from 12 to 16 days.

Size. According to Hessel the average weight of a carp at three years is from 3 to $3 \frac{1}{4}$ pounds; with abundance of food it will increase more rapidly in weight. The carp continues to add to its circumference till its 35th year, and in the southern parts of Europe Mr Hessel has seen individuals weighing 40 pounds and measuring $3 \frac{1}{2}$ feet in length and $2 \frac{3}{4}$ feet in circumference. A carp weighing 67 pounds and with scales $2 \frac{1}{2}$ inches 
in diameter was killed in the Danube in 1853 . There is a record of a giant specimen of 90 pounds from Lake Zug in Switzerland. Examples weighing 24 pounds have been caught recently in the Potomac river at Washington D. C.

Food. The carp lives principally on regetable food, preferably the seeds of water plants such as the water lilies, wild rice and water oats. It will eat lettuce, cabbage, soaked barley, wheat, rice, corn, insects and their larvae, worms and meats of various kinds. It can readily be caught with dough, grains of barley or wheat, worms, maggots, wasp larvae, and sometimes with pieces of beef or fish.

During the summer of 1897 two female leather carp died in captivity as a result of retention of the eggs.

Large individuals are found in Prospect park lake. Brooklyn, where the species was introduced. The food of the fish in captivity includes hard clam, earthworms, wheat, corn, lettuce and cabbage. Its growth is remarkable. A leather carp has fully doubled its weight in one year.

Linnaeus says the carp was introduced into England about the year 1600. De Kay places the first introduction into New York waters in the year 1831 and publishes a letter of Henry Robinson, Newburg, Orange co., who brought them from France, reared and bred them successfully in his ponds, and planted from one dozen to two dozen annually in the Hudson dur ing the four years preceding his letter. Mr Robinson stated that they increased greatly and were frequently taken by fishermen in their nets.

\section{Order ArOWES}

\section{Eels}

\section{Suborder ExCHELYCEPHALI}

Family ANGIILIHAE

True Eels

Genus avionut.d shaw

Borly elongate, subterete, compressed posteriorly, corercd with small, linear, embedded scales which are placed obliquely, some of them at right angles to others; lateral line well devel- 
oped; head long, conical, pointed; eye small, well forward, over the angle of the mouth; teeth small, villiform, subequal, in bands on each jaw and a long patch on the vomer; tongue free at tip; lips rather full, with a free margin behind, attached by a frenum in front; lower jaw projecting; gill openings rather small, slitlike, about as wide as base of pectorals and partly below them; nostrils superior, well separated, the anterior with a slight tube; vent close in front of anal; dorsal inserted at some distance from the head, confluent with the anal around the tail; pectorals well developed. Species found in most warm seas (the eastern Pacific excepted) ascending streams, but mostly spawning in the sea. (After Jordan and Evermann)

\section{Anguilla chrysypa Rafinesque}

\section{Eel}

Anguilla chrisypa Rafinesque, Amer. Montl. Mag. II, 120, Dec. 1817. Lake George; Lake Champlain; Hudson River above the falls.

Anguilla vulgaris MItchiLL, Trans. Lit. and Phil. Soc. N. Y. I, 360, 1515;

Goope, Fish \& Fish. Ind. U. S. I, pl. 239, 1851.

Afuraen bostoniensis Le Suevi, Jour. Ac. Nat. Sci. Phila. S1, 1821.

Anguilla tyrammus Grrard, Ichth. U. S. Mex. Bdy. Surv. 75, pl. 40, 1859.

Anguilla blephura Rafinesque, Amer. Montl. Mag. II, 120, Dec. 1817. South shores of Long: Island.

Ifuraena rostrata Le Sueur, Jour. Ac. Nat. Sci. Phila. S1, 1S21. Cayuga Lake.

Anguilla tenuirostris DE KAY, N. Y. Fauna, Fishes, 310, pl. 53, fig. 173, 1842. Anguilla rostrata DE KAY, op. cit. 312, 1812. Copied from Le Sueur.

Lakes Cayuga and Geneva, N. Y.; Jordan \& Gilbert, Bull. 16, U. S.

Nat. Mus. 361, 1883; BeAn, Fishes Penua. 95, pl. 30, fig. 58, 1893.

Anguilla macrocephala DE KAY, op. cit. 313, 1S42. After Le Sueur. Sara-

toga Lake, N. Y.

Anguilla bostoniensis Storer, Hist. Fish. Mass. 214, pl. XXXIII, fig. 1,1S67. Anguilla chrysypa JoRDAN \& DAvis, Rev. Apod. Fish. 668, 1892; JoRDAN \& Evermann, Bull. 47, U. S. Nat. Mus. 34S, 1896, pl. LV, fig. 143.

In the eel the body is elongated, roundish throughout most of its extent, compressed behind. The scales are deeply embedded and very irregularly placed, some at right angles to others. The head is conical, elongated with pointed snout and small eye, except in the male. The lower jaw is longer than the upper. The jaws with small teeth in bands; a long patch of teeth on the romer. The gill openings are partly below the 
pectoral fins, small and slitlike. The beginning of the dorsal is at a distance of nearly twice the length of the head belind the gill opening. The anal begins still fartler back, and the vent is close to its origin. The dorsal and anal fins are continuous around the tail. Hight of body nearly two thirds the length of the head, which is contained about cight and one fourth times in the total. The distance from the gill opening to the rent equals two and one half times the length of the hear. The color varies greatly, but is usually dark brown, more or less tinged with yellow; lower parts paler. In the male referred to the upper parts were silvery gray sharply separated from the satiny white of the abdomen. In the eel the lateral line is very distinct.

The eel appear's to have only one common name. It is one of the best known and most singular of our fishes, yet its breeding habits are even now enveloped in doubt. The species ascends the rivers of eastern North America from the Gulf of St Lawrence to Mexico, the former being the northern limit of the species on our coast. In the Ohio and Mississippi ralleys it is extremely common, and its range has been much extended by the opening of canals and by artificial introduction. It has been transferred to the Pacific coast.

The eel has been known to exceed a length of 4 feet. The average length of individuals howerer is about 2 feet. The female is larger than the male, paler in color, and is different in certain other particulars, which will be mentioned in the description of the species.

This is a rery important food fish. It is caught chiefly when descending the rivers in the fall. In 1869 about a ton of eels were caught in a single fish basket above Harrisburg. At the present time this method of capture is illegal. Both adults and roung eels ascend the streams in spring, the young coming in millions, but in the fall run small eels are seldom seen. Till a comparatively recent date it was not certainly known that the eels have eggs which are dereloped ontside of the body. Even now the breeding. 
habits are unknown, but it is supposed that spawning takes place late in the fall or during the winter near the mouths of rivers on muddy bottoms. Dr Jordan has expressed the belief that the eel sometimes breeds in fresh water, since he has found young eels less than an inch long in the headwaters of the Alabama river, about 500 miles from the sea. It is estimated that a large eel contains about 9,000,000 eggs. The eggs are very small, measuring about 80 to the inch, and can scarcely be seen by the naked eye.

The difference of size in the sexes has already been referred to. According to one writer the males are much smaller than the females, rarely exceeding 15 or 16 inches in length. The question whether ecels will breed in fresh water has an important bearing on their introduction into places from which they can not reach the sea. The generally accepted belicf is that, while the eels will grow large and fat, they will not reproduce under such eircumstances.

When the eels meet obstructions in streams, they will leave the water and travel through wet grass or over moist rocks. They have not been able to surmount the falls of Niagara. At the foot of this barrier hundreds of wagon loads of young eels have been seen crawling over the rocks in their efforts to reach the upper waters.

Dr. Mitchill heard of an eel, which was caught in one of the south bays of Long Island, that weighed $16 \frac{1}{2}$ pounds. He records the use of eclpots and the practice of bobbing, and also the winter fishing by spearing. Dr Mitchill states distinctly that the ovaries of exls may be seen like those of other fish, but they are often mistaken for massus of fat. Dr DeKay states that he had examined the silver eel of the fishermen and was disposed to consider it only a variety of the common eel. He characterizes it as "silvery gray above, with a clear, satiny white abdomen, separated from the color above by the lateral line." We found exls moderately common in Great South bay late in September. At Bellport thousands of eelpots are employed, and these are fastened to stakes which are set in straight lines 
orer a large extent of the bottom. These stakes project from four to six feet above the surface of the water. At Bhe Point cove, Great River beach and Fire Island we found five individuals of a kind of eel known to the fishermen as silver eel. These were taken between September 25 and October 7 , and they were the only ones of the kind seen by us. They attracted attention at once, both on account of their colors, large eyes, short snonts and long pectoral fins, as compared with the common form. There is still some doubt in my mind as to whether this represents a distinct species or not. It may be the silver eel, $\mathrm{Ang}$ u i l l a a r gentea, of Le Sneur, which is described as silvery gray above, separated from the silvery white abdomen by a distinct lateral line. But, to whaterer species they may be referred, the greatest interest attaches to them because they have proved, on examination by Prof. John A. Ryder, to be males with the generative glands so well developed as to leave no doubt concerning the sex of the indiriduals. Prof. Ryder has published a report on these specimens, with figures showing sections of the srrskian organs, and annonnces the fact that the male eel has now been positively indentified from at least two points along our eastern coast, the other locality being Woods Hole Mass. He felt little doubt that, if the eels had been taken a few weeks later, ripe spermatozoa would have been found in them, and he considers it probable that the eggs are cast some time during the months of December or Jannary. The specimens from Woods Hole nere taken in November 18s1, and they show slightly larger syrskian organs than in the Fire island specimens.

In captivity eels live many years. They delight to lie buried in the mut or sand with only their heads out, ready for anything edible to come within reach. Mussels and snails are picked out of the shells by them. (After Engene Smith')

The eel in captivity is particularly liable to attacks of fungus, which do not always rield to treatment with salt or brackish

\footnotetext{
${ }^{\mathrm{I}}$ Linn. Soc. ‥ Y. Proc. 1597. no. 9, p. 29.
} 
water; but the parasite can be overcome by placing the eel in a poorly lighted tank.

In Cayuga lake, X. I., according to Dr Meek, the eel is not common, but is occasionally taken at cach end of the lake.

II. H. Ballon makes the following remarks about their feeding habits:

They are among the most voracious and carnirorous fishes. They eat most inland fishes except the gar and the chub. . They are particularly fond of game fishes, and show the delicate taste of a connoissen in their selections from choice trout, bass, pickerel and shad. . On their hunting excmrsions they overturn huge and small stones alike, working

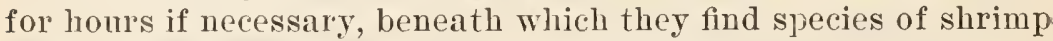
and crayfish, of which they are exceedingly fond. . They are among the most powerful and rapid of swimmers. . They attack the spawn of other fishes open-mouthed, and are even said to suck the eggs from an impaled female. . . They are owllike in their habits, committing their depredations at night.

Family LEITTOCEPHALIDAE

Conger Eels

\section{Genus heptocephans (Gronow) Scopoli}

Body formed as in A n $g$ u illa; no scales; head depressed above, anteriorly pointed; lateral line present; mouth wide, its cleft extending at least to below middle of eye; teeth in outer series in each jaw equal and close set, forming a cutting edge, no canines, band of romerine teeth short, tongue anteriorly free; vertical fins well developed, confluent around the tail, pectoral fins well developed, dorsal beginning close behind pectorals; gill openings rather large, low; eyes well developed; posterior nostril near eye, anterior near tip of snout, witl a short tube; lower jaw not projecting. Skeleton differing in numerous lespects from that of A $\mathrm{n} g \mathrm{u}$ ill a . Vertebrae about $56+100$. In most warm seas. This genus contains the well known and widely distributed conger eel and three or four closely related species. (After Jordan and Evermann)

Lateral line in a deep, pale furrow, decurved slightly from the head to balow dorsal origin, rery conspicuous pores in its anterior third. 


\section{Leptocephalus conger (Limnaeus)}

Conger Eel; Sea Eel

Muraena conger Linxaeus, Syst. Nat. ed. X. I, 245, 175S.

Anguilla conger MitchuL, Trans. Lit. \& Phil. Soc. N. Y. I, 360, 1815.

Anguilla occaniea Mitchill, Jour. Ac. Nat. Sci. Phila. I, 407, 1818, off New York.

Conger occidentalis DE KAY, N. Y. Fauna, Fishes, 314, pl. 53, fig. 172, 1812, very poor.

Conger vulgaris Güxther, Cat. Fish. Brit. Mus. VIII, 38, 1870.

Conger niger Jordan \& Gilbert, Bull. 16, U. S. Nat. Mus. 362, 1883.

Leptocephalus conger Goode, Fish \& Fish. Ind. U. S. I, pl. 240, 1884; JorDan \& Evermann, Bull. 47, U. S. Nat. Mus. 354, 1896, pl. LVII, fig. 148, 1900; Sмiтh, Bull. U. S. F. C. XVII, 90, 1898.

Dorsal fin begins opposite to or just belind tip of pectoral; eye one and one half in snout, fire to six in head; snout three and one fourth to four and one fourth in head; gape extending nearly or quite to below hind margin of eye; head one and four fifths to one and six sevenths in trunk; tail longer than rest of body; pectorals three and one half in luead; upper lip full, with conspicuous pores. Length of head one ninth of total length, depth of body two fifths length of head. Pores in lateral line rery conspicuons. Color dark olive brown, sometimes nearly black, abore; chin, space behind pectorals and lower parts soiled white.

The conger eel occurs on both coasts of the Atlantic, on our coast extending from Cape Cod to Brazil, but not often coming into shallow bays. An exception is noted in Great Egg Harbor bay, where the fish is not lare in summer. It is sometimes caught in Gravesend bay also in summer, and occasional individuals are captured on hand limes off sonthanpton L. I., by men fishing for sea bass and scup. The fishermen dislike to handle the species on account of its puguacity and strength; it snaps viciously at everything near it when captured in our waters; yet, strangely enough, the writer has seen a hundred or more, taken on traml lines off the north coast of France, in a boat at one time, and not one gave evidence of ferocity.

In captivity in the aquarium the sea cal suffers sererely flom fungus attacks, which are not relieved by changing the fish from salt water to fresh. Perhaps the salinity of the water in some 
localities is too low, and relief might be obtained by supplying sea water of normal ocean density.

The young and larval form of the conger is a curious, elongate, transparent, bandlike creature with a minute head, a very small mouth and with the lateral line, belly, and anal fin dotted with black points.

An individual nearly 3 feet long was captured with a hand line by A. P. Latto in the ocean, near Southampton L. I. Aug. 3, 1898, while fishing for sea bass and scup.

In the Woods Hole region, according to Dr Smith, "it comes in July and remains until fall; very common for several years, but rather rare formerly. Fishermen as a rule do not distinguish it from the common eel. A few are taken in traps and with lines, but many large ones, weighing from 8 pounds upward, are canght in lobster pots. A specimen in the collection weighs 10 pounds. One caught on a line at Falmouth, Aug. 30, 1897, weighed 12 pounds. The smallest observed are 15 to 20 inches long."

Mitchill declared the flesh to be very dainty eating. DeKray said the flesh has a peculiar unsarory taste. He discovered that it is a vicious animal, snapping when captured at everything near it. In France the conger eel is among the cheapest and least esteemed of the food fishes.

The observations of 1)r Otto Hermes, director of the Berlin aquarimm, on the habits and the reproduction of the conger eel are of very great interest. Reference is made to them by Goode in Fish and Fisher!l Industrics of the I'nited stutes, s? 1, p. 657, and two figures copied from drawings of Dr Hermes are given in the text. The ovary of the conger, says $\mathrm{Dr}^{2}$ Hermes, is developed in captivity, and th.s s often the cause of the death of the eel. 'In a conger which a ed in the Berlin aquarium the ovaries protruded rery extens, $y$ and a specimen in the Frankfort aquarium burst on aiv' i of the extraordinary development of the oraries. The ora! \& of this eel, which weighed $22 \frac{1}{2}$ pounds, themselves weigl: "nuds, and the number of eggs was about $3,300,000$. The $w \cdots$ if a natural opening for the escape of the eggs was evidentiy this case, the cause of death. In the fall 
of 1879 Dr Hermes received a number of small sea eels taken in the vicinity of Harre. These eels ate greedily and grew rapidly. Only one was tardy in its development, so that it could easily be distinguished from the rest. This one died June 20, 1880, and was examined the same day. It proved to be a sexually mature male and served to clear up some very doubtful problems in the reproduction of the species, as well as its ally, the common. eel.

\section{Order ISOSPONDYLI}

\section{Isospondylous Fishes}

Family ELOPIDAE

\section{Tarpons}

\section{Genus Trmox Jordan \& Evermann}

Body oblong, compressed, covered with rery large, thick, silvery, cycloid scales; belly narrow, but not carinated, its edge with ordinary scales; mouth large, oblique, the lower jaw prominent, maxillary broad, extending beyond the eye; villiform teeth on jaws, vomer, palatines, tongue, splienoid, and pterygoid bones; eye vers large, with an adipose erelid; lateral line nearly straight, its tubes radiating widely orel the surface of the scales; branchiostegals 2:3; pseudobranchiae wanting; gill rakers long and slender; dorsal fin short and high, inserted behind the ventrals (orer the rentrals in $M$ egalops), its last ray elon. gate and filamentous as in M e g a p s, Dorosoma, and Opistlo n e ma ; anal fin much longer than dorsal, falcate, its last ray produced; caudal widely forked; pectorals and ventrals rather long; anal with a sheath of scales; dorsal nalied; caudal more or less scaly; a collar of large scales at the nape. Vertebrae about $57(28+29)$. Size very large, the largest of the herringlike fishes. (After Jordan and Erermann)

\section{Tarpon atlanticus (Cuv. \& Tral.) Tarpum: Turpon: Graude Écaille; Silier Kiny}

Megalops atlanticus Curter \& Vulexcmenxes, Hist. Nat. Poiss. Xix, 39?, 18t6. . Guarlaloupe.

Megalops elongatus GIRAlin, Proc. Ac. Nat. Sc.i. Phila. 224, 1Sis, Inng Islanil. Megalops thrissuides Güxtıier, Cat. Fish. Brit. II us. VII, 472, 1Ses; Jordax E Gilbert, Bull. 16, U. S. Nat. Mus. 262, 1SS3; Goode, Fish \& Fisl. Ind. U. S. I, 610, pl. 217 B, 1SS4; American Fishes, 406, fig. 1sSS. 
Tarpon atlanticus Jordan \& Evermann, Bull. 47, U. S. Nat. Mus. 409, 1896; pl. LXYII, fig. 177, 1900; Sмiтh, Bull. U. S. F. C. XVII, 90, 189s; Evermaxi \& Marsh, Fishes Porto Rico, Bull. U. S. F. C. 1900; 80, fig. $10,1900$.

Body elongate, compressed, not deep, its greatest hight about one fourth of total length without caudal. Length of head nearly equal to greatest hight of body. Mouth large, oblique, the lower jaw very prominent, the maxillary extending beyond the vertical from hind margin of eye; eye moderately large, two thirds lengtlı of snout, two elevenths leugth of head; dorsal origin midway between tip of snout and end of middle caudal rays, dorsal base two fifths as long as head, dorsal filament nearly as long as the head; rentral origin midway between tip of snout and end of anal fin, the rentral fin two fifths as long as the head; base of anal three fourths as long as the head; pectoral fiu as long as the longest ray of dorsal; caudal deeply forked, its longest rays equal to dorsal filament. Size large, weight reaching nearly 200 pounds and length 6 or 7 feet. Color silvery, darker abore. I). III, 12; A. III, 23; P. 13; V. I1, 9. Scales $12-1 \%$.

The tarpon inhabits the western Atlantic from Cape Cod to Brazil and the West Indies, being rather uncommon northward, but abundant toward the south, ascending rivers in pursuit of smaller fishes on which it feeds. The species grows to the length of 7 feet and the weight of 150 pounds, or upward. It is not prized for food, but is now very celebrated as a game fish of great endurance and strength. The scales are an article of commerce as curiosities. Fishermen dread the tarpon because it leaps through their nets with great riolence, and the Pensacola seiner's have known of persons being killed or severely injured by its leaping against them from the seine in which it was inclosed. As to the edible qualities of the flesh opinions differ, but the fact is that the species is seldom eaten.

Girard had a specimen from Long Island which he described in 1858. Since that time it has been seen there occasionally. In the fall of 1898, Capt. H. E. Swezey reported to me that he found one about 4 feet long in Swan rivel at Patchogue. The fish was 
recently dead, and he believes it came into the rirro alive. In the ricinity of Woods Mole Mass. it is now a regular summer visitor. According to $\mathrm{Dr}^{\circ}$ Smitl, it is "taken every rear in traps at South Dartmonth, also ocrasionally at Quissett and at Menemsha, in latter part of September. All are about one size, so to 100 pounds. Fishermen call them 'big scale fish.' An effort has been made to find a market for them in New Bedford, but the people did not like them, owing to the toughness of the flesh."

The tarpon evidently breeds at Porto Rico, as Evermann and Marsh collected a number of individuals measuring from $2 \frac{1}{4}$ to $3 \frac{1}{4}$ inches at Fajardo in February 1899, these apparently being the first roung of the species so far recorded.

\section{Genus Euops Linnaeus}

Body elongate, subcylindric; scales small, silvere; head moderate; conical anteriorly, with rery long jaws, the lower slightly included; branchiostegals 30; eye large and placed high; dorsal fin high in front, the last rays short, origin of fin about midway between tip of snout and end of middle caudal rays, the fin depressible into a scaly sheath; anal fin short, well belind end of dorsal, also depressible into a sheath; pectorals and rentrals each with a $\operatorname{long}$ appendage; caudal fin long and deeply forked; opercular bones thin, with expanded, membranaceous borders, a collar of scales on occiput; lateral line continuous, nearly straight, its tubes simple; large pseudobrauchiae. Vertebrae $43+29=72$. Large fishes of the open seas. The young are ribbonshaped, elongate, and pass through a series of metamorphoses similar to the changes observed in the congers.

\section{Elops saurus Limnacus}

\section{Big-eyed Herring}

Elops sturus Linxaets, Syst. Nat. ed. XII, I, 518, 1766; LE Kir. X. Y. Fauna, Fishes, „ofi, pl. 41, fig: 131, 18 2; Jordix \& Gilbekt, Bull. 16, U. S. Nat. Irus. 261, 18s3; Goone, Fish \& Fi:h. Iud. U. S. I, 611, pl. 218, upper tigure, 1854; Jormax \& Evermaxx. Bull. 47, U. S. Nat. Mus. 410, 1896; pl. LXVII, fig. 17S, 1900; BeAx, Bull. Amer. Mus. Nat. IIist. IX, 384, 1897; SмIтn, Bull. U. S. F. C. XVII, 90. 1894; BeAx, 521 Am. Rep't N. Y. State dis. 96, 1900; Everanand \& Marsi, Bull. U. S. F. C. for 1900,81 , fig. 11, 1900 .

Elops inermis Mrtenll, Trans. Lit. \& Phil. Soc, X. Y. I. 445. 
Body elongate, subcylindric, compressed toward the tail, its greatest depth contained from five to six times in its length withont candal; caudal peduncle slender, its least depth three eighths of length of head; head moderate, obtusely conical, its length four and one fourth to four and one half in total witlout candal, flattened above, with a broad, deep furrow between the eyes; ere large, one fifth as Iong as the head; upper jaw broad, rounded, entire, longer than the lower, which is received into it, the maxillary reaching far behind eye, almost to hind edge of preopercle; the gular plate three or four times as long as broad. D. 20; A. 13; V. 15; B. 30. Scales 12-120-13. Length 3 feet. Tropical and temperate seas; common in America, north to Virginia and the Gulf of California; occasional as far north as Cape Cod. Color bright silvery, with a greenish tinge along the back. Pupils black; iris golden; summit of the head bronzed; opercles with golden metallic tints; all the fins more or less punctate with black; dorsal and caudal light olive brown; lower fins tinged with yellow.

Mitchill found some individuals in the New York market in September 1813, under the name of salmon trout. One which he bought was 22 inches long and weighed 42 ounces. The fish were sold at $75 \mathrm{c}$ each, a remarkably good price for a species now generally considered unsalable because the flesh is dry and bony.

All adult was caught in Gravesend bay Oct. 5, 1896. Among the fishermen there it is known as "seering" and "cisco". Several examples, each about 1 foot long, were taken at Southampton L. I. in October 189S, by A. P. Latto, and presented to the State Musemm.

At Cape Cod, according to Dr Smith, it is "common in fall, none appearing before October. Taken in traps in Vineyard sound and in herring gill nets at Vineyard Haven. Average length, 18 to 20 inches. No young observed."

The fish does not breed on our coast. The young are known to be ribbon-shaped and elongate and to pass throngh a remarkable series of changes similar to those observed in the ladyfish, A lbula rulpes. 
Family albutidaE

\section{Ladyfishes}

\section{Genus a touta (Gronow) Bloch \& Selnneider}

Body rather elongate. little compressed, covered with rather small, hrilliantly silvery scales; head naked; snout conical, subquadrangular, shaped like the snout of a pig, and overlapping the small, inferior, liorizontal month; maxillary rather strong, short, with a distinct supplemental bone, slipping under the membranous edge of the rery broad preorbital; premaxillaries slort, not protractile; lateral margin of upper jaw formed by the maxillaries; both jaws, vomer, and palatines with bands of villiform teeth; broad patches of coarse, blunt, paved teeth on the tongue behind and on the sphenoid and pterysoid bones; eve large, median in liead, with a bony ridge above it, and almost covered with an annular adipose eyelid; opercle moderate, firm, preopercle with a broad, flat, membranaceous edge, which extends backward over the base of the opercle; psendobranchiae present; gill rakers short, tuberclelike; gill membranes entirely separate, free from the isthmus; branchiostegals about 14; a fold of skin across gill membranes anteriorly, its posterior free edge crenate; no gular plate; lateral line present; belly not carinate, flattish, covered with ordinary scales; dorsal fin moderate, in front of ventrals, its membranes scaly; no adipose fin; anal very small; caudal widely forked; pyloric caeca numerous; parietal bones meeting along top of head. Vertebrae numerous, $42+28=70$. A single species known, found in all warm seas. In this, and probably in related families, the young pass through a metamorphosis, analogous to that seen in the conger eels. They are for a time elongate, band-shaped, with very small head and loose transparent tissues. From this condition they become gradually shorter and more compact, shrinking from 3 or $3 \frac{1}{2}$ inches in length to 2 inches. According to Dr Gilbert, this process, like that seen in various eels, is a normal one, through which all individuals pass. In the Gulf of California, where these fishes abound, these band-shaped soung are often thrown by the waves on the beach in great masses. (After Jordan and Erermann) 


\subsection{Albula vulpes (Limnaeus)}

\section{Ladyfish: Bone Fish ; Banana Fish}

Esox vilpes Linxaets, Syst. Nat. ed. X, I, :313, 17 .

Butirimls vulpes De KAY, N. Y. Fanua, Fishes, 268, 1842, name only.

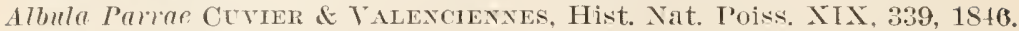
Albula erythrocheilos Cutier ot Talenciennes, op. cit. 372 , ll. $574,1846$. Albula conorhynchus GëNTner, Cat. Fish. Brit. Mus. VII, 468. 1868.

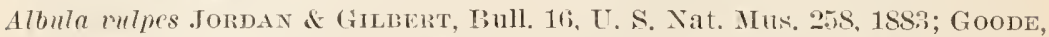
Fish of Fish. Ind. U. S. I, 612, pl. 218, lower fig. 185t; 13 Edx, 19th Rep. comm. Fish. N. Y. Separate, 42. pl. XXIII, fig. :1, 1S90; Jordax \&

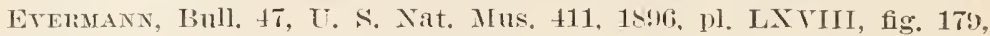
1900; smiti, Bull. U. S. F. C. X'TI, 91, 1Sis; Evermaxy \& Marsi, Bull. L. S. F. C. for 1900,82 , fig. 12, 1900.

Body fusiform, elongate, rounded, its greatest depth, at dorsal origin, contained foul and two thirds times in total length to base of caudal fin and equal to distance from postrrior nostril to end of head; caudal peduncle rather slend'r, its least depth about one third of greatest depth of body; head longe, conical, the suout rather acutely pointed, length of head about three and two thirds in total; eye moderate. onc half of snout, one fifth of head, placed lighli mouth inferiol', small, the maxilla not reaching to below front of eye: rollar of enlarged scales on the nape extending down to the base of the pectoral; dorsal origin about midway between tip of suout and base of caudal, the base of the fin a little more than one half the length of head, the lougest ray as long as the head withont the snout, the last ray one third as long as the longest. The pectoral reaches to below the 15th scale of the lateral line. The rentral origin is under the 32 d scale of the lateral line; the fin three eighths as long as the head. Anal origin roqually distant from base of candal fin and end of rentral base, the longest lay one third as long as head, tho last lay less than one half as long as the longest; caudal fin long, decply forked, the onter rays equal in length to hight of body. D.III, 14; A. I, S; V. I, 10. Scales S75-S. Bright silvery; upper parts olivaceons; fins pale; axils of pectorals and rentrals dusky. Size large, length reaching 3 feet.

'Tropical seas, on sandy coasts, on our coasts ranging northward to Cape Cod and San Diego. A valuable food fish, but 
not esteemed in northrin waters. Highly prized at Ker West and the Bermudas; not mmell in faror at Porto Rico.

The ladyfish is found on our roast from Cape Cod to the Gult of Mexico. It also oceurs in the Bermudas and West Indies. The Bermuda names are bony fish and grrmber. It is considered an excellent food fish on these islands, and Dr Goode testifics from personal experience to its valne as an edible species. It Gozmmel, off the coast of lucatan, it is highly esteemed. On om coast it is oceasionally foumd as far north as Cape Cod.

The ladyfish is not described by either Mitchill or DeKay as one of the fishes of $\mathrm{N}$ (eW York: and I did not see it in Great South bay, but it was taken later in the fall by Capt. Lewis I3. Thurber, of lateliogue, who forwarded it to me.

Dr Smith says it is very rare at Woods Hole Mass. where it was reported by Prof. Baird in 1871. Since 1871 it has been observed only once or twice, and none has been taken for many years.

\section{Family HIODONTIDAE}

\section{Iooneyes}

\section{Genus Howor le Sueur}

In the mooneyes the body is oblong, compressed, covered with cyoloid silvery scales of moderate size. Head short, naked, with obtuse snout and no barbels. The mouth is terminal, of moderate size; jaws subequal. The margin of the jaw is formed by the nonprotractile intermaxillaries and the slender maxillaries, which are articulated to the end of the intermaxillaries. The opereular apparatus is complete. Intermaxillary and mandibie with small cardiform teeth. wide set; feeble teeth on the maxillaries: a row of marginal teeth on the tongue, those in front very strong anines; a band of short close set teeth on middle of tongur; vomerine teeth small, close set, in a long double series; teeth on the palatine, sphenoid and pterygoid bones. The lower jaw is received within the upper so that the mandibulary teeth are opposite to those on the palatine bone. The very large eye has a little dereloped adipose ejelid. Nostrils large, close togethere, with a flap between them; gill membranes 
deeply cleft, free from isthmus, their base corered by a fold of skin; branchiostegals 8 to 10 ; no pseudobranchiae; gill rakers short, thick and few in numbers; a straight and well developed lateral line; belly without scutes; no adipose fin; dorsal fin ove' the caudal part of the rertebral column; anal long and low; ventrals large; candal deeply forked; stomach horseshoe-shaped, with blind sac; intestine short; one pyloric appendage; air bladder large and simple. The eggs fall into the abdominal cavity before exclusion.

\section{Hiodon tergisus (Le Sueur)}

\section{Mooneye; Toothed Herring}

Hiodon tergisus Le Sueur, Jour. Ac. Nat. Sci. Phila. I, 366, Sept. 181S, Ohio. River and Lake Erie.

Hiodon clodalus LE Sueur, op. cit. 367, Sept. 1818, Pittsburg.

Glossodon harengoides Rafinesque, Amer. Month. Mag. III, 354, Sept. 1S18, Ohio River.

Cyprims (Abramis ?) Smithii Richardsox, Fauma Bor.-Amer. III, 110, fig. 1836.

Hyodon tergisus DE ǨAY, N. Y. Fauna, Fishes, 265, pl. 41, fig. 130; Cuvien \& Valenciennes, Hist. Nat. Poiss. XIX, pl. 572, 1816; Günther, Cat. Fish. Brit. Mus. VII, 375, 1868; Jordan \& Gilbert, Bull. 16, U. S. Nat. Mis. 260, 1SS3; Goone, Fish \& Fish. Ind. U. S. I, 613, pl. 219, 1884.

Hyodon clodalis DE KAY, op. cit. 266, 1842, but fig. 164, pl. 51, represents alosoides.

Hyodon claudalus Cuvier \& Valenciennes, Hist. Nat. Poiss. XIX, 313.

Hyodon tergisus BEAN, Fishes Penna. 5i, pl. 25, fig. 44 (named alosoides), 1893; Jordan \& Evermane, Bull. 47, U. S. Nat. Mus. 413, 1896, pl. I.XVIII, fig: 180, 1900.

The sliape of the body is similar to that of the northern mooneye. The belly has a slight but obtuse keel in front of the rentrals and is compressed to a rather sharp edge behind the ventrals. Head short, its length two nintlis of total without caudal; the eje much longer, about one third the length of head. The greatest depth of the body is nearly one third of total length. The pectoral is as long as the head without the snout; the ventral not much more than two thirds the length of head, its origin under the 18 th scale of the lateral line. The anal origin is under the 7 th developed ray of the dorsal. The longest anal ray is less than one half the head. The anal base is as long as the head; its last lay is less than one half the longest 
ray. The anal has a deep notch. The longest dorsal ray is little more than length of dorsal base. The last ray is not much more than one half the longest. The caudal is deeply forked. D. 12; A. 28 to 32. Scales 6-5S-S. Upper parts greenish in life. the sides and abdomen brilliant silvery.

This species is called mooneye, toothed herring and silver bass. It is found in Canada, the Great lakes region and the upper part of the Mississippi valley, being very common in large streams and lakes. It abounds in Lake Erie and the Ohio and is seined in large numbers. BeKay observed the fish in the Allegheny river, X. Y. He records it also from Buffalo and Barcelona, on Lake Erie, at which places it is known as mooneye, shiner, and lake herring. He says it is very indifferent food.

This species grows to a length of 1 foot and, like the other, though a beautiful fish and possessed of excellent game qualities, its flesh is full of small bones. It is a good fish for the aquarium; it will take a minnow or the artificial fly very readily, and the utmost skill is required in its capture. Its food consists of insects, small fishes and crustaceans.

Dr Richardson describes this fish as a member of the minnow family, which he says is known to the Canadians under the name la quesehe. The fish is described as having the back brilliant green, sides and abdomen with a silvery luster. The specimens which were taken in the Richelien, where it falls into the st Lawrence, were about 9 or 10 inches long.

\section{Hiodon alosoides (Rafinesque)}

\section{Northern Mooneye; La Quesche}

Amphiodon alosoides Rafintseve, Jour. Phys. Paris, 421, 1819. Ohio River. Hyodon amphiodon RafinesQue, Ichth. Ohien. 42, 1820.

Hiolon chrysopsis Richardson, Fauna Bor-Amer. III, 232, 1836.

Hyodon alosoides Jordan \& Gillelit, Bull. 16. U. S. Nat. Mus. 259, 1893; Goone, Fish \& Fish. Ind. U. S. I, 612, 1884.

Hiodon alosoides BEAN, Fishes Penna. 57, 1898 (not figured); JornaN \& Evermane, Bull. 47. บ. S. Nat. Mus. 413, 1896.

Hyodon clodalis DE KAY, N. Y. Fauna, Fishes, pl. 51, fig. 161, not description, 1812.

Body deep, much compressed, its greatest depth equaling two serenths of the total without caudal. The head is short, con- 
taining the length of the ere about three and one half times and equaling a little more than one fifth of the total without caudal. The snout is very blunt, the mouth large and oblique, the maxilla reaching beyond the middle of the eye. There is a well developed keel along the entire length of the belly. I. 9 ; A. 32. Scales 6-56-7.

The general color is bluish silvery on the sides with golden reflections.

The northern mooneye is found froul the Ohio river throughout the Great lakes region to the Saskatchewan. It is very com mon in Manitoba and other parts of British America. In Pennsylyania it is limited to the western region.

Je Kay must have had the northern mooneye for study, though his description seems to alply to anotler species. The figure of his II $y$ o d o n cloda $\mathrm{l}$ is represents a fish with a short dolsal fin, quite unlike his acrount in the text.

The northern mooneye is very readily distinguisled from the other species of the genus by its short dorsal fin, which contains ouly nine rays, and by its ralrinated belly. It grows to the length of 1 foot. The flesh is not greatly astecmed as a rule, but the fish is beatiful and has excollent game qualities.

Richardson says the fish inluabits lakes which communicate with the Saskatchewan, in the Sid and 5tth parallels of latitude, but does not approach nearer to Hudson bay than Lake Winnipeg. This we know to be a mistake. He says furtles that it is taken during the sumnor months only, and in small rumbers, in gill nets set for other fish. It bites eagerly at an artificial tly $\mathrm{ol}^{2}$ worm. Its fiesh is white. resembling that of the perels in flavol, and excelling it in richness.

\section{Family DOROSONIDAE Gisaral Shads}

Genus Dorosoma Rafinesque

The genus Dorosom a has a herringlike bodr, with a short and obtuse snout. The body is much compressed and is roveled with moderately hage, thin, cycloid scales. The head is scaleless, short and small: the ere large and provided with 
an adipose eyelid. The bolly is rompressed to an edge, which is armed with sharp serratures. Month small, transverse; the lower jaw the shorter, jaws toothless. The maxilla does not extend to the middle of the rye. Gill rakers numerous, modelately long and slender; will membranes deeply cleft and free from the isthmus: psendobranchiar well developed; lateral line wanting. The dorsal fin is placed nearly over the mildh of the body, slightly behind the origin of the rentral. Its last ray is produced into a long filament. The pectorals and ventrals are rather long and each is provided with an appendage formed of several elongate, overlapping accessory scales. The caudal is deeply forked. Inal very long, its last rays low. The stomach is stont and short, resembling the gizzard of a hen.

\section{S Dorosoma cepedianum (Le Sneur)}

\section{Gis:ard Shad}

Wegalops cepediana Le Suetr, Jour. Ac. Nat. Sci. Phila. I, 361, Sept. 1S1S. (Baltimore and Philadelphia markets).

Clupea heterurus Riffinesque, Amer. Nouth. Mag. III, 355, Sept. 1818. Olio River.

Dorosoma notuta RAFINEsqLe, Ichth. Ohien, 40, 1920. Ohio Rirel.

Chatö̈sus cepcdianus and cllipticus DE KAY, N. Y. Fauna, Fishes, 265, 1842, as extra-limital.

C'hatö̈ssus cllipticus KinthdxD, Bost. Jour. Nat. Mist. IV, 235, pl. X, fig. 1, 1844.

Chatö̈ss"ls cepcdianus Cuvier \& VAlencrennes, Hist. Nat. Poiss. XXI, 99, pl. 612, 1848. New York, Philadelphia, New Orleans; Günther, Cat. Fish. Brit. Mus. VII, $409,1865$.

Dorosomu cepedianum Jornat \& Gilbert, Bull. 16, U. S. Nat. Mus. 2i1, 1SS3; Goode, Fish. \& Fish. Ind. U. S. I, 610, pl. 217 A, 18S4; BeAN, Fislies Pemna. fis, 1893; Jordan \& Evermann, Bull. 47, U. S. Nat. Mus. 416, 1896, pl. LAIX, fig. 183, 1900.

The depth of the body is contained two and two thirds times in the total without candal, the length of the head four and one third times. Ere longer than snout, one fourth length of lead. The third ray of the dorsil is two thirds as long as the head, and the filamentoms ray nearly equals the head in length. Length of dorsal base abont one lualf that of head; anal base two serenths of total length of body without caudal, its longest ray two thirds of length of rentral nr one third of that of head. Pertoral three fourths as long as head. Lower candal lobe 
longer than upper, its length equal to that of the head. D. iii, $10 ;$ A. ii, 31. Scales 56 to 64 , about 20 in a transverse series. Scutes in front of ventrals 17 , and from rentral to vent 12 . Upper parts bluish; sides silvery, sometimes with golden reflections. In young individuals there is a large dark blotch on each side not far behind the head. This disappears with age.

The mud shad, also known as gizzard shad, winter shad, stink shad, white-eyed shad, hickory shad, hairy back, and thread herring, is found in brackish waters along the coast from New York southward to Mexico, ascending streams and frequently becoming landlocked in ponds. A variety of this fish is aisu common in the Ohio and Mississippi valleys, whence it has spread through canals into Lakes Erie and Michigan.

Cuvier and Valenciennes had the species from New York, whence it was sent by Milbert. De Kay mentions it only as an extralimital fish; but in his time the fish fauna of Lake Erie was rely little known.

This fish grows to a length of 15 inches and a weight of 2 pounds. It spawns in summer, and its food consists of algae, confervae, desmids and diatoms. With its food it takes large quantities of mud, from which it separates the organic substances after swallowing. This is a beantiful species, somewhat resembling the shad in general appearance and has been very successfully kept in the aquarium, where its bright colors and graceful movements make it attractive, but its llesh is soft, tasteless and seldom eaten when any better can be obtained. In most regions fishermen consider it a great nuisance and throw away their entire catch. Negroes eat the mud sliad from tributaries of the Chesapeake, and in Florida the fish has been utilized to some extent in making guano. The name gizzard shad alludes to the form of the stomach, which is rery much like that of a hen.

\section{Fimily CLUPEIDAE}

\section{Herrings}

Body oblong or elongate, more or less compressed, covered with cycloid or pectinated scales; belly sometimes rounded. sometimes compressed, in which case it is often almed witl 
bony serratules; head naked, usually compressed; mouth rather large, terminal, the jaws about equal, maxilaries forming the lateral margins of the npper jaw, each conposed of about three pieces; premaxillaries not protractile; teeth mostly small, often feeble or wanting, valiously aranged; adipose eyclid present or absent; gill rakers long and slender, gill membranes not connected, free from the isthmus; no gular plate; gills four, a slit behind the fourth; branchiostegals usually few (6 to 15); posterior lower part of opercular region often with an angular emargination, the tips of the larger branchiostegals being abruptly truncate; pseudobranchiae present; no lateral line. Dorsal fin median or somewhat posterior, rarely wanting; no adiprose fin; rentrals moderate or small (wanting in Prist i g a ste $\mathrm{r}$ ); anal usually rather loug; caudal fin forked. Vertebrae 40 to 56 . Genera about 20 ; species 150 ; inhabiting all seas, and usually swimming in immense schools; many species ascend fresh waters, and some remain there permanently. The northern and fresh-water species, as in many other families, differ from the tropical forms in having a larger number of vertebral segments.

\section{Genus atromes Plecker}

Body rather elongate, somewhat compressed; the abdomen rounded and without serratures; mouth terminal, of moderate width, formed as in C l u pe a, but the maxillary more slender; teetl moderate, in patches on jaws, palatines, pterygoids, and tongue; scales cycloid, entire, rer.y deciduous; branchiostegals numerous, very slender. V'entrals inserted posteriorly, entirely behind dorsal; the dorsal fin rather long, of 18 to 20 rays; anal low, of moderate length. Psendobranchiae well developed; pyloric caeca numerous. No silvery lateral stripe. Few species. Asiatic and American. ( $\triangle$ fter Jordan and Erermann)

\section{Etrumeus teres (De Kaý)}

\section{Round Herring}

Alosa teres DE KAY, N. Y. Fauna, Fishes, 262, pl. 40, fig. 129, 1S42. New York harbor.

Etrumeus teres Günther, Cat. Fish. Brit. Mus. VII. 467, 18G6; Jondan \& Gilbert. Bull. 16, U. S. Nat. Mus. 263, 18s3; Bean, Bull. U. S. F. C. VII, 14S, 1SSs; 19th Rep. Comm. Fish. N. Y. separate, 41, 1890.

Etrumeus sadina Jondan \& Evermann, Bull. 47, U. S. Nat. Mus. 420, 1S96, not Clupea sadina Mitchill; Smrtr, Bull. U. S. F. C. XVII, 91, 1 S9S. 
Body slender, rounded, elongate, its greatest depth one sixth of total length without raudal: head lather long, one fourth of total witlunt caudal; mouth small, the jaws subequal in frout, the maxilla extending to or slightly begond the forout of the rye; the mandible not at all projecting when the month is closed. lut rather included; thickness of body more than two thirris of its deptli: romerine teeth present, lingual teetlo well dereloped, tepth in the jaws weak; eye large, equal to snout, three and one third in length of head; dorsal origin midway between tip of snout and origin of anal, the longest dorsal ray nore than one half length of head: ventrals well behind dorsal, the length little mole than one third length of head; anal basis short, ahout one third length of head; axiliary seales above pertorals and rentrals very long, those over the pectoral more than one half ats $\operatorname{long}$ as the fin. 1). 18; A. 13. Color, bright silvery; darker above, with a tinge of blue and yellow on the sides. IIrat metallir silvery with coppery reflections; iris golden; dorsal and candal tinged with rellow, the remaining fins translurent, with minute dark specks. Cape Cod to the Gulf of Mexico, not rare southward; a farorite food of bluefish.

The "New York shadine" of Mitchill can not be identified with this species; it was evidently a species of P'o molo b u s bearing a close reserublance to the shad. Mitclinll's shadine had a spot buhind the gill cover, a wide and toothless mouth, a projecting lower jaw and 15 anal rays. These characters are in opposition to the known characters of the round herring, and there is no probability that this little fish was before him for description. Te Kay saw only a single specimen of the round herring from the harbor of New York. A cops of Mitchill's description is here given for complyison.

1:) New York Shadine, C: 1 n peas a $1 \mathrm{i}$ in a

In elregant species with a small smutty spot behind the gill cover; but with neither spots nor stripes on its back or sides. Mouth wide and toothless. Tongue small.

Back delicately variegated witl green and blue. Lateral line straight. Sides silvery white, considerably above that line; and

${ }^{1}$ Mitchill. Lit. and Phil soc. N. Y. Thans. 181., 1:t5i. 
below it quite to the belly. The white roflects rividly green, red, and other splendid hues. Head lathele elongated. Lower jal

Srales rery easily deridnous. Form neat, taper, and slender. Gills lise into the throat on rarh side of the loot of the tongue. Eres pale and larene. Tail derply forked. On aceount of the eren commertion of the false ribs, the belly is not at all serrated, but puite smooth. I semitransparent sjace in front of the eyes frolll side to side.

Rays: Br. 7; P. 16; V. 9;11.18; 1. 15; C. 19.

This species was not taken in Great South bay. but on thes ocean beach adjacent to the Blue Point lifesaving station.

It is the slender herring described hy Dr lockay from a single specinen taken with a soine in New York harbor in the latter part of Oetober. He found it associated with nmmeroms sperimens of the bigeged herring, E l o j s s a n r us. Mekily states that the Elops appeared to be known to the fishermen as the round herring, but the name is more applicable to the litth species now under consideration. Several specimens wer. seined on the ocean beach at Blue Point Lifesaving station, Or.tober 7 . None were obtained in the bay. September 24. 51 exam. ples of this fish were found lying on the beach, in the ricinity of the same station, having been driven ashore by blucfish. In August 1890 great schools of round herring werestranded in this way. Prof. Baird found a number of specimens along the beach of Great Egg Harbor bay in 1854, and a single specimen was seined by Capt. Thomas steelman in the same locality in Octoher 1SST.

loung individuals, from $4 \frac{1}{2}$ to $4 \frac{3}{4}$ inclues long, were taken in Gravesend bay July 30, 1896. Thry were associated with young mackerel, of slightly larger size, in bunches and schools. John B. De Nyse sat some schools that he estimated to contain 25,000 fisli.

J) Smitl says it is apparently lare at Woods Hole; known to. have been found on only a few occasions. In Octobere, some years ago, several were taken in traps at Meucmsha bight, Martlıs Vineyard. 


\section{Genus curea (Artedi) Linnaeus}

True herrings with the body elongate, numerous vertebrae, the rentral serratures weak, and an orate patch of small but persistent teeth on the romer. The few species belong to the northern seas, where the number of individuals is inordinately great, exceeding perhaps those of any other genus of fishes. Not anadromous, spawning in the sea.

The genus $\mathrm{Cl}$ u p e a, which includes the shad, river alewife or herring and the Ohio golden shad or skipjack, admits of divisiou into several subgenera, one of which includes the common sea herring and other marine species, another the shad and still another the river alewives. The last have the suborbital bone longer than deep and are supplied with teeth on the tongue and in some species in the jaws.

\section{Clupea harengus Linna eus}

\section{Sea Herring}

Clupea harengus Linnaeus, Syst. Nat. ed. X, I, 317, 175S; Mitchilt, Amer. Month. Mag. II, 323, Mar. 1818; Cuvier \& Talexciennes. Hist. Nat. Poiss. XX, 30, pl. 591, 18t7; Günther, Cat. Fish. Brit. Mus. VII, 415, 1868; Jordan \& GILbert, Bull. 16, U. S. Nat. Mus. 265, 1883: Goode, Fish \& Fish. Ind. U. S. I, 549, pl. 204, 1884; BEAN, 19th Rep. Comm. Fish. N. Y. separate, 42, pl. XXIV, fig. 32. 1890; Jordax \& Evermaix, Bull. 47, U. S. Nat. Mus. 421, 1896, pl. LXX, fig. 185, 1900; Sмiтн, Bull. U. S. F. C. XVII, 91, 1898.

C7upea halee Mitrchill, Trans. Lit. \& Phil. Soc. N. Y. I, 451, 1815.

clupea pusilla Mitcinll, op. cit. 452, 1815.

Cluper coeruler Mitchill, op. cit. 457, 1815.

Clupea clongata DE KAY, N. Y. Fauna. Fishes, 250, 1842; STORER, Hist.

Fish. Mass. 152, pl. XXVI, fig. 1, 1867.

Body elongate, slender, fusiform, compressed, its greatest depth one fourtl of total length without caudal; caudal peduncle slender, its least depth one third of length of head; liead moderate, two ninths of total length without caudal; eye large. three and one half to four in head, and with a well dereloped adipose eyelid; lower jaw strongly projecting; maxilla reaching to below middle of pupil, its length three serenths of leugth of head; cheeks longer than high; an ovate patch of small teeth on vomer, palatine tectl minute or wanting, small teeth on the tongue, small teeth in the jaws in young examples, usually dis- 
appearing with age; gill rakers very long and slender, about 40 on the lower part of the first arch; dorsal origin midwar between tip of snout and end of scales, dorsal base one eighth of total length without caudal, longest dorsal ray equal to postorbital part of head, last dorsal ray one lalf the length of longest; rentral under about middle of dorsal, its length three eighths of head; anal base a little shorter than dorsal base, its longest ray one fifth, and its shortest ray one tenth of greatest depth of body; caudal fin well forked, its longest rays three fourths of head; pectoral fin about two thirds as long as the head. Scales rery deciduous. Ablomen with weak serratures, before and behind the rentrals, as scutes in front of and 13 behind the rentrals. D. 1S; A. 17. Scales 14-57. Tertebrae 56. Peritoneum dusky; back and head deep blue, tinged with rellow; opercles yellowish, tinged with violet; iris silvery; sides silvery with bright reflections. length 12 to 17 inches. North Atlantic ocean, on our east coast south to Cape Hatteras, spawning in the sea.

The sea lierring is the most important food fish of the world and it is undoubtedly the most abundant of all the fishes. Its food consists of small invertebrates, chiefly copepods and the larvae of rorms and mollusks. It forms the most important food of many of our valuable food fishes including the cod, hadTock, halibut, bluefish, and a great many others. Herring spawn at two seasons, spring and fall, the first spawning continuing from April to June and the second season between July and December. The eggs are adhesive and are deposited on the bottom, where they adhere to seaweeds and other objects of support. The egg is about $\frac{1}{20}$ inch in diameter. The hatching period lasts from 12 days to 40 days, according to the temperature of the water. Sea herrings were artificially hatched as early as 1STS, both in Germany and in the United States. It has been estimated that the annual yield of sea herring is $3,000,000,000$ fish, principally taken in Norway.

The herring occurs on our east coast from Labrador to New York. When found as far south as New York, it usnally occurs 
in midwinter. Capt. Thurber obtained it in Great South bay in the fall.

The young of the sea herring is well known as the whitebait of England and the Enited States, though in the latter country the young of other species are sometimes ningled with those of the sea herring.

Many young, transhucent fish of the genus Clupe a, a little under : inches long, are seen in spring in the shad fykes and pounds of cravesend bay. They are called "shad bait," because they are said to be taken frequently from shad stomachs. John B. We Nyse brought some of them to me for examination Ap. 30. 1896. They slowed the following characters.

I. $18 ; 1.17$. Muscular impressions along sides of body about 60. The ventril is very slightly in advance of the origin of the dorsal. Intestinal tract full of minute orange-colored substances resembling entomostraca. A row of black dots on sides, low down, extending from pectoral to anal. Iris silvery; top of eye rery dark.

Large sea herring, according to W. I. De Nyse, are rare in Gravesend bay. Only about 100 or 200 are obtained there during fall and winter.

Young examples, from $4 \frac{3}{4}$ to 6 inches long, were obtained in that bay Nor. 2:;, 1897.

In the vicinity of Woods Hole Mass., aceording to Dr Smith, schools of large herring, in a spawning condition, appear about October 15 and lemain till very cold weather sets in, their departure coldesponding with that of the cod. By January young herring $\frac{1}{+}$ inch long are taken in surface tow nets; by May 1 they are 1 to $1 \frac{1}{4}$ inches long, and by 1 ugnst $1,2 \frac{1}{2}$ to 3 inches. Fish 3 to 5 inches long, called "sperling," are found from September" 1 to end of season and are used for mackrel bait. About June. 1 there is a large run of herring, smaller than those in the fall rum. This lasts two weeks, during which the traps are full of them. No use is made of the early rum, but in fall they are caught in gill nets for food and bait. 
Genus pomolowes Rafinesque

Body obloug, more or less compressed; mouth moderate, terminal, the jaws about rqual, or the lower projecting, the upper scarcely notched at tip; teeth feeble, variously placed, probably nevel wholly absent, mandibles rery deep at base, shutting within the maxillaries; gill rakers more or less long and slender, numerous; adipose evelid present; scales thin, cycloid, deciduous, entire, rounded posteriorly; cheeks with the free part longer than deep; dorsal fin rather short, nearly median, beginning in adrance of ventrals, its posterior ray not lrolonged in a filament; rentral present; anal moderate; belly compressed, strongly serrated before and behind rentrals. Flesh rather dry and poor, less oily than in Clu p a no d o n . Vertebrae 46 to 55 in number, usually 50. Species numerous, ilostly anadromous.

\section{Pomolobus chrysochloris Rafinesque}

\section{Skipjack: Blue Herring; Gold Shad}

I"omolobus chysochloris RAfixesque, Ichth. Ohien. 39, 1820. Ohio Rivel; Jordax \& Everuaxe, Bull. 4i. U. S. Nat. Mus. 425, 1896, pl. LXX. fig. 187,1900 .

II cletta suocrii Cuvier \& VAlenciennes, Hist. Nat. Poiss. XX, 375, 1847.

Alosa chrysochloris Kintland, Bost. Jour. Nat. Hist. IV, 307, pl. XV, fig. 3, 1844 .

Clupea chrysochloris Jordax \& GILBERT, Bull. 16, U. S. Nat. Mus. 266, 1863; Goode, Fish \& Fish. Ind. U. S. I, 594, pl. 211, 1851; BeAn, Fishes Penna. 59, 1893.

This species has a few strong and distinct teeth in the jaws, the lower jaw strongly projecting, the caudal peduncle stout and the belly strongly serrated. In shape the body resembles that of the sea herring; it is compressed, rather low, its depth slightly more than one fourth of the total length without caudal and about equal to the length of the head. The eye is large, nearly one fourth the length of liead; the maxilla extends nearly to the hind margin of the eye; the length of the upper jar is more than one half the length of head. The origin of the dorsa] is orer the ninth series of scales, and the length of its base corresponds with 10 lows of seales. The rentral origin is under 
the middle of the dorsal; the tin is one half as long as the head. The pectoral reaches the 14 th series of scales of the lateral line; its length is two thinds of that of the lead. The anal is moderately long and low; its longest ray about twice the length of eye and one half the length of its base. The longest dorsal ray equals postorbital part of head. The "andal is deeply forked. There are 23 gill rakers brlow the angle of the first arch. 1). iii, $15 ; 1$. iii, 16 . Scales $15-52$ to 58 . Scutes $20+13$ to 14 .

The body is blue with reflections of green and gold; the lower parts silvery.

The golden shad or skipjack is a common inhabitant of the Ohio and Mississippi valleys and the Gulf of Mexico. In Pennsylvania this fish is confined to the Ohio and its tributaries. It prefers large streams. It has made its way into the creat lakes throngh canals. The presence of the golden shad in the salt water of the Gulf of Mexico was discovered by Silas Stearns near Pensarola Fla. This species grows to a length of 18 inches.

Cnlike most other species of herring, this one, according to observations of Prof. S. A. Forbes of Illinois, is predaceous, feeding on other fishes. Two "xamples examined by him hat eaten gizzard shad, D o r o s o m a and another one, individuals of sone unidentified tish. The young of the golden shad, $2 \frac{1}{\ddagger}$ inches long, had ronsumed nothing but terrestrial insects, includin: flies, small spiders, ete.

As far as I can learn it never aserends small streams. In the lower palt of the Mississippli valley it migrates into salt water. In the upyer portion of this region its permanent residence is in fresh water. The name skipjack is given in allusion to its habit of skipping along the surface of the water.

The fish is full of small bones, and its flesh is reputed to be tasteless and without ralue as food; ret Kirtland says it is esteemed in Ohio as a good paln fish. In the water its morements are graceful and active, and its peeuliarity of leaping above the surface when in pursuit of its prey is interesting and unusual in this fanily. 


\section{1: Pomolobus mediocris (Ilitehill)}

\section{Hickory shad ; Full Herriug: Sthal Herring}

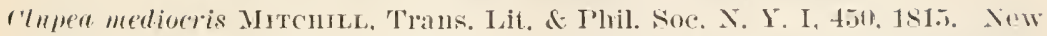

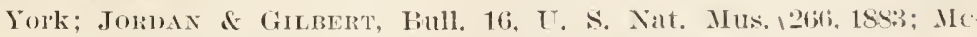

DoxALD, Fisl of Fish. Ind. L. S. I, 607, pls. 2161, 216B, 18St: BEAX,

19th Jiep. Conme. Fish. N. Y. separate. 4:, pl. XXV, fig. :34. 18 !.

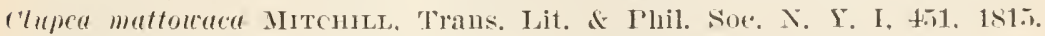

Long Island.

C'lupeq virescens DE KaY. X. Y. Fauna, Fishes, 252. pl. 13, tig. 37. 194:.

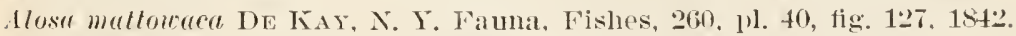

Alosa lineala Storer. Hist. Fisl. Mass. 162, pl. XXYI, fig. 2, 1867.

chupe matowaed Gixtmer, Cat. Fish. Brit. Mus. VII, 438, 1869.

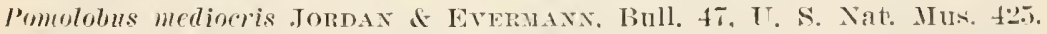

1896, pl. LXXI, fig. 108. 1900; SmTi, Bull. U. S. F. C. XVII. 91. 1898:

Bear. J2al Ann. Rep. N. Y. State Mus. 96, 1900.

Head comparatively lomg, its lemegth being contained fome times in that of the body; the profile straight, and not rery steep, form more elliptic than in oflexs, and less heary forwad; lower jaw considerably projecting, upper jaw emarginate. The depth of the body is contained three and three eighths times in the length. Opereles rathere less emanginate below and behind

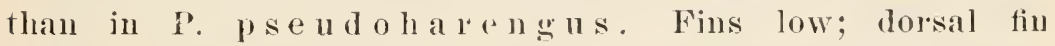
inserted nearel snout than base of randal. Blnish silvely; sides with rather faint lomgitudinal stripes. Peritonemum pale. Length 24 inches. Cajer cod to Florida; lather common; not bighly valued as a food fislı; not ascending streams to sparro. J. $15 ;$ 1. 21 . Lateral line 5() ; abdominal seutrs $20+16$.

This species is refered to by 10 Mitchill as the Staten Islanci

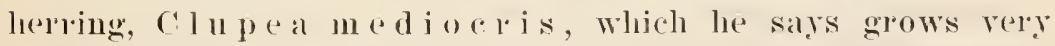
lalege for a hering, being frepuently 18 inches long and alunost as big as a small shad. It has " six or eight blown spots, longitudinally, below the lateral liure, as reported by an iuhabitant of that part of the bay of New lork which borders oul staten Island." Mitchill, also, has the same spocies mule the mame of

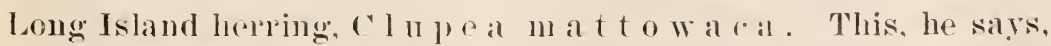
is also called the antmmmal or fall hrulnge, as well as shal herring and fall shad. Mitrhill rerognized it as probably the full-glowe fish of the (". 11 a d o e r is. Ho was not able to distinguish it from that species. The length of the greenback, 
according to this writer, frequently reaches 2 feet with a depth of from $4 \frac{1}{2}$ to 6 inches. It the time of his writing the fish was taken in October and Norember in seines on the surf side of the beaches fronting Long Island. Dr DeKay mentions examples in the market early in Inly, which are brought from the Connecticut river, where they are called weesick. He states that the specific name bestorred on it by Mitchill was derived from the aboriginal name of the island, Mattowaca or Mattowax. In Great South bay the name greenback is well established for the species. A single example was seined September 29 at Fire island. Oct. 1,1890 , considerable numbers of large greenbacks were caught in a trap at Islip. The hickory shad is caught in Gravesend bay during September, Octobcr and Norember, but is less plentiful than it was formerly. Large hickory shad, weighing from $\frac{1}{2}$ pound to $2 \frac{1}{2}$ pounds, wele shipped from waters near New York city to Fulton market Oct. 30, 1896. Each of them had in its stomach from 15 to 20 sand lance from $3 \frac{1}{2}$ to 5 inches long. A few specimens wele seined at Blue Point cove, Great South bay, and at Howell's point, in the same bay, Aug. 31, 189S.

At Woods Hole Mass. it comes in the spring, but is most numerous late in September and till trap fishing ends. In October 1895 a trap near Tarpaulin cove caught 3500 at one lift. These brought $10 \mathrm{c}$ earll in New York. In spring and summer the fish has no market value, but it sells in the fall.

The name hickory shad is applied to this species from the Chesapeake bay region southward, and in some Georgia rivers this is abbreviated to hicks. In the Potomac, and some other rivers tributary to the Chesapeake, the name tailor shad is applied to this fish. The lickory shad occurs from Maine to Florida, entering rivers except in New England. The species is nuch less valuable than the shad, for which it is often sold by dealers. Nothing definite is known about its habits, but Marshall McDonald mas of the opinion that it spawns in the rivers at a little earlier period than the shad, which it always precedes in the ascent of the streams in spring. 


\section{Pomolobus pseudoharengus (Wilson)}

\section{Branch Herring; Alewife}

Clupea pseudoharengus WiLsor, Riees's Encycl. IX, about 1811.

"Inpra rerualis Mitchild, Rep. Fish. N. Y. 22, 1814; Trans. Lit. \& Phil.

Soc. N. Y. I, 45t, 1815; Jordax \& Gllbert, Bull. 16, U. S. Nat. Mus. 267. 1883; Bean, Fish \& Fish. Ind. U. S. I, 588, 1884; Fishes Penna. 58, pl. 25, fig. 45, 1893; Goode, Fish \& Fish. Ind. U. S. I, pls. 207, 208, 1851.

Alosa tyramms DE KAY, N. Y. Famna, Fishes, 258, pl. 13, fig. 38, 1842. Pomolobus vernalis Goode \& BEAN, Bull. Essex Inst. 24, 1879.

Pamolubus psendoharengns Gitl, Riep. U. S. F. C. I, S11. 1873; Jordar \& Everdanx, Bull. 47, U. S. Nat. Mus. 426, 1S96, pl. LXXI, fig. 189, 190?; Syith, Bull. U. S. F. C. XVII, 91, 1898; BEAN, 52d Ann. Rep. N. Y. State Mus. $96,1900$.

Body deep and heavy forward, much compressed. Its greatest depth, at dorsal origin equals one third of total length to base of (audal. The least depth of caudal peduncle equals but one half of length of head. The head is short, being almost as deep as long, about one fifth of the standard length. The eye is large, deeper than Iong, its length slightly greater than its distance from tip of smout-about three and one half in head. Maxillary broad, extending to the rertical through pupil; upper jaw emarginate, lower jaw slightly projecting. Length of dorsal base almost equal to that of head; its highest ray about two thirds as long as the base, or equal to anal base. The anal is low, its longest ray being equal to length of eje. Caudal deeply forked, partially scaled near base. Length of pectoral less than that of dorsal base. D. $16 ; \mathrm{A} .17$ to 19 . Scales $15-50$ to 54 .

In the male the dorsal is higher, its longest ray about equal to length of dorsal base, or two thirds the length of head.

Color on black blue silvery and paler on sides and underneath; a black spot behind head; dusky lines on body, which are only visible on large examples.

Described from no. 27197 U. S. National Museum from Potomac river. Length 11 inches.

The branch herring, liver herring or alewife has a variety of additional names. It is the ellwife or ellwhop of Connecticut river, the spring herring of New York, the big-eyed and wall- 
eyed hereing of the Albemalle, the sawbelly of Maine, the grayback of Massachusetts, the gaspereau of Canada, little shad of rertain localities, and the Caynga lake shad of New York. The recorded lange of the branch herring is from the Nense river. X. r., to the Mirantrhi river, in New Brunswick, ascending streams to their head waters for the purpose of spawning. The fish is found abundant in Cayuga and Seneca lakes, N. Y., where it has probably made its ray natmally. In Lake Ontario, since the introduction there of the slat, the alewife has become so plentiful as to cause great difficulty to fishermen, and its periodial mortality is a serions menace to the health of people living in the vicinity. The belief is that the fish were muintentionally introduced with the shad. In Pennsylyan the branch alewife oceurs in the Jelaware and the susquehanna in great numbers in early spring.

The U. S. Fisl Commission, in 1894, obtained specimens at the following localities of the Talie Ontario region.

Cape Vincent

June 21

Grenadier island

June 27

Mouth Salem liver, Selkirk

July 25

Long pond, Charlotte, N. Y.

Ang. 17

Lake Shore, mouth Long pond

Aug. 17

Sandy croek, North Hamlin

Aug. 20

Sot a native of Cayuga lake but often found there in large numbers. Known to the fishermen as sawbelly. It is thought to have been introduced into tho lakes of central New York by the state fish commission. Large numbers are often found dead on the shores of Seneca and Cayuga lakes. (After Meek) De Kay says it appears in New York waters with the shad about the first of Ipril, but never in sufficient numbers to form a separate fishery.

The branch herring. or alewife, is the first of the alewives to apleal in Gratresend bay: it comes with the shad. It endures captivity well. Sor. 30,1897 , individuals above 7 inches in length wele canght in Gratresund bay, which were probably the roung of the year. 
This alewife seldom exeeds 1 foot in length, the arerage markot examples heing abont 10 inches. 'The weight of the largest is about $\frac{1}{2}$ pound, and the average weight is about $50^{\circ} 6$ 0 olincess.

The fish enter the rivers earlier than the shad and return to the sea, or to esturiries adjacent to the river mouths, at some undetermined date in the fall. During the summer months enormous schools of full grown, but sexually immature alewires migrate along the coast, feeding on small crustaceans and themselves furnishing food for bluefish, sharks, porpoises and other predaceous animals; but nome of them are known to enter fresh waters. In the rivers the alewives appear to eat nothing, but they can be captured with small artificial flies of rarious colors. Therir eggs are somerhat adhesive and number from 60,000 to 100,000 to the individual. They are deposited in shoal water; spawning begins when the rirer water is at $55^{\circ}$ to $60^{\circ} \mathrm{F}$. The period of hatching is not definitely known, but is believed to rxceed four days.

During the spring and summer the roung grow to a length of 2 or:3 inches; after their departure from the streams nothing is known of their progress, but it is helieved that they peach maturity in four rears. We have no means of learning the age of the immature fish seen in great schools off shore, and thus far the rate of growth is unsettled.

The branch alewife, thomgh full of small bones, is a very valuable food tish and is consmmed in the fresh condition as well as dry salted, pickled and smoked. The fry ran be reared in ponds by placing adults in the waters to he stocked a little before their spawning season; and they furnish excellent food for bass, rockfish, trout, salmon, and other choice fishes. The proper utilization of the immense oversupply of these fish in Lake Ontario has become a serions eronomic problem.

Alewives are eanght in suines, gill nets, traps and pounds and they are often taken by anglers with altificial thies. 


\section{Pomolobus cyanonoton (Storer)}

\section{Glut Herring; Blueback}

Alosa cyanonoton Storer, Proc. Bost. Soc. Nat. Hist. II, 242, 1848, Hist.

Fish. Mass. 161, pl. XXYII, fig. 1, 1867.

l'omolobus aestiralis Goode \& BEAN, Bull. Essex Inst. 24, 1879; Jordan \& Evermann, Bull. 47. U. S. Nat. Mus. 426, 1896, pl. LXXI, fig. 190, 1900;

Smith, Bull. U. S. F. C. XVII, 91, 1898.

clupea apsticalis JorDAN \& Gilbert, Bull. 16, U. S. Nat. Mus. 267, 1883:

ICDOxald, Fish \& Fish. Ind. U. S. I, 579, pls. 209, 210, 1S\$1, not

clupca aestiralis Mitcinll, Trans. Lit. \& Phil. Soc. N. Y. I, 456, pl. V', fig. 6,1815 .

Boty moderately deep and compressed, its greatest depth two sevenths of the length without caudal; least depth of candal prouncle two serenths of greatest depth of body; head short, one fifth of total length without caudal, the maxilla extending to below the middle of the eye, its width about one third of its length, lower jaw somewhat projecting, upper jaw notehed; eye smaller than in P. p s e $u d o$ h a $\mathrm{r}$ e $\mathrm{n} g \mathrm{~g}$, equal to snout and one fourth of length of head, chiefly covered by an adipose membrane; yill rakers about 44 below and 21 above the angle of the first arch, the longest about equal to iris; lower candal lobe the louger, about equal to length of head. Dorsal fin begins in adrance of rentral origin, over the 13 th row of scales; the longest ray is about three fourths as long as the base of the fin and twice as long as the last ray. Anal base two and one half times as long as the longest ray and as long as the head without the snout. Ventral under the 6 th developed ray of dorsal, the fin one half as long as the head; its axillary scale about one half as long as the ventral fin. A small black spot behind the opercle on the level of the top of the eye. Narrow dark streaks on about five rows of scales above the median line. Peritoneum very dark. D. iii, 15; A. ii, 18; V. i, 8; P. i, 15. Scales 13-53; scutes $21+14$. Above bluish, sides and gill covers with coppery leflections, lower parts silrery. Irish golden. Here described from a male specimen taken in the Potomac river and now in the U. S. National Minseum.

Mitchill's name, a es t i r a $\mathrm{l}$ is, can not be applied with any certainty to the "glut herring"; it appears to be a synonym of 
mediocris and mat towaca of the same author. Its relation to $m$ a t to $\mathrm{W}$ a $\mathrm{e}$ a was long since pointed out by $\mathrm{Ir}^{\circ}$ Gill. The description ${ }^{1}$ herewith appended appears to make this ronclusion incritable.

Summer herring of New Tork (C 1 u pea a estivalis). Has a row of spots to the number of seven or eight, cxtending in the direction of the lateral line. Tail forked. Belly serrate; and, in most respects, resembling the C. h a l e c. herein alloady described. Rays: Br. 6; P. 15; V. 9; I. 16; A. 19; C. 19.

The figure shows a row of eight dark spots on the side extending as far back as the end of the dorsal fin on the level of the eye. 'This resembles the hickory shad, P o molo b u s m e d i ocris, more than anything else, and it probably was that species.

The glut herring arrives later than the branch herring and does not ascend streams far above salt water. It appears to spawn only in the larger streams or their tidal tributaries and at a temperature of $70^{\circ}$ to $75^{\circ}$; while the branch herring spawns in water as low as $55^{\circ}$ to $60^{\circ}$ and ascends far up the streams and their small fresh-water branches.

In Gravesend bay the glut lerring is called shad herring. Nov. 30, 1897, two young fish of the year, measuring about 7 inches in length, were obtained from that bay. In Great South bay the species is called herring. A single example was secured there on Sep. 29, 1890. In 1898 it was not collected either in Great South bay or Necox, in both of which the branch herring was abundant.

At Provincetown the species is known as the blueback and kiouk. According to storer, it appears there in small numbers in May, but is not abundant before June 10, and it remains on the coast for a short time only. The alewife, or branch herring, arrives on the coast of Massachusetts abont the end of March, and is taken till the middle or last of May.

\section{Gellus alosa Curier}

Body decp, compressed, deeper than in related American genera, the head also deep, the free portion of the clecelis decpere

${ }^{1}$ Mitchill. Lit. and Phil. Soc. N. Y. Trans. 1S15. p. 456, pl. 5, fig. 6. 
than long; jaws wholly toothless (excent in roung); npper jaw with a shall, deep noteh at tip, thr premaxillarjes meeting at a vely acute angle. Vertebrae 56 (in 110 s a a 10 sa), othermise as in Pomolobus, to which genus d los a is ver? closen allied. Sipecies three of the north Atlantic, ascending rivers; highly valued as food fishes. Though very full of suall bones, the flesh is white and rich, but not oily.

\subsection{Alosa sapidissima (Wilson)}

\section{shad}

('Tupfa stmidissima linson, Rees's New Cyclopedia, IX. about 1811. no pagination, no date; IiAfinesque, Amer. MIonth. Mag. II, 205, Jan. 1S18, silys Wilson first distinguished and named the Shad; MCDoxAln in Fish \& Fish. Ind. U. S. I, 594, pls. 212, 213, 1854; BeAx, Fishes Penna. 60, pl. 22, 1893; Cuener, 4th Ann. Rep. N. Y. Comm. Fish. colored plate facing p. 8, 1899.

Clupet alosa Mrtemin, Trans. Lit. \& Phil. Soc. N. Y. I, 449, 1815.

Alosa mapstabilis DE KAY, N. Y. Fauna, Fishes, 2.5, pl. 15, fig. 41, 1842: Storer, Hist. Fish. Mass. 154, pl. XXVI, fig. 2, 1867.

Alosa sapidissima HNsLex, Am. Jour. Sei. Alts, XLTII. 70, 1844; Storel. sym. Fish. N. A. 206, 1846; Jordax \& Evermaxx, Bull. 47, U. S. Nat. Mus. 427, 1896, pl. LXXII. fig. 191. 1900; Sмuth, Bull. U. S. F. C. X'II. $91,1898$.

The American shad. Goope, Imerican lishes, 400, fig. 1868.

The shad was formurly refered to the genus o l u pe a, but differs from the typical sea herring in the shape of the cheek bone, which is somewhat deeper than long. The adult is toothless, but the poung has well developed, though small, teeth in the jaws, which sometimes fersist till the fisin has reached a length of i.j inches. To this subgenus the name. A lo s a was given by Cuvier.

The shad has a deel, body and a large month, with the jaws about equal. The gill rakers are very long and slender, vareing with age from 40 to 60 below the angle of the first arch. In the female the dorsal originates a little in front of the middle of the length; in the male somewhat farther in front. The dorsal of the male is rather higher than that of the female, while the lody is not so deep. In the female the greatest depth is one third of the total without randal and the length of the head two ninths. In the male the length of the head is one 
fomrlo of the total without abudal. The dorsall has l:3 divided rays ambl 4 simplo ones; amal 19 divided and $: 2$ simple. Neales 16-60) to 65. sicutes $20+16$.

'The color is bluish ol greenish with much silvery; a dusly blotrh rlose behind the head, two thireds as lallege as the reve, and frepuently form several to mally, in one or two rows, behind this. The lining of the brelly walls is pale.

The shad is known also as the white shad, and in the colonial days it was known to the negroes on the lower lotomac river as the whitefish. It is found natmally along the Itlantic coast of the Enited states from the Ginlf of st Lawence to the riulf of Mexico, asconding streams at valoions dates foum January in its extreme sonthern limit to June in far northern waters. In the Itraware and Fuspmehamma it makes its apjoaldance in April and departs after spawning; but remains somutimes as late as .July 18, and nany die.

The original distribution of the shad has been widely extended by artificial introduction. In certain rivers flowing into the Gulf of Mexico the fish has been established by planting. In the Ohio river a fishery has been created by the same method; and in the sacramento rivele, (all., the slad was successfully introdnced, and it hals colonized not only this river but all suit. able rivers from San Franciseo to southern dlaska. It is now out of the conmon mated spereses in san Francisco and other west roast cities.

In the susquehama. the shad was formery one of the most important native food fishes, but its range is now rery limited on aceount of obstrution by dams. 20 years ago the fish commissioners reported that a few shad are taken yearly above the Clark's Ferry dam, none or at most a few dozen alove the Shamokin dam, nome ahow the Nanticoke dam and none above Williamsport. The largest run of shad that has been known to pass the Columbial dam was that of 1867. "In 1871 the finest Columbia sload Were hawked in the market at Harrisbura, 30 miles from the fisheries, at considerably less than a dollat at pair. The cateh at Columbia exceded 100,000." 
The obstructions in the Delaware have been almost entirely orercome. In 1891 shad were caught ligher up the Delaware than for many years, and spawned in the upper reaches of the river beyond the New York state line. In 1891 the Delaware, for the first time since 1823, was restored to its normal condition by means of the fishway at Lackawaxen; and, according to Col. Gay, it is at present the best shad river in the country. The number of eggs obtained for artificial propagation in the lower river was unsually small, but the number naturally deposited in the upper water's was greater than for many years. Col. Gay observed a large number of big female shad at Gloncester City, but a great scarcity of males. This necessitated a long run up the river before spawning. The cause is believed to be the low temperature of the water during May, the lack of rain cutting off the usual supply of warm surface water and the tributaries of the upper river bringing down nothing but cold spring water, keeping the temperature of the river below the normal for spawning purposes. Consequently, the shad as. cended more than 300 miles. Mr Ford noticed that every pool in the upper river was full of shad, and he saw them playing in the water by hundreds. Mr Van Gordon saw them above Port Jervis, and they were observed as far up as Deposit N. Y.

The shad reaches a length of 2 feet. It is asserted that 50 years ago shad weighing from $\&$ to 13 pounds were not uncommon in the Susquehanna. It is said that even larger individuals were taken. In California the shad reaches a larger size than it does in the east, specintens weighing from 13 to 14 pounds being often seen in the markets. The average weight of females is 4 or 5 pounds. The male is much smaller.

The young shad remain in the rivers till the approach of cold weather, when they descend to the sea, and they are usually seen no more till they return as mature fish ready for reproduction. They are known to feed on small flies, crustaceans and insect larvae. They have been fed with fresh-water copepods and kept alive in this way till they had obtained a length of more than 1 inch. In the carp ponds, at Washington, Dr 
Hessel succeeded in loaring shat en thr I) a plo $\mathrm{n}$ i a and Cyclops to a length of 3 or 4 inches, and one time, when they had access sureptitiously to an abundant supply of young calp, well fed individuals reached a length of 6 inches by the first of November. Flad have been kept at the central station of the T. S. Fish Commission orer the winter, but at the age of one year, doubtless for lack of sufficient food, the largest was less than 4 inchos long. It this age they were seen to rapture smaller shad of the season of 1891 , which were an inch or mole in length. The commissioner of fisheries detected roung shad also in the act of eating young California salmon; and on one oceasion found an undigested minnow, 2 or 3 inches long. in the stomach of a large shad; and they have been canght with minnows for bait. The principal growth of the shad takes place at sea, and. when the species enters the fresh waters for the purpose of spawning, it ceases to feed. but will sometimes take the artificial fly and live minnows. The migratory habit of the shad has already been referred to. The spawning habits have been thus described by Marshall McDonald.

The farorite spawning grounds are on sandy flats bordering streams and on sand bars. The fish appeal to associate in pairs, usually between sundown and $11 \mathrm{p}$. m. When in the act of spawning they swim rlose together near the surface, their dorsal fins projecting above the watel and their movements producing a sound which the fishermen call "washing." The egas are expressed by the female while in rapid motion; the male following close and pjecting his milt at the same time. Such of the eggs as come in contact with the milt are impregnated, but the greater portion of them are carried a way by the ("urent or destroyed by spawn-eating fishes. After impregnation the ega sinks to the bottom, and under favorable conditions derelops in from three to eight days.

According to Seth Green, the embryo shad srim as soon as they break the shell, and make their way to the middle of the stream, where they are comparatively safe from predaceous fishes. A mature female shad of 4 or 5 pounds contains about 25,000 eggs on the average, but as many as 60,000 have been obtained from a 6 pound fish, and 
100,000 Nores obtained from a single female on the Potomate. There is great mortality among the shad after spawning. Dead fish of both soxes are frequently sown floating in the water in the late months of summere.

Mitchill states that the shad visits New York ammally about the end of March or beginning of April; that is, ascends toward the somress of the Hudson; that it usually weighs 4 or 5 pounds. but sometimos as much as 12 pommos. 1) Kay says a larege variety, supposed to be an old fish, and weighing from 10 to 12 pounds, were frequently taken in the Hudson, under the name of yellow barks. The shad, in his time, ascended the river 150 miles, to stawn, and descended in the latter part of May. The introduction of gill nets, he writes, has caused a searcity of the fish and will drive them from the rivel before many years.

Nets set ofï shore in Gravesend bay in the fall frequently inclose larege puantities of young sluad, sometimes a ton and a. laalf at one lime, during their migration seaward, but they are at once liberated. The fish are usually about $i$ to $\&$ incles long. Oct. 17, 1895, 60 or 70 were caught in John R. De Nyses pound, among them a male 11 inches long and 23 inches derpe, and a female 12 jnches long and : inches drep. Oct. 31 , 1895), a male $13 \frac{1}{2}$ inches long and $3 \frac{1}{2}$ inches deep, and a female $123 \frac{1}{2}$ inclues long and $3 \frac{1}{8}$ inches dere were obtained in the same pound. Aplatrently the shad do not all remain at seal afore their filst migration till they are sexually mature. In the Potomac river young shad 8 to 9 inches long ocrasionally enter in the spring with the adults in large numbels. Mr the Nyse informs me that in the first spring run of small shad in Graveseud bay fully go\% aro males.

\section{Genus subrvelus luviel and Talencirnnes}

Small herrings of the tropieal seas, with the verteblate in resduced numbers, about 40 to 44 , and with the scales large, usually firm and adherent, often crossed by rertical striar. Ventral srutes strong, 2.5 to 35 in number ; alipose eyelid obsoletr; lower jaw projecting, nppre jaw somewhat emarginate, tecth weak; rentrals inserted behind front of dorsal; body compressed; 
rheeks not deep; rill rakers long and numbens atlerwise

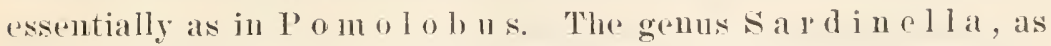
here understood, covers a wide diversity of forms and may be divisible into several genera when the anatomy of the species is better known. (After Jordan and Frermann)

\section{1 it Sardinella siperies}

\section{śculed șardine}

An individual about ! inches long was obtained by IV. I. De Nyse in Glaresend bay in 1895. This was the only one observed in that locality, and it is the only record known of the oremerence of a fish of this gents north of Florida. The specimen

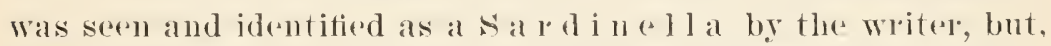
before loe had opportunity to make a detailed stndy, it disappeared from the tank in which it was placed and conld not be found.

\section{Gellus opisthonent Gill}

Characters esserntially those of s'a l d i lle l lat. except that the last ray of the dorsal is produced in a long filanent as in Dorosoll a, Megalops and Tarpon. Species few, Inel'ic:an.

\section{Opisthonema oglinum (I، Nivell)}

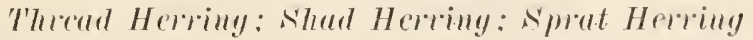

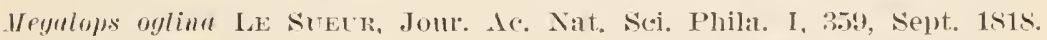
Nenport, I. I.

Ifyalops notata LE SuEvk, op. cit. :361, Sept. 1818. Fuadeloupe.

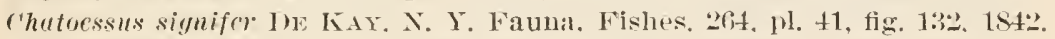
opisthoneme ogline Goode of BeAx. Proc. I'. S. Nat. Ius. VIIl, 206, June 8, 1885 .

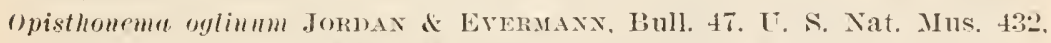
1896: Bean, Bull. Amer. Mus. Nat. Hist. IX. 336, 1897; Sмити, Bull. U. S. F. C. XVII, 91, 1898.

Body oblong, decperompressed, its greatest depth one third of the total length without candal; randal pedunele short. stout. its least depth one half the length of head; head short, deep. its length one fourth of total length witlout candal; rye large. two serenths to one third of length of head, slightly longer than snout; maxilla reaching to below frout of pupil, its wilth more 
than one half its length, the bone almost covering the mandible, which is scarcely projecting; gill rakers very long and slender; pseudobranchiae well developed; dorsal origin much nearer to tip of snout than to base of caudal, equidistant from snout and origin of anal, base of dorsal as long as the longest ray and two thirds as long as the head, filament reaching to base of caudal, much longer than the head in examples measuring from 7 to 9 inches; anal base as long as the head without the snout, its longest ray three fourths of diameter of eye; ventral origin under Sth or 9th developed ray of dorsal, the fin half as long as the head; pectoral four fifths as long as the head. Scales smooth, firm, but easily detached. Bluish above; lower parts silvery; an indistinct bluish spot behind the operculum; each scale on the back having a dark spot at its base, these forming streaks as in the glut herring. Length 12 inches. 1). 19; A. 24. Scales $15-50$; scutes $\mathbf{1 7}+\mathbf{1 4}$. (WVest Indies, northward to Cape Cod in summer.)

The thread herring appears in July and August in Gravesend bay, and is sometimes so abundant as to fill the nets (fykes) of the fishermen. The great run begins toward the end of July and lasts two weeks. The fish is known there as the sprat lierring.

De Kray, in Newo York Fauna, Fishes, p. 264, pl. 41, fig. 132, describes the species under the name C h a to ës s us s ig 1 if er. The colors, according to that author, are as follows: "Bluish above, with a series of dark points along the sides of the back, forming four or five longitudinal lines. A round black spot behind the upper part of the branchial aperture. Pectorals, rentrals and anal white. Dorsal and caudal yellow; the membrane finely punctate with black, and bordered with dusky. Irides white varied with yellowish." He furthel says: "It appears in our waters about the beginning of September, where it is often called the shad herring. It has also the names of thread herring and threadfish, in allusion to its last filamentous dorsal ray." 
In the Woods Hole region of Cape Cod it is rery rare, according to Dr Smith. A number were taken in the fall of 1871. In 1855 it was common in Buzzards bay and Vineyard sound in July. It remained about a month, and specimens were taken in traps at almost every lift. During the next four years the fish was also noticed, but none has been seen since 1890 .

\section{Genus mrevoorta Gill}

Body elliptic, compressed, deepest anteriorly, tapering behind; head very large; cheeks deeper than long; mouth large, the lower jaw included; no teeth; gill rakers rery long and slender, densely set, appearing to fill the mouth when it is opened; gill arches angularly bent. Scales deeper than long, closely imbricated, their exposed edges vertical and fluted or pectinated. Dorsal fin low, rather posterior; anal fin small. Intestinal canal elongate. Vertebrae 4S. Peritoneum dusky. Species few; inhabiting the Atlantic; spawning probably in brackish water in the spring. Coarse, herbirorous fishes, not valued as food, but the young of the greatest value as food to other fishes. (After Jordan and Evermann)

\section{Brevoortia tyrannus (Latrobe)}

\section{Menhaden; Mossbunker}

Clupea tyrammus Latrone, Trans. Am. Phil. Soc. Phila. V, 77, pl. 1, 1802, (Chesapeake bay)

Clupea menhaden Mitchild, Trans. Lit. \& Phil. Soc. N. Y. I, 453, pl. V, fig. 7, 1815, New York; Günther, Cat. Fish. Brit. Mus. VII, 436, 1868. Alosa menhaden DE KAY, N. Y. Fauna, Fishes, 259, pl. 21, fig. 60, 1812; Storer, Hist. Fish. Mass. 158, pl. XXVI, fig. 4, 1S67.

Brevoortia tyrannus Goode, Proc. U. S. Nat. Mus. I, 531, 1S78; Fish \& Fish. Ind. U. S. I, 569, pl. 205, 1861; JornAN \& Gilbert, Bull. 16, U. S. Nat. Mus. 269, 1SS3; BeAv, 19th Rep. Comm. Fish. N. Y. separate, $4 t_{.}$ pl. XXV, fig. 35, 1990; Bull. Amer. Mus. Nat. Hist. IX, 336, 1897; $52 d$ Ann. Rep. N. Y. State Mus. 96, 1900; Jordan \& Evermañ, Bull. 47, U. S. Nat. Mus. 433, 1S96, pl. LXXIII, fig. 195, 1900; SмITH, Bull. U. S. F. C. XVII, 91, 1898 .

The menhaden has the exposed surfaces of its scales very narrow and deep. The body is similar in shape to that of the shad, the depth being one third of the length without caudal, and somewhat greater than the length of the head. Mouth large; jaws toothless. The maxilla extends to below the hind 
margin of the eye. The exe is about as long as the snout, one fifth of length of head. The fins are small, the pectoral not much more than half the length of the head and twice as long as the ventral. The dorsal base is equal in length to the pectoral; longest dorsal ray more than twice as long as the last ray and about two fifths of length of head. The anal rays are shorter than those of the dorsal; length of anal base little more than one half the length of head. The origin of the dorsal is about midway between tip of snout and end of middle caudal raps. The sides and fins are silvery, yellowish, the upper parts bluish. Behind the head there is a large dark spot, larger than the pupil, and behind it numerous smaller dark spots.

The menhaden has receired more than 30 common names, among which the one here employed is the best known and most suitable. In New Jersey it is frequently called bunker or moss. bunker, and in some other localities it is the bony fish. It is also called bugfish, because of a crustacean parasite which is found in the mouth.

The menhaden reaches a length of 15 inches or more; its average size is about 1 foot. It is found along our east coast from Maine to Florida, swimming in immense schools and fluctuating greatly in abundance. In certain localities its morements are affected chiefly by temperature.

The use of the menhaden as a sonrce of oil and a material for fertilizer's is so well known as scarcely to need mention here. As an edible fish it is not generally esteemed; in most localities it is seldom eaten, though in some places it is considered a good food fish. Since the mackerel is becoming scarce, menhaden are often salted in barrels as a substitute for that fish.

The menhaden appears in Dr Mitchill's Fishes of New Tork as the bony fish, hardhead or marshbanker. The aboriginal name menhaden, and the one most suitable for the species, is mentioned by this writer. Dr De Kay, in his New York Fauna, introduced the name mossbunker as well as the Indian names pan. hagen and menhaden. He notes also the names skippang and bunker as in use at the east end of Long Island. For a survey 
of the $30 \mathrm{or}^{\circ}$ more additional appellations of this well known fish, the reader is referred to the complete history of the American menhaden by Ir G. Brown Goode.

The menhaden comes into Gravesend bay in May and through the summer. Occasional individuals are seen there in the fall as late as November. The fish can be kept alive in the winter in captivity, provided the water temperature does not fall below $50^{\circ} \mathrm{F}$. It makes its appearance on the shores of Long Island about the beginning of June, sometimes in May, and remains till the cold season sets in. A few specimens were taken September 22 in Blue Point core in 1884, and Oct. 1, 1890, many thousands were caught in a trap at Islip; these were large and very fat fish. The use of the menhaden as a bait fish is too well known to need special mention. In "chumming" for bluefish near Fire island inlet this is the favorite bait. In 1898 the young were obtained at Duncan's creek, Howell's point and Nichols's point August 29. Adults were sent from Islip by W. F. Clark August 18 .

In the ricinity of Woods Hole Mass., according to Dr Smith, menhaden arrive in schools about May 20, but scattered fish are taken in March with alewires; they remain till December 1, sometimes till December 20 , but are most abundant in June. When the schools first arrive, the reproductive organs of many of the fish are in an adranced stage of development, but after July 1 none with large ovaries are found. Late in fall the fish again have well developed roes. The smallest fish are about an inch long; these are fomnd in little schools about the shores and wharves as early as July 1J. The young are abundant throughout summer and fall. The arerage length of adults is 13 or 14 inches; one fish 18 inches long was caught at Wroods Hole in 1876.

$$
\text { Family ENGRAULmIDAE }
$$

Anchories

Genus strolepronus Lacépède

Body oblong, compressed, covered with rather large, thin, deciduous scales; belly rounded, or weakly compressed; snont conical, compressed, projecting berond the very large mouth; 
maxillary narrow, little movable, usually formed of three pieces, extending backward far behind the eye, to the base of the mandible, or beyond, not beyond gill opening; premaxillaries. very small; teeth small, subequal, present at all ages, usually on the jaws, vomer, palatines, and pterygoids. Anal fin moderate, free from caudal (its rays 12 to 40 ); no pectoral filaments; dorsal inserted about midway of body, posterior to ventrals; pectorals and ventrals each with a large axillary scale. Adipose eyelid obsolete. Vertebrae about $40(40$ to 42$)$ in species. examined. Flesh rather pale and dry, more or less translucent, the bones firm. Pseudobranchiae present; branchiostegals nine to 14; gill rakers long and slender; gill membranes separate, freefrom the narrow isthmus.

\section{Stolephorus brownii (Gmelin)}

\section{Striped Anchovy}

Atherina brownii GmeLin, Syst. Nat. I, 1397, 1788.

Clupea vittata Mitchill, 'Trans. Lit. \& Phil. Soc. N. Y. I, 456, 1815; De Kĩs,

N. Y. Fauna, Fishes, 25t, $18+2$.

Engraulis vittata BAIRD, 9th Ann. Rep. Smith. Inst. 347, 1855.

Engranlis brownii Günther, Cat. Fish. Brit. Mus. VII, 389, 1868.

Stolephorus brouni JordaN \& GILBert, Bull. 16, U. S. Nat. Mus. 273, 1S83;

Bean, Bull. U. S. F. C. VII, 149, 18ss; 19 th Rep. Comm. Fish. N. Y. 279,1890 .

Stolephorus brounii Jordan \& Everman, Bull. 47, U. S. Nat. Mius. 443, 1896; Sмith, Bull. U. S. F. C. XVII, 92, 1898; Bean, 52d Ann. Rep't N. Y. State MIus. 9T, 1900.

Body moderately elongate, compressed, but thicker than in S. mitchilli, its greatest depth two ninths of the total length without caudal, and equal to length of head without the snout, the thickness one half length of head; head moderate, its length rather more than one fourth of total without caudal, the snout short and obtusely pointed, one fifth of length of head, two thirds of length of eye; eye equal to width of interorbital space, about two sevenths as long as the head. The maxilla reaches as far back as the mandible, but not to hind edge of opercle. The mandible is partly covered by the maxilla, its tip. in advance of the front of eye and overhung by the snout. Teeth moderately strong, those on the posterior part of the maxilla 
raking forward. Gill rakers rather long and slender, numerous, the longest on first arch three fourths as long as the eye. Origin of dorsal fin midway between base of caudal and front of ere, its length of base four sevenths of length of head, its longest ray one half as long as the head, a sheath of scales at base; anal with a strong sheath of scales, its base as long as the head witlout the snout; rentrals small, originating in adrance of dorsal origin, the length cqual to ere; axillary scale of pectoral one half as long as the head. Width of silvery band one fourth the length of hear. D. 14 to 15 ; A. 20 . Scales 40 to 42 . Upper parts light brown; sides silvery; a broad, bright silvery lateral stripe. Lengtli sometimes above 6 inches. Here described from an example taken at Lifesaring station no. 22, Long Island, and now in the U. S. National Museum.

The species occurs from Cape Cod southward to Brazil and the West Indies.

This is the satin striped herring of Mitchill's Fishes of New Fork, p. 456. By some of the fishermen in Great South bay it is supposed to be the whitebait and is so called. The anchory was extremely abundant in the bay in September 1884. I found it at the mouth of Swan creek, in Blue Point cove, near the Lifesaving station, at Oak island and at Fire island. Specimens were seen as late as October 7 .

This anchory forms a rery important part of the food of the young weakfish and bluefish in Great South bay. It is present in very large numbers and could be utilized as a food species. The largest examples of this fish which we have seen were taken in Great Egg Harbor bay in August; indiriduals measuring $5 \frac{1}{2}$ inches in length were taken in the surf by hundreds, and weakfish were feeding on them ravenously. In two hauls of a 20 fathom seine we took here 54 weakfish.

This species was not common in Great South bay during the summer of 1S98. It was found at Blne Point core August 18, and young were obtained at Nichols's point September 1.

Dr Smith records it as usually abundant at Woods Hole, occasionally rather uncommon. Found from August to late in fall. More numerous than any other ancliory. 


\section{Stolephorus argyrophanus (Cur. \& Val.)}

\section{Silvery Anchovy}

Engraulis argyrophanus Cuvier \& Valenciennes, Hist. Nat. Poiss. XXI, $49,1848$.

Stolephorus perfasciatus Jordan \& Gilbert, Bull. 16, U. S. Nat. MIus. 278, 185?, not Engraulis perfasciatus Poey, Mem. Cuba, II, 312, 1858.

Stolephorus eurystole Swain \& MEEk, Proc. Ac. Nat. Sci. Phila. 34, 1S51; BEAN, Bull. U. S. F. C. VII, 150, pl. III, fig. 19, 1 SSS.

Stolephorns argyrophames Jordan \& Everuann, Bull. 47, U. S. Nat. MIus. 444, 1896; BeAn, Bull. Amer. Mus. Nat. Hist. 337, 1S97; SмIт1, Bull. U. S. F. C. XVII, 92, 1898.

Body elongate, much more slender than in S. brown i i, and not so much compressed; head not so deep as in $\mathbf{S}$. b r ow ni i, more pointed, the snout rather sharp; eve rather small, four and one half in head, not larger than snout; maxillary teeth well developed, mandibulary teeth ver'y slender; gill raker's rery long, as long as the eye; maxillary shorter than in S. b r o w n i, not reaching quite to the base of the mandible; belly slightly compressed, not serrated. Scales rery deciduous. Ventrals short, very slightly in front of dorsal; caudal peduncle long and slender; dorsal inserted scarcely nearer caudal than snout. Silvery stripe broad, half wider than the eye, bordered above by a dusky streak. Head three and four fifths; depth 6. D. 12; A. 20. Tength 4 inches. Test Indies; occasional northward. A specimen in our collection from Toods Hole Mass. (After Jordan and Gilbert)

The types of this species were obtained by Kuhl and Van Hasselt in the equatorial Atlantic. Cuvier and Valenciennes, in their original description ${ }^{1}$ of the fish, contrast it with $\mathbf{S}$. b r o w n i and others, from which it is distinguished by its form and by other characters.

It has the body longer and slenderer; the cleft of the mouth more oblique; the pectoral and anal much shorter; the teeth excessively small. B. $11 ;$ D. $15 ;$ A. 17 . The color is blue, more pronounced on the back than on the belly. A silrery band running along the sides. Cuvier and Valenciennes

Young individuals were seined at Ocean City N. T. Aug. 1, 18S7; again at Longport N. T. numerous young were taken Aug.

${ }^{2}$ Hist. Nat. Poiss. 1S4S. 21:49. 
29, 1SS7; no adults were seen. A figure of the young is published by $\mathrm{Dr}$ Bean in bulletin for $18 S 9$ of the U. S. Fish Commission, rol. 7 , pl. 3, fig. 19. 'The example figured was nearly $1 \frac{1}{2}$ inches long. It has the following cluaracters: The hight of the body is one sixth of the total length withont caudal; least hight of caudal peduncle one third of length of head. Head rather large, two serenths of total length without caudal, with obtusely pointed snout which is about equal to the eye and one fourth as long as the head. The maxilla does not reach to the hind edge of the preopercle. Dorsal origin nearer to caudal base than to tip of snont; the base of the fin as long as the long. est ray and one half as long as the head. Pectoral short, three sevenths as long as the head; ventrals in adrance of dorsal, under the 16th row of scales, the length two fifths of length of head; anal origin under the end of the dorsal, anal base about two thirds as long as the head and one fiftl of total length without caudal; longest anal lay one half as long as the head; caudaI fin large and deeply forked. D. ii, 10; 1. ii, 1s. Scales S-3S.

Mans indiriduals were collected at Fire island near the end of September. None were seen in other parts of the bay. The species is known there as whitebait, like the other anchovies. In Gravesend bay the species is not common, but it occurs more frequently in bays communicating directly with the Atlantic.

\section{Stolephorus perfasciatus (Poey)}

\section{Banded Anchovy}

Engraulis perfaseiatus PoEx, Mem. Cuba, II, 312, 185S; Guxther, Cat. Fish. Brit. Mus. VII, 391, 1868.

Stolephorus perfasciatus SwaIN \& MeEk, Proc. Ac. Nat. Sci. Phila. 34, 1SSt; Jordan \& Evermañ, Bull. 47, U. S. Nat. Mus. 441, 1896.

Body elongate and not much compressed, its greatest hight about one sixth of total length without caudal and two thirds of length of head, its greatest thickness more than one third of length of head; least hight of caudal peduncle equal to thickness of body behind the head; head long, with pointed snont, one fourth of total without caudal, snout equal to eye and two ninths of length of head. The maxilla extends backward to 
front edge of preopercle and not to joint of mandible. Interorbital space equal to eye; gill rakers numerous, about as long as the eye; teeth minute and weak, nearly uniform in size. Dorsal origin about midway between tip of snout and base of caudal, dorsal base short, scarcely more than one half as long as head, and about equal to longest dorsal ray; ventrals little in advance of dorsal origin, very short, only two fifths of length of head; pectoral moderate, equal to postorbital part of head. Axillary scale rely slender, less than one half as long as the head. Width of silvery band about equal to length of eye. D. ii, $12 ;$ A. i, 15 to 16 . Scales 44 to 45 . Here described from specimens obtained at Toank Ct. and in Graresend bay, L. I., the largest about 3 inches long.

Upper parts light brown, sides silrery; dark punctulations on base of caudal and sometimes on anal; belly even in alcoholic specimens with iridescent colors.

The example obtained in Gravesend bay was collected by W. I. De Nyse. It has D. 12 ; A. 15 or 16 ; scales 45 .

The close resemblance of this species to $\mathrm{S}$. a $\mathrm{rg}$ y r o p h a n u s Cur. \& Val. makes a farther comparison of the two necessary. Perhaps, as long ago suggested by Dr Günther, ${ }^{1}$ the two are identical. S. a r g y r o phanus was collected in the equatorial Atlantic, and Poey's species, perfasciatus, is from Cuba and Porto Rico. There seems to be little to distinguish them except the slightly greater number of anal rays in $\mathbf{S}$. a rgy o phan $\mathrm{s}$, and these have been counted differently by different students; the authors, for example, discorered 17 , while Dr Jordan found 19 in the same type.

\section{Stolephorus mitchilli (Cuv. \& Val.)}

\section{Anchovy; Whitebait}

Engraulis mitchilli Cuvier \& VAlenciennes, Hist. Nat. Poiss. XXI, 50, 1848. New York; Caroliua; New Orleans.

Stolephorus mitchilli Jordan \& Gildert, Bull. 16, U. S. Nat. Mus. 248, 1883; Jordar, Cat. Fish. N. A. 38, 1885 (name only); Bean, Bull. U. S. F. C. VII, 149, 1sss; 52d Ann. Rep. N. Y. State Mus. 97, 1900; JoRdAN \& Evermann, Bull. 47, U. S. Nat. Mus. 446, 1896; Sмith, Bull. U. S. F. C. XVII, 92, 1898.

${ }^{1}$ Cat. Fish. Brit. Mus. 1S68. $7: 391$. 
Engraulis vittatus STORER, Hist. Fish. Mass. pl. XXVII, fig. 3, not description on page 163 .

Bodr compressed, short and deep, its greatest depth one fourth of the total lengtl without caudal, caudal peduncle slort and deep, its least depth one lialf the length of head. Thickness of bodr equals three serenths of length of head. Head rather short, its length two ninths of total without caudal. Snout shorter than eye, which is two serenths as long as the head. The maxilla extends slightly beyond the hind end of mandible, and nearly to the edge of operculum. Interorbital distance not quite equal to eye. Gill rakers nearly as long as the eye. Origin of dorsal fin much nearer to base of caudal than to tip of snout. Length of dorsal base equals two thirds of length of lead; longest dorsal ray one half as long as head. Anal origin under the middle of dorsal; length of anal base equals two serenths of total length without caudal; longest anal ray about two thirds as long as the head. Ventral short, in advance of dorsal, its length one third of length of head. Pectoral one eighth of total length without caudal. Width of silvere band about two thirds of eye. Dorsal and anal scaly sheaths rery strong. D. ii, 10; 1. 28; V. i, 6. Scales 37. Length of specimens examined, 4 inches. Taken at Fire island.

Cape Cod to Texas, on sandy sliores; the most abundant of the New Iork species. It enters Graresend bay in May and remains till October. Locally known as anchory and whitebait. An excellent food fish and very important as the food of larger fishes.

It is rery generally distributed in bays along the south shore of Long Island, having been found abundant in Scallop pond, Peconic bay, in Mecox bay, and almost ererswlere in Great South bay from July to September 1898. A specimell taken at Fire island had a lernacan parasite attached to it. At Moods Hole Mass. Dr Smith reports it abundant, associated with $\mathbf{S}$. b r o w n i .

$$
\text { Family SALNONIDAE }
$$

\section{Salmons}

The whitefislies of New York belong to seven species, representing the four divisions of the genus Coregon us. In two 
of the species the lower jaw is included within the upper, the mouth is small, and the intermaxillary bone broad and more or less rertical in position. These two may be readily distinguished by the structure of the gill rakers, and the size of the mouth. The remaining five whitefishes hare the lower jaw as long as, or longer than, the upper, the mouth large, and the intermaxillary narrow and not vertical in position. They are easily separated from one another by the shape of the body, and the size and contour of the scales. The relations of the groups are shown in the following liey.

1 Lower jaw shorter than upper.

1 a Month very small, upper jaw not reaching to eye; gill rakers short and stout, 13 to 16 below angle of first arch ( $\mathrm{Pros}$ p i u m)

Q U A D R I L A T E R A L I S

$1 b$ Mouth moderate, upper jaw reaching beyond front of eye; gill rakers long and slender, 20 or more below angle of first arch (Cor e gon us)

CLUPEIFORMIS

2 Lower jaw equal to or longer than upper.

2 a Body slender. elongate; scales small, and convex on their free margin; lower jaw longer than upper (A g g roso m u s)

O SMERTFO R M I S

A R T E D I, II O Y I

PROGNATH US

26 Body deep, short; scales large, deep, the free margin scarcely convex; jaws equal (Allos o mus)

T ULIIBEE

\section{Genus conegorus (Artedi) Linnaeus}

Body oblong or elongate, compressed; head more or less conical, compressed, the snout more or less projecting beyond the lower jaw; mouth small, the maxillary short, not extending beyond the orbit, with a well developed supplemental bone; teeth extremely minute, if present; scales moderate, thin, cycloid, rather firm. Dorsal fin moderate; caudal fin deeply forked; anal fin somewhat elongate; rentrals well dereloped. Pseudobranchiae large; gill rakers varying from short and thickish to long and slender; air bladder very large; rertebrae 56 to 60 ; stomach horseshoe-shaped, with mauy (about 100) pyloric caeca; ova small. Species about 15 , inhabiting the clear lakes of northern Europe, Asia, and America, in aretic regions descending to the sea. Most of them spawn in late fall or 
winter near the shore, at other seasons often frequenting considerable depths.

\section{Coregonus quadrilateralis Richardson}

\section{Round Thitefish: Frostfish}

Coregonus quadrilateralis Ricilardsox, Franklin's Journ. 714, 1820. Fort Enterprise, British America; Agassiz, Lake Superior, 351, 1850; Güntuer. Cat. Fish. Brit. Mus. VI, 176. 1S66; Jordan \& Gilbert, Bull. 16, U. S. Nat. Mus. 29S. 1S53; BeAN, Fishes Peuna. 66, pl. 26, fig. 47, 1S93; Bull. Amer. Mus. Nat. Hist. IX, 337, 1S97; JordAN \& EverMaxn, Bull, 47, U. S. Nat. Mus, 465, 1896.

Salmo (Coregonus) quadilatcralis Ricinardson, Fauna Bor.-Amer. III, 204, pl. S9, fig. 1, 1836. Great Bear Lake.

Coregonns norae angliae PrescotT, Amer. Jour. Sci. Arts. XI, 342, 1851. Lake Winipiseogee, N. I.

Coregonus novae angliae Güxtier, Cat. Fish. Brit. Mus. VI, 1S6, 1866.

This is a small species and very readily distinguished from all other American species except Williamson's whitefish by its diminutive mouth. The body is slender, elongate, subterete, its greatest depth slightly exceeding one fifth of total length to base of caudal. The head is long, its length one fifth of total without caudal, and the snout is thin and obtuse at tip. The broad maxilla does not reach to below the front of the eye, its length less than one fifth of length of head. D. 11; A. 10. Scales in lateral line, 80 to 90 . Upper parts dark bluish; sides silvery.

This species is called frostfish in the Adirondacks; other names are Menominee whitefish, roundfish, shad-waiter, pilotfish and chirer, the last term applied to the fish in Maine.

The roundfish is found in lakes of New England, sometimes running into streams, the Adirondack region of New York, the Great lakes and northward into British America and Alaska. Its distribution has been extended by transplanting on account of its great value as food for the lake trout and other large fish of the salmon family. It seldom exceeds a length of 12 inches and a weight of 1 pound. Like some other species of whitefish, it spawns in shallow parts of lakes or ascends their small tributary streams for that purpose. The food consists of small 
shells and crustaceans. The species frequents deel waters, where it falls an easy prey to the voracious lake trout.

The rondfish is excellent for the table. Its capture with hook and line is difficult because of its rery small mouth and its habit of retiring into deep water. In the Great lakes it does not constitute an important element of the fishery, but in northern regions it is one of the most useful and highly prized of the food fishes.

This small whitefish is one of the characteristic species of the Adirondack lakes. James Annin jr sent specimens for identification from Hoel pond and Big Clear lake, in Franklin county, N. Y., and from the third lake of the Fulton Chain. He states that the fish spawns in the little inlets or on the sand beaches. It never appears till about the time the water begins to chill and freeze about the edges. On the Fulton Chain of lakes the spawning season of 1895 was practically closed about November 20 .

The frostfish, according to Mr Annin, is " a delicious morsel."

The following notes were made on fresh examples received from the third lake of the Fulton Chain Nor. 26, 1895.

A male $11 \frac{3}{4}$ inches long to end of candal fin had the middle caudal rays, from end of scales, $\frac{5}{8}$ inches long; upper caudal lobe, measured horizontally, $1 \frac{7}{5}$ inches; liead, $1 \frac{13}{6}$ inches; maxilla, $\frac{3}{8}$ inch; eye, $\frac{3}{8}$ inch; gill rakers, $5+10$; the longest $\frac{1}{4}$ as long as the eye; scales, 8-St-S. A female $11 \frac{7}{8}$ inches to tip of caudal lias upper caudal lobe 2 inches, measured horizontally; middle caudal rays from end of scales, $\frac{9}{16}$ inch; depth of body, $2 \frac{1}{4}$ inches; head, $1 \frac{7}{5}$ inches; maxilla and eye, each $\frac{3}{8}$ inch; gill rakers, $5+10$, the longest $\frac{1}{4}$ as long as the eye; scales, 8-79-8.

Three males received bec. 11, 1595, showed the following colors.

In the male, $13 \frac{3}{5}$ inches long, from Hoel pond, the back and sides were dark steel gray; the belly white; pectoral, ventral and anal orange; dorsal and caudal chiefly yellow. A male 12 inches long, from Big Clear lake, had the back and sides silvery gray, darker between the lines of scales; the lower fins orange; the dorsal and caudal with traces of yellow. A male $11 \frac{1}{8}$ inches 
long, from Big Clear lake, slowed the same colors as the last. The following measurements in inches and notes were taken.

\begin{tabular}{|c|c|c|c|}
\hline & $\begin{array}{c}\text { Hoel pond } \\
\hat{\delta}\end{array}$ & $\begin{array}{c}\text { Big Clear } \\
\text { lake } \\
\delta\end{array}$ & $\begin{array}{c}\text { Bir Clear } \\
\text { lake } \\
\delta\end{array}$ \\
\hline 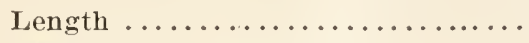 & $13 \%$ & 12 & $111 / 8$ \\
\hline Caudal lobe, horizontally........... & $2_{16}^{3}$ & $17 / \mathrm{s}$ & $1 \% / 8$ \\
\hline Middle caudal rays.............. & $3 / 4$ & $5 / 8$ & $\frac{9}{16}$ \\
\hline 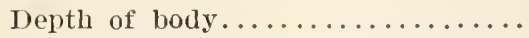 & $21 / 2$ & $23 / 8$ & $2 \frac{3}{16}$ \\
\hline Least depth of caudal peduncle..... & $7 / 8$ & $3 / 4$ & $\frac{1}{16}$ \\
\hline 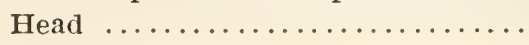 & 2 & $13 / 4$ & $15 / 8$ \\
\hline Snout $\ldots \ldots \ldots \ldots \ldots \ldots \ldots$ & $1 / 2$ & $\ldots$ & $\ldots$ \\
\hline 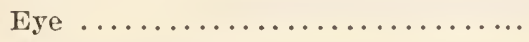 & $\frac{7}{16}$ & $\frac{7}{16}$ & $3 / 8$ \\
\hline Maxilla $\ldots \ldots \ldots \ldots \ldots \ldots \ldots \ldots$ & $1^{\frac{7}{6}}$ & $3 / 8$ & $3 / 8$ \\
\hline
\end{tabular}

In all, the gill rakers are minute, and number: $5+10,5+10$. and $5+9$. The scales are: 10-S6-9, 10-76-9, and 9-S6-S.

An example sent by the New Jork Commission of Fisheries, Game and Forest, from Saranac Lake, Nov. 23, 1S97, showed the following characters.

\section{MEASUREMENTS}

Inches

I

Length to end of scales.................... 111/2

Length of middle caudal rays (from end of scales)..... $7 / 8$

Length of upper caudal lobe (obliquely)........... $21 / 8$

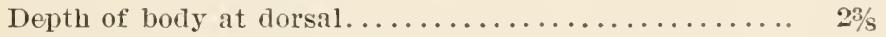

Least depth of caudal peduncle................ ${ }_{13}^{\frac{3}{6}}$

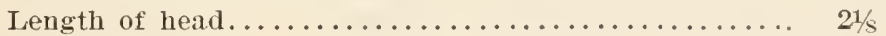

Diameter of eye.........................

Length of maxilla (does not reach orbit)..........

Length of mandible..................... $3 / 4$

Distance from sriout to dorsal origin........... $51 / 8$

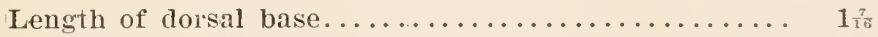

Length of longest dorsal ray..................... 15

Length of last dorsal lay..................

Distance from snout to ventral origin........... $5 \%$

Length of rentral. ........................

Length of ventral appendage................ $1 / 2$

Distance from snout to anal origin............ $83 / 4$

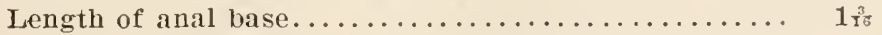

Length of longest anal ray.................... $1 \frac{7}{16}$

Length of last anal ray .................. $1 / 2$

Length of pectoral...................... 2

Distance from snout to adipose fin............ $91 / 1$

Length of base of adipose fin ..............

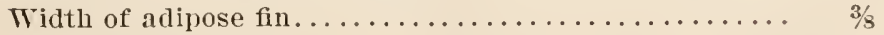

Length of adipose fin.....................

Length of longest gill rakel............... $1 / 8$ 
D. 11 ; A. 11; V. i, 10; P. i, 14 . Scales, 10-84-8. Gill rakers, $6+10$, the longest $\frac{1}{8}$ inch.

Purplish gray; lower parts whitish; pectorals, ventrals and anal vermilion; eye pale golden; head, specially behind the eyes, with iridescent gold and purple tints; caudal, chiefly rermilion in life.

The fish is a male with ripe milt. There are numerous small tubercles on the scales of the sides above and below the lateral line.

\section{Coregonus clupeiformis (Mitchill)}

\section{Common Whitefish; Labrador Whitefish; Shadwaiter}

Salmo clupeiformis Mitchill, Amer. Month. Mag. II, 321, March, 1818.

Lake Huron; Cayuga Lake.

Coregomis albus Le Sueur, Jour. Ac. Nat. Sci. Phila. I, 232, May, 1818.

Lake Erie; Thompson. Nat. Hist. Termont, I, 143, figure, 1842; Kint-

LAND, Bost. Jour. Nat. Hist. III, 47T, pl. XXVIII, fig. 3, 1S11; DE INAY,

N. Y. Fauna, Fishes, 247, pl. 76, fig. 240, 1842; Günther, Cat. Fish.

Brit. Mus. VI, 184, 1866.

Salmo (Coregonus) labradoricus Richardson, Fauna Bor.-Amer. III, 206,

1836.

Coregonus sapidissimus AgAssiz. Lake Superior, 344, 1850.

Coregomus latior Agassiz, op. cit. 348, 1850.

Coregonus clupeiformis Jordan \& GILberT, Bull. 16, U. S. Nat. Mus. 299,

18S3; Goode, Amer. Fishes, 489, figure, 1888; Bean, Fishes Penna. 67, color pl. 3, 1893; Jordan \& Evermann, Bull. 47, U. S. Nat. Mus. 465, 1896, pl. LXXYI, fig. 202, 1900; Cinener, Third Ann. Rept. N. Y. Comm. Fish. color pl. facing p. 190, 1898.

Coregonus labradoricus Günther, Cat. Fish. Brit. Mus. VI, 176, 1866, and of authors generally.

The common whitefish of the Great lakes is so well known that it scarcely needs an elaborate description. The body is stout and deep, its depth at the nape greatly increased in adults. The greatest depth is two sevenths of the total length to caudal base. Caudal peduncle short, its depth one half the length of head, which is about one fifth of total without caudal. The snout is sharp, conical, two serenths as long as the head and about twice as long as the eye. The maxilla reaches to below front of eye. The dorsal origin is above the 2:id scale of the lateral line, and the rentral begins under the middle of the dorsal. The longest dorsal ray equals length of head without snout, adipose fin stout and low. The dorsal and anal bases 
are equal to each other and two thirds of length of head. D. 10 dirided rays; A. 11 divided rays; T. 11; P. 15. Scales in lateral line 74 to 80 . The upper parts are grayish or light olive in color; the sides white and lustrous in life.

Names. The name whitefish is thoroughly identified with this species and is seldom raried except by means of the prefix "common" or "lake." A well marked rariety in Otsego lake, N. Y., has long been known as the Otsego bass.

Distribution. The common whitefish occul's in the Great lakes and northward into British America; its northern limit is not definitely known. In Alaska, where the species was formerly supposed to exist, it is replaced by a similar, but well marked form, the Coregonus rich a r d soni of Günther. The rariety known as Otsego bass is found in Otsego lake. If we may judge from the yield of the fisheries, Lake Michigan has more whitefish than any of the other lakes; Superior ranks second; Erie third; Huron fourth; and Ontario is saly in the rear.

Size. The largest individual on record was taken at Whitefish Point, Lake Superior; it weighed 23 pounds. I 17 pound specimen was caught at Termilion, in Lake Erie in 1si6. The size raries greatly with locality. ranging in general all the way from $1 \frac{2}{4}$ pounds to 14 pounds. In Lake Eric in 18S.J the arerage weight was between 2 and 3 pounds. The length of adults will average 20 inches.

Habits. There is a morement of the whitefish in many lakes from the deep) water early in the summer into the shoal water near the shore. In the midsummer, howerer, the usual retreat of this species is the deep and cold parts of the lakes which they inhabit. Again, as the spawning season approaches in October, the whitefish come toward the shore to deposit their eggs. It is said that they do not sparn till the water has reached a temperature of about $40^{\circ}$. After spawning they again retire to deep water, where they remain during the winter. Mr Milner observed that the shoreward migration raries with locality, and is influenced also by depth of water and temperature. In Lake Erie, for example, which has a high summer temperature, there 
is no shoreward migration in summer. It is to be noted also that the whitefish mores along the shore, and in some cases it ascends rivers for the purpose of spawning. It is believed also that when the feeding grounds of the whitefish are polluted by mud, the fish temporarily seek other localities. There appear's to be a spring and summel migration likewise from lake to lake. Spawning takes place during October, November and December, on shoals or occasionally in rivers. The female is larger than the male. According to the observations of George Clark, the two sexes, in the act of spawning, frequently throw themselves together above the surface, emitting the spawn or milt with the rents close together. Spawning operations are most active in the erening, are continued at night, and the eggs are deposited in lots of sereral hundred at a time. The number of eggs in a fish of $7 \frac{1}{2}$ pounds was 66,606 ; the arerage numbe $\mathrm{I}^{\circ}$ being nearly 10,000 for each pound of the female's weight. The period of incubation depends on the temperature. The usual time of distribution of the roung is in March and April. The very young are described as swimming near the surface and not in schools. They are very active and soon seek deep water to escape from their enemies. Their food consists chiefly of small crustaceans. The adults subsist on the same food with the addition of small mollusks.

Growth. The only means of determining the rate of growth of the whitefish is by artificial rearing. Samuel Wilmot had young fish which were 5 inches long at the age of four months. The growth under natural conditions must be even greater than this. Mr Wilmot, himself, has seen whitefish measuring 7 inches in December in his ponds.

Enemies and diseases. The eggs of the whitefish are destroyed in immense numbers by the lake herring, Coregon us a r tedi. The water lizard, $\mathbf{M}$ e $\mathrm{n}$ obran $\mathrm{chus}$, also consumes vast numbers of the eggs. The young whitefish are eaten extensively by the pike perch, black bass, pike, pickerel and freshwater ling. The lake trout also feed on the whitefish. A leach parasitic on the whitefish proves very troublesome to that spe- 
cies, and the scales are liable to a peculiar roughness which has been observed late in Norember or during the spawning season. There is also a lernean which fastens itself to the gills and other parts of the whitefish.

Uses and capture. The excellence of the flesh of the whitefish is so well known as scarcely to require mention. Its commercial value is great. In Lake Erie in 1855, according to statistics collected by the U.S. Fish Commission, 3,500,000 pounds of whitefish were caught, more than 2,000,000 of this amount by fishermen from Erie alone. In this year Erie county had 310 persons employed in the fisheries. The capital invested in the business was nearly $\$ 250,000$. The wholesale value of the fish products was upward of $\$ 400,000$. The whitefish was the third species in relative importance, blue pike ranking first and the lake herring second. In Erie county whitefish are caught chiefly in July, August and Norember, and the bulk of them are taken in gill nets. Pound nets are also employed in the capture of whitefish.

Artificial propagation. Carl Mïller of New York and Henry Brown of New Haren are credited with the first attempt to propagate the whitefish artificially. Their experiments were made in Lake Saltonstall, near the city of New Haven. The result of the experiments, which were repeated in 1858, is not known. In 1868 Seth Green and Samuel Wilmot began a series of experiments in the same direction, and in $1869 \mathrm{~N}$. W. Clark, of Clarkson Mich. took up the same work. In 1870 a half million eggs were placed in hatching boxes by Mr Clark. In 1872, through the aid of the U. S. Fish Commission, Mr. Clark's hatching house was doubled in capacity, and a million eggs were taken from Lake Michigan. Since that time both the national and state governments have made the whitefish the object of their most extensive operations.

Dr Meek saw no specimens of whitefish from Cayuga lake, but he thinks it is an inhabitant. The U. S. Fish Commission obtained a specimen at Cape Vincent N. Y. Nov. 17, 1891.

I young individual was received from Wilson, Niagara co. N. Y.; canght in a gill net in Lake Ontario and sent by .Jannes Annin jr. 
A male and a female were receired through James Annin jr from Epper Saranac lake Nov. 16, 1895. Both fish were nearly spent. They were believed to be the common whitefish. A male from Chazy lake arrived through the same source Nor. 22, 1895. It was doubtfully called "blackfin whitefish." At that time the fish had left the spawning beds and were in deep water. June 17, 1896, a female $19 \frac{5}{3}$ inches long was shipped by $\mathbf{M r}^{2}$ Annin from Canandaigua lake. Its stomach is pear-shaped with walls more than $\frac{1}{4}$ inch thick; it contained numerous small shells of several genera, not yet identified.

The species is reported by fishermen to be very abundant in that lake, and to be destructive of eggs of other fish. They say it comes in great numbers into shallow water near the shore in early summer when the water is roily, and can be caught on set lines. Mr Annin saw men baiting their set lines with small minnows on Canandaigua lake, and, when the lines were taken up in the morning, the whitefish was found on the hooks. It is said that one so taken weighed 6 pounds. Sup't O. H. Daniels, of the New Hampshire fish commission, forwarded a specimen from Lake Winnesquam, at Laconia, $19 \frac{7}{8}$ inches long, weighing 46 ounces, and he wrote that individuals weighing $7 \frac{1}{2}$ pounds had recently been taken. The species was called "bluefin" and whitefish.

The fish-eating habit of the whitefish was fully verified in the aquarium on examples obtained in Canandaigua lake in November 1896, by Mr Annin. Knowing that the species usually subsists on small mollusks and crustaceans, efforts were made to provide the fish with $\mathrm{Phys}$ a and Ga m ar us; but this became difficult in winter, and an experiment was made with small killifish (Fundulus heteroclitus and majalis), which proved satisfactory during the cold months. In summer, however, it was found necessary to return to the use of $\mathrm{G}$ a $\mathrm{m}$ m a $\mathrm{rus}$. The whitefish at first took the killifish without any eagerness, but they soon learned to chase their prey and take it much as trout do.

A female received from Canandaigua lake June 17, 1896, in a fresh state, showed the following colors: membrane of pectoral 
:ins dusky; that of the pectorals tinged with lemon yellow; rentrals dusky at the tip; anal pale; caudal pale except a narrow dusk portion of the middle rars; eyes pearly with golden iridescence. The maxilla reaches about to front of ere. The adipose dorsal extends straight backward, and its base is covred with a sheath of small scales $\frac{3}{16}$ of an inch wide. The vill rakers are $9+17$, the longest $\frac{3}{5}$ of an inch. Vers small teeth alle present on the tongue. The eggs are minute.

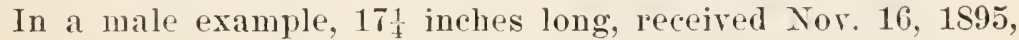
from Upper Saranac lake and nearly spent, no tubercles could be seen on the scales; but several of the males from Canandaigua lake had them well developed. There is a great differance in the derelopment of the lingual teeth, some of our individuals showing only a trace of them, and it seems as if there mas be some relation between their condition and the sexual maturity of the fish. For example, in a male 14 inches long, sent from the fourth lake of the Fulton Chain Nor. 9, 1897, the lingual teeth were present in a large patch; in three males, only a little smaller but sexualy immature, from saranac lake Nov. 11. 1597, the teeth on the tongue could be perceired by the itouch only. The following measurements, in inches, and addi. tional notes, were made from the fresh fish.

\section{MEASUIEMENTS}

Length, including caudal.............

Length of middle caudal rays (from eud

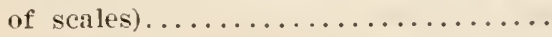

Length of upper caudal lobe (horizon-

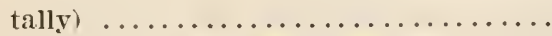

Length of longest candal ray .........

Depth of hody at dorsal..............

Least denth of caudal peduncle.........

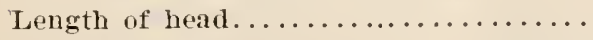

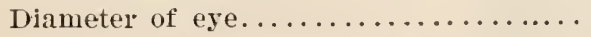

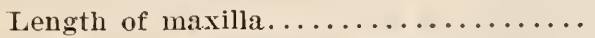

Distance from snout to dorsal origin....

Length of dorsal base.

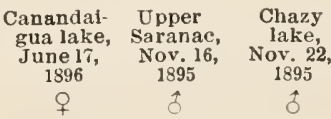

$195 / \mathrm{s} \quad 171 / 4 \quad 151 / 2$

1

$1 \frac{5}{16} \quad 7 / 8$

Iength of longest dorsal ray

3

$31 / 4$

$43 / 4$

$11 / 2$

$33 \%$ $5 / 8$ 1 8 
MEASUREMENTS

Length of last dorsal ray............ Distance from snout to ventral origin...

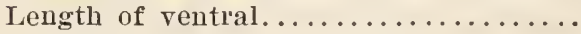

Length of ventral appendage..........

Distance from snout to anal origin......

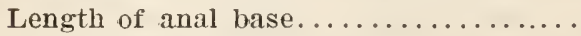

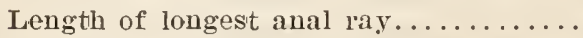

Length of last anal ray.............

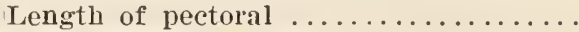

Distance from snout to adipose fiu.....

Length of base of adipose fin.........

Length of adipose fin..............

Width of base of adipose fin.........

Length of longest gill raker...........

\begin{tabular}{|c|c|c|}
\hline $\begin{array}{c}\text { Canandai- } \\
\text { gua lake, } \\
\text { June } 1 \overline{7}, \\
1896 \\
q\end{array}$ & $\begin{array}{c}\text { Upper } \\
\text { Saranac, } \\
\text { Nov. 16, } \\
1895 \\
3\end{array}$ & $\begin{array}{c}\text { Chazy } \\
\text { lake, } \\
\text { Nov. } 2 Z_{2}, \\
1895 \\
\hat{0}\end{array}$ \\
\hline $3 / 4$ & $\ldots$ & $\ldots$ \\
\hline 9 & $\ldots$ & $\ldots$ \\
\hline $2 \%$ & $\ldots$ & $\ldots$ \\
\hline$T / 8$ & $\ldots$ & $\ldots$ \\
\hline 13 & $\ldots$ & $\ldots$ \\
\hline 2 & $\ldots$ & $\ldots$ \\
\hline $13 / 4$ & $\ldots$ & $\ldots$ \\
\hline $5 / 8$ & $\ldots$ & $\ldots$ \\
\hline 3 & $\ldots$ & $\ldots$ \\
\hline 14 & $\ldots$ & $\ldots$ \\
\hline 1 & $\ldots$ & $\ldots$ \\
\hline $3 / 4$ & $\ldots$ & $\ldots$ \\
\hline $1 / 2$ & $\ldots$ & $\ldots$ \\
\hline $3 / 5$ & $3 / 5$ & $\frac{5}{16}$ \\
\hline
\end{tabular}

Taking the fish in the order above given, the gill rakers are: $9+17,10+16$, and $9+17$. The scales are: $10-76-8,10-87-9$, and 11-81-10. The branchiostegals in rarious specimens examined are 9 to 10 ; divided dorsal rays, 10 to 11 ; anal rays, 10 to 11.

\section{Genus Argroosones Agassiz}

This genus is rery close to Coregon us, from which it differs in the larger mouth and more produced jaws, the premaxillaries being placed nearly horizontally, and the lower jaw decidedly projecting beyoud them. Gill rakers very long and slender, about 30 on lower limb; vertebrae 55. These characters are associated with the greater voracity and, in general, greater activity of the species of $A r^{\circ} \mathrm{y}$ ros o in $\mathrm{us}$. The species are numerous in the northern parts of Europe, Asia and North America, and all are ralued as food.

\section{Argyrosomus osmeriformis (H. M. Smith)}

\section{Smelt of New York lakes}

Coreyonus hoyi Bean, Proc. U. S. Nat. Mus. V, 658, 18s3; Goode, Fish \& Fish. Ind. U. S. pl. 197 B, 1SSt; not Coregonus hoyi Gill.

Coregonus osmeriformis SmTH, Bull. U. S. F. C. XIV, 2, pl. 1, fig. 2, 1835. Lakes Seneca and Skaneateles, New York.

Argyrosomus osmeriformis Jordan \& Evermann, Bull. 47, U. S. Nat. Mus. 468, 1896. 
Body elongate, moderately compressed, slender ; head less compressed than body, its greatest width equaling one half the distance from tip of lower jaw to nape, the lower jaw projecting considerably even when the mouth is closed; mouth large, the maxillary reaching to the vertical through the anterior margin of the pupil; preorbital bone long and slender, more than one third as long as the head; supraorbital as long as the eye, four times as long as broad.

The greatest hight of the body is considerably less than the length of the head, and is contained five times in the total length without caudal. The greatest width of the body is less than one half its greatest hight. The least hight of caudal peduncle equals the length of the orbit and about one third of the greatest hight of the body. Scales small, nine in an oblique series from the dorsal origin to the lateral line, 82 tube-bearing scales, and eight in an oblique series from the ventral origin to the lateral line.

The length of the head is one fourth of the total length to the end of the lateral line. The distance of the nape from the tip of the snout is nearly one third of the distance from the tip of the snout to the origin of the first dorsal. The length of the maxilla is one third of the length of the head. The mandible is one half as long as the head. Lingual teeth present. The eye is as long as the snout and one fourth as long as the head. Gill rakers long and slender, the longest five sixths as long as the eye; there are 55 on the first arch, 35 of which are below the angle. The insertion of the dorsal is nearer the tip of the snout than the end of the middle caudal rass. The longest ray of the dorsal equals the greatest length of the rentral and is contained seren times in the total length to the end of the middle caudal rays (six and two thirds times in length to end of lateral line). The length of the pectoral is one sixth of the standard body length.

The insertion of the ventral is midway between the tip of the snout and the end of the middle caudal rays. When the rentral is extended, the distance of its tip from the rent is only one 
fourth of the length of the fin. In this respect this species. differs widely from C. a $r^{2}$ te d i .

Colors. Pack grayish silvery; sides silvery; dorsal and caudal. with darker tips.

Radial formula. D. iii, 9; A. ii, $13 ;$ V. i, $12 ;$ P. i, 1i. Scales 9-S2-S.

\section{MEASUREMENTS}

Current number of specimen.

$\begin{array}{cc}\ldots \ldots \ldots \ldots \ldots \ldots & 32,162 \\ \begin{array}{c}\text { Milli- } \\ \text { meters }\end{array} & \begin{array}{c}\text { Hundredths } \\ \text { of leugth }\end{array} \\ 258 & \ldots \ldots \ldots \ldots \\ 217 & 100\end{array}$

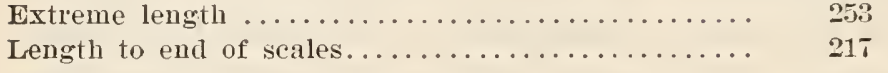

Body:

Greatest hight .................... 41

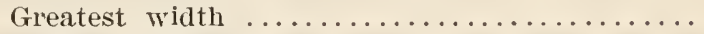

Hight at ventrals....................

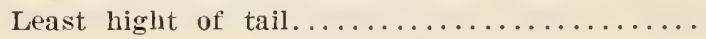

Head:

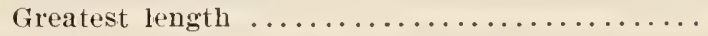

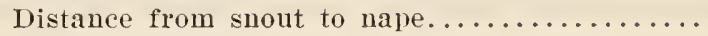

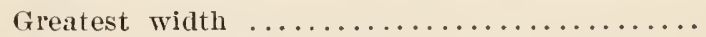

Width of interorbital area..............

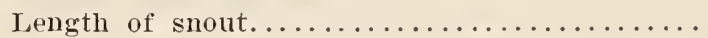

Length of operculum.................

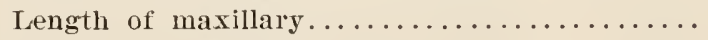

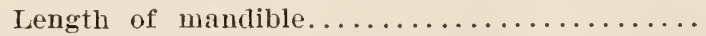

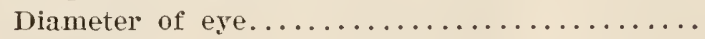

Dorsal (first):

Distance from snout................... 112

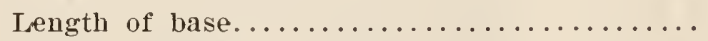

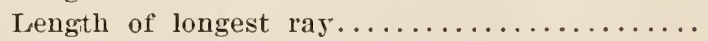

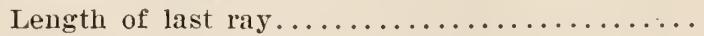
Anal:

Distance from snout.................. 162

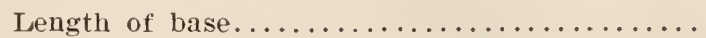

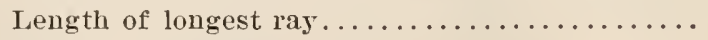

Length of last ray...................

Caudal:

Length of middle rays from end of scales..... 12

Lengtl of external rays................. 11

19

$1 \mathrm{~S}$

40

15

$\mathrm{S}$

$151 / 2$

7

52

36

20

12

14

13

18

26

13

$241 / 2$.

$161 / 2$

9

อ $1 / 2$

$61 / 2$

6

$\mathrm{S}$

12

6

20

33

11

24

20

Pectoral:

Distance from snout.................

Ventral:

Distance flom snout................... 118

Length ........................ 32

End of extended rentral to anal origin....... 


\begin{tabular}{|c|c|c|}
\hline (1) & $\begin{array}{l}\text { Milli- } \\
\text { meters }\end{array}$ & $\begin{array}{l}\text { Hundredths } \\
\text { of length }\end{array}$ \\
\hline 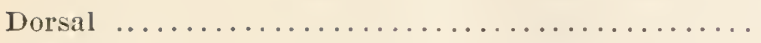 & iii, 3 & $\ldots \ldots \ldots$ \\
\hline 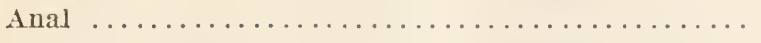 & ii, 13 & $\ldots \ldots \ldots$ \\
\hline Pectoral $\ldots \ldots \ldots \ldots \ldots \ldots \ldots \ldots \ldots \ldots \ldots$ & $\mathrm{i}, 16$ & $\ldots \ldots \ldots$ \\
\hline 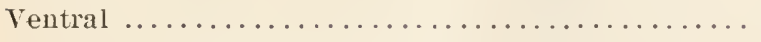 & $\mathrm{i}, 12$ & $\ldots \ldots \ldots$ \\
\hline Number of scales in lateral line................. & 82 & $\ldots \ldots \ldots$ \\
\hline Number of transverse rows above lateral line...... & !) & $\ldots \ldots \ldots$ \\
\hline Number of transverse rows below lateral line...... & 8 & $\ldots \ldots \ldots$ \\
\hline
\end{tabular}

The attention of the writer was called to this graceful little whitefish by the Rev. W. M. Beauchamp and J. C. Willetts. Mr Willetts forwarded numerous specimens from Skaneateles. Individuals were obtained also from Prof. H. L. Smith, which he received from Seneca lake. One of these specimens, 10 inches long, is described above.

The fish was then somewhat doubtfully supposed by me to be identical with Hoy's whitefish, but it is now known to be distinct.

\section{Argyrosomus artedi (LeSueur)}

\section{Lake Herring; Ciseo}

Coregonus artedi Le Sueur, Jour. Ac. Nat. Sci. Phila. I, 231, May, 1818. Lake Erie \& Lewistown, Upper Canada; Jordan \& Gilbert, Bull. 16, U. S. Nat. Mus. 301, 1883; Bean, Fishes Penna. 69, pl. 26, fig. 48, 1893.

Salmo (Coregomus) harengus Richardsox, Fauna Bor.-Amer. III, 210, pI. 90, fig. 2, 1836.

Coregonus clupeiformis DE KAY, N. Y. Fauna, Fishes, 248, pl. 60, fig. 198, 1842; Günther, Cat. Fish. Brit. Mus. VI, 198, 1866.

Coregonus harengus G̈̈nther, Cat. Fish. Brit. Mus. VI, 199, 1866.

Argyrosomus artedi Jordan \& Evermann, Bull. 47, U. S. Nat. Mus. 468, 1896.

The body of the lake herring is moderately elongated, compressed, and the head pointed. The greatest hight of the body at the origin of the dorsal is one fourth of the total length without caudal. The caudal peduncle is short and stout; its least depth is somewhat more than one third of its greatest depth. The eye is contained four to four and one half times in length of head; the snout three and one half times. The maxillary reaches nearly to below the middle of the eje. The lower jaw projects strongly. The dorsal begins midway between tip of snout and base of tail. Its longest ray equals length of 
hear without snout. 'The ventral begins under the middle of the dorsal, its longest ray two thirds of length of head. The pectoral is slightly longer than the rentral. The anal base equals the length of its longest ray, which is nearly one half the lengtlı of head. The adipose dorsal is slender, its width one half its light, and about one half the length of eye; 25 to 30 gill rakers below the angle of the first arch. D. $11 ; A .10$ (counting only divided rays in doraal and anal); V. 10. Scales 9-80-S. The upper parts are greenish or bluish black; the sides silvery and with narrow pale streaks along the rows of scales. specially above the lateral line.

This species is known as the lake herring or cisco. The name cisco is applied more particularly in the small lakes of Wisconsin. Indiana and New York. The lake herring is most abundant in the Great lakes, extending northward into British America; eastward it has been obtained from Labrador. It becomes rariable in certain parts of its habitat, notably in Labrador and in the lakes in which it is known as cisco. In 1885 more individuals of this species were taken in Lake Erie than in all the other Great lakes put together, more than $19,000,000$ pounds having been caught there out of a total of less than $26,000,000$.

The arerage length of this species is about 1 foot, and the weight 9 to 12 ounces, but examples measuring 19 inches in length and weighing 2 pounds have been recorded.

The lake herring frequents shoal waters moderately, and occurs in enormous schools, as one may judge from the quantit? captured in Lake Erie. Its food consists of insects and crustaceans. During the spawning season of the whitefish, however, it feeds exclusirely on the eggs of this species and prores very destructive. The lake herring will take the hook, and has been caught with live minnows. Spawning takes place about the end of Norember in shoal waters.

As a food fish this species is inferior to the whitefish, but it is in great demand orer an extensive area of the country, and is shipped in the fresh condition many hundreds of miles east and rest. I have elsewhere referred to the enormous number 
Jaken in 1855 in Lake Erie. These are caught chiefly in pound and gill nets. The eateh in 1885 amounted to more than one third of the entire quantity of fishes taken in this lake. There is no apparent diminution in the number of these fishes, and their artificial propagation has not been practised.

A male and a female were forwarded by Mr Annin from Threemile bay, Lalke Ontario, Nor. 22 and 25, 1895.

\section{MEASUREMENTS}

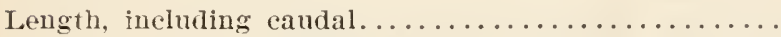

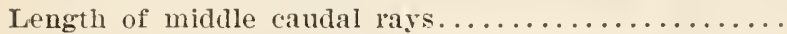

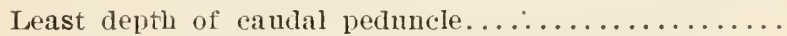

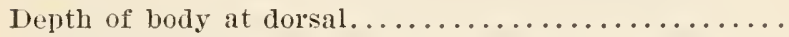

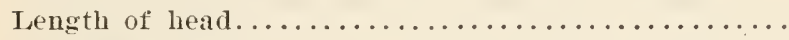

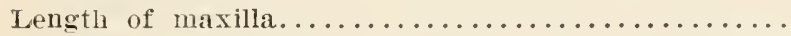

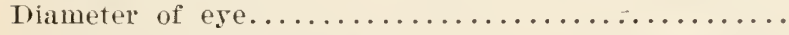

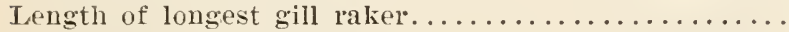

\begin{tabular}{|c|c|}
\hline $\begin{array}{l}\text { MALE } \\
\text { Inehes }\end{array}$ & $\begin{array}{l}\text { FEMALE } \\
\text { Inches }\end{array}$ \\
\hline $131 / 2$ & 13 \\
\hline $3 / 4$ & $\ldots \ldots$ \\
\hline 1 & $\ldots \ldots \ldots$ \\
\hline 3 & $21 / 2$ \\
\hline $21 / 4$ & $21 / 4$ \\
\hline $3 / 4$ & $7 / 8$ \\
\hline $1 / 2$ & $1 / 2$ \\
\hline $5 / 3$ & \\
\hline
\end{tabular}

The male has $17+31$ gill rakers; the female, $4 \pi$. Scales of the male, $8-74-8$; of the female, 76 .

In the female the maxilla reaches to the front of the pupil; the lower jaw projects a little; the dorsal and anal each have 10 divided rays; the dorsal has a black tip; the pectoral is dusky above; the rentral and anal are pale; the caudal is dusky towards its margin.

The cisco, according to $M r$ Annin, lires in deep waters and spawns in brooks in December.

Dr. Meek saw a few specimens of the species from Cayuga lake. The U.S. Fish Commission obtained four specimens at Cape Vincent X. Y. Nor. 11 and $1 \bar{\tau}, 1891$. The U. S. National Museum has a number of examples from Lake Champlain, some of them from Yergennes Tt., and other's from Ticonderoga X. Y. DeKay says the shad salmon occurs in the smaller lakes in the interior of the state, which still communicate with our inland seas.

\section{Argyrosomus hoyi Gill}

\section{Ilooneye Ciseo; Shiner}

Argyrosomus hoyi Gill, Mss. Jondax, Amer. Naturalist, 135, Mareh, 1875. Lake Michigan, near Racine, Wis; EvernANx \& Smith, liept. U. S. F. C. XX, 310, pl. 22, 1S96; Besx, Bull. Amer. Mus. Nat. Hist. IX, 342, 1\$97, Cananłaigua Lake; Jordax \& Evermaxx, Bull. 47. C. S. Nat. Mus. 469, 1896. 
Coregomus hoyi Jordax, Man. Tert. ed. 2, 275, 1S7S; Jordan \& GILbert, Bull. 16, U. S. Nat. Mus. 299, 1S83; Smiti, Bull. U. S. F. C. XIV, 6, pl. 1, fig. 1, 189 .

Head, four; depth, four and four serenths; eye, five (nearly); snout, three and one half; maxillary; nearly three in head, reaching to rertical through front of pupil. D. $10 ;$ A. 11. Scales, 8-70-9. Gill rakers, $14+28$, left side, 40 on right side, longest about $\frac{1}{4}$ inch, about two in eje. Branchiostegals, S. Body rather elongate, compressed, the bacli little elevated; mouth rather large, terminal, the lower jaw slightly longer than upper when the mouth is closed; tip of muzzle conical as in $A$. a r te $\mathrm{d}$; mandible nearly reaching vertical through posterior edge of eve, nearly two in head; head rather long and slender, with pointed snout; interorbital width equal to eye; supraorbital and preorbital long and narrow; distance from tip of snout to occiput two in distance from occiput to origin of dorsal fin; dorsal rays much longer anteriorly than posteriorly, the longest ray nearly equal to distance from front of pupil to end of head, the last ray only one third as long; longest anal ray two and one half in head, last anal ray two fifths as long as the longest; pseudobranchiae well developed; tongue with evident teeth. Color in spirits silvery, with purplish iridescence on back; scales without punctulations; belly whitish; dorsal and caudal fins dark on terminal half, pale at base; other fins all pale. Length,

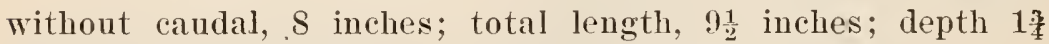
inches; head, $2 \frac{1}{8}$ inches ; eye, $\frac{7}{16}$ inch; maxilla, $\frac{11}{16}$ inch; interorbital widtl equal to diameter of ese.

Mr Annin wrote me that the people at Canandaigua lake told him that there were large quantities of small lake shiners, as they are called, in the lake. I fisherman said that they are seen in immense schools at the top of the water occasionally, and, by firing a gun loaded with shot into them. men can stun them so as to pick up quite a number. They are eagerly sought after for trolling bait for the salmon trout found in that lake.

This species is recorded with certainty from Lake Michigan only. It is takell in gill nets in deep water and, notwithstanding its small size, has become commercially important. It is 
here for the first time announcel as a member of the New lork fauna, and the description leares no doubt of the correctness of the identification. The fisl examined, a female with ripe eggs, was taken in Canandaigua lake, Dec. 19, 1896, by Mr Annin's men. It was the only one caught, and was captured by becoming gilled in the funnel of the net. M1 Annin is satisfied that this is the lake shiner of the fishermen, which they sometimes see in immense selools at the surface, and kill for trolling bait by shooting them.

\section{S Argyrosomus prognathus (H. M. Smith)}

\section{Long Jaw; Bloater}

Coregonus prognathus Hugir M. Smitr, Bull. U. S. F. C. XIV, 4, pl. 1. fig. s. 1S95, Lake Ontario, at Wilson N. Y.

Argyrosomus hoyi MILNer, Rept. U. S. F. C. II, S6, 1STt, Outer Island. LakeSuperior, not of GiLL.

Argyrosomus prognathus Evermaxy \& SMth, Rept. U. S. F. C. XX, 314, pl. 26, 1896; Jordax \& Evermann, Bull. 47, U. S. Nat. Mus. 471. 1894.

Body oblong, much compressed, back elevated, tapering rather abruptly toward the narrow caudal peduncle, the adult fish having a slight nuchal hump as in C. c l u pe i for $\mathrm{r}$ is ; greatest depth three and one half to four in body length; head rather short and deep, pointed, four to four and one third in length; greatest width half the length, cranial ridges prominent; snout straight, its tip on level with lower edge of pupil; top of head two in distance from occiput to front of dorsal; mouth large and strong, maxillary reaching to opposite middle of pupil, two. and one half in head, length three times its width, mandible long, projecting beyond upper jaw when moutl is closed, reaclsing to $\mathrm{or}^{\circ}$ beyond posterior edge of eye, one and three fourths to one and seren eighths in head; eye snall, fire in head, one and one half in snout, one and one third in interorbital space. one and one half in suborbital space; gill rakers slender, about length of eye, 13 above and 25 below angle. Adipose fin the length of eye, its width half its length. Sallowest part of calldal peduncle contained nearly four times in gatest body deptl. Dorsal rather high, with nine or ten developed rays, the longest one half longel than base of fin and contained one and three. 
fourths times in greatest body deptl, three and one fourth times in distance between dorsal and snout, and one and one half times in head; free margin slightly concave; origin midway between end of snout and base of caudal; dorsal base opposite nine scales. Anal with 10 to 12 developed rays, the longest ray equal to base of fin and two thirds of hight of dorsal. Ventrals as long as dor'sal is high, their origin midway between anterior edge of orbit and base of caudal. Ventral appendage short, corering about three scales. Pectorals as long as ventrals. Scales rather large, about 75 in lateral line, seven or eight above the lateral line, seven or eight below the lateral line. Lateral line straight except at origin, where it presents a rather marked curve. Sides of body uniformly bright silvery, with pronounced bluish reflection in life; the back dusky, the under parts pure white without silvery color. Above lateral line, light longitudinal stripes involving central part of scales extend whole length of body. Fins flesh color or pinkish in life, the dorsal and caudal usually showing dusky edges; postorbital area with a bright grolden reflection; iris golden, pupil black. Branchiostegals, eight. Average length, 15 inches.

Mabitat: Lake Ontario, Lake Michigan, Lake Superior, and doubtless the entire Creat lake basin, in deep water. This fish is called long-jaw in Lakes Michigan and Ontario. Specimens were obtained from John S. Wilson of Wilson N. Y. and from George M. Schwartz of Rochester N. Y. Dr R. R. Gurley also secured examples at Nine Mile Point N. Y. in June 1893.

This species is quite different from any other whitefish inhabiting the rireat lake basin. It may be at once distinguished from all the whitefishes known to occur in the United States by the general form of body combined with the very long lower jaw, which is contained less than twice in the length of the head and extends backward to or bryond the posterior edge of orbit.

\section{9) Argyrosomus tullibee (Richardson)}

\section{Tulliber: Mongrel Whitefish}

Satmo (Corcgonus) tullibce Richandson, Fauna Bor.-Amer. III, 201, 1836, Cumberland House, Pine Island Lake. 
Coregonus tullibee Günther, Cat, Fish. Brit. Mus. VI, 199, 1866; Jordar \& Gilbert, Bull. 16, U. S. Nat. Mus. 301, 1S53; Jordan, Cat, Fish. N. 1. 43, 1855; BeAn, Fishes Penna. 70, pl. 27, fig. 49, 1893.

Argyrosomus tullibee Jordan, Man. Vert. ed. 2, 361, 187S; Evermaxx \& Smith, Rept. U. S. F. C. XX, 320, pl. 28, 1896; Jordan \& Everuanx, Bull. 47 , U. S. Nat. Mus. 473, 1896; Bean, Bull. Amer. Mus. Nat. Hist. IX, 343, 1897 .

The body of the tullibee is very short, deep and compressed; its greatest hight about one third of the length without caudal. The head is pointed, as in the blackfin, the mouth large, with the lower jaw scarcely longer than the upper. The maxilla extends to below the middle of the eye. The eye equals the snout in length and is two ninths of length of the head. Scales much larger on front part of body than on the caudal peduucle. The gill rakers are long, slender and numerous, about 30 below the angle on the first arch. 1). 11; 1.11 . Scales in lateral line 74, eight rows above and seven below lateral line; pyloric caeca, 120. The upper parts are bluish; sides white and minutely dotted. The spermary, according to Richardson, is wood brown.

This species is usually called the tullibee, but in Lakes Erie and Michigan it is sometimes styled the mongrel whitetish on the supposition that it is a cross between the common whitefish and the lake herring.

The tullibee has been taken recently in Lake Michigan; and Dr E. Sterling had a specimen from Lake Erie. It is found occasionally in others of the Great lakes and extends northward into British Anerica; but is comparatively little known to the fisher. men and is very rare in collections. This fish grows to a length of 18 inches.

The late F. C. Gilchrist was the first to describe the habits of the tullibee, and this he did in Forest and Stream in the following language.

In Suptember they will again be found gradually nearing the shoal water, feeding heavily, and plump with fat and the now swelling ovaries. Later on they appear to eat little or nothing and devote all their time to playing until about the 25th of October, whon they have settled down to the business of propagation, which they have finished by November 10. They prefer shallow water close to shore with clean sand to spawn on, and 
during the day they may be seen in pairs and small schools, poking along the shores, but at night they come in thousands and keep up a constant loud splashing and fluttering, very strange and weirl on a calm night. Two years ago I carefuly counted the ova from a ripe fish $2 \frac{1}{2}$ pounds in weight, and found there were $2: 700$, closely resembling whitefish eggs in appearance, but somewhat smaller. After suawing the fish are very thin, lank, dull in color, and quite unfit for human food.

James Annin jr furmished me the following notes on the spawning of the tullibee in Onondaga lake, N. Y.

They generally commence running up onto the shoals about Norember 15, and the season extends into December. They come up to the banlis or gravelly shoals and spawn in from 3 to 6 and 7 feet of water. They have nevel been caught with the hook in this lake; and an old fisherman told me that he had tried almost every kind of bait, and had used the very finest gut and the smallest hooks baited with G a m m a us (fresh-water shrimp) and other kinds of natural food-that is, he supposed the food was natural to them. At the same time, he claims he could see them in large schools lying in the water $S$ or 10 feet from the surface.

I female tullibee was sent from Onondaga lake by $\mathbf{M r}^{\circ}$ Annin Nor. 1s, 1895, and another of the same sex Nov. 25, 1896.

The following notes relate to the female obtained Nor. 1S, 1895.

Inches

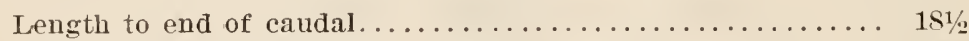

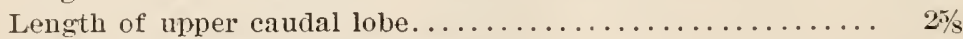

Length of middle caudal rays................... 1

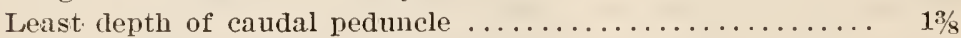

Depth of body at dorsal origin................... $4 \%$

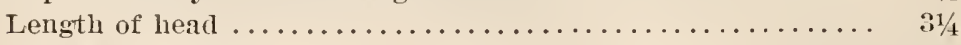

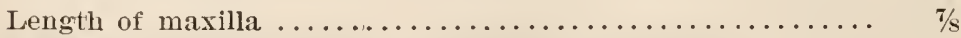

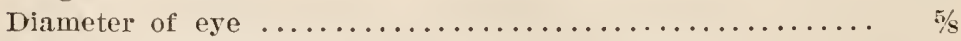

Length of longest gill raker....................

The mandible projects slightly. B. S; D. 11; A. 11; V. 11. Scales S-75-8; gill rakers, $17+27$.

The female received Nov. 25, 1896, is 15 inches long.

New York is well supplied with Coregonidae, having seven of the 16 North American species. C. quadrilateralis is the frostfish of the Adirondacks and the Great lakes. $C$. c lu peifor $\mathrm{m}$ is, the common whitefish, inhabits the Great jakes and Lake Champlain; it is rery abundant also in the 
Adirondaclis. Argyosomus osmeriformis is a shapely little herring of Seneca and skaneateles lakes. A. a $\mathrm{l}^{2} \mathrm{t} \mathrm{d} \mathrm{i}$ is the common lake herring or cisco of the Great lakes and Lake Champlain. A. hoyi. the lake shiner, or Hoy's whitefisle, is ahore recorded from Canandaigua lalie. A. prognathus, the long-jaw, the only summer spawning whitefish so far as linown, lives in Lake Ontario; and, finally, $\mathrm{A}$. t 11 l i bee, is the fine whitefish of Onondaga lake.

\section{Genus oxcornumus suckley}

Body elongate, subfusiform, or compressed; mouth wide, the maxillary long, lanceolate, usually extending beyond the eye; jaws with moderate teetl, which become in the adult male enormously enlarged in front; romer long and narrow, flat, with a series of teeth both on the head and the sliaft, the latter series comparatively short and weak; palatines with a series of teeth; tongue with a marginal series on each side; teeth on romer and tongue often lost with age; no teeth on the hyoid bone; branchiostegals more or less increased in number; scales moderate or small; dorsal fin moderate; anal fin comparatively elongate, of 14 to 20 rars; pyloric appendages in increased number; gill rakers rather numerous; ova large; sexual peculiarities rery strongly developed; the snout in the adult males in summer and fall greatly distorted, the premaxillaries prolonged, hooking orer the lower jaw, which in turn is greatly elongate and somewhat hooked at tip, the teeth on these bones also greatly enlarged. The body becomes deep and compressed, a fleshy hump is dereloped before the dorsal fin, and the scales of the back become embedded in the flesh; the flesh, which is red and rich in spring, becomes dry and poor. Salmon, mostly of large size, ascending the rivers tributary to the north Pacific in North America and Asia, spawning in the fall.

\section{0ncorhynchus tshawytscha (Wralbaum)}

\section{King Salmon; Quinnat Salmon; Chinook Salmon (Introduced)}

Salmo tshawytscha Walbaum, Artedi. Gen. Pisc. III, 71, 1792.

Salmo quinnat Richardsox, Fauna Bor.-Amer. III, 219, 1836; Girard, Pac. R. R. Exp. Fish. 306, pl. 67, 1858.

-Oncorhymchus quinnat GüNTher, Cat. Fish. Brit. Mus. VI, 1es, 1866. 
Oncorhynchus orientalis GüNTHER, op. cit. 159, 1866.

Oncorhynchus chouicha JordAN \& GilderT, Bull. 16, U. S. Nat. Mus, 306, 1883; Stone in Fish \& Fish. Ind. U. S. I, 479, pl. 186, lower fig. 1854; Bean, Bull. U. S. F. C. IX, 190, pl. Xlvi, fig. 1, 1891; Fishes Penna. T2, 1893.

Oncorflynchus tschawytscha Jordan \& Evermann, Bull. 47, U. S. Nat. Mus. 479, 1896, pl. LXXVII, fig. 206, 1900.

Body stout, moderately elongate, its greatest depth contained three and two thirds to four times in total length without caudal; caudal peduncle short and stout, its least depth one third of greatest depth of body; head conical, pointed, its length one fourth of total length without caudal; eye suall; less than oue half of length of snout, and about one serenth of leugth of head; maxilla slender, its width scarcely one fourth its length, which is one half the length of head; nostrils nearly midway between eye and tip of snout; teeth small, longer on sides of lower jaw than in front, romerines few and weak, disappearing in the males; gill rakers usually about 23, of which 14 are below the angle of the first arch; dorsal origin midway between tip of snout and base of upper external caudal rays, the base of the fin as long as the longest ray, one half as long as the head, the last ray two fifths as long as the lougest; adipose fin over the end of the aual, its width scarcely one half its leugth, which is two sevenths of the length of the head. The anal base is three fifths as loug as the head; the longest anal ray is two fifths as long as the head and more than twice as long as the last ray. The ventral is under the last rays of the dorsal, midway between front of eye and base of caudal, its length one half the length of head, its appendage one half as long as the fin. Pectoral as long as postorbital part of head. B. usually 17 or $18 ;$ D. 11 ; A. iii, $15 \mathrm{or}^{\mathrm{r}}$ 16. Scales usually $27-146-29$, sometimes as many as 155 in a longitudinal series. Vertebrae 66. Pyloric caeca 140 to 1 Sร.

The quiunat salmon is the largest and finest of the Pacific salmon. It ranges from Monterey Cal. to Alaska and eastern. Asia, ascending rivers in some cases 1500 miles ol farther from the sea. It has been introduced into lakes of New York, but there is no evidence that it has become established in any waters of the state. Possibly better results might be secured if larger fish were selected for the experimental stocking. 
This is the largest fish of the salmon family, individuals weighing 100 pounds and measuring upward of 5 feet in length being on record from the Yukon and other Alaskan rivers. The average weight of adults is above 20 pounds. The flesh of this salmon is paler in color than that of the red salmon, but it is superior in flaror to all others.

The quinnat is the first to arrive near the shores in the spring, and the time of the run depends on the latitude, becoming later and later till, in Norton sound, the present known northern limit of its migration, it appears early in June. Unless the spawning period be close at hand, it does not ascend rivers rapidly, but generally plays around for a few days, or eren a couple of weeks, near the river limit of tide water. It luas been estimated that it proceeds up the Columbia river at the rate of 100 miles a month till the exigencies of reproduction compel a faster rate of travel.

In the sea this salmon feeds on herring, caplin, and clustaceans. A male of about 35 pounds, taken at Karluk August 4, had in its stomach 45 caplin. In fresh water the fish take no food.

Spawning takes place near the head waters of streams in clear shallow rapids. The fish excarate oblong cavities in the grarel beds where there is a current, and in these nests the eggs and milt are deposited. The eggs are protected from some of their enemies and fatalities by their environment, but are still a prey to freshets and to the pestiferous little fresh-water sculpins, or blobs, that abound in all trout and salmon waters, so far as observed. The poung are hatched in from 60 to 100 dass. They are destroyed in large numbers by aquatic birds, blobs, and large fishes. The adults ale killed by seals, sea lions, and sharks. After spawning, nearly all the parent fish die, specially those that ascend river's a long distance.

The quinnat is a very valuable fish for canning, salting and smoling. If it could be acclimated in the Great lakes, it would form the basis of new and important industries. The practicability of rearing this species in fresh waters without access to the sea has been satisfactorily demonstrated in France by Dr Jonsset de Bellesme, director of the aquarium of the Trocadéro. 
The results of the experiment of introducing this salmon into New York waters are as yet unknown, but it is to be hoped that it will be successful. Since the change of method by which larger fish are employed for transplanting, the outlook appears to be more favorable.

\section{Genus sımo (Artedi) Linnaeus}

Body elongate, somewhat compressed; mouth large, jaws, palatines, and tongue toothed, as in related genera, vomer flat, its shaft not depressed, a few teeth on the chevron of the vomer, behind which is a somewhat irregular single or double series of teeth, which in the migratory forms are usually deciduous with age; scales large or small, 110 to 200 in a longitudinal series; dorsal and anal fins short, usually of 10 to 12 rays each; caudal fin truncate, emarginate or forked, its peduncle comparatively stout; sexual peculiarities variously dereloped, the males in typical species with the jaws prolonged and the front teeth enlarged, the lower jaw being hooked upward at the end and the upper jaw emarginate or perforate. In the larger and migratory species these peculiarities are most marked. Species of moderate or large size, black spotted, abounding in the rivers and lakes. of North America, Asia and Europe; no fresh-water species occurring in America east of the Mississippi valley; two Atlantic species, marine and anadromous. The nonmigratory species (subgenus $\mathrm{T}$ r u t $\mathrm{t}$ a) are in both continents rery closely related and difficult to distinguish, if indeed all be not necessarily re. garded as forms of a single one. The excessive variations in color and form have given rise to a host of nominal species.

\section{Salmo salar Linnaens}

\section{Atlantic Salmon}

Salmo salar Linnaecs, Syst. Nat. ed. X, I, 30S, 175s; Seas of Europe; Mitchill, Trans. Lit. \& Phil. Soc. N. Y. I, 435, 1815; DE KAY, N. Y. Fauna, Fishes, 241, pl. 38, fig. 122, 1842; Günther, Cat. Fish. Brit. Mus. VI, 11, 1866; Storen, Hist. Fish. Mass. 142, pl. XXV, fig. 2, 1867; Jordan \& Gilbert, Bull. 16, U. S. Nat. Mus. 312, 18s3; Goode, Fish \& Fish. Ind. U. S. I, 468, pl. 186, upper fig. 1884; Bran, Fishes Penna. 74, color pl. 4, 1893; Jordan \& Evermanx, Bull. 47, U. s. Nat. Ius. 486, 1896; BEAN, Bull. Amer. Mus. Nat. Hist. IX, 34, 1897. 
The Atlantic salmon has a moderately thick and elongate body. The greatest hight, at the origin of the dorsal fin, is two ninths of the total length without candal. The candal peduncle is rather slender; its least depth abont one third of the greatest depth of body. The head is comparatively small; its length in the female about one fifth of total withont candal. The eye is placed at a distance from the top of the head equal to its own diameter. It is one half as long as the snout, and about one serenth of length of head. The maxillary reaches a little past the eye in adults. Its length equals the depth of caudal peduncle. The dorsal origin is midway between tip of snout and adipose fin. The adipose fin is long and narrow, its width one half its length, and equal to length of eje. The base is slightly longer than its longest ray, and nearly one eighth of total without caudal. The last dorsal ray is about one third of length of dorsal base. The rentral origin is nearly under the end of the dorsal base. The length of the fin equals one half the length of head. The alpendage is two fifths of the length of the fin. The pectoral is as long as the dorsal base. The distance of the rentral origin from the anal origin is a little more than length of head. The longest anal ray equals length of ventral. The last lay is two fifths of length of longest. B. 11; D. 11 divided rass and 3 rudiments; $A$. 9 divided rays and 3 rudiments. Scales 2:, 120, 21. Vertebrae 60 . Pyloric carca 60 to 70 . In the adult the npper parts are brownish or grayish; the sides silvery. Numerous X-shaped or XX-shaped black spots on the upper half of the body, side of the head, and on the fins. Males in the breeding season thare red blotches along the sides. In the young there are from 10 to 12 dark crossbars mingled with red blotches and black spots.

The salmon in America has but a single common name. When the soung have reached a length of 2 inches and taken on the vermilion spots and dark cross bands, they are called parr, and retain this name while they remain in fresh water. Before descending to the sea in the sccond or third spring, the parr assumes a bright silvery coat and is then known as a smolt. 
After a sojourn in salt water lasting from four months to about two years, it may return to its natice river either as a sexually immature salmon or as a grilse, the female not yet ready forreproducing its species thougl the male is sexually mature. The landlocked rariety of the Atlantic salmon has been variously denominated fresh-water salmon, Schoodic trout, Sebago trout, dwarf salmon and winninish, the last in use in the Saginaw region. In some Nora Scotian rivers a misnomer, grayling, is applied to the landlocked salmon.

This species inhabits the north Atlantic, ascending rivers of Europe and America for the purpose of reproduction. In Europe it extends sonthward to France, and in the United States the most southern river in which specimens have been: obtained is the Potomac. It occurs in small numbers in the Delaware and in large numbers in the Hudson, but in the last three river basins mentioned its presence is the result of artificial introduction. It is not found in abundance south of the Merrimac, and in rivers of New England and Canada in which it is native it is maintained almost exclusively by artificial culture. The usual weight of the Atlantic salmon ranges from 15 to 40 pounds, but individuals weighing 60 pounds have been recorded. The growth of the salmon is accomplished chiefly in the occan. As a rule the adults enter the rivers on a rising temperature when ready to deposit their eggs, the spawning occurring on the falling temperature in water not warmer than $50^{\circ}$. The time of entering the Delaware and Hudson is April, the Connecticut a little later, the Merrimac still later; to the Penobscot the salmon come most abundantly in June and July; and to the Miramichi from the middle of June to October. The salmon is not much affected by changes in temperature of the water, enduring a range of fully $45^{\circ}$. The eggs are deposited. in shoal water on sandy or gravelly bottom, the parent fish making deep depressions by means of their noses or by flopping motions of the tail. The period of egg-depositing lasts from 5 to 12 days. The spawning season begins about the middle of October and may run into December. In, some European 
rivers the season continues till February. The eggs are about one fompth of an inch in diameter, and the female is estimated to have about $1000 \mathrm{fol}^{\circ}$ each pound of hel weight. In the Penobscot, according to the observations of $\mathrm{Mr}$ Atkins, an eight pound female vields from 5000 to 6000 eggs; and a female of 40 pounds abont 15,000 eggs. The hatehing period ranges from 140 to 200 days or more, depending on the temperature. A newly hatched salmon is about three fom ths of an inclu long, and the yolk sack is absorbed in from a month to six weeks. It then begins to feed on small organisms in the water. At the age of two months it measures $1 \frac{1}{2}$ inches and begins to show crosshars and red spots, gradually coming into the parr stage. In the sea the salmon feeds on herring, caplin, sand lance, smelt and other small fishes, besides crustaceans; but during its stay in fresh water it takes no food.

Among the worst enemies of samon eggs are trout, eels, suckers and frogs. Numerous species of birds destroy the fre, among them sheldrakes, kingfishers, gulls and terns.

The value of the salmon as a food and game fish is so well known as to require no description here. Those that find their way into market are usually canght in pound nets, gill nets or seines, and the bulk of them are taken at or near the mouths of the streams which they are about to enter for the purpose of spawning. Many are captured in the upper reaches of streanis by the spear.

Eggs of the Atlantic salmon, just on the point of hatehing, from the Restigonche river, Canada, were received at the New York aquarium from Percy Baker about May 1, 1897. Several hundred healthy embryos were obtained from them. These were reared almost without loss till June 18, when the temperature of the water had reached $76^{\circ}$ and nearly all perished. November 27 , one of the few survirors was $3 \frac{3}{5}$ inches long. Liver was the principal food of the fry.

Mitchill, in the first rolume of the transactions of the Literary and Philosophical Society of New York, sass that the salmon "s has been taken, since the discorery, a few times in the Hudson. 
But here he is a straggling fish, and not in his regular home. There is no stcady migration of salmon to this river. Thougb pains hare been taken to cherish the breed, salmon has never frequented the Hudson in any other manner than as a stray."

In 1842 DeKay published the following note:

The sea salmon rarely now appears on our coast except as a straggling visitor. Such an occurrence took place in Angust 1.840 , when a salmon weighing $S$ pounds entered the Hudson river, and ascended it more than 150 miles, when it was taken near Troy. . It now is only seen on our northern borders, ascending the St Lawrence from the sea, and appraring in Lake Ontario in April, and leaving it again in October or Norember. They were formerly rery abundant in the lakes in the interior of the state which communicated with Lake Ontario; but the artificial impediments thrown in their way hare greatle decreased their numbers, and in many rases cansed their total destruetion. I have seen some from Oneida lake weighing 10 and 15 pounds.. They are occasionally found in Lake Ontario during the whole year; but, as the same instinct which compels them to ascend rivers also leads them again to the sea, and as there is no barrier opposed to their return, we may presume that these are sickly or possibly barren individuals.

Experiments for restocking the Hudson are now in progress, and it is probable that the river may again become a salmors stream.

\section{Salmo salar sebago (Girard)}

\section{Landlocked Satmon (Introduced)}

Salmo sebago Girard, Proc. Ac. Nat. Sci. Phila. 380, 1853, Sebago Lake, Maine; Grinther, Cat. Fish. Brit. Mus. VI, 153, 1866.

salmo salur var, scbago Jordan \& Gimbert, Bull. 16, U. S. Nat. Mus. 312 1883.

Salmo gloverii Girard, Proc. Ac. Nat. Sci. Phila. S5, 1854; Günther, Cat. Fish. Brit. Mus. VI, 153, 1866.

Salmo salar sebago Jomnax \& Evermanx, Bull. 47, U. S. Nat. Mus. 4St. 1896; Bean, Bull. Amer. Mus. Nat. Hist. IX, 344, 1897.

There are at least two well marked races of salar salmols which do not enter the sea but live permanently in fresh water. Both of these differ from the migratory salmon in several particulars: they are smaller, their eggs are larger, they retain the parr marks much longer, they are more subject to disease attending the egg-producing seasom, and the roung grow more 
rajidly. The o u a 11 a $n \mathrm{i}$ " lo o of the Saguenay: rivor countre is the farthest remored from the typical sea salmon by its rely much smaller size, larger fins and different pattern of coloration.

The larger of the two landlocked salmon of the Tnited States is found in the fom rirer basins of the state of Iaine, the Presumpseot, Sebec, Lnion and St Croix. Here the weights vale considerably, spawning fisle ranging all the way from 3 pounds to 10 n 12 pounds, while occasional individuals reach 25 pounds. The Sebago form is the one that has bern introduced into the ldirondack lakes and other New York waters. Spawning begins late in October, but is at its hight in Norember. Eggs are shipped in January, February and March, and thre fry are l'ady for planting in Jnue.

it Green lake, Me., the landlocked salmon often minue a summer temperature above so $\mathrm{F}$., but they refuse to tale food when lhe water reaches $75^{\circ}$.

This salmon has been introduced into New York waters from Maine, and appeal's to have become established in sereral localities. I rely fine example was obtained from the Sonth side Sportsmen's Club of Long Island, but it was injured in transportation and never lecorered. In April 1896 sereral individnals from Mraine were presented by Eugene G. Blackford. One of these lived in a tank of salt water in the New Iork aguarium for 19 months, and was then frightened by risitors when the water was drawn low for cleaning, and injured itself so badly that it died after a few hours of struggling. The following measurements were obtained from the fresh fish.

Length

Inches

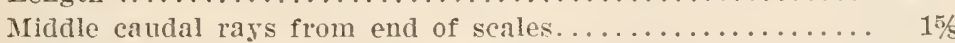

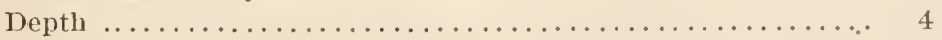

Least depth of caudal peduncle....................... 15/8

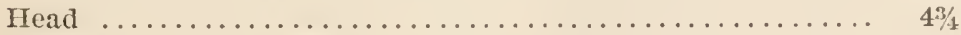

Snout .................................

Eye ........................................

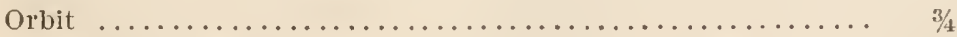

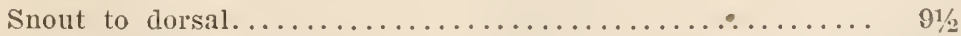

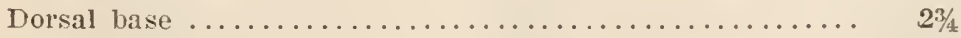

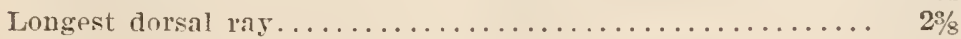

Last dolsal ray.......................... $11 / 1$ 
Inches

Snout to ventral. ......................... 111/t

I

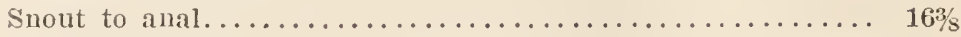

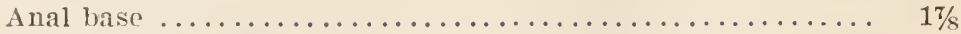

Longest anal 1 ay............................ 17/s

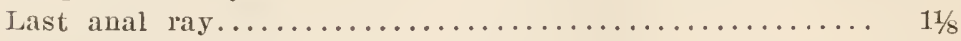

Snout to adipose dorsal......................... 175/8

Width of adipose dorsal. ....................... 1/:

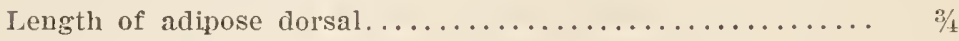

Length of pectoral .......................... $31 / 4$

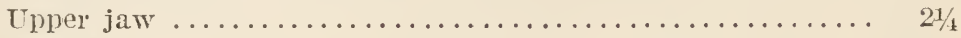

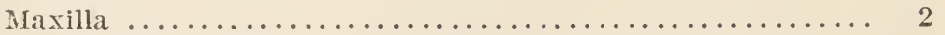

The head has about 28 dark spots, the largest on the gill cover, oblong, $\frac{5}{8}$ inch long. Body with many large and small black spots, a few with a pale ring around them, and some as large as the largest on the gill corer; one on the caudal peduncle of one side distinctly $X$-shaped. General color dark bluish gray; belly and lower parts iridescent silvery; fins all dusky; the dorsal with many black spots; eye pale lemon, the upper part dusky.

Gill rakers, $9+11$, the longest $\frac{5}{16}$ inch. B. 11; D. 10. Scales, 21-123-20.

\section{Salmo henshawi Gill \& Jordan}

\section{Lake Tahoe Trout; Rerl-throat Trout (Introduced)}

Salmo henshawi Gill \& Jondan, Man. Vert. ed. 2, 35S, 1S7S, Lake Tahoe;

Rept. Chief Eng. Part 3, 1878, App. NN, 1619, pl. IV; Jordax, Proc.

U. S. Nat. Mus. I, 75, 1878.

Salmo purpuratus var. henshaui Jordan \& Gilbert, Bull. 16, U. S. Nat. Mus. 316, 1883.

Salmo mykiss Cheney, Third Ann. Rept. N. Y. Comm. Fish. 239, color pl. facing p. 238, 1898.

Salmo myliss henshawi Jordan, Bull. U. S. F. C. IX, 14, pl. II, fig. 5, 1891; Jordan \& Evermann, Bull. 47, U. S. Nat. Mus. 493, 1896.

Salmo clarkii henshawi Jordan \& Evermann, op. cit. 2819, pl. LXXIX, fig. $208,1000$.

Body elongate, not much compressed, its greatest depth one fourth of the total length without candal; caudal peduncle rather long; its least depth equaling two fifths of the length of the head; head long, conical, slender, its length contained about four times in the total to caudal base; a slight keel on the top of the head; snout obtusely pointed; maxilla not extending far behind the eye, about equal to pectoral, which is three fifths of 
lengtl of head; gill rakers short and stout, about 18 on the first arcll, of which 18 are below the angle; romerine teeth in two long, alternating series; hroid teeth rather weak, in a small patch; dorsal fin small, its last rays two thirds as long as the highest; anal fin rather high; caudal short and distinctly forked. D. 9 to 11 ; A. 12 ; B. 10 . Scales 27 to $3 \bar{T}-160$ to $200-27$ to 40 ; pyloric caeca 50 to 60 .

Color dark green in life, varying to pale green; the sides silvery with a broad coppery shade which extends also on the cheeks and opercles; a yellowish tinge on the sides of the lowel jaw and red or orange dashes between its rami; back ererywhere corered with large, roundish black spots; dorsal, adipose fin and caudal fin with similar spots, and a few on the anal; belly with black spots.

The Taloe trout is a large species inhabiting Taloe lake, Pyramid lake, Webber lake, Donner lake, Independence lake, Truckee river, Humboldt rirer, Carson river, and most streams of the east slope of the Sierra Nevada; it occurs also in the head waters of Feather rirer, west of the Sierra Nerada, probably by introduction from Nevada.

The usual weight is 5 or 6 pounds, but indiriduals weighing 20 to 29 pounds are recorded.

Eggs of the Lake Tahoe (Cal.) trout were obtained by James Annin jr at Caledonia N. Y., and young fish reared at his establishment were sent to the aquarium in Norember 1896. They throve till the latter part of June 1S97, when they were orercome by the warm water. They conld not endure a transfer to the cooler salt water, like most of the other fish of the salmon family.

At Caledonia station, according to Mr Cheney, this fish begins to spawn before the middle of Narch and continues for two months. The impregnation of eggs is from $90 \%$ to $95 \%$, but just before the hatching period a large number of the eggs burst and the embryos are lost. There is loss too between the hatching and feeding times, and the fry do not feed as readily as the brook trout. Altogether, $M r$ Annin, the superintendent of 
hatcheries, estimates the total loss between impregnation of the eggs and feeding of the fry as about $40 \%$. After the fro begin to feed, they are not more diflicult to rear than brook trout.

\section{Salmo gairdneri Richardson}

Steelhead; Gairdner's Trout; Salmon Trout (Introduced)

Salmo gairdnerii Rrcirardson, Fauna Bor-Amer. III, 221, 1836, Columbia River.

Fario gairdneri Girand, Pac. R. R. Surv. Fishes, 313, pl. LXXI, fig. 1, 1858.

Salmo purpuratus Güntiner, Cat. Fish. Brit. Mus. VI, 116, 1S66, not of. Pallas.

Salmo gairdnerii GÜNTHER, op. cit. 11S, 1866.

Salmo gairdneri Jordan \& GILeERT, Bull. 16, U. S. Nat. Mus. 313, 18S3; BEAN, Bull. U. S. F. C. IX, 198, pl. XLIX, fig. 9, 1891, not fig. 10. which is young mykiss; Jordax \& Evermans, Bull. 47, U. S. Nat. Mus. 498, 1896, pl. LXXXi, fig. 215, 19nn; RHExex, Third Ann. Rept. N. Y. Comm. Fish. 241, color pi., 1898.

Form of S. s a 1 a r. Body elongate, little complessed, its greatest depth two ninths of the total length without caudal; caudal peduncle short, its least depth three serenths of length of head; head rather short, one fifth of total length without caudal, maxilla reaching far behind the eye, its length one half the length of head; eye small, two thirds of length of snout, two elerenths as long as the head; teeth rather small, romerines in two long, alternating series about as long as the palatine series; gill raker's sliort and stout, about 20 on the first arch, of which 12 are below the angle; dorsal origin much nearer to tip of snout than to base of caudal, base of dolsal two thirds of length of head, longest dorsal ray one half the length of head and twice as long as last ray; adipose fin relr small and narrow, orer the beginuing of the anal; caudal fin moderately forked in the young; rentral origin midway between tip of snout and base of caudal, rentral fin one half the depth of body: anal base one half as long as the head, longest anal ray equal to postorbital part of head; pectoral fin one eighth of total length without caudal. B. 11 or $12 ; 10.11 ;$ A. 12. Scales from 137 to 177 , usually about $150-28$; pyloric cacca 42 ; vertebrae $38+20=$ 58. Color olive green above, sides silvery, lead, back, dorsal 
and caudal tius profusely covered with.smill black spots. no red between the rami of the lower jaw.

The steelhead trout is found in coastwise streamis from southern Califormia to Bristol bay, Alaska. It spawns in the late winter and early spring; ripe eggs werc obtained at Sitlia, Alaska, June 10 . Spent fish of this species are frequently taken with the spring run of the king salmon.

The economic value of the steelhead is rery great; the fish reaches a weight of 30 pounds, though the average weight is under 20 pounds, and the non-anadromous forms seldom excerd 5 or 6 pounds.

From information furnished by Mr Annin it appears erident that some of the eggs of trout receired at Caledonia N. Y. many years ago from the McLeod river, Cal., as rainbows, really included both rainbows and steelheads. He finds certain females producing deep salmon colored eggs, while in the same pond and receiving the same food as other females which furnish rery light colored, almost white, eggs. Some of the females also differ from others in going to the spawning beds nearly two months earlier. It is now known also that the McLeod contains a small-scaled form of the rainbow, known to the Indians as the no-shee, and this also may easily have been sent to the east under the name of rainbow. Striking differences in the appearance and habits of so called rainbows introduced into the various states, lend color to this supposition.

Steelheads were obtained for the New York aquarium in Norember 1896, from the U. S. Fish Commission. They were hatched from eggs shipped from Fort Gaston Cal. to the station at Craig brook, Me. The length of the trout when receired ranged from 4 to $4 \frac{1}{2}$ inches. After one sear they were 10 inches long on the arerage, and weighed many times as much as they did when received. None of them at any time showed a red lateral band such as is present in the rainbow, and they are farther distinguished by the presence of white tips on the rentral and anal fins; the dorsal also has a small white tip. The have been lept almost from their arrival in salt water, and 
could not have been kept in the warm Croton water in June. The salt water nerer rose above $71 \frac{1}{2}^{\circ} \mathrm{F}$ and continued at this high temperature only 10 days.

The N.Y. Fisheries, Game and Forest Commission planted some of these trout in a Long Island stream and some in a lake in northern New York. Those that were planted on Long 1sland, says Mr Cheney, when rather more than a year old rose to the fly of the trout fisherman and made a most gallant fight, but it is too early to tell the outcome of the experiment. The eggs are one fifth of an inch in diameter; they hatch in 42 to 50 days with water at $50^{\circ}$.

\section{Salmo fario Linnaeus \\ Brown Trout (Introduced)}

Salmo fario Linnaeus, Syst. Nat. ed. X, I, 30, 1758; Bloch, Ichth. I, 121, taf. 22, \& 157, taf. 23, 1785; Richaroson, Fauna Bor.-Amer. III, 144, pl. 92, fig. 3, A \& B, 1836; DAY, Fish. Great. Brit. \& Ireland, II, 95, plates CIX, fig. 3, CXIII, CXIV, CXVI, fig.1, 1881; Bean, Fishes Penna. 78, color pl. 6, 1893; Jordan \& Evermann, Check-List Fish. N. A. 512, 1896.

Salmo fario ausonii Günther, Cat. Fish. Brit. Mus. VI, 64, 1866.

Salar ausonii Cuvier \& VAlenciennes, Hist. Nat. Poiss. XXI, 319, pl. 618, 1818.

The brown trout of Europe was introduced into the United States from Germany in February 1883 and in subsequent years; it has now become thoronghly acclimated in the fresh waters of many of the states.

The body of this trout is comparatively short and stout, its greatest depth being contained about four times in the length without the caudal. The caudal peduncle is short and deep, its depth equal to two fifths of the length of the head. The length of the head in adults is one fourth of the total length without caudal or slightly less. The diameter of the eye is about one fifth of the length of the head, and less than length of snout. The dorsal fin is placed nearer to the tip of the snout than to the root of the tail; the longest ray of this fin equals the distance from the eye to the end of the opercle. The rentral is under the posterior part of the dorsal; its length is about one half that of the head. The adipose dorsal is placed orer the end 
of the anal base; it is long and expanded at the end. The candal is emarginate in roung examples, but nearly truncate in specimens 10 inches long. The pectoral is nearly one sixth of the length without the caudal. In the male the jaws are produced, and very old ones have a hook. The maxilla extends to the hind margin of the eje. The triangular head of the romer has a transrerse series of teeth, and the shaft of the bone bears two opposite or alternating series of strong persistent teeth. D. 13-14; A. 10-11; P. 13 ; V. 9 : Scales 25-120-30; pyloric caeca $38-51$; rertebrae $57-58$.

On the head, body and dorsal fin usually numerous red and black spots, the latter circular or X-shaped and some of them with a pale border; a yellowish margin usually present on the front of the dorsal and anal and the outer part of the ventral. The dark spots are few in number below the lateral line. The ground color of the body is brownish or brownish black, varring with food and locality.

Names. In European countries in which this species is natire it bears the name of trout or brook trout or the equivalents of these terms. In Germany it is bachforelle; in Italy, trota; in France, truite. In the United States it is known as the browr trout and ron Behr trout, the latter in honor of Herr von Behr, president of the Deutscher Fischerie Tercin, who has been very active in the acclimation of the fish in America.

Distribution: The brown trout is widely distributed in continental Europe and inhabits lakes as well as streams, specially in Norway and Sweden. Tributaries of the White sea, the Baltic, the Black-sea and the Caspian eontain this species. In Great Britain it lives in lakes and streams and lias reached a high state of perfection; in Germany and Austria, however, the front is a characteristic fish, and our supply has been drawn principally from the former country. Moreau found it at an eleration of 7000 feet in the Pyrenees, and a color variety is native to northern Algeria in about $37^{\circ}$ north latitude. In the United States the brown trout has been successfully reared in Colorado at an elevation of nearly 2 miles above sea level; it is now well 
established in New York, Pennsylvania, Maryland, Missouri, Michigan, Wisconsin, Nebraska, Colorado, and sereral other states. This tront has proved to be well adapted to thr region east of the Rocky mountains, which has no native black spotted species, though the western streams and lakes contain many forms in a high state of development.

Size. Under farorable conditions the brown trout has been credited with a weight of 22 pounds and a length of 35 inches. In New Zealand rivers, where it was introduced with unusual success, it now approximates equal size; but in most localities 10 pounds is about the limit of weight and 5 or 6 pounds is a good average, while in some regions the length seldom exceeds 1 foot and the weight ranges from $\frac{1}{2}$ pound to 1 pound. In the United States a wild specimen, seven year's old, weighed about 11 pounds. In a well in Scotland an individual aged 15 years measured only about 1 foot in length. These illustrations will serve to show how much the growth of a brown trout is affected by its surroundings and food supply. The species has been known to become sexually mature when two years old and 8 inches long.

Habits. The brown trout thrives in clear, cold rapid streams and at the mouths of streams tributary to lakes. In its movements it is swift, and it leaps over obstructions like the salmon. It feeds usually in the morning and evening, is more active during evening and night, and often lies quietly in deep pools or in the shadow of overhanging bushes and trees for hours at a time. It feeds on insects and their larvae, worms, mollusks and small fishes and, like its relative, the rainbow trout, it is fond of the eggs of fishes. In Europe it is described as rising eagerly to the surface in pursuit of gnats and is said to grow more rapidly when fed on insects.

Reproduction. Spawning begins in October and continues through December and sometimes into January. The eggs are from $\frac{1}{5}$ to $\frac{1}{5}$ of an inch in diameter and yellowish or reddish in color; they are deposited at intervals during a period of many days in crevices between stones, under projecting roots of trees, and sometimes in nests excarated by the spawning fishes. The 
parents cover the eggs to some extent with gravel. The hatching period varies according to temperature from 40 to 70 days. Females aged three years furnish on the average about 350 eggs each, but individuals of this age have yielded as many as 700, and even at the age of two years some females produce from 400 to 500 . Then they are four or five years old, the number of eggs has reached 1500 to 2000. The young thrive in water with a temperature of about $50^{\circ}$ F: Sterility in the females is common, and breeding females have been observed to cease reproduction when eight years old.

Qualities. The brown trout is in its prime from Mar to the last of September. Its flesh is rery digestible and nutritious, and deeper red than that of the salmon when suitable food is furnished; the flaror and color, however, vary with food and locality. Insect food produres the most rapid growth and best condition. This species has been so long known as one of the noblest of the game fishes and its adaptability for capture with artificial fies because of its feeding habits is so well understood that I need not drell on these familiar details.

The brown trout is remarkably hardy in captivity. A large female, received from Eugene G. Blackford in April 1896, and placed in a salt-water tank at the aquarium, lived there and throve till 1898. During most of the time the trout was in salt water, but at certain intervals fresh water was substituted for a short time, specially when symptoms of fungus made their appearance. In Norember 1896 she excavated a shallow depression in the gravel bottom and deposited a lot of eggs. The fish was extremely shy, and never lost its fear of the attendants. Tiver and live killifish were used for its food.

1 very beantiful and interesting hybrid is produced by crossing the brown trout and the brook trout. The following is a description of this hybrid:

\section{Salmo (HYBRID=fario fontinalis)}

\section{Hybrid Trout}

In a paper published seven. years ago the writer stated, as a result of his studies, that, when a large-scaled trout is crossed 
with a small-scaled one, the hybrid will be large-scaled whichever way the cross be made. The hybrid between the brown trout and the brook is a large-scaled form, and it is sterile as far as reported. The aquarium has had this hybrid from the South Side Sportsmen's Club, and from the New York hatcheries at Cold Spring Harbor L. 1 . and Caledonia. It is always a strikingly handsome fish, and grows to a large size; but it is far less hardy than either of its parents. The cross has always been artificially made, and never occurs naturally. Two specimens studied gare the following measurements in inches:

MEASUREMENTS

Extreme length

Length of middle caudal rays from end of scales.

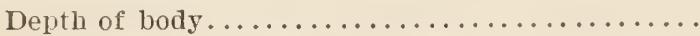

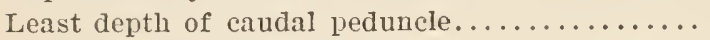

Length of head.

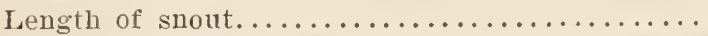

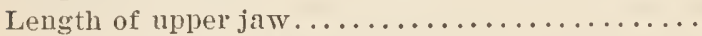

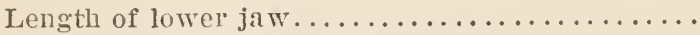

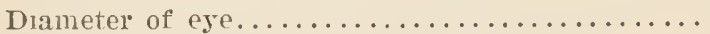

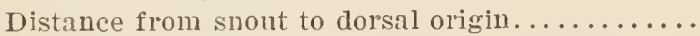

Length of dorsal base.

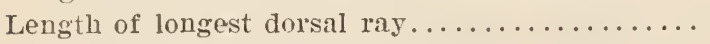

Length of last dorsal ray .................

Distance from snout to rentral origin..........

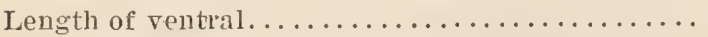

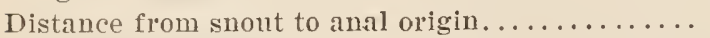

Length of anal base.

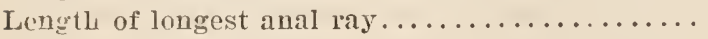

Length of last anal ray. . .
Caledonia N. Y. O.tklale X. Y.

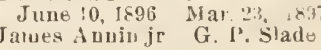

$91 / 4 \quad 141 / 4$

$3 / 4 \quad \ldots$

$17 / 8 \quad 31 / 8$

$7 / 8 \quad \ldots$

$2 \quad 31 / 4$

$1 / 2 \quad 11 / 8$

$11 / 4 \quad \ldots$

$1 \% / 8 \quad \ldots$

$\frac{5}{16} \quad \frac{7}{16}$

$3 \%$...

$1 \frac{3}{16} \quad \ldots$.

$1 \frac{\pi}{16} \quad \ldots$.

$3 / 4 \quad \ldots$.

$41 / 2 \quad \ldots$.

$11 / 8 \quad \ldots$.

6

$7 / 8$

$11 / 4$

$1 / 2$

The Caledonian specimen has no hyoid teeth; the vomerines are in a very small patch on the head of the bone only. The gill rakers are $4+10$, the Iongest about one half the diameter of the eye. It has about 124 tubes in the lateral line. Branchiostegals, 10. The following color notes were taken from the fresh fish. Dorsal fin with numerous dark blotches resembling those of young rainbow; adipose long and slender, amber color with two obscure dusky blotches, one of these very indistinct; lower half of sides pink; rentral, anal and caudal pink; rentral and anal 
with a milk white front margin, that in the anal limited behind by a dark line as in brook trout; sides reticulated with large meshes of lemon yellow interspersed with darker purplish or olive. Dorsal blotches are mingled with pale lemon. Pectoral frale rermilion. Eye silvery white with yellowish reflections.

The specimen from Oakdale $\mathrm{L}$. I. weighed 20 ounces. It has a triangular patch of vomerine teeth, as found in fonti. n a $l$ is, but continued behind by sereral teeth in a single row, the entire length of the romerine series being $\frac{7}{16}$ of an inch.

136 Salmo trutta levenensis (Walker)

\section{Loch Leven Trout (Introduced)}

Sulmo lerenensis Walker, Wern. Mem. I, 541, 1811; YArreld, Brit. Fish. ed. 2, II, 117, 1841; ed. 3, I, 257, fig. 1859; Günther, Cat. Fish. Brit. Mus. VI, 101, 1866; DAY, Fish. Freat Brit. \& Ireland, II, 92, pl. CXVI, fig. ? \& 2a, 1884; BaIrd, Rept. U. S. F. C. XII, LVIII, $18 S 6$.

Salmo trutta levenensis JorDAN \& Evermans, Check-List Fish. N. A. 512, $1 S 96$.

The Loch Leven trout of Great Britain was introduced into the United States from Scotland in 1885 and subsequent years. It is somewhat closely related to the European brown tront, S a Imo f a r i o, and has been artificially crossed with that species in the United States, so that it is sometimes difficnlt to find the pure bred Loch Levens in fish cultural establishments at home.

The body of the Loch Leven is more slender and elongate than that of the brown trout, its greatest depth contained four and one fourth to four and one half times in the total length without caudal. Caudal peduncle slender, its least depth three eighths of the greatest depth of the body, and equal to length of snont and eje combined. The head is rather short and conical, its length two ninths to one fifth of the total length without candal. The snout is one fourth or slightly more than one fourth as long as the head. The interorbital space is somewhat convex, its width equal to three fifths of the length of postorbital part of head. The eye is of moderate size, its long diameter contained five and one half to six times in the length of the head, and equaling about twice the greatest wiath of the 
maxila. The maxilla reaches to or slightly beyomel the hind matgin of the eye. 'Teeth rather strong, those in the intermaxillary and mandible the largest, triangular head of romer with two or three in a transverse series at its base, teeth on the shaft of the vomer usnally in a single, partially zigzag, persistent series. Mandible withont a hook and little produced even in breeding males. Morsal origin distant from tip of snout about as far as chn of dorsal base from base of caudal; the dorsal fin ligher than long, its base one eighth of total length withont caudal, its longest ray equal to longest ray of anal fin. The anal fin is much higher than long, its distance from the base of the ventral enualing length of the head. The rentral origin is nearly nurler the middle of the dorsal; the fin being as long as the postorbital part of the head. Pectoral equals length of leald without the suont. Adipose fin very small, its width one lalf its length which is about equal to eye. Caudal fin cmarginate unless fully extended, when it becomes truncate, the outer rays about one serenth of total length including caudal. 1). 13 (二 iv, 9); A. 12 (- iii, 9); P. 14; V. 9. Scales 24 to 28-118 to 130-26 to 30 ; pyluric caeca 47 to 90 ; vertebrae 56 to 59 .

Upper farts brownish or greenish olive, or sometimes with a ledolish tinges, sides silvery with a valrying mumber of $x$-shalped black spots, or sometimes rounded boown spots or rommded black spots which may be ocellated; occasionally red spots ane secen on the sides, and the arlipose fin may have severall bright oratnge spots, or it maly show a reed redge and sereral dark spots; sidrs of the head with round black spots; dorsal and adipose fins msully with nmmerous small boown spots; tip of pectoral blackish; anal and randal fins unspotterl, but the candal sometimes has an orange matrin and the anal a wite edge with black at its base; a similar edge may sometimes be observed on the ventral.

The Loch leven trout is a nommiglatory species, inhabiting Loch Leren and other lakes of southern scotland and of the north of England. Its range in Great Britain and on the continent of Europe has been greatly extended by fish cultural 


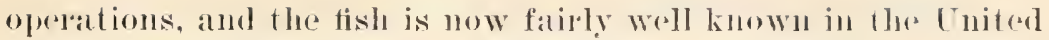
states, though mixed to some rextent with the hown trout, as remarked above.

The Loch Leven trout has berse recordend of the weight of 18 founds, but the arelage weight at 6 years of age is about $t$ pounds, though some individuals of that age may loblell 10 pounds. The matural food of this species includes fresh-water

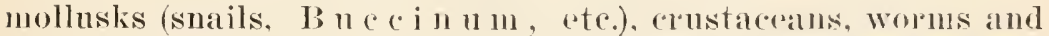
small fish. In captivity it is reared on liver. horse flesh, relopped clams and various other meats.

Is a food fish the Loch leven is highly esteemeel on acoount of the red color and the delicate flaror of its flesh when obtained from suitable waters; in some localities the flesh often becomes white from lack of food or improper food.

The spawning season may begin late in Sejetember or raly in October and continue till 1)ecember. In Michigan it cor $\mathrm{l}^{\circ} \mathrm{C}^{2}$ spouds with that of the brook trout. The eger valies from about $\frac{1}{5}$ to $\frac{1}{4}$ inch in diameter. I trout weighing 2 pounds contained 1944 eggs, the weight of which was $\frac{1}{2}$ pound.

'The Loch Leven will take the artificial $\mathrm{fly}$ as readily as the brown trout and thr brook trout. Its great size and strength add to its attractions for the angler.

\section{1:it Salmo irideus Gibbous \\ Rainbow Trout (Introduced)}

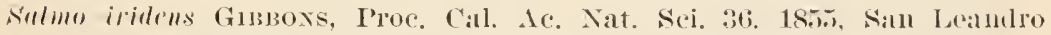
('leek, Alameda County, Cal.; Jordax \& GLbert, Bull. 16, I. S. Nalt. Mus, :312, in part, 18s:; Besx, Bull. U. S. F. O. XII, 36, pl. V. figs. 2 \& :3, 1894; Fishes Penna. 7T, colol pl. Y, 1893; Ann. Rept. X. Y. Comm. Fislı; Jordax of Everuans, Bull, ti, U. S. Nat, Mus, pl. IXXXI, fig. 216, 1900.

Sulmo irideus shasta Jordax \& Evermanx, Bull, 47. U. S. Nat. Mus, 502, 1896.

Body short and deep, its greatest deptl equaling two sevenths of the total length withont caudal. The least depth of caudal peduncle equals one half the length of head. The head is short and decp; its length is contained about four and two thirds times in the total length withont the caudal. The snont is short, 
not much longer than the eye, about one fourth the length of head. Diameter of the eye contained four and two thirds times in length of head; maxilla not quite reaching to below hind margin of eye; romerines in two irregular series; gill rakers about 20. Dorsal origin a little nearer tip of snout than to caudal base. The length of the dorsal base is contained seven and one half times in total without caudal, and slightly exceeds longest dorsal ray; last dorsal ray one half as long as the longest. 'Tentral origin is under middle of dorsal base; the fin is as long as the longest dorsal ray; the ventral appendage about as long as the eye; when the rentral is extended, the distance of its tip from the rent is one third of length of head. The anal base is a little more than one half as long as the head; the longest anal ray equals the longest dorsal ray; the last ray is not quite so long as the eye. Adipose fin short, its width nearly equal to its length and two thirds of diameter of eye. B. 11; D. 11 divided rays and 4 rudiments; A. 10 divided rays and 3 rudiments. Scales 21-135 to 140-20.

The upper parts usually greenish blue, sometimes purplish; the sides more or less silvery and profusely spotted with small black spots, which are most numerous above the lateral line; head, dorsal. adipose, and caudal fins also black spotted. Searun specimens are uniform silvery without black spots. In the breeding stason the broad crimson lateral band becomes brighter, and the sides of both sexes are iridescent purplish. The jaws of the male in the breeding season are not much distorted, but they are very much larger than in the female.

The rainbow trout is a native of the mountain streams of the Pacific coast and ranges from California to southern Alaska. A small example was taken at Sitka, in 1880, by Admiral I. A. Beardslee, U. S. N., and is now in the collection of the U.S. National Museum. This trout is found chiefly in mountain streams west of the Sierra Nevadas. It rarely descends into the lower stretches of the rivers, but occasionally does so and passes out to sea. The rainbow has been extensively introduced into many eastern states, but not with uniform success. In Wisconsin, Michigan, Missouri and North Carolina it has been 
well acclimatized, and it is also fairly established in New York.

The average individuals of this species are less than 1 foot in length, but specimens neasuring more than 2 feet and weighing 1:; pounds have been recorded. At Neosho Mo. the young lave bren artificially grown to a length of nearly 1 foot in a year.

The rainbow feeds on worms, insect larvae and salmon eggs. In streams in which the California salmon and raimbow exist together, the rainbow is more destructive to the salmon eggs than any other species. Spawning takes place in winter and early spring; varying with temperature and locality. The bulk of the eggs are usually taken in January, February and March, and the average yield from each female is about 900 eggs. A few of the females spawn when two years old, but about one half of them begin at three years. The egg is from $\frac{1}{5}$ to $\frac{2}{9}$ inch in diameter; it has a rich cream color when first taken, changing to pink or flesh color before hatching.

The rainbow will live in water of a much higher temperature than the brook trout will endure and it thrives in tidal streams and even in salt water. On Long Island, for example, the Soutlı Side Sportsmen's Club obtains a great deal of fine sport with this trout in the estuary of its trout brook. The flesh of the rainbow is generally muth esteemed, and in most localities the game qualities of the fisl are scarcely inferior to those of the brook trout.

Large rainbow trout do not stand transportation well when ice is used to cool the water in which they are carried. They frequently injure their eyes, and become blind soon after the end of a journey. They are inveterate fighters, and the strongest invariably rules and harasses the rest. Contrary to what has been stated heretofore, they will not endure high temperatures as well as the brook trout, at least in the aquarium.

\section{Salmo lemanus Curier}

\section{Swiss Lalie Trout (Introduced)}

Salmo lemanus Cuvier, Régne Anim. fide Günther; Günriner, Cat. Fish. Brit. Mus. VI, 81, 1866.

Salmo trutta Jurine, Mém. Soc. P'hys. Genève, III, 1, 15S, pl. 4, 1825. 
Furio lemanus Covier of Valexciennes, Hist. Nat. Poiss. XXI, 300, pl. 617 (male) 1S1S.

Swiss lake trout AtKINs, Rept. U. S. F. C. XVII, XVII, XIX, 1893 and 1804.

Head well poportioned in its shafe, of moderate size, hody

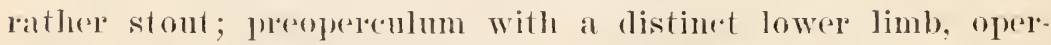
('ulum rather hroad and high; suout of moderate length, rather produced in the male sex, in which a mandibular hook is developed in thr spawning season; maxillary longer than the snout, and at least as strong and broad as in s. f a r i o; in specimens 12 inches long it extends somewhat behind the vertical from the lind margin of the orbit. 'Teeth moderately strong, those on the romer in a single series, alternately bent toward the right and left, persistent throughout life. Pectoral fin roumderl, its length being less, and in young individuals more than, one latf of its distance from the ventral. The caudal becomes trum. cate with age; in specimens of from 12 to 15 inclues in lengtl it is emarginate, the middle rays being half as long as the outer ones. The hind part of the body of moderate depth; there are 13 or 14 seales in a transverse series descending from behind the adipose fin forward to the lateral line.

Back greenish, sides and belly silvery, mumerous vere small X-shaped hlack spots on the sides; opereles and dorsal fin with numerous black dots; the other fins greenish. 1). 13; A. 12; P. 14; T. 9. Suales 26 to $28-115$ to $128-36$; pyloric caeca $45-52$; vertebrae 57 (once), 5S-59. (After Gïnther)

Attempts liave bren made from time to time to introduce into large, cold lakes of the United States the fine lake tront of Lake Genera, switzerland. Eggs have been furnished to the U.S. Fish Commission by the Swiss govermment, and these were hatched at the craig brook (Me.) station, and from there the young were distributed to lakes believed to be suitable for the experiment. In New York, the Adirondack Teague Club obtained 1000 of the young of this species in 1896 and deposited them in Green lake, in Herkiner county. The specimen described below is probably one of the results of that experiment. Swiss lake trout were furnished also to the New York Fish Com- 
mission for planting in Lake George, and 100 yearlings were presented to the New York aquarimm.

I specimen taken in Green lake, Adirondack Isague Club freserer, Herkimer (*0., Inly ï!), 1899, was forwarded to the I. S. Fish ('ommission, Washington 1). C., and there described by 1) W. C. Kondall, from whose notes the following account is draw1.

The total length of the specimen is $11 \frac{3}{8}$ inches. When first

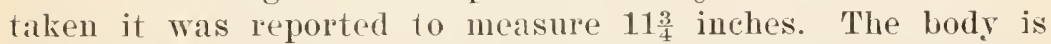
modrately elongate, its greatest depth contained three and thee fiftles times in the total length to base of caudal. Head laloge, slightly mole than one third of total length to base of ratudal: ryr rather larore aloout ome fiftl of lengtl of liead; suont long, about three tentlis of length of head; teeth on jaws, balitines and tongue long, curved and sharp, those of the lower jaw longest, shaft of vomer long with a zigzag row of sharp treth; gill rakers short, the longest one third of diameter of iris, $4+11$ on right side, $5+10$ on left side. Hight of longest lorsal ray two thirds of length of head. Pectoral five eighths as long as the heal. P. 11-12, 1. ii, 9; A. i, 8. Srales in latelal line 115.

General appearance of Sa 1 mo sa 1 ar se bago, from which it would probably not be distinguished by the casual observer. if caught where the landlocked salmon occurs; but the le $u$ a $u \mathrm{us}$ is distingmishable by the heavier appearance for. ward of the dorsal fin.

Color in spirits, brownish on hack, top of head and sides of head; sides and belly rery silvery; large roundish blark spots above lateral line forward and on cheeks and opereles; perpendienlarly elongate spots forward below lateral line; black of all spots most intense on edges of scales; posteriorly the spots show only on the edges of the scales, being variously crescentic, double or triple crescentic, $\mathbf{X}$ or double $\mathbf{X}$ shaped; fins piale with slightly dusky tinge; dorsal with 5 transverse rows of black spots.

Mr De Witt, who sent the specimen, furnished the following notes on Green lake, from wlence it was forwarded. "Maximum deptl 42 feet, with temperature at bottom at that deptl, as far as I have been able to ascertain, about $40^{\circ}$. Has no 
outlet so far as we know. No brown trout have ever been put in it, and we take it for granted that the specimen I send is one of the "Swiss trout."

\section{Genus crs'tromen Gill \& Jordan}

This genus contins one or two species, large, coarse chars, distinguished from $\mathrm{S}$ a $\mathrm{l}$ velin $\mathrm{i}$ s by the presence of a raised crest behind the head of the vomer and free from the shaft; this crest is armed with teeth. The hyoid teeth constitute a strong, cardiform baud. The typical species is a large char or trout, spotted with gray instead of red, and found in the larger lakes of eastern North America. (After Jordan and Fvermann)

The species $\mathbf{n a m}$ a $\mathrm{ycus}$ c is found also in a lake (Henry) in Idaho, in the Columbia river basin, and northwestward to northern Alaska.

\section{Cristivomer namaycush (Walbaum)}

\section{Lake Trout; Salmon Trout}

Salmo namaycush Walbaum, Artedi. Gen. Pisc. III, 68, 1792. Hudson Bay, based on the Namaycush Salmon of Pennant; Richardon, Fauna Bor.-Amer. III, 179, pl. 79 \& pl. 85, fig. 1, 1836, Great Lakes; Tiompson, Nat. Hist. Vermont, I, 140, figure, 1842; Kintuand, Bost. Jour. Nat. Hist. IV, 25, pl. III, fig. 2, 1844; GüNTHER, Cat. Fish. Brit. Mus. $\mathrm{VI}, 123,1866$.

Salmo pallidus Rafinesque, Amer. Month. Mag. II, 120, December, 1817.

Lake George, Lake Champlain and other lakes; not ascending brooks. Salmo amethystinus Mitcinls, Jour. Ac. Nat. Sci. Phila. I, 410, 1818. Salmo hoodii Ricliaroson, op. cit. 17, pl. 82, fig. 2, pl. 83, fig. 2, 1836. Salmo confinis De IAY, N. Y. Fauna, Fishes, 238, pl. 3S, fig. 123, 1842. Salmo amethystus DE IIAY, op. cit. 210, pl. 76, fig. 241.

S'almo adirondacus Norris, American Angler's Book, 255, 1865. Salmo sisconcet Günther, Cat. Fish. Brit. Mus, VI, 124, 1866.

Salvclinus namaycush JordaN \& Gilbert, Bull, 16, U. S. Nat. Mus. 317 , 1883; Goode, Fish. \& Fish. Ind. U. S. I, 485, pl. 191B, 1884; BEAN, Fishes Penna. 82, color pl. 8, 1893.

Cristivomer namaycush Jordan \& Evermann, Bull. 47, U. S. Nat. Mus. 504, 1896, pl. LxXXII, fig. 217, 1900; Bean, Bull. Amer. Mus. Nat. Hist. IX, 348, 1597 .

The lake trout or Namaycush has a stout and moderately elongate body. The caudal peduncle is slender; its hight little more than one third of the greatest hight of the fish. The eye is large, placed near the top of the head, two thirds as long as 
the snout, and contained four and a half to five and a half times in length of head. The maxilla reaches far behind the eye; its length nearly half that of head. The origin of the dorsal is midway between tip of snout and root of tail. The Iongth of the base equals length of maxilla; its longest ray one sixth of total without caudal. The ventral is under the lind part of dorsal; its length half the length of head. 'The appendage is very short, about half the length of eye. The fin, when extended, reaches nearly to the rent. The distance between rentral origin and anal origin is one fifth of total length without caudal. The anal base is about one third of length of head; the longest ray half of length of head; the last ray equal to eye. The pectoral is nearly two thirds as long as the head. B. 11 to 12 ; D. 9 to 10 besides sereral rudiments; A. 9 and several rudiments; V. 9. Scales of lateral line about 200 .

The coloration is extremely variable, generally grayish, in the variety known as the tuladi, nearly black. Alaskan specimens are usually rery dark; occasionally the upper parts are pale. The sides are profusely covered with roundish pale spots, sometimes with a reddish tinge. On the back and top of head there are fine vermiculations resembling those of the brook trout. The caudal in addition to numerous pale spots has many small dark blotehes.

The lake trout has receired many names, among which are the following: Mackinaw, Namaycush, togue, tuladi, and salmon trout. Additional names of the species are lunge, red trout, gray trout, and black salmon. Togue and tuladi are names applied in Maine, New Brunswick and Canada; Mackinaw and salmon tront in the Great lakes region, the latter used also in New York. Namaycush is of course an Indian name.

The lake tront is native in the Great lakes region, lakes of New York and New England, Idaho and northward into Labrador, British America and Alaska. Extending orer such a wide range of country, it varies greatly in size, form and color, which will in part account for the various names which it has received. It has been found above the Arctic circle in Alaska. 
This is one of the largest species of the salmon family resilent in fresh waters. It reaches a length of 3 feet, and specimens weighing 40 ponmes are not mucommon. It is said that all example of 90 pomuls and 6 fort in length has been taken. The species is fommel in its best comdition in Lakes Huron, Michigan and Superior. In Alaska it grows to a large size, and is a very shapely and beantifully colored fish.

The lake trout is one of the most rapacions fishes of its family. In Lake Michigan it feeds largely on the cisco and other snull whitefishes. It Two Rivers Wis. a lake trout measuring 23 inclies was found to contain a burbot about 17 inches long. The gluttony of this species is proverbial. It will devour table refuse, and materials of this kind have frequently been taken from its stomach. Even twigs, leaves and pieces of wood have been taken by this trout. The species is much more sluggish in its habits than the brook trout, and is taken on or near the bottom. The gill and pound nets in which this species is princibally raptured arreset in deep water.

The spawning of the lake trout usmally begins in October and continues into November. For this purpose they rome up on rorky slioals and rerefs in depths of from 70 to 90 feet, and spawn near the edgrs of rock carerns, into which the eggs settle. The young are hatched late in the winter or carly in spring. In some localities the depth of the spawning areas ranges from 15 fathoms to only 7 feet. Mr Milner found 14,94: eggs in a lake trout weighing 24 poumds. In the latchery, with a water temperature of $47^{\circ}$, the yomug hatrh about the last week of January, but their hatching may be retarded several weeks by lower temperatures.

The fishery for the lake tront is nost active in September, October and Norember, and the fish are taken chiefly in pound and gill nets. In some regions many of them also are caught with hooks. In Lake Erie a few large trout of this species weighing from 25 to 40 pounds are taken off the city of Erie. In 1855, according to the statisties of the U. S. Fish Commission, 100,(000 poumds of lake tront were taken in Eric county, Pa. 
The only New Jork examples of lake trout wre beceived from James Inmin jr, Calodonia, in the fall of 1896. 'They lived and Exel rapilly till the wallu watre killed them in June 1897. 'They rould not rendule tramsfore lo salt watele of a lowel temenele-

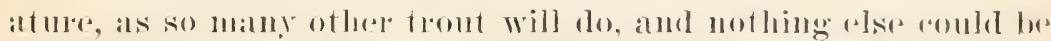
utilized to tide them ores till the completion of the refrigerating plant.

Owing to the extensive individual and raee variation among trout roforeded to this species, it srems desirable lope to gire some notes and neasurements male from individuals obtained from New Hampline and Vermont. Two lake trout weighing about 4 poumds earle were shipped in a can only a few inches longer than the fish, from Roxbury Vt. November 17, and, after an express jonluney of 20 homs witlont an attendant, one of them survired in good condition, while the other was nearly drat on arrival and died within one hour. The latter was a female, and appears to have injured itself severely by jumping in the can; it was not in good condition whrn it left V'ermont. 12 large brook trout shipped with the lake trout in two cans arrived without injury; these and the lake tront were presented lyy John W. 'Titcomb, Fish and Game Commissioner.

Commissioner X. Wentworth of Hudson Center N. H. forwarded the New Hampshire lake trout, one from Newfound lake, the other from Iake Winnepesanke. They were sent to determine whether the trout of the two lakes, which the fisliermen assert are different species, really are distinct. The commissioner wote that "the Newfound tront las darker flesh, more like the sea salmon. This is not caused by their food, as both lakes are alive with smelt. 'The Wimmepesaukee lake trout are better hiters; lons of them are caught through the ice every winter. The Newfound tront are hardly ever caught through the ice. I few were caught last winter for the first time to my linowledge. I am sure there is but one variety of lake trout in Newfound lake. We had one in our tanks this fall that wonle weigh ex pommls." The only differences to be foumd on examination were such as relate to the depths at which 
the two races habitually live; one is the slim, dark colored tuladi, and the other the common lake trout of the Great lakes region.

It is necessary, however, to call attention to the lake trout from northern Vermont which furnished one of the series of measurements given below. The gill rakers in that example are few in number and unusually short, four or five on each side being rednced to mere spiny tubercles.

The following table gives dimensious in inches.

MEASUREMENTS

Length, including caudal.............

Length to base of middle caudal rays.....

Least depth of caudal peduncle..........

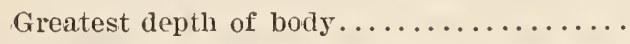

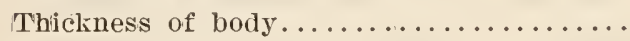

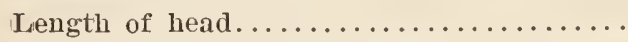

Length of snont $\ldots \ldots \ldots \ldots \ldots \ldots \ldots \ldots$

Length of postorbital part of head........

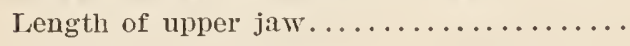

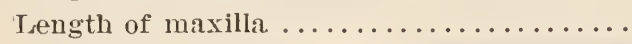

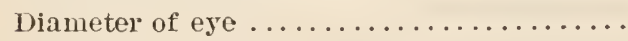

Interorbital width $\ldots \ldots \ldots \ldots \ldots \ldots \ldots \ldots$

Diștance from snout to dorsal...........

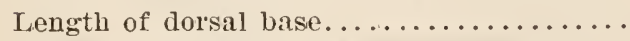

Length of longest dorsal ray............

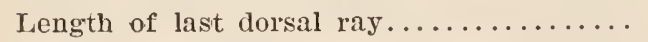

From end of dorsal to adipose fin........

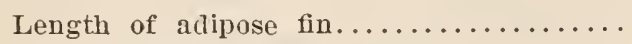

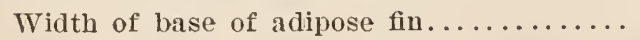

Distance from suout to ventral..........

Length of longest ventral ray...........

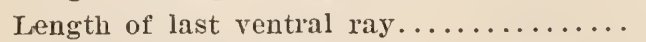

Length of ventral appendage............

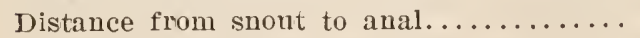

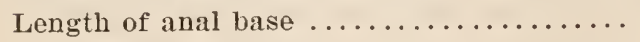

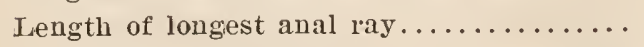

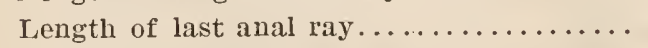

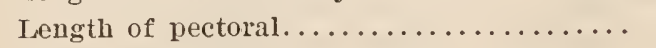

Length of upper caudal lobe.............

Length of lower caudal lobe............

Iength of longest gill raker.
Newfound WInniplseo- Roxbury lake gee lake vt.

o $\hat{0}$ 우

$211 / 2 \quad 271 / 8 \quad 22$

$21 \quad 23 \% / 8 \quad 191 / 2$

$15 / 8 \quad 17 / 8 \quad \ldots$.

$45 / 8 \quad 63 / 8 \quad 41 / 2$

$23 / 4 \quad 2 \% \quad 23 \%$

$53 / 8 \quad 61 / 2 \quad 41 / 4$

$11 / 4 \quad 1 \% / \frac{1}{4} \quad 1 / 8$

$31 / 4 \quad 37 / 8 \quad 21 / 2$

$2 \% / 4 \quad 3 \% / 8 \quad 23$

$\begin{array}{lll}21 / 4 & 3 & 2\end{array}$

$3 / 4 \quad 5 / 8$

$15 / 8 \quad 23 / 8 \quad 11 / 5$

$10 \% / 4 \quad 125 / 8 \quad 10$

$25 / 5 \quad 21 / 2 \quad 21 / 8$

$3 \quad 23 / 4 \quad 23$

$11 / 2 \quad 13 / 8 \quad 11 / 8$

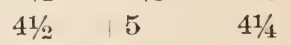

$3 / 4 \quad 1 \quad 3 / 4$

$3 / 8 \quad \frac{9}{16} \quad 3 / 8$

$121 / 4 \quad 14 \% / 8 \quad 115 / 8$

$25 / 8 \quad 27 / 8 \quad 23 / 8$

$13 / 8 \quad 11 / 2 \quad \ldots$.

$\begin{array}{rrr}3 / 4 & 3 / 8 & 5 / 3 \\ 16 & 18 \% / 8 & 151 / 2\end{array}$

$2 \quad 23 / 8 \quad 1 \%$

$23 / 4 \quad 21 / 2 \quad 21 / 2$

$1 \quad 1 \quad 3 / 4$

$31 / 2 \quad 31 / 2 \quad 31 / 4$

$33 / 4 \quad 33 / 4 \quad \ldots$.

$31 / 2 \quad 37 / 8 \quad \ldots$

7. $\frac{7}{16}$ मक 
In the Newfound lalie fish we lave:

F. 11; 1). 11; A. 10 (comnting divirled rays on!y); V. i, S; L'. i, 12. Scales 26-195-34 (about 150 tubes); gill rikers, 9+13, the longrst a little more than one late the length of eye, the one in the angle duh-shaped at the tip. It is a male with spermaries mod(rately small but soft. 'Tle body is glay, darker ou the back. The onter alge of the pectoral and ventral and the fiont nargin of the anal ale white as in fontina $\mathrm{lis}$. I white tip to the lower atudal lobe and a very small one at the top of the dorsal. Otherwise the coloration is like that of ordinary lake trout, which have the pectoral, rentral and amal chiefly vermilion iu the breeding season.

The male from Winnepesaukee lake has:

B. 12 to 13 ; D. $10 ;$ A. $10 ;$ V. i, 8 ; P. 12 . Gill rakers $S+12$, the longest about one half as long as the eye. The ground color is a little lighter than in the Newfound lake trout, and the vermilion of the pectorals, ventrals and anal is less intense. The spermaries are larger than in the specimen from Newfound, and in about the same stage of development; the body is considerably stouter.

The female flom Roxluury Vt. shows the following additional chal'acters.

B. 12 ; D. 10 ; A. $10 ;$ V. i, S. Gill rakers $8+12$, the longest exactly one half as $l o n g$ as the eye. The eggs and ovaries arc sulall as in young females. The pectorals, ventrals and anal are rhiefly vermilion, as in the male from Newfound lake. The body is silvery gray with numbrous small. whitish spots, these present also on the dorsal.

Hon. IT. W. Sage is anthority for the information that the lake tront was formerly conmon in the lake near Ithaca. Abont 1830 a large individual was found stranded in Cayuga lalke inlot, about $1 \frac{1}{2}$ miles from the lake.

\section{Genus sabversts (Nilsson) Richardson}

Body moderately elongate; mouth large or small; teeth of jaws, palatines, and tongue essontially as in $\mathrm{s}$ a $1 \mathrm{mo}$, the hyoid patch present or not; vomer boat-shaped, the shaft much de- 
pressed, without raised resst, with tereth ou the head of the bone and inone on the slaft: seales rely small, 200 to 250 in a lengthwise series; fins moderate, the caudal forked in the young, truncate in some species in the adult; sexual peculiarities not strongly marked, the males with the premaxillaries enlarged and a fleshy projection at the tip of the lower jaw. Coloration dark, with round, crimson spots, the lower fins sometimes with marginal bands of black, reddish, and pale. Species numerous in the clear streaus and lakes of the northern parts of both contincuts, sometimes descending to the sea, where they lose their variegated colors and become nearly plain and silvery. The members of this genus are by fal the most active and handsome of the trout, and live in the coldest, clearest and most secluded Watcrs. (After Jordan and Evermann)

\section{Salvelinus fontinalis (Mitchill)}

\section{Brook: Trout}

Salmo fontinalis Mitcutle, Trans. Lit. \& Phil. Soc. N. Y. I, 435, 1815, near New York; Iirchindoson, Fauna Bor.-Amer. III, 176, pl. \&3, fig. 1, 1836; De İAY, N. Y. Famma, Fishes, 235, pl. 3S, fig. 120, 1842; Güntner, Cat. Fish. Brit. Mus. VI, 152, 1566.

Salmo canadensis IIAwluton Smiti in Griffith's Cuvier, X, 474, 1834,

Canada.

Sulmo immaculatus H. R. STorer, Bost. Jour. Nat. Hist. VI, 364, 1850, lower

Sit Iawrences.

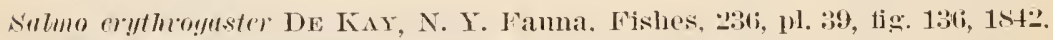
Buione fomtinalis DE KAy, op. cit. 24t. pl. 20, fig. 58, 1842.

salurlinus fontinnlis Joruan, Proc. T. S. Nat. Mus. I, 81, 1S78, in part;

Jompan \& Gument, Bull. 16, U. S. Nat. Mus. 320, 18S3; Goode, Fish \& Fish. Ind. U. S. I, 497, pl. 192, 1S84; BEAx, Fishes Penna. So, color pl. 7. 1893; Inul. Amer. Mus. Nat. Hist. IX, 350, 1897; Bowers. Manual Fish Cult. ed. 2, color pl. frontispiece, 1900; Jordax \& Evermans, Bull. 47, U. s. Nat. Mus. 506, pl. TAXXII, fig. 21S, 1900.

The brook trout varies greatly in the shape of the body, which is somotimes short and deep and again clongate and moderately thin. The depth is nsually about one fourth or two ninths total length without raudal, and is about equal to length of head. The least depth of the caudal peduncle is a little more than one third of its greatest depth. The head is large and the snout somewhat obiuse. The eve is in front of tho middle of its length, a little more than one half as long as the suout, and about one 
sixth of length of head. 'l'he dorsal fin is about mirlway betwe'en tije of smout and root of tail. The length of its base rquals about half its greatrest depth of body. The longest ray equals length of ventral. The rentral origin is a little behind the middle of the dorsal. In the male, when laid backward, it leatches nearly to the vant. The length of the appendage reguals that of the eye. 'Tlo' anal base is two thinds as long as the rentral, its longest lay equal to rentral. The alipose fin is sholet and stout, its width 1 wo thiods of its length and about two thirds of length of ("ve. 1). $10 ; .1$. ). Scales in lateral line 205 to $2: 35$; six gill raliel's above the angle of the first arch; 11. bulow.

The coloration is limbly variable with age and locality. The uplel pals are nsually grayish murh mottled with dark olive or black. The dorsal fin and anterior part of caudal base and top of head are also mottled. The caudal has narow dark bals. 'The Iower fins dusky with a creamy white interior edge bound behind by a narow black streak. On the sides numerous pale brownish blotches encircle small vermilion spots.

The brook or speckled trout of the east is indigenous to the region rast of the Alleghany momtains and the Great lakes legion, "xteuling from North Carolina on the somtl to Labrador on the north. 'The distribution of this trout has been wonderefully axtemeded by atificial infouduction, as it has always bran a favolite with tish culturists. It is now to be found thriving in many of tho western states and territories, and is palticularly theifty in Nobuaska, Colorado, Norada, and cali-

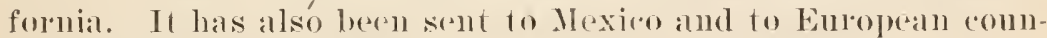

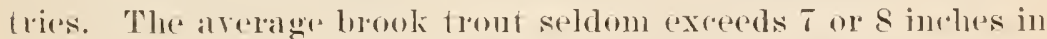
length, and smallere individuals ale much more abmolant and require legal protection. In the northeastern part of its habitat the brook trout grows much larger, specinems weighing from : to 6 pounds being not uncommon; and in one of the Rangeley lakes an individual weighing 11 pounds is recorded; while Seth Green took a 12 ponnd specimen in the Sault Ste Marie, and Hallock mentions one which was said to weigh 17 pounds. 
The brook trout does not flomish in water warmer than $68^{\circ}$, and prefers a temperature of about $50^{\circ}$. It is an inhabitant of the cold, clear monntain streams, and will leave a region which becomes polluted by mill refuse and other hurtful substances. In the Long Island region and around Cape Cod, where the brook trout has free access to salt water, it has the habit of going to sea in the fall and remaining during the winter. It then grows rapidly and becomes a much more beautiful fish than many which live exclusively in fresh water. In hot weather, when the temperature of the streams becomes too high and lakes are accessible, trout seek the deep parts of the lakes and the vicinity of cold springs. In streams they are to be found in deep pools or in channels. They feed in spring and early summer among the rapids on insects and small crustaceans.

The brook trout is a nest-builder. Cavities are made in the gravel, and the nest is shaped with the tail, and the larger stones are carried in the months of the parents. After the eggs are deposited, they are covered with gravel. The eggs are not all deposited at one time. Spawning usually begins in October, but brook trout are spawning at some locality in almost every month of the year except midsummer. The egeg is about $\frac{1}{5}$ inch in diameter, and varies in color from pale lemon to orange red. The arerage yield of the female is from 400 to 600 . Livingston Stone has taken 1800 from a fish weighing 1 pound.

The period of hatching will depend on the temperature, langing from 165 days in water of $37^{\circ}$ to 32 days in water of $54^{\circ}$. The yolk sack is absorbed in from 30 to 80 days, and after its absorption the young fish begin to feed. The rate of growth will of course depend on the amount of food consumed. In artificial culture yearlings, according to $\mathrm{Mr}$ Ainsworth's estimate, will average 2 ounces; fish of two vears 4 ounces; of three years, $S$ ounces, and of four years, 1 pound.

The value of the brook trout as a food fish and its game qualities are so well known that I need hardly refer to them here.

The brook trout is well adapted to domestication in aquarium tauks; it soon orercomes its fear of moring objects, talies its 
food regulary, and is always attractive because of its beauty and graceful movements. It will live in fresh and salt water. When it is attacked by fungus in fresh water, the parasite is easily killed by introducing salt water, gradually increasing in salinity, and the trout is not at all injured or inconvenienced by the treatment. In captivity the food consists almost entirely of chopped hard clams and liver for the young, while hard clams, live killifish and occasional earthworms are given to the large fish. The increase in size with such feeding is remarkable. A brook tront, from Caledonia N. Y., not more than $3 \frac{1}{2}$ inches long in November 1896, measured $12 \frac{1}{4}$ inches in length and $3 \frac{1}{2}$ inches in depth Deec. 10, 1897 .

A single young brook trout from Caledonia survived in water at $76^{\circ} \mathrm{F}$ but that temperature was generally fatal to the species.

Dr Jeck has found the tront in small streams on the uplands throughout the Cayuga lake basin.

Mitchill knew this fish chiefly as an inhabitant of Long Island waters, and has given an interesting account of the fishing at Nichols, Patchogue and Fire Place, where a Mr Robbins, in 12 days in the summer of 1814 , caught 190 trout weighing 139 pounds, 11 ounces. The largest at Patchogue weighed $2 \frac{1}{2}$ pounds, the largest at Fire Place, : pounds. A Mr Purvis of New York, caught a trout measuring 24 inches and weighing $4 \frac{1}{2}$ pounds at Fire Place.

At that time, according to Mitchill, the trout was " bought at the extravagant price of a quarter of a dollar for a single fish not more than $10 \mathrm{Or} 12$ inches long," and New York anglers traveled "away to Hempstead and Islip for the pleasure of catching and eating him."

\section{Salvelinus alpinus (Linnaeus)}

\section{saibling (Introduced)}

Salmo alpinus Lixxafes, Syst. Nat. ed. X, I, 309, 1758, Iaplanrl. West Grothland.

Salmo salvelinus Lixnaeus, op. et loc. cit. Lintz in Austria.

Salmo salmarimus Livnaeus, op. cit. $310,1758$.

Salmo umbla Linnaeus, op. cit. 310,1758 , Lakes of Switzerland and Italy: Salmo ascanii Cuvier \& Valenciennes, Hist. Nat. Poiss. XXI, 256. 1848. 
Salmo rivalis Gaimard, Voyage en Island, Groenland, pl. 15, 1S5̃1, Iceland. Salmo willughbii GüNther, Proc. Zool. Soc. 46, 1S62, Lake Windermere. Salmo grayi Günther, Proc. Zool. Soc. 51, 1862, Lough Melvin, Ireland. Salmo colii Günther, Proc. Zool. Soc. 12, 1863, Lough Esk.

Salmo perisii Günther, Ann. \& Mag. Nat. Hist. XV, 75, 1865, North Wales. Salmo killinensis Güxrher, Proc. Zool. Soc. 699, 1865; Loch Killin, Inverness.

Salvelinus alpims BeAx, Proc. U. S. Nat. Mus. Sterling Lake, New York \& New Jersey; Jordax \& Evermanx, Check-List Fish. X. A. 293, 1896; and Bull. 47, U. S. Nat. Mus. 508, 1896.

\section{Salvelinus alpinus (Iimnaeus)}

Sälbling; Saibling (Introduced)

Body moderately elongate, compressed, its greatest depth two ninths of total length to caudal base; the caudal peduncle short and stout, its least depth two fifths of length of head; head rather short, its length contained flom four and one third to four and one half times in total length to base of caudal (middle candal rays). The body is somewhat elevated at the nape and for a short distance behind it. Mouth large, the maxilla reaching somewhat behind eye, its greatest width less than one fourth of its length, the upper jaw one half as long as the head; eye rather large, nearly equal to snont, one fifth of length of head; interorbital space convex, one and one half times diameter of eye; lower jaw rery slightly projecting; vomerine teeth in a very small patch on the head of the bone, lingual teeth strong; teeth on both jaws well developed, those of the mandible strongest; gill rakers short, straight, very slender, the longest one half as long as the eye, 11 abore and 14 below the angle of the first arch.

The dorsal origin is nearer to tip of snout than to base of caudal, its distance from the snout equaling twice the length of head; the dorsal base is as long as the postorbital part of head; the longest dorsal ray is two thirds as long as the head, and nearly twice as long as the last ray. Adipose fin twice as long as wide, as long as the iris, its origin distant from base of middle caudal rays a space equal to length of head without the snout; the fin is over the end of anal base. Ventral midway between tip of snout and base of middle caudal 
rays, its length two thirds of length of head; its appendage as long as the eye. Anal fin distant from rentral origin a space equal to length of head; anal base as long as snout and eye combined; longest anal ray rqual to rentral and nearly two and one half times last anal ray. Pectoral as long as the head without the snout. Caudal well forked. its onter rays about as long as the pectoral fin.

Color of the upper parts dark gray or greenish, thr sides with a silvery shade passing into a deep led or orange on the lower half and, specially, the belly; red spots on the sides: lower fins margined with white and a blackish shade within the margin; sides of the head silvery; dorsal and caudal fins uniform dusky, unspotted.

The saibling has been introduced into the United States, and a specimen was obtained from Sterling lake, X. T., Dec. 29, 1 SSS. This was presented by A. S. Hewitt jr to Eugene G. Blackford of New York city, and by him forwarded to the U. S. National Museum for identification and preservation. The specimen is $9 \frac{3}{5}$ inches long. It does not differ in any way from European specimens with which it has been compared, as may be seen from the following description.

The greatest hight of the body equals two ninths of the total length without caudal; the least hight of the caudal peduncle is two fiftlis of greatest depth of body and one third of length of head. Head large, one fourth of total length without caudal; snout equal to eye, four in lead; maxilla extending to slight!y behind orbit, its width nearly one fourtl of its length; mandible slightly projecting. Dorsal origin nearer to tip of snout than to base of caudal; base of dorsal one half as long as the head; longest dorsal ray equal to pectoral and nearly two thirds of length of head; last dorsal ray one third of length of head. Adipose fin over the last two or three anal rays, its length about equal to diameter of iris. The ventral origin is under the fifth or sixth divided ray of the dorsal; the fin is as long as the postorbital part of the head; its appendage is not quite one third as long as the fin, and equals the diameter of the iris. 
The anal base is four ninths as long as the head; the last ray of the fin is one half as long as the longest, which is one lialf as long as the head. The pectoral reaches almost to below the origin of the dorsal, its length two thirds of length of head. Candal deeply forked, its middle rays less than one half as long as the outer, which are equal to length of head without the snout.

The fish is an immature male with abont 10 oblong parr marks on the sides and with a few narrow dark blotches simulating lalf bands on the back from near the nape to a point belind the dorsal fin; numerous pale spots along the middle of the sides, each of which no doubt had a vermilion spot in the center in life.

Sterling lake is in New York and New Jersey; and it was stated that the trout are found in streams emptying into the lake. This is noteworthy as being the only instance, as far as known, of successful introduction of the saibling into our waters.

\section{4: Salvelinus alpinus aureolus (Bean)}

sumapee Trout: Golden Trout: Sitrer Trout (Introduced) Sulvelinus unreolus BeAN, Proc. U. S. Nat. II New Hampshire.

Salcelimus alpinus aureolus Jordan, Forest it Stream, Jan. 22. 1891; Quackexbos, Trans. N. Y. Ac. Sci. XII, 139, 1893; Jordan \& EverMANN, Bull. 47, U. S. Nat. Mus. 511, 1896, pl. LXXXIrI, fig. 220, 1900. S'ulmo ulpimus Garman, American Angler, Feb. 5, 1891.

The type of the description, no. 393:34, was obtained in sunapee lake, N. H., in the fall of 1887 by Dr John D. Quackenbos.

The length of the specimen to the candal base is $6 \frac{2}{5}$ inches. The greatest hight of the body equals the length of the head, and is contained about four times in the total withont caudal. The least hight of the tail equals one third the length of the head. The maxilla reaches past the middle, but not to the end of the ere; its length is contained about two and two thirds times in length of head. The lengtl of the upper jaw is contained about two and one third times in the length of the head, and is equal to the longest anal ray. The eve is a little longer than 
the suout, and js contained font and two seventh times in the length of the head. Hyoid reoth well dereloped. The first dorsal is a little neatere the tip of suont than to the hase of candal, and the length of its base is one hatf the lemello of the lead. The adipose dorsal is distant foom end of first dorsal a space equal to twice the length of the ventral. The anal is at a distance from the snont requal to about thees limes the length of the head. The longest anal ray is equal to the length of the

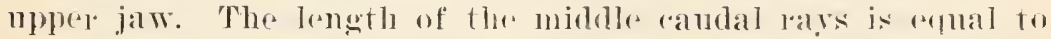
twier the diameter of the "re. The rentral is sitnated midway between the tip of thre suout and atudal batse; its fregth equals one half the length of the hearl. The hength of the pectoral is about twice the widtl of the interebital area. B. 10: 1). iv, 9; 1. iii, s; P. 13; V. 9. Seales 35-210-40; gill rakers 1 i 10-12. The peculiarity of the gill rakeres of this tromt is that they are always (moled mp at the rouds and not straght, as in the 0 1) 11 a $s$ s a from Maimr.

Sides silvery white. Bark with abont six woll detined

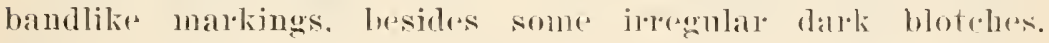
There are about 10 pare malks om the sides, and mumerous small, roundish, white spots. In rolors this rhar is different from the o q 11 a s a from Maine. but, if fresh specincens of the Maine tront were compared with this ronng fish. the difference in rolor might not be so great.

The sporimen described is a young male with the spermaries showing as a mere slight ribbon. Its stomach contained an earthwolm and the wing cases of a squash beetle. Tho other two speciusens (somewhat smaller) are females far from maturity.

In a female. uo. :37tos. 11 inches in total leneth, botle palle marks ant bands arooss tho hark show vely plainly. This fomale has a few freo eges in the abdominal ravity and secms to be noarly spent. In examples of this size the tail is deeply forked, the middle rays being less than one half as long as the extermal rays.

In males the pectoral is always longer than in females of equal size. 
The following color notes were taken from nos. 38321 to 38328, collected by Col. Hodge in Sunaper lake. Dec. 10. 1886. Head and upper parts brownish gray, caudal the same, with the exception of a narow white margin on the lower lobe; under surface of head, in most examples, brownish gray, in others whitish; belly orange, this color extending up on the sides but not to the middle line of the body; anal orange, with white margin in front; ventrals orange, with broad wlite margin on the outer lays; pectorals, gray upper half, and orange lower half; dorsal gray, lighter along the base; sides, both above and below lateral line. with numerous orange spots, fading out to whitish. The largest of these s]ots are little more than one third as long as the iris. No mottlings anywhere.

\section{MEASULEMENTS}

Current number of specimen Locality

Length to base of caudal........ Body:

Greatest hight ...........

Greatest width .............

Hight at ventrals...........

Least hight of tail.........

Length of longest gill raker.. Head:

Greatest length ...........

Distance from snont to nape...

Greatest width ............

Widtl of interorbital area....

Length of snout...........

Length of operculum ........

Length of maxillary........

Length of upper jaw........

Length of mandible........

Distance from snout to orbit.

Diameter of orbit...........

Diameter of iris............

Dol'sal (fir'st):

Distance from snout........

Iength of base............

Length of longest ray........

Length of last ray.........
37408 우

SUNAPEE LAKE, N. H.

$\begin{array}{cr}\begin{array}{c}\text { Millime- } \\ \text { ters }\end{array} & \begin{array}{c}\text { 100ths } \\ \text { of } \\ \text { length }\end{array} \\ 257 & 100\end{array}$

51

25

49

21

$+$

it

36

24

1.5

11

12

21

25

31

13

13

()

112

28

32

15
$39331 \hat{\jmath}$

SUNAPEE LAKE, N, H.

$\begin{array}{cr}\begin{array}{c}\text { Millime. } \\ \text { ters }\end{array} & \begin{array}{r}100 \text { ths } \\ \text { of } \\ \text { length }\end{array} \\ 160 & 100\end{array}$

\section{$3 S$}

$2: 31 / 2$

....

36

13

2

....

22

8

$11 / s$

$231 / 2$

$16 \%$

11

$61 \%$

1

$\cdots$

14

$161 \% \quad 10$

21

8 .

11

$61 / 2$

$81 / 2$

5

47

$11 \frac{1}{3}$

13 $71 \%$ 


\section{MEASUREMENTS}

Current number of specimen

Locality

Dorsal (soft):

From origin of first.........

Length along hind margin...

I.ength of base........... Anal:

Distance from snout........

Iength of base...........

Longest ray .............

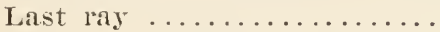

Candal:

Length of middle rays from end of scales.............

Length of external rays...... Pectoral:

Distance from snout........

I ength . . . . . . . . . . . .

Ventral:

Distance from snont.........

Lengtl ...............

fengtl of appendage........

Branchiostegals ............

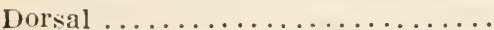

Inal

Pectoral

ientral

Number of scales in lateral line...

Number of transverse rows above

lateral line................

Number of transverse rows below

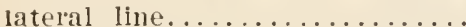

Xumbler of gill rakers.........

Number of caecal appendages.....
37408 오

SUNAPEE LAKE, N. H.

$\begin{array}{cc}\begin{array}{c}\text { Millime- } \\ \text { ters }\end{array} & \begin{array}{c}\text { looths } \\ \text { of } \\ \text { length }\end{array}\end{array}$

$39334 \hat{\jmath}$

SUNAPEE LAKE, N. H.

$\begin{array}{cc}\text { Millime. } & \begin{array}{c}\text { lorths } \\ \text { of } \\ \text { ters }\end{array}\end{array}$
longth

$\begin{array}{rl}90 & 35 \\ 9 & 31 / 2 \\ 5 & 2\end{array}$

\section{(6)}

$371 / 3$

6.

$3 \% 3$

3

$1 \%$

$\begin{array}{cc}189 & 71 \\ 22 & 81 / 3 \\ 28 & 11 \\ 13 & 5\end{array}$

117

73

15

9

$161 / 2 \quad 10$

$\mathrm{s}$

5

\begin{tabular}{|c|c|c|c|}
\hline 18 & $6 \% 3$ & 19 & $\mathrm{~S}$ \\
\hline 41 & $15 \% / 3$ & 32 & $19 \%$ \\
\hline 53 & $201 / 2$ & 86 & 22 \\
\hline 37 & $141 / 3$ & 24 & $14 \%$ \\
\hline $12 \pi$ & 49 & St & $521 / 2$ \\
\hline 31 & 12 & 20 & $121 /$ \\
\hline 14 & $5^{1 / 3}$ & 8 & 5 \\
\hline 10 & $\ldots$ & 111 & \\
\hline 9 & $\ldots$ & $y$ & \\
\hline 8 & $\ldots$ & $s$ & \\
\hline$\ldots$ & & 13 & \\
\hline I, $\mathrm{S}$ & & I, S & \\
\hline & & 210 & \\
\hline
\end{tabular}

34

35

$\begin{array}{rrr}38 & \ldots & 40 \\ \frac{7}{12} & \ldots & \frac{5}{20}-12 \\ a 39 & \ldots & \ldots\end{array}$

5

$S$

$9 \%$

$14 \%$

$21 \%$

$121:$

.

..

.

The golden trout is a native of Sunapee lake and Dan Hole pond, in New. Hampshire, and of Flood's pond, in Maine. Doubtless it exists in other lakes of New England and British North Americal.

It is a large species, reaching a length of 20 inches and the weight of 6 or $S$ pounds; even larger individuals have been reported. Sipanning takes place in Sunapee lake on reefs in sliallow water and not in the streams tributary to the lake; the 
season is about the same as for the brook trout. The color's of the male in the breeding season are gorgeous, and the sight of a loost of spawning fish in the water is one to be remembered.

Many large and small trout of this lind have been deposited in Takr renorge and other suitable waters of the state.

\section{Family ArgENTINIDAE}

\section{Smelts}

\section{Genus osmeris (Artedi) Linnacus}

Body elongate, compressed; lead long, pointed; mouth wide, the slender maxillary extending to past the middle of the eye, lower jaw projecting, jreorbital and suborbital bones narrow; maxillaries and premaxillaries with fine teeth, lower jaw with small teeth, which are larger posteriorly, tongue with a few strong, fanglike teeth, largest at the tip, hyoid bone, vomer, palatines and pterygoids with wide set tecth; gill rakers long and slender; branchiostegals 8 ; scales large, loose, 60 to 70 in the conrse of the lateral line; dorsal small, about midway of the body, over the ventrals; anal rather long; vertebrae about 40 ; pyloric caeca small, few. Small fishes of the coasts of Europe and northern Anerica. sometimes ascending rivers; delicate in fiesh and considerably valued as food. (After Jordan and Frer. mann)

\section{Osmerus mordax (Mitchill)}

\section{Smelt; Ice Fish}

Atherinu morda. Mrtcull, Trans. Lit. \& Phil. Soc. N. Y. 1, 146, 1815, New lork.

Osmerus viridescens Le Sueur, Jour. Ac. Nat. Sci. Phila. I, 230. May, 1816, Boston to Newport; DE IIAr, N. Y. Fauna, Fishes, 243, pl. 39, fig. 124, 1842, streams flowing into Long Island Sound, Hackensack \& Passajc rivels; Stoner, Syn. Fish. N. A. 197, 1816; Günther, Cat. Fish. Brit. Mus. VI, 167, 1866.

Osmerus mordax Jornax of Gilbent, Bull. 16, U. S. Nat. Mus. 208, 1S83; Bean, Fishes Penlla. 64, pl. 26, fig. 46, 1893; Jordan \& Evermann, Bull. 47. U. S. Nat. Mus. 523, 1896, pl. LXXXVI, fig. 228, 1900 ; Evermaxy \& Kendat, Rept. U. S. Commr. Fish \& Fisheries for 1894, 598, 1896, Lake Memphremagog \& Lake Champlain.

The smelt has an elongate and somewhat compressed body and a long, pointed head, with the lower jaw projecting. The mouth 
is large, the maxilla extending slightly hehind the "ye. Simall forth on the intermaxillaries and maxillaries and the front of the lower jaw. Posteriorly the teeth of the mandible an a largere. The tongue is armed with a few latrege fanglike teeth. and there are widely set treth on the romer, palate, and pterygoid bones and at the loot of the tongur. fill rakers long and slender; branchiostegals right; the dorsal small, nearly median orer the relltals; anal moderately long; seales latrege, thin. easily deciduons, in about 75 rows along the sides; lateral line short, not extending much beyoud the end of the pectoral; at few small pyloric cacca. The hight of the body is nearly one fifth of the total lemgth. without caudal. and nearly coual to the length of load. The "ye is nealy one fifth as long as the head. The pectoral equals the longest dorsal ray in length and, also, length of anal bast. The ventral is one half as long as the head. Longest anal lay not murh more than one half the anal base. D. ii, $S$; A. iii, 14; I. ii, T.

The upper parts are greenish; a broad silvery band along the sides; body and fins with numerous minute dusky points.

The smelt is known along our east coast from Labrador to Virginia. It probably extends still farther north, but the record of IT. A. Stearns, published in the proceedings of the National Museum for 1SS3, p. 124, fixes the most northern localitr known at present. He found the smelt common in Angust in shoal water off the whares of rape Breton. In Pennsylrania the fish is common in the spring in the Delaware and Fchuylkill rivers. In numerous lakes of Maine, Tew Hampshire, and other New England states, the smelt is common landlockinl, and thrires as well as in tlee salt water.

De Kay knew the smelt as a marine species ascending the Hackensack and Passaic rivers. The species occurs also in Lakes Clamplain and Memphremagog. In the former lake it reaches a large size. It Port Henry $\mathrm{X}$. Y. the fish is called iere fish.

Its range has been widely extended by artificial introduction. which is rery easily effected by transporting the fertilized egas 
from the small brooks in which the species spawns. The eggs are adhesive and attach themselves to stones, and their transportation is accomplished very easily.

The smelt grows to a length of 1 foot; the arerage size as found in the markets is about $\boldsymbol{i}$ inches. It enters the rivers for the purpose of spawning and is most abundant in the winter and early spring months. Spawning takes place in the Raritan river, N. J., in March. The eggs of the smelt have been artificially hatched by Mr Ricardo, Fred Mather and other fish. culturists.

The smelt is an excellent food fish and is also used for bait, and still more extensively as food for landlocked salmon, lake and brook trout and other important salmonoids, which are artificially reared in lakes. It has proved to be one of the best fishes for this purpose. Immense quantities of smelts are canght during the winter months in nets, seines and by hook and line. They are usually shipped to market in the frozen condition, packed in snow or crushed ice. The fish which have not been frozen, however, are prized nore highty than any others.

The smelt begins to run into Gravesend bay in December and remains during cold weather. In the spring it ascends rivers to spawn. The eggs are small ( $\frac{1}{20}$ inch in diameter) and number 496,000 to the fluid quart; they adhere to stones, twigs etc. on the bottom. Some females begin to spawn when only 3 or 4 inches long.

In fish cultural operations " the spawning fish, of both sexes, are placed in tronghs, which are covered to exclude light, which is rery injurions to the eggs. The eggs are naturally laid and fertilized, and become attached to each other and to the troughs. They are scooped up with a flat shovel, placed on wire trass in water, and are forced through the meshes of the trays to separate them. They are hatched in automatic shad jars, blanketed to exchude light. If during hatehing the eggs bunch, they are removed from the jars and again passed through the meshes of the wire trays."

The fry are hardy in transportation. 
In captivity the adults live till about the end of June, when the water becomes too warm and they die. Their food consists mainly of shrimps and other small crustaceans.

Orrater 1. TOMI

Lantern Fishes

Family S NODONTIDAE

\section{Lizard Fishes}

\section{Genus sryods (Gronow) Bloch \& Schneider}

First superior pharygeal cartilaginous. second without teeth, thind and fourth separate, with teeth: lower pharygeals separate: body elongate, subteretr; head depressed, the snout triangular, rather pointed; interorbital region transversely concave; month very wide; premaxillaries not protractile, very long and strong. more than half length of head, maxillaries closely ronnected with them, very small or obsolete, premaxillaries with one or two series of large. compressed, knife-shaped tecth, the inner and larger depressible. palatine teeth similar. smaller, in a single broad band; lower jaw with a band of rather large treth, the inner and larger teeth depressible, a patch of strong. depressible treth on the tongure in front, and a long row aloug the hyoid bone; jaws nearly equal in front; eye rather large, anterior. supraorbital forming a projection above the ere; pseudobranchiale well dereloped; gill rakers rery small, spinelike; gill membranes slightly connected: top of head naked; checks and opereles sealed like the body; body rorred with rather small, adherent, cycloid scales; lateral line present; no luminous spots; dorsal fin short, rather anterior; pectorals moderate. inserted high; rentrals anterior, not far behind pectorals, large, the inner rays longer than the onter; anal short; 'andal narrow, forked: vont posterior, mnch nearer base of "audal than hase of ventrals; branchiostegals 12 to 16 ; stomach with a long, blind sac and many pyloric caeca; skeleton rather fir'm. 


\section{Synodus foetens (Limnaeus)}

\section{Livard Fish}

Salmo foetens Linvaeus, Syst. Nat. ed. XII, I, 513. 1766, South Carolina. Eso $x$ salmoneus Mitcmll. Trans. Lit. \& Phil. Soc. X. T. I. 442, 1815. New York.

Saurus mexicauls C'rvatr. Règne Inim. ed. II, :14, 1829, Mexico.

Saurus foetens Güntiler, Cat. Fish. Brit. Mus. V, 396, 1864.

Synodus foetens Jordan \& Gilbert, Bull, 16, U. S. Nat. Mus. 281, 1ss3;

BEdN, Bull. T. S. F. C. VII, 148, 1Ss8, 19th Rep. Comm. Fish. X. I.

275, 1890; Jordan \& Evermann, Bull. 47, U. S. Nat. Mns. 538, 1896,

pl. LXXXYIII, fig. 236, 1900.

Body slender, elongate fusiform, its greatest depth about one serenth of total length without caudal; caudal peduncle short. stout, its least depth equal to length of snout; head conical, sharply pointed, its length contained four and one third times in total without caudal; snout much flattened above, pointed, its length about one fourth the length of head, and nearly twice diameter of eye; jaws nearly eyual in front or the lower included. maxilla reaching well behind orbit, the upper jaw as long as postorbital part of head; anterior nostril with a flap, posterior. simple, the anterior nearer to eye tlan to tip of snout; eye small, partly on top of head, two elevenths of length of head, about two thirds of interorbital width; teeth of upper jaw closing down over the mandible; dorsal origin nearer to tip of snout than to base of caudal, orer the 18 th scale of the lateral line, dorsal base one half as long as the head, longest dorsal ray equal to upper jaw, last dorsal ray one third as long as head; adipose dorsal very small and slender, its length not equal to eye; ventral equidistant from tip of snout and rent, the fin four fifths as long as the head; pectoral short and rounded, its length equal to snout and eye combined; anal origin distant from caudal base a space equal to one fourth the length without caudal, anal base three fiftlis as long as the head, lougest anal ray one half as long as head without the snout, last anal ray one half as long as anal base; caudal deeply forked, the middle rays less than one laalf as long as the outer; interorbital space slightly roncave. D. 10, the first two and the last simple; A. 14; V. S; P. 14. Scales T-5?-7; here described from specimens numbered 35936 , U. S. National Museum, from Fire island, I. I. 
Color of npper parts olive brown or grayish, sides below lateral line paler, belly yellowish, pectorals, rentrals and anal with a yellow tint, candal dusky, dorsal with traces of narrow bars, inside of nouth and of gill openings yellow.

The lizard fish reaches a leugth of 12 inches; it is found from ('ape Cod to Brazil, being rery common from Virginia southward. It comes into shallow waters during the summer and remains on the New York coast till October. It is a roracious species, of no value as food.

Idults and young of this species are rather common in the (ijeat Fgg bay region, N. J.

At Beesleys Point, Sep. 2, 1857, a small individual was found to haveswallowed a I'le u r o nectes a me $r^{\circ} \mathrm{c}$ a $n \mathrm{us}$, which distended the stomach of its captor laterally to nearly twice its normal width.

Abundant in thoroughfares near somers l'oint tugust 30. ()ne individual taken is $7 \frac{3}{4}$ inches long. Some very large ones have been seen; an example caught at Beesleys Point, september 9. is nearly 9 inches long, and we hare secured sonur lareger than this.

The species is minown to the fishermen.

The lizard fish, called sand pike by some authors, is the trout pilie of Mitchill. Besides bearing these names, it is known as snakefish, cigar fish and spearfish. The species appears not to have been known to The Kay. It is rery common in Great sout? bay. 36 specimens having been taken in the latter part of september and the first two days of October. Mitchill's examples from the head of New York bay were from $S$ to 9 inches long. in Great Egg Harbor bay, though it is a very common fish, the fishermen have no name for it.

\section{Order Hal'i,uI}

Pikelitie F'ishes

Family LAmBRIDAE

llud Minnows

Genus ı мия. (Ḱramer) Müller

Body oblong. corered with cycloid scales of moderate size. without radiating striae; no lateral line; lead shortish, little 
depressed; eye rather small; cleft of mouth moderate; ventral fins 6-rayed, below or slightly in frout of dorsal; anal fin much shorter than dorsal; pectorals rather narrow, rounded, placed low, with 12 to 15 rays, which are much articulated; caudal rounded; preopercle and preorbital with mucous pores; branchiostegals six; gill rakers short, thick. Size small. Three species, very similar to each other, inhabiting the waters of the United States and Austria.

\section{Umbra limi (Kirtland)}

Iud Minnow; Dogfish

Hydrargire limi İintlaxd, Bost. Jour. Nat. Hist. III, 277, pl. II. fig. 4, $18+1$.

Hydrargira fusca Thompsor, Nat. Hist. Yermont, 137, 1842, Lake Champlain.

Hydrargira atricanda DE KAY, N. Y. Fauna, Fishes, 220, 1812.

Hydrargyre fusca Storer, Syn. Fish. N. A. 182, 1846.

Umbra limi Günther, Cat. Fish. Brit. Mus. VI, 232, 1866; Jordan \& GiLBert, Bull. 16, U. S. Nat. Mus, 350, 18s3; Bfar. Fishes Penna. 88, 1893; Jornan \& Evermann, Bull. 47. U. S. Nat. Mus, 623, 1896.

The mud minnow has a comparatively short and stout body, its depth not equal to the length of the head and about one fourth of total without caudal. The length of the head equals two serenths of the total. The head is flattened above and rather large., D. 14; A. 9; T. 6. Scales in lateral line 35 , in transverse selies 15.

The color is dark olive or greenish, and the sides have irregular, narrow, pale bars, which are sometimes obscure or absent. A black bar at the base of the tail.

The mud minnow, mud dace or dogfish is found in the Great lakes region from Lake Champlain to Mimmesota, being most abundant in IVisconsin. It is occasionally taken in the Ohio valley. It was not found by $\mathrm{Dr}_{\mathrm{r}}$ Meek at Ithaca; but was taken in small numbers near Cayuga and Montezuma. The fish was taken by U. S. Fish Commission collector's in Griffon creek, Chaumont N. Y. July $\bar{T}$, and in Mill creek, Sacketts Harbor N. Y. July 2. De Kíay had specimens from Lake Champlain.

It grows to a length of 4 inches. It has no value whatever except as food for other species. Like the related mud minnow 
mext mentioned, it is hardy and interesting in the aquarium. The name mud minnow relates to a singular habit of the fish of burrowing into the mud when the water evaporates ont of a pond. It has been related that this fish has been plowed up in ponds and swamps which have become dried out. Prof. Baird has recorded the following fact about this species. "A locality which with the water perfectlyclear, will appear destitute of fish will perhaps yield a number of mudfish on stirring up the mud on the bottom and drawing a seine through it. Ditches on the plains of Wisconsin or mere bog holes affording lodgment to nothing beyond tadpoles may thus be found full of me la n u r a s."

The mud minnow shipred from Caledonia X. Y. by James Annin jr in wet moss has survived a 12 hours' journey; but it has never proved hardy either in balanced tanks or in running water. This is remarkable, because there is evidence to prove that the species can endure alternate freezing and thawing without permanent injury.

\section{Umbra pygmaea (De Kay) \\ striped Hud Himou}

Leuciscus pygmucus DE KìY. N. Y. Fauna, Fishes, 214, pl, 42, fig. 134. 1842. Tappan, Rockland Co., N. Y.; Storer, Syn. Fish. N. A. 162, 1816. Fundulus fuscus Arres, Bost. Jour. Nat. Hist. IV, 296, pl. XIII. fig. 2. 18t4, Brookhaven, Long Island.

Melamura amnulata AgAssiz. Amer. Jour. Sci. Arts, 135, 1854.

Umbra pygmaer Jordax, Bull. U. S. Nat. Mus. X, 53, 1877; BeAx, Fishes (Penna. SS, 1893; Jordan \& Evermaxn, Bull. 47, U. S. Nat. Mus. 624, 1896, pl. XCIX, fig. 268. 1900; Mearis, Bull. Amer. Mus. Nat. Hist. $\mathrm{X}, 317,1898$.

Embra limi pygmaea Blatchley, Proc. Ac. Nat. Sci. Phila. 13, 1885. Mfelanura pygmaca BEAN, Bull. U. S. F. C. VII, 147, $18 S$.

The body of the mud minnow is oblong, robust; its greatest depth is contained slightly more than four times in the total length without the caudal and not equal to length of head. The snout is short; eye moderate about equal to snout, four and one half in head. Cardiform teeth on premaxillaries, lower jaw, vomer and palatine bones. The gill openings are very wide, the rakers short and rather numerous; jaws short, gape of mouth 
rather wide. The body is covered with lather large cycloid siales, and the head is almost entirely scaled. D. 14; A. 8. Scales right or nine in a transverse series, 35 from head to tail.

Color dark green, more or less mottled (in spirits brownish); sides with a dozen pale longitudinal streaks, regularly arranged; a darker stripe through eve; black bar at base of tail, which is present in very young examples as well as in the adult.

The eastern und minnow is found from New York to South Carolina in Atlantic streams. According to Prof. Cope it is rery common near Philadelphia. De Kay had rery small individuals from brooks near Tappan, Rockland co. N. I. Dr Theolore Gill colle.ted specimens in the same county in 1855.

The species grows to a length of about 5 inches, and is well adapted for aquarium life, but has no other value except as food for larger fishes. Its habits are similar to those of the species last described.

The body is stouter than in $\mathrm{T}^{\mathrm{m}} \mathrm{m}$ b $\mathrm{x}$ a $\mathrm{lim} \mathrm{i}$; the head is broalder, loss flattened on top, with a larger eve, shorter snout and the profile more convex.

The dogfish is a most peculiar fish, as voracious as a pike and as tough-lived as a catfish. It requires but little water and ran often lo dug from the moist mud of ditches the water of which has eraporated. None may be found in a stream, but the juddles and muskrat holes alongside may be full of them. It is a good deal of an air-breather, rising to the surfare to gulp' in air and then doscending again, in the faslion of the paradise fish. In the aquarium it is very lardy and apt to annoy other species by driving them around and attacking their fins. When exposed to the air in freezing weather, it succumbs almost instantly, also when put into water containing much lime; on the other hand, loot weather does not in the least trouble it, except that it gets its supply of air more frequently.

In movement it is very elratic, now dashing about as if mad, igain standing perfectly motionless in the water, only moving the pectorals and ventrals "like a dog, running;" again only moving pectorals and the rear part of the dorsal or the latter 
fin alone. It can turn its head sideways at an angle and remain awhile in that position.

When feeding, it gorges the morsel at one attempt, after staring at it a while. Sometimes when orerfed, the dogfish can not swim about at all, but lies like a $\log$ on the bottom. (After Eugene Smith1)

\section{Family LucindF}

Pikes

\section{Genus Lucrus Rafinesque}

Body elongate, not elevated, more or less compressed posteriorly, broad anteriorly; head long, the snout prolonged and depressed; mouth rery large, its cleft forming about half the length of the head; lower jaw the longer; upper jaw not protractile, most of its margin formed by the maxillaries, which are quite long and provided with a supplemental bone, premaxillaries, vomer and palatines with broad bands of strong cardiform teeth which are more or less movable; lower jaw with strong teeth of different sizes; tongue with a band of small teeth; head naked abore; cheeks and opercles more or less scaly; gill openings rer'y wide; gill membranes separate, free from the isthmus; gill rakers tuberclelike, toothed; branchiostegals 12 to 20 ; scales small; lateral line weak, obsolete in young specimens, developed in the adult; dorsal posterior, opposite and similar to anal; caudal fin emarginate; pectoral fins small, inserted low; ventrals rather posterior; vent normal; no adipose fin; no barbels; stomach not caecal, without pyloric appendages; pseudobranchiae glandular, hidden; air bladder simple. Basis cranii double (Cope). Fishes of moderate or large size, inhabiting the fresh waters of the northern parts of Europe, Asia and North America.

The genus L u c i s is readily subdivided into three groups distinguished by their size, scaling and coloration. In the first group are three species of true pickerels, in which the cheeks and opercles are entirely scaly, the color is greenish, usually with dark reticulations, and the largest species reaches a

${ }^{1}$ Linn. soc. N. Y. Proc. 1897. no. 9, p. 27-28. 
length of about 2 feet. To this group the subgeneric name Ke $\mathrm{noz}$ a is sometimes applied; it includes the banded pickerel, the little pickerel and the chain pickerel, all of which occur in New York.

\section{Lucius americanus (Gmelin)}

\section{Banded Pickerel}

Esox lucius 3 americamus Guedix, Syst. Nat. 1390, 1788, Long Island, New York.

Esox niger LE Stev', Jour. Ac. Nat. Sci. Phila. I, 415, 1818, Lake Saratoga, New York; Storer, Syn. Fish. N. A. 185̃, 18џ6; Günther, Cat. Fish. Brit. Mus. VI, 229, 1866.

Esox scomberius MitchlL, Amer. Month. Mag. II, 322, March, 1818, Iurderer's Creek, New York.

Esox fasciatus DE KAY, N. Y. Fanna, Fishes, 224, pl. itt, fig. 110, 1842, streams and ponds of Long Island.

Esox raveneli Holbrook, Ichth. S. C. 201, 1860, Charleston, S. C.

Esox amcricanus Jordan \& GILBERT, Bull. 16, U. S. Nat. Mus. 352, 1883; Bean, Fishes Penna. 89, pl. 28, fig. 53, 1893.

Lucius americanus Jordan \& Evermann, Bull. 47, U. S. Nat. Mus. 626, 1896.

The banded pickerel has an elongate body; its depth contained about five times in the total length without candal; the length of the head three and one fourth times in the standard length. The snout is contained two and two thirds times in the length of the head, and the eye five and one half times in the same length. The maxillary extends to rertical through middle of eye; the lower jaw projects considerably beyond the upper. Teeth in the jaws strong, directed backwards. The ventral is placed in middle of body, the dorsal and anal fins far back, opposite each other; their lougest rays of about the same length, much longer than the bases of the fins. Caudal deeply emarginate. B. 11-13; D. 11-14; A. 11-12. Scales in lateral line 105. The body is usually dark green, sometimes brownish black, above; the sides greenish yellow with about 20 dark curved bars, which are generally very distinct; dorsal and caudal fins dark brown, the other fins lighter, sometimes reddish; a dark bar from the eye to angle of jaw, another from the snout through the eye to upper edge of opercle.

The banded pickerel is probably identical with the "mackerel pilie" of Mitchill. It is a small fish, seldom exceeding 12 
inches in length, and will not arerage more than $\frac{1}{2}$ pound in weight. It occurs only east of the Alleghanies, from Massachusetts to Florida in coastwise streams. In Pennsylvania it is limited to waters in the eastern part of the state, and the same is true in New York.

This pickerel is too small to lave much importance as a food fish. It resembles in general appearance and habits the little pickerel of the west. It frequents clear, cold and rapid brooks and is said to associate with the brook trout without injury to the latter.

Dec. 30, 1895, James Annin jr sent from Rockland N. Y. a small pickerel which had attracted his attention on account of its colors and markings. It was taken in a small spring brook, tributary to the Bearer kill, which, about 10 or 15 miles below, unites with the Delaware. Subsequently two examples were forwarded alive from the same place, and one of them is still living in the aquarium 1897. The following notes and measurements, in inches, relate to the first individual of undetermined sex, the organs being undereloped.

\section{MEASUREMENTS}

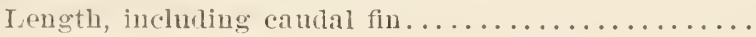

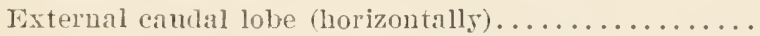

Viddle caulal rays (from end of scales)............

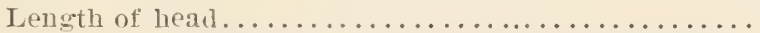

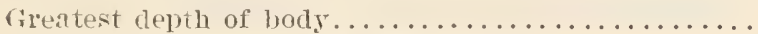

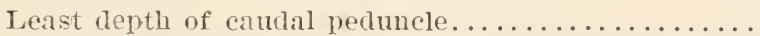

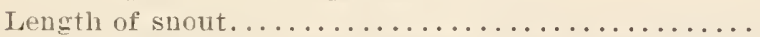

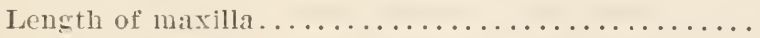

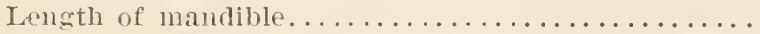

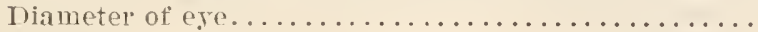

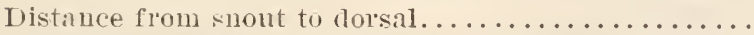

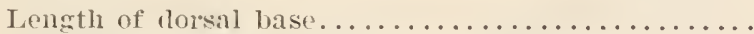

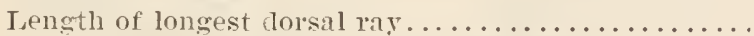

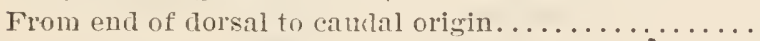

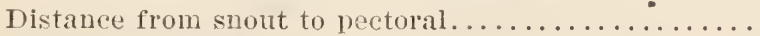

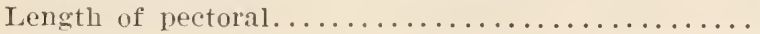

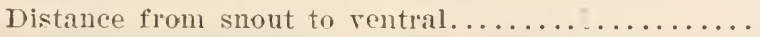

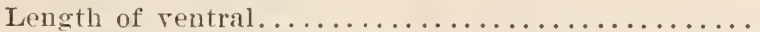

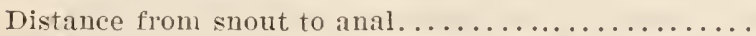

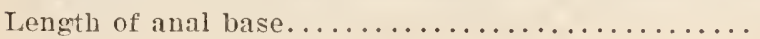

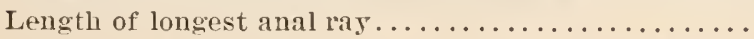

From end of anal base to origin of lower caudal lobe.

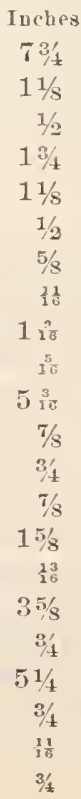


B. $12 ;$ D. $12 ;$ A. 11; V.9. Scales, 24-110. The maxilla reaches to below the middle of the pupil. The mandible projects $-\frac{1}{16}$ of an inch when the mouth is closed. The diameter of the eye is contained five and two thirds times in length of head. The stomach was empty, but insect remains were voided from the vent.

Colors. About 20 oblique, interrupted, dark bands on the body; a narrow oblique dark band under the eye and four rather large dark blotches on the cheek and opercle; pectorals, ventrals and anal orange; a tinge of orange on the dorsal and caudal; general color olivaceous gray, with golden reflections; lower parts creamy white; iris lemon mingled with pale brown; peritoneum silvery.

All the pickerels are liable to fungus attacks without apparent cause, but, as a rule, they can be cured by the salt water treatment. Their food consists of small live killifish, which they approach slowly and deliberately till within 5 or 6 inches, when they rush, seize, and stop as abruptly as if stopped by an obstruction.

Eugene Smith says this pickerel is often found in brackish water in the ricinity of New York, and is then more brown in color. L. ret i culat $\mathrm{s}$ is found also on Long Island close to salt water, as at Water Mill.

\section{Lucius vermiculatus (Le Sueur)}

\section{Little Pickerel}

Esox vermiculatus Le Sunur in Cuvier \& Varenciennes, Hist. Nat. Poiss.

X VIII, 333, 1846, Wabash River, Indiana.

Esox crassus Agassiz, Am. Jour. Sci. Arts, 308, 1854, Tennessee River, Huntsville, Alabama.

E80x umbrosus KíntLANd, Proc. Cleveland Ac. Sci. 79, 185t, Rockport, near Cleveland, Ohio; Cope, Trans. Am. Phil. Soc. Phila. 409, 1 S66.

Esox cypho Cope, Proc. Ac. Nat. Sci. Phila. 78, 1865, Waterford, Michigan;

Günther, Cat. Físh. Brit. Mus. VI, 230, 1866.

Esox porosus Cope, Trans. Am. Phil. Soc. Phila. 408, 1866, substitute for c $\mathrm{y} \mathrm{pho.}$

Esox salmoneus Jordan \& Gilbert, Bull. 16, U. S. Nat. Mus. 352, 1883.

Esox vermiculatus BeAN, Fishes Penna. 90, pl. 28, fig. 54, 1893.

Lucius vermiculatus Jordan \& Evermanx, Bull. 47, U. S. Nat. Mus. 62 $T_{2}$ 1896. 
The little pickerel has a short, stout body and a long head. The greatest depth is nearly one fifth of the length without caudal and two thirds of length of head; length of head two sevenths of total without caudal; ere tro fifths of length of snout, one sixth of length of head. The maxilla reaches to below middle of ere. Cheeks and opercles fully scaled; dorsal origin twice as far from eye as from end of scales, its base two fifths of liead. its longest ray rearly one half of head; anal under dorsal and with slightly longer rajs; ventral nearly midway between tip of snout and end of scales, its length equal to snout and to pectoral. B. 11-13; D. 12; A. 11 or 12 . Scales in lateral line 105.

Body green or grayish, usualls with many irregular streaks or reticulations, which are sometimes entirely lacking; sides of the head generally rariegated; a dark bar extends downward from the eye, and another forward. Fins plain, but the caudal is sometimes mottled at its base.

This pickerel inhabits the valleys of the Ohio and Mississippi rivers and streams flowing into the Great lakes from the southward. In ponds formed in the spring by the overflow of river banks it is one of the characteristic fishes and is often destroyed in great numbers by the drying up of such bodies of water. In Pennsylvania the little pickerel, or trout pickerel, is common in the Ohio and its tributaries. Prof. Cope mentions it also as an inhabitant of the Susquehanna river, in which it is probably not a native.

The U. S. Fish Commission obtained a moderate number of specimens in the Lake Ontario region at the following New York localities.

Black creek, tributary of Oswego river, Scriba Corner

July 15

Lakeriew hotel, $7 \mathrm{~m}$. west of Oswego

Juls 17

Wart creek

July 24

Great Sodus bay

Aug. 16

Outlet Long pond, $4 \mathrm{~m}$. west of Charlotte

Aug. 7

Marsh creek, near Point Breeze

Aug. 21 
This fish grows to the length of 1 foot and is, therefore, too small to have much importance for food.

\section{Lucius reticulatus (Le Sueur)}

\section{Chain Pickerel; Green Pike}

Esox reticulatus LE Sueur, Jour. Ac. Nat. Sci. Phila. I, 414. 1818, Connecticut River, Adams, Mass.; Philadelphia, Pa.; DE KAY, N. Y. Fauna, Fishes, 223, pl. 34, fig. 107, 1S42; Kimtlaiv, Bost. Jour. Nat. Hist. IV, 233, pl. X, fig. 2, 18 14 ; Güther, Cat. Fish. Brit. Mus. VI, 229, 1866; Jordan \& Gilbert, Bull. 16, U. S. Nat. Mus. 353, 1883, BEan, Fishes Penna. 90, pl. 29, fìg. 55, 1893.

Esox tridecemlincatus MrtenlL, Mirror, 361, 1825, Oneida Lake, $\mathrm{N}$. Y. Esow phaleratus (SAY) LE Sueur, Jour. Ac. Nat. Sei. Phila. I, 416, 1S1S, St Augustine, Fla.

Esox affinis HoLbrook, Ichth. S. C. 198, 1860, Charleston, S. C.

Lucius reticulatus Jordan \& Evermann, Bull. 47, U. S. Tat. Mus. 62т, 1896; Evermann \& Kendali, Rept. U. S. Commr. Fish \& Fisheries for 1894, 597, 1596; Mearis, Bull. Amer. Mus. Nat. Hist. X. 317, 18s8; Proc. U. S. Nat. Mus. XXI, 344, 1898.

The chain pickerel has a loug and slender bode, its depth near the middle equaling about two thirds of the length of the hoad and contained fire to six times in the total without caudal. The caudal peduncle is slender, its depth little more than one tinird of greatest depth of bodr. The snout is long and pointed. as long as the postorbital part of the head and about three times the length of the ere, which is one serenth to one eighth of length of head. The dorsal base equals two fifths of length of head, its longest ray equal to snout. The anal begins under the third or fourth ray of the dorsal, its longest ray nearly one half as long as the head. Caudal deeply forked. Veutral half way from tip of snout to end of scales, its length equal to snout and slightly greater than length of pertoral. B. 15; I. 15; 1. 14 . Scales in lateral line about 125. The cheelis and opercles are completely scaled.

The color is usmally greenish, sometimes brown or almost black. On the sides are many narrow, dark lines connected by cross streaks, forming a network which suggested the name reticulatus. Occasionally the body is uniform greenish, as in a specimen taken in the Potomac river a few years ago. In the young the reticulations are very obscure, and a pale stripe 
is found along the middle line on the second half of the body. In adults the sides are often golden or olive yellow, and have dark reticulations. A distinct dark band under the eye.

The chain pickerel is known under other names; it is the jack of the sonth, the federation pike of Oneida lake, N. I. the green pilie of the Great lakes and the eastern pickerel of many writers. It does not occur west of the Alleghanies, but is found from Maine to Florida and Alabama east of this range of mountains. It lives in ponds, lakes and streams and occurs within the same territory as L. a m e r i can u s, but farther away from the coast. (After Eugene Smith. ${ }^{1}$ )

At Watre Mill this pickerel occurs in or near brackish water at the east end of Mecox bay, and it is in rery plump condition, on account of the abundance of small fishes on which it feeds, for example, the silversides, roung sunfisli, and small lillifishes of several kinds.

Ir Meek notes that the species seems to be subject to individual variation. In many respects the specimens from Cayuga lake appear to be intermediate betreen reticul a $\mathrm{us}$ and vermiculatus. It is not rery common.

The pickerel is common in ponds and streams of the Hudson Highlands, according to Dr Mearns, and is taken in winter as well as in summer. A specimen weighing $3 \frac{1}{2}$ pounds was caught in Poplopen's pond in 18S2. It is abundant also in Canterskill lake, of the Catskill mountains. The U. S. Fish Commission obtained it in Black river, Huntingtonville N. Y. July 5 . Examples were sent from Canandaigua lake, and young were obtained in Bronx river.

This pickerel is the largest of its group, reaching a length of 2 feet and a weight, occasionally, of $S$ pounds, though this is much above the arerage.

Like the pike, this is one of the trrants among fishes, a fierce and hungrs marauder; and yet it has been introduced by fishermen into many raters in which it is not native and has greatly multiplied. In the Potomac, the Connecticut, the Delaware and

${ }^{1}$ Linn. Soc. N. Y. Proc. 1897. no. 9. p. 29. 
other large rivers the pickerel abounds; it is to be found in large numbers lying in wait among the river grasses or in ponds under the shelter of leafy water plants for the minnows which it consumes in enormous numbers, or some unlucky insect, frog or snake which attracts its roracious appetite.

Spawning takes place in winter and early in the spring, and the young soon become solitary and wolfish like their elders.

The fish obtained from Canandaigua lake spawned in their tank in Jume 1S97, and the young were naturally hatched, but they died when about $\frac{3}{4}$ inch long for want of acceptable food.

As a food fish not much can be said in praise of the chain pickerel, though it is eaten and doubtless liked by a good many people. The flesh is often coarse and watery and is alwarss full of small bones. This fish, howerer, furnishes considerable sport to the angler, since it is a rers free biter and fights with great boldness and stubbornness when hooked. It is caught by trolling with a spoon or still fishing with live shiners, pickerel frogs and many other baits. A minnow gang is often very effective in pickerel fishing. The hooks must be tied on gimp as a protection for the line from the sharp teeth of the fish.

This species is always hard to keep in good condition in captivity, because of its liability to fungus attacks. The salt water treatment, however, keeps the fungus in check.

\section{Subgenus tecres}

The longest known and most widely distributed species of $\mathrm{Luci}$ us is the common pike, the typical species of the genus. In the subdivision into groups this would be the sole representative of the Lucius group, which has the cheeks fully scaled and the lower half of opercles naked. The sides are pale spotted on a darker ground, and the size is rery much larger than that of the pickerels. Fossil remains of the pike have been found in quaternary deposits in Europe.

\section{Lucius lucius (Linnaeus) \\ Common Pilie; Pickerel}

E60x lucius Linnaeus, Syst. Nat. ed. X, I, 314, 1758, Europe; Richardsox, Fauna Bor.-Amer. III, 124, 1836; Günther, Cat. Fish. Brit. Mus. VI, 226, 1866; Jordan \& Gilbert, Bull. 16, U. S. Nat. Mus. 353, 1883; Bean, Fishes Penna. 91, pl. 29, fig. 56, 1893. 
Esox estor Le Sueur, Jour. Ac. Nat. Sci. Phila. I, 413, 181S, Lake Erie;

DE KAг, X. Y. Fauna, Fishes, 222, 1St2; Stoper, Syn. Fisk. N. A.

184. 1546.

Esoc boreus AgAssiz, Lake Superior. 317, 1850. Lake Superior.

Lucius lucius Jordan \& EverManN, Bull. 47. U. S. Nat. Ius. 62S, 1srif,

pl. C. fig. 269, 1900; Evermany \& Kexpalt, Rept. U. S. Commr. Iish \& Fisheries for $1894,597,1836$.

The pike has a stout, elongate body and a long head, with broad and produced snout. The greatest depth is about one fifth of the length without caudal. The caudal peduncle is nearly equal to one half depth of body. The eye is nearly median and about one sixth of length of head, which is $\frac{3}{1}$ of total without caudal. The mouth is very large and strongly toothed. The tongue, roof of mouth, pharynx and gill arches bristle with teeth in cardlike bands, giving the fish extraordinarer power in seizing and holding its prey. The dorsal and anal fins are near the caudal. The dorsal base is a little longer than its longest ray and equals depth of body at its origin. Tentral fin midway between tip of snout and end of tail fin. B. 14 to $16 ;$ D. 17 to 20 ; A. 16 or 17 . Scales in lateral line 120 to 125 .

The ground color of the body is grayish varying to bluish or greenish gray. The sides are thickly covered with pale blotches, none of them as large as the eye, arranged nearly in rows. The dorsal, anal and caudal fins have many rounded, dark spots. Adults without dark bar below exe. Naked part of opercle bounded by a whitish streak. In the young the sides are covered with oblique yellowish bars, which afterward break up into the pale spots of the adult.

Pike is the best known name for this species, though the misnomer "pickerel" is rather extensively used. The origin of pike is involred in uncertainty; some trace it to the resem. blance in shape of the snout to the pilie or spear, while others beliere it to refer to the darting motion of the fish when speeding through the water. The name pickerel is used in Vermont and around Iake George, N. Y. "Frank Forrester" (Herbert) styles it the great northern pickerel. The name jack is applied in Great Britain to young pike. Brochet is the French name, hecht the German and luccio the Italian designation of the 
species. In Prof. Cope's paper in earlier reports of the Pennsylvania Fish Commission the names lake pilie and grass pike are used for the fish.

Distribution. In the north temperate and arctic regions of North America, Enrope and Asia the pike is equally common. In North America it extends from Pennsylvania to high northern latitudes. In Alaska, Townsend and others found it above the arctic circle, and Dall and Nelson took it in abundance in the Yukon. From Greenland and the islands of the Aretic ocean the pike appears to be absent. The identity of our American pike with the common one of Europe was recognized by Cuvier and Richardson more than half a century ago; the former compared specimens from Lake Huron with European examples, and Richardson with the English pike, and both were nuable to find specific differences between the two.

The pike is said to be common in Lake Champlain and in all its larger tributaries. In the Lake Ontario region the U. S. Fish Commission collectors secured it at the following places. Mud creek, Cape Tincent $\mathrm{X}$. Y. June 25, 1S94, Clammont river July 10, outlet Tong yond. 4 miles west of charlotte $\mathrm{X}$. Y. Ang. 1 ז.

Dr Meek found the species in Caynga lake, where he says low was unable to find any other fish of the genus except the pickerel. James Annin jr obtained the pike in Silver lake, Tyoming co. N. Y. July 1, 1S96. He reports tlat it does not occur in Canandaigua lake.

On the continent of Europe the largest recorded specimen was taken at Bregenz in 1862; this was said to weigh 145 pounds. In Scotland a pilie measuring more than 7 feet and weighing 72 pounds has been reported. W'e do not find monsters like these in America. "Frank Forrester" mentions individuals of 16 to 17 pounds. Lake George, N. Y., is famous for its large pike. In Frank Presbrey of Washington D. C. canght one there in 1889 weighing a little more than 16 pounds, and more than 30 examples, areraging in excess of 10 pounds eacl, were taken that season by another person from WTashington in the same waters. 
Sone of the largest pike were upward of 4 feet loug. The arerage length is about 2 feet.

The fishing season generally begins June 1 and ands Derember 1; but many of the states have no close season. In Pennsylvania the close time lasts from December 1 to . June 1.

The pike is a voracious fisl and destroys everything within its reach in the form of animal life; other fish, water birds and mammals are consumed in enormous numbers. From its concealment, like a beast of prey it darts ont sublemly on its rictims and seldom misses its mark. The pike is eren more destructire than the pickerel, and two of the latter, measuring 5 inches in length, have been reported to eat more than 100 minnows in a day. Spawning takes place in winter and early spring on shallows and frequently on orerflowed meadows. The eggs are abont $\frac{1}{8}$ inch in diameter, and a female weighing 32 pounds was estimated by Buckland to contain 595,000. The young pike has a very large yolk sac. The period of hatching varies, with the temperature of the water, from 14 to 30 days. The female is said to be larger than the male; the fish breeds at the age of three years. At the age of one year the fish may reach a length of 12 inches, and, if well supplied with food, it will increase in weight from 2 to 3 pounds yearly.

The pike is a fairly good food fish and forms an important element of the Lake Erie fisheries. Is a game fish the species is widely knomn; it can be readily caught by trolling or spinning or on lines set under the ice. Live minnows and frogs are farorite baits; and Dr Henshall says it will rise to a large, gaudy fly. In Lake George the white chub is one of the best known baits.

\section{Subgenus mascilotigus}

The largest member of the pike family is the single representative of the section II a s c a long $\mathrm{ns}$, in whiclu the lower half of the cheeks, as well as of the opercles, is scaleless. The scales are smaller than in the other groups.

The sides and rertical fins are profusely corered with roundish black spots on a pale ground. The branchiostegals number 17 
to 19. A color variety is occasionally met with having the body uniformly dark gray, unspotted.

\section{Lucius masquinongy (Mitchill)}

\section{Mascalonge; Spotted Mascalonge}

Esox masquinongy Mrtchll, Mirror, 297, 1824, Lake Erie.

Esox masquinongy (Mitchill) Kintuand, Fishes of Ohio, 194, 183s, Lake Erie.

Esox nobilior Thompson, Proc. Bost. Soc. Nat. Hist. III, 163, 1850, Lake Champlain; Jordan \& GILBERT, Bull. 16, U. S. Nat. Mus. 358, 18s3;

Beax, Fishes Penua. 93, pl. 29, fig. 5\%, 1893.

Lucins masquinongy JorDAN \& Evermant, Bull. 47, U. S. Nat. Mus. 629, 1S96. pl. C, fig. 270, 1900; Everarann \& Kendall, Rept. U. S. Commr. Fish \& Fisheries for 18:4. 595, 1896.

The mascalonge has a stout and moderately elongate body, its greatest depth, midway between the pectoral and ventral fins, one fifth to one sixth of the total length to the end of the scales. The caudal peduncle is short and slender, its depth one third of greatest depth. The length of the head is two sevenths of the total without the caudal, and the small eye equals less than one fourth the length of snout. The eye is nearly in the middle of the length of the head. The mouth is very large; the maxilla extends to below the hind margin of the eye. The teeth are as in the pike, but even more formidable. Dorsal and anal far back, the origin of the former a little in advance of the anal origin; the length of dorsal base about two fifths of head, longest dorsal ray one third of head, caudal deeply forked; rentral midway between end of head and end of anal, its length equal to one half the depth of body; pectoral nearly equal to postorbital part of head. B. 17-19; D. 17; A. 16; V. 12. Scales in lateral line 150 .

The color is usually dark gray, sometimes immaculate as in the color variety i m a culat u s, but generally with numerous distinct, roundish, black spots about as large as buckshot. The dark spots are present only on the basal parts of the dorsal, anal and caudal fins. The lower parts are pale, the belly white.

The name of this giant pike is apparently derived from the language of the Ojibwa or the Cree Indians; it is variously spelled 
and its meaning is uncertain, though the roots, according to H. W. Henshaw, are probably mask (ugly) and kinongé (fish). In the books it appears as muscalonge, muskellunge, muskallunge, mascalonge and maskinonge, all variations of the same term. Some writers style it the great pike, and by others it is confused with the common pike, E. I u ci us. Prof. Cope mentions also the name blue pike.

The mascalonge is recorded by Prof Cope from Conneaut lake, Crawford co. Pa., the specimen measuring 17 inches in circumference behind the eyes. It is found occasionally in the Ohio valley. The species, howerer, is most abundant in the Great lakes region. In Lake Erie favorite localities are Dunkirk and Barcelona N. Y., Erie Pa. and Mills' Grove O. The northern limit of the fish is not definitely fixed.

It is asserted by some persons that the fish inhabits Cayuga lake, but others deny this. Dr Meek was unable to find it there after diligent search. It was known in Lake Champlain more than a half century ago and was described by Rer. Zadock Thompson. Mitchill and Kirtland had it from Lake Erie. De Kay confounded the mascalonge with the pike, and apparently had no example of the former. In the St Lawrence river the species is well known.

It is recorded that in $1865 \mathrm{Mr}$ Schultz caught a mascalonge at Milwakee weighing 100 pounds. In 1864 Fred Alrord declared that he had an 85 pound specimen in Maumee bay. The arerage length of the species is about 3 feet, and there is reason to believe that a length of 8 feet is sometimes reached. Individuals weighing 50 pounds are moderately common. With the exception of the lake trout and some of the salmon, this is undoubtedly the largest game fish in the United States.

The fish seem not to be gregarious, but occur usually in pairs. Their food consists mainly of smaller fishes, and their voracity is notorious. In the spawning season in small rivers falling into Lake Simcoe, Richardson states that they fecd on small fishes and on gelatinous green balls which grow on the sides of banks. under the water. 
This is an excellent food fish, but not common enough to have much commercial importance. As a game fish it has few superiors. The spoon bait is rery effective in the capture of mascalonge, and live fishes are extensively used. A correspondent of Land and Tater describes a singular and successful lure made from a young brown calf's tail, through the center of which the shank of the hook was passed and fastened to a swivel.

\section{5: Lucius masquinongy immaculatus (Garrard)}

\section{C'nspotted Mascalonge; Barred Mascalonge}

Esox immaculntus GArRARD MS; noticed in several fishing journals, Eagle Lake, Northern Wisconsin, fide Jornax \& Evermand.

Esox masquinomgy immacnlatus Jordax. Man. Tert. ed. 5, S9, 1 SSS.

Lncins masquinongy immaculatus Jordax of Evernaxs, Bull. 47, U. S. Nat. Mus. 630, 1896.

Lucins lncins immaculatus BeAv, by error, Bull. Am. Mus. Nat. Hist. IX, 358,1897 .

Body moderately stout and elongate, its greatest depth one sixth of the total length without candal; least depth of caudal peduncle contained two and two serenths times in greatest depth of body, and nearly four times in length of head; head long, its length nearly three and three fourths times in total without candal; the maxilla extending to below the front edge of the pupil, its length abont one third of length of head; snout about two fifths as long as the head; eye about one eleventh as long as the head; the gill rakers mere clumps of spiny tubercles. The dorsal fin is distant from tip of snout a space equal to two and three fourths times length of head; the longest dorsal ray is three serentlis as long as the head, and only a little longer than the dorsal base. The ventral is nearly as long as the snout. The anal base is one third as long as the head; the longest anal ray is as long as the snont, and equal to the pectoral. B. 18-19; D. 16-18 (dereloped rays); A. 15-16 (dereloped rays). Scales about 153; gill rakers $13+28$. Color olive green with golden tints; about 20 entire, blotehlike, irregular dark cross bands and sereral parts of bands and blotehes intervening; lower third of pectoral pink; dorsal, caudal and anal with dark blotches forming psendobands; iris lemon yellow on a silvery white ground; no black spots. 
Examples of unspotted mascalonge were received at the New York aquarium from Chautaugua lake, $\mathrm{X}$. Y. which bromgs to the Ohio river drainage system. It appears that the typical spotted form also inhabits the Ohio basin, but occur's rarely. Mr Annin sent one individual Dec. 4, 1895, and two on May 4, 1896; from these three were obtained the following notes and measurements in inches.

\section{MEASUREMENTS}

\begin{tabular}{|c|c|c|c|}
\hline & Dec. 4,1895 & May 4. 1896 & \\
\hline Length, including caudal fin....... & $231 / 2$ & $271 / 9$ & $25 \% / 8$ \\
\hline Lengilh to end of scales.......... & $\ldots \ldots$ & $23 \%$ & 23 \\
\hline Length of caudal lobe (horizontally). & $35 / 8$ & ... & $\ldots \ldots \ldots$ \\
\hline Length of middle caudal rays..... & $11 / 2$ & $\ldots \ldots \ldots$ & $\ldots \ldots \ldots$ \\
\hline 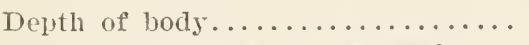 & $35 \%$ & 4 & $3 \pi / s$ \\
\hline Least depth of caudal peduncle... & $11 / 2$ & $13 / 4$ & $15 \%$ \\
\hline Length of head................ & $5 \%$ & $6 \%$ & $61 / 8$ \\
\hline 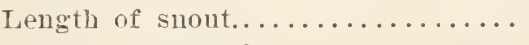 & $23 / 8$ & $23 / 1$ & $21 / 2$ \\
\hline 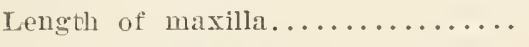 & $21 / 2$ & $23 \%$ & $21 / 8$ \\
\hline Length of mandible............. & $33 / 1$ & $+1 / 4$ & $33^{8}$ \\
\hline 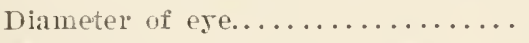 & $1 / 2$ & is & $\frac{9}{16}$ \\
\hline Distance from snout to dorsal..... & $\ldots \ldots$ & $151 / 8$ & $16^{34}$ \\
\hline Length of dorsal bise........... & $\ldots \ldots$ & 234 & $2 \div 8$ \\
\hline Length of longest dorsal ray...... & $\ldots \ldots$ & $2 \pi / 6$ & $25_{8}$ \\
\hline Distance from suout to rentral.... & ... & $13^{1 / 6}$ & $123_{4}$ \\
\hline Length of rentral.............. & $\ldots \ldots$ & $21 / 2$ & $23 / s$ \\
\hline Length of anal base............ & $\ldots \ldots$ & $21 / 4$ & $2 \frac{\pi}{13 \pi}$ \\
\hline Length of longest anal ras....... & $\ldots \ldots$ & $23 / 4$ & $2 \mathrm{r}$ \\
\hline Iength of pectural............. & $\ldots \ldots$ & $23 / 4$ & 29 \\
\hline Branchiostegals $\ldots \ldots \ldots \ldots \ldots \ldots$ & 19 & 18 & 19 \\
\hline Dorsal rays (dereloped)........... & 1S & 16 & 17 \\
\hline Anal rays (dereloped)............ & 16 & 15 & 15 \\
\hline 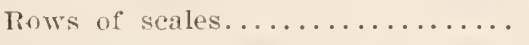 & ca. 153 & & \\
\hline Gill rakers .................. & $13+28$ & & \\
\hline
\end{tabular}

In all the specimens the maxilla exfends to below the front edge of the pupil. The gill rakers are mere clumps of sping tubercles. In the two males the diameter of the eye is contained from four and one third to fire times in the length of the snout, and from 10 to 11 times in the length of the head.

In the individual of Dec. 4, 1895, the lateral line tubes are distributed over rarious parts of the sides without much regularity except in the median line. There are no black spots. About 20 entire, blotchlike, irregular cross hands and several parts of bands and blotches interrening. The lower third of 
the pectoral is pink. The dorsal, caudal and anal with dark blotches making pseudo bands. Iris lemon yellow overlying silvery white. The general color is olive green with golden tints.

The two males of May 4, 1896, furnished the following color notes.

Olive green tinged with golden bronze; sides with about 23 irregular dusky blotches resembling interrupted bands; dorsal, caudal and anal with numerous large dusky blotches, those on dorsal and anal almost forming bands; iris lemon vellow and silvery in the larger, almost vermilion and orange in smaller; a dark blotch at upper edge of opercle.

The Chautauqua lake mascalonge, according to James Annin jr who sent the specimens, is a rery fine food and game fish, and attains to the weight of 50 pounds. In the spring of 1895 it was not unusual to captrre individuals weighing from 40 to 50 pounds, and 20 to 30 pounds was a very common weight. In winter the fish frequent nearly the same localities as in summer, being found in the vicinity of water plants. When the lake becomes very clear in Februars, they go into deep water, but they live in deep water more or less all the year.

For the fish culture operations the nets are set as soon after the first of April as the ice leaves the lake. The fish begin to spawn a few days after and continue till the latter part of April. They go into shallower water for spawning; most of them spawn in from 10 to 15 feet of water. They do not resort to the gravel, like many other fish, but to mud, generally going into bays. The eggs are placed in boxes, all of which are provided with screens at top and bottom. The bottom has an extra screen, to prevent minnows from injuring the eggs. The boxes are sunk from 1 foot to 2 feet under the surface of the water. Every day or two they are drawn up, the covers removed, and all bad eggs and sediment cleaned out.

During the first experiments in Chautauqua lake, N.Y. Monroe Green and Jonathan Mason obtained the eggs in April and May 1890 , and these were artificially hatched. A large female yielded 60,000 eggs. With the water at the temperature of $40^{\circ}$ 
to $46^{\circ}$ rery few of the egas were dereloped, but when it neared $60^{\circ}$, in May, better results were secured. Ma $2 \overline{7}, 75,000$ young fish were planted in the lake. The eggs were hatched in a box suspended about 4 fect from the bottom in 18 feet of water.

\section{Family rofentmat}

\section{Killifishes}

\section{Genus ronneus Lacrpède}

Body rather elongate, little elevaterl, compressed belind; wouth moderate, the lower jaw projecting, jaws each with two or more series of pointed teeth, usmally forming a narrow band, bones of the mandible firmly united; scales moderate; gill opening not restricted above, the opercle with its margin not adnate to shoulder girdle; preopercle, preorbital, and mandible with mucous pores; dorsal and anal fins similar, small, or rather large, the dorsal inserted either in front of, above, or behind, the front of anal; ventrals well developed; air bladder present; sexes differing in color, size, and development of the fins, the anal fin in the male normal; intestinal canal short; first superior pharyngeal without teeth, second with teeth, third and fourth coossified, with teeth. Species very numerous, mostly American, inhabiting fresh waters and arms of the sea. They are the largest in size of the cyprinodonts, and some of them are very brightly colored. They are oviparous and feed chiefly on animals. Some of them are bottom fishes, burying themserves in the mud of estuaries; others swim freely in river channels and bays; still others are "top minnows," surface swimmers, feeding on floating insects in swamps and streams.

\section{Fundulus majalis (Walloamm)}

\section{Bass Killy}

Cobitis majalis Walbaum, Artedi, Gen. Pise. III, 12, 179., Long Islind.

Esox flarulus Mitchill, Trans. Lit. \& Phil. Soc. N. Y. I, 439, pl, IV, fig. 8,1815 , New York.

Esox zonatus MitcinLl, op. cit. 440, 1815, New York.

Fundulus fasciatus DE KAY, N. Y. Fauna, Fishes, 216, pl, 31. fig. 9ऽ, 1842. Hydrargyra majalis Cuvien \& VALexeIExxes. Hist. Nat. Poiss. XVIII, 207, 1846. 
Fundulus majalis Güntrer, Cat. Fish. Brit. Mus. VI, 322, 1866; Jordan \& Gilbert, Buli. 16, U. S. Nat. Mus. 331, 1883; Bean, 19th Rep. Comm. Fish. N. Y. 274, pl. XXII, figs. 28 \& 29, 1890; Fishes Penna. 84, pl. 27, fig. 51, 1893; Jordan \& Evermann, Bull. 47, U. S. Nat. Mus. 639, 1896, pl. CI, figs. 271, 271a, 271b, 1900; BeAN, 52d Ann. Rept. N. Y. State Mus. 98, 1900.

The body is stout, oblong, not rery deep or greatly compressed. The head is contained nearly two and one half times in the total length without caudal, and the depth four times. The snout is moderately long, one and one half times as long as the eye; the eye one fifth as long as head. The scales are moderately large, those on the head about equal to the average of those on the body; scales on the cheeks in about three longitudinal rows; about 12 rows between dorsal origin and nape. The pectoral in both sexes equals the distance from the middle of the eye to the end of the head. The rentral and anal are longer in the male than in the female. In the male the ventral is one half as long as the head, in the female only about two fifths of the head. The longest anal ray of the male equals four fifths of the length of the head, while in the female it is scarcely more than one half as long as the head. The dorsal of the male is differently shaped from that of the female, its last rays being nearly as long as the longest, while in the female the last ray is not much more than one half the length of longest ray. D. 13-14; A.11. Scales $35-15$.

The sexes may be at once distinguished by their difference in color, the female having several narrow lateral stripes, while the male has distinct cross bands varying from 12 to 20 in number. In the male the sides and upper parts are dark olivaceous; the sides are silvery, lower parts a beautiful yellowish green; the sides are also marked by a varying number of dark bands, the width of which varies also. A large black spot on the operculum. The dorsal is olivaceous with a black blotch, sometimes circular in form, on the last three or four rays. The pectorals are yellowish; rentrals yellowish green; anal olivaceous; caudal orange. In the female the lower parts are white, upper parts olivaceous, and along the sides is a median dark 
band, and below this are two short, interrupted dark bars. Two or more short. transverse, dark bars on the caudal peduncle.

The striped killifish, also known as the banded or striped mummichog, bass mummy, bass fry, mayfish, yellow-tail, and New York gudgeon, is the largest member of its family known on our eastern coast. Its range extends from Cape Cod to Florida. Prof. Cope thinks that in Pennsylrania it probably ascends the Delaware as far as the boundary of the state, and I see no reason to doubt its occurrence even in fresh water.

The female is usually larger than the male, and examples measuring $S$ inches in length hare been recorded. It swarms in shallow bays and salt marshes, and though not used as food, it is extremely important for the subsistence of conomic species and is, also, extensively used for bait. The name bass mumms, applied to the speries on Long Island, refers to its use in the capture of striped bass. The species breeds in summer, and the young are abundant in shallow water among eel grass and other aquatic plants.

A permanent resident in Graresend bas. In winter it inhabits deep, mudy holes at the mouths of creeks. In captivity it is the least hardy of all the marine killifishes.

\section{Fundulus heteroclitus (Linnaens)}

Killifish; Hummichog

Cobitis hetcroclita Linvaeus, Syst. Nat. ed. XII, I, 500, 1766, Charleston, S. C.

Poecilia macrolepidota Walbaum, Artedi, Gen. Pisc. III, 11, 1792, Long Island.

Esox pisciculus Mitchild, Trans. Lit. \& Phil. Soc. N. Y. I, 440, 1815, New York.

Esox pisculentus MiтchiLL, op. cit. 441, 1S15, New York.

Fundulus vividescens DE KAY, N. Y. Fauna, Fishes, 217, pl. 31, fig. 99, 1842, New York.

Fundulus zcbra DE KAY, op. cit. 218, 1842, New York.

Fundulus pisculcutus Storer, Hist. Fish. Mass. 294, 1867.

Fundulus heteroclitus Gïnther. Cat. Fish. Brit. Mus. VI, 318, 1866; Jondar \& Gilbert, Bull. 16, U. S. Nat. Mus. 336, 1883; Bean, 19th Rep. Comm. Fish. N. Y. 274, pl. XXIII, fig. 30, 1890; Fishes Penna. 86, pl. 28, fig. 52, 1893; 52d Ann. Rept. N. Y. State Mus. 98, 1900.

Fundulus heteroclitus macrolepidotus Jordan \& Evermann, Bull. 47, U. \$. Nat. Mus. 611, 1896, pl. CII, fig. 273, male, 1900; Ifearns, Bull. Am. Mus. Nat. Hist. X, 317, 1898, salt creeks along the Hudson. 
The body is short and stout in both sexes; its depth one fourth of the length including the tail and slightly greater than the length of the head. The head is moderately short, with an obtuse snout and the space between the eyes very flat. The lower jaw projects slightly. The eye is about two thirds as long as the snout and one fifth the length of the head. The pectoral reaches to the ninth or tenth row of scales; its length is equal to the base of the dorsal. The dorsal is considerably nearer to the end of the tail than to the tip of the snout; its longest ray in the female one half the length of head. The anal is entirely under the dorsal; its longest ray equals the longest of the dorsal, its base about one third the l(ngth of head. The ventral origin is under about the trelfth scale of the median line, its length two thirds of that of the pectoral, considerably less than half the head; when extended it reaches nearly to vent. The least depth of the caudal peduncle is one serenth of the length including caudal. All the fins have rounded ontlines, and the caudal is specially convex. Scales 14-35. D. 11; A. 11.

The females are nearly uniform olivaceous, lighter below; caudal with a median narrow band of a pale color; most of the scales having a narrow, dusky submarginal streak; the scales of the head very irlegularly arranged and mequal in size. The males are dark greenish, with many narrow, irregular, silvery bars on the sides and with the belly yellowish or orange. The sides are also more or less spotted with white or yellow. The dorsal, anal and caudal are dark with many small pale sjots. On the last rays of the dorsal there is frequently a dark blotch, which sometimes is surrounded by paler, giving it an ocellated appearance. In the young this blotch is often subdivided into two parts. Tarrow dark bands are sometimes present in the young male.

The killifish has been found in the Delaware by Prof. Cope. It is frequently called mummichog or salt-water minnow. and the name mudfish has also been applied to it. In the vicinity of Boston it is known to boys under the name of cobbler, and on Long Island it is called mummy or chog-mummy. 


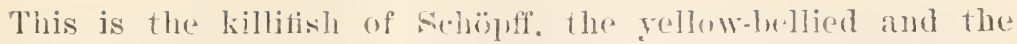
white-bellied killifish of Mitchill, and the big killifish and barred hillifish of Iletay. The Indian name mummichog is applied to this as well as to other species, ant somo prersoms "all it the saltwater minnow. In Great Sonth bay it is the mummy or chogmummy. It is extremely abundant in all parts of the bas. and serves as food for larger fishes.

The striking difference in the colors of the two sexes has led to their separation under distinct names by Mitchill, DeKay and other writers.

It grows to the length of 5 or 6 inches; it lias no importance as a foot fish, but is eaten in large numbers by many of the raluable economic fishes, particularly the striped bass and the weakfisli. Dr Storer says it is an excellent bait for smelts. Piscirorous birds consume it in large quantities, and domestic ducks have been known to swallow it with apparent great relish. Eggs have been fomd in this species as late as August. It spawns in the spring and early summer, and the soung are found in great schools in summer in the eelurass and on sandy beaches in compang with other species of killifish, the common silverside and rarious other fishes.

The killitish is a permanent resident in Gravesend bas, wintering in deep, muddy holes near the mouths of creeks. According to Eugene Smith, it stands captivity well and is often found landlocked in ice or quarry ponds. The flesh has a sweet taste. The range of the species is from Maine to South Carolina, usually in shallom salt or brackish water, but sometimes ascending streams bejond tidewater.

\section{Fundulus diaphanus (Le Surur)}

\section{Fresh-uater Killy}

Hylrargira diaphana Le Stetr, Jour. Ac. Nat. Sci. Phila. I, 130, 1S17, Saratoga Lake; DE LAY, N. Y. Fauna, Fishes, 219. 1 S42.

Hylrargira multifasciata LE SuEur, op. cit. 131. 1S17, Saratoga Lake; DE KAY, op. cit. 220.

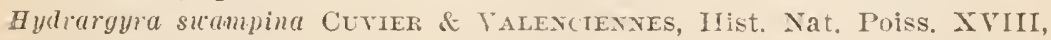
203,1815 , New Jersey.

Fundulus multifasciatus Güntrer, Cat. Fish. Brit. Mus. VI, 32t, 1866.

Fundulus sumpina Jorndx \& Crubert, Pull. 16, U. S. Nat. Mus. 332, 1883. 
Fundulus diaphanus Jordax \& GILBERT, op. cit. 334, 1883; Hugh M. Sirthe, Bull. U. S. F. C. X, 65, 1590; Jordan \& Evermañ, Bull. 47, U. S. Nat. Mus. 645, 1896, pl. CIII, figs. 275, 275a, 1900; BEAN, Fishes Penna. 85, 1893; 52d Anin. Rept. N. Y. State Mus. 98, 1900; Mearns, Bull. A.m. Mus. Nat. Hist. X, 318, 1898.

The body is moderately slender and elongate, its greatest depth equaling about two ninths of the total length without tail, or somewhat less than the length of the head. The head is flat above, the width between the eyes equal to nearly half the length of head. The mouth is very protractile, small, its width somewhat greater than the length of the lower jaw. The upper jaw is as long as the eye, a little more than one fourth the length of head, which equals about one fourth of total length withont caudal. The length of the dorsal base equals the depth of the body and much exceeds length of anal hase. Length of longest dorsal ray less than one half of head; longest anal ray two thirds of length of head. The dorsal is midway between the tip of the snout and the root of the caudal. The anal is wholly under the dorsal. Length of pectoral six and one half times in total. Caudal large, convex behind. 1). 14; A. 12. Scales 44-46-13.

The females are olivaceous with silvery; sides traversed by 1.5. to 25 narrow, dark cross bands; fins pale. The males, at least in the breeding season, are pale olive with about 20 pearly white cross bands.

The barred killifish, also known as the spring mumuichog and toothed minnow, inhabits the Great lakes and their tributaries, east to Massachusetts, south to Virginia and Indiana, west to Colorado, aceording to Cope south to Texas. The species was first made known from Saratoga lake. It is rery abundant in the Lake Ontario region, having heen taken by U. S. Fish Commission collectors at the following New York localities.

Mud creek, Cape Vincent

Grenadier island, Lake Ontario

Horse island, Sacketts Harbor

Mill Creek, Sacketts Harbor
June 25

Tune 28

Tune 30

July 2 
Stony Island

Little Stony brook, Henderson bay

Guffon creck, Chamont

Chaumont rirel

Great Sodus bay

Creek near Pultneyville

Long pond, Charlotte
July 2 and 3

July 4

July T

July 10

Aug. 6

Aug. 7

Ang. 17

St Lawrence river, 3 miles below Ogdensburg

July 17

According to Ir Meek, it is common on the flats and in the souther'n end of Cayuga lake, also in streams on the uplands, at Cayuga and Montezuma. Mr Mearns took it in Echo lake and Long pond of the Hudson Highlands. The state museum secured numerous indiriduals from Shinnecock bay July 21, Scallop pond, Peconic bay July 28, and Mecox bay Aug. 1, 1898.

The fish is rery common in a lake at 110th street and 5th avenue, Central park, New York city.

In Eugene Smith's experience the species throre better in the aquarium than any other killifish except Fundulus heteroclitus, and became very tame in captivity, though always attacking the fins of other fishes. In the New York aquarium the fish proved to be rery delicate, usually dying from fungus attacks before the salt water treatment remored the parasite.

In Ohio, and west, is found a rariety with rery distinct and somewhat irregular bands and the back always spotted, which has been called variety me n o n a by Jordan and Copeland. Eastern specimens have the back unspotted and the cross bands faint and regular, but extremely rariable in number. The difference in coloration of the sexes is rery striking, specially in the breeding season, when the adult males have silvery cross bands.

The barred killifish grows to the length of 4 inches. It runs down into brackish waters along the east coast and ascends far up the streams, delighting in cold water. It is eaten in large numbers by the striped hass and the wealifish. In the fresh waters the black bass and trout also feed on it. 


\section{Genus hocina Giratrd}

The body oblong, compressed; lower jaw prominent, the cleft of the mouth short and rery oblique; moutl moderate, the snout not produced, each jaw with a single series of conical teeth; scales rery large; gill openings not l'stricted; dor'sal and anal rays in moderate number, the dorsal above or slightly in advance of the anal; anal fin not modified in the males. Vry small, oviparous fishes of the brackish waters, swamps ind shallow bays of the United States.

\section{Lucania parva (Baird \& Girard)}

\section{Rainuater Fish}

Cyprinodon parvis BAIRD \& GIRARD, Ninth Smithsonian Rept. 345, 1£55, Greemport, Long Island; G̈̈́xthen, Cat. Fish. Brit. Mus. V'I, 307, 1866.

Lucania parta Jordan \& Gilbert, Bull. 16, U. S. Nat. Mus, 893, 1\$83; BeAv. Bull. U. S. F. C. VII, 118, pl. II, fig. 18, 1Ss8; 19th Rep. Comm. Fish. N. Y. 275, 1890; IUGH M. Smitir, Bull. U. S. F. C. X, 65, 1890; Jordan \& Evernann, Bull. 47, U. S. Nat. Mus. 665, 1896. pl. CIX, fig. 292, 1900; BEAN, 52d Ann. Rept. N. Y. State Mus. 99, 1900.

Body rather short and stout in the adult, its greatest depth two serenths of the length to base of caudal; caudal jeduncle moderately long and deep, its least depth nearly one half the length of head; the mouth small, oblinue, with heavs projecting lower jaw; snout short, nearly equal to eye, about two ninths as long as the head; eye rather large, its horizontal diameter two sevenths as long as the head; head stout, with obtuse muzzle, its length nearly one third of the total to base of caudal; dorsal origin midway between tip of snout and base of middle caudal rays, the dorsal base about one fifth of total length to candal base, the longest dorsal ray one half as long as the head, the last dorsal ray a little more than one third as long as the head. The anal fin hegins under the middle of the dorsal, its base as long as the snout and eye combined, its longest ray one half as long as the head. The ventral is slightly in adrance of the dorsal, its length three eighths of length of head. The pectoral reaches slightly beyond the origin of dorsal, its length nearly one fifth of total length to base of caudal. Caudal large, 
Ionndish, scarecly truncate behind in the adult. 1), ii, S; A. ii. 6; V. i. j. scales $10-27$.

Color in life: males olire or pale brown, with bluish reflections, edges of the scales larker, dorsal dusky orange, sometimes with a large, black spot at the base in front, ocellated with orange, camtal orange rellow, tipped with black, ventrals and anal orange red, tipped with dusky, pectorals translucent; females with the fins pale olive, without black spot or edgings. Length $1 \frac{1}{2}$ to 2 inches.

The species is found along the coast in brackish waters from Massachnsetts to Florida; rery common on Long Island. Abundant in Peconic, shinnecock. and Great South bays, and in a fresh-water stream at Water Mill L. I.; not ret reported from firavesend bay. It seldom exceeds $1 \frac{1}{2}$ inches in length and is interesting chiefly on account of its translucent body and graceful morements. It has not proved hardy in captivity.

The species was first described br Prof. Baird from Greenport I. I.

\section{Genus cy prinomox - Lacépède}

Body rery short and stout, the back elevated; mouth small, the bones of the jaws well formed; snout short; teeth moderate, incisorlike, tricuspid, in a single series; scales very large; dorsal fin moderate, inserted in advance of front of anal, its first ray not enlarged; anal smaller; rentral fins small, occasionally wanting in specimens from desert pools; intestinal canal little longer than body; gill membranes considerably united, free from the isthmus; gill openings restricted, the opercle above adnate to the shoulder girdle. Chubby little fishes, inhabiting the brackish waters of middle America, sometimes liring in warm salt springs, their colors generally brilliant. Oriparous; the sexes similar except in color.

\section{Cyprinodon variegatus Lacépède}

\section{Sheepshead Hinnow}

Cyprinodon variegalus LACÉPÉde, Hist. Nat. Poiss. Y, 486, 1803, South Carolina; Güntner, Cat. Fish. Brit. Mus. VI, 305, 1866; Jordan \& Gilbert, Bull. 16, U. S. Nat. IIus. 329, 1883; BeAN, Bull. U. S. F. O. VII, 148, 1885; 19th Rept. Commrs. Fish. N. Y. 275, 1890; 52d Ann. Rept. N. Y. State Mrus. 99, 1900; Jordan \& ETERMaxi;, Bull. 47, U. S. Nat. Mus. 671. 19\%;, pl. CXI. fig. $29 \% .296 a, 1900$. 
Esox ovinus Mitchill, Trans. Lit. \& Phil. Soc. N. Y. I, 441, pl. IY, fig. i, 1815, New York.

Lebias orinus DE KAY, N. Y. Fauna, Fishes, 215, pl. 27, fig. 84, 1842.

Lebias ellipsoides Le Sueur, Jour. Ac. Nat. Sci. Phila. II, 6, pl. 2, figs. 1, 2, 1821; Storer, Syn. Fish. N. A. 179, 1846.

Body short and stout, heary anteriorly, its width more than one half its hight, its greatest hight two fifths to nearly one half of total length to base of caudal, the males higher than the females; caudal peduncle short, its least depth equal to postorbital part of head; head conical, its width at gill corers equal to its length without the snout, its length one third of total without caudal; jaws rery short, mouth small, terminal, slightly oblique when closed, the lower jaw somewhat prominent, the upper protractile; the maxilla curved abruptly downward at the end, about as long as the eye, not reaching to the front margin of the orbit; eye cirvelar. longer than snout, not quite one fourth as long as the hoad, placed near the top of the skull, about two thirds of width of interorbital space; dorsal origin a little nearel to tip of snout than to base of middle caudal rays, the dorsal base, in males, as long as the head without the snout, three and two thirds in total length without caudal, the longest dorsal ray, in males, about equal to length of head, and twice as long as the last ray. The rentral reaches nearly or quite to anal origin, its length one half length of head. The anal base is two fifths as long as the head, its longest ray one fifth of total without caudal. The pectoral is narrow and as long as the head in males, reaching almost to the beginning of the anal; in females it is not quite so long as the head, and does not reach beyond the middle of the rentral. Caudal fin short and truncate, its length about one fourth of the total without candal, and abont equal to the head without the snout. D. 11 ; A. 10 ; B. 6 . Scales 17 -2s.

This is known in Great South bay as the porgy nummur. Mitchill recorded it as more rare than the other killifishes. Dekay has it as the Sheepshead Lebias.

This little fish seldom exceeds 2 inches in length. The males are more brightly colored and higher bodied than the females, and have a narrow, dark margin to the caudal fin. 
The Sheepshead killifish ranges from Cape Cod to Florida. It is not important except as food for other fishes. Tery common in salt water ditches.

One of the best of its family for aquarium purposes, as it thrives and breeds in captivity; the young, howerer, may be eaten by their parents.

\section{Order SYNENTOGNATHI}

Family esocinae

Needlefishes

\section{Genus Truosures Cocco}

Body elongate, very slender, not much compressed; both jaws prolonged into a beak, the lower jaw somewhat the longer, much the longer in young fishes, the rery young resembling $\mathrm{Hemir}$ a m pus; each jaw armed with a band of small, sharp teeth, beside which is a series of longer, wide set, sharp, conical, unequal teeth; no teeth on romer or palatines; scales sniall, thin; lateral line running along the side of the belly, becoming median on the tail; no finlets; dorsal fin more or less elerated anteriorly; caudal fin short, unequally lunated or forked; pectorals moderate; ventrals small, the latter inserted behind the middle of the body; gill raker's obsolete; bones usually more or less green; size comparatively large. Species numerous. Toracious fishes, chiefy American; one species crossing to Europe; some of them entering rivers. This genus differs from the old world genus E s ox (Linnaeus) Rafinesque (= B e 1 o n e, Cuvier) in the absence of gill rakers and of romerine teeth.

\section{Tylosurus marinus (Talbaum) Billfish; Silver Gar}

Esox marinus Walbaum, Artedi. Gen. Pisc. III, S8, 1792, based on SchöpF, Sea Snipe, Long Island.

Esox longirostris Mrchill, Amer. Month. Mag. II, 322, March, 1818.

Belone truncata Le Sueur, Jour. Ac. Nat. Sci. Phila. II, 126, 1821; De Kar, N. Y. Fauna, Fishes, 227, pl. 35, fig. 112, 1842; Günther, Cat. Fish. Brit. Mus. VI, 244, 1666; STorer, Hist. Fish. Mass. 136, pl. XXIV, fig. 3,1867 .

Tylosurus longirostris Jondax \& Gilbert, Bull, 16, U. S. Nat. Mus. 374, 1883. 
Tylosurus marinus Jordan \& Fordice, Proc. T. S. Nat. Mus. :2.1. 1sst: Beax, Pull. U. S. F. C. VII, 146, 1sss; 19th Rept. Commrs. Fisll. N. Y. 273, 1890; Fishes Penua. 97. 1893; Jordax \& Everuxx, Bull. 47 , U. S. Nat. Mus. 714, 1S96; Medras, Bull. Amer. Mius. Nat. Hist. X, 318, 1898; Bean, 52 d Ann. Rept. N. I. State Mus. 99, 190k.

Body long, slender and somewhat compressed. The depth of the body is less than one fifth of length of head; the ere is rather large, two fifths of the length of the postorbital part of the head. The pectoral is as long as the postorbital part of the head and twice as long as the rentral. The distance of the dorsal from the root of the caudal is one fourth its distance from the tip of the lower jaw. The anal ends under the end of the dorsal and begins in advance of the dorsal origin. The rentral is almost equidistant from the root of the candal and the hind margin of the eye. D. 15 to $16 ; \mathrm{A} .15$ to 17 ; V. 6.

The body is green with a broad silvery band along the sides and a dark bar on the operculum. The scales and bones are green.

The silver gar, also called soft gar, billfish and netdefish, is found along our coast from liaine to Texas, and, though a marine species, it ascends rivers far above the limits of tides. It has been found in the Susquehanna rirer at Bainbridge Pa., and it also runs up the Delaware, the Hudson and other rivers.

Schöpff is authority for the names sea pike and sea snipe for this species at New York. Mitchill refers to it as th long-jaw fresh-water pilie, and also as the billfish, a name still in use in rarious localities for this fish. Billed eel is the name used in Great South bay. DeKay calls it the banded garfish. Still another name used for the species is needlefish; and it is said that gar is derived from a Saxon word meaning needle.

The species is found on our coast from Maine to the Gulf of Mexico. Mearns has found it in the Hudson and its estuaries in autumn. Mitchill observed it so frequently in that river that he considered it an inhabitant of fresh water. In Gravesend bay the fish occurs from June to September. In Shinnecock bay, Mecox bay, and freat Sonth bay the writer collected it almost everswhere. 
This species reaches a length of 4 feet. It is rery destructire to small fishes, which are readily seized in its long and strongly toothed jaws. In the Gulf of Mexico the habits of the silver gar hare been observed by Silas Stearns, whose notes are to be found in the Fishery Industries of the L'nited States. It is foumd at Pensacola Fla. in the summer. but retreats farther south in the winter.

The silver gar swims at the surface and feeds on schools of small fish. On the New York coast it devours killifishes, anchovies, silversides, and other little species. Its morements are swift and its aim certain. It has been known to seize mullet and other fish one third as large as itself and is sometimes killed by attempting to swallow sping fish too large to pass through its throat. It sparns in the bars in May and June. Mr Stearns found it to be an excellent food fish, though it is seldom eaten on the Florida coast.

Though the fish is one of excellent flaror and, according to DeKay, greatly relished by epicures, it meets with little faror in northern markets. Nothing is recorded about its breeding habits except the statement of Silas Stearns that it spawns in the bays of the Gulf coast in May and June. The fish is not hardy in transportation and in capticity.

\section{Tylosurus raphidoma (Ranzani) \\ Houndfish; Guardfish}

Belone raphidoma Ravzaxi, Not. Comm. Ac. Nat. Sci. Inst. Bonon, Tr, 3509, pl. 37, fig. 1, 18t2, Brazil; Güntuer, Cat. Fish. Brit. Mus. VT, 249, 1866.

Belone gerania Cuvier \& VAlenchenses, Hist. Nat. Poiss. Xrili, 437. 1846, Martinique; GüNTHER, op. eit. 241, 1866.

Belone crassu Poer, Memorias, II, 291, 1861, Cuba.

Belone melanochira Poer, op. cit. 294, 1861; Günther, op. cit. 249, 1866.

Tylosmus gladius BEAN, Proc. U. S. Nat. Nus. 239, 430, 1Ss2. Pensacnlat: Bull. U. S. F. C. VII, 146, pi. II, fig. 15, 1SSS, young, Ocean City, N. J.

Tylosurus crassus Jordax. Proc. U. S. Nat. Mus, 112. $18 S 4$.

Tylosurus raphitoma Jordan \& Evermann, Bull. 47, U. S. Nat. Mus. 715, 1896, pl. CXTI, fig. $308,1900$.

Body robust, little compressed, its greatest width a little more than two thirds its greatest depth, which is about one fourth 
the length of head and one thirteenth of total to base of caudal; caudal peduncle slightly depressed, a little broader than deep, with a slight dermal keel; head broad, broader above than below, three tenths of total length to base of caudal; interorbital space nearly two thirds of length of postorbital part of head, with a broad, shallow, naked, median groove, which is wider behind and forks at the nape; supraorbital bones with radiating striae; distance between nostrils a little more than one sixth of length of snout; jaws comparatively short, strong, tapering, very stiff, lower jaw wider and longer than upper, both jaws with broad bands of small teeth on the sides, within these a series of very large knife-shaped teeth. The length of the longest teeth is a little more than three times their breadth. Posterior teeth in both jaws directed backward, anterior teeth erect, number of large teeth about 25 on each side of the upper jaw and 23 below, length of the large teeth about one fifth of diameter of eye, no vomerine teeth. Upper jaw from eye about one and three fourth times as long as the rest of the head; eye large, one seventh as long as snont, three eighths of postorbital part of head, and five ninths of interorbital width; maxillary entirely covered by preorbital; cheeks densely scaled; opercles scaly only along anterior margin; scales minute, specially on the back, somewhat larger below. Dorsal fin rather high in front, beconiing low posteriorly, the hight of its anterior lobe equaling postorbital part of head, its longest ray two fifths of length of dorsal base. In a young example, $6 \frac{1}{2}$ inches long, the posterior part of the dorsal is much elevated, the longest ray equaling the distance from middle of pupil to end of head. Caudal fin lunate, its lower lobe nearly one half longer than the upper; middle rays about as long as eye; anal fin falcate, low posteriorly, its anterior lobe equal to anterior dorsal lobe; ventral fins inserted midway between base of caudal and middle of eye, a little shorter than pectorals, and equal to postorbital part of head; upper ray of pectorals broad, sharp edged, length of pectoral three and two fifths in head, and slightly greater than postorbital part of head. D. i, 21-23; A. i, 20-23; V. 6; P. 14. 
Color dark green abore, silvery below; dorsal and pectoral blackish; rentrals somewhat dusky; anal rellowish, the lobe slightly soiled; caudal dusky olivaceous; no suborbital bar and no scapular spot; a slight dusky shade on upper posterior part of cheeks, and a yellowish bar on anterior edge of opercle; caudal keel black.

This species is rery closely allied to T. f o d i a to $\mathrm{r}$ Jordan \& Gilbert, described from Mazatlan, differing from it apparently in its longer jaws, slightly greater number of fin rass, and larger scales. Here described from the trpe of $T$. g l a d i s Bean, which is 29 inches long.

A young example was seined at Ocean City N. J. Aug. 1, 1887. D. i, 21; A. i, 20 . Length $6 \frac{1}{2}$ inches.

A dark cutaneous flap attached along the side of the mandible and folded underneath, meeting its fellow of the opposite side and concealing a small part of the lower jaw; dorsal black, except on the first six rays, which are pale, much elevated at the posterior part, where the longest ray equals the distance from the middle of the eye to the end of the head. 14 black blotches on sides not extending to caudal, the largest two thirds as wide as length of eje; paired fins and anal pale; caudal the same, except anterior half of upper lobe, on which the membrane corering the rars is blark, while the intervals between the rars are pale; back greenish; under surface, except mandibular flap, silvery.

This species has not previously been recorded in the region.

The usual range of the species is from the West Indies and Florida Keys to Brazil; the young straying northward occasionally in summer. The fish reaches a length of 5 feet and is sometimes dangerous to fishermen in its powerful leaps from the water. The scales and bones are green; the flesh is little esteemed for food on this account. A description and figure of the roung are published by Bean in the Bulletin of the U. S. Fish Commission for 1887, p. 146, pl. 2, fig. 15. 


\section{Tylosurus acus (Lacépède)}

\section{Houndfish}

Sphyraena acus LACEPEDE, Hist. Nat. Poiss. T, 6, pl. 1, fig. 3, 1Si3, Martinique.

Belone latimuna Poer, Memorias, II, 290, 1861. Harana; Günther, Cät. Fish. Brit. Mus. VI, 2t9, 1866.

Belone jonesi Goone, Am. Jour. Sci. Arts, 205, 1877, Bermuda; Gïrrnfr, Aun. Mag. Nat. Hist. III, 150, 1879.

Belone crivibala Gïnther, Cat. Fish. Brit. Mus. VI, 241, 1866, not of LE SUeur.

Tyloswrus acus Jordax \& Fordice, Proc. U. S. Nat. Mus. 355. 18\$6; Jordav \& Lvermann, Bull. 16, C. S. Nat. Mus. 716, 1896, pl. CXY1, fig. 3m, 1000 .

Body slightly compressed, its greatest depth one trentieth of total length, its greatest width alout one twenty-eighth of the same; free part of tail somewhat depressed, quadrate, its depth one third of greatest hight of body; caudal carinat moderate, black; lead somewhat depressed above, striated, with a broad, shallow median groore whicl expands posteriorly into a wide, somewhat depressed triangular area, length of head contained three and one fourth times in total length without caudal; supereiliary region sharply striated; smout equal to maxillars, one fifth of total length, and three times postorbital part of head: mandible slightly shorter than distance from snout to nape, 10 times vertical diameter of eye, and projecting beyond tip of upper jarr; eye equal to width of interorbital area and one eighth of length of head; teeth large, sharp, not very close, maxillary terth about 60 , the largest one sixtl as long as the eye; mandibula ${ }^{2}$ teeth about 60, the largest one ninth as long as the eye; no vomerine teeth; dorsal origin at a distance from tip of snout equal to two and one fifth times length of head, slightly behind anal origin, length of dorsal base fire times long diameter of eye, greatest hight of dorsal fin equal to greatest width of head, and contained seren and one half times in length of head, last dorsal ray about one third of anterior rays; anal base terminating anteriorly to end of dorsal at a distance equal to length of first dorsal lay; rentral origin midway between front of orbit and base of midlle caudal rays, length of rentrals one seventh 
of length of head; length of pectoral slightly greater than that of postorbital part of head; caudal forked, the lower rays about one fourth longer than the upper. D. 23-24; A. 21-22; P. 13; V.5; B. 12. Scales in lateral line (estimated) 380 .

Above deep green, below silvery white, opercles and cheeks silvery white, anterior rays of dorsal and pectoral fins blackish, caudal carinae also blackish.

"The houndfish, as it is called in Bermuda, is a graceful, active species attaining to the length of 3 feet or more. It frequents swift tide courses, where it preys upon small fishes, particularly the schools of silversides and anchovies. It takes the hook well." Goode

The species occurs in the West Indies and sometimes strays northward as far as Buzzards bay in summer; it was first described from Martinique. Individuals have been recorded from Beaufort N. C.

\section{Family HENIIRHANPHIDAE}

\section{Balaos}

\section{Genus mopormuphts Gill}

Body elongate, moderately compressed, the sides of the body not vertical, but more or less convex; the dorsal outline parallel with that of the belly; npper jaw short, lower jaw prolonged into a slender beak, bordered with membrane, this beak shorter in the young; premaxillaries forming a triangular plate, the teeth of which fit against the toothed part of the mandible; maxillaries joined to premaxillaries; teeth feeble, mostly tricuspid; gill rakers rather long; head covered abore with large, shieldlike scales; scales large, deciduous; no finlets; caudal fin more or less forked, the lower lobe the longer; dorsal and anal similar, opposite each other, not modified in the males, last ray of dorsal usually short; rentrals small, inserted well forward, nearly midway between opercle and base of caudal. Oriparous. Air bladder large, simple, not cellular. Young with the lower jaw short. Sides in our species with a distinct silvery band, as in A the rina. Species numerous, in all warm seas, 
going in large schools, but usually remaining near shore, feeding chiefly on green algae. Size comparatively small.

161 Hyporhamphus roberti (Cuv. \& Tal.)

\section{Halfbert:}

Memirhmphus roberti Curier \& VAlexcenses, Mist. Nat. Poiss. XIX, 24, 1846, Cajeme; Güxtmer, Cat. Fish. Brit. Mus. VI, 266, 1866; MeEK \& Goss. Proe. Ac. Nat. Sej. Phila, 223, 18st; BeAx, Bull. U. S. F. C. VII, 147, jl. III, fig. 16, 18ss; 19th Rept. Commrs. Fish. N. Y. 2īt, 1890.

Hemirhamphus unifasciatus Jordan \& Gileert, Bull. 16, U. S. Nat. MIus. 376, 1 SS3.

Hyporhamphus roberti Jordan \& Evermans, Check-List Fish. N. A. 221, 1896; Bull. 47, U. S. Nat. Nus. 721, 1896, pl. CXVII, fig. 312, 1390; Beax, 52d Ann. Rept. N. Y. State Mus. 100, 1900.

Body compressed, elongate, its greatest depth one eighth of total lengtlı to caudal base, its greatest width equal to postorbital part of head; caudal peduncle short and deep, its least depth equal to rye. From eye to end of upper jaw equals one third the distance from end of upper jaw to hind margin of opercle. Head including lowel jaw three eighths of total length without caudal, without projerting part of lower jaw two elevenths of the same; eye equal to interorbital width, about one eighth of length of head (one fourth of head to end of npper jaw); projecting part of lower jaw a little longer than rest of lead; dorsal origin orer the anal origin, 34 rows of scales between it and the nape, base of dorsal equal to eye and postorbital liart of liead combined, longest dorsal ray equal to postolbital part of head, last dorsal ray less than one half the longest, and about two thirds of the eye; anal base slightly shorter than dorsal base, longest anal ray slightly longer than postorbital part of liead, last anal ray one half of eye; rentral origin about midway between 're and base of caudal, the fin about as long as the postorbital part of head; pectoral base high, on the level with the eye, the fin about as long as npper jaw and reye combined; caudal fin symmetrically forked, the middle rays two thirds as long as the external, and nearly twice as long as the eye (from end of scales only a little longer than the (e) ; dorsal and anal fins densely scaled; lateral line com- 
mencing at the isthuns, rmming close to the rentral erge of the bod! (1) the origin of the rentrals, where it rises slightly and is discontinned orer the end of the anal base. D). ii, 13:

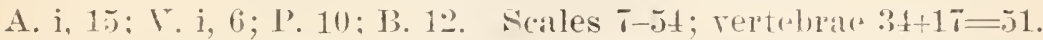
Translucent groen above; the scales above with dark edges; a narrow silvery band, about one latf the widtl of ero, along the side from axil of pectoral to base of caudal; tip of lower jaw crimson in life and with a slort filament; three narrow dark strealis along middle of back; anterior part of dorsal and anal and tips of caudal dusky, almost black; Jeritonemm lolack.

The halfbeak is occasionally found on our northern coast to Cape cod, but appleass to have been unknown to Mitehill and De Kily. The species ranges soutluwal to the Grulf of Mexico. We found 12 small examjles Oct. 1, 1890, at Fire island. Two young examples were taken in Great Ego Harbor bay in 18ST, and a larger one, $6_{+}^{1}$ inchrs long. was taken in the same locality. According to B. A. Bean this fisl was not abundant in the Chesapeake, at Cape Charles, Ka., during September 1890.

The halfbeak is a rare fish in New Tork waters. It attracts attention because of the great inequality in the length of the jaws, the lower jaw being many times as long as the short npper jaw. One of the most striking color marks of this fish is the crimson tip of the lower jitw. The body is silvery, darker on the back, and has a distinct silvery lateral stripe.

In 1898 the writer collected this species for the New York state moseum in small numbers in Great Goutl bay, during August and September. Only one adult was obtained. The loealities are: sonth side Great South bay, Clam Pond cove. and Horsefoot creek. This fish, like the silrer gar, is readily taken at night by means of a lantern. The light dazes the fish, so that it does not see the net.

\section{Genus echepormaphes Gill}

This genus consists of pelagic species related to $H$ (2 $\mathrm{m}$ -

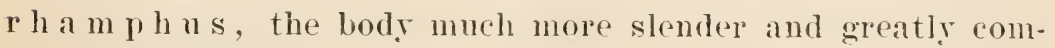
pressed, and the pectorals rery long. approaching those of the flying fishes. Tentrals small, inserted posteriorly. Air blad- 
der not described, probably cellular. One species in our limits.

\section{Euleptorhamphus velox Poey (?)}

\section{Slender Halfbeak}

Euleptorhamphus velox PoEx, Syn. Pisc. Cubens, 383, 1867, Cuba; Jordas \& Evermann, Bull. 47, U. S. Nat. Mus. 724, 1896.

?Hemirhamphus longirostris GüNTHER, Cat. Fish. Brit. Mus. VI, 276, 1866. Euleptorhamphus longirostris Putnam, Proc. Bost. Soc. Nat. Hist. 238, 1870. Hemirhamphus (Euleptorhamphus) longirostris JordaN \& GILBERT, Bull. 16, U. S. Nat. Mus. $377,1883$.

Body much compressed, elongate, its greatest depth one eleventh of total length from tip of upper jaw to base of caudal; greatest width of head equal to long diameter of eye; least depth of caudal peduncle two thirds of eye; snout equal to eye, three and one third in head (length of head here is from tip of upper jaw to hind margin of opercle); length of head including lower jaw two fifths of total to base of caudal, the lower jaw projecting beyond upper a distance equal to three times rest of head; eye three in head, greater than interorbital width; dorsal origin at a distance from tip of snout equal to four and two thirds times length of head (without lower jaw), dorsal base equal to nearly three times hight of body, longest dorsal ray two thirds lengtl of head; the anal begins under the third ray of the dorsal, its base two and one third times hight of body, its longest ray equal to hight of body; ventral short, slightly shorter than eye, three and two thirds in head, extending nearly half way to anal origin; pectorals long, reaching half way from pectoral origin to anal origin, nearly twice as long as the head; caudal lobes very unequal, the upper mucli shorter than the lower. D. 22; A. 21; V.6; P. 7, the upper very broad and long, the others slender. The back with a very thin edge. Color light brown above, the sides from the upper edge of the pectoral base downward bright silvery, this extending also on the head.

The species is found in the West Indies; it has been taken at Newport R. I., and at Cape Cod. It reaches a length of 18 inches. The Hemirhamplus macrorhynchus of 
Cuvier and Talenciennes, taken in the south Pacific, appears to be closely related.

\section{Family SCONBERESOCIDAE}

\section{Sauries}

\section{Genus scommenesox Lacépède}

Body elongate, compressed, covered with small, thin, deciduous scales, the general aspect being that of a mackerel; both jaws in the adult more or less prolonged, forming a slender beak, the lower jaw always the longer, teetl very feeble, pointed, maxillaries joined fast to premaxillaries; pectoral and rentrals small; dorsal and anal low, similar to each other, each witl four to six detacled finlets, as in the Scombridae; gill rakers numerous, long and slender; pharyngeal bones essentially as in Exocoetus, fourth upper pharyngeal on each side wanting or fused with the third, third pharyngeal greatly enlarged, separate from its fellow, covered with tricuspid teeth, sccond with simple teeth, first toothless, lower pharyngeaIs united, forming a triangular bone witl concare surface, covered with tricuspid teeth; into the hollow of this bone the upper phat $1^{2}$ ngeals fit.

Pelagic fishes, swimming close to the surface in large schools in temperate regions. They bear strong analogic resemblances to the mackerels in form, color and habits, as well as in the dorsal and anal finlets. The significance of these resemblances is unknown.

Ioung with the jaws short, precisely as in the genus $\mathrm{Col}$ o1 a b is, but lengthening with age, which is not the case in Colola bis. Air bladder large.

Atlantic.

163 Scomberesox saurus (Walbaum)

\section{Suury; Skipper}

Esox saurus Walbaum, Artedi. Gen. Pisc. III, 98, 1792, Cornwall.

Scomberesox scutellatum Le Sueur, Jour. Ac. Nat. Sci. Phila. II, 132. 1S21, Newfoundland.

Scomberesox equirostrum Le Sueun, Jour. Ac. Nat. Sci. Phila. II, 132, 1 1s21. 
Scomberesox storeri DE KAY, N. Y. Fauna, Fishes, 229, pl. 31, fig. 111, 1842, New York; Storer, Hist. Fish. Mass. 1:T, pl. XXIT, fig. 4, $1 \& 67$. Scomberesax sambs Fleming, Brit. Anim. 1St; Güntmer, Cat. Fish. Brit.

Mus. VI, 25t, 1866; Goode \& BEAx, Bull. Essex Inst. XI. 21, 18і9; Jordan \& Gilbent, Bull. 16, L. S. Nat. Mus. 375, 18s3; Jordan \& Evermaxi, Bull. 47, L. S. Nat. Mus. 725, 1896, pl. CXTII, fig. 314, 1900 .

Bodr compressed, elongate, its greatest hight one ninth of total lengrth to base of caudal; anal equal to eye and postorbital part of head combined; least hight of caudal peduncle equal to eye; both jaws slender and produced, the lower longer than upper, the distance from eye to tip of lower jaw equaling one fifth of total to base of caudal; eye one third as long as postorbital pat of head, about one tifth of length of upper jaw; small scales on operele, but none on suboperele: borly covered with small scales: dorsal origin at a distance from front of ere equal to fire times hight of body, dorsal base three times as loug as the eye, longest dolsal ray one lualf as long as postorbital part of head, last dorsal ray cqual to eyc, fire separate finlets behind the dorsal; anal under the dorsal, its base slightly longer, as long as postorbital part of head, longest anal lay equal to longest of the dorsal, last anal ray scarcely equal to eye, six finlets behind the anal; caudal fin deeply forled, symmetric, the outer rays as long as the anal base; ventrals midway between front of eye and base of caudal, length of fin about twice dianeter of exe, distance from vential origin to anal origin equal to length of npper jaw; length of pectoral one fourtl the length of head to tip of upper jaw; lateral line containing minute, roundish pores, near the ventral edge, in modified scales which extend obliquely backward. D. 11+r; A. 13+vi; V. i, 5; P. 14. Ncales $14-124$ (136 to free part of midile caudal rays, 80 rows from axil of pertoral to origin of dorsal); opercle with about $S$ rows of scales.

Back brownish to upper level of eye; sides with a silvely band, nealy as bioad as the eye and almost on the same level; lower parts silvery witl a golden tinge overlying it.

The sanry grows to the length of 18 inches. It inhabits the temperate parts of the Atlantic in Europe and the Inited 
States, congregating in schools in the open seas, where it is preyed on by porpoises, tunny, bonito, cod, blucfish and other predaceons animals. It Provincetown Mass., according to Storer, large quantities are rearly thrown on the shore, but the a are considered worthless, while on other parts of Cape Cod they are taken in immense numbers, and are considered very nutritious food.

The saury, or skipper, is migratory, arriring on our coast in summer and deprating on the approach of cold weather. It is a surface swimmer and, therefore, is particularly liable to the attacks of roracious fishes. Conch says:

It is sometimes seen to rise to the surface in large schools and fly over a considerable space. But the most interesting spectacle, and that which best displays their great agility, is when they are followed by a large comprny of porpoises, or their still more actire and opluressive enemies, the tunuy and bonito. Multitudes then mount to the surface and crowd on each other as they press forward. When still more closely pursued, they spring to the hight of sereral feet, leap orer each other in singular confusion, and again sink beneath. Still further urged, they mount again and rush along the surface by repeated starts for more than 100 fect, without once dipping beneath, or scalcely seeming to touch the water. At last the pursuer springs after them, usually across their conrse, and again they all disappear together. Amidst such multitudes-for more than 20,000 have been judged to be out of the water togethersome must fall a prey to the enemy; but, so many hunting in company, it must be long before the pursuers abandon. From inspection we should scarcely judge the fish to be capable of such flights, for the fins, though numerons. are small and the pectorals far from large, though the angle of their articulation is well adapted to raise the fish by the direction of their motions to the surface. Its power of springing, therefore. must be chiefly ascribed to the tail and the finlets. It rarely takes bait; and, when this has happened, the boat has been under sail, the men fishing with a "lash," or slice of mackerel made to imitate the living body.

The skipjack is frequently seen springing above the surface on our coasts, and no doubt at such times it is pursued by bluefish, bonito and, probable, mackerel or cod. 


\section{Family ExOCOETIDAE}

\section{Flying Fishes}

\section{Genus Exocoetus (Artedi) Linnaeus}

Body elongate, broad abore, somewhat compressed; head short, blunt, narrowed below; mouth small; jaws rery short, about equal; chin without barbel; maxillaries not joined to the premaxillaries; teeth rery feeble or wanting; eyes large; gill rakers moderate; scales large, decidnous; no finlets; dorsal fin short, opposite anal; caudal widely forked, the lower lobe the longer; pectoral fins rery long, reaching past the beginning of the anal, and serving as organs of flight, their great size enabling these fishes to sustain themselves in the air for some time; rentral fins large, posteriorly inserted, also used as organs of flight; air bladder very large; no pyloric caeca. Species numerous in all warm seas, liring mostly in the open water and swimming in large schools.

\section{Subgenus Exocorers}

\section{$16 \pm$ Exocoetus volitans Linnaeus}

\section{Flying Fish}

Exocoetus volitans Linnaeus, Syst. Nat. ed. X, 316, 1758; JoRdan \& MeEK, Proc. U. S. Nat. Mus. 57, 18s5; Jordan \& Evermann, Bull. 47, U. S. Nat. Mus. 734, 1896, pl. CXVIII, fig. 318, 1900.

Exocoetus rubeseens Rafinesque, Amer. Month. Mag. II, 205, January, 1818, Banks of Newfouudlaud.

Exocoetus affinis Günther, Cat. Fish. Brit. Mus. VI, 288, 1866.

Exocoetus mclanurus Jordan \& Gilbert, Bull. 16, U. S. Nat. Mus. 379, 1883.

Exocoetus exitiens Jordan \& GILbERT, op. cit. $3 S 0$ and 904, $1 S 83$.

The hight of the body is nearly one sixth of the total length without caudal, the length of the head one fourth. The depth of the head equals the distance from the tip of the snout to the hind margin of the orbit. Snout little produced, shorter than eye, which is two seventlis to one third as long as the head; interorbital space flat or slightly concave, slightly greater than diameter of eye; width of body at pectoral base four sevenths of length of head; dorsal origin opposite anal origin, length of longest dorsal ray two fifthis of length of head; anal fin long, its 
longest ray one third of length of head; pectoral fin reaching. slightly beyond dorsal and anal, its length fire serenths of that of the body; rentral origin midway between the eye and the base of caudal, the fin reaching beyond the middle of the anal base, its length two sevenths of length of body. D. 11-13; A. 11-13. Scales 55 (30 to 35 rows between occiput and dorsal origin; 25 rows before ventrals), 6 rows between the origin of dorsal and the lateral line.

Pectoral fin with an oblique white blotch across its lower half, and with a narrow whitish edge; rentrals grayish or whitish, with a slight dusky shade in the axil; dorsal and anal without dark markings.

The flying fish is found in open seas on the Atlantic coast; it extends northward to the Grand Banks of Newfoundland; it is known also in southern Europe, and in the Pacific and the Indian ocean.

The flight of the flying fish has been much discussed, for and against; but no doubt remains in the minds of those who have seen the action at close range that the flight is genuine. Not only can the fish start from the water and rise into the air, but it can also change its direction suddenly at will, to escape its pursuers, and it has been observed to hover like a humming bird or a great moth and then dart off suddenly out of reach of the net thrust out to secure it. Such an occurrence took place at Woods Hole Mass., some years ago in the presence of the writer.

The flying fish is an excellent food fish, but does not come to our markets frequently, because of its habitat in the open sea. It comes aboard ressels occasionally in storms or when trying to escape from its enemies, and is highly prized by its captors.

The species reaches the length of 1 foot.

\section{Subgenus criselcres Swainson \\ 165 Exocoetus heterurus Rafinesque} Flying Fish

Exocoetus heterurus Rafinesque, Caratteri Alc. Nuor. Gen. 5S, 1S10, Palermo; Jordan \& MeEk, Proc. U. S. Nat. Mus. 59, 1855; Jordan E EvermanN, Bull. 47, U. S. Nat. Mus. 735, 1896. 
Exocoetus cometus Mitcinle, Trans. Lit. \& Phil. Soe. N. Y. 418. pl. V, fig. 1, 181;. New York.

Exococtus nomboracensis Nitcmul, Trans. Lit. \& Plil. Soc. X. Y. I, pl. V, fig. 3, 181.); Imel. Month. Mag. II, 329, March, 1S18; If KAY, N. Y. Fauna, Nishes, 2:30, pl. 36, fig. 11t, 1842. near New York; Jordax \& Gilbeis, Bull. 16, C. S. Nat. Mus. 904, 1889.

Body slender, its greatest dejull contained from fire to five and one thiml times in the total length without caudal; length of head contained four and two thirds in total to base of caudal; the snout slightly shortel than eye, its length three and three fourths times in head, while that of the eye is contained three and one fifth times; dorsal origin in adrance of anal origin, dorsal base from one and one half to two times as long as anal base; first ray of pectoral simple, second divided, third and fourth rays longest, extending to last ray of dorsal and contained one and fom ninth times in total length without caudal; rentral origin midway between eye and base of caudal fin, the rentrals reaching last ray of anal, the length contained two and three fourth times in length of body. The lower caudal lobe is three fifths longer than the upper, which is equal in length to the hight of the body. I).14; 1.9; P. 15; T.6. Scales j8-6:3, 39 1.0ws before the dorsal fin, 7 roms between the dorsal origin and the lateral line; rertebrae $31+14=4.5$.

Pectoral fins grayish brown with a broad whitish margin, an oblique white band on their lower half; dorsal and anal uniform grayish without bands; rentrals whitish. slightly dusky in the axils.

The species grows to the length of 1.) inches. The young often have a long barbel at the chin, this disappearing entirely in the adiult.

T) Mitrhill described a specimen, 1 foot long, which was taken in a seine near New Iork.

This flying fish inhabits the Atlantic ocean and is most abundant in the tropical parts. but strays northward to England and to the banks of Newfoundland. 


\section{Exocoetus furcatus (Mitchill)}

\section{Flying Fish}

Eroeortus fureutus Mitcille, Trans. Lit. \& Phil. Soc. N. Y. I, 449, pl. Y, fig. 2, 1815; DE Kis, X. Y. Fauna, Fishes, 231, 184:.

Exocotus untulli LE Suevr, Jour. Ac. Nat. Sci. I'hila. 10, lil. IT, fig. 1,

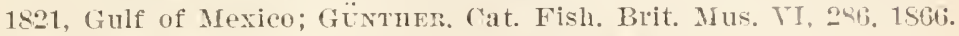

Cypseturus furcatus Jonbax \& Gilbert, Bull. 16, U. S. Nat. Mus. 380, 1883.

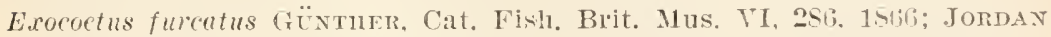
\& MeEx, Proc. U. S. Nat. Mus. 61, 1855; Jordan \& Evenusix, Bull. 47, U. S. Nat. Mus. 73t, 1896.

Body slender, compressed, moderately elongate, its depth contained fire and one fourth times in total length withont caudal; head not very broad, much narowed forward, its length contained four and one half times in total without caurlal; the snout rather pointed. more compressed than in other species; interorbital area fiat, its width at anterior margin of orbit equal to diameter of eye, which is one thind of lengtli of head; month small, maxilary not reaching orbit, its length four and three fomrths in head, mandible two and one half in head: snout four and one fifth in head; eye one third of length of head; pectoral fin long and broad, its length one and two ninths in lenģth of body, extending to 10th ray of dorsal, first pectoral ray simple, slightly mole than one half the length of fin, second ray divided, third and fourth rays longest; rentral origin midway between hind margin of eye and base of caudal, rentrals long. four ninths of lengtl of body, their tips reaching almost to caudal fin; dorsal fin rather high, its longest ray tro thirds as long as the head, its base nearly equal to head; anal fin inserted farther bark than dorsal, its base three fifths as long as dorsal base, its longest ray one half as long as the head: lower caudal lobe two serenths as long as the body. D. 13 ; A. 9 to 10 . Scales in lateral line ti; about 2!) rows in advance of dorsil fin and about 2:3 on the lateral line in advance of the rentrals; s roms between the dorsal origin and the lateral line.

Brownish above, silrery below; the lower posterior half of pectorals black, the uppere pectoral rass with a broad white band, the tipes of the rays whitish, other parts marbled with 
biack; the rentrals black except on two outer rays, on inner ray, and a small spot on next two inner rars, about one fourth distance from rentral origin; axil of rentrals pale. Günther describes the rentral as having the posterior part black. Three black spots on dorsal fin and three blackish cross bands on the lower caudal lobe, a black spot on tips of third, fourth, fifth, and sixth rays of the anal, $\mathrm{ol}^{2}$ the lower part of the fin sometimes black.

The species grows to the length of 6 inches. Young indiriduals have barbels at the symphysis of the lower jaw, which vary in length and disappear with age. The fish is found abundantly in warm seas, ranging north to Cape Cod and to the Mediterranean. Specimens have been taken at Newport R. I.

Dr Mitchill described the species from an example 3 inches long. His specimen had two barbels, each half an inch long. The eyes, according to his description and figure, are very much larger than in Exocoetus heterurus.

\section{Exocoetus gibbifrons Cuv. \& Val.}

Exocoetus gibbifrons Cuvier \& Valenciennes, Hist. Nat. Poiss. XIX, 11S, 18t6, Atlantic; Jordan \& MeEK, Proc. U. S. Nat. Mus. 65, 18s5; Jordax, Proc. U. S. Nat. Mus. 528, 1886; Jordan \& Evermann, Bull. $4 \overline{6}$. U. S. Nat. Mus. $741,1896$.

Body robust, little compressed, its greatest depth one sixth of the total length without caudal; head rather short, interorbital area slightly concare, about one fourth wider than eye; profile of snont convex, descending more abruptly than in any other American species, making a decided curve downward; snout rather blunt, one fourth as long as the head; length of head contained four and three fifth times in total without caudal; maxillary two ninths as long as head; pectoral fins rather broad and long, two thirds of total without caudal, their tips reaching to tips of last rays of dorsal, first ray of pectoral simple, its length five elevenths of length of fin, second pectoral ray simple, about one half longer than first ray, third pectoral ray divided, fourth ray longest; ventral origin midway between hind margin of eye and root of caudal, length of ventrals about one third of total without caudal, the fin reaching to last anal 
ray; dorsal origin far in adrance of anal origin, longest dorsal ray five elevenths of length of head; anal base fire cighths as long as dorsal base, longest anal ray one third of length of head; least depth of caudal peduncle contained three and one fifth times in length of head, the lower caudal lobe two sevenths of total length without caudal. D. 12; A. S. Scales before dorsal 30 ; before ventrals 25 ; between dorsal origin and lateral line $\tau$.

Color brown above, silvery below; on each scale on the upper part of the body a darker brown spot near its posterior extremity, which gires the appearance of a dark brown streak along each row of scales; pectorals uniformly brown, or greenish brown; ventrals dusky, nearly black mesially, the posterior part of the fin still darker; no dark markings on dorsal or anal fins; caudal dusky, plain.

Atlantic ocean, two specimens known, both examined by Dr Jordan, from whose description the above was taken. One individual was secured by Samuel Powell at Newport R. I.; the other was obtained by Dussumier in the Atlantic ocean and by him presented to the Museum of Natural History at Paris. This example is 9 inches long.

\section{Order HEMIBRANCHII \\ Half-gills}

Family GASTEROSTEIDAE

Sticklebucks

\section{Genus excılı Jordan}

Fresl-water sticklebacks, feebly armed, the skin not mailed, the dorsal spines few and nondivergent, the gill membranes forming a free fold across the isthmus, pubic bones fully united. One species known.

\section{Eucalia inconstans (Kirtland)}

\section{Brook Stickleback}

Gasterosteus inconstans Kintr.Axd, Bost. Jour. Nat. Hist. III, 273, pl. II. fig. 1, 1841, brooks of Trumbull County, Ohio; SToner, Srn. Fish. N. A. 64, 1S46; BeAn, Bull. 15, U. S. Nat. IIus, 130, 18i9: JoRjar \& Gilbert, Bull. 16, U. S. Nat. Mus. 394, 1853. 
Eucalia incumstams Jordax, Proc. Ac. Nat. Sci. Phila. 65, 1877; Eigexmaxy, Proc. Ac. Nat. Sci. Phila. 23S, 1886; Beas, Fishes Penna. 9S, 1893; Jorday et Evermaxx, Bull. 47, U. S. Nat. Mus. TH, 1836; Everuanv \& KexidLt, Rept. T. S. Commr. Fish \& Fisheries for 1S94, 595, 18:ii, Franklin County, Termont.

The body is more elongated than in the other sticklebacks describud, and stouter, the candal peduncle has no keel, and the skin is entirely smooth. The rentral spines and pubic bones itre very small, the latter concealed under the skin. The thoracic llocesses are covered by the skin, slender and widely separater. The dorsal spines are slort, nearly equal in length, placed in a straight line, the anterior spines shortest. The ventral spines are small and serrated. The depth equals one fourth and the head two serenths of the total length without ('audal. I). III-IT, I, 10; A. I, 10. Males in the breeding season ale jet blacli, tinged entirely witl coppery red. The females and roung are greenish, variegated with darker.

The brook stickleback occurs in the fresh waters from New York westward to Thiliota and is said to cistend north to Greenland. A valiety from cayuga lake has been described by $\mathrm{Dr}^{\circ}$ Jordan. It lias the rentral spines longer than the pubic bones.

In Pennsylyania the brook stickleback inhabits the Ohio valley. In Nerr Tork it oceurs only in the restern part, being specially abundant in the Lake Ontario region. The U. S. Fish

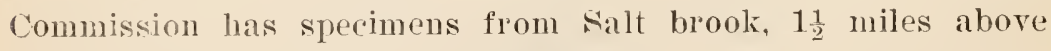
Nine Mile point, June 11, 1S!3, Mill creek, Sacket Harbor, July 2, Cape Vincent, July 2, Black river, Huntingtonville, July 5, Three Mile creek, Oswego, July 27, Four Mile creek, Nine Mile point, near Webster, August 9, and Long Pond, Charlotte, August 17. Erermann and Pean rollected it also July 2S, 1894, at Saranac river, Platisburg. 13* Meek found it common in standing and sluggish watel on the flats of Cayuga lake basin. Jolın W. Titcomb obtained it from a small brook in Franklin county, Tt., the outlet of Franklin pond, a tributary of Pike river, which flows into Missisquoi bay.

It grows to a lengtl of $2 \frac{1}{2}$ inches, and has no value as food, but is an interesting aquarium fish. It is howerer extremely 
pugnacious, and, when these fish are kept in confinement, great nortality is caused by their quarels. The species is abundant in small streams, where it secretes itself among aquatic plants and is always alert to attack small fishes and insects. Specimens have recently been obtained from an artesian well in South Takota, the well having a depth of $700 \mathrm{fect}$. From this great depth the fish were brought up in full strength and rigor, and they were kept in an aquarium several months afterward. A similar occurence has been recorded by Mrs Eigenmann, in the Proceclings of the Tational Museum for 18S3, p. 217, of Williamson's stickleback at San Bernardino Cal. The well in this case was only 191 feet deep. There is no doult that the fish reach the wells through streams which become subterranean in a certain part of their course.

This species is a nest-builder and is rigorous in the defense of its eggs and young.

This fresh-mater stickleback appears to live better in balanced tanks than in flowing water and is not hardy in capticity. It feeds readily on chopped hard clams and $\mathrm{G}$ a $\mathrm{m}$ m a $\mathrm{r}$ us, the latter being one of its natural foods.

\section{Eucalia inconstans cayuga Jordan}

\section{Cayuga Late Stickleback}

Eucalia inconstans cayuga Jornan, Man. Tert. ed. 1, 249, 18T6, Cayuga Lake, Ithaca, N. Y.: MeEk, Ann. N. Y. Acad. Sci. IV, 312, 1ses; Jordan of Evermax, Bull. 47, U. S. Nat. Ius, 7 $14,1896$.

According to Dr Jordan, this rariety has longer rentral spines than the common brook stickleback, these being as long as the pubic bones (two thirds as long in inconstans). The size is generally smalle' ${ }^{2}$, but the fin rays are the same as in in con s t a $\mathrm{ns}$.

The variety occurs in small brooks and in the lakes about Ithaca and Syracuse N. Y.

Genus prosters Brevoort

This genus is characterized by the presence of 9 to 11 divergent spines and by the weakness of its innominate bones. 
As in E c a lia, the gill membranes form a broad fold arposs the isthmus. Vertebrae $\mathbf{1 4}+\mathbf{1 8}=32$. Species two, in northern regions, the following cosmopolitan; a second, P y gos te us s in e n s is Guichenot, from China.

\section{Pygosteus pungitius (Linnaeus)}

\section{0 spined Stickleback}

Gasterostcus pungitius Lrnvaeus, Syst. Nat. ed. I, 296, 1758, Europe; GünTher, Cat. Fish. Brit. Mus. I, 6, 1859; Storer, Hist. Fish. Mass. 43, pl. VIII, fig. 5, 1867; BEAN, Bull. 15, U. S. Nat. Mus. 133, 134, 1879; Jordan \& Gilbert, Bull. 16, U. S. Nat. Mus. 393, 1983; BeAN, 19th Rept. Commrs. Fish. N. Y. 244, 1890.

Gasterosteus oecidentalis DE KAY, N. Y. Fanna, Fishes, 6S, pl. 42, fig. 135, 1842; Storer, Syn. Fish. N. A. 63, 1846.

Gasterosteus concinnus Richandsox, Fauna Bor-Amer. III, 5T, 1836, Saskatchewan River and Great Bear Lake.

Gasterosteus nebulosus Agassiz, Lake Superior, 310, pl. IV, fig. 2, 1850.

Pygosteus pungitius Eigenmann, Proc. Ac. Nat. Sci. Phila. 235, 1886; Jordan \& Evermann, Bull. 47, U. S. Nat. Mus. 745, 1896; Bean, 52d Ann. Rept. N. Y. State Mus. 100, 1900.

Body moderately elongate and compressed, its greatest depth one sixth of total length to base of caudal rays, its width one tenth of the same length and two fifths of the length of the head. The head is one fourth of total length to base of caudal, its width contained two and one third times in its length; the length of the snout equals the width of the interorbital space, and nearly one fourth the length of the head; the upper jaw is slightly more than one fourth the length of head, and the mandible is nearly as long as the eye, which is contained about three and one fourth times in length of head. The spinous dorsal is inserted at a distance from tip of snout equal to two serenths of total length without caudal; its base is a little longer than the head; its first and second spines equal, and one fourth as long as the head; its last spine less than one fifth as long as the head. The base of the soft dorsal is three times as long as the mandible; the antecedent spine is as long as the mandible; the first ray is longest, and is twice as long as the upper jaw. The anal origin is twice as far from tip of snout as the spinous dorsal; the anal base is twice as long as the middle caudal 
rass, and equals trice width of body; the first anal spine is about equal to one half the derith of body; the first anal ray longest and one half as long as the head. The midde caudal rays equal width of head and about three serenths of length of head; the external rays are slightly more than one half the length of head; the length of the caudal peduncle equals three times the leugtl of last dorsal spine; the least hight of the peduncle is contained seven and one third times in length of head. The pectoral is twice as long as the mandible; the rentral is at a distance from tip of snout equal to three times length of reutral spine; the ventral spine is usually about two fifths as long as the head, or somewhat more. The dorsal spines are all in the same line in a furrow, but they direrge so as to form a zigzag series. Pubic bone weak, lanceolate, not serrate, its length about two fifths head; rentral spines siender, pungent, serıulate above and below; gill membranes free from isthmus behind, gill rakers long and slender; caudal fin lunate, slightly emarginate. D. VII to XI, I, $9 ; \mathrm{A}$. I, S. Color brownish above, the upper part of sides with numerous darker blotches simulating bands, lower parts silvery, pubic and thoracic regions often black. Length 3 inches.

The 10 spined stickleback inhabits the northern parts of Europe, the Atlantic coast of America from Long Island to the Arctic ocean; also tributaries of the Great lakes and northward into British America and Alaska. In the Arctic fres!n waters it is represented by a form with shorter rentral spine, smaller eve. lower fins, and other characters.

Notwithstanding its small size, this fish serres a very useful purpose as food for the salmon and trout, and arctic explorers hare utilized it in rast numbers for feeding their dogs. Occurring as it does in shallow fresh-water lagoons in summer, apparently landlocked, and freezing solidly in winter, it lias always been a mystery how it survives.

This stickleback is less abundant in Graresend bay than the two spined and three spined species. In Great South bay it is known as the thornback. In 1890 it was seen only once. In 
1898 the state museum obtained a few specimens from Shinnecock bay, Peconic bay and sereral stations in Great South bay.

This species appear's to run upstream farther than the others. In the aquarium it often attacks fish and tears their fins into shreds. During the breeding suason the male becomes of a rosy hue beneath. It is a hardy fish, enduring captivity better than the other species. Often found in pools in the woods where seemingly no other fish ocemr. (After Eugene Smith1)

\section{Genus Gastekosteus (Artedi) Linnaeus}

Sticklebacks with the innominate bones coalescent on the median line of the bells, behind and between the rentral fins, forming a triangular or lanceolate plate. Gill membranes united to the isthmus; tail slender, and usually keeled; skin variously covered with bony plates; dorsal spines three in number, strong, with nondirergent bases. Species numerons. Fresh waters and shores of all northern regions; the species highly variable, those found in the sea usually with the body completely mailed, the fresh and brackish water forms variously mailed or even altogether naked.

\section{Gasterosteus bispinosus Walbaum}

\section{Two spined stickleback}

Gasterosteus bispinosus Waldaun, Artedi, Gen. Pisc. III, 450, 1792; Jordan \& Gilbert, Bull. 16, U. S. Nat. Mus. 396, 18S3; Jordan \& Evermann, Bull. 47, U. S. Nat. Mus. 748, 1896, pl. CXIX, fig. 320, as aculeatus, 1900; Eugene Suiti, Proc. Liun. Soc. N. Y. 31, 1898; Bean, 52d Ann. Rept. N. Y. State Mus. $100,1900$.

Gasterosteus aculcatus Goode \& BÈAN, Bull. Essex Inst. XI, 5, 1879; JoRDAN \& GilberT, Bull. 16, U. S. Nat. Mus. 395, 1\$83; Bean, Fishes Penna. 98, 1893; not of Linnaeus.

Gasterosteus neoboracensis DE KAY, N. Y. Fauna, Fishes, 66, pl. 6, fig. 17, 1842.

Gasterosteus biaeuleatus MItchill, Trans. Lit. \& Phil. Soc. N. Y. I, 430. pl. I, fig. 10, 1815, New York; DE KAY, N. Y. Fauna, Fishes, 65, pl. 3, fig. 8, 1842, New York and Hudson River to Albany; Stoner, Syn. Fish. N. A. 62, 1846; Hist. Fish. Mass. 40, pl. VIII, figs. 2, 3, 1867.

The body is fusiform, moderately elongate and compressed; the caudal peduncle is short and slender and distinctly keeled. The hight of the body is less than the length of the head and

${ }^{1}$ Linn. soc. N. Y. Proc. 1897. no. 9, p. 30-31. 
about one fourth of the total without caudal. The eye is one fourth as long as the head. The sides are corered by about 33 bony plates. The processes from the shoulder girdle cover the breast except a small naked area between them. At the base of each dorsal spine is a large rough bony plate to which the spine is hinged in such a way that it may be fixed and immorable at the will of the fish. The pelric bone is lanceolate. A cusp at the base of the rentral spine. The spines are all closely serrated, those in front of the anal and soft dorsal smallest. D. II, I, 11-1:; A. I, 9.

The living fish is greenish olive, lighter on the sides, the lower parts silvery. The gill corers are silvery with dusky spots; the iris silvery; pupil black; fins pale; the rentral membrane sometimes red.

The two spined stickleback or burn stickle is found on both sides of the Atlantic, its range on our coast extending southward at least to New Jersey and northrard to Labrador. This is the largest of the sticklebacks and is said to grow to a length of 4 inches. In the North Pacific and Bering sea there is a related species, G. c a t a phractus Pallas, which has been styled the salmon killer. In Pennsylvania Mr seal has found this fish abundant in pools and ditches along the Delaware.

De Kay found this stickleback in the salt creeks about New York and in the Hudson river as far up as Albany. The state museum obtained it in 1898 in Shinnecock bay, July 22, and in Scallop pond, Peconic bay, July $2 S$. It is not common in summer. The following notes are from an article by Eugene Smith of Hoboken.

Exceedingly common in the tidal creeks in the spring. The nest of this fish is mare on and in the sand with the aid of bits of straw, weeds, etc. After the female has deposited the eggs, the male stands orer the nest and fans it with the pectorals, only leaving to get food, or to resent an intrusion; he often kills the female with whom he has paired. During this time the male is red below and bluish and greenish abore, with indistinct darker bars. After the spawning season is orer, they seem to die off, at least they do in captivity. With proper attention the roung can be raised to quite a size. 
The two spined stickleback thrives and breeds in captivity, but will not endure extreme heat in summer, and the adults will eat their young.

\section{Genus apeltes De Kay}

Body moderately elongate, somewhat compressed, the back elevated at the beginning of the soft dorsal fin, thence declining in nearly a straight line to tip of snout; tail very slender, not keeled; no bony dermal plates, the skin naked; innominate bones not joined on the median line but separated, forming a bony ridge on each side of the abdomen, below which the strong ven. tral spines are depressible; chest mostly bony; bare area in front of pectorals small, but distinct; gill rakers rather short, gill membranes attached to the isthmus, without free edge; free dorsal spines three, strong, the first the longest, directed to one side, the next two directed toward the other side at different angles, attached spine of dorsal and anal well developed, a bony ridge on each side of the spinous dorsal.

\section{Apeltes quadracus (Mitchill)}

\section{Four spined stickleback}

Gasterosteus quadracus MitculL, Trans. Lit. \& Phil. Soc. N. Y. I, 430, pI. I, fig. 11, 1815, New York; DE KAY, N. Y. Fauna, Fishes, 67, pl. 6. fig. 18, 1842, the generic name A p e $1 \mathrm{t}$ e s proposed; Günther, Cat. Fish. Brit. Mus. I, 7, 1859; Storer, Hist. Fish. Mass. 41, pl. VII, fig. 4, 1§67. Gasterosteus millepunctutus Arres, Bost. Jour. Nat. Hist. IV, 234, p]. XIr,

fig. 3, 1844. Old Mans Marbor, Long Island.

Apeltes quadracus Goode \& BEAN, Bull. Essex Inst. XI, 5, 1579; JordAN \& Gilbert, Bull. 16, U. S. Nat. Mus. 396, 18s3; Bean, 1:th Rept. Commrs. Fish. N. Y. 244, 1890; Fishes Penna. 99, 1893; Jokdax \& Evermann, Bull. 47, U. S. Nat. Mus. 752, 1896, pl. CXX, fig. 322, 1600 ; Eugene Smth, Proc. Linn. Soc. N. Y. No. 9, p. 31, 1S9S; Mearss, Bull. Am. Mus. Nat. Hist. $\mathrm{X}$, 318, 1895; BeAr, 52d Ann. Rept. N. Y. State Mus. $100,1900$.

The body is fusiform in shape, the snout pointed and the caudal peduncle slender. The sides are somewhat compressed. The depth of the body equals the length of the head and is one fourth of the total without caudal. D. III-IV, I, 11; A. i, S. The skin is scaleless. The first dorsal spine is the highest, its length about half that of head. 
The liring fish has the upper parts greenish brown. Below the lateral line the color is darker and is mottled by the extension upward of the white color of the abdomen. Young specimens liare the brown color aggregated into several cross bands, which become indistinct in the adult. The ventral membrane is broad, scarlet in color, giring rise to one of the popular names.

In Great South Bay the four spined stickleback is called thornback. This is the "bloody stickleback" of Storer's Fishes of Massachusetts. It appear's to be the commonest member of its family in this bay in September and early October. We found it common in rarious parts of the bay at a time when the two spined stickleback, Gas terosteus bispinosus, was not once seined, and only a single specimen of the 10-spined, P. p u n iti u s, was secured. Localities at which we have collected the species are: Swan creek, Blue Point core, Blue Point Lifesaving station, Great River beach and Fire Island. The species is most plentiful in brackish streams where there is an abundance of aquatic plants. In 1898 the state museum obtained it from the following additional localities: Shinnecock bay, Peconic bay, Mecox bay, Howell's point, Great South bay, Bellport Lifesaving station, Nichol's point and Fire Island inlet. Examples taken at Patchogue August 24 were in fresh water.

This species reaches a length of 2 inches. It swarms in the shallow waters, specially in the northern part of its habitat, and is particularly plentiful in brackish streams where there are numerous aquatic plants. In salt marshes it is one of the commonest of the little fishes, and it is not uncommon in the mouths of rivers. In Pennsylvania Prof. Cope records it as abundant in the tide water streams and ditches of the Delaware. It runs up stream into purely fresh water and is commonly associated with the killies in small ditches and pools. This stickleback builds a rudimentary nest of plant bits, and behares like the abore mentioned P. pungitius and G. bis pinosus, in most respects. It is hardy and can be kept all the year 
round. I have successfully raised this fish to nearly mature growth. (After Eugene Smith ${ }^{1}$ )

The remarkable spinning habits of this fish have been described by Prof. John A. Rrder in the bulletin of the U. S. Fish Commission for 1881.

Family FISTLLARIDAE

Cornet Fishes

\section{Genus fisturaria Linnaeus}

Body extremely elongate, much depressed, broader than deep; scaleless, but having bony plates present on various parts of the body, mostly covered by the slin; head very long, the anterior bones of the skull much produced, forming a long tube, which terminates in the narrow month, this tube formed by the s.mplectic, proethmoid, metapterygoid, mesopterygoid, quadrate, palatines, romer, and mesethmoid; both jaws, and usually the romer and palatines also, with minute teeth; membrane uniting the bones of the tube below, rery lax, so that the tube is capable of much dilation; post-temyral coossified with the cranium; branchiostegals five to seren; gills four, a slit behind the fourth; gill membranes senarate, free from the isthmus, gill rakers obsolete; basibranchial elements wanting, pseudobranchiae wanting; air bladder large; spinous dorsal fin entirely absent, soft dorsal short, posterior, somewhat elevated; anal fin opposite it and similar; caudal fin forked, the middle rays produced into a long flament; pectorals small, with a broad base, preceded br a smooth area as in Gasterosteidae, pectoral ossicies 3 ; interclavicles greatly lengthenèd, supraclavicles very small; rentral fins very small, wide apart, abdominal (through partial atrophy of the girdle, by which they lose connection with the interclavicles), far in advance of the dorsal, composed of six soft mass; pyloric caeca few; intestine short; vertebrae very numerons ( $4+44$ to $49+28$ to 33$)$, the first four vertebrae very long. Fishes of the tropical seas, related to the

\footnotetext{
${ }^{1}$ Linu. Soc. N. Y. Pror. 1897. no. 9. p. 31.
} 
sticklebacks in structule, but with prolonged snout and different rentral fins. A single genlıs, with three species.

The bony shields. rlaracteristic of this genus, are the following:

1 A narrow strip along the median line of the bark behind the skull (confluent neural spines).

2 The pair of broader lateral dorsal shields are peculiar bones, separated processes of the occipital bone. These shields are the longest, provided anteriorly with a ridge, which is prolouged and extends far backward between the muscles of the back. This ridge is flexible, and does not interfere with the lateral morements of the fish; it appears to serve as a base for the attachment of muscular fibers.

: The narrow shichl on the side is the postclavicle, its posterior jart being dilated and fixed to the lateral dorsal shields.

4 The rentral shields are the inter laricles; their posterior half is broadest, much pitted inferiorly; they are narrower before the middle, learing a free lanceolate space between them, and are again a littie widened anteriorly, where they join the claricle and urohyal. These plates extend as far backward as thr ankylosed veluhrae. (Aftel Jordan and Everuann)

\section{Fistularia tabacaria Linnaeus}

\section{Trumpet Fish}

Fistularia tabacarin Lixnatus, Syst. Nat. ed. X, I, 312, 1758; DE KAY, N. Y. Fauna, Fishes, 233, 18t2; Storer, Syn. Fish. N. A. 191, 1st6; GüNther, Cat. Fish. Brit. Nus. III, 529, 1561; Jordax \& Gilmert, Bull. 16, U. S. Nat. Mus. 3S9, 18s3; BeAx, Bull. U. S. F. C. VII, 14r. 1Ss8; 19th Rept. Commis. Fish. N. Y. 273, 1890; Jordax \& Everulanx, Bull, 47, U. S. Nat. Mus. 757, 1.596.

Fistularia neoboracensis MITculLL, Trans. Lit. \& Fhil. Soc. N. Y. I, 43T, pl. III, fig. S, 1815 .

Fistularia scrvata DE KAY. N. Y. Fauma, Fishes, 232, pl. 35, fig. 113, 1842. Massachusetts; Storer, Hist. Fish. Mass. 140. pl. XXV. fig. 1, 1867; Goode \& Bean, Bull. Essex Inst. XI, 4, 1879, Rockport Mass., not of Cuvier, Rigne Anim. ed. 1, 349, 181 .

Body greatly depressed, elongate, its deptl about one thirtrfourth of its length to base of caudal and only abont two thirds

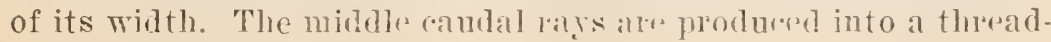


like filament, which is a little longer than the snout. The snout is greatly prolonged, two and three fourths times as long as the rest of the head. Mouth at the end of the long tube oblique, the lower jaw projecting a distance equal to one third of diameter of eye; upper jaw two thirds as long as postorbital part of head, lower jaw nearly twice as long as upper; eye nearly equal in length to upper jaw, about nine and one half in length of head; snout three and two thirds in total length to caudal base; margin of orbit with thin, sharp points in frout and behind; dorsal origin at a distance from tip of snout equal to three times lengtlo of snout, base of dorsal slightly longer than eye, longest dorsal ray one fourth the length of snout; anal exactly opposite dorsal, its base equally long, its longest ray also equal to longest dorsal ray; ventrals small on a narrow base, their distance from tip of snout and end of external caudal rays nearly equal; pectorals short, on a broad base, their length one lialf the length of head without the snout; caudal lobes equal, the upper external rays three fifths as long as the head without the snout. D. 14; A. 13; V. 7.

Reddish brown above, with numerous large, oblong, pale blue spots ou the sides and back, arranged in series; under surface of head and belly at least to ventral fins, pale and silvery.

The fish was known to Dr Mitchill and described by him from a specimen 14 inches long. We are not informed where he obtained this example, but it was an individual in the fresh condition. Dr De Kay called it the spotted pipefish and takes his account from the report of Dr Mitchill.

The trumpet fish is generally common in the West Indies and neighboring seas, where it is said to reacl the length of 6 feet. It is occasionally taken as far north as Cape Cod. It is not common in that region, and is apparently rare in Great South bay, though three examples were taken at Fire island, September 30, and one at Blue Point Lifesaving station, October 7. In Great Egg Harbor bay, N. J. the species is moderately abundant, as the writer seined 25 specimens in August and September 1887.

The species is interesting on account of its peculiar structure, but is without economic ralue. 
Order LOPIIOBRANCHII

Tuftgills

Suborder SYNGNATHI

Family SYNGNATHIDAE

Pipefishes

Subfamily SYNGNATHINAE

Genus siruostoms Rafinesque

Body elongate, very slender, six or seven-angled, not compressed, tapering into a rely long tail, the dorsal keels of the trunk not continuous with those of the tail; head slender, tapering into a long, tubulike, subterete snout, which bears the rery short, toothless jaws at the end; humeral bones firmly united with the "breast ring;" body covered with a series of bony, lieeled, radiated plates, arranged in linear series; dorsal fin distinct, rather short, inserted before or opposite the vent, which is near the middle of the body; caudal fin present, rather small; anal fin minute, close behind rent; pectorals developed, short and rather broad. Male fishes with an egg pouch along the under side of the tail, formed by two cutancous folds, and splitting lengthwise to release the young fishes. Species rery numerous, inhabiting all warm seas; abounding in bays among the seaweeds, and entering the rivers. The females in most species are deeper than the males, with more robust trunk, with longer snout, and a more distinct ventral keel.

\section{Subgenus smprostoma}

\section{7t Siphostoma fuscum (Storer)}

\section{Common Pipefish}

Syngnathus fuscus Stoner, Rept. Fish. Mass. 162, 1839, Nahant.

Syngnathus peckianus StorER, op. cit. 163, pl. 1. fig. 2, 1839, Holmes' Hole.

Marthas Vineyard; Syu. Fish. N. A. 23S, 1816; Hist. Fish. Mass. 218, pl. XXXIII, fig. 3, 1867 .

Syngnathus fasciatus DE KAY, N. Y. Fauna, Fishes, 319, pl. 54, fig. 174, 1842. Synguathus viridescens DE KAY, op. cit. 321, pl. 54, fig. 176, 1812, Hudson River, at Sing Sing.

siphostoma fuscum and peckiamu, Goone \& BEAn, Bull. Essex Inst. XI, $4,1879$.

Siphostoma fuscum Jordan \& Gilbert, Bull. 16, U. S. Nat. Mus. 383, 1883; BeAv, Bull. U. S. F. C. VII, 134, 18\&6; 19th Rept. Commrs. Fish. N. Y. 244, 1890; 52d Ann. Rept. N. Y. State Mus. 101, 1900; Jordan \& EverMAxN, Bull. 47, U. S. Nat. Mus. 770, 1896. 
The female is much deeper bodied than the male, the depth of body equaling one third of length of head, while in males it is only one fourth of this length. Tail very long, slender, and tapering, its length three fifths of total length without caudal; snout a little longer than rest of head, with a well marked median keel above and below, the upper one serrulate; occiput, nuchal plates and opercle keeled, the carinations on opercle sometimes nearly obsolete; belly slightly convex and with a low keel; eye small, fire in snout, three in postorbital part of head; dorsal fin at a distance from tip of snout equal to two and two thirds times length of head, the base of the fin one fifth longer than head, the longest ray two serenths as long as base of fin, and about one third as long as the head, the fin corering $5+5$ body rings $(1-5+5-1)$; anal fin of female reduced to two or three rays on a very nalrow base, its length about equal to length of eye; candal convex when expanded, the middle rays longest, as long as the postorbital part of head; pectoral short, on a broad base, its length one fourth the lengih of head. D. 36 to 40 ; rings $19+37$ (or 18 to $20+36$ to 40 .)

Color brown above, pale below, everywhere mottled with brown; under surface of snout pale, lower part of opercles silvery.

The common pipefish is abundant on our Atlantic coast from Cape Ann to Virginia. It is known as the billed eel in Great South bay. It is abundant in all parts of the bay. Though this species is not raluable for food or bait, it is an interesting aquarium fish and has the same singular breeding habits as the sea horse. After the ova of the females are excluded, they are received and hatched, and the young are cared for, in the marsupium of the male. The species, according to De Kay, ascends the Hudson to Sing Sing, where it breeds in slightly brackish water. It is to be found in shallow water among aquatic plants. The female is conspicuously different from the male in its colors and the much greater deptli of its body. The pipefish is moderately abundant in summer in eelgrass and sea lettuce in Graresend bay. In 1898 the state museum had it from all parts of Great South bay and from Shinnecock, 
Peconic, and Mecox bays. Both young and adults were abundant during the summer.

Males, females and joung were abundant at Ocean City N. J. earls in August 1887; but the males were more numerous than the females. The egg pouches of the males were filled with ejed embryos, arranged in four series on each side. A male $6 \frac{1}{2}$ inches long, taken near Ocean City, August 31, had the pouch unsrmmetrically filled, the left side containing more than two thirds of the whole number of embryos and increasing in carrying capacity from behind forward. This is the billfish at Somers Point.

In the aquarium the species is fond of shrimp eggs and small G a m m a r s ; but, on account of the difficulty of securing proper food, its life in captiritr is usually short. In a slowly circulating tank, at a temperature of $54^{\circ} \mathrm{F}$. sereral individuals were alive and, apparently, in good condition.

\section{Subfamily HIPPOCAMPINAE}

\section{Genus mprocampus Rafinesque}

The body strongly compressed, the belly gibbous, tapering abruptls to a long quadrangular, prehensile tail; head with a distinct curred neck, placed nearly at a right angle with the direction of the body, surmounted by a compressed occipital crest, on the top of which is an angular, star-shaped coronet; top and sides of the head with spines. Physiognomy remarkably horselike, like that of a conventional knight at chess. Body and tail corered with bons plates, forming rings, those on the body each with six spines or tubercles, those of the tail with four; pectoral fins present, short and broad; anal minute, usually present; dorsal fin moderate. opposite the rent; egg pouch in the male a sac at the base of the tail, terminating near the rent.

\section{7.) Hippocampus hudsonius DeKay}

\section{Sea Horse: Horsefish.}

Hippocampus hudsonius DE KAY, N. Y. Fauna, Fishes, 322, p]. 53, fig. 171, 1842; Storer, Syn. Fish. N. A. 239, 1846; Hist. Fish. Mass. 222, pl. XXXIII, fig. 4, 1867; Jordan \& Gilbert, Bull. 16, U. S. Nat. Mus. 907, 1S83; Bean, 19th Rept. Commrs. Fish. N. Y. 243, 1890; Jordan \& EverMANx, Bull. 47, U. S. Nat. Mus. $77 \pi, 1996$, pl. CXXI, fig. 327, 1900; Mearss, Bull. Am. Mus. Nat. IHist. $\mathbf{x}$, 31S, 1S9S; BeAN, $52 d$ Anz. Fiept. N. Y. State Mus. 101, 1900. 
Syngnathus hippocampus, Sea horse Pipefish, Mrtcrill, Trans. Lit. \& Plil. Soc. N. Y. I, 475, 1815.

Hippooampus heptagonus Jordax \& Gimbert, Bull. 1f, U. S. Nat. Mus. 38 . 1883, not of RAFINESQUE.

Body short and deep, much compressed, much shorter than the prehensile tail, which is three times as long as the head and more than three times greatest depth of body; snont as long as postorbital part of head, its depth two fifths of its length; eye circular, two fifths as long as the snout; interorbital space two thirds of diameter of eye; occiput with a fire-pointed crest; a sharp spine above the gill covers on each side, one abore the posterior part of the eye and one on each side of the throat; a blunt spine between the nostrils; the edges of the bony plates of body with the usual blunt spines. There are no cirri on the individual here described, but the species is said to hare them sometimes. DeKay does not mention cirri in his account of the fish. Dorsal fin on $3 \frac{1}{2}$ rings; base of dorsal one half as long as head; longest dorsal ray one half as long as snout. D. 19; rings $12+32$ to 36 . Color light brown or dusky, without spots, but sometimes with pale grayish blotches which are sharply edged with paler and blackish. DeKray's specimens were light brown, with iridescent opercles, the iris yellow.

The sea horse is now known to occur on the New York and New Jersey coasts in moderate numbers during the summer months; its range extends from Cape Cod to Charleston. Mearns states that, during the summers of 1895 and 1896 , a number of sea horses were taken by fishermen when netting shrimp in the eelgrass bordering the salt marshes near Consook island, at low tide. It has sometimes been found abundant in the nets in Graresend bay, but has not occurred in large numbers since 1895. In 1898 only a few indiriduals were taken in Great South bay, and the same scarcity was observed by fisher. men at Southampton L. I.

In captirity it thrires best in balanced tanks, but its life is short on account of parasitic attacks, which lead to swelling and ankylosis of the jaws. Its food in the aquarium includes Unciola and shrimp eggs. The sea horse excites popular interest on account of its singular shape, its prehensile tail, 
and the fact that the male carries the eggs and protects the young in a pouch behind the rent. In this egg sac the roung are protected till large enough to live independently, going out in search of food and returning to their shelter at pleasure.

Order ACANTHOPTERI

Spiny-rayed Fishes

Suborder SAIMIOPERCAE

Trout Perches

Family reRcorsidAE

Sand Rollers

Genus rencorsis Agassiz

Body rather slender, pellucid, corered with rather thin scales; dorsal fin with two slender spines or simple rays; anal with one; scales roughest posteriorly; lateral liue developed; preopercle entire or very nearly so; vertebrae $17+1 \bar{\imath}=34$. Atlantic slope, in cold or clear lakes and rivers.

\section{Percopsis guttatus Agassiz}

\section{Trout Perch; Sand Roller}

Percopsis guttatus Agassiz, Lake Superior, 2S6, pl. I, figs, 1. 2, 1850, Lake Superior; Günther, Cat. Fish. Brit. Mus. VI, 207. 1866; Jornan \& GILBErT, Bull. 16, U. S. Nat. Mus. 322, 1883; BEAN, Fishes Penna. 84, 1893; Everanan \& Tendali, Rept. U. S. Commr. Fish \& Fisheries for 1894, 599, 1996 from Thompson; Jordan \& Evermann, Bull. 47, U. S. Nat. Mus. 784, 1896, pl. CXXI, fig. 329, 1900.

Salmoperca pellucida 'Thomrsoy, Appendix Hist. Vermont, 33. 1S Champlain.

Percopsis hammondi GrzL, Proc. Ac. Nat. Sci. Phila. 151, 1864, Kansas.

Body rather long and moderately compressed, corered with thin ctenoid scales; head scaleless and without barbels; gill openings wide; opercles well developed; gill rakers short, tubercular; skull highly carernous; mouth small; the margin of the upper jaw formed by the short nonprotractile intermaxillaries; no supplemental maxillary bone; small rilliform teeth on the intermaxilliaries and mandible. The tongue is short, not free at tip. Pseudobranchiae dereloped. Six branchiostegals. The lateral line is continuous. The first dorsal over middle of body, with nine to 11 dereloped rass; adipose fin small; the anal and rentral eight raved; caudal long, forked; pectorals narrow, 
placed high. The stomach is siphonal and with numerous prloric caeca, as in certain Salmonidae. The eggs are moder. ately large and are excluded through an oviduct. Air bladder present. The greatest hight of the body is about two ninths of the total without caudal, the head about three elevenths. The maxilla does not reach to the eye. The lower jaw is slightly included. Scales in lateral line 47 to 50 .

Color pale olivaceous, or brown, the upper parts with rounded dark spots made up of minute dots; a silvery median stripe, becoming obsolete in front; peritoneum silvery.

The trout perch is a common fish in the Great lakes and their tributaries. It ranges north to Hudson bay, having been obtained at Moose Factory by Walton Hayden, also from Nelson river, near Rock Factory, by Dr Robert Bell. It has been obtained in the Delaware river by $\mathrm{Dr}$ C. C. Abbott, in the Potomac by Prof. Baird, in the Ohio by Drs Jordan, Henshall and Bean, and Dr Gill has recorded the species from Kansas.

Dr Meek obtained no specimens from Cayuga lake, but he has no doubt it is found there. The U. S. Fish Commission had it from Lake Ontario, Nine Mile point, near Webster N. Y., in 1893; also from Cape Vincent and Grenadier island. The fish is a resident of Lake Champlain, in which it was first discorered by Thompson, several years before Agassiz secured it in Lake Superior.

The trout perch is too small to be valuable for food, but is doubtless an excellent bait. It is one of the most remarkable fishes of our fresh waters, combining as it does the characters of the salmon and some of the perches. Its name indicates this singular relationship. It is voracious, takes the hook freely, and spawns in the spring.

\section{Suborder XENARCHI}

Family APHREDODERIDAE

Pirate Perches

Genus ApHrEDoderus Le Sueur

Body oblong, elevated at the base of the dorsal, compressed behind, the head thick and depressed, the profile concave; 
caudal peduncle thick; mouth moderate, somewliat oblique, the lower jaw projecting, maxillary reaching to anterior border of the eye; teeth in villiform bands on jaws, romer, palatines, and pterygoids; premaxillaries not protractile, maxillaries small, without evident supplemental bone; preopercle and preorbital with their free edges sharply serrate, opercle with a spine; bones of skull somewhat carcrnous, sides of the liead scaly; lower pharyngeals narrow, separate, with villiform teeth; gill membranes slightly joined to the isthmus anteriorly; gill rakers tuberclelike, dentate; pseudobranchiae obsolete; gills four, a small slit behind the fourth; branchiostegals six; scales moderate, strongly ctenoid, adherent, lateral line imperfect or want. ing; rent always anterior, its position varying with age, from just behind the rentral fins in the roung to below the opercle in the adult; dorsal fin single, median, high, with but three or four spines, which are rapidly graduated, the first being rery short; anal small, with two slender spines; rentral fins thoracic, with a very short spine, the number of soft rays usually seren; caudal fin rounded behind; ail bladder simple, large, adherent to the walls of the abdomen; rertebrae $14+15$; Iyloric caeca about 12. A single genus, with probably but one species, confined to the United States.

\section{Aphredoderus sayanus (Gilliams) \\ Pirate Perch}

Aphredoderus sayanus DE KAY, N. Y. Fauna, Fishes, 35, pl. 21, fig. 62, 1842; near PLiladelphia Pa.

Aphredoderus gibbosus Le Sueur, in Cuvier \& Valenciennes, Hist. Nat. Poiss. IX, 448, pl. 278, 1833 .

Aphredoderus sayanus DE KAY, N. Y. Fauna, Fishes, 35, pl. 21, flg. 62, 1842; Storer, Syn. Fish. N. A. 47, 1846; Jordax \& Gilbert, Bull. 16, U. S. Nat. Mus. 460, 1883; BeAn, Bull. U. S. F. C. VII, 145, 18ss; Fishes Penna. 101, 1893; Jordan \& Evermann, Bull. 47, U. S. Nat. Mus. 786, 1896, pl. CXXII, fig. 331, 1900; Eugene Smitr, Proc. Linn. Soc. N. Y. No. 9, 33, 1898; Bean, 52d Ann. Rept. N. Y. State Mus. 101, 1900, Patchogue, Long Island.

The body is moderately stout, oblong, somewhat compressed posteriorly. Scales ctenoid. The dorsal fin is continuous, with three or four spines and 11 soft rays. The anterior spines much the shortest. The anal has two spines and six rays. The mouth 
is rather large for the size of the fish; the lower jaw somewhat longer than the upper; the maxilla reaches to front of eye; jaws, vomer and palatine bones with villiform bands of teeth; lateral line manting. The depth of the body is two sevenths and length of the head one third of the total without candal. The eye is two ninths as long as the head. The origin of dorsal is much in adrance of the middle of the total length; the pectorals do not reach as far back as the rentrals; rentrals more than one half length of head; the longest anal spine three sevenths of length of head; the caudal rounded. Scales in 48 to 55 series. The color is variable, sometimes olivaceous, at other times dark brown with numerous dark punctulations; a dark bar at the base of the caudal followed by a light one.

The pirate perch ranges from New York westward to Minnesota, and in the Mississippi valley it extends to Lonisiana. In Pennsylrania the species occurs in Lake Erie, probably in tributaries of the Ohio and in the lower Delaware. Common in East lake at Patchogue and in the head of Swan river.

The farthest place east from which it is known appears to be Suffolk county on Long Island. ${ }^{1}$

This is one of the most interesting little fishes of the fresh waters, particularly because the position of the rent varies with age. In the young it is behind the rentrals, while in the adult it is in the throat.

The fish grows to a length of 4 inches. Nothing is recorded about its liabits except that it is rery roracious and feeds at night. It is common in sluggish streams and ponds in the sheltel of aquatic plants. In captivity it has never been observed to feed; perhaps it takes food, however, at night, but it does not thrive in the aquarimm.

Suborder PERCESOCES

Family ATHERINIDAE

Silversides

Genus Mevidia (Bonaparte) J. \& G.

Body elongate, more or less compressed; head oblong, compressed; belly before ventrals, more or less rounded in section,

${ }^{1}$ SeC Ayres. Enumeration of the Fishes of Brookharen L. I. ete. Bost. Jour. Nat. IIist. $1 S 44$, IV. 
not compressed to an edge; month small, the gape curved, very oblique, usually not reaching the eye; lower jaw short and weak; maxillary slipping entirely under preorbital; jaws each with a band of simple, usually villiform teeth; premaxillaries rery freely protractile, their spines comparatively long, nearly equal to the eye, extending backward beneath a fold of skin, which connects the basis of the maxillaries; posterior part of the premaxillaries broad; no teeth on romer or palatines; both dorsals short, the usual radial formula being D. V-1, S, first dorsal usually, but not always in front of anal; soft dorsal and anal scaleless; scales rather large, entire.

\section{Menidia gracilis (Günther)}

\section{Slender Silversides}

Atherinichthys gracilis Güntmen, Cat. Fish. Brit. MIus. III, 405, 1861.

Menidia gracilis Jordan \& Evermans, Bull. 47, U. S. Nat. Mus. 797, 1896, Specimens from St George's Island, Potomac River.

The origin of the anteruor dorsal fin is opposite to the rent, exactly in the middle of the distance between the end of tbe suont and the base of the caudal. The distance between the origins of the two dorsal fins is somewhat more than one half of that between the origin of the posterior and the caudal. The light of the body is contained nine times in the total length, the length of the head five and one half times. The silvery band is narrow, and occupies a part of the fourth series of scales. Scales with the margin entire. Caudal lobes equal in length; candal somewhat longer than the pectoral, and rather shorter than the head. 31 lines long. Probably young. Habitat unknown. D. IN, I, S; A. I, 19. Scales 9-40. (After Günther)

The specimens above referred to, from St George's island, lower Potomac river, were obtained by Dr Hugh M. Sinith, of the U. S. Fish Commission, in the summer of 1890.

The specimens were compared with the published descriptions of M. beryllina. (Cope) and were found to differ in some minor details, the dorsal formula being $\mathrm{V}, \mathrm{I}, 10$ instead of $\mathrm{V}, \mathrm{I}$, 11 , the anal rays areraging $I, 16$ or $I, 17$ instead of $I, 18$, and the silvery stripe apparently taking a different course. 


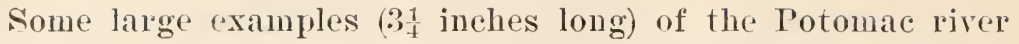
silverside no. 43125, U. S. National Museum, collected by W. P. Seal, apparently in 1890 , agree very well with the description of beryllina and also with the characters of Dr Smith's specimens. It is probable that cope's name must be associated with this fresh-water form, and not the name gracilis of Gïnther. None of om individuals have four dorsal spines, and there is no certainty that Dr Günther's type came from the United States. I have, however, followed Drs Jordan and Everuann in their identification.

The species is said to range from Moods Hole Mass. to Albemarle sound.

\section{Menidia beryllina (Cope)}

\section{Fiesh-water Silversides}

Chirostoma beryllinm Cope, Trans. Am. Flil. Soc. 403, 1866, Potomac River, at Washington, D. C.

Menidia beryllina Jordan \& Gitbert, Bull. 16, T. S. Nat. Mus, 408, 1853; Beax, Fishes Penna, 100, 1893; 521 Ann. Rept. N. Y. State Mus. 102, 1900.

Menidia gracilis beryllina JorDAN \& Evermans, Bull. 47, U. S. Nat. Mus. 797, 1896, pl. CXXIV, fig. 338, 1900.

The body is shorter than usual among the silversides. The spinous dorsal is well separated from the soft dorsal, and its posterior margin extends almost to the vertical from the first anal ray. The ventral reaches to below the first ray of the dorsal. The length of the head is contained four and one fourth times in the total length without caudal. The eye largge, orbit one third as long as the head; month small; the mandible. slightly longer than the maxilla and slightly curved; greatest depth of body one sixth of total length without caudal. Scales in lateral line 36 , transverse series 10 . The lateral line is represented by a pore on the anterior part of the exposed portion of each scale, except on the caudal peduncle, where it runs through a groove. D. V-I, 11; I. I, 18; V. I. 5; P. 15. The caudal is deeply forked.

Pale olivaceous in color with a silvery lateral band, on two and one half rows or scales, with a lead colored margin. The anal base is lead colored; sides of the head silvery. 
This species corresponds in mant particulars with M e n i d i a pe $n$ i n s u la e of Goode \& Bean, but in that species the silvery streak covers only one and one half rows of scales. The soft dorsal in M. p e n in s u 1 a e appears to show considerable rariation in the number of rays.

The fresh-water silversides was first described from the I'otomac river, where it has recently been rediscovered in abundance, both in fresh and brackish water. It is very conmon at Water Mill L. I. and in fresh-water tributaries of Great South bay. Several examples were seined in 1898 in salt water at Clam Pond cove.

In some of the Water Mill specimens the following characters were noted: D. V, I, 10; A. I, 16-17. Scales 8-40.

Its associates in fresh water at Watel Mill were: $\mathrm{F}$ u $\mathrm{n} \mathrm{d}$ u I u s diaphaus, Lucania parra, Eupomotis gibbosus, and Lucius reticulatus. In 1898 it was obtained also in Shinnecock bay, scallop pond (Peconic bay) and Mecox bay. The localities in Great South bay were: Swan river, south side of Great South bay, Horsefoot creek and Bellport Lifesaving station.

\section{Menidia notata (Mitchill) \\ Sitversides; Friar; Whitebait}

Atherina notata MItcunL, Trans. Lit. \& Plil. Soc.'N. Y. I, 446, pl. IT, fig. 6. 1815. New York; De KAY. N. Y. Fauna, Fishes, 141, pl. 28, fig. 88, 1842, New York; SToner, Hist. Fish. Mass. 87, pl. XVI, fig. 1, 1867.

Atherina iridescens Mitcinll, op. cit. 447, 1815, New York.

Chivostoma notatum Goode \& BEAN, Bull. Essex Inst. XI, 21, 1879, and of many other authors.

Atherina menidia DE KAY, op. cit. 142, pl. 74, fig. 236, 1842, New York; not of LixvaEus.

Atherinichthys menidir and notata GüNtwen, Cat. Fish. Brit. Mus. III, 406, 1 S61.

Atherinopsis notatus BAInd, Ninth Ann. Rept. Smith, Inst. 338, 1855.

Henidia notata Jordan \& GILbERT, Bull. 16. U. S. Nat. Mus. 407, 18S3; BeAx, Bull. U. S. F. C. TII, I46, 1Sss; 19th Rept. Commors. Fish. N. I. 271, 1S90; Jordan \& Evermañ, Bull. 47, U. S. Nat. Mus. S00, 1896; Eugexe Suth, P'oc. Linn. Soc. N. Y. No. 9, 32. 189S; BeaN, 52d Ann. Rept. N. Y. State Mus. 102, 1900.

Body elongate, compressed, its greatest depth contained six and one third times in total length without caudal, and equaling 
three fourths of length of head; the caudal peduncle long and slender, its least depth about one third the length of head; width of body about one half the length of head; head short, pointed, its length one fifth of the total without caudal; snout slightly shorter than eye, about three and one fourth in length of head; margin of upper jaw formed chiefly by the curved premaxillary, which is nearly as long as the eye; eye equal to interorbital space, and one third as long as the head; two rows of scales under the eye; exposed part of maxilla two fifths as long as the eye; dorsal origin nearly midway between tip of snout and base of middle caudal rays, base of dorsal about as long as eye, longest dorsal spine one third as long as the head, fifth dorsal spine one fifth as long as head, interspace between the two dorsals contained $10 \frac{1}{2}$ times in total length without caudal, second dorsal base one half as long as head, longest dorsal ray equal to eye and snout combined, last dorsal ray equal in length to snout; anal origin under end of spinous dorsal, also under 25th scale of lateral line, anal base three elevenths of total length without caudal, corresponding with 15 rows of scales, longest anal ray equal to snout and eye combined, last anal ray one fourth as long as head. The rent is under the last spine of the dorsal. The ventrals are distant from the end of the head a space equal to length of head, length of ventral equal to snout and eye combined, 15 rows of scales between ventral origin and throat. Middle caudal rays about one half as long as head, external rays five sixths as long as head, the fin deeply forked. The silvery band nowhere covering more than the width of one scale, though not limited to one row.

Translucent green; lateral band silvery, mostly on the level of the eye, its width less than one half the diameter of eye. Scales of upper parts with dark dots along their edges; chin speckled.

The common silversides grows to a length of 6 inches.

The silversides was first made known by Dr Mitchill under the name of small silverside, A the rina notata, and he described the young of the same species as the green-sided silverside, A therina viridescens. Dr De Kay states that the 
silversides was known in the harbor of New York as the anchory and the sand smelt. Friar is a New England name for the species; capelin is in use about Boston, and merit fish in the vicinity of Watch Hill. Sperling is a name recently applied to this species by some fishermen, and we have known persons to offer the silversides as whitebait. In Great South bay it is known as shiner.

The silversides is known to occur on the coast from Maine to Virginia. It is one of the most abundant of the small fishes in our waters, swimming in immense schools made up of fish of different sizes, and it forms a considerable part of the food of more valuable species, such as the mackerel, bluefish, weakfish and flounders, and is rery much in demand as a bait for hook and line fishing. We seined the silversides in all parts of Great South bay, and found it to be one of the most abundant and characteristic species.

The common silversides, or spearing, lives in Gravesend bay almost all the year, hibernating in spring holes in winter. It is well suited for a captive life and can endure a temperature of $71 \frac{1}{2}^{\circ}$ in the salt water.

In 1898 the species was found for the state museum at all Long Island localities visited, Peconic bay, Mecox bay, the ocean at Southampton, and throughout Great South bay. Small individuals are sold in the markets as whitebait. In the time of De Kay the fish was called anchovy and sand smelt and was esteemed a savory food. 20 years before he wrote of the fishes of New York, it was caught from the wharves and sold for bait.

\section{Genus KrRtusma .Jordan \& Evermann}

This genus is close to M e n i d i a, but differs from it in having the scales laciniate and the dorsal and anal fins scaly. Three species known from the United States and Martinique.

\section{Kirtlandia vagrans (Goode $\&$ Bean)}

\section{Rough Silversides}

Chirostoma vagrans Goode \& BEAN, Proc. U. S. Nat. Mus. 148, 1579, Florida. Mienidia vanians Jordax \& GILberT, Proc. U. S. Nat. Mus, 267, 1S82, Bull. 16, U. S. Nat. Mus. 407, 1883. 
Menidia vagrans laciniata Swain MS in Jordan \& Gilmert, Bull. 16, U. S. Nat. Mus. 908,969, 1883, Beaufort, N. C.; Jordan \& Gilbert, Proc. U. S. Nat. Mus. 589. 1883.

Menidia laciniata SWAIN in Jordan of Gilbert, Bull. 16, U. S. Nat. Mus.

969,1883 ; BeAn, Bull. U. S. F. C. VIl, 146, 1s89, Great Egg Harbor

Bay, N. J.; Jordan \& Evermann, Bull. 47, U. S. Nat. Mus. 795, 1ะ96;

BEAN, 52d Ann. rept. N. Y. State Mus. 102, 1900.

Kirllandia vagrans Jordan \& Evermans, Bull. 47, U. S. Nat. Mus. 794, 1896. pl. CXXIV, fig. 336, 1900.

Kirllandia laciniata JordaN \& EverMANN, op. cit. 795, 1896; BeAN, 521 Aun.

Rept. N. Y. State Mus. 102, 1900.

Hight of the body contained five and one half to six times in length without caudal, and six and two thirds times in total length, considerably less than length of head and length of pector:al; origin of spinous dorsal fin situated behind a point midway between origins of ventral and anal fins and opposite the middle of the interspace between anal fin and rent; eye longer than snout, one third as long as the head, and less than width of interorbital space; mouth slightly protractile, lower jaw equal to length of eye; length of head contained four and three fourths times in total length without caudal, and equal to length of pectoral; pectoral reaching only a very little beyond origin of ventral when extended; ventral not reaching to rent, its length one half the length of head; anal base about as long as the head; caudal slightly forked, the lobes equal; vertical fins excessively scaly; scales of body large, laciniate, some of the exposed edges with 12 points. I). IV to V-I, 7; A. I, 18 to 19 ; V. I, 7; P. 14 . Scales $7-48$ to 50 . Lateral silvery stripe covering the lower two thirds of the third series of scales and the upper one third of the fourth series.

Light greenish abore; sides and belly silvery; tip of snout and of lower jaw yellow mingled with blackish; scales on the back with several to many dark spots on the free edges, these usually forming streaks; caudal yellow with dark points, its margin dusky; dol'sal and pectorals dusky; lower fins pale, the anal with dark points at its base.

As here described, the species includes M. I a ciniat a (Swain) which has been recorded from New Jersey and North Carolina. The only difference discoverable between them is in 
the number of the dorsal spines, which is generally four in la c in i a t a, but sometimes five, as observed in examples from Great Egg Harbor bay, N. J., no. $4515 \mathrm{~S}$ U. S. National Museum.

The rough silversides grows to the length of 4 inches; it is not important for food, but serves as food for the larger fishes. It Was found abundant at Somers Point N. J. in August 1SS7, where it had previously been unknown. The largest individual taken in Great Egg Harbor bay, $4 \frac{1}{3}$ inches long, was secured at Longport N. J.

The only example so far known in New York waters was caught in Mecox bay, L. I. Aug. 1, 189S. Though the bay was seined repeatedly afterward in search of the fish, no other specimens were seen. The following notes were obtained: D. V, I, T; A. I, 20; P. 14; V. I, 5. Scales 7-47.

\section{Genus mamoesthes Cope}

This genus differs from Menidia chiefly in the prolongation of the jaws, both of which are produced into a short depressed beak. The scales are small as in Le uresthes and B a s i l. i c h th s s, their edges entire.

\section{Labidesthes sicculus (Cope) Brook Silversides; Skipjack; Glassfish}

Chirostoma sicculum Cope, Proc. Ac. Nat. Sci. Phila. 81, 1865, Crosse Isle, Detroit River.

Labidesthes sicenlus Cope, Proc. Am. Phil. Soc. Phila. 40, 1870; Jordan \& Gilbert, Bull. 16, U. S. Nat. Mus. 406, 1883; Мeek, Ann. N. Y. Ac. Sci. IV, 312, 18ss, Montezuma, N. Y.; Rean, Fishes Penna. 100, 1893; Bull. Am. Mus. Nat. Hist. IX, 35T, 1897; Chantauqua Lake; Jordan \& Evermann, Bull. 47, U. S. Nat. Mus. 805, 1896.

The body is slender and elongate, its depth one sixth or one serenth of the total without caudal. Iength of head about two ninths of total; eye two serenths of length of head, two thirds of length of suout. I). IV, I, 11; A. I, 22. Scales 14-75. Candal deeply forked.

Color olivaceous, the fish in life translucent, the upper parts with small black dots, the silvery lateral band edged ahove with lead color and covering one row and two half rows of scales; cheeks silvery. 
The genus $\mathrm{L}$ a bidesthes has a very oblique mouth, with the upper jaw flat above and concave beneath, the intermaxillaries forming a rooflike beak. The mandible is convex.

The brook silversides, or skipjack, is found in streams and ponds in the Ohio and Mississippi valleys. It has also been discovered recently in some of the southern states, from South Carolina to Florida. In New York it is recorded from near Montezuma, from Chautauqua lake, where it is called silver skipjack and glassfish, and from Lake Ontario. Dr Meek says it is not found near Ithaca. The U. S. Fish Commission collectors obtained it at the following places in New York:

$\begin{array}{lr}\text { Stony Island } & \text { July } 2 \text { and } 3 \\ \text { Great Sodus bay } & \text { Aug. } 6 \\ \text { Long pond, Charlotte } & \text { Aug. } 17 \\ \text { Sandy creek, North Hamlin } & \text { Aug. } 20\end{array}$

The fish grows to the length of 4 inches and is important only as food for larger species. It has been kept in the aquarium, but does not endure transportation or captivity. The brook silversides is a surface swimmer, and the name skipjack is derived from its habit of skipping out of and along the surface of the water. It abounds in "clear pools left in summer by the fall of the waters in the streams, which has filled them."

\section{Family mugridde}

\section{Mullets}

\section{Genus mugru (Artedi) Linnaeus}

Body oblong, somewhat compressed, covered with large scales, head large, convex, scaled above and on sides; mouth small, subinferior, the lower jaw angulated; jaws with one or a few series of short, flexible, ciliiform teeth, no teeth on vomer or palatines; eye large, with a large adipose eyelid, which is little developed in the young; stomach muscular, like the gizzard of a fowl. Species very numerous, living on mud and running in great schools along the shores and in brackish lagoons of all warm regions. We here exclude from $\mathbf{M ~ u g}$ il the old world group, Liza (type Mugil capito) similar in habit 
to $\mathrm{M} \mathrm{u} \mathrm{g}$ i l, but lacking the adipose eyelid. (After Jordan \& Evermanu)

\section{Mugil cephalus Linnaeus}

\section{Striped Ifullet}

Mugil cephalus Linvaeus, Syst. Nat. ed. X, I, 316, 1758, Europe; JordaN \& Swann, Proc. U. S. Nat. Mus. 263, 18S4; Jordan \& Evermann, Bull. 47, U. S. Nat. Mus. 811, 1896, pl. CXXVI, fig. 343, 1900; BeAn, 52d Ann. Rept. N. Y. State Mus, 103, 1900.

Ilugil albula Linnaees, Syst. Nat. ed. XII, 520, 1766, Charleston, S. C.; Jordan \& Gilbert, Bull. 16, U. S. Nat. Mus. 403, 18s3; Bean, 19th Rept. Comm. Fish. N. Y. 272, pl. XXI, fig. 26, 1890.

Mugil lineutus Mitchild, Cuvier \& Valenciennes. Hist. Nat. Poiss. XI, 96, 1S36, New York; De liAY, N. Y. Fauna, Fishes, 141, pl. 15, fig. 42, 1812,

New York; Storer, Hist. Fish. Mass. 39, pl. XVI, fig. 4, 1867.

Body fusiform, elongate, stout, its greatest width contained one and three fourths times in length of head and equal to length of ventral fin, greatest depth of body one fourth of total length without caudal; snout narrow and somewhat pointed, its length about one fifth of length of head, its profile scarcely more convex than profile of lower jaw; interorbital space little convex, its width one half length of head; thickness of upper lip scarcely more than one third of length of premaxillary; space between the mandibles oblanceolate, its greatest width about one fifth of its length; eyes corered by an adipose membrane leaving a free space only about as wide as the pupil; length of head contained three and one half to four times in total length without caudal; eje about two serenths as long as the head; teeth in upper jaw in a rather broad band, the outer row slightly enlarged, teeth in lower jaw similar but much smaller; scales smaller than in M. curema, about 24 or 25 rows of scales between tip of snout and origin of spinous dorsal, some scales on top of head slightly enlarged, soft dorsal and anal fins almost scaleless; origin of spinous dorsal midway between tip of suout and base of middle caudal rays, about over the middle of the ventral, base of spinous dorsal oue third as long as the head, first spine longest, one half as long as the head, last spine one half as long as the first, interspace between dorsals about one half length of head, upper malgin of soft dorsal deeply concare, base of the fin a little more than one third of 
length of head, longest ray one half the length of head, last ray one fourth the length of head; caudal deeply forked, its middle rays one half as long as the head, its external rays nearly as long as the head; pectoral reaches to the 11th row of scales from its axil, about as far back as the end of the rentral appendage, its length two thirds of length of head; rentral origin midway between tip of snout and fifth ray of anal, its length four sevenths of length of head, the fin extending to below the end of the base of spinous dorsal, the tip distant from the anal origin a space about equal to the length of the fin. D. IV-I, S; A. III, S. Scales 14-42. Color, dark bluish above; the sides silvery; exposed part of seales, specially of eight or 10 upper series, darker than body color, causing a striped appearance; belly and lower part of sides yellowish; ventral fins yellowish; soft dorsal, anal and ventrals dusky; tip and base of pectoral dusky.

The striped mullet grows to the length of 2 feet, but the average size in New York waters is much less.

The fish is known in Great South bay as mullet and jumping mullet; the name mullet is applied to it also in the Gulf of Mexico, and is in general use along the east coast; it is known in the Chesapeake as mullet or fatback. The latter name is probably applied to more than one species.

The striped mullet is known on our coast from Cape Cod to the Gulf of Mexico. The young are much more abundant than the adults. In Great South bay we found the species not uncommon; two examples were taken at the mouth of Swan creek, September 12. Several schools were present. We were informed that they appear occasionally, and one gentleman of Patchogue was very successful in taking this and its allied species with - llook and line. De Kay states that the striped mullet was first cbserved in New York water's by Dr Mitchill. He found them in the markets in the beginning of september. This species is one of our choice food fishes. It is not uncommon in September in Great Egg Harbor bay, N. J., but we were informed that large specimens are never taken in that body of water. 
In 1898 the striped mullet was not abundant in the waters seined till fall; the great schools were absent till October. Sereral individuals were obtained in Mecox bay 1 ugust 2 and a larger number in Clam Pond core, Great South bay, Iugust 2.2.

The young of this species are abundant in Gravesend bay in midsummer; larger ones appear in September and October. One winter, some rears ago, mullet hibernated in the mud in Sheepshead bay and were taken with exl spears. The mullets feed and thrive most of the year in captivity, but will not survive the intense heat of summer. In the aquarium their food includes hard clam and shrimp.

In 1853 Jordan and Gilbert established a genus Queri m a a for "little mullets with but two spines in the anal fin and with the teeth in the jaws less ciliform than in $M \mathrm{u} g \mathrm{i}$. Adipose eyelid wanting; preorbital serrate." The genus was based on M $\mathrm{x} \times \mathrm{s}$ hareng $\mathrm{us}$ of Gïnther. Querim a n a is nothing more than the roung of M $\mathrm{ugil}$. The only good character by which it was distinguished is the presence of two anal spines instead of three; in all other respects $Q$ u e r i m a n a and M u gil agree perfectly. As a matter of fact, all young $M \mathrm{ug}_{\mathrm{i}} \mathrm{ls}$ pass through a $\mathrm{Qu}$ e $\mathrm{r} \mathrm{m}$ a $\mathrm{n}$ stage in which only two of the three anal spines are developed, the adipose eyelid is rudimentary and the teeth are comparatirely stonter than in the adult. The third anal spine of $\mathrm{M} \mathrm{m}$ i l is really a simple articulated ray till the fish reaches a lengtl rarying from about $40 \mathrm{~mm}$ to $50 \mathrm{~mm}$. The first simple ray of the anal becomes a spine by the breaking off at an articulation, the subsequent sharpening of the point, and the deposit of hard material in the articulations, thus forming a somewhat slender, bnt perfect, spine.

This fact of derelopment was carefully studied in large serics of specimens in the U. S. Nationa! Museum, and it is both interesting and important from the fish cultural as well as the systematic standpoint. In $\mathrm{Mug}$ il cephal us one example, $41 \mathrm{~mm}$ long, shows the third anal spine very plainly; it is well developed and has a sharp point, but sereral articulations still 
remain. Other examples of equal length have the first simple anal ray scarcely dereloped into a spine, and in still other's this ray does not take on the character of a spine at all. Q u e r i mana ha a $\mathrm{gus}$, the type of the genus, is the young of M ugil curema, and Q. g y a $\mathrm{m}$ is the immature M u gil trich od on. A reexamination of the types of $\mathrm{Qu}$ e r i m a $\mathrm{n}$ a gy rans shows the presence of 33 rows of scales in some examples instead of 29, as originally recorded.

\section{Mugil curema Cuv. \& Val.}

White Mullet

Mugil curema Cuvier \& Valenciennes, Hist. Nat. Poiss. XI, 87, 1836, Brazil; Martinique; Cuba; BEAN, Bull. U. S. F. C. VII, 145, 1Sss; 19th Rept. Comm. Fish. N. Y. 272, pl. XXI, fig. 26, 1890; JoRdan \& EverMANN, Bull. 47, U. S. Nat. Mus. 813, 1896, pl. CXXVI, fig. 344, 1900; Bean, 52d Ann. Rept. N. Y. State Mus. 103, 1900.

Mugil petrosus Cuvien \& Talenciennes, op. cit. 88, 1836, Brazil to New York; De ISAY, N. Y. Fauna, Fishes, 147, 1842.

II ugil brasiliensis Güntmer, Cat. Fish. Blit. Mus. III, 431, 1861; Jordan \& Gilbert, Bull. 16, U. S. Nat. Mus. 403, 1883.

Body shaped like that of the striped mullet, its width equaling two thirds of length of head, its greatest depth contained three and one half to three and five sixths times in total length without caudal; least depth of caudal peduncle equal to one half the length of head; snout nearly as in M. c e p ha $1 \mathrm{us}$, sometimes with its outline more declivous, its length one fifth of length of head; interorbital space slightly convex, its width nearly one half the length of head; thickness of upper lip scarcely one third of length of upper jaw, space between the mandibles nearly lanceolate, its width one sixth of its length; eyes covered with an adipose membrane leaving only a space about as wide as the pupil exposed, eye about two serentlis as long as the head; head one fourth, or nearly one fourth, of total length without caudal; teeth in outer row on premaxilla somewhat enlarged, distant; scales rather large, about 22 rows between tip of snout and origin of first dorsal; soft dorsal and anal densely scaled, origin of spinous dorsal midway between tip of snout and base of external candal rays, directly over the 10 th row of scales, counting from the axil of the pectoral, the first spine nearly two thirds as long as the head, the last spine less than one half 
as long as the first, interspace between the dorsals equal to three fifths of length of head, upper margin of soft dorsal deeply concare, base of fin equal to length of postorbital part of head, the longest ray three fifths of head, the last ray one fourth the length of head; caudal deeply forked, its middle rays one half as long as the head, its external rays equal to the head; pectoral reaches the eighth row of scales, its length equal to head without snout; rentral origin midway between tip of snout and third ray of anal, its distance from vent equal to its own length, which is two thirds of length of head; about 24 rows of scales between the head and the anal origin, base of anal three fifths as long as the liead, longest anal ray equal to length of postorbital part of head, last anal ray two serenths of length of head. D. IV-I, S; A. III, 9. Scales 12-38.

Color silvery, bluish above; no dusky streaks aloug the sides in life, but faint streaks are erident after preservation in spirits; a small dark blotch at base of pectoral; caudal pale, yellowish at base, dusky at tip; anal and rentrals yellowish; two yellow blotches on side of head.

The white mullet reaches the length of 1 foot. On the Atlantic coast it ranges from Cape Cod to Brazil; in the Pacific it is recorded from California to Chile. It is a very important food fish.

The white mullet appears with the striped species, but is less abundant in Gravesend bay and is smaller in size. The young were taken in Great South bay in August 1898, and half grown individuals were abundant in September and October. Adults were scarce.

Dr Mitchill calls this the summer mullet. He records a specimen that weighed $2 \frac{1}{2}$ pounds, the heariest coming under his observation. DeKay found the species in New York markets in July and August.

\section{Mugil trichodon Poey}

\section{Whirligig Mullet (young); Fantail Mullet}

Mugil trichodon Poer, Ann. Lyc. Nat. Hist. N. Y. XI, 66, pl. 8, figs. 4 to S, 1875, Cuba; Jordax \& Evermann, Bull. 47, U. S. Nat. Mus. 816, 1896.

Mrugil brasiliensis Jordan \& SwaIn, Proc. U. S. Nat. Mus. 270, 18St; not of Agassiz fide Jordan \& EveruranN. 
Querimana gyrans Jordan \& Gilbert, Proc. U. S. Nat. Mus. 26, 1884; JorDAN \& Evermann, Bull. 47, U. S. Nat. Mus. \$18, 1896.

Body robust, its greatest depth three elevenths of the total length withont candal; head short, its length contained four and one fifth times in total to caudal base; snont moderately acute, its uper and lower profiles equally oblique; interorbital space little convex, its width two fifths of the length of the head; upper lip remarkably thick; space between the mandibles underneath narrow, oblanceolate, rather pointed behind; an adipose membrane corering all but the central part of the eye; teeth comparatively large and wide set, about as long as the nostril; about 21 rows of scales between origin of spinous dorsal and tip of suout, soft dorsal and anal densely'scaled, the margin of soft dorsal concare, the sccond, and longest, ray two and three fourths times as long as the seventh; anal similar to soft dorsal; the pectoral short, not reaching nearly to vertical from front of spinous dorsal; caudal large, deeply forked. D. IV-I, 8; A. III, S. Scales 33-11.

Upper parts dusky, olivaceous, with bluish reflections, lower parts silvery; scales without dusky spots; a dark blotch at base of pectoral; dorsals and caudal pale, the dorsals with minute dark points, caudal with a dark margin; anal and rentrals yellowisls; pectorals pale, with fine brown punctulations.

The fantail nullet ranges from Brazil to the Florida Keys and Cuba. The young. which is $\mathrm{Querimana} g \mathrm{rans}$ of Jordan \& Gilbert, migrates northward in summer to Cape Cod; it has been recorded from Long Island and the vicinity of Woods Hole Mass.

The species reaches the length of 10 inches.

$$
\text { Family SPIYRAENIDAE }
$$

\section{Barracudas}

Genus spuranara (Artedi) Bloch \& Schn.

Body elongate, subterete, covered with small cycloid scales; head very long, pointed, pikelike, scaly above and on sides; mouth horizontal, large; jaws elongate, the lower considerably projecting, upper jaw nonprotractile, its border formed by the 
premaxillaries, behind which are the broad maxillaries, large, sliarp teeth of unequal size on both jaws and on palatines; none on the romer; usually a very strong, sharp canine near the tip of the lower jaw; opercular bones without spines or serratures; gill openings wide, the gill membranes not mited, free from the isthmus; gill rakers very short or obsolete; branchiostegals seren; gills four; pseudobranchiae well developed; air bladder large, bifurcate anteriorly; many pyloric caeca; lateral line well developed, straight; pectoral fins short, placed in or below the line of the axis of the body; ventrals I, 5, abdominal, in advance of the middle of the body; first dorsal over ventrals, of five rather stont spines, second dorsal remote from first dorsal, similar to and opposite anal; caudal fin forked; vertebrae 24 ; first superior pharyngeal absent, second, third, and fourth separate, with teeth, lower pharyngeals separate.

\section{Sphyraena guachancho Cuv. \& Val.}

\section{Long Barracuda}

Sphyraena guachancho Cuvier \& Valenciennes, Hist. Nat. Poiss. III, 342, 18ж9, Havana; Jornan \& Erermann, Bull. 47, U. S. Nat. Mus. S24. 1896.

Sphyraena guaguancho Goode of Bean, Proc. U. S. Nat. Mus. II, 146, 1880; Jordan \& Giliber', Bull. 16, U. S. Nat. Mus. 411, 1883.

sphyraena guaguanche Poer, Memorias, II, 166, 1860; MeEk \& Newrand, Proc. Ac. Nat. Sci. Phila. 70, 1884.

Sphyracna gïntheri HaLr, Ann. \& Mag. Nat. Hist. XV, 270, 1875, Colon.

Body moderately elongate, subcylindric, its greatest depth one seventh of the total length withont caudal, its width two thirds of its depth and one third of length of liead; the eaudal peduncle stout and not elongate, its least depth one fourth the length of head. The head is long, nearly one third of total withont caudal, its width two serenths of its length; the lower jaw projects a space one half as long as the iris, the top of head flat and with a long and well marked median groore; the interorbital space equal to iris; the maxilla broadly expanded and abruptly bent downward, its width at the posterior end one fourth of its length, its end reaching about to front of ophit; mandible as long as head without postorbital part; preocular ridge three fourths as long as iris; 
premaxillary teeth small, about 43 developed in the individual examined (sometimes 35 to 40), front of the premaxillaries with four large canines, the posterior pair slightly larger, one third as long as the eye; three large, bladelike fangs on each side of palatines; a large compressed fang at symphysis of lower jaw, mandible with about 17 moderately large, compressed teeth on each side; eye one sixth of length of head, one half postorbital part of head; dorsal origin at a distance from snout equal to three times length of snout, base of spinous dorsal one third length of head from tip of upper jaw, second spine longest, nearly one third of length of head, fifth spine one half as long as the second, interspace between first and second dorsal equal to suout and eye combined, base of second dorsal two sevenths of length of head, including lower jaw, longest ray as long as base of fin, last ray one fifth of length of head; ventral a little in advance of spinous dorsal, its distance from the head equal to length of pectoral, its length two sevenths of length of head; anal origin nnder middle of dorsal base, anal base one fourth the length of head, longest anal ray equal to rentral, last ray one ha'f the postorbital part of head; middle caudal rays very short, external rays as long as snout and eye combined; pectoral as long as postorbital part of head; top of head with minute embedded scales; cheeks and opercles scaly, but interopercle and posterior half of opercle naked. B. VII, D. V-I, 9; A. I, 8; V. I, 5; P. I, 12. Scales 15 to $16-112$ to $121-13$ to 17 .

Color pale green abore, soft dorsal yellowish; anal and rentral fins chiefly pale but basal part of ventral dusky; pectoral and caudal dusky at tip; dark punctulations on spinons dorsal and on upper part of body. The specimen described is no. 30015, Jamaica, in the U. S. national museum.

An individual $21 \frac{3}{5}$ incles long was taken at Woods Hole Mass., and is described by Goode and Bean in Proceedings of the U. S. National Iruseum, II, 147, 1880. The species ranges from the West Indies to Florida, and occasionally northward in summer to Cape Cod. 


\section{Sphyraena borealis De Kay}

\section{Northern Barracuda.}

Sphyraena bovrutis De Kis. N. Y. Fanna, Fishes, 39, 11. 60, fig. 196, 19+2, New York; Meek \& Newland, Proc. Ac. Nat. Sei. Phila. is, 1s84; BEAx, Bull. U. S. F. C. VII, 145, 1SSS; 19th Rept. Comm. Fish. N. Y. 271, 1890; Jordan \& Everuans, Bull. 47. U. S. Nat. Mus. S25, 1S?6. Sphyruena spet Jorday \& Gilbert. Bull. 16. U. S. Nat. Mus. 411, 1883; not of IIAUY.

Body moderately elongate and compressed, its greatest depth equal to length of snout, and contained seven and one half times in total leugth without caudal, its width equaling two sevenths of length of head; caudal peduncle subterete and tapering, its least deptlo one fifth of length of head. The head is one third of total length without candal, its width one fourth of its length, the lower jaw projecting a space equal to pnpil, top of head slightly convex, a rery shallow median groove, the interorbital space equal to length of eye; maxilla broadly expanded posteriorly, its greatest width one fourth of its length, its end not reaching frout of orbit by a space two thirds as long as the eye; mandible as long as snout and eye combined; preocular ridge two thirds as long as the eye, not very prominent; premaxillary teeth small, smaller anteriorly, about 45 in number, front of the premaxillaries with three large canines on each side, one of them much larger than the others, one third as long as the eye; two large fangs on one side of the palatines, three on the other, followed on each side by three smaller teeth; a large, compressed fang at the symphysis of lowel jaw, mandible with 10 to 12 teeth, increasing in size and becoming more widely separated posteriorly; eye equal to interorbital width and its length contained six and one fourth times in length of head; dorsal origin at a distance from tip of snout equal to a little more than three times length of snout, base of spinous dorsal nearly one third as long as the head, second dorsal spine longest, about one third length of head, last dorsal spine one half of postorbital part of head, interspace between dorsals one half of length of head, base of second dorsal equal to longest dorsal ray and two sevenths of length of head, last dorsal ray equal to long diameter of eye, 
and one seventh of length of head; ventral under the second spine of the dorsal, its distance from the head one half of length of head, and much greater than length of pectoral; anal origin under fourth ray of second dorsal; the anal base two sevenths of length of head, longest anal ray equal to base of anal fin, last ray three fourths of diameter of eye, one third of postorbital part of head; middle caudal rays very short, external rays one half as long as the head; pectoral equal to postorbital part of head; top of head with numerous minute, embedded scales and with many series of mucous pores; cheeks and opercles scaly and without naked spaces. B. VII; D. V-II, 9; A. III, 8; V. I, 5; P. I, 12. Scales 13-126-13.

Color greenish above; lateral line yellow; lower parts silvery; iris golden; young with dusky blotches on the back and along the lateral line.

This fish seems to have been unknown to the early writers on New York fishes, the species not appearing in any publication earlier than De Kay's New York Fauna, in 1842. Dr De Kay calls it the northern barracuda, to distinguish it from the southern species.

The young barracuda have been taken from Cape Cod to New Jersey, the southern limit being indefinite. Individuals of 1 foot in length have been rarely seen, but examples measuring from 2 to 6 inches are extremely common as far north as Cape Cod annually, in the summer. De Kay makes the following statement about the barracuda: "This is a very active and voracious little fish. A number of them were caught in the harbor of New York and placed in a vessel with several other species. In a few hours they had devoured them all, and then commenced devouring each other. It has not been rery commonly observed, owing to the difficulty of capturing them; but I have reason to believe that they are not very rare." In Great Egg Harbor bay the young were found in abundance. The smallest example seen there by myself was $2 \frac{3}{8}$ inches long. The species was unknown to the fishermen. In Great South bay a single example was captured at Oak island September 30 . 
This barlacuda is not seen in our markets, but the adults of more sontherly species are considered excellent food fishes. At Key West and on Cozumel island, and in the West Indies, the barracuda is highly prized.

Several young barracuda were caught in Gravesend bay in September 1896. The species is not common in that bay. An individual $5 \frac{1}{2}$ inches long was seined at Sandy Hook, Oct. 8, 1897. The fish does not live long in captivity.

Suborder riHegropteri

Family IOLL TEMIDAE

Threadfins

Genus powdontus Lacépède

Anal fin not much longer than soft dorsal, of about 13 or 14 rays; romer with teeth; preoperculum serrate; free filaments of pectorals mostly shorter than body; teeth in villiform bands on both jaws, romer, palatines, and pterygoids; preopercle sharply serrated on its posterior margin, its angle with a scaly flap; scales ratler small, finely ctenoid; first dorsal with seven or eight feeble, rather high spines, the first and last short, soft dorsal and anal fins about equaling each other; pectoral filaments three to nine; pyloric caeca in great number. Species numerous, in warm seas.

\section{Polydactylus octonemus (Girard)}

\section{Threadfin}

Polyuemus octonemus Girard, Proc. Ac. Nat. Sci. Phila. 167, 1858, Brazos; Santiago; Galveston; young; Günther, Cat. Fish. Brit. Mus. II, 320, 1560; Goode \& Bean, Ploc. U. S. Nat. Mus. II, 12S, 1850; Jordan \& Gilbert, Bull. 16, U. S. Nat. Mus. 413, 1883.

Polydactylus octoucmus Jordax \& Evermann, Bull. 47, U. S. Nat. Mus. \$30, 1S96, pl. CXXVIII, fig. 350, 1900; Bean, Bull. Am. Mus. Nat. Hist. $\mathrm{IX}, 358,1897$.

Trichidion octofilis Gilt, Proc. Ac. Nat. Sci. Phila. 280, 1861, New York; adult.

Thichidion octonemus GILL, op. cit. 2S0, 1861.

Polynemus octofilis Jordan \& Gilibert, Proc. U. S. Nat. Mus. 590, 1Ss2; Bull. 16 , U. S. Nat. Mus. $413,1883$.

Body compressed, moderately elongate, its greatest depth from one third to two sevenths of the total length without caudal, its thickness equal to two fifths of length of head; 
candal peduncle short and stout, its least depth one half the length of head; head short, a little more than one fourth of total length without caudal, its width nearly one half its length; snout obtusely conical, its length varying with age from one seventh to one fifth of length of head; eye equal to interorbital space and its length contained from fom and one third to five and one half times in length of head; mouth inferior, slightly oblique, wide, the lower jaw included, maxilla broadly expanded behind, its end reaching far behind ese, length of upper jaw nearly one half of length of head; hind margin of preopercle with numerous rather coarse spines. Distance of spinous dorsal from tip of snout equals one third of total length without caudal, base of spinous dorsal one half as long as the head, second spine longest one fifth of total without caudal, last dorsal spine two ninths as long as the second, interspace between dorsals equal to postorbital part of head, base of second dorsal contained one and three fourth times in length of head, longest dorsal ray equal to postorbital part of head, last dorsal ray one third as long as the head. Anal origin is under the fifth or sixth ray of the second dorsal, the base of the fin equals the second spine of the dorsil in length; the longest ray is one half as long as the head; the last ray is as long as the snout and eye combined. The rentral origin is under the middle of the spinous dorsal; the length of the fin is about one half the length of head. The pectoral reaches beyond the end of the spinous dorsal, but not to the rent, its length equal to length of head without the snout; the pectoral filaments are eight in number on each side, the longest reaching past the rent. Candal deeply forked, its "xternaI rays longer than the head. D. VIII-I, 12; A. III, 13; V. I, 5; P. I, 15, S; B. VII. Gill rakers, 21 below the angle, the longest nearty ronal to eye; scales 6-70-10. Color light olivaceous, with dark punctulations; belly whitish; pectoral black in adult, pale in young.

The threadfin is found on the east coast of the United States from New York to Texas, occurring northward in summer only. Sep. 24, 1896, three specimens were obtained by John B. De 
Nyse in Givesend bay and sernt to the aquarimn dead, as they would not endure captirity. The fish agrees in cololation and in every other respect with I'. octofilis Gill, and is bolieved to be the adult form of $P$. o c to n e n us Girarl. This is probably the first recold of its ocenrence in New York waters for more than :30 years.

\section{FASULEMLNTS}

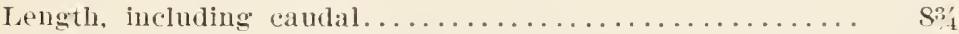

Length to end of middle caudal rays................ $71 \frac{2}{2}$

Length to oligin of middle caudal days.............. 050.8

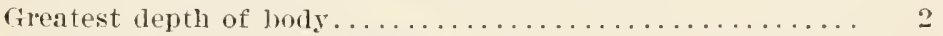

Least depth of candal peduncle..................

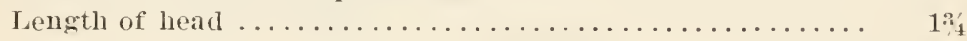

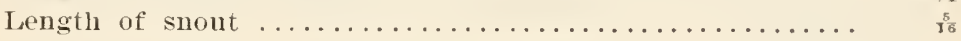

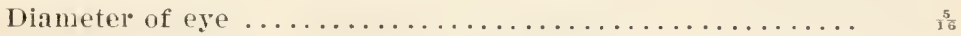

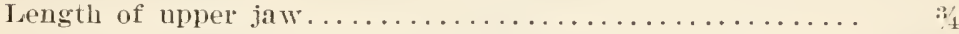

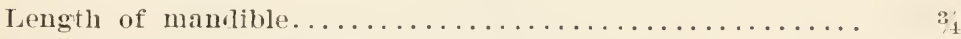

Length of longest pectoral filament............... $2 \%$

Length of upper and lower caudal lobes............. 21/4

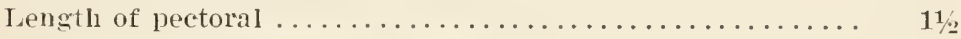

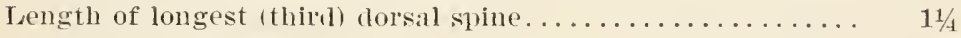

Length of second dorsal ray...................... 11/4

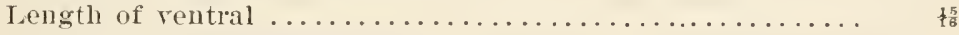

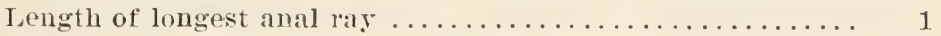

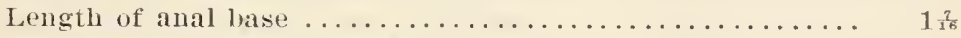

Length of base of first dorsal. ......................

Length of base of second dorsal. . . . . . . . . . . . .

The longest pector:al filament reaches to below the interspace betwen the two dorsals and slightly past the rent. The dianeter of the eye equals the length of the snout and one fifth the length of the head.

\section{Group AMMOIMTOLDEI}

Family AMIODITIDAE

\section{Sand Lances}

Genus Arnonsws (Artedi) Linnaeus

Body elongate, lanceolate, the skin with many transrerse folds running obliquely downward and backward, the small cycloid scales mostly placed in cross series between them; lat. eral line concurrent with the back; a fold of the skin along each side of the belly; romer not armed with a bicuspid tooth; color silvery; rertebrae 62 or 63 ; one prloric caecum. Carnirorous 
fishes inhabiting sandy shores in cold regions, living in large schools, burying themselves in the sand near the tide mark. Valued as bait and useful as food for salmon and other larger fishes.

\section{Ammodytes americanus De Kay}

\section{Send Lance: Sand Eel}

Ammodytes americamus DE KAY, N. Y. Fauna, Fishes, 317, pl. 52, fig. 167, 1812, Queens County, New York, and Stratford, Conn.; Storer, Hist. Fish. Mass. 216, pl. XXXIII, fig. 2, 1867; Goone \& BEAN, Bull. Essex Inst. XI, 20, 1879; Jordan \& Gilbert, Bull, 16, U. S. Nat. MIus. 414, 1S83; Jornan \& Evermant, Bull. 47, U. S. Nat. Mus. 833, 1896, pl. CXXIX, fig. 351, 1000; BeAn, Bull. Am. Mus. Nat. Hist. IX, 359, 1897. Ammodytes vittatus DE İAY, N. Y. Fauna, Fishes, 318, pl. 60, fig. 197, 18t2, New York, apparently based upon a mutilated specimen, fide JorDAN \& Evermann.

Argyrotaenia viltata Jordan \& Gulbert, Bull. 16, U. S. Nat. Mus. 415, 1883.

Body long, slender, subterete, its greatest depth one tenth to one twelfth of total length without caudal, its width two fifths of length of head; head moderately long, with acutely pointed snout, length of liead one fifth of total without candal; snout nearly one third as long as the head; eye small, one sixth as long as the head, and equal to width of interorbital space; lower jaw somewhat projecting, the mandible nearly one half as long as the head, the maxilla reaching back to front of orbit; dorsal origin in advance of tip of pectoral; length of pectoral about one half the length of head; length of anal base nearly one third of total without candal; dorsal and anal rays about equal in length and not much longer than the eye; intermaxillary protractile; romer not armed with a bicuspid toothlike prominence, 1). 55 to $63 ; 1.27$ to 31 . Lateral folds 127 to 141 .

The specimens examined are from $\frac{17}{8}$ to $T$ inches long, from Nantucket, Woods Ilole and Bass Rocks, Mass.

Colors as given by Dr. Storer: of a dirty greenish brown on the back, the sides and abdomen silvery, the top of the head flesh-colored, the preopercles silvery, operculum cupreous and silvery, pupils black, iris silvery.

The sand lance orcurs on sandy shores from Newfoundland to Cape Hatteras. In certain harbors of Cape Cod and Marthas Vineyard it often schools in myriads, so that the entire bottom 
is covered from 1 to 2 inches deep and appears like an immense sheet of silver. These little fish are a very important source of food for the cod, salmon and other valuable fishes and are excellent for bait.

De Kay found the roung frequently washed on slore after heary northerly gales.

The sand lance appears in Gravesend bay in July, but is more plentiful in winter. The fish buries itself in sand and sometimes, when alarmed, will leap 4 inches above the sand. In captivity it swims continually and soon dies. It will not thrive for want of sand and proper food.

\section{Group BERYCOIDEI}

Family dILLIDAE

\section{Surmullets}

\section{Genus Mulus Linnaeus}

Villiform tecth in the lower jaw and on the romer and pala. tines, none in the upper jaw, the bone forming a hook over the maxillary well developed; opercle without spines; interorbital space flat and wide. Otherwise as in Upeneus, the head rather shorter. One species known.

\section{Mullus auratus Jordan \& Gilbert Red IIullet; Goatfish}

Mullus barbatus auratus Jordan \& Gilbert, Proc. U. S. Nat. Mus. 2\$0, 18s2, Pensacola, Florida; Bull. 16, U. S. Nat. Mus, 931, 1883.

Imllus auratus Jornan. Proc. U. S. Nat. Mus. 39, 18s4; BeAn, Bull. Am. Mus. Nat. Hist. IX, 359, 1897; Jordan \& Evermann, Bull. 47, U. S. Nat. Mus. 856, 1896, pl. CXXXII, fig. 360, 1900.

Body moderately deep and compressed, its width equal to postorbital length of head, its greatest depth nearly equal to length of head and contained three and one half times in total length without caudal; least depth of caudal peduncle equal to postorbital part of head; head two sevenths of total length without caudal; anterior profile rather steep; intermaxilla protractile; mouth small, terminal, the upper jaw one third as long as the head and about equal to length of mandible; eye placed high, interorbital space nearly flat, its width greater 
than long dianeter of the eye, and about two serenths of length of head, eye about three elevenths of length of head; barbels one fifth of total length to end of scales, and equal to length of pectoral. The spinous dorsal begins orer the fifth scale of the lateral line, its base one half as long as the head, its longest spine two thirds as long as the head, its last spine scarcely as long as the eye, interspace between dorsals equal to one third the length of head, base of second dorsal one half as long as the head, longest ray slightly more than one half the length of head, last ray as long as the eye. The ventral origin is under the axil of the pectoral, also under the third scale of the lateral line; the length of the rentral is one fifth of total length to end of scales; the rentral fin reaches a little farther back than the pectoral, to a point below the twelfth scale of the lateral line. The anal origin is under about the third ray of second dorsal; the base is as long as postorbital part of head: the longest ray one half, and the last ray two serenths of length of head. Caudal deeply forked, the middle rays, from end of scales, two fifths as long as the outer rays, which are three fourths as long as the head. Pectoral fin three fourths as long as the head, reaching to below the 12th scale of the lateral line, and (end of spinous dorsal base. D. VII-I, S; A. II, 6; T:I. 5; P. 16. Scales $32-35-6$.

Color searlet; side with two yellow longitudinal stripes; snout and caudal fin scarlet, the latter with about five narrow dusky bands after preservation in spirits; first dorsal fin with an orange band at hase and a rellow band higher up, the rest of the fin pale; second dorsal fin with about three narrow bands of scarlet; anal and rentrals pale; pectoral reddish; iris violet or golden; sides of head silvery. iridescent.

The red mullet ranges from Cape Cod to Florida; it is found at Woods Mole Mass, occasionally in summer; on the red snapper banks off Pensacola Fla. it is moderately abundant. The fish grows to the length of $S$ inches. It has no economic value, but furnishes food for the red snapper, groupers and other food fishes. 
Three individuals of II $1111 \mathrm{~s}$ were captured in a seine at Sandy Hook N. J. Oct. S, 1897, and brought alive to the New Jork alualium, where they are now (Nov. 30, 1897) in good con. dition and feed freely on shrimp. As the fish are living, it is uncertain whether or not they are M. a u r a tus; but they agree in the main with the description of that species. Their endurance of water at a temperature of $50^{\circ} \mathbf{F}$. is unexpected. Fishermen at sandy Hook reported that large numbers were seen there in september and October 1897.

Recent examination of one of the specimens above referred to (Xo. 48т96, U. S. National Museum) shows its entire agreement with the type of M u l l us a uratus.

\section{Group sCOMBROIDEI}

Family SCONIBIIDAE

\section{MIackerels}

\section{Genus scovisn (Artedi) Limnaeus}

Body fusiform, rather elongate, somewhat compressed; caudal peduncle slender, without median keel, but with two small keels on each side; mouth wide, with a single row of rather small, slender teeth in each jaw and on the romer and palatines; maxillary slipping moler the broad jreorbital, a fleshy lobe on each side of lower jaw near its junction with maxillary; scales very small, not forming a corselet; first dorsal of nine to 12 feeble spines, separated from the sccond by an interspace greater than the base of the fin, second dorsal small. followed by fire to nine detached finlets; anal similar to second dorsal, with similar finlets; pectorals and rentrals small, the former placed high, on the level of the eyes; caudal fin small, widely forked; pyloric appendages exceedingly numerous; air bladder small or wanting: rortebrac normally formed, $14+1 \tau=31$; sill rakers long and slender.

\section{Subgenus scouber}

191 Scomber scombrus Linnaeus

Common, Hackierel

Scomber scombrus Lixpaeus, syst. Nat. ed. X, 297, 1758, Atlantic; Goode \& Bean, Bull. Essex Inst. XI, 14, 1879; Jordan \& Gilbert, Bull. 16, U. S. Nat. Mus, 424, 18S3; Jordan \& Everuranx, Bull. 47, U. S. Nat. Mus. S65, 1896, pl. CXXXIII, fig. 363, 1900. 
Scomber vernalis MIrcullt, Trans. Lit. \& Phil. Soc. N. Y. I, 423, 1815, Sandy Hook, New Jersey; DE KAY, name omitted from chapter heading, N. Y. Fauna, Fishes, 101, pl. 12, fig. 34, 1842, New York coast; Storer, Hist. Fish. Mass. 5t, pl. XI, fig. 2, 1867.

Scomber scomber Linnaeus, Syst. Nat. ed. XII, 492, 1766; Günther, Cat. Fish. Brit. Mus. II, 357, 1860.

Body moderately long, subterete, fusiform, the snout acute and the caudal peduncle much tapering posteriorly, the greatest hight two ninths of total length without the caudal, the least depth of caudal peduncle equal to the short diameter of the eye, the width of body one half the length of head; head conical, pointed, its length one fourth of total without caudal, its width one half its length, the width of the interorbital space one half postorbital length of head; snout rather long, one third as long as the head; lower jaw slightly projecting, the mandible extending behind orbit, its length more than one half the length of head, the maxilla reaching to below front of pupil. The eye is one fifth as long as the head. The spinous dorsal originates over the middle of the pectoral; its base is a little longer than the mandible; the second, and longest, spine is two fiftlis as long as the head; the last spine is very short, about one third of length of eye; the interspace between the dorsals is about equal to depth of body; the second dorsal base is nearly opposite anal base, slightly in adrance, its length two fifths of length of the head; the longest ray is one fourth as long as the head, the last ray two thirds as long as the eye; the second dorsal is followed by five finlets, each as long as the last ray. The anal origin is under the fourth or fifth ray of the second dorsal; the base of the fin is one third as long as the head; the longest ray is one half of postorbital length of head; the last ray is two thirds as long as the eye; the fin is followed by five finlets which are immediately opposite the dorsal finlets and of about the same size. The middle caudal rays, from end of scales, are equal to one half the greatest depth of body; the external rays are nearly twice as long as the middle rays. The ventral origin is very slightly in advance of the origin of spinous dorsal, its distance from tip of snout equaling the distance from origin of second dorsal to root of caudal fin; the length of the ventral equals three 
(-ighths of length of head. The pectoral is one half as long as the head; the fin reaches to below the sixth spine of the dorsal. No air bladder. D. XI-I, 11-V; A. I, 11-V; V. I, 5; P. I, 16.

Color dark blue, or greenish blue, abore, the upper parts with 30 or more wary transverse bands of a darker hue, these extending below the lateral line and nearly to the median line of the body; bentath the ends of these lines and slightly separated from them is a narrow, longitudinal, dark streak running almost the entire distance from the pectoral to the caudal; top of the head rery dark; a dark bloteh in the axil of the pectoral; gill corers and jaws silvery; sides white with cupreous refiections; belly white.

The mackerel is one of the best known food fishes of the north Atlantic, ranging from Norway to Spain in Europe and from Labrador to rape Hatteras in North America. It reaches the length of 18 inches. The fish is nigratory and frequently disappears for a short or long period of time from its accustomed localities. On the New Iork coast the mackerel appears in May and June in great schoois, but the number varies greatly in different year's.

'Two young, $3 \frac{1}{4}$ to $5 \frac{1}{2}$ inches long, were taken in Gravesend bay, L. I., May 28, 1S96, in John B. De Nyse's shad fyke. No more were seen, and these were the first for the year. They come about the time of the appearance of anchory and weakfish. They are often seen swimming at the surface of the bay in small bunches of $18 \mathrm{or}^{\circ} 20$, occasionally 100, in the latter part of May or early in June. They are always split up into small bunches, probably by the attacks of weakfish and other predaceous speeies which are present at the time. Fhkes attack them also in shallow water.

\section{Subgenus patratorhorus Jordan \& Gilbert}

\section{Scomber colias Gmelin}

\section{Chub Mackerel; Thimbleeye IIackeral}

Scomber colias Gurelin, I. Syst. Nat. 1329, 1788, Sardinia; DE ISAX, N. Y. Fauna. Fishes, 104, pl. 11, fig. 33, 1842; Jordax \& Evermann, Bull. 47, U. S. Nat. Mus. S66, 1896, pl. CXXXIII, fig. 364, 1900; BeAN, Bull. Am. Mus. Nat. Hist. IX, 360, 1897. 
Sconber pmenmatophorus De LA Rocue, Ann. Ius. Nat. Hist. XIII, 315, 334, 1809, Balearic Islands.

Scomber gicx Mitchile, Trans. Lit. \& Plil. Soc. N. I. I, 422, 1S15; Storer, Syn. Fish. N. A. $90,1846$.

Scomber dckayi S'Torer. Hist. Fish. Mass. 52, pl. XI, fig. 1. 1S67; Goode \& BEAx, Bull. Essex Inst. XI, 15, 1879.

Body fusiform, subterete, moderately rlongate, its greatest depth two ninths of total length to base of caudal fin; least depth of caudal peduncle two thirds of the short diameter of the eye, its width more than one half the length of head and equal to snont and eye combined; head conical, pointed, compressed, its length contained three and three fourths times in total to base of caudal, its width equal to one half its length, width of interorbital snace three fifths of length of postorbital part of head; snout long, pointed, two serenths as long as the head; lower jaw slightly projecting, the mandible extending to below hind adge of pupil, its length less than one half the length of head; the maxilla reaching nearly to front of pupil. The eye is large, corered in front and behind by an adipose membrane, its length three elevenths of length of head or two thirds of length of postorbital part of head. The spinous dorsal originates over the middle of the pectoral, a little behind the insertion of the rentral; the base is as long as the head without the snout and is much longer than the mandible; the second spine longest. one half as long as the head, the last spine minute, about one fifth as long as the eye. The interspace between the dorsals is only two thirds of depth of body. The second dorsal base is chiefly opposite anal base, but more in advance than in

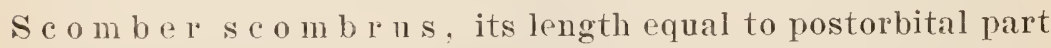
of head; the longest ray is one fourth as long as the head, the last ray one half as long as the eye; the second dorsal is followed by five finlets, which increase in size posteriorly, the last one larger than last ray of dorsal, and two thirds as long as the eye. The anal origin is under the fifth or sixth ray of the second dorsal; the base of the fin is as long as the postorbital part of the head; the longest ray equals the longest of the dorsal: the last ray is one half as long as the eye; the fin is followed by fire finlets of the same size as the dorsal finlets and 
placed neally opposite to them. The middle caudal rous are very short: the external lays are as long as the snout and eye combined. The rentral origin is equally distant from tip of snout and rent; the fin is two fifths as long as the head. The pertoral is one half as long as the head and reaches to below the fifth spine of the first dorsal. dir bladder present. I). IX

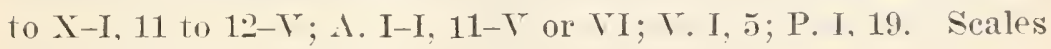
nearly 200 .

Colors essentially the same as in Scomber s combrus, the wary transverse bands about 30 in number; sides mottled with sull dusky blotches below the median line; about 20 black specks on base of preopercle, usually arranged in more than one series; belly and sides silvery; a black blotch in axil of pectoral.

The chub mackerel is found in the Atlantic and Pacific oceans, north to England and Yaine and to San Fraucisco; very common in the Mediterrancan and in southern California; somelimes abundant on our eastern coast and frequently absent for long periods. It rearhes the length of 14 inches and is an important food fish.

Tuly 25, 188T, the schooner Peter Coopler caught 6000 thimbleeye mackerel off Manasquan X. J. About 50,000 mackerel were taken by the menhaden steamer. A. Morris, near Ocean City, July 19, 18st. Some of these were preserved in brine by $\mathbb{W}$. B. Steeluan, and I found them to be s. coli as.

The thimbleeyes usually arrive in August. In 1886 they were often caught. This species was not found in large numbers in iraresend bay in 1897 , but in 1896 it abounded in all the little creeks, and in some instances the fish could be dipped up br the boat load with scoop nets. The fisle reached 10 inches in length before the and of the summer.

\section{Gemus axdm Guter}

body obiong, plump, mostly nalied posteriorly, anteriorly cor"red with small seales, those of the pectoral region enlarged, forming a corselet; snout very sluort, conical, scarcely comjressed; mouth rather small, the jaws equal; teeth very small. mostly in a single series, on the jaws only; tail rery slender, 
depressed, with a rather large keel on each side; first dorsal short, separated from the second by a considerable interspace, second dorsal and anal small, each with seven or eight finlets; pectorals and rentrals small; no air bladder; branchiostegals seven; pyloric caeca dendritical; gill rakers very long and slender, numerous; vertebrae 39 in number, peculiarly modified, essentially as in $\mathrm{G}$ y $\mathrm{m} \mathrm{nos}$ a $\mathrm{r}^{\mathrm{d}} \mathrm{d}$.

\section{Auxis thazard (Lacépède)}

\section{Frigate Mackerel}

Scomber thasard Lacepede. Hist. Nat. Poiss. III, 9, 1802, Coast of New Guinea.

Auxis vulgaris Cuvier \& Valenciennes, Hist. Nat. Poiss. VIII, 139, 1831, Mediterranean.

Auxis rochei Günthen, Cat. Fish. Brit. Mus. II, 369, 1860; Jordan \& GILBert, Bull. 16. U. S. Nat. Mus. 425, 1883.

A uxis thazard Jordan \& Gilbert, op. cit. 911, 18S3; Jordan \& Evermand, Bull. 47, U. S. Nat. Mus. S67, 1S96, pl. CXXXIII, fig. 365, 1900.

Body stout, subterete, fusiform, tapering to a very low caudal peduncle, the greatest depth one fourth of total length without caudal, the width nearly two thirds of the depth; the least depth of caudal peduncle about two fifths of length of iris; head short, conical, pointed, its length one fourth of the total to end of middle caudal rays, its width two thirds of its length, the width of the interorbital space one half postorbital length of head; snout short, as long as the eye, one fifth as long as the head; the lower jaw not projecting when the mouth is closed, the maxilla reaching to below middle of pupil, the mandible two fifths as long as the head and reaching nearly to below hind margin of orbit. The eye is as long as the snout and one fifth as long as the head. The spinous dorsal originates a little behind the origin of pectoral and ventral, at a distance from tip of snout nearly equal to one third of total length to caudal base; its base is nearly one half as long as the head; the second spine longest, two fifths as long as the head, the last spine minute, about one sixth as long as the eye. The interspace between the dorsals equals the length of the head without the snout. The second dorsal is in advance of the anal; its base is about one fourth as long as the head; its longest ray equals snout, and its last ray is less than 
one half the snout; the fin is followed by eight finlets, which decrease in size posteriorly. The anal origin is below the interspace between the end of the second dorsal and its first finlet; the anal base is as long as the second dorsal base; its first ray is as loug as the snout, its last ray is one half the short diameter of the eye; it is followed by seven finlets, decreasing in size posteriorly. The middle caudal rays, from end of keel, are one fourth as long as the outer rays, which are one half as long as the head; the caudal lobes form a very obtuse angle with the caudal peduncle. The rentral origin is directly under the root of the pectoral; the fin is as long as the snout and eye combined, the rentral sheath about as long as the fin. The pectoral is falcate, many-rayed, its length four ninths of length of head; the fin reaches to below the last spine of the first dorsal. D. X-12VIII; A. 13-VII; V. I, 5; P. 22; B. VII.

Color dark blue above with reticulated markings on the back, chiefly in the second half of the length and all above the lateral line; sides, lower parts and head silvery; ventral dark.

The frigate mackerel is found in all warm seas and ranges northward occasionally to Cape Cod; it is a rare visitor in our waters, but sometimes appears in immense schools. It has little ralue as food. It reaches the length of 16 inches. The species was unknown on our shores till 1880, when it arrived in almost countless numbers. Its food is the same as that of the common mackerel.

\section{Genus Grmosand Gill}

This genus according to Lütken differs from $\mathrm{T} \mathrm{h} \mathrm{u} \mathrm{n} \mathbf{n} \mathrm{u} \mathbf{s}$ 1) in the absence of teeth on romer; 2) by the complete absence of scales outside of the corselet (for in $\mathrm{T} h \mathrm{~h} \mathrm{n} \mathrm{nus}$ of the same size the skin is corered with small scales; and the limits of the corselet in the tunny and albicore are obscure, so that it can not properly be said that they have distinct corselets), and 3) by an important osteologic character, namely the peculiar development, in the form of a network or trellis, of a portion of the abdominal part of the backbone, between the vertebrae proper and the hemapophyses. Vertebrae 38. Species of smaller size than the tunnies, also pelagic, and of little ralue as food. 


\section{Gymnosarda pelamys (Linnaeus)}

\section{Oceanic Bonito}

Scomber pelamis Linnaeus, Syst. Nat. ed. X, I, 297, 1758, tropical seas.

Thynn pelamys Cutien \& VAlexciexnes, Hist. Nat. Poiss. VIII, 113, 1531. orcynus pelemys Poer, Syn. Pisc. Cubens. 362, 1S6S; Goode \& Beax, Proc.

U. S. Nat. Mus. I, 24, 1878; Bull. Essex Inst. XI, 15, 1879.

Euthynns pelamys Jordan \& GIlber', Bull. 16, U. S. Nat. Mus. 430, 1883. Gymosarda pelamis Inesslar \& FesLer, Bull. U. S. F. C. VII, 436, 1889;

Jordax \& Everannx, Bull. 47, U. S. Nat. Mus. S68, 1896.

Body obloug, abruptly tapering at both ruds, stout, short, its greatest hight one fourtl of total length to end of middle caudal rays, its width a little more than one lialf the length of head, equal to postorbital part of head; least hight of caudal peduncle one half the length of eye; keel one fourth as long as the head; head rather long, somewluat compressed, acute in front, conical, its length two sevenths of the total without caudal, its width orer the opercles one lialf its length; snout not long, acute at tip, somewliat compressed, its length two sevenths of length of liead; the mandible heavy and prominent, scarcely projecting; the maxilla with rounded extremity extends to below middle of pupil; the mandible extends to below hind margin of eye, its length nearly one half the length of liead. The eye is obliquely obloug, its length about one fifth of lengtl of head. The spinous dorsal orginates immediately over the origins of the pectoral and rentral; the base of the fin is four fiftlis as long as the head; the first and longest spine one half as long as the head, the last spine one fourtlu as long as the snout. The interspace between the dorsals equals two thirds of length of suont. The second dorsal is equidistant from the upper angle of the gill opening and the base of the caudal fin; the base of the fin is as long as the snout and equal to base of anal; the longest ray is a very little louger than the base of the fin, the last ray is one fourth as long as the snout; the fin is followed by eight finlets, the largest in front, two fifths as long as the snout. The middle caudal rays, measured from keel, one third as long as the outer rays, which are nearly two thirds as long as the head (equal to postorbital part of head). The anal origin is nearly under the end of the second dorsal; the base of the fin is two seventlus as long as the 
head; the longest ray is as lomg as the base of the fin, the last ray one third of length of snont; the fin is followed by seren: finlets, which are rather boader than those of the dorsal. The ventral origin is directly under the origin of spinous dorsal; the length of the fin is two fifths of length of liead; the ventral sheatle is bifurcate and less than one half as long as the fin. The pectoral is scarcely falcate, its length one half the leugth of head, the fin reaching to below the 11th spine of the dorsal.

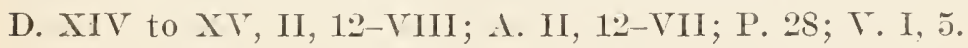

The corselet is rery prominent. Its contour is defined by lines at the edge of the branchial cleft, about midway between the axil of the pectoral and the median line of the belly, extending below, beyoud, and around the extremity of the pectoral (which, when normally placed, touches with its tip the onter margin of the corselet), then extending beyond its tip for a distance nearly equal to its length, around up into the lateral line, down which a narrow tract of scales continues to its extremity, though narrowed to a single row after passing its curve; passing the lateral line, the contonr of the corselet curves forward and inward, then, ascending to a point distant from the median line of the back about the diameter of the orbit, it follows backward in a direction parallel to this line, to a point opposite the posterior extremity of the second dorsal, where it curves upward to the median line of the body, and completes its circuit.

- When riewed from above, the rows of scales appear to be arranged concentrically about the origin of the first dorsal fin. The scales are largest along the edges of the pectoral arch and the dorsal fin, decreasing rapidly in size as they recede from these regions. There are about 30 rows between the dorsal and the upper margin of the pectoral, normally placed.

The upper parts deep bluish in life; the belly and flanks below lateral line, the opercles and throat pearly opalescent white; the lower part of the pectoral arch and tracts at the base of the rentrals and anal, as well as those parts of the opercles where the bone is close to the outer skin, chalky white. The corselet is bronzed brown in the alcoholic specimen. There are four dis- 
tinct bluish lines on the sides, which are nearly parallel with the lateral line, and constitute the most prominent specific character. The first of these begins directly under the tip of the pectoral, the second at the margin of the corselet, at a point in the line from the upper to the Iower axillars angles of the pectoral. The third and fourth are rather indistinct anteriorly, but very distinct in the posterior half of the body, and are about as far distant from each other as are the first two, the interval between the two pairs being slightly greater than that between the members of each pair, and equal to the diameter of the orbit. The first or uppermost line is nearly straight, the others, following the lower contour of the body, curve upward over the anal fin, and all four become lost in the darker color of the caudal peduncle.

If the Japanese fish, which has been referred to this species, be really the oceanic bonito, we must add the following notes on color's; three shorter dark stripes on the middle of the body, between the lateral line and the uppermost of the four long stripes; dark blotches on the membrane connecting the dorsal spines, begimning between the sixth and serenth spines and continuing to the end of the fin. It is not at all certain, in my estimation, that the Japanese form is the same as ours, since it appears to have a more compressed body, the spinous dorsal more posteriorly placed, and the color differences above mentioned.

The oceanic bonito is said to inhabit the warmer parts of the Atlantic and Indian oceans and the seas of China and Japan. It is a rare visitor in our waters and has no importance for food. Persons who have eaten it say the flesh is dry and, sometimes, disagreeable. It feeds on flying fish, skipjacks, small cuttlefish, mollusks, and marine plants. The maximum length recorded is 30 inches.

\section{Gymmosarda alleterata (Rafinesque)}

\section{Little Tunny}

Scomber alleteratus Rafinesque, Caratteri Alc. Gen. 46, 1S10, Palermo.

Thynnus thumina Cuvier \& VAlenciennes, Hist. Nat. Poiss. VIII, 104, 1831, Mediter'ranean; Güntıer, Cat. Fish. Brit. Mus. II, 364, 1860.

Thymms brasiliensis Cuvier \& VAlencrennes, op. cit. 110, Mediterranean. Thymus brevipinnis Cuvier \& Valencrennes, op. cit. 112, Mediterranean. 
Orcynus alliteratus GiLl, Rept. U. S. Fish. Comm. 802, 1S73; Goode \& BEAN, Bull. Essex Inst. XI, 15, 1579.

Euthynus alliteratus Jordan \& Gimbert, Bull. 16, U. S. Nat. II 430 , 1 S 83.

Thynnus affinis GüNTHer, op. cit. II, 363, 1860.

Thynu brevirostris Güstuen, op. cit. II, 365, 1860.

Gymnosarda alleterata JordAx \& Evernaxa, Bull. 47, U. S. Nat. Mus. S69, 1896, pl. CXXXIV, fig. 366, 1900.

Bods fusiform, much tapered at both ends, moderately compressed, its greatest light one fourth of total length without caudal, its width one half the length of the head; least depth of caudal peduncle one third of length of snout; keel well dereloped, three eighths as long as the head; head moderate, pointed in front, its length one fourth of the total to end of middle raudal rays, its width over the opercles equal to ere and snout combined; snout not long, acute at tip, its length two serenths of length of head; the interorbital space equal to snout; the mandible heary, not projecting, the maxilla expanded posteriorly, extending to below middle of pupil; the mandible extends to below hind margin of orbit, its length nearly one lalf the length of head. The ere is one fifth as long as the head, and two thirds of width of interorbital space. The spinous dorsal originates directly above the insertion of the rentral and slightly behind that of the pectoral; the base of the fin is nearly as long as the head; the longest spine is one half as long as the head, the last spine about one half as long as the eye; the interspace between the dorsals extremely short. The second dorsal is preceded by a short, stiff spine, which is about one third as long as the eye; the base of second dorsal is one fourth as long as the head; the longest ray is two nintlis as long as the head, the last ray one half as long as the eye; the fin is followed by eight finlets, of which the fourth is longest, two thirds as long as the eye. The middle caudal rays, measured from the root of the fin, are two fifths as long as the outer rays, which are two thirds as long as the head. The anal origin is under the first detached finlet; the base of the fin is as long as the snout; the longest ray two ninths as long as the head, the last ray two thirds as long as the eye; the fin is followed by seven finlets, which are similar to the dorsal finlets. The 
ventral origin is at a distance from tip of snout equal to one third of total length to candal base; the fin is two fifths as long as the head, extending as far back as the pectoral, to a point below the ninth spine of the dorsal. The rentral sheath is little bifurcate at its tip, its length little more than one half the length of rentral fin. The pectoral is somewhat falcate, its length equal to postorbital part of head. D. XV-I, 12-VIII; A. ii, 12-VII; V. I, 5; P. I, 26.

Color bluish above, sides and lower parts silvery; several wavy, more or less interrupted, dark streaks above lateral line, beginning under the middle of the spinous dorsal; five or six roundish brown spots, about as large as the pupil, between the pectoral and ventral fins; tip of spinous dorsal and inner surface of ventral dusky.

The little tunny is common in the Mediterranean and the West Indies and ranges northward occasionally to Cape Cod. It is said to reach the length of 4 feet, but no individuals of that size are recorded from on waters. Prof. S. F. Baird collected an example about 2 feet long at Woods Hole Mass. in 1871. A specimen 13 inches long was taken at Pensacola Fla. by Silas Stearns in 18is. Though eaten in Mediterranean conntries, the flesh is not much esteemed.

\section{Genus Thuxvus South}

Body oblong, robust, with very slender caudal peduncle; head conical; mouth wide, with one series of small, conical teeth in the jaws and bands of minute villiform or sandlike teeth on the vomer and palatines; scales present, those of the pectoral region forming an obscure corselet; first dorsal of 12 to 15 spines, which grow gradually shorter backward, the interval between last spine and second dorsal slight; second dorsal and anal short and rather high, each with eight to 10 finlets; ventrals moderate, pectorals moderate, inserted rather below the level of the eye; vertebrae normal, 39 to 41 in number, the lower foramina very small. Open seas; the single species widely distributed. Size very large. 


\section{Thunmus thynnus (Linnaeus)}

\section{Tumn; Horse Mackerel}

Scomber thymnus Lixxdeus, Syst. Nat. ed. X, 297, 175S, Europe.

Thymms mlgaris CuVien of TALexciexases, Hist. Nat. Poiss. VIII, 58, pl. 210, 1531, European Seas; De Kíar, N. Y. Fauna, Fishes, 105, pl. 10, fig. 28, 1S 12 , after STORER.

Thymus brachypterus Crvier \& VALExCIENNES, op. cit. 9S, pl. 211, 1831, Iediteranean.

Thynnus secundidorsalis Storen, II ist. Fish. Mass. 65, pl. XII, fig. 4, 1867. Oreymus thymus Goode \& Bear, Bull. Essex Inst. XI, 15, 1879; Jordax \& Gileert, Bull. 16, U. S. Nat. Mus. 429, 1883.

Thumms thymm, Jordax \& Everdar, Bull. 47, U. S. Nat. Mus. 870, 1896.

Body oblong, tapering greatly at both ends, very robust, its greatest depth nearly one fourth of the total length to end of middle caudal rass, its greatest width one sixth of the same length. The least depth of caudal peduncle equals the length of the ere. The head is two sevenths of total length without the caudal; the snout is rather short, acute, its length contained three and one third times in length of head; the maxilla does not quite reach to below front of eye; eye small, two fifths as long as the snout, one seventh as long as the head. The spinous dorsal originates above the insertion of the pectoral; the fin is rery long, reaching almost to second dorsal, high in front and rapidly and regularly diminishing in hight posteriorly, its first spine longest, four ninths as long as the head, the last spine about as long as the pupil. The second dorsal base is as long as the anal base and two fifths as long as the head; the fin is deeply concave and rery low behind, its longest ray one half as long as the head; the fin is followed by nine finlets which are about two thirds as long as the eye. The anal origin is under the end of the second dorsal; the base of the fin is two fifths as long as the head; the longest ray is nearly one half as long as the head; the fin is deeply concare like the second dorsal, and is followed by eight finlets of about the same size as the dorsal finlets. The caudal fin is rery deeply forked, almost lunate in shape, the middle rays, measured from caudal base, contained two and one third times in the outer; the caudal keel is enormously developed, its length equal to length of snout. The ventral origin is under the second spine of the dorsal; the fin is 
one half as long as the head; when extended it reaches to below the 11th spine of the dorsal. The pectoral reaches to below the 12th spine; it is falcate, its leugth equal to length of head without the snout. The corselet is not so well defined as in some other related species, because the entire body is scaly: The lateral line curves downward from a point under the origin of the second dorsal. D. XIV, i, 13-IX; A. i, 12-VIII; V. I, 5.

Color dark blue above; gravish below with silvery spots; pupil black, iris golden with greenish reflections; rays of spinous dorsal dusky, the connecting membrane nearly black, second dorsal reddish brown; pectorals silvery gray; rentrals black above, white beneath; dorsal and anal finlets bright yellow, dark at base and on anterior edge; gill cover's silvery gray.

The tunny is the largest fish of the mackerel familr, reaching a length of 10 feet or more. It is pelagic, but comes to all warm coasts, northward to England, Newfoundland, San Francisco, and Japan. In our waters it appears usually in summer and is often taken in rather large numbers off Block Island, and on Cape Cod and Cape Ann. On account of its enormous size and great strength, it is often destructire to the fishermen's fixed nets.

D) Storel sars it comes into Massachusetts hay about the middle of June and remains till early in October. It was not uncommon to observe an or more in a day at Provincetown. It feeds on menhaden, mackerel, whiting, logfish and other small fishes. The usual implement of capture at first was the harpoon, but, now that its flesh has become raluable for canning and when marketed fresh, it is taken in pound nets and by line fishing. The fish arrives on the coast in poor condition and without value; but becomes rery fat during the summer months, and is then utilized for the oil, which is obtained from the head and belly by boiling, and for its flesh, which is farorably regarded, either fresh, salted or prescrved in cans.

The tunny is said to spawn in .June, and the recently hatched young, according to Yarrell, weigh $1 \frac{1}{2}$ ounces, growing to 4 ounces by August and 30 ounces in October. Adults often: 
weigh 1000 pounds. The killer whale is the most dreaded enemy of the tunny.

In southern California this fish is lighly prized by anglers who are fond of big game and hard play. In the Bay of Chaleur and off Caraquette, in the Gulf of St Lawrence region, 100 tunny were captured by means of baited lines, and the fishing was considered exciting because the fish pulled with such violence as to endanger the lires of the fishermen by dragging them overboard. This kind of exercise might be had near Rockport Mass. or off the New Jersey coast annmally in summer.

\section{Genus sarda Curier}

Body rather elongate, corered with small scales, those of the pectoral region forming a corselet; caudal peduncle slender, strongly keeled; lead large, pointed, compressed; month large; teeth in the jaws rather strong, conical, slightly compressed, similar teeth on the palatines, but none on the romer; maxillary not concealed by preorbital; gill rakers long and strong; first dorsal long and rather low, of 18 to 22 rather stout spines, which are gradually shortened behind; interral betreen the last spine and the second dorsal slort; second dorsal small, followed br S-9 finlets; anal fin similar, msually with one less finlet; paired fins small; pectorals placed below the level of the pupil; no air bladder; pjloric caeca rery numerous, treelike; rertebrae normally formed, 50 to $5 t$ in number. Fishes of rather large size, of metallic coloration. (After Jordan and Erelmann)

\section{Sarda sarda (Bloch)}

\section{Bonito}

Scomber sarda BLocr, Ichth. X, 35, pl. 325, 1793, Europe.

Pelamys sarda DE KAr, N. Y. Fauna, Fishes, 106, pl. 9, fig. 27, 1812; Gü̃THer, Cat. Fish. Brit. Mus. II. 367, 1S60; Storer, Hist. F'ish. Mass. 63, pl. XI, fig. $5,1867$.

Sarda pelamys Goode \& BeAN, Bull. Essex Inst. XI, 15, 1879.

Sarda mediterranca Jordd \& Gilbert, Bull. 16, U. S. Nat. Mus. 427. 1883.

Sarda sarda Bear. Bull. U. S. F. C. VII, 138, 1SSS; Dresslar \& Fesler, Bull. U. S. F. C. VII, 440, pl. VIII, 1S89; JordAx \& Everiranx, Bull. 47, U. S. Nat. Mus. 872,$1896 ;$ BeAs, Bull. Am. Mus. Nat. Hist. IX, 360 , 1897, Gravesend Bay. 
Body fusiform, much tapered at both ends, moderately elongate, robust, its greatest hight nearly equal to length of head and nealy ome fourth of total lengtl without caudal, its greatest width two thirds of its hight: least depth of caudal peduncle one third of length of snout; head four fifteenths to one fourth of total length to caudal base, its width orer the ojercles equal to length of its postorbital part; interorbital space strongly convex, one thild of length of head, greater than snout, twice diameter of orbit; snout rather long, one third as long as the head, acute, the jaws equal in front; maxilla much expanded behind, reaching slightly bethind orbit, the upper jaw one half the length of head; mandible equal to width of body, reaching comsiderably behind eye; eye small, rertically oblong, its rertical diameter about one half the length of snout. The spinous dorsal begins directly over the insertion of pectoral; the fin is very long, high in front, tapering rapidly and almost regularly to the last spine, which is only about one sixth as long as the second, and longest, this being two fifths as long as the head. The interspace between the dorsals is one half as long as the eye. The second dorsal base is as long as the suout and eye combined; the longest ray is four times as long as the last ray and one third as long as the head; the upper margin of the fin is deeply concave; the fin is followed by eight small fiulets, the longest as long as the eye. The anal origin is under the last dorsal ray or the first dorsal finlet; the base of the fin is as long as the snout; the longest ray is nearly five times as long as the last ray and three eighths as long as the head; the fin is followed by seven or eight finlets (usually seren) the longest equal to length of eye; the anal is deeply concave, like the second dorsal. The caudal fin is crescentic, the external rays three times as long as the midolle rays and the lobes narow and tapering, their widtl at base about one third of their length and one fourth the length of head. The ventral origin is under the second or third spine of the dorsal; the fin is three tenths as long as the head; its sheath is small and raylike, less than one half as long as the fin. The pectoral is falcate, broad at base, short, reaching to 
below the elerenth spine of the dorsal, its length one half the length of head. 'The lateral line very wary but with no great curves; the caudal keel nearly as long as the eje and snout combined. The corselet is dereloped only as a narpow stripe extending from the nape to a point a little behind the tip of pectoral, its widtir about one fifth of its length, and about equal to eye. 1. XI to XXI, 1.3 to 14 -V'II; A. 14-VI or VII; T. I, 5; P. I, 24.

Color steel blue abore, the sides silvery, the abdomen and under surface of head silvere white; from 10 to 20 dark bluish, narrow bands obliquely downward and forward from the back, some of them almost reaching the belly; iris yellowish; first dorsal fin sometimes pale, sometimes nearly black; pectoral dark above, light beneath.

The bonito inhabits the Atlantic ocean on both coasts and is common in the Mediterranean. On our coast it ranges habitually north to Cape Ann. It reaches the length of 30 inches and the weight of 10 or 12 pounds. Though not generally esteemed as a food fish, it meets with a steady sale either fresh or salted, like the mackerel. The fish is believed to live in the open sea, coming to the shores only to feed or to deposit its eggs. It is predaceous and active, feeding insatiably on mackerel and menhaden; it takes trolling bait as freely as the bluefish, to which it is not inferior in quality of flesh.

The fish is generally scarce in Gravesend bay. Five were taken in one day in a pound net in October 189\%, an unusual number for that species. The bonito will not lire in captirity.

Genus scommerovorzs Lacépède

Bodr elongate, wholly covered with rudinentary scales, which do not form a distinct corselet; head pointed, comparatively short and small; mouth wide, the strong teeth in the jaws more or less compressed or knife-shaped; villiform or sandlike teeth on the romer and palatines; maxillary not concealed br preorbital; gill rakers few; caudal peduncle with a single keel; spinous dorsal low, of 14 to 18 feeble spines; soft dorsal and anal short, similar, somewhat elevated and falcate, each followed by 
seren to 10 finlets; veutrals small; pectorals moderate, near the level of the eye; air bladder present; rertebrae normally formed, 45 in number. Fishes of the high seas; graceful in form and beautiful in color; among the best of food fishes. (After Jordan and Erermann)

\section{Scomberomorus maculatus (Vitchill)}

\section{Spanish Mackerel}

Scomber maculatus Mrtchill, Trans. Lit, \& Phil. Soc. N. Y. I, 426, pI. VI, fig. S, 1815, New York.

Cybium maculatum De KAY, N. Y. Fauna, Fishes, 10S, pl. 73, fig. 232. 1S12,

New York; Günther, Cat. Fish. Brit. Mus. II, 372, 1860; Storer,

Hist. Fish. Mass. 6s, pl. XIII, fig. 1, 186i; Goode \& BEAN, Bull. Essex Inst. XI, 15, 1879.

Scomberomorus maculatus Jordan \& Gilbert, Bull. 16, U. S. Nat. IIus, 426, 18S3; Bean, Bull. U. S. F. C. TII, 13S, 18Ss; 19th Rep. Comm. Fish. N. Y. 254, pl. VII, fig. 9. 1890: Jordan \& Evermaxi, Bull. $4 \bar{i}$, U. S. Nat. Mus. S7t, 1896, pl. CXXXIY, fig. 368, 1900.

Body elougate, much compressed, fusiform, its greatest depth from one fourth to two ninths of total length without caudal, its width two fifths of its depth and equal to postorbital part of head; least depth of caudal peduncle one half the postorbital part of head; head rather short, compressed, the lower jaw heary, but not projecting, length of head one fifth of total without caudal; maxilla somewhat expanded posteriorlr, extending to hind margin of orbit, the upper jaw equal to snout and eye combined; 16 strong conical teeth on each side in upper jaw, and 13 in the lower, vomer with a broad, short patch of minute, villiform teeth, palatine teeth similar, in club-shaped patches; mandible equal to head without snont; snout one third as long as head, very acute; posterior nostril twice as large as anterior; eye one fifth as long as head; interorbital space rery conrex, its width nearly equal to snout; gill rakers short, 2 abore and 11 below the angle of the first arch. The spinous dorsal originates over the insertion of the pectoral and considerably in adrance of the rentral origin; the base of the fin is long, as long as the head plus the length of the snout; the second and longest spine is three serenths as long as the head and four times as long as the last spine, the fin decreasing in hight regularly from 
the second to the last spine. The interspace betreen the dorsals is about one half the lengtl of the eye. 'The second dorsat base is three fourths as long as the head; the longest ray nearly four times as long as the last ray, and one half as long as the head; the fin is followed by eight finlets, none of which are longer than the eye. The anal originates under the middle of the soft dorsal; its base is two thirds as long as the head, its longest ray three and one half times as long as its last ray, and one half as long as the head; the fin, like the second dorsal, is deeply concave; it is followed by eight finlets equal in size to the dorsal finlets. The caudal is rery deeply forked, its outer rays as long as the head. The rentral originates under the fourth spine of the dorsal, its length three elevenths of length of head, the fin reaching to below the ninth spine of dorsal; there is no rentral corering, the inner rays of the two sides being slightly united at the base. The pectoral is broad, falcate, extending to below the 10 th dorsal spine, its length equal to head without snout. D. XVII to XVIII-16 to 18-VIII to IX; A. ii, 16 to 17 ; T. I, 5; P. i, 21. Lateral line strongly developed, with a moderate curve under the second dorsal, its comse from there to caludal somewhat wary.

Color silvery; upper parts bluish; sides with numerous oblong spots of a dull orange, none of them more than one third as long as the snout, these spots fully as numerous abore the lateral line as below it; the membrane connecting the first eight spines of the dorsal black, the rest of the fin white; soft dorsal with a yellowish tinge, its margin dark; anal and rentral white; peetoral black inside, yellowish with dark borders outside and corered with dusky points; caudal dusky except at base.

The Spanish mackerel inhabits the Atlantic and Pacific coasts of North America, on our coast ranging north to Maine and south to Brazil. It is one of the choicest of our food fishes and grows to the length of 3 feet and the weight of 10 pounds. The species spawns on the Long Island coast in August or earlier. The eggs are very small, about $\frac{1}{25}$ inch in diameter, and they float in salt water. The rate of growth is unknown, as the 
young are seldom or never seen by persons who know the fish. The Spanish mackerel is caught chiefly in pound nets.

It is recorded that the species has been obtained off the coast of Maine by Capt. Atwood. Mitchill describes the species without making any remark on its abundance or scarcity, and states that it comes in July. In 1854 the species had rery little importance in the New York market, but at the present time it is one of the most highly prized fishes and is obtained in large numbers. Spanish mackerel have been sparingly caught by trolling off Fire island inlet. We did not obtain the species in Great South bay, but Erastus Gordon of Patchogue informed us that it is obtained in moderate numbers. In 1884 the fish was not plentiful and the arerage price was about $\$ 1$ each. Thes appear in New York waters in July and usually leave in September. The spawning season at Long Island begins late in August and continues about a month. The Spanish mackerel congregate in enormous schools. Mr Earll records the appearance of a school off Long Island which was estimated to contain several million individuals. The fish are taken principally in traps; a few are caught by trolling, but this is an unsatisfactory method of capture.

\section{Scomberomorus regalis (Bloch)}

\section{Cero}

Scomber regalis BLoch, Ichth. pl. 333, 1795, Martinique. Cybium. regale Gürmer, Cat. Fish. Brit. Mus. II, 372, 1860.

Scomberomorus regalis Jordan \& GILBert, Bull. 16, U. S. Nat. Mus. 426, 1S83:; Jordan \& Evermann, Bull. 47, U. S. Nat. Mus. S75, 1896, pl. CXXXT, fig. $369,1300$.

Ver? sinilar in shape and general appearance to $\mathrm{S}$. $\mathrm{macu}$ latus; the greatest depth of body one fifth of total length without caudal, the greatest width two fifths of length of head; the least depth of caudal peduncle one half the length of snout; head longer than in S. maculatus, two ninths of total withont caudal; the snout long and very acute, three eighths as lorig as the head; the interorbital space scarcely convex, its width two serenths of length of head; jaws equal in 
front, maxilla not reaching to hind margin of orbit, the upler jaw equal to snout and eye combined and much more than one half the length of head; the mandible equal to head without snout, reaching to below hind margin of orbit; 15 or 16 large, compressed, conical teeth in each side of upper jaw, and about the same number of similar teeth in lower; eye large, more than one fifth of jength of head, nearly equal to interorbital slace; gill rakers $3+12$, the longest one half as long as the eye. The spinous dorsal originates a little farther back than the pectoral and nearly orer the insertion of the rentral; the base of the fin equals its distance from tip of snout; the second spine. is the longest, one half as long as snout and eye combined; the fin is shaped as in S. ma culat u s, the last spine being rery short. The interspace between the dorsals is about one third the diameter of the ere. The second dorsal base is one half as long as the head and equal to its longest ray; the last ray is one half as long as the eye; the fin is followed by eight or nine finlets; its upper margin, like that of the anal, is deeply conrex. The anal origin is under the middle of the second dorsal; the longest ray a little exceeds longest of dorsal; the last ray one half the length of eye; the fin is followed by eight finlets. The caudal keel is one third as long as the head; the caudal fin is rery deeply forked, the outer rays as long as the head and the lobes narrow at the base. The rentral origin is midway between tip of snout and rent; the fin is two thirds as long as the snout and extends to below the seventh spine of the dorsal. The pectoral is broad at the base, falcate, its length equal to suout and eye combined, the fin extending to below the 10 th spine of the dorsal. D. XVII-i, 15-VIII; A. is, 14-VIII; V. I. 5; P. i, 24. Lateral line curved downward below the second dorsal and the second half of it more or less undulating; pectoral scaly.

Color silvers; a narrow longitudinal stripe of brownish or bronze beginuing behind the pectoral and running to base of caudal; numerous oblong brownisl spots mostly below this stripe, none of them more than one half the diameter of eve; 
upper anterior part of spinous dorsal black, the rest of the fin white.

The spotted cero is found from Cape Cod to Brazil, but is not common northward; it is abundant in the West Indies. The species grows to the length of 5 feet and the weight of 20 pounds; it is a fish of the same good qualities as the Spanish mackere] and is readily caught by trolling.

\section{Scomberomorus cavalla (Cuvier)}

\section{Kingfish ; sierra}

Cybium cavalla Cuvier, Règne Anim., ed. 2, II, 200, 1829, Brazil.

Cybim caballa Cuvier es VAtencienses, Ilist. Nat. Poiss. VIII, 18i, 1831, Caribbean Sea; Storer, Syu. Fish. N. A. 93. 1S46; Gǘther, Cat. Fish. Brit. Mus. II, 373, 1860.

Scomberumorns criballa Jordan \& GILBent, Bull. 16, U. S. Nat. Mus. 427, 1583.

Scomberomorus caculla Dresslar \& FesLer, Bull. C. S. F. C. TII, 444, pl. XI, 1SS9; Jordax \& Evermaxa, Bull. 47, U. S. Nat. Mus. 875, 1896.

Body more slender and elongate than in the other species of the genus, its greatest depth one sixth to one fifth of total length without caudal; rather less compressed than in S. r e ga 1 e ; the least depth of caudal perluncle one half the length of snout; head one fifth of total length without caudal; snout acute, two fifths as long as head; maxilla long, reaching beyond hind margin of orbit; mandible a little longer than snout and eye combined; eye small, one sixth of length of head, the interorbital space convex; teeth triangular, much compressed, about 25 to 30 in each side of each jaw; gill rakers very short, eight below the angle on first arch. The spinous dorsal is inserted directly above the origin of the pectoral and slightly behind the rentral; its base equals one half the distance from tip of snout to origin of second dorsal; the second, and longest, spine is three times as long as the last spine and two sevenths as long as the head. The interspace between the two dorsals equals diameter of eye. The second dorsal originates midway between tip of snout and end of middle caudal rays; the base is as long as the snout and eye combined and is about equal to anal base; the longest ray is six times the length of last ray and equal to snout; the upper margin of the fin is deeply concave; the fin is 
followed by nine small finlets, all nearly equal in size, about two thirds as long as the eye. The caudal fin is crescentic, the width of the lobe at base two fifths of its length, the external rays two and one half times as long as the middle rays, measured from root of fin, and one third of distance from tip of snout to origin of second dorsal. The anal origin is under the middle of the second dorsal; the longest anal ray is four times length of last ray and equal to snout; the upper margin is deeplr concare; the fin is followed by eight finlets, the longest about one half the diameter of eye. The rentral is a little in adrance of pectoral; its length one half the lengtl of mandible, the fin reaching to below the sixth spine of dorsal. The pectoral is falcate, median, its length equal to snout and eye combined, and reaches to below the ninth spine of dorsal. A patch of elongate scales on lead behind and below the exe and at the upper angle of the gill opening; sereral much enlarged scales behind the head, in front of and abore the base of pectoral. The lateral line makes a deep downward curre under the end of the spinous dorsal, and its second half is sinuous. A well developed caudal keel. D. XIY to $X Y$, i, 15-VIII to IX; A. ¿i, 15-VIII; V. I, 5; P. i, 23.

Color grayish silvery, the sides sometimes with dark spots, or yellowish in the young; spinous dorsal blackish abore, or without dark blotch.

The kingfish, or cavalla, is a rery important and raluable food fish of the tropical Atlantic, coming in immense numbers to the Florida Keys, the West Indies, and north to Charleston, occasionally, in summer, to Cape Cod. Southward it extends to Africa and Brazil, frequenting the open seas. It grows to the length of 6 feet and the weight of 100 pounds. In habits it resembles the Spanish mackerel; it is caught by trolling. and at Key West it is so abundant that two men in a small sailboat sometimes catch more than 100 in a day. The flesh is excellent, either fresh or smoked. 


\section{Family TRICHIURIDAE Cutlas Fishes}

Genus Tricmrrers Linnaeus

Body extremely elongate, bandlike, the tail very slender, tapering to a fine point, withont caudal fin; head long, with a rery wide mouth; the jaws armed with unequal and very strong teeth; upper jaw with about four long, strongly compressed barbed teeth; teeth on the palatines, none on the romer; lower jaw iongest; preorbital corering cleft of mouth posteriorly; dor. sal fin single, low, occupying the whole of the back, the spines not distinguishable from the soft rays; anal very long, its base more than half the length of the body, composed of detached spines which are very short, nearly hidden in the skin, the anterior directed backward, the posterior forward; ventral fins wanting; pectorals small; no scales; lateral line decurved, concurrent with the belly; rertebrae $39+120$, ribs excessively frail. Color silrery. Toracious fishes of the high seas, reaching a considerable size. (After Jordan and Evermann)

\section{Trichiurus lepturus Linnaeus}

\section{Scabbard Fish; Hairtail}

Trichiurus lepturus Linnaeus, Syst. Nat. ed. X, I, 246, 175S, America; Cutier \& VAlexciennes, Hist. Nat. Poiss. VIII, 237, 1831; DE KaY, ․ Y. Fauna, Fishes, 109, pl. 12, fig. 35, 18t2, Jamaica, Sandy Hook; G̈̈nther, Cat. Fish. Brit. Mus. II, 346, 1860; JordaN \& Gilbert, Bull. 16. U. S. Nat. Mus, 422, 1883; Jordan \& Everuañ, Bull. 47, U. S. Nat. MIus. SS9, 1S96, pl. CXXXTII, fig. 375, 1900; BEAN, Bull. Am. IIus. Nat. Hist. IX, 360, 1897.

Trictiurus argenteus SHAw, Gen. Zool. IV, 90, pl. 12, 1803, after Lrxadeds;

Mrtchils, Trans. Lit. \& Phil. Soc. N. Y. I, 36t, 1815.

Body greatly compressed, elongate, tapering to a rers fine point, the greatest hight little more than one half of length of head, which is contained from seven and one half to eight and one half times in total; mouth wide, oblique; the lower jaw strongly projecting, the maxilla mostly concealed under the preorbital, reaching to below front of pupil, the mandible one half as long as the head and extending to a point behind the orbit; interorbital space flat, its width equal to diameter of eye; snout long and acute, three tenths as long as the head; a single large 
nasal opening near the front of the orbit; eye round, one sixuh as long as the head; gill raliers sping, few, about seven above the angle of the first arch, those below the arch mostly small or $^{*}$ obsolete, the longest above angle about one third of diameter of ere; opereulum produced into a long, thin flap, acute behind. The dorsal fin begins at a distance from tip of suont equal to two thirds of length of head; its origin is not far behind the eye; the longest ray is about three eighths as long as the head. The pectoral is partly covered by the opercular flay; its length equals length of snout. The vent is at a distance from tip of snout which equals two and three fourths times length of lead. The anal fin, consisting of low, almost concealed, detached spines, begins close behind the rent; its base is fire and one half times as long as the head. The lateral line drops rapidly dowuward from the upper angle of the gill opening to a point below the median line. Fom long and strong fanglike teeth in the front of the upper jaw and one or two fangs on the front of the mandible, from seren to 10 sharp tectl in each side of each jaw; small teeth on the palatines, none on the vomer. D. 135; A. 109. The individual described was taken at Point Pleasant Y.J. It is number 19224 , U. S. National Museum. Color silvery.

The scabbard fish frequents warm seas and ranges north to Cape Cod and Lower California; it is very abundant in the West Indies. The fish is a roracious inhabitant of the high seas, and reaches the length of 5 feet. It is highly esteemed for food in Jamaica and at Pensacola; in Jamaica it forms the object of a very important hook and line fishery.

The scabbard fish is rarely seen in Gravesend bay. A young individual was obtained from John B. De Nyse's pound in August 1897. It had been captured by another fish while in the pound; but was rescued in good condition.

\section{Family ISTIOPHORIDAE}

\section{Sailfishes}

Genus rs'rormones Lacépède

Body slender, much compressed, covered with elongate scales; numerous small teeth on the jaws and palatines; ventral fins 
present, of two or three rays; dorsal fin extremely high, continuous, as in the young of Tetrapturus and $\mathrm{Xiphias,} \mathrm{the}$ rays rery numerous, none being aborted, the hight of the first much greater than that of body; anal fin divided; air bladder sacculate; intestine short, nearly straight; sword usually shorter and less flattened than in $\mathrm{X}$ i p hi a s, the edge more rounded, the lower jaw more dereloped. The skin is also rougher. Large fishes of the warm seas; the number of species uncertain, probably several. (After Jordan and Evermann)

202 Istiophorus nigricans (La cépède)

$$
\text { Sailfish; Spikefish }
$$

Makaira migricans Lacépène, Hist. Nat. Poiss. IV, 688, 1803, Rochelle.

Histiophorus americamus Cuvier \& VAlenclennes, Hist. Nat. Poiss. VIII, 303, 1831, Brazil.

Istiophorus nigricans Jordax \& Everuaxx, Bull. 47, U. S. Nat. Mus, 891, 1896, pl. CXXXVII, fig. 376, 1900; Suтth, Bull. U. S. F. C. XVII, 97. 1S98; Goode, Proc. U. S. Nat. Mus. IV, 415, 1852.

Body compressed, highest in front, elongate, the greatest hight one seventh of the total length from tip of upper jaw to end of middle caudal rays; least hight of caudal peduncle one half of postorbital length of head; the upper jaw projecting beyond thelower a distance more than equal to greatest hight of body; the profile of the head descending very steeply from the origin of the dorsal to the eye; the lower jaw extending in front of the eye a distance equal to postorbital part of head. The dorsal fin begins on the nape and extends nearly the entire length of the back, but the first is separated from the second by a very deep and long notch and a short interspace; the longest spine equals one half the distance from the eye to the second dorsal and is one fourth of total length including caudal; the spinous dorsal forms almost a semicircle when fully expanded, with a deep anterior and a deeper median notch. The second dorsal base is one sixtl as long as the head to tip of upper jaw; its longest ray is one half the length of postorbital part of head. The caudal is very deeply forked, its width at base one fourth of length of external rays, which are nearly one fourth of total without caudal. There are two small keels on the base of the caudal. The divided anal fin 
begins under the :3ad spine of the dorsal, the base of the two fins equaling one fourth the distance from tip of upper jaw to origin of second dorsal; the longest ray equals postorbital part of head; the sceond anal is similar to the second dorsal, but somewhat smaller. The reutral originates under the fifth spine of dorsal; its length is a little more than one fourth of total lengtl to end of middle caudal rays. The pectoral is one half as long as the beak and eye combined and nearly equals the greatest hight of body. Exe small, one third of postorbital part of head. D. XLIV-7; A. !) to $10-7$; T. 2.

Color bluish black, paler below; dorsal dusky bluish, with numerous roundish black spots, from one third to one fourth the diameter of orbit, on its membrane.

The sailfish lives in the warmer parts of the Atlantic, ranging northrard to France and, occasionally, to Cape Cod. Here described from a drawing of specimen taken at Woods Hole Mass.; color notes from Dr Jordan. The species reaches the length of 10 feet. It is raluable for food but rarely comes to our markets.

\section{Genus tatrapturus Rafinesque}

Body much compressed, covered with rudimentary embedded scales; sword rounded on the edge; caudal keel double; small teeth in the jaws and on the palatines; rentral fins represented each by a single spine; dorsal fins separate in the adult, part of the midale rays being aborted, not greatly elerated, their hight not greater than the depth of the body; air bladder sacculated; rertebrae $12+12$; intestine short, nearly straight; $p y^{\circ}$ loric caeca rery numerous. Large fishes of the deep seas. They swim in deep, water, according to Poey, and pass Cuba in pairs in summer, hound for the Gulf of Mexico. Males smaller than females. (After Jordan and Erermann)

\section{2(1:) Tetrapturus imperator (Bloch \& Sclıneider)}

\section{Billfish: : spenfish}

Jiphins imperalor Blocti \& ScineIDER, Syst. Ichth. 98, pl. XXI, 1801, Meditermean.

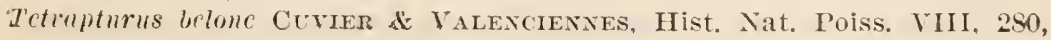
1 ถะ3. 
Tetrapturus albidus Poer, Memorias, II, 237, 1861, Marana; Jordar \& Giliert, Bull. 16, U. S. Nat. Mus. 420, 1883.

Histiophorus belone Günther, Cat. Fish. Brit. Mus. II, 513, 1860.

Tetrapturus imperator Goode. Proc. U. S. Nat. Mus. IV, 417, 1SS2; JordaN \& Evermann, Bull. 47, U. S. Nat. Mus. 892, 1896; Smith, Bull. U. S. F. C. XVII, 9T, 1S9S.

Body similar in shape to that of the sailfish, its greatest depth contained six and one fourth times in total length without caudal; the least hight of caudal peduncle one fourth of the greatest depth. The head forms one third of total length without caudal; the upper jaw is exactly twice as long as the postorbital part of the head and extends beyond tip of mandible a space equal to length of eye and postorbital part of head combined; the maxilla extends far behind the eye; the eye is about one fifth as long as postorbital part of head. The dorsal begins on the nape, over the upper angle of the gill opening. The first dorsal occupies nearly one half of the total length without candal; its anterior sixth is elerated and the rest of the fin is low; the longest spine (the fourth) is about one third as long as the head, the 10th is only one serenth as long as the head, and the last is scarcely one half as long as the ere. The interspace between the dorsals is three elevenths of length of head. The second dorsal base is one seventl as long as the luead; its first ray is one and one half times as long as the eye, and its last ray is about equally long, but some of the intervening rays are shorter. The caudal fin is narrow, crescentic, its width at base of lobes one fourth of its length, the external rays equal to one fourtl the distance from eye to caudal base. The first anal fin originates under the 29 th ray of the dorsal; the base is one fourth as long as the head; the longest ray two sevenths as long as the head, the last ray minute. The interspace between the anals is one third as long as the head. The base of the second anal equals one third of postorbital length of head, the first and last rays equal, and as long as the base of the fin, the intervening rays shorter; two strong keels on the base of the caudal, each of them about twice as long as the eye. The rentral is very slender and long; it originates under the ninth ray of the dorsal, its length equal to postorbital part of 
head. The pectoral insertion is under the sixth ray of the dorsal; the fin is nearly one half as long as the head; its position is in the lower fourth of the hight. The sword is rounded on the edges and much narower than in the swordfish. D. III, 3is to $39-6 ;$ А. II, $13-6$ : V. I, 4; P. 19 ; vertebrae $12+12$.

Color deep blue abore, a little lighter on the flanks, passing into white below; fins intense blue, second anal and outside of pectoral clearer. first dorsal with rounded spots, more intense, of same color; iris clear blue, cornea blackish.

Body coreped with lanceolate, embedded scales. The color notes here giren are from Dr Goode's excellent description in Procedings of the U. S. National IIuseum, IV, 420, 1882.

The sperartish is found in the West Indies and on our Atlantic roast, ranging northward to Cape Cod. Individuals more than 7 feet long have been taken, and the species is said to reach the length of 26 feet. At Troods Hole it is generally rare; but between 1885 and 1890 numbers were captured in the traps in Tineyard somd and Buzzards bay during July and August, according to Dr Hugh M. Smith. Most were caught in the trap farthest up Buzzards bay, at Quissett harbor.

The spearfish in our waters is said to resemble the swordfish in its movements and manner of feeding. Nothing is known of its breeding habits or its young. It is taken by means of hooks in deel water or by spearing at the surface. The hook fishing is not altogether a safe pastime, as the fishermen are often liable to be wounded or drowned by the fierceness and strength of the fish. Numerous instances are reeorded of ressels having been pierced by the heak of the spearfish, and parts of such ressels containing the spear are exhibited in several museums.

The flesh of the spearfish is highly esteemed in some localities.

\section{Family XIIHIDAE \\ suordfishes \\ Genus minas Linnaeus}

Swordfishes withont teeth, and without rentral fins. Body somewhat compressed; dorsal fins two, the anterior beginniug opposite the gill openings, falcate and elerated, its hight rather 
less than that of the body, second dorsal very small, on the tail, opposite the small second anal. In the roung, teeth are present, and the two dorsal fins are connected, the fin being elevated as in the species of $\mathrm{I}$ s $\mathrm{t}$ i o $\mathrm{ph}$ or $\mathrm{us}$. First anal similar to first dorsal, but smaller, less falcate, and far behind it; pectoral fins moderate, falcate; skin naked, more or less rough, specially in the roung, which have rudimentary scales; sword flattened and trenchant; candal keel single; intestines long, sinuous; air bladder simple; pelvic arch obsolete. Fishes of great size, reaching a weight of 300 to 400 pomnds, the flesh red and rich in flavor, highly valued as food. (After Jordan and Evermann)

\section{Xiphias gladius Linnaeus}

\section{Suordfish}

Xiphias gladius Linnaeus, Syst. Nat.ed.X, I, 248, 175S, Europe; BLoch, Ichth. pl. 76, 1784; Mitchill, Am. Month. Mag. II, 242, Feb. 1815; Cuvien \& Talenciennes, Hist. Nat. Poiss. VIII, 255, pl. 225, 226, 1831; DE KAY, N. Y. Fauna, Fishes, 111, pl. 26, fig. 79, 1842; Güsther, Cat. Fish. Brit. Mus. II, 511, 1S60; Storer, Hist. Fish. Mass. 71, pl. XIII, fig. 2, 1867; Goode \& Bean, Bull. Essex Inst. XI, 14, 1579; Jordan \& Gilbert, Bull. 16, U. S. Nat. Mus. 420, 1883; JordaN \& Evermañ, Bull. 47, U. S. Nat. Mus. S94, 1896; Sмiтh, Bull. U. S. F. C. XVII, 97, 1898.

Body fusiform, tapering greatly toward the caudal fin, the head not long, but with a rery long upper jaw produced into a beak or "sword," the greatest depth of the body one sixth of total length to base of caudal, the least hight of caudal peduncle nearly equal to length of eye. The npper jaw is three times as long as the rest of the head; the "sword" is broad and rather thin. The lower jaw extends in front of the eye a space equal to one half of postorbital part of head. The augle of the mouth is well behind the eye. The eye is circular, its diameter one third of postorbital part of head and about $\frac{1}{16}$ of total length of head. The dorsal begins orer the uppera angle of the gill opening; it is very high, nearly as high as the body, strongly falcate, its upper margin deeply concave, and the posterior rays very short. The distance between the dorsals is less than one third of length of head. The second dorsal is very small, its base only one half as long as the eye, and its hight one and four 
fifths times its length of base; it is located a very little in front of the caudal keel. The candal is crescentic, its external rays two fifths as long as the head. The caudal keel is single, median, its length nearly one sixth of length of head. The second anal is directly under the second dorsal and is of about the same size; the filst anal is equidistant from the root of the caudal and the end of pectoral base; its base is as long as the caudal keel; its longest ray equals postorbital part of hear, its last ray minute; the margin of the fin deeply concare. The pectoral origin is below the hind margin of the operculum; the base is narrow, about one fifth of length of fin, which is equal to depth of body. D. 39 to $40-2$ to 4 ; A. 1 s to $21-3 ;$ P. 20.

Color "abore rich purplish blue, shading into whitish beneath, the sides and belly with a silvery luster. Fins dark bluish with silvery sheen except dorsal. Top of head rich purplish blue, the color extending upon the rostrum. Lower side of rostrum rich brownish purple. Exe deep blue."

The swordfish inhabits the Atlantic and comes near both coasts; it is most abundant between Cuba and Cape Breton, rather common in the Mediterranean, and is occasionally taken off southern California. The fish appear in the vicinity of Sandy Hook about June first, and the fishing season continues as far east as Marthas Vineyard and Nantucket shoals till about the middle of September. They disappear to the southward as soon as the cold winds begin to blow. They feed on mackerel, menhaden, and squid. They are often caught on trawl lines, but the chief means of capture is the harpoon.

The average length of swordfish is 10 feet, but individuals measuring 16 feet are on record. An individual weighing 750 pounds was killed in 1874 off Portland.

The flesh of this fish is very palatable, and the fishery is an important one as well as an exciting occupation.

Young swordfish have the skin covered with small, rough excrescences, the jaws much more nearly equal, and the dorsal and anal fins not divided into two separate parts. 


\section{Family CARANGIDAE Crevalles \\ Cremus olgorlates Gill}

Body eomplessed, oblong or lanceolate; raudal peduncle slender, not leceled; head short, compressed, acute, occipital liecl sharp; mouth ratler large, with small, sharp tecth in bands on jaws, tongue, romer and palatines, mone on the pterygoids; jaws about equal, the upper not protractile, except in the very young, in which it is movable as in other Carangidae; maxillary very narrow, without distinct supplemental bone; gill rakers rather long; scales small, linear, and extremely narrow, embedked in the skin at different angles; lateral line nnarmed; dorsal spines ratler strong. three to fire in number, nearly free in the adult; second dorsal very long, its posterior rays penicillated and nearly or quite disconnected, forming finlets; anal rather longer than soft dorsal, muclı longer than the abdomen, its last rays forming similar finlets, anal spines strong; ventral fins depressible in a groove; pectoral fins rery short. Species few, in the tropical seas of America. L Ifter Jordan and Evermann)

\subsection{Oligoplites saurus (Bloch of Sclnncider)}

\section{Leather. Jacket}

Scomber samms Blocil \& ScInxeider. Syst. Ichth. 321, 1S01, Jamaica. Chorinemus occidentalis Güntier, Cat. Fish. Brit. Mrus. II, 475, 1860; not Gasterostens occidentatis LinaAers, Syst. Nat. ed. XII, I, 490. Oligoplites orcidentatis Gill, Ploc. Ac. Nat. Sci. Plila. 166, 1863. Scombroides occideutalis Jomnax \& Gilbert, Bull. 16, U. S. Nat. Mus. 447, 1893.

Oligoplites saums JoRDAN \& GILDERT, op. cit. 973. 1883; JORDAN \& EVERMANN, Bull. 47, U. S. Nat. Mus. 898, 1896, pl. CXXXVIII, fig. 378, 1900; BeAn, Bull. Am. Mus. Nat. Hist. IX, 360, 1897; Smith, Bull. C.S. I. C. XVII, 97, 1895.

Body elongate, much compressed, fusiform, its greatest hight contained three and two thirds times in total length without caudal ( 1 times in total to end of middle caudal rays), its width two serenths of its light and two fifths of length of head; least depth of caudal peduncle equals length of eye; head short, one fifth of total without caudal, its width three serenths of its length; snout moderately pointed, its length about equal to orbit 
and three sevenths of length of head; nostrils a little nearel to eye than to tip of snout, the anterior tubular ane much smaller than the posterior; interorbital space conver hut with a narrow, shar 1 , low keel, the width of the space equal to length of snout; the slender maxilla reaches to below the hind margin of the eye, the length of the upper jaw being a little more than the snout and ere combined; the mandible is two thilds as long as the head; a double series of small, sluap, curved, conical teeth in each jaw; romer and lalatines with bands of villiform teeth, an oblong patch of villiform teeth on the tongue; gill rakers about 15, mostly below the angle, the longest two thirds as long as the eyc. The origin of the spinous dorsal is nearly over the tip of the pectoral and at a distauce from tip of snout equal to one thild of total length without caudal; the lingth of the base equals length of head without the snout; the first spine, depressible forward as well as backward, is nearly as long as the pupil, the third and fifth equal and nearly as loner as the snout; the membrane behind the second to fifth spines one half the hight of spines; the interspace between the dorsals is very short. The second dorsal base eouals one half the distance flom ere to root of caudal: the fin is composed chiefly of detached $\mathrm{Ol}^{\circ}$ semiletached finlets; the longest lay is rqual to length of snont and 'ye combined; the last finlet equal to length of eye. A woll developed plocumbent spine before the dorsal. The midlle caudal rays ale one third as long as the cxternal raps, which are as long as the head. The anal fin is precerled hy two strong, sharp, subequal spines, the second as long as the eye, both followed by membrane; the base of the anal equals that of the soft dorsal; the longest ray tro fifths as long as the head, the fin romposed chiefly of partly dotached rays, the last ruy about as lone as the snout. The rentral origin is directly under the lower axil of the pectolal; the fin reaches to the vent and to a point below the third spine of dorsal. The pectoral is on thr lovel of the lower magin of the rye; it is three fifths as lome as the head and reaches to below the second spine of the dorsal. Head 
naked; body covered with small, linear, embedded scales, which are irregularly arranged; fins scaleless. D. V, I, 20; A, II. I, 20 ; I. I, 5; P. I, 16 . Top of head and back bluish; sides and lower parts silvery; fins, interopercle and iris yellow.

The leather jacket inhabits both coasts of tropical America, extending northward to Cape Cod and Lower California; it is very common in the West Indies and the Gulf of Mexico. Rare at Wroods Hole, Mass., where only three examples were secured from 1874 to 1886 in traps and pound nets. At Newport R. I. the species is occasionally seen. The fish is rare in Gravesend bay; an example $9 \frac{3}{4}$ inches long and $2 \frac{1}{2}$ inches deep was secured in John B. De Nyse's pound in the summer of 1896. The fish has no value as food.

\section{Genus saccrates Rafinesque}

This genus differs from Se riola only in the reduction of the spinous dorsal to a few (four ol five) low, unconnected spines. The young. called $\mathrm{Nauclerus}$ and $\mathrm{Xys}$ topho r us, have the spines of the dorsals connected by membrane, and a more or less distinct strong spine at the angle of the operculum. A single pelagic species widely distributed in the open seas.

\section{Naucrates ductor (Linnaeus)}

\section{Pilotfish}

Gasterosteus ductor Livxafus, Syst. Nat. ed. X, I, 295, 1758, pelagic. Scomber ductor Mitcinll. Trans. Lit. \& Phil. Soc. N. Y. I, 424, 1815.

Naucrates noreloraccusis Cuvier \& Valenciennes, Hist. Nat. Poiss. Vili, 325, 1831; DE KAY, N. Y. Fauna, Fishes, 112, 1842, and figure of Naucratcs ductor, pl. 7 t, fig. 235.

Naucrates ducter Cuvier of Talexciennes, Hist. Nat. Poiss. Vili, 312, pl. 232, 1831; Güntiler, Cat. Fish. Brit. Mus. II, 374, 1860; Jordan \& Gilbert, Bull. 16, U. S. Nat. Mus. 443, 1883; Jordan \& Evermann, Bull. $t \bar{t}$, U. S. Nat. Jius. 900. 1896, pl. CXXXIX, fig. 379, 1900; Suith, Bull. U. S. F. C. X TII, 97, 1898.

Nancrates indieus Cuvier, Règne Anim. 11l. Poiss. pl. 54, fig. 1, 1830.

Body fusiform, elongate, moderately thick, its greatest hight one fourth of total length without the caudal, and about equal to length of head, its width equal to three fifths of length of head; least depth of caudal peduncle about equal to long diameter of eye; head subconical, the snout obtuse, length of 
head one fourth of total without caudal; snout two serenths as long as the head; interorbital space convex, its wisth one half the length of head without the snout; maxilla expanded behind, reaching to below front of ere; mandible three serenths as long as the head, reaching to below hind margin of eye; top of head and cheeks scaly, most of opercle and preopercle and all of interopercle naked; teeth in bands in the jaws but comparatively few and weak; romerines and palatines also small and the lingual patch narow; gill rakers stont, short, abont 17 below the angle, the longest one half the length of eye; yye one sixth as long as the head. The spinous dorsal consists of four short, isolated spines, the first located nearly above the end of the base of rentral, the second and third spines the longest and about one fourth as long as the snout. The second dorsal begins midway between tif of snont and base of caudal; the base of the fin is nearly three times as long as the pectoral; the second ray is longest and one half as long as the head, the last ray as long as the eye; the npper margin of the fin is slightly concare. There is a long, fleshy keel on the caudal peduncle, longer than the postorbital part of the lead. The candal is deeply forked, its outer rays more than twice as long as the middle rays, both measured from base of caudal fin; the onter rays are as long as the head. The anal is preceded by two very small spines; the base of the fin is as long as the head; the longest ray is as long as the suout and eye combined, the last ray as long as the snout. The vent is under the 10th ray of the dorsal. The rentral fin is under the lower axil of the pectoral; its length is three fifths of length of head; when extended, it reaches to below the origin of the second dorsal. The pectoral fin is below the level of the eye; its length is about rqual to length of rentral; it reaches to below the third spine of the dorsal. D. IV-I, 26 to 27 ; A. II, I, 16 to 17 ; V. I, 5; P. I, 20. Scales minute, about 55 rows between gill opening and origin of second dorsal. Color bluish with five to scren broad, dark bands, some of these extending on the fins; onter margin of caudal, ventral and pectoral nearly black. 
The pilotfish is pelagic in all tropical and temperate seas; it is occasionally taken on our coast as far north as Provincetown Mass., but is not at all common. It was reported at Wroods Hole Mass. by Prof. Baird in 1871. The young are developed in the open ocean and are so different in appearance from the adult that they have been described as a distinct genus. The fish has no economic ralue.

\section{Genus sermora Cuvier}

Body obloug, moderately compressed, not elevated; occiput and breast not trenchant; lead usually more or less conical, not rery blunt; mouth comparatively large, with broad bands of villiform teeth on both jaws, tongue, romer and palatines; a broad, strong, supplewental maxillary bone; premaxillaries protractile; scales small; lateral line slightly arched, forming a keel on the eaudal peduncle, not armed with bony plates; sides of head with small scales; first dorsal witl about seven low spines, comnected by membrane; second dorsal very long, elevated in front; anal similar to the soft dorsal but not nearly so long, shorter than the abdomen, preceded by two very small free spines, which disappear in old fisles; no finlets; rentral fins very long; pectorals slort and broad; gill rakers moderate. Species of moderate or large size.

\section{Seriola zonata (Mitchill) \\ Banded Rudder Fish}

Scomber zonatus Mitchitu, Trans. Lit. \& Phil. Soc. N. Y. I, 427, 1S15, New Yolk Bay.

Seriola somatu Cuties of Palexciennes, Hist. Nat. Poiss. IX, 213, 1833: I'E KAY, X. Y. Fanna, Fishes, 128, pl. 9, fig. 26, 18t2, Long Island Sound; fï̀mtier, Cat. Fish. Brit. Mus. II, $46 \overline{5}, 1860$; Storer, Hist. Fish. Mass. 79. pl. XT, fig. 5, 1S67; JordaN \& Gilbert, Bull. 16, U. S. Nat. Ius. 415, 18s3; Goode \& BeAN, Bull. Essex Inst. XI, 16. 1879; Bean, Bull. U. S. F. C. TII. 139, 1SSS; Jordan \& Evermann, Bull. 47, L. S. Nat. Mus. 902, 1S!6; BeAx, Bull. Am. Mus. Nat. Hist. 1X, 360 , 189т; sutit, Bull. U. S. F. C. XVII. 97, 1898.

Halatretus zomatus GiLL, Proe. Ac. Nat. Sei. Phila. 442, 1862.

Body fusiform, rompressed, moderately deep, its greatest depth one thind of total length withont candal, its width less than one half the depth and equal to postorbital length of head; least deptli of candal peduncle equals one half length of snout; 
head rather long and subconical, compressed, its length nearly equal to dejith of body, nearly one third of total length withont caudal; snout long and pointed, threr eighths as long as the head, twice as lonm as the eye; interorbital space convex, indistinetly keeled, its widtl equal to length of snont; maxilla broadly expanded behind, reaching to below middle of pupil; mandible extending to below hind margin of exe; nostrils small, midway between tip of snout and eye; gill rakers $3+18$. the longest two thirds as long as aye. The spinous dorsal orjginates a little behind the pectoral insertion and directly orer the origin of the ventral; the base of the fin is as long as the postorbital part of the head; the first spine is much shorter than the second, the third or fourth is longest, about as long as the eye, the last is minute. The second dorsal is preceded by a rely short, stout spine; the base of the fin equals its distance. from the nostril; the longest ray is equal to postorbital part of head, the last ray one fourth as long as the head and reaclies to the base of the candal fin. A low, unarmed keel is developed on the caudal peduncle. The caudal fin is deeply forked, the outer rays being nearly as long as the head. The aual fin is preceded by a single very small spine; the longest ray is one third as long as the head, the last ray one fouth as long as the head; the margin of the second dorsal and anal fins is very slightly concave. The ventral is very long, reaching nearly to the vent, and to below the 13th ray of the dorsal, its length nearly equal to length of head. The pectoral reaches to below origin of second dorsal, its length equal to snout and eye combined. Lateral line strongly arched orer the pectoral. D. VII, I, 37 to 38 ; A. I to 1 I, i, 20 to 21 ; V. I, 5; P. i, 19.

Color bluish above, lower parts white; five or six broad dark bands.on the sides, extending on the dorsal and anal fins; a narrow dark band obliquely from the spinous dorsal to the eyc; spinous dorsal black; rentral black above, pale beneath; tips of candal fin white. The bands become fainter or disappear in old fish.

The banded pilot is found on our east coast from Cape Ann to Cape Hatteras; it reaches the length of 2 or 3 feet. The 
Young are rery common as far north as Cape Cod. The species is seldom used for food. The name, shark's pilot, is in use at Somers Point N. .J.

Two individuals of the banded pilot were taken in Graresend bay in september 1897. The species will live in captivity only when it has ample room. It feeds on small killifish, which it takes with a rush much like that of the brook trout.

208 Seriola lalandi Cuv. \& Val. (?)

Amber Fish

Seriola lalandi Cuvier of Valenciennes, Hist. Nat. Poiss. IX, 208, 1S33, Brazil; Günther, Cat. Fish. Brit. Mus. II, 463, 1860; Goode \& Beax, Bull. U. S. F. C. I, 43, 18s1; Jordan \& Gilbert, Proc. U. S. Nat. Ius. 271. 1SS2; Jordan, Proc. U. S. Nat. Mus. 122, 129, 1884; Jordan \& Evermann, Bull. 47, U. S. Nat. Mus. 903, 1896, pl. CXL, fig. 3S2, 1900; Beax, Bull. Am. Mus. Nat. Hist. IX, 160, 1897; Sмrтн, Bull. U. S. F. C. XVII, 97, 1898.

Seriola gigas Poex, Memorias, II, 227, 1860, Cuba.

Zonichthys gigas Poey, Syn. Pisc. Cubens, 371, 1868.

Body oblong, moderately elongate, robust, its greatest hight contained four and one fourth times in the total length without caudal, its width seven times; the least depth of the caudal peduncle equals one seventh of the length of head; head long. conical, its length two sevenths of total length without caudal; snout long and somewhat pointed, its length two and one fifth times diameter of eye and one third of length of head; the jaws are equal in front; the maxilla reaches to below middle of pupil, and the length of the upper jaw is contained two and two sevenths times in length of head; the mandible is slightly more than one half as long as the head; the expanded end of maxilla exceeds the diameter of the eye, which is contained six and two fifths times in length of head; gill rakers $4+10$, the longest nearly as long as the ere, very thin, much wider at base, and tapering gradually to a small, rounded point, very finely toothed on inner margin; teeth in broad, villiform bands in both jaws, an arrow-shaped patch with long, slender backward process on romer, similar bands on palate and pharynx. The distance from snont to reitical from origin of spinous dorsal is nearly three times the length of base of the fin; the third and longest spine 
is seren and one half times as long as the last spine and nearly one fourth as long as the head; the base of spinous dorsal is rontained two and two sevenths times in length of head. The interspace between the two dorsals is less than the length of the eje. The second dorsal hase is one and one half times as long as the head; the second ray is the longest and equals three times the length of the eye, the last ray about one third as long as the second. The anal origin is under the middle of the second dorsal and at a distance from the vent equal to on s $^{2}$ fourth the length of head; the anal base is as long as the head; the longest ray is nearly one half as long as the head, the last ray about equal to the last of the dorsal; the anal and second dorsal fins are elevated in front but very low for the most of their length. The rentral origin is directly under the insertion of the pectoral; the fin when extended reaches to below the last spine of dorsal, its length more than one half the length of head. The pectoral is broad at its base, somewhat falcate, its length nearly one half the length of liead, the fin extending to below the serenth spine of the dorsal. D. VII, 36; A. I, 24; V. I, $\check{5} ;$ P. 21. Scales abont 24-160-30.

The ground color is gray with purplish iridescence. A golden bronze stripe beginning on the snout and continued behind the reve to the caudal in a nearly straight line, slightly abore the median line. Another bronze stripe begins above the eye and extends to the first dorsal. In life two dark bands showed between the eyes and extended to the first dorsal. Sides and lower parts much mingled with silvery white; iris gray orerlaid with golden rellow; pupil bluish black; all the fins colored like the body except the rentrals, which are whitish underneath, and gray mingled with white above.

The weight of the fish was 13 pounds $1 \frac{1}{2}$ ounces.

The specimen described was obtained by Mr De Nyse in Graresrend hay, July 15, 1896. For the purpose of comparison and rerification of this identification, a series of measurements is lere given in tabular form. 


\section{MEASUREMENTS}

Length, including caudil. . .

Inches
$331 / 2$
$301 / 2$
7
2
$63 / 4$
$11 / 8$
4
8
$31 / 2$
$11 / 2$
$41 / 5$
$23 / 4$
$11 / 4$
$5 \% 5$
$101 / 4$
$31 / 2$
$5 / s$
$11 / 4$
$17 / 8$
$1 / 4$
$141 / 4$
$113 / 4$
$33 / 4$
$17 / 5$
$13 / 5$
$37 / 8$
$45 / 8$
$101 / 5$
2

The amber jack here mentioned is supposed to be identical with the $\mathrm{S}$. I a l a n di of Cuvier \& Valenciennes, a species. ranging regularly from Brazil to West Florida and occasionally northward in summer to Cape Cod. It grows to the length of 5 or 6 feet and the weight of 100 pounds, and it is a good food fish as well as a robust and vigorous prize for the angler.

\section{Genus elagatrs Bennett}

Body long and slender; second dorsal and anal long, each with one detached finlet composed of two rays behind the rest of the fin. Otherwise essentially as in Seriola. The short spines preceding the anal fin are somewhat remote from the rest of the fin. Branchiostegals 7 ; lateral line not armed; villiform teeth in bands in the jaw, on the vomer and the palatines. 


\section{Elagatis bipinnulatus (Quoy \& Gaimard)}

\section{Runner}

Seriola bipinnulata QUoY \& GAIMARD, Voyage Ulanie, Zoöl. I, 363, pl. 61, fig. 3, 1824, Keeling islands.

Scriolichthys bipinuulatus GüNther, Cat. Fish. Brit. Mus. II, 468, 1860. Seriola pimmulata, PoEY, Memorias, II, 233. 1860.

Elagatis pinnulatus JordaN \& GILuEnt, Bull. 16. U. S. Nat. Mus. $446,18 \$ 3$. Elagatis bipinnulatus Jordan \& Evermaxx. Bull. 47, U. S. Nat. Mus. 906, 1896; Bean, Bull. Am. Mus. Nat. II ist. IX, 361, 1897.

Body moderately elongate, slender, fusiform, its greatest depth one fourth of total length without caudal, its width three eighths of length of head; least depth of caudal peduncle equals diameter of eye; head conical, compressed, its width orer opercles equal to length of postorbital part; a low occipital keel; snout moderately long, obtusely pointed, its length nearly equal to width of interorbital space, and contained three and one fourth times in length of head; lower jaw slightly projerting; maxilla almost reaching to below front of eye, the upper jaw one third as long as the head; mandible reaching nearly to below front margin of pupil, its length equal to postorbital part of head; interorbital space with a low keel between two shallow furrows, its width one third of length of head; eye one fourth the length of head (in young examples $5 \frac{1}{2}$ inches long), about one fifth in older fish; gill rakers $9+27$, the longest one half as long as the snout. The spinous dorsal base is short, equal to postorbital part of head; the spines are very slender, closely placed, the longest not so long as the eye; the spines are depressible into a sheath; the origin of the fin is over the middle of the length of the pectoral. The soft dorsal originates about orer the end of the ventral, midway between tip of snout and base of caudal; the longest ray is as long as the postorbital part of the head; the fin is shaped as in Se ri o l a, the second half being very low, the last ray about two thirds as long as the ere; the fin is followed by two finlets, the longest as long as the eye. The caudal is deeply forked, the middle rays, from base of fin, one third as long as the outer rays, which are as long as the head; no keel on the caudal peduncle. The anal origin is under the 15th ray of the dorsal; the base of the fin is as long as the head; 
the longest ray is three eighths as long as the head; the last ray two thirds as long as the eye; the fin is followed by two finlets, the longer as long as the eye. The ventral reaches a little be. yond the origin of the soft dorsal; the length of the fin is equal to snout and eye combined. The pectoral is as long as the ventral; it reaches to below the last spine of the dorsal; the fin originates slightly in advance of the ventral insertion. Body corered with small, cycloid scales; head naked except on suborbital and postorbital regions; scales extending somewhat on bases of soft dorsal and anal fins. D. VI-I, 26 to 27, 2; A. II, I, 16 to 17,2 ; V. I, 5; P. I, 20 . Scales 16-110-20.

Color of upper parts bluish; lower parts pale yellowish; caudal fin yellowish, the margin dusky; ventrals and pectorals yellowish tinged with blue; a blue band as wide as the eye from orbit to upper margin of caudal peduncle; another from snont along lower margin of orbit and continuing to the caudal, passing above the pectoral.

The runner is recorded from the East Indian archipelago, Polynesia, and tropical parts of the Atlantic, straying northward in summer, rarely to Long Island, where specimens have been taken by Dr Seth E. Meek and John B. De Nyse. The fish attains to the length of 30 inches. The example captured by $\mathrm{Mr}^{*}$ De Nyse was taken in his pound at Gravesend bay Aug. 2, 1895; it is now preserved in the U. S. National Museum. The length of the specimen is about 15 inches. Young fish, about 4 to 6 inches long, are before me from Florida and Cuba.

\section{Genus Decapterus Bleeker}

Body elongate, little compressed, almost perfectly fusiform; head short, pointed; mouth rather small; jaws about equal, the dentition feeble; maxillary rather broad, with a supplementary bone; premaxillaries protractile; scales moderate, enlarged for the whole length of the lateral line, but spinous and bony posteriorly only; second dorsal and anal each with a single detached finlet; free anal spines very strong; first dorsal well developed, persistent; pectorals comparatively short; abdomen rather shorter than anal fin; gill rakers long and slender. Species numerous. 


\section{Decapterus punctatus (A gassiz)}

\section{Scad; Round Robin}

Scomber hippos Mitchill Trans. Lit. \& Phil. Soc. N. Y. I, pl. V, fig. 5, 1815; Am. Month. Mag. II, 246, Feb. 1818, not of Linnaeus.

Caranx punctatus Agassiz, Spix. Pisc. Bras. 108, pl. 56a, fig. 2, 1829, Brazil; Cuvier \& Valenciennes, Hist. Nat. Poiss. IX, 38, 1833; De KaY, N. Y. Fauna, Fishes, 122, pl. 73, fig. 293, 1842; Güntmer, Cat. Fish. Brit. Mus. II, 426, 1860.

Decapterus punctatus Poey, Syn. Pisc. Cub. 368, 1868; Jordan \& Gilbert, Bull. 16, U. S. Nat. Mus. 432, 1883; BeAs, 19th Rep. Comm. Fish. N. Y. 256, 1590; Bull. Am. Mus. Nat. Hist. 362, 1597; Jordan \& Evermany, Bull. 47, U. S. Nat. Mus. 907 , 1896; Surth, Bull. U. S. F. C. XVII, 97, 1898.

Body scombriform, moderately elongate, its greatest depth one fifth to two ninths of total length without candal, its width one half the length of head; least depth of caudal peduncle one sixth the length of head; head subconical, moderately compressed, its width one half its length, the snout obtusely pointed, as long as the eye, two serenths as long as the head, the jaws subequal in front; maxilla expanded posteriorly, reaching to below front of eye; premaxilla projectile; mandible one half as long as the head, reaching to below front of eye; eye round, equal to snout, two serenths of length of head; interorbital space convex, covered with small scales, its width equal to eye; a low, but distinct nuchal keel; opercular bones partly naked; gill rakers rel'y numerous, long and slender; a small prominence on the shoulder girdle in front of base of pectoral; teeth in jaws uniserial, teeth on romer and palatines, present or absent on tongue. The spinous dorsal originates orer the 13th or 14 th scale of the lateral line and slightly in advance of the middle of the pectoral; the base of the fin is as long as the head without the snout; the first spine is rery slender, and as long as the eye; the longest spine as long as the snout and ere combined. The soft dorsal base is one third of total length including the caudal: the longest ray is one half as long as the head, the last ray two thirds as long as the eye; the fin is followed by a single finlet consisting of two rays, the length equal to length of eve. The middle caudal rays are two fifths as long as the onter, which are five sixths as long as the head. The anal base is one 
third of total length without caudal; the fin is preceded by two short, stiff spines with a membrane behind each, the first of these spines two thirds as long as the eye; the longest anal ray is one half as long as the head and three times as long as the last ray; the fin is followed by a single two-rayed finlet which is three fourths as long as the eye. The ventral origin is equally distant from tip of snout and anal origin; the fin reaches to below the sixth spine of the dorsal, its length one half the length of head. The pectoral reaches to below the end of the spinous dorsal, its length three fourths of length of head. Head scaly except on the nasal, mandibular and preorbital regions; body covered with small scales; dorsal, anal and pectoral fins more or less scaly at base; lateral line with a long arch in its anterior one half, passing through enlarged scales in its curved part and armed with 41 scutes in its straight part. D. VIII-i, 31-I; A. II-i, 24 to $27-I$; V. I, 5; P. i, 20.

Color slaty blue above, silvery below; a small, dark, opercular spot, smaller than the pupil; a series of 12 or 13 dark points in the curved part of the lateral line.

The dotted scad, or round robin, is a very common fish at the Bermudas and in the West Indies. On the east coast it is found from Cape Cod to Brazil, but only young or half grown specimens are taken on Long Island and around Cape Cod. The species grows to the length of 1 foot. In the Bermudas it is an important food fish and furnishes infinite sport for the small angler's.

Dr Mitchill illustrates it in fig. 5, pl. 5, of his Fishes of New York, and names it the hippos mackerel. In Dr De Kay's New York Fauna it is the spotted caranx. It is taken not uncommonly at Woods Hole Mass. The species appears to be rare in New York waters, as it was known to De Kay only from the descriptions of Mitchill and Cuvier. The fish has not been recognized in Gravesend bay, but it is abundant in August at South. ampton L. I. and has been taken at Fire Island in October during the fall migration. 


\section{Decapterus macarellus (Cur. \& Val.)}

\section{Mackerel Scad.}

Caranix murallas Cuvier of Valenciennes, Hist. Nat. Poiss. IX, 40, 1833 (Martinique); GǘnTnEl, Cat. F'ish. Brit, Mus. II, 426, 1860.

Decapterus macarellus PoEY, Euumeratio, 79, 1875; JordAN \& GILBERT, Bull. 16, U. S. Nat. Mus, 433, 1853; Jordan \& Evermann, Bull. 47, U. S. Nat. Mus. 909, 1896, pl. CXI, fig. 353, 1900; BeAN, Bull. Am. Mus. Nat. Hist. IX, 362, 1897; Sмrтh, Bull. U. S. F. C. XVII, 97, 1898.

Body elongate, fusiform, subterete, its greatest depth one fifth of total length, its width one half the length of head; least deptli of caudal peduncle one eighth of length of head; head long, subconical, snout obtusely pointed, lower jaw slightly projecting, length of head one fourth of total without caudal; maxillary not quite reaching to front of orbit; the upper jaw equal to length of snout; mandible extending to below front of eye, its length equal to postorbital part of head; nostrils on top of head, nearer eye than to tip of snout; eye large, one fourth the length of head; interorbital space convex, its width equal to eye; a very low keel on top of head; no scales on nasal and preorbital regions; gill rakers $S+30$, the longest two thirds as long as the eye. The spinous dorsal originates at a distance from tip of snout equal to one third the total length without cardal; the longest spine is one lialf as long as the head, the last spine minute. The interspace between the two dorsals is ont half the diameter of eye. The second dorsal base equals one thixd of total length to end of middle caudal rays; the anterior one fourtl of the fin is much higher than the rest, the longest ray one third of length of head, the last ray one half as long as the snout; the fin is followed by a single finlet of two rays, the longer two thirds as long as the eye. The caudal fin is moderateìy forked, the middle rays, from base of fin, four serenths as long as the outer, which are equal to snout and eye combined. The anal fin is preceded by two short, sharp spines, the first longer, one half as long as the snout; the rays begin under the ninth lay of the second dorsal; the base is as long as the distance from rentral origin to preanal spines; the longest ray about one third as long as the head, the last ray one half as Jong as the snout; the fin is followed by a single two-rayed finlet, 
which is two thirds as long as the snout. The ventral insertion is under the lower axil of the pectoral; the fin extends to below the fifth spine of the dorsal, its length equal to postorbital part of head. The pectoral extends to below the sixth spine of the dorsal, its length equal to the head without the snout. Small scales on nape; nasal, preorbital and mandibular regions naked; sides of head mostly with enlarged, thin scales; small scales on opercle; margin of subopercle finely serrate; body covered with small scales; anterior half of lateral line with a slight curve, the scales prominent; posterior half of lateral line straight and armed with about 31 keeled scutes, the armed portion constituting the second half of the length. D. VIII-i, 34-1; II-i, 28-1; V. I, 5; P. i, 24. Scales 15-100+31-18.

Color slate blue or plumbeous above, silvery below; a small, black opercular spot, smaller than pupil; upper axil of pectoral black.

The mackerel scad inhabits the warm parts of the Atlantic, ranging northward in summer to Cape Cod. It has not yet been reported in Gravesend bay, but was seined in abundance in theAtlantic at Southampton L. I. Aug. 31, 1897, associated with Decapterus punctatus, young Scomber, Pomatomus, Rhombus, Clupea, Etrumeus, two species. of Stolephorus, and Paralichthys.

The species grows to the length of 1 foot. It is excellent for food but large individuals seldom reach our coast. It is said to be more abundant along the south Florida coast, where it lives in shallow water and in harbors, usually moving about in small schools. At Key West the fish are caught in seines, and. are eaten.

\section{Genus trachunus Rafinesque}

Body rather elongate, somewhat compressed, not elevated, tapering to a slender caudal peduncle, which is as broad as deep; scales present, not rery small; lateral line armed throughont with plates, those on the caudal peduncle larger and spinous; an accessory dorsal branch to the lateral line; snout rather long; mouth moderate; minute teeth mostly in single series ob 
jaws, vomer and palatines; dorsals two, the first preceded by a procumbent spine, no finlets; two strong spines before the anal, connected by membrane; pyloric caeca numerous. About 4 species known; found in all warm seas.

\section{Trachurus trachurus (Linnaeus) \\ Gascon; Saurel}

Scomber trachurus Linsaeus, Syst. Nat. ed. X, I, 298, 1758, Mediterranean. Caran $x$ trachurus Cuvier \& Valexcienses, Hist. Nat. Poiss. IX, 11, pl. 246, 1833; Cuvier, Règne Anim. Ill. Poiss. pl. 57, fig. 1.

Trachuius saurus Jordan \& Gilbert, Bull. 16, U. S. Nat. Mus. 912, 1883.

Trachurus trachurus BlocH, Naturgesch. Ichth. II, 138, pl. 36, 17S4; Günther, Cat. Fish. Brit. Mus. II, 419, 1860 (in part); Lütken, Spolia Atlantica, 125, 1880; Jordan \& Gilbert, Proc. U. S. Nat. Mus. 269, 1882; Jordan \& Evermans, Bull. 47, U. S. Nat. Mus. 910, 1896, pl. CXI, fig. 384, 1900.

Body strongly compressed and moderately deep, the depth contained four times in the length of the body; head rather long, its length being contained three and one half times in that of the body; eye large, equal to snout, its length contained four times in that of the head; mouth moderate, the maxillary reaching the front of the eye; arch of lateral line short, reaching scarcely beyond pectoral, one and one third in the straight part, the plates high, nearly as high anteriorly as posteriorly, their hight more than half of eye. Greenish, sides silvery; a dusky opercular spot. Length one foot. North Atlantic, chiefly on the coasts of Europe, south to Spain and Naples; it is very rare on our coast, recorded from Newport R. I., Pensacola, and Cape San Luras. D. VIII-I, 29 ; A. II-I, 28 ; scutes $40+37$.

The saurel, or scad, ranges north to the Trondhjem fiord, latitude $65^{\circ}$, and is said to occur as far south as Portugal. On the coast of Holland it is known as the marse banker, ol hors. It is interesting to American ichthyologists, since the similarity of its habits to those of the menhaden caused the latter fish to be called among the early Dutch colonists of New York by the same name.

The scads are described by European writers as occurring on those coasts in enormous schools, moving like menhaden but with feeding habits similar to those of our bluefish. They are fairly 
good food fishes, but of small size, seldom exceeding 1 foot in length. Only a few specimens have been recorded on our Atlantic coast from Newport R. I., Pensacola Fla., and Cape San Lucas, Lower California.

\section{Genus Trachurops Gill}

This genus is close to $\mathrm{Ca} \mathrm{r}^{\mathrm{a}} \mathrm{n} \mathbf{x}$, differing in the more elongate form and specially in the structure of the shoulder girdle, which has a deep cross furrow at its junction with the isthmus, with a fleshy projection above the furrow.

\section{Trachurops crumenophthalmus (Bloch)}

\section{Big-eyed Scad; Goggler}

Scomber crumenophthalmus BLocH, Ichth. pl. 343, 1793.

Scomber plumieri Bloch, op. cit. pl. 344, 1793, Antilles; Storer, Syn. Fish. N. A. $100,1846$.

Caranx crumenophthalmus LAcépède, Hist. Nat. Poiss. IV, 107, 1803: Cuvier \& Valenciennes, Hist. Nat. Poiss. IX, 62, 1S33; Günther, Cat. Fish. Brit. Mus. II, 429, 1860; Jordan \& Gilbert, Bull. 16, U. S. Nat. Mus. 434, 1883.

Trachurops crumenophthalmus Jondan \& Gilbert, Proc. U. S. Nat. Mus. 196, 1S83; Jordan \& Evermann, Bull. 47, U. S. Nat. Mus. 911. 1896, pl. CXLI, fig. 385, 1900; BEAN, Bull. Am. Mus. Nat. Hist. IX, 362. 1897 ; Sмгтн, Bull. U. S. F. C. XVII, 97, 1898.

Body oblong elongate, little compressed, the back not elevated. The depth is contained three and one half times in the length. Head elongate, rather pointed, the lower jaw projecting; maxillary reaching past the front of the eye, which is very large, longer than snout, much deeper than cheeks, and greater than the interorbital width. The length of the head is contained three and one half times, while that of the eye is contained three times in the length of the body. A single series of teeth in each jaw, very weak teeth on vomer and palatines, a patch of teeth on tongue. Shoulder girdle near isthmus with a fleshy projection, in front of which is a deep cross furrow; adipose eyelid largely developed; scales comparatively large; cheeks and breast scaly; gill rakers long and numerous; lateral line scarcely arched, its scutes weak, but little carinated; dorsal spines slender; free anal spines strong; pectorals falcate, shortish, about one and one seventh in the head; an angle at lower posterior part of opercular region as in $\mathrm{Clupea.} \mathrm{Bluish} \mathrm{olive} \mathrm{above,} \mathrm{silvery}$ 
below; a faint opereular spot. Length about 2 feet. D. VIII-I, 26; A. II-I, 22; scutes 35.

Found on botll coasts of tropical America, and extending northward on our east coast to Cape Cod; common in the West Indies and on the west coast of Mexico; also found on the coast of Africa and in most tropical seas; abundant in the Caribbean sea in winter.

This is the goggler or goggle-eyed jack of the Bermudas and the Cicharra of Cuba. In the Bermudas it is a food fish of some importance. In January 1885 a few individuals were seined at the island of Cozumel, off Yucatan. The fish was found to be excellent for the table.

At Woods Hole Mass., according to Dr Smith, it is common every rear from about October 15 to Norember 15 , the individnals taken measuring from 4 inches to 6 inches in length.

July 25, 1901, a single example, about 4 inches long, was picked up dead on the ocean beach opposite Clam Pond cove; one of a number of little fish which had probably been driven ashore by bluefish or some other predatory species, for the fish had recently died, and there had been no storm. Seren species in all were found in a distance of about 2 miles; they were common mackerel, bluefish, mackerel scad, two species of anchory, young sea herring, and the big-eyed scad.

The big-eyed scad is taken in the fall in Gravesend bay. It was found Aug. 31, 1897, in the surf at Southampton L. I. This fish will not endure close confinement, but will live within suitable limits of temperature in large bodies of water. In captivity it feeds on small killifish, shrimp, and chopped clams.

Genus caraxx Lacépède

Body ovate or oblong, compressed, the back sometimes considerably elerated, sometimes little arched; head moderate or rather large, more or less compressed; mouth moderate or large, oblique; maxillary broad, with a well developed supplemental bone, extending to below eye; premaxillaries protractile; teeth dereloped in one or few series, unequal, or at least not in villiform bands, villiform teeth usually present on romer, palatines, 
and tongue, wanting or deciduous in some species; gill raker long; eye large, with an adipose eyelid; dorsal spines rather low, connected; second dorsal long, usually elevated in front, both fins depressible in a groove; anal fin similar to second dorsal and nearly as long, preceded by two rather strong spines, its baselonger than the abdomen; caudal fin strongly forked, the peduncle very slender; ventral fins moderate; pectorals falcate; no finlets; scales present, mostly very small; lateral line with its posterior part armed with strong bony plates, which grow larger on the tail, each plate armed with a spine, a short dorsal branch: of lateral line usually present; preopercle entire in the adult, serrate in the young, usually with a membranaceous border. Species very numerous in all warm seas.

\section{Subgenus тrichoptenus Rafinesque}

\section{Caranx hippos (Linnaeus)}

\section{Crevallé}

Scomber hippos Linnaeus, Syst. Nat. ed. XII, I, 494, 1766, Charleston, Soutls. Carolina.

Caranx carangus Cuvier \& Valenciennes, Hist. Nat. Poiss. 1X, 91, 1833; Günther, Cat. Fish. Brit. Mus. II, 44S, 1860.

Caranx defensor DE KAY, N. Y. Fauna, Fishes, 120, pl. 24, fig. 72, 1842; HоLввоок, Ichth. S. C. 87, pl. 12, fig. 1, 1860.

Carangus hippos Gill, Proc. Ac. Nat. Sci. Phila. 433, 1862; Goode \& BeAN, Bull. Essex Inst. XI, 16, 1879.

Caranx hippus Jordan \& Gilbert, Bull. 16, U. S. Nat. Mus. 437, 1883; Jordan \& Gilbert, Proc. U. S. Nat. Mus. 200, 1853.

Caranx hippos Bean, Bull. U. S. F. C. VII, 139, 1885; Bull. Am. Mus. Nat. Hist. IX, 362, 1S97; 52d Ann. Rept. N. Y. State Mus. 103, 1900; Jordan \& Evermann, Bull. 47, U. S. Nat. Mus. 920, 1S96, pl. CXLI, fig. 387, 1900; Mearns, Bull. Am. Mus. Nat. Hist. X, 318, 189S; Surtir Bull. U. S. F. C. XVII, 98, 1898.

Body oblong, the anterior profile rery strongly arched. The depth is contained two and one half times in the length. Head large and dcep, its length being contained three and one half times in that of the body; mouth large, low; lower jaw prominent, maxillary extending to nearly opposite.posterior borderof eye, two and one third in head; teeth in upper jaw in a broad villiform band, an outer series of large, wide set, conical teeth, teeth of lower jaw in one row, a distinct canine on each side of symphysis; villiform teeth on romer, palatines, 
pterygoids, and tongue; lateral line with a wide arch, its length one and one third in straight part, the angle under fifth dorsal ray, plates not corering all of the straight part, lateral line (scutes) about 30; dorsal spines short, rather stont; gill rakers. stout, rather long, 15 below angle; occipital keel sharp; eye not very large; pectoral falcate, one fifth longer than head; breast naked, with only a small triangular patch of scales in front of ventrals; caudal lobes equal, nearly as long as head. D. VIII-I, $20 ;$ A. II-I, 17.

Olivaceous above, sides and below golden; a large, distinct black blotch on opercle, bordered behind with pale; a large faint black spot on lower rars of pectorals, the latter sometimes wanting in young; axil of pectoral with a black blotch; edge of soft dorsal black; upper edge of caudal peduncle dusky.

The crevalle is found on the east coast from Nora Scotia. southward, ranging to the West Indies and Brazil. The roung are very common along the coast of southern New England in. summer. De Kay calls it the yellow caranx, and Mitchill mentions it as the yellow mackerel. The specimens seen by both. these authors came from the bay of New York.

At Wroods Hole Mass. the young arrive in July and leare in October. In Great Egg Harbor bay, N. J., roung indiriduals were taken sparingly in August. De Kay records the species. as abmulant in New York bay in September and October. The writer saw several examples from a fish trap at Islip L. I.. Oct. 1, 1890.

Young crevalle make a croaking sound when captured in a net or held in the hand.

On the gulf coast of Florida, Alabama and Mississippi the fish is migratory, just as it is here; it makes its appearance in April, spawns in July or August, and then disappears and is replaced by the young. It feeds on small fish, which it pursues eagerly, and is presed on by sharks and porpoises.

It grows to the length of 15 inches and is highly prized for food.

The crevalle can be successfully kept in captivits in large. pools with a temperature above $50^{\circ}$ in winter. The fish occasionally school together under a large shark and follow it abont. 


\section{Subgenus P.ırıtractos Gill \\ 215 Caranx crysos (Mitchill) \\ Yellow Mackerel}

Scomber crysos Mitchill, Trans. Lit. \& Plil. Soc. X. Y. I, 421, 1515, New York.

Caranx pisquetus Cuvier of Valenciennes, Hist. Nat. Poiss. IX, 97, 1833,

San Domingo, Cuba, and Brazil; Jordax \& Gilbert, Bull. IG, U. S. Nat. Mus. 435, 185.

Paratractus pisquctus GiLl, Proc. Ac. Nat. Sci. Phila. 432, 1862; Goode \& BEAN, Bull. Essex Inst. XI, 16, 1879.

Caranx chrysos Storen, Hist. Fish. Mass. 75, pl. XIV, fig. 3, 1S67; Güxtrer, Cat. Fish. Brit. Mus. II, $445,1860$.

Caranx chrysus JordaN \& Gilbert, Bull. 16, U. S. Nat. Mus. 970, 1853;

Bean, 19tl Rep. Comm. Fish. N. Y. 256, pl. VII, fig. 10, 1890.

Caranx crysos DE KAY, N. Y. Fauna, Fishes, 121, pI. 27, fig. S5, IS42;

Jordai i Evermanx, Bull. 47, U. S. Nat. Mus. 921, IS96, pl. CXLII, fig. 38S, 1900; BeAx, Bnll. Am. Ius. Nat. Hist. IX, 362, 1897; Sмiтh, Bull. U. S. F. C. XVII, 98, 1S9S.

Body oblong, moderately elevated, the dorsal and ventral outlines about equally arched. The depth of the body is contained about three and one fourth times in the length. Profile forming a uniform curre. The length of the head is contained three and three fourths times in the length of the body. Snout rather shary; mouth slightly oblique, a little below axis of body; maxillary reaching about to middle of orbit; teeth comparatively large, a single series in lower jaw, upper jaw with an inner series of smaller teeth, no canines, teeth on romer, palatines and tongue; eye rather small, shorter than snout, three and one half in head; gill rakers long and numerous; pectoral as long as head, barely reaching anal, rarely longer than head in certain specimens from Key West, possibly referable to C. c a b a $11 \mathrm{us}$; scales moderate; cheeks and breast scaly; lateral line with a weak arch anteriorly, which is about half the length of straight portion, lateral scutes numerous, developed on whole straight part of lateral line, lateral line 50 (seutes). D. VIII-I, 24; A. II-I, 19.

rreenish olive, golden yellow or silvery below; a black blotch on opercle; fins all pale. An individual $3 \frac{1}{2}$ inches long, taken 
at Beesleys Point N. J. Aug. 11, 1887, showed the following colors: caudal yellow; basal half of elerated part of anal yellow; cheeks and lower half of sides also yellow; a black opercular spot, but none on pectoral; several narrow pale bars on sides; tip of elevated part of soft dorsal dusky; membrane between dorsal spines dusky; iris copper color.

The yellow mackerel is a widely distributed fish in warm seas; it is recorded from the East Indies, both coasts of tropical America, and northward to Cape Ann and the Gulf of California. The young are common at Woods Hole Mass., where they appear in July and become most abundant in October. Indiriduals 1 inch long have been obtained there about July 1; larger fish occur in the fall. In August 1598 only a few young ones were secured in Great South bay and at Southampton L. I.

The fish probably spawns in west Florida in May in the salt water bayous, as the young fish are seen coming out of such places in schools in the fall on their way to the sea. Fish weighing about a pound or two are considered equal to pompano for the table, but large fish are not esteemed, the flesh being dark and almost tasteless. The species reaches the weight of 20 pounds.

The yellow mackerel resembles the big-eyed scad in its endurance of captivity and its feeding habits. At the end of Norember it has been known to thrive in a pool containing about 50,000 gallons of water in company with the crevalle, the big. eyed scad and other species.

\section{Genus alectis Rafinesque}

Body rhomboid, deep, strongly compressed, more or less completely covered with minute embedded scales, sometimes apparently naked; scutes on the straight part of the lateral line enlarged, bony and spinous, as in $\mathrm{C}$ a r a $\mathrm{n} x$, but much less developed; mouth moderate, with bands of villiform teeth on jaws, vomer, palatines and tongue; first dorsal fin little developed, the spines short and rudimentary, mostly disappearing with age; soft dorsal and anal similar to each other; the first five or six 
rays of each fin elongate and villiform in the young, becoming shorter with age; ventral fins elongate in young, short in the adult; pectorals falcate; no finlets; caudal peduncle narrow, the caudal widely forked; gill rakers moderate, stout. This genus is not essentially different from $\mathrm{Ca} \mathrm{r}$ a $\mathrm{n} \mathrm{x}$, the great change in form arising from no important modification of the skeleton. The changes due to age are surprisingly great, as Dr Lütken has shown, the characters of the nominal genera being chiefly stages in the growth of individuals. The young individuals are almost orbicular in form, with the filaments excessively long. Tropical seas.

\section{Alectis ciliaris (Bloch) \\ Threadfish; Cobblerfish; Shoemakerfish}

Zeus ciliaris BLOCH, Ichth. VI, 29, pl. 29, 17S8, East Indies.

Zeus crinitis AKerly, Amer. Jour. Sci. Arts, XI, 144, pl. 2, 1826, Shoreham. Blepharis crinitus De IrAY, N. Y. Fauna, Fishes, 123, pl. 25. fig. 76, 1842.

Blepharichthys crinitus GrL, Proc. Ac. Nat. Sci. Phila. 262, 1862.

Caranx sutor GüNTHER, Cat. Fish. Brit. Mus. II, 454, 1860.

Alectis criniths Jordan \& Gilbert, Bull. 16, U. S. Nat. Mus. 438, 1883.

Alectis ciliaris JordaN \& EvermanN, Bull. 47, U. S. Nat. Mus. 931, 1896;

BeAn, Bull. Am. Mus. Nat. Hist. IX, 362, 1897; 52d Ann. Rept. N. Y.

State Mus. 103, 1900; Sмiтh, Bull. U. S. F. C. XVII, 98, 1898.

Body oval, much compressed, highest at the elevated bases of the dorsal and anal fins. The depth of the body is contained from one and one fourth to two times in the length of the body. The length of the head is contained three and one third times in that of the body. Mouth nearly horizontal in the adult, very oblique in the young; preorbital very deep; first rays of dorsal and anal filamentous, exceedingly long, in the young much longer than body, becoming shorter with age; lateral with a wide arch, the curved part about equal to the straight part; scaly sheath of fins little developed; scutes 12, scutes becoming stronger and blunter with age; ventrals broad; occipital keel sharp; pectorals long and falcate, longer than head. D. VI-I, 19; A. II-I, 16. Bluish above, golden yellow below; a dark blotch on opercle; a black spot on orbit above; a black blotch on dorsal and anal in front.

The threadfish is found on the east coast from Cape Cod to the Caribbean sea and on the Pacific coast of tropical America. In 
western Mexico it attains to the length of 3 feet and is used for food. At Woods Hole Mass., it is usually uncommon, but sometimes abundant, appearing about the middle of June and remaining till November.

De Kay described a specimen from Long Island sound, the only one observed by him. One was taken in a pound net at Islip Aug. 1S, 1898, by W. F. Clock. The threadfish enters Gravesend bay occasionally in summer. In captivity it will not endure a water temperature much below $60^{\circ}$.

\section{Genus vomer Cur. \& Val.}

This genus is closely allied to $\mathrm{C}$ a $\mathrm{r}^{\circ} \mathrm{a} \mathrm{x}$, from which it differs only in its distortion of form, and in its weak teeth and very low fins. Body broad, ovate, very strongly compressed, all the outlines sharply trenchant; head rery gibbous above the eyes, its anterior profile vertical; lateral line strongly arched, its posterior part with very weak shields; scales minute, rudimentary; soft dorsal and anal extremely low, not falcate. Young much deeper in form than the adult, all the fins higher, resembling S ele ne. Warm seas.

\section{Vomer setipinnis (Mitchill)}

\section{Horsefish; Moonfish}

Zeus setapinnis Mitchil, Trans. Lit. \& Phil. Soc. N. Y. I, 384, pl. I, fig. 9, 1815, New York.

Vomer brounii Curien \& Valenciennes, Hist. Nat. Poiss. IX, 1S9, pl. 256, 1S33, New York \& West Indies; DE KAr, N. Y. Fauna, Fishes, 12\%, pl. 25, fig. $7 \mathrm{~S}, 1 \mathrm{~S} \pm 2$.

Argyreiosus setipinnis GüNTher, Cat. Fish. Brit. Mus. II, 459, 1860.

Selene setipimis Jordan \& Gilbert, Bull, 16, U. S. Nat. Mus. 440, 1883.

Tomer setipinnis Gilt, Proc. Ac. Nat. Sci. Phila. 436, 1S62; Jordan \& GILBert, Bull. 47, U. S. Nat. Mus. 931, 1S96, pl. CXLIT, fig. 392, 1900; Bean, Bull. Am. Mus. Nat. Hist. IX, 362, 1897; Sмrth, Bull. U. S. F. C. XVII, 9S, 1 S98.

Body oblong, rhombic, less elevated than in sel e ne vo me r; profile anteriorly nearly rertical, highest above eye, snout somewhat protruding, belly mostly arched in young; mouth oblique; maxillary reaching rertical from front of orbit. The depth of the body is contained twice in the length in an adult but only from one and one fourth to one and three fourths in the young. The length of the body is three and one fourth times the length 
of the head. Scutes 20; rentral fins minute; dorsal and anal very low, specially in adult, the long rays disappearing very early; pectorals falcate, about as long as head. D. VIII-I, $21 \mathrm{Or}^{\circ}$ 22 ; A. II-I, 19 or 20.

Color above plumbeous or greenish; sides and lower parts lustrous silvery; membrane of second dorsal light yellow at base, the membrane with minute black points; pectorals greenish, tinged with dusky; young with a black blotch, smaller than the eye, at the beginning of the straight part of the lateral line.

The horsefish inhabits the seas of tropical America, ranging from Maine to Brazil and from Lower California to Peru. In summer it is sometimes abundant as far north as Saco Me., and at Woods Hole Mass., in Buzzards bay and Vineyard sound, but sometimes it is rare in those waters. When present, it appears in August and remains till September. The fish is also reported in western Africa. Mitchill calls it the bristly dory. He records it from New York bay. De Kay states that it appears in New York waters in July and August, and that it is esteemed for food. An individual was brought from Graresend bay Oct. 21, 1896, and a young example, known there as dollarfish, was received from the same locality Oct. 22, 1896.

The species reaches the length of 1 foot. It is esteemed an excellent article of food. It finds its way to New York in considerable numbers every year but is rarely seen in other markets. Nothing is known of its breeding habits.

The horsefish has several additional common names: sunfish, jorobado (Cuba), blunt-nosed shiner, pug-nosed shiner, and humpbacked butterfish.

\section{Genus secene Lacépède}

Body very closely compressed and much elevated, the profile very oblique or nearly vertical; edges of body everywhere trenchant, specially anteriorly; head short and very deep, the opercle very short, and the preorbital extremely deep; an abrupt angle at the occipital region; mouth rather small; premaxillaries protractile, fitting into a notch between the bases of the maxillaries; maxillaries broad, each with a supplemental bone; tongue nar- 
row, free; teeth minute, on jaws, tongue, romer, and palatines; gill rakers long and slender; spines of fins usually weak, more or less filamentous in the young; free anal spines immovable, sometimes obsolete in the adult; soft fins falcate, much elevated; no finlets; head naked; scales minute; lateral line wholly unarmed. Coloration silvery. Tropical seas. Notwithstanding its extraordinary form, this genus differs in no important regard from Ca r a $\mathrm{n}$.

\section{Selene vomer (Linnaeus)}

\section{Lookdown; Moonfish}

Zeus vomer Linnaeus, Syst. Nat. ed. X, I, 266, 1758, America.

Argyreiosus vomer LAcÉPÈne, Hist. Nat. Poiss. IV, 566, 1808; DE İ́AY, N. Y. Fauna, Fishes, 124, pl. 75, fig. 238, 1812; Güntuer, Cat. Fish. Brit. Mus. II, 458, 1S60; Gill, Proc. Ac. Nat. Sci. Phila. 437, 1S62; BeAn, 19th Rep. Comm. Fish. N. Y. 256, 1890.

Argyriosus vomer Goode \& BEAN, Bull. Essex Inst. XI, 16, 1879.

šelene argentea LAcÉPÈDE, Hist. Nat. Poiss. IV, 560, pl. 9, fig. 2, 1803. (adult). Zeus eapillaris Mitcinll, Trans. Lit. \& Phil. Soc. N. Y. I, 3S3, pl. II, fig. 2, 1815, (young), New York.

Zeus rostratus MitcmLL, Trans. Lit. \& Phil. Soc. N. Y. I, 381, pl. II, fig. 1, 1815, (young), New York.

Zeus geometrieus Mitchill, Ars. Month. Mag. II, 245, Feb. 1818, (adult), New York.

Argyreiosus capillaris DE KAY, N. Y. Fauna, Fishes, 125, pl. 27, fig. \$2, 1812, New York.

Selene romer Cuvien \& VAlenciennes, Hist. Nat. Poiss. IX, 177, 1833; Brevoort, Ann. Lyc. Nat. Hist. N. Y. V, 68, pl. 4, 1853; Jordan \& Gilbert, Bull. 16, U. S. Nat. Mus. 439, 1883; Jordan \& Evermann, Bull. 47, U. S. Nat. Nus. 936, 1896, pl. CXLIV, fig. 393, (young), pl. CXLV, fig. 393a, adult, 1900; BeAN, Bull. Am. Mus. Nat. Hist. IX, 363, 1897, 52d Ann. Rept. N. Y. State Mus. 108, 1900; Sмтн, Bull. U. S. F. C. XVII, 98, 1898 .

Selene gallus BEAn, Bull. U. S. F. C. VII, 139, 1898.

The depth of the body is contained one and one half times in the length; while the length of the head is contained three times in the length of the body. Diameter of eye, length of opercle, and distance from eye to profile about equal; eye twice in maxillary, two and one half in preorbital; mandibles rery deep, the dentary bones thin, approximate; one or two of the dorsal spines greatly elongate and filamentous in the roung, short in the adult; ventrals rariable in length, usually as long as the eye in the adult, variously elongate in partly grown specimens; the 
long dorsal rays contained twice in the length of the body; the pectoral two and three fourths times; and the long anal rars two and two thirds. D. VII-I, 22; A. II-I, 20. Bluish above, sides and below silvery with golden reflections; anterior edge of soft dorsal black; axil dusky.

Examples measuring from 3 to 4 inches, taken at Beesleys Point N. J. Aug. 10-11, 1Sst, showed the following colors: silvery; five golden bands on sides, one of which extends through the eye and below it half way to maxilla, or slightly farther. The second and third soon fade, persisting only abore median line and at their lower extremities.

The example taken August 11 is 4 iuches long; its longest first dorsal ray measures $6 \frac{7}{3}$ inches; the other is 3 inches long, and has a filamentous spine measuring 5 inches.

The lookdown is found on both coasts of tropical America and in temperate parts of the Atlantic north to Cape Cod and Inower California. At Woods Hole Mass. it is rare, but a few are taken annually in traps and seines, usually in September. Storer describes a specimen $5 \frac{1}{2}$ inches long from New Bedford Mass. Mitchill mentions the fish under two names, hair-finned dory and rostrated dory, but gives no special locality. De Kay calls it the hair-finned argyreiose and notes its appearance in New York waters about the latter end of August and its capture in gill nets. The writer obtained four young examples by seining at the Blue Point Lifesaving station Oct. 7, 1890. Aug. 29, 1898 , he took another young individual in the seine at Duncan's creek, Great South bay.

The fish is interesting only from its silvely colors and singular shape, which make it a great attraction for the aquarium. Three individuals of the moonfish were obtained from Graresend Hay sep. $S$ and 29,1897 . In November they were transferred to a tank in which the water was at a temperature of $68^{\circ}$ to $70^{\circ}$ $\mathbf{F}$, and they were successfully kept through the winter.

\section{Genus chronosconnes Girard}

Fody oblong orate, closely compressed, but not elevated; the abdomen mominent anteriorly, its curve being much greater 
than the curve of the back; occiput and thoracic region trenchant; caudal peduncle very narrow, the fin widely forked; scales small, smootli: lateral line arched in front, unarmed, or with a few small plates; head nearly naked; preorbital low; mouth rather small, oblique, lower jaw scarcely projecting, upper jaw protractile; maxillary broad, emarginate behind, with a larce supplemental bone; jaws, vomer and palatines with feeble teeth, mostly in single series; first dorsal of feeble spines, connected by membrane; second dorsal and anal long and low, similar, much longer than the short abdomen; no finlets.

\section{Chloroscombrus chrysurus (Linnaeus)}

\section{Casabe; Bumper}

Scomber chrysurus Lixpaeus, Syst. Nat. ed. XII, I, 494, 1766, Charleston. Scriola cosmopolita Cuvien \& Valencienres, Hist. Nat. Poiss. IX, 219, pl. 259, 1833; De IIAY, N. Y. Fauna, Fishes, 129, pl. 74. fig. 237, 1842. Chloroscombrus caribbaeus Girard, Mex. Bound. Surv. Zoöl. 21, pl. 9, fig. 6. 1559, Joseph Island, Texas.

Micropteryx chrysurus GüNTHER, Cat. Fish. Brit. Mus. II, 460, 1860.

Chloroscombrus chrysurns Gild, Proc. Ac. Nat. Sci. Phila. 437, 1862; Jordan

\& Gilbert, Bull. 16, U. S. Nat. Mus. 441, 1853; Jordax \& Evermaxx, Bull. 47, U. S. Nat. Mus. 935, 1896, pl. CXLV, fig. 394, 1900.

The depth of the body is contained two and one third times in the length; length of head contained three and three fourths times in the length of the body; head rather deep than long; opercles very short; snout short; mouth very oblique; maxillary reaching anterior margin of eye; eye very large, longer than snout, about three in head; chord of curved part of lateral line scarcely longer than head, one and two thirds to one and three fourths times in length of straight part; lateral line wholly unarmed; caudal peduncle longer than deep, its diameter less than that of the eye; rentrals very small, fitting into a groove in which the rent is situated; pectorals long, falcate, one third the length. I. TIII-I, 26; A. II-I, 26.

Color of upper parts pale greenish; sides of head and body silvers iridescent; a nearly square black bloteh on caudal peduncle above; dark spots on opercle and axil of pectoral; inside of month black; first dorsal translucent with a vellow tinge anteriorly and with minute dusky points, second dorsal translucent 
at base, numerous black points anteriorly, margin yellowish, pectoral yellowish, ventral white, preanal spines and connecting membrane white, anal translucent at base, rest of fin yellowish with a few dusky points.

The casabe is a small fish of wide distribution along our east coast, ranging from Cape Cod to Brazil; it is common in the Gulf of Mexico, the Caribbean, and in Cuba, but rather rare from Charleston northward. The only authority for its occurrence in New York waters till recently has been Cuvier and Talenciennes, who claimed to have a specimen from New York. De Kay did not regard it as a member of the fish fauna. In 1899, however, $\Pi$. I. De Nyse secured several fine examples at Gravesend beach, L. I., and one of these, 8 inches long, is now in the U. S. National Museum, where it is numbered 49219.

The fish grows to the length of 10 inches. It has no value as food, but is a beautiful species.

\section{Genus trachuotus Lacépède}

Body compressed, moderately elevated, the general outline orate; caudal peduncle short and rather slender; abdomen not trenchant, shorter than the anal fin; head moderately compressed, very blunt, the snout abruptly truncate; mouth neariy horizontal the maxillary reaching the middle of the eye; premaxillaries protractile; maxillary without distinct supplemental bone; jaws, vomer and palatines with bands of villiform teeth, which are deciduous with age; preopercle entire in the adult; gill rakers short; gill membranes considerably united; spinous dorsal represented by six rather low spines, which are connected by membrane in the young but are free in the adult. In old specimens the spines appear small on account of encroachments of the flesh, and ultimately often disappear. Second dorsal long, elevated in front; anal opposite to it and similar in form and size; two stout, nearly free spines in front of anal, and one connected with the fin, these often disappearing with age; scales small, smooth; lateral line unarmed, little arched; no caudal keel. 
When extremely youmg, the preopereulum is armed at the angle with three large spines, and smaller ones above and below. The spinous dorsal is developed as a perfect fin, and teeth are present on the jars and palatine arch. In this stage the species has never been described by previous naturalists, and consequently has received no nante, as the corresponding stage of Na u c a tes ( $\mathrm{N}$ a u clerus) has. It an early period the preopercular spines are absorbed into the substance of the preoperculum and disapjear. The spinous dorsal and the teeth are still retained. In this rondition it remains for some time, the spinous dorsal. however, gradually losing its relative size, while the soft rertical fims increase. In this stage the species belongs to the genus Doliodon of Girard. At a later period the membrane connecting the dorsal spines las become obsolete, and the species then reprosents the genus $\mathrm{T} r$ a $\mathrm{ch}$ r not us, as understood by Curier and Valenciennes, and others. Finally, in old age, the teeth of the jaws, palate, and pliaryngeal bones have fallen out, and the lobes of the dorsal, anal and caudal fins attain their greatest extension and become pointed. This final stage has been made known by Holbrook moler the new generic name of $\mathrm{B}$ ot h ro la e m u s Gill

The psendobranchiae also disappear in old specimens. Some of the species of Trachinotus (carolinus ete.) are among the most highly ralned of our food fishes. Most of them aie howrer not of superior quality.

\section{- 200 Trachinotus falcatus (Limnaeus)}

\section{Round Pompano; Ovate Pompano}

Labrus falcatus Lindaeus, Syst. Nat. 'ed. X, I, 281, 175̃s, America.

The spinous Dory Mrtcincl, Trans. Lit. \& Phil. Soc. N. I. I, pl. VI, fig. 10, no description.

Zeus spinosns Miтcinle, Am. Month. Mag. II, 246, Feb. 181 .

Trachinotus spinosus DE KAY, N. Y. Fauna, Fishes, 117, pl. 19, fig. 53, 1S12, New York harbor.

Trachimotus rhomboiles Cuvier \& TAlexcrexnes, Hist. Nat. Poiss. VIII, $40 \mathrm{~T}, 1 \mathrm{~s} 31$.

Trachinotus fuseus Cuvier of Talexciexyes, op. cit. VrII, 410, 1S31, Brazil. Trachymotus rhomboides JorDAx \& Gilbert, Bull. 16, U. S. Nat. Mus. 974, 1S\$3; BeAx, Bull. U. S. F. C. VII, 139, pl. III, fig. 5, 1SSS, young.

Trachynotus ovatus Güntuen, Cat. Fish. Brit. Mus. II, 481, 1S60, (in part, not Gasterostens onatus of Linvaecs); Jordax \& Gildert, Bull. 16, U. S. Nat. Mus. 442, 18s3; BEan, 19th Rep. Comm. Fish. N. Y. 25e, pl. IX, fig. 12,1590 . 
Trachinotus falcatus Jordan \& Evermans, Bull. 47, U. S. Nat. Mus. 9+1, 1S96, pl. CXLvi, fig. 396. 1900; BeAn, Bull. Am. Mus. Nat. Hist. IX, 363, 1897; Sмiтi, Bull. U. S. F. C. XVII, 9S, 1898.

Body broadly ovate, moderately compressed, profile very evenly convex from procumbent spine to level of upper edge of eye, where it descends almost vertically. The depth of the body is contained one and three fifths times in the lengtli; the Iength of the head is contained three and three fourths times in that of the body. The rertical part is about one and one third times the eye; the length of snout nearly equal to eye; mouth nearly horizontal; maxillary reaching to vertical from middle of eye, its length two and two thirds in head; jaws without teeth in adult; dor'sal spines short and thick, not connected by membrane in adnlt; rentrals short, their tips scarcely reaching half way to anterior anal spine, three in head; caudal widely forked; lobes about two and two thirds in length of body; dorsal and anal fins falcate; anterior rays reaching almost to posterior end of fins; in adults, dorsal lobe two and two thirds, anal lobe four and one half, in length of body. 1). VI-I, 19; A. II-I, 1 .

Color, bluish above, silvery below; the fins all bluish with lighter tips. In the young the coloration is different from that of the adult. An indiridual $1 \frac{1}{2}$ inches long, taken at Beeslers Point N. J. September 2, was mainly silvery when captured, but on being placed in a small aquarium almost instantly became dark brown, the dorsal and anal nearly black. On the rentrals, the anal spines, and the anterior tip of the anal fin was observed the. usual vermilion, shading into orange. Fire goung, from 1 inch to $1 \frac{3}{4}$ inches long, seined August 10 and 11 at Beesleys Point, exhibited, after immersion for several days in alcohol, the following colors: general color silvery, thickly sprinkled with dusky; sides wholly or partly suffused with pink; ventrals and tip of anterior anal lays orange; dorsal and anal duskẹ, with $x$ narrow, pale marginal band; caudal milk white, the lower lobe faintly tinged witlı yellow; iris pink.

The orate pompano inhabits the Atlantic coasts of tropical and temperate America; it is common in the West Indies; on our east coast it occurs north to Cape Cod and south to Brazil; 
young individuals are very common about Cape Cod iu summer, but no adults are seen. The young, from $\frac{1}{2}$ to 1 inch long, appear in July, according to Dr Hugh M. Smith, and by September, when they disappear, they are two inches long. 13 young, averaging a little more than 2 inches in length, were obtained at Oak Island beach September 30 .

The young of the round pompano are caught occasionally in summer in Graresend bay. Early in September 1897 a small one was placed in a tank, where it lived and fed regularly till Norember. The low temperature of the water then killed it.

Mitchill gives a figure of the fish in the Transactions of the Literary and Philosophical Society of New York under the name spinous dory, but no description. De Kay calls it the spinous trachinote, and describes a specimen 3 inches long from the harbor of New York, taken in September 1817. He mentions it as a casual risitor from the south.

According to Dr Goode the species is known in the south as the shore pompano and in the Bermudas as the alewife. About the Bermudas this pompano is sometimes very abundant as, in 1875 , a school containing 600 or 700 was seined on the south shore of the islands. The fish is highly esteemed there for table use.

The orate pompano grows to the length of 15 inches and is generally prized for food.

\section{Trachinotus argenteus Cur. \& Val.}

\section{Silvery Pompano}

Trachinotus argenteus Cuvien \& Valencrennes, Hist. Nat. Poiss. VIII, 413, 1831. New York and Rio Janeiro; DE KAY, N. Y. Fauna, Fishes, 116, 1842; BeAx, 19th Rep. Comm. Fish. N. Y. 255, pl. X, fig. 13, 1890; Jordan \& Evermann, Bull. 47, U. S. Nat. Mus. 944, 1896; Smith, Bull. U. S. F. C. I VII, 98, 1898.

Trachinotus cuprens Cuvier \& VAlenciennes, Hist. Nat. Poiss. VIII, 414, 1831, Martinique.

Body oblong, compressed, deep, its greatest depth one half of total length without caudal, its thickness one fourth the depth and nearly one half the length of tiead; least depth of caudal peduncle one sixth of greatest depth; head short, two sevenths of total without caudal; eye small, circular, equal to snout, one 
fourth as long as head; interorbital space convex, its width two fifths of length of head; maxilla reaches to below front of pupil; mandible reaching to below hind margin of orbit, its length equal to snout and eye combined; nostrils nearer to tip of snout than to eye, the anterior in a very short tube; teeth in villiform bands in both jaws, but more developed in the lower than in the upper; gill rakers short and stout, the longest about one half as long as eye. The origin of spinous dorsal is a little behind origin of ventral; the base of the fin equals postorbital length of head; the spines are all short, the third, and longest, two thirds as long as the eye. The antecedent spine of the soft dorsal is two thirds as long as the eye; the base of the fin equals three times the length of snout and eye combined; the longest ray is three times as long as the last ray and two thirds as long as the head. The middle caudal rays are three sevenths.as long as the outer rays and one fourth longer than the head. The anal origin is under the sixth ray of the soft dorsal; the fin is preceded by two short isolated spines and a third closely connected with the first ray; the second of the antecedent spines is two thirds as long as the eye; the longest ray is two thirds as long as the head, and the last ray is about as long as the eye. The rentral origin is at a distance from tip of snout equal to one third of total length to end of middle caudal rays; the fin reaches to the vent and to below the fourth spine of the dorsal. The pectoral reaches to below the fifth spine of the dorsal, its length equal to length of head without the snout. D. V, I, 24; A. II, I, 22; V. I, 5; P. I, 17. Color silvery, with tips of anterior part of dorsal black and with blackish on the middle of the pectoral.

The measurements above are from an example nearly 6 inches long, no. 15085, U. S. National Museum, taken at Tompkinsville N. Y. Another example $3 \frac{1}{4}$ inches long, no. 36036, U. S. National Museum, was collected at Blue Point cove, L. I. There are a number of additional examples in the U. S. National Museum from localities south of New York. The individual from Tompkinsville is almost exactly of the size of the type of the species 
as recorded by Cuvier and Talenciennes and it agrees perfectly with the description of their 'T. a r gente us. 'These authors had two specimens, one from New Iork and the other from Rio Janeiro, cach 6 inclies long. Dl Jordan, who has examined the types of the species, says one of them is a foot long, and that it has 25 dorsal rays and $2: 3$ rays in the anal.

There is still some question whether or not the a r ge n te us of Curier and Talenciennes is the young of T. ca ro $\mathrm{T} \mathrm{n} \mathrm{us}$ (Linnacus). If we consider them identical we must assume that the very young, say from 1 inch to 2 inches long, are much more. elongate than when they reach the length of 3 inches. I am unable to decide the question at present, but still incline to the belief that the silvery pompano is a distinct species. I have examined specimens fully 10 inches long which retain the depth of body characteristic of the roung, that is, one half of total without caudal.

The example from Blue Point cove, Great Soutl bay, was figuled by the writer in the 19th report of the N. Y. Fish Com. mission, pl. 10, fig. 13. De Kay, in his work on the fishes of New York, p. 116, translates the description of Curier and Valenciennes, not having obtained a specimen of the fish.

\section{Trachinotus carolinus (Linnaeus)}

\section{Common Pompano}

Gasterosteus carolimus Lixxates, Syst. Nat. ed. XII, I, 490, 1766, Carolina. Trarhinotus pampanus Cuvier \& VAlexciexnes. Hist. Nat. Poiss. VIII, 415 , pl. 237, 1S31, Brazil, Charleston.

Trachynotus pempanus G̈̈хтнer, Cat. Fislı. Brit. Mus. II, 481, 1860.

Bothrolucmus pampauus Ноцвrook, Ichth. S. C. 81, pl. 11, fig. 2, 1856.

Lichia carolina DE KAY, N. Y. Fauna, Fishes, 114, pl. 10, fig. 30, 18t2, off Sandy Hook.

Trachynotus caioliuns Jordax \& Fildert, Bull. 16, U. S. Nat. Mus. 442, 1SS3; BEAn, Bull. U. S. F. C. VII, 140, 1SSS, 19th Rep. Comm. Fish. N. Y. 254, pl. VIII, fig. $11,189$.

Trachinotus caroliuus Jordax \& Evermaxs, Bull. 47, U. S. Nat. Mus, 944, 1S96. pl. CXLVII, fig. 395, 1900; BEAx, Bull. Am. Mus. Nat. Hist. IX. 363. 1897, 52d Ann. Rept. X. Y. State Mus. 104, 1900; SмIтII, Bull. I. S. F. C. XVII, 98, 1898 .

Body oblong orate, elerated, profile forming a gentle curve from the midale of the bacli to the snont, where it descends 
abruptly. The depth of the body is contained two and one third times in its length; the length of the head is contained foul times in that of the body. Dorsal and anal falcate, their lobes reaching when depressed nearly to the middle of the fin; pectoral reaching to opposite the vent. Gill rakers short; slender in the young, becoming thick in the adult. Length 18 inches. D. VI-I, 25; A. II-I, 23.

Uniform bluish above, sides silvery, golden in the adult, without bands, fins plain silvery or dusky.

This fish has no other name on our east coast except the southern variation of pompeynose. In Great South bay the name butterfish is applied to it because it is confounded with the Poronotus triacanthus, to which the name properly belongs. Mitchill described it under the name thornbacked grunt, a name not now in use. The pompano ranges on our coast from Cape Cod to Florida, the adults rarely or never coming into northern waters, but the young are taken in variable numbers every year. At Woods Hole they sometimes. occur in considerable numbers, and they have been taken in great abundance in Great Egg Harbor bay, but not recently. In Great South bay, in 1890, only a single young individual was secured at Oak Island beach on the last day of September. It occurs occasionally also on the Pacific coast. Dr De Kay, in 1842, mentioned it as an exceedingly rare species on the New York coast. His description was based on a specimen taken off Sandy Hook more than 20 years before. In 1898 young specimens were found in moderate numbers at Oak Island beach, Great South bay, September 14, and on the east side of Fire Island beach September 16 . The young are summer and fall visitors in Gravesend bay. 22 individuals were placed in a tank in August 1897, and grew rapidly till the temperature of the water fell below $60^{\circ} \mathrm{F}$ in Norember. During this month all of them died.

The species reaches the length of 20 inches. It is one of the finest of our food fishes. 


\section{Family I'ONATOMIDAE}

\section{Bluefishes}

\section{Genns ponstomis Lacépède}

Body oblong, compressed, covered with rather small scales, which are weakly ctenoid; caudal peduncle rather stout; head large, compressed; mouth large, oblinue; premaxillaries protractile; maxillary not slipping under the preorbital, provided with a large supplemental bone, lower jaw projecting; bands. of rilliform teeth on romer and palatines, those on the vomer forming a triangular patch; jaws each with a single series of rery strong, compressed, unequal teeth, widely set, upper jaw with an inner series of small depressed teeth; villiform teeth. on the base of the tongue; occipital keel strong; free edge of preopercle produced and serrated; gill membranes free from the isthmus, not united; branchiostegals seven; gills four, a slit behind the fourth; pseudobranchiae large; gill rakers slender, rather fer; opercle ending in a flat point, cheek and opercles scaly; lateral line present, unarmed; dorsal fins two, the anterior of about eight weak, low spines connected by membrane and depressible in a groove; sccond dorsal long, similar to the elongate anal, both fins boing densely scaly; fin rays slender; two rery small, free anal spines, sometimes hidden in the skin; rentrals thoracic, I, 5; peduncle stout; pectorals rather short; caudal fin forked, the lobes broad; air bladder simple, with thin walls; prloric caeca very numerous; vertebrae $\mathbf{1 0}+\mathbf{1 4}=\mathbf{2} t$ as usual in Carangidae. A single species, found in nearly all warm seas.

\section{Pomatomus saltatrix (Linnaeus)}

\section{Bhuefish: Snap 1Lackerel: Snapper}

Perca saltatrix Linvaeus, Syst. Nat. ed. X, I, 293, 175s, Carolina.

Gasterostcus saltatix Linvaets, op. cit. ed. XII, 491, 1766.

Scomber plumbens Mitcintl, Trans. Lit. \& Phil. Soc. X. X. I, 424, pl. IV, fig. $1,1815$.

Temnodon saltator Curier \& Valencienses, Hist. Nat. Poiss. IX, 225, pl. 260. 1833: De KAx, ․ I. Fauna, Fishes, 130, pl. 26, fig. \$1, 1S42; HoLBrook, Iclith. S. C. 02, pl. 9, fig. 2. 1856; Günther, Cat. Fish. Brit. II I I , 479. 1860; Storer, Hist. Fish. Mass. 81, pl. XT, fig. 1. 1867.

Pomatomus saltator Jordax \& Gilment, Bull. 16, U. S. Nat. Mus. 44S, $18 S 3$. 
Pomatomus saltatrix Goode \& BeAv, Bull. Essex Iust. XI, 20, 1979; Jordan \& Gilbert, Bull, 16, U. S. Nat. Mus. 914, 1S83; Bean, Bull. U. S. F. C. VII, 145, 1Sss; 19th Rep. Comm. Fish. N. Y. 269, pl. XX, fig. 24, 1890; Bull. Am. Mus. Nat. Hist. IX, 363, 1897; 52d Ann. Rept. N. Y. State Mus. 104, 1900; SmTH, Bull. U. S. F. C. XVII, 9S, 1S98; Mearns, Bull. Am. Mus. Nat. IIist. X, 319, 1S9S; Jordan \& Evermaxy, Bull. 47, U. S. Nat. IIus. 246, 1S96, pl. CXlYIII, fig. 400, 1900; Eugene Sмiтh, Proc. Linn. Soc. N. Y. 1S97, 32, $189 S$.

Body robust, moderately compressed; belly compressed to a bluntish edge. The depth is contained four times in the length of the body. Head deep; top of head and a ridge on each side above the cheeks naked; cheeks much longer than opercles. The length of the head is contained three and one third times in the length of the body. Pectorals placed rather low, their length a little more than half that of the head. D. VIII-1, 25; A. II-I, 26; Iat. 1. 95. Bluish or greenish, silvery below, a black blotch at the base of the pectoral.

Some of the many names applied to this widely distributed fish are the following: mackerel (New Jersey), horse mackerel (New York and Rhode Island), snapping mackerel (New England and New Jersey), skip mackerel (New York), snapper and blue snapper (New England), greenfish (Maryland, Virginia and North Carolina), salt-watel jack (southern states), tailor (Chesapeake bar), whitefish (Hudson river). Bluefish is the name most extensively used on the coast and in the Gulf of Mexico.

The bluefish ranges on our coast from Maine to the Gulf of Mexico, and is believed to frequent warm seas of both continents. It has ranged farther to the northward this year than for many rears before. We have heard of its capture in the ricinity of Mount Desert Me. On our coast and elsewhere its movements are elratic, and its abundance fluctuates greatly within certain periods; it disappears sometimes altogether for a term of roars. The roung: nnder about 1 inch in length, seem to be nnknown. The spawning habits and localities have not been recorded. The smallest known examples were obtained at the surface offshore by the U. S. Fish Commission. The writer has seined individuals a little more than an inch long at Ocean City N. J. the last of August. The young ascend aivers into fresh water. 
This is one of the most destructive of all fishes. It feeds ravenously, and, when gorged with food, continues to destroy its victims for the sake of gratifying its killing propensity. It follows the great schools of alewives, weakfish, mullets and other valuable food fishes along our coast in summer, and the young may be discovered in shallow bays and sounds pursuing the silversides, young herring, anchovies and other fishes smaller than themselves. According to De Kay bluefish were unknown on the New York coast till about 1810, when a few appeared. In 1815 Dr Mitchill wrote: "Young ones are taken plentifully with the hook at our wharres by the boys in August." The largest mentioned by Mitchill was 13 inches long, 3 inches deep and weighed about 14 ounces. The name bluefish was in use at the time of Mitchill's report.

De Kay noticed the gradual disappearance of the weakfish with the increasing abundance of bluefish.

The best known methods of taking bluefish are by trolling at the surface with a squid of metal or bone and by hearing and hauling in the surf near the mouths of streams into which ale. wives are running. Artificial minnows are also used with a light rod, when young bluefish are seen feeding near the surface. The most recent method in use by anglers is that of chmming in the manner usually employed in striped bass fishing. This method, which involves the use of rod and reel, was in use near the inlet at Fire Island early in October 1890. During the sum. mer, in this bay, it was not an uncommon thing for anglers to catch 150 or 200 small bluefish with hook and line in a single day. The species is to be found in all parts of the bay visited by us. It was taken at the following localities: Blue Point cove, Oak Island and Fire Island. Large numbers of bluefish were caught late in September by means of gill nets set in the ocean near Blue Point Lifesaving station. A fisherman caught 450 at one time and 250 at another, the dates being Sep. 23 and 24, 1890. In August of that rear bluefish drove immense schools of round herring ( $\mathrm{Etr}$ u e us teres) on the ocean beach, near the Lifesaving station. September 24, while walking alongthe beach of East Island, not far from the Blue Point station, in: 
a distance of half a mile, I saw 51 round herring lying on the beach, having been chased in a short time previously by bluefish. When the fishermen find the round herring on the shore, they know that bluefish are present. Small bluefish were caught in a trap at Islip Oct. 1, 1890. In the summer of 1898 young bluefish were abundant in all the waters risited in Peconic bay and Great South bay and were taken as late as October 16.

During the warm season they often run up the rivers, the young, called snappers, frequently into nearly fresh waters. (After Eugene Smith')

The bluefish is so actire in its morements that it is difficult to keep it in captivity. As with the species of $\mathrm{Car}$ a $\mathrm{n}$ and Seriola, howerer, its longerity depends on range and temperature; in a large body of water, not co'der than $60^{\circ}$ in winter, it can be maintained easily.

\section{Family RACHYCENTRIDAE}

\section{Sergeant Fishes}

\section{Genus R.chrcentrox Kaup}

Body elongate, fusiform, subcylindric, covered with very small, smooth, adherent scales; lateral line nearly parallel with the back; head rather broad, low, pikelike, the bones above appearing through the thin skin; mouth rather wide, nearly horizontal, the maxillary about reaching front of eye; both jaws, vomer, palatines and tongue with bands of short, sharp teeth, lower jaw longest; premaxillaries not protractile; preopercle unarmed; first dorsal represented by about eight low, stout, equal, free spines, each depressible in a groore; soft dorsal long and rather low, somewhat falcate, similar to and nearly opposite anal; two weak anal spines, one of them free from the fin; pectorals moderate, placed low; rentrals thoracic, I, 5; caudal fin strong, forked, on a moderate peduncle; no caudal keel; no finlets; gill rakers rather short, stout; no air bladder; branchiostegals seren; pyloric caeca branched; vertebrae $\mathbf{1 2}+\mathbf{1 3}=\mathbf{2 5}$. Probably only one species; a large, strong, voracious shore fish, found in all warm seas. Its relations are with the scombroid fishes, though not

${ }^{1}$ Linn. Soc. N. Y. Proc. 1S97. no. 9, p. 32. 
close ro any of the other groups. The superficial resemblance to Echeneis, as Dr Gill has shown, is not connected with any intimate liomology. (After Jordan and Evermann)

\section{Rachycentron canadus (Limnaeus)}

\section{Crabeater; Cobia}

Gasterostens canadus Linnaeus, Syst. Nat, ed. XII, 491, 1766, Carolina.

Centronotus spinosus Mitchild, Trans. Lit. \& Phil. Soc. N. Y. I, 490, pl. III, fig. 9. 1S15, New York.

Elacate atlantica Cuvier \& Valenciennes, Hist. Nat. Poiss. VIII, 334, pl. 233. 1S31, Brazil; De KAY, N. Y. Fauna, Fishes, 113, pl. 2., fig. 7т, 1812.

Elacate nigra Güvtier, Cat. Fish. Brit. Mus. II, 375, 1860.

Elacate canada Jordan \& Gilbert, Bull. 16, U. S. Nat. Mus. 41S, 1853; Bean, Bull. U. S. F. C. VII, 144, pl. II, fig. 13, 1SsS, 19 th Rep. Comm. Fish. N. Y. 270, pl. XX, fig. 25, 1890, (young), Great Egg Harbor Bay. Rachycention canadus Jordan \& Evermaxx, Bull. 47, U. S. Nat. Mus. 948, 1S96, pl. CXLTIII, fig. 401, 1900; Sнiтн, Bull. U. S. F. C. XVII, 9S, 1898 .

Head much depressed. The length of the head is contained four and one fourth times in the length of the body; while the width of the body is contained five and two thirds times in its length. Month moderate, the short maxillary reaching front of orbit; pectorals broad and falcate; caudal deeply emarginate, the upper lobe slightly the longer; lateral line wary and irregular, descending posteriorly. Length 5 feet. D. VIII-1, 26; A, II, 25. Color, olive brown; sides with a distinct broad dark band and a less distinct band above and below it; lower parts silvery.

The crabeater inluabits all warm seas, occasionally appearing on our Northern coast in summer and ranging northward to Massachusetts bay. Individuals are occasionally taken at Troods Hole Mass.

Dr Mitchill had a specimen of the crabeater which was caught in New Jork bay June 11, 181.5. He found in its stomach 20 spotted sand crabs and sereral young flounders. The fish was eaten at his table, and pronounced one of the best he had ever tasted. This example was 31 inches long. Dr De Kay styles it the northern crabeater. The specimen described by him was captured in Boston harbor, and placed in a lice car with other fish, chiefly porgies (Stenotomus chrysops), and it de- 
stroyed and ate every fish in the car. Dr A. K. Fisher of Washington has found the young of the crabeater in the Hudson near Sing Sing. Though we have no specimens of the crabeater from: Great South bay, there is scarcely a doubt of its occurrence in that body of water.

A young example, $3 \frac{7}{8}$ inches long, was caught at Somers Point N. J. near the club house, Aug. 2, 18s7, by Capt. Richard Chamberlain. Ground color nearly black; a white stripe, about as wide as pupil, from upper angle of gill opening to caudal; another one, but narrower, begins at lower extremity of pectoral base, curves very slightly upward, fading out near the tail; uppercaudal lobe with a narrow whitish margin along its upper surface, relieved by a trace of orange red at its base; lower caudal lobe with a narrow orange red margin; pectorals, ventrals, and caudal black; back fades to a dark green; belly grayish white; iris golden bronze. This species has not previously been recorded from Great Egg Harbor bay, and the young seems not to have been described.

Another example, 4 inches long, was seined in one of the thoroughfares in the bay August 23. This has the same markings as the first. The caudal when fully expanded, is rounded, the end truncate; there is no emargination as in the adult. A figure of the young is published in the bulletin of the U. S. Fish Commission, 18s8, v. 7, pl. 2, fig. 13.

Family Coryphaenidae

Dolphins

Genus coryphatex Limnaeus

Body elongate, compressed, covered with small cycloid scales; cleft of the mouth wide, oblique, the lower jaw projecting; cardiform teeth in the jaws and on the romer and palatine bones, a patch of villiform teeth on the tongue, no teeth on the esophagus; opercular bones entire; skull with a crest which is more elevated in the adult than in the young; a single, many-rayed dorsal fin, not greatly elerated, extending from the nape nearly to the caudal fin; anal similar, but shorter, both without distinct spines; pectoral fins very short and small; rentrals well developed, 
thoracic, I, J, partly received into a groove in the abdomen; caudal fin widely forked; lateral line present; gill membranes free from the isthmus; branchiostegals seven: no pseudobranchiae; no air bladder; pyloric appendages rery numerous; rertebrae about 30 . I genus with probably only two species. Very large fishes, inhabiting the ligh seas in warm regions, noted for their brilliant and changeable colors. (After Jordan and Evermann)

225 Coryphaena hippurus Linuaeus

Common Dolphin

Coryphacna hippurus Iinxateus. Syst. Nat. ed. X. I, 261, 1758, opon seas; Günther. Cat. Fish. Brit. Mus. II, 40乞, 1860; Curier \& Valexciennes, Hist. Nat. Poiss. IX, 27S. pl. 266, 1833: Jondax \& Gilbent. Bull. 16, U. S. Nat. Mus. 914, 18S3; Jordar \& Evermarx, Bull. 47, U. S. Nat. Mus. 952, 1S96, pl. CXLIX. fig. 402. 1900; BeAx, Bull. Am. Mus. Nat. Hist. 363, 1597; Sнтті, Bull. U. S. F. C. XYII, 99, 1898.

Coryphaena hipmris MItchut. Trans. Lit. \& Phil. Soc. N. Y. I, 378, 1515. Coryphaena sucmrii CUVIER \& YALENCIENNes. Hist. Nat. Poiss. IX. 3ৎ2 1 s33. Coryphaena globireps De KAY, N. T. Fama, Fishes, 132, pl. 10, fig. 29. 1842. off New Tork.

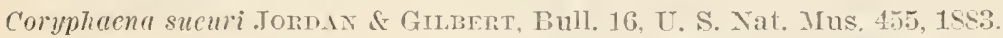

Body elongate, compressed, highest anteriorly, the greatest depth equal to length of head and to one fourth of total length without caudal: the greatest width about equal to postorbital length of head; least hight of caudal peduncle one fourth the length of head; maxilla reaching neirly to below end of eye; upper jaw equal to snout and eye combined; mandible reaching past hind margin of orbit. The profile of the snout becomes nearly rertical with age; the male has the forehead elerated, forming a crest which projects slightly beyond the upper jaw. Eye small, one half the length of snout, one sixth the length of head. The dorsal origin is nearly above the eve; the fin occupies the entire back, the longest spines (12th to 11th) equal postorbital iength of head, the last spine two ninths as long as heac. Caudal rery deeply forked, the middle rays less than one sixth as long as the external rays, which are one third as long as the lorsal base. The anal begins under the $32 \mathrm{~d}$ spine of the dorsal: its base is as long as the head and pectoral combined. its longest ray one third as long as the head, its last rar equal to eye, the 
fin emarginate anteriorly. The ventral origin is directly under the pectoral base and under the 13th spine of the dorsal, its length one sixth of total length without caudal. The pectoral origin is below the 13th spine of the dorsal; the fin extends to below the $23 \mathrm{~d}$ spine, its length equal to length of head withont snout. D. 56-64; A. 25-30; V. I, 5; P. I, 19 . Scales about 175; gill rakers 10 , all below angle, the longest one half as long as the eye.

Color's in life brilliant, changing suddenly at death; greenish above, white or golden below, with bright blue spots, the largest on the back and head, forming bands on the snout; dorsal purplish blue, with pale longitudinal lines; other fins tinged with blue; caudal yellow; in spirits, silvery with blackish spots, smalier than the pupil, on the sides below the lateral line.

The dolphin inhabits all warm seas; it is common in the Gulf of Mexico, and its summer range includes Cape Cod. Large individuals are rare in Vineyard sound, but the young, from 2 to 12 inches long, are observed nearly every year in floating gulf weed, usually in July and August.

Mitchill mentions the species without referring to a particular specimen; but De Kay states that an individual 42 inches long was captured off the harbor of New York and presented to the Lyceum of Natural History. An example, 17 inches long and 23 inches deep, was caught off Sandy Hook late in August 1897 by a fisherman while trolling for bluefish.

The dolphin attains to the length of 6 feet. It is an excellent food fish.

\section{Coryphaena equisetis Linnaeus}

\section{Small Dolphin}

Coryphaena equisetis Linnaeds, Syst. Nat. ed. X, I, 261, 1758, higlı seas; Cuvier \& Valenciennes, Hist. Nat. Poiss. IX, 297, pl. 267, 1833; GínTher, Cat. Fish. Brit. Mus. II, 407, 1860; Jordan \& Gilbert, Bull. 16. U. S. Nat. Mus. 914, 1883; Jordan \& Evermann, Bull. 47, U. S. Nat. Mus. 953, 1896.

Lampugus punctulatus Cuvier \& VALexciennes, op. cit. IX, 327, 1833; DE KAY, N. Y. Fauna, Fishes, 134, pl. 11, fig. 31, 1812.

Coryphaena punctulata Jordan \& GilberT, Bull. 16, U. S. Nat. Mus. 454, 1883. 
This is said to be the Lampugus punctulatus of Cuvier and Valenciennes, ${ }^{1}$ to which is ascribed the following characters. Hight of body contained nearly fire times in its length; head fire and one fourth times; depth of head fire sevenths of its length; profile obliquely descending; pectorals one tenth of total length; rentrals one eighth; caudal lobes one fifth; 10 or 12 posterior rays of dorsal and anal dilated at their extremities and projecting beyond the comnecting membrane. Color silvery, blackish on the back, with a few small black dots on the body. D. 51; A. 25; T. I, 5; P. 19.

The specimen described is 13 inches long. It was taken in the Atlantic at the equator.

De Kay has described a dolphin measuring 2 feet which was taken on a hook at the light-ship off the harbor of New York and which he supposed to be identical with the species just mentioned. The characters of the fish are given as follows. Length of head rather less than one eighth of total length; hight of body one eighth and of caudal peduncle at its lowest part one twentieth of total; eye large, its length contained four and four serenths times in length of head and more than one diameter distant from tip of snout; dorsal fin beginning just behind the orbit, its last 10 or 12 rays somewhat elevated and projecting beyoud the connecting membrane; pectoral origin under ninth dorsal spine; the fin one twelfth of total length including candal; rentral length contained nine and three fifths times in total; anal origin nearly midway between posterior margin of orbit and base of candal. Length 24 inches; head $3 \frac{x}{5}$ inches; hight 3 inches. D. 53 ; A. 25; V. I, 5; P. 20.

Color sea green above the lateral line; silvery on the sides, with metallic reflections on the opercles; iris rellowish; dark reddish brown stripes across the head; a series of distant rounded spots along the base of the dorsal fin; a few scattering ones on the back part of the head, and confused series of similar spots on the sides below the lateral line; dorsal, pectorals and rentrals brown; anal and caudal fins light colored.

${ }^{1}$ Hist. Nat. Poiss. 1833. 9:327. 
Jordan and Evermann, in Bulletin 47, U. S. National Museum, p. 953 , state that the small dolphin is not recorded from the coast of the United States; but that it inhabits the open Atlantic and occurs rarely in the Trest Indies. De Kay, however, described a dolphin, abore mentioned, which appears to agree with the published descriptions of the $\mathrm{Col}^{2} \mathrm{p}$ h a e $\mathrm{na}$ e qu i se $t$ is Linnaeus; and there is no reason to suppose that this pelagic species does not occasionally visit our shores. It is true that all the young dolphins from the New England and New York coasts examined by me belong to the larger species; but materials for study are scarce, and it is unwise to base a conclusion on insufficient inrestigation.

\section{Family CENTROLOPIIDAE}

\section{Rudderfisties}

\section{Genus Paldnurichtirs Bleeker}

Body oblong, orate, moderately compressed; profile rery blunt and convex; mouth moderate; maxillary narrow, with a small supplemental bone; premaxillaries protractile, little movable; jaws nearly equal, each with about one series of small, slender teeth; no teeth on romer or palatines; preoperculum, interoperculum, and suboperculum finely serrated; gill rakers long; gill membranes separate, free from the isthmus; scales small, smooth, larger, thicker, and more adherent than in $\mathrm{Stroma}$ te us ; clieeks scaly; fins rather low; dorsal fin long, preceded by six to eight short, subequal, rather strong spines, the last ones connected by membrane, the others nearly free, all much lower than the soft rays; anal fin similar but shorter, preceded by three spines, which, like the dorsal spines, are nearly embedded in thick skin; vertical fins densely scaly toward theil bases; caudal fin emarginate; caudal peduncle stout; rentral fins large, thoracic, I, 5; pectoral fins morlerate, rounded, or falcate.

\section{Palinurichthys perciformis (Mitchill)}

\section{Rudderfish; Black Pilot}

Coryphaena perciformis MitchiLL, Am. Month. Mag. II, 24, Feb. 181S, New York Harbor.

Palinurus perciformis DE KAY, N. Y. Fauna, Fishes, 118, pl. 24, fig. 75, 1812; Storer, Hist. Fish. Mass. 74, pl. XIII, fig. 3, 1867. 
Pammelas perciformis Güntmen, Cat. Fish. Brit. Mus. II, 4S5, 1860. Livus perciformis JordaN \& GIlbert, Bull. 16, U. S. Nat. Mus. 452, 1883. l'ulimmichthys pereiformis GiLL, Proc. Ac. Nat. Sci. Phila. 20, 1S60; TordaN \& Fvermand, Bull. 47, U. S. Nat. Mus. 964, 1896; Goode \& Bean, Bull. Essex Inst. XT, 10, 1879; BeAn, Bull. Am. Mus. Nat. Hist. IX, :66, 1897; Sumtir, Bull. T. S. F. С. XVII, 99, 1S98; BeAn, 52d Ann. Rept. N. Y. State Mus. 104, 1900.

Body orate, compressed, its depth two fifths of its length without the caudal; head short, blunt, its profile conrex, its length two sevenths of the total without caudal; mouth moderate; maxillary narrow, reaching to opposite front of pupil; a small supplemental bone; eye with adipose eselid; eye nearly equal to snout, two ninths as long as the head; top of head scaleless; cheeks scaly; jaws nearly equal, each with about one series of small, slender teeth, no teeth on vomer or palatines; gill rakers long; pectorals nearly as long as the head. D. VIII, 20; 1. III, 16. Lateral line 75. Blackisl green, everywhere dark. the belly almost similar and not silvery, sirles often mottled with linear blotches. Length 1 foot.

The rudderfish is found on the Atlantic coast of North America from Maine to Cape Hatteras; usually off shore under drifting logs, boxes and otler objects, but occasionally entering bays; one specimen was taken off Cornwall, haring drifted across the Atlantic. The rudderfish is rare in Gravesend bay. One or two will usually appear there during the summer, but some years none are seen. The fish is common 2 or 3 miles off shore, and its capture with a dip net is not difficult. Numerous young and half grown examples were so taken off Southampton L. I. Aug. 3, 1S9S, and a fine adult was captured bs Capt. George Yarrington in Clam Pond core, Great South bay, Oct. 11, 1898.

Aug. 4, 1901, a school of rudderfish numbering about 50 was seen at the dock at Water Island, Great South bas, and one of them was obtained for the state museum.

\section{Family STRONATEIDAE \\ Harvestfishes \\ Genus Ruombes Tacépède}

Body orate or suborbicular, strongly compressed, tapering into a slender candal peduncle, which is not keeled or shielded; 
head short, compressed, the profile obtuse; mouth small, terminal, the jaws subequal; premaxillaries not protractile; jaws each with a single series of weak teeth; scales very small, cycloid, silvery, loosely inserted. extending on the rertical fins; opercular bones entire; gill membranes separate, free from the isthmus; gill rakers moderate; lateral line continuous, concurrent with the back; dorsal fin long, more or less elevated in front, preceded by a few indistinct spimes-nsually one or more procumbent spines in front of dorsal and anal, each of these with a free point both anteriorly and posteriorly; anal fin similar to dorsal, or shorter, usually with three small spines; rentral fins wanting; a single small, sharp spine, attached to the pubic bone, occupying the place of the rentrals; pectorals long and narrow; caulal widely forked. Species few, mostly American. This genus differs from Strom a te us chiefly in the prominence of the pelvic bone, which projects as a lamina beyond the skin. (After Jordan and Evermann)

\section{Subgenus rноние \\ 228 Rhombus paru (Linnaens) \\ Harkestfish; Pappyfish}

Stromateus paru LinnaEus, Syst. Nat. ed. X, I, 248, 1758, Jamaica; Jordav \& Gileert, Bull. 16, U. S. Nat. Mus. 914, 1883.

Chactodon alepidotus I.INxaEcs, Syst. Nat. ed. XII, 460, 1766, Charleston. Stromatens alepidotus Jordan \& Gilbert, Bull. 16, U. S. Nat. Mus. 45I, 1853. Stromateus longipinnis Mitchild, Trans. Lit. \& Phil. Soc. N. Y. I, 366, 1815, New York Bay.

Rhombus longipinnis Curier \& Valenciennes, Hist. Nat. Poiss. IX, 401, pl. 274, 1833; DE ḰAY, N. I. Fauna, Fishes, 136, pl. 75, fig. 239, 1842. Stromateus gardenii G̈̈̈ther, Cat. Fish. Brit. Mus. II, 399, 1860.

Rhombus paru Jordan \& Evermanx, Bull. 47, U. S. Nat. Mus. 965, 1896, pl. CL, fig. 404, 1900; BeAn, Bull. Am. Mus. Nat. Hist. IX, 364, 1897; Sirte, Bull. U. S. F. C. XYII, 99, 1898.

Body orate or suborbicular, strongly compressed, its greatest depth about three fourths of its length without the caudal; caudal peduncle short and slender, its least depth contained two and three fifths times in the length of the short head; mouth very small, oblique, the maxilla reaching to below front of eye; no pores along side of back; eye round, as long as the snout, and about one fourth as long as the head; profile of head very 
obtuse; dorsal origin a little behind pectoral origin, base of dorsal almost equal to greatest depth of body, front of fin elevated, the longest ray as long as the pectoral, its length contained two and three fifths times in total length without caudal; anal base nearly as long as dorsal base, the longest anal ray much longer than the pectoral, the last dorsal and anal rajs very short, scarcely two thirds as long as the eye, caudal deeply forked, its lobes equal, the longest rays as long as the pectoral. Scales small, thin and deciduous. D. IV to $\mathrm{V}, 45$; A. II, 43. Scales about 90 ; vertebrae $15+15$.

Color greenish above, golden yellow below. Mitchill gires the following description: "silvery, with tints of blue, green and iridescent; dusky on the head, and with inky patches on the belly towards the tail, which in certain lights appear beantifully red and purple; back bluish, with occasional clouds."

The larrestfish inhabits the West Indies and is found on our Atlantic coast from Cape Cod southward, ranging to Brazil. The young are frequently seen swimming beneath the Portuguese men-of-war.

De Kay had several specimens of the species, but found it less common than the short-finned harvestfish, R. tri a c a $\mathbf{n} \mathbf{t} \mathbf{h} \mathbf{u}$. It Charleston the fish is called rudderfish.

The species reaches a length of 8 inches. It is a valuable food fish. It is a summer visitor in Gravesend bay and is sometimes rare, but was formerly abundant there. It is not adapted to a captive life. At Woods Hole Mass. Dr Smith reports it as usually rare, but occasionally common. As a rule only three or four are taken in a season, but one year 300 or 400 were obtained. It occurs mostly in June and July, associated with the butterfish, R. tria c a $\mathrm{n}$ th us.

\section{Subgenus poroxotus Gill}

\section{Rhombus triacanthus (Peck)}

\section{Butterfish; Harvestfish}

Stromateus triacanthus Peck, Mem. Amer. Acad. II, part 2, 48, pl. 2, fig. 2, 1S00, Piscataqua River, N. H.; Jordax \& Gilbert, Bull. 16, U. S. Nat. Mus. 451, 1883; Gǘther, Cat. Fish. Brit. Mus. II, 398, 1860. 
Stromatens (ryplosus Mitchil., Trans. Lit. \& Plil. Soc. N. Y. I, 365, pl. I, fig. 3, 1815. New York Bay.

Rhombus triacanthus De KAx, N. Y. Fauma, Fishes, 197, pl. 26, fig. 80, 1842; Storer, Hist. Mish. Mass. pl. XV. fig. 4, 1867; Jordan \& Evermann, Bull. 47, U. S. Nat. Iíus. 967, 1894, pl. CL, tig. 405, 1900; BeAN, Bull. Am. Mus. Nat. Hist. IX, 363, 1s!t; Sмmтн, Bull. U. S. F. C. XVII, 9!, 1895; BeAN, 52l Ann. Rept. N. Y. State IIus. 104, 1900.

Puronotus triaranthus Goode \& BEAN, Bull. Essex Inst. XI. 16, 18i9; Bean,

- Bull. U. S. F. C. YII, 140, 185s; 19th Rep. Comm. Fish. N. I. 25T, 1). XI, fig. 1t, 1890.

Body oral, much compressed. The depth is contained two and one third times in the length. Dorsal and ventral outlines about equally curved. The length of the head is contained four times in that of the hody. Snout rery blunt, rounded in profile; mouth small, the maxillary not reaching the orbit; caudal peduncle rery slort; anterior rass of dorsal and anal little elevated; lateral line high, a series of conspicuous pores above it near the base of the dorsal; pectorals much longer than head; gill rakers ratler long, two thirds the diameter of the eye, which is four in head. Length 10 inches. D. 1II, 15; A. III, 38 . Bluish abore, below silvery. Maime to Cape Hatteras; very abundant.

This is known as the dollarfish, harvestfish and lafayette. Mitchill called it the cryptons broad shiner, and De Kay described it under the name short-finned harvestfish. About Cape Cod it is the sheepshead and skipjack. In Connecticut it is called pnmpkin seed and at Norfolk starfish.

The butterfish ranges from Maine to South Carolina, and is gradually replacco southward by the long-finned harvestfish, $R$ ho m bu s par u. It is a summer visitor, associated with the mackerel. De Kay records it in New York bay July 1, and obtained it flom fyke nets in New York harbor as late as Octo ber 12. We seined joung examples at Blue Point Lifesaving station October 7 , and others were secured September 30 at Oak Island beach. It is taken chieffy in pound nets, and has recently become a highly prized market fish. A few rears ago it was little estremed. The ronng are to be found in the summer months swimming at the surface in sleltered bays and fre- 
quently under the shelter of the streamers of jellyfishes, where they are sometimes destroyed hy the lasso cells of their host.

The harrestfish is present in Gravesend bay from April to November. Adnlts wore taken at Sonthampton beach Ang. 1 and $\mathrm{dug}$. $: 3,1898$. The fish was not found in Great Sonth bay during the summer and fall of 1898.

\section{Group PERCOIDEA \\ Perchlike Fishes}

Family CENTrRArCHIDAE Sunfishes

Genus pomoxys Rafinesque

Body more or less elongate, strongly compressed, the snout rrojecting; mouth large, oblique; maxillary broad, with a well dereloped supplemental bone; teeth on romer, palatines, entopterygoids and tongue; lower pharyngeals narrow, with sharp teeth; gill rakers long and slender, numerous; opercle emarginate; preopercle and preorbital finely serrated; scales large, feebly ctenoid; fins large, the anal larger than dorsal, of six spines and about 17 rays; dorsal with six to eight graduated spines, the spinous dorsal shorter than the soft part; caudal fin emarginate; pectorals rounded or obtusely pointed, with 15 or 16 rays, the upper longest; ventrals close together, each with a strong spine; branchiostegals seren; lateral line complete, the tubes straight and extending at least on the anterior half of the exposed surface of the scale; posterior processes of the premaxillaries not extending to the frontals; supraoccipital and par:etal crest very strong, produced forward on the frontals to between the orbits; vertebrae $18+15=33$.

\section{Pomoxis anmularis Rafinesque}

\section{Crappie}

Pomoxis annularis RAfinesque, Jour. Ac. Nat. Sci. Phila. I, 417, pl. 17, fig. 1, 1S1S, Ohio River "Silver perch or Goldring"; JoRDAN \& GILBERT, Bull. 16, U. S. Nat. Mus. 461, 18s3; Beax, Fislies, Penna. 103, pl. 30, fig. 59, 1893; Jordax \& Evermaxx, Bull. 47, U. S. Nat. Mus. 9S7, 1S96, pl. CLIV, tig. $415,1900$.

Pomoxis nitidus fimard, Proc. Ac. Nat. Sci. Phila. 200, 1s5 or. U. S. Pac. R. R. Exp. Fislı. (i, 11. 2, figs. 5-8, 1858; Günther, Cat. Fislı. Brit. MIus. I, $25 \%, 1859$. 
In the crappie the deptl of the body is two fifths of the total length, not including the tail. The length of the head is one third of the total. The mouth is oblique and larger than in the calico bass. The eye is about equal to the snout and nearly one fourth the length of the head. The upper jaw nearly one half the length of head; the maxilla reaches slightly beyond the middle of the eye. The longest rays of the dorsal and anal are about one half as long as the head. The pectoral is longer than the ventral and reaches only to above the origin of the anal. The ventral when laid back reaches to the vent. D. VI, 16 ; A. VI, 17. Scales $7-45-13$. There is considerable variation in the number of spines and rays in the dorsal and anal fins.

Color clear silvery olive, the sides mottled with dark greenish blotches. On the upper part of the body are traces of narrow vertical bars. The dorsal and caudal are mottled, but the anal is usually uniform pale.

Among the many names which have been applied to the crappie are: bachelor, newlight, campbellite, sac-a-lait, bridge perch, strawberry perch, chinquapin perch, speckled perch, tin perch, goggle-eye, Jolın demon, shad, white croppie and timber croppie.

In the lower Mississippi valley the crappie is one of the most common fishes. It is abundant also in the Ohio valley and occurs rarely in Lake Erie. The Ohio, Illinois and Mississippi rivers are particularly noted for an abundance of crappies, and the fish is very plentiful in Lake Pontchartrain, La., where it is one of the most highly prized of the smaller game fishes.

Dr Meek did not obtain the crappie in the Cayuga lake basin, but says it may be found in the canal near Montezuma, where the calico bass is said to be frequently taken.

The crappie is a very general favorite for pond culture, can be readily transported and under favorable conditions multiplies prodigiously. Its range has been very much extended by artificial means. The best distinguishing marks between the crappie and the calico bass are the more elongated form of the crappie, the presence of six spines in the dorsal and the nearly uniform whitish color of the anal. In the crappie the greatest 
depth of the body is usually contained two and one half times in the total length without the tail, while in the calico bass the depth equals one half the length. These two species are so similar in size and habits that they are rarely distinguished except by ichthyologists.

The crappie grows to a length of about 1 foot and usually weighs 1 pound or less; but in a lake near. St Louis an individual weighing 3 pounds has been recorded.

Crappie fishing usually begins in June and lasts till the coming of cold weather. Targe numbers of these fish are collected near Quincy Ill. for distribution to other waters. At Peoria Ill. Prof. Forbes has taken them in March and April; he has found them also in Pistake lake and at Ottawa. Cedar lake, Ind. and King's lake, Mo. are celebrated crappie waters. Near Covington Ky. in private ponds belonging to Joseph Schlosser there are myriads of crappies as well as other game fishes.

Prof. S. A. Forbes has studied the feeding habits of the crappie, and finds that the young live chiefly on entomostraca and small insect larrae. The adults subsist on the same food when obtainable, but in times of scarcity they fecd to some extent on other fishes. Small minnows and darters have been found in their stomachs. In the autumn Prof. Forbes has found a larger percentage of small fishes, sometimes constituting nearly two fifths of their food. The hellgramite is eaten by the crappie. In cold weather it does not consume one fourth the amount of food which it takes in the early spring. The crappie prefer's still waters, thriving even in warm and muddy water, and has been taken in large numbers in midsummer at depths of only a few feet; in cold weather it retires to deeper water, becomes rather sluggish and takes little food. Dr Henshall states that the crappie is found about dams and in deep still parts of streams and ponds, specially about logs, brush and drift.

The crappie is a rery free biter and can be caught readily with minnows or worms. Spoon bait has been successfully used in trolling for this species. It is recorded that two men have 
taken a thousand crappies in three days' fishing with hook and line. As the fish is gregarious, congregating in large schools, and fearless, it can be taken in the immense numbers given. The best bait for crappie is a small shiner. It rises well also to the artificial fly. Is a food fish this is one of the best in our inland waters, and its adaptability for life in artificial ponds should make it a farorite with fish culturists.

\section{Pomoxis sparoides (Lacépède)}

\section{Calico Bass; Strawberry Bass}

Labrus sparoides LACÉPÈDE, Hist. Nat. Poiss. III, 517. 180?, South Carolina. Cantharus nigromaculatus Le Suetr, in, Cuvier \& TAlenciennes, Hist. Nat. Poiss. III, 88, 1829, Wabash River.

Centrarchus hexacanthus Cuvier of VAlexciennes, Hist. Nat. Poiss, VII, 458, 1831, Charleston, S. C.; Krretrand, Bost. Jour. Nat. Hist. III, 480, pl. XXIX, fig. 2, 1S41; Güntier, Cat. Fish. Brit. Mus. I, 257, 1859.

Pomotis hexacanthis Holbrook, Ichth. S. C. 15, pl. 3, fig. 1. 1856.

Pomoxys sparoides Jordax \& Gilbert, Bull. 16, U. S. Nat. Mus. 465, 1883; Bean, Fishes Penna. 102, color pl. 9, 1893.

Pomoxis sparoides MeEK, Ann. N. Y. Ac. Sci. IV, 312, 18ss; Bollanan, Rep't. U. S. F. C. XTI, 559, pl. 68, fig. 2, 1892; Jordan \& Evermann, Bull. 47, U. S. Nat. Mus. 987, 1896, pl. CLIV, fig. 416, 1900; Eugene SMith, Proc. Linn. Soc. N. Y. for 1897, 33, 1898.

The calico bass has the depth about one half the length, not including the tail, the head about one third. The mouth is rery oblique and smaller than in the crappie. The eye is as long as the snout and one fourth as long as the head. The maxilla reaches to slightly beyond the middle of the eye. The dorsal and anal fins are very high; the longest rays are half as long as the head. The pectoral is as long as the rentral, slightly shorter than the longest ray of the dorsal. The rentral reaches to third anal spine. D. VII, 15; A. VI, 17-18. Scales 7-42-15. The sides are olivaceous with silrery reflections and mottled with pale green. The dorsal, anal and caudal show pale spots surrounded by green reticulations.

The calico bass, on account of its wide distribution and variability, has receiced a profusion of names. Many of these are variations of the term bass. It is known, for example, as strawberry bass, grass bass, lake bass, Lake Erie bass, bank lake bass, silver bass, and big-fin bass. Other names for the species are 
strawberry perch, chinupapin perch, goggle-eye perch, silver perch and sand perch. Still other names of local application are barfish, bitter head, tinmonth, ste-a-lait, lamplighter, razorback, goggle-ere, black croppie and lake croppic. The species is mentioned in the fish laws of Pennsylvania under the name of Lake Erie bass or grass bass.

The distribution of the calico bass is naturally cxtensive, and it has been still further increased by artificial introduction. The fish has been carried to France, and examples measuring about $S$ inches in length were recorded there sereral rears ago. There is, however, some confusion in that country between the calico bass and the common sunfish, and there is no loubt that some of the latter species hare been introduced into Germany under the mistaken belief that they were calico bass.

This bass is indigenous east of the Alleghanies from New Jersey southward to Georgia. It abounds in the Great lakes region, Mississippi valley south to Lonisiana, most common northward and occurs in the Missouri. In the Ohio ralley it was rather uncommon till its introduction in large numbers. It was introduced into the Susquehanna river by the Pennsylrania Fish Commission, and has become acclimatized there; also into the Monongahela, the Lehigh, and other waters.

Fishermen of the region about Montezuma informed Dr Meek that the fish is frequently taken from the canal near that place, where it is known as calico bass. The U. S. Fish Commission obtained two examples in Long pond, at Charlotte N. I. Aug. 17, 1894.

This bass grows to a length of ahout 1 foot and a maximum weight of nearly 3 pounds, but the average weight is about 1 pound. It spawus in the spring, and the close season in some states extends to June 1. Gravid females were caught near Harre de Grace Mr. in May. These were taken in the Susquehanni and Tidewater canal, where the species is becoming rather abundant. The food of the calico bass consists of worms, small crustaceans and fishes. Though a natire of deep, sluggish waters of western rivers and lakes, it readily adapts itself to 
cold, rapid streams and thrives even in small brooks. The species is suitable also for pond life and maly be kept in small areas of water provided they have sulficient depth. It does not prey on other fishes, and its numerous stiff spines protect it from larger fredaceous species. It swims in large sclools and is often found in comparatively shoal water. The nest-building habits have been described by Indos from observations made at Tersailles. France. This writer unfortmnately had under observation both the ralico bass and the common sunfish, and lis statements need comfirmation. The game qualities of this bass are noteworthy. It is a free, vigorous biter, its endmanre is rather remarkable considering its size; as a food fish the species is highly prized, and its increase in eastern rivers is greatly to be desired.

\section{Genus acivthamchus Gill}

Body oblong, robust, not much compressed or elevated; mouth not rery large, the broad maxillary with a well developed supplemental bone; lower jaw projecting; tecth on romer, palatines, pterygoids and tongue, lingual teeth in a single patch, pharyngeal teeth sharp; gill rakers few, rather long and strong; opercle enarginate; preopercle entire; scales cycloil, large; lateral line complete; dorsal spines usually 11; anal spines five; caudal fin rounded bchind. Close to A m b l o plites, differing chiefly in the rounded caudal. One species known.

\section{2:32 Acantharchus pomotis (Baird)}

\section{Mud Sunfish}

Ceutrarchus pomitis BAIrd, Ninth Smithsoll. Rep't, 325, 1555, New . Jersey, New York; GünmHen, Cat. Fisl. Brit. Mus. I, 256. 1859.

Acantharchus pomolis Jomnar \& Gilbert, Bull. 16, U. S. Nat. IIus. 469, 1SS3; BeAN, Bull. U. S. F. C. VII. 143, 18s8; Fishes Penna. 107, 1s!3; Jordan \& Evermann, Bull. 47, U. S. Nit. Mus. 989, 1896, pl. CLT, fig. 118,1900 ; Eugene SMitu, I'roc. Limn. Soc. N. Y. for 1897, 34, 1898.

The mud sunfish has an oblong and moderately elongate bodr, its greatest deptl, near the vent, two fiftlis of the total length without the caudal. The greatest thickness is a little less than one half the depth. The caudal peduncle is short and deep, its least depth two fifths of greatest depth of body. The head 
is moderately large, rather more than one third of total length withont the caudal, its width ergual to the length of its postorbital part. The snout is rery short and obtuse, its length about one half that of the ere. The eye is placed high, its diameter contained three and two thirds times in the length of the head. The interorbital space is slightly convex, its width three fourths the length of the eye. The mouth is large, the maxilla broadly expanded behind and reaching nearly to below the hind margin of the eye. A well developed supplemental maxillary bone, two thirds as long as the eye. Six rows of scales on the cheeks. The operculum ends in two thin, flat points, between which there is a black spot, about two fifths as long as the eye. Gill rakers short and few, five developed on the first arch, the longest two fifths as long as the eye. The spinous dorsal begins over the fifth scale of the lateral line; its base is as long as the head without the snout. The first spine is very short, one half as long as the eye; the spines increase very gradually in length to the last, which is as long as the eje and snout combined. The soft dorsal base is two thirds as long as that of the spinous dorsal; its rays are longer than the spines, the longest (fourth to sixth) about one half as long as the head. The anal begins under 1 Sth scale of the lateral line; the first spine one half as long as the ere; the spines increase in length to the last, which is one third as long as the head; the rays are long, the longest (fourth) equal to postorbital length of head. The rentral reaches to the rent. The pectoral reaches to below the 15th scale of the lateral line. The caudal is rounded, its middle rass five sevenths as long as the head. The lateral line is complete and runs parallel to the dorsal outline. D. XII, 11; 1. VI, 10; V. I, 5; P. 14. Scales 6-4:-12. In spirits the color is dark brown; two or three dusky stripes on the sides below the lateral line; a dark shade around the nape extending backward behind the eye; two dark stripes across the cheeks and operculum; a dark opercular flap as described abore; the fins unspotted. In life the fish is dark green. The example described, no. 17S44 U. S. National Museum, from New Jersey, 
is $4 \frac{1}{5}$ inches long. It has more dorsal and anal spines than are usually present in this sunfish.

The colors of liring specimens were described by Prof. Baird as follows:

Dark greenish olive, with three or four irregular longitudinal bands of dull greenish yellow. and occasionally cloudy spots of golden green. Sides of the head of this color, with three indistinct bands of dark olive. Iris purplish brown; cornea olive green. Fins quite uniform, rery dark greenish olive, with darker margins, except the pectorals, which are light olivaceous, and the ventrals, the spinous rays of which are uncolored. Some specimens may be better described as dark golden green, with longitudinal bands of dark olive, broken up by clourlings of greenish.

Baird called it the bass sunfish because of its resemblance in sliape to some of the basses. The speries ranges from New York to North Carolina in sluggish streams near the coast. Baird collected it in Rockland comnty, N. Y. Eugene Smith took it in the upper Hackensack ralley. Baird found it not rare in Cedar Swamp creek, near Beesleys Point N. J. in 1854; and the writer obtained a single individual in Gravelly run, not far from that locality, in $188 \overline{6}$, associated with the pirate perch, striped mud minnow, barred killifish and young pickerel.

The mud sunfish reaches a length of 6 inches. It prefers muddy water and may even lie embedded in mud. Eugene Smith says it is shy, seclusive and nocturnal in its habits.

\section{Genus ambloplites Rafinesque}

Rody oblong, moderately elerated, compressed; mouth large, the broad maxillary with a well developed supplemental bone, lower jaw projecting; teeth on romer, palatines, tougue, entopterygoids and ectopterygoids, lingual teeth in a single patch, pharengeal feeth sharp; branchiostegals six; opercle ending in two flat points; preopercle serrate at its angle; other membrane bones chiefl c entixe; gill rakers rather long and strong, dentate, less than 10 in number, dereloped only on the lower part of the arch; scales large, somewhat ctenoid; lateral line complete, the tubes occupying at least the anterior half of the surface of the scale; dorsal fin much more developed than the anal fin, with 10 
or 11 rather low spines; anal spines normally six; pectorals obtusely pointed with 14 or 15 rays, the upper longest; caudal fin emarginate.

\section{3.) Ambloplites rupestris (Tafinesque)}

Rock Bass; Redeye

Bodianus rupestris Rafinesque, Am. Month. Mag. II, 120, Dec. 1S17, Lakes of New York, Vermont \& Canada.

Cichla aenea Le Sueur, Jour. Ac. Nat. Sci. Phila. II, 214, pl. 12, 1S22, Lake Ontario.

Centrarehus aeneus Cutier \& Valencienses, Hist. Nat. Poiss. III, 81, 1S29; De FAY, N. I. Fauna, Fishes, 2i, pl. 2, fig. 4, 1S42, Lake Champlain, Great Lakes, streams of western New York, IIudson River; StorER, Syn. Fish. N. A. 37, $18 \pm 6$.

Ambloplites rupestris Jordan \& Gilbert, Bull. 16, U. S. Nat. Mus. 466, 1S8?; Bean, Fishes Peuna. 105, color pl. 10, 1893; Evermari \& Kendall, Rept. U. S. I'. C. for 1894; 600. 1896; Jordan \& EvermanN, Bull. 4i, U. S. Nat. Mus. 990, 1S96, pl. CLVI, figs. 419, A, B, C; MeEk, Ann. N. Y. Ac. Sci. IV, 313, 1S98; Eugene Smith, Proc. Linu. Soc. N. Y. for 1897, 33, 1S9S; Mfarns, Bull. Am. Mus. Nat. Hist. X, 319, 1S9S; BeAN, 521 Aun. Rept. N. X. State Mus. 104, 1900.

The rock bass has a robust oblong body; its depth is contained two and one third times in the total length without caudal, the head two and four fifths in this same length. The caudal peduncle is stout, almost as deep as long. The dorsal profile is rather steep; strongly concave over eye. The eye is large, about one fourth the length of head, equal to snout. The mouth is large, the maxillary reaching to rertical from posterior end of pupil. The heary lower jaw projects slightly. The romer, palatines, tongue and pterygoid bones all toothed; the teeth on the tongue in a single patch. The pharyngeal teeth are sharp. The opercle ends in two flat points; preopercle serrated at its angle. Gill rakers long and strong, less than 10 in number; six branchiostegals; scales large, those on the cheeks in about eight rows; caudal rather deeply emarginate. The dorsal base is about one and one half times as long as that of the anal. The spines of both fins are stout and rather short. The first spine of the dorsal is orer the serenth scale of the lateral line, and the last spine is over the 25th scale. The first soft ray is over the 26 th scale, and the last ray over the 35 th. The anal origin is under the middle of the spinous dorsal, and 
the last anal ray is opposite the last dorsal ray. First dorsal spine shortest, one half the length of longest spine, which is about three fifths as long as the longest ray. The spines and rays of the anal are in about the same proportion to each other as those of the dorsal, the first spine being the shortest and the longest about three fifths as long as the longest anal ray. The soft parts of the dorsal and anal are high and rounded. The pectoral is rather short and broad. The rentral long and slender, directly under base of pectoral. The lateral line is complete, placed high on body and follows the contour of the back. I. XI, 11; A. VI, 11. Scales 5-46-14.

Color olive green with a brassy tinge and much dark mottling; the youmg are pale or rellowisl, irregularly barred and blotched with black; adults with a dark spot at the base of each scale, these spots forming interrupted black stripes; a dark spot on the opercle; soft dorsal, anal, and caudal fins with dark mottlings; iris golden overlaid with crimson.

The rock bass is known under a variety of names. Among them are the following: redeye, red-eyed perch, goggle-ere and lake bass. It is found in Lower Canada, Vermont and throughont the Great lakes region, west to Manitoba, and it is native in Minnesota and Dakota; southward it ranges through the Mississippi valley to Texas. In the Ohio valley it is rery common, while in the Middle Atlantic states, east of the Alleghanies, it has probably been introduced. Its existence in the Susquehanna has been known for many years. Whether it is indigenous in Pennsylvania waters is uncertain. It has been introduced into some parts of Virginia, while in other portions of tinat state it is native. It is indigenous in North Carolina. Its distribution in Pennsylvania has been greatly extended by artificial introduction, and it is now well established in the Delaware, specially in its upper waters. De Kay records it from Lake Champlain, the Great lakes and the larger streams in the western counties of New York. Meek says it is a very common and well known species in the Cayuga lake basin. In the Passaic river and other waters it is an introduced species. Evermann 
and Bean obtained a specimen in scioto creek, Coopersville N. Y. July 19, 1894. In the Lake Ontario region the U. S. Fish Commission collector's secured it at the following localities in New York state in 1894 and previous rear's.

Marsh creek, near P'ointbreeze.

Mouth Little Salmon creek

Chaumont river

Guffon creek, Chaumont

Mill creek, Sacketts Harbor

Black creek, tributary of Oswego river, Scriba Corner

Sandy creek, North Hamlin

Mouth Salmon river, Selkirk

Cape Vincent

Little Stony brook, Henderson bay

Long pond, Charlotte

Cemetery creek, Watertown

Great Sodus bay

Grenadier island, Lake Ontario

Salt brook, $1 \frac{1}{2}$ miles above Nine Mile point

Nine Mile point, Webster

Under circumstances favorable as to water and food supply the rock bass grows to a length of 14 inches and a weight of 2 pounds. It increases in depth and thickness with age. The largest example we have examined is one of 2 pounds weight, length 14 inches, from the James river, Ta., taken near Richmond. Dr William Orerton reports that rock bass weighing $3 \frac{3}{4}$ pounds have been taken in his ricinity at Stony creek, Va.

In February and March this fish frequents the mouths of small streams, and in summer it seeks shady places under high banks or projecting rocks. The species is gregarious, going in large schools. It thrives where there is not much current and is very well adapted for culture in artificial ponds. It is as common in lakes and ponds as in the streams. Sluggish, pure dark water suits it best.

The fishing season begins in June and lasts till the approach of cold weather. The rock bass feeds on worms, crustaceans 
and larrae of insects early in the season; later its food consists of minnows and crawfish. The young feed on insects and their larvae. The spawning season is May and June, and gravelly shoals are resorted to for depositing the eggs.

The rock bass bites very freely and is a fair game fish and excellent for the table. It fights rigorously, but its endurance is not great. Suitable baits are white grubs, crickets, grasshoppers, crawfish and small minnows. Common earthworms are also successfully used.

\section{Genus Channobrtats Gill}

This genus has the general form and dentition of $\mathrm{Amblo}$ plites, with the convex opercle, 10 dorsal and three anal spines of L e p o m is. Preopercle entire; branchiostegals six; caudal fin emarginate; scales weakly ctenoid; vertebrae $13+16=$ 29 ; posterior processes of the premaxillaries extending nearly to the frontals; frontals posteriorly with a transverse ridge connecting the parietal and supraoccipital crest, which are very strong.

\section{Chaenobryttus gulosus (Cuv. \& Val.)}

\section{Warmouth; Goggle-eye}

Pomotis gulosus Cuvier \& Valenciennes, Hist. Nat. Poiss. III, 498, 1829, Lake Pontchartrain and lagoons about New Orleans.

Centrarchus viridis Covier \& VAlenciennes, op. cit. VII, 460, 1S31, Charleston, S. C.

Centrarchus gulosus Cuvier \& Valenciennes, op. cit. VII, 459, 1S31; Günther, Cat. I'ish. Brit. Mus. I, 258, 1859.

Chaenobryttus antistius McKAY, Proc. U. S. Nat. Mus. S8, 18S1, Lake Michigau; Jordan \& Gilbert, Bull. 16, U. S. Nat. Mus. 467, 1883.

Chaenobryttus gulosus Jordan \& Gilbert, Bull. 16, U. S. Nat. Mis. 468, 1SS3; Bollman, Rept. U. S. F. C. XVI, 562, pl. 69, fig. 3, 1892; Jordan \& EvermanN, Bull. 47, U. S. Nat. Mus. 992, 1896, pl. CLVII, fig. 421, 1900.

The body of the warmouth is heavy and deep, more elongate than in Le po mis, its greatest depth contained irom two to two and one half times in total length without caudal; head rather long, its length contained from two and one fifth to two and two thirds times in the total without caudal; eye large, about one fourth as long as the head, and about equal to the snout; month large, the maxillary reaching to below hind margin of eye; gill rakers eight or nine besides some rudinents; oper- 
cular spot about as large as the eye. The dorsal begins farther back than the pectoral, its spines low, the longest equal to distance from tip of snout to middle of pupil; pectoral short, not reaching to anal; rentrals nearly reaching vent, the spine about one half the distance from origin of rentral to rent. D. X, 9 to 10 ; A.IIr, $S$ to 9 . Scales $6-40$ to $46-11$ to 12 ; pores 37 to 42 ; 6 to $S$ rows on cheek.

Color in life clear olive green clouded with darker, usually without red or blue; a dusky spot on each scale more or less distinct; vertical fins mottled with dusky; a faint spot on last rays of dorsal bordered by paler; three oblique dusky bars radiating from eye; belly yellowish.

The warmouth inhabits the eastern Cnited States from the Great lakes to South Carolina and Texas, ranging west to Kansas and Iowa. It occurs chiefly west or south of the Alleghanies. The fish reaches a length of 10 inches and is a food species of some importance. It is extremely roracious and, consequently, a farorite for angling. In form and color it varies greatly.

\section{Genus exreacastus Gill}

Body rather short and deep, compressed; mouth small; the supplemental maxillary bone well developed; teeth on romer and palatines, none on the tongue; opercle ending behind in two flat points, with a dermal border; preopercle entire; scales rather large, the lateral line sometimes interrupted; gill rakers short, nine or 10 below angle of arch; dorsal fin continuous, normally with nine spines; anal fin smaller than the dorsal, with three spines; caudal fin conrex behind; branchiostegals six. Species of small size and bright coloration, intermediate between Le pomis and $\mathrm{Centrarch} \mathrm{s}$. Abnormal variations in the number of dorsal and anal spines have given rise to the nominal genera $\mathrm{H}$ e mioplites and $\mathrm{Copel}$ a n d ia.

\section{Enneacanthus obesus (Baird)}

\section{Banded Sunfish}

Pomotis obesus BAIRd, 9th Ann. Rept. Smith. Inst. 324, 1555, Beeslers Point, N. J.

Bryttus fasciatus Hocbrook, Jour. Ac. Nat. Sci. Phila. 51. pl. 5. fig. 3, 1855, St John's River, Fla.; Guxtner. Cat. Fish. Brit. Mus. I, 260, 1859. 
Pomotis guttatus Morris, Proc. Ac. Nat. Sci. Phila. 3, 1559. Delaware River, Philadelphia, Pa.

Enneacanthus obesus Jordax \& Gilbent, Bull. 16, U. S. Nat. Mus. 470, 18s3; Bean, Fishes Penna. 108, 1893; Eugene Smitir, Ploc. Linn. Soc. 1897, 34,1898 , Hackensack Valley, N. Y.

The body of the banded sunfish is elliptic in form, its depth more than one half the total length without caudal, its thickness equal to two fifths of its depth. The caudal peduncle is short and stout, its least depth one third of greatest depth of body. The head is short, two fifths of total length without the caudal; the snout is very short and obliqne, its length about two thirds of the diameter of the eye, which is one third as long as the head, and exceeds the width of the interorbital space. The mouth is oblique, moderate in size, the maxilla broadly expanded posteriorly and reaching to below the middle of the eye; a supplemental maxillary bone. A black opercular flap, two thirds as long as the eye. Scales on cheeks in four rows. Gill rakel's short and spiny, 13 developed on the first arch, the longest scarcly one half as long as the eye. The first dorsal spine is orer the pectoral base, minnte, less than one half as long as the second, which is two thirds as long as the eye; the spines increase in size to the last, which is one half as long as the head; the fourth and longest soft ray is two thirds as long as the head. The rentral begins a little behind the pectoral base; the spine is two fifths as long as the head; the fin reaches to the second anal ray, its longest ray produced into a filament. The anal begins under the 13th scale of the lateral line; the base is two thirds as long as the head; the first spine is two thirds as long as the second, which is as long as the eye; the last spine is as long as the eye and snont combined. The anal lays increase in length to the fifth. which is as long as the heat without the snout. The pectoral is below the median line and reaches to above the third anal spine. The caudal is romuled, the middle rays as long as the head without the snout. The lateral line is imperfect after the 1 ith to the 1 !)th scale. 1). IX, 11; I. III, 10; V. I, 5; P. 12. Seales 5-:32-10. The type of the species, no. 15:38. U. S. National Musemm, from Porstegs Point X. J. is here described; it is $3 \frac{3}{x}$ inches long. 
The banded sunfish inhabits coastwise streams from Massachu. setts to Florida. It occurs in southeastern Pennsylyania but is rare.

This species grows to a length of $: 3$ inches. It is olive green in color with five to eight dark cross bars intermingled with golden or purplish spots. There are lines and spots also on the cheeks. The flap on the opercle contains a relrety black spot with a purple border. Below the eye is a dark bar. This is a beautiful litte species, but has no economic importance.

In our vicinity it inlubits the entire Hackensack valley, preferring quiet, weedy places. For the aquarium it is the most desirable of all the sunfishes, as well on account of its hardiness as of its harmless nature. Eugene s'mith

\section{Enneacanthus gloriosus (Holbrook)}

\section{bilue-spotted sumfish}

Bryttus gloriosus Holbrook, Jour. Ae. Nat. Sci. Phila. 52, pl. 5, fig. 4, 1S55, Cóoper River, s. C.; Güntmer, Cat. Fish. Brit. Mus. I, 260, 1859. Hemioplites simulans Cope, Jour. Ac. Nat. Sci. Phila. 21S, 1868, Tuckahoe Creek, near Richmond, Ta.

Enmeacanthus simulaus Jordax \& Gilbert, Bull. 16, U. S. Nat. Mus. 470, 1SS3; Bean, Fishes Penna. 10S, 1S93, Trenton, N. J.

Enncacanthus criarchus JomDAx \& Gilbert, Bull. 16, U. S. Nat. Mus. 4t9, 1883.

Euncacauthus criarchus JORDAx \& GILBERT, op. cit. $469,1583$.

Enncacauthus gloriosus Bollyax, Rept. C. S. F. C. XVI, 561, 1892; Jordan \& Evermaxi, Bull. 47, U. S. Nat. Mus. 993, 1896, pl. Clvili, fig. 442, 1900 ; Menris, Bull. Al1. Mus. Nat. Hist. X, 319, 1895.

The blue-spotted sunfish has an elliptic bodr, its greatest depth one half of the total length without the caudal, its thickness nearly two fiftlis of its depth. Caudal peduncle short, its least depth one third of greatest depth of body. Head moderately large, three eighths of total length without the caudal; snout rery short and oblique, two thirds as long as the eye, which is nearly one third as long as the head; month moderately large, oblique, the broadly expanded maxilla reaching nearly to below front of pupil: lower jaw slightly projecting; the operculum cuds in two flat points, between which there is a dark spot two thieds as long as the eye aud holdered bolon hy a narew pearly streipe: gill ralkers sholet and stont, 11 dereloped on first 
arch, the longest one third as long as the ere; four rows of scales on the cheeks. The spinous dorsal begins over the fourth scale of the lateral line; its base is two thirds as long as the head; the first spine is nearly one half as long as the eye; the spines gradually increase in length to the fourth, which is equal to those that follow it and to the length of the postorbital part of the head; the fifth, and longest, soft ray is as long as the head without the snout; the last soft ray is as long as the postorbital part of the head. The anal origin is under the 14th scale of the lateral line; the base of the anal fin is as long as the head without the snout; the first spine is one fourth as long as the head; the third and longest spine equals the postorbital part of the head in length; the third and fourth soft rays are longest, as long as the head without the snout. The ventral reaches to the second anal ray, its spine as long as the postorbital part of the head. The pectoral is placed below the median line of the body; it reaches to below the 14th scale of the lateral line. The caudal is rounded; its middle rays are three fourths as long as the head. The lateral line is usually completc, sometimes imperfect on one side. D. IX, 11; A. III, 10; V. I, 5; P. 11 . Scales 4-31-10.

In spirits the color is brownish; about seren or eight rows of scales below the lateral line with pearly blotches forming interrupted stripes; a dark band under the eye; the dorsal, anal, and caudal profusely spotted with roundish, pearly spots. Young individuals are obscurely banded. In life the spots of the male are blue, and the fins are higher than in the female; the opercle bears a pearly blue spot. The specimens described, no. 20356, U. S. National Museum, are from Trenton N. J. The largest is 3 inches long.

The blue-spotted sunfish is found from New York to South Carolina. According to Cope, it is rery common in southeastern Pennsylvania. Mearns obtained it only in Long pond, a sheet of deep water almost a mile in length, 4 miles west of Highland Falls N. Y. He discovered the species there more than 23 years ago, and reports it still common. 
This is a small species, not much larger than the banded sunfish. It is a handsome fish, but has $n 0$ importance for food.

\section{Genus apowotrs Rifinesifue}

This genus is very close to $\mathrm{I}_{1}$ e p o m is, from which it differs only in the development of the supplementary maxillary bone, which becomes rudimentary or wanting in the adult of $\mathrm{Le}$ pomis. The mouth is largest in the species in which this bone is best developed. Lower pharyngeals narrow, with acute teeth; gill rakers well dereloped, long and stiff; pectoral bluntish, shorter than head; scales moderate, 43 to 50 . Species widely distributed in American waters, similar in habit to the species of L e p o mis.

\section{Apomotis cyanellus (Rafinesque) \\ Green Sunfish; Redeye}

Lepomis cyanellus Rafixesque, Jour. de Phys. 420, 1819, Ohio Rivel; Jordan \& Gilbert, Bull. 16, U. S. Nat. Mus, 473, 18S3; Bean, Fishes Penna. 110, pl. 31, fig. 61, 1893; MeEr, Ann. N. Y. Ac. Sci. IV, 313, 18SS; Evermanx \& Kendall, Bull. U. S. F. C. XII, 111, 1994.

Pomotis longulus Baird \& Girard, Proc. Ac. Nat. Sci. Phila. 391, 1853. Otter Creek, Arkansas; Irarcy's Expl. Red Rirer, 245, pl. 12.

Bryttus longulus BaIrd \& GIRARd, 1. c. 25, 1S54; GüNther, Cat. Fish. Brit. Mus. I, 259, 1859.

Callinus longulus Girard, U. S. Pacif. I. R. Exp. Fishes, 16, pl. 5, figs. 5-8, pl. 6, figs. 5-S, 1S58; Rept. U. S. Mer. Bound. Surr. Ichth. 5, pl. IV, figs. 1-4, 1559 .

Callinrus formosus Girard, Proc. Ic. Nat. Sci. Phila, 200, 1857, Arkansas;

U. S. Pacif. R. R. Exp. Fishes, 14, pl. 5, figs. 1-4, 1858.

Apomotis cyanellus Rafinesque, Jour. de Phys. Paris, 420, 1S19; Boulenger,

Cat. Fish. Brit. Mus. I, 21, 1896; Jordan \& Evermann, Bull. 47, U. S.

Nat. Mus. 996, 1896.

The green sunfish has an oblong body, its greatest depth, at the rentrals, equal to three serenths of the total length without the caudal, and its thickness three eighths of its depth. The least depth of the candal peduncle equals four fifths of its length, and about one third of greatest body depth. The head is one third of total length without the candal, its width nearly one half its length. The snout is moderately pointed, and as long as the eye, which is two ninths as long as the head. The interorbital space is nearly flat, its width a little greater than the length of the eye. The nape is moderately arched. The 
mouth is moderately large. the maxilla not widely expanded behind and reaching to below the front of the pupil. Supplemental maxillary bone well developed; seren rows of scales on the cheeks; gill rakers short and stiff, 11 dereloped on the first arch, the longest one third as long as the eye; a short, broad opercular flap, its width and length about equal and two thirds of length of eye. The spinous dorsal begins orer the sixth scale of the lateral line, its base nearly equal in length to the head; the first spine is two thirds as long as the eye; the spines increase gradually in length to the seventh, which is two fiftlis as long as the spinous dorsal base and one half the length of the head without the snout; the 10th spine is nearly as long as the serentli; the seventh and longest soft ray is one half as long as the head; the last ray is one third as long as the head. The base of the soft dorsal is about two thirts as long as the spinous dorsal base. The anal begins under the zth scale of the lateral line; the first spine is three fourths as long as the eye; the second is nearly twice, and the third two and one half times as long as the first; the length of the anal base equals one fifth of the total without the caudal; the fourth and longest anal ray is as long as the postorbital part of the head; the last ray is a little more than one half as long as the fourth. The caudal fin is emarginate, the middle rays three fourths as long as the external. The rentral reaches to the rent, its spine one half as long as the head, without the snout, its length one fifth of the total without the caudal. The pectoral reaches to below the 17 th scale of the lateral line. The lateral line follows the outline of the back. D. X, 11; A. III, $10 ;$ T. I, 5; P. 13. Scales $7-47-14$.

In spirits the color is pale brown, the fins paler. The opercular flap has a dark spot as described above. In life there is generally a black blotch on the hinder part of the dorsal and anal; the ground color is greenish with a brassy tinge on the sides, the lower parts rellowish; blue spots and gilt borders usually ormament the scales, and faint dark lands are often present. The dorsal, anal and camdal have blue or green mark- 
ings, and the anal is margined in front with orange. The iris is red and the cheeks are striped with blue. The specimen described, no. 36313, U. S. National Museum, from the Sac river, Mo., is $T$ inches long.

The blue-spotted sunfish, also known as the green sunfish and redeye, occurs from the Great lakes region, throughout the Ohio and Mississippi valleys south to Mexico. It does not occur in the Middle Atlantic states east of the Alleghanies. Dr Meek did not find this fish near Ithaca. A few specimens were taken near Montezuma N. Y. None of the collectors of the U. S. Fish Commission obtained it in the Lake Ontario region.

The species reaches a length of $\tau$ inches, and is an extremely variable one. Prof. Cope refers to it as a good panfish and states that it is abundant in the Ohio basin. In the Ohio ralley it is one of the characteristic fishes, inlabiting ponds and ascending small streams. It frequents deep holes and the shelter of overhanging roots.

\section{Genus Lepoms Rafinesque}

Body oblong or orate, more or less compressed, the back in the adult somewhat elevated; mouth moderate or small, the jaws about equal; maxillary narrow, the supplemental bone reduced to a mere rudiment, or altogether wanting; teeth on vomer and usually on palatines, none on tongue or pterygoids, lower pharengeals narrow, the teeth spherical or pared, all or nearly all sharp, few or none of them conical; gill rakers mostly short; preoperculum entire; operculum ending behind in a conrex flap, black in color, which in some species becomes greatly dereloped with age; branchiostegals six; scales moderate; dorsal fin continuous, with 10 spines; anal with three spines: candal fin emarginate; pectorals long or short; rertebrae usually $13+16$ or $1 \bar{\imath}=\mathbf{2}$ or 30 . Coloration brilliant, but eranescent. A large genus, one of the most difficult in our fish fauna in which to distinguish species. The form of boly, derelopment of ear flap, and hight of spiues vary with age and condition, while the general appearance and the numbers of fin rays and scales are essentially the same in all. Sereral at- 
tempts have been made to subdivide the group, but the char. acters used, drawn from the pliaryngeals, gill rakers, palatine teeth, and pectoral fins, are themselves subject to rariation, changing or disappearing by degrees without marked gaps.

\section{Lepomis auritus (Linnaeus) \\ Lony-eared Sunfish}

Labrus auritus Linnaeus, Syst. Nat. ed. X, I, 28:, 1758, Philalelphia, Pa. Labrus appendix Mitchill, Am. Month. Mag. II, 24t, February, 1818.

Pomotis appendix DE KAY, N. Y. Fauna, Fishes, 32, 1St2, from Mitchill; Storer, Hist. Fish. Miass. 14, pl. III. fig. 4, 1867.

Pomotis rubricauda Storer, Bost. Jour. Nat. Hist. IV, 177, 1St2, Concord, N. H.; Günther, Cat. Fish. Brit. Mus. I, 262, 1859.

Lepomis elongatus and mystacalis Jordan \& GILBert, Bull. 16, U. S. Nat. Mus. $475,1883$.

Lepomis auritus JordaN \& Gilbert, Bull. 16, U. S. Nat. Mus, 477, 18\$3;

Bean. Fishes Penna. 113, pl. 31, fig. 63, 1893; Jordan \& Evermand,

Bull. 47, U. S. Nat. Mus. 1001, 1596, pl. CLXIX, figs. 425, 425a, 1900;

Mearns, Bull. Am. Mus. Nat. Hist, X, 319, 189S; Eugene Smith, Proc.

Linn. Soc. N. Y. 1897, 34, 1898.

The long-eared sunfish has an oblong, moderately elongate body, its depth nearly one half of the length without the caudal and its thickness a little more than one third of its depth. The caudal peduncle is moderately short, its least depth three fourths of its length and one third of greatest depth of body. The head is rather large, its length without the flap one third of the total without caudal, its width one half of its length. The space between the eyes is conrex, its width a little more than the length of the snout, wlich is two ninths as long as the head including the flap. The upper edge of the snout is oblique. The eye is one fourth as long as the head without the flap. The mouth is moderate in size, the maxilla not very broadly expanded behind and extending to below the front of the pupil. The scales on the cheeks are very small, in about eight rows. The opercular flap is long, narrow and pointed, its length equal to that of the snout and about twice its width. The gill rakers are short and stout, about 11 developed on the first arch, the longest one third as long as the eye. The spinous dorsal begins over the sixth scale of the lateral line; its base is two sevenths of total length without caudal; the first spine is two thirds as 
long as the second, which is as long as the eye; the fourth (longest) is one and one half times as long as the eje; after the fourth the spines slightly decrease in length, the last being little longer than the eye; the fifth (longest) soft ray is as long as the base of the soft dorsal and equal to the snout and eye combined; the last soft ray is a little more than one half as long as the longest. The anal begins under the 21 st scale of the lateral line; the length of its base equals that of the soft dorsal; the spines are short and stout, the first two thirds as long as the second and one half as long as the third, which is one and one half times as long as the eye; the fourth (longest) soft ray is as long as the base of the fin; the last ray. is two thirds of this length. The candal is emarginate, the middle rays two thirds as long as the outer. The ventral reaches beyond the vent, sometimes to the origin of the anal. The ventral spine is one half as long as the fin. The pectoral has a broad base and extends to below the 19th scale of the lateral line. D. X, 10; A. III, 9; V. I, 5; P. 14. Scales 7-43-13. The lateral line follows the curve of the back.

In spirits the color is pale brown; the fins somewhat paler; the ear flap black; a brownish streak in front of the eye and another horizontal one beneath it. In life the color is olivaceous; the belly, specially in breeding males, orange. The scales on the sides have reddish spots on a bluish ground. Dorsal, anal and caudal nsually yellowish. The stripes on the head are bluish.

The specimen described, no. 33152, U. S. National Museum, from Bainbridge $\mathrm{Pa}$. is $5 \frac{1}{2}$ inches long.

The long-eared sunfish has a rery extensive range and is known under many common names, among which are the following: bream, red-tailed bream, redhead bream, red-bellied bream, perch, sun perch, red-bellied perch and redbreast.

The species is common in streams east of the Alleghanies from Maine to Florida, and in tributaries of the Gulf of Mexico to Louisiana. In the southern states the typical long-eared sunfish is replaced by a variety with larger scales on the cheeks 
and belly and a dusky blotch on the posterior part of the soft dorsal fin.

Mearns found this sunfish abundant in the Hudson and in Poplopen's creek, a tributary of the Hudson; he took it also in Highland lake. Eugene Smith reported it to be very common in the upper Passaic river, in the Great swamp and in the Bronx river.

The long-eared sunfish arerages about $S$ inches when adult and weighs about 1 pound. In the south the size and number of individuals are greatly increased. This fish feeds on worms, insect larvae, crustaceans, mollusks and small fishes. In the Susquehanna this is one of the most common of the sunfishes; in the Delaware also it is abundant, and reaches a large size. Though not important commercially, it is taken in large numbers on the hook and is an excellent food fish. It takes any kind of live bait very readily and furnishes good sport also with the artificial fly. In the Hudson Highlands region, according to Mearns, it is commonly sold in the markets; fishermen take it in fykes, and by angling, using dough, grasshoppers and angleworms for bait. He has caught it in the most rapid parts of Poplopen's creek when angling for brook trout.

\section{Lepomis pallidus (Mitchill)}

\section{Bluegill; Blue Sunfish}

Labrus pallidus Mrtchild, Trans. Lit. \& Phil. Soc. N. Y. I, 407, 1815, near New York.

Pomotis incisor Cuvier \& Talenchennes, Hist. Nat. Poiss. VII, 466, 1831, New Orleans; DE KAY, N. Y. Fauna, Fishes, 33, 1842 (extralimital). Pomotis gibbosus Cuvier \& Valenchenves, op. cit. VII, 467, 1831, Charleston, S. C.

Pomotis speeiosus Günther, Cat. Fish. Brit. Mus. I, 263, 1859.

Lepomis pallidus Jordan \& Grlbent, Bull. 16, U. S. Nat. Mus. 479, 1883; Meer, Ann. N. Y. Ac. Sci. IV, 313, 1888; Bean, Fishes Penna. 112, pl. 31, fig. 62, 1S93; Jotidan \& Evermann, Bull. 47, U. S. Nat. Mus. 1005, 1S96, pl. CLX, fig. 427, 1900.

The blue sunfish has a deep, elliptic body, its greatest depth at the ventrals one half of the total length without the caudal; the thickness equals about one third of the depth. The caudal peduncle is short and deep, its least hight nearly one half the length of head. The head is one third of the total length with- 
out the caudal; its widtl equals one half of its length. The snout is short, obtuse and oblique, less than the eye in length. The interorbital space is slightly convex, its width one third of the length of the head. 'The mouth is small, oblique, the maxilla not greatly expanded bchind, reaching to below the front of the eye. The width of the preolbital equals one half the diameter of the eye. Scales on the checks in five rows. The gill raker's are short and stout, about 15 developed on the first arch, the longest little more than one fourth as long as the eye. No supplemental maxillary bone. No palatine teeth. The lower pluarygeal bone narrow, with teeth in only about four series, chiefly acute. The spinous dorsal begins over the fourth scale of the lateral line; the spines are stout, the first as long as the snout and one half as $\operatorname{lon} g$ as the fifth and longest; the spines following the fifth not much shorter; the first seren soft rays about equal in length and one half as long as the head; the last ray one third as long as the head. The base of the spinous dol'sal is nearly as long as the head; the soft dorsal is two thirds as long as the spinous. The anal begins under the 20 th scale of the lateral line; its base is as long as the head without the snout; the spines are short and heary, the first five sixths as long as the eye, the second a little longer than the eye, and the third one half as long as the head without the snout; the longest rars are the fourth to the seventh, which are one half as long as the head. The caudal is notched, its middle rays three fourths as long as the outer. The ventral reaches almost to the anal, its spine being one half as long as the head without the snout. The pectoral is broad and reaches to below the 18th scale of the lateral line. The lateral line follows the culve of the back. I. X, 11; A. III, 10; V. I, 5; P. 13. Scales 7-41-15.

In spirits the color is pale brown, the scales with a pale margin; a large dark blotch on the hind part of the soft dorsal; a black opercular flap, its width and length about equal, shorter than the eye. The living fish varies with age from light green to dark green. The young have the sides silvery, tingrod with 
purple and with many vertical greenish bands, which are sometimes chainlike. The dark blotch of the soft dorsal is often indistinct in the young. In rery old individuals the belly is often coppery red. The specimen described, no. 27845, U. S. National Museum, from Peoria I11., is $7 \frac{1}{2}$ inches long.

The propriety of using Mitchill's name pallidus for the blue sunfish is extremely doubtful. His description can be much more readily referred to a species of $\mathrm{E} n \mathrm{n}$ e a c a $\mathrm{n} t \mathrm{~h} u \mathrm{~s}$, and the locality "near New Tork" does not possess this sunfish among its natire species.

The blue sunfish, blue bream, copper-nosed bream or dollardee, is a very widely diffused species and varies greatl $\Gamma$ in size, color and length of the ear flap. It is found in the Great lakes and throughout the Mississippi ralley to Mexico. East of the Alleghanies it ranges from New Jersey to Florida. In Pennsylvania it is abundant only in the western part of the state, including Lake Erie. Ir Abbott has recorded it from the Delaware river. Dr Meek says that it is found in the Cayuga lake basin in small number's with the blue-spotted sunfish, A po motis c y a nell us, which he took near Montezuma.

The blue sunfish grows to a length of nearly 1 foot, and individuals weighing nearly 2 pounds are on record. Adults, howerer, arerage 8 inches in length, with a weight of less than 1 pound. The size of the individuals depends on the habitat. In large lakes and streams it grows to a greater size than in small bodies of water. In southern waters it attains to a larger size than in northern waters. It lives in ponds as well as in streams and thrives in warm waters. It is considered equal to the rock bass as a panfish and can very readily be taken by hook flshing.

\section{Genus Euponotis Gill \& Jordan}

Very closely related to $\mathrm{L}$ e p o mis, differing only in the blunter and more parementlike teeth of the lower pharyngeal bones. These bones are, in typical species, broad and concare. specially in the adult. There is considerable rariation among the species, and it is possible that this division can not be maintained. Most of the species have long pectoral fins, the sup. 
plemental maxillary lost or very much reduced, and the opereular flap always with an orange patch on its lower posterior part. Gill rakers various, usually short. The retention of this genus is possibly justified by convenience, but neither the longer pectorals nor the blunt pharyngeals separate it sharply from Le pomis.

\section{Eupomotis gibbosus (Linnaeus)}

\section{Sunfish; Pumplin Seed}

Perca gibbosa Linnaeus, Syst. Nat. ed. X, I, 292, 175S, Carolina.

Sparus aureus Walbaum, Artedi. Gen. Pisc. 290, 1792, lakes of New York. Morone maculata MitcinLL, Report in Part, 19, 1814.

Pomotis vulgaris Cuvier \& Valenciennes, Hist. Nat. Poiss. III, 91, 1529, Lake Huron, New York, Vilginia; and Carolina; DE KAY, N. X. Fauna, Fishes, 31, pl. 51, fig. 166, 1S12; Holbrook, Ichth. S. C. 6, pl. 1, fig. 2, 1856.

Pomotis auritus Günther, Cat. Fish. Brit. Mus. I, 261, 1859.

Lepomis gibbosus JordaN \& Gilbert, Bull. 16, U. S. Nat. Mus. 4S2, 1S83; Meek, Amn. N. Y. Ac. Sci. IV, 313, 1SSs; BeAx, Fishes, Penua. 115, pl. 32 , fig. $65,1593$.

Eupomotis aureus MAther, App. 12th Rept. Adirondack Surv. N. I. †, 1856.

Eupomotis gibbosus Jordan \& Evermann, Bull. 47, U. S. Nat. Mus, 1009, 1896, pl. CLXI, fig. 429, 1900; BEAr, Bull. Am. Mus. Nat. Hist. IX, 364, 1S97; Mearns, Bull. Am. Mus. Nat. Hist. $\mathrm{I}$, 320, 189S; Eugene Suith, Proc. Linn. Soc. N. Y. 1897, 35, 1S9S; BeAN, 52d Ann. Rept. N. Y. State Mus. 104, 1900.

The body of the common sunfish is nearly orate, its depth one half the total length without caudal; its thickness one third of the depth. The caudal peduncle is short and compressed, its least depth less than the thickness of the body. The head is moderately large, one third of the total length without caudal, its width one half its length. The snout is short and depressed, its length four fifths of the diameter of the eye, which is one fourth as long as the head. The interorbital space is nearly flat, its width one and one lualf times the diameter of the eye. The mouth is small and oblique; the maxilla not much expanded behind and reaching to below the front of the eye. Scales on the cheeks in four rows. The opercular spot is short, less than two thirds the diameter of the eye, and has a whitish. margin behind. The gill rakers are very short, moderately stout, 10 or 11 developed on the first arch, the longest less than 
one fourth the diameter of the eye. The spinous dorsal begins orer the third scale of the lateral line; its base is as long as the head without the opercular flap; the first spine is two thirds as long as the eye; the spines increase in size, the fourth, fifth and sixth being nearly equal in length and about as long as the eye and snout combined; the sixth and longest soft ray is as long as the postorbital part of the head, while the last ray is less than one third as long as the head. The base of the soft dorsal is as long as that of the spinous dorsal. The anal origin is under tlie $23 \mathrm{~d}$ scale of the lateral line. The anal base is two thirds as long as the head; the first spine is about one half as long as the third (longest), which is two fifths as long as the head. The first and second rays are the longest, nearly as long as the base of the fin. The last ray is two thirds as long as the first. The rentral reaches beyond the rent; its spine is one half as long as the head without the snout. The pectoral reaches to above the anal origin. The caudal is emarginate, its middle rays four fifths as long as the outer. The lateral line follows the curve of the back. D. X, 12; A. III, 10; V. I, 5; P. 13. Scales 6-42-13.

In spirits the color is pale brownish, the opercular flap black with a narrow whitish margin behind and beneath, and the dorsal fin with faint dusky blotches. In life this is one of the most brilliant of sunfishes, the upper parts being greenish olive with a bluish tinge, the sides profusely spotted with orange, the belly and lower fins orange and the dorsal and caudal fins bluish with orange spots. The cheeks are orange with undulating blue stripes; the opercular flap is black, emarginated behind and underneath with bright scarlet.

The specimen described, no. 20304, U. S. National Musenm, from the Susquehanna at Harre de Grace, is nearly 6 inches iong.

The common sunfish, or sunny, pumpkin seed, bream, tobacco box, and pondfish is one of the best known fishes of the United States.

It is found from Maine westward through the Great lakes region to Minnesota and in the eastern states south to South 
Carolina. In western rivers, howerer, it is seldom found south of the latitude of Chicago. In New York the sunfish abounds almost everywhere, in the lowlands as well as the highlands and in brackish as well as fresh waters; it has even been taken occasionally in salt water on Long Island. Large individuals have been receired from Canandaigua lake and from lakes in the Adirondacks. Dr Heek found it very common throughout the Cayuga lake basin. The collectors of the U. S. Fish Commission obtained it in almost all the waters visited by them (21 localities) in the Lake Ontario region. Eugene Smith reports it from most of the moraine ponds of Long Island and Staten Island, and in quarry ponds of the Palisades, wherein it is frequently placed by boys. Ponds and lakes in the parks of New Jork city are well stocked with this species. Mearns reported it as abundant in the Hudson and in all the ponds and slow streams of the Hudson Highlands. Mather recorded it as a common fish in most of the Adirondack waters, the exceptions being Piseco lake, G lake, Coald lake, Sents' lake, 'T lake, W'illis pond, Mrphy, Warner and Bug lakes.

The common sunfish grows to a length of $S$ inches and a weight of about $\frac{1}{2}$ pound. Its food is similar to that of the long-eared sunfish; and it is one of the readiest biters known to the angler. The habits of this fish have been described by Dr Theodore Gill and W. P. Seal. The latter states that the male in the breeding season is readily identified by his brighter coloration, conspicuous ear flaps and a Iuminous border around the fins while in the water. The nest is a depression in the mud, sand or gravel, hollowed out by means of the fins. In the Potomac he found a number of nests which were located from a few inches to several feet apart. The male watches the nest and drives away all intruders. The eggs are only about $\frac{1}{32}$ of an inch in diameter and not very numerous. They are attached to stones and aquatic plants. Mr Seal has reason to believe that the male alone is concerned in building the nest and in the care of the eggs and young.

The species is usually hardy in captirity, but is subject to fungus attacks which yield readily to treatment with brackish 
water. In the aquarium, according to Eugene Smith, the common sunfish by incessant attacks often kills associates of many kinds. It is a very gany fish, common everywhere and is usually found in the company of shiners, minnows and killies. In quarry ponds, of the Palisades, says the same author, the fish will thrive and multiply as freely as the goldfish, provided there is water enough throughout the year.

\section{Genus miropteris Lacépède}

Body oblong, compressed, the back not much elevated; head oblong, conical; mouth very large, oblique, the broad maxillaly reaching nearly to or beyond the posterior margin of the eye, its supplemental bone well developed; lower jaw prominent; teeth on jaws, vomer and palatines in broad villiform bauts, the inner depressible, usually no teeth on the tongue; preopercle entire; operculum ending in two flat points without cartilaginous flap; branchiostegals normally six; gill rakers long and slender; scales rather small, weakly ctenoid; lateral line complete, the tubes straight, occupying the anterior half of each scale; dorsal fin divided by a deep notch, the spines low and rather feeble, 10 in number; anal spines three, the anal fin much smaller than the dorsal; pectorals obtusely pointed, the upper rays longest; ventrals close together below the pectorals; caudal fin emarginate; posterior processes of the premaxillaries not extending to the frontals; frontals posteriorly with a transverse ridge connecting the parietal and supraccipital crests, which are very strong; vertebrae $16+16$ or $17=32$ or 33 . Size large. Two species, among the most important of American "game" fishes.

\section{Micropterus dolomieu Lacépède}

\section{Small Mouthed Black Bass}

Micropterus dolomien LAcÉréde, Hist. Nat. Poiss. IV, 325, 1S02; Jordan \& Gilbert, Bull. 16, U. S. Nat. Mus. 485, 18s3; MATHER, App. 12th Rept. Adirondack Surv. N. Y. 5, 18S6; MeEK, Ann. N. Y. Ac. Sci. IV, 313, 18ss; Bean, Fishes Penna. 116, colol pl. 11, 1893; Evermann \& Tíndall, Iiept. U. S. F. C. for 1894, 600, 1896; Jordan \& EvermanN, Bull. 47, U. S. Nat. Mus. 1011, 1896, pl. CLXII, figs. 430, 430a, 1900; Bean, Bull. Am. Mus. Nat. Hist. IX, 364, 1897; Mearns, id. X, 320, 1898; Eugene Smith, Proc. Linn. Soc. N. Y. 1897, 35, 1898. 
Centrarchus obseurus DE KAY, N. I. Fauna, Fishes, 30, pl. 17, fig. 48, 1842, Onondaga Creek, N. Y.; Günther, Cat. Fish. Brit. Mus. I, 25S, 1859.

The small mouthed bass difler's most markedly from the large mouthed in the size of its jaws, the shallower notch in the dorsal fin and the smaller scales. There are about 11 rows of scales above the lateral line and seven below it; $72-74$ scales in the lateral line. The ninth spine of the dorsal is longer than the eye and fully two thirds as long as the fifth and longest spine. The upper jaw extends backward to below the hind margin of the re. The body is ovate oblong in shape, its greatest depth about equal to length of the head and one third of the total without caudal, becoming deeper with age. The ere is less than two thirds as long as the snout and about one sixth the length of head. The pectoral is not much longer than the rentral and slightly more than one half the length of head. The soft dorsal and anal are more scaly at the base than in the large-mouthed species. The scales on the cheeks and breast are very much smaller than those on the middle of the sides. D. X, 13-15; A. III, 10.

The young are dull yellowish green, the sides mottled with darker spots, which sometimes form short vertical bars. Three dark stripes on the head; caudal yellowish at the base; a broad black band near middle of tail and a broad whitish margin bchind. The dark lateral band characteristic of the large mouthed species is not found in the small-mouth. In the adult the prevailing color is olive green, the stripes on the head remaining more or less distinct.

One of the early names for the small mouthed black bass is that of growler, which appears in the writings of Cuvier, who was under the impression that the name was applied because of a noise sometimes produced by this bass. At the time of his writing the name growler was pretty generally identified with the black bass. Among the names applied to this fish by Rafinesque are lake bass, big bass, spotted bass, and achigan. He also mentions it under the names painted tail, bridge perch, sellow bass, gold bass, brown bass, dark bass, minny bass, little 
bass, hog bass, yellow perch, black perch, trout perch, streaked head, white trout and brown trout. In the southern states the small-mouth is known as the trout, perch and jumper. In Alabama it is called mountain trout. Some persons style it the bronze backer. The most appropriate name and the one by which it is best known is that of black bass or small mouthed black bass.

This species is indigenous to the upper parts of the St Lawrence basin, the Great lakes region and the basin of the Mississippi. East of the Alleghanies it is native to the headwaters of the Ocmulgee and Chattahoochee rivers, but north of these streams, though not originally an inhabitant of the waters, it has been widely distributed by artificial introduction.

In the St Lawrence river Evermann and Bean obtained the fish 3 miles below Ogdensburg N. Y. July 17, 1894, evidently the young of the year, as the specimen is $1 \frac{3}{4}$ inches long. In Scioto creek at Coopersville $\mathrm{N}$. Y. they secured an example $1 \frac{5}{8}$ inches long July 19, 1894. Field assistants of the U. S. Fish Commission, collecting in the Lake Ontario region of New York in 1894 and preceding years, took specimens in the following localities.

Big Stony creck, Henderson Harbor

Mouth SaImon river, Selkirk

Marsh creek, Point Breeze

Four mile creek, Nine Mile point, Webster.

Wart creek

Black river, Huntingtonville

Cape Vincent

Mouth Little Salmon creek

Great Sodus bay

Sandy creek, North Hamlin

Long pond, Charlotte

Meek did not find this species in the vicinity of Ithaca. Near Caruga and Montezuma it is less common than the largemouthed black bass. Mather reported the species in Racquette, Forked, White, Fourtl, Bisby and Sucker lakes, Black and Moose rivers, and in Partlo pond, St Lawrence county, in all of 
which it has been introduced. The fish is not uncommon in take Champlain; it is abundant in the vicinity of Caledonia N. Y. Eugene smith records it from the Passaic river. The writer has found it abundant in the Bronx. Mearns mentions it from Long pond, in the Hudson Highlands, where it reaches the weight of 5 or 6 pounds.

This bass does not grow so large as the large monthed, seldom exceeding $S$ pounds in weight and averaging but $2 \frac{1}{2}$ pounds. A fish of the latter weight will measure 15 inches in length, while one of $S$ pounds will measure 2 feet.

The food of the black bass consists of crawfish, frogs, insects and their larrae, minnows and other aquatic animals of suitable size. The young can be fed on small fresh-water crustaceans, - such as Daphnia and Cyclops. Among the successful baits for this species are stone catfish, hellgramites and crickets.

The black bass prefers rapid water, is extremely active, and frequents clear, pure, swiftly flowing streams, and thrives at greater elevations than those preferred by the large mouthed species. It hibernates in the winter and spawns in the shallows on gravelly bottoms in spring. It follows its prey into shallow water and frequently leaps far out of the water in its efforts to escape from the hook or when frightened by the sudden approach of an enemy. It swims in schools and is often found in the shelter of sunken logs and in the vicinity of large rocks.

The spawning season begins in March and ends in July. The period of incubation lasts from seren to 14 days. The eggs are bound together in bands or ribbons by an adhesive substance. They adhere to stones on which they are deposited. The parent fish build nests and protect the eggs and young. In the Delaware the current is more rapid and the temperature lower than in the susquehanna; hence the bass spawn earlier in the latter than in the former. The spawning fish have nearly all left their spawning beds in the Susquehanna early in July, but at this time most of the nests in the Delaware are still full of eggs. By some writers it is believed that the female prepares the nest before the male joins her. The males fight for the 
possession of the female and are said to help the process of ejecting the eggs by biting or pressing the belly of the female. After the eggs are deposited, the female guards the nest from the attacks of the crawfish and other fishes. The young are consumed by many birds and by frogs and snakes. Iet, notwithstanding the numerous enemies of the black bass, its multiplication has been rapid and enormous.

The small mouthed black bass ceases to take food on the approach of cold weather and remains nearly dormant through the winter, except in artificially heated water. A number of the roung of the year, received from James Annin jr of Caledonia N. Y. Oct. 6, 1896, scarcely fed at all in the following winter, but when the spring was advanced they fed eagerly and grew rapidly.

\section{Micropterus salmoides Lacépède}

\section{Large mouthed Black Bass}

Labrus salmoides LacÉrède, Hist. Nat. Poiss. IV, 716, 1802, South Carolina. Huro nigricans Cuvier \& Valenciennes, Hist. Nat. Poiss. II, 124, pl. 17, 1828, Lake Huron; De Kay, N. Y. Fauna, Fishes, 15, pl. 69, fig. 224, 1842; Günthen, Cat. Fish. Brit. Mus. I, 255, 1859.

Micropterus pallidus Goode \& BEAN, Bull. Essex Inst. XI, 19, 1879.

Mieropterus salmoides JondaN \& GilberT, Bull. 16, U. S. Nat. Mus. 484, 1SS3; Meer, Ann. N. Y. Ac. Sci. IV, 313, 18s8; Bean, Fishes Penna. 118, pl. 32, fig. 66, 1893; Bull. Am. Mus. Nat. Hist. IX, 364, 1897; Jordan \& Evermann, Bull. 47, U. S. Nat. Mus. 1012, 1896, pl. CLXIII, fig. 431, 1900; Mearns, Bull. Am. Mus. Nat. Hist. X, 320, 189S; Eugene Surth, Proc. Linn. Soc. N. Y. 1897, 36, 1898; BeAN, 52d Ann. Rept. N. Y. State Mus. $105,1900$.

The large mouthed black bass takes its common name from the size of its jaws; the lower jaw projects very strongly, and the maxilla in the adult extends beyond the hind margin of the eye. The depth of the body is about one third of the total without caudal, and does not equal the length of the head. The eye is shorter than the snout, about one sixth of the length of the head. The pectoral is half as long as the head, much longer than the ventral. The spinous dorsal is very low, its ninth and 10th spines not so long as the eye, its fourth spine longest, about one fourth the length of head. Seven to eight scales above the lateral line, below 16 and in the lateral line about 
68. The color is greenish, silvery below. The young lave a broad dark lateral band. D. X, 13; 1 . III, 10-11.

This sprecies may best be distingnished from the small mouthed black hass by the size of its mouth and the number of rows of scales ahove the lateral line. The young of the small monthed species, also, never have a dark lateral band.

Common names for this species are, Oswego bass, river bass, green bass, moss bass, bayou bass, trout, jumper. chub and Welshman. Throughout the north it is generally known as bass, in Tirginia and North Carolina as chub and in Florida and west to Texas as trout.

The large monthed bass has a wide distribution, being indigenous to the eastern United States, from Manitoba to Florida and Texas, except New England and the Middle Atlantic states east of the Alleghanies, where it has been extensively introduced. It inhabits the fresh-water ponds, lakes and sluggish streams. It is found also at the mouths of rivers emptying into the Gulf of Mexico, where the water is brackish.

Dr Meek found the large mouthed species scarce near Ithaca and more common near Montezuma and Cayuga. James Annin jr collected the young at Caledonia. The U. S. Fish Commission had it from the following places in the Lake Ontario region:

Lakeriew hotel, $7 \mathrm{~m}$. n. e. of Oswego

Marsh creek, Point Breeze

Mouth Salmon river, Selkirk

Mouth Little Salmon creek

Stony Island

Four Mile creek, Nine Mile point, near Webster

Creek at Pultneyville

Chaumont river

Great Sodus bay

Three Mile creek, Oswego

Long pond, Charlotte

Dr Mearns first observed the species in the Hudson in the autumn of 1882, where the fish were caught in fyke nets during October and November. Eugene Smith records it from all lakes and rivers adjacent to New York city. 
Toung individuals, from $1 \frac{1}{2}$ to 2 inches long, were seined in Bronx river in August 1897.

The average weight of the large mouthed bass in southern waters is less than 5 pounds, and still less in northern waters. In Florida it attains a large size, as much as 3 feet in length, and a weight of 25 pounds. Its growth and size depend on the waters where it is found, and the natural food supply of small fish, crawfish and frogs.

It is a very active fish; its morements are affected by seasonal changes and the search for food and places for spawning. In polluted streams the bass are often compelled by the impurities to seek new haunts in pure water. The young bass feed on animal food at an early age. The large mouthed bass is said to be more cannibalistic than the small mouthed. Small fishes (minnows) of all kinds, crawfish, frogs, insects and their larvae, and aquatic animals of all kinds, suitable in size, make up thediet of this fish. It feeds both at the surface and on the bottom, pursuing its prey with great activity. When surrounded by seines or caught on hooks this species will often leap $5 \mathrm{or}^{2}$ 6 feet out of the water, and its habit of jumping orer the cork lines of seines has given it the name of "jumper."

In cold weather the bass seeks deep places, often hibernating under rocks, sunken logs and in the mud. Farorite localities are under orerhanging and brush-covered banks, in the summer, and among aquatic plants, where the fish lies in wait for its prey.

The spawning season of the large mouthed bass is about the same as that of the small mouthed species, beginning in 1 pril and lasting till July. Its eggs are adhesive, sticking to stones during the incubation period, which lasts from one to two weeks according to the temperature of the water. The young bass remain in the nest a week or 10 days, and at the age of two weeks will measure about $\frac{3}{4}$ of an inch in length. In suitable waters it is estimated that the large mouthed bass will weigh at the age of three years from 2 pounds to 4 pounds.

The Oswego bass is eren more destructive to fish than $M$. do $\mathrm{lomieu}$. It will eat any fish which it can manage to get 
into its montl and will lie on the bottom for days so gorged that it can not stir. In voracity it is only equaled, but hardly excelled by the pike. This bass bears captivity well. After Engene Smith ${ }^{1}$ )

The young above referred to as coming from Caledonia N. Y. hibernated and took scarcely any food during the winter, but fed ravenously in spring, summer, and fall. They proved rery hardy in captivity.

\section{Family PERcIDAE}

\section{Perches}

\section{Genus strzostedion Rafinesque}

Body elongate, fusiform, the back broad; head subconical, long; cheeks, opercles, and top of head more or less scaly; mouth large, the jaws about equal; premaxillaries protractile, little movable; teeth in villiform bands, the jaws and palatines with long, sharp canines; gill rakers slender, strong; gill membranes separate; preopercle serrated, the serrae below turned forward; opercle with one or more spines, terminations of radiating striae; dorsal fins well separated, the first with 12 to 15 spines, the second with 17 to 21 soft rays, last dorsal spine not erectile, bound down by membranes; anal spines two, slender, closely appressed to the soft rays, which are rather long, 11 to 14 in number; rentral fins well separated, the space between them equal to their base, rentral spine slender, rlosery appressed to the soft rays; scales small, strongly ctenoid; lateral line continuous; branchiostegals seren; pseudohranchiae well developed; pyloric caeca three to seren. Two species, differing considerably from each other. Large carnivorous fishes of the fresh waters of North America.

\section{Subgenus strzostedion}

\section{4: Stizostedion vitreum (Mitchill)}

\section{Pike Perch: Pike: Wall-eyed Pike}

Perca vitiea Mitchul, Am. Month. Mag. II, 247, Feb. 181S, Cayuga Lake, N. Y.

Lucioperca americana Cuvier \& Valenciennes, Hist. Nat. Poiss. II, 122, 1S2S, New York; De Fiy, N. Y. Fauna. Fishes, 17, pl. 50, fig. 168, 1942; Güntuer, Cat. Fish. Brit. Mus. I, $74,1859$. 
Stizostcdium vitreum Jordan \& Gildert, Bull. 16, U. S. Nat. Mus. 525, 1893. Lucioperel vitrea Eugene Suith, Proc. Linn. Soc. N. Y. 189T, 3S, 1898. S'tizostedion vitreum MeEr, Ann. N. I. Ac. Sci. IV, 314, 1SSS; BEAN, Fishes Pemma. 127, color pl. 13, 1S93: Evermanx and Kendat, Rept. U.S. F.C. for 1S94. G01. 1S96: Jordax \& Evermann, Bull. 47, U. S. Nat. Mus. 1021, 1836, pl. CLXIT, fig. 433, 1900; BEAN, Bull. Am. Mus. Nat. Hist. IX, 364, 1897.

The pilie perch belongs to the genus $\mathrm{s}$ tiz o s tedio $\mathrm{n}$, which has been distinguished from the saugers by the structure of its prioric caeca, which are three in number, nearly equal in size, and about as long as the stomach, and also by the presence of 21 soft rays in the second dorsal, while the saugers have 18. It may be lemarked that all of these characters are more or less variable. The $\mathrm{S}$. vit re u $\mathrm{m}$ has the body long and moderately deep, its depth varying with age and equaling from one sixth to one fourth of the total length without caudal; the length of the head is contained in the same standard four and two thirds times; the eye is moderate, about two thirds as long as the snout and a little more than one sixth of the length of the head; the lower jaw projects slightly; the maxilla reaches to beyond the pupil; the cheeks and opercles are more scaly than in the saugers; the soft dorsal is nearly as long as the spinous; length of longest dorsal spine about half the length of head. D. XIII, I, 21; A. II, 12 to 13. About 90 scales in lateral line, 10 above and 19 below. The pectoral reaches to below the 10 th spine of the dorsal; it is as long as the rentral and one half the length of head; the vent is under the fifth ray of the second dorsal.

Color olivaceous, mingled with brassy; sides of the head rermiculated; the dorsals, caudal and pectoral with bands; those of the dorsals and caudal not continuous; sides with about seren oblique dark bands, diftering in direction; a jet black blotch on the membrane behind the last spine of the dorsal.

The pike perch has received a great many common names. One of the most unsuitable is "Susquehanna salmon," which is used in Pennsylvania. In the eastern states the species is styled the perch pilie or the pike perch, glasseye and wall-eyed pike. In the Great lakes region it is known as blue pike, yellow pike, green pike and grass pike. In the Ohio valley and western North Caro- 
lina it is the jack; in Lake Erie and Canada, the pickerel; in some parts of the Ohio valley, the white salmon or jack salmon. The Cree Indians call it the oliow and the French Canadians doré or picarel. Among the fur traders of British America it is ealled the hornfish.

The pike perch or wall-eyed pike inhabits the Great lakes region and extends northward into British America, where it has been recorded as far as $55^{\circ}$ north by Dr Richardson. It ranges south in the Mississippi valley to Arkansas, and in Itlantic streams to Georgia. According to Dr Meek the species is found in Cayuga lake, but is not common. In Lake Champlain it is one of the principal game fishes. James Annin jr of Caledonia obtained specimens in the Canandaigua lake region. It has been introduced into numerous lakes by the Fisheries, Game and Forest Commission of New York. The U. S. Fish Commission secured examples in the Oswego river at Oswego and at Point Breeze in August 1894.

This species is said to reach a weight of 50 pounds, but the average weight of the market specimens is less than 5 pounds. In the Susquehanna it occasionally reaches 10 pounds or upward in weight. The pike perch feeds on the bottom on other fishes, and has been charged eren with destroying its own young. It prefer's clear and rapid waters, and lurks under submerged logs and rocks, from which it can readily dart on its prey. Spawning takes place in April and May, and in Pennsylrania continues till June. Farorite spawning localities are on sandy bars in shallow water. The period of hatching varies from abont 14 to 30 days, depending on the temperature of the water. The eggs rary from about 17 to 25 to the inch, and a single female has been estimated to contain from 200,000 to 300,000 . In a state of nature only a small percentage of the eggs are hatched out; the greater proportion are driven on the lake shores by storms or devoured by fishes on the spawning beds. The number of pike pereh annually hatched by artificial methods is enormous. This advance is due to improvements in the treatment of adhesive eggs. Formerly these were hatched by placing them on glass plates, to 
which they readily adhere. Recently it has been found that the sticky substance can be washed off the eggs, after which they are placed in jars and hatched like eggs of the shad and whitefish.

"Dexter," in Forest and Strcam, Aug. 14, 1890, makes the following statement about the habits of this species in the lakes.

These fish run up the rirers before or as soon as the ice is out, and after spawning lie off the river's mouth feeding on and off the sand flats, as the spring rains bring down plenty of worms, and probably other matter which they feed on. As soon as the water gets warm, they sag off and work along the shores in 10 to 30 feet of water, preferring cobbly bottom; from here they go into very deep water, coming on the reefs to feed, and when the wind blows very hard, or for a day or so after a big blow, you will find them right on top of a reef. I think the wind changes the water over the reefs, making a new current and cooler water, so they come up to feed. They are a bottom fish, and to fish for them successfully one must go to the bottom for them. They are nearly as particular as salmon trout about the water they inhabit and consequently rank very high as a food fish, being white, solid and extremely free from bones.

The colors of the pike perch change remarkably with age. The young have oblique dark bands much like those of the kingfish of our east coast, and bear little resemblance in the pattern of coloration to the parent. The eye of the living fish is like a glowing emerald. The rate of growth must be rapid. In July $18 S S$ we took examples from 4 to 6 inches long, some of which seemed to be the young of the year.

This is one of the finest food and game fishes of the United States. Its flesh is firm and white, flaky and well flavored. Commercially the species ranks high in the Great lakes region, being next in importance to the whitefish. In angling for the pike perch live minnows are used in preference to all other baits, particularly such as are more or less transparent and with silvery sides, as the fallfish or dace, the corporal roach, the redfin and the gudgeon. On some parts of the Susquehanna, between Columbia and Harrisburg, the favorite mode of capture is by trolling with the spoon with the same kind of tackle as is used for the black bass. 
James Annin jo of Caledonia sent two individuals Ap. 23, 1896, for identification. They furnished the following notes and measurements in inches.

Length, including caudal...........

Length to end of middle caudal rays. .

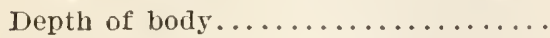

Least depth of candal peduncle......

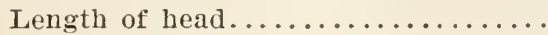

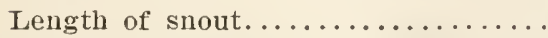

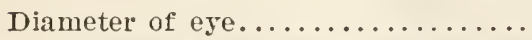

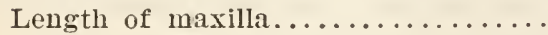

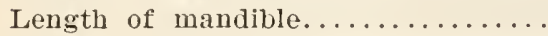

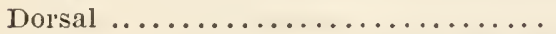

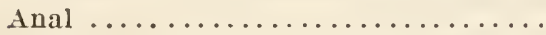

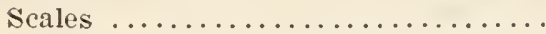

\begin{tabular}{|c|c|}
\hline q & $\hat{\jmath}$ \\
\hline $183 / 4$ & 18 \\
\hline 18 & $171 / 8$ \\
\hline $31 / 2$ & $31 / 2$ \\
\hline $11 / 8$ & $1 \frac{1}{4}$ \\
\hline $4 \%$ & $43 / 8$ \\
\hline $11 / 4$ & $11 / 8$ \\
\hline$\frac{1}{16} \frac{7}{2}$ & $\frac{13}{16}$ \\
\hline 2 & $17 / 8$ \\
\hline $23 / 4$ & $21 / 2$ \\
\hline $\mathrm{XIV}, \mathrm{I}, 21$ & XIV, I, 20 \\
\hline III, 11 & III, 11 \\
\hline 92 & 93 \\
\hline
\end{tabular}

The pyloric caeca are long and loaded witl fat. The male is brassy; the female gray and whitish.

In November of 1896 and $1897 \mathrm{Mr}$ Annin shipped adult individ. uals from Canandaigua lake by expless without an attendant, and there was scarcely any loss of fish in transportation, though the journey lasts 12 hours.

The blue pike of Lake Erie, or white salmon of the Ohio river, was formerly distinguished by name from the common pilie perch, but is now considered unworthy of a separate name. This is a rery small rariety seldom exceeding 15 inches in length and a weight of 2 pounds. The dorsal has 14 spines and 20 rays. The spines are rather lower than in the pike perch, the coloration similar, but the adult is bluish or greenish and has no brassy mottling. The fins are darker, and there is a trace of a band along the dorsal, besides the black blotch on the hind portion.

Jordan $\&$ Evermann say of this rariety: "The name s a l. m o n e a m has been applied to the so called 'blue pike' origin. ally described from the Ohio river, but more common in the Great lakes, particularly Ontario and Erie. It is smaller and deeper in body than the ordinary $r$ it $\mathrm{r} \mathrm{e} \mathrm{u} \mathrm{m}$ and different in color, but it is not likely that any permanent distinctions exist, this species, as usual among fresh-water fishes, varying largely with the environment and with age." 


\section{Subgenus croperca Gill \& Jordan \\ 244 Stizostedion canadense (Smith) \\ Sauger; Sand Pike}

Lucioperca canadensis C. H. Smitr, in Griffith's Cuv. Règne Anim. X, 275. pl. 7, 1834; DE KAY, N. Y. Fauna, Fishes, 19. pl. 6S, fig. 221, 1842 (extralimital); Günther, Cat. Fish. Brit. Mus. I, 75, 1859.

Stinostedium canudeuse Jordan \& Gilbert, Bull. 16, U. S. Nat. Mus. 526, 1883.

Stizostedion canadense MeEK, Ann. N. Y. Ac. Sci. IV, 314, 18Ss; BeAN, Fishes Penna. 130, pl. 34, fig. 70. 1893; Evermann d Kendall, Rept. U. S. F. C. for 1894, 601. 1896; Jordan \& Evermaxx, Bull. ti. U. S. Nat. Mus. 1022, 1S96, pl. CLXIT, fig. 434, 1900.

Body slender, not much compressed, roundish; its depth contained four and one half to five times in the total without caudal. The head is pointed, about two sevenths of standard length and contains the eye five to five and one half times. The mouth is smaller than in the pike perch; the maxilla reaches to the hind margin of the eye. D. XII to XIII, I, 17 to 18; A. II, 12. Scales 92 to $98 ; 4$ to $T$ prloric caeca, unequal in size and all of them shorter than the stomach.

Color olivaceous abore; sides brassy or pale orange, mottled with black in the form of irregular dark blotches, which are best defined nnder the soft dorsal. The spinous dorsal has sereral rows of round black spots on the membrane between the spines; no black blotch on the hind part of the spinous dorsal. Pectorals with a large dark blotch at base; soft dorsal with sereral rows of dark spots irregularly placed; caudal yellowish witl dark spots forming interrupted bars.

The sauger is known also as sand pike, gray pike and green pike, pickering, pickerel and horsefish. It is found in the St Lawrence river and Great lakes region, the upper Mississippi and Missouri rirers and in the Ohio, where it is said to have been introduced from the lakes through canals. This is a small fish, seldom exceeding $1 \mathrm{~S}$ inches in length, and embraces sereral varieties. It is very common in the Great lakes and is abundant in the Ohio riser. It is doubtful whether it is native to Ohio or introduced. It is also found rarely in Cayuga lake. Rev. Zadock Thompson, in his History of Termont, says it is much 
less common in Lake Champlain than the pike perch, but is frequently taken in company with it. It usually swims very near the bottom of the water, and hence it has receired the name of ground pike (pike perch). As an article of food this species is locally held in the same high esteem as the common pike perch.

John W. Titcomb of St Johnsbury T't. informed Evermann and Kendall that the sauger, or rock pike, as it is locally called, is caught in seines while fishing for the pike perch. It does not grow as large as the latter, and is not much ralued as a food fish. The authors mentioned received two examples of the fish from A. L. Collins of Swanton Vt., one of them a nearly ripe female $14 \frac{1}{2}$ inches long, weighing three fourths of a pound, the other an unripe male 15 inches long, weighing three fourths of a pound. These specimens were believed to indicate that the sauger spawns earlier than the pike perch. The stomach of the male contained a three inch minnow, too badly digested for identification, and a number of small insects.

It is rery extensirely used for food, but is not generally considered equal to the pike perch.

\section{Stizostedion canadense griseum (DeKay)}

\section{Gray Pike; Sauger; Sand Pike}

Lucioperca grisea DE KAY, N. Y. Fauna, Fishes, 19, 1842, Great Lakes; streams and inland lakes of western New York; Günther, Cat. Fish. Brit. Mus. I, 76, 1859.

Lucioperca pepinus EsTes, in Hallock's Sportman's Gazetteer, 322. 1877, Lake Pepin.

Stizostedium canadense var. griseum JoRDAN \& GILBERT, Bull. 16, U. S. Nat. Mus. 526, $18 S 3$.

Stizostcdion canadense griscum Jordan \& Evermann, Bull. 47, U. S. Nat. Mus. 1022, 1896.

This is the common sand pike or sauger of the Great lakes. region and southwestward. It differs from the typical c a $n$ a $d$ ense chiefly in the smoother opercles and head bones, the fewer opercular spines, and the less complete scaling of the head. The two need fuller comparison and may prove to be distinct species, but this is unlikely. Length 10 to 18 inches. 


\section{Geuns PERca (Artedi) Linnaeus}

Body oblong, somewhat compressed, the back elevated; cheeks scaly; opercles mostly naked; the operculum armed with a single spine; preopercle and shoulder girdle serrated; preopercle with retrorse, hooked serrations below; mouth moderate, terminal; premaxillaries protractile; teeth in villiform bands on jaws, vomer, and palatines, no canine teeth; branchiostegals seven; gill membranes separate; pseudobranchiae small, but perfect; no anal papilla; scales rather small, strongly ctenoid, lateral line complete, the tubes straight and not extending to the extremity of the scale; dorsal fins entirely separate, the first of 12 to 16 spines; anal fin with two slender spines, well separated from the soft rays; ventral spines well developed, the ventral fins near together; caudal emarginate; air bladder present; pyloric caeca three; vertebrae rery numerous, $21+20$ or $21=41$ or 42 . Fresh waters of northern regions; three closely related species now known, $P$ e r c a $\mathrm{flu} r$ iatilis in Europe, P. s e hrencki i in Asia, and P. flarescens in North America.

\section{Perca flavescens (Mitchill)}

\section{Yellow Perch; Ring Perch}

Morone flavescens Mitchill, Report in Part, 18, 1814.

Bodianus favescens MitchilL, Trans. Lit. \& Phil. Soc. N. X. I, 421, 1815.

Perca serrato-granulata Cuvier \& Valenciennes, Hist. Nat. Poiss. II, 47, 1828, New York; De KAY, N. Y. Fauna, Fishes, 5, pl. 22, fig. 64, 1842. Perca granulata Cuvier \& VAlenciennes, op. cit. II, 48, pl. IX, 182S, New York; DE KAY, op. cit. 5, pl. 68, fig. 220, 1842.

Perca acuta Cuvier \& Valenciennes, op. cit. II, 49, pl. X, 182S; De Tar, op. cit. 6, pl. 68, fig. 222, 1842.

Perca gracilis Cuvier \& VALenciennes, op. cit. II, 50, 1S28, Skaneateles Lake, N. Y.; De İAy, op. cit. 6, 1842; Günther, Cat. Fish. Brit. Mus. I, $60,1859$.

Perca americana Jordan \& Gilbert, Bull. 16, U. S. Nat. Mus. 524, 1883.

Perca flavescens Cuvier \& VALEnciennes, op. cit. II, 46, 182S; De KAy, op. cit. 3, pl. 1, fig. 1, 1St2; Günther, op. cit. 1, 59, 1S59; Stoner, Hist. Fish. Mass. 4, pl. II, fig. 1, 1867; Meer, Ann. N. Y. Ac. Sci. IV, 314, 1S8s; BEAN, Fishes Penua. 126, color pl. 12, 1893; EverMANN \& IIENDALL, Rept. U. S. F. C. for 1S94, 602, 1896; Jordan \& EvermanN, Bull. 47, U. S. Nat. Mus. 1023, 1S96, pl. CLXV, fig. 435, 1900 ; Bean, Bull. Am. Mus. Nat. Hist. IX, 365, 1897; Mearns, Bull. Am. Mus. Nat. Hist. $\mathbf{X}, 320,1898$; Eugene Smitr, Proc. Liun. Soc. N. Y. $1897,37,189 S$. 
The yellow perch has a fusiform and moderately elongate body, its greatest hight at the ventral origin two sevenths of the total length without the caudal and nearly equal to the length of the head. The least depth of the caudal peduucle equals one third of length of head. The greatest width of the body equals one half its greatest hight. The head is moderately long, its length contained three and one fourth times in the standard, with pointed snout, one and one third times as long as the eye. The interorbital region is flat, its width one and one half times the diameter of the ere. The mouth is rather large, the jaws equal, and the maxilla reaching to below middle of pupil. The preopercle is coarsely dentate on its hind margin, the teeth on the superior border directed partly upward and partly backward, those on the lower limb pointing downward and some of them forward. The scapula and humerus are finely serrate. Scales on the cheeks in about 13 rows from before backward; a single row or two imperfect rows of scales on the subopercle; four short rows of scales on the upper anterior part of the opercle. Gill rakers $6+14$, the longest one half as long as the eye. The spinous dorsal begins over the base of the pectoral; the first spine is one third as long as the head to the end of the opercular spine; the fourth and Iongest spine is as long as the eye and snout combined; the last spine is minute and concealed in the dorsal furrow. The soft dorsal in the specimen described is preceded by two spines, the first two thirds as long as the eye and one half as long as the second; the longest ray is as long as the longest spine, and twice as long as the last ray. The ventral origin is under the fourth spine of the dorsal; the fin equals one fifth of the total length without the caudal. The anal origin is under the fourth or fifth soft dorsal ray; the first anal spine one third as long as the head and nearly as long as the second; the last anal ray less than one half as long as the longest, which is one half as long as the head. The caudal is notched, the middle rays contained one and one third times in the length of the outer rays. The pectoral is as long as the ventral. D. XT, II, 13; A. II, S; 
V. I, 5; I'. 15. Seales 7-57-13. The lateral line curves upward in a long curve following the dorsal outline till below the end of the soft dorsal, where it becomes straight and median. Color olivaceons varying into greenish or bluish, the sides yellow, with about six to eight dark bands, the widest wider than the eye is long. The upper fins are olivaceous, the lower orange and rosy. The specimen described, no. 22862, U. S. National Museum, Washington 1. C., is 9 inches long.

The yellow yerch, ringed perch or striped perch is found throughout the Great lakes region, rivers and ponds of New England and northwestward, and in streams east of the Aleghanies south to Georgia. It does not occur in the Ohio valley or southwest, though, after the construction of the Ohio anal, Kirtland recorded it from the Ohio river. In 1790 Dr. Mitchill transferred some of them from Ronkonkoma to Success pond, a distance of 40 miles, where they soon multiplied. In 1825 yellow perch were transported from Skaneateles to Otisco lake and Onondaga lake; in the latter they increased remarkably. In Otsego lake DeKay caught some weighing nearly three pounds. Meek states that the species is common throughont the Cayuga lake basin. Evermann and Bean took it in the St Lawrence river, 3 miles below Ogdensburg; also in Scioto creek, Coopersville N. Y., July 19, 1894, young specimens $1 \frac{1}{2}$ to $1 \frac{3}{4}$ inches long. In the Lake Ontario region the U. S. Fish Commission collectors obtained it at the localities in this state here mentioned.

Moutl of Salmon river

Mouth of Little Salmon creek

Black creek, tributary of Oswego river, Scriba Corners Sandy creek, Hamlin

Grenadier island

Stony island

Chaumont river

Outlet of Long pond, Charlotte

Little Stony brook, Henderson bay

Cape Vincent 
Creek at Pultneyville

Great Sodus bay

Four Mile creek, 1 mile above mouth

Lakeview hotel, $\tau$ m. n. e. of Oswego

Three Mile creek, near Oswego

Long pond, Charlotte

Salt brook, $1 \frac{1}{2}$ miles abore Nine Mile point.

The yellow perch is one of the most abundant fishes of Lake Champlain and in the mouths of rivers falling into that lake.

The fish abounds in the parks of New York and Brooklyn. In the Hudson Highlands Dr Mearns reported it as abundant in the Hudson as well as in all of the larger mountain lakes and ponds. It habitually frequents Poplopen's creek from its source to its mouth. In the Hudson, he was informed, it is unusual to take specimens weighing more than 1 pound; but in Poplopen's pond he has taken a number that weighed about 2 pounds each. In the same pond Jerome Denna caught two which weighed 21 to 3 pounds each; and a fisherman named Samuel Runnels assured Dr Mearns that he had taken a yellow perch there which weighed $4 \frac{1}{\ddagger}$ pounds. The fish continue to feed in that region throughout the winter. Engene Smith obtained the fish in Greenwood lake, Orange co., and in Hackensack streams, in Rockland county.

The species reaches a length of 1 foot and weight of two pounds. It is one of the best known of our food fishes and has excellent game qualities. Its flesh, howerer, is rather soft and coarse and is far inferior to that of the black bass and other member's of the sunfish family. It is a voracious feeder, its food consisting of small fishes, crustaceans and other animal matter.

The yellow perch spawns early in the spring. The eggs are adhesive and inclosed in thin translucent strips of adhesive mucus. The spawning of this species was described by William P. Seal in Forest and Stream of Ap. 17, 1890. The spawning season extends from December to April. Mr Seal describes the egg mass as haring the shape of a long tube, closed at the ends 
and arranged in folds like the bellows of an accordion. When folded the mass was about 8 to 12 inches long, but was capable of being drawn out to a length of 3 or 4 feet. Spawning in the aquarium took place at night and was observed by William Maynard, who describes it as follows. "The female remained quiet in one spot on the bottom of one of the hatching aquaria tanks, one or more of the males hovering over and about her with pectoral fins vibrating with intense activity. The males would at times lie close alongside of her and at other times endearor to force themselves under her with the evident intention of assisting in the extrusion of the eggs." Mr Seal remarks that "the roe when taken from the dead fish not yet ripe is in a single compact mass, corered by a thin membrane; but in spawning the mass separates, one side being spawned before the other." This was noticed in a specimen which had spawned one side and appeared to be unable to get rid of the other. It was stripped from her and artificially fertilized successfully. $M r$ Seal believes that the yellow perch spawns at the age of one year.

The yellow perch thrives moderately in captivity, though susceptible to attacks of fungus, which are easily overcome by the use of brackish water. Its food in captivity consists chiefly of chopped hard clams; sometimes live killifish are used.

\section{Genus perciva Haldeman}

Body elongate, slightly compressed, covered with small, ctenoid scales; lateral line continuous; rentral line with enlarged plates which fall off, leaving a naked strip; head depressed, rather pointed, the mouth being small and inferior, overlapped by a tapering, subtruncate, piglike snout; upper jaw not protractile, maxillary small, exposed; teeth on vomer and palatines, gill membranes scarcely connected; dorsal fins well separated, the first the larger, of 13 to 15 spines, the second dorsal rather longer than the anal, which has two spines, the first of which is usually the shorter; pectorals symmetric, rounded or bluntly pointed, their rays 14 or 15 , their spines moderate; rentral fins well separated, the interspace about 
equal to their base; air bladder and psendobranchiae present, rudimentary; rertebrae ( $\mathrm{P}$. c a p ro des ) $23+21=44$. General pattern of coloration olivaceous, with dark vertical bands alternately long and short. Size largest of the darter's, approaching that of $\mathrm{As} \mathrm{p} \mathrm{l}^{\circ} 0$, a genus to which it is more nearly related than the other darters are.

\section{Percina caprodes (Rafinesque)}

\section{Log Perch; Hogmolly}

Sciaena caprodes Rafinesque, Am. Month. Mag. 534, 1818, fide Jordan \& EVERMANN.

Ethcostoma caprodes Rafinesque, Ichth. Ohien, 3S, 1S20; Storer, Syn. Fish. N. 1. 18. 18t6; BeAN, Fishes Penna. 122, pl. 33, fig. 68, 1893.

Pilcoma semifasciatum. DE KAY, N. Y. Fauna, Fishes, 16, pl. 50, fig. 162, 1812; GüNrher, Cat. Fish. Brit. Mus. I, T6, 1859.

Percina caprodes JopDAN \& Gilbert, Bull. 16, U. S. Nat. Mus. 499, 1883; Evermann \& Kendal, Rept. U. S. F. C. for 1S94, 602, 1896; Jordan \& Everuand, Bull. 47, U. S. Nat. Mus. 1026, 1896, pl. CLXV. fig. 436, $436 \mathrm{a}, 1900$.

Body long, moderately compressed; head long, with pointed suont; mouth small, the lower jaw not reaching near to tip of snout, and the maxilla not extending to the front of the eye. The head forms one fourth of the total length without the caudal, and the depth equals about one sixth. Scales on cheeks and gill corers, also on the space before the first dorsal; breast scaleless. A row of enlarged plates on the belly, which are sometimes deciduous. Fins moderately low and rather long. D. XY, 15; A. II, 9. Lateral line with 92 scales. Color greenish yellow; sides with about 15 dark cross bands, extending from back to belly; alternating with these above the lateral line are fainter bars. Fins barred. A black spot at the base of the caudal.

The log perch, hogfish, hogmolly, rockfish or crawl-a-bottom is found in the Great lakes region, Quebec and the eastern states south to Virginia, also in the Mississippi valley south to Alabama and Texas. De Kay obtained it at Westport on Lake Champlain, where it appeared to be very abundant, as well as in many streams in that vicinity. Its local name there he gives as little pickerel or pickerel, which it sliared in common with 
many other species. Evermann and Kendall had it from Rouse Point and Plattsburg, on the west shore of Lake Champlain.

This is the largest of the darters, reaching a length of 8 inches, and in many respects resembles the perches. It lakes the hook very readily. The log perch is found in rapid streams with gravelly or rocky botton and prefers clear waters.

\section{Percina caprodes zebra (Agassiz)}

\section{Manitou Darter}

Pileoma zcbra Agassiz, Lake Superior, 308, pl. IV, fig. 4, 1850.

Percina maniton Jordan, Proc. Ac. Nat. Sci. Phila. 53, 1877.

Pereina caprodes var. manitou Jordan and Gilbert, Bull. 16, U. S. Nat. Mus. 500, 1883.

Percina coprodes acbra Jordan and Everiann, Bull. 47, U. S. Nat. Mus. $1027,1896$.

Head four and one fourth; depth seven; nape always naked; lateral black bars short, shorter than in cap rodes, not extending much above lateral line, these also more or less confluent, about 20 in number; a black caudal spot; dorsal and caudal mottled. D. XV-14; A. II, 10. Scales 90.

Lakes of northern Indiana, Michigan, Wisconsin and northward to Lake Superior; the common form in the Great lakes. The typical z e bra is well distinguished from caprodes, but specimens varionsly intermediate have been obtained in Illinois by Dr Forbes, and in the Potomac by Dr Bean. (After Jordan and Evermann)

Evermann and Bean obtained the Manitou darter in the Racket river, at Norfolk N. Y. and in the St Lawrence 3 miles below Ogdensburg; also in Scioto creek, at Coopersville N. Y. Collectors for the U. S. Fish Commission secured specimens at the following places in 1893 :

Nine Mile point, Lake Ontario June 11 Grenadier island June 27 Hor'se island, Sackett's Harbor June 30 Mouth Salmon river, Selkirk July 25 Mouth Little Salmon creek July 25 Marsh creek, Point Breeze Aug. 2 
Genus Homopterts Igassiz

Body rather elongate, compressed or not; mouth rather wide, terminal, the lower jaw included, the snout above not protruding beyond the premaxillaries, which are not protractile; teeth on vomer and usually on palatines also; gill membranes separate or more or less connected; scales small, ctenoid, corering the body; belly with a median series of more or less enlarged spinous plates or ctenoid scales, which in most species fall off at interrals, leaving a naked strip, in some species persistest and but slightly enlarged; sides of head scaly or not; lateral line complete or nearly so; fins large, the soft dorsal smaller than the spinous or the anal; anal spines two (one of them very rarely obsolete); dorsal spines 10 to 15 ; ventral fins more or less widely separated, specially in species with caducous plates. Vertebrae 39 to $44 ; \mathrm{H}$. a s p r o, $19+23=42 ; \mathrm{H}$. e vides, $18+2 \cdot=40$; H. s c i e r u s, $18+22=40 ; \mathrm{H} . \mathrm{p} \mathrm{hox} \mathrm{o} \mathrm{c} \mathrm{e} \mathrm{p} \mathrm{ha} \mathrm{lus,}$ $19+20=39$. Parietal region more or less depressed, not strongly convex in cross-section; supra-occipital crest usually present, but small. Pyloric caeca two to four. Coloration bright, often brilliant, sides usually with dark blotches.

\section{Subgenus Amondus Girard}

\section{Hadropterus aspro (Cope \& Jordan)}

\section{Black-sided Darter}

Alvordius aspro Cope \& Jordan, Proc. Ac. Nat. Sci. Phila. 51, 1877, substi-

tute for Etheostoma blennioides of KintLAND and Agassiz; Jordax of GilberT, Bull. 16, U. S. Nat. Mus. 501, 1583.

Etheostoma aspro BeAN, Fishes Penna. 123, 1893.

Hadropterns aspro Jordan \& Evermans, Bull. 47, U. S. Nat. Mus, 1032, 1896, pl. CIXXVI, fig. 438, 1900.

Body slender, fusiform, elongate, its greatest depth one sixth of length without candal; least depth of caudal peduncle nearly one third of length of head; head rather long and pointed, one fourth of total length without caudal; the maxilla extends slightly past front of eye; the mandible is included; the eye large, equal to length of snout and to one fourth the length of head; gill membranes slightly connected; postorbital part of head a little longer than the remainder; the nape scaly or naked; cheeks 
with very small scales, sometimes hardly visible; large scales on opercles; dorsal origin at a distance from eye equal to length of pectoral, base of spinous dorsal nearly equal to one third of total length without caudal, fourth to seventh spines longest, equal to snout and eye combined, last spine two thirds as long as the first and equal to snout; base of second dorsal one half as long as first, the longest ray twice as long as last ray and equal to postorbital part of head; the caudal peduncle rather long and slender, from end of second dorsal to end of scales being nearly equal to the head; caudal fin slightly emarginate, the middle rays three fourths as long as the external, and one third of length of head; the anal origin at a distance from tip of snout equaling twice the length of spinous dorsal base, the anal base equal to postorbital length of head, the two spines nearly equal, about one third as long as the head, the longest ray (fifth) equal to one half the length of spinous dorsal base; the ventral not far behind the base of the pectoral, its length about one half the distance from its origin to origin of anal; pectoral one fifth of total length to end of middle caudal rays; lateral line straight, extending from eye to base of caudal fin; breast naked; a series of enlarged caducous scales on median line of belly. D. XII to XV, 11 to 13 ; A. II, \& to 10 ; T. I, 5; P. 14. Scales $9-65$ to $80-17$; vertebrae $19+23-42$; pyloric cacea three.

The sides are straw colored or greenish yellow, with dark tessellations and marblings above and with about seven large dark blotches, which are partly confluent; the fins are barred, and there is a small spot at the base of the candal.

The black-sided darter, or blenny darter, is found in the Great lakes region westward to Manitoba and southward to Missouri, Indiana, Kentucky and Arkansas, being specially abundant in the Ohio valley. The U. S. Fisin Commission had it from Marsh creek, Point Breeze. It prefers clear streams with gravelly bottoms and is mole active in its habits than most of the other darters, not concealing itself so closely under stones. It grows to the length of 4 inches. As an aquarium fish it is unsurpassed by any of its kindred, and its sudden and remarkable changes 
of brilliant colors during the breeding season render it unusually attractive.

\section{Genus cotrogas'en Putnam}

Body rather robust, little compressed; head moderate, bluntish; month moderate or small; the lower jaw included; premaxillaries protractile or occasionally (in shumardi) joined by a narrow frenum to the frontal region; maxillary not adherent to the preorbital; teeth on vomer; gill membranes nearly separate; scales ctenoid; the middle line of the belly anteriorly naked or with caducous scales; lateral line continuous; dorsal fins large, the second usually smaller than the first and smaller than the anal; anal spines two, the first the longer; pyloric; caeca three; vertebrae $18+20=38$ (c o p e 1 a n d i); skull short, the frontal region not very narrow, parietals little convex transversely, sutures distinct; no supra-occipital crest. Coloration not brilliant. Size moderate.

\section{Cottogaster copelandi (Jordan)}

Copeland's Darter

Boleasoma tessellatum Thompson, Appendix Hist. Vermont, 5, 1853, not of DE KÁ, N. Y. Fauna, Fishes, 20, 1842.

Rheoerypta copclandi Jordan, Bull. 10, U. S. Nat. Mus. 9, 1877.

Cottogaster putnami Jordan \& Gilbert, Bull. 16, U. S. Nat. Mus. 498, 1883. Cottogaster copelandi Jordan \& Evermann, Bull. 47, U. S. Nat. Mus. 1045, 1896.

Body rather slender and elongate, the depth being contained from five and one half to six and one half times in the length; head rather large and long, somewhat narrowed, resembling that of $\mathrm{Boleos}$ om a. Its length is contained from three and three fourths to four and one fourth times in the length of the body. Mouth small, horizontal, subinferior; cheeks naked; opercles and neck each with few scales; throat naked; rentral plates well dereloped; scales moderate, strongly ctenoid; pectoral as long as head. D. X to XII-10 to 12 ; A. II, 8 or 9. Scales 6-44 to 56-8.

Color brownish olive; a series of rather small, horizontally oblong, black blotches along the lateral line, forming an interrupted lateral band; back tessellated; blackish streaks forward 
and downward from eye; ventral fins dusky in the male; vertical fins with dusky specks; a small inklike speck at base of caudal persistent in most specimens; a black spot on anterior rays of spinous dorsal.

Length $2 \frac{1}{2}$ to 3 inches. Great lakes region, from Lake Champlain to Lake Huron; represented in New York waters by the subspecies C. p u t $\mathrm{n}$ a $\mathrm{m}$ i.

\section{Cottogaster cheneyi Evermann \& Kendall}

Cottogaster cheneyi Evernaxi \& Inendald, Bull. U. S. F. C. 1897, 129, pl. S, fig. S, 189S, Racket Rirer near Norfolk, N. Y.; Jondan \& Evermann, Bull. 47, U. S. Nat. IIus. III, 2S51, 1898.

Head four; depth six; eye four in head; snout four; maxillary three and one half; interorbital width fire and one half. D. XI-12; A. II, S. Scales 7-56-6. Body rather stout, heavy forward, compressed behind; head heary; mouth moderate, slightly oblique, lower jaw included, maxillary reaching front of pupil; premaxillaries protractile; cheeks, opercles, breast, and nape entirely naked; scales of body large and strongly ctenoid; lateral line complete, straight; median line of belly naked anteriorly, with ordinary scales posteriorly; fins large; dorsals separated by a space equal to half diameter of eye, origin of spinous dorsal a little nearer origin of soft dorsal than tip of snout, its base about equal to length of head, longest dorsal spine two and one half in head, the outline of the fin gently and regularly rounded; soft dorsal higher than spinous portion, the second to 10th rays about equal in length, scarcely twice in head, the first, 11th, and 12th rays but slightly shorter than the others; anal moderate, its origin under base of third dorsal ray, the spines slender, the second a little longer than the first, whose length is three and three fourths in head, longest anal rays about two and one fifth in head; caudal lunate, the lobes more produced and pointed than usual among darters; pectorals long and pointed, the middle rays longest, about one and one sixth in head, reaching tips of rentrals; ventrals well separated, not nearly reaching vent, the longest rays one and one fourth in head. Color in alcohol, back dark brownish, covered with 
irregular spots and blotches of darker; side with about eight or nine large dark spots lying on the lateral line; belly pale; top of head dark; snout black; lower jaw and throat dark; a broad black line downward from eye to throat; cheek and opercles rusty; spinous dorsal crossed by a median dark line; ventrals blue black; other fins pale, but dusted with rusty specks.

An examination of the 14 cotypes shows some variation in the species. In two examples there is a well developed frenum, rendering the premaxillaries nonprotractile, and in a third specimen the frenum is partially developed; in some individuals the origin of the spinous dorsal is exactly midway between the tip of snout and origin of soft dorsal. The females and immature males are less highly colored than the adult male described above. Length $1 \frac{3}{4}$ to $2 \frac{1}{4}$ inches.

This species seems most closely related to $\mathrm{Cot}$ to gas ter s h u mar d i, from which it may be readily distinguished by the shorter snout, the naked cheeks and opercles, the smaller soft dorsal, the smaller anal and the coloration.

15 examples of this interesting darter were obtained July 18, 1894, by Evermann and Bean in the Racket river near Norfolk, St Lawrence co. N. Y. It did not seem to be rery common, as only 1.5 examples resulted from numerous hauls of the collecting seine.

Named for A. Nelson Cheney, state fish culturist of New York in recognition of his valuable contributions to our knowledge of the food and game fishes of that state. (After Evermann and Kendall)

\section{Genus diplesiox Rafinesque}

Body rather elongate, subterete; head rery short and blunt, with tumid cheeks; the profile very convex; month small, inferior, lorizontal; premaxillaries protractile, little movable, joined to the forehead mesially by a slight frenum; maxillary not protractile, adnate for most of its length to the fleshy skin of the preorbital; lower jaw rery short; teeth in jaws strong, no teeth on vomer or palatines; gill membranes broadly con. 
nected; gill raker's very short; scales moderate, rough; lateral line complete; no enlarged ventral plates; dorsal fins large, the spinous dorsal longer and lower than the second, of about 13 spines; anal smaller than second dorsal, with two strong spines; ventrals moderately separated; pectorals long, symmetric; vertebrae (b l e n n i o i d e s) $19+23=42$; pyloric caleca four; frontal region of skull very narrow, ethmoid region abruptly decurved, parietal region moderately convex (less so than in $\mathrm{E} t \mathrm{~h}$ e o $\mathrm{s} t$ o $\mathrm{m}$ a, more so than in $\mathrm{B}$ o l e o s o m a); no supraoccipital crest. Coloration largely green.

\section{Diplesion blennioides (Rafinesque)}

Green-sided Darter

Etheostoma (Diplesion) blennioides RAFinesque, Journ. de Physique, 419, 1819.

Etheostoma blennioides BEAit, Fishes Penna. 121, 1893.

Diplesion blennioides Jordan \& Gilbert, Bull. 16, U. S. Nat. Mus. 497, 1883; Jordan \& Everucann, Bull. 47, U. S. Nat. Mus. 1053, 1896, pl. CLXX, fig. $449,1900$.

The body is stout and long; the head moderate in size, its length contained four and one half times in the total without caudal and slightly exceeding the depth of the body; mouth small; lower jaw included within the upper; eyes large, placed high and narrowly separated by a longitudinal furrow; scales rather small except some larger ones on the belly, which are not shed; cheeks finely scaled; gill covers with large scales; nape scaly; breast naked. The males have a large anal papilla. Anal spines stout; caudal fin notched. Males have the lower pectoral rays and the ventral and anal rays enlarged and thickened. D. XIII-13; A. II, 8. Scales 65 to 78 ; vertebrae 42.

Color olive green; upper parts tessellated; sides with seven or eight double crossbars, each forming a Y-shaped figure, these bars sometimes joined above so as to form an undulating lateral band and clear deep green in life, and the sides speckled with orange. There is a dark bar from the eye forward and another downward, besides some olive stripes on the head. Spinous dorsal blue above with a pale margin and dark orange brown at base; soft dorsal and anal deep blue green tinged with 
red; caudal greenish with faint bars. Females and young are less conspicuously colored, but in the same general pattern.

The green-sided darter extends from Pennsylvania westward to Kansas and south to Alabama. The U. S. Fish Commission had specimens from Sandy creek, North Hamlin N. Y., Aug. 20.

The species is notable for its beauty; it grows to a length of 5 inches; it is common in gravelly streams and occurs only in clear water. In habits it is similar to the Johnny darter, but it is less tenacious of life than that fish. In the aquarium it is shy and retiring, spending most of its time in the concealment of water plants or decorative rock work.

\section{Genus moueosoma De Kay}

Bods moderately elongate, fusiform, but slightly translucent; head small, narrowed forward, the profile convex; month small, horizontal, the lower jaw included; premaxillary protractile; maxillaries not adnate to preorbital; vomerine teeth present; scales large; lateral line continuous or interrupted behind; belly with ordinary scales; gill membranes broadly or narrowly connected; dorsal spines usually nine, very slender and flexible, soft dorsal much larger than anal; anal normally with a single, short, slender spine, the first soft ray simple, but articulate; ventrals well separated; vertebrae (B. ni grum) 15+22=37; pyloric caeca three to six; frontal region of skull very short and narrow; parietal region flattish above; no supraoccipital crest. Coloration olivaceous and speckled, the males with inky black in spring; no red or blue. Size small. Very active little fishes, abounding among weeds in clear streams.

\section{Boleosoma nigrum (Rafinesque)}

\section{Johnny Darter}

Etheostoma nigrum RAfinesque, Ichthyol. Ohien, 37, 1820; BEAx, Fishes Penna. 120, 1893.

Boleosoma maculatum Agassiz, Lake Superior, 305, pl. IV, fig. 3, 1850, Fort William; Günther, Cat. Fish. Brit. Mus. I, 77, 1859.

Boleosoma nigrum Jordan \& GILBERT, Bull. 16, U. S. Nat. Mus. 492, 18\&3; JordaN \& EvermanN, Bull. 47, U. S. Nat. Mus. 1056, 1896, pl. CLXX, fig. $450,1900$.

The body is slender, spindle-shaped. The conical head is contained slightly more than four times and the depth about fire 
times in the total lengtl. The snout is somewhat decurved. Mouth small and the lower jaw included within the upper. The gill cover's are scaly, cheeks naked except in occasional individuals, and the nape is usually scaled: The fins are high, but lower and smaller than in other species of $\mathrm{B}$ ol e o s o m a. D. VIII to $\mathrm{X}, \mathbf{1 0 - 1 4}$; A. I. 7 to 9 ; scales $5-44$ to $55-9$.

Color olivaceous; the back with brown tessellations; sides with many $\mathrm{W}^{\prime}$-shaped blotches. The head is speckled above; in males generally black. In the breeding season the whole anterior part of the male is often black. A dark line forward from the eye and sometimes another downward. This is one of the small species, attaining a length of only $2 \frac{1}{2}$ inches. It is found on the bottom in clear small brooks, where it lies partly concealed by sand, and clianges its colors according to its surroundings.

The Johnny darter ranges from western Pennsylvania to Missouri and Dakota. In the Great lakes region it is abundant, and it is one of the commonest darters in the streams of Ohio. It does not occur in eastern Pennsylvania. In New York it appears to occur in the Great lakes region only.

\section{Boleosoma nigrum olmstedi (Storer)}

\section{Tessellated Darter}

Etheostoma olmstedi Storer. Jour. Bost. Soc. Nat. Hist. 61, pl. 5, fig. 2, 1811;

Hist. Fish. Mass. 30, pl. IV, fig. 1, 1867; BeAn, Fishes Penua. 120, pl. 33, fig. $67,1893$.

Boleosoma olmstcdi Goode \& BeAx, Bull. Essex Inst. XI, 19, 1879.

Boleosoma olmstedi Jordan \& GILbErt, Bull. 16, U. S. Nat. Mus. 492, 1883; BeAN, Bull. Am. Mus. Nat. Hist. IX, 365, 1897.

Ethcostoma nigrum olmstedi MEEK, Ann. N. Y. Ac. Sci. IV, $313,188 S$.

Boleosoma nigrum olmstedi Evermand \& KENDALL, Rept. U. S. F. C. 1894, 603, 1896; Jordan \& Evermann, Bull. 47, U. S. Nat. Mus. 1057, 1896, pl. CLXXI, fig. 451, 1900; Eugene SmriH, Proc. Linn. Soc. N. Y. 1897, $36,1898$.

Boleosoma tessellatum DE Kix, N. Y. Fauna, Fishes, 20, pl. 20, fig. 57, 1842.

The head is contained four and one fourth times in total length; depth fire and one fourth times. The cheels and opercles are scaly; nape and breast naked. The lateral line is complete, with about 50 scales. D. IX, 14; A. I, 9.

The color is olivaceous; fins with many narrow bars; the back tessellated; sides with blotches and zigzag markings. Head in 
spring males black. A dark streak forward from the eje and another downward.

This darter secretes itself on the bottom in small clear brooks, swimming rapidly for a short distance when alarmed. The sexes are very different in appearance, the males having higher and more brightly colored fins than the females. The males are larger than the females and in the spring are much spotted with black. The common darter, or tessellated darter, is found from Massachusetts to Georgia. It is replaced in Cayuga lake and some other regions to the southward by a black spotted rariety, which differs from the common form still further in having the nape and breast closely scaled. De Kay states that it occurs in most of the fresh-water streams of the state. It is found in Lake Champlain. Evermann and Bean took it in Scioto creek, at Coopersville, in the Saranac, at Plattsburg, in the St Lawrence river, 3 miles below Ogdensburg, and in Racket river, at Norfolk. In the Lake Ontario region the U. S. Fish Commission collectors obtained it in the following localities:

Cape Vincent

June 21

Mud creek, Cape Tincent

June 25

Grenadier island

June 27

Horse island, Sackett's Harbor

June 30

Mill creek, Sackett's IIarbor

July 2

Stony Island

Little Stony brook, Menderson bay July 2 and 3

Cemetery creek, Watertown

July 4

Guffon creek, Chaumont

July 5

Chaumont river

July 7

Spring brook, Pulaski

July 10

Month of Salmon river, Selkirk

July 24

Mouth Little Salmon creek

July 25

Three Mile creck, Oswego

July 25

Great Sodus bay

July 27

Long pond, Charlotte Aug. 6

Sandy creek, North Hamlin Aug. 17 Aug. 20 
According to Dr Meek it is common at each end of Cayuga lake, but is not found in the streams at the southern end above the falls. The species was obtained in small number's by the writer in Bronx river in August, 1897. Eugene Smith has obtained it in tidal creeks where the water is impure but not saline. It is recorded from streams of Long Island.

The tessellated darter grows to the length of $3 \frac{1}{2}$ inches. It is a near relative of the Johnny darter, B o l e os o m a $\mathrm{n} \mathrm{i} \mathrm{gr} \mathrm{u} \mathrm{m}$ of Rafinesque. In captivity Eugene Smith has found it delicate, able to live only in water of low temperature and not deep unless in circulation. In balanced tanks it thrives and feeds freely on minced clam, G a m m a r u s, and earthworms, the last to be used only occasionally.

De Kay observed it usually at the bottom of clear springs or streams, lying for a while perfectly still near the bottom, and then suddenly darting off with great velocity at its prey, a habit from which is derived its name of darter. He mentions also the name grand-oranchee, applied to it in New York by the descendants of the Dutch colonists, but this name is not satisfactorily explained.

The best account of the movements of the fish is given by Zadock Thompson in his History of Vermont. He noted its power of bending its neck and moring its head without moving the body, a very unusual faculty among fishes.

\section{Genus etheostoma Rafinesque}

Body robust, or rather elongate, compressed; mouth terminal, or subinferior, varying in size; the lower jaw included or projecting; premaxillaries not protractile; maxillary movable; teeth rather strong, usually present on vomer and palatines; gill membranes separate or more or less broadly connected; scales moderate or small, ctenoid, top of head without scales, scales of the middle line of the belly persistent and similar to the others; lateral line well developed, nearly straight, often wanting posteriorly; fins large, with strong spines, first dorsal usually longer and larger than the second, with seven to 15 spines; anal with two strong spines, the anterior usually the 
larger, the second rarely obsolete, anal fin always smaller than the soft dorsal; rentral fins more or less close together; skull narrow, the parictal region rery strongly convex in crosssection, supraocipital crest very small or wanting; lower pharyngeals very narrow; rertebrae 33 to 39 , usually $15+21=36$; pyloric caeca three or four; bones rather firm. Coloration various, often brilliant. As here understood, a rery large genus corering a great variety of forms. Many attempts at further subdirision hàre been made. Intergradations of all sorts occur, and the technical characters do not always indicate the real relationship. Many of the species are excessively variable, each brook having its peculiar race.

\section{Subgenus oligocephatus Girard}

\section{Etheostoma coeruleum Storer}

\section{Blue Darter; Rainbow Darter}

Etheostoma coerulea Storer, Proc. Bost. Soc. Nat. Hist. II, 47, 1845, Fox River, Ill.

Poecilichthys coeruleus Jordan \& GILbert, Bull. 16, U. S. Nat. Mus. 517, $18 S 3$.

Etheostoma coeruleum MEEK, Bull. U. S. F. C. 119, 131, 155, 1891; BEAN, Fishes Penna. 125, 1893; Jordan \& Evermann, Bull. 47, U. S. Nat. Mus. 1088, 1896.

Body short, comparatirely stout; head large; mouth moderately large, the lower jaw included within the upper. The maxilla extends to the front of the eye. The length of the head is contained three and three fourth times in the total length without the caudal, and the depth of the body four and one fourth times. Five rows of scales above the lateral line, eight rows below the lateral line, and 45 rows from head to base of caudal, nape and breast generally scaleless. D. X, 12; A. II, 7.

The body of the male is olivaceous with darker blotches on the back, 12 bar's of indigo blue running obliquely downward and backward across the sides. The spaces between the bars are orange, as are also the throat, breast and cheeks. The base of the spinous dorsal is crimson, surmounted by orange and margined with blue. The soft dorsal is orange, its base and margin blue. In the female the blue and orange colors are 
chiefly wanting, and the dorsal, anal and caudal are checked or barred.

The blue darter, blue Johnny, rainbow darter, or soldier fish, is found in the Ohio valley and in some parts of the Mississippi valley. It abounds in gravelly streams and ascends small brooks, but not in large numbers. The U. S. Fish Commission obtained many individuals in Marsh creek at Point Breeze N. Y. Aug. 2, and a few in Salt brook, $1 \frac{1}{2}$ miles above Nine Mile point, June 11, 1893.

The blue darter reaches a length of 3 inches. It is not so active as some of the other darters, but in coloration it is the most beautiful of all. One of the most interesting accounts of its habits is republished in Bulletin 47, U. S. National Museum, from the writings of Jordan and Copeland. It will follow to the surface of the water a piece of meat suspended by a thread and has been seen to catch a water insect by a swimming leg and release it several times, apparently for the mere pleasure of. playing tricks.

\section{Subgenus ETHEOSTOMA}

\section{Etheostoma flabellare Rafinesque}

\section{Fantail Darter}

Etheostoma flabellaris RAfinesque, Joul. de Physique, Paris, 419, 1819.

Etheostoma linsleyi Storer, Proc. Bost. Soc. Nat. Hist. 37, 1S51, Wolcott, Wayne County, N. Y.

Catonotus fasciatus Girard, Proc. Ac. Nat. Sci. Phila. 68, 1859, Madrid, N. X.

Catonotus flabellatis VAILLANT, Recherches sur Etheostom. 121, 1573, with plate.

Etheostoma flabellare Jordan \& Gilbert, Bull. 16, U. S. Nat. Mus. 513, 1S83; MeEk, Ann. N. Y. Ac. Sci. IV, 314, 1Sss; BeAN, Fishes Penna. 125, 1893; Jordan \& Evermann, Bull. 47, U. S. Nat. Mus. 1097, 1S96; Eugene Shith, Proc. Linn. Soc. N. Y. 1S97, 37, 1895.

Body slender, elongate; head long, lower jaw strongly projecting. The species is readily recognized by its low fins, specially the spinous dorsal, and its prominent lower jaw. It runs, however, into several varieties, one of which, occurring in Indiana and northwestward, has black spots on the scales forming lateral stripes; another variety from the Cumberland river 
is distinguished by its thick jaw and nearly plain coloration. In the male the spinous dorsal is one half as high as the soft dorsal. The female has higher spines than the male; the spines hare fleshy tips. No scales on nape, head and breast. A large black humeral scale. The length of the head equals one fourth of the total leugth without caudal, and the depth one fifth. D. TIII, 12; A. II, S. Scales $7-50-7$. The lateral line ends at the middle of the length.

The general color is olivaceous, the upper parts dusky; the sides with dark streaks formed by the spots at the base of the scales. The males have dusky crossbars; the soft dorsal and caudal barred. The spinous dorsal of the male has an orange margin.

The fantail darter is found from western New York to Nortl Carolina, and in the Ohio valley. In the Lake Ontario region the U. S. Fish Commission collectors obtained it from the following places in 1893 :

Salt brook, $1 \frac{1}{2}$ miles above Nine Mile point

June 11

Grenadier island

June $2 S$ and 29

Horse island, Sackett's Harbor

June 30

Mill creek

July 2

Little Stony brook, Henderson bay

July 4

Cemetery creek, Waterıwn

July 5

Chaumont river

July 10

Big Sandy creek, Bellerille

July 12

Wirt creek

July 24

Spring brook, Pulaski

July 24

Three Mile creek, Oswego

July 27

Great Sodus bay

Aug. 6

Four Mile creek, Nine Mile point, Webster

Aug. 9

Sandy creek, North Hamlin

Aug. 20

Marsh creek, Point Breeze

Aug. 21

Writing of the fishes of Cayuga lake basin, Dr Meek makes the statement that the fantail darter is found with the tessellated darter at each end of Cayuga lake; that these two 
are the only species of darters in the lake, and neither of them occurs in the streams on the uplands.

Though usually considered as being limited to western New York, Eugene Smith sass it is not altogether rare in the Hackensack valley streams, perhaps the easternmost locality in which it occurs.

It grows to a length of $2 \frac{1}{2}$ inches and abounds in clear rocky streams. It is very active and tenacious of life and is an excellent species for the aquarium.

\section{Genus вoLeichthys Girard}

This genus contains small and slender species allied to those of the section Oligocephalus under Etheostoma. The lateral line is incomplete and has a slight upward curve anteriorly instead of being straight, as in all the species of Etheostoma. Top of head not scaly. Lowland streams and swamps. The species few, variable and hard to determine.

\section{Boleichthys fusiformis (Girard)}

Boleosoma fusiformis Girard, Proc. Bost. Soc. Nat. Hist. 41, 1854.

Hololepis fusiformis VaIllant, Recherches sur Etheostom. 131, 1873, with plate.

Poecilichthys fusiformis Jordan \& GILBert, Bull. 16, U. S. Nat. Mus. 520, 1883.

Etheostoma fusiforme Evermand \& Kennali, Bull. U. S. F. C. XII, 115, 1894; Eugene Surth, Proc. Linn. Soc. N. I. 1S97, 37, 1898.

Boleichthys fusiformis Jondan \& EvermanN, Bull. 47, U. S. Nat. Mus. 1101, 1S96, pl. CLXXVII, fig. 469, 1900.

Body moderately elongate, strongly compressed. The depth is contained six times in the length. Head rather long and narrow. The length is one fourth that of the body. The muzzle short, decurved, shorter than eye; mouth comparatively large, terminal; maxillary reaching past front of eye; eyes. large, four in head; opercular spine strong; lateral line beginning at the eje, on about 12 to 15 scales; neck scaly; belly and throat scaly. D. X-9; A. II, 7; lateral line 55 .

Olivaceous, dotted with dusky points; second dorsal and anal speckled. 
This little darter is recorded from Massachusetts to New Jersey and will doubtless be found in New York. It grows to the length of 2 inches.

\section{5̃ Boleichthys fusiformis eos Jordan \& Copeland}

Boleichthys eos Jordan \& Copeland, Proc. Ac. Nat. Sci. Phila. 46, 1877, Rock River, Wisconsin; Wisconsin River, Wisconsin; Fox River, Illinois.

Poecilichthys cos Jordan \& Gilbert, Bull. 16, U. S. Nat. Mus. 520, 1883. Boleichthys fusiformis cos Jordan and Evermann, Bull. 47, U. S. Nat. Mus. 1102, 1896.

Body elongate, slender, somewhat compressed, specially behind, rather heavy forward, with very long and slender caudal peduncle; head long, rounded in front; mouth small, little oblique, the upper jaw a very little the longer; dorsal fins high, about equal; caudal truncate; cheeks, opercles, and neck closely scaled; breast naked, or with a median series of small scales; lateral line developed on 22 to 26 scales. Head one fourth of total length without caudal; depth $\frac{3}{16 .}$ D. IX-11; A. II, 7; lateral line $5 \mathrm{~s}$.

Color dark olive, with darker markings; 10 or 12 dark dorsal spots or bars, and as many short dark blue bars across the lateral line nearly opposite the dorsal bars, but not continuous with them; the interspaces between these bars, as well as most of the rentral region, bright crimson in the males, nearly plain in the females; lower parts of the sides, cheeks, etc. with various sharply defined but irregular black markings; second dorsal, caudal, and pectorals strongly marked with wary bands; first dorsal bright blue in the males, with a broad median band of crimson, speckled in the females; top of head dark; black streaks downward and forward from eye.

The describers of the species recorded its distribution from Indiana to Minnesota; abundant in clear cold streams. It grows to the length of $2 \frac{1}{2}$ inches, and is one of the prettiest of the darters. Specimens were obtained for the U. S. Fish Commission in Mud creek, Cape Vincent N. Y. June 25, the species being abundant there, at Grenadier island, June 27, and in Guffon creek, Chaumont N. Y. July 7. 


\section{Family SERrANidAE Sea Basses}

\section{Genus roccus Mitchill}

Base of tongue with one or two patches of teeth; anal spines graduated; dorsal fins entirely separate; anal rays III, 11 or 12; supraoccipital crest scarcely widened above; lower jaw projecting. Tertebrae $12+13=25$. Otherwise as in $\mathrm{M}$ or $\mathrm{r} \mathrm{ne}$, the body more elongate, the scales smoother, and the fins more slender than in M o r o ne. Species all American, valued as food fishes. In both $\mathrm{Roccus}$ and Morone, the antrorse preopercular spines (characteristic of the European genus or subgenus Dicentrarchus) are wanting.

\section{Roccus chrysops (Rafinesque)}

\section{White Bass}

Perca chrysops Rafinesque, Ichthyol. Olien. 22, 1820.

Labrax albidus De FiY, N. Y. Fauna, Fishes, 13, pl. 51, fig. 165, 1S42, Buffalo.

Labrax notatus Richardson, Fauna Bor.-Amer. III, 8, 1836; Günther, Cat. Fish. Birit. Mus. I, 67, 1859.

Roccus chrysops GiLl, Rept. Capt. Simpson's Surv. Great Basin Utah, 391, pl. 1, fig. 1-7, 1876; Jokdan \& Gilbert, Bull. 16, U. S. Nat. Mus. 529, 1683; Benx. Fishes Penna. 132, pl. 34, fig. 71, 1993; Bull. Am. Mus. Nat. Hist. IX, 365, 1897; Jordan \& Evermaxn, Bull. 47, U. S. Nat. Irus. 1132, 1896, pl. ClXXX, fig. 47т, 1900; Eugene Smin, Proc. Linn. Soc. ․ Y. $1897,38,1898$.

The white bass has the body oblong, elevated and compressed; its depth contained two and one half times in the total length without candal, the length of the head about three and one third times in this length; head subconical, depressed orer eye; mouth moderate, the maxillary reaching to below middle of eye; length of eve almost equal to length of snont; rilliform teeth in bands on jaws, palatines, romer and tongue; the dorsal outline is much curved, the fins well separated.

D. IX, I, 14; A. III, 11 to 12. Scales S-60-13. General color silvery, tinged with golden on sides; eight or more blackish longitudinal streaks on sides, those below more or less interrupted. 
The following measurements were taken from a specimen obtained by Mr James Innin jr, in Oneida lake, Sep. 4, 1896.

Inches

Extreme length................. 121

Length to end of middle caudal rays....... 11

Length to end of scales............. 10

Depth of body.................... 4

Least depth of caudal peduncle......... $1 \frac{3}{5}$

Length of head.................. 3

Length of snout................

Diameter of eye.............. $\frac{9}{16}$

Length of fourth dorsal spine......... $1 \frac{3}{3}$

Length of second dorsal ray........... $1 \frac{3}{4}$

Length of second anal ray............ $1 \frac{3}{4}$

Weight, $16 \frac{1}{2}$ ounces.

The white bass is sometimes called striped bass, and is probably the silver bass of Canada. Its center of abundance is the Great lakes region, but it is also widely distributed orer the Ohio and Mississippi ralleys. In Pennsylrania the species is found in Lake Erie and in the tributaries of the Ohio river. The U.S. Fish Commission secured three specimens at Horse island, Sacketis Harbor N. I., June 30. The New Jersey Fish Commission has introduced the fish into Greenwood lake.

The white bass weighs from 1 to 3 pounds, and its flesh is considered almost if not equally as good as that of the black bass. It prefer's the deeper parts of rivers and thrives best in lakes and ponds. In April and May they leave the deeper waters and go in near shore or to the mouths of rivers where they spamn. The spawning period is in May and June.

The white bass feeds upon minnows, crawfish and other freshwater crustaceans, also minute mollusks or slellfish, and it is said to derour many soung whitefish upon the sparning grounds of that species.

It is a game fish and affords good sport to the angler. 


\section{Roccus lineatus (Bloch)}

\section{Striped Bass; Rockfish}

Sciaena lineata BLoch, Ichthyol. IX, 53, pl. 305, 1792.

Perca septentrionalis Bloch \& Schneider, Syst. Ichth. 90, pl. 70, 1801, New York.

Roccus stritus Mrtcrill, Rep. Fish. N. Y. 25, 1814.

Perca mitchilli Mitchill, Trans. Lit. \& Phil. Soc. N. X. I, 413, pl. IlI, fig. 4,1815 .

Perea mitchilli alternata Mitcnill, Trans. Lit. \& Phil. Soc. N. Y. I, 415. 1815.

Perea mitchilli interrupta MiтchiLl, Trans. Lit. \& Phil. Soc. N. Y. I, 415, 1815.

Labrax lineatus De KAY, N. Y. Fauna, Fishes, 7, pl. 1, fig. 3, 1842; Güntiler, Cat. Fish. Brit. Mus. I, 64, 1859; Storer, Hist. Fish. Mass. 6, pl. I, fig. 4,1867 .

Roccus lineatus Gill, Ichth. Rep. Capt. Simpson's Expl. Great Basin Utah, 391, 1876; Goode, Fish \& Fish. Ind. U. S. I, 425, pl. 170, 1894; BEAs, 19th Rep. Comm. Fish. N. Y. 26 7 , pl. XVIII, fig. 22, 1890; Fishes Penna. 131, color pl. 14, 1893; Bull. Am. Mus. Nat. Hist. IX, 365. 1897; Jordan \& Evermann, Bull. 47, U. S. Nat. Mus. 1132, 1896, pl. CLXXX, fig. 47S, 1900; Eugene Surth, Proc. Linn. Soc. N. Y. 1897, 38, 189S; Mearis, Bull. Am. Mus. Nat. Hist. X, 321, 1898; H. M. Sumth, Bull. U. S. F. C. for 1897, 99, 1898; Beax, 52 d Ann. Rep. N. Y. State Mus. 105,1900 .

The genus Roc cus, to which the striped bass belongs, has two patches of small teeth on the base of the tongue, the anal spines increasing regularly in size backward, the lower jaw much longer than the upper, the scales on the cheeks nearly smooth along their margin and the dorsal fins separated by a narrow interspace. The body is moderately elongate and rather stout; the caudal peduncle is slender. The greatest depth of the body is two sevenths of the total length without caudal and equals length of head. Eye small, one half as long as the snout and one sixth to one eighth the length of the head. The eves are placed near the top of the head; the maxilla reaches to. below the middle of the eye. The anal spines are slender, the third longest, about one fifth length of head. The fourth and fifth dorsal spines are longest, about two fifths length of head. Pectoral a little longer than ventral, one half length of head.

D. IX, I, 11 to $12 ;$ A. III, 10 to 11 . Scales $7-65-19$.

Sides greenish above, silvery below, sometimes with a brassy lustre and marked by seven or eight longitudinal streaks none of 
which are half as wide as the eye, one of them passing along the lateral line; the lowermost stripe is somewhat below the middle of the deptli.

In the southern United States from New Jersey to Florida the striped bass is known as the rock or rockfish. In the northern states the name striped bass is more generally used than the other, specially along the coast. In the Delaware, Susquehanna and Potomac rivers it is called rockfish. Greenhead and squid hound are names applied to large individuals found in the sea in New England waters. One of the old names of the fish is streaked bass.

Rockfish and striped bass, according to Schoepff (1787), are among the early New York names for this highly prized species. Dr Mitchill (1814) calls it Mitchill's perch, striped basse and rockfish. De Kay describes it as the striped sea bass. Streaked bass is another name in use in 1815, and a rery interesting account of the fish under this name is published by Dr James Mease in the first volume of the Transactions of the Literary and Philosophical Society of New York. Dr Mease in this article states that rockfislı weighing from 25 pounds to 60 pounds are called greenheads. At the time of his writing the fishing-ground for the Philadelphia and New York markets was between Long Branch and Cranberry inlet, an extent of about thirty miles, and the great places of winter resort were Motetecunk, 30 miles from Long Branch, and the rivers of Elk and Egg Farbor.

At the time of Dr Mitchill's report the greatest run occurred late in the fall, and great hauls were made during the coldest season, including some very large fish. He saw, howerer, a dozen at a time weighing כ0 pounds each in New York market during rery mild weather in early October.

The range of the striped bass or rockfish includes the entire Atlantic coast from the Gulf of st Lawrence to the Gulf of Mexico, the fish entering rivers and ascending them long distances. In the Alabama river this fish is known to be taken every year and some large individuals have been obtained from that stream. It has been captnred also in the lower Mississippi. 
It is rery abundant in the great bays and sounds from North Carolina to Cape Cod. In Albemarle sound many large individuals are said to occur. In the St John's river, Florida, according to $\mathrm{Dr}$ Goode, the fish is rather rare. In the vicinity of Pensacola the late Silas Stearns occasionally obtained a specimen of the fish.

The striped bass has been introduced into California and has now become fairly acclimated there. In the Delaware and Susquehanma rivers this is one of the common fishes and it is one of the most highly esteemed.

This is a permanent resident of Graresend bay, but the hight of the fishery occurs from October 10 to November 10. Large fish, up to 45 pounds, are caught in May, but the fall fish range from 9 inches to 24 inches in length. In Great South bay the writer has obtained specimens at Blue Point cove, Great river, Nichols's point, and off Widow's creek. A great haul was made on Lone Hill Middleground about the middle of October, 1901. The fish remains in some of the tributaries of Great South bay throughout the year. According to Dr Mearns the species is taken in great numbers in nets set through the ice of the Hudson in winter, and in drift nets by shad fishermen in spring. Large indiriduals of 60 pounds and upward are sometimes caught in the winter and early spring. He once took a specimen a little above the estuary of Poplopen's ereek, in fresh water.

It Woods Ilole Mass. the fish is not common, and apparently does not spawn; it arrires about Mar 1 and leares about Norember 1 ; in size it ranges from $\frac{1}{2}$ pound to 65 jounds.

This fish lives in the sea or in brackish or fresh water indifferently and it has been successfully liept in artificial ponds. In cold norther'n waters its becomes icebound occasionally and is said to hibernate. It prefers cold water, is carnivorous and predaceous, feeding upon small fishes in the streams, consuming specially large quantities of the alewife or river herring and the young of the shad. In the shallow bays along the coasts its food consists of killifish, silversides, anchovies, lant and other small fishes, besides crabs, squid, clams, mussels and other 
marine invertebrates. Its movements while feeding depend greatly on the tides. It is to be found frequently at the mouths of small creelis and in tideways, where it lies in wajt for the large schools of small fishes, which constitute its food.

The largest striped bass recorded was said to weigh 112 pounds. It Aroca, North Carolina, Dr Capellart took a striped bass weighing 95 pounds. It reacles a length of four and one half or five feet.

Spawning takes place from April to June, either in the rivers or in the brackish waters of bays and sounds. Eggs have been hatched artificially in May on Albemarle sound. Dr Capehart took a 58 pound spawning fish April 22, 1891. The eggs are smaller than those of the shad and after fertilization they increase greatly in size and become light green in color. This 58 pound fish probably contained more than one half million eggs. Dr Abbott has found the young an inch long in the Delaware the second weeli in June and by the middle of October some of these had grown to a length of $4 \frac{1}{2}$ inclies. The striped bass has been kept in a small pool of fresh water and fed upon crabs and oysters increasing in about eleven months from 6 inches in length to 20 inches. In the aquarium the species is hardy and grows rapidly; it can be kept in sood condition almost indefinitely. In a Rhode Island pond it is stated that bass weighing $\frac{1}{2}$ pound to 1 pound in June had reached a weight of six pounds in the following October.

In fresh water, salted eel tail is a farorite bait for taling striped bass, and the spoon or spinner is also a good lure, but live minnows are prefered to all other baits. For surf fishing shedder crab well fastened to the hook is a very killing bait.

\section{Genus morove Mitchill}

Body rather short and deep, compressed; maxillary broad, naked, without supplemental bone; teeth subequal; lower jaw scarcely projecting; no canines; no movable teeth; base of tongue without tecth; edge of tongue with linear patches of teeth. Lower margin of preopercle finely serrate or entire, the serrae not greatly increased in size toward the angle, and none 
of them developed as antrorse hooks. Spines strong, 10 in the dorsal fin; dorsal fins more or less connected by membrane; second anal spine much enlarged, not shorter than third; anal rays III, eight or nine. Vertebrae $12+13=25$. Scales rather large, ctenoid; top of head scaly; lateral line little arched. Ventrals inserted well behind pectorals. Two known species, both American.

\section{Morone americana (Gmelin)}

\section{White Perch}

I'erca americana Gareld, L. Syst. Nat. I, III, 1308, 17S8, New York. Morone Rufa Mitcinld, Rep. Fish. N. Y. 18, 1814, New York. Jiorone Pallida Mrtchils, Rep. Fish. N. Y. 18, 1814, New York. Bodianus rufus Mitchild, Trans. Lit. \& Phil. Soc. N. Y. I, 420, 1815. I.abrax rufus DE KAY, N. Y. Fauna, Fishes, 9, pl. 3, fig. 7, 1842; Gǜther, Cat. Fish. Brit. Mus. I, 65, 1859.

Labrax pallidus DE KAY, N. Y. Fauna, Fishes, 11, pl. 1, fig. 2, 1S42; Günther, Cat. Fisl. Brit. Mus. I, 67, 1859.

Labrax nigricans DE KAY, N. Y. Fauna, Fishes, 12, pl. 50, fig. 160, 1842. Roceus americanus BEaN, 19th Rep. Comm. Fish. N. Y. 268, pl. XIX, fig. $23,1890$.

IIorone amerieana GilL, Ichth. Rept. Capt. Simpson's Surv. Great Basin Utah, 397, 1S76; BeAn, Fishes Penna. 133, pl. 15, 1893; Jordan \& Evermand, Bull. 47, U. S. Nat. Mus. 1134, 1896, pl. CLXXXI, fig. 479, 1900; BeAn, Bull. Am. Mus. Nat. Hist. IX, 366, 1S97; Mearns, Bull. Am. Mus. Nat. Hist. $\mathbf{X}$, 321, 1S98; Eugene Sirth, Proc. Linn. Soc. N. X. 1897, 39, 1898; H. II. Surti, Bull. U. S. F. C. 1S97, 99, 1S98; Bean, 52d Ann. Rept. N. Y. State MIus. 105, 1900.

The genus Morone of Gill differs from Roc cus in haring the dorsals joined, the spines strong, the anal with 10 soft rays, its spines not graduated, the jaws subequal and base of the tongue toothless. It includes the common white perch and the yellow bass.

The white perch has an oblong body, with the back convex, mouth moderate, the maxillary reaching a little beyond the front of the ere; the eye is nearly as long as the snout, and is contained five and one half times in the length of the head; the head is about one third of total without caudal; the depth of body is contained two and two thirds times in total without caudal; the fourth anal spine is the longest, two fifths length of head; the second is stouter and slightly shorter than the third, its length one third that of head. 
D. IX, I, 12; A. III, 10. Scales 7-51-11. The dorsal fins are separated by a very deep notch, but connected by membrane; upper parts grayish or greenish; sides silrery; young individalals have pale, longitudinal streaks.

This is the perch or river perch of Schoepff, which he records as an inhabitant of the coasts of New York and Long Island, in and at the mouths of fresh-water streams. Dr Mitchill (1815) gires it the name of red perch, and states that when not in the breeding season it is called black perch because its colors are browner and darker. De Kay describes it, in the Fishes of New York, as the ruddy bass. In Great Egg Harbor bay individuals taken from salt water are sometimes called yellow perch or peerch.

The species is found from Nora Scotia to South Carolina, and inhabits both salt and fresh water. Mitchill saw specimens 14 inches long and nearly 5 inches deep, from Quag, Long Island. There is an important winter fishery for the white perch at Bellport. It is taken in seines and gillnets. The writer has occasionally found this species in various parts of Great South bay, for example, at Smith's point, Whale House Hole, Swan river; also in the east end of Shinnecock bay, in the fresh water of Head of Creek, near Southampton. The fishermen affirm that when its feeding grounds are disturbed by seining the fish suddenly leave the locality. The white perch is never plentiful in Gravesend bay; it is abundant in fresh-water lakes of Central park, New York, and Prospect park, Brooklyn. Near Montauk, Long Island, the species is abundant and reaches a large size. Eugene Smith has found it common in brackish waters near New York, where it occur's all the year; he had it also from fresh water. Mearns states that it remains in the Hudson throughout the year and is taken in abundance in winter in nets set through the ice. In Oscawana lake, Putham county, individuals weighing 2 or 3 pounds were reported to him.

In the vicinity of Woods Hole Mass. the fish is abundant in fresh-water ponds connected with salt water.

It is said that the white perch formerly extended south to Florida and the Gulf of Mexico, but this is discredited by com- 
petent observers. The perch of Lake Ponchartiain is rery likely the species now known in many portions of the western. states as the fresh-water drum, A p lo d i n o t us gr u n n i e n s.

The arerage length of the white perch is about 9 inches and its weight $\frac{1}{2}$ pound or less, but numerous specimens measuring 14 inches and weighing 2 pounds or more have been taken, specially in New England waters.

At the time of Dr Mitchill's writing the species was a favorite in New York markets, and it is now one of the best known species though probably not ranking among the choicest kinds.

Thaddeus Norris was one of the most earnest supporters of the white perch, and has published interesting observations concerning its habits. Comparatively little, howerer, is known about its life. It is an associate of the striped bass, and, according to Dr Abbott, resembles this species in its feeding habits. It differs from the striped bass in its tendency to seek warm water's.

The white perch is a lorer of brackish water, and may be found in tidal creeks in rast numbers associated with mummichogs, silversides and eels, feeding upou shrimp and minnows. Spawning takes place in May and June. According to Professor John A. Ryder, the egg of the white perch is rery adhesive, and on this account is troublesome to hatch artificialls. In the experiments made by him the eggs were taken upon cotton yarn, which was drawn up through a funnel into which the eggs and milt had been squeezed from the spawning fish. The cord, covered with the adhering eggs, was then wrapped upon a wooden reel and sent under cover of damp cloths to the central station, where they arrived in fine condition, almost evers egg being impregnated. 'This system was derised and carried out under the superintendence of Col. M. McDonald. After reaching the central station the cotton cord with the adhering eggs was cut into lengths of $10 \mathrm{or}^{\circ} 12$ inches and suspended in the glass hatching jars. The derelopment was soon interfered with by the growth of fungus. When the wooden reel with the ad- 
hering eggs was introduced into a wide aquarium fungus also attacked the eggs as before but the results were somewhat more farorable. With the water at $58^{\circ}$ to $60^{\circ} \mathbf{F}$. the eggs hatched out in 6 days.

The white perch congregates in large schools and is one of the freest biters among fishes. The shrimp is one of the best baits, though worms, sturgeon eggs, minnows and strips of cut fish with silvery skin are equally effective. Dr Abbott has known as many as 20 dozen to be taken with a line in a few hours, and Spangler mentions catches of six or seven hundred in a day by two rods, the fish ranging in weight from $\frac{3}{4}$ to $1 \frac{1}{4}$ pounds.

Engene Smith, on several occasions, found a long, green, brackish-water alga (Enteromorpha) in stomachs of white perch, indicating that they sometimes eat regetable matter, though perhaps only for the minute organisms found upon it.

In captivity the fish is rery susceptible to fungus attaclis, but the parasite is readily killed by changing the water supply from salt to fresh, or rice rersa.

\section{Genus porypriox Cuvier}

Body robust, moderately elevated, not much compressed, corered with small, firm, ctenoid scales which extend on the bases of the vertical fins. Lateral line complete, partly concealed nnder adjacent scales, the tubes covering the whole length of the scale. Mouth large, the lower jaw projecting; maxillary with supplemental bone. Teeth in broad, villiform bands on jaws, vomer, palatines, and tongue; no canine teeth. Head scaly. Preopercle serrate; orbital region with spinous projections; opercle with a strong spine and with a strong, rough, bony longitudinal ridge; gill membranes separate; gill rakers long, few. Dorsal fin continuous, low, with 11 strong spines and 11 or 12 rays, the spinous portion longest; caudal rounded; anal short, with three spines, the third the longest; rentrals large, inserted below, little behind pectoral; caudal rounded or truncate; pectorals short, unsymmetrical, of 18 or 19 rays, the 
upper longest. Spines of anal and rentrals somewhat serrate on the anterior edge. Vertebrae $13+14=27$. Pyloric caeca about seventy. Branchiostegals seven. Posterior processes of premaxillaries not reaching frontals; parietal and supraocular crests not extending between postfrontal processes; supraoccipital crest strong, but not produced forward on cranium. Species inhabiting deep waters in the warm seas, reaching a rery great size. The one is confined to the coasts of Southern Europe and neighboring waters; the other ( $\mathbf{P}$ oly p r i o $\mathbf{n}$ ox y g neios) is recorded from Juan Fernandez and about New Zealand.

\section{Polyprion americanus (Bloch \& Schneider)}

Wreclifish; Stome Bass; Cernier

?Amphiprion americanus BLoch \& ScuneIder, Syst. Ichth. 205, pl. XLVII, 1801.

Polyprion cernium Cuvier, in Valenciennes, Mém. du Mus. d'Hist. Nat. XI, 265, pl. XVII, 1S24; Cuvier \& Valenciennes, Hist. Nat. Poiss. III, 21, pl. 42, 1829; Günther, Cat. Fish. Brit. Mus. I, 169, 1859.

Polyprion oxygenius Jordan \& Gilbert, Bull. 16, U. S. Nat. Mus. 532, 1853.

Polyprion americanns Jordar, Cat. Fish. N. A. 83, 1885; Jordax \& Evermaxn, Bull. 47, U. S. Nat. Mus. 1139, 1896, pl. CLXXXI, fig. 480, 480a, skull, 1900.

Body robust, moderately elevated, the depth being contained from two and two thirds to three and one half times in the length; mouth large, the maxillary reaching to posterior border of eyes; teeth in villiform bands on jaws, romer, palatines, and tongue; supraocular region, supraclavicle, post-temporal, preopercle, and a ridge on opercle spinigerous; dorsal fin low with 11 strong spines; caudal rounded; anal spines short, serrate anteriorly, the third much the longest; ventrals large; pectorals short. The length of the head is contained three times in the length of the body. D. XI, 12; A. III, S. Color grayish brown, the caudal edged with white; young clouded with light and dark. This large fish is not uncommon off the coast of Europe in the deep waters of 300 fathoms or more, the young only swimming near the surface, specially southward. It is said to live most abundantly about wrecks; hence the common name of wreck- 
fish. It reaches a length of 5 or $^{\circ}$ feet. A single young specimen has been talin in deep waters of the Gulf stream by the T. S. Fish Commission, but there is no other record from Anerica.

\section{Genus apivephequs Ploch}

Body stout, compressed, corered with small, ctenoid scales, which are often somewhat embedded in the skin; scales of the lateral line triangular, cycloid; soft parts of the rertical fins generally more or less scaly. Cranium narrow above. Parietal crests not produced on frontals which are without transverse ridge posteriorly; frontals with a process or knob on each side behind interorbital area; premaxillary processes fitting into a notch or cavity on the anterior end of the frontals. Preopercle modelately serrate behind, its lower limb entire, without distinct antrolse spine; opercle witl two strong spines. Nostrils well separated. Mouth large; maxillary large, with a well. developred supplemental bone, its surface usually with small scales. Canine teeth few, large in the front of the jaws; enlarged teeth of the inner series of each jaw depressible. Gill rakers short and rather few. Horsal spines usually 11, rarely 10, not filamentous, the last ones somewhat shorter than the middle ones. Anal spines three, the second usually the larger; the number of soft rays seren to nine. Caudal fin rounded or. 1unate. Pyloric caeca few (usually 10-20). Pectorals rounded, shortish, nearly symmetric, of 15 to 20 rays. Ventrals moderate. inserted below pectorals, close together, each with a strong spine. Species very numerous, most of them of large size, abonnding in all the tropical seas, where they are valuable food fishes. This is the largest and most important gemus of the Se r r a 1 i d a e, and its speries are most widely distributed.

\section{6i3 Epinephelus niveatus (Cur. \& Val.)}

\section{Spotted Grouper; Snoury Grouper}

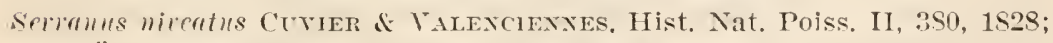

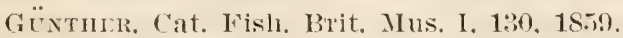

Serramus margaritifer Güxrnter, op. cit. 131, 1859.

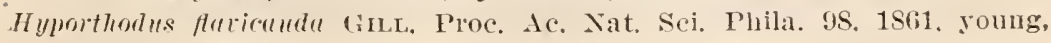
Newport Ir. I. 
Epincphelus niveatus Poex, Syn. Pisc. Cubens. 286, 1868; Jordan \& Gilbert; Bull. 16, U. S. Nat. Mus. 541, 1883; Jordan \& Evermañ, Bull. 47, U. S。 Nat. Mus. 1156, 1896; H. M. Sмrтtr, Bull. U. S. F. C. 1897, 99, 1898; op. cit. 1901, 32, 1901.

Body oblong, compressed, the back elerated; the anterior profile somewhat convex; the snout short, rather sharp, its length contained three and three fourths times in length of head. Head three sevenths and depth of body about one third of total length without caudal. Mouth large, the maxillary extending to below posterior margin of eye, its length one half length of head. Canines rather strong, specially in upper jaw. Lower jaw considerably projecting. Eye rather large. Interorbital space flattish, its width contained seren and one half times in length of head and twice in length of snout. Preopercle with a salient angle armed with stronger teeth, a slight notch above the angle. Gill rakers 15 below the angle of first arch, the longest as long as the gill fringes. Dorsal spines rather high, the fourth contained about two and three fifths times in length of head; soft dorsal of moderate hight; candal truncate, one half as long as the head; anal moderate, its second spine about as long as the third, three eightlus as long as the head, its longest soft ray three sevenths as long as the head. Pectorals not reaching to the tips of the long rentrals, about one half as long as the head. Ventrals about as long as pectorals, nearly reaching rent. D. X1 (rarely X), 14 or 15; A. III, 9; scales $18-115$ to $120-50$; pores of lateral line 67 to 75 .

Color of young in alcohol: brown, with round whitish spots on the body, rather smaller than pupil, regularly arranged in rertical and horizontal series, about fire in horizontal and four in vertical row; these rows sometimes show irregularities; no distinct spots on breast; a very large black blotch on upper part of caudal peduncle extending to below lateral line; a dark mustache above edge of maxillary; fins nearly plain, probably yellowish in life, the dorsal with a median row of dusky spots on the membranes. Some specimens lack the saddlelike blotch or the tail, but the pearly spots on the side are persistent in all. 
The spottro grouper occurs in the West Indies and south to Brazil frequently straying northward in the Gulf Stream as far as Cape Cod. A young specinen was taken many years ago at Newport R. I. and others have been secured in Rhode lsland waters. It Woods Hole Mass. according to Ir H. M. Smith, it is not rare. First reported in 1895, when as many as $1001^{\circ} 12$ specimens were obtained in the Woods Hole region. In 1897 several others were taken in summer and fall; one was caught August 7 in a dredge in Vineyard Sound in 6 fathoms of water and in November several were taken in a fye net in Great Harbor. Ali lave been of small size (3 inches or less), and most of them have been brought up in lobster pots. Dr Smith also recorded 35 specimeus, taken in Katama bay on nine occasions between August 15 and October 26, 1900.

The example described by Dr Günther, from South America, under the name $\mathrm{Ser}$ r a $\mathrm{n}$ s m a r g r it if e r was $11 \frac{1}{2}$ inches long. The colors of his specimen were as follows:

The ground color is reddish olive, lighter on the belly; on each side of the body are four series of pearl-colored spots, each occupying the place of five or six scales. The uppermost series reaches from the occiput along the base of the dorsal fin to the black blotch of the tail, and is composed of eight spots; the second, following the lateral line, of six; the third, from the angle of operculum, of four; and the fourth, from the base of the pectorals, of five. There is a blackish streak belind the maxillary bone. The black blotch on the tail occupies nearly the whole space between the dorsal and caudal fins and between the two lateral lines. The fins are nearly unicolored; a single pearl-colored spot is to be seen on the serenth spine and on the rentral fins; the anal has a whitish edge; ventrals blackish, with whitish lateral margin; pectorals nniform yellowish.

\section{Genus cextropristes Cuvier}

Body robust. somewhat compressed, covered with rather large ctenoid scales. Mouth large, formed as in Serra $\mathrm{n} \mathrm{u} \mathrm{s}$ and Pa r I a b a $x$, the canines small. Tongue smooth. Preopercle selrate, the lower teeth somewhat antrorse. Gill rakers rather long and slender. Supraoccipital and parietals with strong crests extending forward to between postfrontal processes; frontals posteriorly with an angular transverse ridge in front of 
supraoccipital connecting the parietal crests; posterior processes of premaxillaries not reaching frontals. The characteristic smooth area on top of cranium very short and small. Dorsal short, its rays $\mathbf{X}$, 11; anal rays III, 7 ; caudal usuall. three lobed or double concave; the canines very weak and the top of the head naked. The rentrals as in P r i o n o des, close together and inserted in advance of axil of pectoral; pectoral with 19 rays, its upper half truncate behind. The three species of $\mathrm{Centropr}$ is tes are closely related.

\section{Centropristes striatus (Linnaeus)}

\section{Sea Bass; Blackish}

Labrus striatus Linnaeus, Syst. Nat. ed. $\mathbf{X}, 285,1758$, America. Perca atraria Linnaeus, Syst. Nat. ed. XII, 485, 1766, Carolina.

Perea varia Mitcuill, Rep. Fish. N. Y. 11, 1814; Trans. Lit. \& Phil. Soc. N. Y. I, 415, pl. 3, fig. 6, 1S15, New York.

Centromistes nigricans Cuvier \& VAlencienres, Hist. Nat. Poiss. III, 37, pl. 44, 1829, New York; De KAY, N. Y. Fauna, Fishes, 24, p1. 2, fig. 6 , 1S42; BEAN, 19th Rep. Comm. Fish. N. Y. 266, pl. XVII, fig. 21, 1890. Centropristes atrarius Günther, Cat. Fish. Brit. Mus. I, 86, 1S59; Goode \& BEAN, Bull. Essex Inst. XI, 19, 1879.

Serranus atrarius Jordax \& Gilbert, Bull. 16, U. S. Nat. Mus. 533, 1883. Serranils nigrescens Jondax \& GILBERT, Bull. 16, U. S. Nat. Mus. 917, 1883. Centropristes striatus Jordan \& Eigenmand, Bull. U. S. F. C. VIII, 391, pl. 64, 1S90; Jordax \& Everiats, Bull. 4i, U. S. Nat. Mus. 1199, 1896, pl. CXC, fig. 500, 1900; BEAx, Bull. Am. Mus. Nat. Hist. IX, 366, 1897; H. M. Smitu, Bull. U. S. F. C. 1897, 100, 1898; BeAN, $22 d$ Ann. Rep. N. Y. State Mus, 105,1900 ; SHerwood \& EDwards, Bull. U. S. F. C. $1901,28,1901$.

Body ovate, robust, the back somewhat elevated; axis of body below the middle of the depth. The length of the body is three times its depth and two and three fourths times the length of the head. Head large, thick, little compressed, somewhat pointed; top of head naked; cheeks and opercles scaly; scales ou cheeks in about 11 rows. Mouth oblique, low, rather large, the premaxillary below the level of the eye; lower jaw prominent; maxillary broad, its upper edge anteriorly slipping under the edge of the preorbital, which is nearly as wide as the eye. Eye large, wider than interorbital space, less than snout, $4 \frac{1}{4}$ in head. Gill rakers long, about 18 below the angle. Canines very small, scarcely differentiated. Teeth all fixed, the 
bands rather broader than usual. Dorsal spines rather strong, not filanentous, the middle ones rather higher than the posterior, which are considerably lower than the soft rays, the highest spine as long as from snont to middle of eye. Anal short and high, its spines graduated. Pectoral very long, $1 \frac{1}{4}$ in head, reaching rent. Ventrals long, nearly reaching vent, inserted below front of the base of pectorals. Caudal slightly double concave; fins little scaly except at base; a rudimentary groove at base of spinous dorsal, over which scales do not pass. Length 12 inches. D. X, 11; A. III, T; Lat. 1. 50 to 5.) pores; caeca $4-7$.

Dusky brown or black, adults often bluish; more or less mottled, with traces of pale longitudinal streaks along the rows of scales; young greenish, often with a dark lateral band, sometimes broken up forming crossbars; dorsal fin with sereral series of elongate, whitish spots, forming interrupted lines; other fins dusky, mottled.

The sea bass is the Perca va $\mathrm{r}^{\mathrm{i}}$ a of Mitchill, Fish. T. Y.p. 415. Common names given by this author are sea basse, blackhar'y, hanna hills and bluefish. Schoepff (178T) gives the New York name as blackfish; De Kay has it as the black sea bass, also black bass and blackfish. Dr Storer records the Massachusetts name of black perch. Other common names on the coast are black will (Middle States) and rock bass (New Bedford).

The sea bass is found from Vineyard sound southward, its southern limit not being accurately determined, but probably not extending below Cape Hatteras. The sonthern form, which was described by Linnaeus from Sonth Carolina, may be distinct from the northern, and if so it should be designated by the Linnaean name a traria.

The northern form has been found occasionally north of Cape Cod, at Nahant, Salem, and Beverly bar. Dr Smith reported it as very common at Woods Hole in 1898, where it arrives in May and departs from the inshore waters about October 1, being most abundant from July to September. It spawns there in June. The young are first seen about Angust 1. The maximum weight is 6 pounds. In 1900 the sea bass was said to be remarkably scarce 
at Woods Hole. Acrording to the observers of the Fish Commission this fish is derereasing rapidly in numbers. Handlining, even on the sllawing gremuls off Hyannis was remarkably poor and young tislı were less numerous than usual. As a rule the first adults aplear in their seasonal miglation during the first or second week in May, when the water has reached a temperature of $48^{\circ}$ to $500^{\circ} \mathrm{F}$. Howerer, in spite of the cold of 1900 , they appeared at Cutyhunk and Menemsha Bight on April 28-with one exception the earliest arrival recorded in 25 years. Formerly the young were abundant everywhere, but at present they are restricted to a few localities-Katama bay, Quisset harbor, and Wareham river. The first fry were seined July 31 and measured $\frac{3}{4}$ of an inch in length. On October 20 young fish 2 to 3 inches long were very plentiful in Katama bay.

In 1884 the writer obtained young examples only, and these in moderate numbers, at Fire Island near the end of September. In 1890 a few indiriduals were observed in a net at Islip. In 189S, adults were taken in abundance offshore at Southampton in August and halfgrown specimens were secured from a pound at Islip. Ioung sea bass were rather common at Point of Woods. Great Soutl bay, Clam Pond Cove, Fire Island inlet, Oak Island beach. and Nichols's Point. In the summer of 1901, early July to the middle of October, only a few young individuals were taken, and these were secured in eel pots off Widows' Creek, Great South bay.

The sea bass makes its appearance in Cravesend bay in May. It is not abundant. The young in October are found in the eel grass, measuring from $1 \frac{1}{2}$ to 2 inches in length. The species is well adapted to life in aquarium tanks during all but the coldest months.

The sea bass is distinguished for its roracity and its persistent biting. The young are found in the channels of shallow bays and about wharves and landings. Large fish frequent the offshore banks where the bottom is rocky. A famous locality is Five Fathom bank, off the coast of New Jersey. In the shallow waters of Great Egg Harbor bay liundreds of small-sized sea 
bass may be taken in a day, and it is difficult to find a locality which is free from them. Their food consists of shrimp, crabs, seal worms, squid, small fishes and all other animats of suitable size. The species is sluggish in its habits and resembles the tautog in its tendency to hide in rock crevices. The sea bass breeds in the summer months and the young grow rapidly. The eggs have been hatched artificially, and when it becomes desirable the fry can be produced in vast quantities. The eggs are $\frac{1}{26}$ inch in diameter and hatch in 5 days in water at the temperature of $59^{\circ}$ or $60^{\circ} \mathrm{F}$. At Woods Iole Mass. they are deposited in June.

This is a valuable food fish, reaching a length of 18 inches and the weight of 6 ponnds.

\section{Genus Duses Curiel}

This gemus is close to Prionodes, from which it differs in the possession of but six branchiostegals, and in the truncate form of the candal fin. In one species the third dorsal spine is prolonged in a whiplike spine. Three American species.

\section{Dules auriga (Cuv. \& Val.)}

\section{Coachman}

Dutes amriga Cuvier \& Valexciennes, Hist. Nat. Poiss. III, 112. pl. 51, 1829. Brazil; De Kay, N. Y. Fauna, Fishes, 34, pl. 19, fig. 54, 1842. New York luarbor, perluaps erroneously so ascribed, but given on the authority of Mr Hamilton; Güntuen, Cat. Fish. Brit. Mus. I, 266, 1S59; JoRDAN \& Gilbert, Bull. 16, U. S. Nat. Mus. 542, 18S3; JordAx \& EverMAxv, Bull. 47, U. S. Nat. Mus. 1220, 1896.

Serranus brasiliensis Jordan, Proc. U. S. Nat. Mus. 533, 1856.

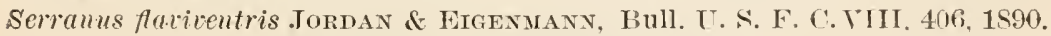

Body rather deep and compressed, its depth contained two and fon fifths times in total length withont candal, and equal to the length of the head; anterior profile steep and nearly straight; mouth rather small, the lower jaw projecting; preorbital rather narow, as broad as pupil; eye two sevenths as long as the head; snout one fourth length of head; top of head naked; the frontal area large and well defined, broader than long; occipital crest low and short, shorter than the frontal area; teeth small, with no marked canines; length of maxillary five twelfths length of head; gill rakers short and slender, nine 
developed below the angle and from three to five rudiments; scales large, those above in series parallel with the lateral line; scales on breast small. Third dorsal spine extremely long, reaching beyond middle of soft dorsal; other spines all short and even; soft dorsal moderate, a little scaly at base; dorsal not notched; caudal truncate; second anal spine about one third as long as the head, equal to third, and a little stouter; pectoral about one half as long as the head.

D. X, 13 ; A. III, 7 ; scales $6-4 S-15$, pores 45 to 50 ; B. 6.

Coloration in spirits brownish; a dark area from front of anal up to soft dorsal; before this a whitish area; upper parts with faint, interrupted dark streaks along the rows of scales; a dark band upward from middle of base of ventrals; fins clonded. Length 10 inches. (After Jordan \& Evermann)

De Kay described a specimen $4 \frac{1}{2}$ inches long as of a vellowishgray color, with three or more dusky vertical bands, and with ventral fins tinged with blackish toward their tips. He re. garded it as an accidental visitor from the tropics. The subject of his notes was an example seen several years prior to the publication of his work in the collection of Mr Hamilton, who informed him that it had been taken in the harbor of New York. There appears to be no later record of the occurrence of the species on our coast. De Kay refer's to a specimen from Jamaica, but the range is generally restricted to the coasts of Brazil and Uruguay.

\section{Genus Rypteus Cuvier}

Body oblong, compressed, covered with very small, smooth, rmbedded scales. Lateral line normal; head scaly. Mouth rather large, oblique, the lower jaw the longer; maxillary with a supplemental bone, as in Epinephelus, with which genus this form agrees in general osteology; smooth area on top of cranium rery large, transversely convex, much longer. than the supraoceipital crest; interorbital area very narrow; parietal and supraocipital bones short, with feeble crests which do not extend on the frontals; premaxillaries reaching frontals, which have a fossa in front; teeth all villiform, in 
bands on jaws, romer", and palatines; preopercle crescentshaped, without angle or serratures, but provided with two or three spinous hooks on the posterior margin; opercle with two or three spines; gill rakers short. Branchiostegals $\tau$. Dorsal fins separate, the first of two or three (rarely four) small spines, the second of many (about 25) soft rays; anal long, rounded, of soft rays only; caudal rounded; pectorals rounded, nearly symmetrical, of 17 rays; rentrals small, I, 5, inserted slightly before pectorals, the spine slort and strong. Vertebrae $10+14=24$. Skeleton generally similar to that of E p in e p he I us.

\section{Subgenus inomicror'reress Gill}

266 Rypticus bistrispinus (Mitchill)

\section{Soapfish}

Bodianus bistrispinus Mitchile, Am. Month. Mag. II, 247, February, 1S1S, Bahamas.

Rhypticus maculatus Holbrook, Ichth. S. C. ed. 1, 39, pl. 6, fig. 2, 1856: ed. 2, 42. 1860, Cape Romain S. C.; Günther, Cat. Fish. Brit. Mus. I, 173, 18.59; Jordan \& Gilber', Bull, 16, U. S. Nat. Mus. 543, 1853.

Rhypticus decoratus JoRdAN \& GILBERT, op. cit. $543,1883$.

Rypticus bistrispinus JoRdaN \& EIGENMANN, Bull. U. S. F. C. VIII, 33S, 1S90;

Jordax \& Evermanx, Bull. 47, U. S. Nat. Mus. 1233, 1596, pl. CXCIV, fig. $509,1900$.

This species has a moderately deep body. its deptli greatre than the length of the head, specially in the adnlt in which the. back is considerably elerated; profile of head much depressed before eye, the sharp snout abruptly projecting. The Irugth of the head is one third of the standard body length; the depth of body is contained from two and one third to two and two thirds times in its length; the ere in adult nearly as long as snout, its length contained five and one half times in length of head; maxillary three serenths as long as the head, reaching to below posterior margin of eye; preopercle with only two dereloped spines, the uppermost usually wholly wanting; the median spine often divided, the lower one largest and directed partly downward; opercular spine small; first dorsal spine a little lower than second, which is nearly or quite free from the soft rays; gill rakers slort and thick, close set, eight to 10 in number. D. II, $25 ;$ A. 14 or 15 . 
Color. Dusky olive brown, somewhat clouded; sides with a few irregular whitish spots; young spotted with brownish.

South Atlantic coast, U. S., straying northward to coast of Rhode Island. The species is frequently taken in moderately deep water off Charleston, Pensacola and Key West. Mitchill described it from the Straits of Bahama. The common name is given in allusion to the soapy feeling of the skin. The fish is small and has no value for food. Nothing is recorded of its habits.

\section{Family lobotidae}

\section{Triple-tails}

\section{Genus цовотеs Curier}

Body oblong, compressed, and elerated, covered with moderate-sized, weakly ctenoid scales; profile of head concare, the snout rominent; mouth moderate, oblique, with thick lips; upper jaw rery protractile; lower jaw the longer; maxillary without supplemental bone; jaws with narrow bands of villiform terth, in front of which is a row of larger conical teeth directed backward; no teeth on romer or palatines; preorbital narrower than eye; preopercle strongly serrate. Branchiostegals six. Torsal fin continuous, with 12 spines which may be depressed in a shallow groore; soft rays of dorsal and anal fins elerated; anal spines graduated; bases of soft dorsal and anal thickened and scaly; caudal rounded. Air bladder present. Pyloric caeca three.

\section{¿6it Lobotes surinamensis (Bloch) Flasher; Triple-tail}

Hotocentrus suvinumensis BLOCH, Ichthyol. pl. 243, 1790, Surinam.

Bodians trintus Mrtenll, Trans. Lit. \& Phil. Soc. N. I. I, 418, pl. III, fig. 10, 1S15. Powles Hook, N. J.

Lobotes auetornu Güntıer, Cat. Fish. Brit. Mus. I, 338, 1859.

Lountes sminamensis Curier of Valexciexnes, Hist. Nat. Poiss. V, 319, 1S:30; DE KAY. N. Y. Fauna, Fishes, SS, pl. 18, fig. 49, 1S42, New York; Holbrook. Ichth. S. C. ed. 1,159, pl.23. fig. 2, 1556; Jordan \& GILBERT, Bull. 16. U. S. Nat. Mus. 555, 1S\$3; Jordan \& Evermann, Bull. 47, U. S. Nat. Mus. 1295, 1896, pl. CXCIT, fig. 510, 1900; H. M. Sмiтh, Bull. U. S. F. C. 1897, 100, 189S; Sinerwood \& EDWARds, Bull. U. S. F. C. 1901, 28, 1901, Narragansett Bay.

The body is oblong, deep, its depth four ninths of its length without the caudal; least depth of caudal peduncle three tenths 
of body depth; profile of head very oblique; nuchal region convex; head short, its length less than one third of total without caudal; lower jaw prominent; maxillary rery heary, extending bejond middle of orbit, its width one half diameter of eve; snout about equal to ere which is one sixth as long as the head; scales around eye very small, those on opercle large; first dorsal spine shortest, two thirds as long as the second, two fifths as long as the third, one fourth as long as the fifth and longest, which is three eighths as long as the head; the longest ray of soft dorsal is one half as long as the head, and about equal to the longest ray of the anal; anal spines graduated, the first being two thirds as long as the eye and the third one fourth as long as the head; the pectoral reaches to below the serenth spine of the dorsal, its length one half the length of head; the ventral origin is under the lower axil of the pectoral; the ventral fin equals the postorbital part of the head in length, and reaches to below the tenth spine of the dorsal. Base of soft dorsal, anal, and caudal with fine scales. D. XI, I, 16: A. III, 11; V. I, 5; P. I, 15; scales 59 (pores about 53).

Blackish above, silvery gray on the sides, often blotched and tinged with yellow; fins dusky gray, sometimes mingled with jellow.

The flasher is a large species, found in all warm seas, ranging on our coast from Cape Cod to Panama; it reaches the length of 3 feet and is used for food. At Woods Hole, according to Dr Smith, it is very rarely taken. Specimens were secured, however, in August 1873, December 1875, Sep. 20, 1886, and in August 1890 . The individual obtained in 1886 was caught in a trap at Menemsha, Martha's Vineyard. The Rhode Island Fish Commission has a specimen weighing 6 pounds and measuring 22 inches, which was taken Sep. 10, 1900, in a trap off Prudence island, Narragansett bay. The example described and figured by Mitchill was taken at Powles Hook N. T. According to Mitchill specimens weighing four or five pounds were occasionally secured, and the fish was sometimes called black grunt. De Kay knew the fish only from the accounts of it given by Mitchill and Holbrook. 


\section{Family PIRIACANTHIDAE}

\section{Catalufas}

Genus pmacastuus Cuvier

Scales very small, 80 to 1.00 in the lateral line; body oblong, more than twice as long as deep; preopercle with a spine at angle; interorbital area externally transversely convex, the cranium itself transversely concave, the elevation being formed of flesh; a conspicuous foramen in the interorbital area; lateral line extending upward and backward from upper angle of gill opening toward second dorsal spine, below which it changes its course, following outline of back to end of dorsal fin, thence direct to middle of caudal; anal fin rather long, its rays about III, 14; dorsal rays about $\mathrm{X}, 13$. Species rather numerous, in the tropical seas.

\section{Priacanthus arenatus Cuv. \& Val.}

\section{Catalufa; Bigeye}

Priacrinthe arenatus Cuvier \& Valenciennes, Hist. Nat. Poiss. III, 101, 1829, Brazil; Jordax \& Gilbert, Bull. 16, U. S. Nat. Mus. 971. 1883; Jordan \& Evermann, Bull. 47. U. S. Nat. Mus. 1237, 1896, pl. OKCT, fig. 511, 1900; H. M. Sмrтh, Bull. U. S. F. C. 1897, 100. 1898, Toods Hole, Mass.

Priacnthus macrophthalmus Curier \& VAlenciennes, Hist. Nat. Poiss. III, 97. 1829, based upon Anthias macrophthalmus Blocm, an Asiatic species; Günther, Cat. Fish. Brit. Mus. I, 215, 1859; Jordax \& Gilbert, Bull. 16. U. S. Nat. Mus. 54t, 1883.

Body oblong, compressed, moderately long, its greatest depth about one third of the total length without candal; the caudal peduncle slender, its least depth equal to length of snout. The head is rather slort, about two sevenths of total without caudal; the snont is short, one fourth as long as the head, and two thirds as long as the eye; the interorbital space is narrow and convex; the posterior nostrils are in a common oblong opening within which is a septum considerably below the surface; gill rakers 20 to 29 ; the maxillary is broad posteriorly and reaches to below the front of the pupil; the lower jaw projects considerably: preopercle with an oblique point at its angle; opercle with a flat pointed spine, not projecting. Dorsal spines all slender, the first only one half as long as the last and two ninths as 
long as the liead; the anterior portion of the spinous dorsal is regularly graduated; no noteh between the spines and soft rays and the soit rays are not louger than the spines; dolsal spines more or less granulate on the edges. Candal slightly concave, its lobes subequal, the middle rays nearly one half as long as the head. Tentral origin slightly in advance of origin of spinous dorsal; the fin reaches to a point nearly under the eighth spine of the dorsal, but not to the anal origin. Pectorals about one half as long as the head. First anal spine two thirds as long as the third, and one fourth as long as the head; the longest anal rar is less than one half as long as the head. D. X, 14; A. III, 15; T. 1, 5; P. 1, 16; scales 9-9S to 115-42; pores wanting on some of the scales.

Color, silvery red; anal, soft dorsal, and caudal with a black edge; no spots on dorsal; posterior half of ventral black; about eight small dark blotches along lateral line, the largest less than one lialf as long as the pupil.

The catalufa is a native of the tropical parts of the Atlantic; it has been recorded from Brazil, the West Indies, and Madeira, and sometimes migrates northward in the Gulf Stream to Narragansett Bay, Vineyard sound, and neighboring water's in summer.

At Woods Hole it is rare; seren specimens were obtained in September and October 1876 , and afterward for sereral years three or four were caught annully. On Oct. 2,1888 , a specimen $3 \frac{3}{4}$ inches long was taken in a seine at Quisset Harbor.

Genus pseudormacantuus Bleeker

Scales large, very rough, 35 to 50 in the lateral line; body ovate, not twice as long as deep; preopercle with two small spines at angle; interorbital space broad and flat, there being little flesh between skin and skull; no foramen in interorbital area; lateral line changing its course below the fourth dorsal spine; anal short, its rays III, 9 to 11 ; dorsal $\mathbf{X}, 11$. Otherwise essentially as in $\mathrm{Pr}$ iacan $\mathrm{th} u \mathrm{~s}$, the species living in deeper water. 


\section{Pseudopriacanthus altus (Gill)}

\section{Short Bigeye}

Priacanthus altus Gill, Proc. Ac. Nat. Sci. Phila. 132, 1862, Narragansett Bay; Jordan \& Gilbert, Bull. 16, U. S. Nat. Mus. 545, 1883.

Pseudopriacanthus altus Goode \& BEAN, Bull. Essex Inst. XI, 20, 1879; Jordan \& Eigermaxx, Proc. U. S. Nat. Mus. 269, 1857; Jordan \& Evermann, Bull. 47, U. S. Nat. Mus. 1239, 1896, pl. CXCV, fig. 512, 1900; H. М. Sмітн, Bull. U. S. F. C. 1897, 100, 1898; op. cit. 1901, 33, 1901, Woods Hole, Mass.

Body ovate, compressed, its greatest depth one half of the total length without caudal; the caudal peduncle short and stout, its least depth two thirds of its length and equal to postorbital part of head. Profile little oblique; mouth large, subvertical; suout short, one half as long as the eye, which is nearly one lhalf as long as the head; maxillary very broad posteriorly, its width nearly one half its length, exteuding to beyond the middle of the pupil. Head large, nearly two fifths of total length without caudal; teeth in upper jaw in a narrow villiform: hand, the outer series enlarged; similar teeth in the lower jaw, but the inner teeth larger than in the upper jaw; preorbital strongly serrate, narrow, one half diameter of pupil; preopercle serrate, the serrae of the lower margin largest; no preopercular spine; opercle and subopercle serrate on their lower margins. Dorsal spines from the first to the fifth graduated, the first two fifths as long as the fifth, which is as long as the snout and eye combined; the last spine is one half as long as the head; the first soft ray is two thirds as long as the head, and the longest soft ray equals the length of the head without the snout, the last dorsal ray is about as long as the first dorsal spine. The caudal is slightly convex, its middle rays equal to snout and eye. combined. Anal spines graduated, the first one third as long as. the head, the third nearly one half as long as the head; the anterior soft rays are produced as in the dorsal, the longest as. long as snout and eye combined. The short and broad pectorals are nearly one half as long as the head. Ventrals large, extend. ing to the third spine of anal fin. Scales all extremely rough, very strongly ctenoid, smallest on the head, but larger on the 
maxilla than elsewhere on the head; lateral line ascending orcr the pectoral, then nearly following the outline of the back to the caudal peduncle, where it becomes median.

D. X, 11; A. III, 9; scales 10-45-23.

Color in life bright red or crimson; the fins, except the pectorals, with black tips; the eye glowing like molten gold.

The species is found in rather deep water in the West Indies and from the Caribbean to Charleston, the young often follow. ing the Gulf Stream northward in summer to Cape Cod. The largest individual recorded is 11 inches long. Most of the specimens taken near Cape Cod are small. The northern limit of the fish appears to be Marblehead Mass., where an example was taken Sep. 3, 1859.

The type of the species was collected in Narragansett bay. Individuals were obtained at Woods Hole Nass., Sep. 29, 1875, Sep) 26, 1877 and Nor. 28, 1885. On Nov. 1, 1890, a specimen was found in the Acushnet river, at New Bedford. In 1899 orer 100 specimens were taken at Woods Hole, and in 1900 only niue were observed between August 15 and September 8 . The writel' obtained the species in moderate numbers in the Gulf of Mexico in 1886. The colors of large individuals appear to be less brilliant than in the young, but the fish is always strikingly handsome.

\section{Family LUTIANIDAE}

\section{Snappers}

\section{Genus Neonatsis Girard}

Body oblong, compressed, the back somewhat elerated; head long, naked above, except for a broad oblique band of scales at the nape; nostrils normally close together, neither with a tube; mouth large, the jaws with bands of rilliform teeth, besides which there is usually an outer series of larger teeth in each jaw, and two to four stronger teeth or canines in front of upper jaw; vomer with villiform teeth; villiform teeth on the palatines; usually one or more patches of teeth on the tongue in the adult; no molar teeth; no teeth on pterygoids; preopercle without notch or with a shallow emargination; posterior liunb 
of preopercle finely serrate; gill rakers rather few, shortish; soft rays of dorsal and anal scaly at base; dorsal spines 10 (rarejy 1.1). continuous with the soft rays; caudal lunate or forked; anal rayss seven to nine. Interorbital area not flat nor separated from the occipital region, the median and lateral crests procurlent on it, and the frontal narrowed forward; fronto-occipital crest ceasing anteriorly far from front of frontal, usually behind eye; prefrontal with posterior areas impressed, long and cribriform; parietal crest not confluent with orbital rim, but nearly or quite joined anteriorly to fronto-occipital crest (in species examined); prefrontals with the articular facets arising from diverging $\mathrm{V}$-shaped ridges; basisphenoid with an anterior lobiform extension. Vertebrae $10+14=24$.

\section{Neomaenis griseus (Linnaeus) \\ Gray Snappor; Mangrove Snapper}

Labrus grisens Linnafus, Syst. Nat. ed. X, I, 283, 1758.

Mesoprion grisens Cuvien of Valenchennes, Hist. Nat. Poiss. II, 469, IS:8, San Domingo.

Lobotes emarginatus BArrd \& GiRARD, 9th Smithson. Rep. 332, 1855, Beesley's Point, N. J.

Mesoprion caballerote PoEr, Repertorio, II, 157, 1868.

Lutjanus eaballerote Poes, Syn. Pisc. Cubens, 293, 186S; Jordan \& (imbert. Bull. 16, U. S. Nat. Ius. 921, 1883; Goode \& BEan, Proc. U. S. Nat. Mus. VI, 42, 1884.

Lutjanus stearnsii Goode \& BEAN, Proc. U. S. Nat. Mus. I, 179, 1878, Pensacola Fla.; Goode, Fish \& Fish. Ind. U. S. I, 396, pl. 142, 1884.

Lutjanus griseus Jondan \& Swarn, Proc. U. S. Nat. Mus. 439, 1884; JolndaN \& FesLer, Rept. U. S. F. C. 1889 to 1891, 441, 1893.

Aeomaenis griseus Jordan \& EvermanN, Bull. 47, U. S. Nat. Mus. 1255, 1898; H. M. Sмmтн, Bull. U. S. I'. C. 1897, 100, 1898; op. cit. 1901, 33, 1901.

Body elongate, its depth about one third of total length without caudal; back not much compressed; profile from snout to nape almost straight; outline of back slightly convex. Head rather large, four elerenths of total length without caudal; the snout pointed, one third as long as the head; eye small, two thirds as long as the snout, rather more than one fifth as long as the head; preorbital broad, about as broad as the interorbital space which is gently convex and one sixth of length of head; occipital keel low. Mouth large, the jaws nearly equal in front; 
the maxillary reaches to below front of pupil, its length contained two and three fiftlis times in length of head; eight developed gill rakers on the first arch, one above and seveu below the angle, the longest one half as long as the eye; there are seven rows of scales on the cheeks; the single patch of lingual teeth twice as long as broad; romerines in a triangular patch on the head, with a long, narrow backward extension; palatines in a broad band; scales extend upon the nembranes of the dorsal, anal and caudal fins for about one half their hight, or rather more on the caudal; two very strong canines in the upper jaw, and two much smaller ones between these and the symphysis; mandible without enlarged canines; preopercle finely serrate abore, coarsely serrate at angle, the posterior margin nearly vertical, with a broad and deep notch; scales comparatively large, in horizontal rows below the lateral line, those above lateral line running parallel with it till below the soft dorsal, where they become slightly irregular and oblique; seven rows of scales on cheek; an embedded row on interopercle; a row on subopercle, and seren rows on opercle; temporal region with about three rows of large scales; top of head, snout, and jaws naked.

The first dorsal spine is one eighth as long as the head, one half as long as the second and the last; the fourth and longest spine is one third as long as the head; the longest ray of the soft dorsal is equal to the longest spine; the last ray is one half as long as the upper jaw. The caudal is slightly emarginate, the upper lobe slightly the longer, the middle rays five ninths as long as the head. The first anal spine is three serenths as long as the third which is nearly as long, but not so strong, as the second and nearly one fourth as long as the head; the second anal ray is longest, nearly four ninths as long as the head, and more than one serenth of total length without caudal. Ventrals one fiftl of total length without caudal; pectorals one fourth of the same lengtl, and scarcely reaching vent. B. VII; 1). X, 14; A. III, S; V. I, 5; P. I, 16; scales $7-47$ to $50-12$ to 14 ; 47 pores in lateral line. 
The edge of the spinous dorsal membrane is black. The caudal has a narrow black margin. The included portion of the maxilla is brown. The scales of the body below the lateral line have median golden stripes, as in some species of $\mathrm{M} \mathrm{u} \mathrm{gil}$.

Color in life, very dark green above, the middle part of each scale brassy black, its edge broadly pearly whitish; below lateral line the duskiness of the middle of the scale passes into brassy, and below into bright coppery, the belly and lower parts of head being more or less distinctly bright coppery red; the lower jaw grayish; no blue stripe below eye except in the very young; top of head blackish olive; dorsal blackish, its margin darker and tinged with maroon red; soft dorsal dusky, anteriorly slightly edged with whitish; caudal violaceous or maroon black; anal wine color, edged with whitish; pectorals pale flesh color; ventrals whitish, faintly marked with reddish. Young with a blackish band from snout through eye to nape; a blue streak below eye; spinous dorsal with a maroon colored band along edge.

The gray snapper inhabits the West Indies, the Caribbean sea and southward to Brazil, the Gulf of Mexico, and our Atlantic coast northward regularly to New Jersey, and, frequently, to Cape Cod. The fish is raluable as food; it probably reaches a length of nearly 3 feet and the weight of 20 pounds. Only young examples have been identified with certainty from the Cape Cod region. On Sep. 21, 1897, a specimen, $2 \frac{1}{2}$ inches long, was taken in Eel pond, at Woods Hole Mass., and on Sep. 26, 1897, an individual 2 inches long was caught in Great Harbor. Woods Hole. This is the first record of its occurrence in the locality. On Aug. 29, 1900, five specimens, the largest $1 \frac{7}{8}$ inches long, were taken in Katama bay, near Woods Hole, according to Dr Smith. In these "the general color is pale, with 6 to 8 narrow, dark, longitudinal stripes; spinous, dorsal fin dark, with a sharply defined blackish bar involving the distal part of the fin, the extreme edge being white."

\section{Neomaenis blackfordi (Goode \& Bean)}

\section{Red Snapper}

Lutjanus blaclfordii Goode \& BEAN, Proc. U. S. Nat. Mus. I, 176, 1Sis (full description of adult); II, 137, 138, 1879, characters and measurements of young; Goode, Game Fishes N. A., 16, 1878, with colored plate. 
Lutjanus blackfordi Jordan of Gilmert. Bull. 16, I. S. Nat. Mus. J49, 1S83; ReAn, 19th Rep. Comm. Fish. N. Y. 269, pl. X VI. fig. 20, 1890.

Lutjanus campcachianus Jondax \& GilbERT, op. cit. 971 (not Mesoprion cempeachanus Poer, Mém. Cub. II, 149, 1S60); Jordax, Proc. U. S. Nat. Mus. VII, 35, 1884.

Teomuenis aya Jordan \& Evermanx, Bull. 4i, U. S. Nat. Mus. 1264, 1S98, 1). CXCVII. fig. 516.1900 (not Bodianus aya BLoch, Ichthyol. 227, 1790);

II. M. Sмrti, Bull. U. S. F. C. 1897, 100, 1898.

Neomacnis blackfordi H. M. Smitn, Bull. L. S. F. C. 1901, 33, 1901.

Body much compressed; its upper profile ascending from the snout, with a slight concavity in flont of ere, to the origin of the spinous dorsal, thence descending in a long curve to the base of the caudal; under profile much less arched. Jaws equal. Greatest hight of body equals lengtl of head, which is three eighths of total length without caudal. Least depth of caudal peduncle equals one third of the distance from the snout to the pectoral. Preoperculum finely and evenly serrated, except at the angle, where the denticulations are coarser; a slight emargination above the angle, in which is receired an eleration upon the interopercle, and two shallower emarginations abore. Maxillary not reaching to below front of orbit; mandible not below middle of orbit. Lingual teeth in two patches. Vomerine patch a quadrilateral figure, with concave sides, and with the longest sides posteriorly. Palatine patches somewhat spatulate, broadest posteriorly. Exe circular, its diameter contained seren and one third times in length of head. Snout nearly equal to maxillary. Mandible equal to one half hight of body at rentrals. Distance of spinous dorsal from snout about three times length of snout; length of its base about equal to pectoral. Longest dorsal spine three times as long as the first, and twice as long as the second anal spine; it is nearly as long as the snout. The longest dorsal ray (sixth) is contained three and one fourth times in the length of the head. The anal base is a little longer than the mandible; the first anal spine is one half as long as the second, which is one third as long as the ventral fin; the third spine is slenderer and slightly longer than the second; the longest ray of the anal is twice as long as the snout. Caudal much emarginate, crescent-shaped; the middle 
rays two thirds as long as the outer. Pectoral midway between snout and origin of anal, its length twice that of the maxillary. Ventral as long as snout and eye combined, slightly more than one half as long as head; it extends to below the eighth spine of the dorsal. B. VII ; D. X, 14; A. III, 9; V. I, 5; P. I, 16; scales 8 to $9-50-15$ to 16 ; gill rakers on lower arch, 8 .

The scales extend half the length of the anal rays on the membrane; on the external caudal rays they extend nearly to the tip, and with slight traces upon the spinous dorsal in front of the spines; and in the soft dorsal somewhat more extended.

Color uniform scarlet. Center of scales lighter, also the belly, which is silvery; inside of axil of pectoral darker maroon.

On Oct. 26, 1887, Mr E. G. Blackford, Fish Commissioner of the State of New York, forwarded to the National Museum a young red snapper, four and one half inches long, which was caught in Great South bay, at Bay Shore, Long Island. This is the smallest red snapper that we have obtained, and it is the first record of the occurrence of the species so far north. The specimen has been catalogued as 39213 of the Museum Fish Register.

As in other young fishes the size of the eye, the length of the head and the colors are different from these characters in the adult.

$A$ description of the colors of the fresh fish follows:

A dark band nearly as wide as the diameter of the eye is placed immediately in front of the spinous dorsal; it fades out about the median line of the body. Three similar bands, and of like size, under the dorsal, separated by narrow interspaces and fading out below. The fourth band contains a blotch as large as the eye, which passes slightly beneath the lateral line. A fifth band is under the last third of the soft dorsal and continues backward to the caudal, not descending below the lateral line. The second and third bands are traversed vertically by a narrow median stripe of the rosy body color. Membrane of dorsals and caudal with a narrow black edge. Spine and external ray of ventral milk white. Anal rosy, except membrane of first two spines and last three rays, which is milk white. 
On July 12, 1890, Mr Tinal $\mathrm{N}$. Edwards obtained a specimen of the red snapper, which weighed 12 pounds, from a bass trap set in 10 feet of water, at Menemsha, Martha's Vineyard. Mr Edwards believed this to be the first one taken on the Massa. chusetts coast, but thought one was caught some years ago near Block Island.

On October 10, 1890, a specimen weighing $8 \frac{1}{2}$ pounds was taken at the same place. On September 7 and 11, and October 20, 1900, nine specimens were taken in the vicinity of Woods Hole Mass. and recorded in the article of Dr Smith. The largest of these was under 2 inches long. Dr Smith described the colors as follows: "General color, red like the adult fish; body marked by about seven double dark cross-bands; in the cross-band nearest the junction of the two parts of the dorsal fin is a large jet black blotch extending from the fin to below the lateral line; spinous dorsal dusky; soft dorsal with a dusky median zone and a dark edge; caudal pale, with a dark narrow border."

The red snapper has become one of the most famous fishes of our northern markets, and is always attractive on account of its large size, brilliant color, and the excellence of its flesh. We know that the species is to be found on our east coast from Cape Cod to the Carribbean sea. It is rare, however, north of Cape Hatteras and the principal fisheries are located off the coasts of Georgia and Florida, and in the Gulf of Mexico.

When the red snapper was named in honor of $\mathrm{Mr}$ Eugene G. Blackford, in recognition of his invaluable contributions to the science of ichthyology, the describers of the species had carefully considered the question of nomenclature and satisfied themselves that none of the names lnown to them could with certainty be associated with this fish. Various earlier names have been suggested from time to time by several authors as possibly available for the species. In $1883 \mathrm{Dr}^{*} \mathrm{D}$. S. Jordan considered it to be the L. c a m pechian us, described by Poey in 1860. This, however, is a species with much smaller scales if the description be accurate. The type has not been examined by any one in the United States so far as I am informed. 
A little later Dr Jordan suggested that the name $\mathrm{Lu}$ t j a $\mathrm{n}$ u $\mathrm{s}$ vivanus of Cuv. \& Val. should be accepted for the red snapper; but my examination of the types of this species in the Museum at Paris showed it to be a small Lut $\mathrm{j}$ a n u s, and very distinct in every way from $L$. b la $\mathrm{ckf} \mathrm{or} \mathrm{di}$. In recent lists Dr Jordan has adopted the specific name a $y$ a of Bloch, published in 1787 in the Auständische Fische. This name was used for a species of $\mathrm{L} u \mathrm{t} j$ a $\mathrm{n} u \mathrm{~s}$ more than twenty years ago by Dl Theodore Gill.

I will now state what may be learned from the literature concerning the a ya. The Bodian us ay a Bloch is distinctly based upon the Acara a y of Maurice, prince of Nassau, as set forth in his mss, tome 2, page 351. The plate published by Bloch is copied from a drawing by Prince Maurice, and his description is drawn from the same source. The fish which formed the subject of the description and illustration by the prince of Nassan was the a y or Garanha of Brazil, a red species, said to attain to a length of 3 feet. The a $y$ a is distinctly described as having 9 spines and 18 articulated rays in the dorsal. It is represented as having 40 scales in the lateral line, and the scales are said to be ornamented with silvery, submarginal stripes. Bloch was informed that the fish was known to the French, Germans and English as the a y and to the Brazilians as the garanha. Elsewhere in the description the general color is said to be red, the back dark red, and the belly silvery. This is all the information to be derived from Bloch's account of the species, and if the data mentioned are to be relied upon, the fish is certainly not our red snapper. We have no other knowledge concerning the ay a of Brazil. It has not been shown that our species ranges so far south and several red forms resembling L. b l a c k f o r d i are associated with it. Various interpretations of the a $y$ a have appeared in ichthyological works. Dr Günther, in his Catalogue of Fishes in the British II useum, rol. I, page 198, adopts the name for a small-scaled $\mathrm{Lu}$ t ja $\mathrm{n} \mathrm{us}$, which has 65 scales in the lateral line and 32 in a transverse series. Of this he has a fine 
specimen from South America. A rery curious translation of the earlier descriptions of the a $y$ a is to be found in Lacépède's account of the species, which is given below. The diagnostic characters are stated as follows:

Nine spines and 18 articulated rays in the dorsal; one spine and eight divided rays in the anal; the caudal crescent-shaped; eacl opercle terminating in a long and flat spine; the general color red; the back blood color; the belly silvery.

The author, in another part of his Natural History of Fishes, writes:

A figure of the aya has been published by Marcgrave, Piso, Willughby, Jonston, Ruysch, the prince of Nassau [Maurice] and Bloch, who has copied the drawing of Prince Maurice. It is found in lakes of Brazil. It frequently reaches a length of one meter, and it is so plentiful that large. numbers of this species are salted or sun-dried for export. It may be very desirable and, perhaps, sufficiently easy to acclimatize this large and beantiful bodianus, the fiesh of which is very agreeable to the taste, in the fresh waters of Europe, and particularly in lakes and ponds of France.

\section{Family haEMULIDAE}

\section{Grunters}

\section{Genus овтнориіstis Girard}

Body moderately elongate, compressed, the back arched; head compressed, the snout usually long; mouth rather small, placed low; teeth in jaws in villiform bands, the outer teeth above somewhat enlarged; eye moderate; preopercle with its rertical limb straight, finely serrate or entire; gill rakers rather long and slender; dorsal spines rather slender, 12 or 13 in number, the fin usually not much notched; soft dorsal long and low, usually with 15 or 16 rays, the membranes usually naked; anal spines small; caudal lunate. Scales rather small, those above lateral line arranged in series not parallel with it; usually no smaller accessory scales at base of the larger ones. This genus contains a considerable number of species differing from $\mathrm{P}$ o $\mathrm{m}$ a $\mathrm{d}$ a $\mathrm{s}$ is in the long anal fin, the smaller scales, and in the less development of the dorsal spines. Nearly all the species are American. 


\section{Orthopristis chrysopterus (Linnaeus)}

\section{Pigfish; Hogfish}

Perca chrysoptera Linnaeus, Syst. Nat. ed. XII, 485, 1766, Charleston, S. C. Labrus fulvomaculatus Mitchild, Trans. Lit. \& Phil. Soc. N. Y. I, 406, 1815, New York.

Pristipoma fasciatum Cuvier \& Valexciernes, Hist. Nat. Poiss. V, 285, 1830, New York, young; Gunther, Cat. Fish. Brit. Mus. I. 301, 1859, New Orleans.

Hatemulon fulvomaculatum DE KAY, N. Y. Fauna, Fishes, 84, pl. 7, fig. 21, 1842, New York; Holbrook, Ichth. S. C. 156, pl, 22, fig. 2, 1856.

Pristipoma fulvomaculatum Gunsher, Cat. Fish. Brit. Mus. I, 301, 1859, copied from HоLвRоок.

Orthopristis duplex Girard, U. S. Mex. Bd. Surv. Zool. Fish. 15, pl. 9, figs. 1 to 4,1859 , Texas.

Pomadasys fulvomaculatus Jordan \& Gilbert, Bull. 16, U. S. Nat. Mus. 551, 1883.

Orthopristis chrysopterus BEAN, Bull. U. S. F. C. VII, 142, pl. III, fig. 11, 1888; Jordan \& Fesler, Rept. U. S. F. C. 499, 1893; Bean, Bull. Aṇ. Mus. Nat. Hist. IX, 366, 1897; Jordan \& EvermanN, Bull. 47, U. S. Nat. Mus. 1338, 1898, pl. CCX, fig. 541, 1900.

Body oblong, compressed, not much elevated. The depth of the body is one third of the length, which is three and one third times the length of the head; head long; snout conic; mouth low and small, the maxillary barely reaching to the nostrils; outer teeth slender and rather short; eye placed high, $4 \frac{1}{2}$ in head, nearly midway in its length, its diameter two thirds depth of the broad preorbital; dorsal and anal entirely naked, with a sheath of scales at base; anterior spines of dorsal higher than the posterior, which are lower than the soft rays; anal spines short, graduated; pectoral moderate, reaching past tips of rentrals; caudal forked, the upper lobe the longer. Length 1 foot to 15 inches.

D. XII, 16; A. III, 12 ; Lat. 1 , 75 ; pyloric caeca six.

Light brown, silvery below; sides with numerous orange colored and yellow spots; those above the lateral line in oblique series, those below in horizontal; vertical fins with similar spots; head bluish with yellow spots; angle of mouth and gill membranes with orange.

The pigfish ranges along the Atlantic coast from New York southward; adult individuals are rarely seen even as far north as New Jersey, but the young are common. 
At Beesley's Point N. J. Aug. 10, 1Ss7, many young individuals were taken in the seine. D. XII, 16; A. III, 13; scales, 75.

A dark stripe beginning on nape and dividing sends one branch along the back on each side not far from dorsal outline; a dark stripe from eye to root of caudal; cheeks and opercles with several narrow orange stripes; a narrow orange stripe between the two dark body stripes and another below the lower dark stripe; below the second orange stripe with numerous orange spots, not continuous. These specimens are from less than 1 inch to more than 2 inclies long.

Young examples were seined at Somers Point, August 13, and abundantly at Ocean City, August 16. The croaking sound made by these little fishes is quite noticeable.

September $5, \mathbf{M r} \mathbf{W}^{*}$. S. Keates brought in two examples which luad been caught on a hook with clam bait; these are $5 \frac{1}{4}$ inches long, and much larger than the average size. Specimens from $4 \frac{1}{2}$ to 5 inches long were caught at Beesley's Point, August 23; in these there is only a trace of the black lateral stripe along the median line, and the sides have several broad, dark bands.

September 9 an individual $5 \frac{1}{3}$ inches long was taken at Beesley's Point. This species is unknown to the fishermen. One angler described its croaking as resembling the quacking of a duck.

Several examıles were taken in Gravesend bay, Oct. 24, 1894. De Kay mentions it as a rare fish, but occasionally appearing, he was informed, in New York harbor in considerable numbers. He states that it is a very savory food.

\section{Family SPARIDAE \\ Porgies \\ Genus stexotomus Gill}

This genus is close to $\mathrm{C}$ a 1 a $\mathrm{m}$ us, having the same quill like interhaemal bones, the flattened incisors and antrorse dorsal spine mainly distinguishing it; temporal crest obsolete; frontal bones not gibbous nor porous; antrorse spine attached to the fourth interneural by a downward projecting spine about thrice as long as the spine; lateral crest nowhere coalescing with the 
supraoceipital crest; interorbital area flattish, with two low ridges, a small foramen in each of these abore front of pupil; interorbital area much contracted anteriorly; a strongly projecting prefrontal process, which makes an acute angle with the supraorbital. American shore fisles.

\section{Stenotomus chrysops (Linnaeus)}

Scup); Porgy; Sand Porgee

Sparils chrysops Linnaeus, Syst. Nat. ed. XII, 471, 1766, Charleston S. C. sporils argyrops Linnaeus, Syst. Nat. ed. XII, 471, 1766, Charleston S. C. young.

Labrus versicolor Mtтchul, Trans. Lit. \& Phil. Soc. N. Y. I, 404, pl. III, fig. 7,1815 , New Tork.

Sargus arenosus De KAY, X. Y. Fauna, Fishes, 91, pl. 22, fig. 67, 1812, Long Island, young.

l'agi"lls argyrops DE KAY, op. cit. 95, pl. IX, fig. 25, 1812; adult; Günther, Cat. Wish. Brit. Mus. I, 472, 1859.

Sargus ambassis Günther, Cat. Fish. Brit. Mus. I, 449, 1859, New York. Diplolus argyrops Jordan \& Gilber', Bull. 16, U. S. Nat. Mus. 557, 1863. Stenotomus argyrops Goode \& BEAN, Bull. Essex Inst. XI, 17, 1879, Cape Ann Mass.

Stenotomus chrysops BEAN, Bull. U. S. F. C. VII, 142, 18ss; 19th Rep. Comm. Fish. N. Y. 261, pl. XIV, fig. 18, 1890; Jordan \& Fester, Rept. U. S. F. C. 1899 to 1891, 507, 1893; BEAN, Bull. Am. Mus. Nat. Hist. IX, 366, 1897; H. M. SмIth, Bull. U.S. F. C. 1897, 100, 1898; Jordan \& Evermann, Bull. 47, U. S. Nat. Mus. 1346, 1898, pl. CCXI, fig. 544, 1900; BeAN, 52d Amn. Rept. N. Y. State Mus. 106, 1900; SHerwood \& Einwards, Bull. U. S. F. C. 1901, 28, 1901.

Body ovate-elliptic, compressed, its greatest depth nearly one half of total length without caudal; anterior profile steep, nape convex, a strong depression above and in front of eye; least depth of caudal peduncle one fourth of greatest depth, and equal to postorbital part of head. Head short and deep, its lengtl contained three and one fourth to three and one half times in total without caudal; snout one third as long as head; eye one fourth to one fifth as long as head, much narrower than the preorbital; mouth small, terminal, the maxillary reaching to below the posterior nostrils; incisor teeth very narrow, almost conical; molars in two rows above; cheeks short and deep, with four rows of scales; top of head, snout, orbitals, and chin naked; gill rakers small, about $6+10$ on first arch; temporal crest obsolete; supraoccipital crest continuous with the frontal bones; a procumbent 
spine in front of the dorsal; first dorsal spine as long as the eye; third, and longest, dorsal spine as long as the head without the snout; last dorsal spine nearly one third as long as head; soft dorsal highest in the middle, its longest ray (sixth) equal to snout. Caudal deeply forked, its middle rays two fifths as long as the external, and equal to snout. First anal spine three fourths as long as the eye; second and third about equal, two sevenths as long as the head; soft rays rather short, the first and second about as long as the suont. Pectoral long, reaching to above the second ray of the anal. Ventral four fifths as long as the head, reaching nearly to rent. D. XII, 12; A. III, 11; T. I, 5; P. I, 15. Scales 8-50-16.

Color silvery, with bright reflections, dusky above, upper part of head deep brown; dorsal horm color, the last rays with a yellowish tinge; axil of pectoral dusky; young with fire or six dusky bars; iris golden, mottled with silvery and brownish. Length, about 1 foot.

The scup is one of our best known fishes. In many places it is better known under the name porgee. Mitchill and De Kay described it as the big porgee. Another spelling for the same name is pogy. Scup is an abbreviation of scuppang, which in turn is a shorter form for the Narragansett name, mishcuppanog. The name fairmaid, which is said to be given to the scup on the Virginia coast, does not lightfully belong to this species, but rather to the sailor's choice (L a g o d o n). The name fairmaid is regularly applied to the latter species at Cape Charles Va. according to B. A. Bean. In Norfolk Va. Mr Bean heard the name maiden for the young of the common scup.

The scup seldom migrates north of Cape Cod, though it has been taken occasionally off Cape Ann. Attempts to introduce it into Massachusetts bay have been unsuccessful.

The scup comes into our northern waters in great schools, the large spawning fish coming first, making their appearance in New York waters in May. The species feeds upon small crustaceans, mollusks and annelids, and is one of the readiest biters along the coast. The fishery fluctuates greatly; in certain year's 
the fish is comparatively scarce, and in others it is extremely abundant. It is caught in pounds and traps, and remains in Great South bay till cold weather sets in. It has been taken on Cape Cod as late as December 10. Sometimes a sudden cold spell kills the fish in large numbers.

In 1890 we found only a few specimens at Fire Island and at East Island, late in September, and on October 1 à few examples were taken in a trap at Islip. In 1898, adults were taken in moderate numbers off Soutlampton, August 3 . Half grown specimens were obtained at Islip, August 18. A single young individual was seined at Nichols's Point, September 1, and a noderate number of young, about 2 inches long, were secured at the east side of Fire Island inlet, September 16. In 1901 small scup, about 6 inches long, were obtained in a gill net, August 13, and in Watts's pound, July 31, in Clam Pond cove.

The scup arrives in Gravesend bay in May, and is taken as late as Norember. In captivity it lives till December, and in properly heated water it can be kept indefinitely. It is thrifty, and is seldom in bad condition.

It Woods Hole Mass. according to Dr Smith, the fish appears about May 1 and leares about October 15 or 20, being most abundant in June and July. Spawning occurs during first part of June, and young $\frac{1}{2}$ inch to $\frac{3}{4}$ inch long are observed by the middle of July. The eggs are $\frac{1}{26}$ inch in diameter and hatch in four days at a mean temperature of $62^{\circ} \mathrm{F}$. In 1900 , the scup arriced off Newport April 21, at Cutty Hunk April 26, and at Wroods Hole May 1 . Hundreds of roung are killed there annually by a sudden fall of temperature. The growth of the roung is recorded by Sherwood and Edwards as follows: July 3, length $\frac{1}{2}$ to $1 \frac{1}{2}$ inches; August 2, $1 \frac{1}{2}$ to 2 inches; September 6 , 2 to 3 inches; September 29, 3 to 4 inches; November 1,4 inches. The largest individual observed weighed 3 pounds.

The young are devoured in large numbers by cod, weakfish, bluefish and other predaceous species. 


\section{Genus ragomox Holbrook}

The essential character of this genus is in the form of the skull. Supraoccipital and temporal crests nowhere coalescent, the interorbital area not swollen; frontal bone in the interorbital area thin, concave in transcerse section; temporal crest low, separated from supraoccipital crest by a flattish area which extends forward on eacl side of supraoccipital crest and to groove of premaxillary spines. Otherwise essentially as in A r c hos a rgus, the antrorse dorsal spine present, the second interhaemal not modified. One species, the incisors deeply notched.

\section{Lagodon rhomboides (Linnaeus)}

\section{Sailor's Choice}

Sprrus rhomboides Lrnxaeus, Syst. Nat. ed. XII, 470, 1766, Charleston S. C. suryus rhomboides Cuvier \& Valexciennes, Hist. Nat. Poiss. VI, 68, pl. 143, 1830; DE KAY, N. Y. Fauna, Fishes, 93, pl. 71, fig. 228, 1842, copied from Cuvier \& Valenciennes; Günther, Cat. Fish. Brit. Mus. I, 447, 1859.

Diplodus rhomboides Jordan \& Gilbert, Bull. 16, U. S. Nat. Mus. 558, 1853. Lugodon rhomboides IIoLbrook, Ichth. S. C. ed. 1, 56, pl. 8, fig 1. 1856; ed. 2, 59, 1860; BEAN, Bull. U. S. F. C. VII, 142, 18s5; 19th Rep. Comm. Fish. N. Y. 263, 1890; Bull. Am. Mus. Nat. Hist. IX, 366, 1897; H. M. Shith, Bull. U. S. F. C. 1897, 101, 1898; Jordan \& Evermanx, Bull. 47, U. S. Nat. Mus. 1358, 1898, pl. CCXV, fig. 552, 1900.

Body ovate, elliptic, compressed, and somewhat elerated, the axis of the body near the middle of its depth; snout about in the axis. The depth of the body is contained two and one third times in its length. Head rather sharp, the length contained three and one half times in that of the body. Mouth small, the upper jaw more freely protractile than usual. Molars in two series; anterior incisors each deeply notched. Cheeks with 5 or 6 rows of scales; scales on the breast little reduced in size. A procum. bent spine before the dorsal fin; dorsal spines high, much higher than soft rays, the fourth highest; second anal spine little larger or longer than the third. Pectorals as long as the head; rentrals two thirds as long, not reaching to vent. D. XII, 11; A. III, 11. Scales S-66-18.

Brownish, white below; sides of head and body with horizontal stripes of light blue and golden; six or seven very faint 
darker vertical bands, disappearing with age; vertical fins yellowish, with bluish stripes; a dark axillary spot.

This is called the salt water bream by Schoepff and the rhomboidal porgee by DeKay. In Chesapeake bay it is the fairmaid. It is also called pinfish, squirrel fish, porgee, yellowtail and shiner. In Great South bay the name of the fish was unknown to the fishermen, and this is true in Great Egg Harbor bay, where the young are not uncommon in summer.

In Gravesend bay it is not a common fish, but is found occasionally in summer.

A single individual was obtained at Fire Island, October 1. The sailor's choice occur's as far north as Cape Cod, but it is not present in sufficient numbers to be considered among the important food fishes; south of Cape Hatteras, where it is abundant, it is valuable for food, and in many places is considered superior to sheepshead; this is specially so in the St John's river.

The sailor's choice feeds upon small invertebrates and minnows. It is caught with the hook and in cast nets and seines.

The eggs are described as pale blue in color and as large as mustard seed. Spawning takes place in the Gulf of Mexico in winter or early spring. The colors of the fish are very beauti. ful, the sides being ornamented with golden stripes on a pearly white ground and having numerous dark vertical bands.

\section{Genus archosargus Gill}

Body robust, short and deep, compressed, covered with large scales. Head deep, mouth moderate, the jaws with broad incisors in front and coarse molars on the sides; incisors entire or with a shallow notch; posterior nostril slitlike; opercles entire. Dorsal and anal spines strong, the soft parts of the fin short and rounded; a procumbent spine before the dorsal; caudal forked. Gill rakers small. Supraoccipital and temporal crests coalescent anteriorly, both disappearing in the gibbous interorbital area; frontal bone between eyes transversely convex and more or less honeycombed; temporal crest separated from occipital crest by an excavated area, bounded anteriorly by the lateral crest, which merges into the supraoccipital above eye. 
This genus, like I. a go d o u. St e n o t o m u s and Otry n t e r, which show the same character of the procumbent dorsal spine, is confined to American waters. There are two color types in the genus, one group being made up of the species with broad black crossbands, the other of species with golden streaks and inconspicuous crossbands, resembling the species of

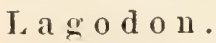

\section{Subgenus ArChosargus}

\section{Archosargus probatocephalus (Walbaum)}

\section{Sheopshead}

sparns probatocephalus Walbaum, Art. Gen. Pisc. 295, 1792, New York.

Sparus oris Mrtchull, Trans. Lit. \& Phil. Soc. N. Y. I, 392, pl. 2, fig. 5, 1815, New York.

Surgus otis Cuvier \& Valenciennes, Hist. Nat. Poiss. VI, 53, 1830; De Kay, N. I. Fauna, Fishes, S9, pl. S, fig. 23, 1842; Hozвrook, Ichth. s. C. ed. 1, j1, pl. 8, fig. 2, 1856; Günther, Cat. Fish. Brit. Mus. I, $447,1859$.

Diplodus probatocephalus Jordan \& Gilbert, Bull. 16, U. S. Nat. Mus. 558, 1 183.

Arhosargus probatocephalus GiLL, Cat. Fish. East Coast N. A. 27, 1873; BeAx, Bull. U. S. F. C. VII, 142, pl. III, fig. 10, 18s8, Somel's Point N. J., young; 19th Rep. Comm. Fish. N. Y. 262, pl. XV, fig. 19, 1890; Bull. Am. Mus. Nat. Hist. IX, 366, 1897; H. M. Sмrтr, Bull. U. S. F. C. 1897, 101, 1998; Jordan \& Evermaxn. Bull. 47, U. S. Nat. Mus. 1361, 1898, pl. CCX VI, fig. 554, 1900.

Body robust, becoming deep with age, the back compressed and elevated, the greatest depth from two fifths to one half of total length without caudal; the least depth of caudal peduncle equal to eighth dorsal spine, and three eighths length of head. Head one third or nearly one third of total length without caudal: eye placed ligh, one fifth to one fourth length of head; interorbital space one third greater than diameter of eye; mouth low, horizontal; maxillary reaching nearly to below front of pupil, slightly more than one third as long as the head; incisors entire or slightly notched, serrate in the young, their breadth about one half their length; molars in three series above, in two below; those of the inner series larger; those behind the incisors very small. Gill rakers about $3+6$. Cheeks with six rows of scales; scales on breast very small, crowded. Occipital crest broad. Dorsal spines rery 
strong, the last considerably shortened so that the outline of the fin is emarginate, the fifth spine longest, four serenths as long as the head, the first spine shorter than the eye; the third and fourth soft rays longest, two fifths as long as the head. The second anal spine more than twice as long as the first, very strong, two fifths as long as the head, and as long as the longest soft ray. Pectoral very long, longer than the head, and reaching nearly to or, sometimes, beyond the anal origin. Ventral large, one fifth of total length without caudal, reaching to below 19 th spine of the dorsal.

D. XII, 10 to 12 ; A. III, 10 to 11 ; V. I, 5; P. I, 14 . Scales T to $8-45$ to $48-15$ to 16 .

Grayish, with about eight vertical black bands, which are about as broad as the interspaces; dorsal dusky; rentral and anal black; base of pectoral dusky; the dark bands are most. distinct in the young.

The sheepshead ranges along the coast from Cape Cod to Texas; it is very rare as far north as Woods Hole Mass., but in southern waters it is still abundant. The species reaches a length of 30 inches and the weight of 20 pounds; it is one of the most valuable of our food fishes and is highly prized for its game qualities.

In August 1887, the sheepshead was known to have bred in Great Egg Harbor bay, N. J., where about 20 young individuals measuring from 1 inch to $1 \frac{1}{4}$ inches were seined between August 10 and September 9 . Adults at that time were present in the bay, but they were scarce. The bottom was covered with algae and convenient hiding places were found under the sod banks.

The fish is very unusual in Gravesend bay, Long Island. A large individual, weighing 13 pounds, was caught September 16, 1897, at Coney Island. That example proved hardy in captivity and the sheepshead generally can be easily kept if the water temperature be properly maintained.

The sheepshead was at one time common in Great South bay. For this statement we have the authority of Mr Erastus Gordon, of Patchogue, and the following account from Dr Mitchill's 
Fishes of New York will substantiate the fact: "The sheepshead swims in shoals and is sometimes surrounded in great numbers by the seine. Several hundreds have often been taken at a single haul with the long sweeping-nets in use at Ravnortown, Babylon and Fire Island. They eren tell of a thousand brought to land at a draught. . . This fish is sometimes speared by torchlight in the wide and shallow bays of Queens county and Suffolk. His term of continuance is only during the warmest season; that is, from the beginning of June to the niddle of September. ... I have, however, known him to stay later; for one of the most numerous collections of sheepshead I erer saw in the New York market was on October 4, 1814; I have seen them as late as the 17th."

Scott, in 1875 , referred to Fire Island as a good locality for sheepshead fishing, and also mentions superior feeding places in the South bay and about the wreck of the Black Warrior, near the Narrows.

We did not obtain the sheepshead in Great South bay, and believe it occurs there very rarely at the present time, though fishermen still seek them in a few localities and, I am informed, occasionally catch one. Dr Smith says not one has been seen or heard of in Vineyard sound or Buzzards bay since 1894; but formerly it was quite common and was often caught while linefishing for tautog and scup.

\section{Family GERRIDAE}

\section{Mojarras}

\section{Genus Eucunostonus Baird \& Girard}

Interhaemal bone of the second anal spine greatly modified, expanded into a hollow cylinder, into which the posterior end of the air bladder enters. Preopercle and preorbital entire; body comparatively elongate, subelliptic in form; anal spines three; the second anal spine and fourth dorsal spine not greatly enlarged. Species numerous in warm seas, remarkable for the structure of the second interhaemal, which is formed somewhat as in Calam $\mathrm{us}$, but much more modified than in the latter genus. 


\section{Eucinostomus gula (Cnv. \& Val.)}

\section{Mojarra de Ley; Silver Jenny}

Gerres gula Cuvier \& Valenciennes, Hist. Nat. Poiss. VI, 464, 1830, Martinique; Günther, Cat. Fish. Brit. Mus. I, 346, 1859.

Eucinostomus argenteus BAIRD \& GIRARD, 9th Smithson. Rep. 345, 1855, Beesley's Point, N. J.

Gerves argenteus Jordan \& Gilbert, Bull. 16, U. S. Nat. Mus. 584, 18S3;

BEAx, Bull. U. S. F. C. VII, 138, 18s8, Great Egg Harbor Bay, N. J.

Encinostomus gula Jordan \& Everman,, Bull. 47, U. S. Nat. Mus. 1370, 1898; H. M. Sмiтн, Bull. U. S. F. C. 1897, 101, 1898; BEAN, 52d Ann.

Rep. N. I. State Mus. 106, 1900.

Body elliptic, compressed, back moderately elevated, the greatest depth contained two and two fifths times in total length without caudal. Head short, pointed, its length three tenths of total without caudal; mouth small, the maxillary reaching slightly past the vertical from the front of orbit; exposed portion of maxillary nearly oblong, its length twice its width, and equal to one fourth or one fifth the length of the head; preorbital and preopercle entire; snout two sevenths and interorbital width one third length of head; eye one third length of head. Gill rakers small and weak, seven below the angle of first arch; premaxillary groove scaly in front, posterior part naked forming a sort of pit. Longest dorsal spine two thirds as long as head. Second anal spine shorter and stronger than third, about three tenths as long as the head. Ventrals reach nearly to rent, five sevenths as long as head. Pectorals reach front of anal, and equal one third of total length without caudal. Second interhaemal hollow and enlarged.

D. IX, 10 ; A. III, S; scales $5-42$ to $45-9$; vertebrae $9+\mathbf{1 5}$. Color silvery, greenish, darker above; no distinct longitudinal lines except in very young; upper margin of spinous dorsal more or less black; dorsal and anal fins dusky; other fins pale.

The silver jenny occurs from Cape Cod to Brazil and the West Indies; only the young come far north in summer. The species reaches a Jength of 5 inches and is used for bait.

At Woods Hole Mass., writes Dr Smith, the species is usually very uncommon. In 1897 five specimens were taken at one seine haul in Quisset harbor on Angust 14; two in the same 
locality September $\boldsymbol{T}$, and one in Eel Pond on September 23; all of these were 1 to 2 inches long. On October 5 the fish was abundant in Quisset harbor.

Young fish of this species were obtained in abundance at Beesley's Point, Somers Point, and Ocean City N. J. in August 1887. No adults were seen.

The only individual observed in Great South bay was a vers small one, seined in Clam Pond cove, Aug. 22. 1898. Diligent search was made for the species in 1901, but no specimens were taken.

\section{Family ITPHOSINAE}

\section{Rudder fishes}

\section{Genus rxphosus Lacépède}

Body elongate-orate, regularly elliptic, moderately compressed; head short, with blunt snout; eye large; mouth small, horizontal; maxillary barely reaching front of eye; each jaw with a single series of rather narrow obtusely lanceolate incisols, implanted with compressed conspicuous roots posteriolly; behind these a narrow band of villiform teeth; fine teeth on vomer, palatines, and tongue. Branchiostegals seven; gill rakers long. Preopercle obtusely serrate; preorbital narrow, corering but little of the maxillary. Squamation rery complete, the space between and about the eyes being the only naked part; scales smallish, thick, ctenoid, 60 to 70 in the lateral line, which is continuous; similar scales entirely covering the soft parts of the rertical fins, and extending upon the paired fins. Dorsal fin low, with about 11 spines, which are depressible in a groore of scales, the fin continuous, but the last spines low, so that a depression occurs between the two parts of the fin, the bases of the spinous and soft parts about equal; soft dorsal rather low in front, not falcate, pointed behind; anal similar to soft dorsal, with three spines; caudal fin moderately forked; pectoral fins small, rentrals well behind them. Intestinal canal long; pyloric caeca rery numerous. Tertebrae 9 or $\mathbf{1 0 + 1 5}$ or $^{\circ}$ $16=25$. 


\section{Kyphosus sectatrix (Linnaeus)}

\section{Bermuda Chub}

Perca sectutrix Linsaeus, Syst. Nat. ed. XII, 486, 1766.

Pimelepterus boscii Cuvier \& Valenciennes, Hist. Nat. Poiss. VII, 25̃, pl. 187, 1831; DE KaY, N. Y. Fauna, Fishes, 100, pl. XX, fig. 56, 1842, copied from Cuv. \& Val.; Jordan \& Gilbert, Bull. 16, U. S. Nat. Mus. 561, 1883.

Kyphosus scctatrix Jordan \& Fesler, Rept. U. S. F. C. 1889 to 1891, 525, 1893; Bean, Bull. Am. Mus. Nat. Hist. IX, 366, 1897; H. M. Smith, Bull. U. S. F. C. 1897, 101, 1898; Jordan \& Evermann, Bull. 4i, U. S. Nat. Mus. 1387, 1898, pl. CCXIX, fig. 559, 1900.

Body orate-elliptic, somewhat compressed, its greatest hight two fifths of the total length without caudal; the least depth of caudal peduncle nearly one half length of head. Head short, one fourth of total length without caudal; snout short; mouth small, the maxillary reaching to below front of orbit; teeth 35 to 40 on each side, their horizontal process not much longer than the vertical; width of interorbital space two fifths length of head; eye equal to snout, and more than one fourth length of head; top and sides of head finely scaled; interorbital region gibbous; preopercle serrulate; gill rakers long. Tongest dorsal spine equals snout and is nearly one fifth depth of body; longest ray of soft dorsal two sevenths as long as the head. The second anal spine is about two thirds as long as the eye; the longest anal ray is one third as $l o n g$ as the head. Caudal deeply forked, the middle rays about one half as long as the outer, which are nearly as long as the head. Pectoral two thirds as long as the head, and equal to ventral, which reaches to below the ninth spine of the dorsal. Soft dorsal and anal closely scaled; most of caudal scaly.

D. XII, 12; A. III, 11; V. I, 5; P. i, 16; scales 10-66-16; vertebrae $9+16$.

Color in life dusky or steel gray, very slightly bluish, not much paler below; the edges of each row of scales on back aud sides slightly brassy so that very faint yellowish stripes alternate with bluish ones of about equal width; the stripes thus formed vary from 25 to 34 in number. A diffuse pale stripe below the eye; a yellowish one above and below this; fins all dull grayish; ventrals and anal blackish; edge of opercle slightly darker. 
The Bermuda chub grows to the length of 18 inches. It ranges from Cape Cod to the West Indies, the Gulf of Mexico, across the ocean to the Canary Islands, and is accidental in the Mediterranean. Its name of rudier fish refers to its habit of following ressels, presumably to secure the waste food thrown from them. The fish is said to have game qualities.

At Woods Hole Mass. according to Dr Smith, the species is not rare in summer and fall and has occasionally been found in Ipril; it is sometimes taken among gulf weed at the surface. Only roung specimens, up to 6 inches long, have been secured there.

The Bermuda rhub is a rare fish in Gravesend bay, but was found there in October 1896, and in September 1897. It has great endurance in eaptivity and will survive the winter in artificially heated water.

\section{Family SCIAENIDAE \\ Croakers \\ Genus croscrov Gill}

Body elongate, little compressed, the back not elevated. Head conival, rather pointed; moutl very large, terminal, not very oblique, the lower jaw projecting, the symphysis produced, the angle at hase of maxillary not prominent. Maxillary very broad. 'Teeth sharp, not closely set, in rather narrow bands; tip of the lower jaw without canines; upper jaw with two long anines, one of which is sometimes obsolete; canines tapering from base to tip; lateral teeth of lower jaw larger than anterior. Prepercle with its membranaceous edge serrulate, the bone entire. Lower pharyngeal bones separate, their teeth all pointed. Gill rakers strong, rather long. Vertebrae about $14+10$ (instead of $10+14$ as in sciaenoids generally). Pseudobranchiae well developed; dorsal spines slender, the fins closely contiguous; anal spines one or two, very feeble, the soft rays seven to 1.3 ; second doisal long and low, more than twice length of anal; ventrals inserted below pectorals, the pubic bone long and strong; caudal fin subtruncate or lunate. Large fishes chiefly of the waters of America, closely related to the old World genus Ot ol ith us, from which they ale distinguished 
by the absence of canines in the lower jaw. All of them rank high as food fishes; the flesh is rich, but in some species tender and easily torn, hence the popular name weakfishes.

\section{Subgenus croscion}

\section{Cynoscion regalis (Bloch \& Schneider)}

Weakifish; Squeteague

Johnius regalis Bloch \& Schnerder, Syst. Ichth. 75, 1801, New York. Roccus Comes Mitchill, Rep. Fish. N. Y. 26, 1814, New York.

Labrus squetcague Mrtchils, Trans. Lit. \& Phil. Soc. N. Y. I. 396, pl. 2, fig. 6,1815 , New York.

Otolithus regalis Cuvier \& Valenciennes, Hist. Nat. Poiss. V. 67. 1530; DE KAY, N. Y. Fauma, Fishes, 71. pl. 8, fig. 24, 1842; Güntuer. Cat. Fish. Brit. Mus. II, 307, 1860.

Cynoscion regale Gill, Proc. Ac. Nat. Sci. Phila. 18, 1862; Jordix \& GiLBert, Bull. 16, U. S. Nat. Mus. 581, 18s3; Bean, Bull. U. S. F. C. VII, 140, pl. II, fig. 6. 18ss; 19th Rep. Comm. Fish. N. Y. 25i. pl. XII, fig. 15,1890 .

Cynoscion regalis Goode \& BeAN, Bull. Essex Inst. XI, 17, 1679, Cape Aun; Bear, Bull. Am. Mus. Nat. Hist. IX, 367, 1897; Jordan \& EverMANN, Bull. 47, U. S. Nat. Mus. 1407, 1898, pl. CCXX, fig. 562. 1900;

H. M. Sirth, Bull. U. S. F. C. 1897, 101, 1898; BeAr. 52d Aun. Rel. N. Y. State Mus. 106, 1900; Sinerwood \& Edwards. Bull. U. S. F. C. 1901, 29, 1901.

Body elongate, little compressed, its greatest deptl contained foul aud one fourth times in the total length without caudal; the least depth of caudal peduncle one third length of head, which is three tenths of total length without candal. Eye moderate, three fourths length of snout, and one fifth to one seventh length of head. Maxillary reaching to below hind margin of eye, its length nearly two fifths length of head. Teeth sharp, in narrow bands; canines large. Gill rakers long and sharp, 5 above and 11 below the angle of the first arch. The second and longest dorsal spine is two fifths as long as the head; the first spine is one third as long as the head; the last two spines are very short; the longest soft ray of the dorsal is one third as long as the head. Caudal lunate behind, the longest rays equal to the head withont the snout. The anal base is as long as the snout and eye combined; the longest ray slightly exceeds the base of the fin. Pectoral about equal to postorbital part of head and about one sixth of total length without caudal. 
Ventral about one half as long as the head, reaching to below the seventh spine of the dorsal.

D. X, I, 26 to 29 ; A. I, 11 to 13 ; scales $8-78-17$, about 66 pores in lateral line.

Silvery, darker above and marked with many small, irregular dark blotches, some of which form nndulating lines running downward and forward; back and head with bright reflections; dorsal and caudal fius dusky; ventrals, anal, and lower edge of caudal yellowish, sometimes speckled. The young show traces of a few dusky bands on the sides, one under the spinous dorsal being most plainly marked, and extending to below the median line.

The weakfish, so called in Dr Mitchill's Fishes of New York, appears also in his report as the squeteague and checouts, the former being a Narragansett Indian name and the latter derived from the Mohegans. The Narragansett name is sometimes spelled scuteeg. Chickwick is the Connecticut name for the species; on Cape Cod, because of the sound produced by the fish, it is called the drummer; large weakfisli in Buzzards bay are termed yellow fins. In Great Egg Harbor bay the name bluefish is applied to it, notwithstanding the presence of the real bluefish ( $\mathrm{P}$ o m a t o m u s). On our southern coast we hear the names trout, with its rariations gray trout, sea trout, shad trout, sun trout and salt-water trout. The latter name is used to distinguish it from the fresh-water trout of the sonthern states, which is the black hass. Dr Mitchill thus accounts for the name weakfish: "He is called weakfish, as some say, be cause he does not pull very hard after he is hooked; or, as others allege, because laboring men who are fed upon him are weak by reason of the deficient nourishment in that kind of food." De Kay explains the name from the feeble resistance the fish makes on the hook and the facility with which it breaks away from it by reason of its delicate structure. At the time of De Kay's writing in 1842, and for some years previonsly, the weakfish was present on our coast in diminished numbers. The bluefish was then present in abundance and the disappearance of the 
weakfish was supposed to be connected with the reappearance of the bluefish. A similar observation was made by Dr Storer on the Massachusetts coast. Again, at Woods Hole Mass. in 1900, the weakfish was remarkably abundant, the traps at Menemsha having taken 10.000 in a single day; the bluefish, on the other hand, was unusually scarce during the entire season, not over 50 having been recorded froni the adjacent bay and sound.

The weakfish ranges from the Bay of Fundy to the east coast of Florida. It fluctuates in abundance from year to year. The late Capt. N. E. Atwood is authority for the statement that in 1845 the weekly supply in the New York markets was not above 1000 pounds.

The species feeds in the channels upon shrimp, crabs and small fish. In Great South bay we found them eating large quantities of anchovies, and the same observation was made in one of the inlets of Great Egg Harbor bay, N. J. The fish enters the mouths of rivers and migrates freely with the tide.

The species swims in large schools near the surface and is very voracious, destroying the young even of its own kind. A specimen of about 4 pounds, taken at Islip October 1, 1890, had in its stomach a weakfish weighing about 6 ounces. Fish of 4 pounds and a little larger were moderately abundant at this date.

Weakfisin spawn in New York waters in May, and at Cape Cod about the first of June. The egg is Tinch in diameter and hatches in two days at an average temperature of $60^{\circ} \mathrm{F}$. It is buyant and, under natural conditions, is subject to the influence of wind and current. The spawning season is evidently prolonged in some localities; in Great Egg Harbor bay, for example, young weakfish only $1 \frac{1}{8}$ inches long were taken in August, that is, sereral months after spawning began.

The earliest arrival in New York was on May 12, 1889, at Great Hills, Gifford, Staten Island. During the latter part of August 1859, the west channel of Great South bay furnished great numbers of weakfish. The young were found in Blue Point cove late in September; also some half grown individuals. 
The fish are in their finest condition during the fall migration in September and October. On September 21, 1887, two men caught 200 , including some very large ones, on a single tide near the inlet of Great Egg Harbor bay, N. J. The most favorable tide for catching this species is generally considered the latter half of the flood and first half of the elbb. At night the weakfish runs up the creeks to feed in the salt meadows and will take the hook freely.

Some of the best baits for the weakfish are the common shrimp, soft or shedder crabs, pieces of clam and common mussel, the white skin of the throat of weakfish, and sometimes the eye of this species; other good baits are silversides and anchovies. In Great South bay the fish are taken extensively in pound nets and gill nets. The gill nets are set in the shape of a horseshoe, and the attending sloop sails back and forth across the open end of the horseshoe, one of the crew meanwhile beating the deck with his heels to frighten the fish into the nets. This method, called drumming, is in great disfavor amoug those who follow other modes of fishing.

In 1901, young weakfish were seldom taken in Great South bay and only two localities-Duncan's creek and Smith's Point - furnished them in very small numbers. Adult fish, howerer, were remarkably abundant and were caught in many parts of the bay.

The reakfish endures captivity very well and can be kept during winter in water of the proper temperature. The species is said to reach the weight of 30 pounds.

\section{Cynoscion nebulosus (Cur. \& Val.) Spotted Weal:fish: Sea Trout}

Labrus squetcaguc var. maculatus MitchilL, Trans. Lit. \& Phil. Soc. N. Y. I, 396. 1815, New York; not Labrus maculatus Blocir.

Otolithus ncbulosus Cuvier \& Valenciennes, Hist. Nat. Poiss. V, 79, 1830. Otolithus carolinensis Cuvier \& Valenciennes, Hist. Nat. Poiss. IX, 475. 1833, South Carolina; DE KAY. N. Y. Famna, Fishes, 72. 1812, extralimital; Ноцввоок, Ichth. S. C. ed. 1, 133, pl. 19, fig. 2. 1956; GÜnther, Cat. Fisl. Brit. Mus. II, 306, 1860, New York.

Cyuoscion maculatum Jordan \& Gilbert, Bull. 16, U. S. Nat. Mus. js1, 1883. 
Cymoscion nebulosus Jordan \& Evermann, Bull. 47, U. S. Nat. Mus. 1409. 1898, pl. CCXXI, fig. 563, 1900.

Body elongate, compressed, its greatest depth two ninths of the total length without caudal; the least depth of caudal peduncle one half postorbital length of head. Head long, two sevenths of total length without caudal; snont long and acute, about two sevenths as long as the head; eye small, about one seventh as long as head; maxillary reaching to below hind margin of orbit, as long as snout and eye combined; canines strong; lower pharyngeals narrow, each with seven or eight series of short teeth, the inner enlarged; gill raker's short and thick, about $4+\bar{\tau}$ on first arch; maxillary, preorbital, and lower jaw naked. Spinous dorsal base as long as postorbital part of head; first dorsal spine one half as long as second, which is one third length of head; third and longest spine nearly one half as long as head; spines decreasing rapidly in length from the fifth to the last, which is minute; soft dorsal base one third of total length without caudal; the longest soft ray one third length of base. Caudal shallow concave, the middle rays one half as long as the head. Anal base short, one third as long as the head; longest anal ray one half depth of body. Pectoral short, reaching to below sixth spine of dorsal. Ventral longer than pectoral, one sixth of total without caudal, reaching to below end of spinous dorsal. Ventral appendage nearly as long as the eye. D. X, I, 24 to 28 ; A. I, 10 to 12 ; V. I, 5; P. I, 15; pores in lateral line about 90 .

Body silvery with bright reflections; numerous black spots on back, beginning under the spinous dorsal; soft dorsal and caudal similarly spotted, the largest spots smaller than pupil; anal fin dusky.

The spotted wealifish is a better food fish than the common northern species; it ranges from New York to Texas, but is rare north of Virginia.

\section{Genus Lanimus Cuvier \& Valenciennes}

Body rather elongate, compressed; skull firm, not greatly cavernous; interorbital space rather narrow; preorbital flattish, not turgid; upper jaw with the usual slits and pores little de- 
veloped; no barbels; no canines; snout very short; mouth large, terminal, very oblique or eren vertical, the lower jaw projecting; teeth minute, equal, uniserial or partly biserial above; preopercle entire or nearly so, without bony teeth. Scales moderate, subequal. Pseudobranchiae well developed. "Fins essentially as in $\mathbf{B}$ a $\mathrm{i} r \mathrm{~d}$ i e $1 \mathrm{l}$ a, the second dorsal long, the anal short, its spines moderate or small; fins not thickened by accessory scales. Gill rakers long and slender. Vertebrae $10+14=24$. Silvery fishes, all American.

\section{Subgenus Lanius}

\section{Larimus fasciatus Holbrook}

\section{Banded Larimus}

Larimus faciatus HoLbroor, Ichth. S. C. 153, pl. 22, fig. 1, 1556, Charleston; Günther, Cat. Fish. Brit. Mus. II, 269, 1S60; Jordan \& Gilbert, Bull. 16, U. S. Nat. Mus. 578, 1883; Jordan \& Eigenuane, Rep. U. S. F. C. for 1S86, 876, 1S89; BEAN, Bull. Am. Irs. Nat. Hist. IX, 367, 1897 ; H. M. SMith, Bull. U. S. F. C. 1897, 101, 1898; Jordan \& EverMANא, Bull. 47, U. S. Nat. Mus. 1424, 1898.

Body oblong, compressed, ventral outline nearly straight, dorsal outline considerably arched; the depth of the body is contained about three times in the length. Snout very short, much less than diameter of the large eye; mouth large, very oblique, maxillary reaching to posterior margin of orbit; the lengtl of the head is contained three and one half times in that of the body. Tip of mandible on level of lower part of pupil; second anal spine small; pectoral fin short; caudal subtruncate. D. X-I, 24; A. II, 6; Lat. 1. about 62 .

Silvery gray, clouded above; sides marked with about seven nearly vertical dusky bars, running from back to below the lateral line. South Atlantic coast and southward; rare. An individual was captured in Graresend bay July 25, 1895, and another one August 2 of the same year. These fed freely, and were kept in a healthy condition till January 16, 1896, when the low temperature of the water killed them. The fish is not common anywhere, and had not before been recorded north of Chesapeake bay, except a single example which was taken at Woods Hole Mass. on August 13, 1889; the specimen was caught in a trap at the breakwater, Buzzards bas. 


\section{Genus BaIrdield Gill}

This genus is characterized by the oblique mouth, little cavernous skull, few rows of small teeth, slender gill rakers, and the preopercle armed with a plectroid spine. It is certainly a very natural group, and worthy of recognition as a distinct genus, though its relationships with ophioscion and specially with stellifer are very close. The numerous species are all American, all small in size and silvery in coloration, and some of them are remarkable for the great size of the second anal spine. In others this spine is quite small. These variations among species unquestionably closely allied show how slight is the systematic value to be attached to the size of this spine.

\section{Subgenus BambreLLA}

\section{Bairdiella chrysura (Lacépède)}

\section{Yellowtail; Silver Perch}

Dipterodou chrysurus LACÉPEDe, Hist. Nat. Poiss. III, 64, 1802, South Carolina.

Bodianus argyrolencus MrtchiLL, Trans. Lit. \& Phil. Soc. N. Y. I, 417, pl. 6, fig. 9, 1815, New York.

Corvina argyroleuca Cuvier \& Valenciennes, Hist. Nat. Poiss. V, 105. 1830; DE KAY, N. Y. Fauna, Fishes, 74, pl. 18, fig. 51, 1842, New York; Günther, Cat. Fish. Brit. Mus. II, 299, 1860.

Homoprion xathurus HoLBRook. Ichth. S. C. ed. 1, 170, pl. 24, 1856 (not Leiostomus xanthurus LACÉPEDE).

Sciaena punctata Jordan \& GILBERT, Bull. 16, U. S. Nat. Mus. 570, 1853. Sciaena chrysura JoRdAN \& GilBert, op. cit. 933, 1883.

Bairdiella chrysura Goode, Fish. \& Fish. Ind. U. S. I, 375, pl. 126, 1SSt; BEAN, Bull. U. S. F. C. VII, 141, pl. I, fig. 9, 1SsS; 19th Rep. Comm. Fish. N. Y. 259, 1890; Bull. Am. Mus. Nat. Hist. IX, 367, 1897; JordAN \& Evermann, Bull. 47, U. S. Nat. Mus. 1433, 1888, pl. CCXXII, fig. 566, 1900; BEAN, 52d Anu. Rep. N. Y. State Mus. 106, 1900.

Body oblong, compressed, rather robust, its greatest depth one third of total length without caudal; least depth of caudal peduncle one eighth of total without caudal. Head compressed, conical, not depressed nor broadened, its length three tenths of total without caudal; eye equal to snout and about one fourth length of head; interorbital region depressed, transversely convex, narrower than the eye; mouth rather large, somewhat oblique, jaws about equal in front, maxillary long, reaching 
nearly to below hind margin of orbit, its width posteriorly nearly one third of its length; both jaws with stout recurred teeth, behind which, in the upper jaw, are a few series of smaller teeth; mandibulary teeth mostly in one series outside of which are a few smaller teeth; preoperele strongly serrate or spinous at its angle; gill rakers slender, moderately long, $8+16$ on first arch; lower pharyngeals small, with sharp teeth. Spinous dorsal high in front, triangular, the first spine very short, the fourth lougest, equal to postorbital part of head; base of soft dorsal one third of total length without caudal, longest ray equal to suout and eye combined. last ray two thirds as long as the eye. Caudal concaro-convex, the middle rays equal to longest dorsal spine. Anal base three eighths as long as the head; longest anal ray equal to snout and eye combined; first anal spine very short, second two fifths as long as the head. Soft dorsal and anal fins considerably scaly. Pectoral and ventral of equal length, one fifth of total without caudal, the pectoral scarcely reaching to below end of spinous dorsal. $D$. XI, I, 22; A. II, 9 or 10 ; scales $8-50$ to $54-11$.

Greenish above, silvery below, each scale with series of dark punctulations through the center, usually very conspicuous, sometimes obscure, these forming narrow somewhat irregular streaks along the sides; fins plain, the caudal yellowish.

Dr Mitchill describes this fish as the silver perch, and De Kay explains the origin of this name from the resemblance which the yellowtail bears in its appearance and habits to the common white perch. At Pensacola Fla. the name mademoiselle is applied to the species. In Great South bay we heard the name lafayette given it, but this belongs more properly to the spot Liostomus $\mathrm{xanthurus.}$

The yellowtail accurs on our coast from Cape Cod to Florida. It was a common fish in Great South bay in September 1890 , and during the early part of October, occurring at Blue Point cove, at the Blue Point Lifesaving station, Great River beach and Fire Island. It is frequently taken in the pounds. In 1898 , the young were found in abundance at Nichols's Point, Great 
South bay, September 1. In 1901, the species was not observed at all during a season extending from the middle of July to the middle of October.

The breeding season must continue into early summer as many young fish, from 1 inch to $2 \frac{1}{2}$ inches long, were obtained in Great Egg Harbor bay, N. J. early in August.

The young of the silver perch are found every summer in Gravesend bay, and adults are to be seen occasionally. On September S, 1896, Mr De Nyse took an example $1 \frac{1}{4}$ inches long with a shrimp net in eelgrass back of the flats at extreme low tide. Pools containing 2 feet of water are common here, and many species of fish become imprisoned in them. In August Mr W. I. De Nyse has captured a half dozen adult $H$ i p p o c am pus in such localities. On October 5,1896 , and again in the fall of 1897, the silver perch was obtained in the bay.

The species seldom exceeds 10 inches in length, but is regarded as an excellent panfish, and is secrred in enormous number's.

\section{Genus scinenops Gill}

This genus is close to $\mathrm{Ophios}$ cio $\mathrm{n}$, from which it differs in the loss of its preopercular armature with age, the serrate edge of the bone becoming entire. The caudal fin is truncate or concave, the soft dorsal scaleless; the slits and pores of the upper jaw are well developed and the single species reaches a very large size. The group is not well separated from $\mathrm{O}$ p h i o sc i $\mathrm{n}$ on the one hand, or from Sciaena on the other, but its retention seems to be convenient.

\section{Sciaenops ocellatus (Linnaeus) \\ Red Drum; Channel Bass}

Perce ocellata Linnaeus, Syst. Nat. ed. XII, 483, 1766, South Carolina. Sciacna imberbis Mitchill, Trans. Lit. \& Phil. Soc. N. Y. I, 411, 1815, New York.

Cortina ocellata Cuvier \& Valenciennes, Hist. Nat. Poiss. V, 134, pl. 108, 1830; De KAY, N. Y. Fauna, Fishes, 75, pl. 21, fig. 61, 1842, New York; Holвrook, Ichth. S. C. ed. 1, 149, pl. 21, fig. 2, 1856.

Jolnius ocellatus Girard, U. S. Mex. Bd. Surv. 14, pl. 8, figs. 1-4, 1859. Sciacna ocellata Günther, Cat. Fish. Brit. Mus. II, 2S9, 1860, America; Jordan \& Gilbert, Bull. 16, U. S. Nat. Mus. 571, 1883. 
Sciaenops ocellatus BeAn, Bull. Am. Mus. Nat. Hist. IX, 367, 1897, New Jersey; H. M. Smitir, Bull. U. S. F. C. 1897, 101, 1898; Jordax \& Evermann, Bull. 4i, U. S. Nat. Mus. 1453, 1898, pl. CCXXII, fig. 567, 1900.

Body elongate, robust, its greatest depth one fourth of total length without caudal, least depth of caudal peduncle about one third of greatest depth; back somewhat arched; profile of head convex. Head rather long, three tenths of total length without caudal; eye small, about one seventh as long as the head; snout obtuse, two ninths as long as the head. Mouth large, nearly horizontal, the lower jaw rather shorter than the upper; the maxillary reaching to below the hind border of the orbit, its length more than two fifths length of head; bands of villiform teeth in both jaws, the outer teeth of the upper jaw much enlarged; lower jaw with subequal teeth. Preopercle strongly serrate on its bony margin in the young, entire in large individuals and with the edge of the bone covered by skin. Gill rakers $5+7$ on first arch, shorter than the diameter of the pupil. Spinous dorsal triangular, the first spine minute, the fourth, and longest, four ninths as long as the head, the last two thirds as long as the eye; base of soft dorsal twice as long as that of spinous dorsal, the longest ray one third as long as the head. Anal base short, one third as long as the head, two thirds as long as longest anal ray; the end of the anal base is under the 17th ray of soft dorsal, second anal spine about three eighths as long as the head; caudal nearly truncate, the middle rays one half as long as the head. Pectoral equals postorbital part of head, the fin extending to below the end of spinous dorsal. Ventral equal to pectoral, and not reaching nearly to vent. Scales of the breast embedded, cycloid; no scales on soft dorsal except in a very narrow strip at its base. D. X, I, 24 to 25 ; $\mathrm{A}$. II, 8; scales 4-45 to 55-10 to 12 . Color grayish silvery, iridescent; often washed with coppery red; each scale with a center of dark points forming obscure undulating stripes along the rows of scales; a jet black ocellated spot about as large as the eye at base of caudal above; sometimes two or more such spots are present; the body occasionally covered with ocelli.

The red drum is one of the largest of the food fishes of the southern waters, reaching the length of 5 feet and the weight 
of 75 pounds. It inhabits the Atlantic coast from New York to Texas, and has once been taken near Cape Cod.

A red drum, or spotted bass, weighing 14 pounds, was oibtained by Mr E. G. Blackford from New Jersey, and was purchased alive for the New York aquarium. At the time of writing (December 11, 1897) it is in the central pool, and is, apparently, in perfect health. It swims sometimes immediately under the sand shark. Its food consists of large pieces of herring, which it takes readily.

The only specimen known to have been taken at Cape Cod was caught in a trap in Buzzards bay at the breakwater in 1894 . The example is 34 inches long and weighs about 14 pounds. On account of the ocellated markings at the base of the caudal fin it has sometimes been called the branded drum.

\section{Genus LEIostonus Lacépède}

Body oblong, ovate, the back compressed; head obtuse; mouth small, horizontal, the upper jaw with a band of feeble teeth, the lower nearly or quite toothless; slits and pores of upper jaw well developed; lower pharyngeals separate, the teeth paved; preopercle with a membranaceous border; dorsal spines 10, slender, rather high, the last connected with the soft rays; soft dorsal and anal long; anal spines two, the second not large; caudal fin emarginate; gill membranes slightly connected; gill rakers slender. This genus is distinguished from $\mathrm{Sci}$ a e $\mathrm{n}$ a chiefly by the obsolescence of the teeth in the lower jaw, and by the more paved teeth of the pharyngeals. The soft rays of the dorsal fin and specially of the anal are more numerous than in related groups. One species.

\section{Leiostomus xanthurus Lacépède}

\section{Spot; Lafayette}

Leiostomus xanthurus LAcÉPĖde, Hist. Nat. Poiss. IV, 439, pl. 10, fig. 1, 1802, Carolina; Cuvier \& Valenciennes, Hist. Nat. Poiss. V, 142, 1830; DE KAY, N. Y. Fauna, Fishes, 70, 1842, extralimital; JordaN \& Gilbert, Bull. 16, U. S. Nat. Mus. 574, 1883; Bean, Bull. U. S. F. C. VII, 141, 1888; 9th Rep. Comm. Fish. N. Y. 260, 1890; Bull. Am. Mus. Nat. Hist. IX, 367, 1897; Eugene Smith, Proc. Linn. Soc. N. Y. 1897, 39, 1898; Mearns, Bull. Am. Mus. Nat. Hist. X, 321, 1898; H. M. Smith, Bull. U. S. F. C. 1897, 101, 1898; Jordan \& EvermanN, Bull. 4i, U. S. Nat. Mus. 1458, 1898, pl. CCXXIII, fig. 569, 1900. 
Bigail obliquus Mrschrl, Rep. Fish. N. Y. 16, 1814, New York; Trans. Lit. \& Phil. Soc. X. Y. I, 405, 1S15, New York.

Leiostomus obliquns DE KAY, N. Y. Fauna, Fishes, 69, pl. 60, fig. 195, 1842. Sciatna obliqua G̈̈хтиer, Cat. Fish. Brit. Mus. II, 2SS, 1860.

Sciaena xanthurus Günther, op. cit. 2S8, 1860.

Body short, deep, compressed, its greatest depth one third, or more than one third, of the total length without the caudal; least depth of caudal peduncle three serenths length of head; back in front of dorsal compressed to a sharp edge; profile steep, convex, depressed orer the eyes; dorsal outline convex, highest at dorsal origin. Head short, its length contained three and one third to three and two thirds times in the total without caudal; snout short and rery blunt, about two sevenths as long as the head and slightly longer than the eye. Mouth small, inferior, horizontal; maxillary rather more than one third length of head, extending to below middle of pupil; lower jaw toothless in the adult, upper jaw with a series of narrow minute teeth; gill rakers short, slender, $8+22$ on the first arch; lower pharyngeals small, with three series of molars posteriorly and many villiform teeth anteriorly; preopercle entire; preorbital about equal to eye in width. Spinous dorsal triangular, but rounded at tip, the first spine rery slender and very closely attached to the second, the third and fourth longest, three fifths as long as the head, the last two spines very short, only about as long as the pupil. Soft dorsal long and low, the base twice as long as that of spinous dorsal, the longest ray three eighths as long as the head. Caudal forked, the middle rays one half as long as the head. Anal elevated in front, low behind, the longest ray more than one half as long as the head, the last shorter than the ere; the second anal spine as long as the ere; the first spine very small. Pectoral large, extending to below the' sixth ray of second dorsal, nearly as long as the head. Tentral as long as the head without snout, not reaching nearly to rent. Seales small, ctenoid, extending on caudal and base of pectorals, but not on other fins; soft dorsal, however, has a sheath at base formed by a single series of scales; scales below lateral line in oblique series. Lateral line little curved anteriorly. 
D. X, I, 30 to 32 ; A. II, 12 ; P. I, 17 ; scales $9-60$ to $70-12$ to 14 .

Color bluish above, silvery below; about 13 to 15 narrow dark lines extending from the dorsal fins downward and forward to below the lateral line; a roundish black humeral spot about two thirds as long as the eye; fins plain olivaceous.

This little fish was formerly known on the New York coast as lafayette. Mitchill calls it the little porgee. According to De Kay its appearance on the New York coast in the summer of 1824 happened to coincide with the arrival of General Lafayette and his name was bestowed upon the species. The name spot is derived from the presence of a dark blotch about as big as the eye near the root of the pectoral fin. Other names for the species are goody, oldwife, roach and chub.

The spot is found from Cape Cod to Florida and is sometimes abundant as far north as New York. In Great South bay several specimens were taken early in October in Great river. A single example was seen among some fishes taken in a poundnet in Islip, Oct. 1, 1890. In 1898 the species was not obtained by the writer, and in 1901 only a few specimens, mostly adults, were secured at Quantic bay, Duncan's creek, and Widow's creek.

Rather common in Gravesend bay from July to as late as: December, and is well adapted to captive life. It is most abundant usually in September.

Dr Mearns states that the fish, locally known as the sand porgee, is of frequent occurrence in summer in the Hudson river and its estuaries. H. M. Smith records it as common in the fall in the vicinity of Woods Hole Mass. leaving in October or November, when the water temperature reaches $45^{\circ} \mathrm{F}$. All the specimens observed there were about 6 inches long.

It is a small fish, seldom exceeding 10 inches in length, but is one of the farorites among the panfishes. The spot feeds on the bottom on small invertebrates, and can be taken readily with hook and line. In Great South bay it is caught in seines and pound nets. It ascends creeks into brackish water and is a common associate of the white perch. In Great Egg Harbor 
bay it is extremely common in summer and is sometimes known as porgee.

\section{Genus mcropogon Cuvier \& Valenciennes}

Body moderately elongate, compressed, somewhat elevàted; preopercle strongly serrate; teeth in villiform bands, the outer row in the npper jaw enlarged; lower jaw with a row of minute barbels on each side; gill rakers short, thickish; spinous dorsal rather short of 10 or 11 stoutish spines; second anal spine moderate; caudal fin double truncate; lower pharyngeals narrow, distinct, with sharp, conical teeth; air bladder with long horns. A well marked genus, the species all American, allied to Ophioscion and sciaenops, but distinguished by the presence of barbels; species all closely related, similar in form, size, and color.

\section{Micropogon undulatus (Linnaeus)}

\section{Croaker}

Perca undulata Linnaeus, Syst. Nat. ed. XII, 483, 1766, South Carolina. Bodianus costatus Mrtchill, Trans. Lit. \& Phil. Soc. N. Y. I, 417, 1815, New York.

Micropogon lineatus Cuvier \& Valenciennes, Hist. Nat. Poiss. V, 215, pl. 119, 1830, New York.

Micropogon costatus DE KAY, N. Y. Fauna, Fishes, 83, pl. 72, fig. 230, 1842. Micropogon mululatus Cuvier \& VAlenciennes, Hist. Nat. Poiss. V, 219, 1830; De Kay, N. Y. Fauna, Fishes, 81, 1842, extralimital; Holbrook, Ichth. S. C. ed. 1, 145, pl. 21, fig. 1, 1856; Günther, Cat. Fish. Brit. Mus. II, 271, 1860, in part; JordaN \& GilberT, Bull. 16, U. S. Nat. Mus. 575, 1883; BeAn, Bull. Am. Mus. Nat. Hist. IX, 368, 1897; H. M. SMiti, Bull. U. S. F. C. 1897, 101, 1898; Jordan \& Evermann, Bull. 47. U. S. Nat. Mus. 1461, 1898, pl. CCXXIV, fig. $570,1900$.

Body rather elongate, little compressed, its greatest hight equal to length of head, and two sevenths of total length without caudal; caudal peduncle short, its least depth equal to snout, and about one third length of head. Head long, two serenths of total length without caudal, the snout prominent, obtuse, nearly twice as long as the eye, which is one fifth as long as the head. Nouth rather Iarge, nearly horizontal, the maxillary reaching to below front of eye. Preopercle strongly serrate, the spines near angle diverging. Dorsal fins nearly separate, the spinous dorsal triangular, the first and last spines 
shorter than eye, the third and fourth longest, equal to snout and eye combined, the base of the fin as long as the ventral. Soft dorsal long and low, one fourtl longer than head, the longest ray one third as long as head. Caudal slightly produced in the middle, the middle rays one half as loug as head. Anal base three eighths as long as head; the first spine minute, second spine one fourth as long as head, first ray about one half length of head, last ray two nintlis as long as head. PectoraI long, reaching beyond origin of soft dorsal. Ventral one sixth. of total length without caudal, not reaching nearly to vent. Interorbital width somewhat exceeds diameter of eye.

D. X, I, 27 to 30 ; A. II, 8; V. I, 5; P. I, 16; scales 9-60-12; pyloric caeca eight; gill rakers $\mathbf{7}+\mathbf{1 6}$.

Color grayish silvery, with bright reflections; sides and back with narrow, irregular, undulating lines of dots; dorsal tins with three lines of dots along base.

The croaker inhabits the east coast of the United States, ranging from Cape Cod to Texas; it is not very common north of the Chesapeake. It grows to the length of 15 inches and is an important food fish. The fish was described by Mitchill but was unknown to De Kay from personal observation. Though known in Gravesend bay, the species is a rery uncommon one there. The only specimen recorded at Woods Hole Mass. is 15 inches long; it was taken in a trap at the breakwater in Buzzards bay on Sep. 9, 1893.

\section{Genus mentrorrmus Gill}

Body comparatively elongate, little compressed; head long, subconic, the bluntish snout considerably projecting beyond the mouth; mouth small, horizontal, both jaws with bands of villiform teeth, the outer teeth in the upper jaw more or less enlarged; chin with a single stoutish barbel; preopercle with its membranaceous edge serrulate; gill rakers short and tubercular or obsolete; dorsal spines high, slender, 10 or 11 in number (13) in Cirrimens); second dorsal long and low; caudal fim with the lower angle rounded, the upper sharp; anal fin with a single weak spine; no air bladder. Lower pharyngeals separate, 
the teeth varying from sharp to very obtuse. This genus is one of the most strongly marked in the family. It has been confounded by all European writers with $\mathrm{U} m$ b r in a, with which it has not very much in common except the presence of the barbel at the chin. All the species are American, and all bottom fishes. The low, elongate body, the large pectorals, and the obsolete air bladder are all characters related to this peculiarity of habit.

\section{Subgenus мexтcmRnus Gill \\ 285 Menticirrhus saxatilis (Bloch \& Schneider) \\ Kingfish; Whiting; Sea llink}

Johnins saxatilis Bloch \& SchneIder, Syst. Ichth. 75, 1801, New York.

Sciena neblosa Mitchild, Trans. Lit. \& Phil. Soc. ‥ Y. I, 408, pl. 3, fig. 5, 1815 .

Umbrina alburnus DE KAY, N. Y. Fauua, Fishes, 7S, pl. 7, fig. 20, 1812.

Umbrina nebulosa GüNther, Cat. Fish. Brit. Mus. II, 275, 1860; Storer, Hist. Fish. Mass. 46, pl. IX, fig. 4, 1867.

Menticirrhus nebulosus Goode \& BEAx, Bull. Essex Inst. IX, 17, 1879; Jordan \& Gilbert, Bull. 16, U. S. Nat. Mus. 57t, 1883.

Menticirrhlls saxatilis BEAN, Bull. U. S. F. C. VII, 141, pls. II, III, figs. 7 and S, 18s8; Jordan \& Eigenmann, Rep. U. S. F. C. for 1886, 43I, 1S59; Bean, 19th Rep. Comm. Fish. N. Y. 259, pl. XII, fig. 16, 1\$90; Bull. Am. Mus. Nat. Hist. IX, 368, 1897; H. M. Smiti, Bull. U. S. F. C. 1S97, 101, 1S95; Jordan \& Evermann, Bull. 47, U. S. Nat. Mus. 1475, 1S98; BeAN, 52d Ann. Rep. N. Y. State Mus, 106, 1900.

Body robust, elongate, its greatest depth about two ninths of total length without candal; the least depth of caudal peduncle one third length of head. Head one fourth to two sevenths of total length without caudal; snout one fourth as long as the head; eye small, two thirds as long as snout. Mouth large, the maxillary reaching to below middle of eye. Outer teeth of upper jaw not much enlarged. Spinous dorsal elerated, the third spine longest, two thirds as long as the head, reaching slightly past origin of soft dorsal; first spine minute, last two spines very short. Base of soft dorsal one third of total length without caudal; the longest ray less than one third length of head. Caudal concare above, convex below, the middle rays about one half as long as the head. Anal base under the middle portion of the soft dorsal, its length about equal to least depth of caudal peduncle, the spine one third as long as the pectoral, the longest 
ray eryal to snout and eye combined. Pectoral large, nearly as long as the head, reaching, past origin of soft dorsal. Ventral one half as long as the head. Scales all ctenoid. D. X, I, 26 or 27 ; A. I, S; scales 7-53-14.

Color dusky gray above, sometimes blackish, the back and sirles with distinct dark oblique cross bands running downward and forward, the anterior one at the nape extending downward, meeting the second and thus forming a $\mathrm{V}$-shaped blotch on each side; a dark lateral streak bounding the pale color of the belly, most distinct posteriorly, and extending on lower lobe of caudal; inside of gill cavity scarcely dusky; pectorals dark.

The lingfish, according to De Kay, was so named by the early English colonists because of its excellent flaror. The name hake is giren to it in New Jersey and Delaware; in the Chesapeake it is sometimes called black mullet; in North Carolina, the sea mink; in the south it is the whiting or Bermuda whiting; on the Connecticut coast it is known as the tomcod.

The kingfish occurs northward to Cape Ann and south to the Gulf of Mexico. Large individuals are not common as far north as Cape Cod, but the young may be seen in moderate numbers in the summer months. They occur in abundance throughout Great South bay and near the inlet their number is increased. We have collected them at the mouth of Swan creek, in Blue Point cove, at the Blue Point Lifesaving station, Oak Island and Fire Island. An individual was obtained October $\tau$, in the bay, and others were found during September. Adult kingfish used to be common in Great South bay, but in $18 \$ 4$ they were rare, according to $\mathrm{Mr}$ Erastus Gordon, of Patchogue. In 1898 only one adult was taken by the writer and that was found in Clam Pond cove, August 26. Young were seined at Fire 1sland inlet, Nichols's Point, Howell's Point, Blue Point cove, and in Peconic bay. In 1901, large kingfish were not uncommon in Great South bay, but the joung were unusually rare, only two specimens measuring from $3 \frac{3}{4}$ to 4 inches having been obtained; these were seined at Duncan's creek, September 14.

The kingfish was formerly abundant in Gravesend bay, but it seldom occurs there now. 
The species evidently breeds at Woods Hole Mass. Dr Smith says that adults full of spawn are common there in June and uncommon after .July 15. The young about an inch long appear in the middle of July, and the young are numerous on sandy beaches during the summer and till early October, when they leave, having attained a length of 4 or 5 inches. Some of the young are almost entirely black, while others of the same size taken at the same time show the color markings of the adults. The maximum wright tlere is about 2 pounds.

The species is a favorite in New York waters and well merits its reputation as a choice food fish. It takes the baited hook very readily. Hard clam, cut small, shedder crab, black mussels and various kinds of fish are good baits. It goes in sclools and associates with the weakfish.

The name lingfish is said to have been given it in honor of the king by colonial New Yorkers, who esteemed the fish highly.

\section{Genus pogonas Lacépède}

Body short and deep, the dorsal outline much elevated, the ventral nearly straight. Mouth moderate, the upper jaw longest; teeth small, in villiform bands, the outer not enlarged; lower pharyngeal bones large, fully united, armed with strong paved teeth; lower jaw with numerous barbels, each about one half as long as the eye; preoperculum entire, with a membranaceous edge. Dorsal fins slightly connected, the spines high and strong; caudal fin subtruncate; first anal spine short, the second exceedingly large, nearly as long as the soft rays; pectorals and ventrals long; gill rakers short and bluntish. Psendobranchiae large. Marine species, reaching a rery large size, among the largest of the sciaenidae, two species known.

\section{Pogonias cromis (Linnaeus)}

\section{Drum}

Labrus cromis Linnaeus, Syst. Nat. ed. XII, 479, 1766, Carolina.

Pogonias fasciatus LACÉpÉde, Hist. Nat. Poiss. III, 137, 1802; Cuvier \& Valenciennes, Hist. Nat. Poiss. Y, 210. pl. 118. 1830; De KAY, N. Y. Fauna, Fishes, 81, pl. 14, fig. 40, 1St2; Guvtiter, Cat. Fish. Brit. Mus. II. 270,1860 .

Mlugil grunniens Mitchild, Rep. Fish. N. Y. 16, 1S14, New York.

מrugil gigas MitcmlL, Rep. Fish. N. Y. 16, 1814, New York. 
Labrus grunniens Mirchild, Trans. Lit. \& Phil. Soc. N. Y. I, 405, 1815. Sciena fusca Mitchild, Trans. Lit. \& Phil. Soc. N. Y. I, 409, 1815, NewYork.

Sciena gigas MitcmlL, Trans. Lit. \& Plil. Soc. N. Y. I, 413, 1815, New York.

Pogonias chromis Cuvier \& Valenciennes, Hist. Nat. Poiss. V, 206, 1830; De KaY, N. Y. Fauna, Fishes, 80, 1812; HoLbrooK, Ichth. S. C. ed. 1, 112, pl. 16, fig. 2, 1856; Günther, Cat. Fish. Brit. Mus. II, 270, 1860; Jordan \& Gilbert, Bull. 16, U. S. Nat. Mus. 568, 1883; Bea., 19th Rep. Comm. Fish. N. I. 261, pl. NiII, fig. 17, 1890.

Pogonias cromis BeAv, Bull. Am. Mus. Nat. Hist. IX, 368, 1897, Gravesend. Bay; H. M. Smith, Bull. U. S. F. C. 1897, 101, 1898; Jordar \& EverMANN, Bull. 47, U. S. Nat. Mus. 1482, 1898, pl. CCXXV, fig. 573, 1900.

Body oblong, compressed, heavy forwards, its greatest depth two fifths to one third of total length without caudal; least hight of caudal peduncle one third length of head. Head large, its length about two serenths of total without caudal; snout short, strongly declivous, a very shallow depression over the eyes, nape much arched. Lower jaw slightly shorter in front than upper; maxillary reaching to below middle of eye. Teeth. in broad bands, the outer series in maxillary scarcely enlarged; lower pharyngeals large, completely united, covered with many blunt molars and a small patch of conical teeth at the outer posterior corner. Gill rakers $4+12$ on first arch, very short and slender. Spinous dorsal triangular, the fourth and fifts: longest, two fifths as long as the head, the spines rapidly diminishing in size to the front and rear, the first one being minute; the base of spinous dorsal as long as the head without the snout. Soft dorsal lower than spinous, the longest rays one. third as long as the head. Anal base short, under second half of soft dorsal, the first spine minute, the second about one third as long as the head, the longest ray twice as long as the last ray and one half as long as the head. Caudal truncate, the middle rays about one half as long as the head. Pectoral long, reaching to below the fourth ray of soft dorsal, as long as the head. Teutral equal to postorbital part of head, reaching to below the origin of soft dorsal. Scales on breast small, others large. D. X, I, 21 to $22 ;$ A. II, 5 to 6 ; P. I, 17; V. I, 5. Scales $7-47$ to 52-11.

Color grayish silvery, with five broad dark bars three of which extend upon the dorsal fins, these bars disappearing with age; 
usually no oblique dark streaks along rows of scales above; fins dusky.

Dr Mitchill describes the drum under the names, black drum and red drum. The black drum which he described weighed 34 pounds. He had a specimen of 80 pounds, and states that he was. credibly informed of one that weighed 101 pounds. The species, according to $\mathrm{Dr}^{2}$ Mitchill, was taken abundantly during the summer with line and net. 'The name drum, he says, is derived from the drumming noise made by the fish immediately after being taken out of water. "He swims in numerous shoals in the shallow bays on the south side of Long Island, where fishermen during the warm seașon can find them almost like a flock of sheep; is a dull sort of fish." The red drum he considered merely a variety of the black drum. Dr De Kay says of the species, which he calls the big drum: "They are gregarious, and frequently taken in great numbers by the seine during the summer along the bays and inlets of Long Island." De Kay adopted a different specific name for the young of this species, and called it the banded drum. Other names for this stage given by De Kay are: grunter, grunts, young drum and young sheepshead. He saw the young in September, and states that it is found in New York waters also in October and November. The adults, according to. De Kay, are a coarse food, but the young are considered a great delicacy.

The drum is occasionally taken on our coast as far north as Cape Cod; southward it extends to the Gulf of Mexico.

The drum is an occasional summer risitor in Gravesend bay. In the fall of 1896,14 young individuals, $S$ inches long, were brought from there alive to the aquarim, and lived till February 10,1897 , when the low temperature of the water $\left(38^{\circ}\right)$ killed them. In the fall of 1897 none were seen in the bay.

In the vicinity of Woods Hole Mass. the drum is rery rare. Dr Smith records the first one as luving been taken May 7 , 1874, and it has been observed only three or four times since. The recent specimens have been caught in traps at Quisset Harbor, in the latter part of September or early in October; 
these specimens weighing each $4 \frac{1}{2}$ or 5 pounds. The largest drum recorded was taken at St Augustine Fla. and weighed 146 pounds. The large fish are not much valued for food, but small ones are said to be excellent.

\section{Genus aplodinotus Rafinesque}

Body oblong, the snout blunt, the back elevated and compressed; mouth rather small, low, horizontal, the lower jaw included; teeth in villiform bands, the outer above scarcely enlarged; no barbels; pseudobranchiae rather small; gill rakers short and blunt; lower pharyngeals very large, fully united, with coarse, blunt, paved teeth, as in Pogonias; preopercle slightly serrate; dorsal spines strong and high, with a close fitting scaly sheath at base, the two dorsals somewhat connected; second anal spine very strong; caudal double truncate; air bladder very large, simple, with no appendages; pylorio caeca seven; vertebrae $\mathbf{1 0}+\mathbf{1 4}=\mathbf{2 4}$. Fresh waters of the United States; large, coarse fishes, feeding chiefly on crustacea and mollusks. The geuus is apparently allied to Pogonias, and both may be descended from allies of $\mathrm{Ron} \mathrm{c}$ a $\mathrm{d}$ or $\mathrm{r}$, which is intermediate between them and $\mathrm{s}$ c i a e $\mathrm{n}$.

\section{Aplodinotus grunniens Rafinesque}

Fresh-water Drum; White Perch

Aplodinotus grumiens Rafinesque, Jour. de Phys. Paris, 88, 1819, Ohio Rivel; Bean, Fishes Pemma. 135, pl. 35, fig. 73, 1893; Jordar \& EverMANN, Bull. 47, U. S. Nat. Mus. 1484, 1898, pl. CCXXVI, fig. 574, 1900. Scinena oscula Le Sueur, Jour. Ac. Nat. Sci. Phila. 252, pl. 13, 1822, Lake Ontario.

Amblodon neglectus Girard, U. S. Mex. Bd. Surv. Fish. 12, pl. 5, figs. 6-10, 1859.

A mblodon grunniens Girard, U. S. Pac. R. R. Surv. Fish. 96, pl. 23, 1858. Haploidonotus grumiens GILL, Proc. Ac. Nat. Sci. Phila. 104, 1861; Jordan \& Gilbert, Bull. 16, U. S. Nat. Mus. 567, 1883.

Corvina oscula DE KAY, N. Y. Fauna, Fishes, 73, pl. 21, fig. 63, 1812, Lakes Erie \& Ontario; Güntmer, Cat. Fish. Brit. Mus. II, 297, 1860.

The shape of the fresh-water drum is similar to that of the salt-water species, the body being moderately elongate, its greatest hight one third of its length without the caudal; the :sides are moderately compressed and the back very much so. 
The least depth of the tail is less than one third of the depth of the body. The head is rather short, its length contained three and two thirds times in the total without caudal. The eye is about four fifths as long as the snout and one sixth length of head. Snout obtuse. The maxilla reaches to below the middle of the eye; the lower jaw is shorter than the upper. The pectoral is nearly as long as the head and reaches to below the beginning of the soft dorsal. The ventral is about two thirds length of head. The third dorsal spine is the longest, nearly one half as long as the head. The second anal spine is much the longer and stouter, its length two fifths that of head. The rays of the soft dorsal are longest near the end of the fin. The scales are very irregularly placed, about 55 in the lateral line.

D. IX, I, 30-31; A. II, 7 .

The color is grayish, darker on the back; lower parts silvery. Young specimens have dark spots along the rows of scales, forming oblique lines.

The fresh-water drum has received a great number of common names. In the Ohio valley and South it is known as the white perch; in the Great Lake region it is called sheepshead or freshwater dium on account of its resemblance to the salt-water drum. At Buffalo and Barcelona, New York, it is known as sheepshead. The name crocus, used on lakes of northern Indiana is a corruption of croaker, a name of a marine fish of the same family. In the southern states the name drum is generally applied to the species, and in addition the terms thunder pumper, gaspergou and jewel head are used. Gaspergou is a term used in Arkansas, Louisiana and Texas. The names drum, croaker and thunder pumper have reference to certain sounds produced by the fish either by means of its air bladder or by grinding together the large molarlike teeth in the pharynx. The name jewel head probably refers to the otoliths or earbones, frequently called lucky stones, which are found in the skull of this species. In Texas, adjacent to Mexican territory, occurs the name gaspagie, a variation of the name gaspergou.

The fresh-water drum is widely distributed; it occurs in Lake 
Champlain and the entire Great lakes region, the Ohio and Mississippi valleys southward to Texas. The U.S. Fish Commission obtained a specimen at Point Breeze N. Y. on Lake Ontario. De Kay reported it as very common in Lake Erie and called sheepshead at Buffalo. At the time of his writing the fish was scarcely erer eaten. It is found principally in large streams and lakes and rarely enters creeks and small rivers. In western Texas the species is rare. In the wilds of Texas, New Mexico and northern Mexico Mr Turpe has found this fish in clear limestone streams emptying into the Rio Grande.

This species is usually found on the bottom, where it feeds chiefly on crustaceans and mollusks and sometimes small fishes. It is specially fond of crawfish and small shells such as Cyclas and Paludina. Mr Turpe mentions water plants as forming part of its food and states that it will take a hook baited with worms or small minnows.

The fresh-water drum grows to a length of 4 feet and a weight of 60 pounds, but the average market specimens rarely exceed 2 feet in length and in many parts of the West much smaller ones are preferred. Nothing is recorded about the breeding habits of this species, and as to its edible qualities there is the greatest difference of opinion. Some writer's claim that its flesh is tough and coarse with a disagreeable odor, specially in the Great lakes. Indiriduals from the Ohio river and from more southern streams are fairly good food fish, while in Texas Mr Turpe considers it one of the most excellent of the fresh-water fishes, comparing favorably with black bass. Mr Robert Ridgway of the National Museum at Washington, pronounces the species from the Wabash river in Indiana, a fine table fish though, he says, other people there consider it inferior. Richardson described what is supposed to be a deformed specimen of this dium under the name of malashegany, which he had from Lake Huron. He described it as a firm, white, well-tasting fish, but never fat and requiring much boiling. 


\section{Suborder PHARYNGOGNA'THI}

\section{Labroid Fishes}

Family LABRIDAE

Wrasse Fishes

\section{Genus Taurogolares Günther}

Body oblong, not elevated, comparatively slender and compressed; head moderate, more or less pointed, but the jaws not notably produced; teeth in the jaws in several series, the outermost very strong; the teeth unequal, conical and pointed; no posterior canines. Cheeks with small scales; opercles with large ones; interopercles naked; preopercle with the vertical limb finely serrated. Branchiostegals five. Gill membranes considerably united, free from the isthmus; gill rakers short. Scales moderate, 35 to 50 in the lateral line; lateral line continuous, abruptly bent opposite posterior part of second dorsal; dorsal long and low, the spinous portion much longer than the soft, of 18 or 19 low, subequal, rather strong spines; soft dorsal slightly elevated; anal fin similar to soft dorsal, with three strong graduated spines; caudal truncate; pectorals short, the ventrals inserted behind their axils. Species two, both Amerjcan. This genus is very close to the European genus $\mathrm{C}$ te no -

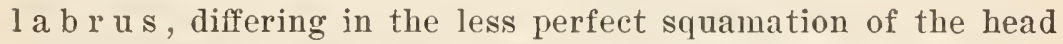
and in the greater number of dorsal spines and vertebrae.

\section{Tautogolabrus adspersus (TIalbaum)}

$$
\text { Bergall; Cunner; Chogset; Nipper }
$$

Labris adspersus WALBaum, Art. Gen. Pisc. 254, 1792.

Tautoga Caerulea Mrtcrill, Rep. Fish. N. Y. 24, 1814, New York.

Labrus chogset Mitchill, Trans. Lit. \& Phil. Soc. N. Y. I, 402, pl. 3, fig. 2, 1815, New York.

Labrus chogset fulva MitchiLl, l. c. 403, 1815, New York.

Ctenolabris uninotatus Cuvier \& Valexciennes, Hist. Nat. Poiss. XIII, 239, 1839, New York, young; DE KAY, N. Y. Fauna, Fishes, 174, pl. 29, fig. 90, 1842; GüNther, Cat. Fish. Brit. Mus. IV, 90, 1862.

Ctenolabrus burgall GüNTHFr, 1. c. 90, 1862, Canada.

Ctenolabrns chogset Cuvier \& Valenciennes, Hist. Nat. Poiss. XIrI, 237, 1839.

Ctenolabrus ceruleus DE KAT, N. X. Fauna, Fishes, 172, pl. 29, fig. 93, 1812. Ctenolabrus adspersus Jordax \& GILBERT, Bull. 16, U. S. Nat. MIus. 599, 18s3; BeAr, 19th Rep. Comm. Fish. N. Y. 251, pl. IV, fig. 6, 1890. 
Tautogolabrus adspersus Goone \& BEAN, Bull. Essex Inst. XI, 14, 1879; Bean, Proc. U. S. Nat. Mus. 87, 1880; Bull. Am. Mus. Nat. Hist. IX, 368, 1897; H. M. SMith, Bull. U. S. F. C. 1897, 102, 1898; JoRdAN \& EvermanN, Bull. 47, U. S. Nat. Mus. 1577, 1898, pl. CCXXXVI, fig. 595, 1900; Bean, 52d Ann. Rep. N. Y. State Mus. 107, 1900; Sherwood \& Edwards, Bull. U. S. F. C. 1901, 30, 1901.

Body fusiform, stout, its greatest depth nearly one third of total length witlout caudal, the profile much less convex than in the tautog; least depth of caudal peduncle one half of greatest depth of body. Head one third of total length without caudal, the snout pointed, and forming one third of the length of head; eye placed high, its diameter one fifth length of head; preorbital bone not equal in width to the eye; jaws equal, with thick lips; mouth moderate, the maxillary nearly reaching to vertical from front of eye; five canines in front of upper jaw, about four in lower, the teeth on sides of jaw largest in front; bands of small concave teeth behind canines; gill rakers very short, about $6+11$ on first arch; scales rather small; top of head, preorbital, maxillary, mandible, interopercle, and posterior edge of preopercle and opercle naked; preopercle with about five rows of small scales; opercle with four or five rows of larger ones; fins naked. Base of spinous dorsal two and one half times as long as that of soft dorsal; the spines gradually increasing in length up to the seventh, from which they are about equal, the seventh about three eighths as long as the head, the first only one sixth as long as the head. Soft dorsal a little higher than spinous, the longest ray one half as long as the head. Caudal rounded, its middle rays about one half as long as the head. Anal under the second half of the dorsal, its base as long as the head without the snout; the spines stout and sharp, the first equal to the eye in length, the second and third nearly equal and a little more than one third length of head; the fourth and fifth soft rays equal, longest, one half as long as the head. Pectoral broad, short, one half as long as the head. Ventral slightly longer than pectoral, not reaching to vent.

D. XVIII, 9 or 10 ; A. III, 9 ; scales $6-47-13$; vertebrae $17+19$. 
Color bluish or brownish, usually with a brassy luster on sides; head and back sometimes spotted with brassy; young with darker blotches and markings, and often with a black blotch near the middle of the dorsal fin. Some indiriduals are yellowish and the young are often green.

The cunner is known also as chogset and bergall (this changed to bengal in Great Egg Harbor bas, N. J.). Mitchill gives the name of bluefish as in use in New York in 1815; percli, sea perch and blue perch are New England names given for this fish. Names used with reference to its bait-stealing propensities are: nipper and bait-stealer.

The cunner is common from Labrador to at least as far south as New Jersey.

The bergall is found in Gravesend bay throughout the year. In 1898, the writer found it in Peconic bay and the adjacent Scallop pond; south side of Great South bay opposite Patchogue; Fire Island inlet; Blue Point cove; and Duncan's creek. In 1899, young examples were taken at $\mathbb{T}^{\top}$ ater Island ocean beach, June 6 . In 1901, young of a yellow color and only $1 \frac{3}{3}$ inches long were seined in a creek near Fire Island inlet, August 15. Half grown and adults were caught at a wreck on Tobey's Flat, August 14, and at Smith's Point, August 2?.

At Woods Hole Mass. the cunner is very abundant and remains during the entire year. Thousands perish from cold every winter. The fish spawns in June. The egg is about $\frac{1}{26}$ inch in diameter, buoyant, and has been hatched in the tidal cod-jar in five days in water of a mean temperature of $56^{\circ} \mathrm{F}$. By August 1 the young an inch long are observed. Outside of Gayliead and Cuttyhunk the fish reaches a weight of $2 \frac{1}{2}$ pounds, but the usual weight is from $\frac{1}{4}$ to $\frac{1}{2}$ pound. In February 1901, thousands of cunners were killed by extreme cold at Woods Hole.

The cunner endures captivity rere well, individuals having been kept three years or longer. The species is usually associated with the tautog or blackfish; in many places it proves a great annoyance to fishermen. In some parts of New England the fish is highly esteemed, but farther south it is not in high 
repute, the hard scales and stiff, sharp spines making it inconrenient to prepare for cooking.

Dr Mitchill describes a yellow variety of the cunner, and De Kay has considered the young, which has a black spot on the anterior portion of the dorsal fin, as a distinct species, named by him the spotted bergall.

The young vary greatly in color. We have seen some dull brown, others that were yellowish, and still others of a bright green. Dusky bands are characteristic, also, of the young stages. Examples were taken at Blue Point cove and at Fire Island. The cunner is a permanent resident, and does not retreat into deep water except in very cold weather. Its spawning takes place in June and July. The species is fished for with the hook, and is taken in nets, which are baited and set among the rocks. The catch of the Irish cunner boats of Boston has been estimated at about 300,000 pounds annually.

\section{Genus TaUToga Mitchill}

Body long, not elevated nor greatly compressed. Head large. nearly as deep as long, with a conrex profile. Mouth rather small. Teeth rery strong, conical, in two series; the outer somewhat incisorlike; the two anterior teeth in each jaw strong; the posterior teeth small, without canines. Eye small, high up. Cheeks with small scales; interopercle naked; opercles naked, except above; scales on body rather small, in about 60 transverse series, those on rentral region reduced in size; lateral line continuous, abruptly decurved opposite the end of the soft dorsal. Dorsal fin long, low, continuous, the spinous part much the longer, with about 16 low, strong, subequal spines, each with a small cutaneous appendage at tip; soft dorsal higher than spinous; anal similar to soft dorsal, with three stout, graduated spines; pectorals broad and rather short; caudal short, truncate, with rounded angles; the soft parts of the vertical fins with the membranes somewhat scaly; rentrals conspicuously behind pectorals. Branchiostegals five. Gill rakers very short and feeble; gill membranes some what connected, free from the isthmus. Vertebrae $16+18=34$. This genus contains a single species, a large Labroid, abundant on the Atlantic coast of the United States. 
289 Tautoga onitis (Linnaens)

$$
\text { Blackifish; T'autog }
$$

Labrus onitis Lindaeus, Syst. Nat. ed. X, 286, 175S; ed. XII, 478, 1766.

Tautoga niger Jrtchll, Rep. Fish. N. I. 23, 1S14, New York.

Labrus tautoga Mrtchilx, Trans. Lit. \& Phil. Soc. N. Y. I, 399, 1S15, Long Island.

Tautoga americana DE KAY, N. Y. Fauna, Fishes, 175, pl. 14, fig. 39, 1842; Storer, Hist. Fish. Mass. 110, pl. XX, fig. 2, 1867.

Tautoga onitis GüNther, Cat. Fish. Brit. II IS. IT, 88, 1862; GoodE \& BeAN, Bull. Essex Inst. XI, 14, 1879; Jordax \& Gilbert, Bull. 16, U. S. Nat. Mus. 600, 1S83; BeAN, Bull. U. S. F. C. VII, 13т, pl. III, fig. 3, 1S83; 19th Rep. Comm. Fish. N. I. 252, pl. V, fig. 7, 1590; Bull. Am. Mus. Nat. Hist. IX, 368, 1897; H. M. SnIтн, Bull. U. S. F. C. 1897, 102, 1898; Jordan \& Everdann, Bull. 47, U. S. Nat. Mus, 1578, 1898, pl. CCXXXVII, fig. 596, 1900; BEAx, 52d Ann. Rep. N. Y. State Mus. 10 1900; Sherwood \& Edwards, Bull. U. S.. F. C. 1901, 30, 1901.

Body deep, moderately compressed, the outline of head and back convex, the greatest depth three eighths to one third of total length without caudal, the least depth of caudal peduncle equal to postorbital part of head. Head short, blunt, its length contained three and one forrth to three and one half times in total without caudal; profile of snout very steep; preorbital very wide, wider than the eye; month small, with rery thick lips, the maxillary reaching the rertical from anterior or posterior nostril; eye one fifth as long as the head; snont one third as long as the head; jaws nearly equal in front, with two or three large canines and smaller ones on the side, gradually diminishing in size backwards. A patch of small scales behind ese extending downward to middle of cheek where there are five or six series; a small patch of scales at upper edge of opercle: head elsewhere naked. About $3+6$ rery short and blunt gill rakers on first arch. Spinous dorsal composed of stout, sharp spines, the connecting membrane between them projecting beyond them; the first spine as long as the eye; the spines gradually increasing in length to the 11th which is one third as long as the head and twice as long as the first; the remaining spines are about equal to the 11th: the base of soft lorsal is one half as long as the head; the longest ray is nearly twice as long as the last ray and more than one half as long as the head. Caudal convex, the middle rays about one half as long as the 
head. Anal base coterminous with the dorsal base, two thirds: as long as the head, the spines rather long, stout, and graduated, the first a little longer than the eye, the third twice as long as the eye; the third and fourth rays longest, as long as postorbital part of head. Pectoral large, as long as the head without the snout, reaching to below the 10th spine of the dorsal. Ventral one half as long as the head, reaching to below the 12 th spine of the dorsal. D. XVI to XVII, 10 ; A. III, S; Y. I, 5; P. I, 15. Scales $14-60$ to $65-29$.

Color blackish, greenish, frequently pale bluish or bluish black with metallic reflections. Often with irregular bands of a deeper hue. Lips, lower jaws and abdomen lighter, sometimes pale, sprinkled with black points, and sometimes of the same color as the rest of the body. Eye greenish.

This is better knowu in New York as the blackfish; farther south it is styled chub or salt-water chub, Moll, Will George and oyster fish. Mitchill gives the name tautog as of Mohegan origin. He publishes for the species the names toad, blackfish and runner. The Mohegan name tautog, according to De Kay, is said to mean black. The fish is found from Nova Scotia to Virginia. It occurs in all parts of Great South bay visited by us. Some of the localities at which it was taken are the following: Blue Point cove and Lifesaving station, Great River beach and Fire Island. The name used at Patchogue is blackfish. We saw a few tautog among the fishes caught in a trap at Islip, October 1, 1890. In 1898 specimens were obtained in Peconic bay, at Blue Point cove, Islip, Nichols's Point and Fire Island inlet; young individuals were taken July 29, August 25, September 1 and 16. Following is a list of localities in which the tautog was sparingly taken in Great South bay in 1901:

Clam Pond cove......................July 19

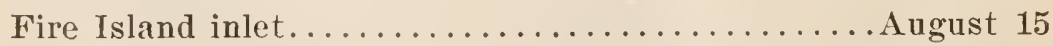

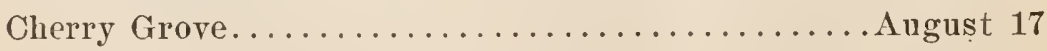

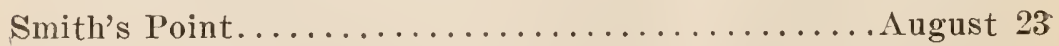

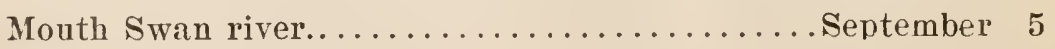

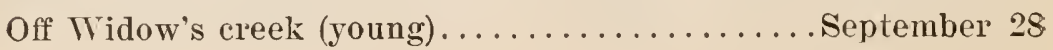

Off Swan river (young)............... October 7 and 11 
Dr Mitchill gives a most entertaining account of the habits and mode of capture of this well known species. At the time of his writing, in 1814, the price raried from eight to 12 cents a pound.

It has been known to reach a length of 3 feet and a weight of $21 \frac{1}{2}$ pounds. Individuals of 12 to 14 pounds have occasionally been taken off Cape Ann. The fishing season begins in April and may last till winter. Examples are sometimes speared in the winter months in New England rivers. The tautog is not inigratory, but hibernates in cold weather, going into the mud in November or December. It is sometimes destrored by freezing; such accidents have occurred in ponds on Martha's Vinerard and elsewhere.

The spawning season begins late in April. The eggs are reposited in depths of 6 to 8 feet or more among the rocks. In the fish cultural operations at Woods Hole Mass. it was found that the egg is buoyant and only- $\frac{1}{26}$ inch in diameter; in the automatic tidal box they hatched in about fire dass with the water temperature at $69^{\circ} \mathrm{F}$., and in two or three days with the temperature at $71^{\circ}$.

There is great diversity in the colors of the roung, just as in the case of the young cunners. Some are bright green, others brown or red and some are mottled with brown, red and green, intermingled with pale areas. The food of the tautog consists wo mollusks and crustaceans; crabs, and specially fiddlers, barmacles, clams and lobsters are among the farorite articles of food. The annelids, known as sandworms, are also very attractive to it.

The tautog is an excellent food fish and one of the commonest of our market species. It is a permanent resident in the bays and is hardy in captivity. Individuals have been kept longer than three years and some of them have grown remarkably. Their food includes chopped hard clam, live killifish, shrimps, and fiddler crabs, of which latter they are extremely fond. Spawning takes place regularly in the tanks in spring, but, as the eggs are very small and buoyant, they must invariably be lost at the orerflow. As the newly hatched embryos are only $\frac{1}{12}$ inch long they too would flow out unseen if any were left for development. 


\section{Group ZEOIDEA}

Family ZEIDAE

\section{John Dories}

\section{Genus zwopsis Gill}

Body ovate, much compressed, without scales, and without warts or humps in the adult. Head deeper than long, its anterior profile steep. Mouth lather large, upper jaw protractile; teeth small on jaws and vomer, none on the palatines. Various bones of the head and shoulder girdle armed with spines. Series of bony plates along the sides of the belly and the bases of both doisal and anal, each plate armed with a strong spine. Eye large, placed high. Gill rakers short. Dorsal spines very strong, usually 10 in number, some of them filamentous; anal spines three; ventral fins long, the rays I, six or I, seven. Caudal peduncle slender, the fin not forked. Three species. known, differing from the European genus $\mathrm{Z}$ e us mainly in. the presence of three anal spines instead of four, and in the greater development of the spinous armature. Pelagic.

\section{Zenopsis ocellatus (Storer)}

\section{John Dory}

Zeus ocellatus Storer, Proc. Bost. Soc. Nat. Hist. VI, 3S5, 185S. Frovillcetown Mass.; Putnam in Storer, Hist. Fish. Mass. 279, 1867.

Zenopsis ocellatıs GILt, Proc. Ac. Nat. Sci. Phila. VI, 126, 1862; Jordax \& Gilbert, Bull. 16, U. S. Nat. Mus. 456, 1S83; Goode \& BeAx, Oceauic Ichth. 224, with plate, 1896; Jordan \& Everuann, Bull. 47, U. S. Nat. Mus, 1660, 1898, pl. CCXLVI, fig. 618, 1900.

Body short, deep, compressed, its greatest depth one half of total length including caudal; the caudal peduncle short and rery slender, its least depth scarcely more than one half diameter of eye. Head subquadrangular, large, the mouth large and very oblique, the maxillary one sixth of total length without caudal, its width posteriorly nearly one half its length. A slight concavity over the ejes. Eye two ninths as long as the head and placed high. Snout two fifths as long as head. Top of head with roughish ridges, but without spines; a spine at the base of each dentary bone; a supplemental maxillary bone; teetle nearly obsolete. Gill rakers short. Skin naked except for the 
bony bucklers which are armed atch with a central spine hooked backward and marked with radiating ridges; seven bucklers along the base of the dorsal, the fifth and sixth largest, these located under the fifth to the 19th dorsal ray; two on the median line in front of the rentrals, the second larger, as long as the eye; about eight plates between rentrals and anal origin, and five along base of anal. Dorsal spines stout and long, the first four or five filamentous, the second longest, equal to total length without the head and the caudal fin; the base of the fin fire sixths as long as the head. Soft dorsal base a little longer, as long as the head; the rays short, the longest, near the end of the fin, equal to diameter of eye. Caudal fin short, rounded, the middle rays as long as the postorbital part of head. Pectoral short, about as long as snout. Ventrals long, nearle as long as the head, and almost reaching to the anal origin. Anal long, one half of total length withont caudal, the spinous and soft portions scarcely connected; the first spinc longest, one and one half times as long as the third, and one fifth as long as the head; the longest anal ray nearly one third as long as the head. D. X, 24; A. III, 24; V. I, 5; P. 12.

Color silvery, nearly plain; a black lateral ocellated spot in life, disappearing in spirits.

Of this pelagic species only one specimen is known; this was taken off Provincetown Mass. and presented to the museum of the Boston Society of Natural History by Capt. X. E. Atwood.

\section{Suborder SQUAMIPINAES}

Scaly Fins

Family eprimpinae

spadefishes

\section{Genus chatemon'terts Lacépède}

Body much elerated and compressed, its outline nearly orbicular, the anterior profile nearly rertical. Scales small, 55 to 70 in the course of the lateral line. Jaws about equal; no teeth on romer or palatines; teeth on jaws slender, somewhat morable; preopercle finely serrulate. Branchiostegals six. Dorsal fins two, somewhat connected. the first of usually nine spines, 
the third of which is elongate; anal spines three, small, the second the longest; ventral with a large accessory scale. Pyloric caeca four to six. American; distinguished from the Asiatic genus $\mathrm{E} p$ h i p p s by the very much smaller scales.

\section{Chaetodipterus faber (Broussonet)}

Spadefish; Triple-tail; Angclfish; Iroonfish

Chaetodon faber Broussonet, Ichth. Decas. 1, V, pl. 4, 17S2, Jamaica; Carolina.

Chaetodon oviformis MitchlLL, Trans. Lit. \& Phil. Soc. N. Y. I, 247, pl. V, fig. 4, 1S15, New York; Am. Month. Mag. II, 247, February, 181 .

Ephippus gigas Cuvier, Règne Anim. ed. 2, vol. 2, 191, 1829, America; DE KAY, N. Y. Fauna, Fishes, 99, pl. 23, fig. 71, 1S42, New York; Ноцвкоок, Ichth. S. C. ed. 1, 105, pl. 15, fig. 2, 1856; Güntrer, Cat. Fish. Brit. Mus. II, 61, 1860.

Ephippus faber DE KAY, N. Y. Fauna, Fishes, 97, pl. 23, fig. 68; Holbrook, Ichth. S. C. ed. 1, 108, pl. 15, fig. 1, 1856; GüN'mer, Cat. Fish. Brit. Mus. II, 61, 1860.

Chatodipterus faber Jordan \& Gilbert, Bull. 16, U. S. Nat. Mus. 613, 1883; BEAN, 19th Rep. Comm. Fish. N. Y. 253, pl. VI, fig. 8, 1890; H. M. Suith, Bull. U. S. F. C. 1897, 102, 189S; Jordan \& Evermann, Bull. 47, U. S. Nat. Mus. 1668, pl. CCXLVII, fig. 619, 1900.

Body oblong-ovate, its greatest depth equal to the distance from the eye to the end of the dorsal base or anal base; least depth of caudal peduncle one half length of head. Head short, two serenths of total length without caudal; snout two fifths as long as the head; preorbital deep, equal to diameter of eye, which is three tenths as long as the head; mouth moderate, nearly horizontal, the maxilla reaching to below front of eye; chin with a row of pores; dorsal and rentral outlines similar, greatly convex. First dorsal spine minute; second very short, one half as long as the eye; third spine longest, as long as the head without the snout; fourth spine one third as long as the head; the remaining spines rapidly diminishing in size to the last which is one third as long as the eye. The soft dorsal is separated from the spinous by a deep noteh; the anterior part of the fin is greatly elerated, the longest ray being three serenths of total length without caudal; the fin is falcate, the last rays being short. Caudal crescentic with the outer rays produced, and about as long as the head. Anal similar in shape 
to the soft dorsal; the first spine one half as long as the eye, the second as long as the eye, and the third three fourths as long as the second; the longest rays equal one half of greatest depth of body. Pectoral short, rounded, one half as long as the head. Tentral much longer, as long as the head, reaching besond the rent.

D. VIII, I, 20 to 22 ; A. III, 18; T. I, 5; P. I, 16; lateral line 60 to 65 ; pyloric caeca 4 to 6 ; vertebrae 9 or $10-14$.

Grayish; a dusky band across the eye to the throat; a second similar band, broader, beginning in front of the dorsal and extending across the base of the pectoral to the belly; a third band, narrower, extending to the middle of the sides from the base of the fourth and fifth dorsal spines: a fourth broader band from the last dorsal spines to anal spines, the remaining bands alternately short and long; all of these bands growing obscure and disappearing with age; ventrals black.

The moonfish is the sleepshead chaetodon of Mitchill, and the banded ephippus of De Kay. Dr Mitchill records it as taken at the east end of Long Island, July 27, 1815. De Kay, in his New Tork Fauna, has the following concerning the species: "About twenty years since, they were caught here in seines in great numbers and exposed in the markets for sale. Some of them were 18 inches long. Those described by Mitchill were captured in 1815 and 1817. The popular names of three-tailed sheepshead and three-tailed porgee were given them by the fishermen in allusion to their prolonged dorsal and anal fins. . Schoepff states that it is called angelfish in South Carolina."

The species is callor sparlefish in the states bordering the Gulf of Mexico.

The moonfish has occasionally been taken as far north as Cape Cod. Dr Smith records it as a rery rare straggler in Vineyard Sound, Mass. A specimen was obtained in 1889, and three have been observed since. All were taken in traps at Menemsha in August and September. The fish were uniform in size and about 16 to 18 inches long. The species reaches a length of 2 to 3 feet. Southward it is recorded from as far as Guatemala. 
It occurs in the West Indies. In Chesapeake bay it is moderately common.

As a food fish this species is highly prized by those who are familiar with its qualities.

\section{- Family chaetodontidae: Butterfly Fishes}

\section{Genus снағтопох (Artedi) Linuaeus}

Body short, deep, rery strongly compressed, specially above and behind; head small, compressed, almost everywhere scaly; mouth very small, terminal, the jaws provided with long, slender, flexible, bristlelike teeth; romer sometimes with teeth; preoperculum entire or nearly so, without spine. Dorsal fin single, continuous, not notched, the spinous part longer than the soft part, of about 13 spines, the spines not graduated, some of the middle ones being longer than the last; last rays of soft dorsal usually rapidly shortened, some of them occasionally filamentous (in East Indian species); candal peduncle short, the caudal fin fan-shaped; anal similar to soft dorsal, preceded by three or four strong spines. Body coverd with rather large ctenoid scales, somewhat irregular in their arrangement; the lateral line curved, high, parallel with the back. Gill openings rather narrow, the membranes narrowly joined to the isthmus; branchiostegals six. A rery large genus of singular and beautiful fishes abounding in the tropical seas, specially about rolcanic rocks and coral reefs; most of them have the body crossed by transverse black bars. They are all rery active, feeding on small animals.

\section{Subgenus CHAEToDontrops \\ 292 Chaetodon ocellatus Bloch}

\section{Parche}

Chaetodon occllatus BLoch, Ichth. III, 105, pl. 211, fig. 2, 17S7; Eigexustix \& Honning, Ann. N. Y. Ac. Sci. IV, 7, 1Ss7; BeAn, Bull. Am. IIus. Nat. Hist. IX. 368, 1897; H. M. Sмiтн, Bull. U. S. F. C. 1897, 102, 1895; Jordan \& Evermann, Bull. 47, U. S. Nat. Mus. 1674, 1898, pl. CCXLIX, fig. 621, 1900; H. M. Sмiтн, Bull. U. S. F. C. 1901, 33, 1901.

Chatodon bimaculatus Blocir. Ichth. pl. 219, fig. 1, 1790; Cuvier if Valenciennes, Hist. Nat. Poiss. VII, 67, 1831; Günther, Cat. Fish. Brit. Mus. II, 9, 1860; Jordan \& Gilbert, Bull. 16, U. S. Nat. Mus. 940 , 1883. 
Sarothrodus maculocinctus Gill, Proc. Ac. Nat. Sci. Phila. 99, 1861, Newport R. I.; young.

Chaetodon maculocinctus Jordax \& Gilbert, Bull. 16, U. S. Nat. Mus. 616, 1S83; BeAN, Bull. U. S. F. C. VII, 13S, pl. I, fig. 4, 1898.

Body suborate, strongly compressed; greatest depth three fifths to two thirds of total length without caudal; least depth of caudal peduncle about one third length of head. Head two fifths of total without caudal; the upper profile concave except for a slight protuberance over eyes; snout equals five sixths diameter of eye, which is one third as long as the head; the maxilla reaches to below the anterior nostril, its length equal to length of snout; lower jaw somewliat produced; suborbital bone one half as wide as the eye. First dorsal spine one fourth as long as the head; second spine about one half as long as head; third and fourth spines longest, as long as the head without the snout; last spine two fifths as long as head; longest soft ray one half as long as the head. Anal fin under the posterior half of the dorsal; the first spine as long as the snout; the second longest, nearly one half as long as the head; the third nearly as long as the second; the longest ray as long as the second spine; the base of the fin equals one third of total length without caudal. Caudal rounded, the middle rays one half as long as the head. Pectoral reaching to below the 10 th spine of the dorsal, as long as the head without the snout. Ventral reach. ing to the second anal spine, four fifths as long as the head.

D. XII or XIII, 18 to $20 ; A$. III, 16 to $18 ;$ V. I, 5. Scales $8-15$ to $50-20$.

Color golden gray, sometimes jellow or orange; a large, oblong, dark bloteh on base of soft dorsal extended downward by a black band crossing the body and continuing faintly upon the base of the anal; a dark band from the origin of the dorsal through the eye and extending downward across the cheek. The bands are nowhere more than one half as wide as the eye.

The parche belongs to the West Indian fauna; it is common at Harana, and the roung follow the Gulf Stream northward in summer to Nen Jersey, Long Island, Rhode Island, and Cape Cod. In the ricinity of Woods Hole Mass. according to Dr Smith, 
it must now be regarded as a common species, for, in 1900 , the number of specimens taken at Katama bay was 123 ; these were observed on 13 different occasions between August 15 and October 26; on September 8 the number taken was 26 and 21 were seined on October 3. Up to 1897 only a few specimens had been secured annually in October and Norember-not more than five in any one season.

A single individual, $1 \frac{1}{4}$ inches long, was taken in the seine at Beesley's Point N. J. September 2.

The general color of the sides was yellow, more persistent in alcohol on the ventral surface and caudal peduncle than elsewhere.

D. XIII, 20; A. III, 18; lateral line, 45; third and fourth dorsal spines equal, and as long as the head without the snout.

The parche is very rare in Gravesend bay. Two small individuals were taken by Mr De Nyse in October 1898. Mr De Nyse informs me that the roundish black spot in the soft dorsal remains fixed under all conditions, while the band extending from it to the anal fin sometimes disappears. The whole body of the fish at times appears to have an orange tinge, but at other times it is gray.

An individual about 2 inches long was obtained from a fish pound near Clam Pond cove, Oct. 17, 1898. This species is conspicuously beautiful on account of the orange color of its fins contrasting sharply with the dark bands on the head and body.

\section{Family teutimidae}

Surgeons

Genus TeuThIs Linnaeus

This genus includes those $\mathrm{T}$ e $\mathrm{uth} \mathrm{id}$ ida e which have the tail armed with a sharp, antrorse, lancetlike, movable spinc; strong, fixed, incisor teeth; ventral rays $I$, five, and usually nine spines in the dorsal fin. The numerous species are found in all tropical seas, herbivorous fishes living about coral reefs. The adult is protected by the murderous caudal spine, which grows larger with age. 


\title{
293 Teuthis hepatus Linnaeus
}

\author{
Surgeons; Doctor Fish; Tung
}

Teuthis hepatus Linxaeus, Syst. Nat. ed. XII, 507, 1766, Carolina; MEEK \& Hoffman, Proc. Ac. Nat. Sci. Phila. 229, 1884; Bean, Bull. Am. Mus. Nat. Hist. IX, 368, 1897; Jordan \& Evermann, Bull. 47, U. S. Nat. Mus. 1691, 1898.

Acanthurus phlebotomus Cutier \& Valenciennes, Hist. Nat. Poiss. X, 176, 1835, New York, etc.; DE KAy, N. Y. Fauna, Fishes, 139, pl. T3, fig. $234,1842$.

Acanthurus chirurgus Cuvier \& Valenciennes, Hist. Nat. Poiss. X, 168, 1835; Günther, Cat. Fish. Brit. Mus. 329, 1861; Jordan \& Grlbert, Bull. 16, U. S. Nat. Mus. 617, 1883.

Acanthurus nigricans JORDAN \& GILBERT, 1. c. 941, 1883.

Body ovate, its greatest depth one half of total length without caudal; anterior profile moderately convex, forming an angle of $45^{\circ}$ with axis of body. Caudal lunate, its inner rays about two thirds length of outer rays; caudal lobes subequal, the upper never filamentous. Head rather short, two serenths of total length without caudal. D. IX, 26; A. III, 24.

Color dark olive brown, more or less distinctly greenish; middle of sides paler; sides with about 12 distinct blackish vertical bars, rather narrower than the interspaces, most distinct orel front of anal; a brownish stripe along base of dorsal; spinous dorsal with alternate stripes running upward and backward, of dark blue and bronize olive, the two colors of about equal width; soft dorsal with a bluish streak on the anterior side of each ray, and a bronze stripe behind it; fins very dark, often almost black.

The surgeon is common in the West Indies and from Florida to Bahia and nortliward in summer to Cape Cod.

A young indiridual, about 3 inches long, was caught in Mr John B. De Nyse's pound, Gravesend bay, Oct. 22, 1897. The species had not been certainly known before to occur north of Charleston S. C. De Kay described and figured it as a New York species solely on the authority of Cuvier and Valenciennes. Dr Smith records the capture of a few specimens in the ricinity of Woods Hole Mass. during the summer of 1900. It was last observed on October 3 when one example was taken. 


\section{Group PLECTOGNATHI}

\section{Suborder SCLERODERMI}

Family BALISTIDAE

Triggerfishes

\section{Genus malstes (Artedi) Linnaeus}

Body compressed, covered with thick, rough scales or plates of moderate size, 50 to 75 in a lengthwise series; a naked groove before eje below nostrils; lateral line more or less developed, very slender, undulate, conspicuous only when the scales are dry, extending on the cheeks. Pelvic flap large, movable, supported by a series of slender, pungent spines. Caudal peduncle compressed, its scales unarmed, without spines or differentiated tubercles similar to those on rest of body. Gill opening with enlarged bony scutes behind it; cheeks entirely scaly, without naked patches or grooves. Both jaws with irregular, incisorlike teeth, usually four on each side in each jaw. First dorsal of three spines, the anterior of which is much the largest, the second acting as a trigger, locking the first when erected; the third nearly as large as second and remote from it; second dorsal and anal long, similar to each other, in the adult always falcate or filamentous in front; caudal fin rounded, with the outer rays much produced in the adult; branchiostegals six; vertebrae $7+10$. Species rather few, chiefly American; some of them straying to the Old World.

\section{Subgenus capriscus Rafinesque \\ 294 Balistes carolinensis Gmelin \\ Leather Jacket; Turbot; Triggerfish}

Balistes carolinensis Gmelin, Syst. Nat. I, 1468, 1788, Carolina; BeAN, Bull. Am. Mus. Nat. Hist. IX, 368, 1897; I. M. SмIтH, Bull. U. S. F. C. 1897, 104, 1898; Jordan \& EvermanN, Bull. 47, U. S. Nat. Mus. 1701, 1898, pl. CCL VIII, fig. 632, 1900.

Balistes capriscus Grelin, Syst. Nat. I, 1471, 1788, Indian \& American Oceans; GüNther, Cat. Fish. Brit. Mus. VIII, 217, 1870; Goode \& Bean, Bull. Essex Inst. XI, 3, 1879; Jordan \& Gilbert, Bull. 16, U. S. Nat. Mus. 855, 1883.

Balistes fuliginosus DE KAY, N. Y. Fauna. Fishes, 339, p1. 57, fig, 188, 1812, New York. 
Body oblong, compressed, its greatest depth one half of total length to end of middle caudal rays; least depth of caudal peduncle one third length of head. Head nearly one third of total leugth without caudal; eye small, placed high, one fourth as long as the snout, and one fifth as long as the head; mouth small, terminal, the maxillary as long as the eye. Dorsal origin slightly behind rertical of hind margin of orbit; base of spinous dorsal one fourth of total length without caudal; first spine longest, one half as long as the head; second spine slender, one third as long as the head; third spine stouter than second, one fifth as long as the head. An interspace between spinous and soft dorsal. Soft dorsal base slightly longer than the head; the third and fourth rays longest, as long as the snout; the last ray shorter than the ere. Middle caudal rays one half as long as the head; external rays five sixths as long as the head. Anal opposite and similar to soft dorsal, its base as long as the head, its longest ray one fifth of total length without"caudal. Pectoral short, one half as long as the head, reaching to below third spine of dorsal. V'entral flap large, supported by several slender pungent spines. D. III, 27; A. 25; scales 55 to 63 (58 in specimen examined), about 38 in a transverse series from vent upward and forward. Lateral line rery inconspicuous, extending from the eye backward to below the third dorsal spine, where it descends to a point nearly orer the sixth or seventh ray of the anal; here it turns to form a $V$-shaped figure ascending to the median line and along the middle of the caudal peduncle to the base of the caudal fin; a branch from behind eje extends obliquely downward and forward to the breast below pectorals; the lateral lines of the two sides are connected by a cross branch at the nape.

Color in life olive gray; a more or less distinct darker crossbar under front of second dorsal and one under last ras; some small violet spots on upper part of back; usually a ring of blue spots, alternating with olive green streaks, about eye; violaceous marks on sides of snout; first dorsal spotted and clouded with bluish; second dorsal pale sellowish with clear sky-blue 
spots separated by olive green reticulations, the spots arranged in rows; blue markings all fading in alcohol, learing the olivaceous streaks; base of dorsal with three or four dark diffuse shades in the young; base of pectoral bluish, with olive spots; anal colored like soft dorsal; pectoral greenish.

The triggerfish inhabits the tropical parts of the Atlantic occasionally following the Gulf stream northward as far as Cape Cod. In the Colonial Museum at Halifax is a specimen said to have been taken on the coast of Nova Scotia. At Troods Hole Mass. it is very rare and does not occur every year; the young have not been observed there.

The species is uncommon in Gravesend bay, Long Island, but is seen occasionally in summer in the bays opening into the Atlantic. De Kay described a specimen measuring $12 \frac{1}{2}$ inches. In the year 1820, a specimen was obtained for him from New York harbor.

\section{Subgenus BALISTES \\ 295 Balistes vetula Linnaeus \\ Blue-striped Triggerfish; Bessy Corka}

Batistes vetula Linnafus, Syst. Nat. ed. X, I, 329, 1758, Ascension Island; Günther, Cat. Fish. Brit. Mus. VIII, 215, 1870; Jordan \& Gilberm, Bull. 16, U. S. Nat. Mus. 855, 1883; H. M. SмIтH, Bull. U. S. F. C. 1897, 103, 1898; Jordan \& Evermann, Bull. 47, U. S. Nat. Mus. 1703, 1898.

Body shaped as in B. c a r o lin e $\mathrm{n}$ s is, its greatest depth five ninths of total length without caudal. Head one third of total length without caudal. Lateral line placer as in B. c a r o $\mathrm{l}$ in e n s is, but the median part, from base of first dorsal to front of caudal peduncle wanting in the adull, branch on cheek ceasing opposite gill opening; cross branch present; ventral flap well developed, with slender, sharp spines. Scales on head much smaller and more crowded than those on body. 'Third dol'sal spine rather shorter and weaker than second, remote from it. Caudal fin widely forked, the lobes filamentous and about equal. Dorsal in adult filamentons at tip. Anal little elevated. anteriorly. D. III, 29; A. 27; lateral line 63.

Two curved, bluish, dark-edged bands on the side of the head, the lower from the angle of the mouth towards the throat, the 
upper from above the snout to the root of the pectoral; a black light-edged line, similarly curved below the eye; several other similar lines radiating from the eye; caudal fin margined above and below with bluish, and with an intramarginal bluish kand; dorsal and anal fins with transverse bluish bands; young with some irregular oblique black lines following the rows of scales.

The blue-striped triggerfish is common in the West lndies and occurs occasionally northward on our coast as far as Cape Cod. According to Dr Smith it is found in Vineyard Sound every season, mostly in September, adult specimens being taken in some numbers in the traps at Menemsha. During summer and fall the young, $1 \frac{1}{2}$ or 2 inches long, are found at the surface in Vineyard sound in gulf weed and also around the shores.

Family MONACANTHIDAE:

\section{Filefishes}

\section{Genus movacanthus Cuvier}

Body short and deep, very strongly compressed, covered with minute, rough scales. Mouth very small; upper jaw with a double series of incisorlike teeth, usually 6 in the outer and 4 in the inner series; lower jaw with about 6 incisors in a single scries; teeth connivent, unequal; gill opening a small shit, shorter than the eye, nearly vertical, below the posterior part of the eye, and just in front of upper edge of pectoral. Dorsal spine large, armed with two series of retrorse barbs, and no conspicuous filaments; second dorsal and anal fins similar to each other, of about 2.5 to 35 rays each; caudal fin moderate, rounded: pelvic bone with a blunt, movable spine, the bone connected by a morable flap of varying size; side of tail often with a patch of spines, specially in the males. Vertebrae $\tau+11$ to $14=18$ to 21 . Species rery numerous, in warm seas, most of them reaching a small size. All are lean fishes with leathery skin and bitter flesh, unsuited for food.

\section{Subgenus STEPHANoLepis Gill}

296 Monacanthus hispidus (Linnaeus)

\section{Filefish}

Ijatistes hispidus Linnatus, Syst. Nat. ed. XII, 405, 1766, Carolina. Balistes broccus MitchiLL, Trans. Lit. \& Phil. Soc. N. Y. I, 467, 1815, New York. 
Honacunthus mussuchusettensis DE KAY, X. Y. Fauna, Fishes, 336, pl. זт, tig. 157, 1842, Massachusetts Bay; N'Torer, Hist. Fish. Mass. 2:1, 1). XXIV, fig. 4, 1867.

Honurunthus setifer DE KAY, X. Y. Fauna, Fishes. 33T, pl. 59, fig. 194, 1812, New York Harbor; Goone \& BEAx, Bull. Essex Inst. XI, 4, 1879.

Monteanthus borcus DE KAY, N. Y. Fauna, Fishes, 335, pl. 56, tig. 18?, 1812; Jordax \& Gilbert, Bull. 16, U. S. Nat. Mus. 856, 1883.

Monacanthus hispidns BEAN, Bull. U. S. F. C. TII, 133, 18ss; 19th Rep. Comm. Fish. N. Y. 241, 1890; Bull. Am. Mus. Nat. Hist. IX, 309, 1s!t; H. M. SMiti, Bull. U. S. F. C. 1897, 104, 1898; Jordan \& Everiaxi, Bull. 47. โ. S. Nat. Mus. 1715, 1898, pl. CCLIX, fig. 635. 1900: ReAs, 521 Ann. Rej). N. Y. State Mus. 107, 1900, Great Sonth Bay.

Body rather deep, the length being one and three fourths times the depth and three and two fifths times the length of the head; jaws subequal; eyes large, more than one third lengtl of snout; gill opening about as long as eye, separated from the eye by an interspace nearly equal to its length; anterior profile slightly concare; dorsal spine somewhat shorter than snont, inserted above posterior part of eye, stont, rough, armed behind with two rows of retrorse barbs; first ray of soft dorsal sometimes filamentous, one balf of total length without caudal; pectorals small, one half length of snont: pelvic bone long, ending in a short. blunt, movable spine, beyond which the abdominal flap does not extend; length of free edge of flap when expanded not greater than diameter of eve; scales minute, each with a crest of about three prickles, those on the candal peduncle villons, those on the v'ntral flap larger, elongate; no naked areas; recurved spines on tail. Length 10 inches. D. I-22 to :3: A. 22 to 33; P. 15.

Dull greenish mottled with darker fins olivaceous, somewhat blotehed. Massachusetts bay to tropical seas; abundant on om? South Atlantic coast. Also found thromgh the West Indies to Brazil, in the Canaries and Madeira.

Mitchill and De Kay both recorded the filefish from New York, where it was not uncommon in summer.

This fish is taken in Gravesend bay in moderate numbers occasionally in the fall. Individuals weres sent from there in September and November 1897. Some were living in a tropical tank and feeding freely on I ecember 11. A single specinen was taken at l'oint of Woods, Great South bay, Aug. 16, 1898. 
In the ricinity of Woods Hole Mass. according to Dr Suith, it occurs every year; some rears rather scarce, some years abundant. In 1897 it was extremely numerous in July and August, and several hundred were often taken in one day in the seine. It may often be obtained under gulf weed, but is usually most plentiful in eelgrass and rockweed. No large fish are observed. the size ranging from 1 inch to nearly 4 inches. The smallest are rather miformly dull brownish or greenish yellow in color, but those: 3 or 4 inches long are mottled with white and several shades of dark green. In aquaria, small filefish often annoy and injure other fish, biting their fins, eyes, and other parts.

At Beesley's Point N. J. the writer seined an individual, Aug. 23,1887 , which had several parasites attached to the fins.

\section{Genus atomen Cuviel}

liody oblong or rather elongate, strongly compressed, corered with minute, rougl scales; month and teeth esentially as in If o n a c a $\mathrm{n}$ thus, but the lower jaw more projecting, so that the lower teeth are directed obliquely upward and backward; gill opening an oblique slit, longer than eye, situated below and in advance of eye, its posterior end behind base of pectorals; pelvic bone long, falcate, movable under the skin, without spine at its extremity; dorsal spine small, inserted over the "ye, rough, but without barbs; soft dorsal and anal long, each of 36 to 50 rays; caudal fin courex; pectorals small.

\section{Subgenus cefaticaxthes Gill}

\section{Alutera schoepfii (Walbaum)}

\section{Orange Filefish}

Bulistes sedqepfii Walbatu, Art. Gen. Pise. 461, 1792, Long Island. batistes amantiacus Mitchils, Trans. Lit. \& Phil. Soe. N. Y. I, 468, pl. VI, fig. 1, 1815, New York; adult.

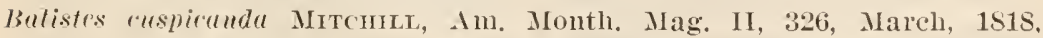
Nerr York; young.

Lluteres cuspiequld DE KAY, X. Y. Fauna, Fishes, 338, pl. 59, tig. 192. 1842, New York; young.

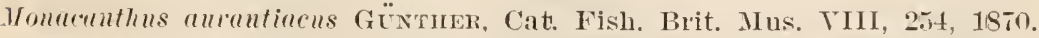
Hlutera sellocpfi Jordax of Grlisert, Bull. 16, U. S. Nat. Mus. Sis, 188:;

BeAx, Bull. U. S, F. C. VII, 134, 1888. 
Alutera schoepfi Goode \& BEAN, Bull. Essex Inst. XI, 3, 1879; BEAN, Bull. Am. Mus, Nat. Hist. IX, 369, 1897; H. M. SмIтн, Bull. U. S. F. C. 1897, 104, 1898; Jordan \& Evermann, Bull. 47, U. S. Nat. Mus. 1718, 1898, pl. CCLX, fig. 636, 1900; BEAx, 52d Ann. Rep. N. Y. State Mus. 107, 1900.

Body oblong, rather elongate, narrowed posteriorly; the greatest depth four ninths or nearly one half of total length without caudal; least depth of caudal peduncle nearly one third length of head. Profile of head very oblique; space between dorsals almost horizontal; rentral outline convex. Head short, its length contained three and one fourth times in total without caudal; the gill opening oblique, two and one lialf times as long as the eye; eye small, one fifth as long as the head; twice its own diameter from top of head, and placed far back over the posterior part of the gill opening; snout one fourth of total length without caudal; mouth very small, the lower jaw prominent. Dorsal spine slender, varying greatly in length, placed over the eye. Interspace between the dorsals as long as the head. Base of second dorsal one third of total length without caudal; the longest dorsal ray equals one third length of dorsal base; the outline of the fin greatly convex. Caudal moderately long in adult, rounded behind, much produced in young; the middle rays in adult as long as the snout. Anal similar to soft dorsal, but extending farther back, its base somewhat longer than dorsal base, its longest rays equal to longest of dorsal. Pectoral short, one third as long as the head. Scales minute, shagreenlike, uniform over the body. D. I, 36; A. 38.

Coloration nearly uniform dirty olive gray, varying to orange yellow, often, specially when young, mottled above with darker bluish or dull orange; caudal sometimes dusky, edged with white, usually dull yellowish in the adult. Tength 24 inches.

The orange filefish is found from Cape Cod to the Gulf of Mexico, the young usually abundant every summer on the south shore of Long Island and in the bays.

The young are rather common in Gravesend bay in August, September, October, and sometimes as late as November. Adults are rarely seen. The species will not survive the winter except 
in warmed water. It feeds freely when the temperature is agreeable.

Young indiriduals were obtained in 1898 at the ocean beach, Southampton, Long Island, August 3, Islip, August 18, and Fire Island inlet, September 16 . No adults were seen; the largest eximple was about 9 inches long. In 1901, an adult was obtained from Watts's pound, in Clam Pond cove, August 13, and another was speared in Fire Island inlet, August 1; no young were observed.

At Woods Hole Mass. according to Dr Smith, it is rather common every year in August and September. The largest are 18 inches long, the smallest 3 inches. The position constantly assumed in the aquarium is with the head down. Succulent algae are often eaten by the fish in captivity, the long branches of some species being bitten off and swallowed in a surprisingly short time. The color of the young is a dirty white, with large reddishbrown mottlings or blotches; the larger are orange-colored with the same mottlings as when young.

The species is seldom found north of Cape Cod. An individual taken at Forest River lead works, Salem, Mass. Aug. 9, 1845, was preserved in the museum of the Essex institute. At Somers Point N. J., a few young were found in August and September, but the adults were absent. This is called sunfish at Somers Point.

\section{Suborder OSTRACODERMI \\ Trunkifishes}

Family OSTRACIDAE

\section{Genus Lגctopurs Swainson}

Trunkfishes with the carapace three-angled, the ventral surface flat or concave, never carinate; carapace closed behind the anal fin; carapace with or without frontal and abdominal spines; dorsal rays nine or 10 ; caudal rays always 10 . This genus contains five species, four of them American, and differs from the old World genus Ostracion only in the form of the carapace. The median dorsal ridge of the carapace is much more developed than the others, so that the body is three-sided and 
three-angled, instead of four-sided and fomr-angled, as in Ostracion. Though this character is a striking one it is not one of high structural importance. Hollard and Bleeker have discarded it as being of no real systematic value. All writers agree that the species of the group are most closely related, and that the relations of the species are closer than they appear. We think, with Dr Goode, that the shape of the carapace affords "the most reliable guide in the arrangement of the species of the genus," and we think it not improper to accord generic distinction to the three-angled species, as distinct from the more specialized four-angled forms. Jordan and Evermann.

\section{Lactophrys trigonus (Linnaeus) Subgenus ractophrs \\ Trunkfish; Cuckold}

Ostracium trigonus Lrnxaeus, Syst. Nat. ed. X, 330, 1758.

Ustracium trigonum Jordan \& Gilbert, Bull. 16, U. S. Nat. Mus. 853, 1583.

Ostrucion trigonus Güntiner, Cat. Fish. Brit. Mus. VIII, 256, 1870.

Gstruciom yulei Storer, Bost. Jour. Nat. Hist. I, 35̃3, pl. S, 1837, Holmes IIole, Marthas Vineyard.

Lactophrys yulci DE KAY, N. I. Fauna, Fishes, 342, 1842, after S'Toner; Storer, Mem. Am. Ac. VIII, 429, pl. 35, fig. 3, 1861.

Luctophrys trigonus Poer, Memorias, II, 362, 1861; BeAx, Bull. Am. Mus.

Nat. Hist. IX, 369, 1897; Jordan \& Evermann, Bull. 47, U. S. Nat.

Mus, 1723, 1898, pl. CCLXIII, fig. 641, 641a, 1900; II. M. Sмrтा, Bull. U. S. F. C. $1897,104,1898$.

Body three-angled and with greatly compressed, thin edges; the greatest height one half of total length without the caudal. The caudal peduncle long and slender, its least depth three fourths diameter of eye. Each ventral ridge with a large, flat spine; no spine in front of eyes. Horsal ridge high, greatly compressed, descending rapidly forward to opposite posterior margin of orbit and backward to caudal peduncle; carapace open behind the dorsal fin. Eye one third as long as the head; a pronounced supraccipital ridge, the interorbital space exceeding diameter of eye. Dorsal base five sixths as long as the eye; longest dorsal ray one half as long as head. Anal farther batk than dorsal and somewhat smaller. Length of gill opening not equal to eye.

D. $10 ;$ A. $10 ;$ P. 12. 
Four teoth in rach side of lower jaw.

color olive gray or brownish; a faint blus spot in the centel' of rach of most of thre seates; nostril in a rellow spot; boun. daries of upper scutes blarkish, of low ${ }^{\wedge}{ }^{2}$ bluish; outlines of

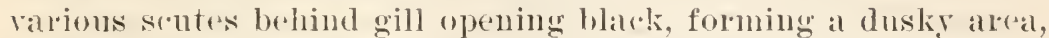
specially distinct in the roung; a similar smaller dusky area on side on level of ero: iris yollow; fins all pale olive: vent yellow; belly light olive, ontlines of the seutes bluislu; base of pectorals yellowisli.

The trunkfish reaches the length of about 1 foot; it is comnon in the Mrst Indies, the Bermudas, and the eastern pallt of the (inlf of Mrexico, occasionally migrating northward in sumlinel under gulf weed as far as Cape Cod. I) Storel had it from Holmes Hole, on Marthas Vinvyad. Mr H. M. Snith records no adults from the ricinity of Woods Hole Mass. but young individuals are not murommon and are taken every year. They are found from July to Ortober. On quirt days they are seen, singly or in scattreed bodies, in the exlgrass abont the wharves. The largest sprecimens secured by Do smith are 1 inch long, and the sumallest $\frac{1}{t}$ inch. They are takin under the sulf weed, in surface tow nets and in shore seines. Seroual dozen have bern obtained at one seine haul.

De Kay knew the fish only from the description by 1) storel.

The only individual taken in Gravesend bay was found in Ingust 1897; it was $\frac{3}{8}$ inclu long. The fish lived a very short time in a balanced jar, though it appeared to feed freely upon mincerl hared clam.

\section{Suborder Glyomontes}

Family TETrAODONTIDAE

\section{Puffers}

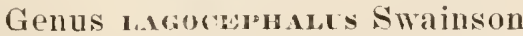

Body comparatively elongate; skin smooth or rariously prickly, thr prickles most developed on the abdomen; abdomen (a) able of vely ereat inflation. Dorsal and anal rather long. faleate. of 120 to 15 lays each; candal lunate. Nostril without distinet papilla, ("ach one with two distinct openings; mucous 
tubes on upper part of head and on sides of body very conspicuous. Lower side of tail with a fold. Species reaching a rather large size, chiefly tropical, one of them, L. l a g o c e pha l u s I., reaching the coasts of southern Europe. Vertebrae in increased number (about $S+13=21$ ). The increased number of vertebrae and of rays in the vertical fins mark a transition toward the allied family, $\mathrm{Ch}$ o $\mathrm{n}$ e $\mathrm{r}$ h in i d a e, in which there are about 29 vertebrae, the dorsal rays about 35 , the anal 30 .

\section{Lagocephalus laevigatus (Linnaeus)}

\section{Smooth Puffer; Rabbitfish}

Tetrodon laevigatus Linnaeus, Syst. Nat. ed. XII, 411, 1766, Charleston, S. C.; Mitchill, Rep. Fish. N. Y. 28, 1814; Günther, Cat. Fish. Brit. Mus. VIII, 274, 1870.

Tetruodon lacvigatus DE KAY, N. Y. Fauna, Fishes, 329, pl. 56, fig. 182, 1842.

T'etrodon curvus Mitchill, Trans. Lit. \& Phil. Soc. N. Y. I, 474, 1815; New York; young.

Tetrodon mathematicus Mitchill, Trans. Lit. \& Phil. Soc. N. Y. I, 474, pl. VI, fig. 6, 1815.

Lagoccphalus lactigatus Jordan \& Gibbert, Bull. 16, U. S. Nat. Mus. 860, 18s3; BeAN, Bull. U. S. F. C. VII, 133, 18ss; Bull. Am. Mus. Nat. Hist. IX, 369, 1897; H. M. SмIтн, Bull. U. S. F. C. 1897, 104, 1898; Jordan \& Evermann, Bull. 47, U. S. Nat. Mus. 1728, 1898, pl. CCLXIII, fig. 642, 1900; SHerwoon \& Edwards, Bull. U. S. F. C. 1901, 30, 1901.

Body elongate, stout, its depth about one fourth or two ninths of total length without the caudal. Caudal peduncle rather slender, tapering, its least depth about equal to diameter of eye. Head short, very obtuse in front, its length two sevenths of total without the caudal. Mouth very small, terminal. Nostrils midway between eye and tip of snout. Snout twice as long as the eye, which is one fourth as long as the head, and two thirds of width of interorbital space. Dorsal and anal fins opposite, about midway between eye and origin of middle caudal rays; each fin on a fleshy base. Base of dorsal two sevenths as long as the head; longest dorsal ray about one half as long as the head. Anal equal in size to dorsal. Caudal fin lunate, the middle rays as long as the snout; fold of skin on side of tail very distinct. Back and sides smooth; belly prickly, the spinous region extending backward from the throat nearly to the vent 
and on the sides as high as the base of the pectoral; spines rather large, three-rooted, well separated, and with no smaller ones intermixed. Pectoral short and deep, its longest rays nearly one half as long as the head.

D. $14 ;$ A. 12 ; P. 15 .

Upper parts greenish, sides and lower parts silvery white; no distinct marlings.

The smooth puffer is a common resident of tropical seas, on our coast ranging from Cape Cod to Brazil. It reaches a length of 2 feet. According to Parra its flesh is poisonous. No recent observations have been recorded, however, on this subject.

In the waters of Cape Cod the species is not common though a few specimens are taken annually in traps in Buzzards bay and Vineyard sound, chiefly in September and October. The young are not found at all, the individuals observed being 11 or 12 inches long. During 1900 several specimens were taken in the vicinity of Woods Hole Mass. The Rhode Island Fish Commission secured three specimens in Narragansett bay, the largest weighing 10 pounds.

Occasionally taken in the fall in Gravesend bay. Five young were obtained in October 1897, but all of them died in Norember, notwithstanding that they had been taking food readily. The temperature could not be endured.

Thongh this fish was unknown to the fishermen met in Great Egg Harbor bay in 1887, it was moderately common there, 13 examples having been taken from August 27 to September 18. It has the same habit as the swellfish of inflating its abdomen.

\section{Genus spheroines Lacépède}

Body oblong, not elongate; skin variously prickly or smooth, sometimes with cirri. A single, short, simple nasal tube on each side, with two rather large openings near its tip. Dorsal and anal fins short, little falcate, of six to eight rafs each; caudal truncate or rounded, rarely slightly concave. Vertebrae $8+10=18$. Frontal bones expanded sidewise and forming the lateral roof of the orbit, the postfrontals limited to the posterior portions. Species numerous, in warm seas; largely 
American. Our species represent two well marked subgenera. the extromes of which appear very different from each other so far as the sliulls are concerned. Some of the typical species of Spheroides approacl Canthigaster in the narrow. ness of the frontal area.

\section{Subgenus spheromes}

300 Spheroides maculatus (Bloch \& Schneider)

\section{Suellfish; Puffer}

Tetrodoin hispidus var. maculatus BLOCH \& Schneider, Syst. Ichth. j04. 1801, Long Island.

Tetrodon turgidus Mrtcinll, Traus. Lit. \& Phil. Soc. N. Y. I, 473, pl. VI,

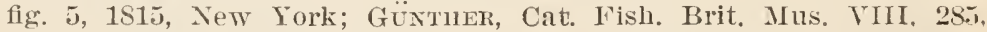
1870; Jordan \& Gilbert, Bull. 16, U. S. Nat. Mus. 861, 1883; Bear, Bull. U. S. F. C. VII, 193, 1885; 19th Rep. Comm. Fish. N. Y., ¿42. 1890 .

Tetraodon turgidus DE KAY, N. Y. Fauna, Fishes, 327, pl. 55, fig. 178, $1 S+2$.

Spheroides maculatus Jordan \& EDwards, Proc. U. S. Nat. Mus. 232. 1856; BeAn, Bull. Am. Mus. Nat. Hist. IX, 369, 1897; H. M. Surtr, Bull. U. S. F. C. 1897, 104, 1895; JordAy \& EverManN, Bull. 47. U. S. Nat. Mus. 1733, pl. CCLXIY, fig. 645, 1900; BEAx, $52 d$ Ann. Rep. N. Y. State Mus. 108, 1000.

Body fusiform, thick, its width and depth about equal and one third of total length without the candal. Head moderately large, three eighths of the length without caudal. Eve smali, about two fifths of interorbital widtl and one ninth as iong as the head. Snont long, four serenths as long as the head. Interorbital space slightly concare; profile not steep, depressed in front of the cres. Dorsal origin twice as far from midale of eye as from base of middle candal rays; base of dorsal fin as long as the eye; longest ray one third as long as the head. Anal origin under the end of dorsal base, the fin about equal to dorsal. Caudal convex, the middle rays two fifths as lon as the head. Pectoral deep, but short, its upper rays three eighths as long as the liead. Distance of nostrils from front of eye one? lialf their distance from tip of snout. Sides of bead and body always prickly; back prickly from upper lip to base of corsal; belly prickly from lower lip to vent; prickles all sinilar, small, mostly three-rooted, stiff and close set, rather larost pos- 
teriorly on back and belly, never obsolete; sides without cirri. 1. 7 ; A. 6; C. 7 ; P. 16.

Color darkish olive green on the upper part of the head, hody and tail, with a yellowish tinge along the sides. Sides and under surface white. Along the sides from bencath the eve to the candal fin is an indefinite series of six to eight oblong black blotches, which occasionally take the appearance of transverse bars. De Kay observed some indiriduals which were nearly a uniform black above. Caudal fin nearly uniform pale, the tip darker.

The swellfish inhabits the Atlantic coast from Cape Ann to Florida; it grows to a length of 10 inches. In most localities the fish is not eaten, but at Somers Point $\mathrm{X}$. J. certain persons professed to find in it excellent food qualities. De Kay states that the species is scarcely erer eaten in New York.

This species is known also by the additional names, puffer, blower, eggfish, swelltoad, sucking toad, toadfish (at Somers Point N. J.) It is the puffer and toadfish of Mitchill's Fishes of New Yor\%.

The swellfish is extremely abundant about the eastern end of Long Island, and is caught by hundreds at a time in pound nets during the summer. The writer has taken it at the following localities in Great South bay: Fire Island inlet, Oak Island beach, Clam Pond cove, Islip, Cherry Grove, Nichols's Point, Blue Point. In Graresend bay the species is found at all times except during the cold months; it is hardy in captivity, but can not be kept with other fish because of its predatory habits.

In the ricinity of Woods Hole, according to Dr Smith, it appears about June first, and is abundant during the run of scup. It is common throughout the summer at the head of Buzzards bay. The spawning season is June 1 to 10 . From about July 1 to October 15 , the young, from $\frac{1}{2}$ inch to 1 inch long, are ex. tremely abundant at Woods Hole, frequenting chiefly sandy beaches, where as many as 100 are often taken in one seine haul. The fish leares as soon as cold weather sets in. 
The name swellfish is derived from its luabit of inflating itself by means of air or water. It can be made to inflate itself by scratching its belly. During the process of inflation the fish makes a sucking sound, from which doubtless comes the Chesapeake bay name of "sucking toad." Mitchill gives the following account of the inflation:

The air is inllaled with a sucking or swilling noise. When received into the cavity it is confined there by a valve in the throat. This ralre is so strong and so tight that not a particle of air can escape. The hardness equals that of a football, and the fish will bear to be kicked about without discharging it. I have seen them stamped upon and still retain their charge of air. I have known them to bonnce from the surface of a rock, against which they have been thrown, as turgid as ever. And it is a piece of sport, common enough among fishermen, to burst them between two stones, when the air is let loose witlı a noise almost equal to the report of a pistol.

The habit of inflation is a protective one. By means of it the fish can readily'escape from the closed hand unless particular effort is made to retain it. When the abdomen is infiated the swellfish often remains on the surface of the water, and is driven by wind and tide till it desires to sink, when the air is suddenly discharged and the abdomen returns to its normal state.

It often takes a baited hook, notwithstanding the small size of its mouth and its clumsy teeth.

\section{Subgenus снепцснтну Müller}

301 Spheroides testudineus (Linnaeus)

Globefish; Blowfish

Tetrodon testudineus LrnNaeus, Syst. Nat. ed. X, 332, 1758; Günther, Cat. Fish. Brit. Mus. VIII, 282, 1870; Jordan \& GILbent, Bull. 16, U. S. Nat. Mus. 861, 1883.

Sphcroides testudineus Jordan \& Edwards, Proc. U. S. Nat. Mus. 239 , 1886.

Spheroides testudineus Jordan \& Evermann, Bull. 47, U. S. Nat. Mus. 1734, 1898, pl. CCLXr, fig. 646, 646a, 1900.

Body fusiform, subterete, moderately elongate, its greatest width and depth equal, and two seventlis of total length without caudal. Caudal peduncle comparatively stout, its least depth one third length of head, the width not decreasing rapidly 
toward the base of the caudal. Head one third of total length without caudal; eye small, its length nearly one fourth length of snout and nearly one seventh that of head; interorbital width two fifths length of head; nostrils one diameter of the eye in advance of eye. Gill opening one fourth length of head. Origin of dorsal fin twice as far from front of eye as from root of middle caudal rays. Dorsal base one fifth as long as the bead, two fifths as long as longest dorsal ray. Anal origin slightly behind dorsal origin, the anal fin a little smaller than the dorsal, and mostly opposite to it. Caudal slightly concavoconvex, the lower lobe a little the longer, the middle rays two thirds as long as the head. Pectoral rery deep but short, its longest ray two fifths as long as the head. Lateral line beginning behind the nostril, extending under the nostril to the middle of the snout, thence curving back on the cheek, ascending below and behind eye in a broad curve, its highest point on the level of the eye, to the middle of the caudal peduncle and thence nearly straight to the base of the caudal. Small, sparsely set prickles on back from nape to about middle of total length; larger, closely set prickles on belly from throat to vent, extending up to lower edge of pectoral fin; these prickles rarely obscure or absent; sides sometimes with cirri.

Back dark brownish or grayish and with whitish narrow curved lines and streaks, one of these usually a rhomb in the middle of the back surrounded by a long ellipse which often contains also a short crescentic streak. Two half ellipses on posterior part of back between dorsal and caudal fins. Two pale streaks across the interorbital space. Entire body and head, except back and belly, profusely corered with roundish black spots, the largest smaller than the pupil. A dark bar at base of pectoral. Caudal dusky at base, then pale, the posterior half blackish. D. 8; A. 7 ; C. 10; P. 15.

The globefish abounds in the West Indies, occasionally ascending rivers, and sometimes ranging northward in the Gulf Stream as far as Newport R. I. No specimens have yet been recorded from New York waters, but its occurrence is to be 
expected in bays of the south side of Long Island. The species reaches the length of $\tau$ or 8 inches; it is known in Cuba as the Tambor.

\section{Spheroides trichocephalus (Cope) \\ Hairy Blowfish}

Tetrodon trichocemalns Cope, Proc. Ac. Nat. Sci. Phila. 120, 1870, Gulf Stream off Newport, R. I.; Jordar \& Gilbert, Bull. 16, U. S. Nat. Mus. S62, 1883.

sphacroiles triehoephhahus Jordan \& Edwards, Proc. U. S. Nat. Mus. 236, 1886 .

spheroides trichorephalus Jordax \& Evermaxn, Bull. 47, U. S. Nat. Mus. $1787,1898$.

Head two sevenths of total leugth; eye two sevenths as long as the head; introrbital width four fifths diameter of eye. I'rofile suddenly descending from prefrontal region to premaxillary, arched from the former point backward; belly spinous to near rent; dorsal region spinous from a little behind the nares to above the ends of the pectoral fins; spines on the head long, close set, like seal bristles; caudal fin truncate, with prominent angles.

\section{D. $8 ; \ldots .7$.}

Brownish above, faintly rermiculated with lighter; sides yellowisl, becoming white below; fins uniform light yellow; a brown spot at base of prectoral. (After Cope)

The hairy blowfish is known only from the suall specimen 4 inches long described by Professor Cope; the specimen was taken in the Gulf Stream off Newport. Jordan and Erermann suggest that it may be the young of spheroides pa chy "za a t e $r^{\circ}$ (Müller \& Troschel), from Barbados. Possibly it may be nearel to s. ne phelus (Goode \& Bean), Proc. U. S. Nat. Mus., 412. 1882, a southern species known from Georgia to 'Texas.

To specimens liave been recorded from water's of New York.

\section{Family DIODONTIDAE}

\section{Porcupine Fishes}

Genus Trichodiodon Bleeker

Borly oblong, little depressed; nasal tentacle present; dermal ossifications very small, each with a pair of lateral roots, and 
each terminating in a fine, flexible, bristlelike spine; fins as in D i o d o n, of which the species are possibly the very young.

\section{Trichodiodon pilosus (Mitchill)}

\section{Hairy I'orcupine Fish}

Diodon pilosus Mitchill, Trans. Lit. \& Phil. Soc. N. Y. I, 471. pl. VI. fig. 4. 1815; supposed to be from New York Harbor; specimen 11! 2 inches long.

Trichodiodon pilosus Güntuer, Cat. Fish. Brit. Mus. VIII. 316, 1870; Jorida \& Gilbert, Bull. 16, U. S. Nat. Mus. 862, 18\$3, name lut mobably not description which is from DE KAY; JoRDAN \& EveliMAxN, Bull. 47, U. S. Nat. Mus. 1743, 1898.

Mitchill's description as given by Jordan and Evermann is as follows: "Hairy diodon (T) i o d o u p i l o s u s), witl a cor. ering of bristly hair. Iength about $1 \frac{1}{2}$ inches; breadth less than $\frac{1}{2}$ inch; depth nearles a quarter, making a blunt lump of a fish; corered all orrl-back, sides, head and belly-witl bristly hail. The bristles strong and flexible, without the power to scratch or to prick; hair about $\frac{1}{8}$ inch in lengtl. Complexion dun or brown, with spots on the back, sides, and toward the belly; has, at first glimpse, the appearance of a young mouse. Mouth small, midway, and horizontal. Eyes vertical, lateral, and large. No rentral fins. l'ectorals broad. Torsal and anal rely far hack, and no hair between then and the tail. This is but a small projection from the thick and clumsy body, and is terninated by a fin of seren rays. Dorsal, anal, and pectoral fins rontain each about $1: 3$ rays."

Giinther (Cat. Fish. Brit. Mus., TIIJ, 316. 1870) drscribes a yomng example, $\frac{7}{5}$ incli long, and by some antlors supposed to be of the sance slrecies as Mitchill's haire diodon, as follows: "Trichoorchis. Jaws withont median suture. Body corered with long. hairlike bristles. No nasal tentacle. (Dorsal and aual fius absent?). 1. Trichocyclus erinatens.

Owing to the indifferent preservation of the specimen, I can give but an incomplete description of it. It is $\frac{7}{5}$ inch long, and the longest hairs (which are those on the sides) about $\frac{3}{8}$ inch. The entire body, except the smont, is corered with such hairs. The jaws are prominent, depressed: and the upper terminates 
in a slight look, orerlapping the lower jaw. The caudal fin is distinct, and the pectoral a narrow fringe behind the gill opening; but I an unable to find a trace of the dorsal and anal fins." Habitat unknown.

Under the name Diodon pilos us De Kay describes and figures a specimen 2 inches long which he considered identical witlı the Diodon yilosus of Mitchill, but which may be the young of Diodon hystrix, a species not yet recorded in New York waters.

\section{Geuns CHLOMYCterus Bibron}

Body broad, depressed, moderately inflatable. Dermal spines short, stout, immovable, triangular, each with three roots; nasal tube simple, with two lateral openings; the tube sometimes rounded, sometimes flattened, and with the partition feeble and easily torn so that the tentacle appears divided; caudal peduncle short; fins small, formed as in D i o d o $\mathbf{n}$; jaws without median suture. Species numerous, of smaller size than those of $\mathrm{D}$ i o d o $\mathrm{n}$, the spines broader and lower, their bases forming a coat of mail.

\section{Subgenus crchichтнs Kaup}

\section{Chilomycterus schoepfi (Walbaum)}

\section{Spiny Boxfish; Burfish; Cucumberfish}

Diodon schoepf Walbaum, Art. Gen. Pisc. 601, 1792, Long Island.

Diodon maculostriatus MrTchill, Trans. Lit. \& Phil. Soc. N. I. I, 470, pl. VI, fig. 3, 1815, New York; DE KAX, N. Y. Fauna, Fishes, 323, pl. 56, fig. 1S5, 1842.

Diodon rivulatus Cuvier, Mém. Mus. Hist. Nat. IV, 129, pl. 6, 1818, New \ork.

Diodon vigrolineatus Ayres, Bost. Jour. Nat. Hist. IV, 68, 1842, Brookhaven, Long Island.

Chilomycterus geometricus Günther, Cat. Fish. Brit. Mus. VIII, 310, 1870; Jordan \& Gilbert, Bull. 16, U. S. Nat. Mus. 863, 1883; BeAn, Bull. U. S. F. C. VII, 132, 1888.

Chilomycterus schoopfii BEaN, Bull. Am. Mus. Nat. Hist. IX, 369, 1897.

Chilomycterus schoepfi Jordan and Evermans, Bull. 47, U. S. Nat. Mus. 1748, 1898, pl. CCLXVI, fig. 649, 1900; H. M. Sмгтн, Bull. U. S. F. C. $1897,105,1898$.

Body elliptic, a little broader than deep at gill openings, the depth four ninths of total length without caudal. Caudal 
perlumele very short, one thind as lomg as the hearl, its least denth one laalf of its greatest depth, and less than diametro of cye. Eye plared high, one fourth as long as the head, about efual lo width of gill opening; interorbital space broad, concalve. Snout nearly equal to eye. A cirrus, longer than pupil, alume callu eye. Origin of dorsal four times as far from tip of sumb as from base of middle candal rays. Dorsal base one thirel as lomg as the head; longest dorsal ray one half as long as the houd. Anal inmuediately muder the dorsal and abont equal to it in size. Candal rounded, the middle lays as long as the postorbital part of the head. l'ectoral one half as long as the head, its depill when expanded six sevenths of length of head. A suall cirrus on ahin. Abont nine spines between eye and tail, their hight aboul two thirds diancter of eye; spines on belly much smaller, flartly enledeled in slin; some of the posterior with cirri; spines on candal peduncle; anterior root of each spine little if any lat ger thitl others. 1).12;.1. 10; C. 9; P. 20.

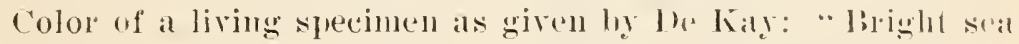
green abore, with longitudinal olive-buown irregular stripes on the hack and npler part of the sides; on the checlis. below the

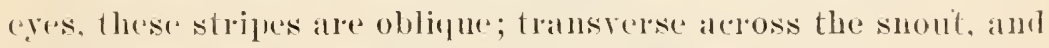
sloping downwall orere the fieshey portion of the tail. The laregere

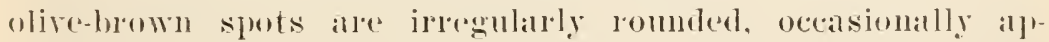

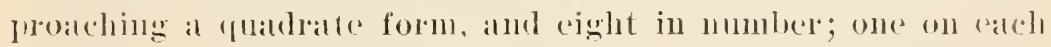
side, above the base of the pectorals. of all obleng oval form;

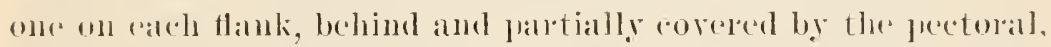
irregularly subquadrate; one on each side of the base of the dorsal, ascending upon that fin; this is considered by curier as a sillgle spot; finally a small oblong spot on raloh side, abont midway between the dorsal fin and the rent. Abdomentight. anloled, with a light tinge of pink. Fyines on this purtion of the hody inclining to orangec. P'upils dark greenish: irirles

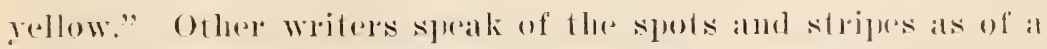
lolack colol", and state that the belly is oftell black in the romeng.

The spiny boxfish grows to the length of ten inclus. 11 is fonut on our coast from cale corl to Florida. The lorly is 
capable of consiclerable inflation, but less than in the common sirellfish.

I young example, 3 inclies long, seined at Longport $\mathrm{N}$. J. Ang. 29, 1S87, is much less elongate than the adult, and has the orbital tentacles greatly developed. The black spot which is present near the anal origin in the adult is absent in the young. The sproies is known as "Cucumberfish" at Somers Point N. J. It takes the hook. The fish is found occusionally in small numbers from May to October in Gravesend bay, but no very small ones are seen. It lives in the aquarium in winter only in water leated to a temperature of $68^{\circ}$ to $70^{\circ} \mathrm{F}$.

\subsection{Chilomycterus fuliginosus (1)e Kia y) \\ Burfish; Unspotted Balloonfish}

Diodon: fuliginosus DE TAY. N. Y. Fauna, Fishes, 324, pl. 55, fig. 181, 1812.

New York IIarbor; BAind, Ninth Ann. Rep. Smith Inst. 351, 1855, Great Egg Ilarhor Rirer, N. J.

Chilomycterus geometricus subsp. (?) fuliginosus Jondan \& Grubert, Bull.

16, U. S. Nat. Mus. S64, 1883.

Chilomycterns fuliginosns Bean, Bull. U. S. F. C. VIf, 133, 18ss; 19 th Rep.

Comm. Fish. N. Y. 243, 1890.

The following is the original description of the species:

Body subcubical, rather more slender toward the tail. Irregular series of triangular spines on the upper surface, the cxtremities of wlich, in the living animal, are furnished with long strips of membrane. Similar spines, but more numerous, smaller and recurved, on the abdomen. Three spines orer each orbit, and another equidistant between cach orbit. Lips fleshy and susceptible of being drawn orer the teeth. Three or four minute barbels moder tle chin. Pectorals short and broad, with a slightly sinuous margin; the upper rays longest. Dorsal placed far back, and obtusely pointed. The anal fin long, placed on an elongated fleshy base. Tail slender, supporting a lanceo. late candal fin. All the fins exceedingly feeble and delicate.

Color. Above dark olive-green, tinged with brown. with meandering dusky lines. . chin rellowish white. Abdomen black; but the bases of the spines are bright orange, which so far predominates as to give this color to the whole underside.

Length, 2 inches. Deptl and transverse diameter, 1 inch. Fin rays, 1). 14; P. 22; A. 8; C. 9.

This species, which might be mistaken for the young of the preceding, [the spot-striped balloonfish] is readily distinguished 
by its lanceolate tail. . The specimen which furnished me with the above description was found in a net in the harbor of New York in the latter part of October.

By some ichthyologists this has been considered the yomng of the common C. g e o m etri cus, but by Drs Goode and Bean, who base their opinion on a specimen taken at Block Island and the example found in Great South bay in 1884, near the Blue Point Lifesaring station, it is accepted as a ralid species. I'nofessor Baird recognized it also in Great Egg Harbor river, N. J. in 18.54 .

The following is a recent description:

Entire body corered with large three-rooted spines, which are numerons and close set, specially on the belly; spines of the belly as large or eren larger than those on the back; not embedded. D. 12; A. 10.

Dark brownish olive above, with wary duslig lines; belly black, the base of the spines bright orange. Atlantic coast, from Cape Cod sunthward; not common.

\section{Family Molmate}

\section{Headfishes}

Genus nowa Curier

Body orate, strougly compressed, covered with a thick, rough, leathery, e'astic skin, which is without bony plates. Profile forming a projecting fleshy nose above the mouth. Dorsal fin beginuing not far behind pectorals, short and high, falcate, confluent with the anal around the tail; no large spines on the body. Clumsy fishes, found in most warm seas, reaching a great size; the young ( Molacanthus) with the body deeper, much compressed, without trace of caudal fin, its place taken by a row of marginal spines.

\section{Mola mola (Linnaeus)

$$
\text { Sunfish; Mola; Headfish }
$$

Telrodon molu Iaxyaeus, Syst. Xat. ed. X, 334, 412, 1758, Mediteranean. Cephatus brevis Mrtcnitu, Trans. Lit. \& Plil. Soc. N. Y. I, 471, 1815.

Jiudon curinatus Mtтchill, Ann. Lyc. Nat. Hist. X. Y. II, 264, pl. 5. fig. 1, 1815, New York; young.

Actenthosoma carinatum DE KaY, X. X. Fauna, Fishes, 330, pl, 5i, fig. 170. 1842. 


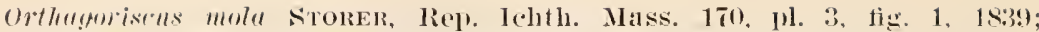
IJE FAY, X. Y. Fauna, Fishes, 381, pl. 59, fig. 193, 1842, New York

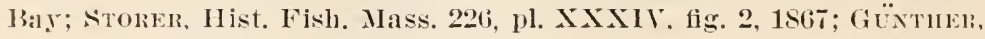
Cat. Fisll. Brit. Mus. V111, 317. 1870.

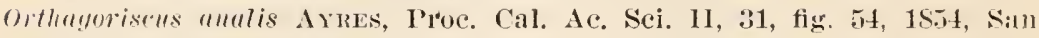
Filincisco.

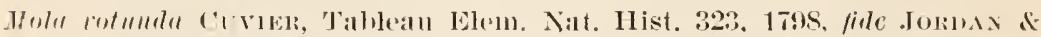

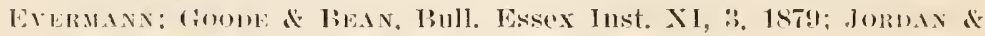

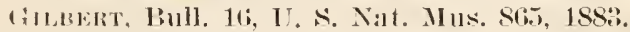

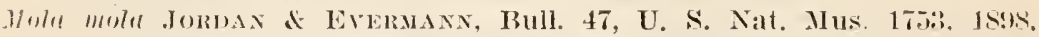

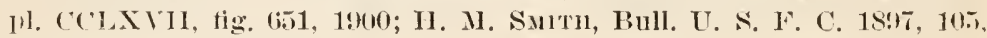
10 !s, Villeyald sound.

The length of the head is one third of the length of the lody which is one and three fifths times the depth of the body; dorsal and anal fins high in front, rapidly decreased backwards; candal fin low, and with a way ontline; depth always more than half length, and in the young the vertical diameter exceeding the longitudinal; form varying with age, the body becoming more ebongate, the fins comparatively shortened, the eye much smaller, and a hump being developed above the mouth, topped hy an osseous tubercle. D. $17 ;$ 1. 16.

1)ark gray; sides grayish brown, with silvery reflections, belly Ausky; a broad blackish bar rumning along the bases of the dorsal, caudal, and anal fins. Pelagic, inhabiting most temperate and tropical seas, swimming slowly near the surface, with the highlı dorsal fin exposed.

It langes northward to San Francisco, Cape Ann, and Eneland, occurring rarely in the West Indies. The Essex Institute las a specimen which was taken in Salem harbor in the summer af 1863. An individnal, 4 feet long, was caught off Gloucester Mass. July 31, 1860. Dr Smith reports it rarer now than formerly in the virinity of Woods Hole, Mass. It was not musmal to ubserve cight or 10 specimens ammally in Vineyald Sound, but of late not more than one in a season is seen. In 1896 a 400 pound fish was seen off Tarpaulin Cove. A 200 pound specimen, callght off Great Harbor, was kept alive at the station for about a week in 1SST. 'The sunfish are usually found there in Iugust. Mr T. N. Erwards has opened a number of stomachs and found in them only ctenophores and melusae. The largest individual 
recorded was captured at Redondo Beach, California, in June $189:$; this was 8 feet 2 inches long and weighed 1800 pounds. The specimen mentioned loy Mitchill and De Kay from lower New

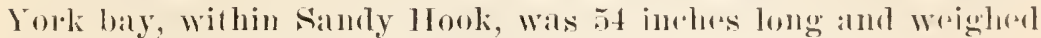
200 pounds.

The sunfish is not edible. De Kiay states thal vilrious palalsites are frequently found adhering to its body; this is rendered easy on accomnt of the sluggish morements of the fish.

The young sunfish is very different in appearance from the adult and has been described under various generic names and erroll inferred to a distinct family.

\section{Suborder loricati}

Inil-cheeked Fishes

Family SCORPAENIDAE: Rockifishes

Group SEBASTINAE

Genus semastes Cuvier

Body oblong, compressed. Head large, scaly above and on sides; ranial ridges well developed. Mouth terminal, very broad, obligue, the broad, short maxillary extending to below the 'ye; lower jaw projecting, with a bony knob at the symplysis, fitting into a rostral notch; villiform teeth on jaws, vomer and palatines. Eve very large, close to upper profile, preoperele will five diverging spines, operele with two; supraseapular spincs strong; gill rakers long, slender. Scales small, ctenoid, irregularly arranged; no dermal flaps. Dorsal fill continuous, very long, the spinous part much longer than the soft part, of 15 strong spines; anal spines three, strong; caudal emarginate; pertorals long, narrow. Branchiostegals seven. Tertebrae 12̈+ 19=31. Coloration mostly red. Ovoviviparous. One species known, in the North Atlantic.

\section{Sebastes marinus (Linnaeus) \\ Rosefish; Noruay Haddock}

Pereq murinu Linvaeus, Syst. Nat. ed. X, I, 290, 1758, Norway.

Sebustes notuegicus Cuvier \& Valenciennes, Hist, Nat. Poiss. IV, 827, 11. 87, 1829); GüNTher, Cat. Fish. Brit. Mus. II, 95, 1860. 
Sebastes norvegicus DE KAY, N. Y. Fauna, Fishes, 60, pl. 4, fig. 11, 1842, off New York in deep water; Stoner, Hist. Fish. Mass. 3S, pl. VII. fig. 1, $186 \pi$.

Sclustes marinus Goode \& BEAx, Bull. Essex Inst. X1, 14, 1879: Jordax \& Gilbert, Bull. 16, U. S. Nat. Mus, 651, 1883; Goode \& Beas, Oceanic Ichth. 260, pl. LXIX, fig. 248, 1896; H. M. Surtri, Bull. U. S. F. C. 1897, 105, 1898; Jordan \& Evemaxx, Bull. 47, U. S. Nat. Mus. 1760, 1896, pl. CCrxiII, fig. 653, 1900.

The depth of the body is contained two and four fifths times in the length of the body which is three times the length of the head. Body ovate; back elevated, the rentral outline straightish; top of head evenly scaled; interorbital space with two low ridges, between which it is concave; nasal spines present; cranial ridges moderate, rather low and sharp; preocular, supraocular, postocular, tympanic, and occipital ridges present, the latter with tips abruptly divergent; suprascapular spines very sharp and prominent; opercular spines long and sharp; sub: opercular spine prominent; preopercular spines slender and sharp, the second longest; suborbital stay not reaching preopercle; rreorbital narrow, with two spines. Eye exceedingly large, three in head, more than twice as wide as interorbital space. Mouth very large, oblique; maxillary very broad, reaching middle of eye, its length two and one third in head; premaxillaries on level of middle of pupil; tip of lower jaw much projecting, with a conspicuous, pointed symplyseal knob; mandible and maxillary scaly; psendobranchiae very large; gill rakers long, stiff and strong. Dorsal spines sharp, the longest about as long as eye; the fin deeply emarginate; soft rays not very high, higher than the spines; caudal narrow, moderately forked; anal spines moderate, graduated; the second a little shorter than eye; pectoral rather long, reaching vent, its base narrow; ventral reaching vent. Scales small, irregular, not strongly ctenoid. Peritoneum brownish. D. XV-13; A. III, 7; Lat. 1. 40 (tubes); scales about 85.

Orange-red, nearly uniform, sometimes a dusky opercular blotch, and about five vague dusky bars on back. Peritoneum brownish.

The rosefish is abundant at the hundred fathoms line off the south coast of New England, and has been found in depths of 
180 fathoms. It breeds abundantly in late summer at these depths, and there is no reason to believe tlat the young rise to the surface. The fry were canght by the bushel in the trawl net of the U. S. Fish Commission steamer Fish Hark.

The species was originally described from Norway by Linnaens. Cuvier had specimens from Minnelon Newfoundland. Day mentions a number of localities of its rapture about the British Isles, but it is rare south of Faroe Islands. It occurs on the southwest coast of Spitzbergeri, and on the Norwegian coast it is found everywhere from Christiania aromd to the Varanger-Fiord. It also occurs in Greenland, and from labrador, as a shore form, as far south as Cape Cod, and in deeper water as far south as New Jersey.

In the Woods Hole region it was taken on the shore on Dec. 20, 1895 in Great Harbor. Seven or eight specimens, 3 inches long, were found in a hole on a flat where they had been left by the tide; four or five of these had been stranded and were dead; the others were alive when eaptured. Fishermen claim that they sometimes catch these fish in traps very late in fall at Provincetown. (After Smith)

De Kay has the following remarks upon the fisli:

This is a very rare fish in our waters. It is called by our fisher. men red sea perell, and they say it is only found in deep water. by the fishermen of Massachusetts it is known under the villious names of rosefish, hemdurgon and snapper. Fabricius states that it is rather agreeable food, but meager. It feeds on thounders and otleer fish, and takes the hook readily.

The species reaches the length of 2 feet; it is frequently to be found in the boston markets and is seen occasionally in the markets of New Jork with the skin removed on account of the hard scales.

\section{Genus hichicolenus Goode \& Bean}

Body oblong, somewhat compressed; head large, ctenoid scales on its top, and on cheeks and opereles; several series of spinous ridges on head, but no occipital pit; month large, with bands of villiform teeth on jaws, romer and palatines. Dolsal fin continuous, not deeply notched, with 10 stout spines and 10 to 12 rays; anal with three spines and six rays; pectoral broad, 
fan-shaped, with rays arranged in three groups, the first of two simple rays, the second of eight or nine branched rays, the third of eight simple rays, sometimes prolonged, with their tips trudrillike and free from membrane for one half their length or less; soft dorsal with tips free from membrane; suborbital licel smooth, or with a single anterior spine under eye; preorbital with spines small and hidden beneath the skin. Vertebrae $10+14=24$; no air bladder. Atlantic.

\section{Helicolenus dactylopterus (De la Roche)}

\section{Redfish; Seran Imperial}

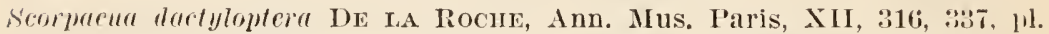
XX̃I, fig. 9. 1809, Ivigga, Barcelona; JordaN \& Gilbert, Bull. 16, I. S. Nat. Mus. 67!), $188:$.

Scbastes durfylopterus Günther, Cat. Fish. Brit. Mus. II, 99, 1860.

Sebustoplus ductylopterns GoOde \& BEan, Bull. Mus. Comp. Zool. X, 110. 5. 214, 1 SS3.

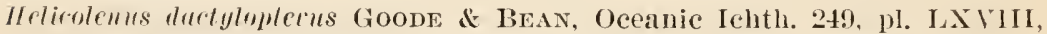
Jig. 244, 1896; Jordan \& Evermann, Bull. 47, U. S. Nat. Mus. 1S:it, $18 \div 8$.

De la Roche states that at Ivica this form is found only at considerable depths, outside of the regions commonly frequented by the fishermen; inderel, that it is rory rare, ol scarcely at all known, in thr mallets of the towns where the fishermen are not in the halit of going far out to sea. II saw many individuals taken off Iviga at a drepth of 260 to 290 meters, and in the vieinity of barcelona saw the same species from a depth of 540 meters. It Irigat the species is known as the Seran imperial, and at lialeclonat at the Fatrogal.

liisso saw specincus at Nice in which locality of the Mediterranean it is rery common and is known as the Cardonniera. He says it grows to a length of $: 30$ centimeters (about 1 foot) and a weight of 2 kilograms ( $4 \frac{2}{5}$ pounds). It is obtained on rocky bottoms at considerable depths thronghout the year, and he has observed females full of aggs in smmmer. The species is recorded also from Naples, Genoa, Messina and Catania.

Capollo states that the fish is found off Lisbon, but it is very lalle and occurs only in summer. Off the coast of France, it has 
been identified from Marseilles, St .Taln dr L.u\%, Biarritz, Valence, and Areachón.

In the western Atlantic the redfish occurs in numerons localities in deep water from Narragansett bay to cleesageake bay.

\section{Family cottunate}

\section{Sculpins}

\section{Group COTTINAE}

\section{Genus cotrus (Artedi) Limnaeus}

Fresh-water sculpins. Body fusiform. Head feobly armed; skin smooth or more or less relvety, its prickles, if mesent, not bony or scalelike; villiform teeth on jaws and vomer, and sometimes on palatines. Gill openings separated by a wide isthmus, orer which the membranes do not form a fold; no slit behind four th gill. Branchiostegals six. Dorsals nearly or quite separate, the first of six to nine slender spines, ventrals moderate, each with a short, concealed spine aud four soft rays. Tateral line present, usually more or less chainlike, sonetimes incomplete. Preopercle with a simple spine at its angle which is ustally curved upward, its base more or less covered by skin, rery rarely obsolete; usually two or three spines turned downward below this; suboperele usually with a contave spine tmrned downward. Vertebrae $10+23=39$. Pyloric carea ahout four. Fishes of small size, inhabiting clear watres in the northern parts of Europe, Asia and America. The species are extremely numerous and are very difficult to distinguish, all being very similar in form, coloration and habits.

The species are most destructive to the eggs of salmon and tront.

\section{Subgenus- PEGEDICTIS}

309 Cottus ictalops (Rafinesque)

Miller's Thumb; Blob

Pegedictis ictalops RAFInesque, Ichth. Ohien. S5, 1820, spring near Lexington, Kientucky.

Collus Richardsoni Agassiz, Lake Superior, 300, 1850, Montreal Rirer; Giralid, Monograph Fresh-Water Cottoids N. A. 39, pl. 1, figs. 1, 2, pl. 3, figs. 18-21, 1850; GüNrner, Cat. Fish. Brit. Mus. II, 15S, 1860.

('ottus Buirdii Girard, Monograph Fresh-Water Cottoids N. A. 4t, pl. 1, figs. 5, 6, 1850. 
Cranidea richardsoni Jordan \& GILberT, Bull. 16, U. S. Nat. Mus. 696, 1s83; Bean, Fishes Peuna. 136, pl. 35, fig. 74, 1893.

Cottus ictalops buirdi MeEk, Ann. N. Y. Ac. Sci. IV, 315, 1888.

Cottus ictulops Meer, op. cit. IV, 314, 1S8S; Jordan \& Evermans, Bull. 47, U. S. Nat. Mus. 1950, 1898.

Body rather robust, gradually tapering to the tail, the depth varying from one fourth to one sixth of the length; the length of the head is contained about three and one third times in the standard length of the body; long diameter of eye almost equal to length of snont; preopercular spine short and sharp, turned upward and backward, with two smaller spines below it; skin usually smooth, sometimes with minute prickles behind axil of pectoral; spinous dorsal begins slightly behind end of head, separated from second dorsal by a deep notch; second dorsal about two and one third times longer than first, and one third longer than anal base which slightly exceeds greatest length of head; pectoral, ventral, and caudal fins well developed.

D. VI-VIII, 16; A. 12-13; V. I, 4. Lateral line conspicuous, sometimes wanting on caudal peduncle.

Color olivaceous, much speckled; sides usually with several distinct and rather broad cross hands; fins barred and mottled.

Bullhead, hlob and muffle-jaws are names applied to the miller's thumb, which has been associated with Richardson's name.

The typical Richardson's miller's thrmb is found in the upper Great lakes. In general it inhabits the "middle and northern states, abounding in all clear, rocky brooks and lakes east of the Dakotas and Kansas to New York and Virginia, extending southward along the Alleghanies to North Carolina and northern Alabama, especially abundant in limestone springs and entering cares."

The U. S. Fish Commission had specimens from Grenadier island and Stony island, in the Lake Ontario region, collected June 28 and July 3; also from the St Lawrence river, 3 miles below Ogdensburg N. Y., July 17, taken by Dr Evermann and Mr Bean in 1894. Meek records the species from the southern 
end of Cayuga lake. It is extremely rariable in size, color and length of fins and number of rays.

This species grows to a length of 7 inches under farorable circumstances and is one of the most destructive enemies of the eggs and young of brook trout and other nembers of the salmon family.

\section{Genus unavioea De Kay}

This genus is very close to $\mathrm{Cot} t \mathrm{us}$, from which it differs in the reduction of its ventrals to a concealed spine and three soft rays, a step further in the degeneration characteristic of freshwater types. The skin is smooth, or very nearly so, the preopercular spines small, and there is usually no trace of teeth on the palatines. Cold streams and springs of the United States from New England and the Great lakes to the Pacific coast.

\section{Uranidea gracilis (Heckel)}

\section{Miller's Thumb}

Cottus gracilis Heckel, Ann. Wien Mus. II, 148, 1837, New York; Gradrd, Monograph Fresh-Water Cottoids N. A. 49, pl. 1, figs. 11, 12, 1551; Güntiler, Cat. Fish. Brit. Mus. II, 157, 1860; Meer, Ann. N. Y. Ac. Sci. IV, 315, 1888; Eugene Suith, Ploc. Linn. Soc. X. Y. 1S97, 40, 1898. Cranidea quiescens DE KAY, N. Y. Fauna, Fishes, 61, pl: 5, fig. 14, 18.2, stream and lake in Hamilton county, $\mathrm{N}$. Y.

Uranidfa gracilis Jordan \& Grlbert, Bull. 16, U. S. Nat. Mus. 699, 1583: Bean, Fishes Penna. 137, 1893; Jordan \& Evermann, Bull. 47, U. S. Nat. Mus. $1968,1898$.

The body is moderately slender, spindle-shaped; mouth large, the upper jaw reaching nearly to the middle of the eye. The preopercular spine is moderately large, covered by skin. The jectorals reach to the origin of the anal, and the ventrals to the vent. The depth of the body is one fifth, and the length of the head two sevenths of the total without caudal. Teeth in villiform bands on the jaws and vomer, none on the palatine bones.

D. VIII, $16 ;$ A. 12.

The sides are olivaceous, mottled with darker; a red margin on spinous dorsal.

The miller's thumb or little stargazer is an inhabitant of New England and New York. In Pennsylvania it occurs in the head- 
waters of the Susquehanna and Mllegheny rivers. In New York it was first taken in a stream emptying into Round lake, Hamilton county, and in Lake Pleasint, of the same county. Dr Meek examined specimens from the soutlern end of Cayuga lake, Beavere reek, Mrlean X. Y., Wolcester N. Y., and Bangor N. Y., but it was not so abundant as the proceding species. Eugene Smith says that it is rele plentiful in the lead streams of the Hackensack and Saddle rivers in New York and New Jersey, in company witl black-nosed dace and darters. This species grows to a length of 4 inches and is represented by several varieties, one of which has the body robust instead of slender and another las the slender boly as in g a c i lis, but with longer fins.

This fisli is found under stones in clear, rocky and gravelly brooks. It has no importance either as food or bait and is very destructive to the eggs of other fishes.

\section{Uranidea formosa (Girard)}

\section{Latie Blob}

Coltus formosus Giraro, Monograph Fresh-Water Cottoids N. A. 58, 1850,

Lake Ontario off Oswego, in stomach of Lota macmlosa.

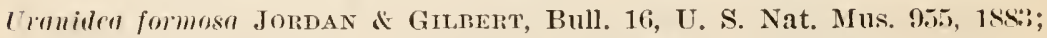

Jornan \& HVEmane, Buit. 47, U. S. Nat. Mus. 1969, 1898.

Body sleuder and graceful; head small, depressed abore; the length of the loxd is contained four and one fourth times in the length of the body; eyes molerate; preopercular spine short, stont, acute, 'urved upwards; a small spine below it; sub. opercular spine well developed. Irorsals well separated; anal beginning uuder thirel ray of soft lorsal; pectorals not reaching to posterior margin of spinous dorsal; rentrals not nearly to vent.

D. VIII-16; A. II; V. 1, 3. Iength $3 \frac{1}{4}$ inches. Deep water in Lake Ontario.

A single mutilated specimen has been recorded, this having been found by Prof. S. F. Baird in the stomach of a Burbot (I,ota ma culos a) off Oswego N. Y., in Take Ontario. 
Genus moxocernalus (Steller) 'Tilrsius

Body slender or robust, subfusiform, corered with thick skin, in which are sometimes emberded prickly plates; deciduous, gramular, or stellate tubereles also somedimes fuesent, but no

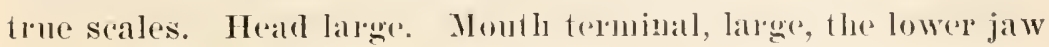

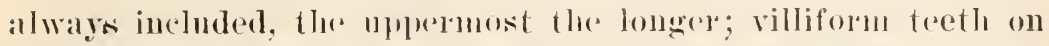
the jaws and vomer. none on the palatiues; suborbital stay strong; Hreoperele with two strollg straight spines above directed backwaled, and one below disected downard and for.

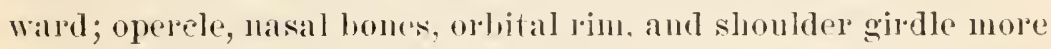
or less armed; gill nemblanm forming a fold across the rather 111\%0W isthmus; slic helind last gill redured to a mele pore, ol wanting; vertebrac about 2s. Hranchiostegals mostly six. Dorsal fius two, sepallate, the first sloot, its spines rather slender; rentral rays I, : ; caudal tin moderate, fan-shaped; pectoral fin broad, its lower lays procurerent. Latelad line well developed, its tubes sometimes frovided with bony ol cartilagimous plates, nerer chainlike nor reduced to separated pores. Species numerous, in the seas of nortlern regions; coarse fishes, little valued as food.

\section{Subgenus acastrocontes Gil‘ald}

312 Myoxocephalus aeneus (Mitchill)

\section{Grubby; Brassy Śculpin: Pigmy Sculpin}

Coltus anens Mitcmul, I'rans. Lit. \& Plil. Soc. N. Y. I, 380, 1815, New York; Cuvier d Vhlexclexpes, Hist. Nat. Poiss. IV, 189, 1820!; Je IAY, N. Y. Fauma. Fishes, 52. 1812 (not figure); Goone d Fedx. Bull. Essex Inst. XI, 13, 1579; Jordax \& Gilbert, Bull. 16, U. S. Nat. II T02, 1883; Hexx, 19tl Rep. Comm. Fish. N. Y. 251. 1890.

collus scorpio Mitcille, Trans. Lit. of Plil. Soc. N. Y. I, 380, 1815, New lork.

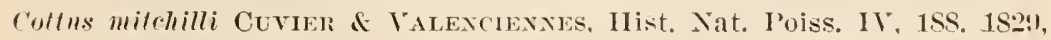

New York; DE KAY, N. Y. Fauna, Fishes, 5i. 11. 17, fig. 47. 154:;

Gëtner, Cat. Fisl. lirit. Mus. II, 164, 1860.

("ottus (Acomthocoths) anceps s.1tr.tre, Nouv. Archir. Mus. P'aris (2), I, 145, 1)l. 1, fig. 13, 18is, New York.

Areluthocoltus aruens BeAx, Bull. Am. Mus. Nat. Ilist. IX, 369, 1897; II. M. SмIтr, Bull. U. S. F. C. 1S97, 10ј, 1898.

Myorocephalus a'neus JorDax d EVErmax, Bull, t7. L. . Nat. Mus. II, 1972 , 1898, pl. CCXCY, fig. 716, 716a, 1900. 
Depth of body onc fourth of total length without caudal. Ifead four elerenths of the same length, rather broad, corered with smooth thin skin; no cirri; a few rery small warts between oceipital ridges. Caudal peduncle short and slender, its least depth about one sixth length of head and less than diameter of eye. Maxillary three serenths as long as head, reaching to below hind margin of pupil. Supraocular and oceipital ridges prominent, each nith a low, bluntish spine; the region between the supraocular spines rather convex, the space before and behind it concare; nasal spines moderate; upper preopercular spine shorter than eye, nearly twice length of next spine, about reaching middle of oprerele. Eye two thirds as long as snont, one fifth as long as head. Lateral line complete, each pore with a concealed cartilaginous plate; scattered, concealed asperities on skin of sides. No trace of slit behind last gill. Dorsal base two thirds as long as head; fourth spine longest, one third as long as head. Base of soft dor'sal nearly as long as head; first soft ray as long as the eye; fifth, sixth and seventh rays longest, one third as long as head. Caudal rounded, its middle rays two fiftlis as long as head. Anal origin under third ray of soft dorsal; anal base three fifths as long as head; longest anal ray nearly one third as long as head. l'ectoral reaches to below origin of soft dorsal; ventral to below eighth spine of dor'sal.

D. IX, 13 ; A. 10; V. I, 3; P. 1 Ј.

Grayish olive, much variegated with darker; no distinct paler spots; back and sides with broad, dark irregular bars; all the fins barred; mandible mottled; belly pale.

This little seulpin was known to Mitchill as the brazen bullhead and also to De Kay, who said it is frequently taken with the hook in Long Island Sound, and the latrbor of New York. De Kily deseribes it again under the name of the smooth browed bullhead and states that it is commonly taken with the hook in company with the flat fishes.

The grubby seldom exceeds 5 inches in length. It ranges from the Bay of Fundy to New Jersey and is rery common in seaweeds near shore. The fish has been found moderately abundant 
at Fire Island in September. In Gravesend bay it is practically a permanent resident, spawning in winter; the eggs have a beautiful green color. In the vicinity of Woods Hole, Mass., according to Dr Smitl, it is rery common, remains during the entire rear, and is the only sculpin found in summer. In winter from 10 to 50 are caught daily in fyle nets set in the harbor. The fish is then in a spawning condition, and the egge adhere to the twine.

313 Myoxocephalus octodecimspinosus (Mitchill) 18-spined Scutpin; Hacklshead

Cottus octodecimspinosus Mtтcull, Trans. Lit. \& Phil. Soc. N. Y. I, 380. 1815, New York; Curiek of Valenomenes, Ilist. Nat. Poiss, IV, 1S1, 1829; Günther, Cat. Fish. Brit. Mus. II, 163, 1860; Goode \& BEax. Bull. Essex Inst. XI, 13, 1Si9; Jordax \& Giciert, Bull. 16, U. S. Nat. Mus. 701, 1883; BeAn, Bull. U. S. F. C. VII, 137, 1888.

Cottus virginianus De KAY, Х. Y. Fanna. Fishes, 51, pl. 5. fig. 13, $18+2$. Acanthocottus virginianus Storer, Hist. Fish. Mass. 2S, pl. IV, fig. 2, 1867. Acanthocottus octodecimspinosus BEAx, Bull. Am. Mus. Nat. Hist. Ix, 370, 1897; H. M. Smiti, Bull. U. S. F. C. 1897, 105, 1898.

Myoroccphalus octodecimspinosus Jordan \& Evermann, Bull. 4T, U. S. Nat. Mus. II, 1976, 1898, pl. CCXCVI, fig. 71s, 1900.

Body moderately robust anteriorly, tapering posteriorly, its depth contained four and one half times in the standard length while the least depth of the caudal peduncle is less than one sixth length of head, the length of the latter being contained two and two thirds times in the standard length; maxilla twice long diameter of ere and contained two and one lalf times in the length of head; the spines of the head are long, the upper opercular spine being longer than in any other species of the genus; the first dorsal originates over the base of the pectoral, its third and fourth spines being longest, about four fifths as long as the base or equal to the distance from the posterior margin of the eye to the tip of the snout; the length of the second dorsal base equals the length of the head, and the longest rays of the second dorsal equal the length of the spines; anal base shorter than second dorsal base; longest rays of anal equal to length of sixth dorsal spine; caudal slightly truncate, its length equal to the depth of body; jectorals long, broad, their bases equal to half the length; the length of the ventrals is equal to the dis- 
tance from the posterior margin of the eye to the origin of first dorsal. 1). IX, 16; ᄉ. 14.

General color dark olivaceous above, paler below, under side of head and belly white; fins barred and mottled.

This large sculpin reaches the length of about 1 foot. It occurs on the Atlantic roast from Virginia to Labrador and is very rommon about rape Cod and in Massalehusets bay. In the soutleren palt of its habitat it is found only in late fall and winter; in Great Eagr bay, for "xample, an individual lä inches long was ealught at fomers Point in Norember. In Gralresend bay the fish is taken only in winter and rarly spring and it ran not endure the temprerature of the water in smmmer. It is known to the fishermen of that ricinity as the haclichead.

le Kay does not mention any particular locality for the species, but says it ranges from Virginia to Newfoundland, and pertalps farther north. IIe makes the following additional remarks: "This species, which, on account of its uncoutl form, is regarded with aversion by fishermen, is nevertheless not a bat article of food. In fact, when freshly taken from the water, aud irritated, they do present rather a formidable appearance. The head is swollen to twice its usual siz. by the disteusion of the branchial membrane; the spines stand out prominently, and the rays of all the fins become erect. It is known under the rarions popular nanes of seulpin, quere scorpion? seal robin, bullheal, sea toad, and pigfish; the latter from its croaking noise when drawn from the water."

Dr. Smith states that it first appears in the vicinity of Woods Hole, Mass., about October 1, becones very abundant by October 1.5, and remains till trecember or Jamury. The spawning time is November and December; the eggos often come ashore by bucketfuls on Nobska beach.

314 Myoxocephalus groenlandicus (Cuv. \& Vil.)

\section{Daddy Sculpin}

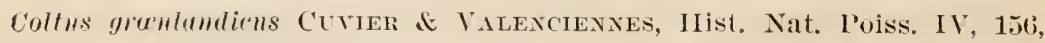
1829; Ricinatidsox, Fiuma Bor.-Amer. III, 46 ; 297, pl. 95. fig. 2, 1s:ti; De KAY, N. Y. Fauna, Fishes, 54, pl. 4, fig. 10, 1S42; Güntiner, Cat. Fish. Brit. Mus. II, 161, 1860. 
Cottus scorpius gronlandicus Goode \& BEAx, Bull. Essex Inst. XI, 19, 1879; Bean, Bull. 15, U. S. Nat. Mus. 118, 1879; Jordan \& Gilbert, Bull. 16, U. S. Nat. Mus. 703, 1883.

Acanthocollus raviabilis Storer, Hist. Fish. Mass. 26, pl. IV, fig. 1, 1867. Acanthocottus gronlandicus H. M. SмIтн, Bull. U. S. F. C. 1897, 105. 1898. Iyoroccphalus gromlandicus JoRDAN \& EvERMANx, Bull, 47, U. S. Nat. Mus. II, 1974, 1898.

The length of the body is four and one half times the depth. Head large, the length being coutained two and one half times in the length of the body. Mouth large, the lower jaw included; maxillary reaching posterior edge of orbit, its length three sevenths length of head; the supraorbital and occipital spines blunt, tuberclelike, without cirrus; a small tubercular spine on front of occipital ridge; upper preopercular spine short, only reaching the middle of opercular spine, its length equaling eye, not twice that of the spine below it; opercular spine sharp; nasal spines sharp; suprascapular spine rather strong and short. Sides of body above lateral line with a series of embedded prickly plates, below which are numerous scattered spines and prickles. Dorsal and anal fins high, their hight more than one serenth total length without caudal. Ventrals long. Pectorals reaching to rent. Eye large, equal to width of interorbital space. D. X, 17; A. 14; V. I, 3; P. 18.

Dark brown abore, with broad darker bars; below yellowish, the belly in the male with large pale spots; back and top of head with grayish blotches; fins brown and yellow, all of them spotted and barred. Sexual differences great, the males more brightly colored; the round white spots strongly marked; females with rough crests on the head.

The daddy sculpin is the largest of its kind on our east coast as it grows to the length of 25 inches. It ranges from New York to Greenland, but is common in New York and Massachusetts waters only in fall and winter. De Kay had met with a single specimen which was taken near Hell Gate. Storer records it as abundant on the coast of Massachusetts feeding on small fish, crabs, sea urchins and other invertebrates; but not valued as food. Dr Smith remarks that it arrires at Woods Hole in October, remains till December or January, spawning in November 
and December when there is a great loss of eggs through storms. Fabricius records its spawning in Greenland in December and January and describes its eggs as red colored. The eggs, he states, are deposited on seaweed. The Greenlanders eat the fish for their daily food and they eat its eggs raw.

\section{Genus Triglopsis Girard}

Body and head slender; skin naked; lateral line chainlike; teeth on vomer, none on the palatines; eye large, the interorbital area concave; bones of lower part of head extensively cavernous; a small but distinct slit behind last gill; gill membranes almost free from the isthmus, forming a broad fold across it; preopercular spines straight, simple, 4 in number, the lower turned downward; fins large. Fresh-water fishes, closely related to Oncocottus, from which they have doubtless becone degraded through fresh-water life. There is no tangible differ $\mathrm{r}^{2}$ ence in structure in any part of the body.

\section{Triglopsis thompsoni Girard}

\section{Lake Sculpin}

Triglopsis thompsoni Girard, Proc. Bost. Soc. Nat. Hist. IV, 19, 1851, off Oswego, Lake Ontario; Monograph Fresh-Water Cottoids, N. A. 65, pl. 2, figs. 9, 10, pl. 3, figs. 22-25, 36-38, 1852; Jordan \& Gilbert, Bull. 16, U. S. Nat. Mus. 709, 1883; Jondan \& Erermann, Bull. 47, U. S. Nat. 11 us. II, 2005, 1898.

Triglopsis stimpsoni Hor, Trans. Wisconsin Ac. Sci. 98, 1872, Lake Michigan.

Ptyonotus thompsonii Güntwer, Cat. Fish. Brit. Mus. II, 175, 1860.

Body elongate, very slender, the depth being one sixth of the length. Head long, depressed above, the length being one third of the length of the body. Snout long and pointed; eye quite large, nearly as long as snont, much wider than interorbital space, one fourth as long as the liead; jaws subequal; month large, the maxillary extending rather beyond middle of eye; preopercle with four sharp spines, the upper much shorter than pupil; cavernous structure of skull highly developed; upper surface of head smootlı; gill membranes not broadly united; nearly free from isthmus. Dorsal fins well separated; spinous dorsal short and low, its hight little more than length of snout; second 
dorsal very large, three times hight of first, its longest rays about as long as head; anal high, half as high as second dorsal; pectoral long, reaching past front of anal; ventrals well dereloped; lateral line chainlike, conspicuous; skin perfectly smooth. Length 3 inches. D. VII-1S; A. 15; V. I, 3; pyloric caeca seven.

Pale olivaceous, with darker blotches; upper fins faintly banded.

Deep waters of the Great lakes; specimens have been taken sparingly in Lakes Ontario and Michigan. The U. S. Fish Commission obtained two examples at Nine Mile Point N. Y. and on June 10, 189:3, a single individual was collected at the same place. The type of the species was taken by Spencer F. Baird off Oswego, Lake Ontario. Dr William Stimpson obtained a specinen in deep water of Lake Michigan which formed the type of Dr Hoy's Triglopsis stimpsoni.

The close relationship of $\mathrm{Triglopsis}$ and $\mathrm{Oncocottus}$ has been pointed out. Both young and adults of $\mathrm{Oncocot} \mathrm{cus}$ have been found occasionally in fresh water and the descent of the lake sculpin from a species of $\mathrm{On} \mathrm{cocot} \mathrm{tus}$ is highly probable.

\section{Genus hemitripterus Cuvier}

Body moderately elongate, scaleless, but the skin covered with prickles and bony protuberances of various sizes and forms. Head large, with numerous bony humps and ridges and fleshy slips above; orbital rim much elevated, the interorbital space deeply concave; a depressed area at the occipnt, behind which are 2 blunt spines on each side. Mouth very wide; jaws, vomer, and palatines with broad bands of teeth; no slit behind last gill; gill membranes broadly united, free from isthmus; preopercle with stout, blunt spines; suborbital stay very strong, forming a sharp ridge. Spinous dorsal much longer than the soft part, of 16 to 18 spines, of which the first two are the highest, and the fourth and fifth shorter than the succeeding ones, the fin thus deeply emarginate; pectoral fins rery broad, much procurrent; rentrals I, 3 . Large fishes of singular appearance, inhabiting the North Atlantic and Pacific. 


\section{Hemitripterus americanus (Gmelin)}

\section{Sea Raven}

Scorpana americana Gneuin, L. Syst. Nat. 1220, 1788.

Cottus hispidus Bloch \& SchneIder, Syst. Ichth. 63, 1801, New York.

Scorpena flaca Mitchild, Trans. Lit. \& Phil. Soc. N. Y. I, 382, pl. II, fig. 8, 1815.

Scorpana purparea and rufa Mitchild, Am. Month. Mag. II, 245, February 1818.

Hemitripterus acadiamus Storer. Hist. Fish. Mass. 35, pl. VII, fig. 4, 1867.

Hemilripterus americanus Cuvier \& Valenciennes, Hist. Nat. Poiss. IV, 268, pl. 84, 1829; DE KAy, N. Y. Fauna, Fishes, 56, pl. 6. fig. 16, 1842; Günther, Cat. Fish. Brit. Mus. II, 143, 1860; Jordan \& Gileer', Bull. 16. U. S. Nat. Mus. 685, 1883; BeAn, 19th Rep. Comm. Fish. N. Y. 251, 1890; Bull. Am. Mus. Nat. Hist. IX, 370, 1897; H. M. Smitr, Bull. U. S. F. C. 1S97, 105, 1S98; Jordan of Evermann, Bull. 47, U. S. Nat. Mus. II, 2023, 1898, pl. CCCV, fig. 738, 1900.

The length of the body is three and three fourths times the depth and two and two thirds times the length of the head. Body villous, the prickles enlarged and tuberclelike along the back and lateral line; nasal spines strong; supraocular ridge much elevated, with dermal flaps and two blunt spines; three pairs of fleshy slips on nasal bones, and two on supravcular ridges; smaller cirri on maxillary, on preorbital, and several on lower jaw; interocular space very deeply concave; two blunt occipital spines on each side, outside of which are two or three others; opercle small, with a bony ridge; preopercle with two blunt spines, below which are one or two others; lower jaw slightly projecting; maxillary reaching beyond eye, and about half as long as the head; pectorals nearly reaching anal; highest dorsal spine three fifths length of head, as long as caudal; ventrals reaching half way to anal.

D. IV, XII-I, 12; A. 13 ; Lat. 1. 40; vertebrae $16+23$.

Reddish brown, marbled with darker brown, and much variegated; yellowish below; fins rariegated with light and dark. Atlantic coast of America; chiefly northward from Cape Cod.

This fish is the Acadian bullhead of Pennant and the yellow s c o r pa en a of Mitclill. According to De Kay the name sea sculpin is sometimes applied to this species. Other names given to it are rock toadfish and deep water sculpin. It is found along the east coast from Nova Scotia to Chesapeake bay. 
De Kay saw it very rarely. In Gravesend bay, specimens have been taken by John De Nyse in April, May, October, November and December.

We are indebted to Captain Lewis B. Thurber, of Patchogue, for specimens, which were taken in the fall of 1884 . These were all the more remarkable for having attached to the head and back a peculiar hydroid.

In the vicinity of Woods Hole Mass. the fish is common in October and November, the individuals usually measuring about 16 inches; the young are rare. It grows to a length of 2 feet and is one of the most brightly colored of the marine fishes. Its colors are subject to great variation. The head is furnished with numerous fringes and the dorsal spines are often produced into filaments. The mouth is large, the skin rough and the belly very distensible at the will of the fish, making this species one of the curiosities of the sea. It feeds upon mollusks and all other invertebrates of suitable size.

The sea raven is not eaten, though its flesh is of excellent flavor. It is useful as a scavenger and as bait for the eel and lobster.

The sea raven spawns in November. Eggs observed Nov. 29, 1897, were in masses adhering tightly together. The egg at that date was $\frac{5}{3 \cdot 2}$ inch in diameter, and showed the form of the fish distinctly. Its color when first deposited is jellow but soon changes to salmon and then to amber before hatching.

Family Agonidae

\section{Group AGONINAE}

\section{Genus aspidophoroides Lacépède}

Body and head more or less slender; head 4 to 6 , width 5 to 8 in length of body; eight longitudinal rows of plates, the lateral line in the upper lateral row; about 40 plates in the dorsal series. Terminal rostral plate present, unarmed; mouth terminal; teeth on jaws, romer, and palatines. Supraocular and occipital spines absent; plates of body more or less keeled, without spines. First dorsal absent; second dorsal and anal small, opposite each other, each with four to seven rays. Gill mem. 
branes united, narrowly joined to isthmus anteriorly, free behind.

\section{Subgenus ulcisa Cramer \\ 317 Aspidophoroides monopterygius (Bloch)}

\section{Sea Poacher}

Cottus monopterygius BLoch, Ichth. II, 156, pl. 178, figs. 1, 2, $17 \mathrm{S6}$.

Aspidophorus monopterygius Cuvier \& VAlenciennes, Hist. Nat. Poiss. IV, 224, 1S29; VI, 5อ̄4, pl. 169, 1830; DE KAY, N. Y. Fauna, Fishes, 62, pl. 2, tig. 5, 1842.

Aspidophoroides monopterygius STORER, Rep. Ichth. Maș. 22, pl. 1, fig. 1, 1839; Günther, Cat. Fish. Brit. Mus. II, 216, 1S60; Storer, Hist. Fish. Mass. 32, pl. VIII, fig. 1, 1867; Goode \& BEAN, Bull. Essex Inst. XI, 12, 1879; Jordan and Gilbert, Bull. 16, U. S. Nat. Mus. 724, 1883; Goode \& BEAN, Oceanic Ichth. 283, pl. LXXII, fig. 260, 1896; Jordan \& Evermand, Bull. 47, U. S. Nat. Mus. II, 2091, 1S98, pl. CCCXII, figs. $756,756 \mathrm{a}, 1900$.

Body very slender, tapering, elongate, its greatest depth nearly one twelfth of total length without caudal, its greatest width about one tenth of the same length. Head triangular, much narrowed anteriorly, its length one sixth of total without caudal; nasal spines very large, diverging, inserted near tip of snout; no otler spines anywhere; eyes very large, longer than snout, one fourth. as long as the head; supraocular ridges very high; a ridge extending backward from eye along temporal region; lower jaw slightly included. Caudal peduncle very long and slender, forming about two fifths of the length. Breast with flat plates. Dorsal ridges high anteriorly, the median line of back from snout to dorsal fin concave. Dorsal origin mid. way between hind margin of orbit and base of middle caudal rays; base of dorsal one half as long as the head and equal to length of second, and longest ray. Anal immediately under dorsal and nearly equal to it in length of rays. Caudal convex behind, the middle rays two thirds as long as the head. Ventral two fifths as long as head. Pectoral reaching to eighth plate of the dorsal ridge, nearly as long as the head. Plates on breast radially striate, the two median ones larger than the rest; a few small plates on hinder median part of gill membranes, and on narrow underside of mandible; two large plates with raised centers in front of and four to eight small spineless plates in one 
or two series on base of pectoral. D. 5 or $6 ; 1.5$ or $6 ; 1$. $9 ; \mathrm{V}$. I, 2; C. 10 or 11; pyloric caeca four or five; lateral line about 50.

Color brownish, pale below, with indefinite cross bands of darker, two in front of, and one under dorsal, and two or three on caudal peduncle; rays of dorsal and upper rays of pectoral brownish, interrupted by lightèr, giving an indefinite appearance of cross bands; caudal dark; ventrals and anal in both sexes pale.

This fish reaches a length of 6 inches; it is found in moderate depths from Greenland to Rhode Island and doubtless occurs off Long Island in suitable depths though specimens have not been recorded in New York waters. The species is very frequently obtained from the stomachs of haddock and cod, and the trawl has taken it in depths as shallow as 44 fathoms. In $187 t$ the liead of a sea poacher was dredged up on the "Pecten Ground," off Watch Hill R. I. The fish exists in great abundance in Massachusetts bay and farther north.

\section{Family CyclopteridaE}

\section{Lump Suckers}

\section{Group CYCLOPTERINAE}

Genus cycloptenus (Artedi) Linnaeus

Body more or less compressed toward the back, somewhat triangular in a transverse section at the first dorsal, covered with conical, rough, bony tubercles; head short, thick, subquad. rangular in a cross section; snout blunt, rounded; mouth anterior, opening slightly upward; teeth simple, small, arranged in a band; eye moderate, lateral; dorsals two; caudal distinct; disk moderately large, anterior, below the head; no barbels about the month; first dorsal fin in the adult completely hidden by the skin, the larger tubercles of the flanks, though in regular series, haring a scattered appearance. One species, reaching a considerable size, in the north Atlantic.

\section{Cyclopterus lumpus Linnaens}

\section{Lumpfish; Lumpsucker.}

cyclopterus coerulens Mitchild, Trans. Lit. \& Phil. Soc. N. Y. I, 480. pl. II, fig. 7,1815 , New York Harbor.

Lumpus muglorum DE KAY, N. Y. Fauna, Fishes, 305, pl. 54, fig. 175, 1512; Storer, Hist. Fish. Mass. 208, pl. XXXII, fig. 2, 186\%. 
Cyclopterus lumpus Linfaeus, Syst. Nat. ed. X, I, 260, 1758; Günther, Cat. Fish. Brit. Mus. III, 155, 1861; Goode \& BeAn, Bull. Essex Inst. II, 11, 1879; Jordan \& Gilbert, Bull. 16, U. S. Nat. Mus. 747, 1883; Bean, Bull. Am. Mus. Nat. Hist. IX, 370, 1897; H. M. SмIтh, Bull. U. S. F. C. 1897, 105, 1898; Jordan \& Evermann, Bull. 47, U. S. Nat. Mus. II, 2096, 1898, pl. CCCXIII, fig. 757, 1900.

Body massive, compressed, subtriangular in transverse section through the middle, belly flattened, the portion behind the abdominal chamber much compressed, and less than one half the length of the body proper; greatest depth of body one half or more than one half of total length including caudal. Caudal peduncle short, its least depth one third length of head. Head short, subquadrangular in transverse section, forehead broad, flattened; length of head one fourth of total length with caudal. Nape high. Snout short, broad, blunt, one fourth as long as the head. Mouth wide, terminal, oblique, the maxillary reaching to below the front margin of the orbit. Eye lateral, placed high, as long as the snout, and one third as wide as interorbital space. Nostrils small, the hinder smaller, near the eyes on interorbital space, the anterior farther forward, halfway to the mouth, with a short tube. Gill opening moderately wide, about three fifths length of head, its lower third in front of base of pectoral. Fins with rounded margins, rough, with small tubercles. First dorsal distinct in very young individuals, variable in shape, thick and fleshy, with weak rays in older stages; second dorsal always distinct, broad, rounded, its origin two and one half times as far from tip of snout as from base of middle caudal rays, its longest ray one half as long as head. Caudal broad,

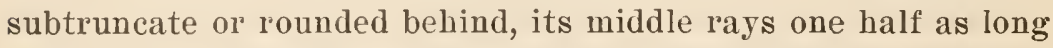
as the head. Anal exactly opposite the dorsal and about equal in size. Pectoral broad, rounded, fringed, not indented at the sides of the disk, its length one sixth of the total without caudal. Disk little longer than wide, about as wide, or nearly three fourths as long, as the head. Skin thickly covered with small, irregular subconical tubercles, the sides of which are roughened with small, conical protuberances. On older individuals, larger, longitudinally compressed tubercles form a vertical series from the nape over the first dorsal; a series of three tubercles at 
each side of the space between the dorsals; a row of larger ones extends from the supraorbital region along the flank to the upper part of the tail; a series, starting a little above the pectoral, passes to the lower portion of the tail; and a third lateral series reaches along each line of the lower surface from the side of the disk to the anal. The fleshy ridge enreloping the first dorsal is subject to considerable rariation; it usually continues forward on the nape and becomes indefinite at the occiput. D. VI to VIII, 11 ; A. 9 or 10 ; V. 6 ; P. 20 ; C. 12 to 14 ; B. 6 ; vertebrae $11+18=29$.

Colors in alcohol, brownish or olive to grayish, the tubercles darker. In life the tints vary from yellowish or greenish in the young to more or less brilliant red in males, or bluish to dark brown in females; spots, blotches, cloudings, or other markings are not infrequent. The young often take the color of their surroundings. De Kay had a specimen with the following colors: above deep blue, becoming paler on the sides, which are tinged with jellowish beneath, approaching to red. Ventrals bright yellow, and in the spawning season, bright red. Irides yellowish. Kumlien had one with iris umber.

The lumpfish is called cock-paddle and hen-paddle in Scotland, lumpsucker, lumpfish, and sea owl in England, Licorne de Mer in France. Its habitat is in the North Atlantic, on rocky shores of both coasts, south to New York and France. It is said to attain to a weight of 17 pounds and a length of 20 inches, but is usually much smaller. The species is rarely used for food in our country, but in Scotland it is said to be considered a great delicacy.

By means of its ventral disk it can adhere firmly to any solid substance. Pennant relates that upon throwing one of these fishes into a pail of water it adhered so strongly that upon taking hold of the fish by the tail he lifted the whole vessel containing several gallons of water.

The lumpfish is found in Graresend bay in May. It will not live longer than a few weeks in captivity. Adults are common in the vicinity of Woods Hole Mass. in April and a few are seen 
in May. The young are very common throughout the summer in Vineyard Sound among driftweed. Spawning occurs in April, sometimes in March, near the shore. After spawning the female retires to deep water and the male guards the eggs which hatch among searreed.

\section{Family LIPARIDIDAE \\ Sea Snails \\ Group LIPARIDINAE}

\section{Genus NEoLiparis Steindachner}

This genus differs from Li p a $\mathrm{r}$ is in having a deep notch in the dorsal fin anteriorly, separating the spines from the soft lays. The species approach more nearly to the cottoid type, from which the liparids are descended. In general the vertebrae are fewer, the fin rays fewer, the ventral disk larger, and the rertical fins better separated than in the more degenerate members of the family. The retention of the notch between the dorsals fully justifies the recognition of $\mathrm{Ne}$ oli $\mathrm{p}$ a $\mathrm{r}$ is as a distinct genus.

\section{Neoliparis atlanticus Jordan \& Evermann}

\section{Sea Snail; Lumpsucker}

Liparis montagni Cuvier, Règne Anim. ed. 1, rol. 2, 227, 1817; Jordan \&

Gilbert, 743, 1883, in part; Garman, Discoboli, 47, 1892, with plate. Liparis Montagni Putnam, Proc. Am. Assoc. Adv. Sci. 335, 1874; Goone i BeAN, Bull. Lissex Inst. XI, 12, 1879.

Neoliparis montagni H. M. Sмгтн, Bull. U. S. F. C. 1897, 105, 1898.

Neoliparis atlanticns Jordan \& Evermann, Bull. 47, U. S. Nat. Mus. II, $2107,1898$.

Body widest at gill opening, compressed posteriorly, deepest below third dorsal spine, its depth two ninths to one fourth of the total length without caudal. Head broader than deep, depressed above the eyes, its length contained four and two thirds times in total withont caudal; snout one third and eye one fifth as long as the head. Month narrow, its cleft transverse and extending to anterior nostril; lower jaw included; teeth tricuspid, the middle cusps highest; gill openings very narrow, the lower border opposite first ray of pectoral; anterior nostril tubular, the tube three fifths as long as the eye; posterior nostril with a low flap; skin loose, lying in folds. Origin of dorsal not far behind pectoral, its distance from tip of snout one third its 
distance to base of caudal. Dorsal with a very shallow notch, the spines nearly continuous with the soft rays; in the males much elevated, the tips thickened and membranes deeply incised; the first or longest spine as long as head; the sixth or last not quite one half as long as head; middle rays of soft dorsal one half as long as head; dorsal and anal joined to base of caudal; caudal nearly as long as head; pectoral almost reaching anal, slightly longer than head; lower rays exserted, forming a slight lobe. Tentral disk one half to four sevenths as long as the head.

D. VI, $25 ;$ A. $23 ;$ P. 30.

Color reddish brown, with small scattered light or bluish dots over the body; fins darker, clouded with pale, the dorsal broadly edged with darker. Described from a specimen about 5 inches long, from Godbout, Quebec, and from other specimens collected at Salem Mass., and Woods Hole Mass. (After Jordan and Evermann)

The sea snail is generally common along rocky shores from Newfoundland to Comnecticut. At Woods Hole it is not common in the shallow waters near the shores. In Massachusetts bay it is a resident of rocky bottoms among the roots of the Kelp ( $\mathrm{L}$ a m in a ria s a c c h a r in a), but is less frequently taken than the striped lumpsucker. Putnam recorded specimens from Salem and Nahant. The species reaches a length of about $\mathbf{5}$ inches.

\section{Genus LIPARIS (Artedi) Scopoli}

Body rather elongate, covered with smooth skin, which is usually freely movable; head short, flattened above; mouth horizontal, the jaws equal or the lower jaw included; teeth in several series, close set, always more or less tricuspid, the adult with the onter cusps often worn or obliterated; maxillary covered by skin of preorbital region; anterior nostrils tubular or not; ventral disk well developed on the breast, its front below or behind the middle of the head, its surface with 13 lobes; an anterior median lobe, and one corresponding to each of the six rays in the fin; each lobe with a horny papilla covering, which is sometimes lost; vent well behind the head, about midway 
between the sucking disk and anal fin; dorsal fin continuous, undivided, its spines not differentiated; caudal well developed; dorsal fin free from caudal or joined; pectoral broad, procurrent at base, emarginate and free at tips, some of the lower rays produced; vertical fins enveloped in the lax skin; vertebrae 35 to 55. Northern seas, near the shores; the species less arctic in distribution and, in general, inhabiting shallower water than is the case with Careproctus and Paraliparis, a fact associated with the reduced number of vertebrae in $\mathrm{L}$ i p a r is. The species are numerous, but in general well defined, their characters varying with age. In most of the species color varieties occur, several having the body often marked everywhere with concentric curved stripes or rings.

\section{Subgenus crrparis (Artedi) Scopoli}

\section{Liparis liparis (Linnaeus)}

Sea Snail; Striped Sea Snail

Cyclopterus liparis Linnaeus, Syst. Nat. ed. XII, I, 414, 1766, Northern Ocean.

Liparis vulgaris Fleming, Brit. Anim. 190, 1828; GüNTHER, Cat. Fish. Brit.

Mus. III, 159, 1861; Goode \& BEAN, Bull. Essex Inst. XI, 12, 1879;

BEAN, Bull. 15, U. S. Nat. Mus. 115, 1879.

Liparis lineata Jordan \& GilberT, Bull. 16, U. S. Nat. Mus. 742, 1883.

Liparis liparis Cuvier, Règne Alim. ed. 1, vol. 2, 227, 1817; Garman, Discoboli, 57, 1S92; Jordan \& EveruanN, Bull. 47, U. S. Nat. Mus. II, 2116, 1S9S; H. M. SuItн, Bull. U. S. F. C. 1897, 105, 1898.

Body thick and subcylindric anteriorly, compressed posteriorly, enveloped in an unctuous, thin, loose skin; its greatest depth about one fifth of the total length. Head obtuse, one fourth of total length; nape slightly swollen. Snout broad, not depressed, moderately long. Cleft of mouth horizontal, not reaching vertical from front of eye; lips rather thick; upper jaw longer than lower. Both jaws with a band of villiform teeth, becoming cardlike in very large individuals. Eye lateral, but interfering with the upper profile of head, one seventh as long as head, one half as long as snout and one half of width of interorbital space. Nostril close before eye. Gill opening reduced to a vertical slit extending downward on upper part of base of pectoral, the remainder of the gill membranes being united with 
the base of the pectorals and with the isthmus. Gills $3 \frac{1}{2}$; pseuod branchiae not evident. Pectoral rery broad, extending downward and forward under the throat; the twelve upper rass reach to the rertical from the origin of the anal, the remainder gradwally becoming shorter as far as the last but six, which are considerably produced. The six rays which constitute the base of the rentral disk may be easily distinguished; the disk is surrounded by about 13 soft and flat papillae. Dorsal fin commencing above middle of pectoral and slightly connected with caudal; its middle rays highest. Caudal moderately long and rounded, its rays simple, articulated. Anal origin below serenth ray of dorsal, the fin continuous with the caudal. Vent inidway between rentral disk and anal fin.

B. 6 ; 39 to 36 ; A. 27 to 29 ; P. 34 to 37 ; C. 10 to 14 ; pyloric caeca 10 to 16 ; rertebrae 38 to 42 .

Color very variable. Some specimens are pale yellowish brown, mottled and spotted with dark brown. Others are reddish gray, with broad, irregular black spots; fins reddish, with black dots arranged in transrerse bands. Others, again, are brownish, with irregular darker longitudinal streaks on the head and body. (After Günther)

The species grows to the length of 5 inches. It inhabits the North Atlantic, on both coasts, extending southward to Long Island Sound and France.

At Woods Hole Mass., according to Dr Smith, it is common in winter on rocky bottoms, and is found full of spawn in December and January. In Massachusetts bay it is a resident of rocky bottoms among the roots of the kelp. Mr J. H. Sears discovered it in the vicinity of Salem, near Baker's island, in 6 feet of water. Kumlien found it fastened to kelp in Cumberland gulf in depths of 5 to 7 fathoms. It is to be noted that Kumlien's specimens had an increased number of rays in the dorsal and anal fins.

Richardson mentions this sea snail from the west side of Davis strait, in lat. $70^{\circ} \mathrm{n}$. and from Regent's inlet.

Professor Collett found the alimentary canal of one specimen filled with small amphipods, one of them being Caprella 
septentrionalis, together with many indiriduals of Protomedeia fasciata. In Gïnther found the stomach of a large specimen filled with shrimp.

\section{Group GOBIOIDEI}

(Gobies)

\section{Family gobIIDAE}

Subfamily GOBIINAE:

Genus gовоомон Girard

Body entirely naked; mouth moderate, horizontal; snout blunt; teeth in several series, the outer row enlarged; no canines; dorsal spines nolmally seven, rarely five or six; second dorsal and anal short; no barbels about head; shoulder girdle without flaps. Species chiefly American.

\section{Gobiosoma bosci (Lacépède)}

\section{Naked Goby; Mud Creeper; Oysterfish}

Gobius bosci LacéPÈne, Hist. Nat. Poiss. II, 555, pl. 16, fig. 1, 1798, Charleston, S. C.

Gobius alepidotus Bloch \& SchneIder, Syst. Ichth. 547, 1801; DE IÁr, N. Y. Fauna, Fishes, 160, pl. 23, fig. 70, 1842, New York Harbor.

Gobins viridipallidus MrtcmlL, Trans. Lit. \& Phil. Soc. N. Y. I, 379, pl. 1. fig. S, 1815.

Gobiosoma alepidotum Günther, Cat. Fish. Brit. Mus. III, 85, 1861; Jordan \& Gilbert, Bull. 16, U. S. Nat. Mus. 63S, $18 S 3$.

Gobiosoma bosci Jordan \& Gilbert, Proc. U. S. Nat. Mus. 613, 18S2; IBenx. Bull. U. S. F. C. VII, 136, 1Sss; 10th Rep. Comm. Fish. N. Y. 24!), 1S90; Bull. Am. Mus. Nat. Hist. IX, 370, 1897; Jordan \& EverMANN, Bull. 47, U. S. Nat. Mus. III, 2259, 1S98; H. M. Sмiтн, Bull. U. S. F. C. $1897,105,1895 ;$ BeAn, 521 Ann. Rep. N. Y. State Mus. $109,1900$.

Body moderately elongate, its deptlı one fifth or one sixth of total length without caudal; head very broad, three tenths of total length without candal, flattisl above, with tumid cheeks. Eye small, longer tlian snout, one fifth as long as the head. Mouth large, little olsique, the jaws subequal, the maxillary, at least in males, extending to below posterior part of orbit, three serenths as long as liead. Teeth in few series, the outer considerably enlarged; two teeth on each side of inner series of lower jaw specially large canines. Dorsal spines slender, not filamentous. Caudal rounded, D. V1I, 14; A. 10. 
Olivaceous or grayish, with darker cross shades of rounded spots; seven or cight paler transrerse bars over the body and tail; fins dark brown, with a bluisl shade. De Kay says the body is greenish brown, with seren rertical dusky bands, and the caudal fin with two or three curved bars.

The naked gobs, or mud creeper, is found on the Atlantic coast from Cape Cod to Florida.

This is the rariegated goby of Drs Mitchill and De Kay. Dr Mitchill deseribed it as Gobius ri ridi-pallidus. He had specimens $2 \frac{1}{2}$ inches long from the bay of New York, and illustrates one of them in fig. 8, pl. I, of his Fishes of New Fork.

The rentral fins of this little fislı form a sucking disk of conlparatively great power, as may be appreciated from the following sentence of Dr. Mitchill: "One of the individuals now lying before me adhered so firmly to a stone that he was lifted out of the water by an oysterman." The variegated goby does not exceed $2 \frac{1}{2}$ inches in length, and is now known from Buzzard's bay southward, its southern limit being undetermined. In the Gulf of Mexico occurs a form which was set apart as a distinct species by Girard, hut this may be merely a color variety. The fish has no economic value. Its name in Great South bay is mudereper. Numerous examples were found at the mouth of swan ereek and in Blue Point cove. Sereral were obtained also at Fire Island. All of these were secured late in September.

In 1901, the young, measuring from $\frac{1}{2}$ inch to $1 \frac{1}{8}$ inches, were taken in Swan river, Angust 8 , and on September 14 some large individuals were secured in empty oyster shells off Duncan's creek. Numerous specimens were caught in eel pots off Swan river and off Widow's creek, and the species was obtained once in fresh water in Swan river.

Taken in moderate numbers in oyster dredges at Eaton's Neck Long Island, in the fall of 1896 . Several individuals lived all winter in a balanced tank, and took food greedily, but on the approach of summer all died.

On August 13, August 30, and September 16, 1887, the writer seined a few examples at Somers Point and Ocean City N. J. 
At the latter place they were associated with $\mathrm{Fundulus \text {, }}$ Cyprinodon, Lucania, Mugil, Bairdiella, A ng $\mathrm{g}$ illa, and swarms of shrimp.

This little goby seizes its food with a snap, and immediately darts off to conceal itself in a rock crevice or behind plants.

\section{Group TRACHINOIDEI}

Trachinoid fishes

Family URANOSCOPIDAE

Stargazers

Subfamily uranoscopinaw

Genus astroscopus Brevoort

Body robust. Head abore not entirely corered with bone, the occipital plate ceasing much behind the orbits; from the middle line anteriorly a Y-shaped bony process extends forward, the tips of the fork between the eyes; a trapezoidal space on either side of the $Y$, corered by naked skin, bounded by the $Y$, the eyes, the suborbitals, and the occipital plate. A covered furrow behind and on the inner side of each eye terminating near front of orbits, its edges fringed. Head without spines; humeral spine obsolete; lips and nostrils fringed; no retractile tentacle in mouth. Young individuals with top of head largely covered by bone. Head scaleless; back and sides corered with close set scales; belly mostly naked. No spine before the ventrals. First dorsal small, of four or five low, stout, pungent spines, connected by membrane to the second dorsal which is rather high and long; pectorals and rentrals large. Species American, distinguished from the Old World genus, Uran os copus, chiefly by the unarmed head.

\section{Astroscopus guttatus Abbott}

Spotted Stargazer

Astroscopns guttatus Aввотт, Proc. Ac. Nat. Sci. Phila. 365, 1860, Cape May, N. J.; BeAn, Bull. Am. Mus. Nat. Hist. IX, 370, 1897; Jordan \& Everdrann, Bull. 47, U. S. Nat. Mus. III, 2310, 1898.

Upsilouphorus gututus BEAN, Proc. U. S. Nat. Mus. 60, 1879; Krrscir, Proc. Ac. Nat. Sci. Phila. 264, 1889.

Astroscopus anoplus Bean, Bull. U. S. F. C. VII, 136, pl. I, figs. 1, 2, 1889, Somers Point, N. J., not Uranoscopus anoplos C. \& V. 
Depth of body contained four times in its length in the soung, three and one fourth times in the adult. Eye small, its diameter contained five and one half times in interorbital space. Naked space between forks of $\mathrm{Y}$ on top of head short and bread, but longer than the restical limb of the $Y$, which is very short. 'Two distinct spinules directed forward before eye; white spots on body rery small and irregular, without dark rings; base of dorsals equaling in length the distance from front of first dorsal to tip of snout; base of first dorsal twice length of its longest spine; first spine equaling second in length, and three times length of last. Middle caudal rays a little shorter than ventral fin. Pectoral slightly longer than rentral, two serenths of total length to caudal base, and extending to fifth anal ray.

D. IV or $T^{T}, 13$ or $14 ;$ A. $13 ; \mathrm{V} . \mathrm{I}, 5$.

$\mathrm{Color}^{\circ}$ of upper parts of body and lower jaw bright chocolate; belly and throat white; darker portions covered witl numerous circular spots much lighter than ground color; membrane of first dorsal black; second dorsal white with three iregular bands of dull black obliquely across it; the caudal with three parallel bands of blackish brown, the middle of which appears to be the continuation of a rariable longitudinal band on the center of each side; the anal having a variable band of dull brown, darker upon the posterior termination.

If the young stargazer identified as Astros copus a noplus lyy the writer in his paper on the Fishes of the Great Egg Harbor Bay, be identical with the A. gut t a t u of Abbott, the following notes will be of interest in connection with the species under discussion:

A single poung individual, 1 inch long, was seined at Ocean City, August 1. The species has not previously been recorded from this bay.

Another example, $2 \frac{1}{2}$ inches long, was caught at Longport, August 26, not far from the inlet. The colors of the specimen, August 28, are as follows: Top of head, cheeks, sides, and a narrow strip along dorsal bases, plum color; back, olive; lower part of head, belly, rentrals, anal, and soft dorsal, whitish; caudal, 
pale, with a faint yellow blotch at base and a dusky streak on middle portions; spinous dorsal. black; chin with a rellow T-shaped marking, the stem of the $\mathrm{T}$ bounded on each side by a wing-shaped blotch of purple, which has a dark inner edge; pectoral, plum color, its lower margin whitish. D. IV, 14; A. 13. A prominent anal papilla. A low fold of skin extends from the ventrals along the median line of the belly to the anal papilla. Two slight furrows between the eyes, with two rows of papillac along their inner margins. Behind these furrows are naked spaces, little developed, but quite distinct. Nostrils surrounded by a row of papillae.

The same stargazer was caught in Gravesend bay Oct. 24,1894 . It lived about a month in captivity and then was killed by the low temperature of the water.

This stargazer inlabits the Atlantic coast of the United States from Long Island to Virginia, but is nowhere plentiful. It has been recorded from Gravesend bay, N. Y., Tompkinsville N. Y. Somers Point N. J., Cape May N. J. and Norfolk Va. The species attains to the length of 12 inches. The changes through which the fish passes from youth to adult age are rather remarkable.

\section{Family BATRACHOIDIDAE:}

\section{Toadfishes}

Genus opsanus Rafinesque

Body comparatively short and robust, scaleless; head large, depressed; jaws, rom 're and palatines each with a single series of strong blunt tecth; mandible with an additional external series at symphysis; teeth of upper jaw small; dentary bones forming an acute angle at symphysis; lips fleshy; upper angle of opercle with two diverging spines, more or less concealed in the skin; no poison glands; spinous dorsal of three stout, short spines, the second the longest; axil of pectoral with a large foramen; lateral line obscure, its pores not conspicuous; young with a series of small, tufted cirri on back and sides; branchiestegals six; vertebrate $12+22$. Shore fishes, mostly of tenperate regions; voracious creatures, living on the bottoms, feeding on mollusks and crustacea, and having great strength of jaw. 


\section{:2:; Opsanus tau (Linnil(11s)}

Toulfish: Oysterfish

Ciedus tan Lixvaeus, Syst. Nat. ed. XII. I, 440. 1766, Carolina.

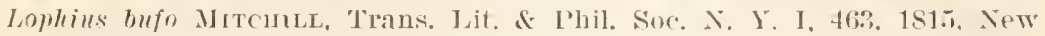
York.

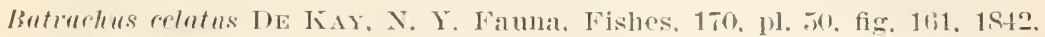
New York.

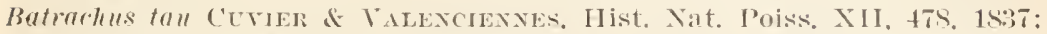
DE KAY, N. Y. Fanua, Fishes, 168, pl. 2S, fig. S6, 1812; Gïrtule, Cat. Fish. Brit. Mus. III, 167, 1S61; Storer. Hist. Fish. Miss. 11t.j. pl. XIX, figs. 1, 2. 1667; foode \& Beax, Bull. Essex Inst. XI. 11. 1879: Bean, Bull. L. S. F'. ('. YII, 135. 18s8; 19th IRel. Comm. Fish. N. Y. 249, 1890 .

Body robust, naked, its depth abent one fourth of the standared length; depth of "andal peduncle one fourth length of heart: hread broad, its length about one third that of the body with head; mouth larege; jaws strong, armed with hlunt teeth; well developed teeth on romer"; long diametre of "ye one third length of mandible; a broad flaj above orbit: tip of maxillary, lower

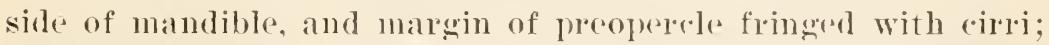
suboperele ending in a sharp spine: first dorsal small, placed over base of pectorals: serond dorsal long, its base about one laalf of total lengtle witheut candal; peretorals broad, the width of their base equaling one lualf length of hear.

I). III, 26-28; 1. 24.

Color dark olive: undrer patres lighter: blatek marlings om sides formingr irregular bars; many pale or yollowish spots on body: soft dorsal, anal, pretoral, and caudal fins with light cross bands formed of light rolored spots.

In some parts of the soutl this species is known as the oysterfish, from its habit of living in dead oyster shells. The toadfish ranges on onr east coast from cape Cod to the Gulf of Mexico. The fish is said to grow to the lengerth of 15 inches. It is a volacious species, fexding rpon other fishes, and upon shellfish, crabs and of hre crustacea, annelids, che.

On rocky bottoms it ofrurs muder stones, and on sandy and muddy areas it frepluents loralities abounding in relgrass. The toadfish lies in concealment for its prey, and darts ont quickly to effect a rapture. Its hreeding season is duling the summer 
months. The habits are fully described by Storer in the Fishes of Massachusetts. 'The eggs adhere to stones in shallow watcr. By the end of August the young have reached a length of about one inch. The nest and young are guarded by the parent fish. The species is not an attractive one, and though the flesh is sweet and palatable it is rarely eaten. To the fishermen this is one of the worst nuisances in our waters, since it is always ready to take the hook and swallow the bait intended for more useful fish. In Great South bay the toadfish was taken at the month of Swan creek and in Blue Point cove late in September. Young individuals were collected September $\mathbf{1 0}$ at the Blue Point Lifesaving station.

In 1898 the toadfish was again found abundantly in Great South bay in August and September. They are distributed in all portions of the bay, except where the water is nearly fresh. In 1901 the eggs were found upon the point of hatching in the middle of July and in the month of August. On July 16, a lot of embryos measuring from $\frac{3}{16}$ to $\frac{11}{16}$ of an inch were obtained. The eggs adhere firmly to the bark of stakes, or the undersurface of sunken wood, stones, or any other heavy substance which will answer the purpose of concealment.

The toadfish is not present in Graresend bay in the hot summer months. Most of the individuals taken were caught in August, September and October. It is possible to keep it in captivity during the summer months by careful management.

\section{Group BLENNIOIDEI \\ Blennylike Fishes}

Family BLENNIIDAE

\section{Blennies}

\section{Genus blennius (Artedi) Linnaeus}

Body oblong, compressed, naked; head short, the profile usually bluntly rounded; mouth small, horizontal, with a single series of long, slender, curred, close set teeth in each jaw, besides which, in the lower jaw at least, is a rather short and stout fanglike canine tooth on each side; premaxillaries not protractile; gill openings wide, extending forward below, the 
membranes free from the isthmus, or at least forming a broad fold across it. Dorsal fin entire, or more or less emarginate, the spines slender; pectorals moderate; ventrals well developed, I, 3; no pyloric caeca; lateral line developed anteriorly. Species numerous, lurking under rocks and algae in most warm seas; some species in the lakes of northern Italy. The European species in general are larger in size than ours, with higher fins.

\section{Blennius fucorum (Cuv. \& Val.)}

\section{Seaweed Blenny}

Blcnius fucorum Curier \& Valenciennes, Hist. Nat. Poiss. XI, 263, pl. 324, 1836, 240 miles south of Azores; DE KAY, N. Y. Fauna, Fishes, 149 , pl. 22, fig. 66, 1842, in seaweed, not far from New York coast; GüNther, Cat. Fish. Brit. Mus. III, 217, 1861; JordAN \& GilberT, Bull. 16, U. S. Nat. Mus. 759, 1853; Jordan \& Evermann, Bull. 47, U. S. Nat. Mus. III, 2379, 1 S98.

Blennius oceanicus Cuvier \& Valenciennes, op. cit. 265, 1836, open Atlantic, $29^{\circ} \mathrm{N}$., $50^{\circ} \mathrm{W}$.

The length of the body is five times the length of the head; orbital eirri nearly as long as head, bifid above, and with fringes at the base; dorsal fin slightly emarginate, free from the caudal, the spines rather stiff. Head very short and deep, its profile nearly vertical; 24 teeth in each jaw; both jaws with very strong canines. Gill membranes free from isthmus posteriorly. Eyes very large, one third as long as head. D. XI, 17; A. 18.

Color olive green, becoming darker above, with numerous brown spots on cheeks and sides of body; below faintly reddish; dorsal with a large black spot in front, behind which are some smaller spots; spinous dorsal edged with paler.

The seaweed blenny was obtained by De Kay in a voyage from Constantinople to New York in 1831. He met the species swimming about seaweed not far from the coast of New York and made notes of it at the time, considering it as either a young individual of some larger species or undescribed. This specimen was not more than $1 \frac{1}{2}$ inches long. The type of the species was taken south of the Azores. The coloration as stated by De Kay is as follows: "Soiled greenish, changing to brownish above, with numerous brown spots on the cheeks and side of the body; 
throat and belly fatintly rosaceous; iris bluish with reddish points radiating about the pupils."

The largest specinen recorded is $2 \frac{1}{2}$ inches long.

\section{Genus chasmones ('ur. \& Tal.}

Body oblong, rompressed, nilked; head triangular in profile, the suout somewhat frointed; month lal ge, with lateral eleft, the maxillary usually, but not always, extending to beyond rye; premaxillaries not protractile; terth in a single series, long and slender, comblike, confined to the front of rach jaw; no canines; rilei very small or wanting; gill oprenings very small, their lower edge above the middle of the base of the pertorals; lateral line incomplete. Fins as in B le n n i us. Imerean. The species with smatler month approath H y psoblan a i ns, which genus is not far separated from C ha smodes..

\section{:305 Chasmodes bosquianus (Lacépère)}

\section{Bameded Blenny}

Blemnius bosquimus Lacepede, Hist. Nat. Poiss. II, 498, pl. 13, fig. 1, 1800. South Carolina.

Blenuius pholis Mitcrill, Trans. Lit. \& Phil. Soc. N. Y. I, 374, 1815.

Chasmodes boscianus Günther. Cat. Fish. Brit. Mus. III, 229, 1861.

Chasmodes bosquimms Cutier \& Talenciennes, Hist. Nat. Poiss. XI, 29., 11. 327. 1836; DE KAY, N. Y. Fauna, Fishes, 15I, pl. 24, fig. 73, 1842. New York Haldbol; Jordan \& Grbbert, Bull. 16, U. S. Nat. Mus. 75i. 1853; Jordan \& Evermann, Bull. 47, U. S. Nat. Mus. III, 2394. 1898.

The depth of the body is coutained three and one half times in its length which is three and one half times the length of the head. Orbital tentare rery minnte or wanting; maxillary extending to rathre bryond eye; interocular space very nareow, not concave. Dorsal fin not emarginate, the spines slender. Dorsal joined to base of caudal; anal free. D. XI, 19; A. 20.

Color (in s) olive green, with about nine horizontal nar.ow blue lines, these somewhat irregular and interrupted, converging backwards; opercular membrane and a broad stripe through middle of spinal dorsal deep orange yellow; anal fin dark, the rays with white membranaceous tips; $q$ dark olive green, reticulated with narow pale green lines, and with s+everal broad dark bars, which are more distinct posteriorly; vertical fins 
similarly marked; head finely dotted with black; a dusky spot at base of caudal in both sexes. New York to Florida.

Mitchill found a specimen of this little blenny in an oyster, and described it under the name Blennius plo olis. Another specimen was sent to Cuvier from New York, and a specimen in the Lyceum in New York, described by De Kay, was obtained from New York harbor. This blenny is common southward in shallow water. It seldom exceeds the length of $3 \frac{1}{2}$. inches.

\section{Family xIPIIDIIDAE}

Rock Eels

\section{Genus phos.s (Gronow) Scopoli}

Body long and low, cousiderably compressed, somewhat bandshaped, the tail slowly tapering; head small, compressed, naked; mouth rather small, oblique; jaws with rather small teeth in narrow bands or single series; romer and palatines usually toothless; gill membranes broadly united, free from the istlumus; scales very small, smooth; no lateral line. Morsal fin long and low, beginning near the head, composed entilely of stiff, sharp, subequal spines; anal similar in form, of two spines and many soft rays; caudal fin short and small, more or less joined to dorsal and anal; pectorals short, rather shorter than head; ventrals very small, of one spine and a rudimentary ray; intestinal ranal short, without caeca. Shore fishes of the Northern seas.

\section{Pholis gunnellus (Tinnaeus)}

\section{Butterfish; Rock Ecl}

Blemuins gunuellus Linnaeus, Syst. Nat. ed, X, I, 25i, 17̄os, Atlantic Ocean.

Centronotus gunnellus Bloci \& SchneIDER, Syst. Ichth. 167, 1501; G̈̈NTner, Cat. Fish. Brit. Mus. III, 285, 1861.

Ophidimm mucronatum Mrterrul, Trans. Lit. \& Phil. Soc. N. Y. I, 249, lll. 2, fig. 1, 1815 .

Gumellus mucronatus DE KAY, N. Y. Fauna, Fishes, 153, pl. 12, fig. 36. 1842, New lork Harbor; Storer, Hist. Fish. Mass. 24, pl. Xlil, fig. 2. 1867 .

Muchembides gmuncllus Goone \& BEan. Bull. Essex Inst. XI, 11, 1879.

Pholis gumnellus BEAx, Bull, Am. Mus. Nat. Hist. IX, 370, 1S97: H. M. Sumt, Bull. U. S. F. C. 1S97, 106, 1698; Jordan of Evermans, Bull. 47. U. S. Nat. Mus, III, 2419, pl. CCCXI.II, fig. S32, 1900. 
Body much compressed, elongate, its greatest depth equal to length of head and one eighth to one serenth of the total length without the caudal. Eye small, twice width of interorbital space, and one fifth length of head. Maxillary' one third as long as head, reaching to below front of orbit. 'Jeeth blunt, in a single row, not close set. Origin of dorsal immediately over the gill opening; the longest spine as long as the snout; the fin separated from the caudal by a slight notch. Pectoral about one half as long as head, reaching to below sixth spine of dorsal. Ventral minute. D. LXXVI to LXXXV; A. II, 38 to 44 ; V. I, 1; P. 12.

Color grayish or brownish, with a series of oval vertical dusky rings on the sides; abdomen grayish white, tinged with yellow; dorsal fin gray, with about 14 black vertical distant stripes; pectorals and caudal yellow; anal fin greenish gray, with alternate darker stripes; iris white.

This fish reaches the length of 12 inches. It is found in the North Atlantic from Labrador south to Cape Cod and from Norway south to France.

Dr. Smith states that this rock eel or butterfish is abundant around the shores in the vicinity of Woods Hole Mass. in March and April, but is rare at other times. It may be taken in Vineyard Sound with a dredge at almost any season at a depth of 4 or 5 fathoms. It occurs only on gravelly bottoms.

The only individuals collected by myself were taken on the oyster beds at Eaton's Neck in the fall of 1896. The species does not live long in captivity.

On June 6, 1899, Captain H. E. Swezey obtained a few specimens of this species on the ocean beach at Water Island. Mitchill described the rock eel or butterfish $(\mathrm{Ophidium}$ m u c r o n a t u m) in Trans. Lit. \& Phil. Soc. N. Y., I, 249, pl. II, fig. 1. De Kay says this fish "is frequently found among rocks along the seashore and in the mud. It swims with great rapidity although its usual habit is that of creeping slowly among rocks, in which it is probably assisted by its spiny ventrals. It abounds in Robyn's reef, in the harbor of New York." 


\section{Subfamily STICHAEINAE}

Genus urvaria Jordan \& Evermann

'This genus is rery close to E $\mathrm{mmesog} \mathrm{r}^{\circ} \mathrm{m} m \mathrm{~m} \mathrm{~m}$, from which it riffers in the absence of the lowermost or third lateral line, the median line being bifurcate.

\section{Ulvaria subbifurcata (Storer)}

\section{Radiated Shanny}

Photis subbifurculus Storer, Rep. Fish. Mass. 63, 1839, Nahant, Mass.; Hist. Fish. Mass. 92, 1867; DE KAY, N. Y. Fauna, Fishes, 150, 1842. Enmesogrammus subbifurcatus Goode \& BEAN, Bull. Essex Inst. XI, 10, 1S79; Jordax \& Gilbert, Bull. 16, U. S. Nat. Mus. 775, 1883.

Ulvaria subbifurcata Jordan \& Evermans, Check-List Fish. N. \& M. A. 475, 1896; Bull. 47, U. S. Nat. Mus. III, 2440, 1898, pl. CCCXLT, fig. 842 .

Body moderately compressed, fusiform, its greatest depth about one fifth of the length without caudal. Head moderately large, nearly one fourth of total length without caudal; mouth large, the maxillary extending to below the middle of the eje, the jaws equal in front; eje large, a little longer than the snout, one fourth as long as the head. Dorsal origin at a distance from tip of snout equal to length of head; longest spines about in. the middle of the fin two fifths as long as the head; first spine two thirds as long as the eye. Caudal rounded, its middle rays one half as long as the head. Anal origin under the 14th spine of the dorsal, the fin not extending to the caudal, its longest ray one third as long as the head. Pectoral extending slightly past the vertical from the ninth spine of the dorsal, its length one sixth of total without caudal. Ventral in advance of dorsal origin, three eighths as long as head. Back somewhat arched; ventral outline nearly straight. Median lateral line forked over the pectoral, the upper branch extending about as far back as the extended pectoral. Scales very simall.

1). XIIT; 1. 28 to $30 ;$ V. I, $3 ;$ P. 14.

"Color", above reddish brown. Opercle and preopercle yellowish. Iight colored circular patches along the base of the dorsal fin; beneatl the lateral line lighter. Abdomen yellowish 
whitr. From beneath the eye, a broad lolack band, which is wirlest at its origin, crosses the opercle obliquely; two other bands of the same color extend from behind the rye backward, in nearly a stratight line, to a distamere of from one to two lines. Numeroris back spots on the dorsal fin [one of these extending from the fifth to the tenth spines. Fertorals light, with darker shades. Anal fin with a dark colmed margin. Candal with small dusky spots," sometimes forming about fom narrow con('entric bals's.

The fish reaches the length of about 6 inches.

This species is very rare in the North Atlantic, south to Cape Cod. Storer records the capture at Naliant Mass. in 18:38. It has been taken by the U. S. Fish Commission at Grand Manan and Halifax, and by Prof. Verrill off Antirosti. 1) Fay had not met with the specios in New York waters and his description is copied from that of Storer in his report upon Fishes of Massachusetts, page 6:3, 18:9. De Kay called it the radiated shanny. Its ocemrence in New York waters remains to be noted.

\section{Genus stromawos Reinhardt}

Body moderately elongate, covered with suall scales; teeth on jaws, vomer, and palatines. Lateral line present, single, running along side of back; pectorals and ventrals well developed. Dorsal moderately high, of spines only; gill openings continued forward below, the membranes scarcely mited to the isthmus; pyloric (‘aecaa present. Arctic seas.

\section{:208 Stichaeus punctatus (Fabricius)}

\section{Spotted Blcnny}

Blennius punctatus FAbricits, Fauna Grönl. 153, 17S0, Greenland.

clinus punctatus Richardson, Fauna Bor-Amer. III, SS, 1836.

Gumnellus punctatus Cuvier \& Valenciennes, Hist. Nat. Poiss, NI, 428, $18: 36$.

Stirlhacus punctatus Güntmer, Cat. Fish. Brit. Mus. III, 2S3,. 1861; JordaN d Gilliert, Bull. 16, U. S. Nat. Mus. 775, 1883; Jordax \& Etermany, Bull. 47, U. S. Nat. Mus. III, 2439, 1898, pl. CCCXI, , fig. $\$ 41,1900$.

Body compressed, tapering at both ends, moderately rongate. its greatest depth one sixth to one seventli of total length without candal. Head two ninths of total length without candal; 
mouth moderate, the maxillary extending to below front of pupil, one third as long as head, the lower jaw slightly slıoter than upper; rye small, one fifth as long as lead; snout slightly longer than eye. Dorsal origin orer top of gill opening; dorsal fin subcontinuous with the audal, its longest spine two sevenths as long as the lead. Caudal fin ronnded in alutt (emarginate in young), the middle rays two thirds as long as the head. Anal origin under 17 th spine of dorsal, the fin well separated from the caudal, its longest ray one third as long as the head. Pectoral extending to below the 14th spins of the dorsal, its length one sixth of the total without caudal. Tentral nearly under dorsal origin, one thirel as long as the head. Balck little arehed; rentral outline also arched. Lateral line single, in the upper fouth of the light of body, and ending about the middie of the total length including caudal. Scales small, but larger than in U l v a r a s b bifurcata. T). XLVIII to I; A. 32 to $36 ; \mathrm{V} . \mathrm{I}, 2 ;$ P. 15.

Color bright scarlet, the cheels witl five or six small dark blotches; smaller dark blotehes on opercle and interoperce; a dark streak from snout through eye and extonding behind the eye; fire roundish dark spots, about as long as the eye, each with a white band near its npuer margin, on the dorsal fin at almost regular distauces apart; the anal fin with eight to ten narow oblique rossbars; caudal with about six narrow, concentric, dark rings.

This blemny inhabits the Arctic seas from Greenland to North Siberia, south to Bristol Bay and Cape Cod. Young individuals were found in considerable numbers in Plover bay, Siberia, and at Cape Lisburne, Alaska. The species grows to the length of about 7 inches. The young are so different in appearance from the adult that tley have been described as the type of a distinct genus. The occurrence of the species in New Iork waters is very doubtful.

\section{Genus rompros Reinliardt}

Body greatly elongate, moderately compressed, covered with small seales; lateral line indistinct or obsolete; lead long; snout 
short; no cirri; eyes large, placed high; mouth moderate, with a single row of rather small conic teeth on each jaw, palatine teeth present or absent; gill openings prolonged forward below, very narrowly united anteriorly to the isthmus, not forming a free fold across it; dorsal composed of numerous sharp, flexible, rather high spines; caudal fin long; anal many-rayed; pectorals large, more than one half length of head, the middle rays longest; ventrals well developed, jugular, I, 3 or I, 4; intestinal canal long; pyloric caeca present; no air bladder. Chietly herbivorous. Northern scas.

\section{Subgenus Leptoblennus Gill}

\section{Lumpenus lampetraeformis (Walbaum)}

\section{Eel Blenny; Snakefish}

Blennius lampetraeformis Walbaum, Artedi Gen. Pisc. III, 184, 1792; Iceland.

Blennius serpentinus Storer, Proc. Bost. Soc. Nat. Hist. III, 30, 1848; Massachusetts Bay; Hist. Fish. Mass. 91, pl. XVII, fig. 1, 1S67.

Leptoblennius serpentinus Goode \& BEAN, Bull. Essex Inst. XI, 10, 1879;

Massachusetis Bay; Jordan \& Gilbert, Bull. 16, U. S. Nat. Mus.

778, 1883.

Stichaeus islandicus Günther, Cat. Fish. Brit. Mus. III, 281, 1861.

Lumpenus lampetraeformis CoLLETT, Norske Nord-Havs Exp. 71, 1S80;

Jordan \& Gilbert, Bull. 16, U. S. Nat. Mus. 778, 1883; Jordan \&

Evermann, Bull. 47, U. S. Nat. Mus. III, 2438, pl. CCCXLIV, fig. $810,1898$.

The depth of the body is one fifteenth of the length, which is nine times the length of the head. Head not large, its sides sparsely covered with small scales; eye as long as snout; maxillary reaching front of pupil; gill openings extending forward below for a distance less than length of snout; pectorals long, seven eighths length of head; ventrals moderate, two and two thirds in head. D. LXXV; A. 50; V. I, 3.

Olive above with lighter cloudings; pale below; dorsal fin brownish, with broad, oblique, white bands; pectorals pale.

The snakefish inhabits the North Atlantic and Arctic on both shores, ranging south to Sweden and Norway, east to Spitzbergen; on our coast extending south to Cape Cod and perhaps Long Island. It is a common resident of the deep waters of Massachusetts bay, where it is a favorite food of the cod and 
halibut. The species grows to the lengtl of 12 to 15 inches. Other names for it are eel blenuy and snakc blenny. No record of its occurrence in New York waters has yet appeared, but it may be found in moderate depths off Long Island.

\section{Family CRPTTACANTHODIDAE}

\section{Wrymouths}

\section{Genus CRYPTACAN'THodes Storer}

Body $\operatorname{long}$ and slender, compressed, naked, without lateral line; head cuboid, with vertical cheeks and conspicuous muciferous cavities; eyes small, placed high; month large, rery oblique, the very heavy lower jaw prominent in front; jaws, vomer, and palatines with stoutish conic tecth, in few series; gill openings prolonged forward below, narrowly attached to the isthmus; dorsal fin of stontish spines, hidden in the skin; dorsal and anal joined to caudal; pectorals short; ventrals wanting.

\section{Cryptacanthodes maculatus Storer \\ Ghostfish; Wrymouth}

Cryptacanthodes maculatus Storer. Ren. Fish. Mass. 28, 1839; Hist. Fish. Mass. 34, pl. VIII, fig. 6, 1867; DE KAY, N. Y. Fauna, Fishes, 63, pl. 18, fig. 50, 1S42, from Massachusetts specimen; Linsler, Am. Jour. Sci. Arts, XLVII, 60, 1844, Long Island Sound; Günther, Cat. Fish. Brit. Mus. III, 291, 1861; Goone \& BEAN, Bull. Essex Inst. XI, 10, 18т9; Jordan \& Gizbert, Bull. 16, U. S. Nat. Mus. 780, 1883; H. M. Smitir, Bull. U. S. F. C. 1897, 106, 1898; Jordan \& Everiann. Bull. 47, U. S. Nat. Mus. III, 2443, 1898, IV. pl. CCCXLV, fig. 843, 1900.

The depth of the body is one thirteenth of the length, which is six and one half times the length of the head. Eyes small, placed high, not so wide as interorbital space, which has two ridges and three pits; orbital rim raised; two deep pits behind ese at the temples, a deeper pit on top of head between them; a raised ridge continned backward on each side of head behind orbital rim; maxillary extending to beyond eve; pseudobranchiae small; pectorals short, three in head, their tips reaching beyond front of dorsal; vent a little in front of the middle of the body.

D. IXXIII; A. 50.

Light brownish, with several series of smallish dark spots, arranged in more or less regular rows, from the head to the 
base of the caulal; rertical fin closely spotted with darker; head above thickly speckled; body sometimes ("inomatus") entirely immarulatr. The wrymouth or ghostfish has been taken from labridor to Lomg lsland somnd. It is recopded by Linsley in his ratalogue of the Fishes of Connecticut. The species grows to a lengtle of 24 incles or wore. According to Dr. Smith, it is very rare at Woods Hole Mass. I specimen flom Woods Hole, now in the National Musenm, was taken about 1S7.5. Sep. 18. 1896, an indivilual 18 inclues long was caught the ${ }^{2}$ e in a fyce net set in Great harbor. In Massachusetts bay the fish is also rather rare. Storer, in his History of the Fishes of Massachusetts, 1S67, mentioned serru spreinens: one from Nahant, one from Dorchester, one from Provincetown, three from Massachusetts bay; the seventh was from a beach in Nova Scotia. The U.S. Fish Commission collected seren specimens on the coast of Massachusetts previous to 1S79. There is an albino form of this fish, of which four individuals were lnown prior to 1879. One of these was obtained at Marblehead and another at Swampscott.

\section{Family ANARHICHADIDAE}

\section{Wolf Fishes}

\section{Genus Ivarmichs (Artedi) Linnacus}

Body moderately elongate, corered with rudimentary saales; lead scaleless, without ripri, rompressed, narrowed above, the profile strongly decurved; mouth wide, oblique; premaxillary not protractile; jaws with very strong conic canines anteriorly; lateral teeth of lower jaw either molars or with prointed tuber(les; mper jaw without lateral tecth; romer extremely thick and solid, with 2 series of roarse molar teroth; palatines with one or two similar serics: gill menubrues broady joined to the isthmus; no lateral line; dolsal fin lather high, composed entirely of flexible spines which are enveloped in the skin; anal fin lower; caudal fin developed, free from dorsal and anal; no ventral fius; pectoral fius broad, placed low; air bladder present; no pyloric racea. Northern seas. 
:31 Anarhichas lupus Linnaens

Wolf Fish

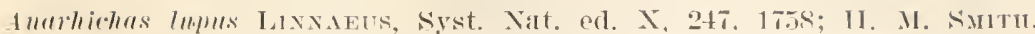

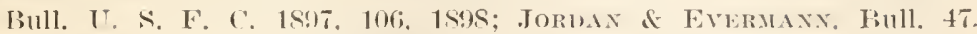

I. s. Nat. Mus, 11I, 24t6, 1s!s; IV, pl. CCCXIJII, fig. St6, 1!00.

Aumrhirus lums MItrould, Am. Month. Mag. II, 242. February, 1sis:

Storer, Ri(p) Fistr. Mass. 69, 1839: DE Kiy, N. Y. Fauna, Fishes, 1.s.

JI. 16. fig. 4 : 1842 .

luarhirhus hryus GoOne of BeAs, Bult. Essex Inst. XI. 11, 1879.

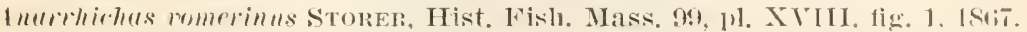

'The deptle of the body is contained five and one half times in its length, which is six times the length of the head. Maxillary reaches beyond orbit; band of vomerine teeth extending much farther hack than the short palatine band; pectorals large, rounded, two thirds length of lead; dorsal high, heginning over the gill openings, its longest rays about half length of head.

D. LXII; A. 42.

Brownish; sides with mumelous (9-12) vely dalk transvelese bars, which are continued on the dorsal fin, besides numerous dark spots and reticulations; fins dark; raudal tipped with reddish.

This is the sea wolf of Mitchill, mentioned by him in the American Jonthly Magazine, r. 2, 1. 242. De Kay writes of the species as follows:

The voracious and salvage ehalateter of this fish is maluifest in the formidalle array of teeth with which he is porovided, and hy his rieions and pugnacious popensities when first drawn from the water. . He is known muder the valdous popular llames of cat, wolf fish, and sea cat. His ill-farored asperet allses him to be regarded with aversion by fishermen, but his flesle is by no means musary: when smoked it is said to have somewhat the flavor of salmon. He prefers rocky coasts and is said to spawn in May. Not unfrequently taken off Rockaway beacl, as I am informed, in company with the common cod. This I suppose to be the most extreme southerly limit ret observed. In high northeren latitudes it is satel to attain to the length of (i) and $s$ feet.

In the deep waters of Massachusetts bay it occurs frequently, approaching the shore, particularly in winter. In Vineyard sound it is quite rare and has been taken late in fall in traps 
and also on lines fished for cod. The range of the species is, in the north Atlantic, south to Cape Cod and France. It is rather common both in America and Enrope. In Norway the skin of the fish is tanned and makes a very good leather.

\section{Group opHIDIOIDEI \\ Eelpouts \\ Family zOAROIDAE:}

\section{Genus zoArCes Gill}

Body elongate, compressed, tapering posteriorly; head oblong, heavy, narrowed above, the profile decurved; mouth large; teeth strong, conic, bluntish, in two series in the front of each jaw and one series on the sides; teeth in outer series larger; no teeth on romer or palatines; dorsal fin rery long, low, some of its posterior rays much lower than the others, developed as sharp spines; pectoral fins broad; ventrals jugular, of three or four soft rays; scales small, not imbricated, embedded in the skin; lateral line slender, lateral in position; size large; species viviparous. The American and Asiatic species (subgenus M a c r o zoares) differ from the European type of Zoarces (Cuvier) in the increased number of fin rays and rertebrae. In Z o a r c s vivipar us (Linnaeus), the Enropean eelpout, the iorsal rays are about 100, the anal about S5, and the number of vertebrae is proportionally diminisher.

\section{Zoarces anguillaris (Peck) \\ Muttonfish; Ling; Eelpout}

Blemins anguillaris PEcK, Mem. Am. Ac. Sci. II, 46, figure, 1804, New Hampshire.

Blennius ciliatus Mitchil, Trans. Lit. \& Phil. Soc. N. Y. I, 374, pl. I, fig. 6, 1815.

Blennius labrosus Mrrchir, op. cit. 375, pl. I, fig. 7, 1815.

Zoarees anguillaris Storer, Rep. Fish. Mass. 66, 1839; DE KAy, N. Y. Fauna. Fishes, 155, pl. 16, fig. 45, 1842; Günther, Cat. Fish. Brit. Mus. III, 296, 1S61; Storer, Hist. Fish. Mass. 97, pl. XVII, fig. 4, 1S67; Goode \& Bean, Bull. Essex Inst. XI, 9, 1879; Jordaî \& Gilbert. Bull. 16. U. S. Nat. Mus. 784, 1883; H. M. Smith, Bull. U. S. F. C. 1997, 106, 1S98; Jordan \& Evermann, Bull. 47, U. S. Nat. Mus. III. 2457, 1898; IV; pl. CCCXIXIII, fig. 850, 1900.

The depth of the body is one seventh of the length, which is six times the length of the head. Maxillary reaching beyond 
orbit; pectoral long, about two thirds length of liead; rentrals one fifth head; highest ray of dorsal about equal to snout; the posterior spines about one third length of eye; first ray of dorsal above preopercle. D. 95, XTIII, 17; А. 105.

Reddish brown, mottled with olive, the scales paler than the skin about them; dorsal fin marked with darker; a dark streak from eye across cheek and opercles; lower jaw included.

This fish grows to the length of about 3 feet. De Kay noticed it most abundantly in the New York market in February and March. He states that it is caught on the coast in company with the common cod. It feeds on various marine shells and affords a very savory food. At the time of his writing it was called by the fishermen ling and conger eel. De Kay employed for it the English name eelpout. Fishermen who go out for cod off Sandy Hook at the present time catch this fish in large numbers and know it under the name of muttonfish. The range of the fish is from Labrador to Delaware. It is rather common north of Cape Cod. Dr Smith says it is abundant in the fall off Gayhead and Cuttyhunk; it is caught while line fishing for cod on rock bottom and occasionally late in fall in Vineyard sound, off Great harbor, on lines baited for tautog. In Massachusetts bay it is a common resident of deep water, frequently approaching the shore.

\section{Family OPHIDIDAE}

\section{Genus Rissola Jordan \& Evermann}

This genus contains species agreeing with $\mathrm{Oph}$ idion in general characters, but with the air bladder short, broad, spherical or kidney-shaped, with a posterior foramen. Species chiefly of the Mediterranean.

\section{Rissola marginata (De Kay)}

\section{Slippery Dick}

Ophidium marginatum DE KAY, N. Y. Fauna, Fishes, 315, pl. 52, fig. 169, 1842, New York Harbor; BaInd, Ninth Ann. Rep. Smith. Inst. 351, 1855; Jordan \& Gilbert, Bull. 16, U. S. Nat. Mus. 792, 1883; Beax, Bull. U. S. F. C. VII, 135, 1888.

Rissola.marginata Jordan \& Evermann, Check-List Fish. N. \& M. A. 483, 1896; Bull. 47, U. S. Nat. Mus. III, 2489, 1895; IV, pl. CCCLIII, fig. 868, 1900; BEAN, Bull. Am. Mus. Nat. Hist. IX, 370, 1897. 
Ophidium barbatum Mitchill, 'Trans. Lit. \& Phil. Soc. N. Y. I, 362, pl. I, fig. 2,1815 .

De Kay writes of the species as follows:

This very rare and curious species was taken in a seine in the harbor of New York in company with a school of the striped bass. It is doubtless the 0 . b a $r$ b a $t u m$ of my venerable friend, Dr Mitchill, which is too succinctly noted in the work cited above. . . It has so much the habit of some of the Gadidae, and more especially of the genus $\mathrm{Brotula}$, that our fishermen call it the little cusk.

The fish inhabits the coast of the United States from New York south to Pensacola and Texas. It is not very common. It glows to the lengtl of about 10 inches. A specimen was taken in Great Egg Harbor bay during the winter of 1S53-54, but collectors who have visited the region since have not found it again. In Gravesend bay, where the species is rare, an example was obtained Oct. 24, 1894. The fish is known there as Slippery Dick.

\section{Suborder CRANIOMI \\ Eamily TRIGLIDAE \\ Gurnards}

Genus Prionotus Lacépède

Body subfusiform; profile of head descending to the broad, depressed snout, which is much longer than the small eye; ejes close together, high up; surface of head entirely bony, the bones rough with ridges and granulations; scales on head few or none; preopercle with one or two sharp spines at its angle; opercle with a sharp spine; nape with two strong spines, a spine on shoulder girdle; mouth rather broad; bands of small, almost granular, teeth on jaws, vomer, and palatines; gill membranes nearly separate, free from isthmus; gill rakers rather long; body covered with small, rough scales, which are not keeled; lateral line continuous; scales on breast very small; dorsal fins distinct, the first of $S$ to 10 rather stout spines, the third usually highest, but mostly shorter than head; anal fin similar to soft dorsal; pectoral fin with the three lower anterior rays thickened, entirely free from each other and from the fin; ventrals I, 5, 
wide apart, with a flat space between them, the inner rays longest; pyloric caeca in moderate number; air bladder generally with lateral muscles and divided into two lateral parts; rertebrae 10 or $11+15$. Species numerous, all but one being American. Representing in America the old world genus Trigla . Some of them in deep water. They are well defined and easily recognized, but vary considerably with age, and ale not easily thrown into subordinate groups. . Toung examples in most cases differ from the adults in the following respects, in addition to those characters which usually distinguish young fishes. The spines on the head are sharper, more conspicuous, and more compressed in the young, and some spines, specially those on the side of the head, disappear entirely with age. The interorbital space is more concave in the young. The pectoral fins are also much shorter. The gill rakers are longer in the young, and proportionately more slender, and some of the color markingsspecially the darker cross shades-are more conspicuous, while the spots on body and fins are less so.

\section{$33 \pm$ Prionotus carolinus (Linnaeus)}

\section{Sea Robin; Gurnard}

Trigla carolina Lincaeus, Mantissa, 52S.

Trigla palmipes MıтснıLц, Trans. Lit. \& Phil. Soc. N. Y. I, 431, pl. IV, fig. 5, 1815, New lork Harbor.

Prionotus palmipes Storer, Hist. Fish. Mass. 1S, pl. V, fig. 1, 1S6i; Jordav \& Gilbert, Bull. 16, U. S. Nat. Mus. 734, 1S83; Goode, Fish \& Fish. Ind. U. S. I, 255, pl. 71, $1 S S 4$.

Prionotus corolinis Cuvier \& Valenciennes, Hist. Nat. Poiss. VI, 90, 1S29; DE KAY, N. Y. Fauna, Fishes, 46, pl. 5, fig. 15, 1St2; Günther, Cat. Fish. Brit. Mus. II, 192, 1860; BEAN, Bull. Am. Mus. Nat. Hist. IX, 371, 1897; H. M. Sмптн, Bull. U. S. F. C. 1897, 106, 1898; JorddN \& Evermaxx, Bull. 47, U. S. Nat. Mus. II, 2156, 189S; IV, pl. CCCXVIII, fig. 765,1900 .

The depth of the body is one fifth of the length, which is three times the length of the head. Head comparatively smooth; preopercular spine strong; band of palatine teeth short and broad, shorter than eye; pectorals short, not reaching middle of second dorsal, two and one third in length; pectoral appendages strong, more or less dilated at their tips; rentrals long, reaching anal; 
gill rakers rather short, about 10 below angle; maxillary three and one third in head. D. X-13; A. 12; Lat. 1. .58.

Brownisl above, clouded with darker; throat and branchiostegals dark; a distinct dark blotch abore on membrane between fourth and fifth dorsal spines, this ocellated below; two longitudinal light streaks below dorsal blotch; second dorsal. with oblique whitish streaks.

The sea robin, known also as the red-winged sea robin, common gurnard, flying fish, butterfly fish, wingfish, grunter, and cuckoo fish, is very common on our east coast, its range extending from the coast of Maine to South Carolina, chiefly northward. The name flying fish is applied to the species in Great Egg bay, N.J. This sea robin appears in Gravesend bay in May, and is caught in the shad fyke nets. It is the earliest of the sea robins to arrive. At Woods Hole Mass., according to Dr Smith, it appears in May or June and remains till October or later, and it is more abundant than the striped sea robin.

This fish grows to the length of about 1 foot. It is not a marketable fish, and causes fishermen a great deal of annoyance by its wonderful roracity, and yet its flesh is firm and white, and the species deserves a place among the food fishes. It feeds on crabs, shrimp and similar crustaceans, and occurs on clean bottoms. This sea robin-begins to spawn at Woods Hole early in June. Its eggs are bright orange. The young are very common in Waquoit bay in summer, but are rather rare elsewhere. The young were found in Great South bay, at Point of Woods, and both sides of Fire Island inlet in August and September. Adults are also found in large numbers at Fire Island and at other parts of Great South bay. This fish is taken in enormous' numbers in pound nets in. spring and summer. Curiously enough, De Kay refers to this as a rery rare species. He says that in the course of eight jears he has not met with more than six or eight individuals. One specimen which he examined, had its stomach filled with the remains of crabs. 


\section{Prionotus strigatus Cuv. \& Tal.}

Red-winged Sea 'Robin

Trigla lineatu MitcinLl, Trans. Lit. \& Phil. Soc. N. Y. I, 430, pl. IV, fig. 4, 1S15; not Trigla lineata Fuoch.

Trigla strigata Curier, Règne Anim. ed. II, 2, 161, 1829, New York.

Prionotus lineatus IE KAY, N. Y. Fauna, Fishes, 45, pl. 4, fig. 12, 1842; Günther, Cat. Fish. Brit. Mus. II, 192, 1860.

Prionotus evolans rar. lineatus, Jordan \& Gilbert, Bull. 16, U. S. Nat. Mus. 736, 1853.

Prionotus erolans Goode, Fish \& Fish. Ind. U. S. I, 255, rl. 71, 1881; not Trigla erolans LiNNAEUs.

Prionotus strigatus Cuvier \& Valenciennes, Hist Nat. Poiss. IV, S6, 1829; Jordax \& Gilbert, Bull. 16, U. S. Nat. Mus. 974, 1S\$3; Beax, 19th Rep. Comm. Fish. N. Y. 250, 1890; Bull. Am. Mus. Nat. Hist. IX̣, 371, 1897; H. M. SмITH, Bull. U. S. F. C. 1897, 106, 1898; JoRDAN \& Evermann, Bull. 47, U. S. Nat. Mus. II, 2167, 1898.

The length of the head is contained two and two thirds times in the length of the body, which is four and one half times the depth of the body. The length of the exe is contained two and one half times in the length of the snout. Gill rakels rather long and slender, 15 below angle; band of palatine teeth wide, shorter than eye; spines on head moderate in size, compressed, the one at upper posterior angle of orbit little developed; membranous edge of opercle scaly; rentral reaching to front of anal; pectoral reaching past middle of soft dorsal and anal, from one and seven eighths to two and one fourth in length. D. X-12; A. 11; Lat. 1. about 60 .

Olive brown above, mottled and spotted with blackish; whitish below; a narrow streak along the lateral line, with a broader one below it, which terminates behind in a series of spots and blotches; lower jaw and branchiostegal membranes sometimes bright orange yellow; pectorals blackish edged with olivaceous and orange, with numerous transcerse dark lines; membrane of spinous dorsal with a black blotch between third and sixth spines; soft dorsal plain or with two black blotches at base; rentrals and anal orange; pectoral appendages slender, dusky. Cape Cod to Cape Hatteras; common northward. Perhaps a distinct species but seeming to vary into P. e rolans. 
The red-winged sea robin is distinguished from the striped sea robin by the following characters: pectoral with its rass each crossed by fine black bars, these specially distinct toward the base of the fin; free rays spotted; scales comparatively small, $10+1+23$ in a vertical line from last dorsal spine to vent; interorbitai area broad and almost flat, its width a little more than length of eye; first dorsal spine granulated; second spine four elevenths length of head; pectorals about one half as long as body.

In the striped sea robin the pectoral rays are all plain blackish; free rays plain dusky; scales $S+1+21$ in a rertical line from last dorsal spine to rent; interorbital space more deeply. concave, its width in adult not quite length of eye; first dorsal spine nearly smooth; second spine one third length of head; pectorals a little more than one half as long as body.

This fish is found on our Atlantic coast from Cape Cod to Virginia. It is very common in shallow water and is extremely close to Prionotus erolans, of which it may be a geographic variety. Drs Jordan and Evermann have not however seen examples intermediate between the striped sea robin and the red-winged species. This fish is the Prionot us linea tus of De Kay. ${ }^{1}$ De Kay distinguishes this fish, which he calls the banded gurnard, by the broad, reddish brown line along the sides below the lateral line, as well as by other characters. He says it is not uncommon and is known under the various popular names, grunter, gurnard, sea robin and flying fish. He states that the banded gurnard is seldom eaten as food. This is also the gurnard or sea robin, $\mathrm{Tr}$ rg I a $\mathrm{I} \mathrm{incata,} \mathrm{of}$ Mitchill in the Trans. Lit. \& Phil. Soc. N. Y. I, 430, pl. 4, fig. 4. 1815 .

The red-winged sea robin comes into Gravesend bay in May, but later than the common species. It was found more abundantly in Great South bay than the motriped species. Individuals were taken in IBlue Point core, and at Fire Island, late in Septemler. This fish grows larger than the other species.

${ }^{1}$ New York Fauna, Fishes. 1842. p. 45, pl. 4, fig. 12. 
and is much liandsomer; the roung are specially interesting on account of the great derelopment of their pectoral fins.

\section{$3: 36$ Prionotus tribulus (Cuvier)}

Big-headed Sea Robin

Trigla tribulus Cutier, Rigne Anim. ed. 2, II, 161, 1829, America.

Prionotus tribulus Cutien of Talencienses, Hist. Nat. Poiss. IV, 98, pl. 74, 1829, New York; DE KAY, N. Y. Fauna, Fishes 48, pl. 70, fig. 226, 1842; Günther, Cat. Fish. Brit. Mus, II, 195, 1860; Joridan \& Gilbert, Bull. 16, U. S. Nat. Mus. 735, 18S3; Jordan \& Evermann, Bull. 47, U. S. Nat. Mus. II, 2171, 1898.

Pectorals rather short, not reaching end of dorsal, twice in length to base of caudal; pectoral appendages thick, tapering. Body robust. The depth is one fourth of the length of the body, which is two and one half times the length of the head. Head shorter and broader, snout shorter, and bones more strongly striate than in P. e vola n s; interorbital space deeply concave; occipital and superorbital spines very strong and much compressed; band of palatine teeth as long as eye; gill rakers shortish, nine below angle; membranous edge of opercle scaly. D. X-12; A. 11; Lat. 1. about 50.

Dark brown abore, with darker blotches and numerous small, yale spots; belly pale; a black blotch at base of mandible; membrane of spinous dorsal, between the third and sixth spines, with a black blotch abore; second dorsal with brownish spots, forming oblique bars, and with two dark blotches at base, the posterior blotch continued obliquely downward and forward to below the lateral line; pectoral olive brown, with dark crossbars, which are more distinct toward the tip of the fin, its upper edge white, pectoral appendages with dark spots; basal half of caudal paler.

This gurnard is rers common on the soutl Atlantic coast and occasionally ranges northward to Long Island. It is well separated from the other sea robins of the Itlantic by the greater derelopment of the spines of the lead. "The roung liave these spines much larger and more compressed than the adult, and in the very yomeng these or four strong knifelike 
spines are developed on each side of the snout. In very young indiriduals the spine at the base of the preopercular spine is much larger than the latter." De Kay obtains his description of this fish from Cuvier and Valenciennes, but he saw rery small individuals which he at first confounded with the roung of the red-winged sea robin. Cuvier states that he received numerous specimens of the species from New York. De Kay mentions among the characteristics of the fish the long pectoral which reaches the end of the anal fin and acute spines of the head which are flattened like sword blades. As for colors he gires the following: "The first dorsal fin has a black spot between the fourth and sixth ray. The second with two black spots along its base; one from the fifth to the serenth, the other between the fourth and sixth rays; pectorals blackish, nore specially on the interior where the upper border is whitish. Body brownish above, lightish beneath." Specimens $\mathrm{S}$ inches long are recorded.

\section{Genus Trigra (Artedi) Linnaeus}

This genus differs from Che lidon i chth $\mathrm{ys}$, with which it agrees in the absence of palatine teeth, in having the sides of the body armed with transverse bony plates, crossing the lateral line. Species numerous; very abundant in the Mediterranean.

\section{Genus chelidonichthys Kaup}

This genus differs from $\mathrm{Pr}$ io not us chiefly in the absence of palatine teeth. The scales are much smaller, and the pectoral fins less developed; a series of bony, spinous plates extends along the base of the dorsal fin, a pair of them to each ray, the fin thus running in a shallow groove; there are no plates along the lateral line; candal fin usually emarginate; lateral line usually forked at base of caudal, the branches running to tip of fin. The numerous species abound on the coasts of Europe, Africa and India, ranging north to Japan.

\section{Trigla cuculus Linnaeus}

\section{Red Gurnaid}

Trigla cuculus Linnaeus, Syst. Nat. ed. X, I, 301, 17os; Cuvier \& Valenciennes, Hist. Nat. Poiss. IV, 26, 1829; De Kar, N. Y. Fauna, Fishes, 43, pl. 70, fig. 22J, 1812; Jordan \& Evermann, Bull. 47, U. S. Nat. Mus. II, 2177, 1898. 
The depth of the body is one fifth of the length, which is three and one half times the length of the head. Rose-red; profile of suout rather steep, slightly concave; lreorbital with short denticulations; maxillary nearly reaching front of orbit; lateral line with a series of unarmed plates, which are deeper than long; first dorsal spine tuberculated; second longest, two thirds length of head; pectoral reaching past front of anal. D. IX-1S; A. 17; Lat. 1. 7.5.

The red gnrnard is a native of southern Europe. It is said by Cuvier to have been once brought from New York by Milbert, but this is a rery doubtful record, as no collector has recently found any species of $\mathrm{T} r \mathrm{igla}$ in American waters. De Kay dir not see this fish on the coast of New York, and he copied his description from Curier and Valenciennes. De Kay states that Cuvier" and Valenciennes mention haring receired "a specimen from New Tork, which so much resembles the T. c u c ulus, not only in all its generalities but eren in its most minute details, that it is rely difficult for us not to consider it the same species; but, as our specimen was not recent, it may possibls present some distinct characters."

\section{Family CERHALACANTHIDAE}

\section{Flying Gurnards}

Genus cephalacarthus Lacépède

Body elongate, subquadrangular, tapering behind; head rery blunt, quadrangular, its surface almost entirely bony; nasals, preorbitals, suborbitals, and bones of top of head united into a shield; nuchal part of shield on each side produced backward in a bony ridge, ending in a strong spine, which reaches past front of dorsal; interocular space deeply concare; preorbitals forming a projecting roof above the jaws; preopercle produced in a very long rough spine; cheeks and opercles with small scales; opercle smaller than eye; gill openings narrow, rertical, separated by a rery broad, scaly isthmus; pseudobranchiae large; gill rakers minute; mouth small, lower jaw included; jans with granular teeth; no teeth on vomer or palatines; scales 
bonr, strongly keeled; two serrated, knifelike appendages at base of tail; first dorsal of four or five rather high flexible spines, the first one or two spines nearly free from the others; an immorable spine between the dorsals; anal and second dorsal short, of slender rays; caudal small, lunate; pectoral fins divided to the base into two parts, the anterior portion about as Iong as the head, of about six rays, closely connected; the posterior and larger portion more than twice length of head, reaching nearly to caudal in the adult, much shorter in the young; these rays very slender, simple, wide apart at tip; ventral rays $I, 4$, the long fins pointed, their bases close together, the inner rays shortest; air bladder with two lateral parts, each with a large muscle; pyloric caeca numerous; vertebrae $9+13=22$. Warm seas; the adult able to more in the air like the true flying fish, but for shorter distances. Two species known, one of them (C. s p in a rella) East Indian.

\section{Cephalacanthus volitans (Limnaeus) Flying Guruard; Flying Robin}

Trigla volitans Linnaeus, Syst. Nat. ed. X, I, 302, 1758.

Polynemus sexradiatus Mitchill, Trans. Lit. \& Phil. Soc. N. Y. I, pl. IV, fig. 10, 1815; Am. Month. Mag. II, 323, March, 1818.

Daetylopterus rolitans Cuvier \& Talenciennes, Hist. Nat. Poiss. IV, 117. 1829; De Kar, N. Y. Fauna, Fishes, 49, pl. 17, fig. 46; Günther, Cat. Fish. Brit. Mus. I1, 221, 1560.

Cephalacanthus volitans BEAN, Bull. U. S. F. C. VII, 136, 1S8S; Bull. Am. Mus. Nat. Hist. IX, 371, 1897; H. M. Sartim, Bull. U. S. F. C. 1597, 106, 189S; Jordan \& Evermann, Bull, 47, U. S. Nat. Mus. II, 21S3, 1898; IV, pl. CCCXXIII, fig. 778, 1900.

Body elongate, subquadrangular, tapering to caudal, its depth about one sixth of total length; profile blunt, the head being quadrangular in shape; mouth rather small, the lower jaw included; granular teeth in jaws; no teeth on vomer and palatines; eye large, its diameter being contained about three and one half times in length of head; bones of top of head, preorbitals, and suborbitals, forming a shicld, the nuchal part on each side being produced backward in a bony ridge and ending in a strong spine which reache's to the fonth or fifth dorsal spine; another spine extends backward from the preopercle past rentrals; pectorals in adults reaching almost to cauclal, 
shorter in the roung; the first dorsal originates orer the rentrals, its longest spine is equal in length to the distance from tip of snout to posterior margin of orbit; the second dorsal rays are slightly longer; anal base shorter than either dorsal base, equal to base of first six rays of second dorsal; caudal emarginate; rentrals as long as head. D. II-T, S; A. 6.

Color of varying shades of greenish, olive, and reddish brown on upper parts of body, paler underneath; irregular markings of dusky and vermilion, varying to salmon yellow; pectorals with bright blue streaks near base, and blue spots and bars toward the tip, their under sides glaucous blue edged with darker; three brownish red bars on caudal fin.

The flying gurnard is found in the Atlantic ocean on both coasts. It is very abundant on our south Atlantic coast and in the Gulf of Mexico. It ranges as far north as Cape Cod. Sereral specimens were obtained in Great Egg Harbor bay in August and september 1887. Their lengths were respectively $2 \frac{1}{2}, 6 \frac{1}{2}$ and $7-\frac{7}{10}$ inches. In Gravesend bay, L. I., this is an uncommon species. In individual was taken there Oct. 30, 1897. Dr Smith says that a few are taken every year late in the fall in the ricinity of Woods Hole Mass. They sometimes come ashore in Buzzards bay and Tineyard sound, benumbed by cold. They are not so abundant now as they were prior to 1887 . Mitchill described and figured the fish in 1815 under the name Pol y $\mathrm{n}$ mus sexradiatus.

De Kay calls it the sea swallow and has the following notes on it:

Dr Mitchill, in his memoir on the Fishes of New York in 1814 (1815), gave a good figure of this species; and in his supplement to this memoir in the American Monthly Magazine in 1818 furnished a detailed description which sufficiently establishes its identity with $\mathrm{D}$. rolita $\mathrm{ns}$... The subject of our examination was caught in a net in the harbor in the month of August. If our species be identical with that of Europe, it has a wide geographical distribution. On the American coast it ranges from Brazil to Newfoundland. By means of its immense pectorals, it is enabled to spring from the occan and support itsclf for some time in the air. This is often done to protect itsclf from its enemies. It feeds on various small crustacea. 


\section{Suborder DISCOCEPHALI}

Family echeneididae

\section{Remoras}

\section{Genus Echeneis (Artedi) Linnaeus}

Body comparatively elongate, the rertebrae $14+16=30$; disk long, of 20 to 28 laminae; pectoral pointed, its rays soft and flexible; soft dorsal and anal long, of 30 to 41 rays each; caudal lunate in the adult, convex in the young. Species of wide distribution, attaching themselves mainly to sea turtles and large fishes.

\section{Echeneis naucrates Linnaeus}

\section{Sharksucker; Sucking Fish}

Echeneis neucrates (misprint for naucrates) Linsaeus, Syst. Nat. ed. X, I, $261,1758$.

Erfencis naucrates Mitchil, Trans. Lit. \& Phil. Soc. N. Y. I, 377, 1815;

DE KAy, N. Y. Fauna, Fish. 308, 1842; Günther, Cat. Fish. Brit. Mus. II, 384, 1860; Jordan \& Gilbert, Bull. 16, U. S. Nat. Mus. 416, 1883; Bean, Bull. Am. Mus. Nat. Hist. IX, 371, 1897; H. M. Sмiтh, Pull. U. S. F. C. 1897, 106, 1898; Jordan \& EvermanN, Bull. 47, U. న.

Nat. Mus. III, 2269, 1898; IV, pl. CCCXXIX, fig. 796, 1900. Echeneis albacauda Mitchill, Am. Month. Mag. II, 244, February, 1818. Écheneis albicauda DE KAT, N. Y. Fauna, Fish. 307, pl. 54, fig. 177, 1S42; Long Island; Hudson Rirer.

Body elongate, subterete, slender. The length of the body is five and one half times the length of the head. The disk is contained three and two thirds times in the length of the body, which is about seven and one half times the width between the pectorals; disk long. Dorsal and anal fins longer than the disk; inner rays of rentral fin narrowly adnate to the abdomen; caudal becoming emarginate with age. Vertebrae $14+16$. Vertical fins low; pectorals three fourths length of head, rather long and acute; lower jaw projecting, with the tip flexible; maxillary barely reaching rertical from nostril. D. XXI to XXV-32 to 41 ; A. 34 (32-38).

Brownish; the belly dark like the back, as usual in this family; sides with a broad stripe of darker edged with whitish, extending through eye to snout; caudal black, its outer angle whitish; pectorals and ventrals black, sometimes bordered with pale; dorsal and anal broadly edged with white anteriorly. 
The sharksucker or sucking fish is also known as the remora. It inhabits all warm seas, ranging north to Cape Cod and San Francisco. De Kay describes this species under the name of the white-tailed remora, and the Indian remora. He figures the species on pl. 54, fig. 177, of his New Fork Fauna. He sars it is not uncommon on the coast of Long Island, and has been several times brought to him by those who took it in ordinary seines. He states that it is called sharksucker. He saw a specimen which had ascended a considerable distance up the Hudson river. He states further that it appears most commonly in July and August. In Mitchill's account of the fishes of New York, an individual measuring 31 inches in length, and weighing 4 pounds 10 ounces is mentioned. In Gravesend bay the species is found in summer only attached to sharks, usually the sand shark, Ca r c h a rias littoralis. An individual obtained there July 28, 1897, lived and fed till Norember 13, when it ceased feeding, and Nov. 23 it died because of the low temperature of the water. In captivity the fish usually remains stationary on the bottom, with the head and anterior part of the body slightly raised, but will often rise to the surface to take pieces of clam or fish from the hand.

At Woods Hole Mass, according to Dr Smith, the fish is not uncommon. An example 21 inches long was caught at West Falmouth July 16, 1897, on a hook baited with fresh clam. In August 1901 an individual of medium size was caught with a hook on the Cinders, Fire Island, by an angler. This was the only specimen seen during the summer.

\section{Echeneis naucrateoides Zuiew.}

\section{Pilot Sucker}

Echeneis naucrateoides ZuIew, Nova Acta Ac. Sci. Imp. Petropol. IV, 279, 1759; Goode \& Bean, Bull. Essex Inst. XI, 20, 1879; H. MI. SмrTtr, Bull. U. S. F. C. 1897, 106, 1898; Jordan \& Evermann, Bull. 47, U. S. Nat. Mus. III, 2270, 1898.

Echeneis holbrooki Günther, Cat. Fish. Brit. Mus. II, 382, 1860.

The form of the body is similar to that of the sharksucker; its depth forms $\frac{1}{11}$ of the total length. The length of the head is one fifth of the total. The cephalic disk is very long, nearly 
one fourth of the total, and equal to twice the width of the body between the pectorals. The number of laminae is 20 or $\mathbf{2 1}$, and they are far apart. The radial formula, D. XX or XXI-32 to $35 ; \mathrm{A} .33$ to 35 .

The color is the same as in the sharksucker. This species ranges from Cape Cod to the West Indies. It is common on our south Atlantic coast. An individual was recorded by Prof. Baird at Woods Hole Mass. in 1871, and a number of specimens were taken during the next 10 years. According to Dr Smith, however, it has not recently been collected there.

Genus renora Gill

Body rather robust, the vertebrae $12+15=27$; disk shortish, of 13 to 18 laminae; pectoral rounded, its rays soft and flexible; soft dorsal and anal moderate, of 20 to 30 rays; caudal subtruncate. Species attaching themselves to large fishes, specially to sharks.

\section{Remora remora (Linnaeus)}

\section{Remora}

Echeneis remora Linvaeus, Syst. Nat. ed. X, I, 260, 175s; Mitchild, Trans. Lit. \& Phil. Soc. N. Y. I, 378, 1815; DE KAY, N. Y. Fauna, Fishes, 309, 1842; GÜnther, Cat. Fish. Brit. Mus. II, 378, 1860; Jordan \& Gilbert, Bull. 16, U. S. Nat. Mus. 417, 1883.

Remora jacobaea Goode \& BeAn, Bull. Essex Inst. XI, 21, 1879.

Remora remora JoRdan \& EverManN, Check-List Fish. N. A. 490, 1896;

H. M. SMtT, Bull. U. S. F. C. 1897, Iv6, 1898; Jordan \& EvermanN, Bull. 47, U. S. Nat. Mus. III, 2271, 1898.

Body and tail comparatively robust, the latter compressed. The length of the body is four times the length of the head, two and three fourths times the length of the disk and five and one fourth times the width between pectorals. Pectoral fin rounded, short, and broad, the rays soft and flexible; ventral fins adnate to the abdomen for more than half the length of their inner edge. Tip of lower jaw not produced into a flap. Vertebrae $12+15$. Head broad and depressed; disk longer than the dorsal or anal fin; maxillary scarcely reaching front of orbit; caudal lunate; rertical fins rather high; pectoral three fifths length of head. D. XVIII-23; A. 25.

Uniform dark brown. Warm seas, north to New York and San Francisco; usually found attached to large sharks. 
In 1815, Mitchill described this species nnder the name of small oceanic sucker. De Kay did not see the fish but obtained his information from the writings of Mitchill and Schoeff. He states that Schoeff saw this remora taken from the bottoms of ressels in the harbor of New York. At Toods Hole Mass., according to Dr Smith, the remora is rare. It was reported by Prof. Baird in 1871, and the specimen in the collection at that place was taken in July. It is usually found attached to large sharks. In 1879 Messrs Goode and Bean found in the museum of the Essex Institute, at Salem Mass. a specimen which was reported to have come from Salem harbor. If it really was obtained in that locality, it must have been attached to the bottom of some ressel from a southern port.

\section{Remora brachyptera (Lowe). Swordfish Sucker}

Echeneis brachyptera Lowe, Proc. Zool. Soc. Lond. S9, 1839, Madeira; G̈̈nther, Cat. Fish. Brit. II II, 378, 1860; JordaN \& Gilbert, Bull. 16, U. S. Nat. Mus. 417, 1883.

Echeneis quatuordecimlaminatus Storer, Rep. Fish. Mass. 155, 1839; De KAY, N. Y. Fauna, Fish. 309, $18+2$ (extralimital); Storer, Hist. Fish. Mass. 212, pl. XXXII, fig. 4, 1867.

Remoropsis brachypterus GiLL, Ploc. Ac. Nat. Sci. Phila. 60, 1864. Remoropsis brachyptera GoodE \& BEAx, Bull. Essex Inst. XI, 21, 1879. Remora brachyptcra JoRdAN \& EvermanN, Check-List Fish. N. A. 490, 1S96, H. M. SMith, Bull. U. S. F. C. 1897, 106, 1898; Jordan \& Everarans. Bull. 47, U. S. Nat. Mus. III, 2272, 1898; IV, pl. CCCXXX, fig. 797 т97а, 1900 .

The length of the head is contained nearly four times in the length of the body, which is six and one half times the width between the pectorals. Body robust, the greatest depth nearly twice the length of the short pectoral fins; disk shorter than base of dorsal, rather broad; upper jaw angular; caudal nearly truncate. D. XVI-30; A. 26.

Light brown, darker below; fins paler.

The swordfish sucker is an inhabitant of warm seas, ranging northward to Cape Cod, and to Japan. It is a small species and has usually been found attached to the swordfish. Dr Storer, in his Report on the Fishes of IIassachusetts, 1839, recorded a specimen from Holmes Hole, Marthas Vineyard. At Woods Hole 
Mass. this sucker is rare. There is in the U. S. National Museum an individual from that locality. Storer again describes the species in his History of the Fishes of Massachusetts, 1867, and gives a figure of it. De Kay refer's to this description on page 309 of his New York Fauna. He regards this fish as one of the extralimital species. Goode and Bean in 1879 recorded it as a parasite of the swordfish, which not infrequently accompanies that species into Massachusetts bay. They had also seen specimens from Newfoundland.

\section{Genus вномноспичs Gill}

This genus agrees with Remora in every respect excepting the structure of the pectoral fins. These are short and broad, rhombic in outline, the rays all flat, broad and stiff, being partially ossified, though showing the usual articulations; upper rays of pectoral broader than the others. One species known.

\section{Rhombochirus osteochir (Cuvier)}

\section{Spearfish Sucker}

Echeneis osteochir Cuvier, Règne Anim. ed. 2, II, 348, 1829; Günther, Cat. Fish. Brit. Mus. II, 381, 1S60; Jordax \& Gilbert, Bull. 16, U. S. Nat. Mus. 418, 1883.

Rhombochirus osteochir Jordan \& Evermann, Check-List Fish. N. A. 490, 1896; H. M. Surth, Bull. U. S. F. C. 1897, 106, 1898; JordAN \& EverMANN, Bull. 47, U. S. Nat. Mus. III, 2273, 1898; IV, pl. CCCXXX, fig. 798,1900 .

The length of the body is four and two thirds times the length of the head, two and one fourth times the length of the disk and five times the width between the pectorals; mouth very small, maxillary not reaching to the line of orbit; disk very large, broader and rougher than in $\mathrm{Ech}$ e ne is $\mathrm{r}$ e m o ra, extending forward beyond tip of snout; caudal fin emarginate, with rounded angles. D. XVIII-21 to $23 ;$ A. $20 ;$ P. 20.

Light brown; under side of head, ventral line, part of ventrals and a spot on pectorals pale.

This small species inhabits the West Indies and ranges northward occasionally to Cape Cod. It is parasitic on the species of spearfish, and is rather rare. It was recorded at Woods Hole Mass. by Prof. Baird in 1871. According to Dr Smith, a specimen was taken Aug. 6, 1886, in a fish trap at Quissett harbor, near Woods Hole. 
Suborder ANACANTHINI

Jugular Fishes

Family MEIrLICIDAE

Whitings

Genus merudeius Rafinesque

Body elongate, corered with small, deciduous scales; head slender, conic, the snout long, depressed; a well-defined, oblong, triangular excaration at the forehead, bounded by the ridges on the separated frontal bones, these ridges converging backward into the low occipital crest; eye rather large; edge of preopercle free; preopercle with a channel behind its crest, crossed by short radiating ridges; mouth large, oblique; maxillary extending to opposite the eye; lower jaw longer; no barbels; jaws with slender teeth, of various sizes, in about two series, those of the inner row longer and movable; romer with similar teeth; palatines toothless; branchiostegals seven; gill rakers long; gill membranes not united; dorsal fins two, well separated, the first short, the second long, with a deep emargination; anal emarginate, similar to second dorsal; ventral fins well developed, with about seven rays; vertebrae peculiarly modified, the neural spines well developed and wedged into one another; frontal bone double and the skull otherwise peculiar in several respects. Species several, very similar in appearance, ill-favored fishes of soft flesh and fragile fins, inhabiting water of some depth. Large, voracious, little valued as food.

\section{Merlucius bilinearis (Mitchill)}

\section{Thiting; silver Hake}

Stomodon Bilincaris MrTculle, Rep. Fish. N. Y. 7, 1814.

Gadus merlucius MiтchiLl, Trans. Lit. \& Phil. Soc. N. Y. I, 371, 1815.

Gadus albidus Mitchill, Joul. Ac. Nat. Sci. Phila. I, 409, 1817.

Merlucius albidus DE KAY, N. Y. Fauna, Fishes 280, pl. 46, fig. 148, 1812; Storer, Hist. Fish. Mass. 185, pl. XXVIII, fig. 2, 1867.

Merlucius bilinearis Goode \& BEAN, Bull. Essex Inst. XI, 9, 1879; Jordan \& Gilbert, Bull. 16, U. S. Nat. Mus. S09, 1S83; Bean, 19th Rep. Comm. Fish. N. Y. 249, pl. IV, fig. 5, 1890; GoodE \& BEAN, Oceanic Ichth. 386, fig. 330, 1896; H. M. Smith, Bull. U. S. F. C. 1897, 107, 1898; Jordan \& Evermaxx, Bull. 47, U. S. Nat. Mus. III, 2530, 1896; Bean, 52d Ann. Rep. N. I. State Mus. 109, 1900. 
The length of the body is six and one half times the depth of the body and three and three fourths times the length of the head. Top of head with W-shaped ridges very conspicuous; eye shorter than snout and less than interorbital in width; maxillary reaching posterior border of pupil; teeth not very large, smaller than in M. smiridus; scales larger than in other species; pectorals and rentrals long, the latter reaching three fourths distance to rent, their length being three fifths that of the head. I. $13-41$; A. 40; Lat. 1. 100-110.

Grayish, darker above, dull silvery below; axil and edge of pectoral somewhat blackish; inside of opercle dusky silvery; inside of mouth dusky bluish; peritoneum nearly black.

The whiting is known by the additional names of hake and silver hake. Mitchill describes it as the hake, Ga d us merl u c i us. He states that it is caught with the other cod. De Kay called it the American hake. He styles it a rare fish in the waters of New York, and, when caught, always associated with the common cod. The specimen described by De Kay was taken in November off Sandy Hook. In his New York Fauna, he mentions Mitchill's description of a specimen which measured 21 inches in length.

The whiting ranges from Labrador to Virginia. Young examples have been found even farther south in very deep water. This fish occurs in Gravesend bay in spring and fall. In Great South bay no individuals were seen by the writer during the summer, but an individual was obtained late in the fall by Capt. Thurber. Oct. 28,1898 , several examples were received from the Atlantic, off Southampton.

According to Dr Smith, the sprecies is abundant every fall at Woods Hole Mass. and some years it is common in summer. The fish swims close to the shore, and is caught in considerable numbers at Buzzard's bay at night with spears. Large individuals weighing 5 or 6 pounds are caught in traps. The young measuring 21 to 3 inches long, are seined in the fall abont $\Pi$ oods Hole. The names in use for the fish in that locality are silver hake, whiting, and frostfish. In Massachusetts bay the whiting is a 
frequent visitor to the shores and is probably a resident of the middle depths. The young are frequenty trawled in deep water.

$$
\begin{gathered}
\text { Family GADIDAE } \\
\text { Coufishes }
\end{gathered}
$$

\section{Genus rouldchuts Nilsson}

Body ratler elongate, corered - with minute scales; mouth moderate or large, the lower jaw projecting; barbel very small or obsolete; villiform teeth on romer, none on palatines; teeth in jaws equal or the outer slightly enlarged; gill membranes more or less united; subopercle and postclaricle not enlarged and not irorylike; dorsal fins three; anal two; caudal lunate; rent under first dorsal. Large fishes of the northern seas.

\section{Pollachius virens (Linnaeus)}

\section{Pollack:}

fiadus virens Linvaeus, Syst. Nat. ed. X. I. 253. 1758.

Gadus purpureus Mitcinled, Trans. Lit. \& Phil. Soc. N. Y. I. 370, 1S1E.

Merlangus purpureus Storer, Rep. Fish. Mass. 130, 1S39; DE KAY, N. Y.

Fauna, Fishes, 2S6, pl. 45, fig. 147. 1S42; Storer, Hist. Fish. Mass. 180,

pl. XXVII, fig. 3, 186 i.

Jerlungus carbonarins Storer, Rep. Fish. Mass. 129, 1S9y; De Kay, N. Y.

Fama, Fishes, 287, pl. 45, fig. 14t, 1842.

Iferlangus leptocephalus DE KAY, op. cit. 2SS, pl. 45, fig. 146, Long Island. Pallachius carbonarius Goode \& BEAx, Bull. Eissex Inst. XI, 8, 1879.

Polluchius virens Jordax \& EverManx, Check-List Fish. N. A. 498. 1896;

Bean, Bull. Am. Mus. Nat. Hist. IX, 371, 1997; H. M. Smitr, Bull.

U. S. F. C. 1897. 107, 1898; Jordax \& Evermann, Bull. 47, U. S. Nat.

Mus. III, 2534, 1898; IV, pl. CCCLIX, fig. S\$6, 1900.

The lengtlo of the body is four and one fourth times the depth of the body and four times the lengtl of the head. Body rather elongate, compressed; snout sharp and conic; month rather small, oblique; maxillary reaching beyond front of orbit; lower jaw slightly the longer; teetli in upper jaw nearly equal, the outer series not specially enlarged: barbel rudimentary or obsolete; gill membranes considerably united, free from istlunus; vent under first dorsal; caudal fin lunate; pectorals short, scarcely reaching anal; ventrals short. D. 13-22-20; A. 25-20; Lat. l. about 150 ; vertebrae 54 .

Greenish brown above; sides and below somewlat silvery; literal line pale; fins mostly pale; sometimes a black spot on the axil. 
The pollack is a native of the north Atlantic. It is common northward on both coasts, and extends south to France and New Jersey. Mitchill described the fish under the name of the New York pollack. De Kay mentions it under several names: the New York pollack, the coalfish, and the green pollack. De Kay says the fish is taken with the common cod, but is by no means common on the coast of New Jork. He saw a specimen weighing 17 pounds, and measuring 38 inches in length. In another description he states that the coalfish is often taken off the luarbor of New York in company with the cod, and is known as pollack and black pollack. The third form under which the fish was known to De Kay was described by him from a specimen captured by hook out of a large school in Long Island sound. The pollack enters Graresend bay in the fall. In captivity it is a ravenous feeder. It requires cold water and will not endure high temperatures.

De Kay states that the fish flipped in the same manner as the menhaden, and was at first supposed to be of that species. The school seemed to be rery timid; for, on a very slight noise in the boat, they all disappeared.

Dr Smith states that adult pollack appear in Vineyard sound, Great harbor, Woods Hole Mass. in May, following the run of cod. They depart when the temperature of the water reaches $60^{\circ} \mathrm{or}$ $65^{\circ}$. In April there is a run of pollack, measuring from 1 to $1 \frac{1}{2}$ inches long. By June, when these fish leave, they have reached a length of 4 inches. In fall there is a small run of pollack 7 or 8 inches long. The average weight of adults in that locality is about 10 pounds, the largest one seined having weighed 14 pounds. In Massachusetts bay this is an extremely abundant species, and constitutes an important food resource.

\section{Genus merogadus Gill}

Vere small codfishes allied to $\mathrm{G}$ a $d \mathrm{us}$, but with the vent placed before the second dorsal and with a different structure of the cranium. The following is Prof. Gill's account of the skull of M i c r oga $d$ us proximus, the italicised part indicating the difference from $\mathrm{G}$ a $d \mathrm{u}$ s. 
The cranium is proportionally broaler toward the front and less flattened, while the brain case is flattened below, decidedly sirollen on each side of a depressed sphenoidal groove, and has an orate cardiform shape; the paraoccipital or epiotic is not produced into an angle behind, but is obtusely rounded, and its posterior or outuardly descending villge blunt; the opisthotic is well developed, oblong, and with its reentering angle high up, and, on a line with it, the surface is dirided into two parts-a narrow and flattened one, and a lower, expanded one, much swollen; the alisphenoid or prootic is oblong, acutely emarginate in front, swollen from the region of the ligh anterior sinus, and above a little produced forward; the great frontal is a little longer than broad, with supraoccipital crest continued forturd on the bone, and near the front expanded upward, and with the expanded portion behind dividing into narrow lateral wings; the lateral testiform ridges of the frontal are continued forward and curved outuard toward the antero-lateral angles; the anterior frontals are mostly covered in front by the great frontal, and are much developed in the direction of the antero-lateral angles, the inferior expanded axillary portion being very narrow; the nasal has a rounded ridge in front, continued well below, and its posterior crest is laminar and trenchant.

Species American; valued as food.

\section{Microgadus tomcod (Walbaum)}

\section{Tomeod; Frostish}

Gudus tomcod Walbaum, Alt. Gen. Pisc. III, 133, 1792.

Gadus tomcodus Mitchild, Trans. Lit. \& Phil. Soc. N. Y. I, 36S, 1815; Storer, Rep. Fish. Mass. 126, 1839; Gürther, Cat. Fish. Brit. Mus. IV, 331, 1862 .

Gadus pruinosus Mitchild, Rep. Fish. N. Y. 4, 1814.

Norrhua pruinosa DE IIAY, N. Y. Fauna, Fish. 27S, pl. 44, fig. 142, 1S42: Storer, Hist. Fish. Mass. 179, pl. XXVII, fig. 5, 1867.

Mficrogadus tomcodus Goode \& BEAx, Bull. Essex Inst. XI, 8, 1S79; BeAr, 19 th Rep. Comm. Fish. N. Y. 248, pl. III, fig. 3, 1890.

Microgadus tomcod Jondax \& Gilbert, Bull. 16, U. S. Nat. Mus. S06. 1SS3; Bean, Bull. Am. Mus. Nat. Hist. IX, 371, 1997; Meares, Bull. Am. Ius. Nat. Hist. $\mathrm{X}$, 322, 189S; Eugene Smith, Proc. Linn. Soc. Х. Y. 1S97, 40, 1898; H. M. Sмгтн, Bull. U. S. F. C. 1S97, 107, 1S98: Jordan \& Evermann, Bull. 47, U. S. Nat. Mus. III, 2540, 1898; IV, pl. CCCIX, fig. S90, 1900; Besx, 52d Ann. Rep. X. Y. State Mus. 109, 1900 . 
Body subfusiform, moderately robust, its depth slightly less than length of head or about one fifth of the total length; depth of caudal peduncle contained three and one half times in greatest depth of body; snout rounded, the distance from eye to tip of snout twice diameter of ere, the latter being contained five and one half times in length of head; length of maxillary contained two and three fifths times in length of head; mandible much shorter; mandibulary barbel well developed; first dorsal ray inserted over middle of length of pectorals, the distance of this ray from tip of snout being about equal to its distance from end of second dorsal base, the length of the latter being equal to the distance from first dorsal ray to first ray of second dorsal; length of third dorsal base equal to that of second anal, these fins being opposite each other'; first anal opposite second dorsal, its base slightle longer; length of pectoral equals base of third dorsal; ventral filamentous, longer than pectoral. 1st D. 13-15; 2d D. 15-19; 3d D. 16-1S; 1st A. 1S-20; 2d A. 16-20.

Color olive brown with reticulations and blotches of darker; sides and back profusely covered with dark punctulations; under parts lighter' dorsal, caudal and anal fins with dark blotches; pectorals and ventrals dusky.

This fish is very generally known in New York waters und $\mathbf{r}^{\circ}$ the name of frostfish. It ranges from Nora Scotia to Virginia, and is excessively common in shallow bays in cold weather. The name frostfish is derived from the fact that it appears after frosts have set in. The species ascends fresh-water river's fur above the limits of tide, and may be transferred suddenly from salt water to fresh without inconvenience. It spawns in the carly part of winter, and is present at this time in such large numbers as to make its capture with dip nets comparativeìy easy. The frostfish is the commonest member of the cod family in New York waters. Its size is small, but, from the fact that it occurs in such abundance, it is an important market species. It is subject to great rariations in color; Dr Mitchill enumerates among its varieties five forms: the brown, yellow, yellowish white, mixed tomcod and the frostfish. De Kay has published 
the statement that he has known the frostfish to be taken out of the water along the shores of Long Island in great numbers witl a common garden hoe. He was informed that the species occasionally ascends the Hudson as far as Albany. In Great South bay we found large numbers of tomcod, which were cov. ered with a lernaean parasite. The same thing has been observed frequently at Woods Hole Mass. and other northern localities. We found the species in nearly all parts of the bay late in September in moderate numbers, and more plentiful at Fire Island October 1.

July 29, 1898, a few young tomcod were seined in Peconic bas, near Southampton. In Gravesend bay the fish is a fall and winter visitor. It does not live in captivity in summer. Dr Mearns has found this fish in the Hudson river, where it is usually called frostfish by the fishermen, who catch many of them in their fyke and ice nets during fall and winter. It bites readily and is esteemed as an article of food. Dr Mearns has found it during the entire year, and in August has found young tomcod fully an inch or two in length. He states that this fish is rery often found in eel grass along shore, half dead, floating on the surface, but able to swim a little. Mr Eugene Smith says that the tomcod runs up stream into nearly pure fresh water in the vicinity of New York city. At Woods Hole Mass. it is abundant in winter, coming about October 1 and remaining till May 1. It spawns in December. In Massachusetts it is a resident species, entering brackish waters; it is common about the whares and bridges in summer and is taken with nets and hooks in winter, in company with the smelt.

The tomcod reaches the length of about 10 inches. It is an important food fish and its eggs have been hatched artificially by the New York Forest, Fish and Game Commission in large numbers.

\section{Genus Gadus (Artedi) Linnaeus}

Body moderately elongate, compressed and tapering behind; scales very small; lateral line present, pale; head narrowed anteriorly; mouth moderate, the maxillary reaching past front of 
eye; chin with a barbel; teeth in jaws cardiform, subequal; romer with teeth; none on the palatines; cranium without the expanded crests seen in $\mathrm{M} \mathrm{el}$ a $\mathrm{n} \mathrm{o} \mathrm{g} \mathrm{r}$ a $\mathrm{m} \mathrm{m} \mathrm{u} \mathrm{s}$; no part of the skeleton expanded and ivorylike; dorsal fins three, well separated; anal fins two; ventral fins well developed, of about 7 rars. species of the northern seas; highly valued as food.

347 Gadus morrhua Linnaeus

\section{Cod}

Gallus callaritts Linnaeus, Syst. Nat. ed. X, I, 252, 1758, young; Mitcinte, Rep. Fish. N. Y. 5, 1814; Trans. Lit. \& Phil. Soc. N. Y. I, 367, 1815; Jordan \& Gilibert, Bull. 16, U. S. Nat. Mus. S04, 1883; H. M. Sмitir, Bull. U. S. F. C. 1897, 107, 1898; Jornan \& Evermaxt, Bull. 47, U. S. Nat. Mus. III, 2541, 1898; IV, pl. CCCLXI, fig. 891. 1900; SuErwood \& EDWARDs, Bull. U. S. F. C. 1901, 30, 1901.

Giflus arenosus and rupestris MiтchiLL, Trans. Lit. \& Phil. Soc. N. Y. I, 36S, 1815.

Morrhua amcricana Storer, Rep. Fish. Mass. 120, 1839; De Kay, N. Y. Fauna, Fishes, 274, pl. 44, fig. 140, 1842.

Morthun amerieamus Storer. Hist. Fish. Irass. 165, pl. XXVII. fig. 4, 1867. Gadus morhua Linvaeus, syst. Nat. ed. X. I, 252, 1758; Mitchill, Rep. Fish. న. Y. G, 1814.

Gadus morrtha GÜntier, Cat. Fish. Brit. Mus. IV, 328, 1862; Goode \& BEAN, Bull. Essex Inst. XI, 8, 1879; Oceanic Ichth. 354, 1896; BeAN, Bull. Am. Mus. Nat. Hist. IX, 372, 1897.

Body elongate, robust, its greatest depth one fourth of length to end of vertebral column, tapering to caudal, the depth of the peduncle being less than one fourth of greatest depth of body; the length of the head slightly more than depth of body, one fourth of total length; eye one fifth length of head; maxillary longer than snout, reaching vertical through eye, and contained two and one half times in length of head; teeth moderately strong, in bands; the first dorsal originates belind vertical from base of pectorals, its base equal to length of eye and snout; second dorsal base much longer than first, four fifths length of head; third dorsal and second anal fins similar, their bases of equal length; first anal base almost equal to second dorsal base; caudal emarginate; pectorals and ventrals comparatively small. D. $14,21,19 ;$ A. 20,18 .

Color olive or sellowish brown; numerous dark brown spots on body; fins dark. 
The cod is an inhabitant of the north Atlantic and the north Pacific. It is a very important food fish and grows to a large size. Indiriduals weighing about 100 pounds have occasionally been taken. Mitchill has described this fish under several names: the torsh, or common cod, or rock cod of New York. De Kay calls it the American cod. In November 1897 the cod was abundant in Graresend bay. It thrives in captivity duriug the winter and spring, but can not be kept during the rarm months without cooling the water. In Vineyard sound, accordinc to Dr. Smith, the cod appear about April 1 to about April 1.5, when the dogfish drive them away. After the middle of October the cod come again but in less numbers than in the spring, remaining till the first wintry weatler'. The fish spawns during the late fall and winter. The roung are first observed at Toods Hole about the first of April, when fish about 1 inch long are seined. Most of the young leave by June 15, having attained a length of from 3 to 4 inches. No cod are seen between small fish of that size and fish weighing from $1 \frac{1}{2}$ to 2 pounds, which are caught in traps in the spring. Off the coast of New England cod are very abundant in the deep waters, and they come up to the shoals and near the shores to spawn, from Norember about Cape Ann till February on Georges banks.

\section{Genus melanogramud Gill}

This genus is distinguished from $\mathrm{Gadus}$ by its smaller mouth, the produced first dorsal fin, black lateral line, and specially by the great enlargement of the hypocoracoid, which is dense and irorylike. The lateral line is always black, and the supraoccipital and other crests on the head are largely dereloped. Food fishes of large size.

\section{S Melanogrammus aeglefinus (Linnaeus)}

\section{Haddock}

Gadus aeglefimus Linnaeus, Syst. Nat. ed. X, I, 251, 175S; Mitchil.. Tians. Lit. \& Phil. Soc. N. Y. I, 370, 1815.

Morrhua aeglefinus Storer, Riep. Fish. Mass, 124, 1839; DE KAY, N. Y. Fauna. Fishes, 279, pl. 43, fig. 13s, 1812; Storer, Hist. Fish. Mass. 177, pl. XXVIII, fig. 1, 1867 . 
Melanogrammes acylefinus GiLt, Proc. Ac. Nat. Sci. Phila. 2S0, 1S62; Goode \& Beax, Bull. Essex Inst. XI, 8, 1S79; Jordan \& Gilbert, Bull. 16, U. S. Nat. IIus. S03, 1SS3; Goode \& BeAN. Oceanic Ichth. 354, 1896; BeAn, Bull. Am. Mus. Nat. Hist. IX, 372, 1897; Jordax \& Evermaxn, Bull. 47, U. S. Nat. Mus. III, 2542, 189S; IV, pl. CCCLXI, fig. 892, 892a, 1000 .

The lengtl of the body is four and one half times its depth and three and three fourths times the length of the head. Snout long and narrow, overlapping the small mouth; maxillary barely reaching front of orbit; teeth subequal, large, in a cardiform band in upper jaw; in a single series on lower jaw and on romer; occiput carinated; a ridge extending backward from each orbit; eye very large, two thirds length of snout, four in head. Interior rays of first dorsal elevated, three fourths length of head, the fin pointed, higher than second and third dorsals; caudal lunate; vent below front of second dorsal. The skull in this species much more depressed than in $\mathrm{G}$ a $\mathrm{d} u \mathrm{~s}$ c a 11 a $\mathrm{r}$ i a s, broader, and thinner in texture; occipital crest exceedingly high, much higher than in $\mathrm{G}$ a $\mathrm{dus}$, the winglike projections at its base anteriorly spreading widely, raised above the surface of the skull. D. 15-24-21; A. 23-21.

Dark gray above, whitish below; lateral line black; a large dark blotch above the pectorals; dorsals and caudal dusky.

Mitchill described the haddock under the name G a d u a eglefin us. De Kay also describes the fish and gives a figure of it in his New York Fauna. He states that it is nearly as common in the New York markets as the cod, and during the summer it is even more abundant than the cod.

The haddock inhabits the north Atlantic on both coasts, ranging south to France and to North Carolina. Off Cape Hatteras it occurs in the deeper water. It is an important food fish, and reaches a moderately large size, attaining to a length of nearly 3 feet.

At Woods Hole Mass. it was reported by Prof. Baird in 1871. Dr Smith, however, says it is not found in Vineyard sound or Buzzards bay, but is common 6 or 7 miles off Gay head, and the ocean side of Marthas Vinevard. In Massachusetts bay it is a common resident species. 


\section{Genus rote (Curier) Olien}

Body long and low, complessed behind; head small. depressed, rather broad; anterior nostrils each with a small barbel; chin with a long barbel; snout and lower parts of head naked; mouth molerate, the lower jaw included; each jaw with broad bands of equal, villiform teeth; romer with a broad, crescent-shaped band of similar teeth; no teeth on palatines; gill openings wide, the membrane somewhat connected, free from the isthmus; scales very small, embedded; rertical fins scaly; dorsal fins two, the first short, the second long. similar to the anal; caudal rounded, its onter rays procurrent; ventrals of several rays. One or two species, living in fresh waters of northern regions.

\section{$3 \pm 9$ Lota maculosa (Le Sileur)}

Burbot; Lauryer; Ling

Gadus maculosus LE Sueur, Jour. Ac. Nat. Sci. Phila. I, \$3, 1S17, Lake Erie.

Gadus lacustris Mrtchill, Am. Month. Mag. II, 244, February, 1818. Lota brosmiana Storer, Bost. Jour. Nat. Hist. IV, pl. 5, fig. 1, 1839.

Lota inornata DE KAY, X. Y. Fauna. Fishes, 28:, pl. 45, fig. 145, 1842. Hurlson River.

Gadus compressus Le Sueur, Jour. Ac. Nat. Sci. Phila. I, S1, 1817.

Lota compressa DE KAY, op. cit. 2S5, pl. 78, figs. 244. 245, 1842.

Molva maculosa Le Sueur, Mém. Mus. Paris, T, pl. 16, 1819.

Lota maculosa DE KAY, op. cit. 284, pl. 52, fig. 168, 1842; JoRDAN \& GILBERT, Bull. 16, U. S. Nat. Mus. S0t, 18S3; Меeк, Aun. N. Y. Ac. Sci. IT. 315, 18s8, Cayuga Lake; Beax, Fishes Penna. 1:8, pl. 35. fig. T5. 1S9:; Evermañ \& Kendall, Rept. T. S. F. C. 1894, 608, 1896; Beat. Bull. Am. Mus. Nat. IIist. IX. 372, 1897, Canandaigua Lake: Jordix \& Evermann, Bull, 47, U. S. Nat. IIus. III, 25.50. 1898; IV, pl. CCCLXIT. fig. 897,1900 .

The body of the burbot is elongate, eel-shaped; its greatest hight equaling the length of head without snout, and about one sixth of total without caudal; it is roundish, somewhat com. pressed posteriorly. The eye is small, less than one half length of snout and about one eighth length of head. The upper jaw reaches slightly beyond the hind margin of the eye, its length three sevenths length of head. The lower jaw is inclurled within the upper, and has a stout barbel which is nearly onefifth as long as the liead; the ventral is longer than the pectoral, 
but does not reach half way to rent; the pectoral is half as long as the head; the distance of the first dorsal from the head equals the hight of the body; the longest ray of the first dorsal equals half the lengtl of its base; the dorsal fins are separated by a narrow interspace; the second dorsal is higher than the first, and the length of its base is nearly one half total without caudal; the anal begins under the ninth ray of the second dorsal and extends as far back as that fin; caudal rounded; the scales are deepls embedded in the skin, not imbricated. D. 13, 68 to $76 ;$ A. 67 ; V. 7 ; vertebrae, 22 to $23+38$ to 39 ; pyloric caeca, 30 to 138 .

The color is dark olivaceous, reticulated with blackish; the lower parts rellowish or dusky; the dorsal, anal and caudal fins with a narrow dark edge.

The American burbot was first described by Le Sueur from Lake Erie in 181T, and also from Northampton Conn. under a different name. This common fish has received a great many names, including the following: marthy, methy, losh, eelpout, dogfish, chub eel, ling, lawyer, lake cusk, fresh-water cod, aleby trout and mother-of-eels.

The southern limit of this fish appears to be Kansas City Mo.; according to Prof. Cope, it has been once taken in the Susquehanna near Muncy, Lycoming co.; it is extremely common in the Great lakes; westward it ranges to Montana and nortlward throughout British Columbia and Alaska to the Arctic ocean; it is most abundant in the Great lakes and lakes of New York. New England and New Brunswick; it abounds also in rivers and lakes of Alaska.

The burbot was sent from Canandaigua lake by Mr James Annin jr in November 1897. It is hard to transport and still hardel to keep alive in captivity, being specially liable to attacks of fungus.

Dr W. M. Beauchamp, writing from Baldwinsville N. I. Ap. 9,1879 , said that the burbot is found in Seneca river and is abundant in Oneida lake; that it is caught with a look and is seldom eaten, though there is a way of making it palatable. 
According to Dr Meek it is found rarely in Cayuga lake.

The arerage length of this species in the Great lakes region is about 2 feet; in Alaska, according to Dr Dall, it reaches a lengtl of 5 feet and occasionally weighs 60 pounds; the size of the fish depends chiefly on the amount of food accessible to it.

It is stated that the burbot is usmally found in deep water on mud bottom, except during the spawning scason, in Marcl, when it frequents hard or rocky bottoms. The eggs are small and numerous, and are believed to be deposited in deep water; Dr Dall estimates that some individuals contain several millions of eggs; in Alaska the eggs are of a creamy yellow color, and the fish are found full of spawn from November to January. From the observations mentioned, it will be seen that the spawning period extends at least from November to March; according to Dr Dall the males are usually much smaller than the females and have a smaller liver; in some males he found two or three gall bladders opening into a common duct, but he never observed this phenomenon in the female; the eggs are laid separate or loose on the bottom of the river. According to Baron Cederström, a medium-sized female of the European burbot, which is a near relative of the American species, contained about 160,000 eggs; in the European burbot, some eggs are clear, some yellowish and others almost colorless; the period of incubation occupies from three to four weeks; the eyes appear in 15 or 16 days; the embryos swim by quick movements of the pectorals, usually toward the surface of the water, whence they fall passively to the botton.

The burbot is extremely voracious, and feeds on bottom fishes and crustaceans. It destroys the pike and such spiny fishes as the yellow perch and sunfish. In Alaskan rivers it feeds on whitefish, lampreys and other species; large stones have sometimes been found in its stomach. Mr Graham took a stone weighing a pound from the stomach of a burbot.

In the Great lakes region the burbot is considered worthless for food, occasionally the livers are eaten; in Lake Winnepe- 
saukee, when caught through the ice in winter, the fish is highly esteemed; in the fur countries the roe is an article of food; on the Iukon river the liver is eaten and the flesh is liked by some persons; in Montana the burbot is in great demand for food; the quality of the flesh appears to depend chiefly on the nature of the habitat of the fish.

This is the only member of the cod family permanently resident in the fresh waters of America.

\section{Genus dropmers Gill}

Body rather elongate; head subconic; mouth rather large, the maxillary reaching to below eye; lower jaw included; chin with a small barbel; jaws and voner with broad bands of subequal, pointed teeth; palatines toothless; dorsal fins two, the first sometimes produced at tip; second dorsal long, similar to the anal; ventrals wide apart, filamentous, each of three slender rays closely joined, appearing like one bifid filament; gill membranes somewhat connected, narrowly joined to the isthmons.

\section{Subgenus UROPHYCIS}

350 Urophycis regius (W'albanm)

spotted Codling; spotted Hake

Blennius regius Walbaum, Art. Gen. Pisc. III, 186, 1792.

Gadus punctatus MtтchlLL, Trans. Lit. \& Phil. Soc. N. Y. I, 372, pl. I. fig. 5. 1815, New York; DE KAx, N. Y. Fauna, Fishes, 292, pl. 46, fig. 149, $18+2$.

Phycis regalis Günther, Cat. Fish. Brit. Mus. IV, 354, 1862.

Phycis regius Goode \& BEAx. Bull. Essex Inst. XI, 8, 1879; Oceanic Ichth. 357, 1896; Bean, Bull. Am. Mus. Nat. Hist. IX, 372, 1897; H. M. Sмптн, Bull. U. S. F. C. 1897, 107, 1898.

Erophycis regius Gill, Proc. Ac. Nat. Sci. Plila. 240, 1863; JordaN \& EverMAnN, Bull. 47, U. S. Nat. Mus. III, 2558, 1895; IV, pl. CCCI.XIV, fig. S9S, 1900 .

The depth of the body is contained four and one lialf times in its length, which is four and one fourtl times the length of the head. Body rather stout; head broad; mouth large, the maxillary reaching posterior margin of eye; eye less than snout or interorbital width; first dorsal low, its hight about equal to half length of head; ventral fin longer than head, about three and one half in the length of the body; caudal fin subtrun. 
cate. D. S-43; A. about 45 ; scales rather large, about 90 in the lateral line.

Pale brownish, tinged with yellowish, the lateral line dark brown, interrupted by white spots; inside of mouth white; first dorsal largely black, this color surrounded by white; second dorsal oliraceous, with irregular, round, dark spots; caudal, anal and pectorals dusky; rentrals and lower edge of pectorals white; two rertical series of round dark spots on the sides of the head.

Mitchill described and figured the spotted codling under the name of Gadus punctatus. De Kay called it the spottrd codling, P h y e i s p u n e t a $t$ us, and he gires a goorl figure of it. His example was 10 inches long. He says it is an exceedingly rare but distinct species, and that it occurs from the coast of New Tork to the Gulf of St Lawrence. As a matter of fact, the species extends even farther north. The codling ranges southward to Cape Fear. In the northern part of its habitat it is found in shallow water, but at the southern limit it lives in considerable depths, having been taken from 167 fathoms. The fish is said to exhibit electrical powers in life.

The spotted codling appears in Gravesend bay in small num. ber's in the fall. It lives in water below $60^{\circ} \mathrm{F}$, and is easily lept in captivity by refrigerating the water in summer. Its habit of lying on the side. in imitation of the tautog and other labroids is often observed. Prof. Alexander Agassiz discovered electric powers in this fish.

At Woods ITole Mass., according to Dr Smith, it is taken in the seine only late in the fall. It varies in length from $i$ to 12 inches. The species has been observed at Halifax N. S.

\section{Subgenus EMprycus . Tordan \& Ėermann}

This subgenus differs from Uroph y $\mathrm{c}$ is in having the first dorsal fin elevated, with one or more of its rays filamentous.

\section{Urophycis tenuis (Mitchill)}

\section{Hake; Thite Hake}

Galus tenuis Mitchuld, Rep. Fish. N. Y. T, 1814; Trans. Lit. \& Phil. Soc. N. I. I, 372, 1S15, New York. 
Phycis temils De KaY, N. Y. Fama, Fishes, 293, 18t2; Goode \& Beax, Bull. Essex Inst. XI, 8, 1879; Jordax \& Gilbert, Bull. 16, U. S. Nat. Mus. 799, 1853: BeAN, 19th Rep. Comm. Fish. N. Y. 248, pl. III, fig. 4, 1890; Goode \& BEAN, Oceanic Ichth. 359. fig. 312, 1896; BEAN, Bull. Am. Mus. Nat. Hist. IX, 372, 1897; H. M. Sмгтн, Bull. U. S. F. C. 1897, 107, 1898; Jordan \& Evermann, Bull. 47, U. S. Nat. Mus. III, 2555, 1898; IV, pl. CCCLXV, fig. 901, 1900; BeAN, 52d Ann. Rep. N. X. State Mus. $109,1900$.

The length of the body is five and one half times the depth of the body and four and one fourth times the length of the head. Snout longer than eye, narrower and more pointed than in $\mathrm{P}$. chuss. Eye large, usually wider than interorbital space; maxillary reaching beyond pupil; filamentous dorsal ray about two thirds length of head; ventral fins about reaching vent; scales very small. D. 9-57; A. 48; Lat. 1. 138.

Brownish, lighter and yellowish below; fins very dark. Distinguished from U. ch us s chiefly by the smaller scales.

De Kay calls the hake the American codling, adopting Mitchill's common name for the species. He says it appears to feed chiefly on smaller crustacea; that it is very abundant at some seasons, but most abundant in the early part of autumn; and varies in weight from 3 pounds to 30 pounds. He states that it is called indiscriminately hake and codling by New York fishermen. Small individuals were seined in Mecox bay Aug. 2, 1898, and a very young example was received from Southampton Sep. 11. This was caught in the Atlantic. In Great South bay small examples were found sparingly at Blue Point cove and Fire Island late in September.

The hake, according to Dr Smith, is known also as white hake and squirrel hake in the vicinity of Woods Hole Mass. Fish weighing 1 to $1 \frac{1}{2}$ pounds are abundant there in November, when a great many of them enter Eel pond. Young fish 1 inch long and upward associate with pollack in spring and are also found throughout the summer in considerable numbers. They are also obtained in summer at the surface, under gulf weed and eel grass.

As a rule the common hake will not live in water of a temperature above $60^{\circ} \mathrm{F}$, but one individual survired the summer tem- 
perature in $189 \pi$, and became plump and sleek after the arrival of cold weather. In summer it was much emaciated, and suffered greatly from fungus attacks.

It is abundant on our shores from Labrador to Virginia, and its young are among the commonest of the surface fishes in our bays and sounds, during the summer months. The hake reaches a weight of 40 pounds, but in the markets the arerage weight is only about 10 pounds. The species frequents muddy bottoms and is local in its babits. Its food consists of crabs and other crustaceans, besides small fishes.

The chief fishery for hake takes place in the fall and winter months, and they will take the hook at night as well as during the day. Trawl lines are the usual implements of capture.

\section{Urophycis chuss (Walbaum)}

\section{Squirrel Hake}

Blennius chuss Walbaum, Art. Gen. Pisc. III, 186, 1792.

Gadus longipes Mrtchil, Rep. Fish. N. Y. 5, 1814; Trans. Lit. \& Phil. Soc.

N. Y. I, 372, pl. I, fig. 4, 1815, New York.

Phycis filamentosus Storer, Hist. Fish. Mass. 189, pl. XXIX, fig. 4, 1867.

Phycis chuss Gill, Proc. Ac. Nat. Sci. Phila. 237, 1863; Goode \& Bean, Bull.

Essex Inst. XI, 8, 1879; Jordan \& Gilbert, Bull. 16, U. S. Nat. Mus. 799. 1893; Goode \& BEAN, Oceanic Ichth. 359, fig. 311, 1896; BEAN, Bull. Am. Mus. Nat. Hist. IX, 372, 1897; H. M. Sмптн, Bull. U. S. F. C. $1897,107,1898$.

Urophycis chuss Jordan \& EverMANN, Bull. 4i, U. S. Nat. Mus. III, 2555, 1898; IV, pl. CCCLXV, fig. 902, 1900.

The depth of the body is one fifth of its length, which is four and one half times the length of the head. Body rather slender; head depressed; eye large, about equal to interorbital width; maxillary reaching posterior margin of pupil; filamentous dorsal ray about two sevenths length of body, when perfect; pectorals four fifths length of head; ventral fin extending beyond the vent; scales comparatively large. D. 9-57; A. 50; Lat. 1.110.

Brownish above, sides lighter and tinged with yellowish; thickly punctulate with darker; below pale; inside of mouth white; rertical fins somewhat dusky; anal fin margined with pale; lateral line not dark.

According to Jordan and Evermann, this fish is sometimes called codling. It inhabits the Atlantic coast from the Gulf of 
St Lawrence to Virginia, being very common northward. It is sometimes found in waters as deep as 300 fathoms. The squirrel hale occurs occasionally in Gravesend bay; it lives usually in the deep water off shore.

At Woods Hole Mass. according to Dr Smith, it is abundant in May and June, and in October and November. It fills the traps and causes the fishermen much annoyance, as they can not sell the fish. Its weight there is from 2 to 5 pounds. In Massachusetts bay it is less abundant than the common hake. It was described and figured by Storer in 1867, under the name $\mathrm{Phyc}$ is filamentosus.

\section{Genus gaidropsarus Rafinesque}

Body rather elongate, covered with minute scales; head not compressed, the upper jaw the longer; snout with two conspicuous barbels, the chin with one; teeth on jaws and romer in bands, palatines toothless; dorsals two, the anterior of a single long ray followed by a series of short fringelike rays concealed in a groove; second dorsal and anal long, similar to each other; caudal rounded or lanceolate; ventral rays 5 to 7 . Small fishes of the northern seas, descending to deep water.

\section{Gaidropsarus argentatus (Reinhardt)}

\section{Silcery Rockling; Mackerel Midge}

Motella argentata ReinhARDT, Dansk. Vidensk. Selskrift. Afh. VII, 128, 1838, Greenland.

Conchia aigentata Güxtuer. Cat. Fish. Brit. Mus. IV, 365, 1862.

Ciliata argentata Gild, Proc. Ac. Nat. Sci. Phila. 241, 1863.

Onos reimhaidti Gill, op. cit. 241, 1863; Jordax \& GilberT, Bull. 16, U. S.

Nat. Ins. 797, 1883; Goode \& BEAN, Oceanic Ichth. 383, 1896.

Gaidropsarus argentatus Jordan \& Evermann, Bull. 47, U. S. Nat. Mus.

III, 2559, 1898; IV, pl. CCCLXVII, fig. 906, 1900.

The length of the body is five times the length of the head. Head depressed, but rather pointed anteriorly; snout rather short, with two barbels; chin with one; teeth in villiform bands, those of one series in each jaw longer than the rest; first ray of first dorsal short, little longer than snout; vent near middle of length; distance from snout to first dorsal three tenths of length. D. $56 ;$ A. $45 ;$ V. 8. 
Uniform reddish brown; cirri and tips of ins red. Greenland. The silvery rockling, or mackerel midge, inhabits the coast of Greenland, and extends southward probably as far as Long Island, the young having been taken in Vineyald sound.

\section{Gaidropsarus ensis (Reinhardt)}

\section{Rockiling}

Ifotella ellsis Reivinard, Dansk. Vidensk. Selskrift. Afh. VII, 15, 1S38, Greenland.

Onos rufus Gint, Proc. U. S. Nat. IIus. 259, 1583, Gulf Stream; Proc. Ac. Nat. Sci. Phila. 172, 1854.

Onos énsis Gill, Proc. Ac. Nat. Sci. Phila. 211. 1863; Jordan \& Gilbert. Bull. 16, U. S. Nat. Mus. 797, 1SS3; Goode \& BeAr, Oceaule Ichth. 381, fig. $327,1896$.

Gaidropsarus ensis Jondan \& Evermaxx, Bull. 4i, U. S. Nat. Mus. III, 2558, 1898.

Body unusually deep, its greatest depth at rent equaling two ninths of total length without caudal; head small, a little more than one sixth of total without the caudal; eye rather large, nearly as long as snout, equaling interorbital area, and situated in first half of head; posterior margin of orbit nearly equidistant from tip of snout and posterior margin of opercle; mouth normal; supramaxillary ending under posterior margin of pupil; teeth in a narrow band in each jaw. some of those at least in outer row of upper jaw slightly enlarged and brownish colored; romerine teeth in two rows forming a short curved band; nasal barbel about equal to diameter of eje; chin barbel small and not much exceeding one half diameter of eye; foremost ray of first dor'sal springing from back above opercular margin; second dorsal fin low in front, but rising rapidly to serenth or eighth ray, behind which it is nearly uniform for a long distance and highest at posterior portion; anal fin much lower than second dorsal; caudal slightly emarginate, almost truncate behind, its median rays about two thirds as long as the head; pectorals nearly three fourths as long as the head, produced toward the upper angles, the third ray being longest; rentrals with their bases mostly in advance of pectorals, the longest ray filamentous and nearly equaling pectoral; lateral line obsolescent. D. 5?; A. 44 to 46 ; P. 22 to 27 ; V. 8 . 
Inhabits the Atlantic coast of North America from Greenland to Cape Fatteras in deep waters. It reaches a depth in the Gulf Stream of 1081 fathoms. The fish is described and figured by Goode and Bean in Oceanic Ichthyology, p. 381, fig. 327. It is a small species, scarcely reaching 1 foot in length, and is without importance as food.

Genus exchemopus Bl. \& Schn.

Barbels four, one at each nostril, one at tip of snout, and one at the chin; head high and compressed anteriorly; teeth in narrow bands, some of them enlarged; otherwise essentially as in Ga i d r o p s a r u sorth Atlantic.

\section{Enchelyopus cimbrius (Linnaeus)}

\section{Four-bearded Rockling}

Gadus cimbrius Lixnaeus, Syst. Nat. ed. XII, I, 440, 1766, Atlantic Ocean. Motella caudacuta Storer, Hist. Fish. Mass. 183, pl. XXIX, fig. 1, 1867.

Onos cimbrius Jordan \& GIlbert, Bull. 16, U. S. Nat. Mus. 797, 1883.

Rhinonemus cimbrius Goode \& BEAN, Oceanic Ichth. 3S4, tig. 328, 1896; H. M. Smith, Bull. U. S. F. C. 1897, 107, 1898; Sherwood \& Edwards, Bull. U. S. F. C. 1901, 31, 1901.

Enchelyopus cimbrius Jordax \& Evermann, Bull. 47, U. S. Nat. Mus. III, 2560, 1898; IV, pl. CCCLNVII, fig. 907, 1900.

Body slender, tapering, its depth nearly one sixth of the total without caudal; caudal peduncle narrow, one fourth length of head, which is contained five and one half times in total without caudal; snout moderate, blunt, rounded, not depressed, a little shorter than the eye, which is one fourth as long as the head; interorbital space narrow, one sixth length of head; teeth villiform, small and unequal in upper jaw, with about eight enlarged in front, long, slender, and equal in lower jaw, a few somewhat enlarged in front; maxillary reaching beyond posterior border of eye; a barbel at each nostril, one on tip of snout and one on chin; lateral line with about 35 enlarged pores along its entire length; first (free) ray of dorsal nearly as long as the head; ventral one half as long as head; pectoral equal to head without snout; caudal narrow, rounded behind, two thirds as long as head.

Color, light rufous or salmon red; first dorsal ray and posterior end of dorsal and anal abruptly black; lower half of caudal 
black; pectorals and rentrals pale; sides of head somewhat silrery; cavity of mouth dark bluish.

The four-bearded rockling is found in the north Atlantic on both coasts, ranging south in deep water to the Gulf Stream. It is common in Massachusetts bay. This fish is also described in Oceanic Ichthyology, p. 38t, fig. 32s. At Woods Hole Mass., according to Dr Smith, it is a rare visitor, found only in winter. It was once taken in a fyke net in Great harbor. In 1900, according to Sherwood and Edwards, young rockling were taken in the surface towings at the fish commission wharf, Woorls Hole Mass. from June 27 to July 6. They formed into schools in the eddies, around the wharves and were mixed with young sticklebacks. An example measuring 10 inches in length was speared in the Eel pond Jan. 5, 1889. A second example was caught in rittle harbor also in the winter.

Storer described and figured this fish under the name M o t e l la ca u d a c u t a . It is a resident of the deep waters of Massachusetts bay, where it occurs in considerable abundance. The young swim at the surface and have often been erroneously identified with the mackerel midge. The species grows to the length of 1 foot.

\section{Genus вrosme (Cuvier) Oken}

Body moderately elongate, covered with rery small scales; mouth rather large, with teeth in the jaws, vomer and palatines, some of those on the vomer and palatines enlarged; chin with a barbel; branchiostegals seven; dorsal fin single, continuous, not elevated, not notched; anal fin similar, but shorter; caudal fin rounded; ventral fin several-rayed. Northern seas.

\section{Brosme brosme (Miiller) \\ Cusk}

Gadus urosme Müller, Prodr. Zool. Dan. 41, 1766, Denmark.

Brosmius vilgaris? DE KAY, N. Y. Fauna. Fishes, 2S9, pl 44, fig. 143, 1842. Brosmius flavescens Günther, Cat. Fish. Brit. Mus. IV, 369, 1S62; STorer, Hist. Fish. Mass. 190, pl. XXIX, fig. 2, 1867.

Brosmins trosme Günther, op. cit. IV, 369, 1862; Goode \& BEAN, Bull. Essex Inst. XI, 9, 1879; Jordax \& Gilbert, Bull. 16, U. S. Nat. Mus. S02, 1SS3; GoOdE \& BEan, Oceanic Ichth. 385, fig. 329, 1896; H. M. SiIth, Bull. U. S. F. C. 1897, 107, 1 S9S.

Brosme brosme Jordan \& Fveriann, Bull. 47, U. S. Nat. Mus. III, 2561, 1898. 
Body cylindric, posteriorly compressed, its depth contained five and one fourtl times in total length without caudal; head flattened above, its length contained four and one fourth times in total; mouth large, oblique, maxillary reaching beyond orbit; lower jaw included; several 1.0ws of sharp teeth on jaws, romer and palate; barbel about one fifth as long as the head; inter. orbital width greater than diameter of eye; origin of dorsal above anterior half of pectoral; pectoral round, two fifths as long as head; caudal rounded belind. 1). $98 ;$ A. 71; P. 24; T. 5.

Color brownish above, the sides yellowish, sometimes mottled with brown; young uniform dark slate, or with transverse yellow bands; rertical fins bordered with blackish, and with a white edge.

The cusk is described and figured by De Kay, but he did not see the fish and copied his information from Storer and others. Storer mentions a specimen weighing 20 pounds, but the fish grows even larger. It inhabits the North Atlantic, ranging southward to New Jersey and Denmark. It is an important food tish. According to Dr Smith, it was formerly not uncommon in Vineyard sound, and was caught with cod in April and May. It has been very rare for more than 20 years, though a few are still taken iu April. The average weight of individuals in those waters is 5 pounds, and the maximum weight from 12 to 13 pounds. It is known also as ling. In Massachusetts bay and vicinity the cusk is a common resident on the inshore fishing grounds, where it occurs in great abundance, lurking among the stones, but it is soon canght up by the fishermen after the discovery of a new bank.

\section{Family MACIRURIDAE}

\section{Grenadiers}

\section{Genus coelorhyxchus Giorna}

This genus agrees with $\mathrm{Ya} \mathrm{c} \mathrm{I}^{\circ} \mathrm{us}$ in all essential respects, except that the small mouth is wholly below the longpointed, sturgeonlike snout. Dorsal spine smooth in typical species, those with serrate spine haviug been lately separated under the generic name Coelocephalus. Species numerous. 


\section{Coelorhynchus carminatus (Goode)}

Fremadier

Macrurus carminatus Goode, Proc. U. S. Nat. Mus. III. 346, 475, 1850.

Macrurus (Coelorhynchns) carminatus GüNtmer. Challenger Report, Deepsea Fishes, XXII, 129, pl. 5, fig. 13, 1887.

Coelorhynchus carminatus Goode of BEגx, Ocennic Ichth. 395, fig. 336, 1596; Jordan \& Evermann, Bull, 47, U. S. Nat. Mins. III, 25Ss, 1s95; IV, pl. CCCLAIX, fig. 914, 1900.

The body is stout anteriorly, tapering rery rapidly to a rather long and slender tail. The depth is one eightl, and the length of the head about one fifth of the total length. The eye is large, one fifth as long as the head, equaling the interorbital width. The snout is as long as the eye. The body is less elongate than in Baird's grenadier. The snout is long, sharp, depressed, tri. angular. Strong horizontal ridges run from the supraorbital margins to the gill openings, parallel with the subocular ridges. The nostrils are immediately in front of the orbit; barbel very short; teeth small, conic; somewhat recurved, arranged in villiform bands; base of first dorsal fin two ninths as long as the distance from its origin to the snout. The first dorsal spine is rery short, hardly perceptible above tle skin. The second spine is about one half as long as the head, slender and unarmed; when laid back, the tip reaches to or beyond the origin of the second dorsal. The spines decrease in length very gradually, the sixth being nearly as long as the second. The second dorwal begins in the perpendicular from the seventh anal rar. The anal fin is much higher than in Baird's grenadier, nearly equal to one half of the interorbital width; its origin is under the 18th scale of the lateral line; its longest ray is as long as the interorbital width. The distance of pectoral from snout equals twice its own length, and about equals the longest dorsal spine; the origin of the pectoral is below the middle of the depth of the body, and below the level of the middle of the orbit; the tip of the pectoral does not reach the origin of the anal. The insertion of the rentrals is behind the pectoral, slightly in advance of the first dorsal, its distance from the snout greater than twice its length, its long filament not reaching the anal. Color silvery gray. Length of the specimen described 10 inches. 
This grenadier inhabits the West Indies, the Gulf of Mexico, and is found in the Gulf Stream in deep water. It is abundant. The U. S. Fish Commission steamer, Fish Hawk, has taken it in the Gulf Stream off Rhode Island in $\mathbf{1 1 5}$ fathoms. The fish is described and figured by Goode and Bean, Oceanic Ichthyology, p. 398 , fig. 336 .

\section{Order HETEROSOMATA Flatfishes \\ Family PLEURONECTIDAE Flounders \\ Genus mppogrossus Cuvier}

Eyes and color on the right side; form oblong, not strongly compressed; mouth wide, oblique; teeth in the upper jaw in two series, those below in one, anterior teeth in upper jaw, and lateral teeth in lower, strong, no teeth on vomer or palatines, lower pharyngeal teeth in two rows; dorsal fin beginning above the eye, its middle rays elevated, the posterior rays of dorsal and anal bifid; caudal fin lunate; ventral fins both lateral; scales very small, cycloid; lateral line with a strong curve in front; gill rakers few, short, compressed, wide set. Vertebrae $16+34$. Largest of the flounders. One species; abundant on both coasts of the north Atlantic and of the north Pacific.

\section{$35 S$ Hippoglossus hippoglossus (Linnaeus) Halibut}

Pleuronectes hippoglossus Linvaeus, Syst. Nat.ed. X, I, 269, 1758; MitchiLL, Rep. Fish. N. Y. 10, 1814; Trans. Lit. \& Phil. Soc. N. Y. I, 386, 1815. Hippoglossus vulgaris DE KAY. N. I. Fauna, Fishes, 294, pl. 49, fig. 157, 1842; Günther, Cat. Fish. Bit. Mus. IV, 403, 1862; Storer, Hist. Fish. IIass. 192, pl. XXX, fig. 1, 1867; Goode \& BEAN, Bull. Essex Inst. XI, 7, 1879; Jordan \& Gilbert, Bull. 16, U. S. Nat. Mus. 819, 1893; Goode, Fish \& Fish. Ind. U. S. I, 189, pl. 54, 1884.

Hippoglossus hippoglossus Jordan, Cat. Fish. N. A. 133, 1885; H. M. SмттH, Bull, U. S. F. C. 1897, 108, 1895; Jordan \& Everuann, Bull. 47, U. S. Nat. Mus. III, 2611, 1898; IV, pl. CCCLXXI, fig. 918, 1900; SHERwoon \& Edwards, Bull. U. S. F. C. 1901, 31, 1901.

Body comparatively elongate, not strongly compressed, deep mesially, its depth one third of total lengtlı without caudal, tapering rapidly in its posterior half; head broad, moderately 
long, its length contained three and three fourths times in total length without caudal; mouth large, the maxillary reaching to below middle of orbit; eyes large, separated by a rery broad, flattish area; lower eye slightly in advance. D. 105; A. 78; P. $19 ; \mathrm{V} .6$.

Color, nearly uniform dark brown; blind side white.

The halibut lives in all northern seas, ranging southward to Sandy Hook, or beyond, and occasionally to the Farallones off San Francisco.

The halibut was described by both Mitchill and De Kay under its present name. De Kay says that the capture of the halibut on the shores of Nantucket at one time afforded employment to 80 ressels of from 60 to 80 tons each. He says the fish is very voracious, swimming near the ground and devouring other flat fishes as well as shells and crustaceans. It occurs on both shores of the Atlantic as also in the north Pacific, migrating south on the approach of spring and returning in June or July. An individual was found some years ago near Colonial Beach, in the Potomac river. The fish grows to the length of 8 feet or more, and the weiglit of several hundred pounds. It is a very raluable food fish. In the Pacific, according to Jordan and Evermann, it extends its range southward to the Farallones, off San Francisco.

The halibut was formerly not very uncommon in Vineyard sound, where it is now very rare. In $18 \% 2$ and $1873, \mathrm{~V} . \mathrm{N}$. Edwards caught a number weighing 235 or 240 pounds while fishing for cod. Ap. 16, 1900, a halibut weighing 100 pounds was caught off Block island by cod fishermen, and was taken to New. port. The fish was very abundant at one time in Massachusetts bay, but is now found chiefly in depths of 100 to 250 fathoms ou the slopes of the outer banks. In August 1878 a halibut weighing over 200 pounds was caught in Gloucester harbor.

\section{Genus hippoglossoides Gottsche}

Eyes and color on the right side (except sometimes in $H$. e la s s o d o n, a Pacific species); body oblong, moderately com. pressed; mouth rather large, with one row of sharp teeth on each jaw; no teeth on voner or palatines; gill rakers rather 
long and slender; scales ctenoid; lateral line nearly straight, simple; dorsal fin low in front, beginning over or before the eye; ventrals both lateral; caudal double truncate, produced behind. This genus, as here restricted, contains three closely related species, two of the north Pacific, one of the north Atlantic. All are essentially arctic species, inhabiting shallow waters in the regions where they are most abundant.

\section{Hippoglossoides platessoides (Fabricus) Rough Dub}

Plemronectes platessoides FABricius, Fauna Glvenlandica, 164, 1780, Greenland.

Platessu dentata Stonen, Rep. Fish. Mass. 143, 1S39; Hist. Fish. Mass. 197, pl. XXX, fig. 3, 1867; DE KAY, X. Y. Fauna, Fishes, 298, 1842, New York markets.

Hippoglossoides dentatus Günther, Cat. Fish. Brit. Mus. IV, 406, 1562. Hippoglossoides platessoides GiLI, Proc. Ac. Nat. Sci. Phila. 217, 1864; Goode \& Bean, Bull. Essex Inst. XI, 7, 1879; Jordax \& Gilbert, Bull. 16, U. S. Nat. Mus. S26, 1883; Goode, Fish \& Fisl. Ind. U. S. I, 197, pl. 55, 1S84; Goode \& Bean, Oceanic Ichth. 438, 1896; H. I. Surth, Bull U. S. F. C. 1897, 108, 1898; Jordan \& Evermann, Bull. 47, U. S. Nat. IIus. III, 2614, 1898; IV, pl. CCCLXXII, fig. 919, 1900.

The length of the body is two and one half times its depth and three and three fourths times the length of the head. Body orate; mouth moderate, oblique; maxillary narrow, reaching to beyond pupil, two and two thirds in length of head; teeth rather small, conic, larger anteriorly, in one row in each jaw, those in the lower largest; eyes rather large, the upper longer than snout, four and one third in head; lower jaw included, but with a projecting knob at the chin; snout thick and scaly; interorbital space marrow, with a raised obtuse ridge, entirely covered with rongh scales in about six series; mandible with a series of scales; gill rakers rather short and robust, not toothed, about 10 below angle; longest raker less than one third length of eye; fins with small, rough scales; a strong preanal spine; pectoral not quite half length of liead. D. 88 ( 80 to 93$)$; A. 70 (64 to 75$)$; Lat. 1.90 (pores).

Reddish brown, nearly plain. Nortl Atlantic; abundant northward on both coasts. 
De Kay described this flounder mule the name of the toothed llatfish. He said it was extremely common in New York markets, where it is called the smmmer flounder, and that it grows to the length of 25 inches. It is a rather common food fish of the deep waters northward on both sides of the north Atlantic, ranging labitually sonth to Caje Cod and the coasts of England and Scandinaria. At Woods Tole it is sometimes called sand dab and rusty flounder. Dr smith says it is not common there, but is found some rears in winter in inshore waters adjacent to Woods Hole; specimens have been taken in February on lines. One year some nere caught in a fyke net in Great luarbor. In Massachusetts bay it is a common species in the deep waters, approaching the shores in winter.

\section{Genus Faratichthis Girard}

Eyes and color normally on the left side; body oblong; mouth large, oblique; each jaw with a single row of usually slender and sharp teeth, which are more or less enlarged anteriorly, no teeth on vomer or palatines; gill rakers slender; scales small, weakly ctenoid or ciliated; lateral line simple, with a strong curve anteriorly; dorsal fin beginning before the eye, its anterior rays not produced; both rentrals lateral; candal fin double truncate, or double concare, its middle rays producerl; 110 anal spine. Species numerous, found in all warm seas. This genus. as now restricted, contains a considerable number of species, inhabiting both coasts of America and the eastern and sonthern coasts of Asia. As indicated by the reduced number of rertebrae, the species range farther southward than do those of the type of Hippoglossoides.

\section{Paralichthys dentatus (Linnaens)}

\section{summer Flounder}

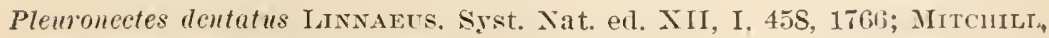
Trans. Lit. \& Phil. Soc. N. Y. I, 390, 1815.

Plenroneetes melanogaster Mitchill, op. cit. 390. 1815, New York. Platessa ocellaris DE FAY, N. Y. Fauma, Fishes, 300, pl. 47, fig. 152, 1St.. Psendorhombus ocellaris GUNTHer, Cat. Fish. Filit. II us. IV, 430, 1862. Platessa oblonga Storer, Hist. Fish. Mass. 201, pl. XXXI, fig. 2, 1567. Pseudorhombus dentatus Goode \& BEAx, Bull. Essex Inst. XI, T, 1879. 
Paralichthys ophryas JordaN \& Gilbert, Bull. 16, U. S. Nat. Mus. 822, 1883. Paralichthys dentatus Goode, Fish \& Fish. Ind. U. S. I, 178. 1884 (part); Jordan, Cat. Fisll. N. A. 12t, 1855; Bean, 19th Rep. Comm. Fish. N. Y. 246, pl. II, fig. 2, 1890; Bull. Am. Mus. Nat. Hist. IX, 372, 1897; H. M. SMrth, Bull. U. S. F. C. 1997, 108, 1898; JoRdaN \& EverMañ, Bull. 47, U. S. Nat. Mus. III, 2629, 1898; IV, pl. CCCLXXIII, fig. 922 , 1900; Bean, 52d Ann. Rep. N. Y. State Mus, 110, 1900.

The depth of the body is contained two and one third times in its length, which is three and two thirds times the length of the head. Body oblong, moderately compressed; mouth wide, oblique, the mandible very heary and much projecting; eight to 10 teeth on side of lower jaw, the two anterior teeth very long; anterior teeth of upper jaw strong, but smaller than those in the lower jaw; the lateral teeth very small and close set; eyes small, shorter than snout, about one sixth length of head, and in adult as wide as the broad, flattish, scaly interorbital area. The latter is much narrower in the young. Scales small, cycloid; accessory scales few; gill rakers lanceolate, dentate, stoutish. wide set, much shorter than eye, the longest two and oue half times as long as broad at base, five and one half in the maxillary, about $2+10$ in number; pectoral fin about as long as maxillary, which extends beyond the eye, and is rather more than lialf length of head; dorsal low, its anterior rays somewhat exserted, but short; caudal double concave, the middle rays produced; anal spine obsolete; ventrals sunall; fins all scaly. D. SS (S5 to 93$)$; A. 66 (65 to 73 ); Lat. 1. about 100.

Blackish olive, mottled and blotched with darker; in life light brown; adults with numerous small white spots on body and vertical fins; sometimes a series of larger white spots along bases of dorsal and anal; about 14 ocellated dark spots on sides, these sometimes inconspicuous, but always present; a series of four or five along dorsal base, and three or four along anal base, tlose of the two series opposite, and forming pairs; two pairs of smaller, less distinct spots midway between these basal series and lateral line anteriorly, with a small one on lateral line in the center between them; a large distinct spot on lateral line behind middle of straight portion; fins without the round dark blotches. 
Is styled flounder, or summer flounder, turbot flounder, toothed flatfish, fluke, and, in Great Sonth bay, it shares the name flatfish with the Pseudopleuronectes ameri. canus. Brail and puckermouth are names applied to it in Rhode Island. The name fluke is the one most frequently used on Long Island.

The fluke is a very abundant fish and is found on the eastern coast from about Cape Cod to the Gulf of Mexico. Centers of abundance are found on the Connecticut coast and on Long Island.

It is a summer visitor in Gravesend bay. arriving in May or June, and leaving when cold weather begins. It frequents the sandy flats for the purpose of feeding on little fishes, which it destroys in large numbers. A fluke will often be found with eight or 10 little blackfish in its stomach, and young mackerel suffer greatly from its depredations. In Great South bay this fish was found at Blue Point cove and at Fire Island late in September, and was caught in traps at Islip October 1, 1890.

Small fluke were collected in Mecox bay, Blue Point cove and at Islip in August 1898. Adults were obtained at Fire Island inlet Sep. 16 of that year, when they were abundant. In 1901 the fish were taken at Fire Island inlet, Blue Point, and Smith's point. Aug. 1 they were feeding on small menhaden. The next day they were seen in Wigo inlet, and again chasing young menhaden. On that date more than half a barrel were caught in the inlet near buoy no. 2, with young menhaden for bait. One of the fluke disgorged a sand lance.

It feeds on small fishes, crustaceans, mollusks and occasionally on sand dollars, and one of its farorite foods is said to be the squid. This fish is found generally in salt water, but frequently ascends fresh streams. Unlike the flatfish, it mores off into deep water in winter, and may be found in summer near the shores. The fluke has the same habit as the flatfish, of burying itself in the sand when alarmed, or secreting itself from its prey. It is often found feeding about wharres, whose supports furnish it a suitable hiding place from which to dart on 
small fishes when they are congregated in schools. I have seen large individnals cantiously wriggling their way upward in the concealment of a wharf pile till within easy reach of a shoal of silversides, when a sudden dart into the midst of the school would result in the capture of a fish, and the flounder would leisurely sink to digest its victim and prepare for another onslanght. It has been known to reach a weight of 26 pounds. Dr Goode has seen individnals measuring 3 feet in length. The fish is caught largely in weirs and traps. It is probable that more of them are taken in Vineyard sound and in Rhode Island waters than on any other parts of our coast. The fishing season extends from May to October. They are carried alive in well. smacks to the markets. Menhaden is the bait principally used for the capture of the fluke by hook and line.

361 Paralichthys lethostigmus Jordan \& Gilbert

\section{Southern Flounder}

Pletessa oblonga DE KAY, N. Y. Fauna, Fishes, 299, pl. 4S, fig. 156, 1812, New York, not Pleuronectes oblongus Miтchis...

Paralichthys dentatus Jordan \& Gilbert, Bull. 16, U. S. Nat. Mus. S22, 1883.

Paralichthys lethostigma Jordax \& Gilbert, Proc. U. S. Nat. Mus. 237, 1884.

Paralichthys lethostigmis Jordan \& Evermann, Bull. 47, U. S. Nat, Mus. III, 2630, 1898.

Body orate, its depth contained two and one third times in its total length without the caudal; length of head about three and one half times in same length; depth of caudal peduncle contained two and one third times in length of head; eyes of moderate size, placed close together on the left side of the head; mouth large, jaws curved; maxilla reaching past rertical through eye; mandible projecting; anterior teeth of jaws strong; posterior small and close set; gill rakers $2+10$, lanceolate, wide set, shorter than eye; scales smooth, small; dorsal originates in front of eye and continues almost to caudal; anal well separated from the ventrals; pectorals short, less than one half length of head; ventral moderately developed, about two thirds length of pectoral. D. $90 ; \mathrm{A} .70 ; \mathrm{V} .6$.

Color dusky olive, with a few darker mottlings and spots. 
This is the fish which was described by Jordan and Gilbert under the name of the southern flounder. It inliabits the south Atlantic and Gulf coast of the United States, ranging north to New York. De Kay described and figured it as the oblong flounder, which he says grows to the length of 15 to 20 inches and oceasionally larger. He states that it is common along the sandy shores of New Tork, and is procured abundantly in the months of September and October; that it is excellent eat. ing, and usually sells at from $6 \mathrm{c}$ to $8 \mathrm{e}$ a pound; that it is tenacious of life and can be preserved in good condition for a long period.

The southern flounder is very closely related to the fluke or summer tounder. It is, howerer, always darker in color and almost uniform, while the fluke is usually profusely spotted. The cluaracter by which it is best distinguished from the fluke, is the number of gill rakers. The southern flounder has only 12, of which 10 are below the angle of the first arch, while the summer flounder has from 20 to 24, of which from 15 to 18 are below the angle of the first arch.

\section{Paralichthys oblongus (Mitchill)}

\section{Fourspotted Flounder}

Pleuronectes oblongus MitchiLl, Trans. Lit. \& Phil. Soc. N. Y. I, 391, 1815.

Platessa quadrocellata Stoner, Hist. Fish. Mass. 208, pl. XXXI, fig. 3, 1867. Pseudorhombus oblongus Goode \& BEAN, Bull. Essex Inst. XI, 7, 1879.

Paralichthys oblongus Goode, Proc. U. S. Nat. Mus. 472, 1880; JordaN \& Gilbert, Bull. 16, U. S. Nat. Mus. S24, 1883; Goode \& BeAx, Oceanic Ichth. 436. 1896; H. M. Smith, Bull. U. S. F. C. 1897, 108, 1898; JoRdAT \& Evermann, Bull. 47, U. S. Nat. Mus. III, 2632, 1898; IT, pl. CCCLXXIY, fig. 924, 1900.

Body comparatively elongate, strongly compressed. The depth of the body is contained two and one fourth times in the length of the body, which is four times the length of the head. Eyes large, nearly four times in head, separated by a prominent narrow, sharp ridge; upper jaw with very numerous small, close set teeth laterally, and four or five canines in front, the lateral teeth abruptly smaller than the anterior, each side of lower jaw with seven to 10 teeth; chin prominent, maxillary narrow; reaching past middle of pupil, two and one fourth in length of 
head; gape curved; scales weakly ctenoid or cycloid; gill rakers thick, rather long, few, about eight below angle; dorsal low, beginning over front of eye, some of the anterior rays exserted, but not elongate, the longest rays behind middle of fin, not quite half head; caudal one and one fourth in head; pectoral one and three fifths; anal spine obsolete. D. 72 ; A. 60; Lat. 1. 93. 79 ; A. 59 , according to Mitchill; D. S6; A.76, according to Storer).

Grayish, thickly mottled with darker and somewhat translucent; four large, horizontal oblong, black ocelli, each surrounded by a pinkish area, one just belnind middle of body below the dorsal, one opposite this above anal; two similar smaller spots below last rays of dorsal and above last of anal. Atlantic coast, northward; not abundant.

The fourspotted flounder inhabits the coast of New England and New York. It is very common on the coast of New York and the neighboring islands. Mitchill described the fish in 1815. It grows to the length of about 14 inches. Its common name relates to the four large horizontal oblong black ocelli. At Woods Hole Mass., according to Dr Smith, it is common in May and June, scarce at other times. It is most abundant about June, during the run of scup.

Young fish are rarely observed, but in the fall of 1885 and 1886 large numbers, two or three inches long, were seen. The average length of adults there is 12 inches. The fish spawns in May, and its eggs have been experimentally hatched at Woods Hole. They are buoyant, $\frac{1}{26}$ of an inch in diameter and hatch in eight days in water having a mean temperature of $51^{\circ}$ to $56^{\circ} \mathrm{F}$. In 1877 a single example was taken at the mouth of Salem harbor by the U. S. Fish Commission.

\section{Genus Lophopsetta Gill}

Eyes and color on the left side; body broadly ovate, strongly compressed, pellucid; mouth large, oblique, the maxillary reaching to beyond eye; teeth subequal, in narrow bands, or in single series; a small patch of teeth on the vomer; scales small, cycloid, imbricate, the skin without bony tubercles; lateral line strongly arched in front, without accessory branch; dorsal fin beginning 
on the smout, its anteriol rats exseleded no preanal spine; ventral of left side free from the anal, insertod nearly on the ridge of the aldomen, its base broad, the rays well separated; pectoral and rentral fins moderate. One slecies. Tery close to the Emropean genus Botlins Rafinesque, from which it differs in the more numerous gill rakers, pellucid body and produced dorsal rays. The European turbot, Pset a Swainson, is also closely related, but the typical species, Psetta $\mathrm{m}$ a $\mathrm{x}$ i m a, is a large, robust fish, scaleless and beset with bony tubercles.

\section{Lophopsetta maculata (Mitchill)}

\section{Window Pane}

Pleuroncetes maculatus Mrculd, Rep. Fish. N. Y. 9. 1814, New York; I'E KAY. ג. Y. Fauna. Fishes. 301, pl. 4i, fig. 151, 1S42; Storer, Hist. Fish. Mass. 204, pl. XXXI, fig. 4, 1S67.

Pleuronectes aquosus Mitchul, Trans. Lit. \& Phil. Soc. N. Y. I, 389, pl. II, fig. 3, 1S15, New York.

Rhombus aquosus GüNTHER, Cat. Fish. Brit. Mus. IV, 411, 1862.

Bothus maculatus Jordan \& Gilbert, Bull. 16, U. S. Nat. Mus. S15, 1883; Bean, Bull. Am. Mus. Nat. Hist. IX, 372, 1897; H. M. Smth, Bull. U. S. F. C. 1897, 10S, 1S98; BeAx, 52d Ann. Rep. N. Y. State Mus. 110, 1900.

Lophopsetta maculata Gill, Proc. Ac. Nat. Sci. Phila. 216, 1S62; Goodf \& Beax, Bull. Essex Iust. XI. 6, 1S79; BeAn, 19th Rep. Comm. Fish. N. Y. 247, 1890; Jordan \& Evermaxx, Bull. 47, U. S. Nat. Mus. III, 2660, 1S95; IV, pl. CCCLXXXII, fig. 938, 1900.

The length of the body is one and three fifths times the depth of the bodr and three and three fourths times the length of the head. Body broadly rhomboid, rere strongly compressed; interorbital area flattish; eje rather large, about equal to snout; teeth in both jaws in one series laterally, in a very narrow band in front; maxillary nearly half length of head; gill rakers rather long and slender, numerous, about 25 below the angle of the arch; scales well dereloyed, crcloid, loosely imbricated; those of the blind side a little smaller; no bony tubercles; vertical fins scaly; anterior rays of dorsal elerated, branched, with free tips. D. 65 ; 1. 5̈2; Iat. 1. 85.

Light olive brown, almost translucent, everywhere marbled with paler, and with many roundish, irregular, blackish blotches; fins spotted. Length 18 inches. Atlantic coast of the United States, rery common northward. Size rather small. 
This is the plaice according to Mitchill; it is known also as the watery flounder. De Kas calls it the spotted turbot and sand flounder. In Great Egg Harbor bay it is the window light. Windowpane and daylight are other names applied to the species. De Kay saw specimens 18 inches long. He says it is a delicate article of food.

The windowpane is found on the east coast from Maine to North Carolina. Though abundant and well flavored and sometimes reaching a length of a foot or more, it is not an important food fish. In Graresend bay the fish delights in cold water. It is not adapted to captive life. In Great South bay we took it at Fire Island beach at the end of September 1890. In 1898 an individual was taken at Islip August 18. Young examples were obtained at Fire Island inlet and Oak Island beach in September. In 1901 young individuals were obtained July 31 and Aug. 15 in Fire Island inlet. At Woods Hole Mass. according to Dr Smith, it is found from April to late in the autumn. There is quite a large rum about June 1, when the fish is full of spawn. The average size there is 10 to 12 inches. In experimental hatching of the eggs at Woods Hole, it was found that the eggs were buoyant, nonalhesive, $\frac{1}{2 \pm}$ of an inch in diameter, and that they hatch in eight days when the average water temperature is $51^{\circ}$ to $56^{\circ} \mathrm{F}$.

\section{Genus etropus Jordan \& Gilbert}

Eyes and color on left side; body regularly oval, deep and compressed; head small; mouth rery small, the teeth close set, slender, and pointed, somewhat incurved, mostly on the blind side, no teeth on romer; ejes small, separated by a narrow, scaleless ridge; margin of preopercle free; rentrals free from anal, that of colored side inserted on ridge of abdomen, its base rather long; dorsal fin beginning above eye; caudal double truncate; anal without spine; scales thin, deciduous, ctenoid on left side, cycloid on blind side; lateral line simple, nearly straight. Size small. This genus is very close to $\mathrm{Cith}$ a $\mathrm{r}$ i chthys, from which it differs only in the very small size of the mouth and in the correspondingly weak dentition. The three 
or four known specirs are similar in appearance to the species of Cith a r ichthys, and they inhabit the same waters. The larval form is translucent and symmetric, as in P' l a to plirys, Monolene, and I r noglossus.

\section{Etropus microstomus (Gill)}

\section{Smallmouthed. Frlounder}

Citharichthys microstomus Gild, Proc. Ac. Nat. Sci. Phila, 223, 1864, Beeslex's Point N. J.; BeAN, Bull. U. S. F. C. VII, 135, 1888, Great Egg Harbor Bay N. J.; Jordan, Proc. U. S. Nat. Mus, 332, 1S90; Goode \& BEAN, Oceanic Ichth. 446, 1896.

Etropus mimostomus Jordax of Goss, Rep. U. S. F. C. for 1586, 27s, 18s9; BeAx, 19th Rep. Comm. Fish. N. Y. $247,1890$.

Body orate. The dejoth of the body is contained two and one tenth times in its length, which is three and one half times the length of the head. Ionth small, very oblique, the gape curved; maxillary two and two thirds times in length of head, reaching beyoud midile of orbit; smont projecting; eres small, even, shorter than snout, about six in head, separated by a narrow ridge, which is concave and scaleless anteriorly; teeth all small, front teoth of mper jaw wide set, much larger than posterior, which are close together and rex small, teeth of lower jaw few, wide apart; gill rakers short and strong, 13 below angle; pectorals short, less than half length of head; scales large, those on middle of sides posteriorly largest. D. S0; A. 61; Lat. 1. 45. Individuals from Great Egg Harbor bay have: 1). 74 ; A. วั5; scales 41 to 42 .

Olive brownish, usually with large blotehes of darker; a series of distinct, obscure, blackish blotches along the basal portions of the anal and clorsal fins. Size small. Tropical America, north to Longr Island occasionally in summer.

The smallmonthed flomnder was first described many years ago by 1) Gill, from a specimen obtained on the New Jersey coast. The fish was not seen again till we collected it in Great South bay. where it was found in mokerate numbers at Fire Island, and near Blue Point cove Lifesaring station in September 1884 . since that time it has been found sufficiently common in various parts of Great Egg Harbor bas, X. J., during August 
and Septrmber, and las also bern taken in Great south bay. The individuals collected in fireat Egen Harbor bar, varied from 2 inches to $4: 1$ inches in length. Une of these was dextral and all the rest sinistral as usual.

\section{Genus monod dottsche}

'Teeth chiefly uniserial; lateral line with a distinct arch in front and without accessory dorsal hamelu; scales imbricated, rough etenoid; vertebrate about 40 . This genus is closely allicd to Pseudopleuronectes, from which it differs only in the presence of an arch on the anterior part of the lateral line.

\section{Limanda ferruginea (Storer)}

\section{Sand Dab}

Platessa ferruginea Storen, Rep. Fish. Mass. 141, pl. 2, 1839; Hist. Fish. Mass. 198, pl. XXX, fig. 4, 1S6T; DE KAX, N. Y. Fauna, Fishes, 29T, pl. 48, fig. 155, 1842.

Platessa rostrata H. R. Stoner, Bost. Jour. Nat. Hist. V, I, 26S, pl. VIII, fig. $2,1557$.

Pleuroneetes ferrugineus Günther, Cat. Fish. Brit. Mus. IV, 44i, 1862; JordaN \& Gilibert, Bull. 16, U. S. Nat. Mus. 834, 1883.

Iimanda ferruginea Goode \& BEAN, Bull. Essex Inst. XI, 6, 1Si9; Oceanic Ichth. 427, 1896; Goone. Fish \& Fish. Ind. U. S. I, pl. 49, 1854; H. M. Smith, Bull. U. S. F. C. 1S97, 108, 1898; Jordan \& Evermavn, Bull. 47, U. S. Nat. Mus. III, 2644, 1S98; IV. pl. CCCLXXVII, fig. 929, 1900.

The length of the body is two and one fifth times its depth and four times the length of the head. Body ovate-elliptic, strongly compressed; teeth small, conic, close set, in a single series on each side in each jaw; snout projecting, forming a strong angle above upper eye with the descending profile; gill rakers of moderate length, rery weak, not toothed; eye moderate, four and one half in head, the lower slightly in advance of the upper, separated by a high, very narrow ridge, which is scaled posterioriy and is continued backward as an inconspicuous but rough ridge to the beginning of the lateral line; scales imbricate, nearly uniform, those on right side rough ctenoid, those on left side nearly or quite smooth, scales on body rougher than on cheels; caudal peduncle short, higher than long; dorsal inserted over middie of eye, its middle ray highest; pectoral less than two fifths length of head; caudal fin rounded; anal spine present; lateral line simple, with a rather low arch in front, the depth of which is 
barels two fifths the length; a concealed spine behind rentrals; ventral of colored side partly lateral, the other wholly so; anal spine strong. D. s.; A. 62; Lat. 1. 100.

Brownish olive, with numerous, irregular reddish spots; fins similarly marked; left side witl caudal fin, cauda] peduncle, and margins of dorsal and anal fins lemon rellow. Atlantic coast, chicefly northward.

This is also known as the rusty dab. It inhabits the coast of North America from Labrador to New York. De Kay calls it the rustr flatfish, which he says is a rare species, reported by the fishermen to occur only in deep water. The specimen described bs lim was 18 inches long. According to Dr Smith, it is rer common in Vineyard sound and observed by him in water from 10 to 12 fathoms deep, where it may be found throughout the year. There is no fishery, but numbers are caught incidently while bottom fishing for other species. In Great harbor a few are taken in fyke nets, only in winter. The average length there is about 14 inches. In Massachusetts bay it is a common resident species, inhabiting deep waters in summer, and approaching the shores in winter.

\section{Genus pseudopleuronectes Bleeker}

liody oblong, with firm flesh; the scales firm, regularly imbricated. strongly ctenoid on eyed side in both sexes; fin rays scaly; mouth small; teeth uniserial, incisorlike, close set, all more or less blunt, lower pharyngeals rery narrow, each with two rows of separate, conic teeth. This genus is distinguished from Ple u ro ne c tes chiefly by the well imbricated ctenoid scales, and from $\mathrm{L}$ i mand a, which it more closely resembles, by the want of arch to the lateral line.

\section{Pseudopleuronectes americanus (Walbaum)}

\section{Flatfish; Winter Flounder}

Plenronectes amerieanus Walbaum, Art. Gen. Pisc. III, 113, 1792; Günther, Cat. Fish. Brit. Mus. IV, 443, 1862; Jordan \& Gilbert, Bull. 16, U. S. Nat. Mus. 837, 1883.

Pleuroneetes planus MitchilL, Trans. Lit. \& Phil. Soc. N. Y. I, 387, 1815, New York.

I'latessa plana Stoner, Rep. Fish. Mass. 140, 1839; De KAr, N. Y. Fauna, Fishes, 295, pl. 48, fig. 154, 1842; Storer, Hist. Fish. Mass. 195, pl. XXX, fig. 2, 1867 . 
Platessa pusilla DE KAx, op. cit. 296, pl, 47, fig. 153, 1842, New York.

Pseudopleuronectes americanus Gill. Proc. Ac. Nat. Sci. Phila, 216. 1S64; Goode, Fish \& Fish. Ind. L. S. I, 182, pl. 44, 18st; Beax, 19th Rep. Comm. Fish. N. Y. 245, pl. I, fig. 1, 1890; Bull. Am. Mus. Nat. Hist. IX, 373, 1S97; H. M. Sмith, Bull. U. S. F. C. 1897, 10S, 189S; JoRdax \& Evermann, Bull. 47, U. S. Nat. IIus. III, 2647, 189S; IV, pl. CCCLXXIX, fig. 933, 1900; BEAx, 52d Ann. Rep. N. Y. State Mus. 110, 1900; Sherwood \& EDwards, Bull. U. S. F. C. 1901, 31. 1901.

Body elliptic, an angle above eye. The length of the body is two and one fourth times its depth and four times the length of the head. Head covered abore with imbricated, strongly ctenoid scales similar to those on body; blind side of head nearly naked; interorbital space rather broad, strongly convex, its width half eje; the space entirely scaled; teeth compressed, incisorlike, and widened toward tips, close set, forming a continuous cutting edge, some of teeth often emarginate, sometimes morable; right side of both jaws toothless; highest dorsal rays less than length of pectorals, and more than half length of head; anal spine present. D. 65 ; A. 48; Lat. 1. S..

Dark rusty brown, spotted or nearly plain; young olive brown, more or less spotted and blotched with reddish.

The common flatfish is equally well known as flounder or winter flounder. It ranges from the Chesapeake bay to Iabrador and appears to be alike abundant in both limits of its distribution. The flatfish was found in Blue Point cove, at Blue Point Lifesaving station, and on Fire Island beach. It was moderately common in all of these localities. The species is a permanent resident of Great South bay, but undergoes a partial hibernation in the mud in winter, and the adults in summer migrate into. deeper and cooler water. A few individuals were observed by me in a fish pound at Islip Oct. 1, 1890.

Dr Mitchill describes two color varieties of the flatfish. One of these had a yellow margin on the lower side, surrounding the. white of that side. This border was three fourths of an inch. wide and in striking contrast with the pearl of the contiguous. parts within it and the brown of the adjacent fins. The other variety, obtained Ap. 9,1815 , has " a whiteness of the upper side. nearly as clear as that of the nether surface over rather more 
than half its extent. The anterior part is blanched in this manner. The dorsal fin rery sensibly partakes of the lighter hue; but its dark brown is tinctured with yellow, specially on the rays. Something of the same kind, though less distinct, is observable on the rentral fins, and on about a dozen rays of the anal. The length of this individual was 5 inches and the breadth $3 . \mathrm{Dr}$ De Kay obtained a specimen in April which was reversed and double. "Its color on both sides was uniform bronze, with a white patch on its right side near the chin, almost entirely denuded of scales; it had the singular protuberance over the ere, noticed by Dr Mitchill in his melanogaster."

On the New Jersey coast young individuals are vers common in summer, but the adults are rarely found except in the winter.

At Woods Hole Mass. this is a very abundant permanent resident. frequenting muddy or grassy bottoms. The arerage weight of those taken in the immediate ricinity of the Fish Commission station was only 1 pound, but larger fish are found in the deeper water of the sound and bay. In October fish areraging 2 pounds and apparently migrating are taken with lines in Vinerard sound on sandy bottom.

In the markets this species is extremels common in the winter and spring months and the flesh is delicious eren when the eggs are nearly mature. It feeds on small shells, crabs and other invertebrates living in the mud. When at rest it partly sub. merges itself in the sand or mud, and changes its color to suit its surroundings.

In Long Island bays the flatfish spawns from February to the end of March, and in July the Joung hare attained to the length of half an inch. At Woods Hole Mass. according to Dr Smith, it spawns from February to April. On being transferred to tanks containing running water, many deposit their eggs during the night. The eggs are $\frac{1}{30}$ of an inch in diameter and very glutinous, sticking together in masses of various sizes. The arerage number to a fish is 500,000 . Mar. 6, 1897, a fish that weighed $3 \frac{1}{2}$ pounds after spawning furnished 30 fluid ounces of eggs, num. bering $1,462,000$. The eggs batch in 17 or 18 days, when the mean water temperature is $37^{\circ}$ or $38^{\circ} \mathrm{F}$. 


\section{Genus pLatophrys Swainson}

Eyes and color on the left side; body ovate, strougly compressed; mouth of the large type, but comparatively small; the maxillary one third or less of the length of the head; teeth small, subequal, in one or two series, no teeth on romer or palatines; interorbital space broad and concave, broadest in adult males; gill rakers moderate; dorsal fin beginning iu front of eye, all its ravs simple; ventral of colored side on ridge of abdomen; caudal convex behind; pectoral of left side usually with one or more filamentous rays, longest in the male; scales very small, ctenoid, alherent; lateral line with a strong arch in front; coloration usually variegated.

All the species are extremely closely related and can be distinguished with difficulty. On the other hand, the variations due to differences of age and sex are greater than in any other of our genera.

\section{Platophrys ocellatus (Agassiz) \\ Sand Flounder}

Rhombus ocellatus Agassiz, Spix, Pisc. Brasil. 85, pl. 46, 1829, Brazil.

Platophrys ncbularis Jordan \& Gilbert, Proc. U. S. Nat. Mus. 31, 143, 1884, Key West; Goode \& BeAn, Oceanic Ichth. 441, 1896.

Rhomboidichthys ocellatus GüNTHER, Cat. Fish. Brit. Mus. IV, 433, 1862; Poex, Syn. Pisc. Cubens. 408, 1868.

Platophrys ocellatus Swainson, Nat. Hist. Class'n Fishes, II, 302, 1839;

Bean, 19th Rep. Comm. Fish. N. Y. 247, 1890; Jordan \& Evermann, Bull. 47, U. S. Nat. Mus. III, 2663, 1898; IV, pl. CCCLXXXII, fig. 939, 1900.

Body rhomboid ovate, its depth one half of the total length; length of head one fourth of total withont caudal; mouth small, oblique; eyes large, the diameter of the upper eye contained two and two thirds. times in length of head, almost equal to depth of caudal peduncle; teeth conic, the upper jaw with two series, the lower with one; the dorsal fin originates a short distance from tip of upper jaw and continues to caudal; ventral origin on a rertical through front of eye; the ventral and anal separated by a short space; pectoral of eyed side about equal in length to caudal; scales of moderate size, those of colored side 


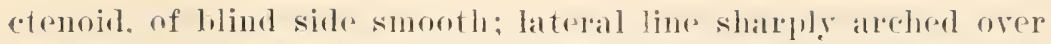

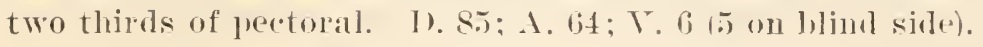

Color light gray with redelish tinger spots and hoteles of darker on lead and body: also lightre rings inclosing spatces of ground color: dorsal and anal witl a black sjot on each sixth or eightitl ray.

The sand flounder, or spotted floumder, is al matirs of the western Atlantic, from New Iork southward to the Gulf of Mexico and the Wrest Indies, and perhaps to Rio Janeiro on sandy shores. It is a small species, the largest individual taken being only 3 inclues in length. Two small examples of this little flounder were collected at Fire lsland inlet beach sep. :0, 1s!0. These specimens were obtained on a sand beacb in shallow water. The discovery of this fish in Great south bay was entirele mexpected, as this is many degrees north of its original habitat.

\section{Family SOLEIDAE}

\section{Soles}

\section{Genus achirus Lacépède.}

Eyes and color on the right side; body oblong, bluntly rounded anteriorly; head small; eyes small, close together, the upper eye in advance of the lower, the two separated by a bony ridge; mouth small, somewhat turned toward the colored side; nasal flaps present, the nostril of the blind side fringed; lip of the colored side fringed; teeth rery small, on blind side only; gill openings rather narrow, but confluent below, not reduced to a slit; the branchiostegal region scaled; head closely scaled everywhere, the scales on the colored side similar to those on the body, those of the nape and chin much enlarged; scales on the blind side anteriorly with their pectinations more or less jro. duced. forming cirri, scales of both sides extremely rough, extending on the fins; lateral line straight; simple; edge of preopercle covered by the scales; dorsal beginning on the snout, low in front and thickly scaled, its rays divided; anal fin simi. lar, without spine; caudal fin free, convex; caudal peduncle very 
short and deep; pectoral fin of left side wanting, that of right side small or obsolete; rentral rays three or four, the ventral fin of the colored side long, connected with the anal by a membrane. 'This strongly marked genus contains numerous species, vll very closely related, and nearly all American.

\section{Achirus fasciatus Lacépède}

\section{American Sole; Hogchoker}

Achirus fasciatus Lacfépène, Hist. Nat. Poiss. IV, 659, 662, 1803. Charleston; Jorinan \& Goss. Rep. U. S. F. C. 1886, 315, 18s9; Bean, Rull. Am. Mus. Nat. Hist. IX, 373, 1897; H. M. Sмгтн. Bull. U. S. F. C. 1897, 108, 1898; Eugene Smith, Proc. Linn. Soc. N. Y. 1897, 41, 1898; Mearis, Bull. Am. Mus. Nat. Hist. $\mathrm{X}, 322$, 1898; Jordan \& Evermann, Bull. 47, U. S. Nat. Mus. III, 2700, 1S9S; IV, pl. CCCIXXXVII, fig. 948, 1900; BeAN, 52d Ann. Rep. N. Y. State Mus. 110, 1900.

Plewomortes mollis Mitcinlt, Rep. F゙ish. N. Y. 9, 1814; Trans. Lit. \& Phil. Soc. N. Y. I, 388, pl. II, fig. 4, 1815.

Achirus mollis IE KAY, N. Y. Fauna, Fishes, 303, pl. 49, fig. 159, 1842; Storer, Hist. Fish. Mass. 206, pl. XXXII, fig. 1, 1S67; Beax, Bull. T. S. F. C. VII. 134, 1sss: 19th Tep. Comm. Fish. N. Y. 244, 1890.

Achirns lineatus Cuvier, Règne Anim. ed. 2, II, 343, 1829, and of varions American author's.

Form a well rounded oval, regular in outline; head small, its length about one fourth of standard body length; the depth of the body equals one half of the total length; eyes minute, close together on right side of head; mouth small, curred; lateral line distinct, straight; dorsal fin continuous from snout to caudal; ventral connected by membrane with anal, the latter then continuous to candal; caudal peduncle broad, the fin thumb-shaped; body everywhere densely sealed; anterior dorsal rays scaled; about 75 rows of scales along lateral line. D. $55 ;$ A. $40 ; \mathrm{V} .4$.

General color olive brown; body and fins with numerous black spots and clouded areas; usually from six to eight vertical narrow cross bands of black; left side whitish, usually much mottled with dark spots and shadings.

This is called hogchoker, cover clip, or cover, calico and American sole, the name calico is used on the New Jersey shore opposite New York. The American sole has a wide distribution along our east coast, but is not important for food, and sometimes proves very inconvenient to pigs, as may be inferred from one 
of its common names. In De Kay has eaten the species, however, and pronounces it to have a delicate flavor. Dr Mitchill also describes it as "delicate eating." De Kay records it as high up the Hudson as Peekskill. The following interesting observations are to be found in his work: "When it is taken from the water, it escapes readily from the hand by an undulating morement, in which it is aided by its mucous surface and by an elevation of its scales beneatl. By the same means it can make considerable progress over a moderately smooth surface. It is extremely tenacious of life, and I lept one alive four days out of water." Another very curious habit of the American sole is that of clinging to the glass front or side of an aquarium for an indefinite length of time. It is common on the shallow flats of Great South bay in the summer and early fall. We obtained specimens at the moutl of Swan creek and in Blue Point cove in September 1890. This species is abundant in Swan creek, at Patchogue L. I., and many very young examples were taken there in the summer and fall of 1898 , where the water was brackish and, at low tide, fresh. In 1901 this species was taken at Howell's point, Duncan's creek and smith's point.

Eugene Smith caught one rery small example in a tidal creek of the Hackensack river, where the water was fresh. He states that it is believed that soles spamn in fresh water.

The American sole, or calico flounder, has been obtained in Gravesend bay every month of the year except the first four. It is hardy in captivity. Its habit of clinging to the glass front and the walls of its tank is interesting.

\section{Order PEDICULATI \\ Pediculate Fishes \\ Family LOPHIDAE \\ Fishing Frogs}

\section{Genus Lophius (Artedi) Linnaeus}

Head wide, depressed, rery large; body contracted, conic, tapering rapidly backward from the shoulders; mouth exceedingly large, terminal, opening into an enormous stomach; upper jaw protractile, maxillary without supplementary bone; lower 
jaw projecting; both jaws with rery strong, unequal, cardiform teetl, some of the teeth caninelike, most of them depressible; vomer and palatines usually with strong teeth; gill openings comparatively large, in the lower axil of the pectorals; pseudobranchiae present: no gill rakers; gills three; skin mostly smooth, naked, with many dermal flaps about the head; spinous dorsal of three isolated, tentaclelike spines on the head, and three smaller ones behind, which form a continuous fin; second dorsal morlerate, similar to the anal; pectoral members scarcely geniculated, each with two actinosts and with elongate pseudobrachia; ventrals jugular, I, 5, widely separated, large, much enlarged in the young. Young with the head spinous. Pyloric caeca present. Vertebrae numerous, about 30 in number. Living on sea bottoms, at moderate depths; remarkable for great voracity.

\section{Lophius piscatorius Linnaeus}

\section{Angler; Goosefish; Bellonos Fish}

Lophius piscatorius Linnaeus, Syst. Nat. ed. X, I, 236, 1758; Mitchill, Trans. Lit. \& Phil. Soc. N. Y. I, 465, 1815; Günther, Cat. Fish. Brit. Mus. III, 179, 1861; Goode \& BeAN, Bull. Essex Inst. XI, 2, 1879; JorDan \& Gilbert, Bull. 16. U. S. Nat. Mus. 844, 1883; Bean, Bull. Am. Mus. Nat. Hist. IX, 373, 1897; H. M. Sмiтн, Bull. U. S. F. C. 1897, 109, 1898; Jordan \& Evermann, Bull. 47, U. S. Nat. Mus. III, 2713. 1898; IV, pl. CCCLxxxyili, fig. 952 (skeleton), 1900; Sherwood \& Edwards, Bull. U. S. F. C. 1901, 31, 1901.

Lophius piscutor Mitcnill, Rep. Fisl. N. Y. 2S, 1S14, Long Island.

Lophins americanus Cuvier \& Valenciennes, Hist. Nat. Poiss. XII, 380,

1837; De KaY. N. Y. Fauna, Fishes, 162, pl. 28, fig. 87, 1842; Storer, Hist. Fish. Mass. 101, pl. XVIII, fig. 2, 1867.

Body depressed, tapering, scarcely longer than head; humeral spine with points, of which the posterior is the longest; head surrounded with a fringe of barbels; top of head in young with many strong spines; anterior dorsal spine elongate, fleshy at tip. D. I-I-I, III-10; A. 9.

Brownish, mottled, below white; mouth from behind the hyoid bone immaculate; pectorals and candal black at tip; peritoneum back. North Atlantic, on both coasts; generally common, from North Carolina northward. A fish of singular ugliness of appearance. 
The Kay ealls this fish the Ameriean angler. He says it is not an uncommon fish in New Jork waters, and that among its popular nanes are seal devil. fishing frog. bollows fish, goosefish, monlifish, and ralous others. The laresest one he saw was 4 feet long. It is not eaten. but is oftrn opened by fishermen for the numerous fishes which are fouml in its stomach. He says it is found on the south side of Long Island.

The angier is moderately abundant on the fishing banks in the vicinity of New York city, and small ones are sometimes caught in Gravesend bay. No examples of this fish were obtained by me in Great South bay during three seasons of summer investigations, but it is found sparingls in the ocean adjacent to the bay.

According to Dr Smith, it is abundant in Vineyard sound, usually from Ap. 1 to Juls 1, some seasons from April to Norember, or as late as the traps are set. Traps often take boat loads of these fish, which are carried to the shore and put on the land. No other use is made of them, though the flesh is considered rery palatable. Those caught in traps are from 4 inches to 4 feet long. The young keep off sllore in deep water and are never taken in the seine. The spawn is often found floating in Tineyard sound. During the fall of 1:000, according to Sherwood and Edwards, anglers were rerr abundant in Great harbor, at Moods Hole Mass. and late in the fall several large ones were washed ashore. The fish ars not often seen near Woods Hole, though abundant at Menemsha and Cuttyhunk, where the shores are frequently strewn with their bleached skeletons.

In Massachusetts bay it is a common resident of the deep waters, often coming to the shores. An individual about 4 inches in length was taken off the banks of Newfomudland in 18.56. This is probably the most northern recorded occurience of the fish in the western Atlantic. except the unconfirmed statement by Pennant of its appearance in Hudson's baỹ. The angler ranges from North Carolina northward. Mitchill called this fish the sea devil.

Family ANTENNATIDAE

Genus r'Terophreve Gill

Body smooth or scarerly gramular. short, somewhat compressed, with tumid abdomen; nouth small. oblique; palate with 
teeth; wrist and pectoral fin slender; rentrals elongated; soft dorsal and aual rertically expanded. Small fishes of fantastic shape in the West Indies and Gulf strean.

\section{Pterophryne histrio (Liunaeus)}

\section{Mousefish}

Lopllins histrio Linnaeus, Syst. Nat. ed. X, I, 237, 1758.

Chironectes laevigutus SToner, Rep. Fish. Mass. 73, 1839; DE KAY, N. Y. Fauna, Fishes, 165, pl. 27, fig. 83, $18+2$.

Antenmarins histrio Jordan \& GIlbert, Bull. 16, U. S. Nat. Mus. S\$6, 1 SS3. Pterophryne histrio GILL, Proc. U. S. Nat. Nus. 216, 1Sis; Goode \& Bean, Oceanic Ichth. 4S6, 1S96; BEAN, Bull. Am. Mus. Nat. Hist. IX, 373, 1897; H. M. Sмiтн, Bull. U. S. F. C. 1897, 109, 1898; Jordax \& EverMAxN, Bull. 47 , U. S. Nat. Mus. III, $2716,1898$.

The length of the body is one and four fifths times its depth and two and one fourth times the length of the head; skin of head and body, as well as dorsal fins, with fleshy tags, which are most numerous on the dorsal spines and abdomen; wrist slender; ventrals large, nearly half as long as head; dorsal and anal with posterior rays not adnate to the caudal peduncle. D. III-14;A. 7 ; V. 5 .

Yellowish, marbled with brown; three dark bands radiating from eve; rertical fins barred with brown; belly and sides with small white sjots. Tropical parts of Atlantic; abundant on our Gulf coast and occasional northward.

The mousefish inhabits the tropical parts of the Atlantic. It is abundant on our Gulf coast and occasional northward to Cape Cod, specially in floating masses of Sargassum. It was once taken in Europe in floating seaweed, from the Gulf Stream, and has been recorded from the coast of Senegambia.

De Kay described this species under the name of the smooth mousefish. He refers to the descriptions of Cuvier and Valenciennes, and storer. He states that the geographic range of the species at that time was known to extend from Charleston to Boston.

This species is not uncommon in summer in floating masses of gulf weed brought near our shores by the Gulf Stream and other currents. An example was caught off the ocean shore of Long 
1sland in August 1897. At Woods Hole Mass., according to Mr Smith, it was taken in 1877. In November 1855, 1:2 specimens were seined in Quissett harbor. From that year till 1897 none were observed, but in 1897 the fish were comparatively common in Vineyard sound. During July there was an musual prevalence of southerly winds, and a large quantity of sargasso weed was blown in from the Gulf Stream, and with it this fish, which he calls the marbled angler. In Vineyard sound, a few miles from Woods Hole, 50 individuals were taken July 24, 1597. Probably not less than 100 specimens were taken during that rear. Many were kept alive in aquaria for sereral weeks. Some remain under or among the gulf weed at the surface, some conceal themselves in the algae on the bottom, some hide behind stones and other objects, and some seek crevices among rocks. While clumsy in their morements, they were adept in approach. ing and capturing other fishes. They were cannibalistic, one about 6 inches long swallowing another 4 inches long, and they frequently bit off the fleshy dermal appendages of their fellows. In August several spawned in the aquarium. The eggs are connected in long bands, like those of the angler. It is reported that in the summer of 1859 the fish was not uncommon off Nantucket, and in 1897 , eight specimens were taken in gulf weed off that island.

\section{Family ogcocephalmaE Batfishes}

\section{Genus ogcocephatus Fischer}

Body stoutish, tapering backward; head rery broad and depressed, triangular in form, the forehead elevated and produced; eyes large, lateral; mouth rather small, subinferior under the snout; villiform teeth in bands on jaws, vomer and palatines; skin covered with rough, bony tubercles; dorsal and anal fins rery small; rostral tentacle present, retractile into a cavity under a bony prominence on the forehead; rentrals present, I, 5, well separated; pectorals large, placed horizontally; gills $2 \frac{1}{2}$; no air bladder; no pyloric caeca. Tropical America, in shallow water. Small fishes of singular form, often regarded by the ignorant as renemons. 
$3 i 1$ Ogcocephalus vespertilio (Linnatus)

Batfish; Malthe

Lophius respertilio Linnafus, Syst. Nat. ed. X, I, 236, 1758.

Malthaea iespertilio Cuvier \& Valencienses, Hist. Nat. Poiss. XII, 440, 1837; UE KAY, N. Y. Fauna, Fishes, 167, 1842.

Malthe respertilio Gunther, Cat. Fish. Brit. Mus. III, 200, 1861; JordAN \& Gilbert, Bull. 16, U. S. Nat. Mus. \$50, 1883.

Ogcocephalus vespertilio Jordan \& Evermann, Bull. 47, U. S. Nat. Mus. III, 2737, 1898; IV, pl. CCCXCII, figs. 95S, 958a, 95Sb. 1900; BEAN, Science, N. S. IX, no. 211, 8, 1899.

Anterior half of body (the head), between eyes and gill openings, much depressed and broadened, the greatest width in front of gill openings equaling distance from tip of rostral process to gill openings or about half length of entire fish; from gill openings to caudal the body is rounded, tapering to the tail; the width of the body at the rent equals one third of the width at gill openings; forehead produced in a subconic process of varying length, its length measured from eye being contained six and one half times or mole in total lengtl without caudal; mouth small, inferior; jaws, vomer, and palatines with bands of villiform teeth. D. $4 ;$ A. $4 ;$ V. I, 5.

Color dark gray and brown, often varying from almost black to light gray and orange.

The batfish is a West Indian species, ranging north to the Florida Keys, and has been taken at least once in the harbor of New York. It grows to a length of 12 inches. De Kay did not meet with this fish on the coast of New York, but he copies the description of Cuvier and Valenciennes. In the midsummer of 1854 or 1855, Dr Theodore Gill saw an individual of this species, which was recently caught at a wharf at the foot of 27 th st. East river, New York. No record of its occurrence was published, but the writer noted this circumstance in Science, Jan. 13 . 1899, n. s. v. 9. 
RECORDED DISTRIBUTION OF NEW YORK FISHES

1 Petromyzon marinus.

2 P. marinus unicolor

3 Ichthromyzon concolor.

4 Lampetra wilderi.-....

5 Pseudotriakis microdon

6 Mustelus canis...................

7 Galeocerdo tigrinus

8 Prionace glauca

9 Carcharhinus obscurus

11 Aprionodon isodon.

12 Scoliodon terrae-novae

13 Sphyrua tiburo

14 S. zygaena

15 Alopias vulpes

16 Carcharias littoralis

17 Isurus dekayi

18 Lamna cornubica ..............

19 Carcharodon carcharias

20 Cetorbinus maximus

21 Squalus acanthias.

22 Squatina squatina.

23 Raja erinacea

24 R. ocellata.

25 R. eglanteria.

26 R. laevi

27 Tetranarce occidentalis

28 Dasyatis centrura

29 D. hastata

30 D. say

31 Pteroplatea maclura

32 Myliobatis freminvillei.

33 Rhinoptera bonasus

34 Polyodon sparhula.

35 Acipenser sturio

36 A. rubicundus

38 Lepisostens osseus............

$39 \mathrm{~L}$. plitostomus................

40 Amia calva...................

41 Felichthys marinus

42 Galeichthys felis .

43 Ictalurus punctatus

44 Ameiurus lacustris............

45 A. natalis....................

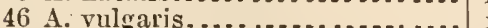

48 A. nebulosus 1 ................... $\mathrm{x}$

49 A. nebulosus marmoratus........ $\mathrm{x}$

50 A. melas ................... $x$

51 Noturus flavus .................

52 Schilbeodes gyrinus ${ }^{1}$

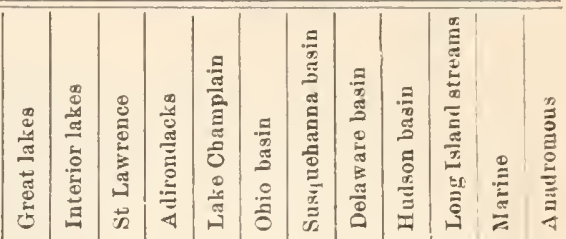

Recorded also from the Walkill, Passaic and Hackensack. 
Recorded distribution of New York fishes (continued)

\begin{tabular}{|c|c|c|c|c|c|c|c|c|c|c|c|c|c|}
\hline & & 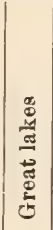 & 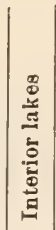 & 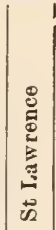 & 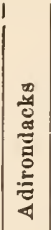 & 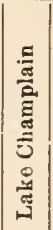 & $\begin{array}{l}\frac{\Xi}{\pi} \\
\stackrel{\Xi}{\Xi} \\
\stackrel{0}{\Xi}\end{array}$ & 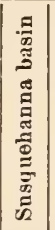 & 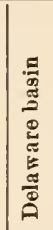 & 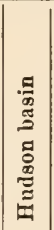 & 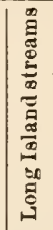 & 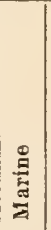 & 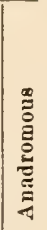 \\
\hline 53 & 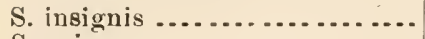 & $x$ & $\ldots$ & $\cdots$ & $\ldots$ & $\ldots$ & $x$ & $\mathbf{x}$ & $\mathbf{x}$ & $\ldots$ & & $\cdots$ & ... \\
\hline 54 & 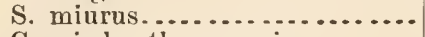 & $\mathbf{x}$ & $\cdots$ & $\ldots$ & $\cdots$ & $\cdots$ & $x$ & $\cdots$ & $\cdots$ & $\cdots$ & $\ldots$ & $\cdots$ & $\ldots$ \\
\hline 55 & Carpiodes thompsoni ......... & $\mathrm{x}$ & $\ldots$ & $\mathrm{x}$ & $\ldots$ & $\mathbf{x}$ & $\ldots$ & $\ldots$ & $\ldots$ & $\ldots$ & $\ldots$ & $\ldots$ & $\ldots$ \\
\hline 56 & Catostomus catostomus........ & $x$ & $\mathrm{x}$ & $x$ & $\ldots$ & $\bar{x}$ & $\ldots$ & $\ldots$ & $\ldots$ & $\ldots$ & $\ldots$ & $\ldots$ & $\ldots$ \\
\hline 57 & C. commersoniil............... & $\mathbf{x}$ & $\mathrm{x}$ & $\mathrm{x}$ & $\ldots$ & $\bar{x}$ & $x$ & $\mathrm{x}$ & $\mathrm{x}$ & $\mathrm{x}$ & $\ldots$ & $\ldots$ & $\cdots$ \\
\hline 58 & 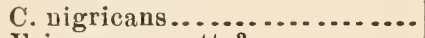 & $\mathrm{x}$ & $\ldots$ & $\cdots$ & $\ldots$ & $\ldots$ & $\mathrm{x}$ & $x$ & $\mathrm{x}$ & $\cdots$ & $\cdots$ & $\cdots$ & $\cdots$ \\
\hline 59 & Erimyzon sucetta ${ }^{2} \ldots \ldots \ldots$ & $\cdots$ & $\ldots$ & $\ldots$ & $\ldots$ & $\ldots$ & $\ldots$ & $\cdots$ & $\ldots$ & $\mathrm{x}$ & .. & $\ldots$ & -.. \\
\hline 60 & E. sucetta oblongus ............ & $x$ & $\mathbf{s}$ & $x$ & $\ldots$ & $\ldots$ & $\ldots$ & $x$ & $\mathbf{x}$ & $\mathrm{x}$ & $\cdots$ & $\ldots$ & .. \\
\hline 61 & Mingtrema melano & $x$ & $\ldots$ & $\ldots$ & $\ldots$ & $\ldots$ & $\mathrm{x}$ & $\ldots$ & $\ldots$ & $\ldots$ & $\ldots$ & $\ldots$ & $\ldots$ \\
\hline 62 & Moxostoma anisurum ......... & $\mathbf{x}$ & $\ldots$ & $\mathbf{x}$ & $\ldots$ & $\ldots$ & ... & $\ldots$ & $\ldots$ & $\ldots$ & $\ldots$ & $\ldots$ & $\ldots$ \\
\hline 63 & 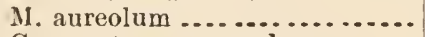 & $x$ & $x$ & $x$ & $\ldots$ & $\mathrm{x}$ & $\mathrm{x}$ & $\ldots$ & $\ldots$ & $\mathrm{x}$ & $\ldots$ & $\ldots$ & $\ldots$ \\
\hline 64 & Campostoma anomalum ...... & $\mathrm{x}$ & $\ldots$ & $\ldots$ & $\ldots$ & $\ldots$ & $\mathrm{x}$ & $\ldots$ & $\ldots$ & $\ldots$ & $\ldots$ & $\ldots$ & $\cdots$ \\
\hline 65 & Chrosomus erytbrogaster...... & $\mathbf{x}$ & $\ldots$ & $\mathbf{x}$ & $\ldots$ & $\ldots$ & $\ldots$ & $\mathrm{x}$ & $\ldots$ & $\ldots$ & ... & $\ldots$ & $\ldots$ \\
\hline 66 & Hybognathus nuchalis ........ & $\mathrm{x}$ & $\ldots$ & $\ldots$ & $\ldots$ & ... & $\ldots$ & $\ldots$ & $\ldots$ & $\ldots$ & $\ldots$ & $\ldots$ & $\ldots$ \\
\hline 67 & Pimephales promelas.......... & $\mathrm{x}$ & $\ldots$ & $\ldots$ & $\ldots$ & $\ldots$ & $\mathrm{x}$ & $\ldots$ & $\ldots$ & $\ldots$ & $\ldots$ & $\ldots$ & $\ldots$ \\
\hline 68 & vatus $\ldots \ldots \ldots . . . . . . . .$. & $\mathrm{x}$ & $\mathrm{x}$ & $\mathrm{x}$ & $\ldots$ & $\mathrm{x}$ & $\mathrm{x}$ & $\ldots$ & $\ldots$ & $\ldots$ & $\ldots$ & ... & $\ldots$ \\
\hline 69 & Semotilus bullaris............ & $\mathbf{x}$ & $\ldots$ & $\mathrm{x}$ & -.. & $\mathbf{x}$ & $\ldots$ & $\mathbf{x}$ & $\mathbf{x}$ & $\mathrm{x}$ & $\ldots$ & $\ldots$ & $\ldots$ \\
\hline 70 & S. atromaculatus............ & $\mathrm{x}$ & $\cdots$ & $x$ & $\ldots$ & $\mathrm{x}$ & $\mathrm{x}$ & $\mathrm{x}$ & $\mathrm{x}$ & $x$ & $\ldots$ & $\ldots$ & $\ldots$ \\
\hline 71 & 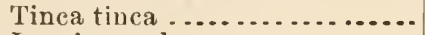 & $\ldots$ & $\ldots$ & $\ldots$ & $\ldots$ & $\ldots$ & $\ldots$ & $\ldots$ & $\ldots$ & $\ldots$ & $\mathrm{x}$ & $\ldots$ & ... \\
\hline 72 & Leuciscus elongatus.......... & $\mathrm{x}$ & $\ldots$ & $\ldots$ & $\ldots$ & $\ldots$ & $\ldots$ & $\ldots$ & |... & $\ldots$ & $\ldots$ & $\ldots$ & $\ldots$ \\
\hline 73 & arita.................. & $\mathrm{x}$ & $\ldots$ & $\ldots$ & $\ldots \mid$ & $\ldots$ & $\ldots$ & $\mathrm{x}$ & 1... & $\ldots$ & $\ldots$ & $\ldots$ & $\ldots$ \\
\hline 74 & Idus idns . . & $\ldots$ & $\ldots$ & $\ldots$ & i... & $\ldots$ & $\ldots$ & $\ldots$ & $\ldots$ & $\ldots$ & $\mathrm{x}$ & $\ldots$ & $\ldots$ \\
\hline 75 & Abramis crysoleucas 1 ....... & $\mathbf{x}$ & $\mathrm{x}$ & $\mathrm{x}$ & $\mid-\cdots$ & $x$ & $\ldots$ & $x$ & $\mathrm{x}$ & $x$ & $\ldots$ & $\ldots$ & $\ldots$ \\
\hline 76 & A. crysoleucas roseus, Cen'l Park & $\ldots$ & $\ldots$ & $\ldots$ & ... & $\ldots$ & $\ldots$ & ... & $\ldots$ & $\ldots 1$ & $1 \ldots$ & $\ldots$ & $\ldots$ \\
\hline $76 \frac{1}{2}$ & 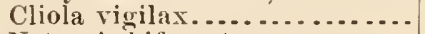 & $\mathrm{x}$ & $\ldots$ & $\ldots$ & $\ldots$ & $\ldots$ & $\ldots$ & $\ldots$ & $\ldots$ & $\ldots$ & $\ldots$ & $\ldots$ & ... \\
\hline $77^{2}$ & Notropis bifrenatus ........... & $\cdots$ & $\ldots$ & $\cdots$ & $\cdots$ & $\ldots$ & $\cdots$ & $\cdots$ & $x$ & $\ldots$ & $\cdots$ & $\ldots$ & $\ldots$ \\
\hline 78 & $\mathrm{~N}$. anogenus $\ldots \ldots \ldots \ldots \ldots \ldots$ & $\ldots$ & $\mathrm{x}$ & $\ldots$ & .. & $\ldots$ & $\ldots$ & $\ldots$ & $\ldots$ & ... & $\ldots$ & $\ldots$ & $\ldots$ \\
\hline 79 & N. caynga $\ldots \ldots \ldots \ldots \ldots \ldots$ & $\mathbf{x}$ & $\mathbf{x}$ & $\ldots$ & $\ldots$ & $\ldots$ & $\mathbf{x}$ & $\ldots$ & $\ldots$ & $\ldots$ & $\ldots$ & ... & ... \\
\hline 80 & 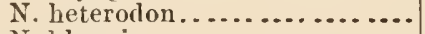 & $x$ & $x$ & ... & ... & $\ldots$ & $\ldots$ & ... & $\ldots$ & $\ldots$ & $\ldots$ & ... & .. \\
\hline 81 & 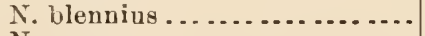 & $\mathrm{x}$ & $\ldots$ & $x$ & $\therefore$ & $\mathrm{x}$ & $\ldots$ & ... & $\ldots$ & $\ldots$ & $\ldots$ & ... & ... \\
\hline $8: 3$ & $\theta, \ldots \ldots \ldots \ldots \ldots$ & $\ldots$ & $\ldots$ & $\ldots$ & $\ldots$ & $\ldots$ & $\mathbf{x}$ & $\mathbf{x}$ & $\mathrm{x}$ & $\ldots$ & $\ldots$ & $\ldots$ & $\ldots$ \\
\hline 83 & 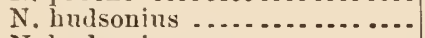 & $\mathrm{x}$ & $\ldots$ & $x$ & & $x$ & $\mathrm{x}$ & $\ldots$ & $\mathrm{x}$ & $\mathrm{x}$ & $\ldots$ & $\ldots$ & $\ldots$ \\
\hline 84 & N. budsonius amarus......... & $\mathrm{x}$ & $\ldots$ & $\ldots$ & $\ldots$ & $\ldots$ & $\ldots$ & $\mathbf{x}$ & $\ldots$ & $\ldots$ & ... & $\ldots$ & $\ldots$ \\
\hline 85 & 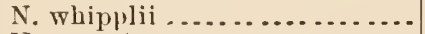 & $\mathbf{x}$ & $\mathrm{x}$ & $\mathbf{x}$ & $\cdots$ & $\mathbf{x}$ & $x$ & ... & $\ldots$ & -.. & $\ldots$ & $\ldots$ & $\mid \ldots$ \\
\hline 86 & 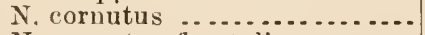 & $\mathbf{x}$ & ... & $x$ & $\cdots$ & $\mathrm{x}$ & $x$ & $\mathrm{x}$ & $\mathrm{x}$ & $\mathrm{x}$ & $\cdots$ & $\ldots$ & ... \\
\hline 87 & us frontalis......... & $x$ & $\mathbf{x}$ & $\ldots$ & & -.. & $\ldots$ & $\ldots$ & $\ldots$ & ... & $\ldots$ & $\cdots$ & ... \\
\hline 88 & 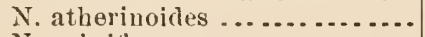 & $\mathbf{x}$ & $\mathbf{x}$ & $\mathrm{x}$ & ... & $\mathrm{x}$ & $\ldots$ & $\ldots$ & $\ldots$ & ... & $\ldots$ & $\ldots$ & $\ldots$ \\
\hline 89 & 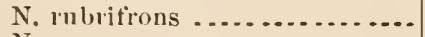 & $\mathbf{x}$ & $\ldots$ & $\mathrm{x}$ & $\ldots$ & $\mathbf{x}$ & $\mathbf{x}$ & ... & $\ldots$ & $\ldots$ & $\ldots$ & $\ldots$ & ... \\
\hline 90 & 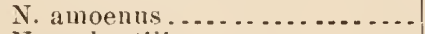 & ... & $\ldots$ & $\ldots$ & $\ldots$ & $\ldots$ & $\ldots$ & ... & $\ldots$ & $\mathrm{x}$ & $\ldots$ & $\ldots$ & $\ldots$ \\
\hline 91 & loratilis ....... & $\ldots$ & $x$ & |... & ... & ... & $\ldots$ & ... & $\ldots$ & $\ldots$ & $\ldots$ & $\ldots$ & $\ldots$ \\
\hline $91 \frac{1}{2}$ & Ericymba buccata........... & $\mathrm{x}$ & $\ldots$ & $\ldots$ & $\ldots$ & $\ldots$ & $\ldots$ & $\ldots$ & $\ldots$ & ... & $\ldots$ & ... & $\ldots$ \\
\hline $9 \cdot 2^{4}$ & Rhiniclithys cataractae........ & $\mathbf{x}$ & $x$ & $\mathrm{x}$ & & $\mathrm{x}$ & -. & $\ldots$ & ... & $\ldots$ & $\ldots$ & $\ldots$ & ... \\
\hline 93 & R. atronasins $1, \ldots \ldots \ldots \ldots$ & $\mathrm{x}$ & $\ldots$ & $\mathrm{x}$ & & $\mathbf{x}$ & $\mathbf{x}$ & $\mathrm{x}$ & $\mathbf{x}$ & $x$ & $\ldots$ & $\ldots$ & -.. \\
\hline 94 & Hybopsis dissiunilis ....... & $\mathrm{x}$ & $\ldots$ & $\ldots$ & $\ldots$ & $\cdots$ & $x$ & -. & ... & $\ldots$ & $\ldots$ & $\ldots$ & ... \\
\hline $94 \frac{1}{2}$ & H. amblops........... & $\mathrm{x}$ & ... & $\ldots$ & 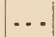 & $\ldots$ & $\cdots$ & $\cdots$ & ... & $\ldots$ & $\ldots$ & $\ldots$ & $\cdots$ \\
\hline $9.5^{2}$ & H. storeri & $x$ & $\ldots$ & $\ldots$ & ... & $\ldots$ & $\cdots$ & .. & ... & ... & $\ldots$ & ... & ... \\
\hline 96 & H. kentuckiensis........... & $x$ & $\mathbf{x}$ & $\ldots$ & & $\ldots$ & $x$ & $\mathbf{x}$ & ... & $x$ & ... & $\ldots$ & -.. \\
\hline 97 & Conesins plnubens ........... & ... & ... & $\mathbf{x}$ & $\mathbf{x}$ & $\mathbf{x}$ & .. & - . & $\ldots$ & $\ldots$ & $\ldots$ & $\cdots$ & $\ldots$ \\
\hline 98 & Exoglossim maxilliugua ...... & $x$ & $x$ & $\mathrm{x}$ & & $\mathrm{x}$ & $\ldots$ & $x$ & $\mathbf{x}$ & $x$ & $\cdots$ & & - . \\
\hline 99 & Carassius auratus ......... & $\ldots$ & $\ldots$ & $\ldots$ & ; & $\ldots$ & $\ldots$ & & ... & $x$ & $\mathbf{x}$ & $\ldots$ & ... \\
\hline y० 0 & Cyprinus carpio ...... & $x$ & $\mathrm{x}$ & $\ldots$ & - & ... & $\mathbf{x}$ & $\ldots$ & $\ldots$ & $x$ & $\mathrm{x}$ & .. & $\cdots$ \\
\hline 101 & Anguilla chrysypa $1 . . . . . . .$. & $x$ & $\mathbf{x}$ & $\mathrm{x}$ & & & & $\mathrm{x}$ & $\mathbf{x}$ & $\mathrm{x}$ & & & \\
\hline
\end{tabular}

${ }^{2}$ Recorded also from the Walkill, Passaic and Hackensack.

${ }^{2}$ Recorded also trom the Passaic and Hackensack. 
Hecorded distribution of Nerr York fishes (continucd)

102 Leptoeephalus conger

103 Tarpon atlanticus. .

101 Elops saurus.

105 Allonla vulpes. .

106 Hiodon tergisus...............

$107 \mathrm{H}$. alosoides

108 Dorosoma cepedianum .........

109 Etrumens teres ................

110 Clupea harengus................

111 Pomolobns chrysochloris .......

112 P. mediocris .....................

$113 \mathrm{P}$. psendobarengus .............

114 P. cyanonoton ...................

115 Alosa sapidissima ..............

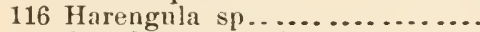

117 Opisthonema oglinum ..........

118 Brevoortia tyrannus

119 Stolephorus brownii

120 S. argyrophauns

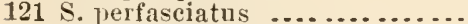

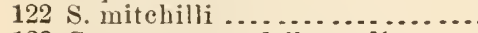

123 Coregoums quadrilateralis ......

124 C. elinpeiformis .................

125 Argyrosomus osmeriformis......

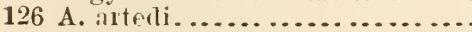

127 A. hoyi .

128 A. prognathus ................

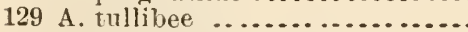

130 Oncorhynchus chouicha ........

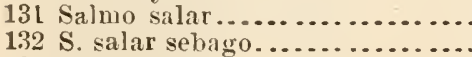

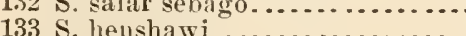

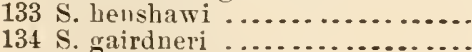

135 S. fario

$136 \mathrm{~S}$. trutta levenensis

137 S. iridens

138 S. lemanus

140 Salvelinus fontiualis 1

141 S. alpinns 2

$142 \mathrm{~S}$. alpinus anreolus ${ }^{3}$

143 Osmerus mordax.

144 Synorlus foeters.............-

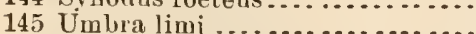

$146 \mathrm{U}, 15 \mathrm{rm} a \mathrm{a}^{4}$

147 Lneius americanus.

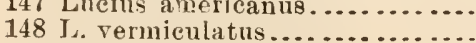

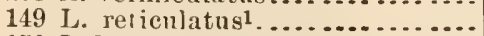

150 L. lueins...........................

151 L. masquinongy

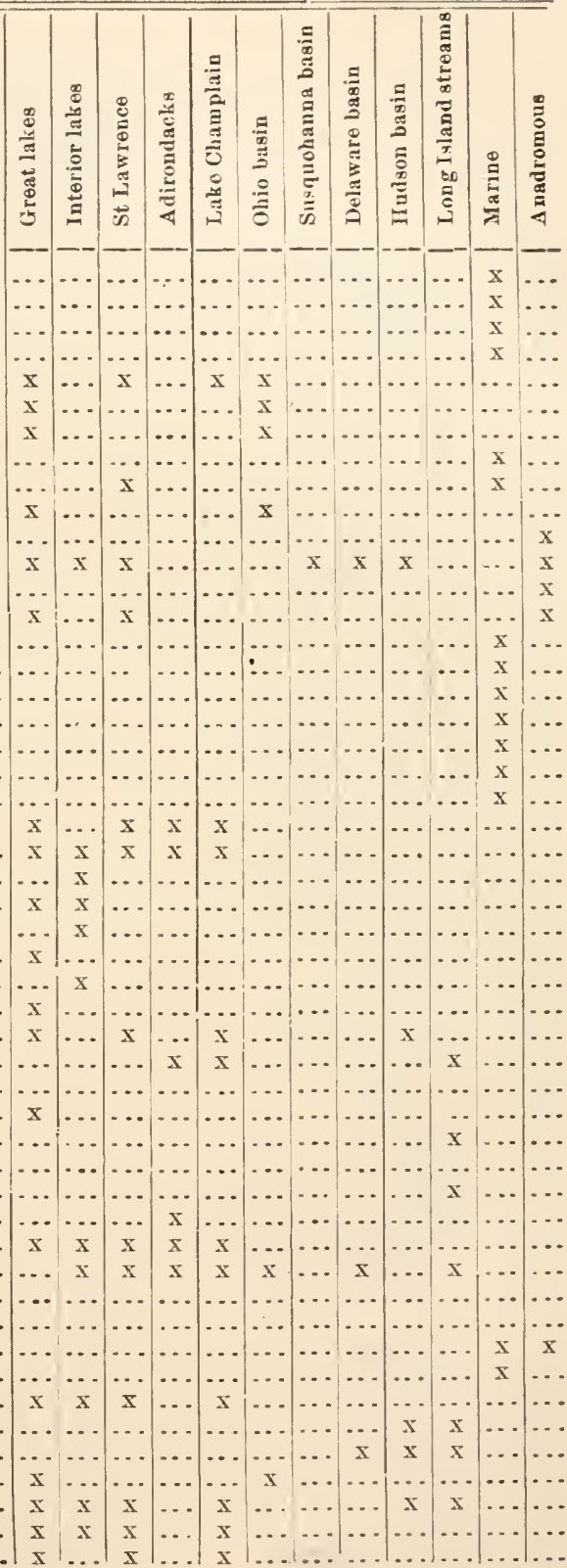

1 Recorded also from the Walkill and Passaic.

2 Introducerl into Sterling lake.

3 Introduced into Lake George.

${ }^{4}$ Recorded from the Passac and Hackensack. 
liecorded bistribntion of New York fislies (continued)

152 L. m. ophiensis (Kirt.)

153 Fundulus inajalis

$154 \mathrm{~F}$, heteroclitus.

155 F. diaphinus 1 .

156 Lucania parva.

157 Cyprinodon variegatus

$160 \mathrm{~T}$. ach hidoma

161 Hyporhamphus roberti

162 Euleptorhamphus velox

163 Scomberesox saurus.

164 Exocoetus volitans.

165 Cypsilurus heterurus.

166 C. fnrcatus

168 Eucalia ineonstans..............

169 E. incoustans cayuga.............

170 Pysosteus pungitius ${ }^{1}$

171 Gasterostens bispinosus ........ $x$

172 A peltes quadracus...............

173 Fistularia tabaccaria

174 Siphostoma fuscum

175 Hippocampus hudsonius.....

176 Percopsis guttatus.............

177 Aphredoderus sayauus......... $x$

178 Menidia gracilis ................

179 M. beryllina

180 M, notata.

181 Kirtlaudia va

182 Labidesthes sieculus...........

183 Mugil cephalus.................

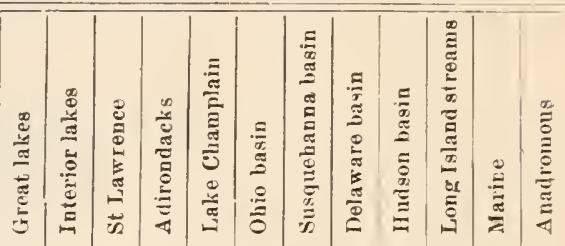

184 M. curema.....................

185 M. trichodon...............

186 Syphraena guachancho............

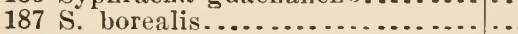

188 Polydactylus octonemus.

189 Aumodytes americanus.........

190 Mullus auratus.

191 Seomber scombrus.

$192 \mathrm{~S}$. colias

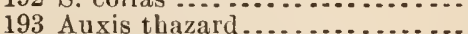

194 Gymnosarda pelanis

$19 j$ G. alleterata ......

197 Sarda sarda

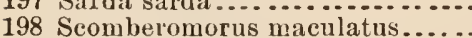

199 S. regalis

200 S. cavalla........................

201 Trichiurus lepturus .............

202 Istiophorus nigricans.

203 Tetrapturus imperator

Recorded also from the Passaic and Hackunsack. 
Recorded histribution of New lorle fishes (continurd)

204 Xiphias gladius.

205 Oligoplites saurns.

206 Nancrates ductor

207 Seriola zonata

208 S. lalandi

209 Elagatis bipinulatus.

210 Decapterus punctatus.

2l1 D. macarellus

212 Tracinurus trachurus

213 Trachurops erumevophthalmus.

214 Caranx hippos

$215 \mathrm{C}$. crysos

216 Alectis ciliaris

217 Vomer setipiuni

218 Selene vomer

219 Chloroseomlirus chrysurus......

220 Trachiuotus filcatus

221 T. argentens:.

$222 \mathrm{~T}$. carolinus

22:3 Pomatomus saltatix

224 Rachycentron cauadum

"2.5 Coryphacna hippurus.

226 C. pquisetis

227 Palinmrichthẹs perciformis

228 Rhombus paru

229 R. triacanthus

230 Pomoxis annularis.

231 P. sparoicles............

233 Ambloplites rupestris 2

234 Chienobryttus grulosus

236 E. gloriosus 3

237 Apomotis cyauellus

-38 Lepomis auritus.

240 Enpomot is gibbosus 4

$\rightarrow 11$ Microptems dolonieu 5

+12 M. salmoides 6

13 Stizostedion vitren.........

$011 \mathrm{~S}$

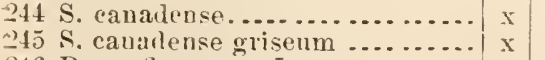

216 Perca tlavescens 7 ...........

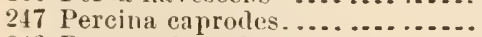

$248 \mathrm{P}$. caprodes zelora

249 Hadropterus aspro

250 Cottogaster copelandi

251 C. cheneyi.

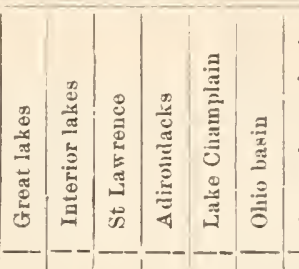

${ }^{1}$ Recorder in the Hackensack.

2 Introduced into the Passaic and Long Island waters.

3 Recorded from Long pond. Hudson Highlands.

- Recorded also from the Walkill, Passaic and Hackensack.

Introducer in to the Passaic.

Recorded from the IValkill, Pasagic and Bronx.

Recorded from the P'assaic and Hackensack. 
Recorded distribution of New Fork fishes (continued)

\begin{tabular}{|c|c|c|c|c|c|c|c|c|c|c|c|c|c|}
\hline & . & 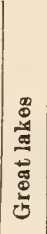 & 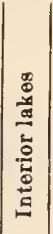 & 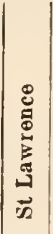 & 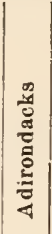 & 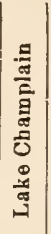 & 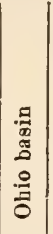 & 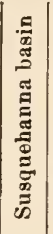 & 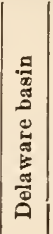 & 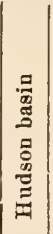 & 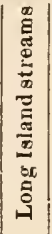 & 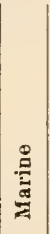 & 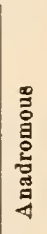 \\
\hline 252 & Diplesion bleuniodes ..... & $\mathrm{x}$ & $\cdots$ & $\ldots$ & . & & $\cdots$ & $\ldots$ & $\cdots$ & & $\cdots$ & & \\
\hline 253 & 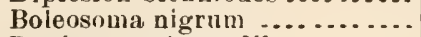 & $\mathrm{x}$ & $\cdots$ & $\cdots$ & $\cdots$ & & $\ldots$ & $\cdots$ & $\ldots$ & .. & & & \\
\hline 254 & B. nigrum olmstedi' $\ldots \ldots \ldots$. & $x$ & $\mathrm{x}$ & $\mathrm{x}$ & $\cdots$ & $\mathrm{x}$ & & $\cdots$ & $\cdots$ & ... & $\mathrm{x}$ & $\ldots$ & \\
\hline 255 & Etheostoma coeruleum ........ & $\mathbf{x}$ & ... & -. & ... & ... & $\mathrm{x}$ & $\cdots$ & ... & $\cdots$ & $\cdots$ & ... & ... \\
\hline $255 \frac{1}{2}$ & E. boreale $\ldots \ldots \ldots \ldots \ldots \ldots$ & $\mathbf{x}$ & ... & $\mathrm{x}$ & .. & & ... & ... & & ... & ... & & ... \\
\hline $256^{\circ}$ & E. flabellare ${ }^{2} \ldots \ldots \ldots \ldots \ldots$ & $x$ & $\mathbf{x}$ & $\mathrm{x}$ & ... & ... & $\mathbf{x}$ & ... & & & ... & ... & ... \\
\hline 257 & Boleichthys fusiformis .... & $\mathbf{x}$ & $\cdots$ & $\cdots$ & $\cdots$ & ... & .. & $\cdots$ & $\cdots$ & .. & $\cdots$ & $\cdots$ & ... \\
\hline 258 & 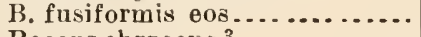 & $\mathrm{x}$ & ... & $\ldots$ & $\cdots$ & $\cdots$ & . & ... & & ... & ... & ... & ... \\
\hline 259 & 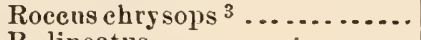 & $\mathrm{x}$ & $\cdots$ & $\cdots$ & ... & -. & $\mathbf{x}$ & & & & & ... & .. \\
\hline 260 & R. lineatus......... & $\cdots$ & $\cdots$ & $\mathrm{x}$ & $\cdots$ & $\cdots$ & $\cdots$ & $\mathbf{x}$ & $\mathrm{x}$ & $\mathrm{x}$ & $\mathbf{x}$ & ... & $\mathbf{x}$ \\
\hline 261 & Morone americana .......... & ... & $\cdots$ & $\ldots$ & $\ldots$ & ... & $\cdots$ & ... & .. & $\mathrm{x}$ & $\mathrm{x}$ & $\cdots$ & $\mathbf{x}$ \\
\hline 262 & Polsprion americanus ......... & $\cdots$ & $\cdots$ & ... & $\cdots$ & $\cdots$ & ... & $\cdots$ & ... & ... & $\cdots$ & $\mathrm{x}$ & ... \\
\hline 263 & Epinephelus niveatus . ......... & ... & ... & ... & ... & & ... & ... & ... & ... & ... & $\mathrm{x}$ & ... \\
\hline 264 & Centropristes striatus .......... & $\cdots$ & ... & .. & .. & ... & .. & .. & ... & & ... & $\mathbf{x}$ & ... \\
\hline 265 & Dules auriga $\ldots \ldots \ldots \ldots \ldots$ & 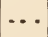 & . & ... & ... & $\cdots$ & ... & $\cdots$ & ... & ... & $\cdots$ & $\mathrm{x}$ & ... \\
\hline 266 & Rรpticus bistrispinus ......... & ... & ... & ... & $\ldots$ & ... & ... & ... & ... & ... & $\cdots$ & $\mathbf{x}$ & .. \\
\hline 267 & Lobotes surinamensis ......... & $\cdots$ & ... & $\cdots$ & $\cdots$ & $\cdots$ & & $\cdots$ & ... & $\cdots$ & $\cdots$ & $\mathrm{x}$ & $\ldots$ \\
\hline 268 & Priacanthus arenatus ......... & & ... & ... & & $\cdots$ & ... & ... & ... & $\cdots$ & $\cdots$ & $\mathrm{x}$ & ... \\
\hline 269 & Psendopriacaurhus altus....... & $\cdots$ & & $\cdots$ & ... & $\cdots$ & & ... & ... & $\cdots$ & .. & $\mathbf{x}$ & ... \\
\hline 270 & Neomaenis griseus ............. & $\cdots$ & ... & $\cdots$ & ... & & & & ... & ... & $\cdots$ & $\mathbf{x}$ & ... \\
\hline 271 & N. blackforil $\ldots \ldots \ldots \ldots . . . .$. & ... & ... & ... & ... & ... & ... & -.. & ... & $\ldots$ & $|\ldots|$ & $\mathrm{x}$ & ... \\
\hline 272 & Orthopristis ehrysopterus ..... & $\cdots$ & & & ... & ... & $\cdots$ & ... & ... & $\cdots$ & $\cdots$ & $\mathrm{x}$ & ... \\
\hline 273 & Sceuotomns chrysops.......... & $\ldots$ & $\cdots$ & ... & ... & ... & ... & $\cdots$ & ... & ... & $\ldots$ & $\mathrm{x}$ & ... \\
\hline 274 & Lagodon rhomlioid & $\ldots$ & $\ldots$ & $\ldots$ & $\ldots$ & ... & $\ldots$ & $\ldots$ & $\ldots$ & ... & $\ldots$ & $\mathrm{x}$ & ... \\
\hline 275 & Archosargiss probatocephalus.. & $\ldots$ & ... & ... & ... & $\cdots$ & ... & $\ldots$ & $\ldots$ & ... & .. & $\mathrm{x}$ & ... \\
\hline 276 & Euciuostomns gula........... & $\cdots$ & ... & -.. & ... & ... & ... & $\cdots$ & ... & $\cdots$ & $\ldots$ & $\mathrm{x}$ & .. \\
\hline 277 & Kyplosus sectatrix............ & $\ldots$ & $\ldots$ & ... & $\ldots$ & $\ldots$ & $\ldots$ & ... & $\ldots$ & $\ldots$ & $\ldots$ & $x$ & ... \\
\hline 278 & Cyuoscion regalis.......... & & ... & ... & ... & ... & .. & ... & & $\cdots$ & $\cdots$ & & ... \\
\hline 279 & ( $\ldots \ldots \ldots \ldots \ldots$ & $\ldots$ & & ... & ... & ... & ... & $\cdots$ & $\cdots$ & & $\cdots$ & $\mathrm{x}$ & ... \\
\hline 280 & Larimus fasciatus............ & $\ldots$ & . & ... & $\ldots$ & $\ldots$ & ... & ... & ... & ... & $\ldots$ & $\mathrm{x}$ & ... \\
\hline 281 & Bairdiella chrysura ........... & & & ... & $\ldots$ & ... & $\ldots$ & $\ldots$ & ... & ... & $\ldots$ & $\mathrm{x}$ & ... \\
\hline 282 & Scia & ... & & ... & $\cdots$ & ... & $\ldots$ & & & & $\ldots$ & $\mathrm{x}$ & ... \\
\hline 283 & Leiostomus xanthur & ... & $\cdots$ & & ... & ... & ... & $\ldots$ & ... & ... & ... & $\mathrm{x}$ & ... \\
\hline 281 & gon undulatus....... & ... & ... & ... & ... & ... & ... & $\cdots$ & $\ldots$ & $\cdots$ & ... & $\mathrm{x}$ & ... \\
\hline 285 & Menticirrbus saxatilis......... & & & & & & & & & & ... & $\mathrm{x}$ & ... \\
\hline 286 & Pogonias crom & ... & & & . & ... & & & & $\ldots$ & ... & $\mathbf{x}$ & ... \\
\hline 287 & Apludinotus grunuiens ........ & $\mathrm{x}$ & .. & & ... & $\mathrm{x}$ & . . & & & & $\cdots$ & & ... \\
\hline 288 & Tautogolabrus adspersus ....... & $\cdot \cdot$ & & & .. & .. & & & & ... & ... & $\mathrm{x}$ & ... \\
\hline 289 & & & .. & 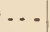 & .. & $\ldots$ & ... & & ... & ... & ... & $\mathrm{x}$ & ... \\
\hline 290 & Zenopsis ocellatus............. & & & $\cdots$ & $\cdots$ & ... & & & & & .. & $\mathrm{x}$ & -.. \\
\hline 291 & Chaetorlipterus fiber.......... & & & & & & & & & & & $\mathrm{x}$ & .. \\
\hline 292 & Chaetodon ocellatus........... & & & & & .. & & & & $\cdots$ & .. & $\mathrm{x}$ & ... \\
\hline 293 & Tenthis b & $\cdots$ & & & $\cdots$ & & & & & & & $\mathbf{x}$ & ... \\
\hline 294 & caroliuensi & & & & & & & & & ‥ & ... & $\mathbf{x}$ & ... \\
\hline 295 & B. vetula ... & & & & & & & & & & & $\mathrm{x}$ & \\
\hline 296 & Monacanthu & & & & & & & & & & & $\mathrm{x}$ &. \\
\hline 297 & schoeptit.. & & ... & & $\cdots$ & ‥ & -.. & & & & & $\mathbf{x}$ & \\
\hline 298 & & & & & & & & & & & & $\mathrm{x}$ & $\cdots$ \\
\hline 299 & Lagncepbalus laevi & 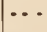 & $\cdots$ & $\cdots$ & $\cdots$ & $\cdots$ & & & $\cdots$ & & & $\mathrm{x}$ & $\cdots$ \\
\hline 300 & $\begin{array}{l}\text { Spheroides macnlatus ..... } \\
\text { S. testudineus }\end{array}$ & & & & & & & & & & & $x$ & \\
\hline
\end{tabular}

1 Recorded from the Passaic, Hackensack and Bronx.

2 Recorded from the Hackensack.

3 Introduced into Greenwood lake. 
Recomenel distribution of New York fisles (eontinucd)

302 S. trichocephalus

303 'T. trichodiodou pilosus.

304 Chilomycterus schoepfii

305 C. fuliginosus.

306 Mola mola

307 Sebastes marinus

308 Helicolenus dactylopterus.......

309 Cottus ictalops

310 Uranidea gracilis 1 .

311 U. formosa

312 Myoxocepbalus aeneus

313 M. octodecim-spinosus

314 M. groenlandicus

315 Triglopsis thompsoni.

316 Hemitripterus americanus.

317 Aspidlophoroides monopterzius

318 Crelopterus lumpus.

319 Neoliparis atlantieus

320 Liparis liparis

321 Gobiosoma bosci

322 Astroscopus guttatus

323 Opsanus tan

324 Blennius fucorum

325 Chasmodes bosquiamus.

326 Pholis gunuellus.

327 Ulvaria subbifureata.

328 Stichaens puuctatus.

330 Cryptacanthofesmis.

331 Anarhichas lupus

332 Zoarces anguillaris.

333 Rissola marginata.

334 Prionotus carolinus

$335 \mathrm{P}$. strigatus.

336 P. tribulus...

337 'Trigla euculus

338 Cephalacanthus volitans

$340 \mathrm{E}$. vancrateoides

341 Remora remora

$342 \mathrm{R}$. brachyptera

343 Rhombochirus osteochir

344 Merlucius bilinearis.

345 Pollachins virens.

346 Mierogadus tomcod

347 Gadus morrhua

348 Melauogrammus aeglifinus.

349 Lota maculosa................

350 Urophycis regius

351 ㄴ. tevuis

352 U. chuss

353 Gaidropsarus argentatus.

354 G. ensis.

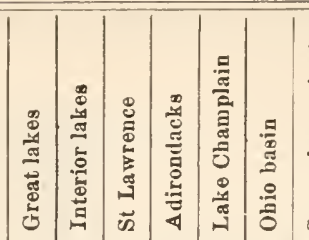

${ }^{1}$ Recorded also in the Hackensack and Passaic. 
Recorded distribution of New York fishes (concluded)

\begin{tabular}{|c|c|c|c|c|c|c|c|c|c|c|c|c|}
\hline & 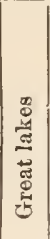 & 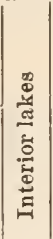 & 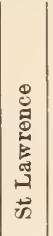 & 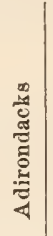 & 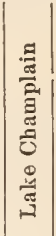 & 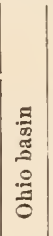 & 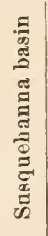 & 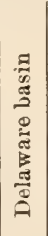 & 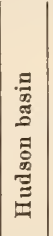 & 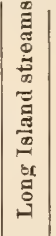 & $\begin{array}{l}\stackrel{0}{\Xi} \\
\stackrel{\Xi}{\Xi}\end{array}$ & 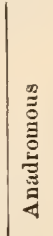 \\
\hline 355 Rhinonemus cimbrius.. & $\ldots$ & $\ldots$ & $\ldots$ & $\ldots$ & $\cdots$ & $\cdots$ & $\ldots$ & & $\cdots$ & $\ldots$ & $\mathrm{x}$ & $\cdots$ \\
\hline 356 Brosmius brosme.............. & & & $\cdots$ & $\cdots$ & & ... & $\cdots$ & & $\cdots$ & ... & $\mathbf{x}$ & $\cdots$ \\
\hline 357 Coelorhynchus carminatus..... & $\ldots$ & $\ldots$ & ... & ... & ... & ... & ... & & $\cdots$ & $\cdots$ & $\mathrm{x}$ & ... \\
\hline 358 Hippoglossus hippoglossus.... & $\cdots$ & & $\cdots$ & $\cdots$ & & $\cdots$ & & & ... & $\cdots$ & $\mathrm{x}$ & \\
\hline 359 Hippoglossoides platessoides... & $\cdots$ & $\cdots$ & $\cdots$ & $\cdots$ & $\cdots$ & $\cdots$ & $\cdots$ & $\cdots$ & $\cdots$ & $\cdots$ & $x$ & -. \\
\hline 360 Paralichthys dentatus........... & $\cdots$ & $\cdots$ & $\cdots$ & $\cdots$ & $\cdots$ & $\cdots$ & $\cdots$ & & $\cdots$ & $\cdots$ & $x$ & $\cdots$ \\
\hline $\begin{array}{l}361 \text { P. letbostigma } \ldots \ldots \ldots \ldots \ldots \ldots \ldots \\
362 \text { P. oblongus } \ldots \ldots \ldots \ldots \ldots \ldots \ldots\end{array}$ & $\cdots$ & $\because$ & $\cdots$ & 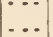 & $\cdots$ & $\cdots$ & $\cdots$ & & $\cdots$ & $\cdots$ & $\bar{x}$ & $\cdots$ \\
\hline 363 Lophopsotta maculata........ & & & & $\cdots$ & & & -. & & & ... & $\vec{x}$ & \\
\hline 364 Etropus microstomus............ & $\ldots$ & ... & ... & ... & ... & ... & ... & ... & ... & ... & $\mathrm{x}$ & ... \\
\hline 365 Limanda ferruginea.............. & ... & .. & ... & $\ldots$ & $\ldots$ & ... & ... & .. & & ... & $\mathrm{x}$ & ... \\
\hline 366 Psendopleuronectes americanus. & ... & - . & $\cdots$ & $\cdots$ & $\cdots$ & $\cdots$ & $\ldots$ & $\cdots$ & $\cdots$ & $\cdots$ & $\mathrm{x}$ & $\cdots$ \\
\hline 367 Platophrys ocellatus........... & $\cdots$ & $\ldots$ & $\cdots$ & $\cdots$ & $\cdots$ & $\cdots$ & $\cdots$ & $\cdots$ & 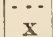 & $\ddot{x}$ & $x$ & $\because$ \\
\hline $\begin{array}{l}368 \text { Achirus fasciatus } 1 . \ldots . \ldots \ldots \\
369 \text { Lophius piscatorius } . . . . .\end{array}$ & & $\cdots$ & $\cdots$ & $\cdots$ & $\cdots$ & & & & & $\ldots$ & $\mathrm{x}$ & \\
\hline 370 Pterophryne histrio...... & $\ldots$ & $\cdots$ & $\cdots$ & $\cdots$ & $\cdots$ & ... & $\ldots$ & ... & .. & ... & $\mathrm{x}$ & . \\
\hline 371 Ogeocephalus vespertilio.. & & & & $\ldots$ & & & & & & ... & $\mathrm{x}$ & \\
\hline
\end{tabular}

1 Recorded also from the Hackensack. 


\section{I $\mathrm{N} \mathrm{D} \mathrm{E} \mathrm{X}$}

Abramis, 132-34

americanus, 132

chrysoleucas roseus, 134

crysoleucas, 132-3t

Smithii, see Cyprinus (Abramis?)

Smithii

ver'sicolor, 132

Acadian bullhead, $6 \pm 6$

Acantharchus, $464-66$

pomotis, $464-66$

Acanthias americanus, 43

rulgaris, 43

dcanthocottus, 639-44

aeneus, 639

anceps, see Cottus (Acanthocottus) anceps

sroenlandicus, $6+3$

octodecimspinosus, 641

variabilis, 643

virginianus, 641

Acanthopteri, 351-608

Acauthosoina carinatum, 629

Acanthurus chirurgus, 607 nigricans, 607

phlebotomus, 607

Acara aya, 5ั4

Achigan, 48T

Achirus, 731-33

fasciatus, $782-33$

lineatus. 732

mollis, 732

Acipenser, $63-69$

brevirostris, $6 \mathrm{~S}$

brevirostrum, 6S-69

maculosus, 66

oxyrinchus, 64

rubicundus, 66-67

sturio, 63-65

var. oxyrrhynchus, $6 t$

Acipenseridae, 63-69

Aelurichthys marinus, 77

Agonidae, $64 i-49$

Agoninae, 647-49
Albula, 1S1-83

conorhynchus, 182

erythrocheilos, 182

Parrae, 182

vulpes, 1S2-S3

Albulidae, 181-83

Alburnellus amoenus, 150

l'ubrifrons, 149, 150

Alburnops blennius, 138 heterodon, 137

Alburnus rubellus, 147 rubrifrons, 149

Aleby trout, 702

Alectis, 431-33

ciliaris, $432-33$

clinitus, 432

Alewife, 5, 199-201, 441

river, 192

Alligator, 71

Alligator gar, 71

Alopecias rulpes, 33

Alopias, 32-34

vulpes, $33-34$

Alopiidae, 32-3t

Alosa, 203-s

alosa, 204

chrysochloris, 195

cyanonoton, 202

lineata, 197

mattowaca, 197

menhaden, 211

praestabilis, 204 ,

sapidissima, 204-S

teres, 189

tyrannus, 199

Alutera, 613-15

schoepfii, 613

schoepfii, 613-1J

Aluteres cuspicauda, 613

Alvordius, $507-9$

aspro, 507

Amber fish, 416-1S

Amber jack, $41 \mathrm{~s}$ 
Amblodon grumnirus, 590 neglectus, 590

Ambloplites, 466-70 rupestris, 467-70

Ameiurus, $81-90$

catus, $85-86$

lacustris, $81-83$

melas, 90

natalis, 84

nebulosus, S5, Si-S9

marmoratus, 89

vulgaris, S4-S5

A merican angler, 735

American cod, 699

American codling, 706

American lake, 692

American sbad, 204

American sole, 732-33

Amia, 73-76

calva, $74-76$

oeciclentalis, 74

Amildae, $73-76$

Amiurus albidus, 86

borealis, $S 1$

catus, St

cauda-fureatus, 80

dekayi, $8 t$

marmoratus, $S \bar{\tau}$, S9

vatalis, 84

nigricans, 82

ponderosus, S2

pullus. 90

rulgaris, 84

Ammocoetes branchialis, 16

concolor, 14

niger, 16

unicolor, 13

Ammodytes, 375-77

americanus, 376-7т

rittatus, 376

Ammodytidae, 375-7T

Ammody toidei, 375-7

Amplionion alosoides, 155

? Amphiprion americauus, 532

Anacantuini, 691-714

Anarhichadidae, 672-74

Anarhichas, 672-74

lupus, 673-74

vomerinus, 673
Ancliovies, 213-19, 359

banded, $217-1 \mathrm{~s}$

silvery, 216-17

striped, 214-15

Angel fish, $45-46,5 \overline{7}, 602-4$

Angel sharks, $45-46$

Angler, 734-35

American, 735

marbled, 737

Anguilla, 169-74

blephura, 170

bostoniensis, 170

chrisypa, 170

chrysypa, 170-74

conger, 175

macrocephala, 170

oceanica, 175

rostrata, 170

tenuirostris, 170

tyranus, 170

vulgaris, 170

Anguillidae, 169-74

Antennaridae, $735-37$

Antennarius histrio, 736

Apeltes, :34:-44

quadracus, $342-44$

Aphredoderidae, 350-54

Aphredoderus, 35:-j4

gibbosus, 353

sayauts, 35:-54

Aplodinotus, 590-92

grumieus, 590-92

Apodes. 169-7

Apomotis, 47.j-Ti

cyanellus, 475- 77

Aprionorlon, 28-29

isodon, $28-29$

punctatus, 28

Auchosargus, 561, 562-65, 563-65 probatocephalus, 563-65

Argentinidae, 282-\$5

Argrreiose, hairfinned, 436

Argrreiosus capillaris, 435

setipimis. 433

vomer, 435

Argyreus atrouasus, 154

nasutus, 152

Argyriosus vomer, 435 
Argyrosomus, 280- -1

artedi, 233-3\%, 241

hoyi, $235-37,237.241$

osmeliformis, 230-:3:, 241

prognathus, $237-38,-241$

tullibee, 238-41

Algrotaenia vittata, 376

Arius equestris, is

felis, is

wilberti, is

Aspidophorojles, $194-49$

monopterygius, 64S-49

Aspidophorus monopterygius, G4S

Asterospondyli, 17-43

Astroscopus, 658-60

anoplus, 65s

guttatus, 658-60

Atherina brownii, 214

menidia, 35T

mordax, 2\&:

notata, $35 \bar{T}$

vilidescens, 357

Atherinichtluys gracilis, 35

meniclia, 357

notata, 357

A therinidae, 354-62

Atherinopsis notatus, 3.56

Atlantic salmon, 244-4S

Autumnal herring. 197

Auxis, 383-85

lochei, $3 s t$

thazard, 3S4-S5

vulgaris, $38 \pm$

Aya, 9, 豞

Bachelor, 460

Bachforelle, 255

Baione fontinalis, 272

Bairdiella, 576-7s chrysura, $576-78$

Bait-stealer, 595

Balaos, 32:-27

Balistes, 60S-11 aurantiacus. 613 broceus, 611 capriscus, 605 carolinensis, 60S-10 cuspicauda, 613 fuliginosus, 608 hispidus, 611
Balistes (routimucd)

schoepfii, 613

retula, $610-11$

Balistidae, fos-11

Balloonfish, spot-striped, 628

unspotted, 6:25-29

Banana fish, 15?-83

Banded anchory, 217-1s

Banded blenuy, fit4-65

Banded dace, 146

Banderl drum, 589

Banded Ephippus, 608

Banded garfish, 315

Banded guruard, 680

Banded larimus, 5 .

Bauded mummichog, 309

Banded pickerel, 292-94

Bamded pilot, 415

Banded rudder fish, 414-16, 425-24

Banded sucker, 104

Banded sunfish, 471-73

Bauk lake bass, 462

Barfish, 463

Barudoor sliate, 50-51

Barracuda, :36S-73

lollg, 369-70

northern, :371-73

Barred killifish, 311, 312

Barred maskalonge, 304-7

Basking shark, 41-43

Bass, bank lake, 462

bayou, 491

big. $45 T$

big-fin. 462

black, 587

brown, 4ST

calico, 462-64

channel, jis-so

dark, tsi

gold. 4 st

grass, 460,463

green, 491

hos, 485

lake, $462,468.487$

Lake Erie, 462,463

large-mouthed black. $490-93$

little, 4ss

minny, 45T

moss, 491

Oswego, 491, 492 
Bass (contiumed)

Otsego, 225

liver, 491

rock, $46 \bar{\tau}-70, \overline{3} \mathbf{\tau}$

ruddy, 529

sea, 522-42

silver, $185,462,523$

small mouthed black, $456-90$

spotted, $4 S T, \check{5} \mathrm{SO}$

stone, 532

stramberry, 462-64

streaked, 525๊

striped, 523, 524-2

striped sea, 525

white, 522-23

rellow, 4 si

Bass fry, 309

Bass killy, 307-9

Bass mummy, 309

Bass sunfish, 466

Basse, striped, ว25

Bat fishes, 737-38

Batoidei, 46-60

Batrachoididae, 660-6;2

Batrachus celatus, 661 tau, 661

Bayou bass, 491

Bellows fish, 734-35

Belone caribbaea, 322

crassa, 319

gerania, 319

jonesi, 322

latimana, 322

melanoclirira, 319

l'alphidoma, 319

truncata. 317

Bengal, 595

Bergall, 593-96

spotted, 596

Bermuda chub, 56S-69

Bermuda whiting, 5st;

Berycoidei, 37т-79

Bessy corka, 610-11

Bigere, 54t-45

short, $546-47$

Big-eyed herring, 199

Big-ered scad, 426-27

Big-fin bass, 462

Big-mouthed cat, $S 6$

Billed eel, 31S, 348
Billfish, 61, 70- $72,317-19,349,405-\vec{\imath}$

Bitter Lead, 463

Black bass, 537

large-mouthed, 490-93

small-mouthed, $486-99$

Black bullhead, 90

Black croppie, 463

Black drum, $5 \$ 9$

Black grunt, $5 \pm 3$

Black lamprey, small, 16-17

Black mullet, $5 \$ 6$

Black-nosed dace, 5, 154-ร6

Black-nosed sucker, $10 \mathrm{~S}$

Black perch, 4SS, 529, 53T

Black pilot, 45 $4-55$

Black pollack, 694

Black salmon, 267

Black sea bass, 537

Black-sided darter, $50 \overline{\mathbf{\tau}}-9$

Black sucker, 104

Black $\pi$ ill, $53 \pi$

Blackfin whitefish, 228

Blackfish, 536-39, 597-99

Blackharry, 53 ๘

Blackhead minnow, 11S-13

Blennies, 662-65

banded, 664-65

eel, 670-71

seaweed, 663-64

snake, 671

spotted, 66S-69

Blemniidae, 662-65

Blennioidei, 662-74

Blennius, 602-6t

anguillaris, $67 t$

bosquianus, $66 \pm$

chuss, 707

ciliatus, 674 .

fucorum, 663-6t

gunnellus, 665

labiosus, 674

lampetraeformis, 670

oceanicus. 663

pholis, 664

punctatus, $66 \mathrm{~S}$

regius, 704

selpentiuus, 670

Blenny darter, 50s

Blennylike fishes, 662-7t

Blepluarichthys crinitus, 432 
Blepharis crinitus, 432

Bloater. 237-35

Blob, 695-37

Bloody stickleharek, $3+3$

Blower, 621

Blomfish, 6:-24 hairy, 624 .

Blue bream, 4S2

Blue cat, so sreat, $\$ 2$

Blue darter, 517-18

Blue herring, 195-96

Blue Johnny, 518

Blue perch, 595

Blue pike, 303, 494, 497

Blue shark, 39 great, 25

Blue snapper, 446

Blue-spotted sunfish, 473-75, 47T

Blue-striped trigger fish, (i10-11

Blue sunfish, 450-52

Blueback, 202-3

Bluefin, 22S

Bluefish, 445-4S, 537, 571, 595

Bluegill, 4S0-S2

Blunt jaw, 117

Blunt-nosed minnow, 120-21

Blunt-nosed shiner, 434

Bodianus argsroleucus, 576

aรa, 554

bistrispinus, 541

costatus, 583

flarescens, 500

rufus, 528

rupestris, 467

triurus, 542

Boleichthrs, 520-21

eos, 521

fusiformis, $520-21$ eos, 521

Boleosoma, 513-16

fusiformis, 520

maculatum, $\mathbf{5 1 3}$

nigrum, 513-14

olmstedi, 514-16

olmstedi, 514

tesselatum, 509, 514

Bone fish, 182-83

Bone shark, 43
Bonito, 393-95

oceanic. 3S6-SS

Eounet skate, 48

Bonnethead, 30-31

Bony fishes, $76-212$

Bony gar, 71

Bouy pilie, 71

Bony-scaled pike, 6

Bony sturgeon, 66

Bothrolaemus, 439

pampanus, 443

Bothus, 723

maculatus, 723

Borfins, $73-76$

Boxfish, spiny, 626-2S

Brail, 719

Branch herring. 199-201

Branded drum, 580

Brassy sculpin, 689-41

Brazen bullhead, 640

Bream, 133, 4S4

blue, 482

copper-nosed, 4S2

salt $\pi$ ater, 562

Breroortia, 211-13

tyramnus, 211-13

Bridge perch, 460,457

Bridled minnow, 135-36

Brier ray, 49-50

Bristly dory, 434

Broad shiner, crsptous, 45s

Brochet. 299

Bronze backer, 485

Brook lamprey, 16

Brook minuow, 154-56

Brook silversides, 301-62

Brook stickleback, 33.j-37

Brook sucker, 101

Brook trout, 6, 255, 272-75

Erosme, 711-12

brosme, 711-12

Brosmins brosme, 711 flarescens, 711 rulgaris? 711

Brotula. 676

Brown bass, 4 s

Brown catfisl, 90

Brown tomeor, 696

Bromu trout, 25t-5i, 4s 
Bryttus fasciatus, 471

sloriosus, 473

louguhus, 475

Buffalo fish, 71

Bugfish, 212

Bullhead, s7-89, 636, 642

Acadian, 646

black, 90

brazen, G10

smooth browed, 610

Bulhead shark, little, 46

Bullpout, 87

Bumper, 437-3S

Bunkel, 212

Burbot, 701-4

Burfish. 620-29

Bul'n stickle, 841

Butirinus vulpes, 182

Butter chub. 163

Butterfish, 444, 457-59, 605-66 humplbacked, 434

Butterfly fishes, bot-6, 67S

Buttertiy ras, 56-5

Calico bass, 462-64

Calico flounder, 733

Calico sole. 732

Calliurus formosus, 475

longulus. 475

Campbellite. 460

Campostoma, 112-14

anomalum. 113-14

dubitum, 113

Cantharus nigromaculatus, 462

Canelin. 350

Capriscus. 60S-10

Carangidae, $410-44$

Carangus hippos, 425

Caranx, 427-31

carangus, 428

chrysos, 430

chrysus, 430

crumenoplithalmus. 426

crysos, 430-31

defensor, 428

hippos, 428-29

hippus, 428

macarellus, 423

pisquetus, 430

munctatus, 421
Caranx (contimued)

spotted, 422

sutol, 432

trachurus, 425

yellow, 429

Carassius, 161-66

auratus, 161-66

Carcharias, $34-37$

americanns, 34

atwoodi, 40

caeruleus, 26

glaucus, 25

(Prionodon) glancus, 25

isorlon, 2s

(Aprionodon) isodon, 25

littolalis, 34-37

(Prinnodon) milberti, 26

obscurus. 25

(Prionodon) obscurus, 25

puuctatus. 2S

tel'ae-novae, 29

(Scoliorlon) terrae-noтae, 29

vulpes. 83

Carcharidae, 34-37

Carcliarinms, ‥-25

glancus, 2.

millerti, 26-2s

obseurus, 2.-26

Carcharodon, 40-41

car'(harias, 40-41

Cardonniera. 684

Carp, 112-69

golden, 165

lake, 98

leather, 168

mirror, 167

scale, $10 \pi$

Carpe blanche, 101

Carpiodes. 97-9s

thompsoni, 9s

Carplike fishes, 97-169

Casalue. 437-38

Catalufas, $\overline{7}+4-\tau$

Catfishes, $76-97$

big-mouthed, S6

blue, $S 0$

blown, 90

channel, 80-\$1, 85-86

chubluy. $S t$

common, st 
Catfishes (contimued)

Hamel-moutl, S2

Florida, s2

great blue, 82

great forli-tailed, s?

lake. \&1-\$3

long-jamed. S4-S5

marlylerl. s9

Mississippi, S2

mud. S?

Sehuylkill. 86

sea, $7 \bar{i}-78,7 \mathrm{~s}-79$

silver, 80

spoonbill, 61-63

spotterl, so-s1

stone eat. 01-92, 03-94

white, so, $55-56$

yellow, $8 t$

Catonotus fasciatus, is

Habellatus, 5is

Catostomidae. 97-112

Catostomus, 99-10t

anisulus, 109

aureolus. 110

carpio. 109

catostomus. 99-101

commersoni, 101

commersonii, 101-3

communis, 101

crprinus, 9s

duquesnii, 110

faseiatus, $10 \mathrm{~S}$

hudsonius. 99

longirostris, 99

melanops, $10 \mathrm{~s}$

nanomyzon. 99

nị̂licaus, 103-1

oneida. 110

pallidus, 101

sucetta. 105

teres. 101

tubereulatus, 105

Caralla. $t 01$

Cayuga lake sluad, 200

Cayuga lake sticklebaclis. 397

Centrarohlue, 459-93

Centrarchus aeneus, 467

sulosus, 470

hexacanthus, 462

pomotis, 464

Firidis, 470
Centrolophidae. 454-55

Centronotus gunnellus, (i6.)

spinosus. 449

Centropristes, 585-39

atrarius, 5:3;

niglieans. .ist;

striatus. $536-39$

Cephalacanthidae, 653-85

Cephalaeanthus, 683-55

spinarella. $6 S t$

volitans. 6st-85

Cephalus brevis, 129

Celatacanthus. 613-15

Ceratichthys biguttatus, 159

cataractac. 152

dissimilis, 157

lucens, 1 .is

micropogon. 1 .

plumbeus. 161

prosthemius. 161

Cernier. 5is?

Cero, 398-40я

spotted. 400

Cetorhinidae, 41-48

Cetorhinus, 41-43

maximus, $42-43$

Chaenolirytus. 470-i 1

antistius, $4 \pi 0$

gulosus. 470-71

Chaetodipterus, 601-1

faber, 602-4

Chaetodon, ant-6;

alepirlotus, 4.56

bimaculatus, 604

faber. 6o:

maenlocinctus. 605

ocellatus, 604-6

oviformis, 602

sheepsluead, 603

Chaetodontirae, 604-6

Chatodontops, 604-6

Chain pickerel. 6, 296-98

Channel bass. 5is-So

Cliannel cat, sn-s1, $55-86$

Chasmodes, 664-6.5

boscianus. 6rit

bosquianus, 664-65

Chatoëssus eepedianus, 157 elliptieus, 1Si

signifer, 209 
Checouts. 571

Cheilichthys, 622-24

Chelidonichthys, 682-83

Chickwick, 5i]

Chilomycter'us, 626-29

fuliginosus, 62S-29

geometricus, 626,629

subsp. (?) fuliginosus, 628

schoepfi, 62628

Chinook salmon, 241-44

Chinquapin perch, 460,463

Chironectes laevigatus, 736

Chirostoma beryllinum, 356

notatum, 357

sicculum, 361

ragrans, 359

Chivey, 221

Chivin, 122-23

chloroscombrus, 436-38

caribbaeus, 437

chrysurus, 437-38

Chog-mummy, 310

Chogset, 593-96

Chondrostei, 63-69

Chonerhinidae, 618

Chorinemus occidentalis, 410

Chrosomus, 114-16 errthrogaster, 114-16

Chub, 123-26, 163, 491, 582, 598

Bermuda, 568-69

butter, 163

das, 163

horned, 159-60

Indian, 160

lake, 161-62

nigger, 160, 162-64

river, 159-60

salt-water, $59 \mathrm{~S}$

silver, 122-23

Chub eel, 702

Chub mackerel, 351-83

Chub sucker, 105- $\bar{\imath}$

northern, 106

Chubby cat, st

Cichla aenea, 467

Cigar fish, 2ST

Ciliata argentata, 708

Circharra, 427

Cirrimens, 5S4
Cisco, 180, 233-35, 241

mooneye, 235-37

Citharichthys, 724 microstomus, 725

Clear-nosed skate, 49-50

Clinostomus, 125-29 margarita, 130

Clinus punctatus, 668

Cliola analostana, 144 hudsonia, 140 procne, 139 storeriana, 142, 158 whipplei, 144

Clupea, 192-94 aestivalis, 202 alosa, 204 chrysochloris, 195 coerulea, 192 cranonoton, 9 elongata, 192 halec, 192 harengus, 192-94 heterurus, 157 hudsonia, 140 mattowaca, 197 mediocris, 197 menhadeu, 211 pseudoharengus, 199 pusilla, 192 sadina, 190-91 sapidissima, 204 tyrannus, 211 rernalis, 199 rirescens, 197 vittata, 214

Clupeidae, 1SS-219

Coachman, $539-40$

Coalfish, 694

Cobbler, 310

Cobblerfislı, 432-33

Cobia, 449-50

Cobitis heteroclita, 309 majalis, 307

Cock-paddle, 651

Cod, 695-99 American, 699 common, 699 fresh-water, 702 rock, 699

Codfishes, 693-712 
Codling, 706, 707 Imerican, Tor; spotted, 704-5

Coelocephalus, 712

Coelorhynchus, 712-14 carminatus, $713-14$

Conger eels, 1it-iт

Conger niger, 175 occidentalis, 175 vulgaris, 175

Copelandia, 471

Copeland's darter, 509-10

Copper-nosed bream, 482

rolegonus, 220-30

albus, 224

artedi, 233

clupeitormis, $224-30,233,-240$

liarengus, 233

hoyi, 230,236

labradoricus, 9,224

latior, 221

novae angliae, 221

osmeriformis, 230

prognathus, 237

quadrilateralis, 221-24, 240

satpirlissimus, 224

tullibee, 239

Colnet fishes, 344-46

Corvina argyrolenca, 576

ocellata, $57 \mathrm{~s}$

oseula, 590

Coryphaena, $450-54$

equisetis, 452-5t

globiceps, 451

hippuris, 451

hippurus, 451-5:

perciformis, 454

punctulata, 452

sueuri, 451

steurii, t51

Coryphaenidae, 450-5t

Cottidae, 635-47

Cottinae, $635-47$

Cottogaster, 509-11

cheneyi, 510-11

copelandi, 509-10

putnami, 509, 510

Cottus, 635-87

aeneus, 639

(Acanthocottus) anceps, 639
Cottus (rontiuner)

Bairllii, 65.

formosus, 638

gracilis, 637

groenlandicus, tit?

hispidus, 646

ictalops, 63.5-3i

bairdi, 636 .

mitchilli, 639

monopterygius, 648

octodecimspinosus, $6+1$

Richardsoni, 68.

scolpio, 639

scorpius groenlandicus, 648

virginianus, 641

Couchia argentata, 70s

Couesius, 160-62

dissimilis, 161

plumbens, 161-62

prosthemius, 161

Cover, 732

Cover clip, 732

Cow-nosed ray, 59-60

Crab-eater, 449-50

Cramp fish, 51-52

Cranberry, mountain, 85

Craniomi, 676-55

Crappie, t59-(i2

Crawl-a-bottom, 104, 505

Creek club, 125

Creek fish, 106-T

Crevalles, 410-4t

Cristivomer, 266-71

namaycush, 266-71

Croaker's, 569-92

Crocus, 591

Croppie, black, 463

lake, 463

timber, 460

white, 460

Clyptacanthodes, 6i71-72 maculatus, 6r1- -2

Cryptacanthodiclae, 671-72

Crsptous broad shiner, $45 \mathrm{~S}$

Ctenolabrus, 593

adsper'sus, 593

hurgall, 593

ceruleus, 593

chogset, 593

uninotatus, 593 
Cuckold, 616-17

Cuckoo fish, 678

Cucumberfish, c26-28

Cunner, 593-96

Cusk, 711-12

lake, 702

little, 676

Cut-lips, 162-64

Cutlas fishes, 402-3

Crbium caballa, $4(0)$

caralla, 400

maculatum, 396

regale, 398

Crclichthys, 626-29

Cycloganoidea, 73-76

Crclopteridae, 649-52

Cyclopterinae, 649-52

Cyclopterus, 649-52 coeruleus, 649

liparis. 654

lumpus, 619-5๊

Cyclospondyli, $43-16$

Cylindrosteus, 72

Crnoperca, 498-99

Crnoscion, 569-74

maculatum, 573

nebulosus, 573-74

regale, 570

regalis, 570-73

Cyprinella whipplii, 143

Cyprinidae, 112-69

Cyprinodon, 315-17

parrus, 314

variegatus, $315-17$

Cyprinus, 166-69

atromaculatus, 123

atronasus, 154

auratus, 164

bullaris, 122

carpio, 167-69

catostomus, 99

commersonnii, 101

cornutus, 145

corporalis, 122

crysoleucas, 132

heminlus, 132

idus, 131

maxillingua, 162

megalops, 145

oblongus, 106
Cyprinus (continued)

(Abramis?) Smithii, 184

sucetta, 105

teres, 101

tinca, 126

vittatus, 154

Cypselurus, 331-35

furcatus, 333

Dab, rusty, 727

saud, $717,726-27$

Dace, 122-23, $1 \pm \mathrm{C}$

banded, 146

black-nosed, 5, 15t-56

horned, 123-26, 160

long-nosed, 152-54

mud, $28 s$

red-bellied, 114-10

Dactylopterus volitans, cst

Daddy sculpin, 612-44

Dark bass, 487

Darter, black-sided, 507-9

blenuy, 508

blue, 517-1S

Copeland's, 509-10

fantail, 518-20

greensided, 512-13

Johnny, 513-14

manitou, 506-7

rainbow, 517-18

tessellated, 514-16

Dasibatis lustata, 54

Dasibatus centrura, 53

Dasyatidae, 53-57

Dasyatis, 53-56

centrura, 53-54

hastata, 54-55

say, 55-56

Dasybatis sayi, $5 \overline{5}$

Day chub, 163

Daylight, 724

Decapterus, 420-24

macarellus, 423-24

punctatus, 421-22

Deep water sculpin, 646

Diodon carinatus, 629

fuliginosus, 62S

hairy, 625

hystrix, 626

maculostriatus, 626 
Diodon (continuch)

nigrolineatus, 626

pilosus, 625

lirulatus, 626

schoepfi, 626

Diodontidae, 624-29

Diplesion. 511-13

blennioides, 512-13

Diplodus argyrops, 558 probatocephalus, 563 1'homboides, 561

Dipterodon chrysurus, 576

Discocephali, 686-90

Distribution of New York fishes, 739- 16

Doctor fish, 607

Dog shark, 23

Dogfishes, 43-45, 75, 2SS-89, 702 horned, 44 smooth, 23 spined, $43-45$

Doliodon, 439

Dollardee, 482

I)ollarfish, 434, 458

volphin, 450-54 common, 451-52 small, 452-54

Doré, 495

Dorosoma, 1S6-88 cepedianum, 187-88 notata, 1S7

1)orosomidae, 186-88

Dory, bristly, 434 hair-finmed, 436 rostrated, 436 spinous, 439

Iotted scad, 422

Irum, 9S, 5S7-90, 591

bauded, 589

big, 589

black, 589

fresh-water, 590-92

red, 589

young, 589

1)rummer, 571

Duck-billed cat, 61

Dules, 539-40

auriga, 539-40

1) usky shark, 25-26

Jwarf salmon, 246
Eagle rays, 57-60

Listern pickerel, 297

Ficaille, grande, 177-79

Echeneididae, 686-90

Echeneis, 656-SS

albacauda, 686

albicauda, 656

brachyptera, 689

lolbrooki, 687

naucrateoides, 6S7-SS

naucrates, 656-ST

neucrates, 686

osteochir, 690

quatuordecimlaminatus, 689

remora, $6 s 8$

Lel blenny, 670-71

Eelpouts, 674, 702

Eels, 169-77

billed, 318,348

chub, 702

conger, 174-77

lamprey, 11-13, 67

rock, 665-71

sand, $376-77$

sea, $175-77$

true, 169-74

E'ggfish, 621

Elacate atlantica, 449

Canada, 449

nigra, 449

Elagatis, 418-20

bipinnulatus, 419-20

pinnulatus, 419

Electric ray, 51-52

Elephant shark, 42-43

Ellwhop, 199

Ellwife, 199

Elopidae, 177-S0

Elops, 179-80

inermis, 179

saurus, 179-80

Emerald mimnow, $147-49$

Emphycus, 705-S

Enchelycephali, 169-77

Enchelyopus, 710-11 cimbrius, $710-11$

Engraulididae, 213-19

Engraulis argyrophanus, 216 brownii, 214

mitchilli, 218 
Engraulis (contimurd) perfasciatus, 217

vittata, 214

vittatus, 219

Enneacanthus, 471-75

eriarchus, 473

gloriosus, 473-75

obesus, 471-73

simulans, 478

Ephippidae, (un1-t

Ephippus, 60:

banded, 603

faber, 602

gigas, 602

Epinephelus, 533-85

niveatus, 533-35

Erimystax, 157-58

Erimyzon, 104-7

goodei, 105

sucetta, 105-6

oblongus, 1067

Esocidae, 317-23

Esox aftinis, 296

americanus, 292

boreus, 299

crassus, 294

cypho, 294

estor, 299

fasciatus, 292

flavulus, 307

immaculatus, 304

longirostris, 317

lucius, 5,298

$\beta$ americanus, 292

marinus, 317

masquinougy, 302

immaculatus, 304

niger. 292

nobilior, 302

osseus, 6, 70

ovinus, 316

phalelatus, 296

pisciculus, 309

pisculentus. 309

porosus, 294

raveneli, 292

reticulatus, 296

salmoneus, 296, 294

saurus, 327

scomberius, 292
Esox (continned)

tridecemlineatus, 296;

umbrosus, 291

reluniculatus, 294

rulpes, 182

zonatus, $30 t$

Etheostomia, 516-20)

aspro, 507

blemnioides, 512

(Diplesion) blenniofles, 512

caprodes, 505

coerulea, 517

coeruleum, 417-18

flabellare, 518-20 •

flabellaris, 518

fusiforme, 520

linsleyi, 518

nigrum, 513

olmstedi, 514

olmstedi, 514

Etropus, 724-26

microstomus, 725-26

Etrunleus, 189-91

sadina, 8,189

teres, 189-91

Eucalia, 335-37

inconstans, $333-34,336$

cayuga, 337

Eucinostomus, 5(55-67

argenteus, 566

gula, 566-67

Eugomphodus littoralis, $3 t$

Eulamia milberti, 26

Euleptorlumphus, 325-27

longirostris, 326

velox, $326-27$

Eumesogrammus subbifureatus, 6ti

Eupomotis, 482-86

aurens, 483

gibbosus, 483-S6

Euthynnus alliteratus, 389

pelamys, 386

Eventognatlii, 97-169

Exocoetidae, 330-35

Exocoetus, 330-35

aftinis, 330

comatus. 392

exilieus, 830

fureatus, $393,335-37$

gibbif rons, $334-35$ 
Exacoctus (contiuned)

leterurus, 331-32

melanurus, 330

noveboracensis, 332

unttalli, 333

lubescens, 330

volitans, 330-31

Exoglossum. 102-64

:Innulatum, 162

(lubium, 113

(Hypentelium) macroptel'nm, 10 s maxillingua, 16-64

nigrescens, 162

rittatum, 102

Fairmaid, ing aio

Fall herring, 197-!s

Fall sharl. 197

Fallfisli, 122020

smaller, 125

loumegal, 634

Fintail elarter, 5is-20

Fantail mullet. 367-68

Fario sairtneri, 252 lemanus, 264

Fatback, 301

Fathead, 118-19

Fithear mimom, 118

Ferleration pilie, 297

Felichthys. 76-7s marinus, TT-Ts

Fiddlefish, 46:

Filefisls. 611-15 orange, 113-15

Fishing flogs, 73:-8.

Fistularia, $344+6$ neoboracensis, 34 serrata, 345

tabacar’a, $345-46$

Fistnlariflae, $344-46$

Flannel-month cat, S2

Flasher, $342-43$

Flatfish, $714-33$

rusty. T:-

toothed. $T 19$

Floricla calt, $s^{2}$

Flomulers, 714-31

calico, 733

fourspotted, 721-22

oblong, 721
Filominders (rontinned)

rusty, 717

Sand. 724, 730-31

small-monthed, 72-i-26

souther'1, 720-21

spotted, 731

summer, $717-20$

turbot. 719

watery, T24

winter, $72--29$

Niuke, 719

Flyiug fisles. 330-35. 678, 680

Flying gumards, fos?-S.

Flying robin, 6St-S5

Fork-tailed cat, S2

Four-bearded rockling. $710-11$

Fourspotted flounder, 721-22.

lrresh-water cod, 702

"lesh-water" drum, 5:90-92

Fresh-water kills, 311-13

"resl1-water salmon, 246

Fresh-watel silversides, 3.6-5

Friar. 3.T-50

Frigate mackerel, 3St-S.5

Frost fish, 221-24, 240, 692. 695-97

Fumdulus, 307-13

diaphanus, 311-13

fasciatus. $30 T$

fuscus. 289

heteroclitus, 309-11

macrolepidotus, 309

majalis, $30 \bar{T}-9$

multifasciatus, 311

pisculeutus, 309

swampina, 311

viridescens, 309

zebra, :09

Gadidae, 676. 69:-712

Gadus, $697-99$

aeglefinus. 699

albidus, 691

arenosus, 698

hrosme. 711

callarials, 695

rimbrius, 710

rompressus. 701

lacustris, S1, T01

longipes, 707

maculosus, 701 
Gadus (continned)

merlucius, 691

morhua, 698

morrhua, 698-99

pruinosus, 695

punctatus, 704

purpureus, 693

rupestris, 695

tau, 661

tenuis, 705

tomeod, 695

tomcodus, 695

virens, 693

Gaff topsail, $7 \tau-\tau \mathrm{S}$

Gaidropsarus, 708-10

argentatus, 70S-9

ensis, 709-10

Gairdner's trout, 252-54

Galeiclithys felis, 78 marinus, 77

Galeidae, 22-30

Galeocerdo, 23-24 tigrinus, 24

Ganoid fishes, 60-76

Ganoidei, 60-76

Gar, alligator, 71 bony, 71

short-nosed, $72-73$

silver, 317-19

soft, 318

Gar pikes, 69-73

Garfisin, banded, 318

Gascon, 425-26

Gaspagie, 591

Gaspereau, 200

Gaspergou, 591

Gasterosteidae, 335-44

Gasterosteus, 340-42 aculeatus, 340

biaculeatus, 340

bispinosus, $340-42$

cauadus, 449

carolinus, 443

cataphractus, 341

concinnus, 338

ductor, 412

inconstans, 335

millepunctatus, 342

nebulosus, 338

neoboracensis, 340
Gasterosteus (continued). occidentalis, 338 pungitius, 338 quadracus, 342 saltatrix, 445

Gerres argenteus, 566 gula, 566

Gerridae, 565-67

Ghostfish, 671-72

Gizzard shads, 186-SS

Glasseye, 494

Glassfish, 361-62

Globefish, 622-24

Glossodon harengoides, isf

Glut herring, 9, 202-3

Goatfish, 377-79

Gobies, 656-58

naked, 656-58

variegated, 657

Gobiidae, 650-5s

Gobiinae, 656-5s

Gobio cataractae, 152 plumbeus, 161.

Gobioidei, 656-5s

Gobiosoma, 656-5s alepidotum, 656

bosci, 656-58

Gobius alepidotus, 656

bosei, 656

viridi-pallidus, 657

rividipallidus, 656

Goggle-eye, 460, 463, 46S, 471-7I

Goggle-eje perch, 463

Goggle-ejed jack, 427

Goggler, 426-27

Gold bass, 487

Gold nerfling, 131

Gold shad, 195-96

Golden carp, 165

Golden ide, 131-32

Golden mullet, 111

Golden red horse, 111

Golden shiner, 182-31

Goldeu sucker, 111

Golden trout, 27S-8'.

Goldfish, 164-60;

Goody, 582

Goosefish, 734-35

Grand-oranchee, 516

Grass bass, 462,463 
Grass pike, 300,494

Gray-back, 200

Gray pike, 498, 499

Gray snapper, $5+8-50$

Gray sucker, 101

Gray trout, $26 \pi$

Grayling, 246

Greenback, 198

Green-backed shark, 30

Green bass, 491

Green pilie, 296-9S, 494, 49s

Green pollack, 694

Green-sided darter, 512-13

Green sunfish, 475-77

Greenfish, 446

Greenhead, 525

Grenadier's, 712-14

Grey trout, 571

Grilse, 246

Grindle, 75

Ground shark, 35

Grouper, snowy, 533-35

spotted, 533-35

Growler, 487

Grubber, 183

Grubby, 639-41

Grunt, 589

thornbacked, 444

Grunters, 555-57, 589, 678, 680

Guardfish, 319-21

Gudgeon, 142-43

New York, 309

Niagara, 152-54

Gunnellus mucronatus, 665

punctatus, $66 \mathrm{~S}$

Gurnard, 676-S3

banded, 680

common, 67s

flying, 683-85

red, 65?-83

Gymnodontes, 617-31

(ismnosarda, 385-90

alleterata, $388-90$

pelamis, 386

pelamys, 386-ss

Hacklehead, 641-42

Iradlock, 699-700

Norway, 631-33
Hadropterus, $507-9$

aspro, รกד-9

Maemulidae, 5.5-ラ

Haemulon fulvomaculatum, 5.56

Hair-finned argyreiose, 436;

Hail'-finned dory, 436

Hairtail, 402-?

Hairy back, 188

Hairy blowfish, 624

Hairy diodon, 625

Hairy poreupine fisl1, 1925-26

Hake, 586, 692, 705-

American. 692

silver, 691-93

spotted, 704-5

squirrel, 706, 707-S

white, 705-7

Halatractus zonatus. 414

Half-gills, 335- 46

Halfbeak, 324-25

slender, 326-27

Halibut, $71+-15$

Hammerlead, 104

Hammerheaded shark, 30-82

Hanna hills, 537

Haploidonotus grunniens, 590

Haplomi, 287-317

Harvestfishes, 455-59

short-finned, $45 \mathrm{~s}$

Headfishes, 629-31

Hecht, 299

Hedgehog ray. 47-48

Helicolenus, 633-35

dactylopterus, 634-35

Hemdurgon, 633

Hemibranchii, 335-46

Hemioplites, 471

simulans, $4 \pi 3$

Ifemirhamphidae, 323-27

Hemirhamphus longirostris, 326

(Euleptorhamphus) longirostris, 326

macrorhychus, 326

roberti, 324

unifasciatus, 324

Hemitremia bifrenata, 1.5 heterodon, 137

Hemitripterus, 645-1

acadianus, $6+6$

americanus, $646-47$ 
Hen-padale, fist

Herring, 1s8-219, 241

autumnae, 197

big-cyed, 17!)-80, 199

blue, $195-96$

brauch, 199-201

fall, 197-98

glut, 9, 202-3

lake, 293-35, 241

Long Island, 1!T

river, 199

round, S, 189-91

satin striped, 215

sea, 192-94

shad, 197-98, 203, 209-11

sprat, 209-11

spring, 199

Staten Island, 197

summer, 203

tluread, 1S8, 209-11

tootlied, 184-85

wall-eyed. 199-200

Heterosomata, $714-33$

Hexamematichtbys, 7 S- 79

felis, $78-79$

Hickory shat, 9, 1SS, 197-9s

Hicks, 198

Hiodon, 183-86

chrysopsis, 185

clodalus, $18 t$

tergisus, 18t-85

Hiodontidae, 183-S6

Hippocampinae, 349-51

Hippocampus, :319-ร1

heptagonns, 350

hudsonius, 34 ! -51

II ippoglossoides, 715-17

dentatus, 716

elassodon, 715

platessoides, T16i-17

Hippoglossus, 714-15

lippogiossus, 714-1j

vulgaris, 714

Hippos mackerel, 422

IIistiophorus americanus, 104 belone, 406

I 0 g bass, 4 SS

II $0 \mathrm{~g}$ mullet, 104

Hog sucker, 103-4

Hogchoker, 732-3.3
Hogfish, 505, 556-57

Hogmolly, 104, 505-6

Holocentrus surimamensis, 512

Hololepis fusiformis, 520

Homoprion xanthurus, 5i6

Hormed chub, 159-60

Horned dace, 123-26, 160

Horned dogfish, 44

Horned pout, S7-\$9

Hornfisl, 495

Hor'ny head, 160

Hors, 4.5

Horse mackercl, 391-93, 446

Iorsefish, 349-51, 433-34, 4!)

Houndfish, 23, 319-21, 322-23

Hoy's whitefish, 241

Iudsonius amarus, 142

Humpbacked butterfish, 1.24

If uro nigricans, 490

Hybognathus, 116-1s

nuchalis, 116-1S

osmerinus, 116

plocne, 139

regius, 116

IIybopsis, 156-60

bifrenatus, 135

dissimilis, 157--.s

heterodon, 137

hudsonius, 140

kentuckiensis, 159-60

procne, 139

storerianus, 142, 158-59

Hyborhynchus notatus, 120

Iybrid trout, ד, 25т-59

Hydrargila atricauda, 285

diaphana, 311

fusca, 2ss

linil, 285

mult ifasciata, 311

Hydrargyra fusca, 2ss

majalis, $30 \tau$

swampina, 311

Hyodon alosoides, 185-86

ampliodon, 185

claudalus, 184

clodalis, 184, 185

Hypentelium macropterum. sec

- Wxoglossum (Iypentelium) nacropterum

Hyperoartii, 11-17 
Hrporhamphus, 323-25 roberti, 324-25

Hrporthodus flaricauda. 533

Hypsilepis cornutus, 145 gibbus, 147

(liplaemia, 151

kentuckiensis, 14

IIypsoblennius, 6rit

Hrisolepis frontalis, 147

Ice fisl, 282-85

Ichthyomyzon, 14-15

argentens, 15

concolor, 14-15

Ictalurus, 79-81

albidus, 85

lacustris, 81

lophins, se

nigricans, $S 1$

punctatus, S0-S1

Ide, golden, 131-32

Itus. 131-32

idus, 131-32

melanotus, 131

Indian chub, 160

Indian remora, 68T

$1110 \mathrm{mi}, 285-57$

Irish roach, 134

Isospondyli, 17\%, 2.5

Isospondylous fishes, 17T-285

Istiophoridae, 403-7

Istiophorus, 403-5

nigricans, 404-5

Istropsis dekari, 3s

Ismlus, 37-39

dekayi, $38-39$

Jack, 297, 299, 495

gogale-eyed, $42 \pi$

salt-twater, 446

Jack salmon, 495

. Terny, silver, 566-6i

Jerker, 160

Jewel head, 591

.Toln-a-grindle. 75

John demon, 460

Juhn dories, 600-1

Johnius ocellatus, 57s

regalis, 570

saxatilis, 585
Johnny, lulue, jis

Johnny darter, 51:3-14

Jorobado, 434

Ingular fislies, 691-714

. 11m]ег, tSS, t91, t92

.Jumping mullet, 3fit

Kenoza, $292 \mathrm{Z}$

Killifishes, :307-17

barred. 311,312

big, 311

sheepshear, 317

striped, 309

white-bellied, 311

yellow-hellierl, 311

Killy, bass, 307-?

flesh-water, 311-13

King, silver. 177-79

King salmou, 241-4t

Kingfish, 400-1. - is5-8т

Kingston, $4 \mathrm{i}$

Kiouk, 203

Isirtlandia, 359-61

laciniata, 9, 360

vagraus. 9, 3-19-61

Kit, 54-5.5

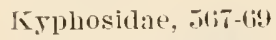

Kyphosus, mit-(is)

sectatrix, ins-(i?)

Ia quesche, 18.7-86

I abeo elegans, 100 esopus, 10.

gibbosus, $10 . ;$

oblougus, 106

I alotilesthes, 361-1;2 sieculus, 361-ti2

Labratlor whitefislı. 9, 22-4-30

Iabrax albirlus, i2:-

lineatus, 524

nigricans, ,os

notatus, , ipez

pallidus, izs

lufus, ios

Isabridate. $598-1000$

Labroid fishes, .703-(301

Labrus adspersus, .79:3

appendix, 4 is

amitus, 478

clogset, .993 
Labrus ("ontiuned)

fulva, 593

cromis, $55 \pi$

falcatus, 439

fulvomaculatus, 556

griseus, 548

grumuiens, 588

onitis, 597

pallidus, 480

salmoides, 490

sparoides, 462

squeteague, 570

var. maculatus, 573

striatus, 536

tantoga, 597

versicolor, 558

Lactophrys, 615-17

trigonus, 616-17

yalei, 616

Ladyfishes, 181-83

Lafa jette, 458, 57т, 580-83

Lagocephalus, 617-19

laevigatus, 618-19

lagocephalus, 615

Lagodon, 561-62

rhomboides, 561-62

Lake bass, 462, 468,487

Lake blob, 638

Lake carp, 98

Lake catfish, 81-S3

Lake chub, 161-62

Lake croppie, 463

Lake cusk, 702

Lake Erie bass, 462, 463

Lake her'ring, 233-35, 241

Lake lamprey, 13-14

Lake minnow, 158-59

Morse, 161-62

Lake mullet, 111

Lake pike, 300

Lake sculpin, 644-45

Lake shiner, 236, 241

Lake sturgeon, 66-67

Lake Tahoe trout, 250-52

Lake trout, 266-71

Swiss, 263-66

Lamna, 39-40

caudata, $2 \tau$

cornubica, 3940

punctata, $3 \mathrm{~S}$
Lamnidae, $3 \bar{\tau}-41$

Lampetra. 15-17

wilderi. 16-17

Lamplighter, 463

Lamprey eel, 11-13, 67

Lampreys, 11-17

brook, 16

great sea, 11-13

lake, 13-14

mud, 16

silver, 14-15

small black, 16-17

Lampugus punctulatus, 452. 453

Lances, sand, 375-77

Landlocked salmon, 246, 24\$-50

Lanteru fishes, 285-ST

Larimus, 574-75

banded, 575

fasciatus, 575

Lawyer, 75, 701-4

Leather carp, $16 \mathrm{~S}$

Leather jacket, 410-12, 608-10

Lebias ellipsoides, 316 ovinus, 316

sheepshead, 316

Leiostomus, 580-S3

obliquus, 581

xanthurus, 580-83

Leopard shark, 24

Lepidsosteus osseus, 71 platystomus, 72

Lepisosteidae, 69-73

Lepisosteus, 69-73 bison, 70

osseus, $70-72$

platostomus, 72-73

platyrhincus, 72

Lepomis, 47T-S2

auritus, $478-80$

cyanellus, 475

elongatus, $47 \mathrm{~S}$

gibbosus, $4 \mathrm{S3}$

mystacalis, 47s

pallidus, 480-s2

Leptoblennius, 670-71 serpentinus, $6 \pi 0$

Leptocephalioae, $174-7 \tau$

Leptocephalus, 174-77 conger, 175-7

Leuciscus, 114, 127-31. 
Leuciscus (continned) atromaculatus, 123 atronasus, 154 biguttatus, 159 chrysopterus, 122 cornutus, 145 elongatus, 128-29 ersthrogaster, 114 froutalis, 147 heterodon, 137 hudsonius, 140 idus, 131 leuciscus, 128 margarita, $130-31$ nasutus, 152 nitidus, 122 procne, 139 proriger, 128 pygmaeus, 289 rubellus, 147 rubrifrons, 149 spilopterus, 143 storerianus, $142,15 \mathrm{~S}$ vittatus, 145

Leucosomus corporalis, 124

Lichia carolina, 443

Licorne de Mer, 651

Limanda, 726-2т ferluginea, 726-27

Ling, 674-75, 701-4

Liparididae, 652-56

Liparidinae, 652-56

Liparis, $653-56$ lineata, 654 liparis, $654-56$ montagui, 652 vulgaris, $65 t$

Lirus perciformis, 455

Lizard fishes, 285-87

Lobotes, $5+2-13$ auctorum, $5 \pm 2$ emarginatus, 548 surinamensis, 542-43

Lobotidae, 542-43

Loch Leven tront, 259-61

Log perch, 505-6

Long-eared sunfish, 478-80

Long Island, species t'rom, 5-6;

Long Island herring, 197

Long jaw, 23T-38, $2+1$
Long-jawed catfisli. 84-S.j

Long-nosed dace, 1.5--54

Long-nosed sucker, 99-111

Long-tailed porbeagle, "2

Lookdown, 435-36

Lophiidae, 733-35

Loplinus, 733-35

americanus, 734

bufo, 661

histrio, 736

piscator, $73 t$

piscatorius, $734-35$

vespertilio, 738

Lophobranchii, 347-51

Lophopsetta, 722-24

maculata, $723-2 t$

Loricati, 681-56

Losh, 702

Lota, 701-4

brosmiana, 701

compressa, 701

inornata, 701

maculosa, 701-4

Lucania, 314-15

parra, 314-15

Luccio, 299

Luciidae, 291-307

Lucioperca americana, 493 canadensis, $49 \mathrm{~S}$

grisea, 499

pepinus, 499

vitrea, 494

Lucius, 291-307 americanus, 292-94 lucius, 298-301 immaculatus, 304 masquinongy, 302-4 immaculatus, 304reticulatus, 294, 296-9s vermiculatus, $29+916$

Lumpenus, 669-71 lampetraeformis, $670-71$

Lumpfish, 649-52

Lumpsucker, 649-52. 65.-ร.

Lumpus anglorum, 619

Lunge, $26 \pi$

Lutianidae, 547-55

Lutjanus aya, $55 \pm$ blackfordi, 551

Blackfordii, 550 
管

Iutpanus (routinued) caballerote, 548 campeachianus, 551 campechianus, 558 griseus, 545 stearnsii, $\overline{5}+\mathrm{S}$ vivanus. 5.14

Luxilus, 145-47 dissimilis, 157 elongatus, 128 erythogaster, 114 kentuckiensis, 144, 159 lncidns, 151

Mackerel, 379-401, 446

(chub, 3\$1-s:

сонmо1, 379-81

frigate, 384-5.j

hippos, 422

horse, 391-93, 446

skils. 446

suap. $445-48$

snapping, 446

spanish, 396-9s

thimbleeye, 3s1-83

rellow, 430-31

Mackerel midge, 70S-9

Mackerel pike. 24r:

Mackerel scarl, 423-24

Mackerel shark, $3 \bar{T}-41$

Mackina $w, 26 \pi$

Macrozoarces, 67t

Macruridae, 712-14

Maclums carminatus, 713

(Coelorhynchus) carminatus, T13

Mademoiselle, 5it

Maiden, 559

Mail-cheeked fishes, fi:1-ä

Makaira nigricans, 404

Malasbegany, 502

IIalthaea vespertilio, T:S

Malthe, Tas

respertilio, 7as

Man-eater, $41-41$

Mangrove suapler, 5ts-in

Maniton rarter, 506-7

Marbled angler, 737

Marloled cat, 89

Margined stone cat, 9.-90;

Marse banker, 425
Marsipobranchii, 11-17

Martlyy, 702

Mascalongus, 301- 7

Maskalonge, 302-4

barred, 304-7

spotted, 302-4

unspotted, $304-\bar{\imath}$

Maskinonge, 303

Masticula, 53-59

Mayfish, 309

Megalops atlanticus, 177 ceperliana, $18 \overline{7}$

elongatus, 177

notata, 209

oglina, 209

thrissoides, $17 t$

Melanogrammus, 699-700 aeglefinus, 699-700

Melanura annulata, 289 pygmaea, 289

Meletta suoerii, 195

Menhaden, 5, 211-13

Menidia, 354-59 beryllina, 356-57 gracilis, 3\%-56 bersllina, 356 laciniata, 360 notata, $357-59$ vagrans, 359 laciniata, 360

Menominee whitefish, 221

Menticirrhus, ist-si nebulosus, 585 saxatilis, $585-87$

Merit fish, 359

Merlangus carlonarus, 693 leptocephalus. 693 purpureus. 698

Merlnciiclae, 691-93

Merlucius, 691-93 albidus, 691 bilinearis, 691-93

Mesoprion caballerote, its grisens, 54s

Metly, 702

Microgadus, 694-97 proximus, 694 tomeodus, 695

Micropogon, 583-S4 costatus, 583 
Micropogon (comlimlled)

lineatus, วs:3

undulatus. Js:;-st

Micropterus, $456-93$ rolomien, $4 \$ 6-90$

pallidus, 490

salmoides, 490-93

Microptelyx chrysurus, 437

Milbert's shark, 26-2S

Millel's thuml, (3:35-:37, 19:37-38

Minister. st

IIimilus blennius, $13 \mathrm{~S}$ corniutus, 145

var. froutalis, 117

dinemus, 148

(liplaemius, 1.51

notatus, 120

percobromus, $1+9$

plumbeolus, 145

l'ubellus, $14 \mathrm{~s}$

l'ubrifions, 149

Minnow, blackhead, 118-1?

bluntuosed, 120-21

bridled, 135-36

brook, $154-56$

emerald, 147-40

fathead, $11 \mathrm{~s}$

lake, 15S-59

Morse lake, 161-62

mud, 2ST-91

pearl, 130-31

plumbeous, 161-92

led-bellied, 115

rosy, 1+7-4?

rosy-faced, 14!)-50

salt-water, 310

sheepshead, 315-17

silvely, 116-1s

spotted, 120-21

steel back, 113

straw-colored, 13S-39

striped mud, 2S9-91

toother, 312

top, 307

Minny bass, 487

Minytrema, 107-9

melanops, 108-9

Mirrol carp, 167

Mishcuppanog, 559

Mississippi cat, 82
Mitcluills pelells .

Iixed tolleod, (i:m;

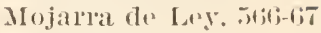

Mojarlas, . - (1..)-6i-

Nola. 639-::1

molit. 6iz9-31

lotumdal, $6: 30$

IIolacanthus, (ion)

Molidae, (;29-31

Moll, э!s

Molva maculosa, T01

ifomareathiclae. (;11-15

Ionacanthus, (i11-18

aurantiacus, fil:

broceus, 1312

hispidus, 611-1:

massachusettensis, 612

setifel, 612

Mongrel whitefisl, "2sS-41

Ionk. \pm 6

Monlifish, $45-46$, 73.5

Iooneye, 183-86 norther'n, 15.5-S6

Mooneye cisco, 235-37

Moonfisl , 433-34, $435-36,602-4$

Morone, 527-31

americana, $525-31$

flavescens. 500

maculata, 483

pallida, 52s

rufa, 5⿻s

Iorrluta aeglefinus, 699

americana, 695

americanus, fos

pluinosa, 69.

Iolse lake minnow, 161-f;

Ioss bass, 491

Mosshmukel", 211-13

Motella argentata, $70 \mathrm{~S}$ caudacuta, 710 ensis, 709

Iother-of-eels, 702

Momntain trout, 4 S

Iousefish, 736-37

smootle, 736

Moxostoma, 109-12

anistultum, 109-10

aureolum, 110-12

crassilabre, 1123

macrolepiclotum, 111

oblomgum, 106 
Mud cat, $\$ 2$

II creeper, 6.56-5s

Mud dace, 2ss

Iud eel, 15

Iud lampres, 16

Iud minnow, 2s7-91

striped, 2\$9-91

Iud shad, 1SS

Ind sucker, 104

Mud sunfish, 464-66

Iudfish, $74-76,310$

Iuffle-jaws, 636

Iugil, 9, 362-6s

albula, 363

brasiliensis, 366,367

cephalus, $363-66$

curema, 366-6i

gigas, $5 \mathrm{~S} 7$

grunniens, 587

lineatus, 363

obliquus, 581

petrosus, 366

trichodon, 9, 366, 36i-6s

Iugilidae, 362-68

Inllet, 106, 111, 362-68

black, 586

fantail, 367-6s

golden, 111

jumping, 364

lake, 111

l'ed, $377-79$

striped, 363-66

summer, 367

whirligig, 367-68

white, 366-67

Mullidae, 377-79

Iullus, 37.7-79

auratus, $377-79$

barbatus auratus, 37

Mrummichog, 309-11

banded or striper, 309

spring, 312

II 1 mmy, 310

porgy, 316

Muraena bostoniensis, 170

conger, 175

rostrata, 170

Muraenoides gunnellus, 665

Muscalonge, 303

. Iuskallunge, 303
Muskellunge, 303

Mustelus, 22-23

canis, 23

Muttonfish, 674-75

IIyliobatide, 57-60

Myliobatis, 57-5s

acuta, 5s

freminvillei, 58

? say, 55

Myoxocephalus, 639-44

aeneus, 639-41

groenlandicus, 642-4t

octodecimspinosus, 641-42

Myxostoma anisura, 109

Myxus harengus, 365

Naked goby, 656-58

Namaycush, 266

Narcobatidae, 51-52

Nauclerus, 412

Naucrates, 412-14

ductor, 412-14

indicus, 412

noveboracensis, 412

Needle-fishes, 317-23

Nematognatui, $76-97$

Neoliparis, 652-53 atlanticus, 652-53

montagui, 652

Neomaenis, 547-55

aya, 551

blackfordi, 9 , 550-55

griseus, 548-ฮॅ0

Nerfling, gold, 131

New York gudgeon, 309

New York pollack, 694

New York shadine, 190-91

Newligut, 460

Niagara gudgeon, 152-54

Nigger chub, 160, 162-64

Nipper, 593-96

Nocomis, 159-60

Northeru barracuda, 371-73

Northern chub sucker, 106

Nolthern mooneye, 185-S6

Northern pickerel, gleat, 299

Northern sucker, 99, 100

Norway haddock, 631-33

Notemigonus, 132-34

chrysoleucas, 132

lucidus, 151 
Notropis, 135-52

amarus, 141, 142

amoenus, 150-51

anogenus, 136

atherinoides, 147-49

bifrenatus, $13 \check{-}-36$

blennius, $138-39$

cayuga, 136-37

(cornutus, 145-47

frontalis, 147

dilectus, 149

dinemus, 149

heterodon, 137-38

hudsonius, $140-42,143$

amarus, 142-43

lsthrurus, 151

megalops, 145

flontalis, 147

photogenis, 151

procne, $139-40$

rubrifrons, 149-50

umbratilis 15 thrurus, 151-52

whipplei, 144

whipplii, 143-45

Noturus, 91-92

Harus, 91-92

gyrinus, 93

insiguis, 95

lemniscatus, 95

marginatus, 96

miurus, 96

Numbfish, 51-ฮ̄2

Oblong flounder, 721

Oceanic bonito, 356-8s

Oceanic sucker, 689

Odontaspis americanus, 34

Ogcocephalidae, 737-38

Ogcocephalus, 737-38

vespertilio, 738

Ohio golflen shad, 192

Ohio rirer sturgeon, 66

Oliow, 495

Oldwife. 582

Oligocephalus, 517-18

Oligoplites, 410-12

occiclentalis, 410

saurns, 410-12

Oncocottus, 644, 645
Oncorhynchns, 241-44

chouicha, 24:2

orientalis, 242

quinnat, 241

tschamytscha, 2 $41-44$

Oneida sucker, 111

Onos cimbrius, 710

ensis, 709

leinhardti, 708

rufus, 709

Ophidiidae, 675-76

Ophidioidei, 674-75

Ophidium barbatum, 676

marginatum, 675

mucronatum, 6itis

Ophioscion, 576, 578, 583

Opisthonema, 209-11

oglina, 209

oglinum, 209-11

Opsanus, 660-62

tau, 661-62

Orange filefish, 613-15

orcynus alliteratus, 389 pelamss, 386 thynnus, 391

Orfe, 131

Orthagoliscus analis, 630 mola, 630

Orthopristis, 555-57 chrysopterus, 556-57 duplex, 556

Osmerus, 282-85 mordax, 2\&2-85 riridescens, 282

Ostariophysi, 76-738

Ostraciilae, 615̄-17

Ostracion, 615 trigonus, 616 yalei, 616

Ostracium trigonum, 616 trigonus, 616

Ostracodermi, 615-17

Oswego bass, 491,492

Dtolithus, 569 carolinensis, 573 nebulosus, 573 regalis, 570

Otsego bass, 225

()uananicle, 249

Orate pompano, 439-41

Oysterfish, 598, 656-58, 661-62 


\section{Paddlefishes, 60-63}

Pagrus argyrops, 5.5

Painted tail, 487

Pale sucker, 101

Palinurichthys, 454-55 perciformis, 454-55

Palinurus pereiformis, 454

Pammelas perciformis, 455

Panhagen, 212

Pappyfish, 456-57

Paralichthys, 717-22

dentatus, $717-20$

lethostigma, 720

- lethostigmus, 720-21

oblongus, 721-22

ophryas, 718

Paratractus, 430-31 pisquetus, 430 .

Parche, 604-6

Parr, 245

Pastinaca hastata, 53, 54 maclura, 56

Pearl minuow, 130-31

Pearl roach, 134

Pediculate fishes. 733-38

Pediculati, 733-38

Pegedictis, 635-37 ictalops, 635

Peixe carago, 18-22

Pelamys sarta, 393

Perca, 500-4 acuta, 500 americana, 500, 528

atraria, $5: 36$

chrysops. 522

chrysoptera, 556

flavescens, 500-4

fluviatilis, 500

gibbosa, $4 \mathrm{S3}$

gracilis, 500

cranulata, 500

marina, 631

mitchilli, 524

alternata, 524

interrupta, 524

ocellata, 578

saltatrix, 445

schrenckii, 500

sectatrix, 568

septentrionilis, 524
Perca (continued)

serrato-gramulata, 500

unclulata, זS3

varia, 536,537

vitrea, 493

Percesoces, 354-73

Perch, 488, 493-521, 529, 505

black, 488, 529, 537

blue, 59.5

bridge, $460,48 \pi$

chinquapin, 460, 463

goggle-eye, 463

$\log , 505-4 j$

Mitchill's, 525

pike, 498-9T

pirate, $852-54$

red, 529

red-eyed, 468

red sea, 633

ring, 500-4

river, 529

sand, 463

sea, 595

silver. 463, 576-7s

speckled, 460

strawberry, 460, 463

striped, 502

tin, 460

trout, 351-52, 48s

white, 528-31, 590-92

yellow, 6, 48S, 500-4, , .29

Perch pike, 494

Perchlike fishes, 459-599

Percidae, 493-521

Percina, 504-6

caprodes, 505-6

rer. manitou, 506

zebra, 506-7

manitou, 506

Percoidea, 459-599

Percopsidae, 351-52

Percopsis, 351-52

guttatus, 351-52

hammondi, 351

Petromyzon, 11-14

americanus, 11

appendix, 11

concolor, 14

mariuns, $1 \mathrm{i}-13$

subsp. dorsatus, 13 
Petromyzon (coutinued)

unicolor, 13-14

nigrum, 16

Petromyzontidae, 11-17

Pharyngognathi, 598-601

Pholis, 665-66

gumuellus, 665-66

subbifurcatus, 667

Photogenis spilopterus, 143

Phoxinus, 114, 130-31

elongatus, 128

margaritus, 130

Plycis chuss, 707

filamentosus, 707

punctatus, 705

regalis, $70 t$

regius, 704

tenuis, 706

Picarel, 495

Pickerel, 5. 29S-301, 495, 49S, 505

banded, $292-94$

chain, 6, 296-98

eastern, 297

great, northern, 299

little, 294-96, 505

tront, 295

Pickering, 498

Pigfisl1, 556-57, 642

Pigmy sculpin, 639-41

Pike, 291-307, 493-97

blue, $303,494,497$

bouy, 71

bony-scaled, 6

common, 29S-301

federation, 297

gar, $70-72$

grass, 300, 494

gray, 498, 499

great, 303

green, 296-9S, 494, $49 \mathrm{~S}$

lake, 300

long-jawed fresh-mater, :3 1 S

rock, 499

sand, 498-99

sea, $31 \mathrm{~S}$

wall-eyed, 493-97

yellow, 494

Pike perch, $493-97$

Pikelike fishes, 257-317
Pileoma semifasciatum, 505

zobra, 506

P'ilot, banded, 415

black, 454-5.5

sliark's, 416

Pilot-fish, 221, 412-14

Pilot sucker, 687-S8

Pimelepterus boscii, כos

Pimelodus atrarius, 55

catus, 5 6

cupreus, 84

Havus, 91

insigne, 95

lemuiscatus, 96

livrée, 96

marmoratus, $\$ 9$

natalis, 84

nebulosus, 87

nigricans, 81

pullus, 90

rulgaris, 84

Pimephales, 11S-21

notatus, 120-21

promelas, 11S-19

Pinfish, 562

Pipefish, 347-49

common, $347-49$

spotted, 346

Pirate perches, 352-54

Pisces, 17-73s

Plaice, 724

Platessa dentata, 716

ferruginea, 726

oblonga, 717, 720

ocellaris, 717

plana, 727

pusilla, 72S

quadrocellata, 721

rostrata, 726

Platophrys, 730-31

nebularis, 730

ocellatus, $730-31$

Plectognathi, 608-733

Plectospondyli, 97-169

Pleuronectes, 727

americanus, $72 \tau$

aquosus, 723

dentatus, 717

ferrugineus, 726

hippoglossus, 714 
Pleuronectes (continucd)

maculatus, 723

melanogaster, 717

mollis, 732

oblongus, 721

planus, $72 \pi$

platessoides, 716

Pleuronectidae, 714-31

Plumbeous minnow, 161-62

Pneumatophorus, 381-83

Poecilia macrolepidota, 309

Poecilichthys coeruleus, 517

eos, 521

fusiformis, 520

Poeciliidae, :307-17

Pogonias, 557-90

chromis, 588

cromis, 587-90

fasciatus, $5 S 7$

Pogs; 559

Pollachius, 693-94

carbonarius, 693

virens, 693-94

Pollack, 693-94

black, 694

green, 694

New York, 694

Polyảactylus, 373-75

octofilis, 375

octonemus, 373-75

Polynemidae, 373-75

Polynemus octofilis, 373

octonemus, 373

sexradiatus, 684

Polyodon, 60-63

feuille, 61

folium, 61

spathula, 61-63

Polyodontidae, 60-63

Polyprion, 531-33

americanus, 532-33

cernium, 532

oxygeneios, 532

oxygenius, 532

Pomadasys fulyomaculatus, 556

Pomatomidae, 445-48

Pomatomus, 445-48

saltator, 445

saltatrix, $445-48$
Pomolobus, 195-203

aestivalis, 202

chrysochloris, 195-96

cyanonoton, 202-3

mediocris, 197-9s

pseudoharengus, 199-201

vernalis, 199

Pomotis appendix, 4is

auritus, 483

gibbosus, 450

gulosus, $4 \pi 0$

guttatus, 472

liexacanthus, 462

incisor, 480

longulus, 475

obesus, 471

rubricauda, 4is

speciosus, 480

rulgaris, 483

Pomoxis annularis, 459-62 niticlus, 459

sparoides, 462-64

Pomoxys, 459-64

sparoides, 462

Pompano, common, 443-44

ovate, 439-41

round, 439-41

slor'e, 441

silvery, 441-43

Pompeynose, 441

Pondfish, 4S4

Porbeagle, 39-40

long-tailed, 27

Porcupine fishes, $624-29$

hairy, $625-26$

Porgee, 5S3

bi $\underline{9}, 559$

little, 5s2

rhomboidal, 562

sand, 5is-61, 582

three-tailed. 603

Porgies, 557-65

Porgy mummy, 316

Poronotus, 45i-59

triacanthus, $45 \mathrm{~s}$

Pout, horned, S7-S9

Priacanthidae, 5 $11-47$

Priacanthus, 544-45

altus, $5+6$

arenatus, 54t-45

maclophthalmus, 544 
Prickly skate, $4-48$

Pritle, 16-17

Prionace, 24-25

slauca, 25

Prionodon glancus, see Carchidrias (I'rionodon) glancus

milberti, see Carcharias (Priono(don) milberti

obscurus, see Carcharias (Prionodon) obscurus

Prionotus, G76-S2

carolinus, 67T-7s

erolans, 679

var. lineatus, 679

lineatus, 679

palmipes, 677

strigatus, 679-\$1

tlibulus, 6S1-S2

Pristipoma fasciatum, 5.56

fulromaculatum, 5.56

Promicropterus, 541-42

Psetta, 729

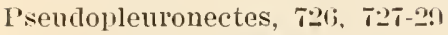
americanus, 727-29

Psendopriacanthus, 545-47 altus, 5 $46-47$

Psendorhombus dentatus, $\mathbf{7 1 7}$ oblongus, 721 ocellaris, 717

Pseudotriakidae, 17-22

Pseudotriakis, 17-22 microdon, 1S-22

Pterophryne, 735-37 histrio, $736-37$

Pteroplatea, 56-57 maclura, 56-57

Ptyonotus thompsonii, 644

Pucliermouth, 719

Puffers, 617-24 smooth, 61S-19

Pug-nosed shiner, 434

Pumpkin seed, 45S, 4S3-S6

Pygosteus, 337-40

pungitius, 338-40

sinensis, $33 \mathrm{~S}$

\section{Querimana, 9, 365}

gyrans, 9, 366, 368

harengus, 366

Quinnat salmon, 241-14t
Rabbitfish, 1i1S-19

Rachycentrirlae, $445-50$

Rachycentron, 448-50

canadus, 4t?-50

Radriated shamny, 607-tis

Liaia eglanteria, 49

laevis, 50

ocellata, ts

litiubow darter, 517-1S

Rainbow tront, 261-6?

Rainwatel fish, 314-15

Raja, 46-51

boriasus, 59

centroura, is

diaphanes, 49

eglanteria, $47,49-50$

elinacea, $47-45$

erinacens, $4 \boldsymbol{\tau}$

linevis, $50-51$

maclura, 56

ocellata, $48-49$

say, 55

torpeclo, 51

Rajidae, 46-51

Rakehead, 32

Ia y, 46-60

brier, 49-50

butterfly, $56-57$

common sting, 53-54

cow-nosed, 59-60

eagle, 57-60

electric, 51-52

hedgehog, $47-45$

southern sting, 5ป-ว6

spotted, $4 \mathrm{~s}$

sting, $53-57$

whip, 55

whip sting, 55

whip-tailed, 53-59

Razor back, 463

Red-bellied dace, 114-16

Red-bellied minnow, 115

Red diาum, รัธ-80, 589

Red-eyed perclı, 468

Red gurnard, 682-S3

Red horse, 110-12 golden, 111

Red mullet, 3тт-79

Red perch, 529

Red sea perch, 683 
Red-sided shiner, 12S-29

Rerl-sided sucker, 100

Red snapper, 9, 550-55

Red sturgeon, 66

Redtail, 160

Redthroat trout, 250-52

Red trout, 267

Rerl-wingerl sea robin, 678, 679-81

Redeye, 467-70, 475-77

Redfin, 145-47, 151-ร2

Redfish, 634-35

Remora, 686-90

brachyptera, 6\$9-90

Indian, 687

jacobaea, $68 s$

lemora, 6SS-S9

- white-tailer, 6St

Remoropsis brachyptera, 689 brachypterus. 659

Reniceps tiburo, 30

Requiem sharks, 22-30

Rhegnopteri, 873.75

Rheocrypta copelaudi, 509

Rhina squatina, 45

Rhinichthys, 152-56

atronasus, $154-56$

cataractae, 152-54

marmoratus, 152

nasutus, 152

obtusus, 155

Rhinonemus cimbrius, 710

Rhinoptera, 58-60

bonasus, 59-60

quadriloba, 59

Rhombochirus, 690

osteochir, 690

Rhomboganoidea, 69-73

Rhomboidal porgee, 562

Rhomboidichthys ocellatus, 730

Rhombus, 455-59

aquosus, 723

longipinnis, 4.56

ocellatus. 730

paru. 456-57

triacanthus, 457-59

Rhypticus decoratus, it 1

maculatus, 5.11

Richarrlsonius, 1.28

Ring pereh. $500-4$
Rissola, 675-76

marginata. $675-76$

River alewife, 192

River bass, 491

River chub, 159-60

River herring, 199

River perch, 529

Roach, 6, 132-34, 5\$2

Irish, 134

pearl, 134

Robin, flying, 684-S5

Roccus, 522-27

americanus, 528

chrysops, 522-23

comes, 570

lineatus, 524-27

striatis, 524

Rock, 525

Rock bass, 467-70, 537

Rock cod, 699

Rock eels, 665-71

Rock pike, 499

Rock sturgeon, 66

Rock toadfish, 646

Rockfish, 155, 505, 524-27, $631-35$

Rockling, 709-10

four-bearded, 710-11

silvery, $708-9$

Roncador, 590

Rosefish, 631-33

Rostrated dory, 436

Rosy-faced minnow, 149-50

Rosy minnow, 147-49

Rough dab, 716-17

Rough-head, 146

Rough silvel'sides, 359-61

Round herring, S. 189-91

Round pompano, 439-41

Round robin, 421-22

Round whitefish, 221-24

Rounded sucker, 106

Roundfish, 221, 222

Rudderfish, 454-55, 45T, 567-69

banded, 414-16, 428-2?

Rudly bass, 529

Ruddy sturgeon, 66

Iinnner, 419-20. 59S

Riusty dab. 727

Rusty flatfish. 727

Riusty flounder, 717 
Rutilus anomalus. 11: storerianus, $15 \mathrm{~s}$

Rispticus, $540-42$ bistrispinus, $541-42$

Sac-a-lait, 460,463

Saibling, 275-7S

Sailfishes; 403-T

Sailor's choice, 561-62

Salar ausonii, 254

Salıno, 244-66, 257-59

adirondacus, 266

alpinus, 275,278

amethystiuus, 266

amethystus, 266

ascanii, 275

canadensis, 272

clarkii henshawi, 250

clupeaformis, 224

colii, 276

confinis, 266

erythrogaster, 272

fario, 254-57

ausonii, 254

foetens, $2 S 6$

fontinalis, 272

gairdneri, 252-54

gairdnerii, 252

glorerii, $24 \mathrm{~S}$

grayi, 276

(Coregonus) harengus, 233

henshawi, 250-52

loodii, 266

immaculatus, 272

irideus, 261-69:

shasta. 261

killinensis, 276

(Coregonus) labradoricus. 224

lemanus, $268-66$

levenensis, 259

myliss, 250

henshawi, 250

namaycush, 266

pallidus. 266

perisii, 276

purpuratus, 25:

rat. henshawi, 250

(Coregonus) quadrilateralis. 221

quinmat, 241

rivalis, 270

\author{
Salmo (continued) \\ silar, 244-4S \\ sebago, 248-50 \\ var. sebago, 248 \\ salmarinus, 275 \\ salvelinus, 275 \\ sebago, $24 \mathrm{~S}$ \\ siscowet, 260 \\ trutta, 263
}

lerenensis, 259-61

tshawytscha, 241

(Coregonus) tullibee, 238

umbla. 275

willughbii. 276

Salmon, 61-62, 219-\$2

Atlantic, 241-4S

black, 267

chinook, 241-4t

dwarf, 246

fresh-water, 246

jack, 495

king, 241-44

landlocked, 246, 24S-50

Quinnat, 241-4t

Susquehanna, 494

white, 495, 497

Salmon killer, 841

Salmon shark, 40

Salmon trout, 180, 252-54, 266-71

Salmonidae, 219-S2

Salmoperca pellucida, 351

Salmopercae, 351-52

Salt water bream, 562

Salt-water chub, 598

Salt-water jack, 446

Salt-water minnow, 310

Salt-water trout, 571

Salvelinus, 271-S2 alpinus, $27 \overline{-}$-TS

aureolus, 278-\$2

aureolus, $27 \mathrm{~S}$

fontinalis, $272-7.5$

namaycush, 266

Sand dab, 717, 726-27

Sand eel, 376- $7 \tau$

Sand flounder, 724. 730-51

Sant lances, 375-7т

Sand perch, 463

Sand pilie, 2St. 49S-0?

sand porgee, 5.5-61, isz 
Sand roller's, 351-52

Sand sllark, $34-37$

Sand smelt, 359

Sand sucker, 108-9

Sircura. 46-52

sarda, 393-95

mediterranea, 393

pelamrs, 393

sarda, 393-95

sardine, scaled, 209

Sardinella, 208-9

$s p ., 209$

Sargus ambassis, 558

arenosus, 558

oris, 563

rhomboides, 561

Sarothrodus maculocinctus, 605

Satin striped herring, 215

Sauger, 498-99

Saurel, 425-26

Sauries, 327-29

Saurus foetens, $2 S 6$

mexicanus, 286

Sawbelly, 200

Scabbard fish, 402-3

Scad, 421-22, 425 .

big-eyed, 426-27

dotted, 422

mackerel, 423-24

Scale carp, 167

Scaled sardine, 209

Scaly fins, 601-8

Schilbeodes, 92-97

sฐrinus, 93-94

insignis, 95-96

miuxus, 96-97

Schoodic tront, 246

Schuylkill cat, 86

Sciaena, 57S, 590

caprodes, 505

chrysura, 576

imberbis, 578

lineata, 524

nebulosa, 585

obliqua, 581

ocellata, 57s

oscula, 590

punctata, 576

xanthurus. 581

Sciaenidae, 569-92
Sciaenops, 57s-50, 583

ocellatus, 57S-S0

Sciena fusca, iss

rigas, zSS

Sclerodermi, 608-15

Scoliodon, 29-30

Scoliodon terrae novae, 29-30

Scolopsis sayanus, 353

Scomber, 379-83

alleteratus, $38 S$

chrysurus, 437

colias, 381-\$3

crumenophthaluus, 426

crysos, 430

dekayi, 382

ductor, 412

grex, 382

hippos, 421, 428

maculatus, 396

pelamis, 356

plumbeus, 445

plumieri, 426

pneumatophorus, 3S2

regalis, 398

sarda, 393

saurus, 410

scomber, 380

scombrus, 379-81

thazard, 384

thynnus, 391

trachurus, 425

rernalis, 380

zonatus, 414

Scomberesocidae, 327-29

Scomberesox, 327-29

equirostrum, 327

sanlus, 327-29

scutellatum, 327

storeri, 328

Scomberomorus, 395-401

caralla, 400-1

maculatus, 396-9S

regalis, $398-400$

Scombridae, 379-401

Scombroidei, $379-459$

Scombroides occidentalis, 410

Scorpaena americana, 646

dactyloptera, 634

flara, 646

purpurea, 646

rufa, 646 
Scorpaenidae, 631-35

Scorpoenta, yellow, 6tti

Sculpin, 635-47

brassy, 639

daddy, 642-41

(deep water, titti

1S-spined, 6+1-42

lake, $644-45$

pigmy, (*39- +1

sea, 646

Scup, 5อ̄ร-61

Scuppaug, $5 \pi 9$

Scuteeg, 571

Sea basses, 520-42, 536-39

striped, 525

Sea catfish, TT-7S. 7S-79

Sea devil, 735

Sea eel, 175-77

S.a herring, 192-94

Sea horse, $349-51$

Sea lamprey, great, 11-13

Sea mink, 585-87

Sea owl, 651

Sea perch, 595

red, 633

Seal pike, 318

Sea poacher, $6+5-49$

Sea raven, 6t6-47

Sea robin, 6t2, 677-7S, 680

big-headed, 6\$1- $\$ 2$

red-winged, 678, 679-81

Sea sculpin, $6 \pm 6$

Sea snails, 652-56

striped, 654-56

Sза snipe, 318

Sea swallow, 685

Sea toad, 642

Sea trout, 571, 573-7t

Sea wolf, 673

Seaweed blenny, 663-64

Sebago trout, $2 \pm 6$

Sebastes, 631-33

dactylopterus, 634

m!arinus, 631-33

norvegicus, 632

norwegicus, 631

Sebastinae, 631-35

Sebastoplus dactylopterus, 634

Seering, 180

Selachii, 17-60
Selachostomi, 60-63

sclachus maximus, 42

Sulcue, $434-36$

argentea, $43 \overline{5}$

gallus, 435

setipinnis, 433

vomer, $435-36$

Semotilus, 121-26

atromaculatus, $123-26$

liguttatus, 159

iullitis. 122-23

corporalis, 122, 124

Selan isperial, $634-35$

Scrogeant fishes, 448-50

Seriola, 414-1S

bipinnulata, 419

cosmopolita, 437

gigas, 416

lalandi, 416-1s

pinnulata, 419

zonata, $\$ 14-16$

Seriolichtliys bipinnulatus, 419

Serranidae, 522-42

Serranus atrarius, 536

brasiliensis, 539

flaviventris, 539

margaritifer, $5: 33$

nigrescens, 536

niveatus, 583

Sllad, 192, 204-8, 460

Cayuga Iake, 200

fall, 197

gizzart, 186-8S

gold, $195-96$

hickory, 9, 18s, 197-9s

lit tJe, 200

mud, 188

Ohio golden, 192

stink, 1 SS

tailor, 198

white, 205

white-eyed, $15 s$

winter, $18 s$

Sllad bait, 194

Shlad herring, 197-98, 203, 209-11

Sllad trout, $5 \pi 1$

shad-waiter, 221, 224-30

Shadine, 190-91

Shanny, radiated, 667-68

Sllark ray, 46 
Sharlss, 17-60

angel, $45-415$

basking, $41-43$

blue, 39

bone, 13

dog. 23

dusky, 25-26

elepliant, $42-43$

great blue. 25

great white, $40-41$

green-backed, 30

ground, 35

hammerheaded, 30-32

leopard, 24

little bullhead, 46

mackerel, $37-41$

Milbert's, :-6-28

requiem, 22-30

salmon, 40

sand, $34-37$

sharp-nosed, 29-30

shovelhead, 30-31

shovelnose, 32

small blue, 27

swingle-tail, 33-34

thresher, $32-34$

tiger, 24

Shark's pilot, 416

Sharksucker, 6S6-87

Sharp-nosed shark, 29-30

Sheepshead, 458, 563-65, 591

three-tailed, 603

young, 589

Sheepshead chaetodon, 603

Sheepshead killifish, 317

Sheepshead Lebias, 316

Sheepshead minnow, 315-17

Shinel, 139-40, 145-47, 160, 235-37, $241,359,562$

blunt-nosed, 434

cryptous broad, 458

golden, 132-34

lake, 236

pug-nosed, 434

red-sided, 128-2?

spotted, 157-5s

Shoemaker, 104

Shoemakerfish, 432-33

Shore pompano, 441

Short-finned harvestfish, 4ॅ8

Short-nosed gar, 72-73
Short-nosed sturgeon, 68-69

Shovel fish, 61

Shovelhead shark, $30-31$

Sloveluose shark, 32

Sier'ra, 400-1

Siluridae, $76-97$

Silurus catus, S.5-87

felis, is

syriuts, 93

marinus, $T \tau$

melas, 90

punctatus, 80

Silyer bass, $185,462,523$

Silver cat, 80

Silver chub, 122-23

Silver gar, 317-19

Silver hake, 691-93

Silver Jenny, 566-67

Silver king, 17т-79

Silver lamprey, 14-15

Silver pereh, 463, 5i6-is

Silver trout, 278-S2

Silverfin, 143-45

Silverfish, 165

Silversides, 354-62

brook, 361-62

fresll-water, $356-57$

rough, 359-61

slender, 355-56

small, 358

Silvery anchovy, 216-17

Silvery minnow, 116-18

Silvery pompano, 441-43

Silvery rockling, 70 -9 9

Siphostoma, 347-49

fuscum, $347-49$

peckianum, 347

Sliate, 17, 46-51, 49

barndoox', 50-51

big, $48-49$

bonnet, $4 \mathrm{~S}$

clear-nosed, 49-50

common, 47-4S

prickly, $47-48$

spotted, 4S-49

sunmex, 48

winter, 49

Skip mackerel, 446

Skipjack, 192, 195-96, 361-62, 4.5

Skippang, 21:2 
Skipper, 327-29

Slender halfbeak, 324-27

slender silversides, 35う-56

Slippery Dick, 675-76

Smelt. 140-42, 143, 2S2-S5 sand, 359

Smelt of New York lakes, 230-33

Smolt, 245

Smooth browed hulliead, 640

Smooth dogfish. 23

Smooth mousefish, 736

smooth puffer, 618-19

Snake blenuy, 671

Snakefislı, 28т, 670-i1

Snap mackerel, 445-4S

Snapper, 445-48, 547-5., 633 blue, 446

gray, 54S-50

mangrove, $548-50$

red, 9. $550-55$

Snapping mackerel, 446

Snipe, sea, $31 \mathrm{~S}$

Snowy grouper, 538-35

Soaptish, 541-42

Soft gar, $31 \mathrm{~s}$

Soft sucker, $10 \mathrm{~s}$

Soldier fish. $51 \mathrm{~s}$

Soleidae, 731-33

Soles, 731-33

American, 732-33

calico, 732

Southern flounder, 720-21

Spadefishes, 601-4

Spanish mackerel, 396-9S

Sparidae, 557-65

Sparus argirops, $55 \mathrm{~S}$

aureus, 483

cluysops, 558

oris, 563

probatocephalus, 563

rlomboides, 561

Spawn-eater, 140-42

Spearfish, 2ST, 405- 7

Spearfish sucker, 690

Spearing, 359

Speckled perch, 460

Speckled trout, 273

Sperling, 194, 359

Sphaeroides trichoceplualus, 624

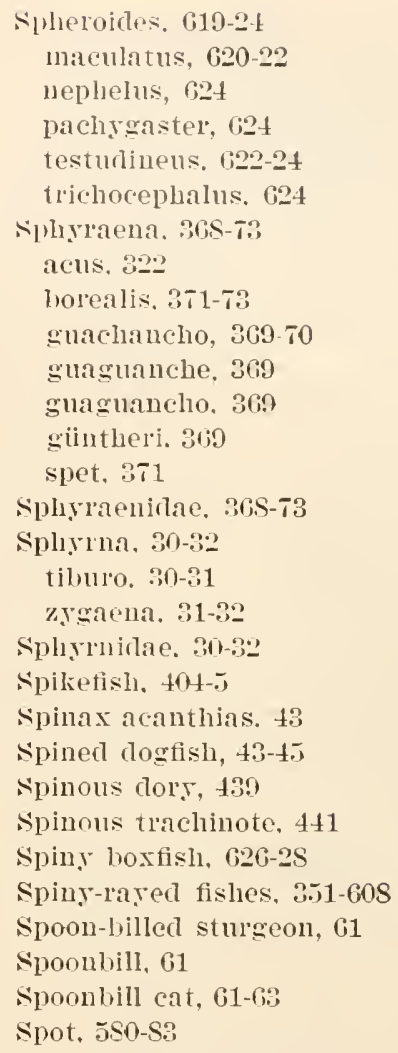

Spot-striped balloon fish, 628 spotted bass. 45. 580

spotted bergall, 5.6;

Spotted blenny, gris-69

Spotted caranx, 422

spotter cat, S0-S1

spotted cero. 400

spotted corling, Tnt-5

spotted flounder, 731

spotted grouper, 533-35

spotted hake, 701-כ

Spotted maskalonge, 302-1

Spotted minnow, 120-21

Spotted pipefisl, 346

Spotted ras, 4S

Spotted shiner, 157-5s

spotted skate, 48-49

spotted stargazer, 658-60

spotted suclier, 10S-9

spotted turbot, i2t 
Spotted weakfish, 573-74

Sprat herring, 209-11

Spring herring, 199

Spring mummichog, 312

Squalidae, 43-45

Squalius elongatus, 128 margaritus, 130

Squalus, 43-45

acanthias, $43-45$

canis, 23

carcharias, 40

cornubicus, 39

glaucus, 25

littoralis, 34

maximus, 42

obscurus, 25

punctatus, 29

spathula, 61

squatina, 45

(Carcharias) terrae-novae, 29

tiburo, 30

vulpes, 33

zygaena, 31

Squamipinnes, 601-7

Squatina, 45-46

angelus, 45

dumerili, 45

squatina, $45-46$

Squatinidae, 45-46

Squeteague, 570-73

Squid hound, 525

Squirrel fish, 562

Squirlel hake, 706, 707-S

Starfish, 458

Stargazers, 655-62

little, 637

spotted, 658-60

Staten Island herring, 197

Steel-back minnow, 113

Steelhead, 252-54

Stellifer, 576

Stenotomus, 557-60

argyrops, $50 \mathrm{~s}$

chrysops, 558-191

Stephanolepis, 611-13

Stichaeinae, 667-71

Stichaeus, 668-69

islandicus, 670

punctatus, 66S-69
Sticklebacks, 385-4t

l,loody, 343

brook, 39.5-37

Cayuga lalie, 337

four-spined, $342-44$

10-spined, 338-40

two-spined, 340-42

Stilbe chrysoleucas, 132

Sting rays. 6is-sT

Stink shad, 188

Stizostedion, 493-99

canadense, 49S-99

grisenm, 499

vitreum, 493-97

Stizostedium canadense, 495 rar. griseum, 499

vitreum, 494

Stolephorus, 213-19

argrophanus, 216-17

browni, 214

brownii, $214-15$

curystole, 216

mitchilli, 218-19

perfasciatus, 216, 217-18

Stomorton Bilinearis, 691

Stone bass, 582

Stone cat, 91-92, 93-94

mal'gined, 9.5-96;

tadpole, 98

variegated, $96-97$

Stone lugger, 104, 113-14

Stone roller, 103-t, 113-14

Stone toter, 104, 113

Straw-colored minnow, 135-39

Strawber'y bass, 462-64

Strawberry perch, 460, 463

Streaked bass, 525

Streaked lead, 438

Striped anchory, 214-15

Striped bass, 523, 5-4-27

Striped basse, 525

Striped killifish, 309

Striped mud minnow, 289-91

Striped mullet, 363-66

Striped mummichng, 309

Striped perch, 502

Striped sea bass, 525

Striped sea snail, 654-56

Striped sucker, 108-9

Stromateidae, 455-59 
Stromateus alepirlotus. 45;

creptosus, $45 \mathrm{~s}$

gardenii, 456

longipinnis, 456

partu, 456

triacinthus, 4.5

sturgeon, 6:s-ti9

bony, 166

common, $68-65$

lake, 66-67

Ohio river, $6 \mathbf{6}$

red, 66

rock, $6 t^{3}$

ruddy, 60

short-nosed, 1is-6i?

spoon-billed, fi1

Sucker's, 97-112

banded, 104

black, 104

black-nosed, 10 s

brook, 101

chub, 105-T

common, 101-3

golden, 111

s1'ay, 101

hog, $103-4$

large-scaled, 104

long-nosed, 99-101

mud, $10 t$

northern, 99, 100

oceanic, 689

Oneida, 111

pale, 101

pilot, 687-8s

red-sided, 100

rounded, 106

sand, 108-9

soft, $10 \mathrm{~s}$

spearfish, 690

spotted, 108-9

striped, 10S-9

street, 106

swordfish, 6S9-90

white, 101

white-nosed, 109-10

Sucking fish, 686-S7

Sucking toad, 621

Summer flounder, $717-20$

Summer herring, . 203

summer mullet, 367
Summer sliate, $4 \mathrm{~S}$

Sun trout, 571

Simapee trout. 27S-S2

Sunfisl, 434, 4.99-93, 4S3-86, 615. 1929 banded, t71-7.

bass, 406

blue, 480-82

blue-spotted, $473-75,475$

green, t7.j-it

long-eared, tis

mul, 46t-66

Sunny, 4 St

Sul'geons, 606-

Surmullets, $377-79$

Susquehanna salmon, 4.94

Sweet sucker, 106

Swellfish, 620-22

Swelltoad, 621

Swingle-tail shark, 33-34

Swiss Lake trout, 268-66

Swordfish sucker, 689-90

Swordfishes, 71, to7-9

Synentoguathi, :317-3.5

Syngnathidae, $347-49$

Synguathinae. $347-49$

Syngnathus fasciatus, 347

fusens, $3 \pm 7$

hippocampus, 850

peckianus, $34 \overline{7}$

viridescens, 347

Synodontidae, 285-ST

Synodus. 2S.-ST

foetens, $286-8 T$

Tadpole stonecat. 98

Tahoe trout, 250-5.2

Tailor, 446

Tailor shad, 198

Tambor, 624

Tang, 607

Tarpon atlanticus, $177-79$

Tarpons, $177-80$

Tarpum, 177-79

Tautog. 597-99

Tantoga, 596-99

americana, $\overline{5} 97$

caerulea, 593

niger, 59

onitis, $597-99$ 
Tautogolabu'us, 593-96

adspersus, $593-96$

Tectospondyli, 45-46

'Teleostei, 76-738

Teleostomi, 60-76

Temnodon saltator, 445

T'ench. 126-27

Tessellated darter, 514-16

Tetraodon laevigatus, 618 turgidus, 620

Tetraodoutidae, 617-24

Tetrapturus, 405-7

albidus, 406

belone, 405

imperator, $405-\tau$

Tetrodon curvus, 618

hispidus var. maculatus, 620

laevigatus, 618

mathematicus, 618

mola, 629

testudineus, 622

trichocephalus, 624

turgidus, 620

Tetronarce, 51-52

occidentalis, 51-52

Tenthididae, 606-7

Teuthis, 606-7

hepatus, 607

Thimble-eye mackerel, 3\$1-83

Tholn back, 339, 343

Thor'n-backed gruut, 444

Threa herring, 1SS, 209-11

Threadfins, 373-75

Threadfish, 210, 432-33

Thresher shark, 32-34

'Tlunder' pumper, 591

Tlıumnus, 390-93

thynuus, 391-93

Thynuus affinis, 389

brachypterus, 391

brasiliensis, $3 S S$

brevipinnis, $38 s$

brevirostris, 389

pelamys, 386

secundidor'salis, 391

thunnina, $38 S$

rulgaris, 391

'Tiburon, 28-29

'Tiger" shark, 24

Timber croppie, 460
Tin mouth, 463

Tin pelch, 460

Tiuca. 126-27

tinca. 126-27

vulgaris, 126

Toad, ias

sucking, 621

'Toatifish, 621, 660-62

rock, $6+15$

Tobaceo box, 484

Togue, 26 t'

Touncor, 586, 695-97

h้оพn, 696

nixed, 6 if:

yellow, 690

yellowisls white, 696

Toothed Hatfish, 719

'Toothed hel'ring, 184-S5

Toothed minnow, 312

'Top' minnows. 307

Topsail, gaff, $77-7 \mathrm{~S}$

'Torpedo, 51-52 occillentalis, 51 .

'Torsh. 699

Trachinoidei, 65S-62

Trachinote, spinous, 441

Trachinotus, 498-44

argenteus, 441-48

carolinus, $443-44$

c':pleus, 441

falcatus, 439-41

fuscus, 439

pampanus, 443

lhomboides, 439

spinosus, 499

Trachurops, 426-27

crumenoplisthalmus, 426-27

'Tracluurus, 424-26

saurus, 425

trachumus, 425-26

'Trachynotus, 489

carolintss, 443

ovatus, 439

pampanus, 443

rluomboides, 439

Tricluidion octofilis, 373

octonemus, 373

Trichiuriac, 402-3

Trichim'us, 402-3

argenteus, 402

lepturus, 402-3 
Trichoerchus erinaceus, 62.)

Trichodiodon, 624-26

pilosus, 62.5-26

Trichopterus, 4-28-29?

'Trigger fishes, 608-11 blue-striped, (i10-11

Trigla, 677,682 carolina, 677 cuculus, 682-S:

erolans, 679

lineata, 679

palmipes, 677

strigata, 679

tribulus, 681

rolitans, 684

Triglidae, 676-s:3

Triglopsis, 644-45

stimpsoni, 644

thompsoni, 644-45

Triple-tails, $5+2-43,602-4$

Trota, 25J

Trout, 488, 491, 5̄1

alchy, 702

brook, 6, 255, 272-75

brown, 254-5T, 48s

Gairdner's, 252-54

solden, 27S-S2

s19y, 267, 571

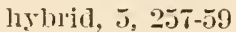

lake, 266-71

Lake Tahoe, 250-52

Loch Leven, 259-61

mountain, 4SS

lainbow, 261-63

lert, $26 \%$

lerl-throat, 250-52

salmon, 1S0, 2-2-J4, 266-71

salt-mater, jٓ1

Schoodic, 246

sea, ว71, 573-74

Sebago, 246

shat, 571

silver, 2TS-82

speckled, 273

steelhead, 252-ð4

suin, 571

Sunapee, 27S-S2

Swiss Lake, 263-66

white, $48 s$

Trout perches, 351-52, 488
Tront pickerel, 29:

Tront pilie. $28 T$

True fisliess, (6)-To

Truite, 25.

Trumpet tisl, .845-t6;

'l'runkfishes, (;1)-17

Toutta, 244

Trygon lustata, in-it

savi, ...

Tuftęills, :3เT-こ1

Tularli, 2407

Tullibee, 2:35-41

'Тuा1, 391-9:?

little, 3ss-90

Turbot, 60s-10

spotterl, 724

Turbot flomuler. 719

Ty]osmuls, $317-23$

acus, ?:20-293

classus, 819

sladius, :319

longirostris. 817

111:10iuts, :317-1!)

laphidoma, 319-21

Ulcina, 6+8-49

Llvaria, 6ij-6s subbifurcata. Gij-cis

L'mbra. 2si-91

limi. 285-89

lygmaea, 2s?

pygmaea. 289-91

T'mbridae, 28т-91

tombrina, jsis

albumus, is

nelunlosa, is.j

Tuspotter halloonfisl, 628-29

Inspotted maskalonge, 304-7

rpsilonphorus guttatus, fj.5s

Craniclea, 6:7-8s

formosa, fi3s

gracilis, fist-3s

quiescens, $6: 3$

richaldsoni, tiisi;

Uranoscopidae. fins-60)

Uranoscopinate, (isis-tio)

Trophyeis, Tot-s

rluuss, 70T-s

regius, $704-5$

tenuis, 705- 7 
Variegated goby, 65̄

Tariegated stone cat, 96-9T

Vomer, 433-34

lrownii, 433

setipinnis, $433-34$

Von Behr trout, 25J

Wall-eyed herring, 199-200

Wall-eyed pike, 493-97

Warmouth, 470-71

Watery flownder, 724

Weakfish, $570-73$ spotted, 573-74

Weesick, $19 \mathrm{~S}$

Welshman, 491

Whip ray, 5.

Whip sting ray, 55

Whip-tailed rays, 53-59

Whilligig mullet, 367-6s

White bass, 522-23

White-bellied killifish, 311

White cat, $80,55-86$

White croppie, 460

Whitceyed shad, 1ss

White hake, 705- 7

White mullet, 366-67

White-nosed sucker, 109-10

White perch, 528-31, 590-92

White salmon, 495, 497

White sluat, 205

White shark, great, 40-41

White sucker, 101

White-tailed remora, 6st

White trout, 4SS

Whitebait, 194, 215, 217, 21S-19, 357-59

Whitefish, 205, 219, 146

blackfin, 225

comimon, 22t-30, 240

Hoy's, 2t1

Labrador, 9, 224-30

Menominee, 221

mongrel, 23S-41

round, 221-24

Whiting, 5Sร-ST, 691-93

Bermuda, 586

W'ill George, 598

Wind fish, 122-23

Window light, T24

Winclowpane, 729-24

Wingfish, $67 \mathrm{~S}$
Winninisl, 246

Winter Hounder, 727-29

Winter shad, 1Ss

Winter skate, 49

Wolf fishes, 672-74

Wrassefishes, 509-600

Wreckfish, 532-33

Wrymouths, 671-72

Xenarchi, 35-54

Xiphias, $407-9$

glaclius, 408-9

imperator, 405

Xiphididae, 665-71

Xipliidae, $407-9$

Xystophorus, 412

Yellow backs, "208

Yellow bass, $48 \mathrm{~T}$

Yellow-bellied killifish, 311

Yellow caranx, 429

Yellow cat, 81

Yellow fins, 571

Yellow mackerel, 430-31

Yellow perch, 6, 485, 500-4, 529

Yellow pike, 4!14

Yellow scorpoena, 640

Yellow-tail, 309, 56i2, 576-7s

Yellowish white tomcod, 696

Zeidae, 600-1

Zenopsis, 600-1 ocellatus, $600-1$

Zeoidea, 600-s

Zeus capillaris, 435

ciliaris, 432

crinitus, 432

geometriens, 435

ocellatus, 600

rostratus, 435

setapinnis, 433

spinosus, 430

romer, 435

\%oarces, 674-75

anguillaris, $6 \bar{t} 4-\bar{\tau}$

viriparus, 674

\%oarcidae, 674-75

Zonichtluys gigas, 416

\%ygaena malleus, 31

tiburo, 80 



is.

$\therefore 4=$ 